\title{
تسبيب الأحكام القضائية \\ دراسة في قانون المرافعات المصري والفرنسي
}

\author{
حســـام أحمد العثطار \\ مدرس بقسم قانون المرافعات \\ كلية الحقوق - جامعة عين شمس المس
}





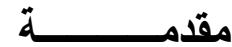

\section{Introduction}

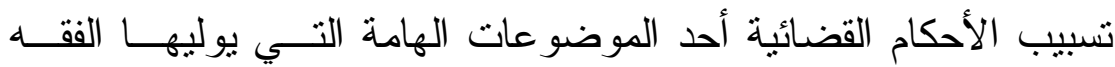

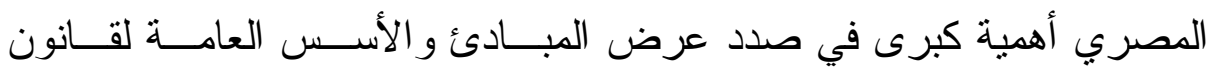

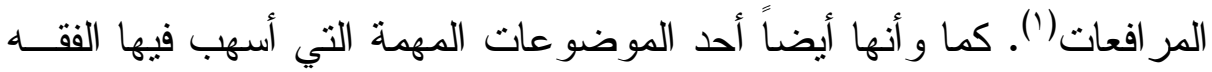

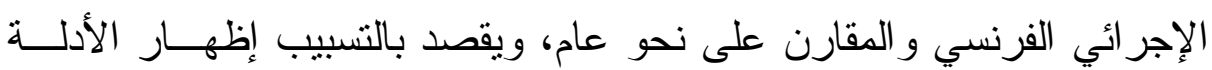

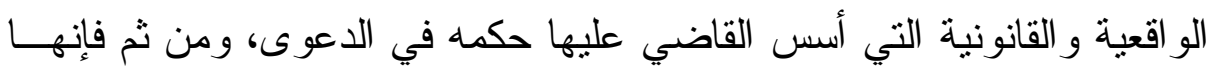

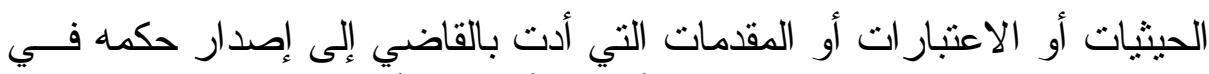

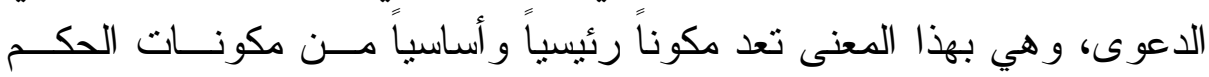

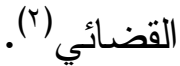

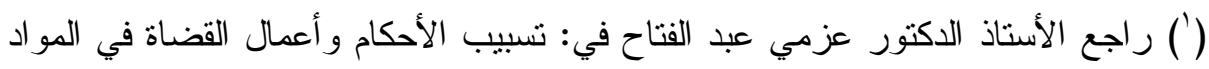

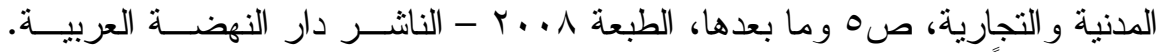

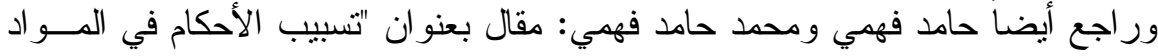

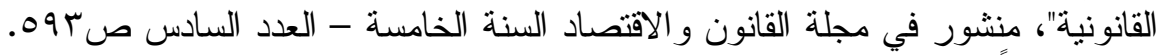

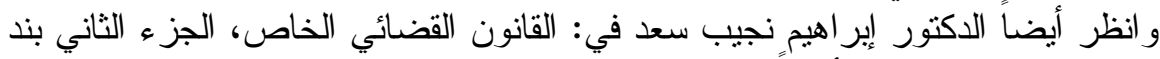

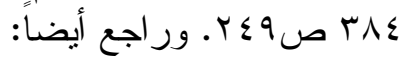

Geneviève Duidicelli. Delage, la motivation des décisions de justice. Thèse Poitiers 1979. Tom. I p. 50.

Max Counelle, la motivation des actes juridiques en droit international public. 1975. pen paris. No 1 p. 10.

$$
\text { ور اجع كذلك: }
$$

Lion Hussson, les trois dimensions de la motivation in la motivations des décisions de justice. Travaux du centre nationale de recherché des logique. Etudes publiées par ch Perelmen et $\mathrm{p}$. foriers. Bruylant. 1978. p. 70.

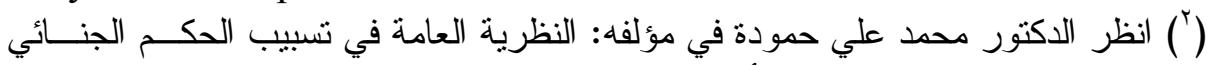

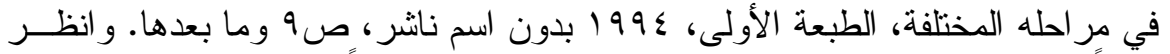

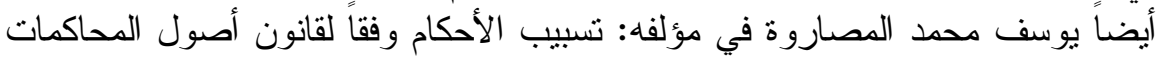

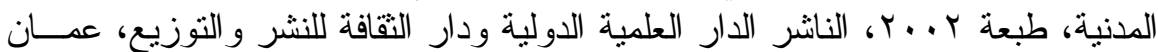

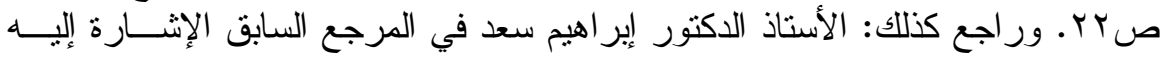

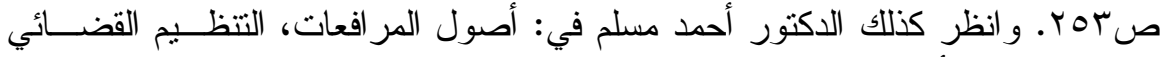

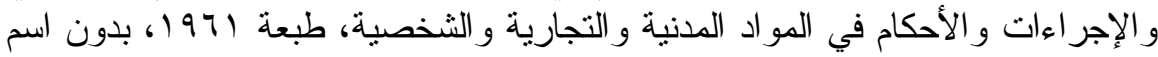

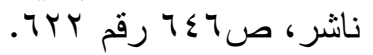




\section{أولاً: علاقة التسبيب بالحكم القضائي:}

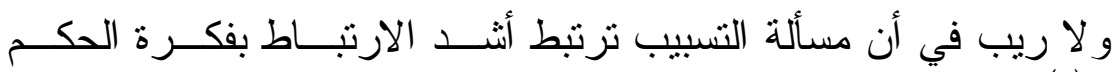

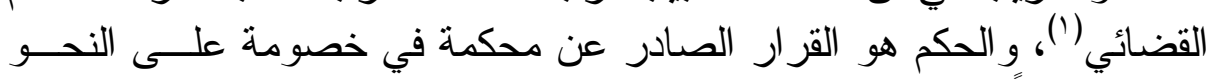

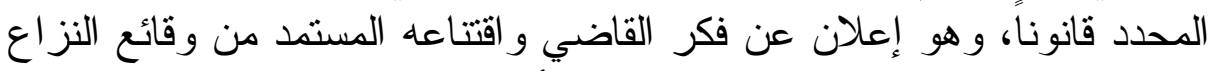

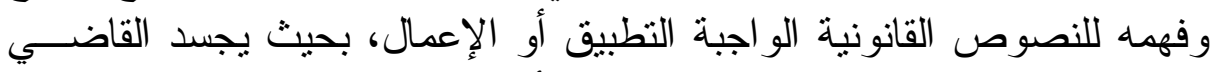

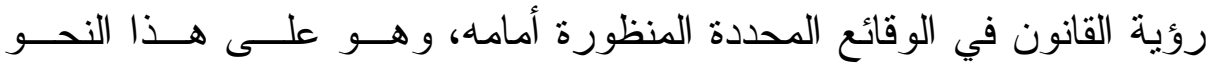

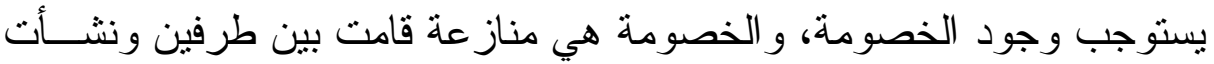

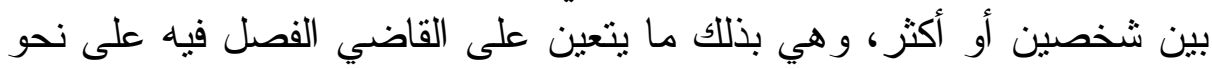

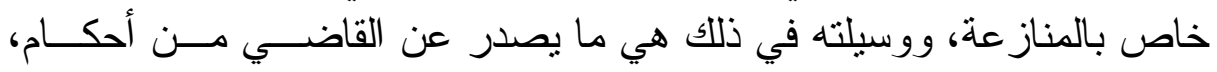

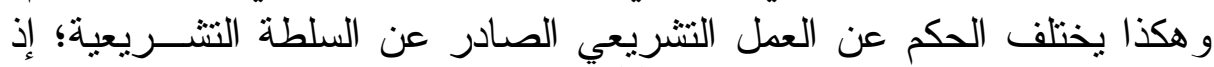

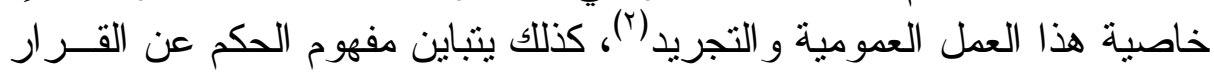

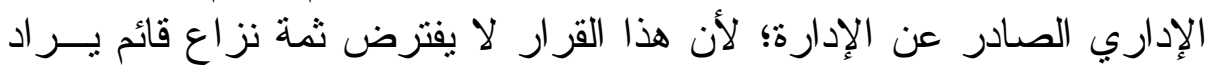

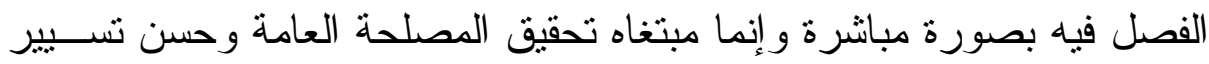

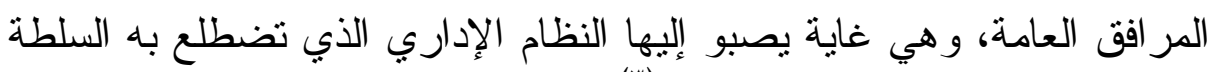

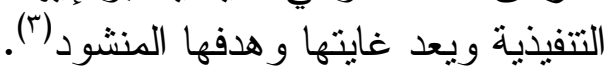

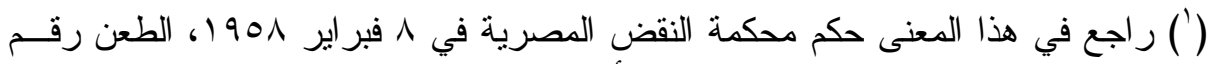

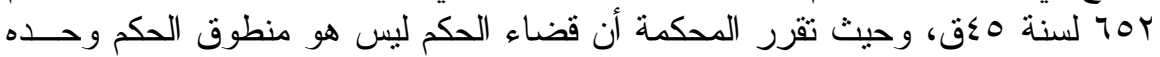

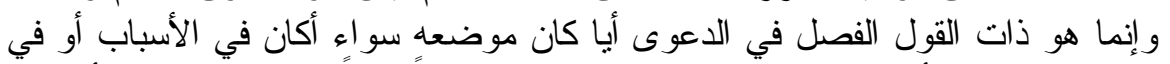

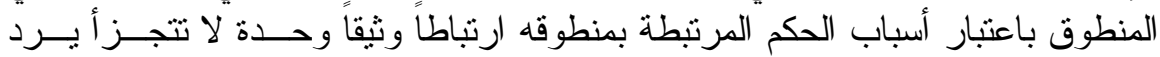

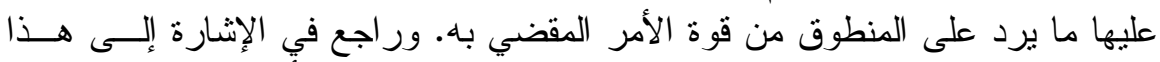

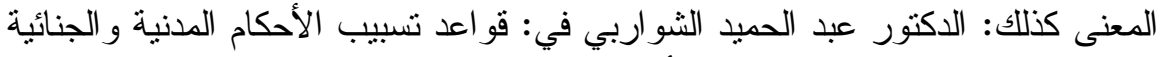

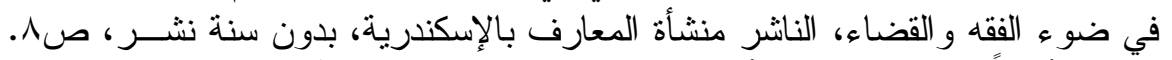

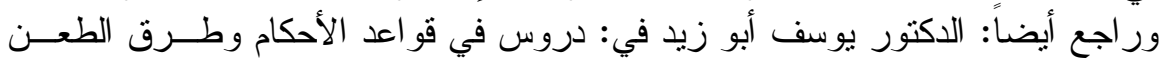

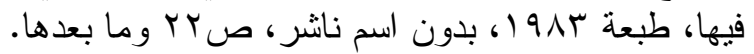

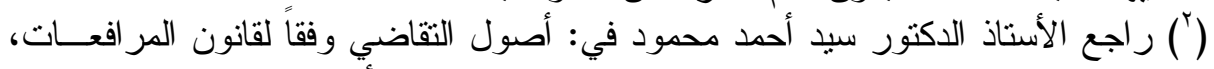

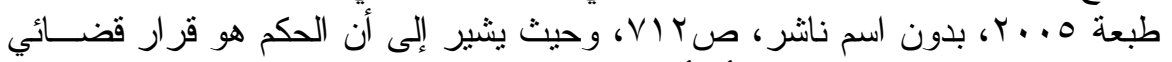

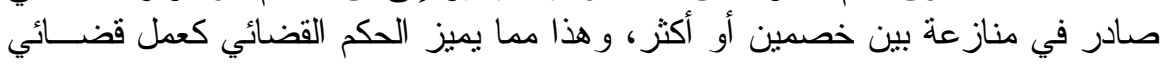

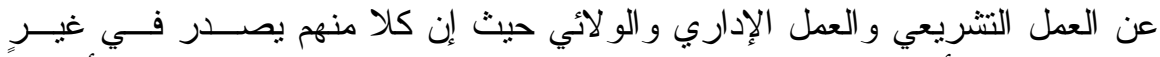

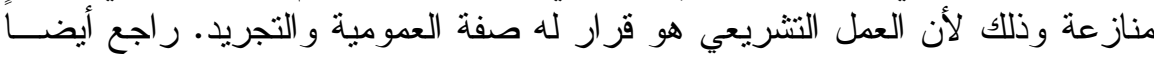

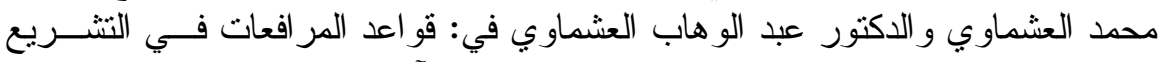

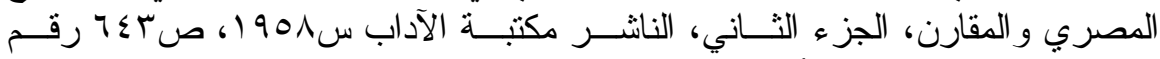

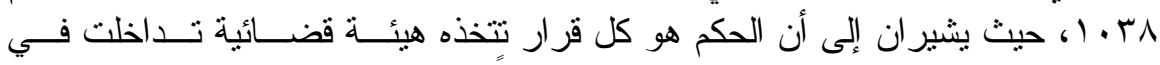

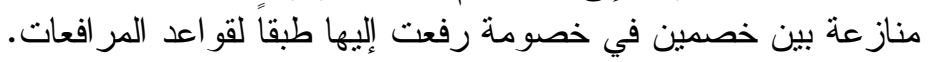

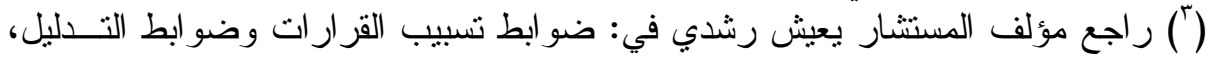


ومتى استقر هذا الفهم الواقعي لطبيعة القرار الإداري أمكن أن نستظهر

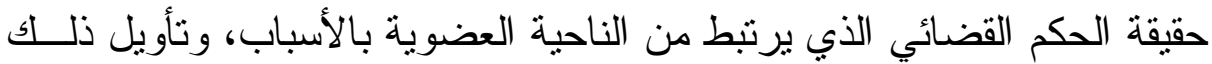

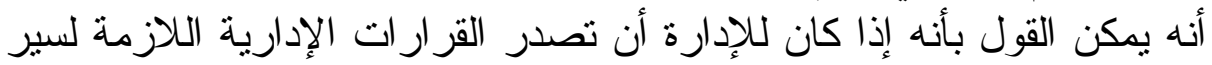

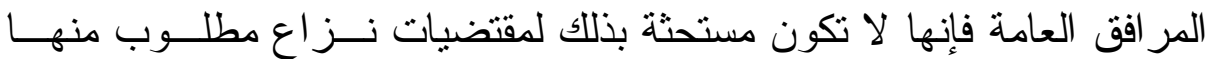

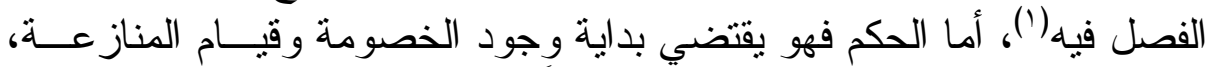

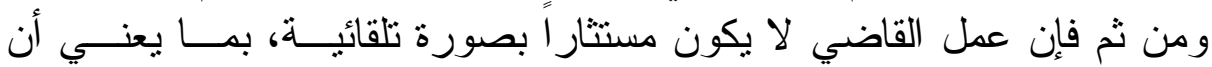

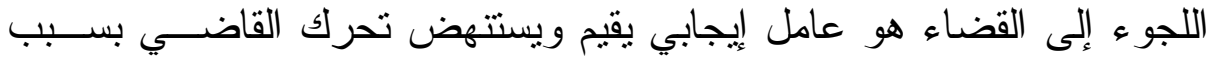

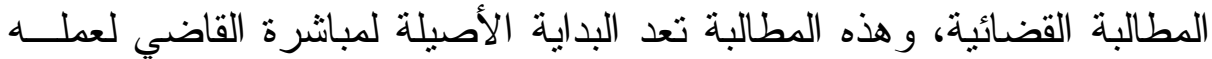

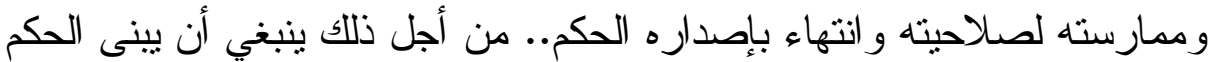

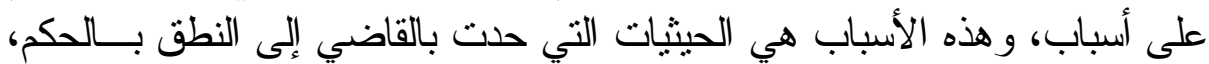

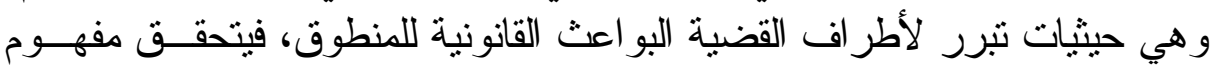

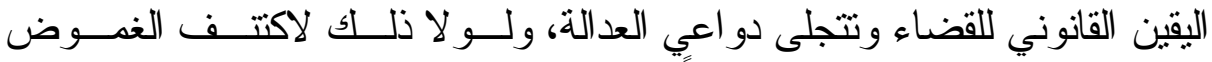

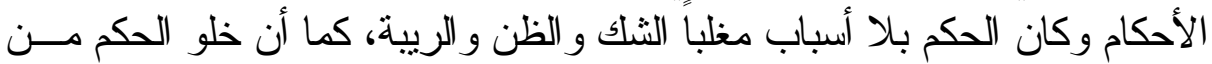

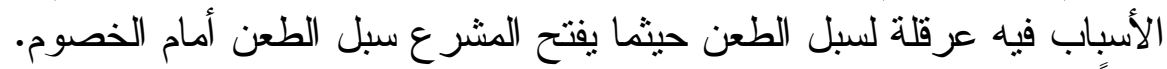
ثانياً: التسبيب في نصوص قانون المر افعات المصري:

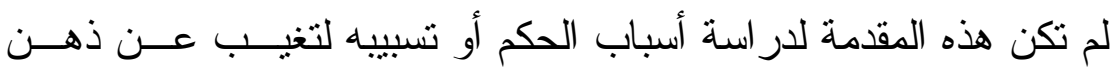

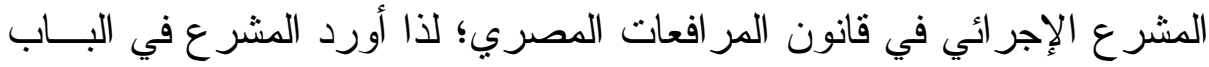

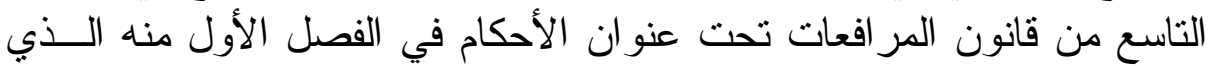

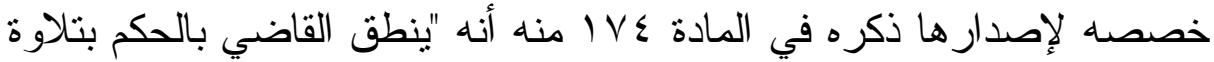

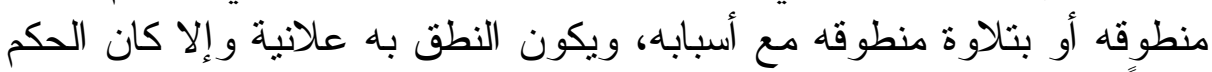

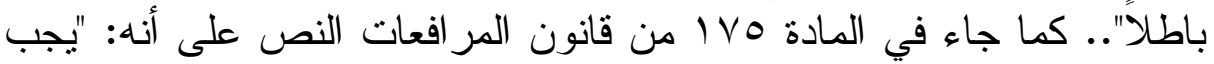

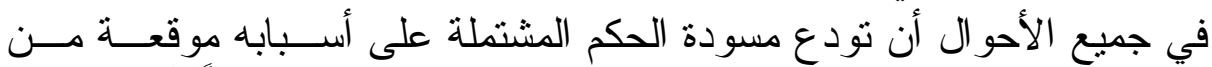

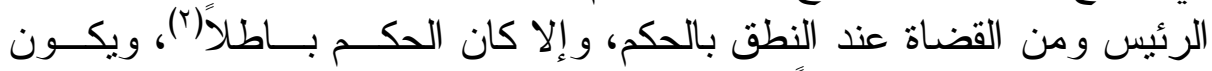

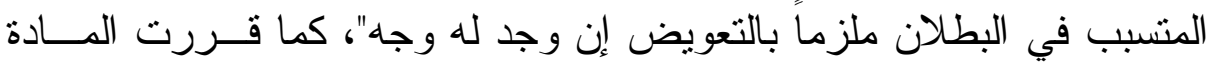

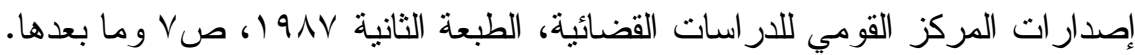

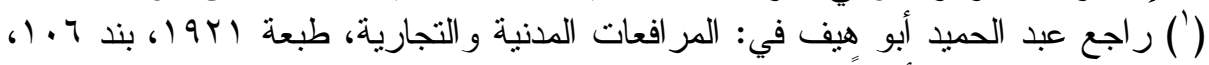

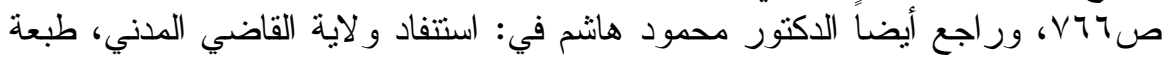

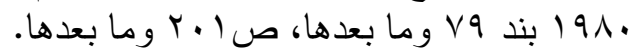

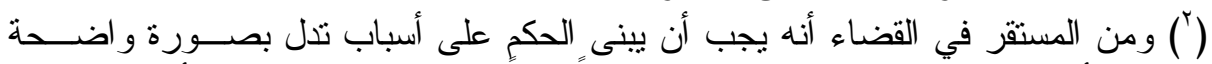

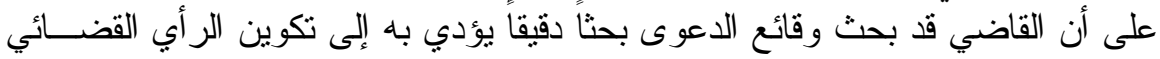

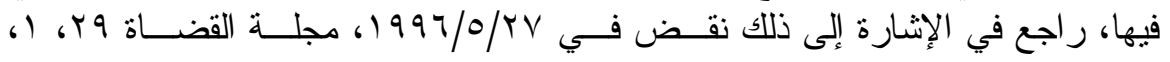

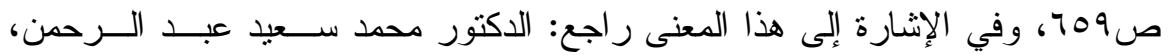

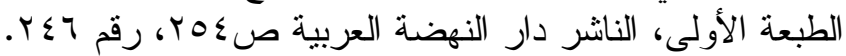




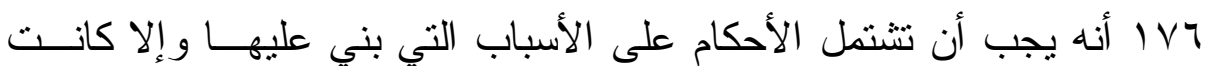

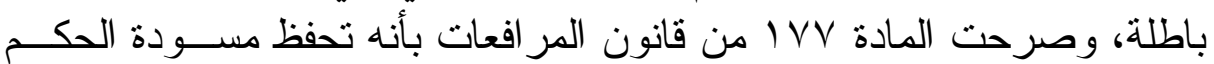

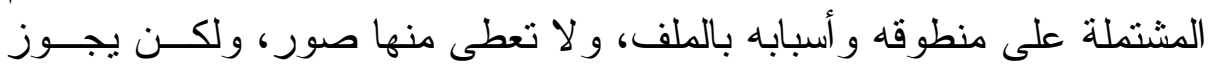

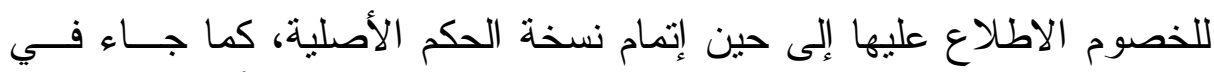

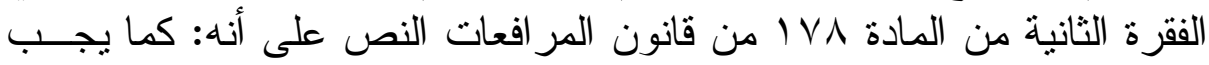

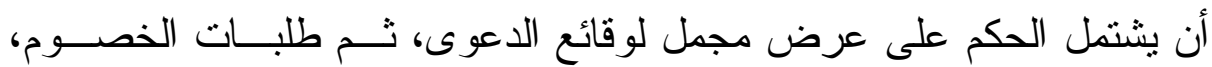

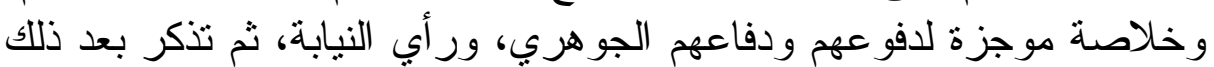

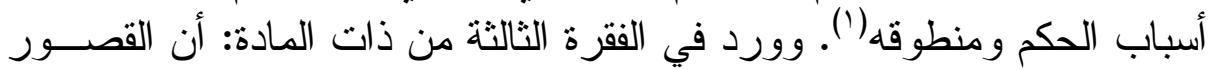

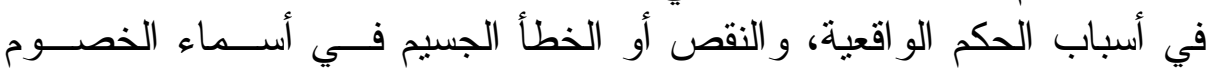

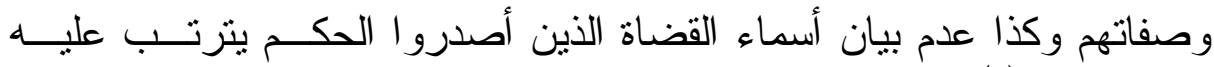

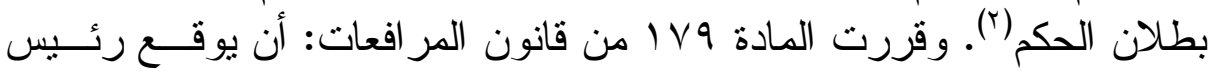

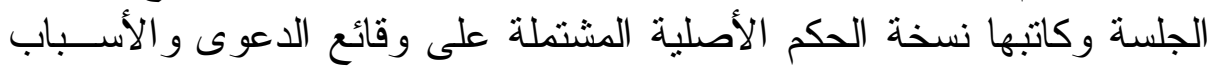

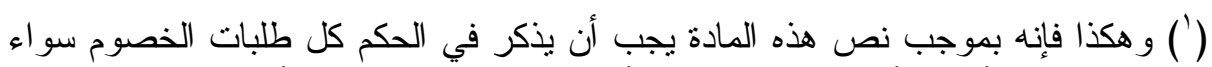

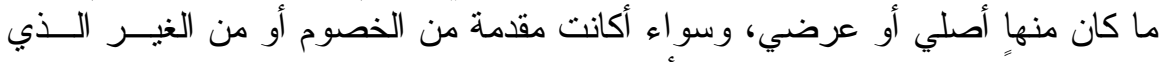

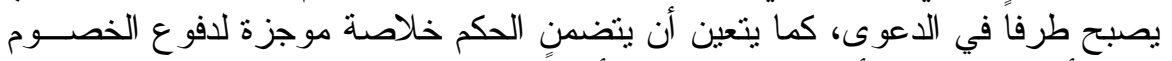

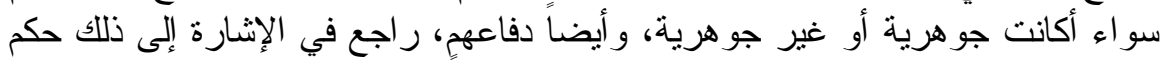

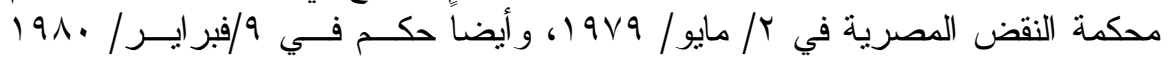

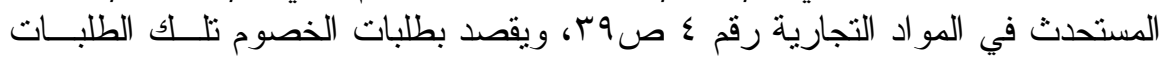

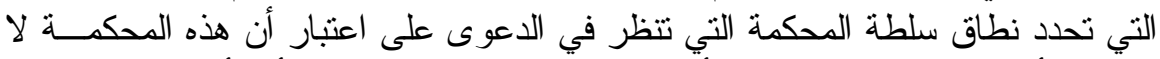

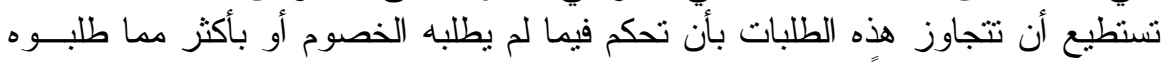

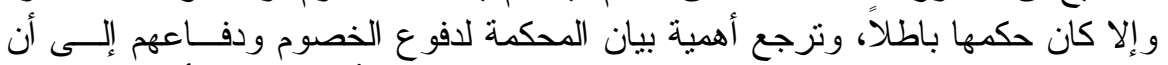

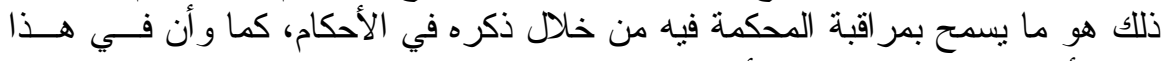

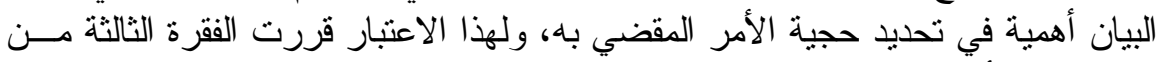

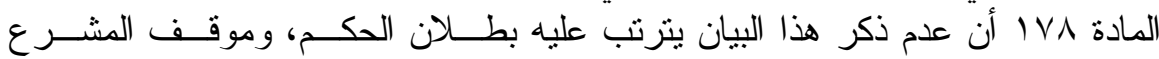

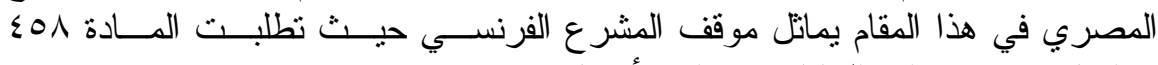

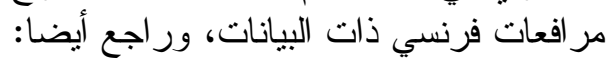

Gérard Cornu et Jean Foyer; Procédure civile 1958; presse universitaires de France. P. 91.

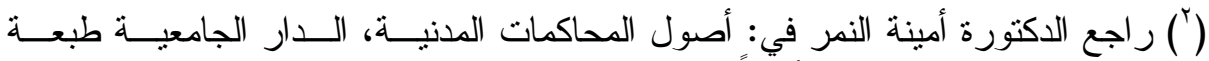

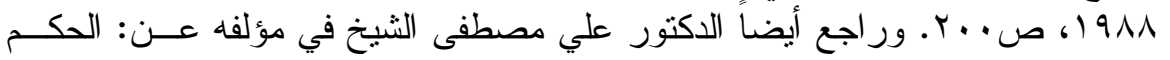

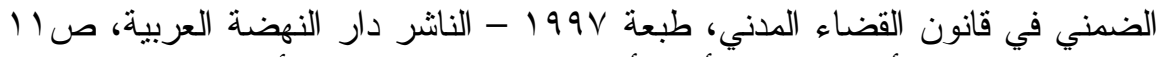

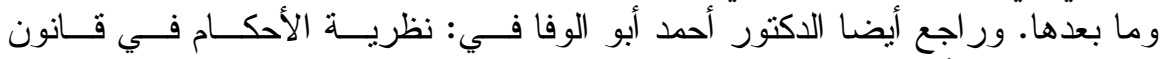

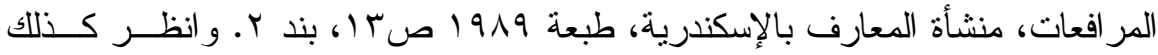

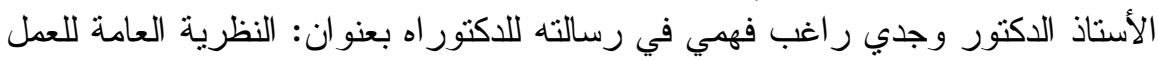

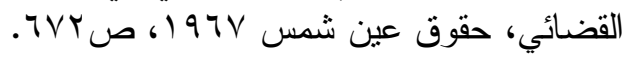




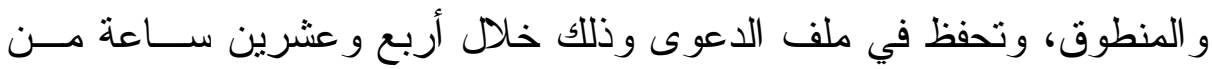

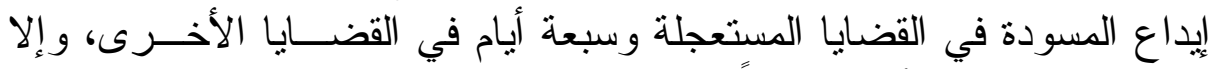

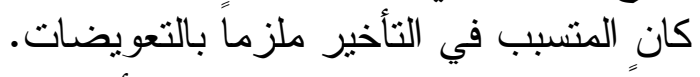
ثالثاً: عدم تعريف المشرع تسبيب الأحكام القضائية:

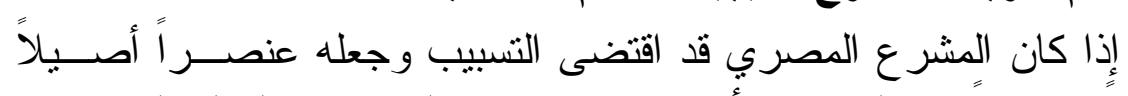

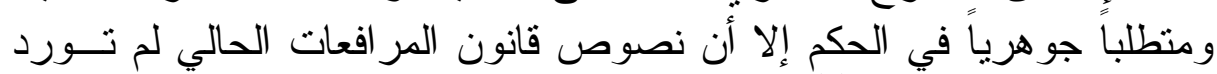

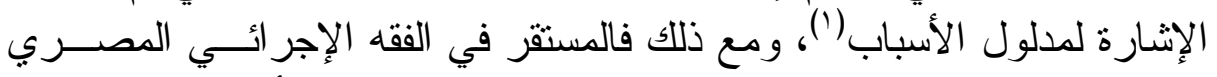

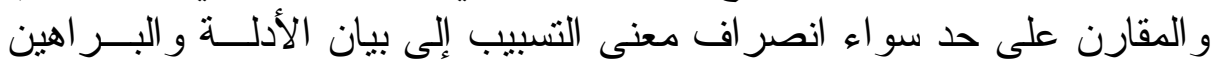

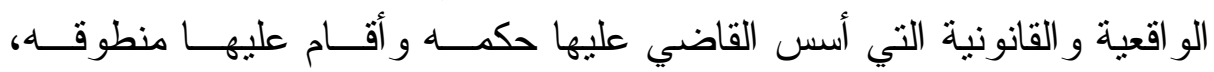

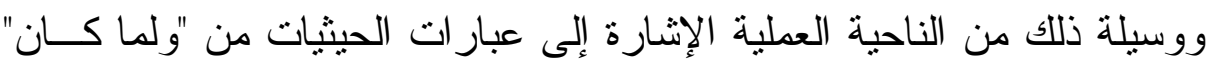

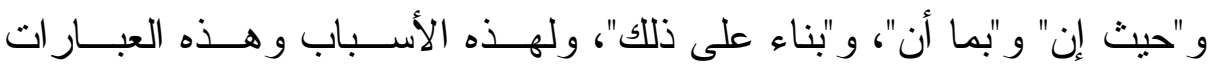

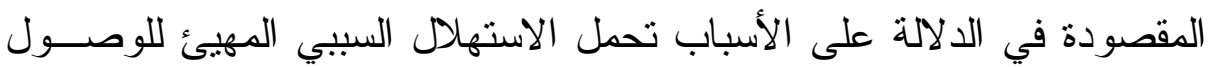

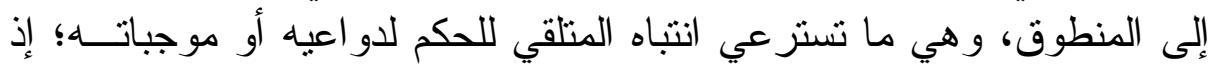

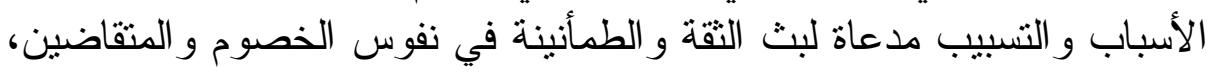

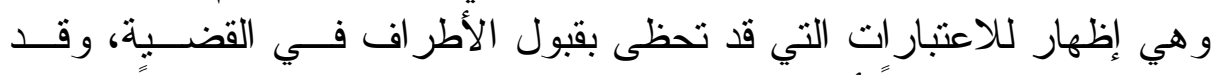

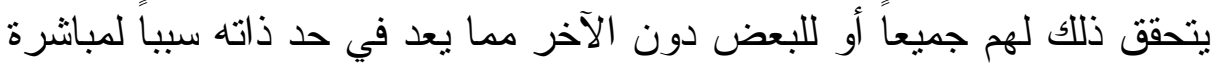

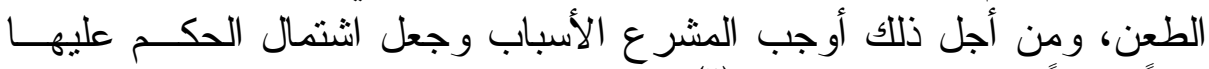

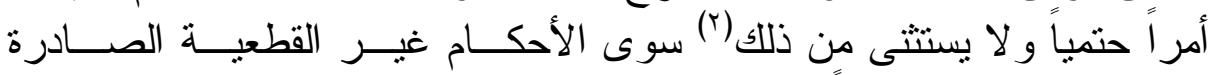
بإجر اءات الإثبات إعمالاً لحكم المادة 0 من قانون الإثبات الحات الحالي.

(') ر اجع في تعريف التسبيب بصورة عامة الدكتور محمد سعيد عبد الرحمن فــي مؤلفـــهـ

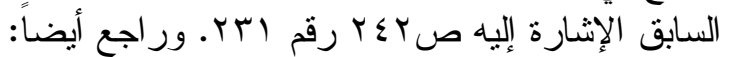

Touffait et Tunc; pour une motivation plus explicite des décisions de justice, notament celles de la cour de cassation R. T. D. C. 1974 p. 487.

Legros; Essai sur la motivation, thèse Dijon 1987.

$$
\text { ور اجع أيضا: }
$$

Estoup, une reforme souhitable, l' assouplissement de certains des règles relatives à la motivation, gaz. Pal. 9 Août. 1990.

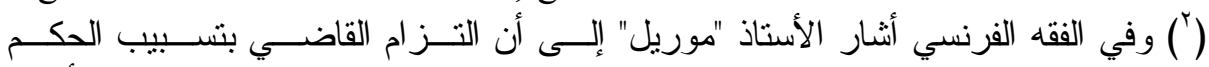

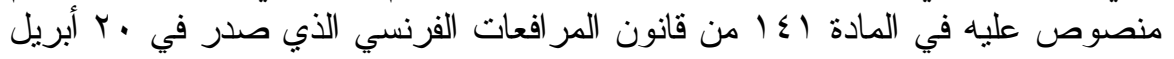
.

René Morel; Traité élémentaire de procédure civile. Recueil sirey 1949 No. 439 No. 559. 
رابعاً: موقف المشرع الفرنسي من مسألة التسبيب: لا يختلف أمر وجوب تسبيب الأحكام القضائية عما هو مقرر في قانون

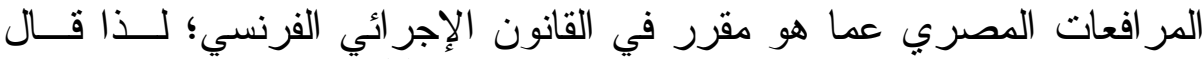

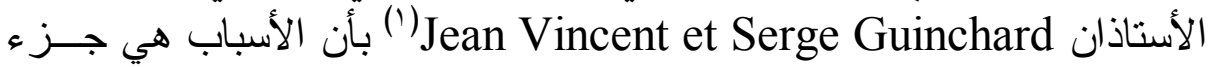

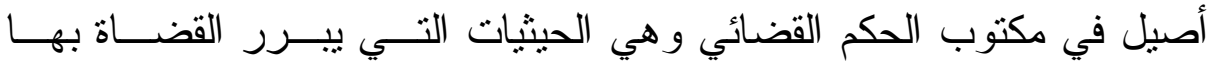

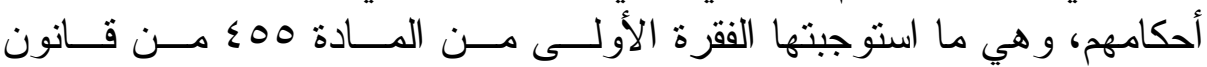

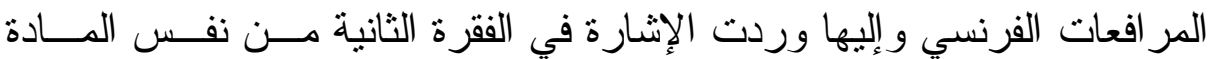

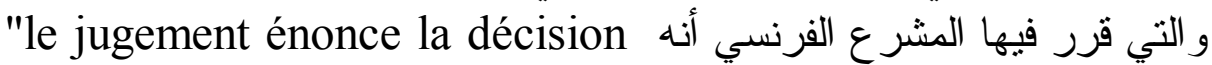
Sous forme de dispositif

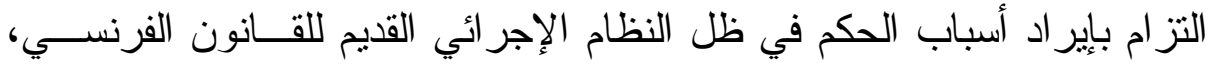

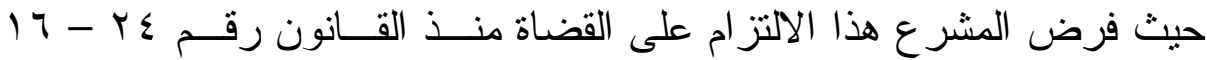

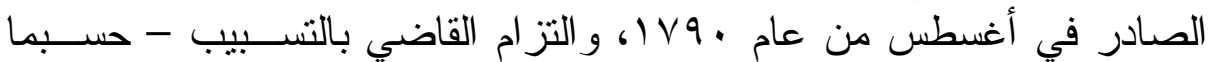

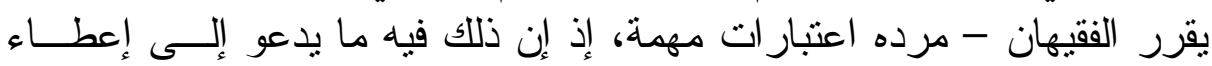

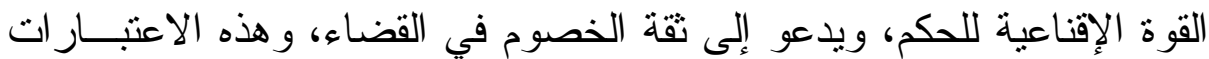

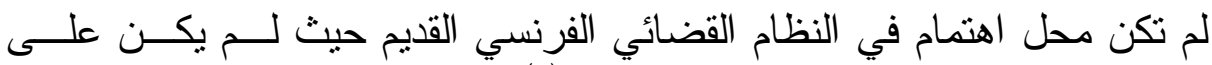

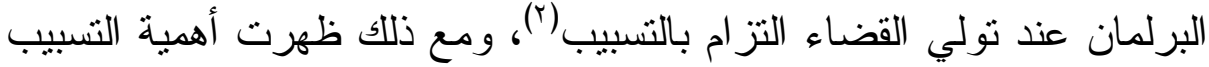
عند إقرار الطعن بالنقض حيث أصبح من اختصاصات محكمة النقض الدر اسة الفنية للأحكام عند الطعن فيها:

Jean Vincent et Serge Guinchard. Procédure civile. $22^{\mathrm{e}}$ édition. P. 530 No. 761.

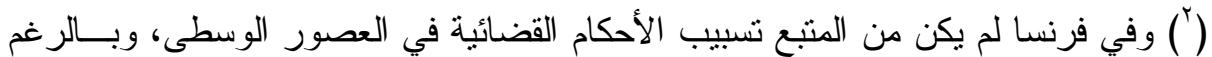

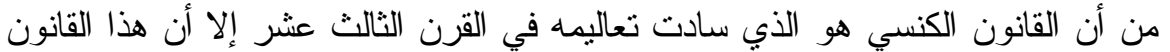

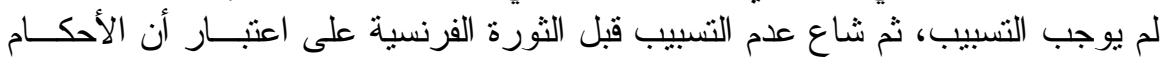

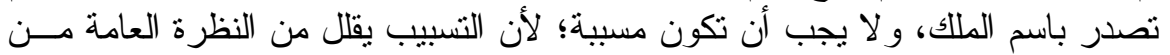

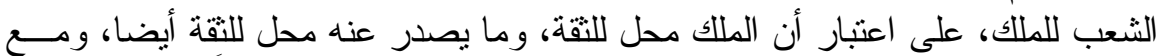

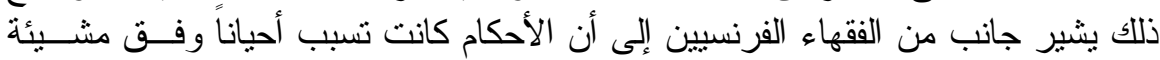

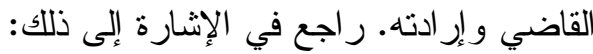

Tony Souvel; Histoire du jugement motivé. Reveue de droit public et de Science politique. 1955. p. 27.

وفي عرض تاريخ تسبيب الأحكام القضائية خلال القرن الثامن عشر في فرنسا راجع: Philippe Godding: Jurisprudence et motivation des sentences du moyen age a la fin de 18é Sicécle. P. 40. 
Cette obligation est indispensable. Elle force le juge à prendre conscience de la valeur de son opinion, elle procure au plaideur une justification de la décision; elle permet ce qui $\mathrm{n}^{\prime}$ est pas possible pour la jurisprudence de anciens parlements, de procéder à une analyse scientifique de la juris prudence; elle permet aussi a' la cour de cassation d' exercer son controle. ${ }^{(1)}$

\section{خامساً: لزوم التسبيب في كل حكم قضائي أيا ما كان نوعه:}

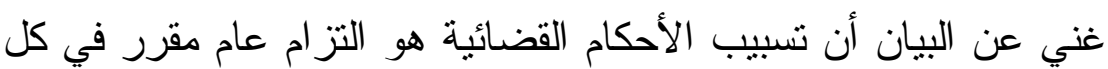

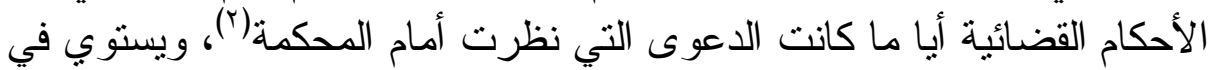

(') راجع في الإثشارة إلِي ذلك "فانساه وجويشار" في المرجع السابق الإشارة إليه الموضــع

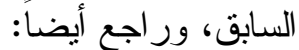

Gérard Couchez; Procédure civile. 10 édition, Sirey. P. 299. No. 400.

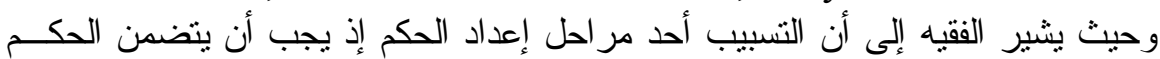

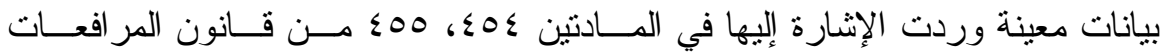

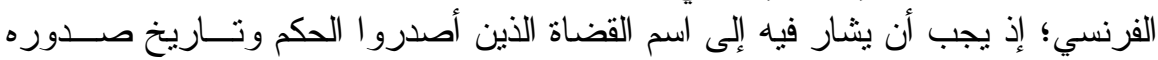

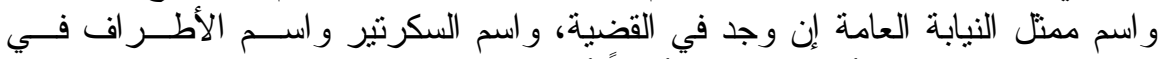

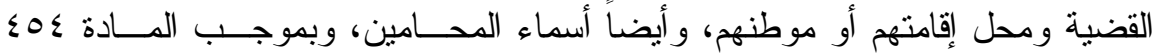

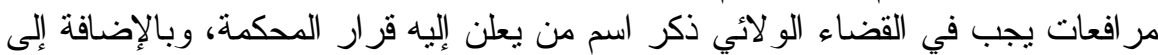

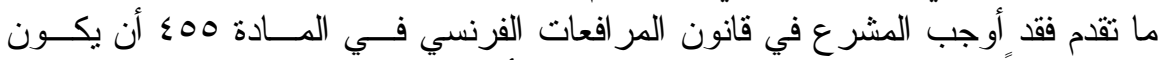

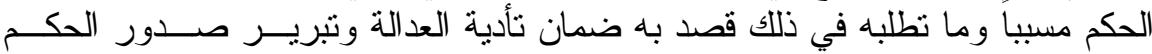

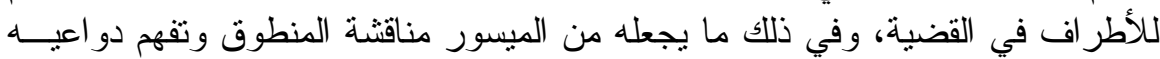

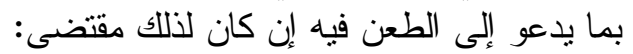
La motivation du jugement est une garantie de bonne justice; le plaideur peut ainsi connaître la justification de la décision, ce qui lui facilite éventuellement la discussion de celle - ci devant une juridiction supérieure dans le cadre de l' exercice d' une voie de recours.

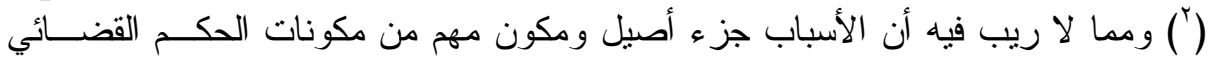

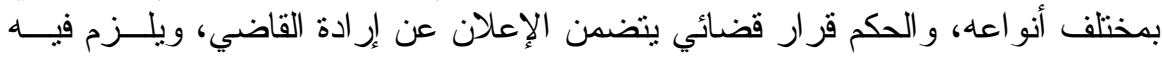

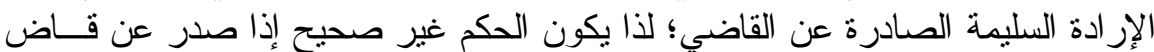

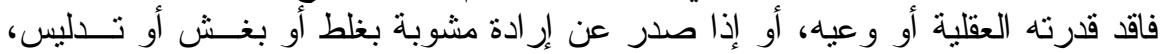

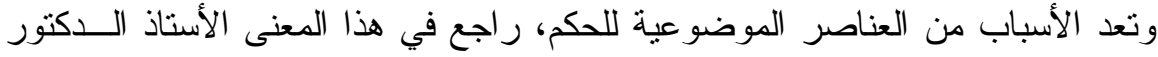

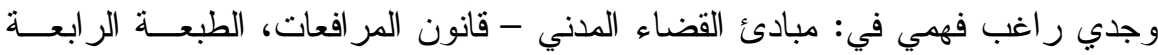

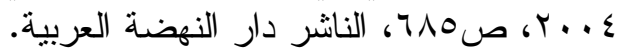




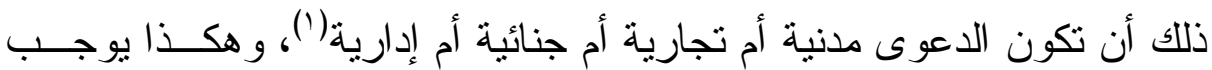

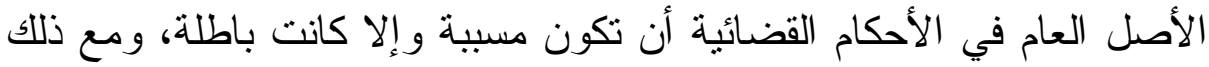

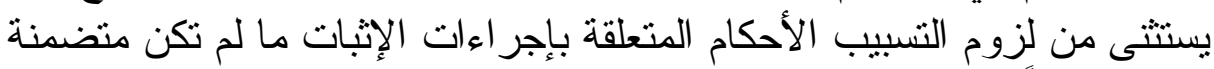

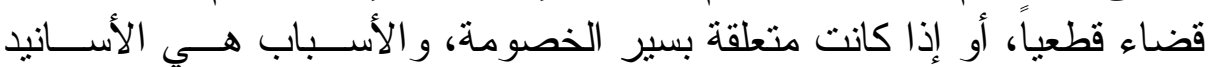

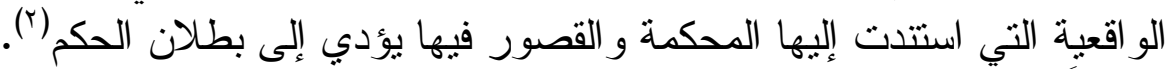

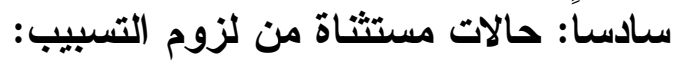

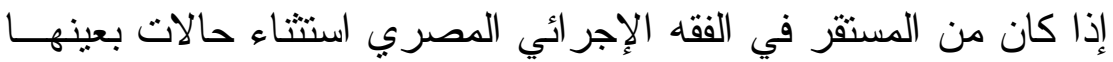

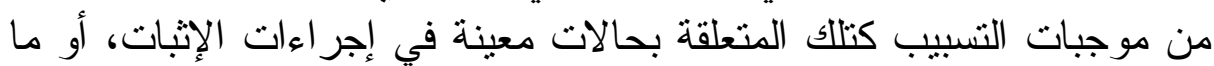

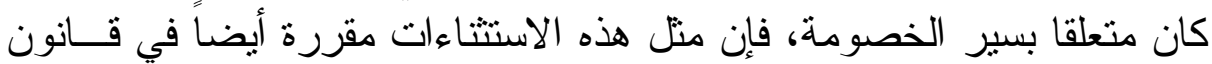

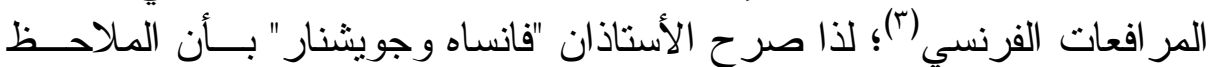

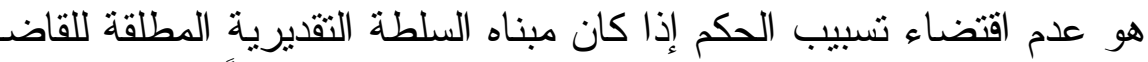

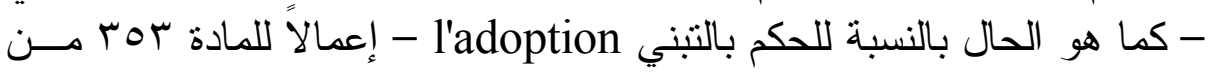

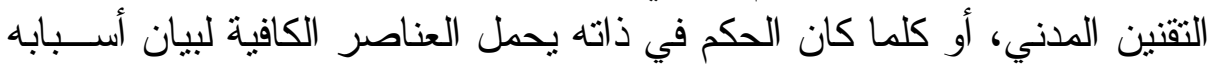

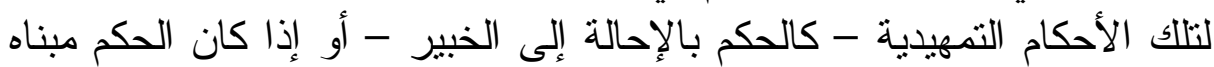

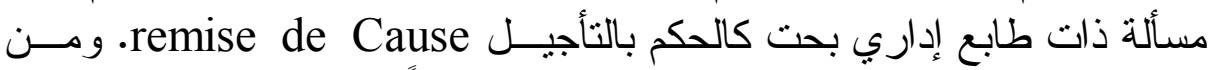

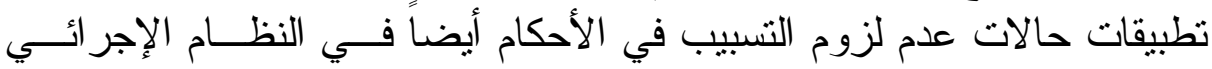

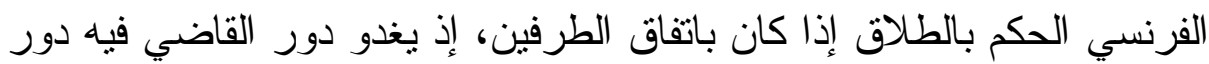
الأعمال الو لائية elle a un caractère gracieux.

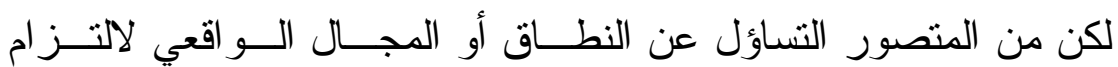

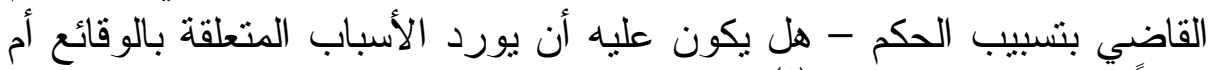

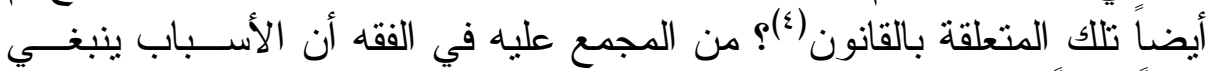

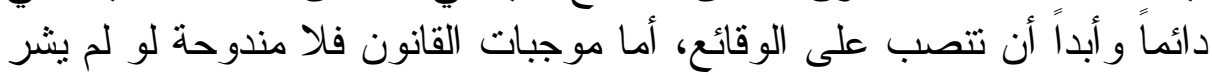

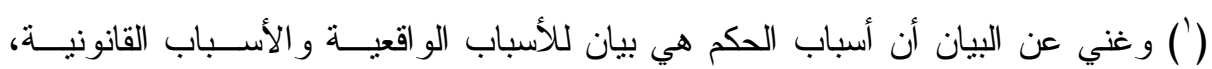

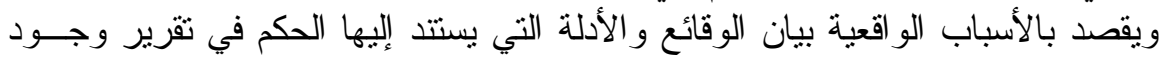

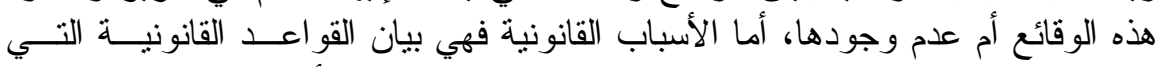

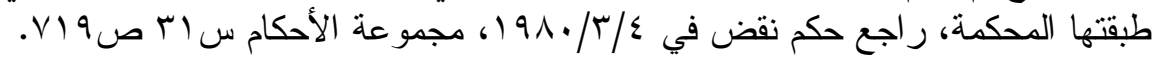

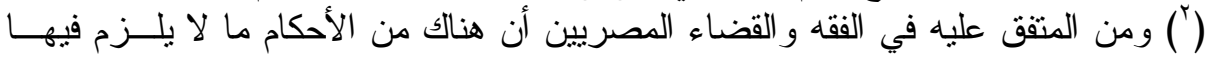

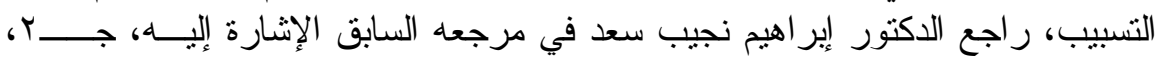

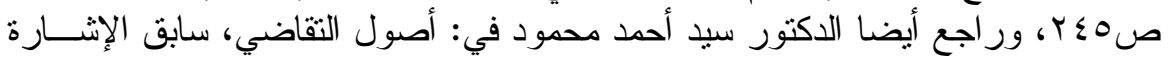

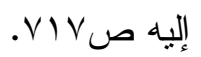

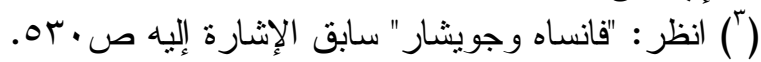

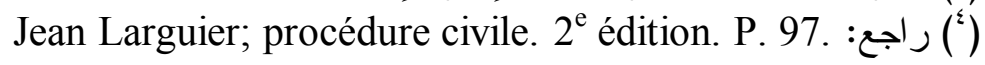


إليها القاضي في أسباب حكمه(')، و علة ذلك أن قصور الحكم في إير اد أسبابه

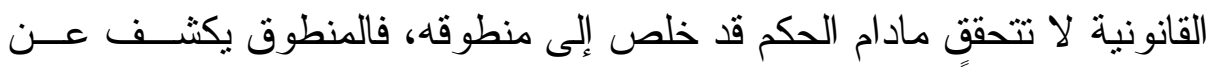

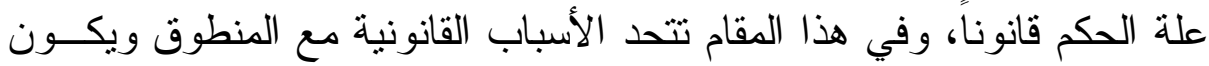

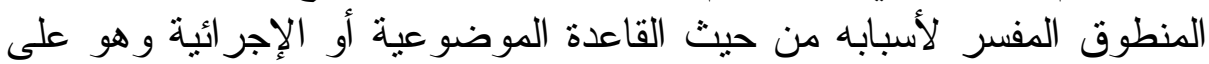

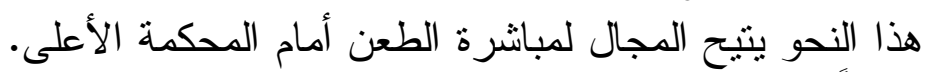

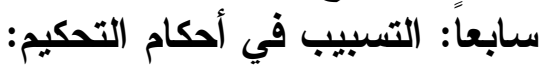

كذلك ثار التساؤل عما إذا كان الالتز ام بالتسبيب هو التزام ام يسري كذلك

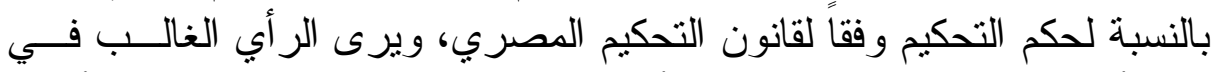

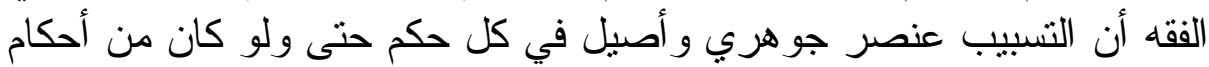

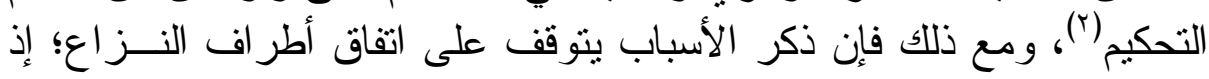

(') ويشير الأستاذ Jean Larguier في فقه المر افعات الفرنسي إلى أن الأسباب هي دعائم

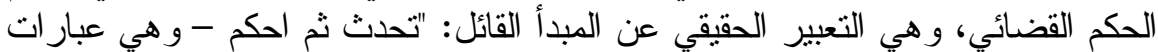

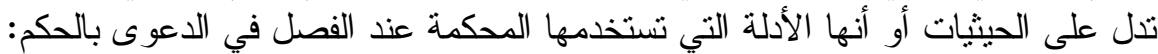
Motifs, arguments fondant la décision: réponse aux "Dire et juger" des conclusions "attendu que: - ou, cour d' appel, Considerant que.. des juges préfèrent aujourd'hui a' la logique concise commandée par ces termes, un exposé paraissant plus accessible, même s'il est plus, long; il ne suffit pas de reproduire le texte legal ou de dire qu' il résulte des pieces versées que la demane parait juste et fondeé.

راجع: . Jean larguier; Procédure civile; op. cit. p. 97

( ) راجع في هذا المعنى الدكتور يوسف محمد المصاورة في: تسبيب الأحكام وفقاً لقـانون

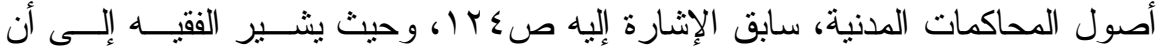

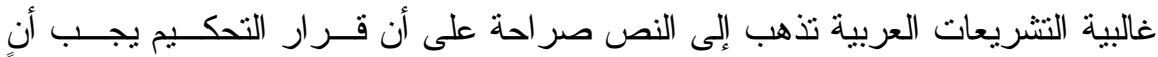

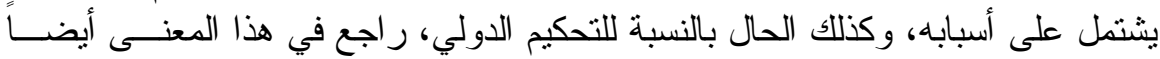

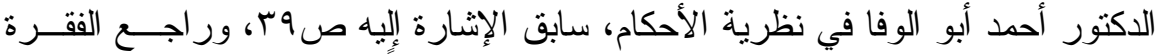

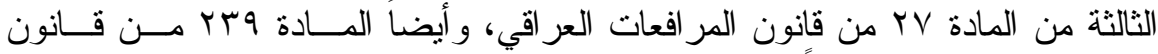

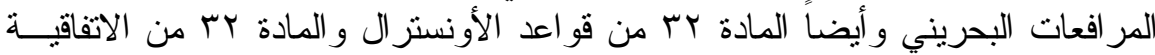

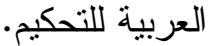
كذلك كان قد ثار في الفقه نساؤل حول مدى لزوم تسبيب أحكام المحاكم الأجنبية و هناك

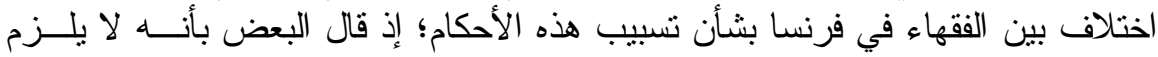

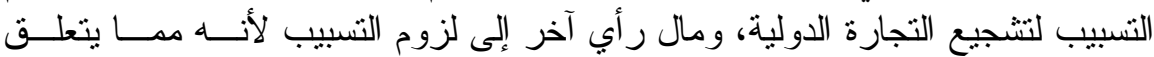

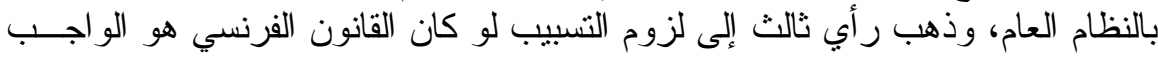

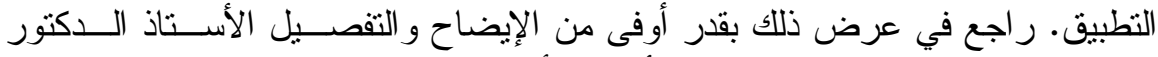

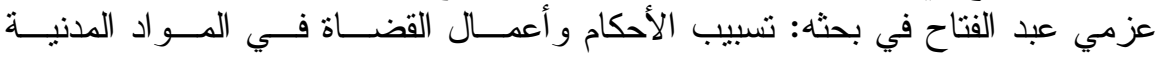

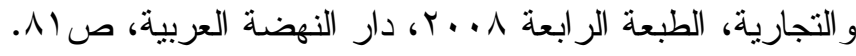




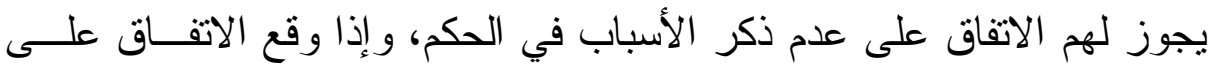

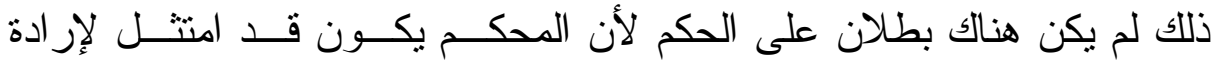

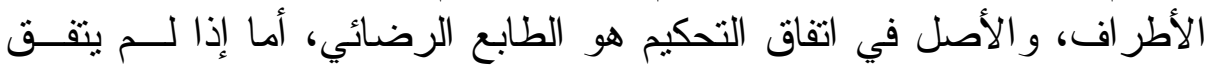

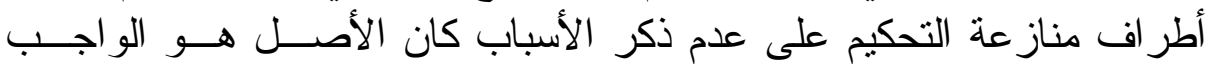

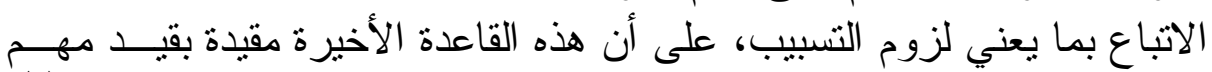

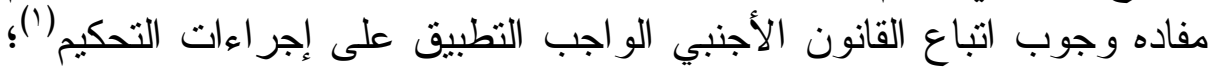

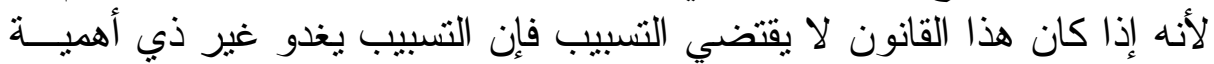

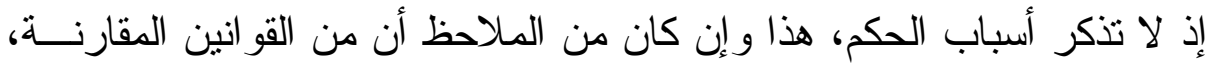

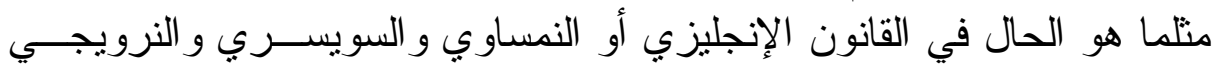

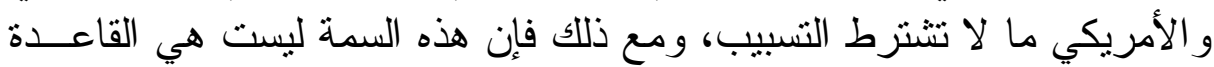

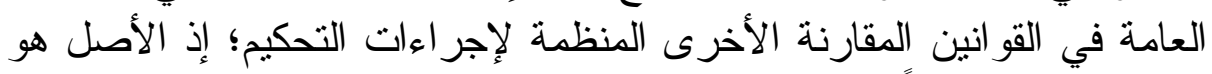

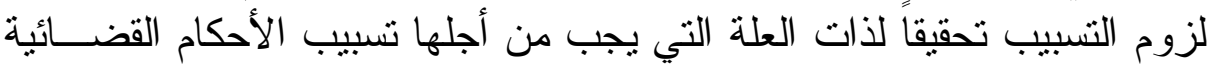

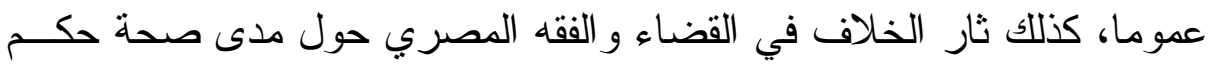

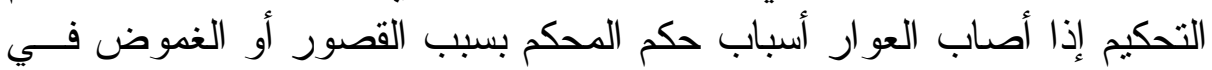

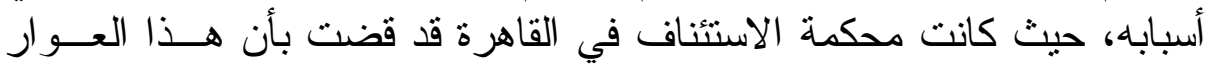

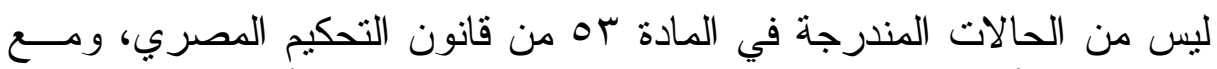

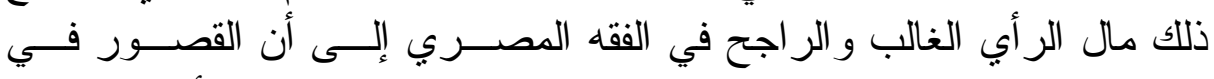

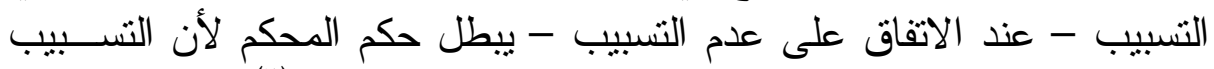
ضمانة كبرى في كل حكم قضائي أو حكم من أحكام التحكيم (؟).

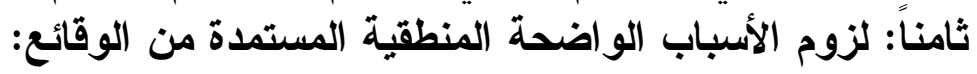

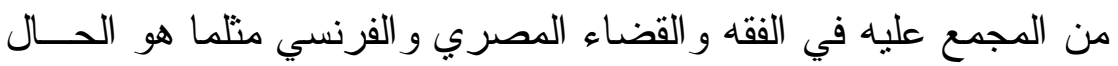

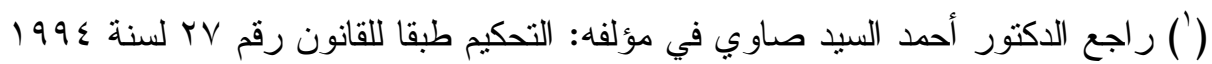

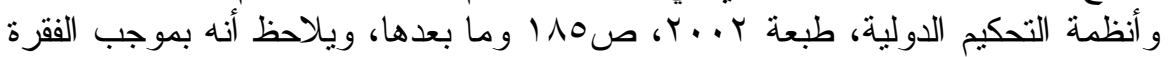

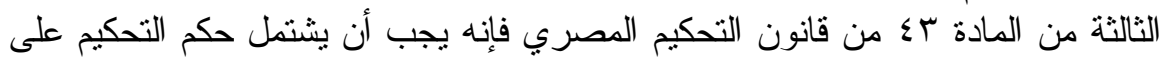

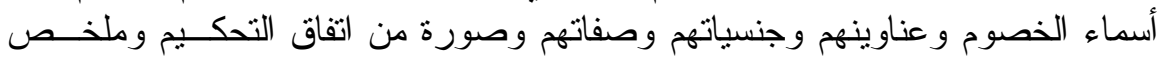

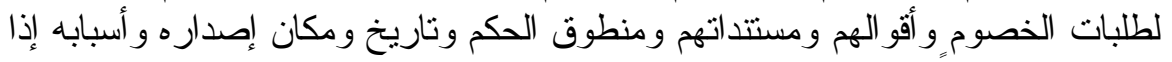
كان ذكر ها و اجباً.

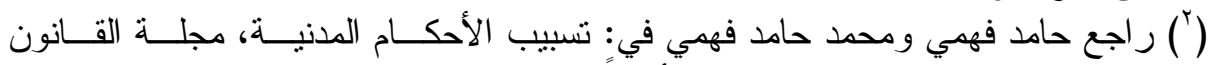

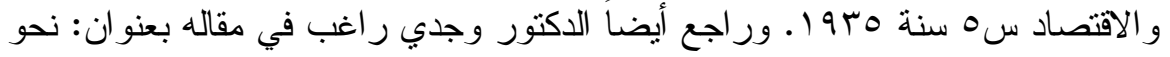

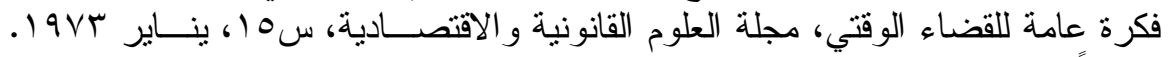

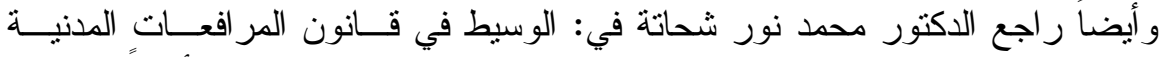

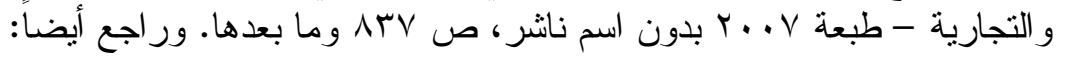

Bertrand; la motivation des acts juridictionnels, thése. Rennes 1974. 
في النظم الإجر ائية المقارنة قاطبة أنه حيثما يلزم تسبيب الأحكام القضــائية -

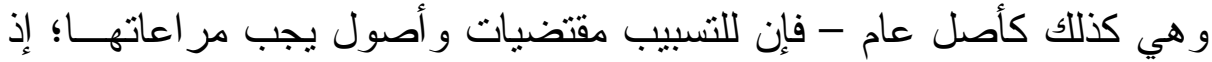

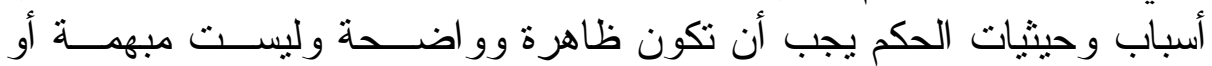

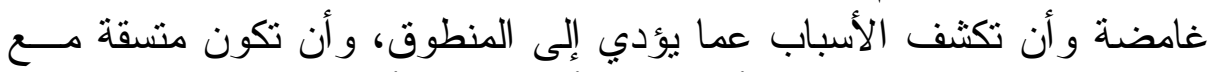

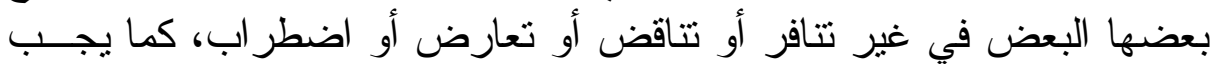

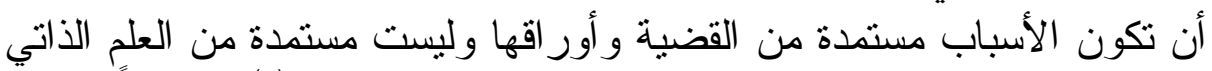

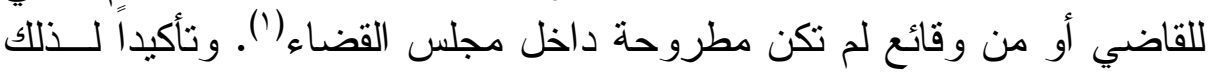

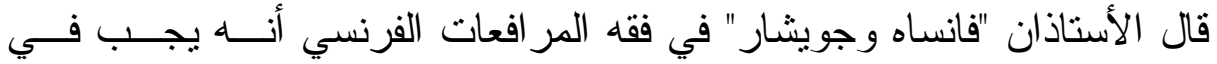

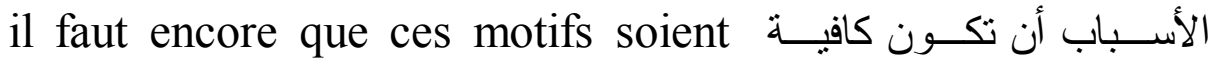
فأ Suffisants

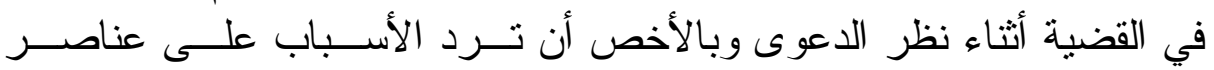

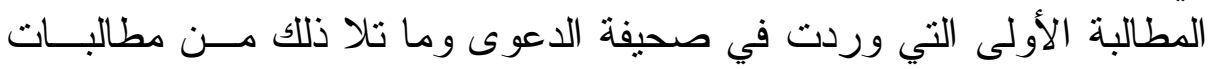

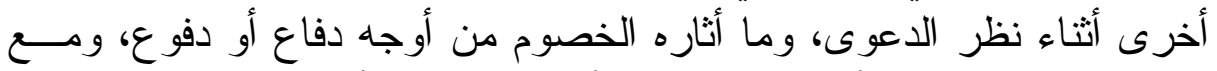

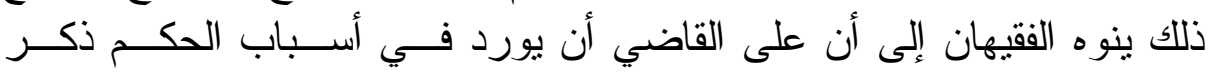

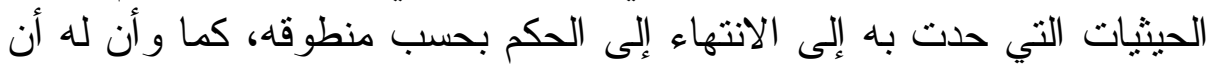

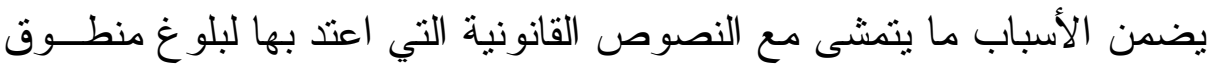
الحكم.

تاسعا: التسبيب في أحكام المحاكم الاستئنافية:

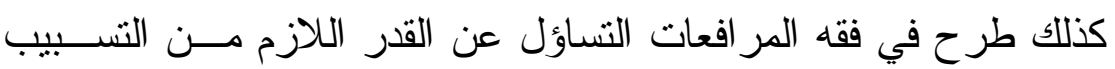

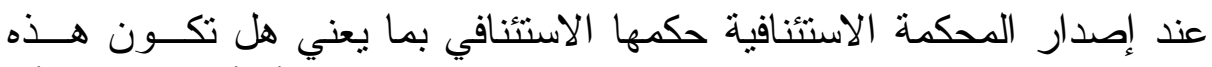

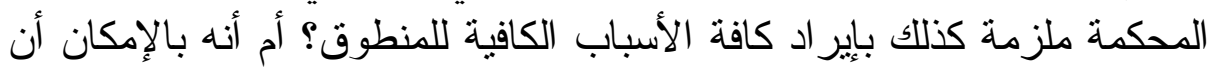

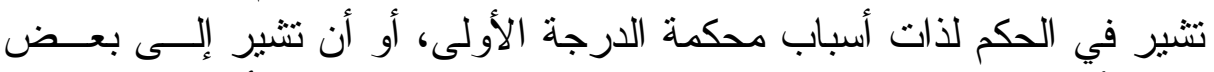

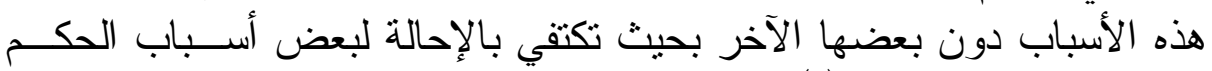

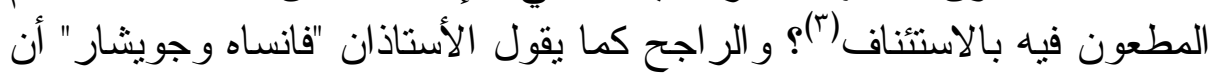

(') راجع الأستاذ الدكتور نبيل إسماعيل عمر في بحثه بعنوان: امتتاع القاضي عن القضاءٍ

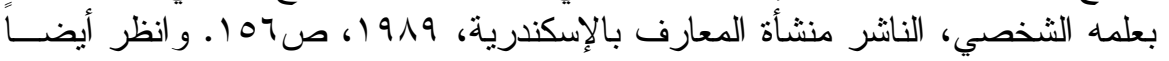

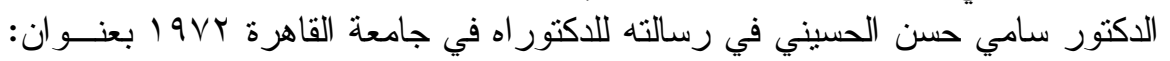

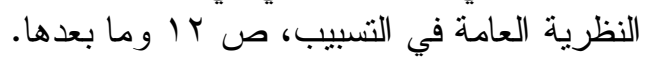

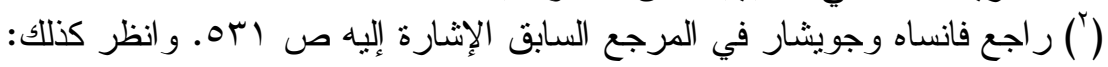
J. Chevaller; Remarques sur l' utilisation par le juge de ses informations personnelles. R. T. 1962 p. 19.

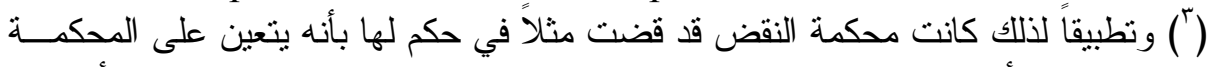

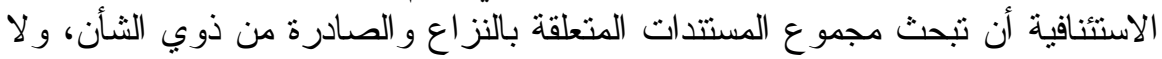




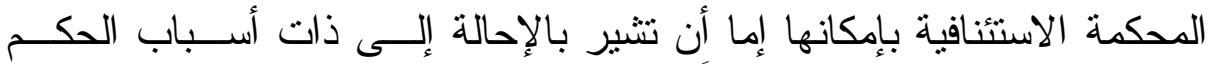

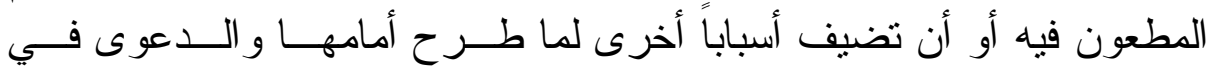

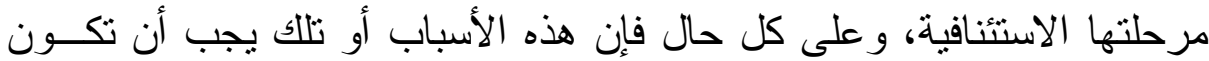

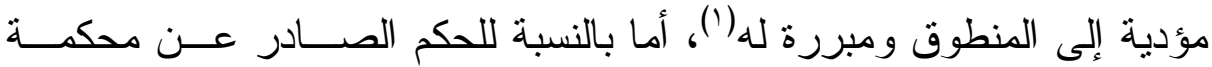

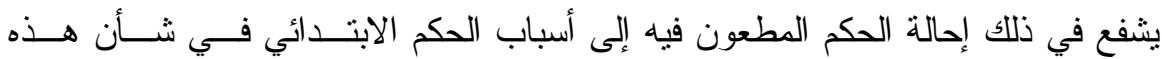

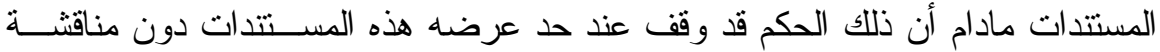

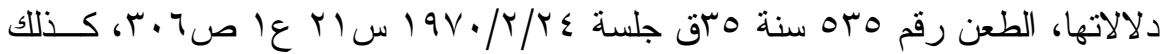

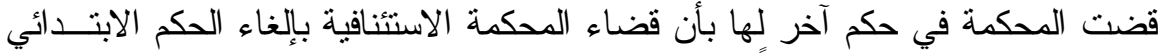

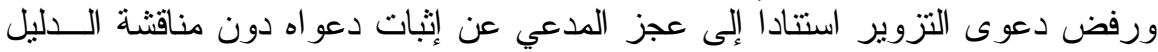

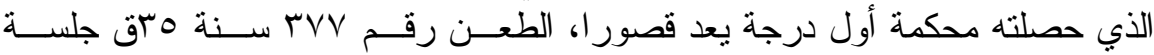

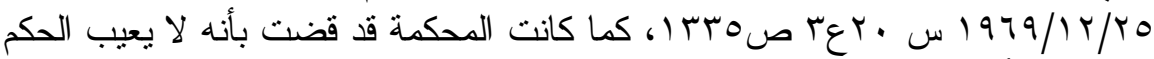

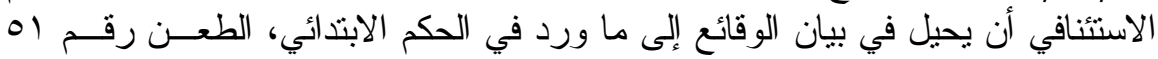

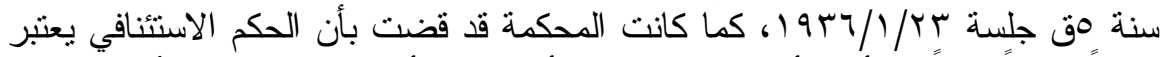

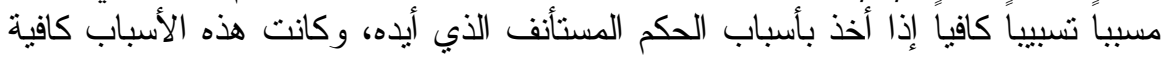

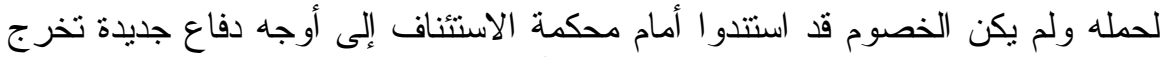

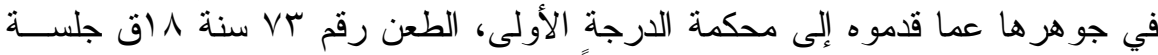

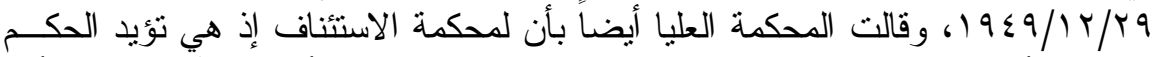

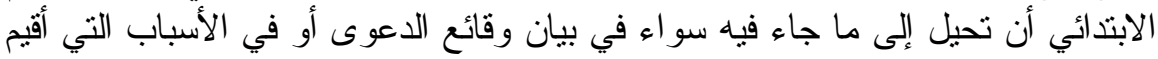

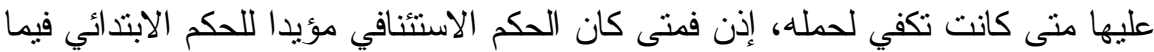

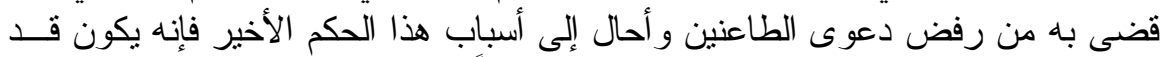

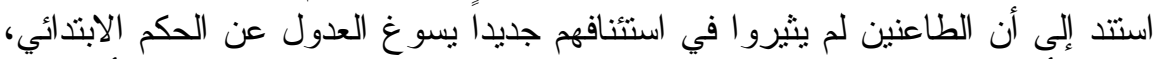

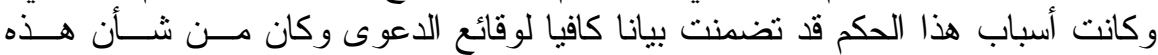

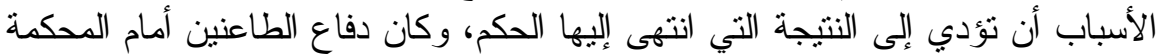

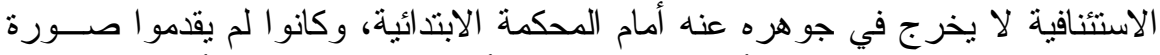

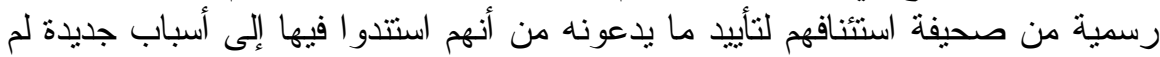

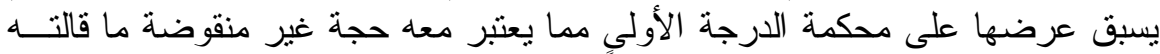

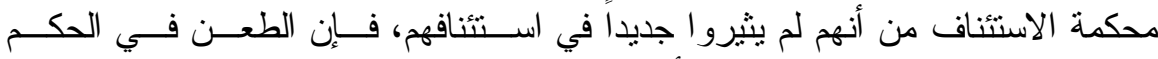

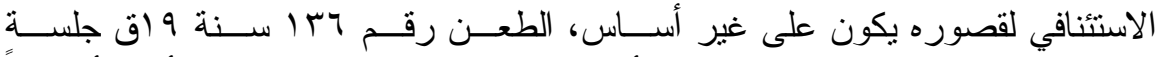

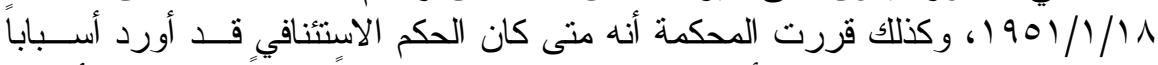

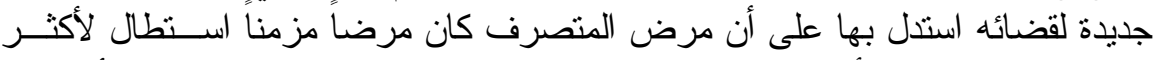

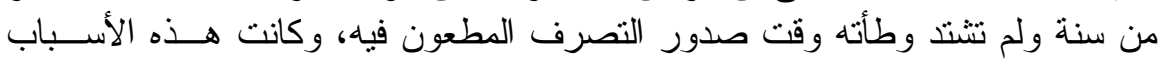

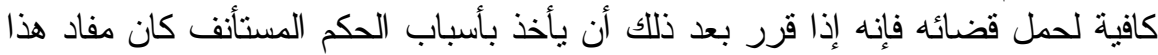

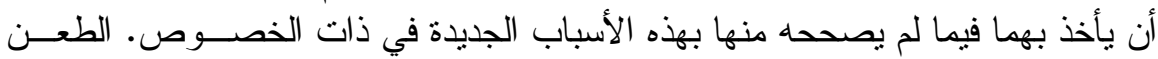

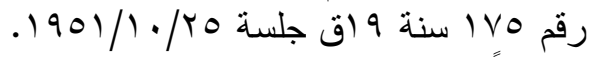

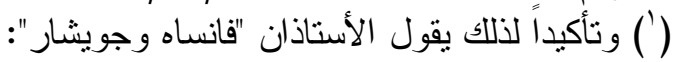

La juridiction du second degré peut, si elle confirme se contenter d' adopter en tout ou en partie, les motifs des premiers juges, la cour de 
النقض فإن المحكمة حرة في الإثارة إلى أسباب حكمها باعتبار رقابتها هـي وإني

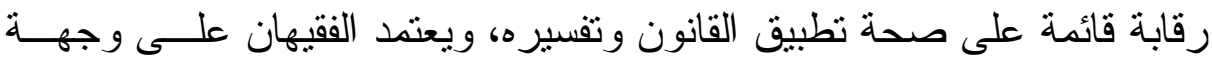

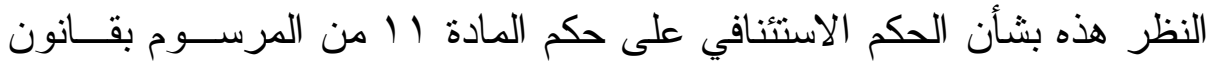

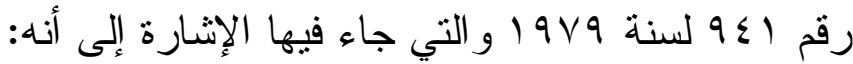

Lorsqu' elle confirme un jugement, la cour d' appel est réputée avoir adopté les motifs de ce jugement qui ne sont contraires aux siens. ${ }^{(1)}$

فأفاد هذا النص أنه بإمكان المحكمة الاستئنافية أن تورد أســباباً جديــدة

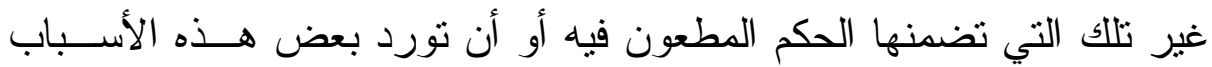

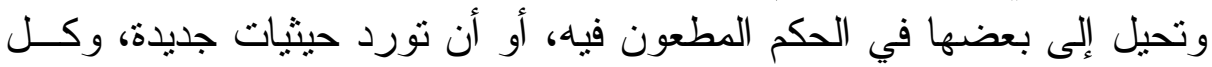

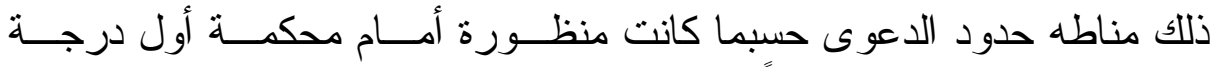

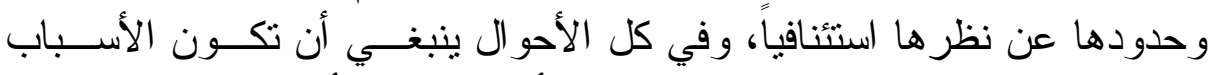

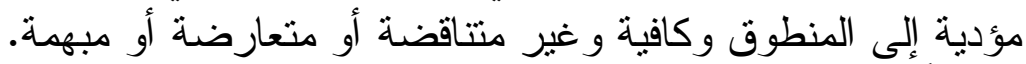
عاشر اً: تسبيب الأحكام من العناصر "الثنكلية" في الحكم:

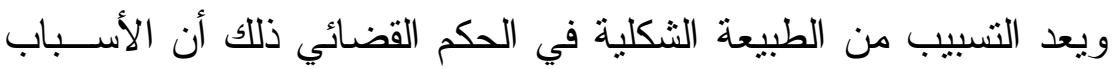

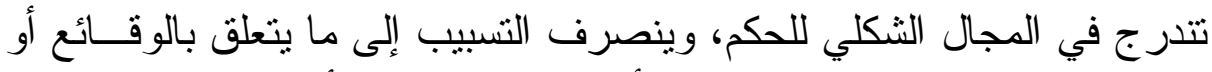

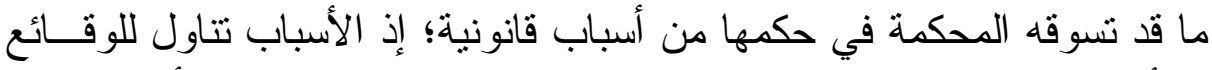

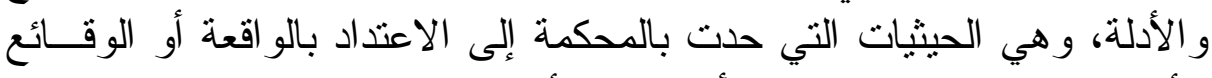

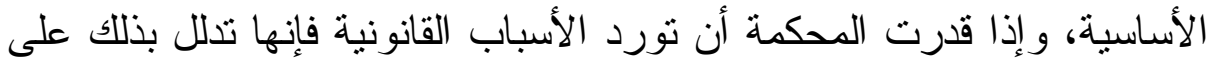
المعطيات المنطقية الدالة على ما انتهت إليه الديه المحكمة في منطوق حكمها، لكن

cassation est assez libérale sur ce point.

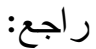

Jean Vincent et Serge Guinchard; procédure civile. Op. cit. p. 531 No 761 .

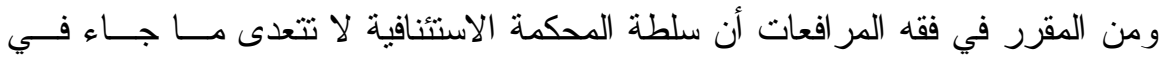

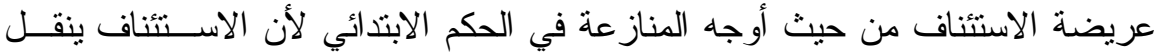

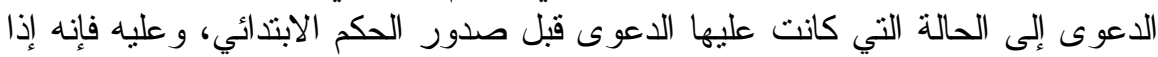

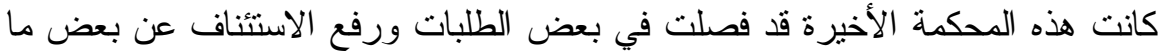

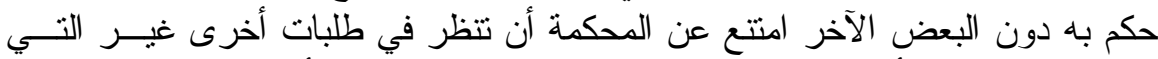

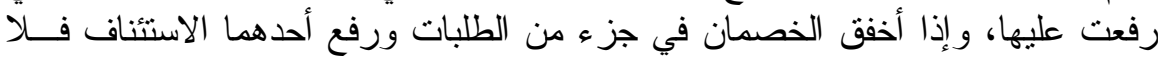

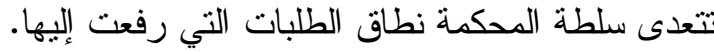

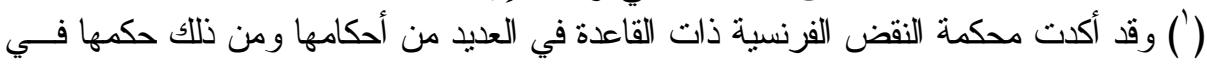

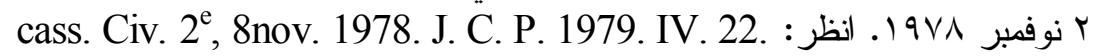


من الملاحظ أن المشر ع يعطي الأسباب الو اقعية المرتبطــــة بالوقـــائع أهميــــة

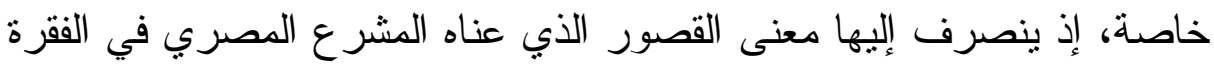

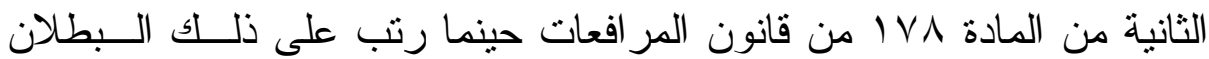

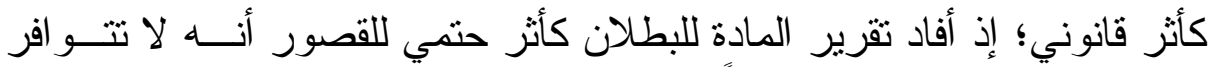

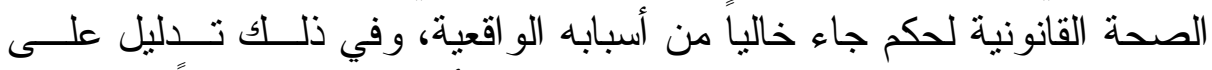

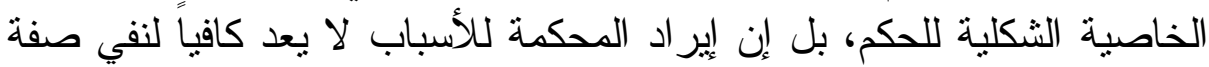

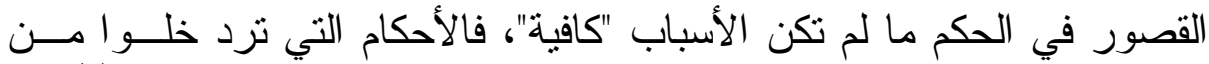

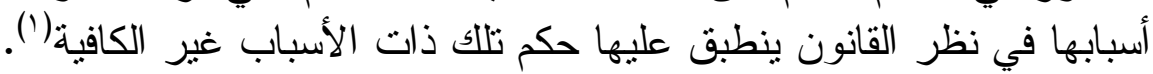
حادي عشر: الأسباب الواقعية و القانونية:

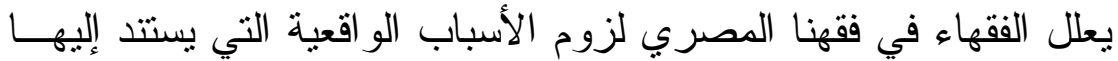

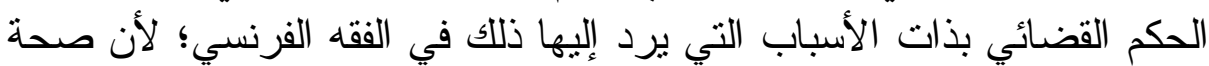

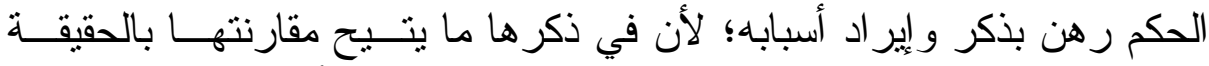

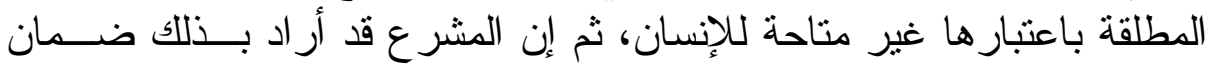

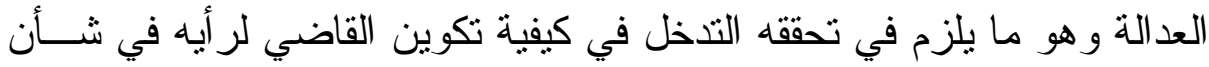

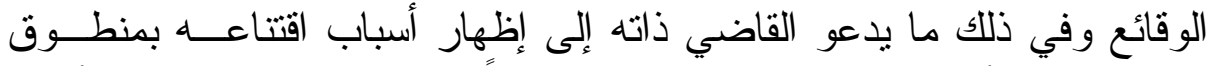

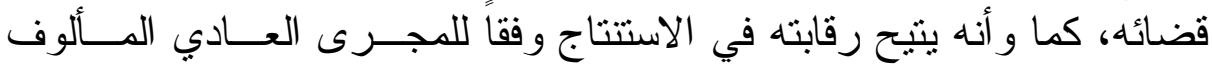

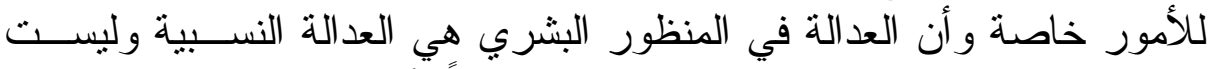
المطلقة التي لا علم للبشر بها و إن وصفت مجاز أب أنها مطلقة حيث إن إن الحقيقة

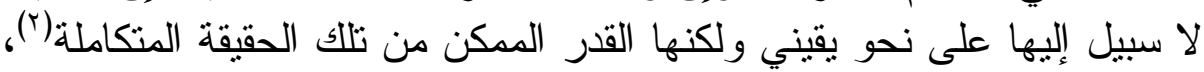

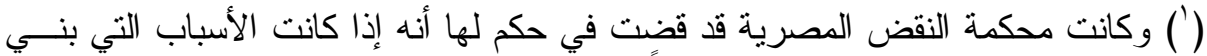

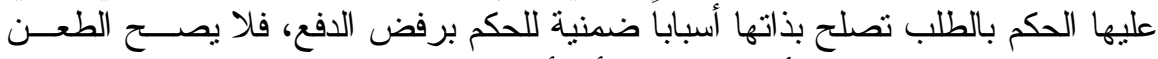

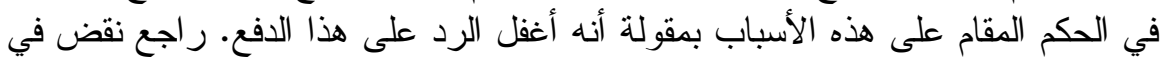

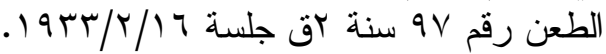

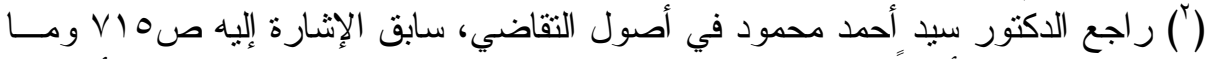

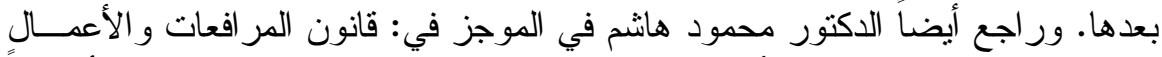

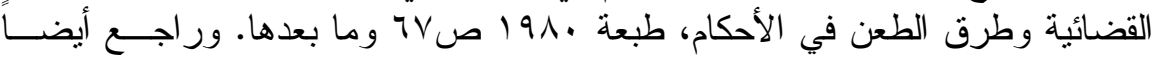

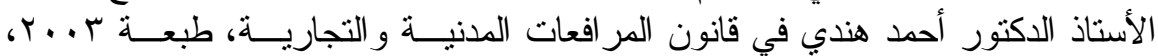

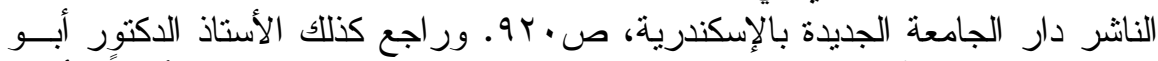

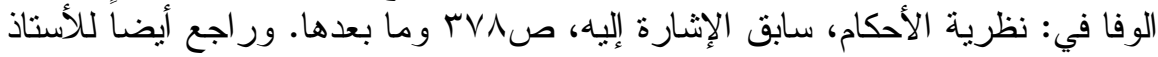

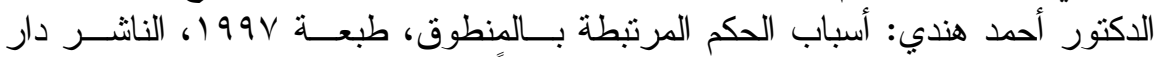

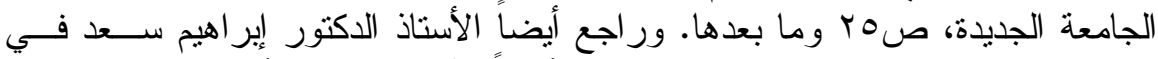

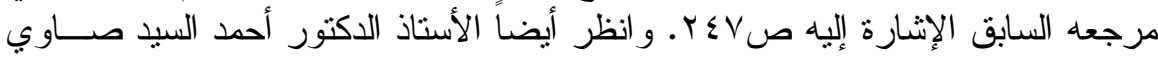

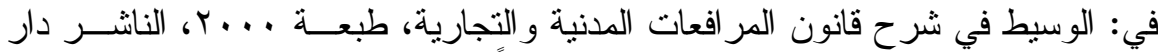

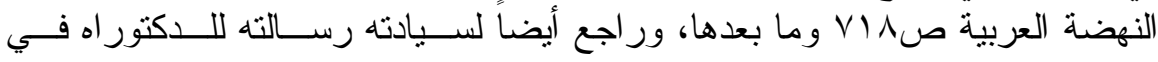




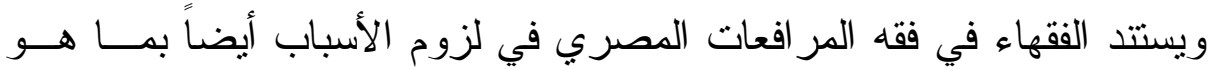
مستقر في الثريعة الإسلامية الغراء حيث روي عن ابن عباس - رضــي الله عنهما - أنه قال: اختصم إلى النبي صلى الله عليه وسلم رجلان فطلب رسول رئ رئ الله صلى الله عليه وسلم أن يؤدي ما وقعت عليه اليمين ووجبت أداءها فأداهـــا

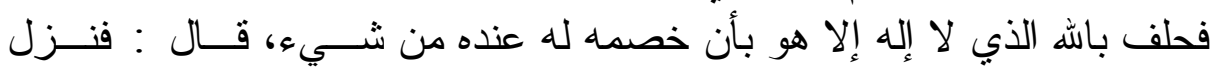

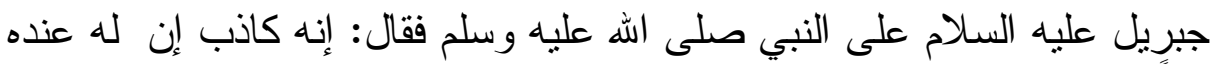

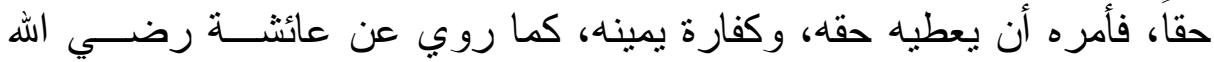
عنها أن رسول الله صلى الله عليه وسلم قال: السابقون إلى ظل الله يوم القيامة

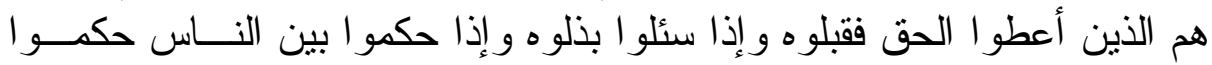
كحكمه لأنفسهم، كما روت أم سلمة عن النبي صلى الله عليه وسلم أنه قـال:

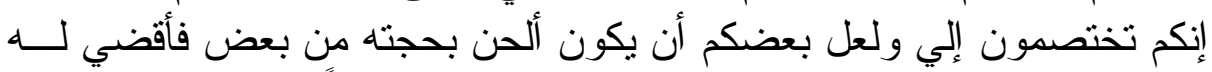

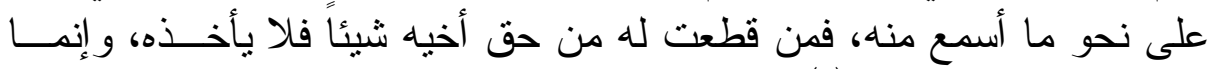

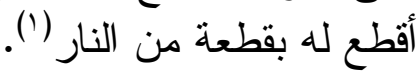
ثاني عشر: لزوم التسبيب في الأحكام في الشريعة الإسلامية:

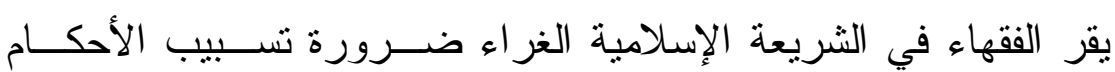

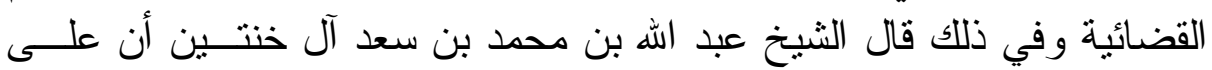

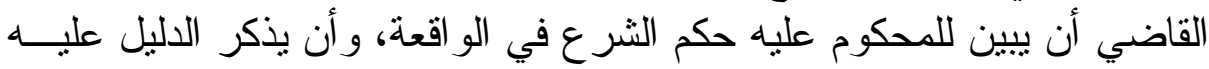
لأن في ذللك إيصال الحقوق لأصحابها على وجه الإتقان و السر عة، كما أن في ذللك تمكين للمتر افعين بإجر اءات التقاضي بما بعينهم على القناعة بالإجر اءات

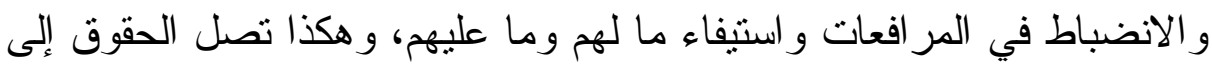

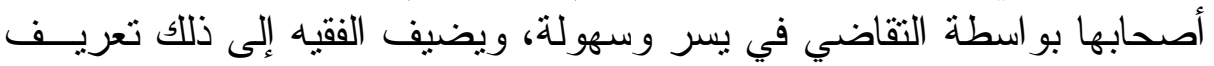

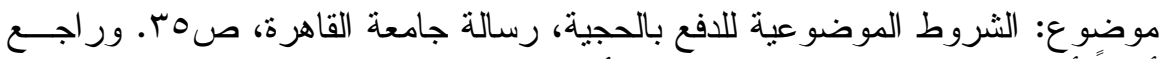

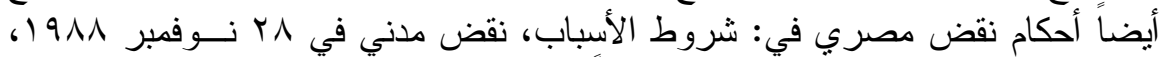

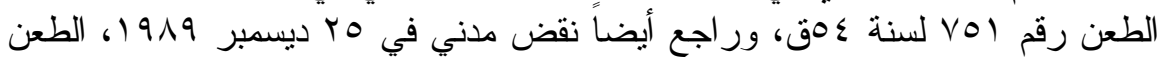

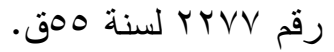
(') راجع الدكتور عبد الله بن محمد سعد آل خنين في مؤلفه: "تسبيب الأحكام القضائية في

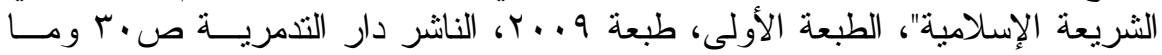

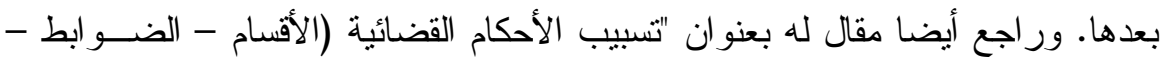

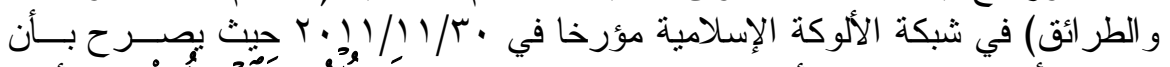

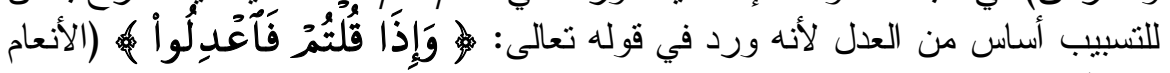

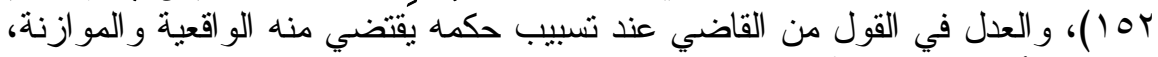
فلا يهول أو يهون في الأسباب، بل تكون مطابقة لو اقع الحال منو ازنة متعادلة. 


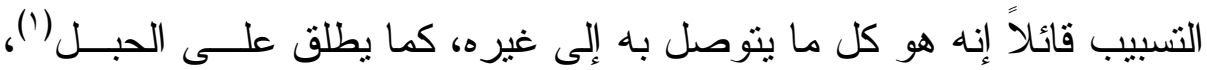

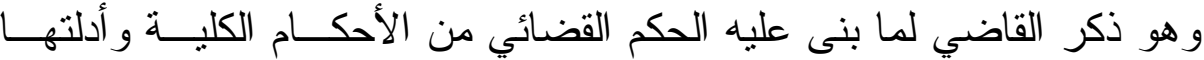

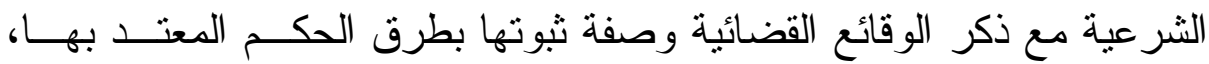

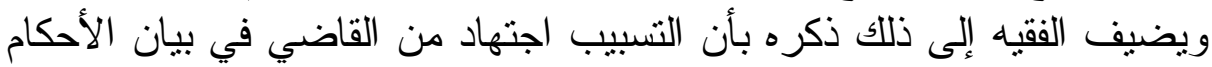

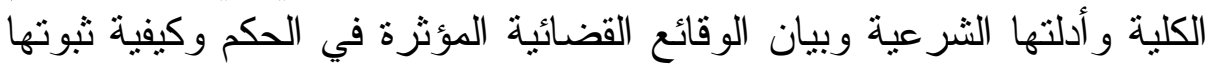

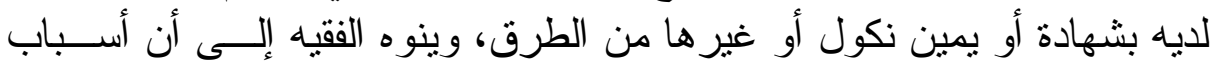

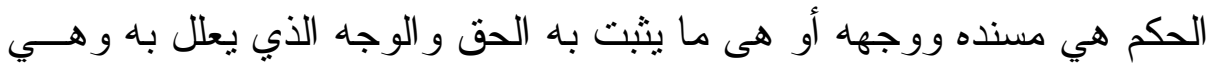

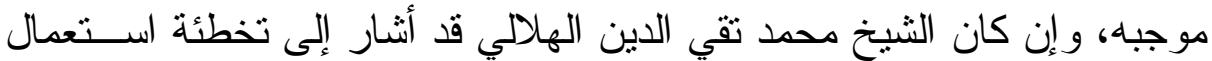

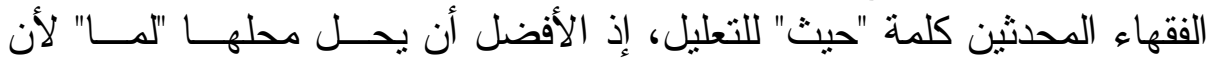

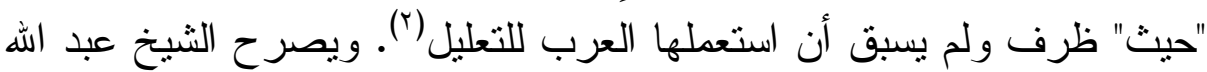

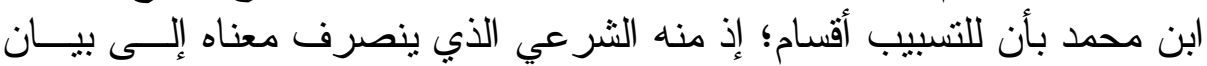

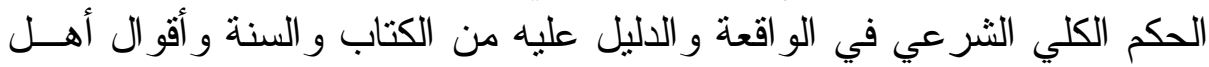

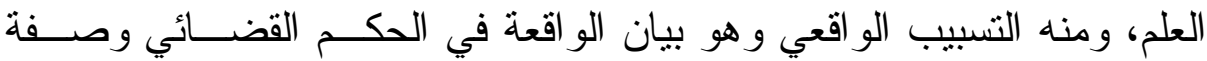

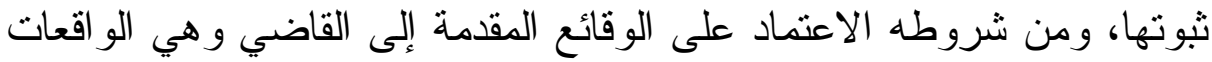

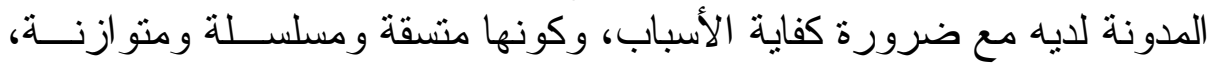
و أن تكون و اضحة في مجال التدليل، ومن موجبات ذللك حسن الصياغة وكنة بما لا

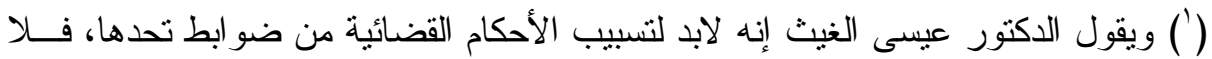

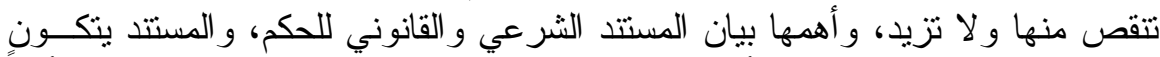

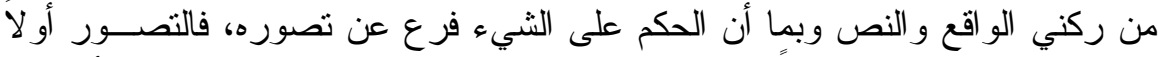

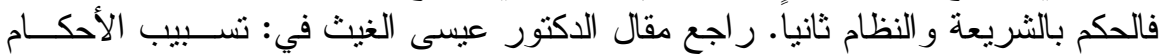

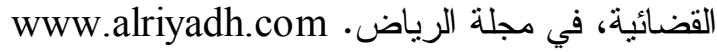

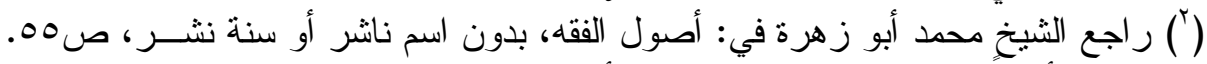

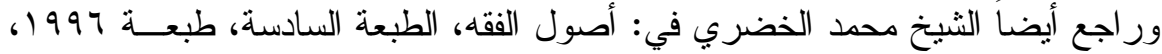

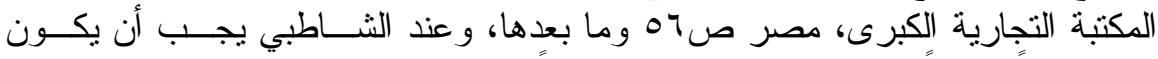

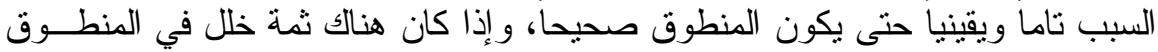

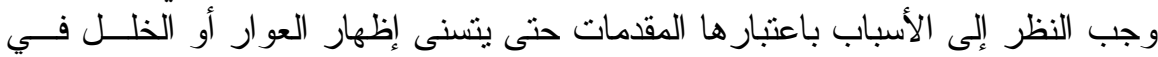

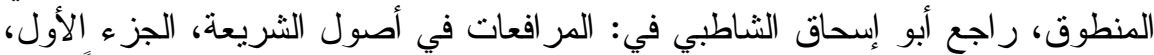

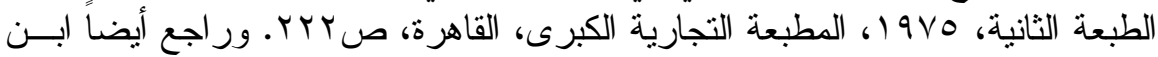

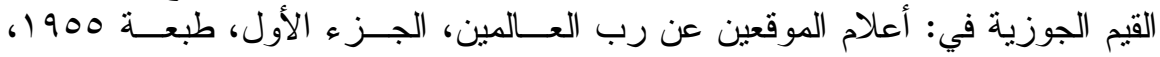

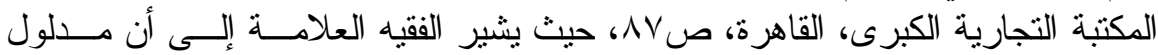

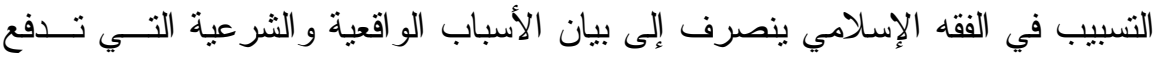

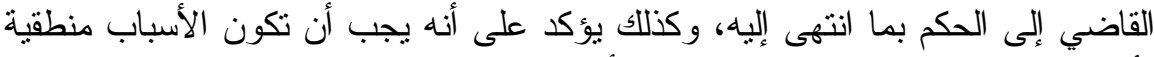

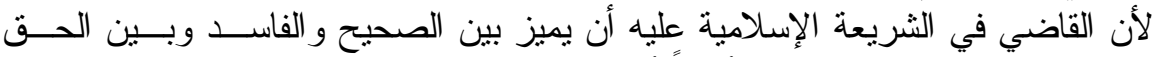
و الباطل و الغي و الرشاد، و عليه أيضاً أن يستنبط الحقيقة ثم يطبق علئ لئها الحكم الثرعي. 
يستعصي على الفهم و الإدر الك(1). ثالث عشر: التسبيب في أحكام القضاء المصري: الادي: وفي القضاء المصري أحكام قضائية عديدة قضت فيها محكمة الــنضض

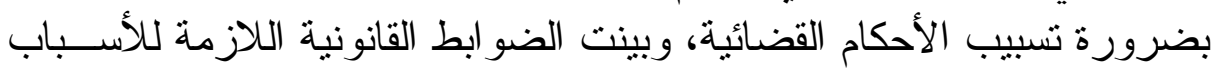

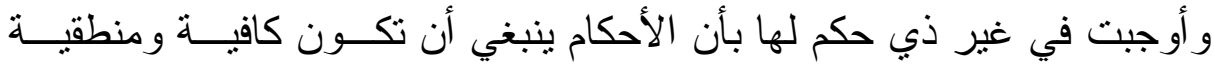
ومستمدة من الإجر اءات. فير دئ.

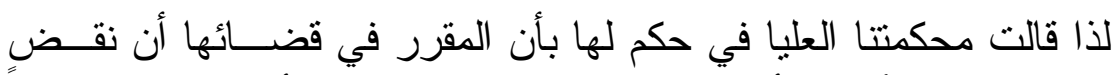

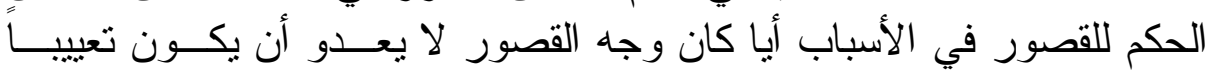

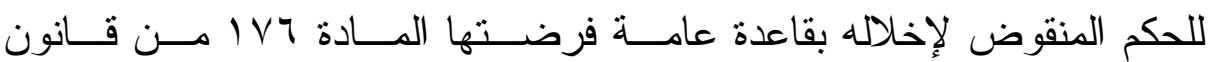
المر افعات و التي أوجبت أن تشتمل الأحكام على الأسباب التي بنيت عليها و إلا

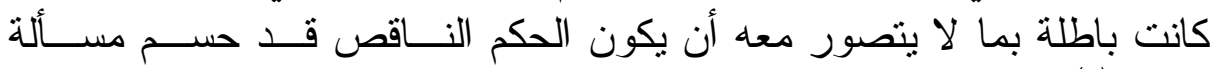
قانونية (r)

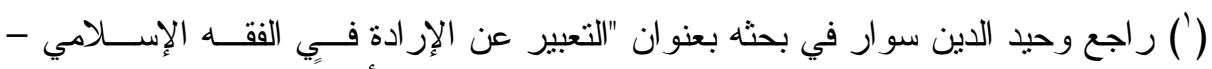

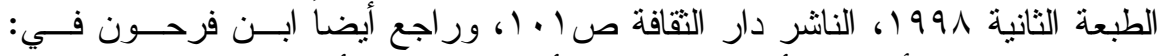

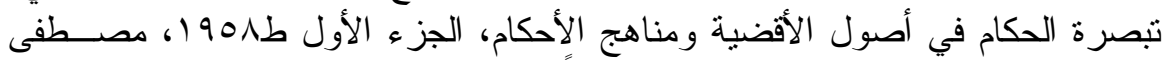

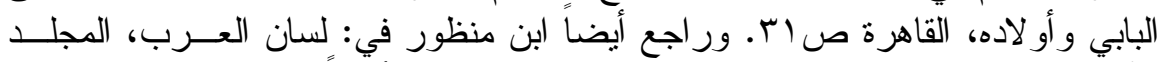

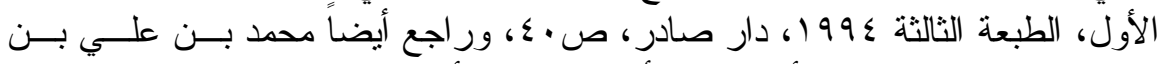

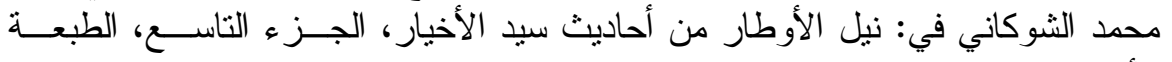

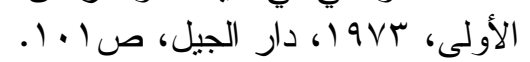

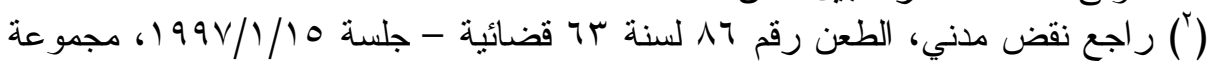

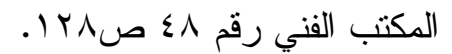
ولا ريب في أن الاهتمام بتسبيب الأحكام القضائية يجد تطبيقاً له في المؤتمرات العبات العلمية

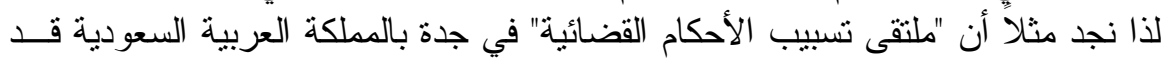

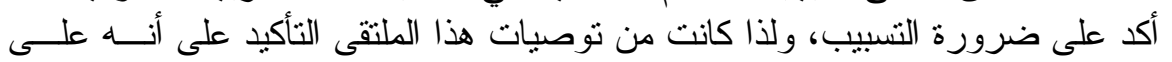

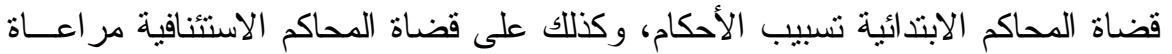

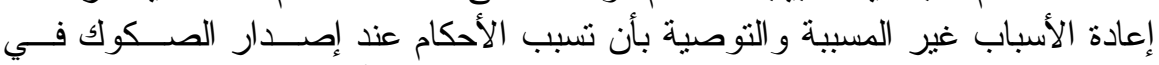

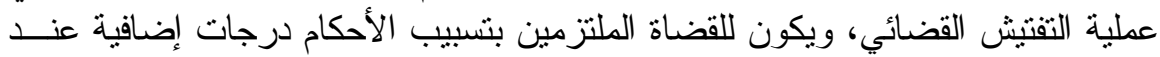

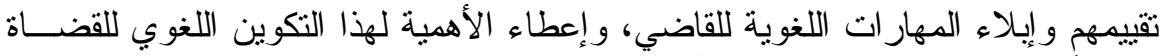

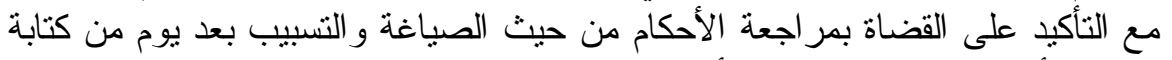

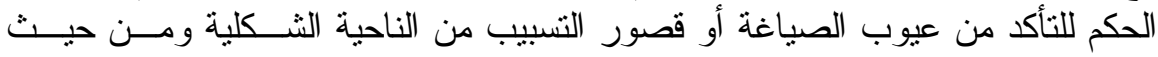

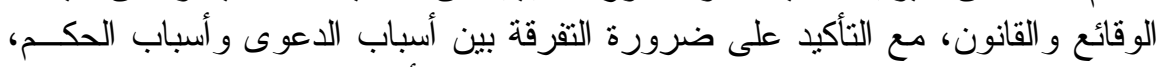

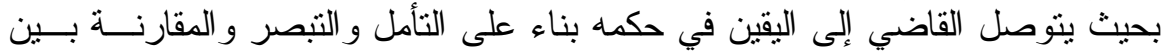
الأدلة، وقد أثبير في هذا الملتقى إلى أن التسبيب هو الأدلة و الأسانيد القانونية التي تبرد

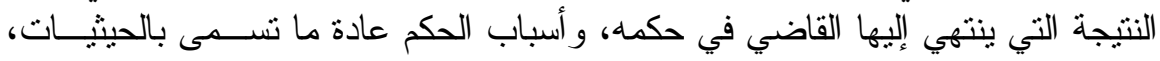

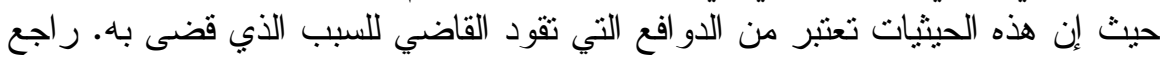


كما قالت محكمة النقض المصرية أيضاً في حكم آخر لها بــأن المقــرر

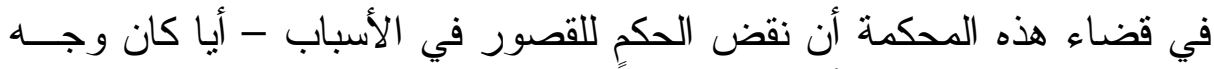

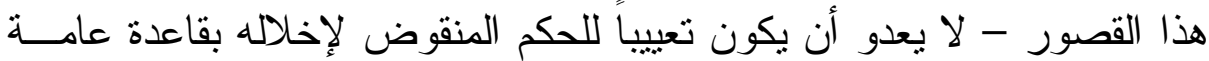

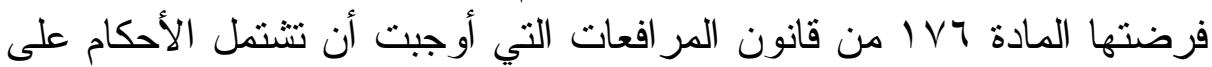

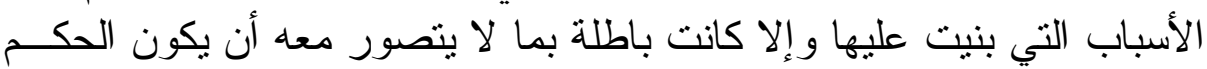

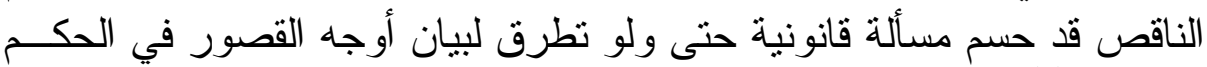

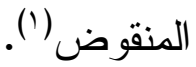

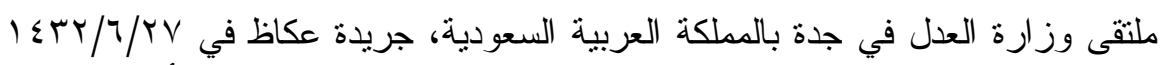

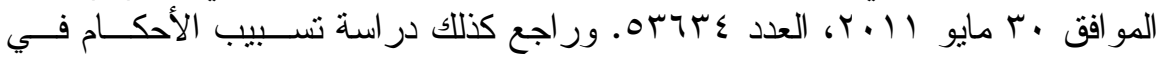

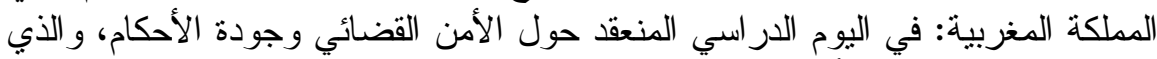

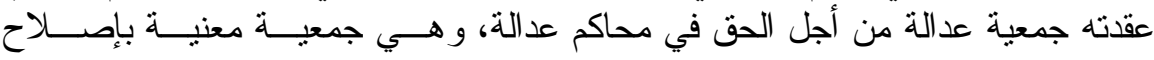

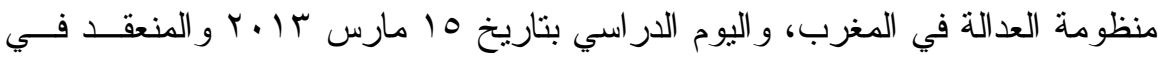

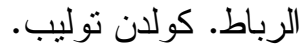

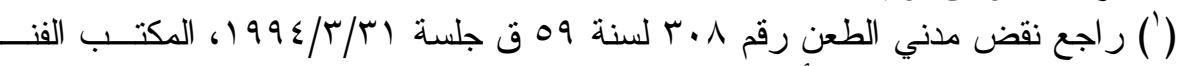

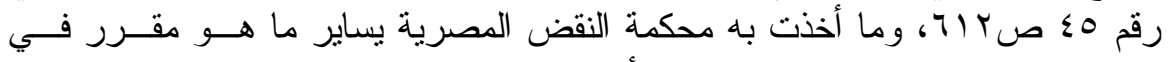

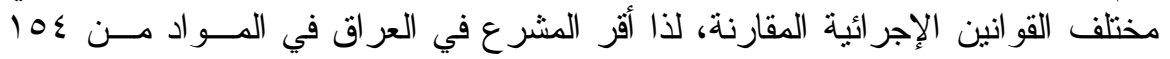

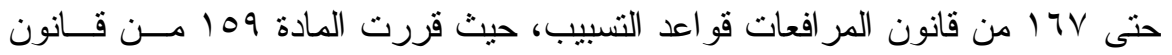

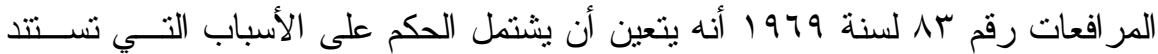

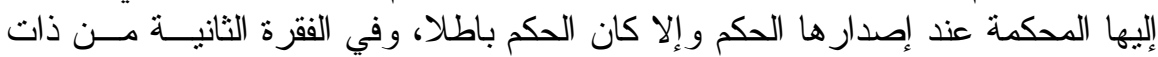

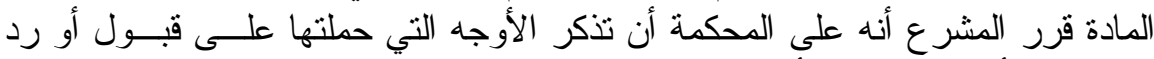

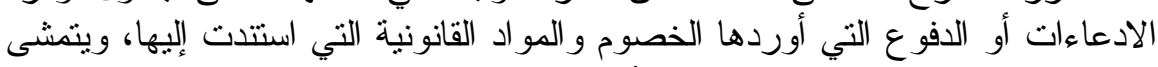

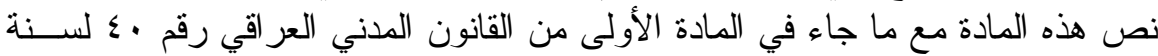

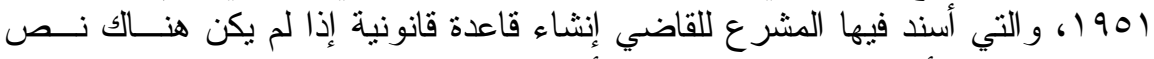

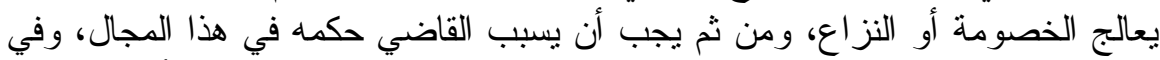

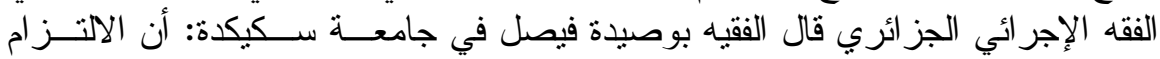

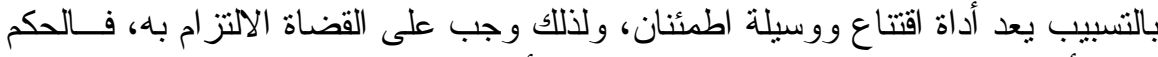

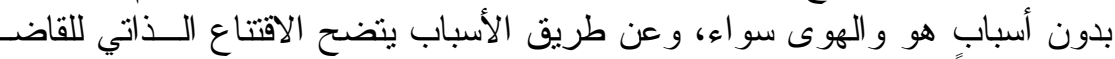

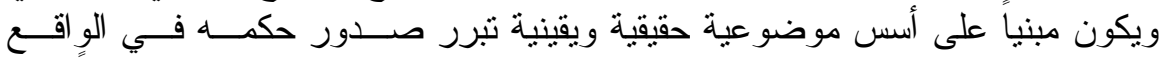

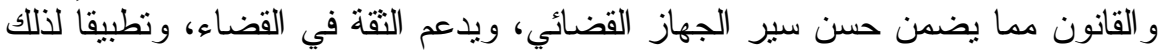

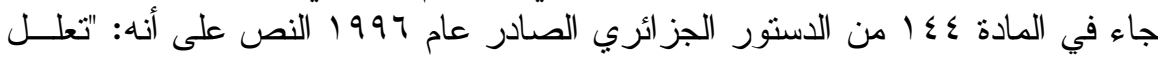

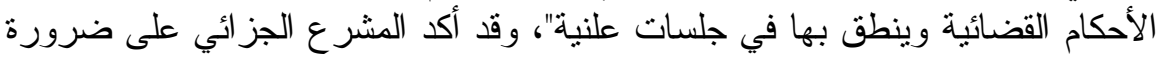

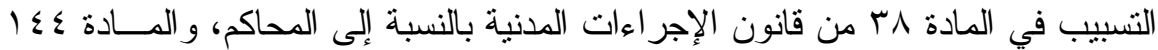

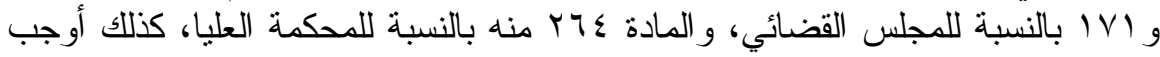

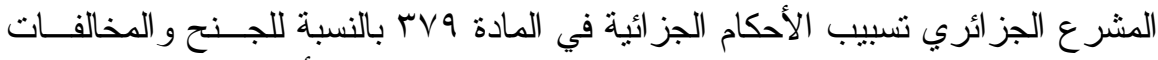

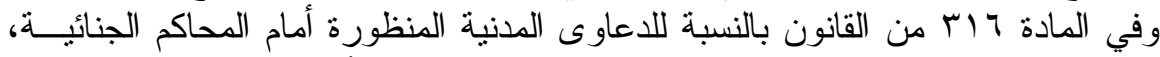

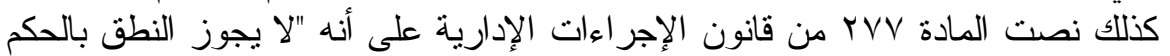


وكذلك قالت محكمتنا العليا في حكم آخر لها بأن القصور في التسبيب -

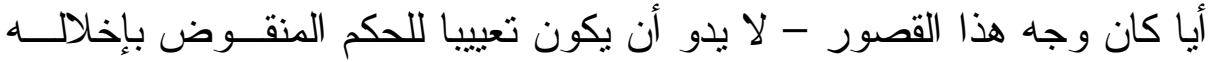

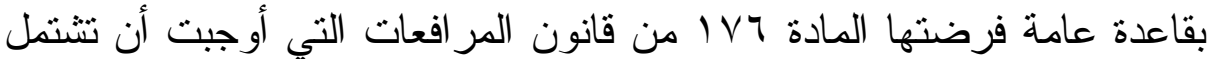

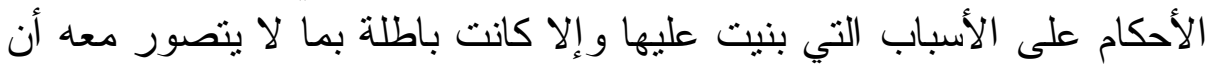

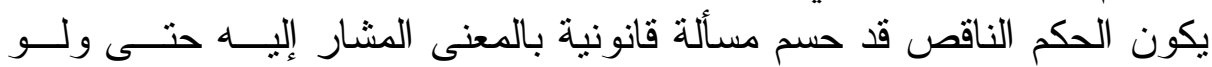
تطرق لبيان أوجه القصور في الحكم المنقوض.

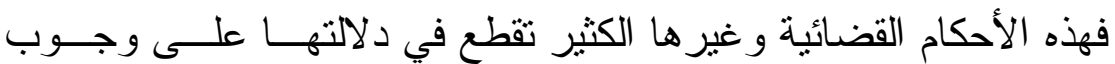

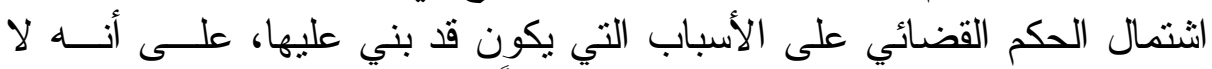
ينبغي الاعتقاد بأن لزوم التسبيب يقتضي دوماً أن تكون الأسباب ذابن ذاتها صالحة

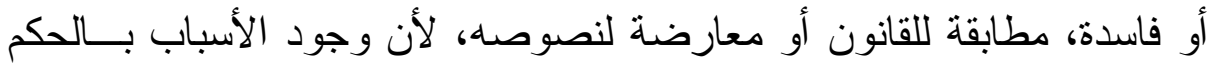

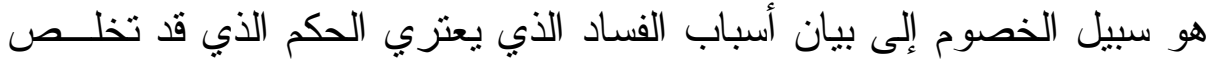

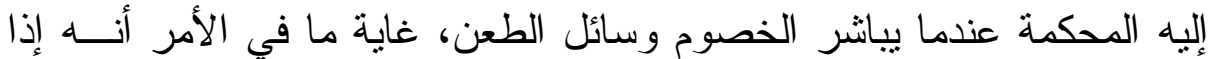

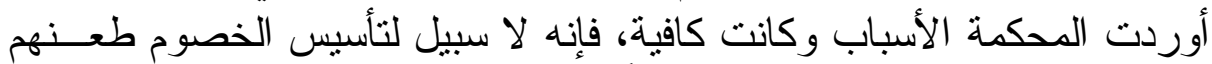

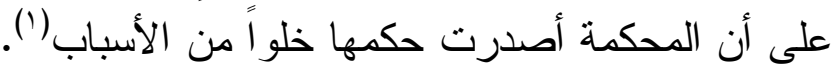

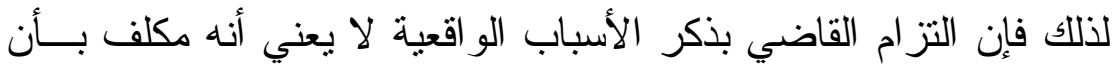

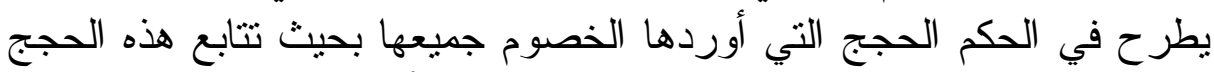

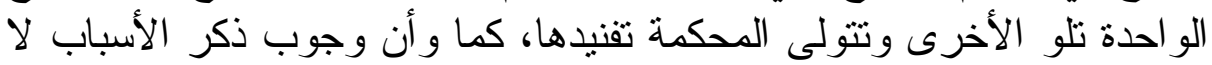

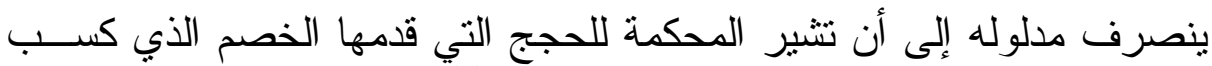

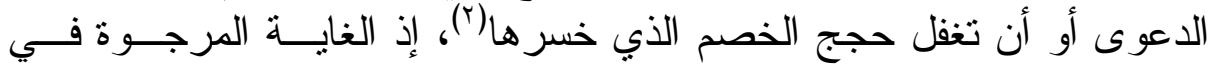

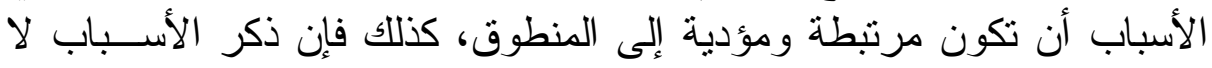

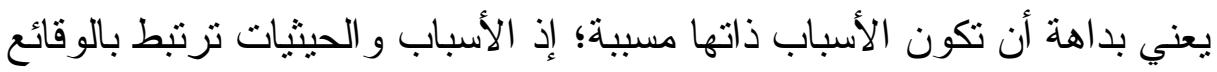

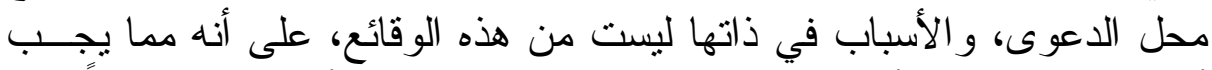

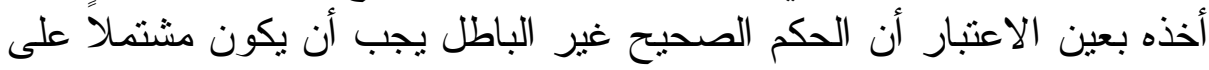

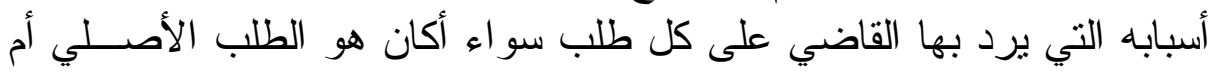

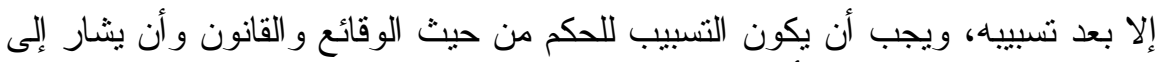

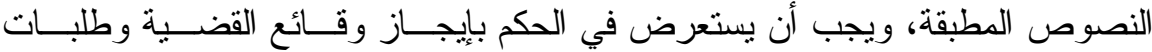

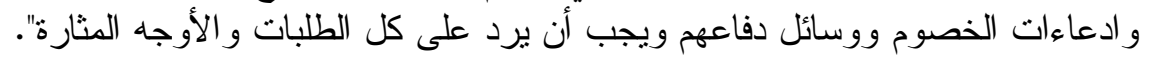

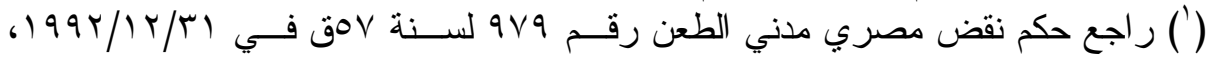

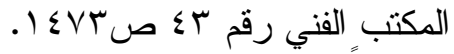

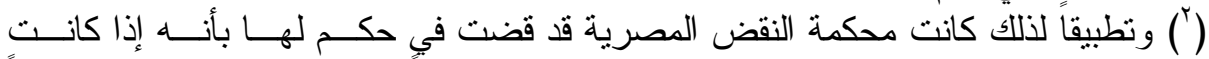

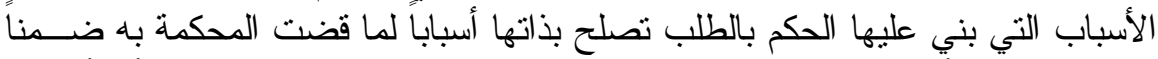

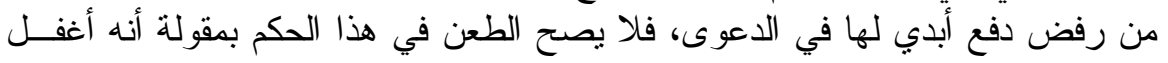

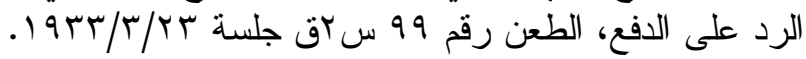


القرعي أم هو دفع بعدم القبول أو ببطلان صحيفة الدعوى أو عدم الاختصاص.

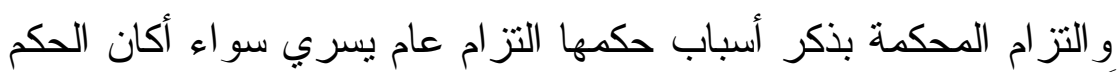

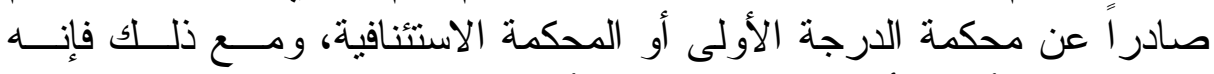
بإمكان هذه الأخيرة أن تذكر في الحكم الأسباب التي وردت الإثشارة إليها فـي الإني

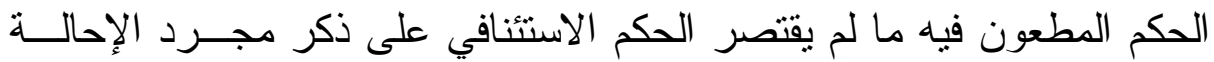

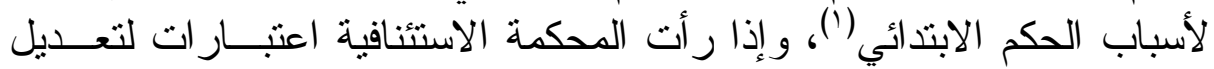

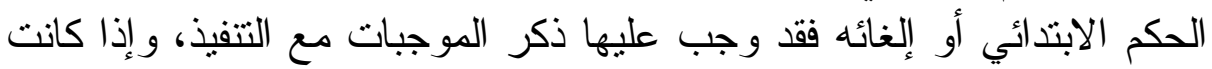

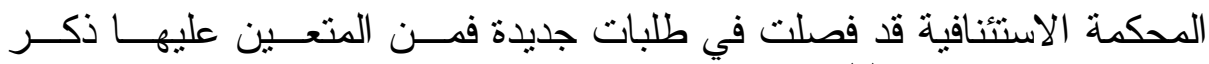
حيثيات ما فصلت فيه( (r).

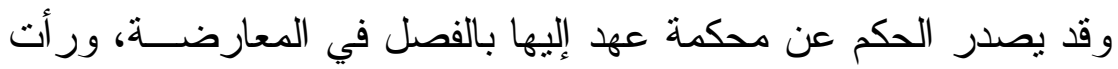

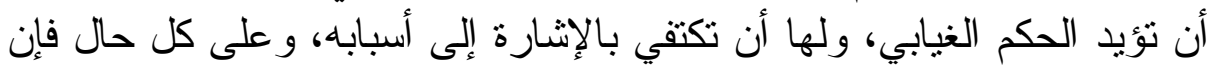

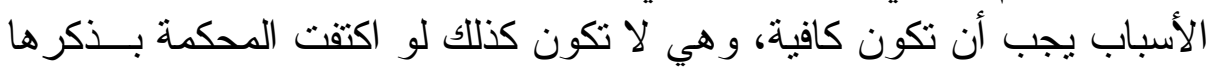

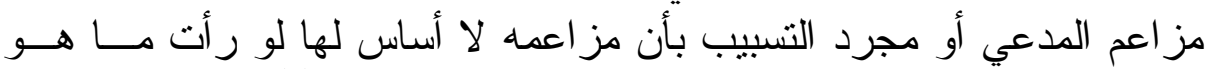

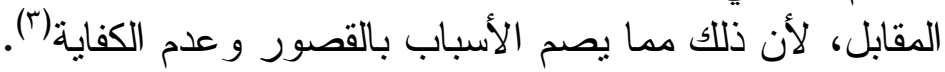

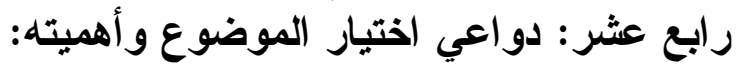

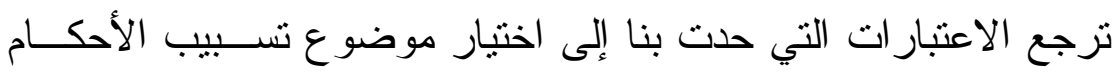

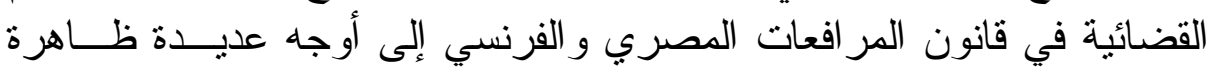

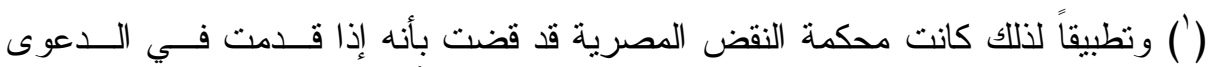

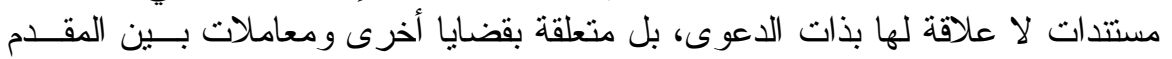

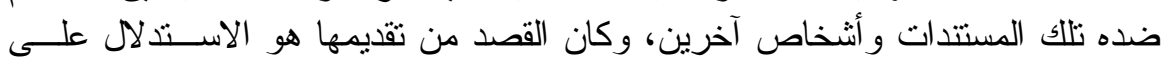

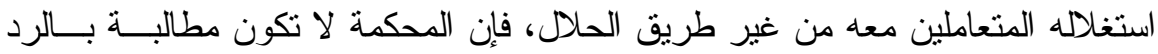

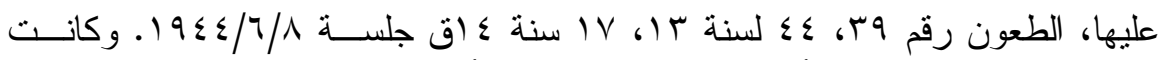

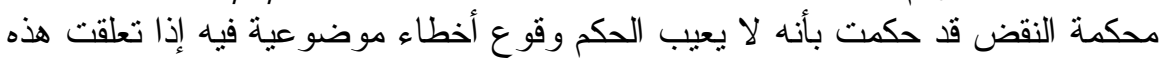

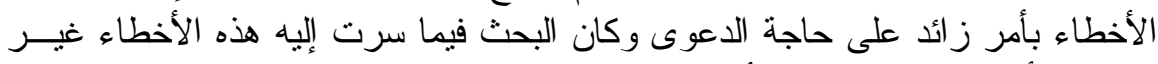

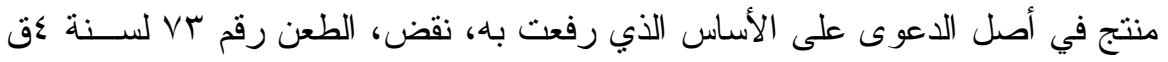

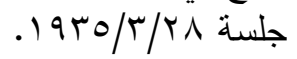

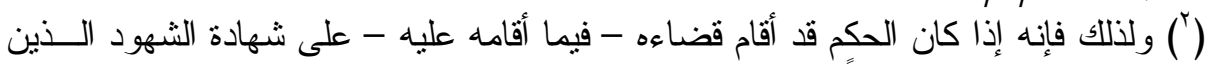

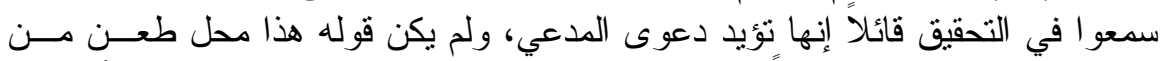

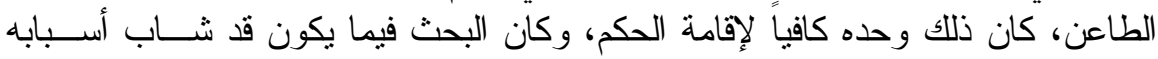

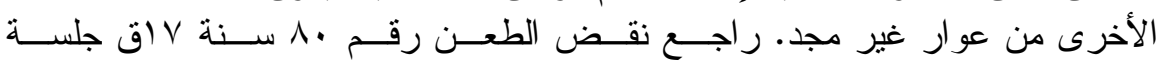
$19 \leq 1 / 1 \mathrm{r} / 9$ (") وتمشياً مع ذلك كانت محكمة النقض المصرية قد قضت بأنه إذا خاض الحكم في أمور

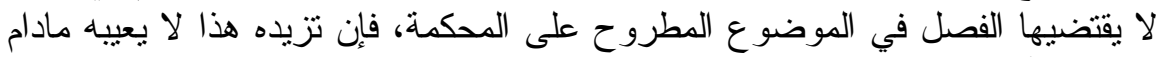

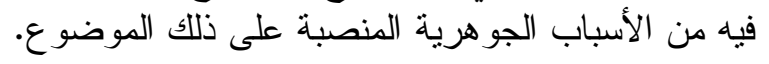




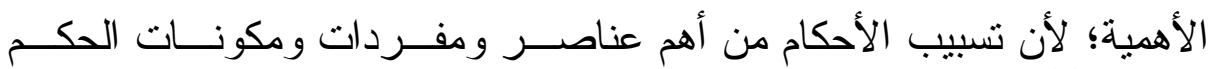

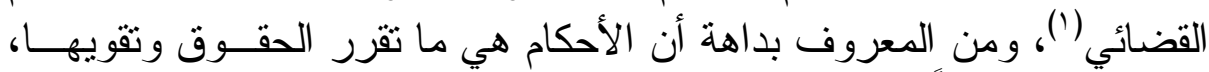

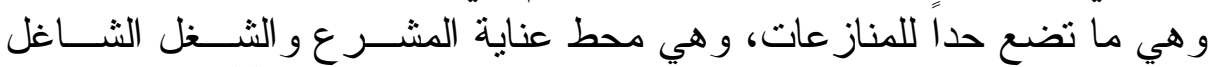

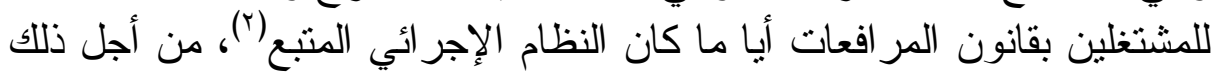

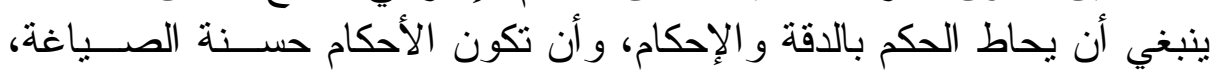

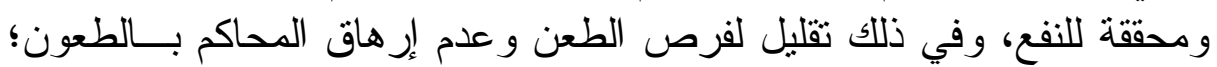

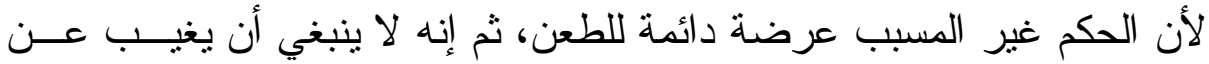

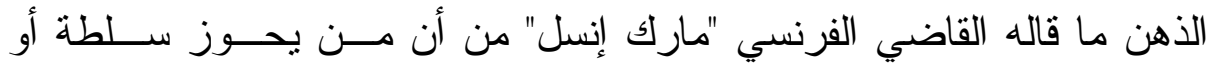

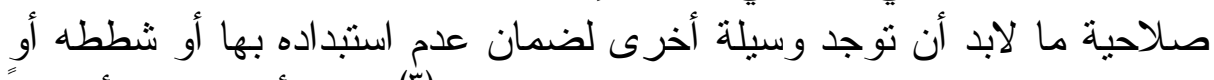

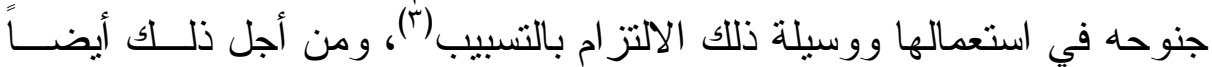

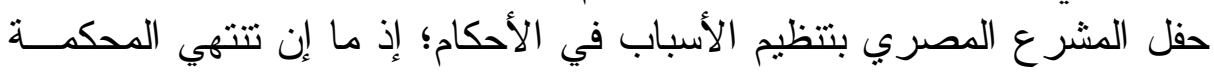

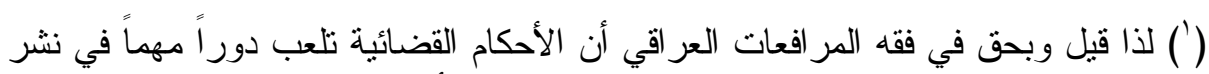

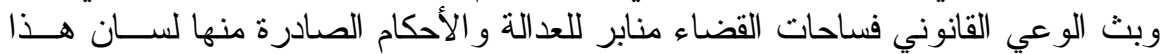

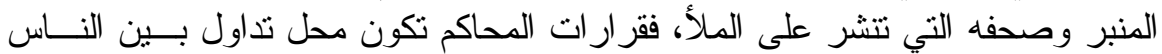

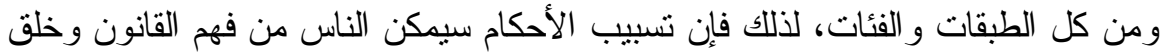

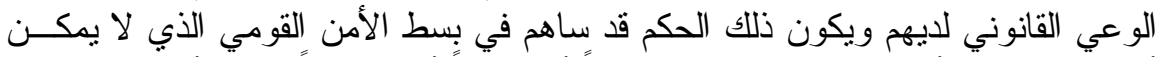

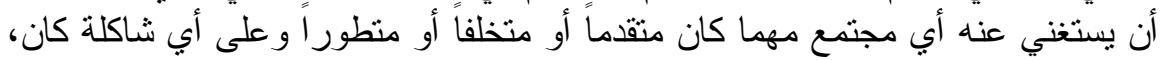

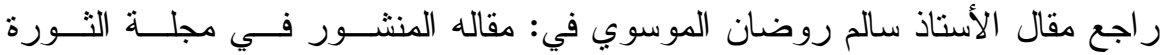

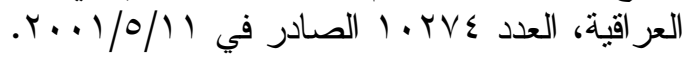

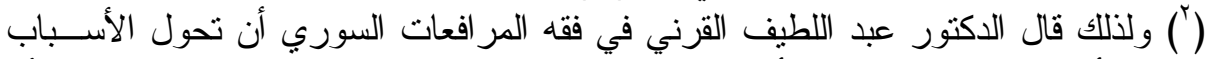

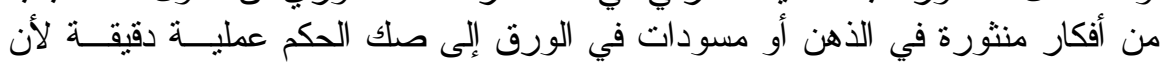

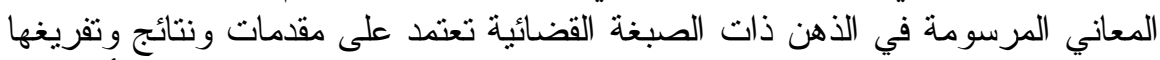

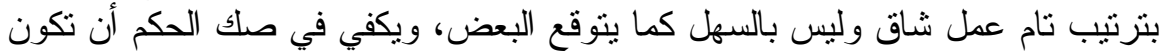

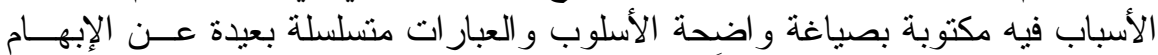

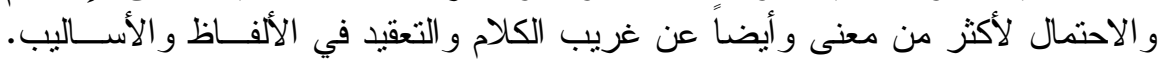

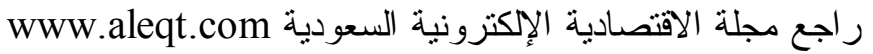

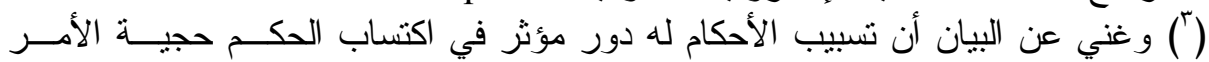

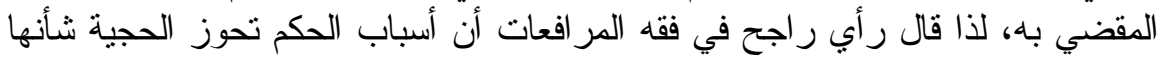

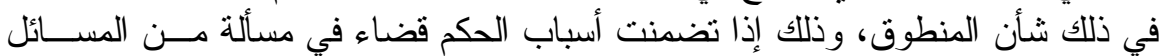

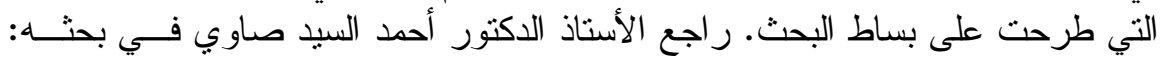

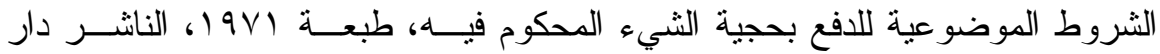

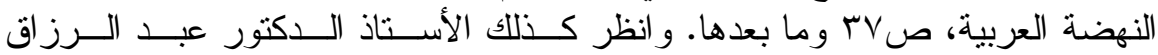

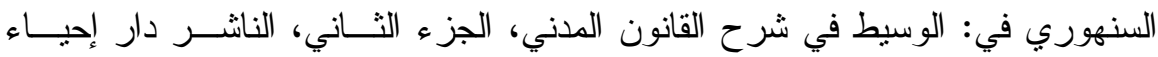

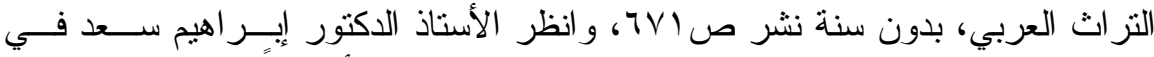

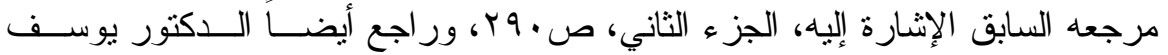

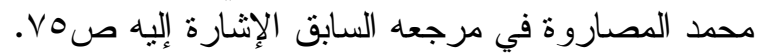




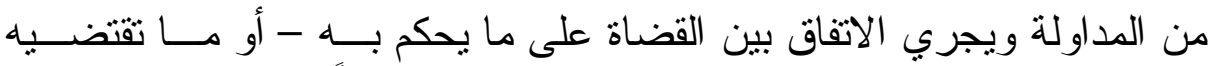

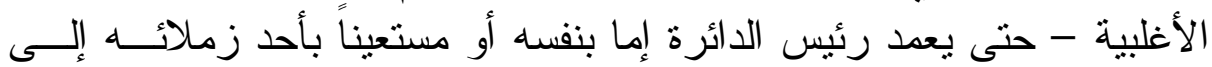

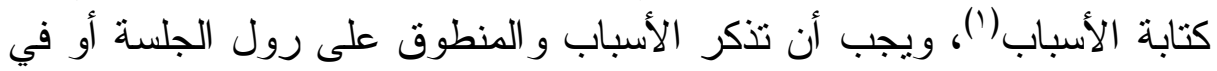

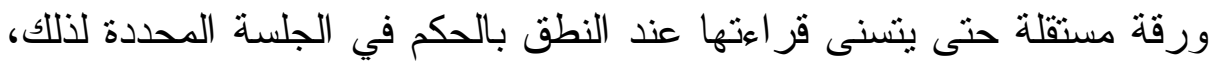

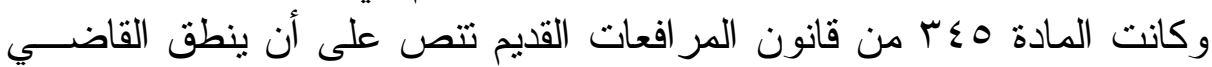

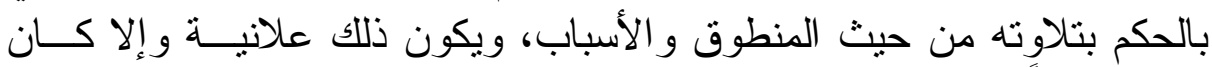

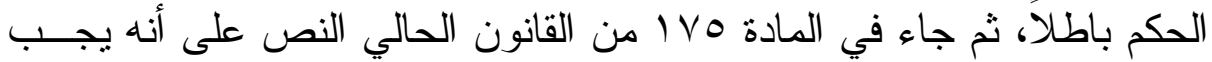

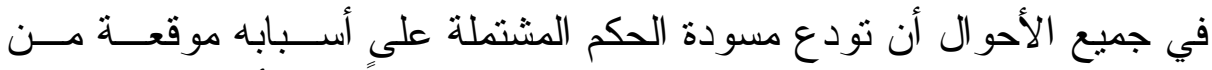

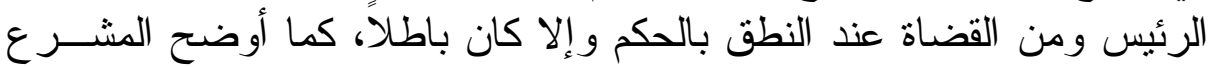

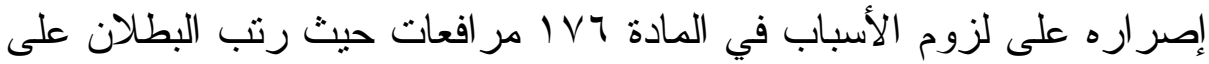

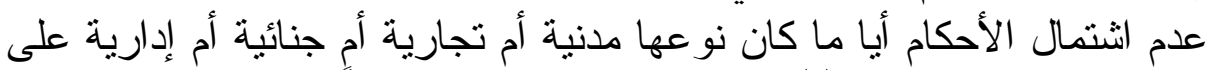

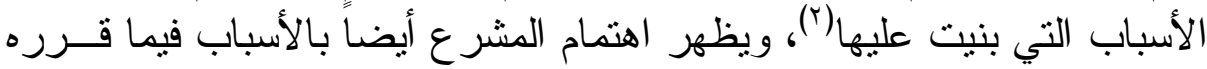

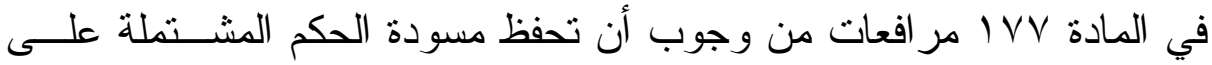

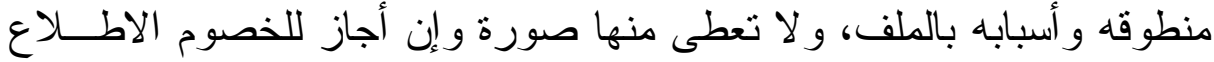

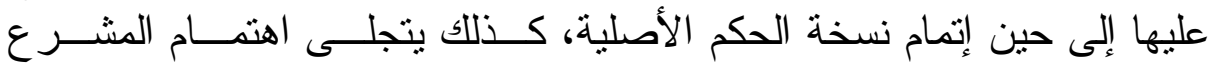

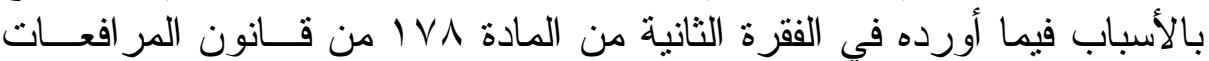

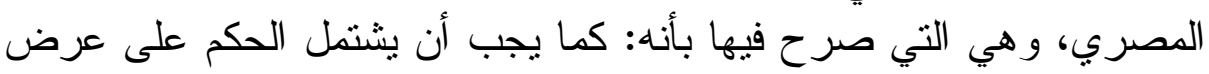

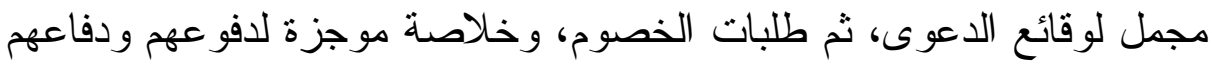

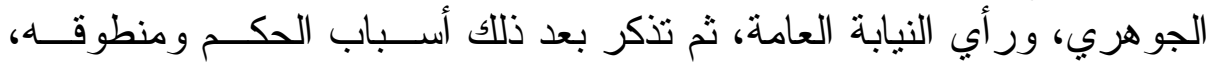

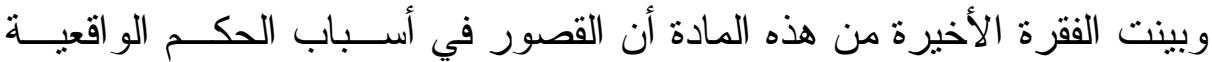

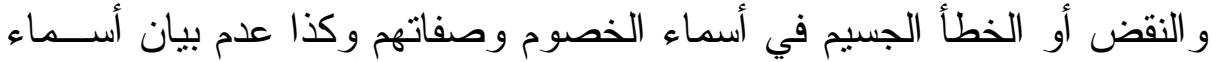

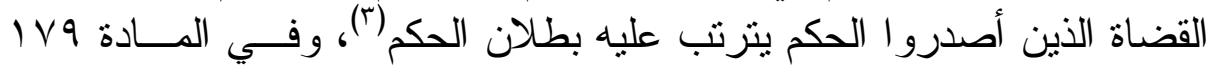

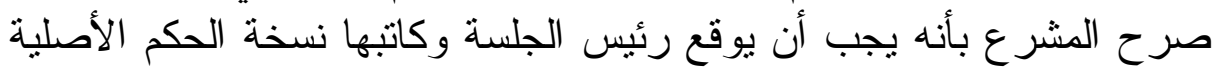

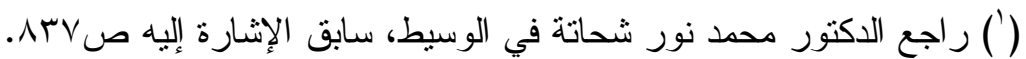

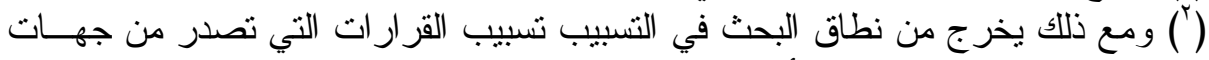

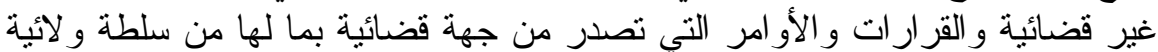

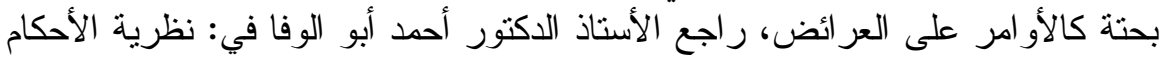

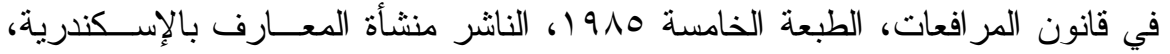

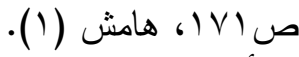

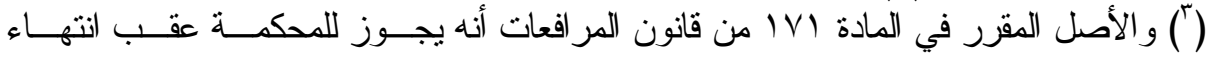

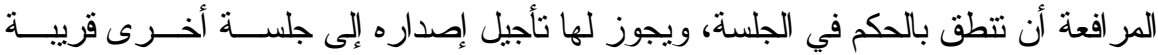

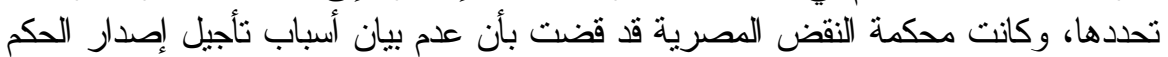

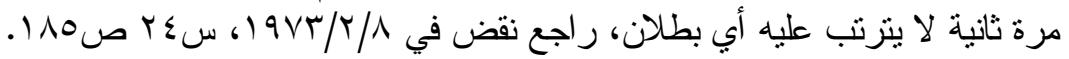


المشتملة على وقائع الدعوى و الأسباب و المنطوق وتحفظ في ملف الدعوى(').

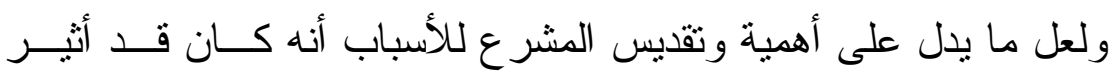

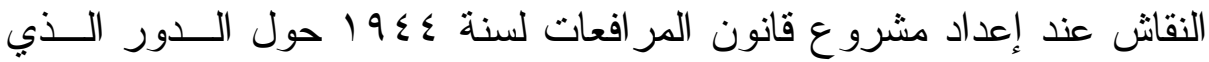

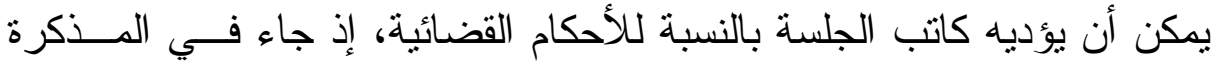

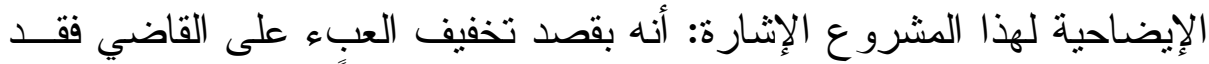

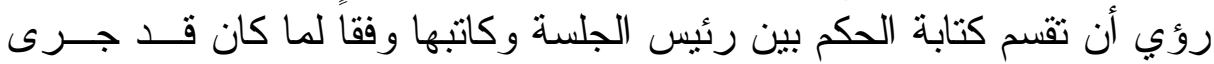

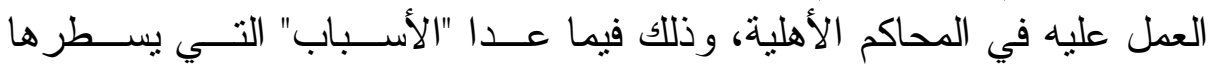

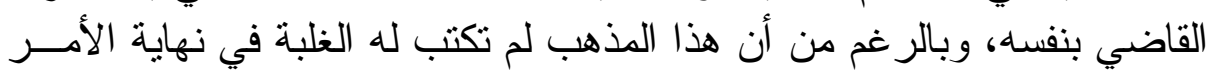

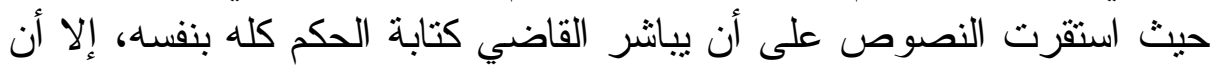
المستقاد من ذلك اعتبار الأسباب و التسبيب من أخص خصائص التص عمل القاضي

$$
\text { وهي عمد الحكم ذاته(ب). }
$$

وتجدر الإشارة في هذا المقام إلى أنه لا يقلل من أهمية در اسة تســبيب

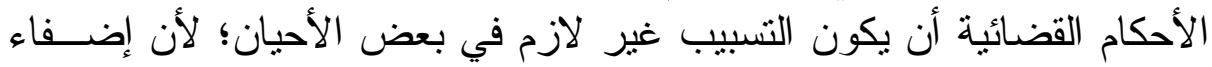

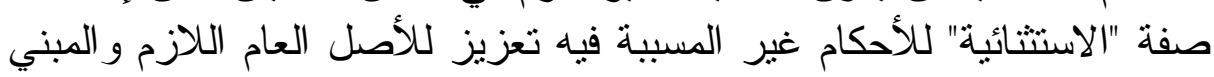

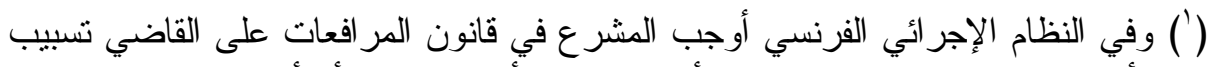

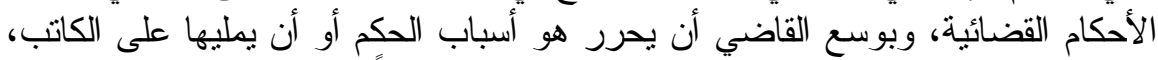

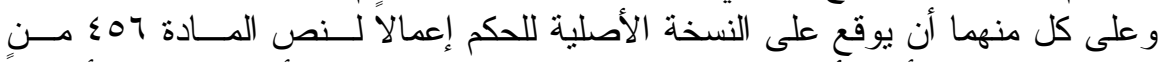

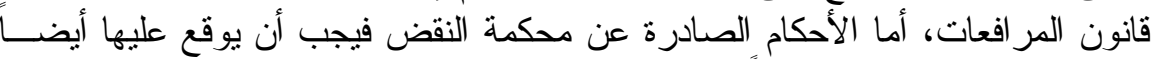

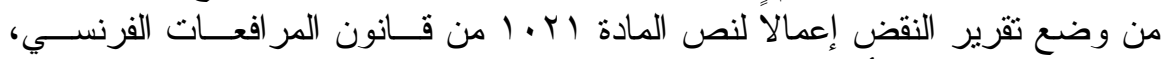

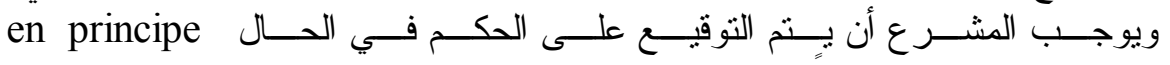
immédiatement

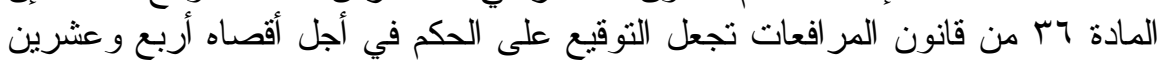

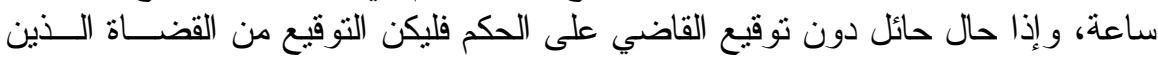

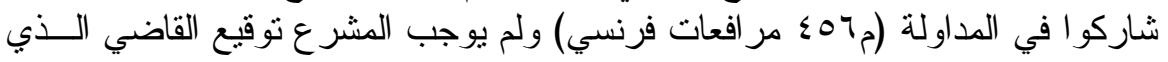
نطق بالحكم في علنية على هذا الحكم. راجع: Jean Vincent et Serge Guinchard; op. cit. p. 532 No. 763.

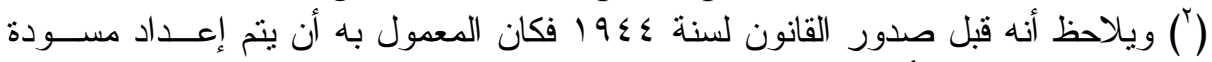

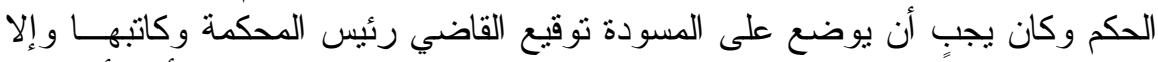

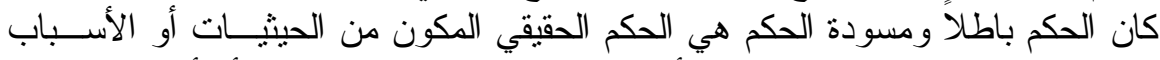

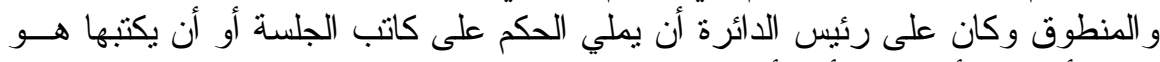

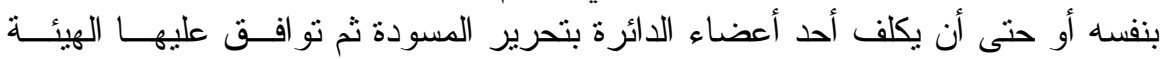

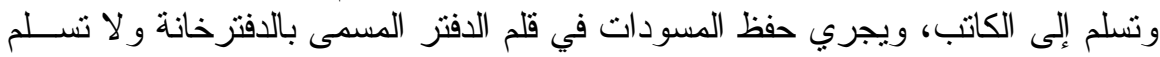

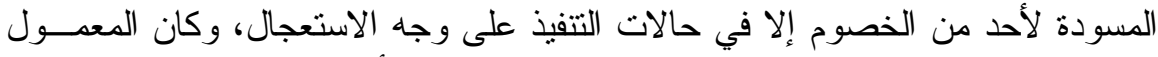

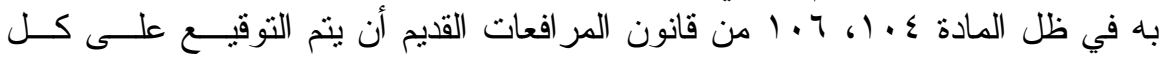
صورة نسخت من المسودة من رئيس المحكمة و الكاتب. 
على ضرورة الحيثيات(')، لذا فإنه من المستقر مثناً أن الأحكام غير القطعيــة

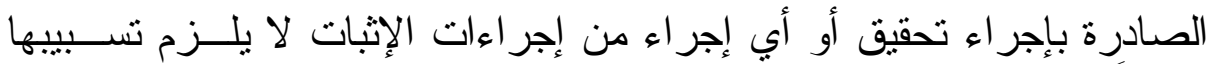

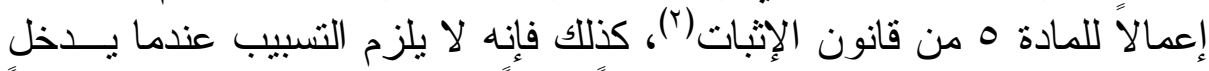

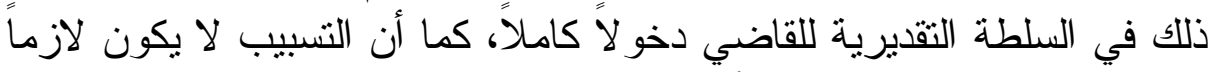

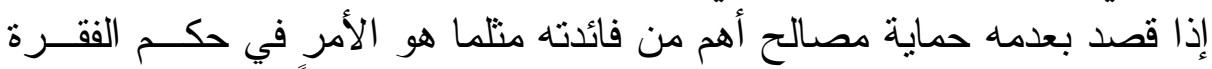

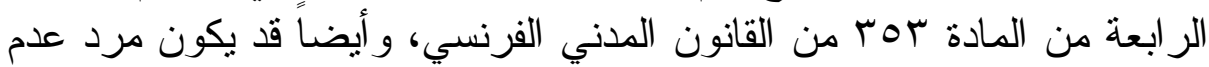

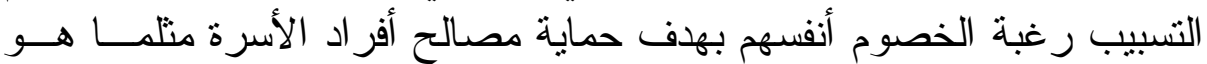

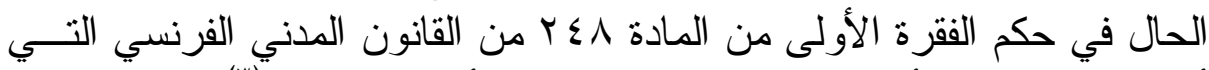
أجاز فيها المشرع أن يطلب الزوجان عدم ذكر أسباب الطلاق" (r). خامس عشر: التسبيب من الناحية التاريخية:

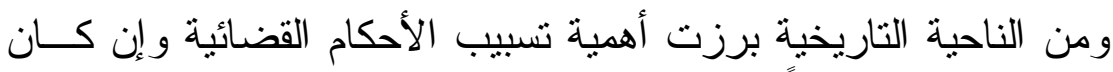

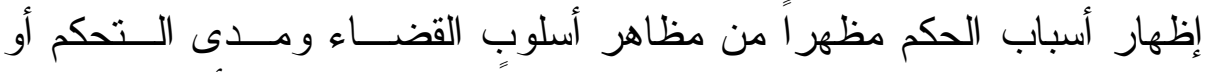

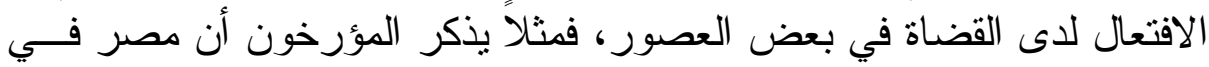

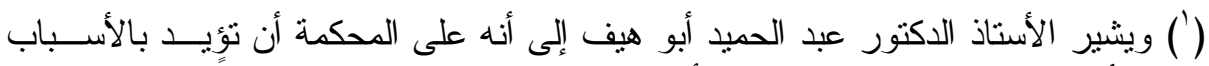

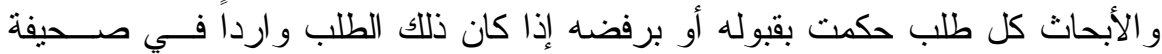

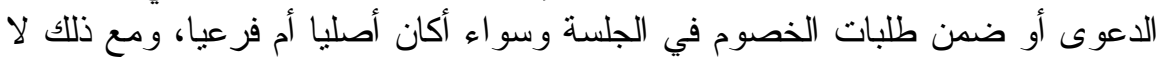

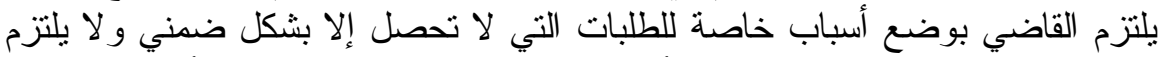

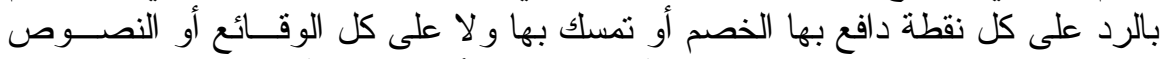

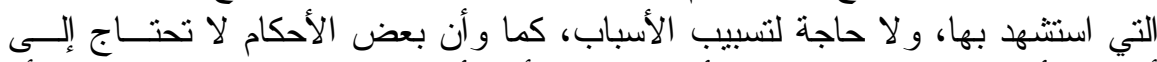

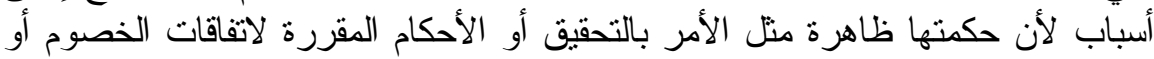

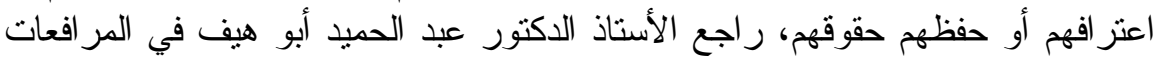

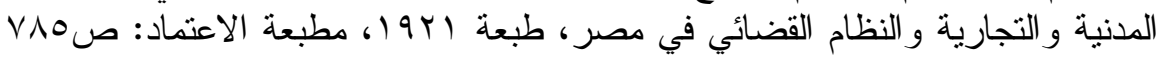

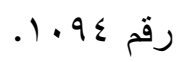

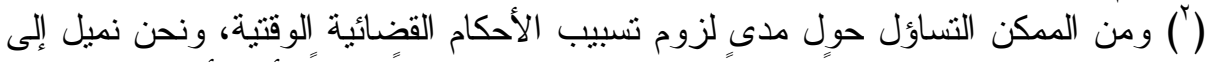

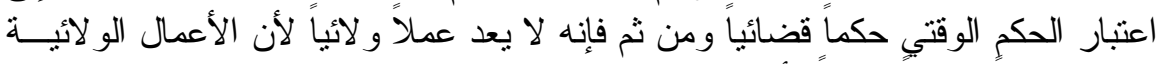

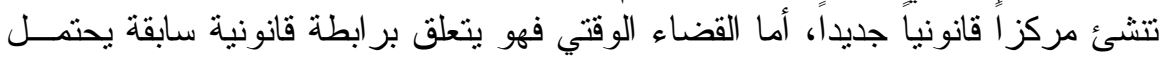

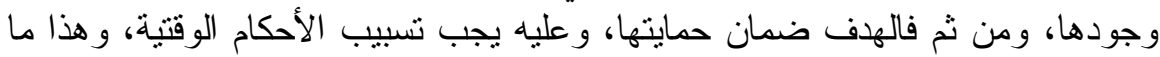

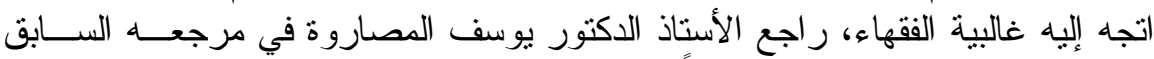

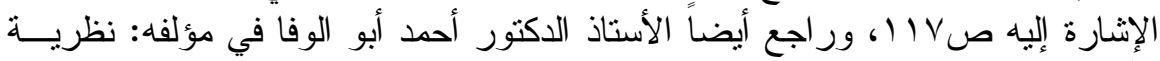

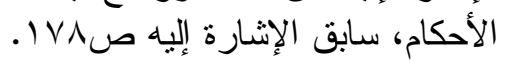

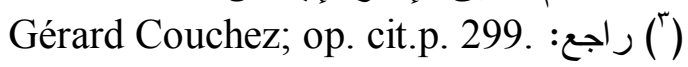
ور اجع في القضاء الفرنسي:

Cass. Civ. $2^{\mathrm{e}}, 16$ avr. 1986. D. 1986. J. 591, note

Richevaux; Caz. Pal. 1986J. 613. Note M. R; civ. 2 e, 6 déc 1989 J.C.P. 1990. IV. 43. 
العصر الفرعوني عرفت تعدد درجات التقاضي وساد فيها نظام متقــدم مــنـ

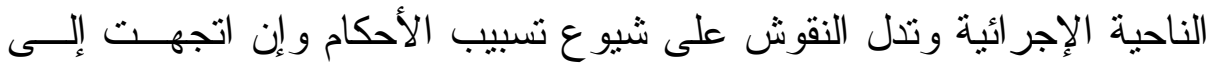

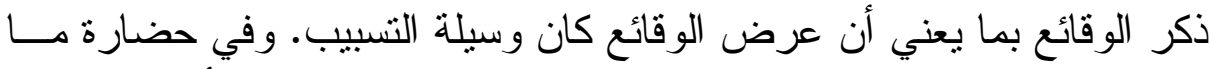

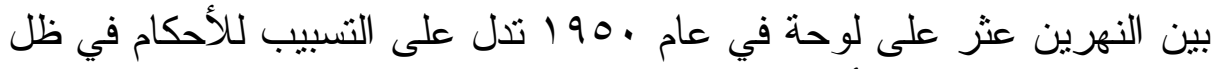

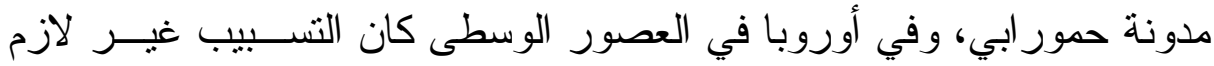

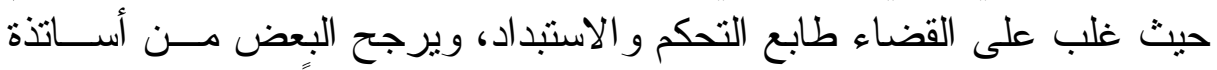

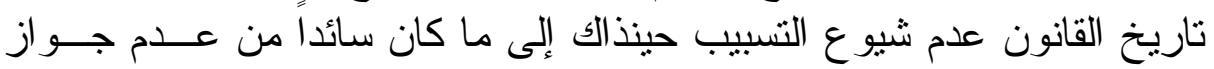

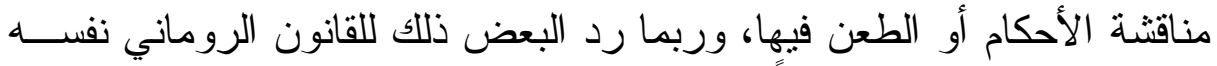
حيث لم يكن التسبيب مطلوباً لأن القضاة وربمار لا يجوز مناقنة أحكامهم.

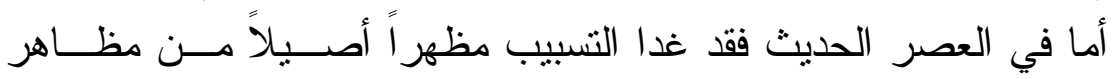

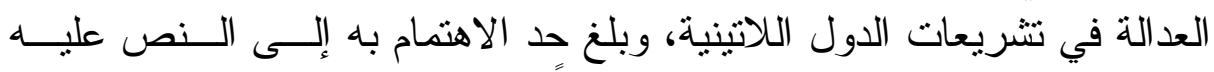

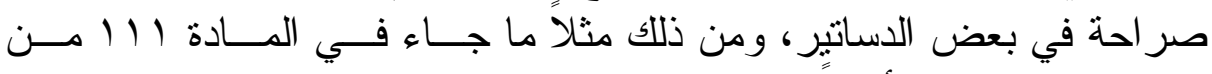

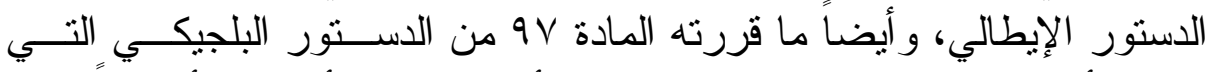

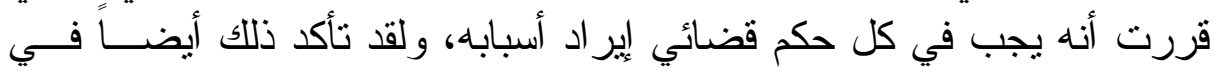

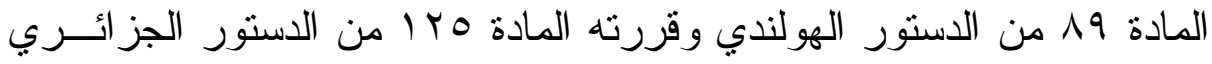

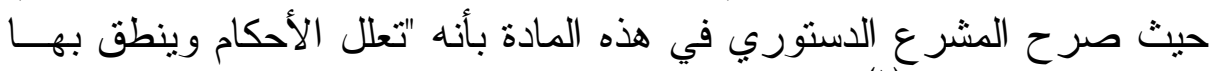

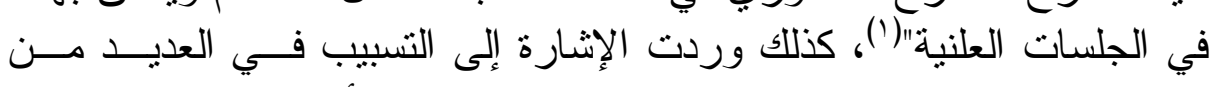

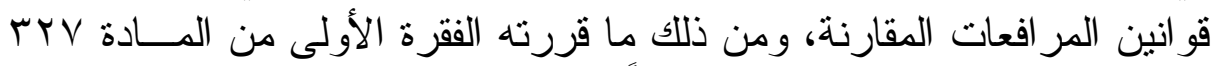

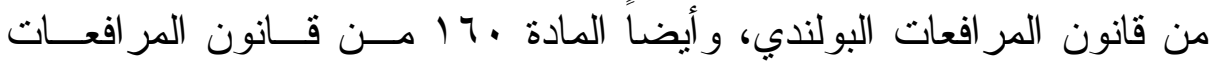
الأردني "قانون أصول المحاكمات المدنية" و التي جاء فيها أنه "يجب أني أن يبـين النين

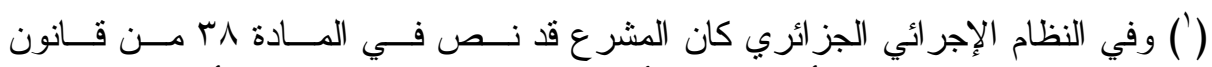

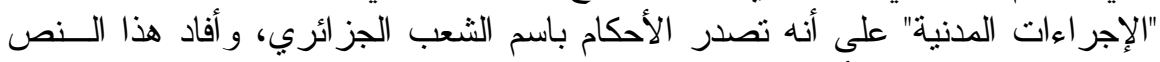

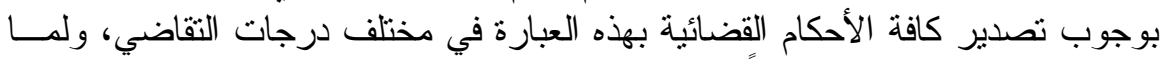

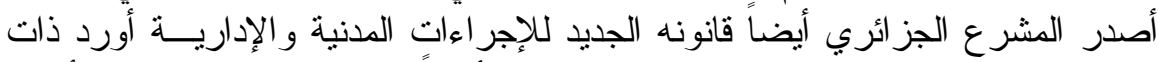

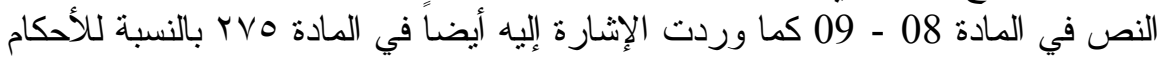

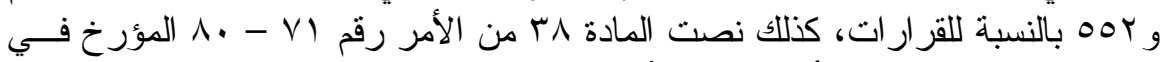

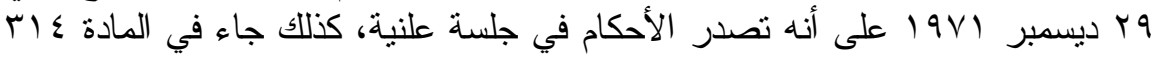

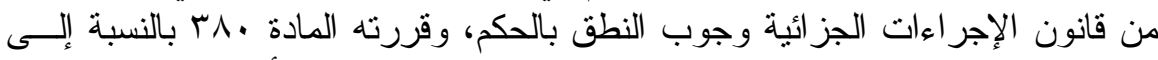

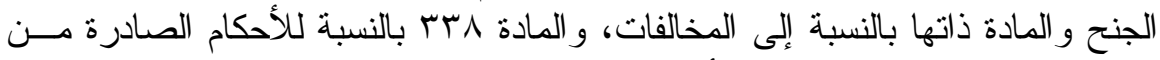

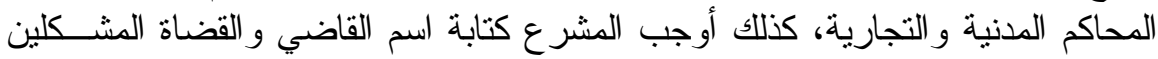

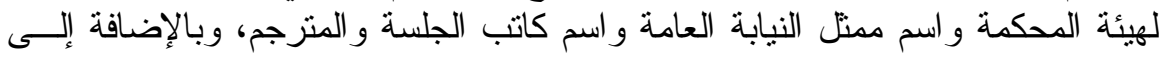

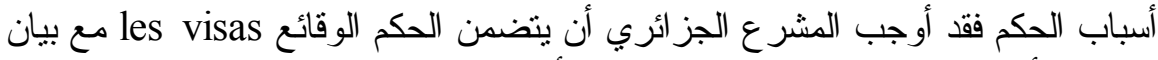

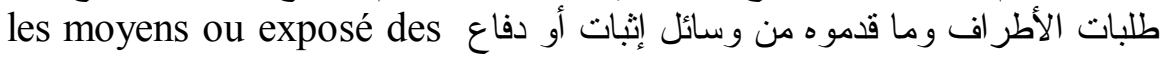
.demandes et faits 
في الحكم المحكمة التي أصدرته وتاريخ إصداره ومكانه و أسماء القضاة الذين

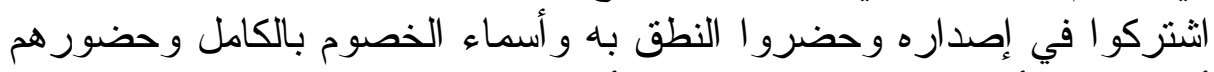

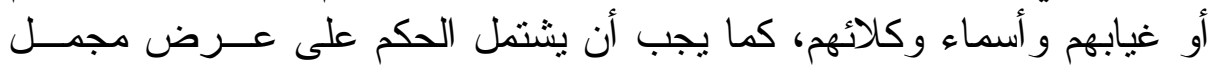

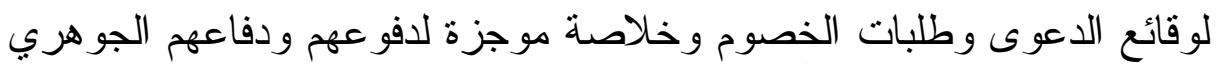

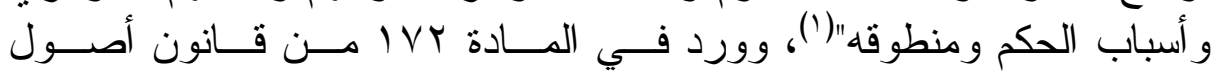

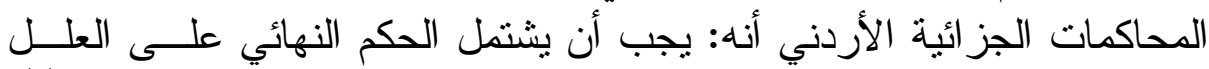

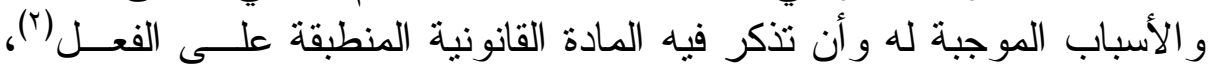

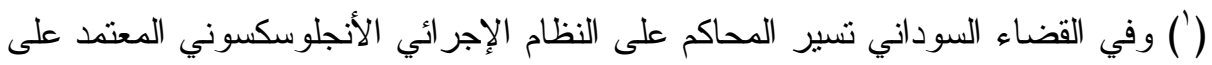

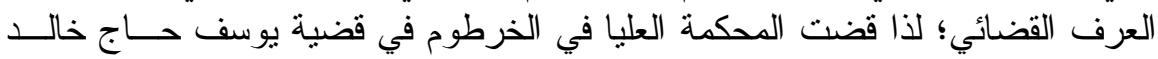

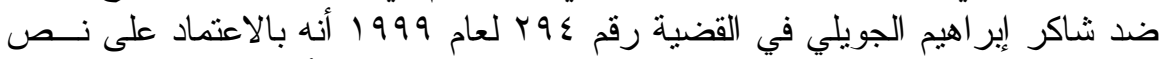

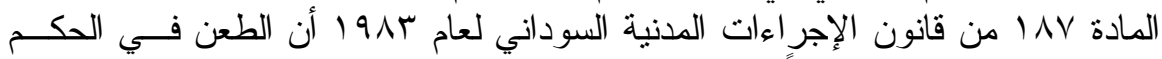

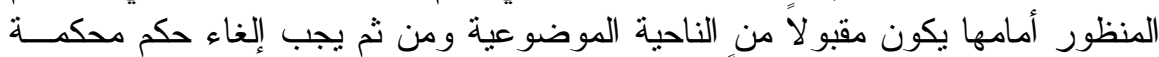

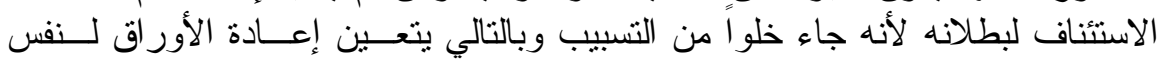

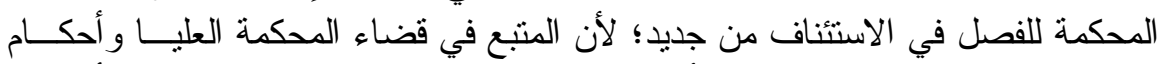

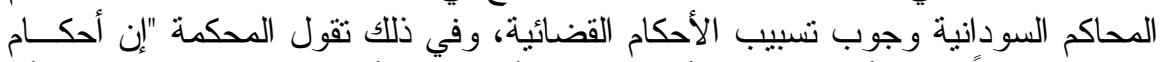

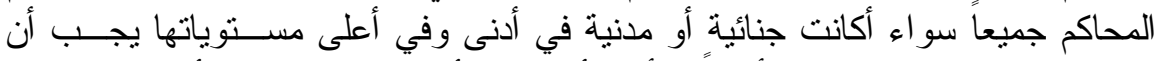

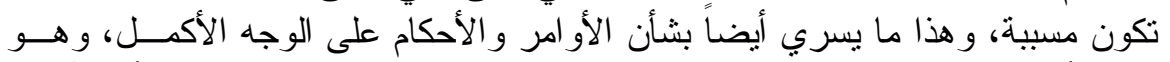

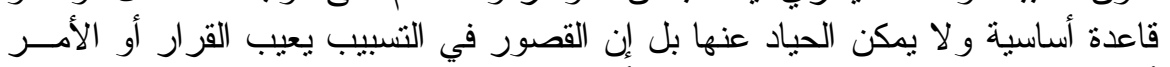

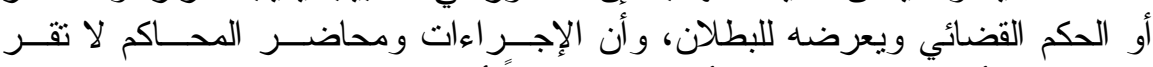

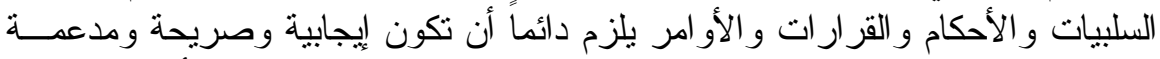

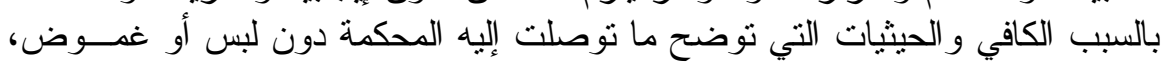

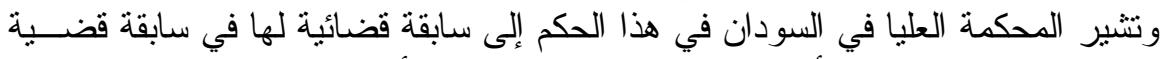

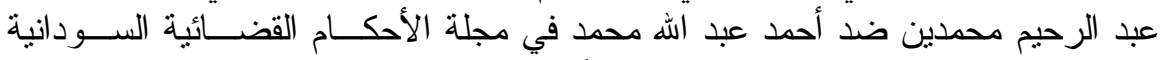

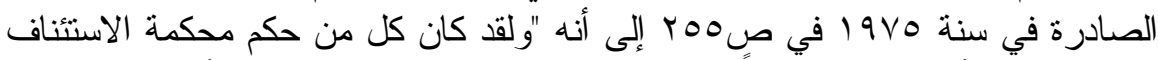

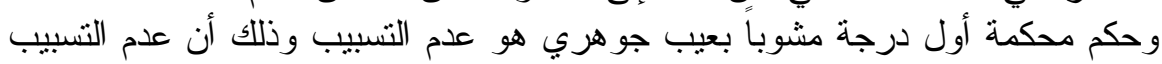

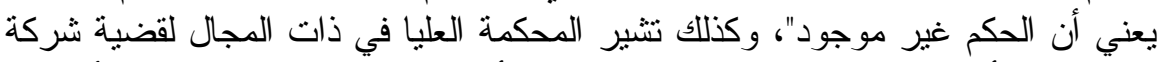

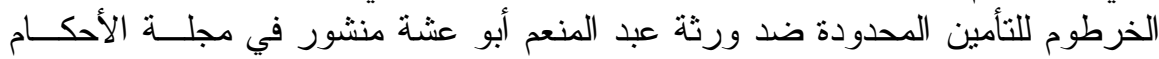

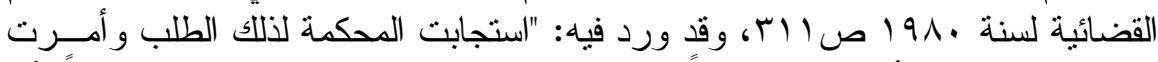

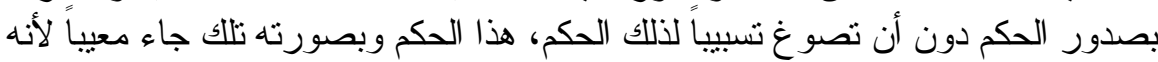

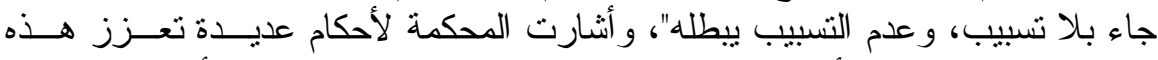

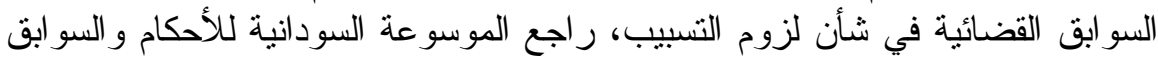

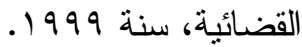

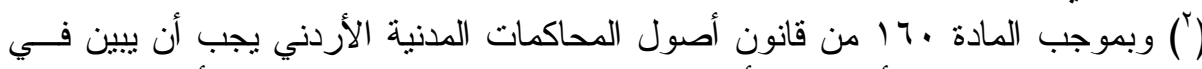

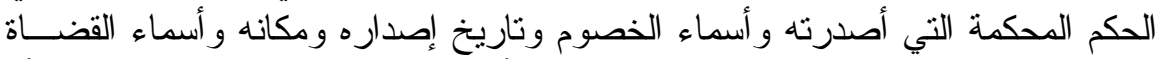

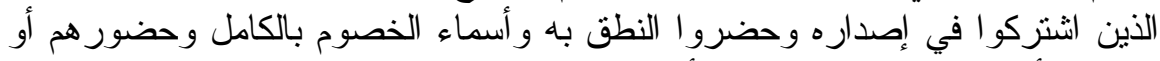

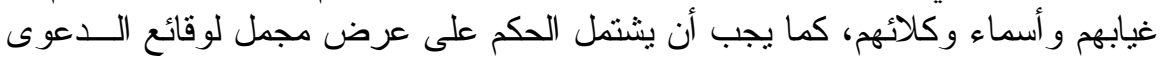




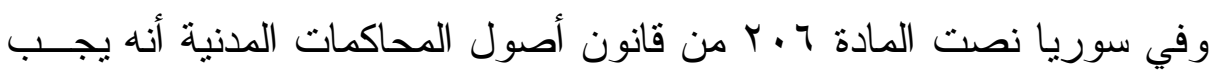

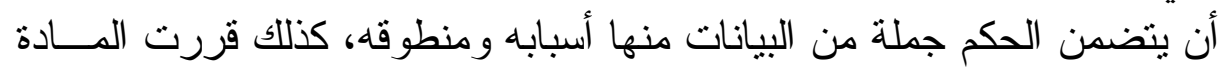

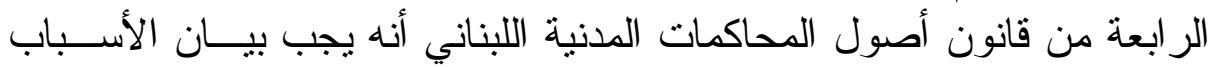

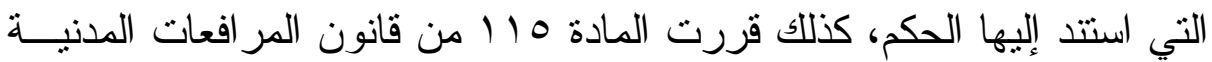
و التجارية القطري أنه: "يجب أن نتنمل الأحكام على الأسباب التي بنيت علئ النيها

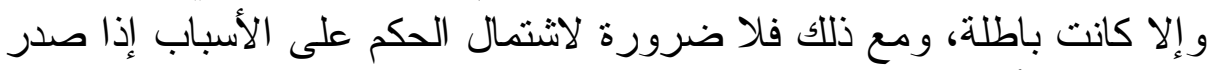

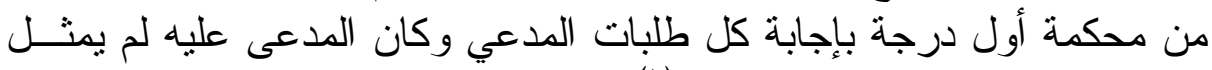

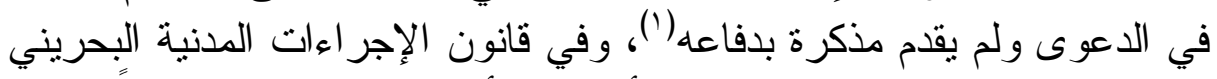

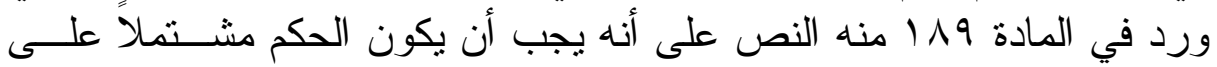

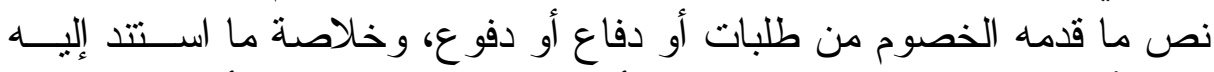

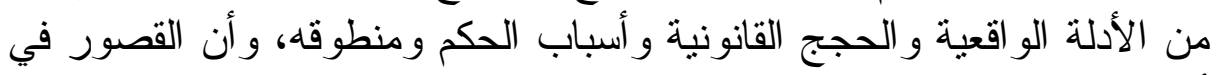

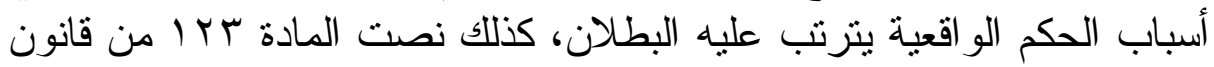

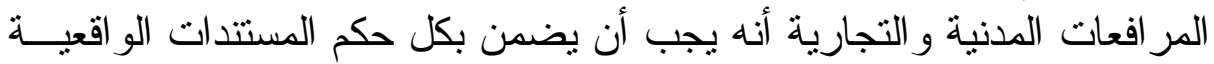

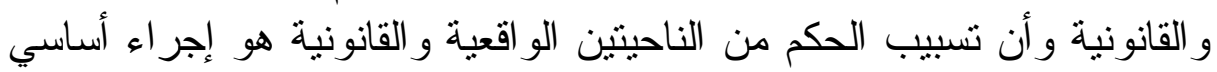

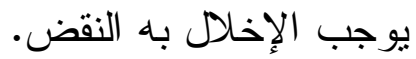
سادس عشر : خطة الدر اسة:

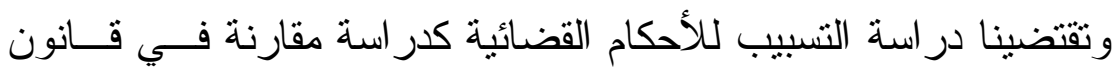
المر افعات المصري و الفرنسي أن نعرض للموضو عات الآتية:

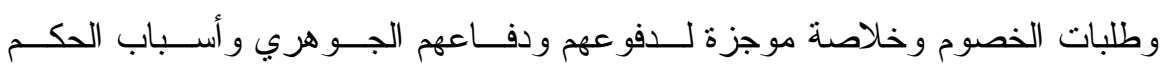
ومنطوقه، وقد أكدت محكمة التمبيز الأردنية على ضرورة لأوة هذه البيانات، راجع في في حكم

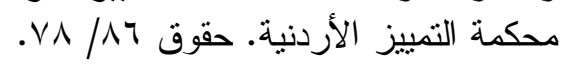

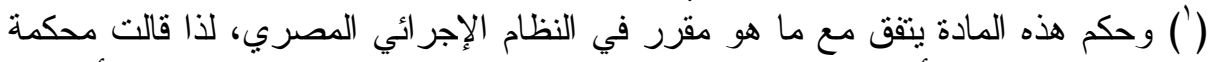

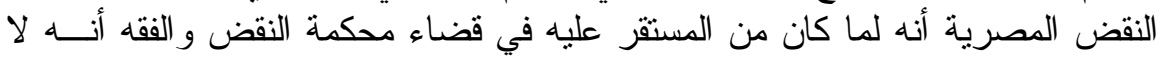

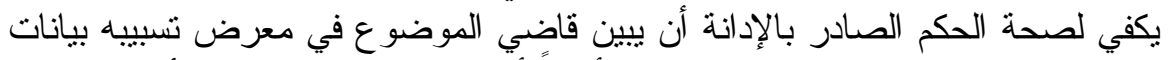

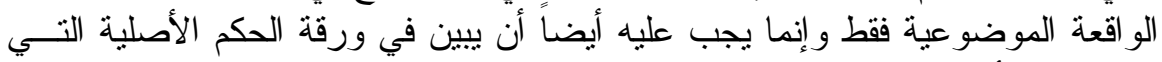

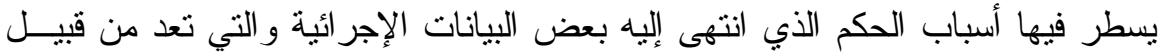

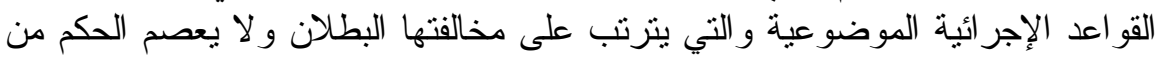

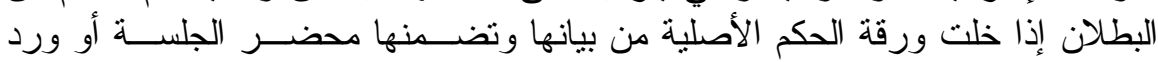

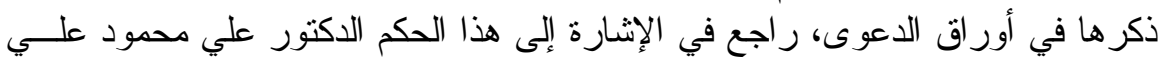

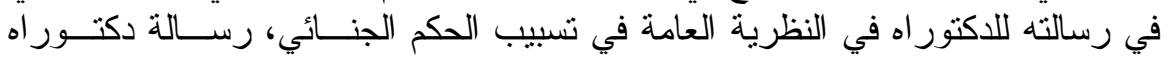

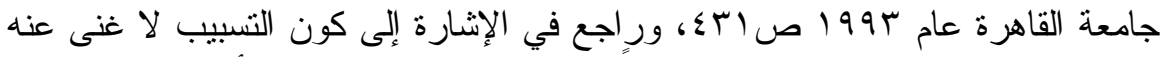

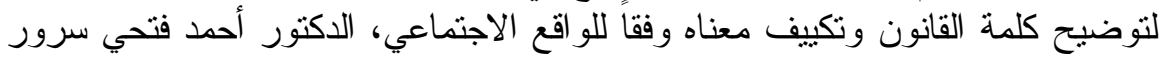

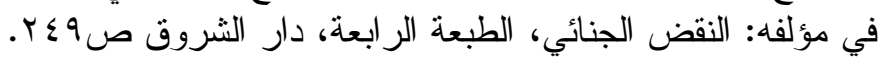


العدد الثاني- الجزء الثاني- السنة الثامنة والخمسون- يوليو 17 .

الفصل الأول: التكييف القانوني للتسبيب.

المبحث الأول: حقيقة تسبيب الأحكام القضائية.

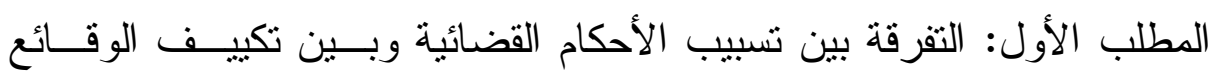
المعروضة في القضية.

المطلب الثاني: التقرقة بين تسبيب الأحكام القضائية وبـيـن تكييــــ الوقــائع المعروضة في القضية.

المطلب الثالث: دور التسبيب في بسط محكمة النقض لرقابتها علــى الســلامة

$$
\text { القانونية للحكم. }
$$

المطلب الرابع: الأثز القانوني لقصور التسبيب لوقائع الدعوى.

المبحث الثاني: النطاق القانوني للتسبيب.

المطلب الأول: الغرض من تسبيب الأحكام القضائية.

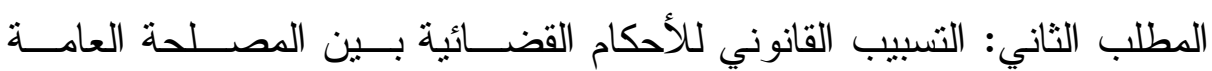

$$
\text { و الخاصة. }
$$

المطلب الثالث: علاقة تسبيب الأحكام القضائية بكفالة الحق في الدفاع. المطلب الر ابع: علاقة تسبيب الأحكام القضائية بالحق في العلم الإجرائي.

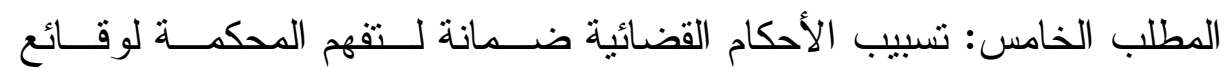

$$
\text { الدعوى في مرحلة التحقيق و المو اجهة. }
$$

المبحث الثالث: الأعمال القضائية اللازم تسبيبها وما لا يتعين التسبيب فيها.

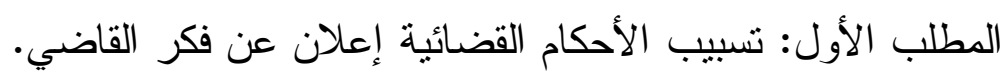
المطلب الثاني: الملامح الأصولية فيما بلزم تسبيبه في الأحكام القضائية. الفصل الثاني: الضوابط المعيارية لصحة التسبيب أو قصوره. المبحث الأول: التسبيب والسلطة التقديرية للقاضي.

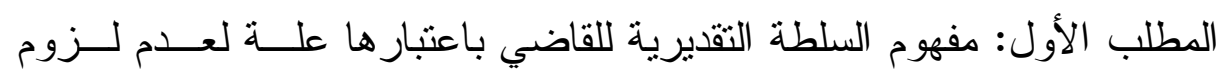

$$
\text { تسبيب الأحكام. }
$$

المطلب الثاني: التسبيب في الأحكام القطعية و الأحكام الوقتية و المستعجلة.

$$
\text { المطلب الثالث: التسبيب الضمني. }
$$

المبحث الثاني: المجالات الواقعية لتسبيب الأحكام القضائية أثناء الخصومة. المطلب الأول: التسبيب في مجال إخخال الغير في الدعوى. 
العدد الثاني- الجزء الثاني- السنة الثامنة والخمسون-يوليو 19.

المطلب الثاني: الارتباط كعلة لعدم تسبيب الحكم في حالة الإحالة إلى محكمــة أخرى.

المطلب الثالث: الاختلاف الفقهي حول لزوم تســبيب القــر ار الصــادر مــن المحكمة برفض إعادة فتح باب المر افعة في الدعوى لأفول.

المطلب الر ابع: التسبيب في مجال وقف الخصومة.

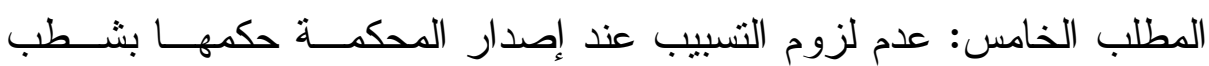
الدعوى.

المطلب السادس: الحكم بالمصاريف بين التسبيب و عدم لزومه. المبحث الثالث: حقيقة التسبيب في الأحكام القضائية بين الاتعدام والقصور. المطلب الأول: انعدام التسبيب كعوار شكلي في الحكم. المطلب الثاني: مو اطن القصور في التسبيب المؤدي إلى بطلان الحكم. خاتمة البحث. 


\section{الفصل الأول \\ التكييف القانوني لتسبيب الأحكام القضائية \\ المبحث الأول \\ حقيقة تسبيب الأحكام القضائية الاول}

كثير اً ما تعرض الفقهاء في فقه المر افعــات لمســألة تســبيب الأحكـــام

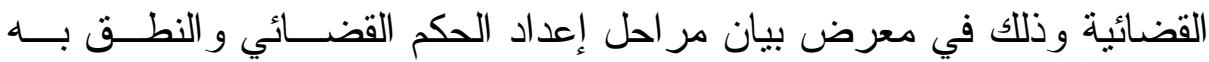

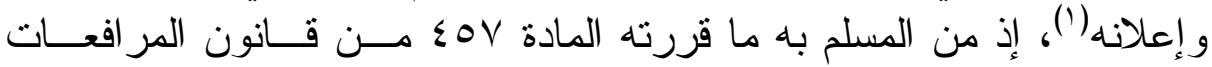

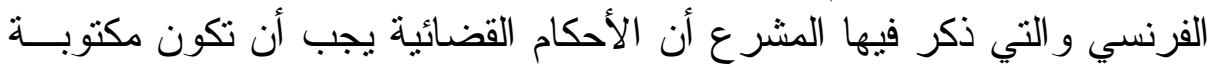

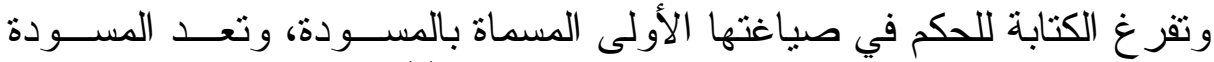

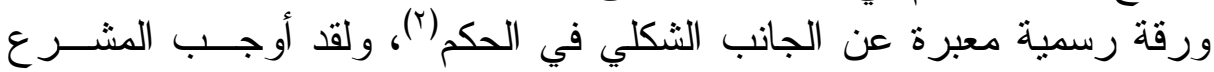

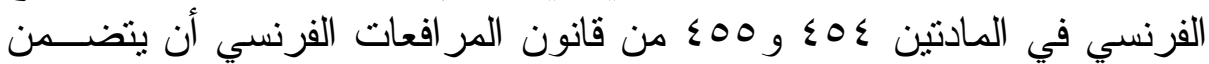

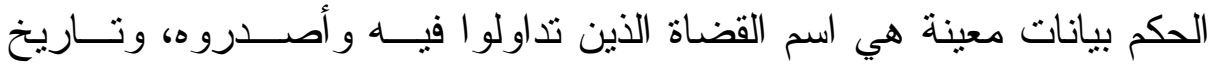

(') ور اجع منثلً في لزوم كون أسباب الحكم حقيقية وكافية في قضاء الــنضض الفرنسـيـي: نقض فرنسي. الدائرة التجارية:

com. 18 juin 1985. Bull. Civ. No 194 p. 162.

Cass. Civ. $1^{\text {er }}, 9$ mars 1994, Bull. Civ. I. no 92. Rev. ور اجع أيضنا: Trim. Dr. civ. 1994. 421. obs. Parrot.

$$
\text { ور اجع في عرض مر احل إصدار الحكم القضائي ومرحلة المداولة والإصدار: }
$$

P. Drai; "le délibéré et L' imagination des juges"; Mélanges perrot.

P. 107 et.s.

L- de Naurois; la procédure de vote du tribunal collégial' وراجع أيضـــا Mélanges Vincent. P. 245. et.ss ( ) وفي الفقه الإجر ائي الفرنسي قال الأستاذان Gérard Cornu et . Jean Foyer بـــأن

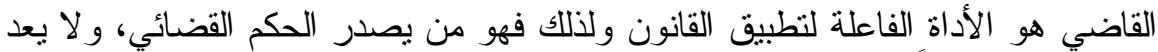

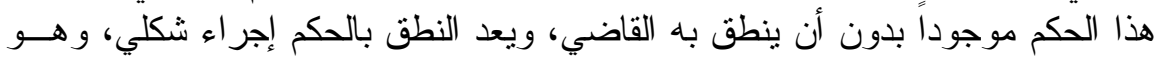
مرحلة أخيرة في إصدار الحكم بعد المداولة.

Le juge est le verbe de la loi; il doit prononcer ses sentences et le jugement n' existe pas tant qu'il n'a pas été prononcé. Le prononcé est entouré de formalité tout comme le délibéré.

ويضيف الفقيهان إلى ذلك قولهما بأنه لئن كان من الكازم أن تكون المداولة سرية فــإن

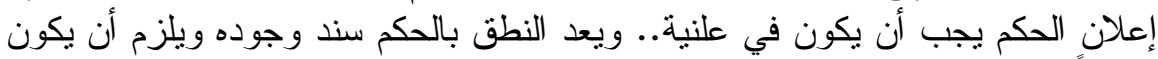

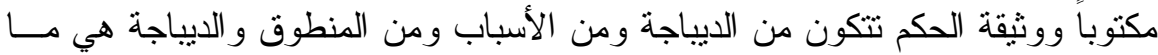

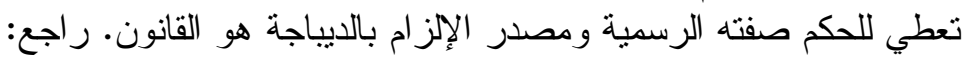

Gérard Cornu et Jean Foyer; Procédure civile; op. cit. p. 436. 
الحكم، و اسم ممثل النيابة العامة في الحالات التي أوجب فيها المشر ع تمثنــلـ

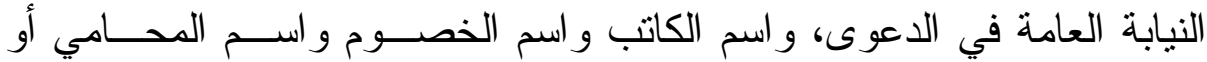

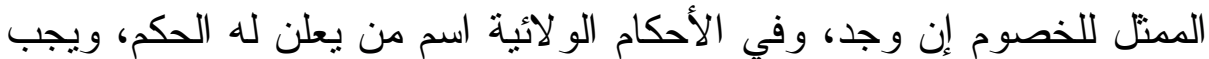

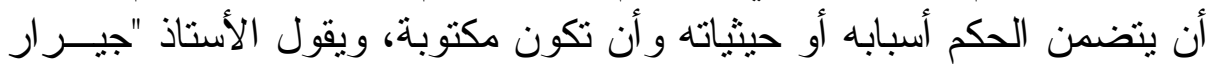

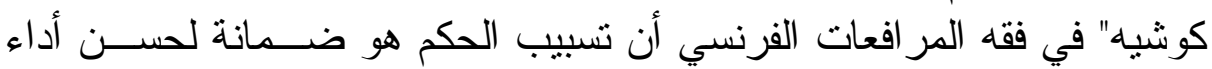

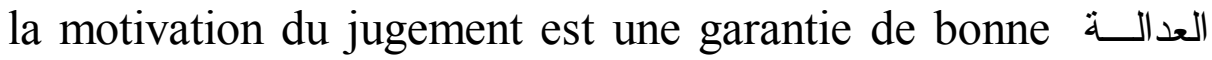
(') لأن معرفة الأسباب هي وسيلة وزن وتقدير الحكم في ذاته و السبيل

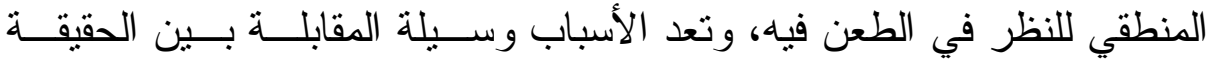

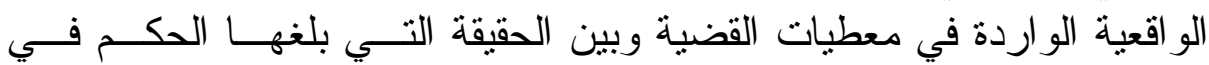
منطوقه:

La partie "motifs" du jugement comprend à la vérité deux séries d' énonciations: c' est qu' en effet sont tout $d^{\prime}$ abord exposés "succinctement les prétentions respectives des parties et leurs moyens" puis sont indiquées les raisons (la motivation stricto sencu) de la décision. ${ }^{(2)}$

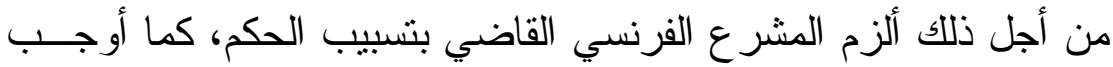

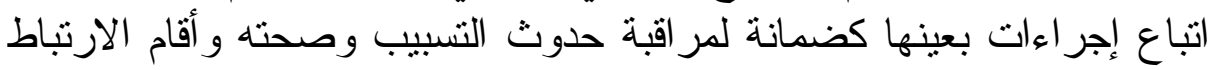

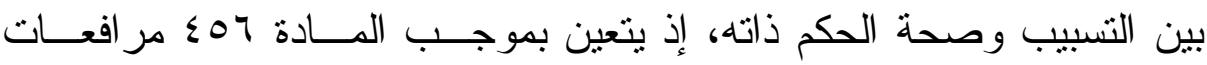

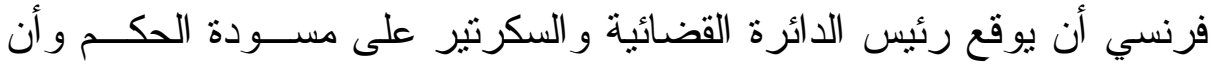

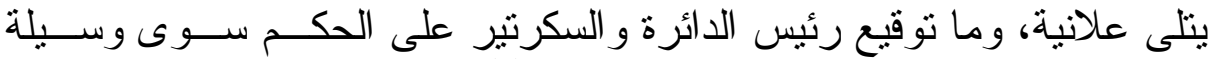

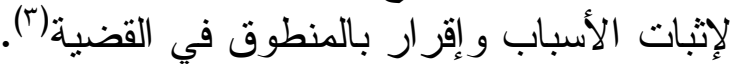

Gérard Couchez; op. cit. p. (') راجع: 299 ور اجع كذلك الأستاذان "كرنو وفوييه" حيث يشير ان إلى أن أسباب الحكم هي الحيثيــات

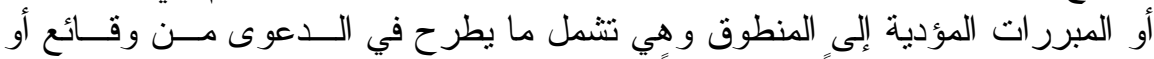

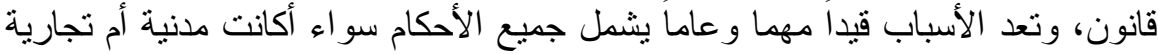
أم جنائية، وذللك بخلاف بعض الحاب الحالات الاستثائية: Les motifs sont 1 ' exposé des raisons de fait et de droit qui ont déterminé la décision. L'indication des motifs est une règle génerale applicalicable en toutes matièrs.

رérard Cornu et Jean Foyer; op. cit. p. 437

Gérard Couchez; op. cit. p. 299. .

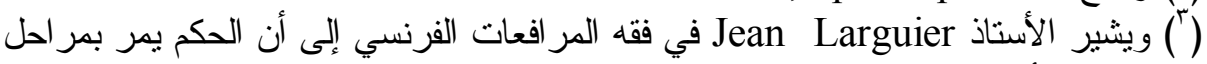

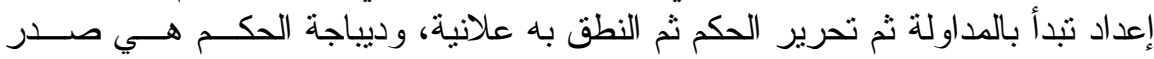




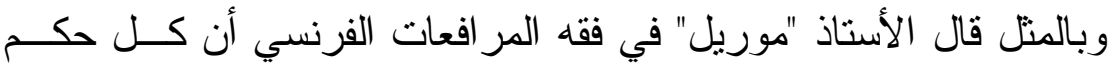

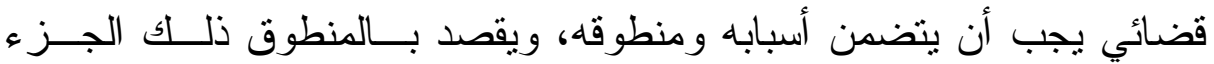
الأخير من الحكم الذي يضمنه القاضي الحل النهائي للقضية، ويستوي في هذا

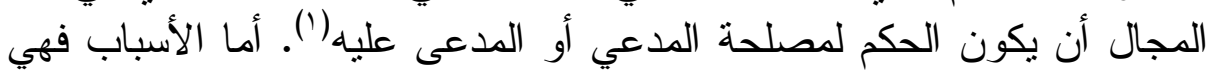

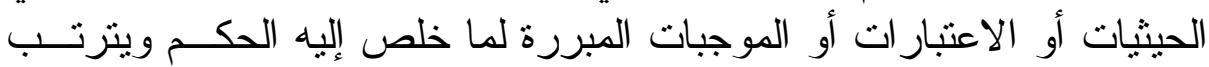

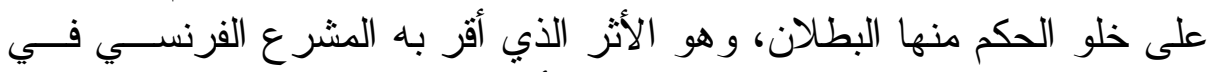

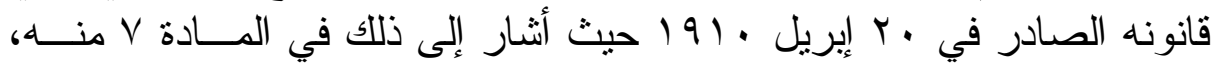

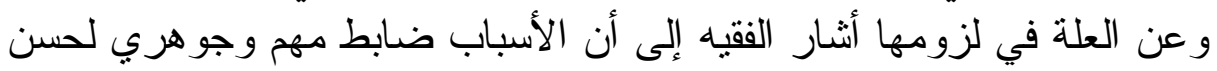

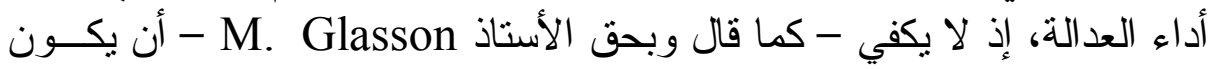

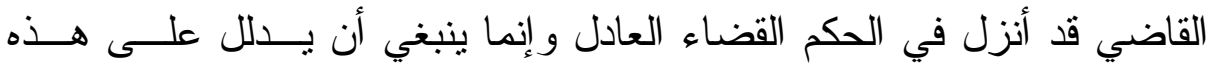

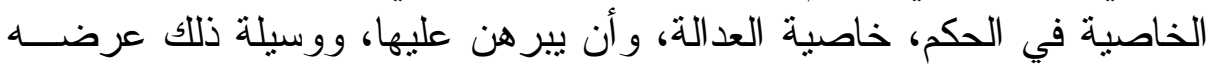

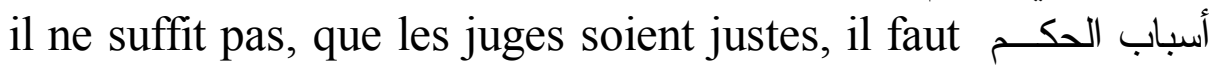
encore qu' ils en donnent la preuve

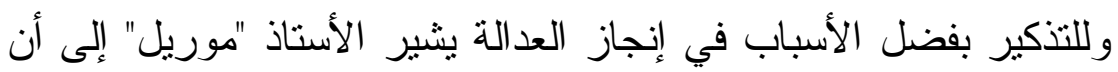

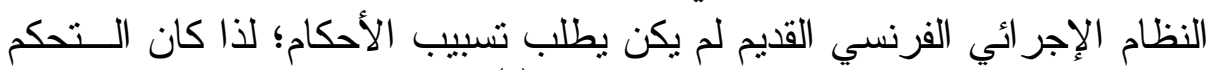

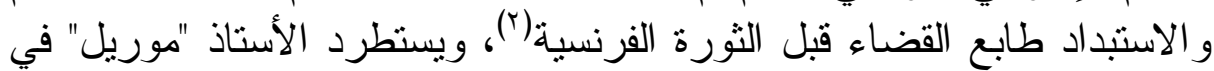

الحكم، و هي ما تضفي عليه طابع الرسمية، أما الأسباب فهي ما تلِي الديباجة، و الأسباب

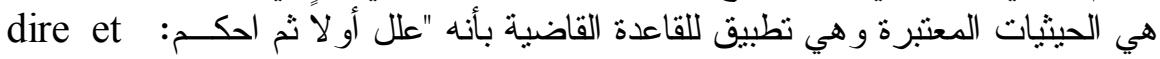

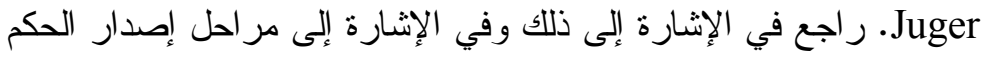
Jean Larguier; procédure civile; op. cit. p. 97 René Morel; Traité élémentaire de procédure civile; op. cit. p. راجع: (')

439. No. 559.

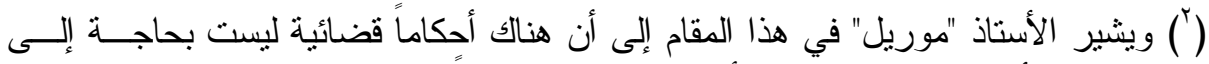

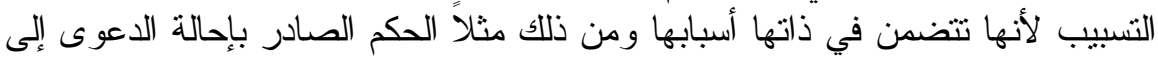

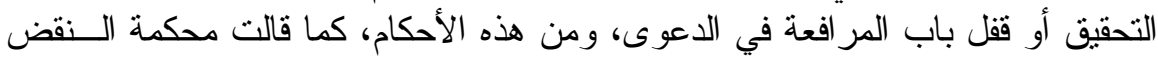

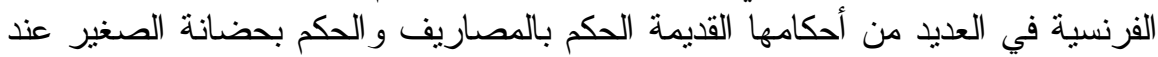
الطلاق و الحكم برفض فئ منح أجل إضافي.

Echappent encore, d' après la cour de cassation à la nécessité d'être motivés, les jugement prononçant une décision qui est l'application pure et simple de la loi, par exemple, la condamnation aux dépens de la partie qui succombe, la decision qui confie la garde des enfants à l'epoux qui a abtenu le divorce et le jugement qui refuse un délai de grâce purement facultatif.

$$
\text { راجع "موريل" في المرجع السابق ص. • ؛ فقرة 009. }
$$




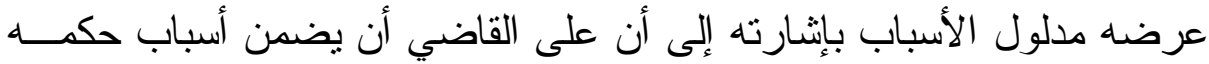

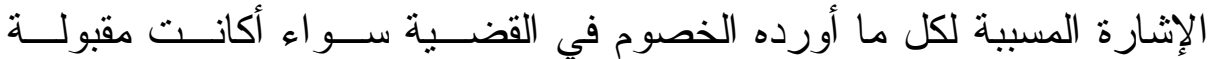

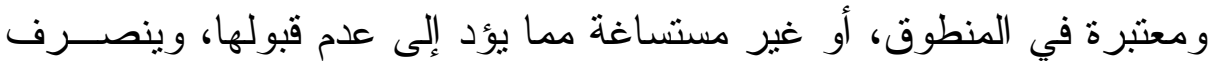

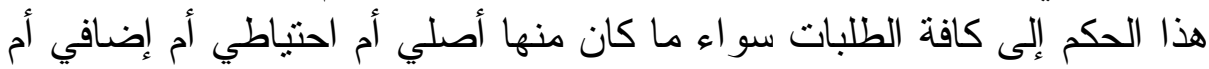

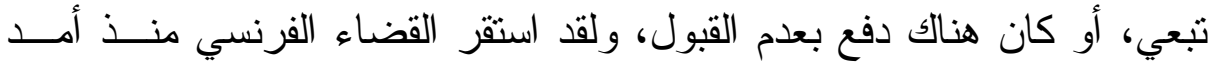

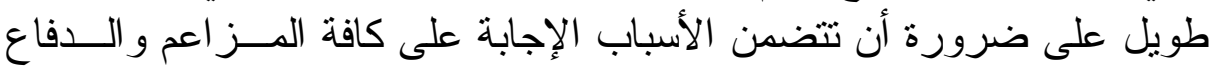

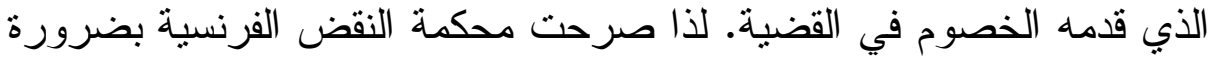

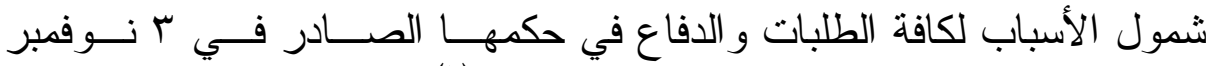

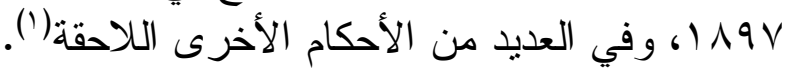

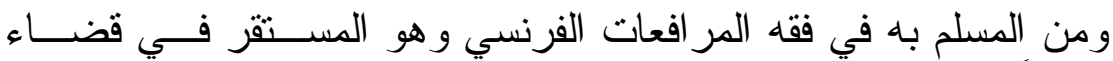

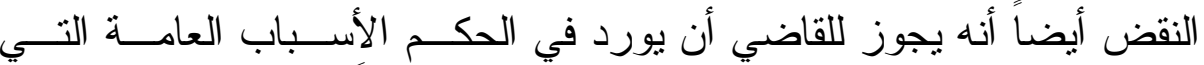

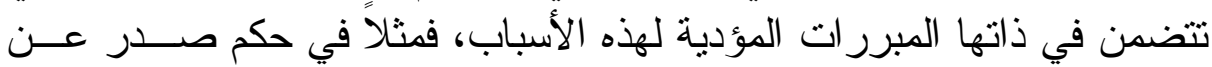

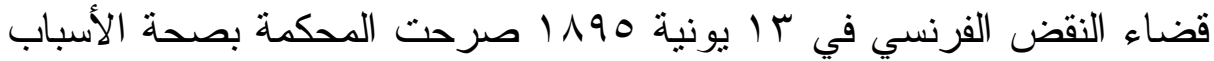

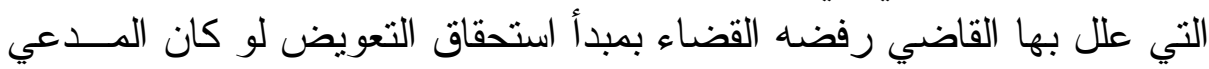

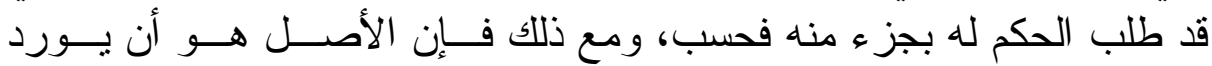

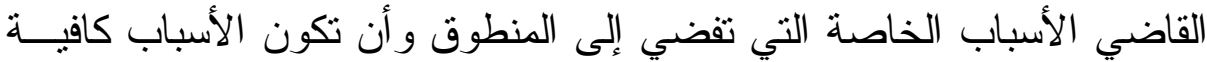

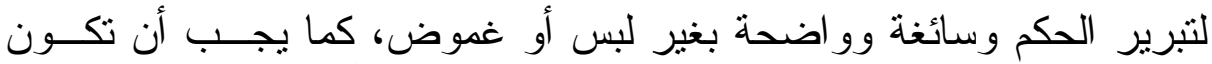

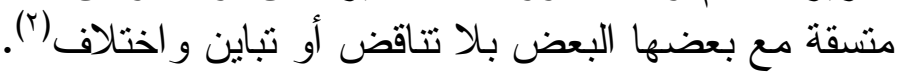

$$
\text { (') راجع "موريل" في المرجع السابق ص •ـءء ، الموضع السابق، وراجع أيضاً: }
$$

H. Motulsky; la cause de la demande dans la delimitation de l'office du juge. Dalloz. 1964 p. 235 ets.

P. Mimin; Hésitations du formalisme dans les jugements; sem. Jur. 1956. 1. 1447.

$$
\text { ور اجع كذلك: }
$$

ph. Malinvaud; il ne suffit pas d' affirmer, encore faut - il motiver, revue de droit immobilier - urbansime - construction, no. 11. Decembre 2008 chroniques p. $556-557$, note a propos de $3^{\text {e }}$. civ. 22 octobre 2008.

(') وقد صارت محكمة النقض الفرنسية على ذات المنو ال في العديد من أحكامها القضائية

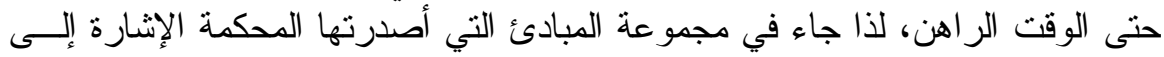

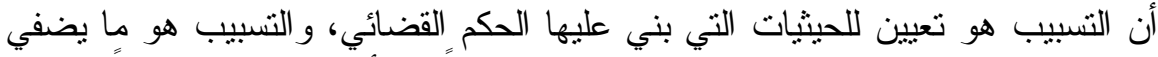
المشروعية على الحكم القضائي، وإذا جاء الحكم خلواً من أسبابه كان ذلانك سبياً لبطلانه

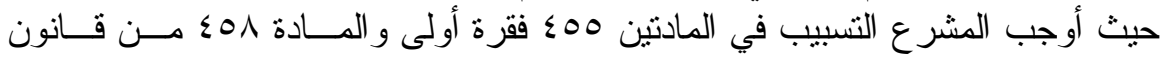


وكثير اً ما تساءل الفقهاء حول الطبيعة القانونية للالتز ام بتسبيب الأحكام

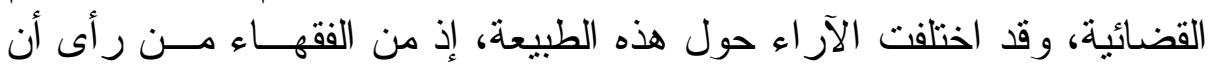

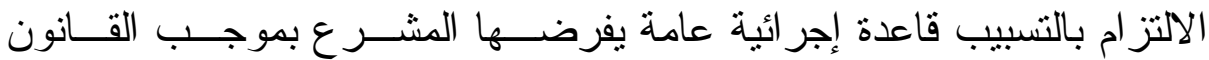
الإجر ائي وبموجب قانون المر افعات، وقال رأي آخر بأن هذا الالتز ام هو مبدأ إجرائي عام وليس مجرد قاعدة إجرائية وحسب، ووجه الاختلاف بين الر أيين

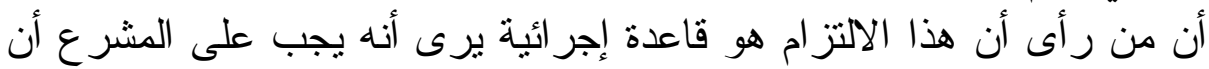

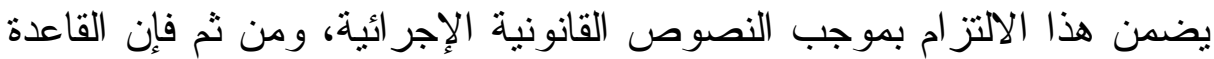
الإجر ائية هي مصدر الالتز ام بالتسبيب(')، لذا فإن النصوص إذا خلت من هذا

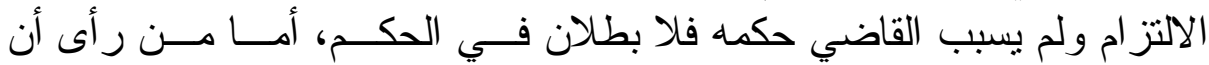
الالتز ام بالتسبيب هو من مفترضات المبدأ الإجرائي فإنه لا يرد هذا الالتــز ام

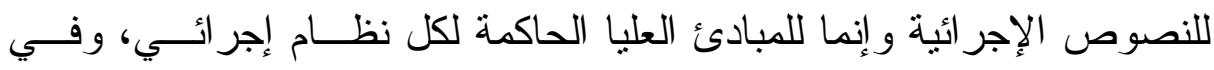

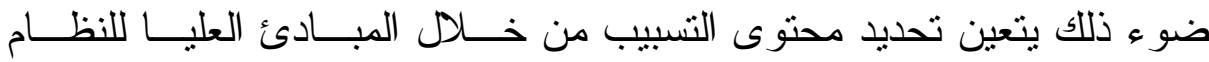

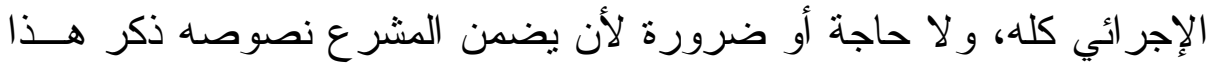

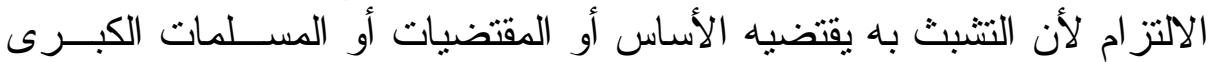

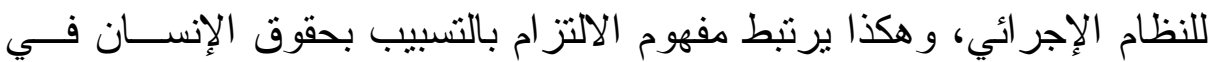

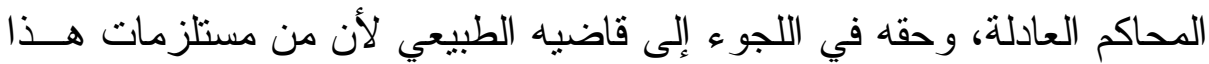
القضاء العدالة، و لا عدالة بدون إظهار الأسباب(؟).

لكن هل يمكن اعتبار التشبيب مجرد إجراء شكلي أم أنه نشاط إجرائي?

$$
\text { المر افعات الفرنسي... راجع: }
$$

Dictionnaire du droit privé de Serge braudo; définition de moyens et motifs.

(') ومن الفقهاء من تساءل عما إذا كان التسبيب شرطاً لازماً في الحكم القضائي في مجال

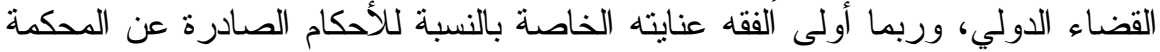

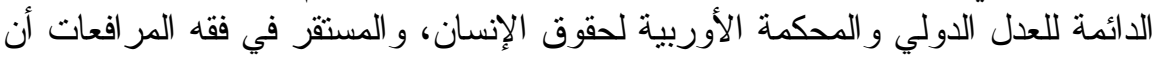

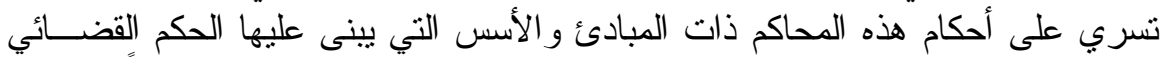

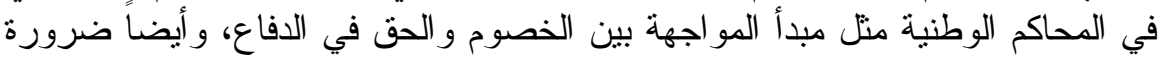

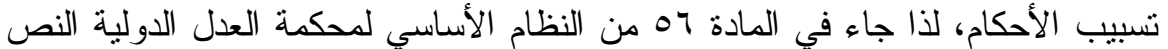

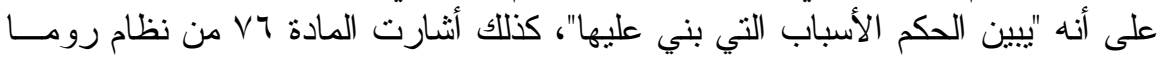

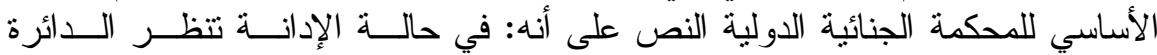

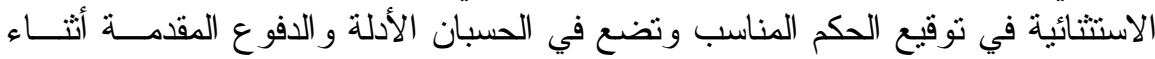

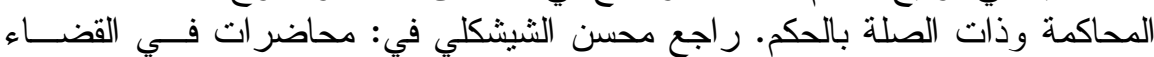

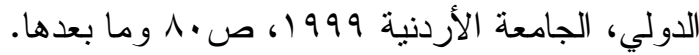

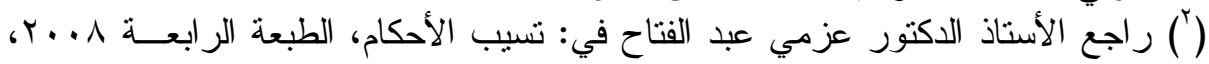
سابق الإثارة إلبه، ص الإن الاكور عزمي وما بعدها. 
من الفقهاء من رأى أن التسبيب إجراء شكلي، و السند في ذلك اعتبار الأسباب

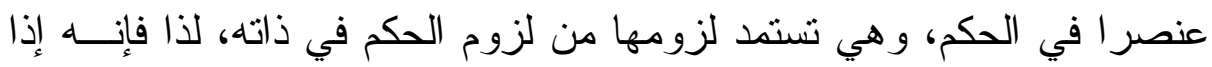

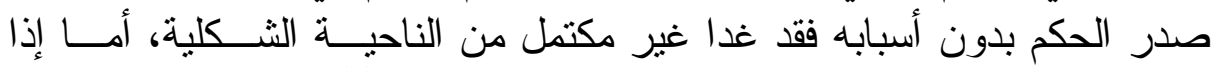

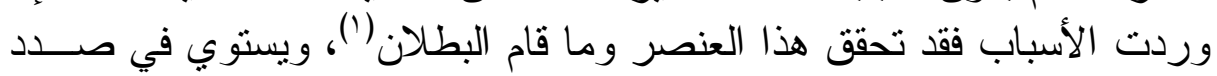

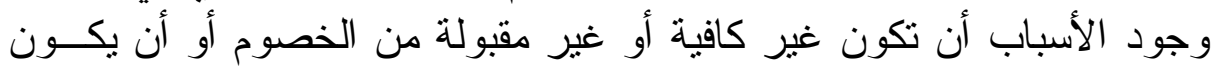
هناك تتاقض بين الأسباب أو أن تكون غير مؤدية إلى ما انتهى النهى إليه الحكم في

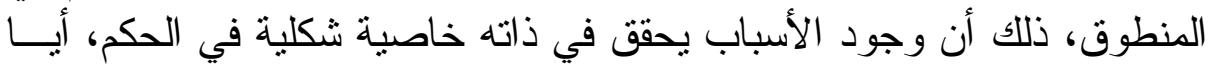

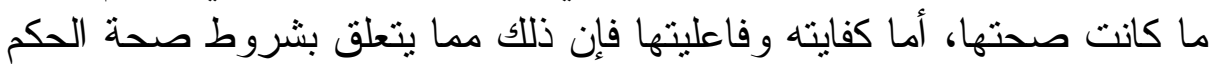

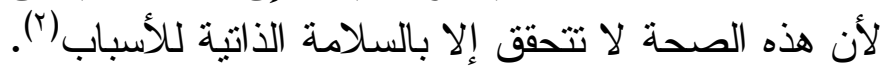

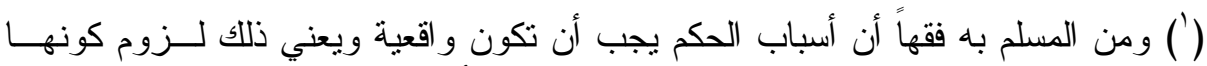

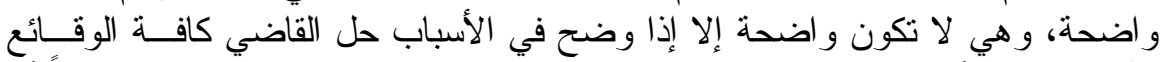

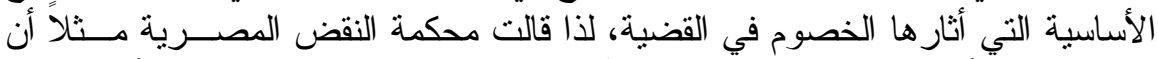

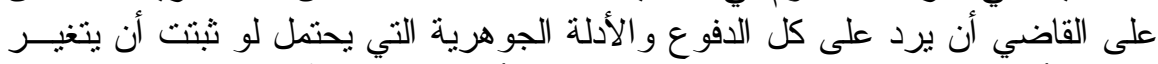

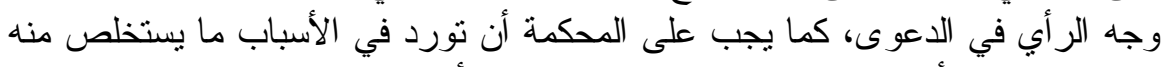

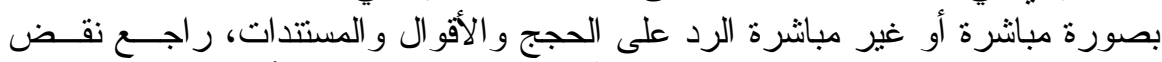

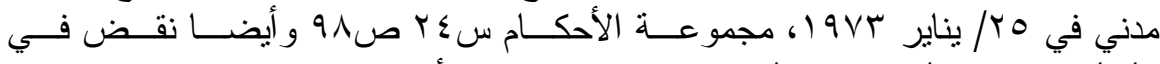

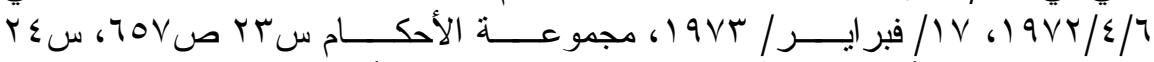

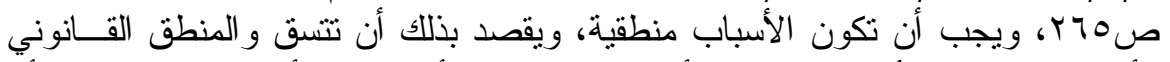

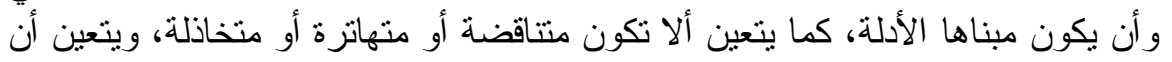

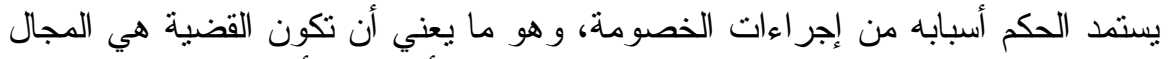

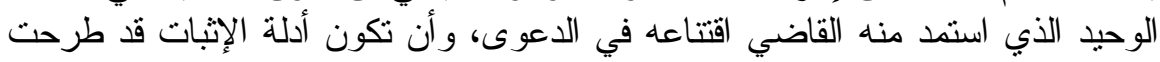

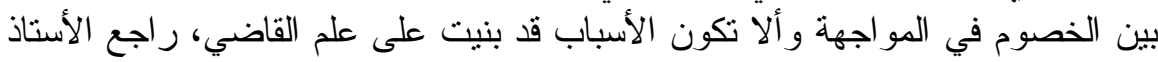

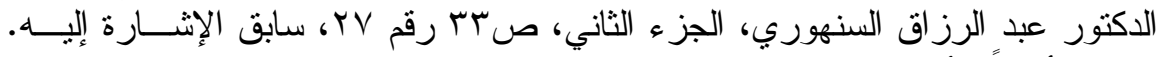

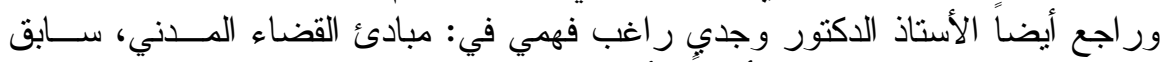

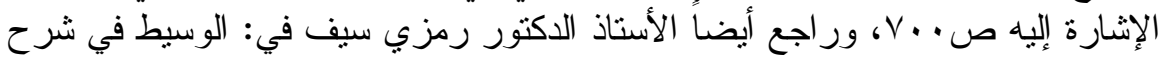

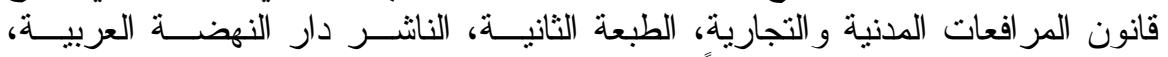

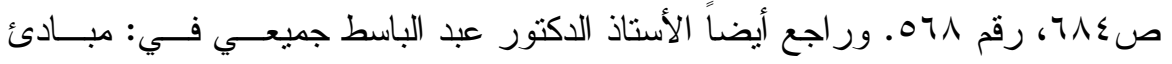

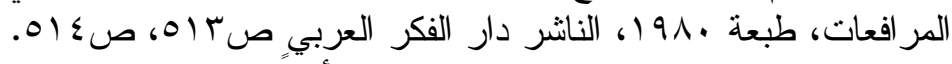

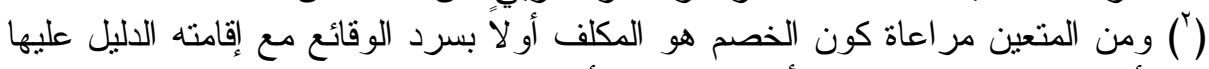

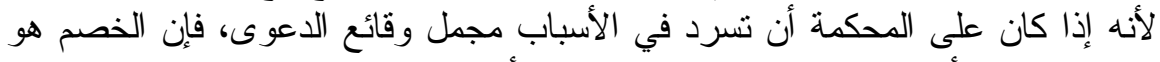

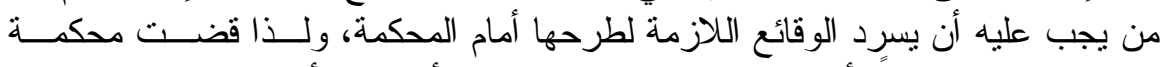

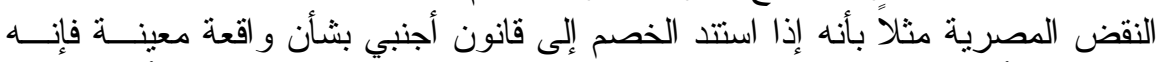

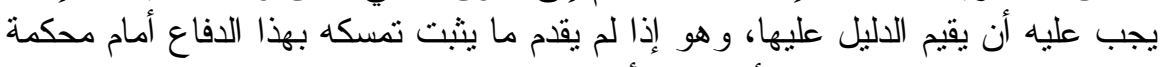

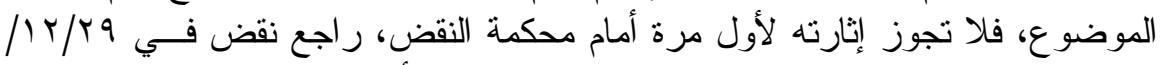

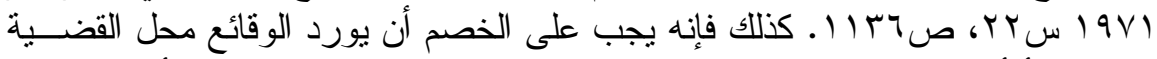

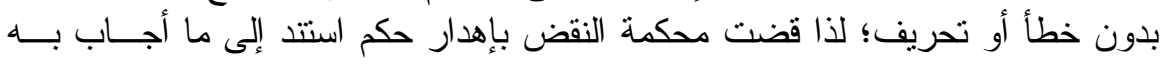




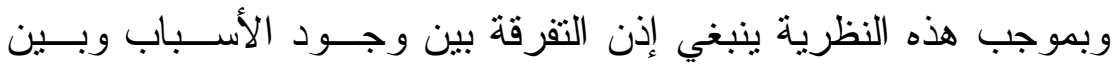

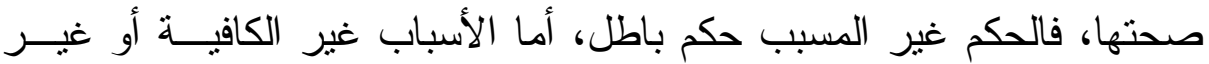

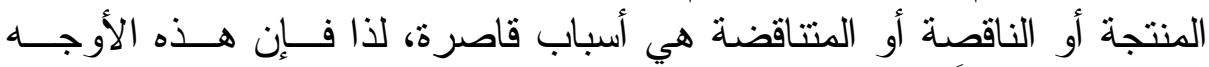

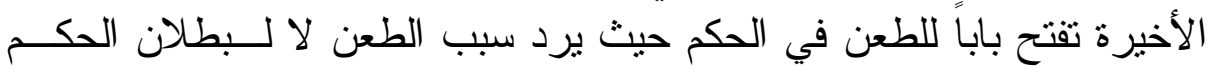

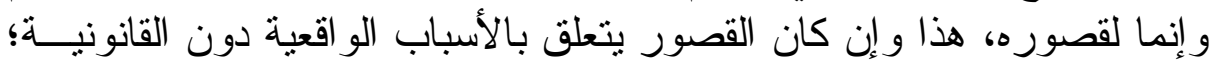

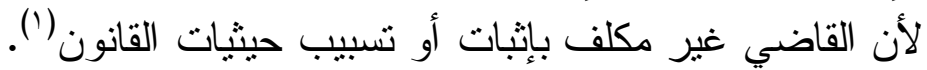

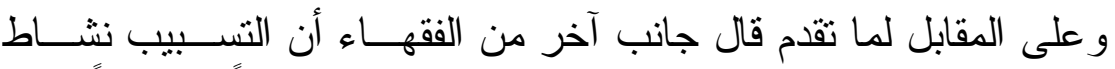

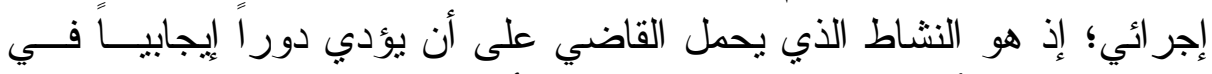

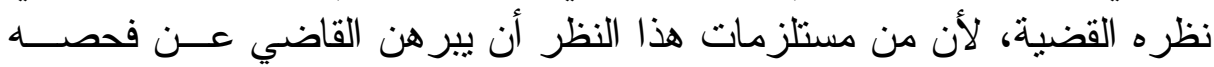

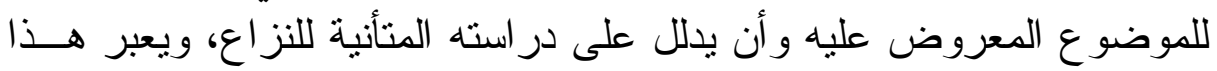

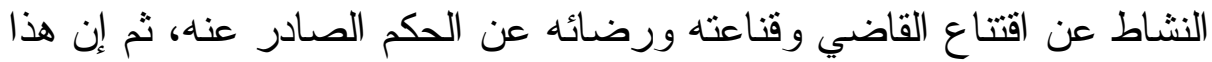

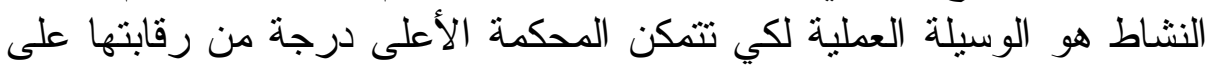

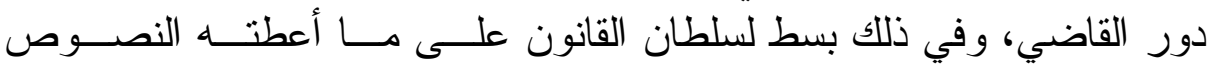

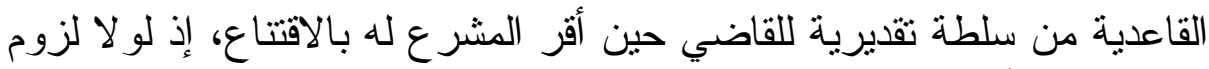

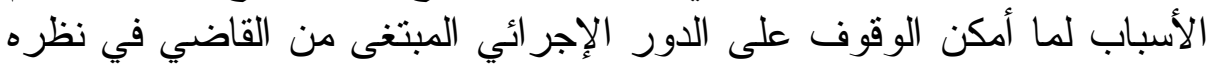

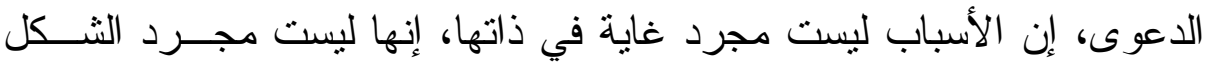

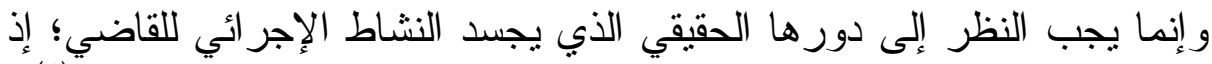

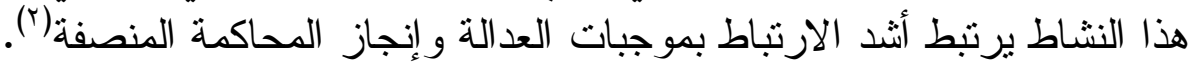

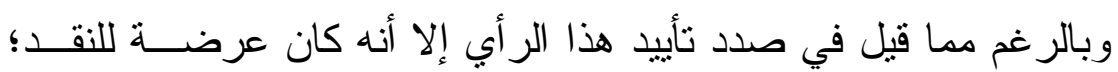

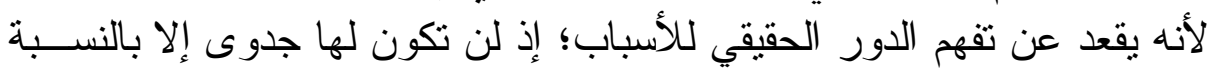

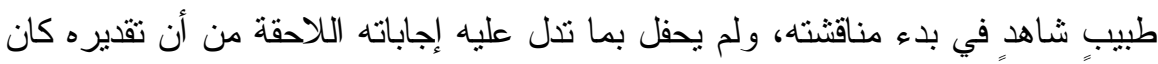

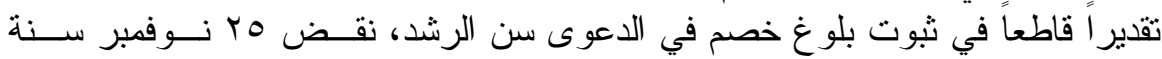

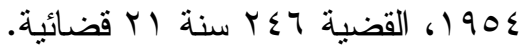

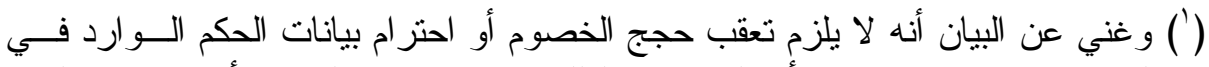

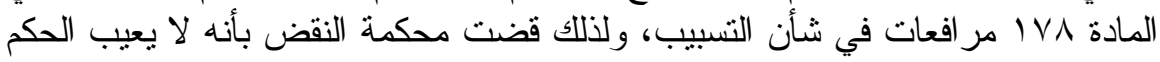

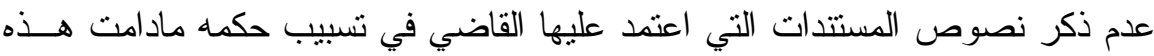

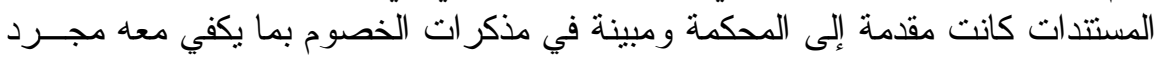

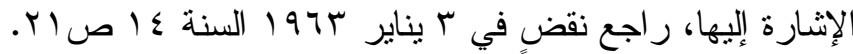

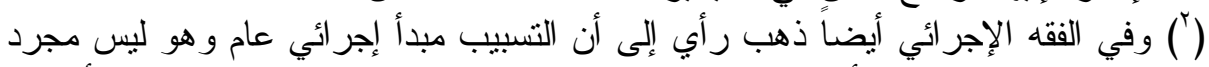

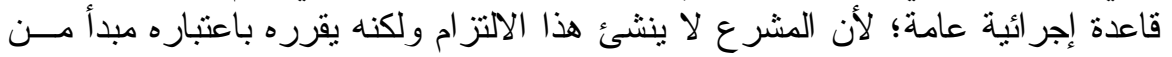

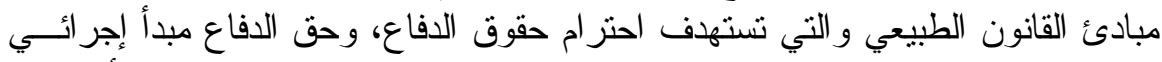

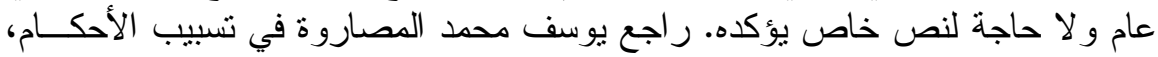

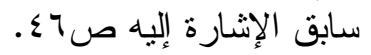


للأحكام الجائز الطعن فيها حيثما يقرر المشرع جواز الطعن في الأحكام، أمســا

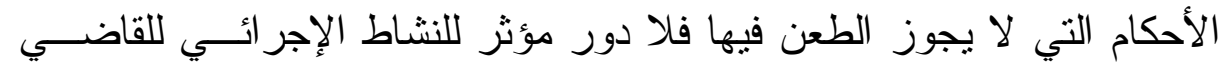

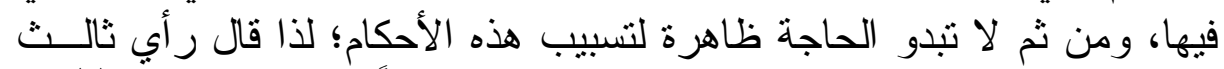

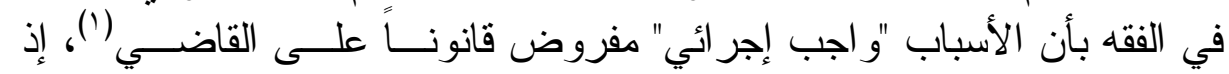

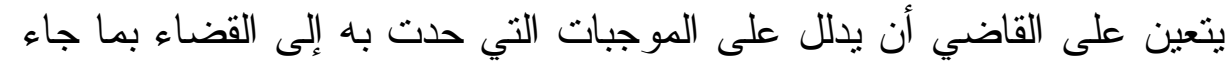

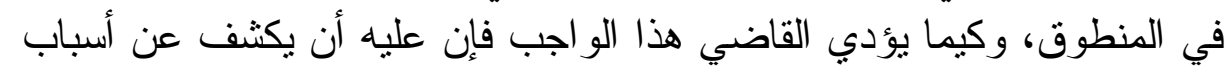

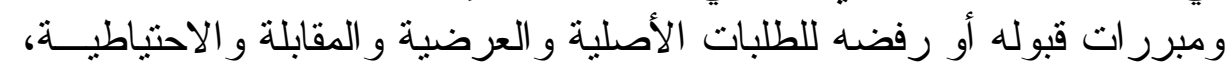

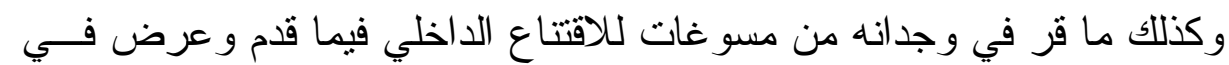

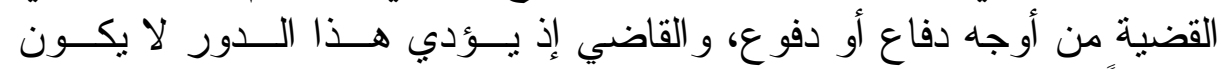

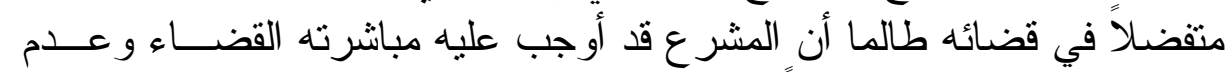

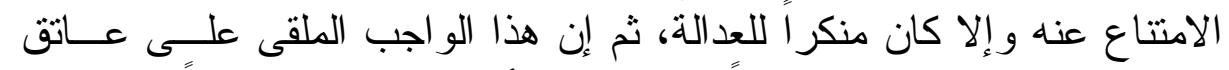

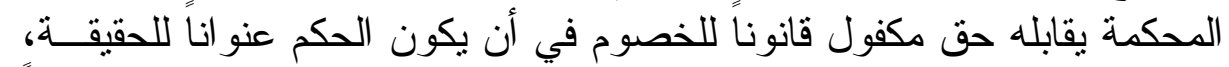

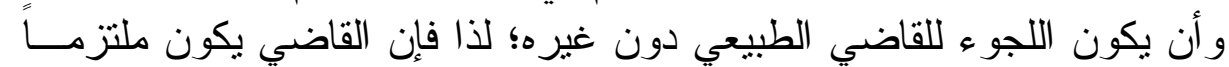

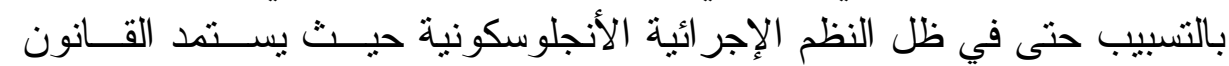

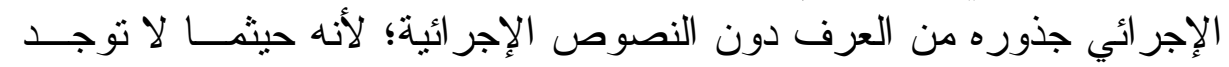

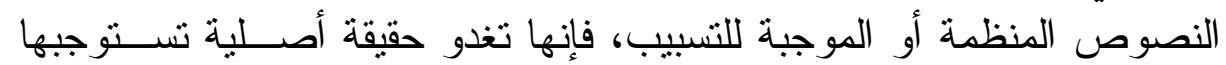
فكرة الو اجب الإجرائي المفروض على الع القاضي (؟).

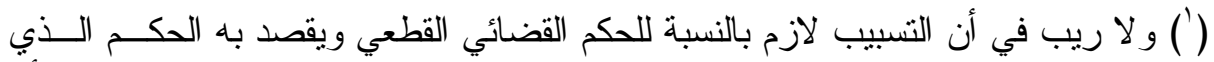

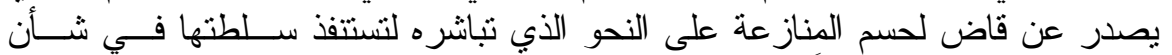

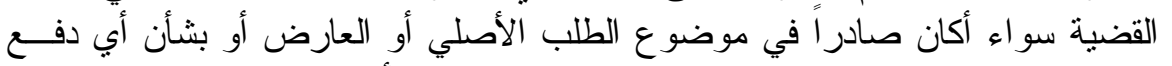

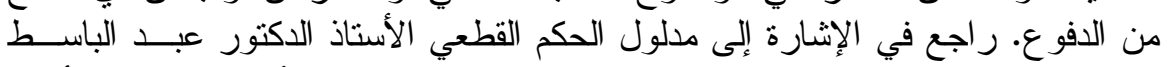

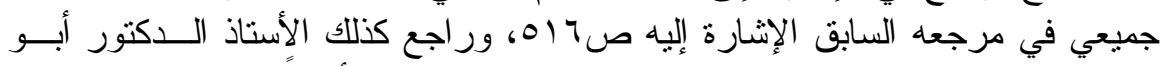

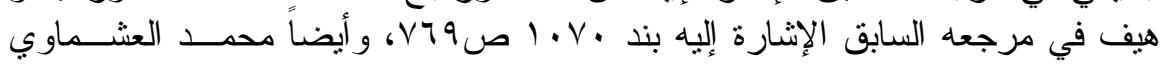

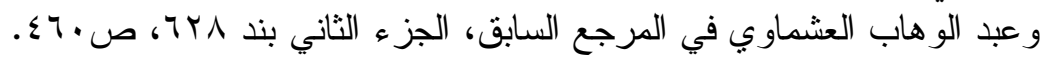

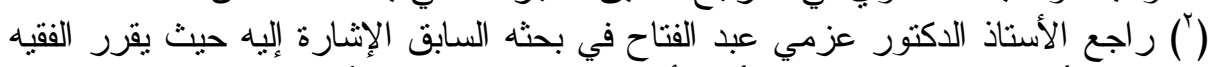

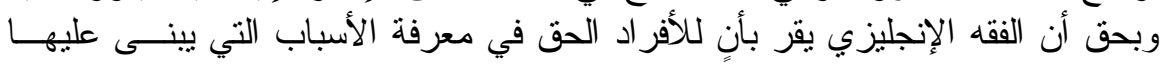

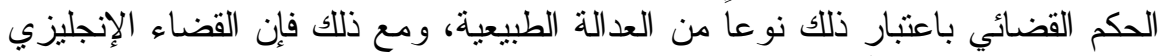

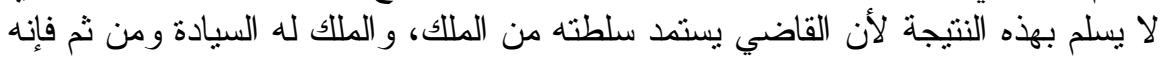

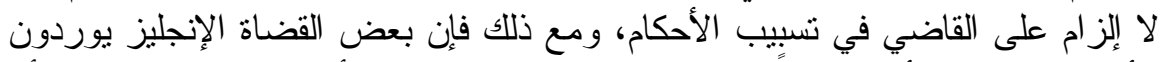

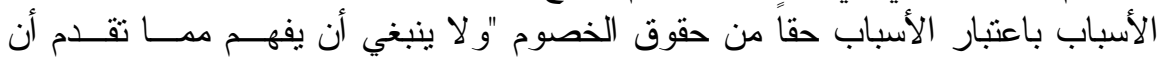

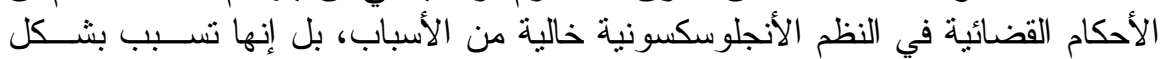

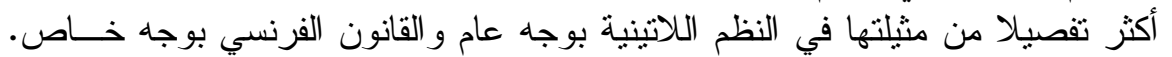

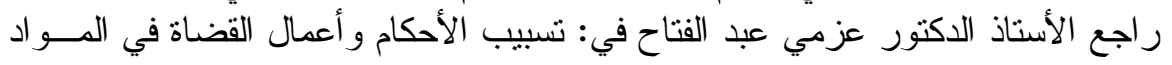

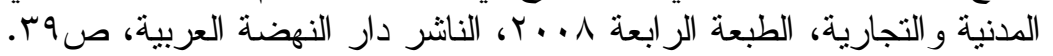


و على كل حال فإنه بالر غم مما قيل من حجج و اعتبار ات نوجب نسبيب

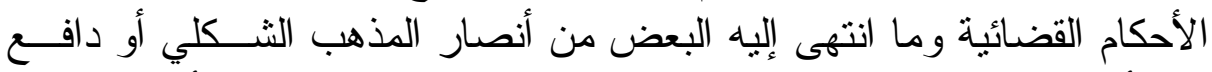

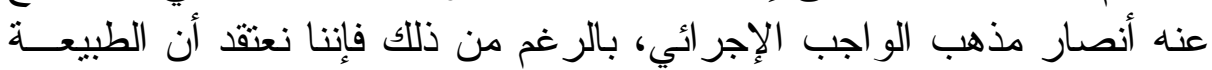

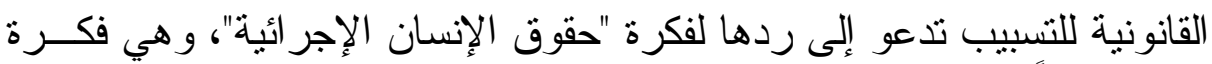

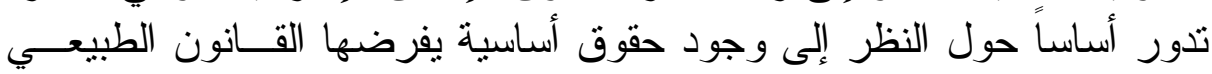

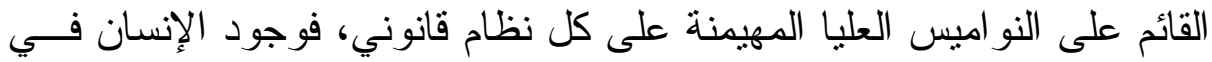

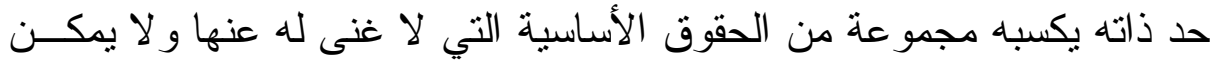

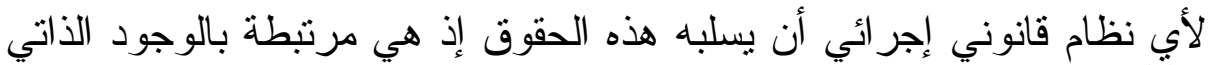

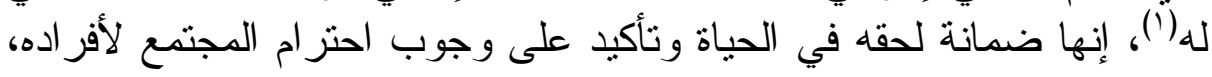

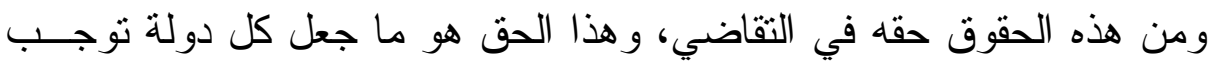

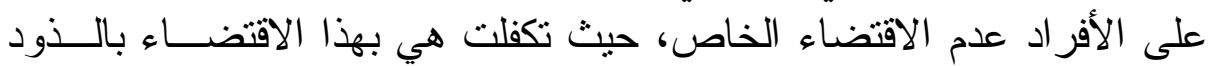

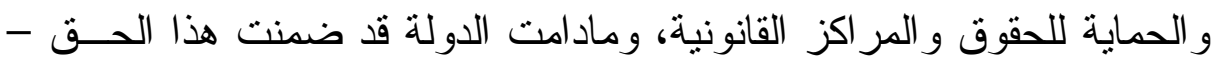

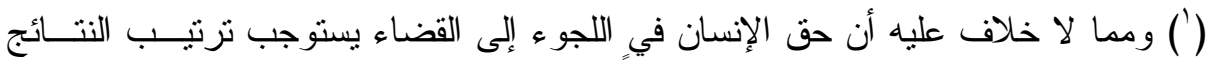

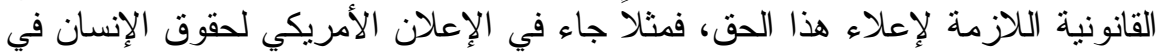

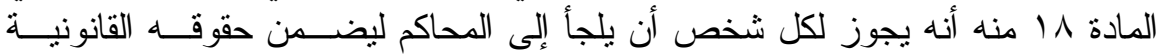

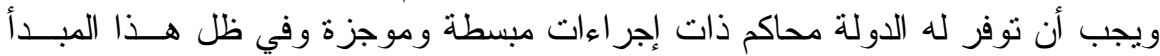

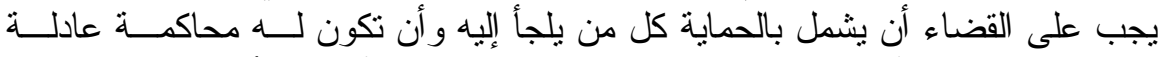
ومنصفة؛ لذا قال الأستاذ Richard B. Lillich في الفقه الأمريكي أنه: Every one is entitled in full equality to a fair and public hearing by an independent and determination of his rights and impartial tribunal, in the obtigations.

Richard B. Lillich, the jurisprudence of human rights in theodor moron; Human rights. Oxford. Civil rights. P. 140

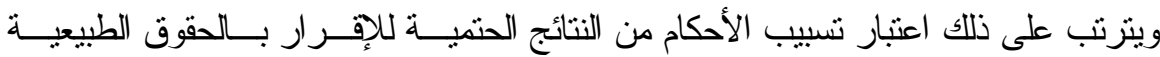
للإنسان، وراجع في عرض فكرة الحقوق الإجر ائية للإنسان وكونها نتيجة للقانون الطبيعي. Jerome Shecstack; the jurisprudence of human rights. Theodor Moron; Human rights. P. 77.

$$
\text { ور اجع أيضا: }
$$

M. Jacques Flour; cours d' introduction a' l' etude du droit et droit civil. 1968 p. 35 ets.

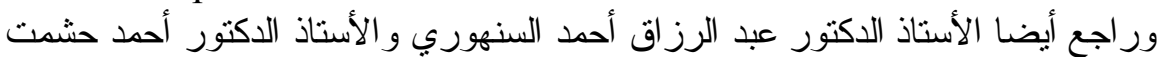

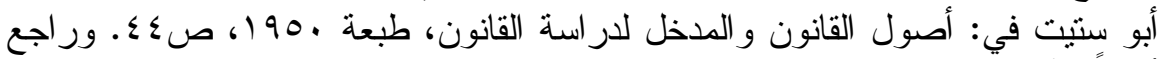

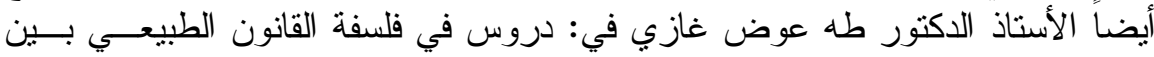
المنادين به و المنكرين له، الناثر دار النهضة العربية بدون سنة نشر ، صري فر وما بعدها. 


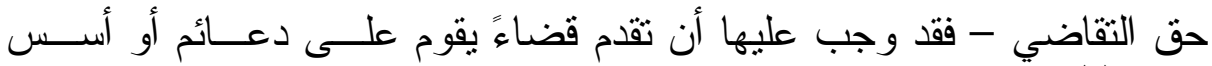

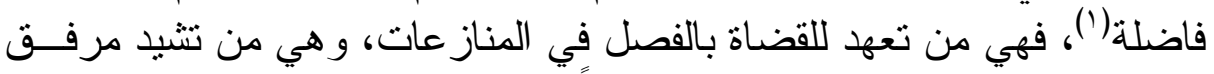

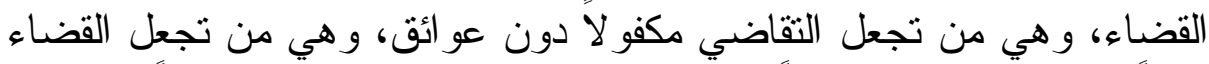

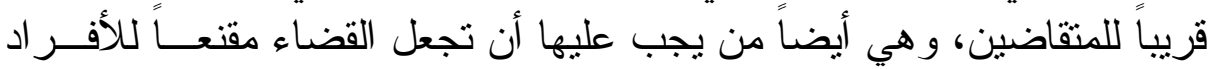
إذا اختصمو ا، ويتقرع عن ذلك عدة نتائج منها أن بكثف القاضي عن عن مبررات

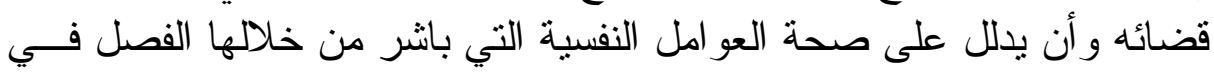

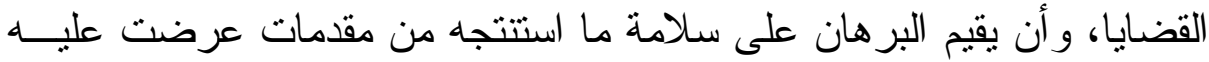
و أن يعزز موجبات الاطمئنان في حكمه، لذا لا يكفي مجرد إير اد الأسباب في الحكم و إنما يجب أن تتو افر فيها خصائص الأسباب الصحيحة من حيث كفايتها

ومعقو ليتها و منطقيتها وتتاسقها وتماسكها (r).

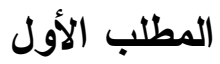

\section{المكانة الإجر ائية للأسباب وعلاقتها بالحكم الأب}

يمكن تعريف الحكم القضائي في معناه الو اسع بأنه القرار الذي يصـــدر

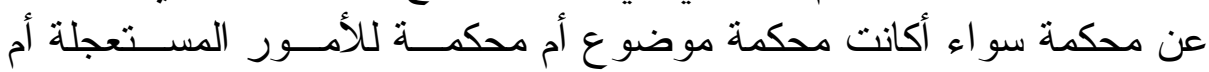
محكمة تتفيذ بشأن قضية مطروحة أمامها فيما يخص الجانــب الإجر أُـي أو فو

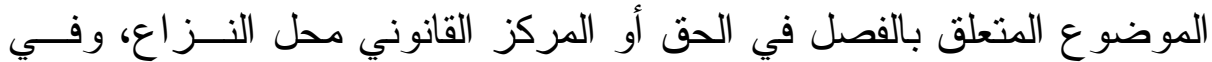

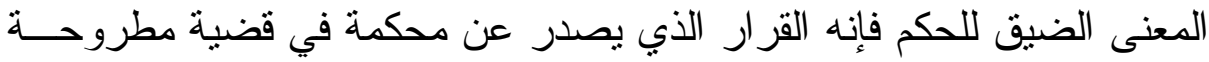

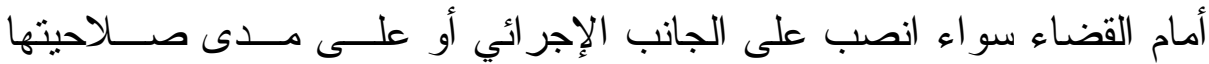
للفصل في الدعوى، ويستوي في هذا الصدد أن يكون هذا الحكم في أثناء سير الدعوى أو نهايتها.

ويتكون الحكم القضائي من مظهر موضوعي و آخر شـــي، فالعنصــر

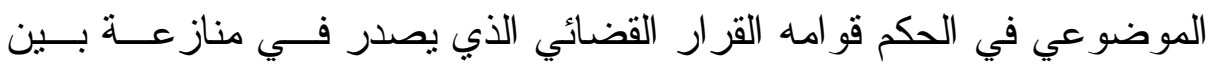

(') راجع في الإشارة إلى ذلك المبادئ الأساسية بشأن استقله السلطة القضائية الصــادرة عـن

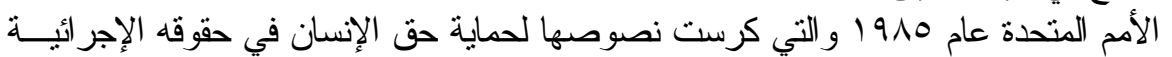

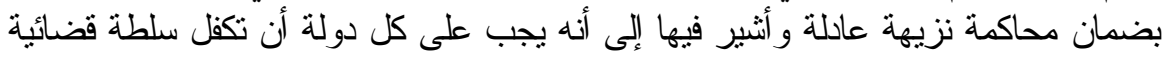

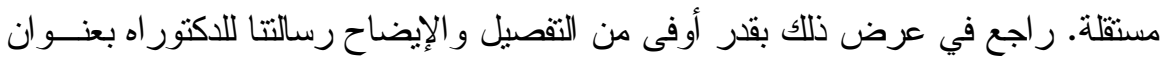

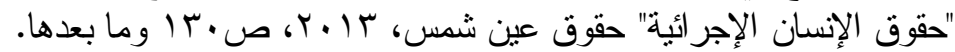

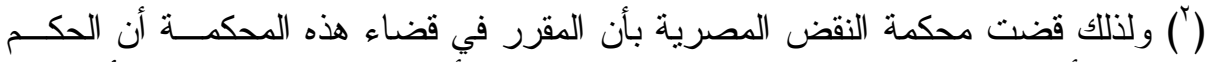

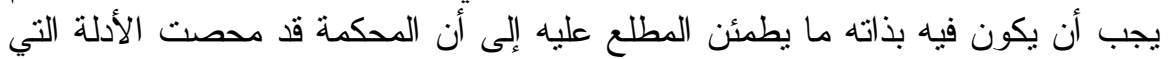

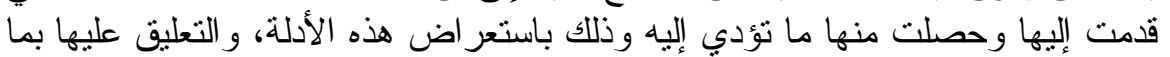

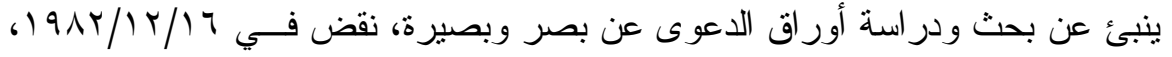

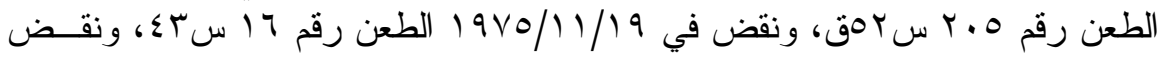

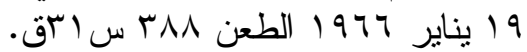


خصمين أو أكثر ، وفي ذلك ما يميز القرار القضائي الذي تتخذه هيءٔـة الحكــم عن القرار الإداري أو العمل التشريعي، ويتزتب على هذا الاختلاف "وجــود

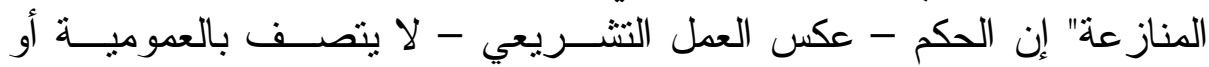

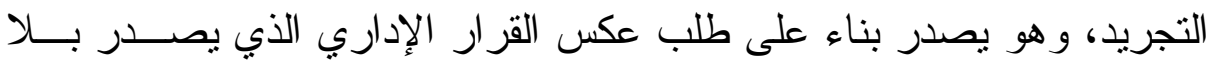

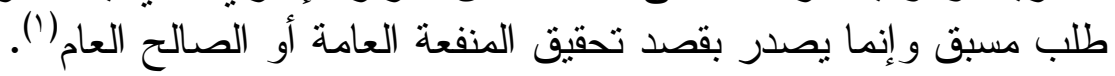
أما المظهر الشكلي في القرار القضائي المتمنل في الحكم فهو تعبير عنٍ وجوب صدور هذا القرار عن قاض له ولاية القضاء، ويجب أن يكون مختصاً

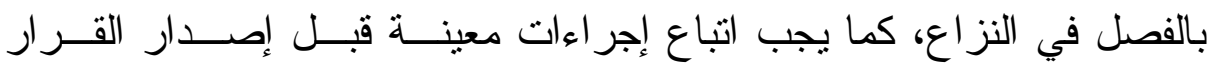

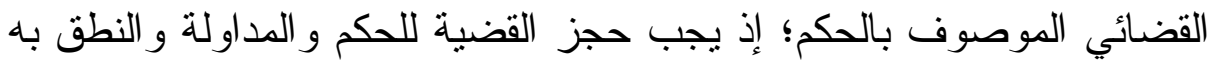

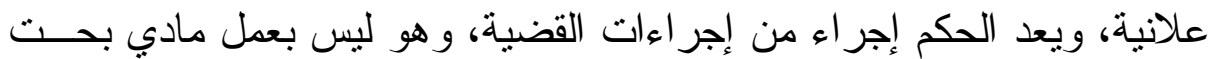

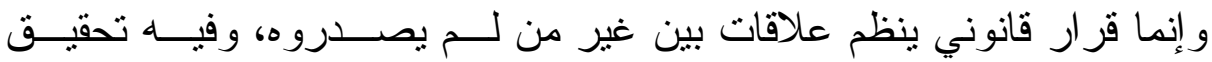

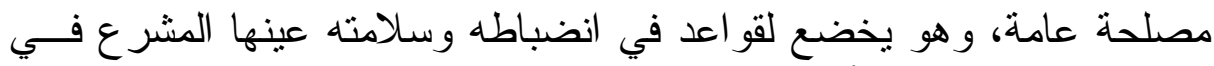

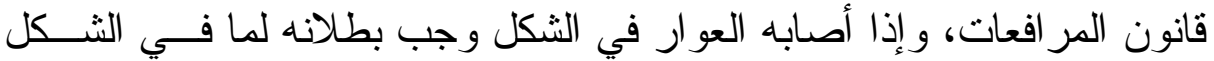

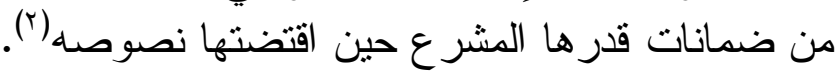

(') ومن المسلم به في الفقه أن هناك ضو ابط عملية تحكم القاضي في مجال تسبيبه الأحكام

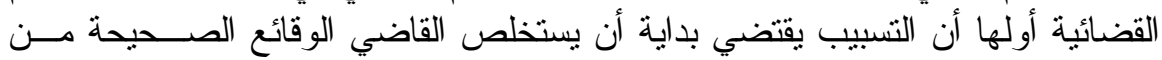

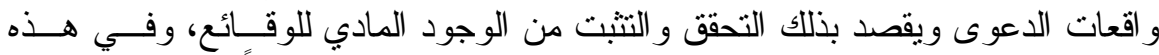

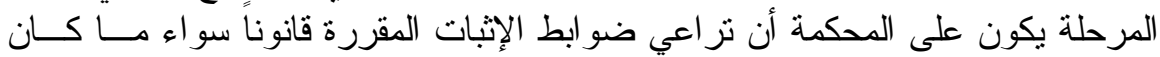

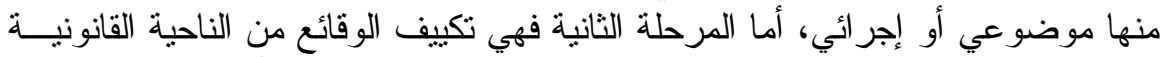

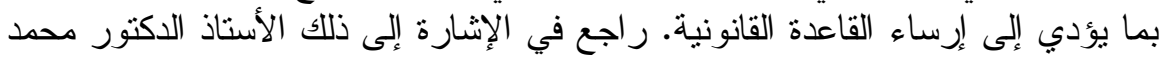

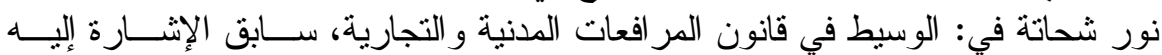

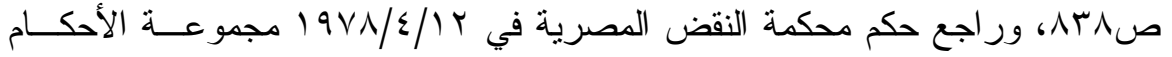

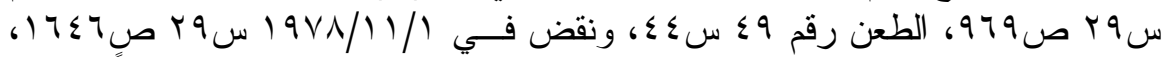

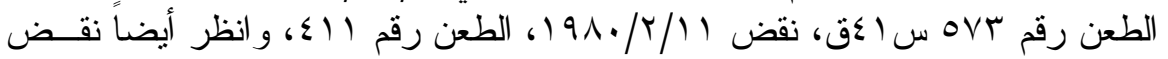

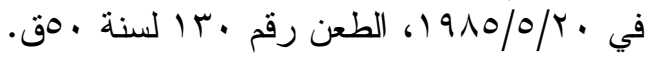

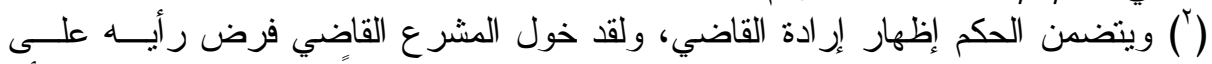

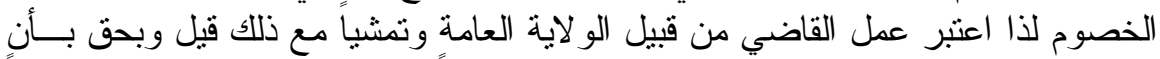

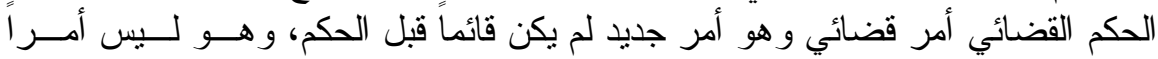

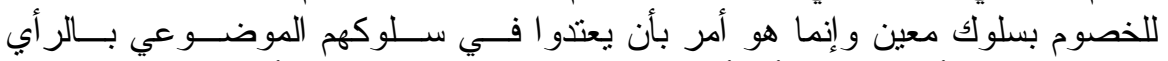

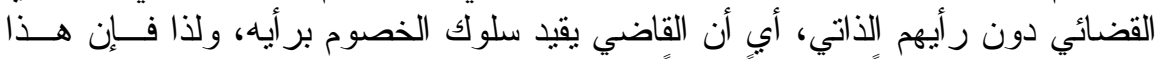

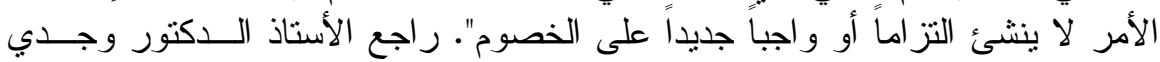

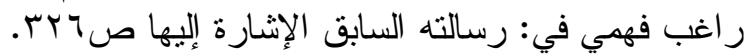

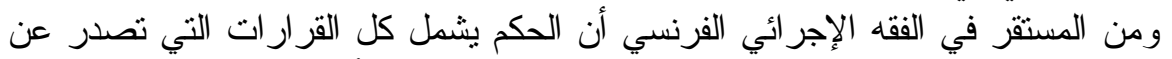

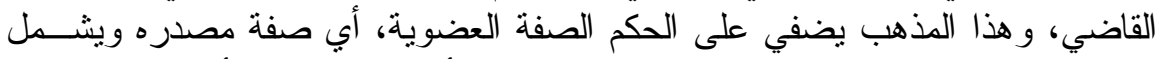
تعبير الحكم كل قر ار قضائي صادر عن قاض سو اء أكان في منازعة أو بدون منازعة، أونة 


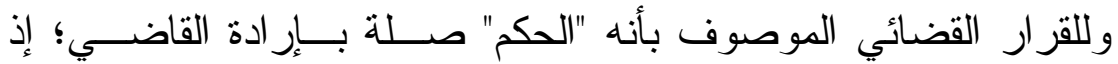

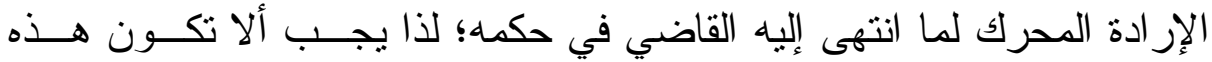

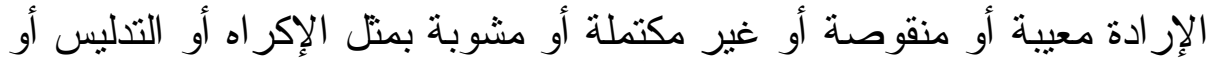

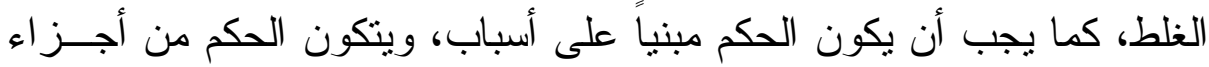

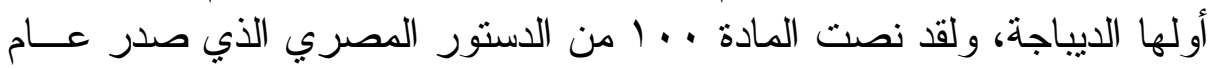

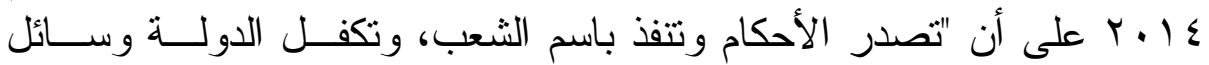

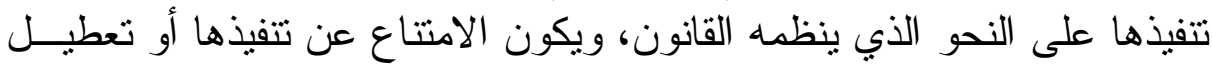

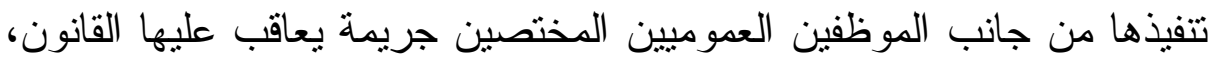

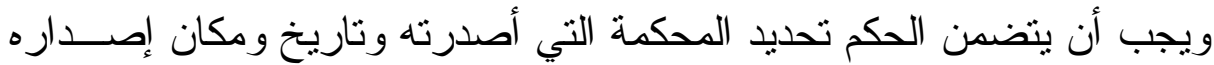

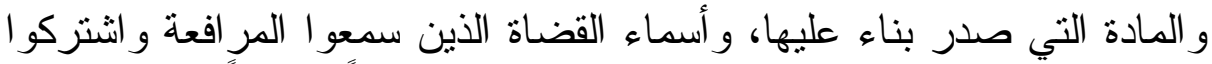

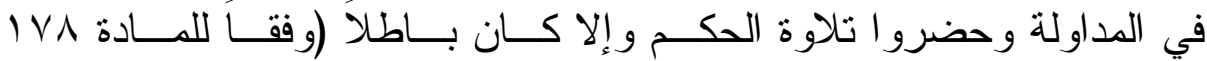

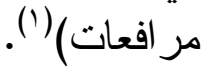

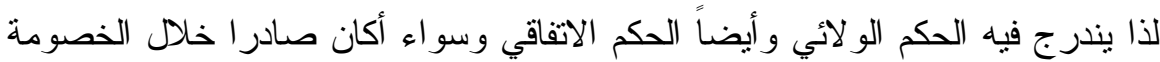

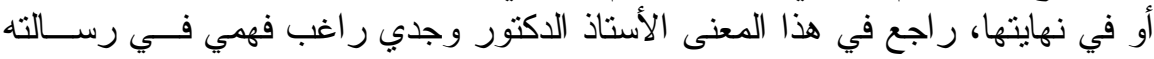

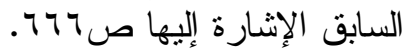

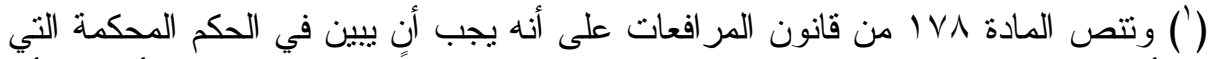

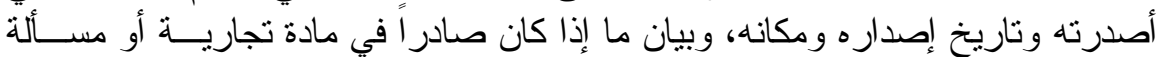

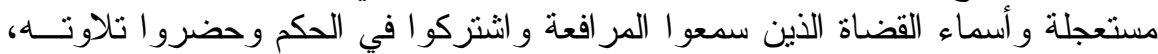

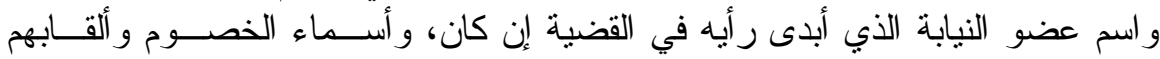

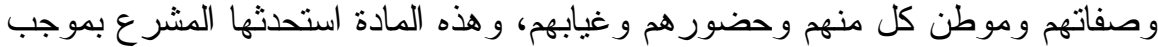

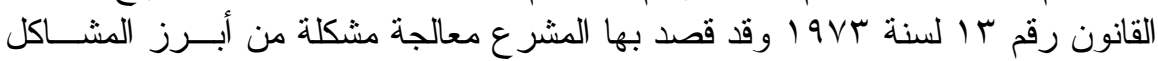

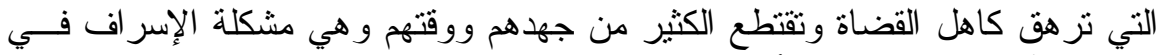

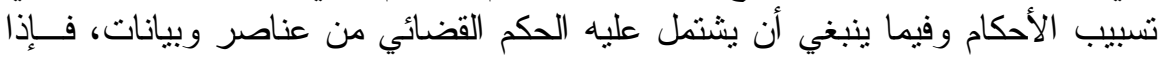

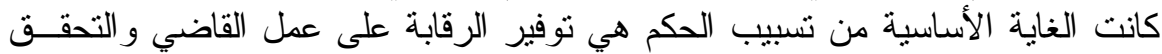

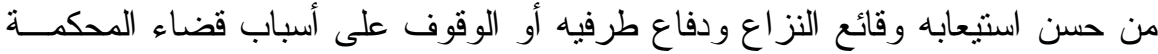

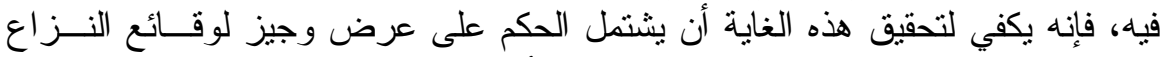

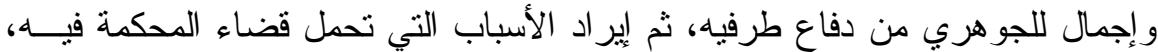

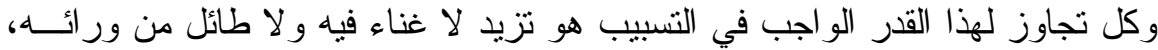

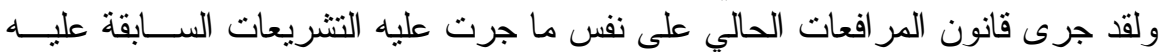

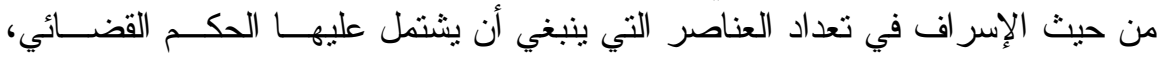

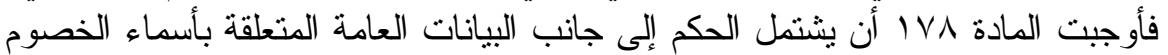

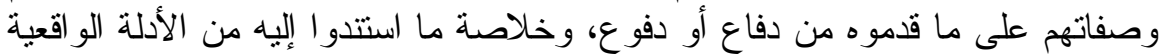

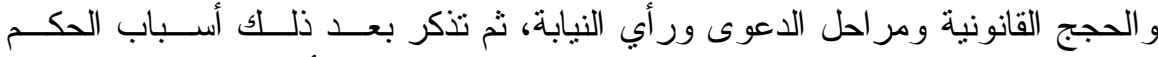
ومنطوقه، وقد كثف التطبيق العملي لهذا النص على الإدحام الأحكام القضائية في كثير

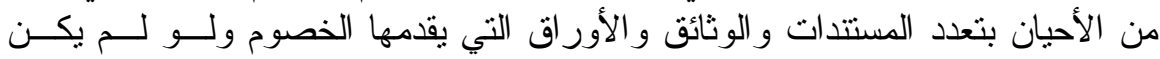


ويتعين أن يتضمن الحكم ذكر وقائع القضية أي تلك الوقائع أو الأحداث

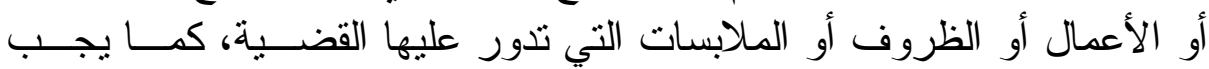

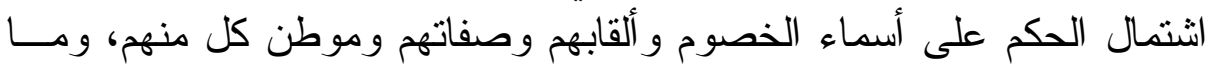

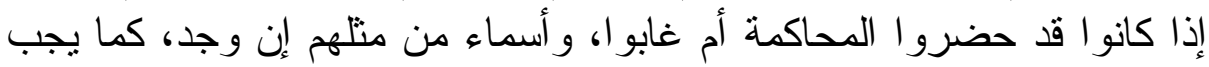

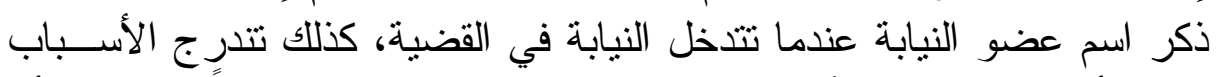

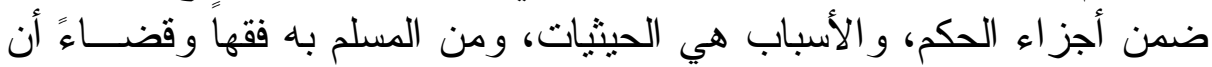

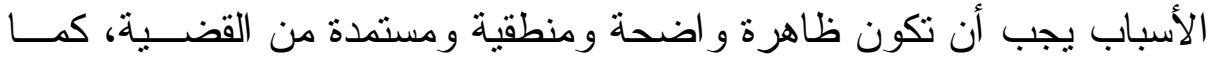

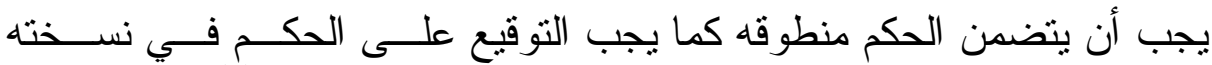

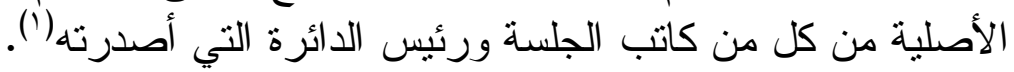

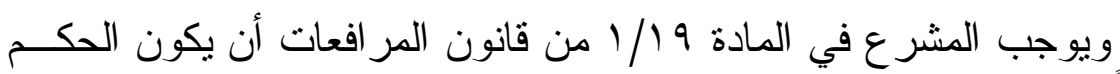

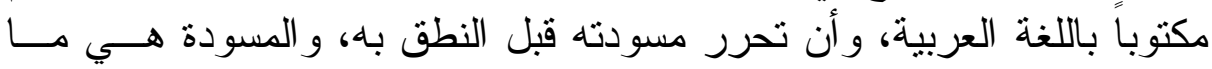

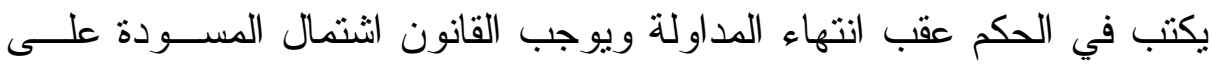

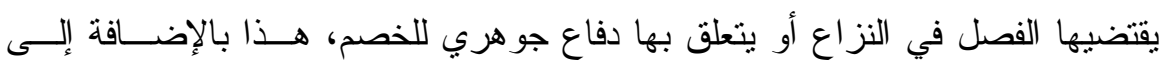

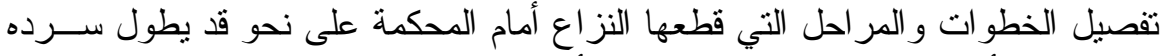

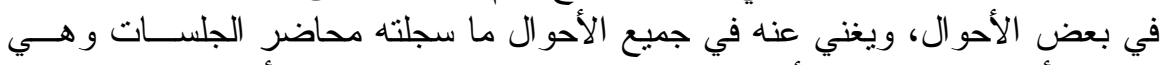

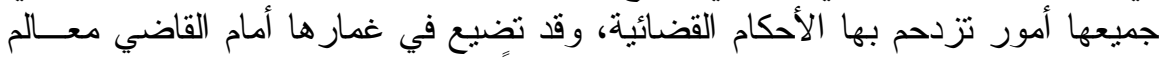

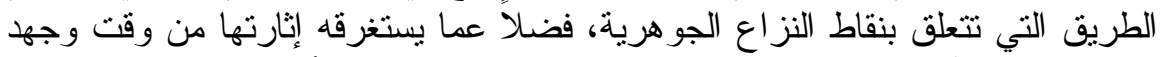

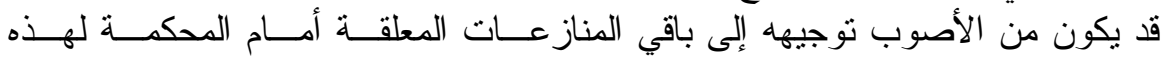

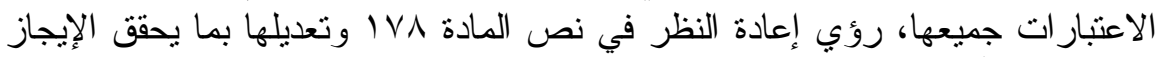

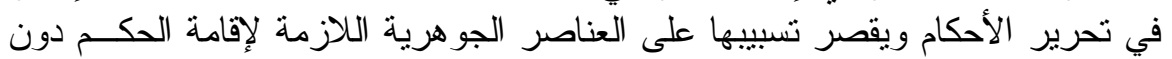

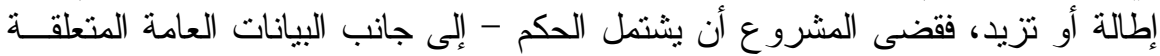

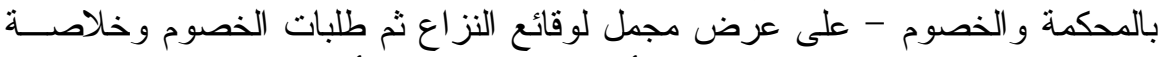

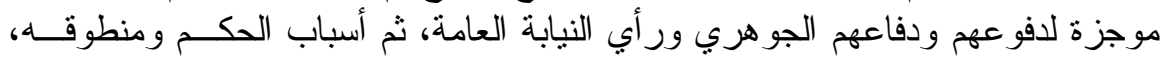

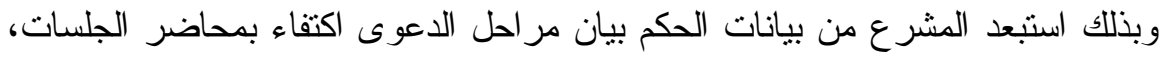

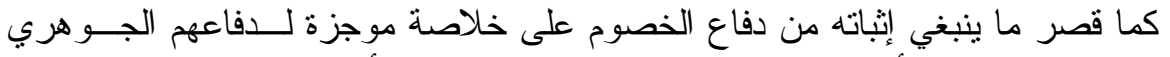

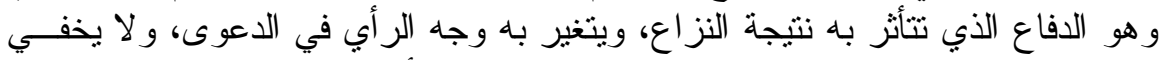

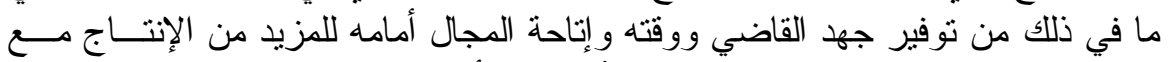
عدم الإخلال في الوقت ذاته فولير جالضمانات الأساسية للأحكام القضائية.

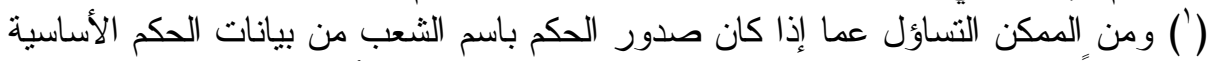

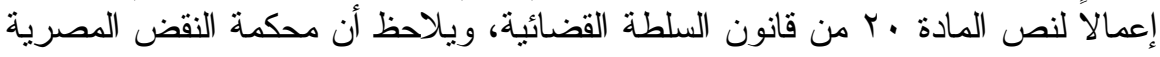

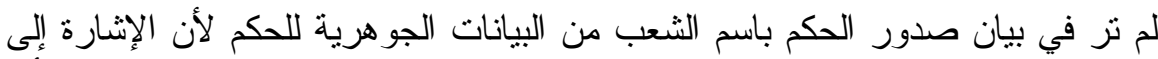

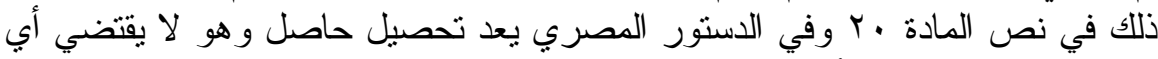

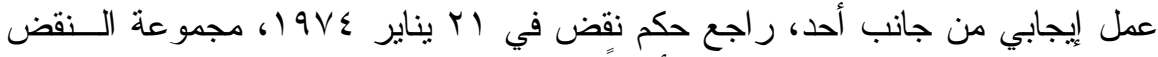

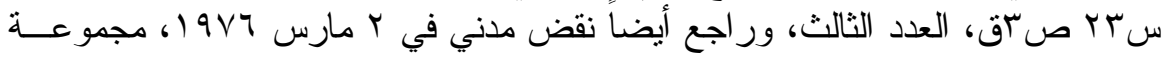
النقض س س r ص ص صr 


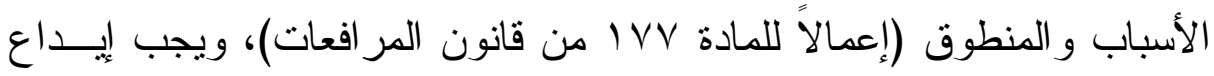

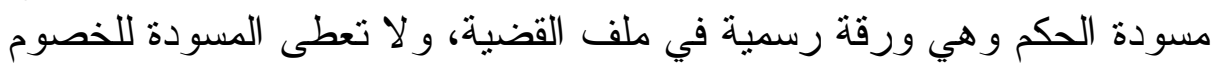

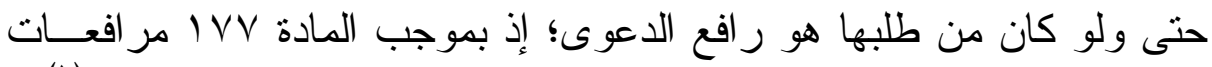

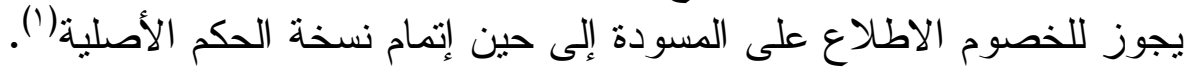

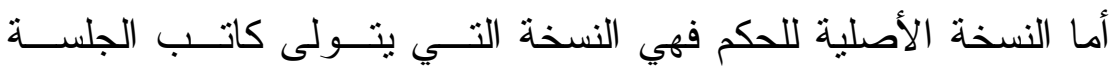

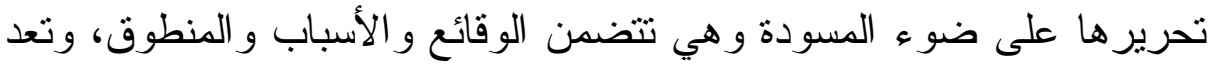

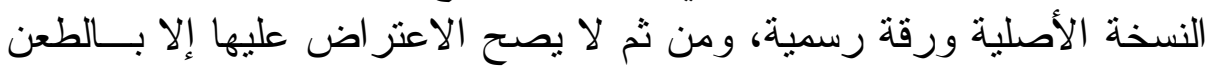

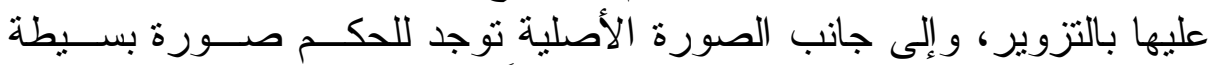

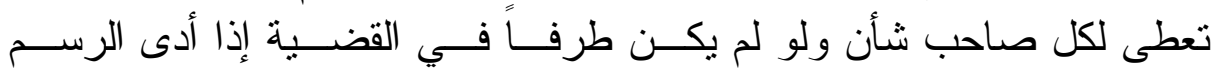

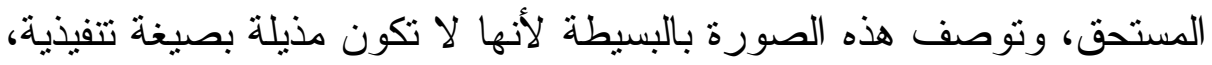

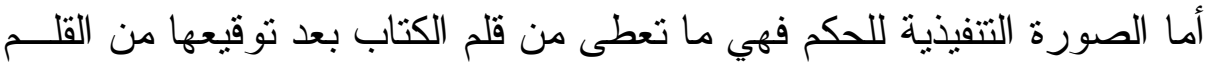

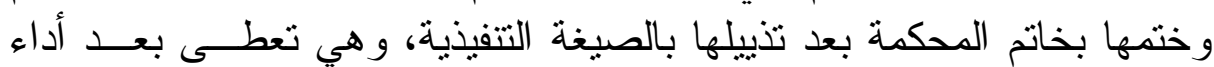
الرسم للخصم الذي تعود عليه المنفعة من تتفيذ الحكم) بـان.

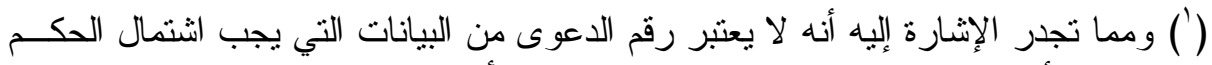

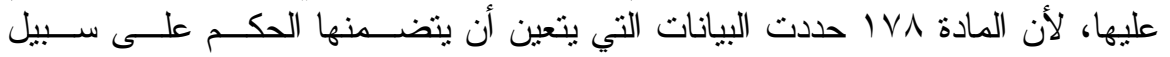

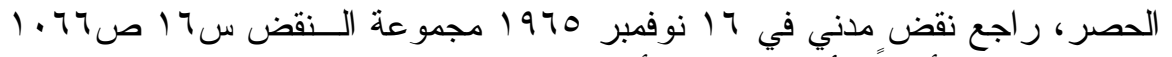
قاليه صن، وراجع أيضاً الأستاذ الدكتور أحمد السيد صاوي في: الوسيط، سابق الإثــارة

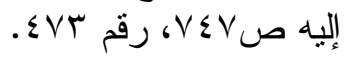

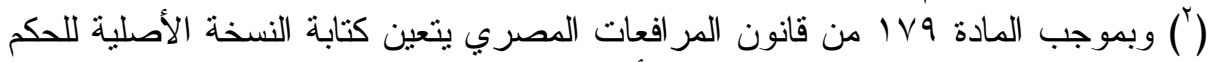

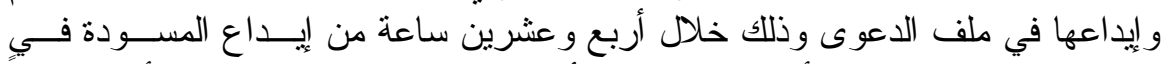

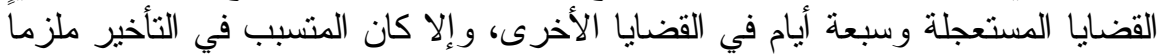

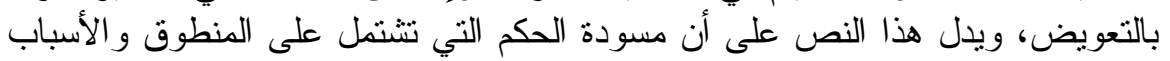

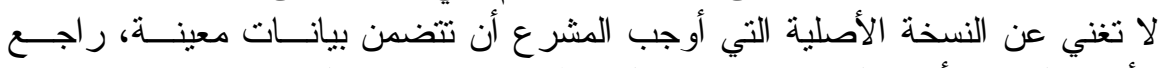

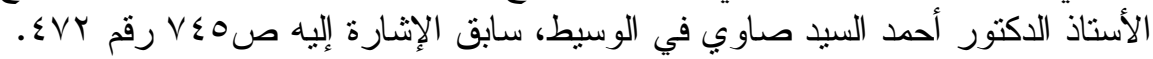

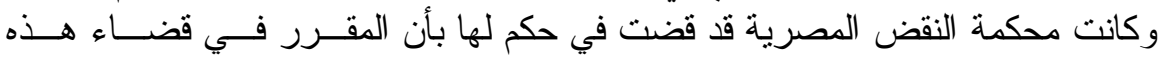

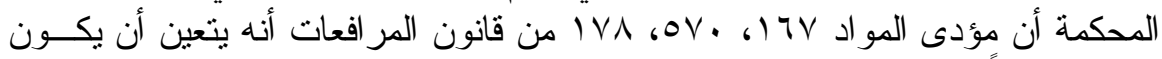

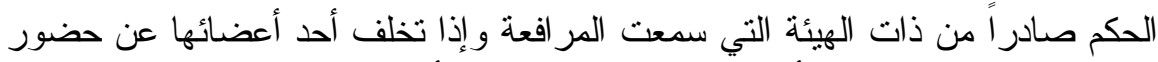

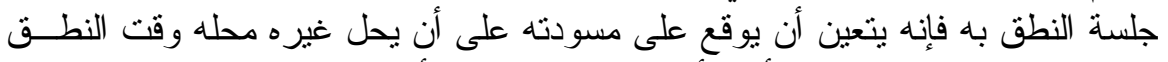

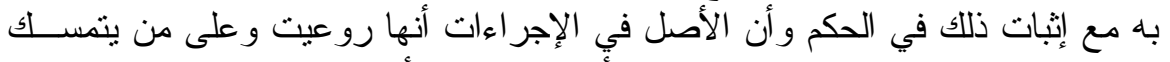

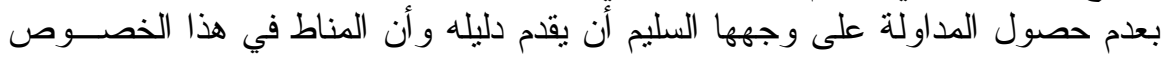

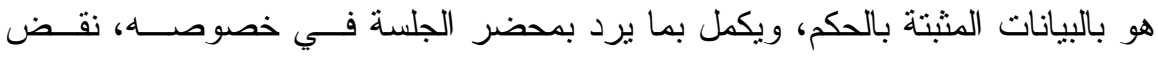

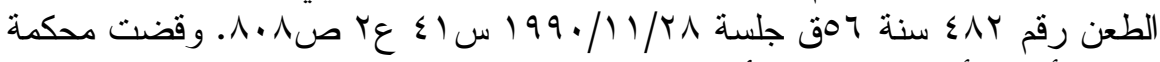

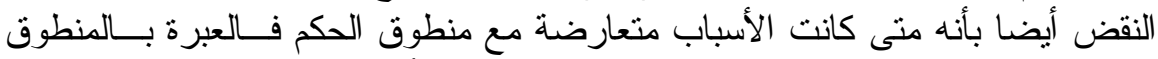

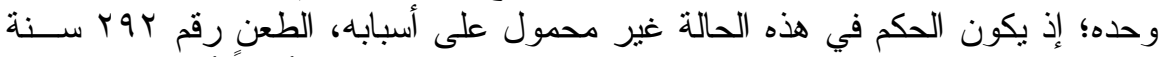

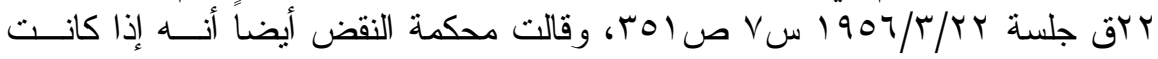


وتتقم الأحكام القضائية إلى أقسام مختلفة؛ إذ منها ما يوصف بالأحكام

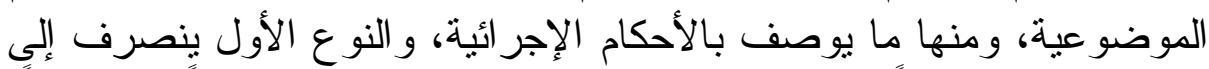

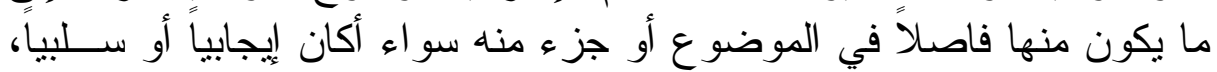

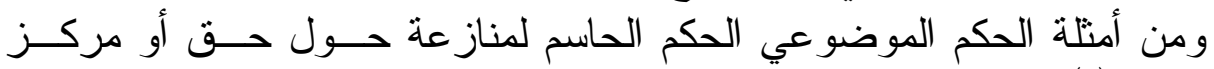

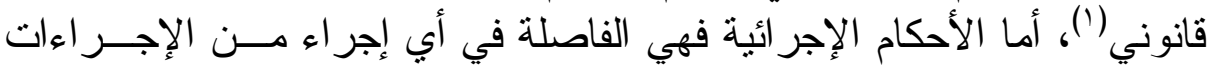

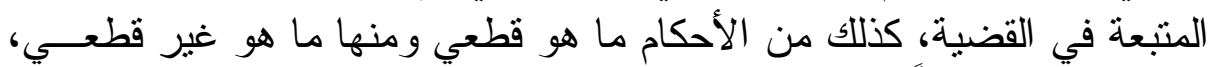

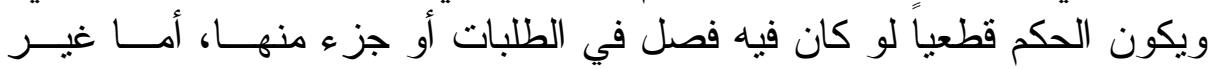

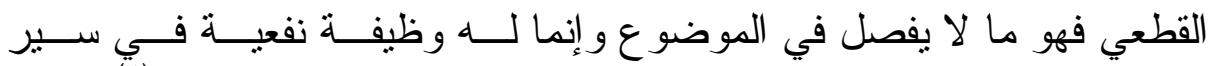

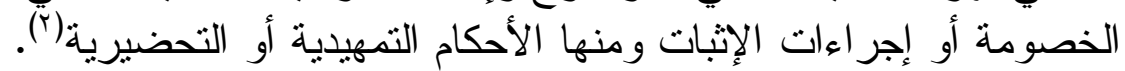

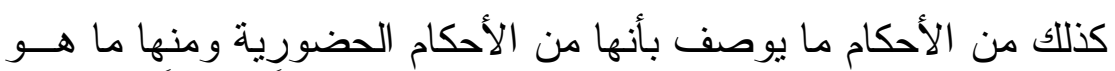

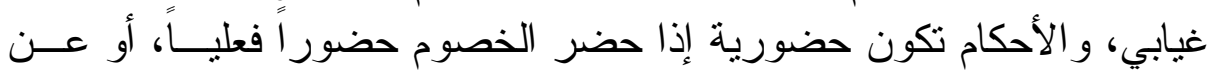

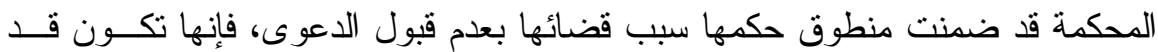

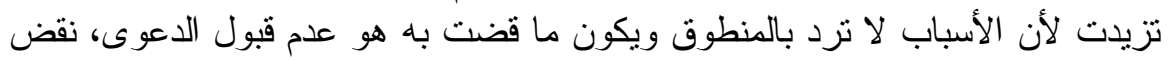

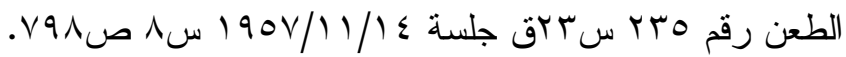

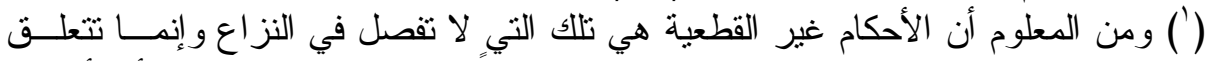

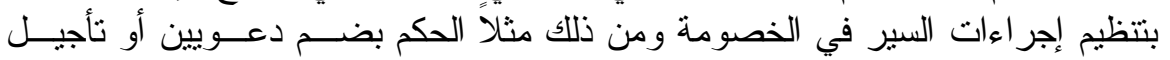

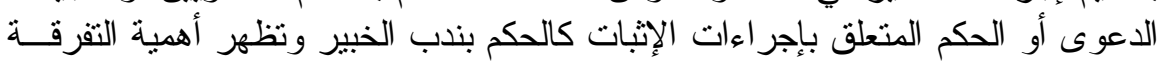

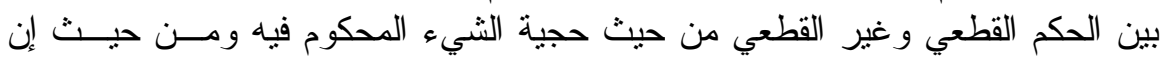

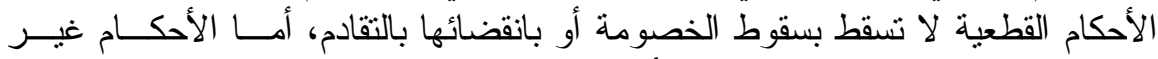

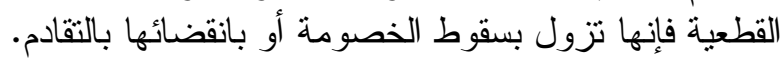

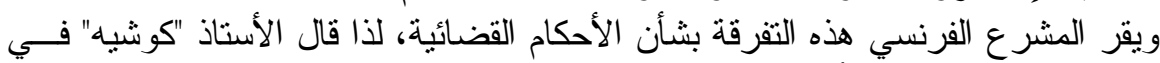
فقه المر افعات الفرنسي أن:

Le jugement ordinaire est celui qui tranche un veritable litige entre les parties celles - ci s' etant opposeés jusqu' a l' intervention de la decision de justice.. est un jugement avant dire droit celui qui se borne, dans son dispositif, a' ordonner une mesure d' instruction ou une mesure provisoire..

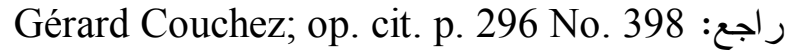

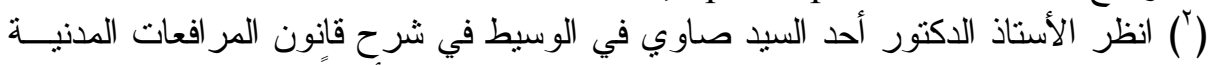

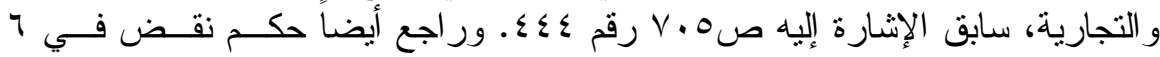

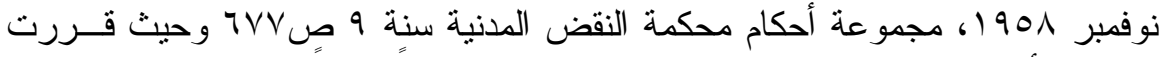

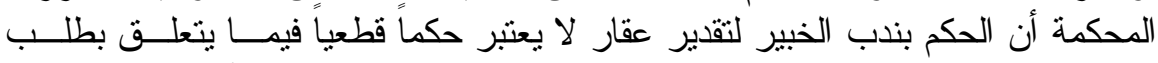

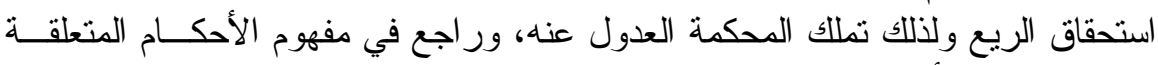

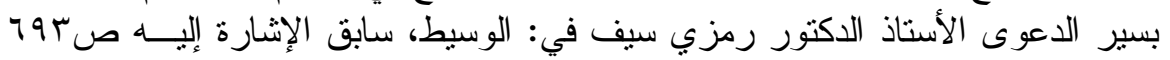
رقم 
طريق من يمثلهم أو كان حضور هم حكمياً، أما الحكم الغيابي فهو الحكم الصادر

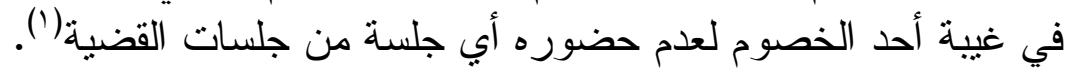

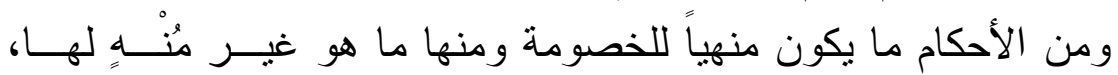

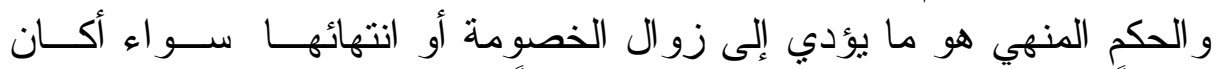

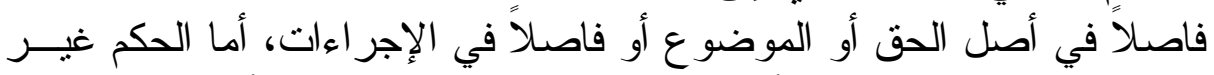

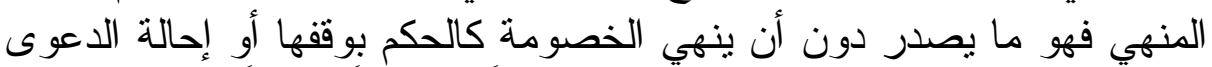

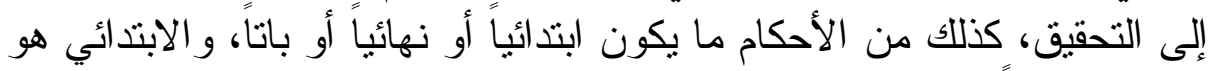

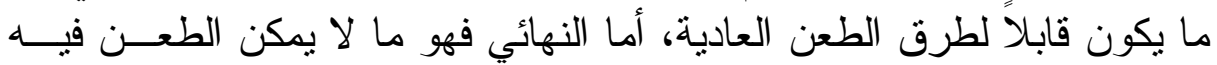

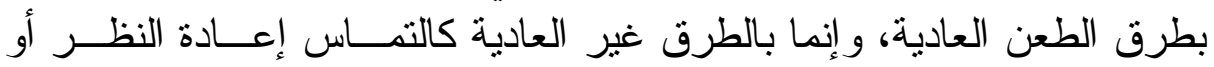

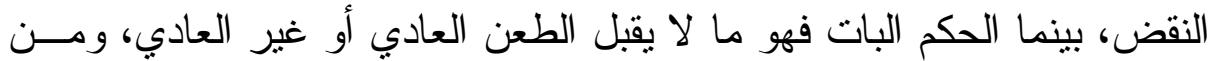

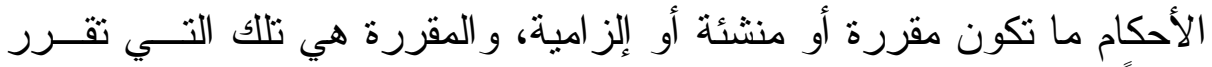

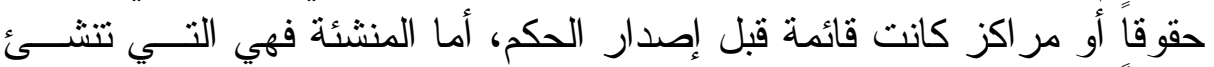

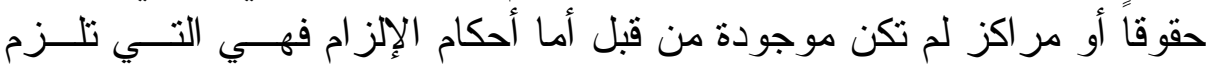
المحكوم عليه بأداء معين.

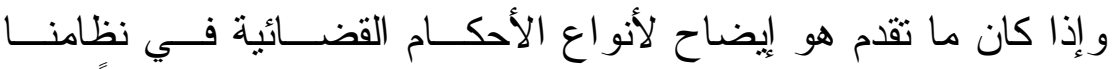

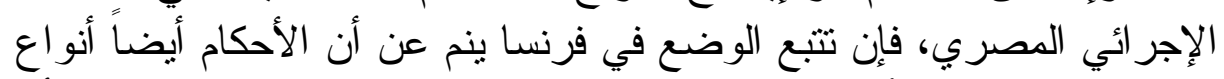

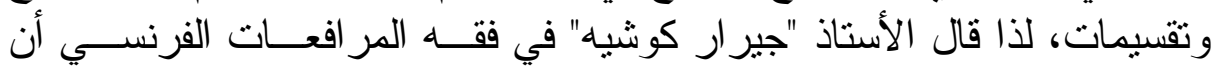

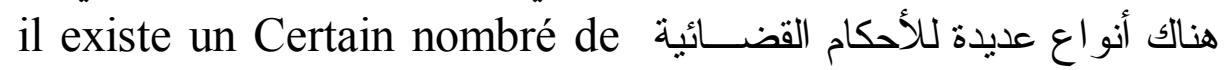
classifications des jugements

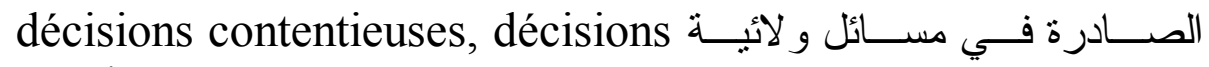
gracieuses

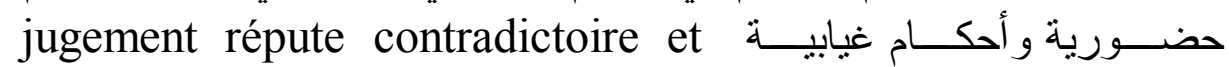
un jugement وإلى أحكام ابتدائية وأخرى نهائية jugements par défaut dit en premier ressort ou en premier et dernier ressort selon qu'il est ou non susceptible d'appel بالاستئناف أو عدم إمكانية الطعن، كذلك تتقسم الأحكام القضائية في فرنسا بين

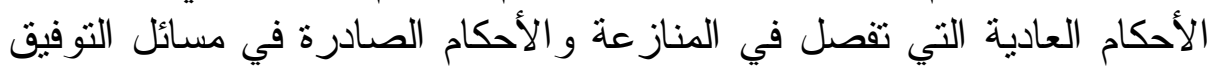

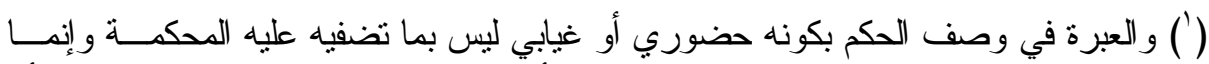

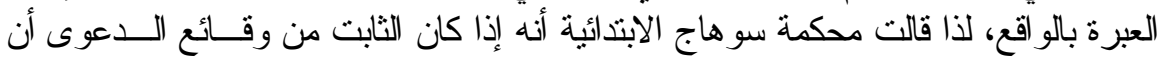

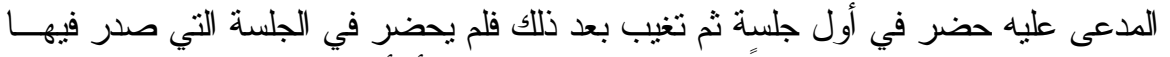

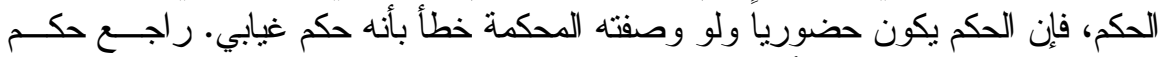

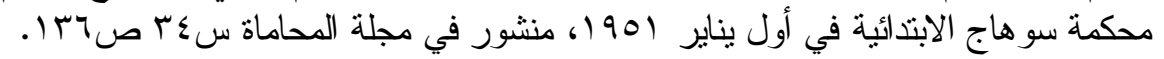




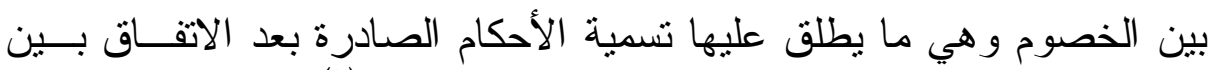

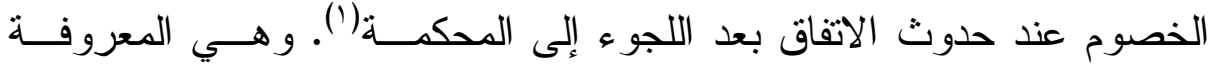

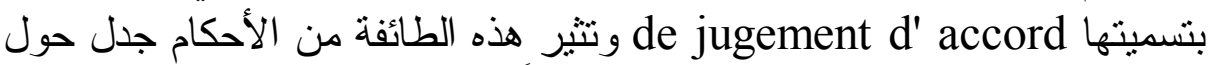

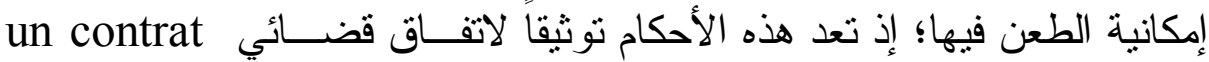
judiciaire

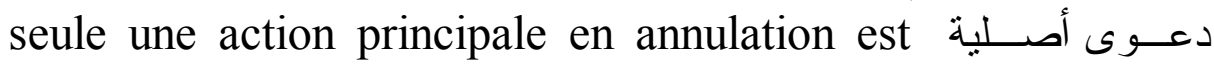
possible

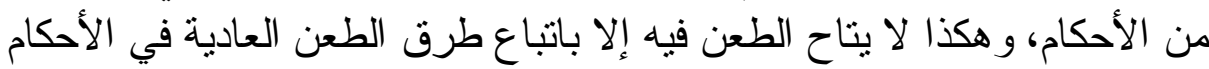

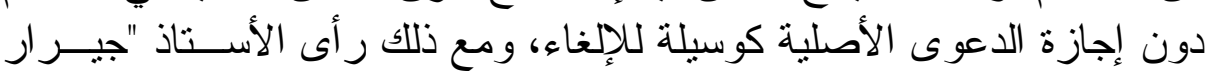

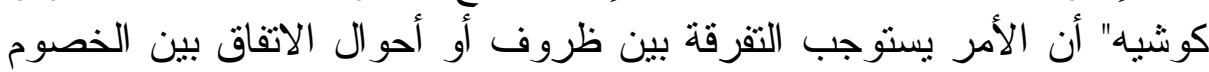

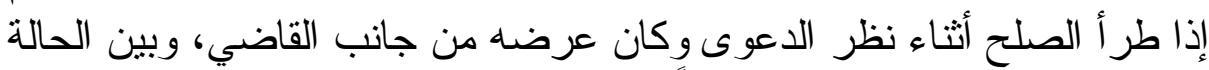

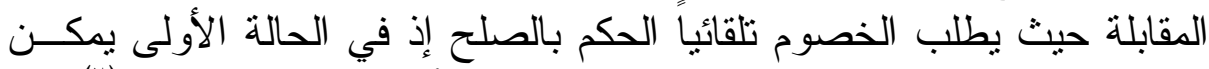

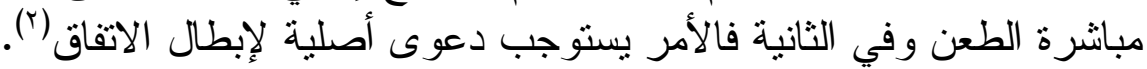

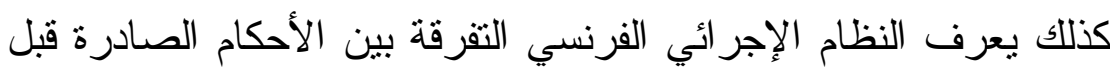

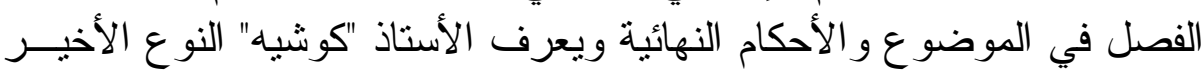

$$
\text { (') وفي الإثارة إلى هذه الأحكام في النظام الإجر ائي الفرنسي. }
$$

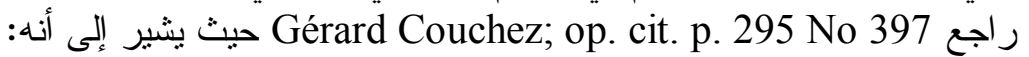
Le jugement ordinaire est celui qui tranche un véritable litige entre les parties, celles - Si s'étant opposées jusqu' à l' intervention de la décision de justice, un jugement est dit convenu ou d' expèdient lorsqu' il ne fait en réalité que consacrer un accord intervenu entre les parties à l' instance. On parle aussi d' ailleurs de jugement d' accord.

راجع: . Gérard Couchez; op. cit. p. 295 No. 397 ور اجع في الإثشارة إلى ما يحيط بهذه الأحكام من غموض من حن حيث طبيعتها باعتبار هـــا

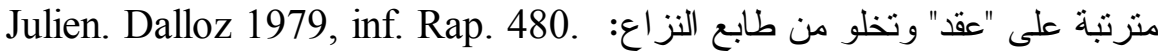
obs. Relatives à civ. $2^{\mathrm{e}}$, 3avr. 1979.

ور اجع أيضا: 1952 Giverdon, Gorphe les décisions de justice.

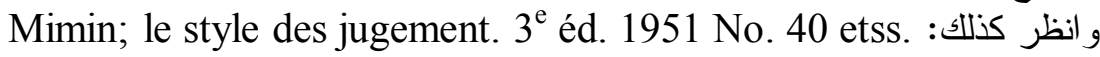
() راجع: (ب)

Garsonnet - Cezar - Bru; Traité théorique et pratique de procédure civile et commerciale. 8 . vol. t. 3 nos 620 ets.

$$
\text { وانظر كذلك: }
$$

Glasson, Tissier, Morel. Traité théorique et pratique d' organisation judiciaire de competence et de procédure civile. 4. vol. T. 3 nos. 728 . 


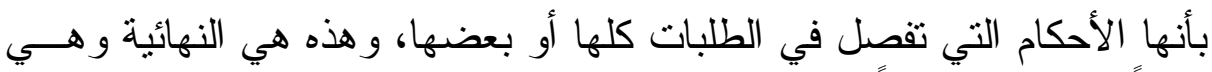

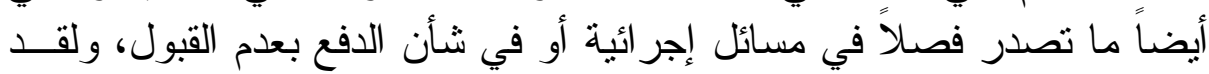

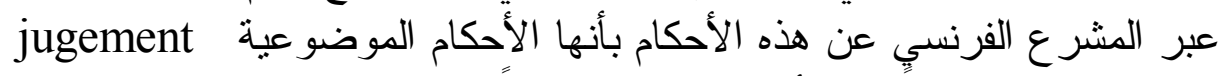

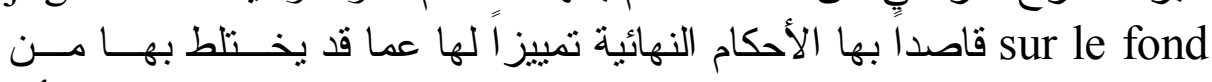

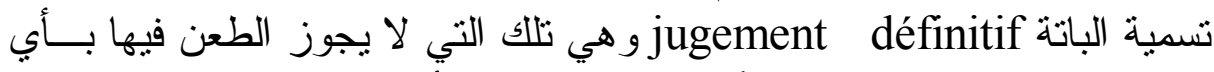

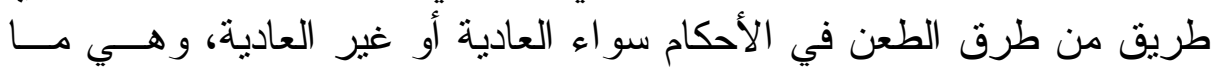
تحوز حجية الأمر المقضي به الطعن في التي وردت أحكام أحكادية في الفقرة الأولى من المادة

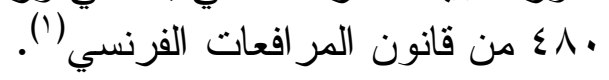

ومن الفقهاء في الفقه الإجرائي من تساءل عن التكييف القانوني للأحكام

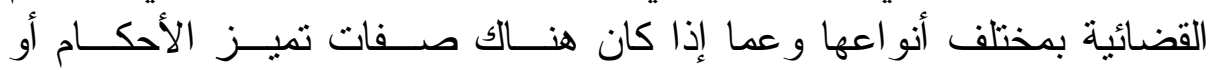

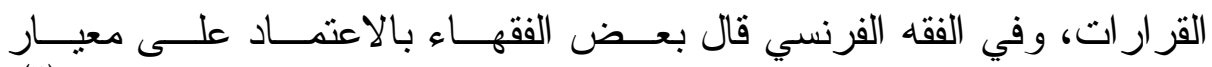

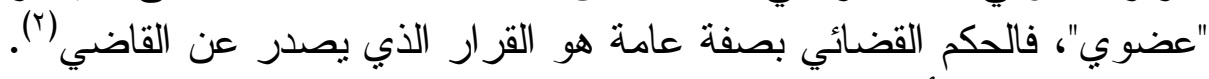

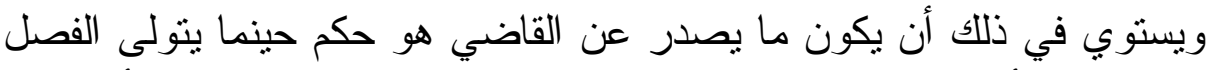

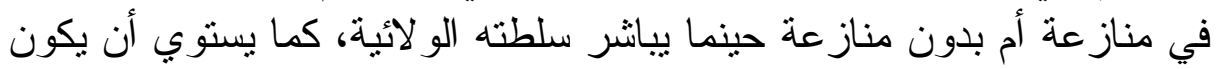

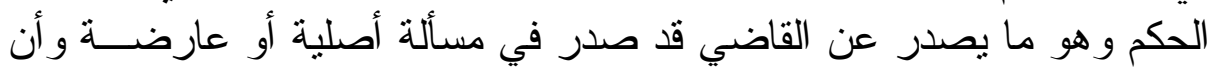

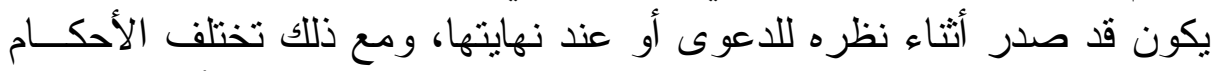

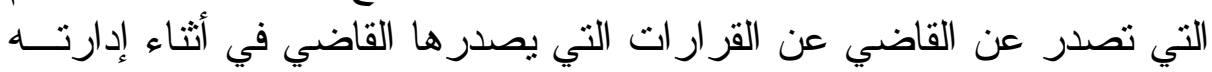

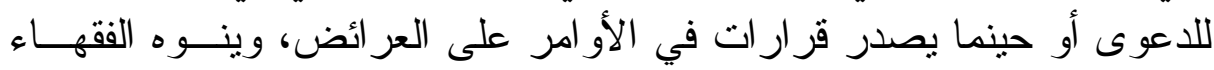

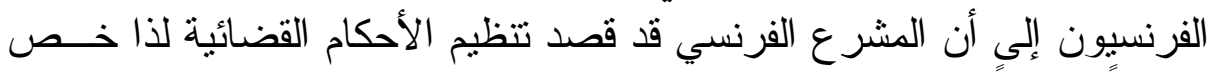

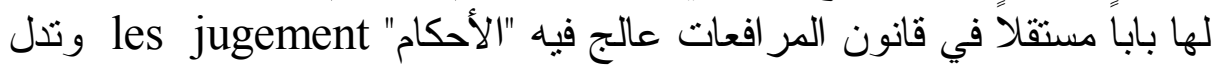

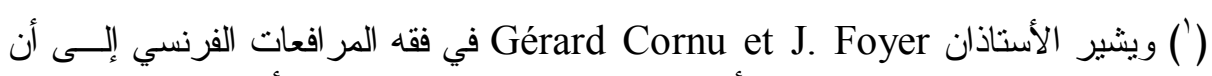

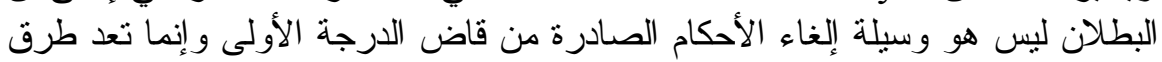

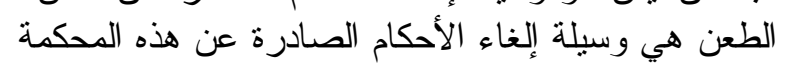
pas de procés principal en nullité de jugement devant un Juge du primier degré. Les moyens directs pour attaquer les jugement resident dans les voies de recours il est aussi des procédés indirects.

راجع: . رأِ

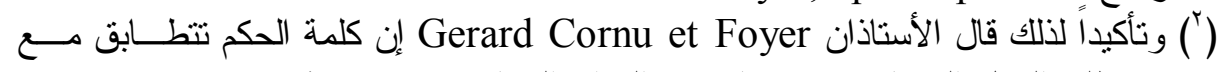

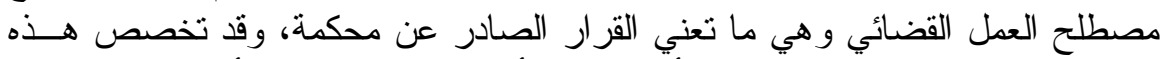

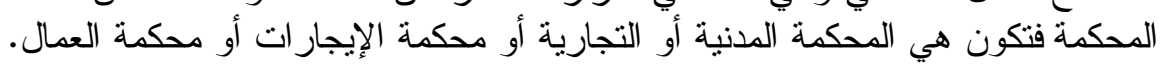
Au sens large; le mot jugement équivaut en effet au terme d'acte juridiction.

راجع: . Gérard Cornu et Foyer; op. cit. p. 433 
النصوص الواردة في هذا المقام على أن المشرع قد تطلب خصـــائص معينـــة في الأحكام تدور حول الصياغة و البيان القانوني و الضو البط المنام المنظمة للشكل (').

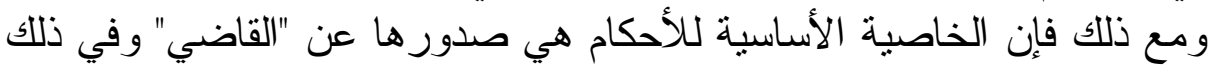

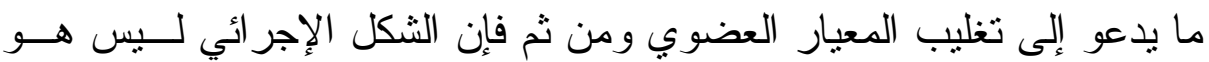

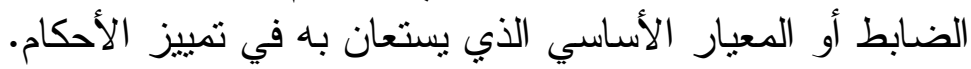

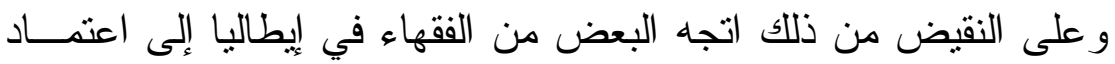

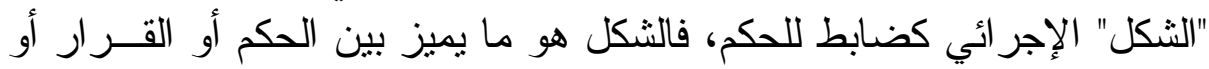

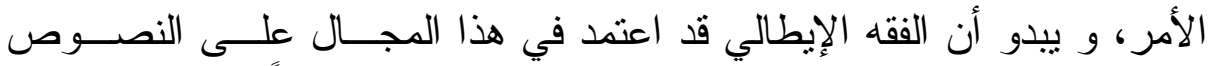

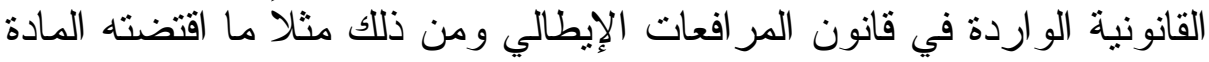

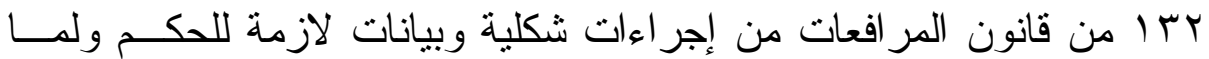

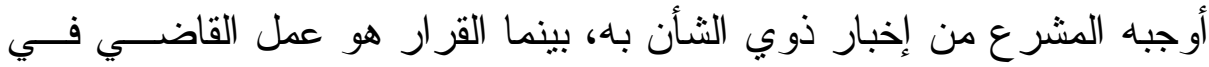

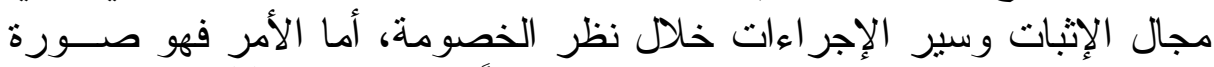

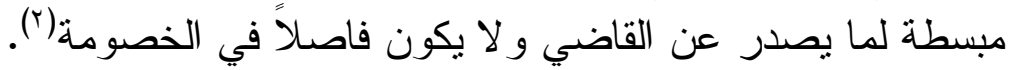

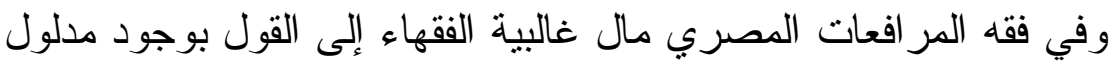

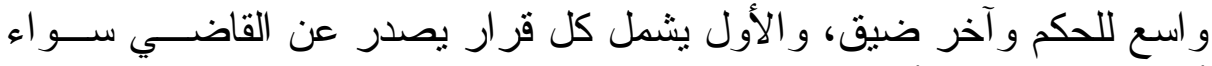

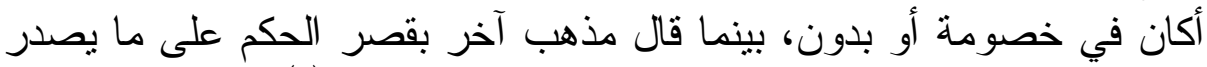

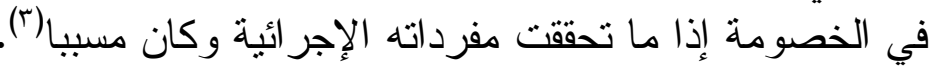

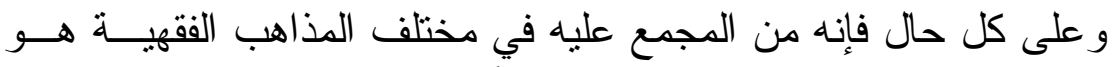
وجوب تسبيب الأحكام الصادرة في المنازعة أو القضية، فالهي فلأسباب هي المجال

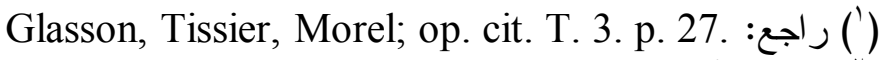

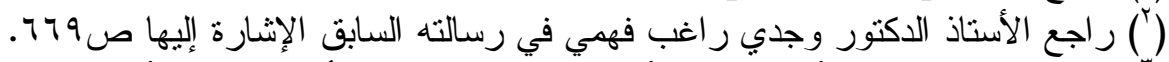

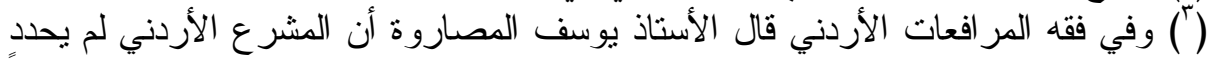

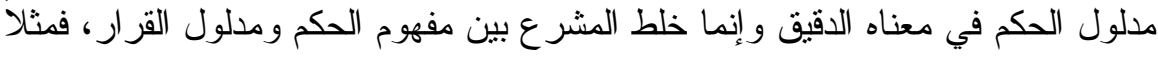

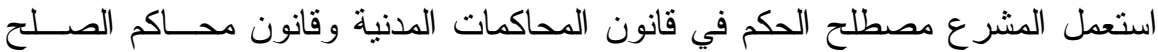

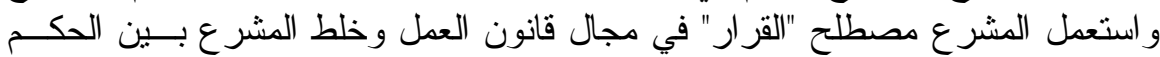

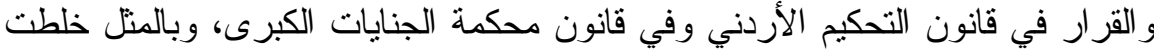

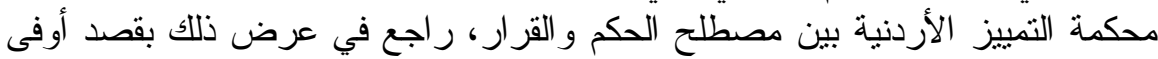

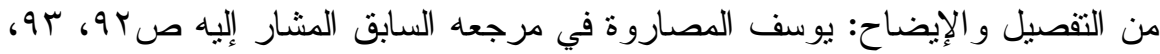

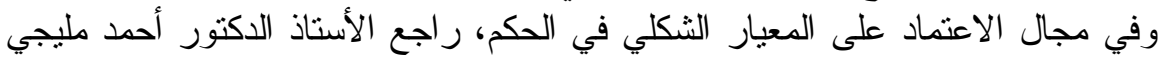

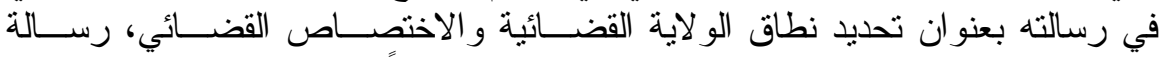

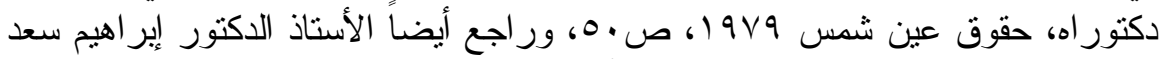

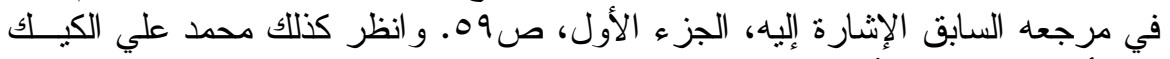

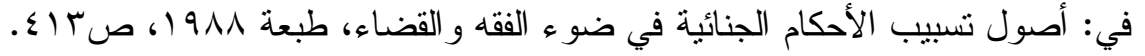




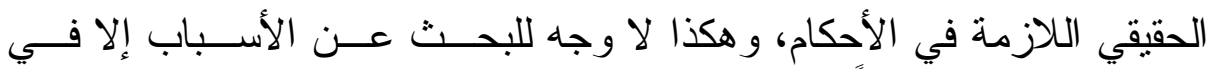

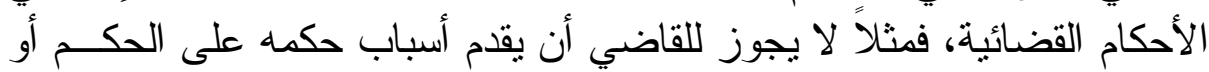

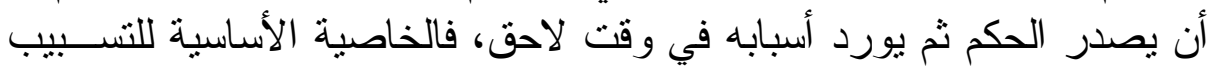

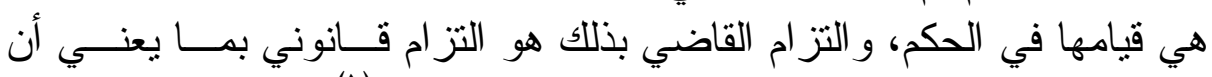

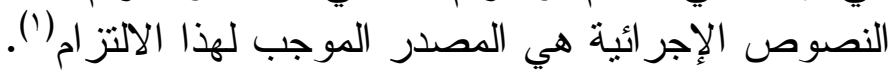

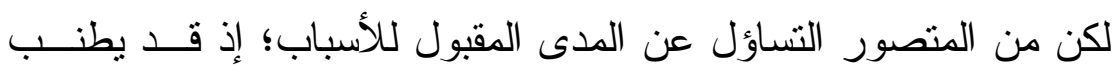

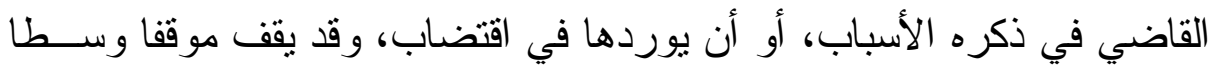
بشأن ما يورده منها.

ويعتبر الإطناب في التسبيب من الفروض المتصورة في بعض الأحكام،

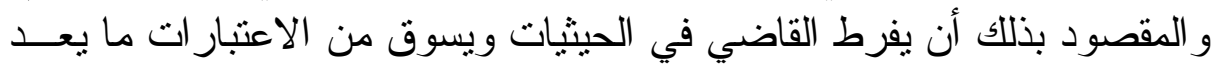

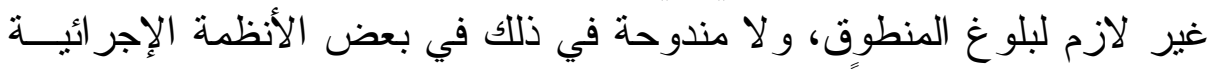

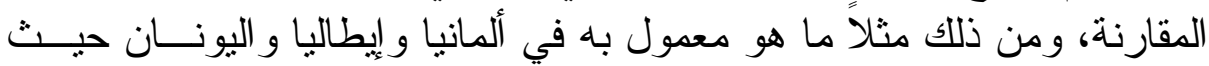

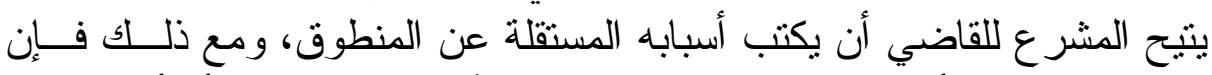

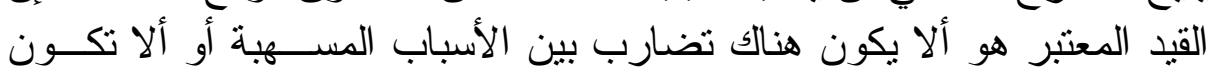

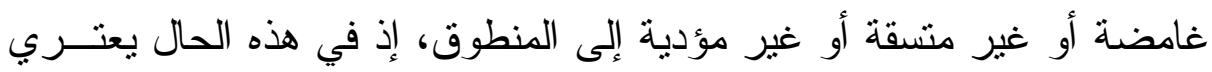

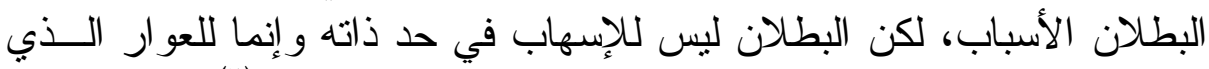

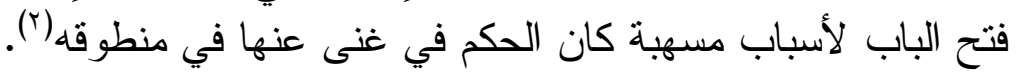

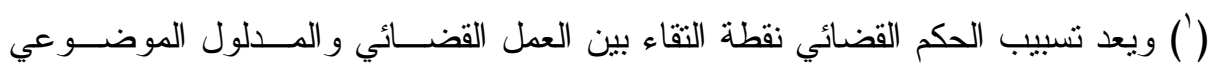

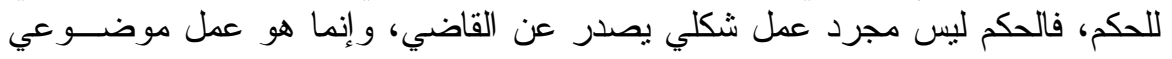

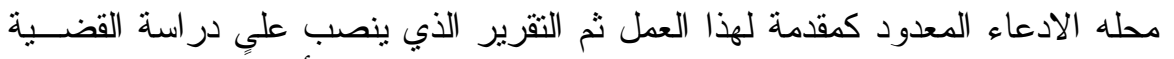

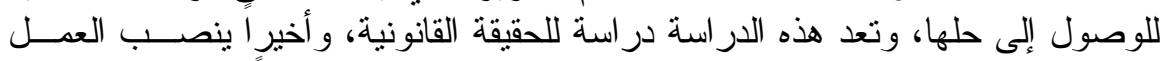

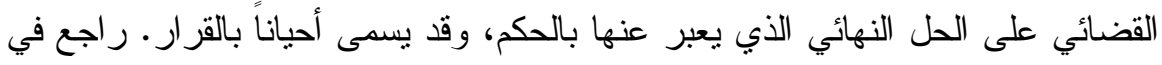

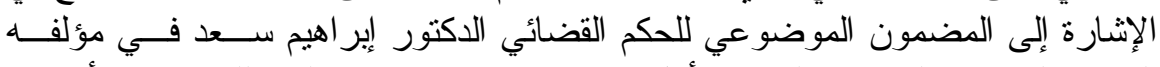

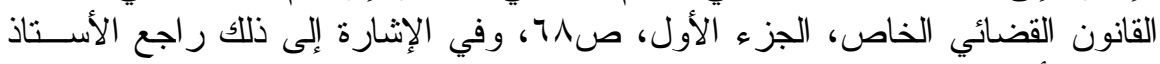

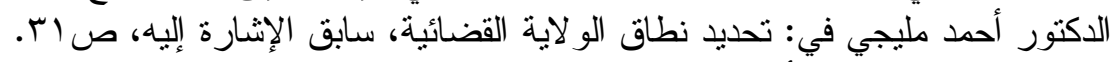

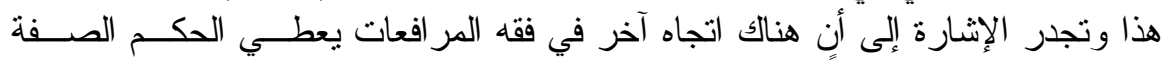

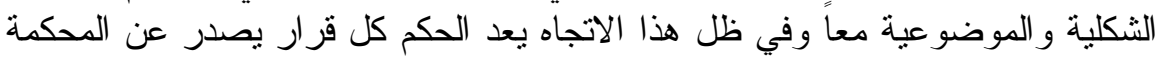

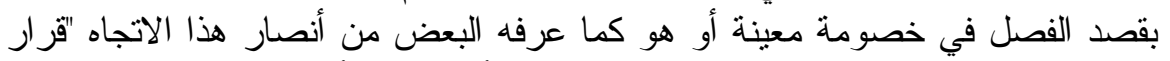

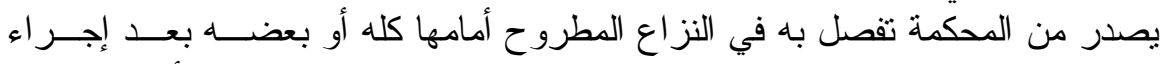

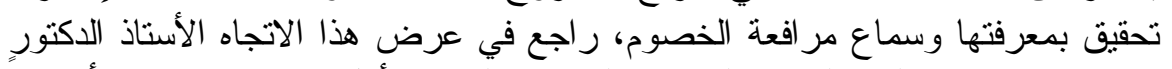

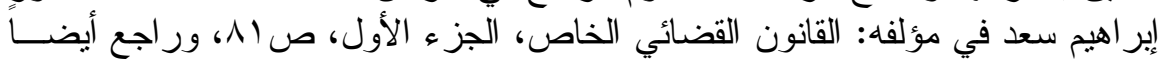

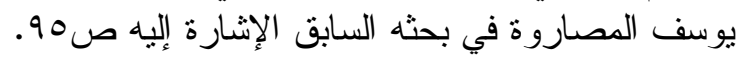

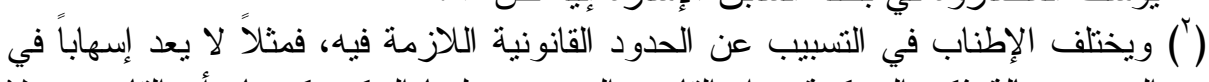

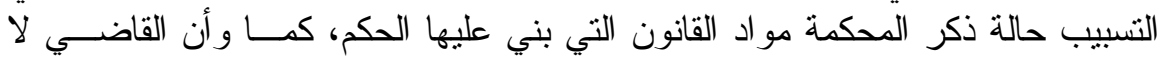


وتعتبر الأسباب الموجزة نقيضاً للأسباب المسهبة وفي ظل هذا النظــام

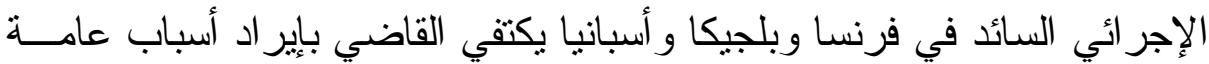

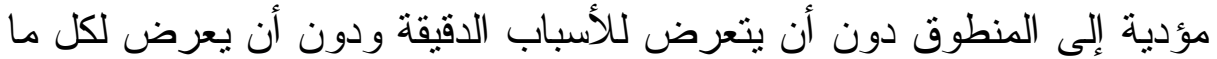

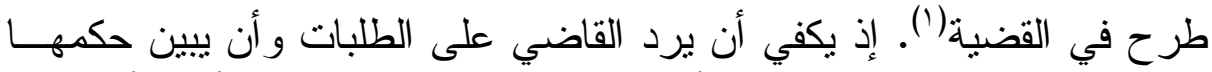

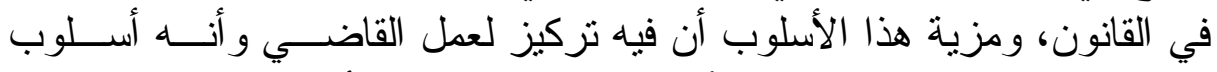

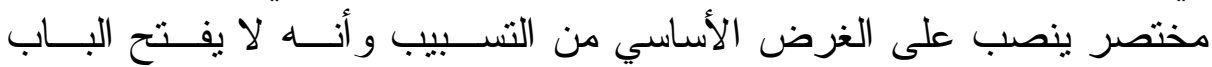

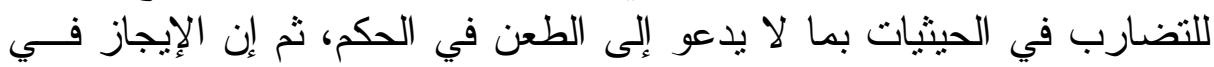

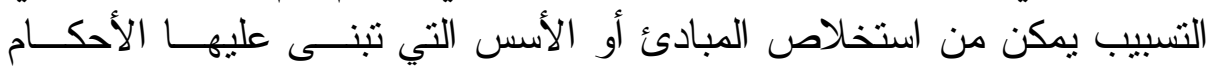

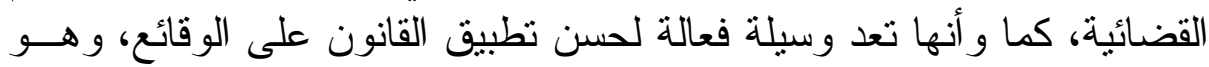

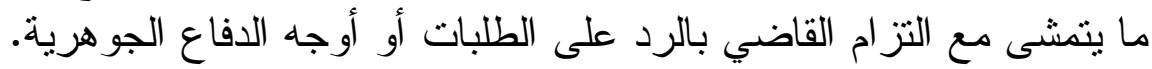

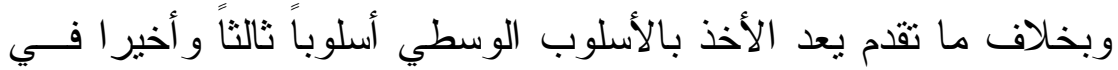

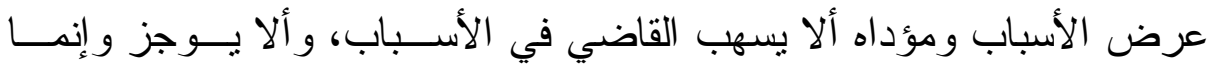

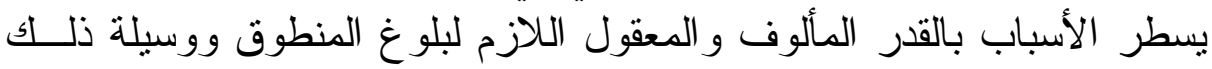

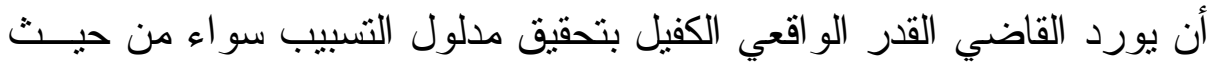

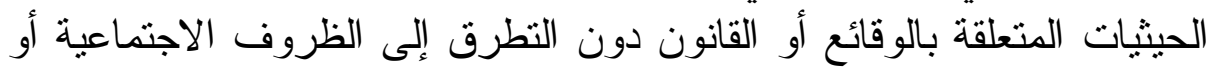

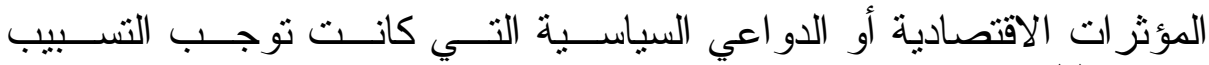

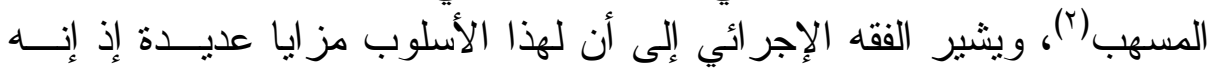

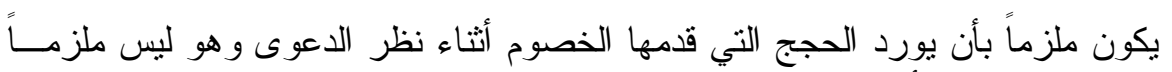

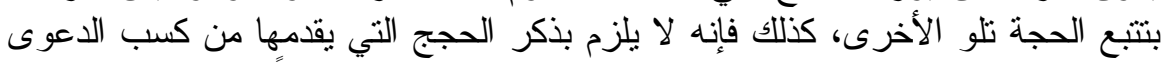

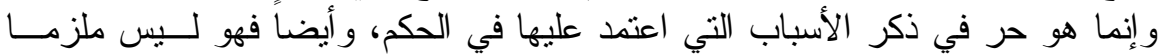

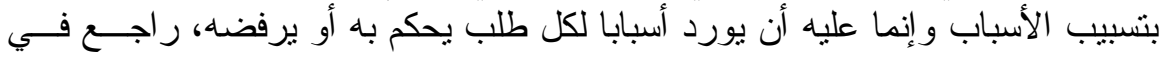

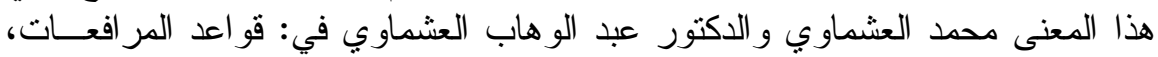

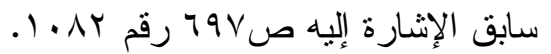

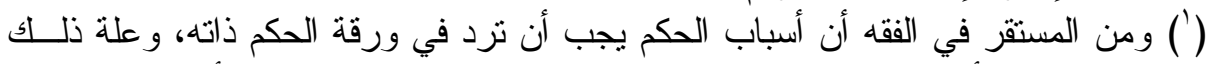

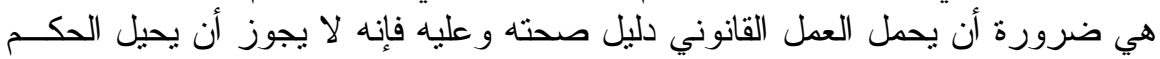

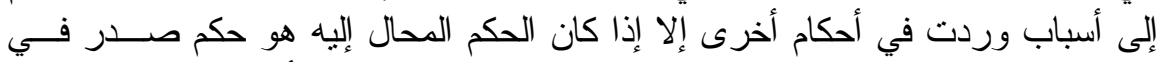

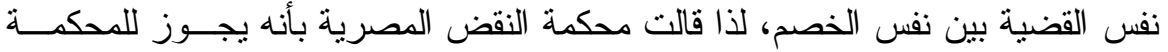

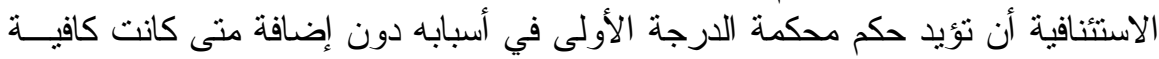

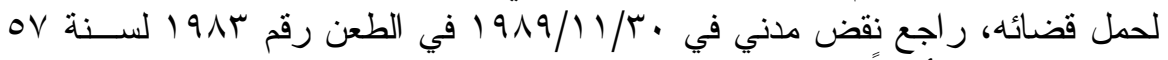

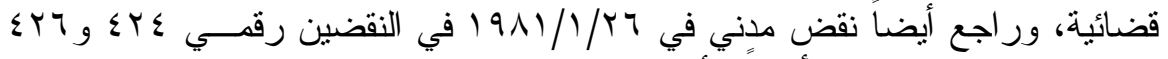

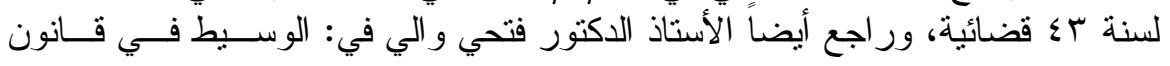

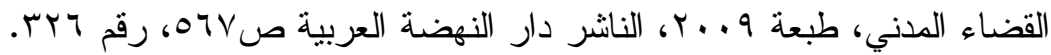

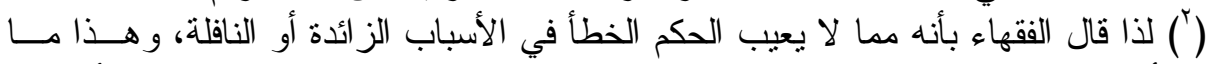

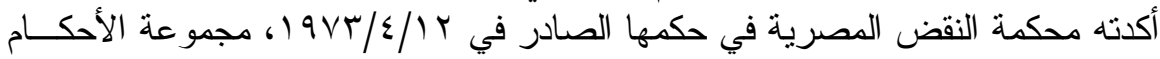


أسلوب وسطي وخير وسائل التسبيب الوسط، ثم إنه لا يجعل الأسباب مــوجزة

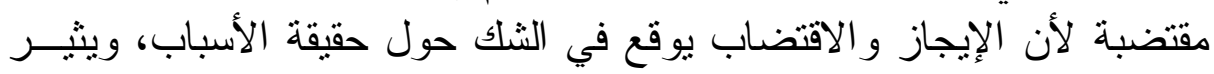

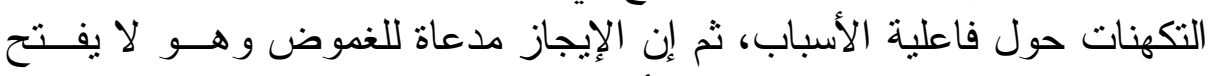

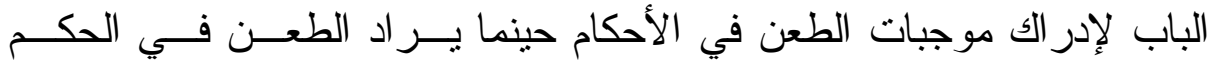

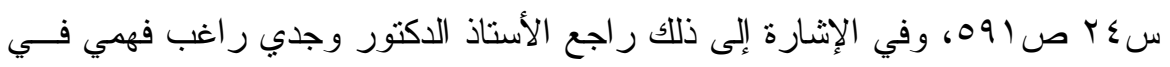

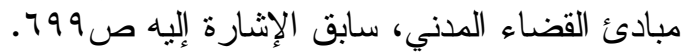

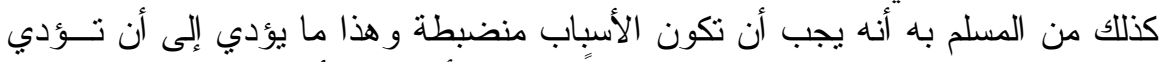

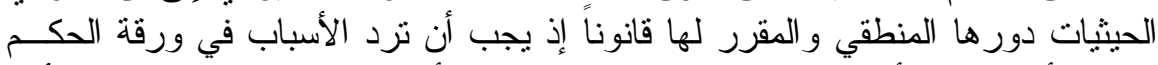

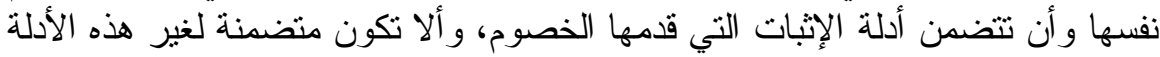

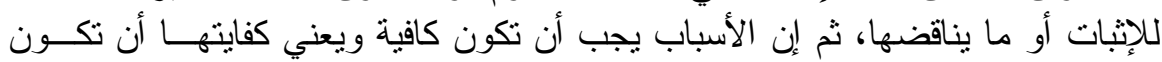

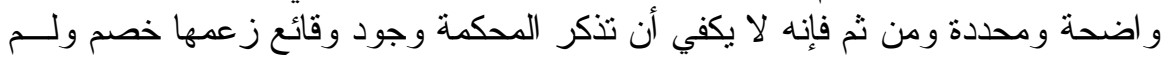

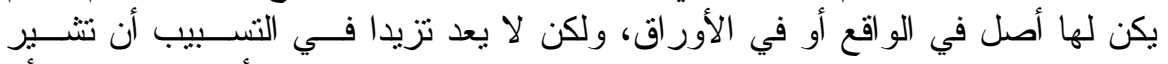

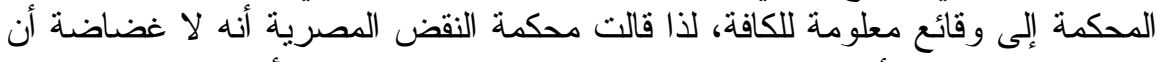

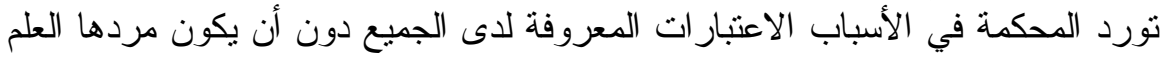

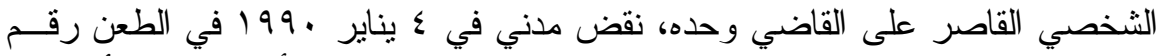

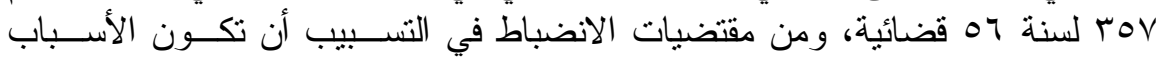

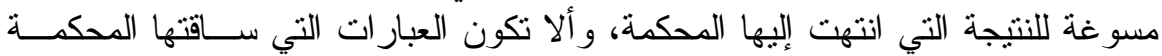

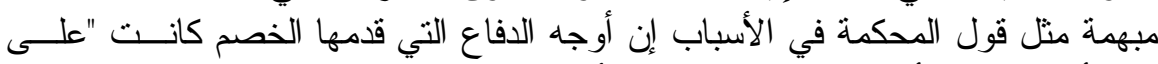

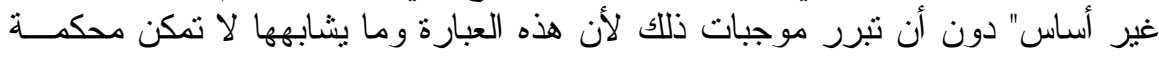

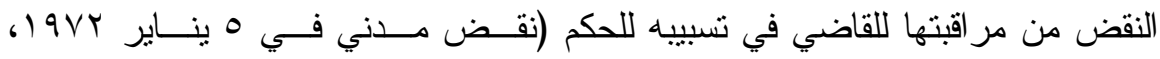

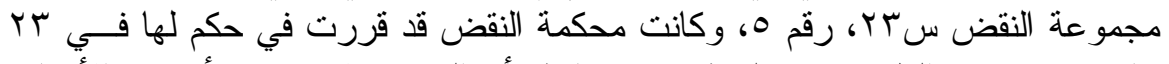

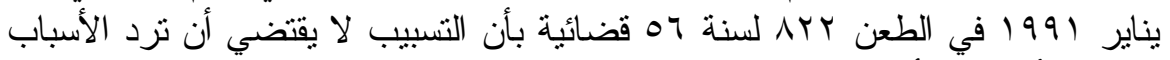

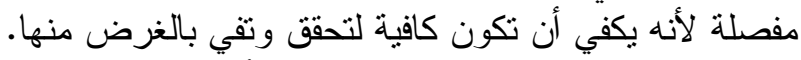

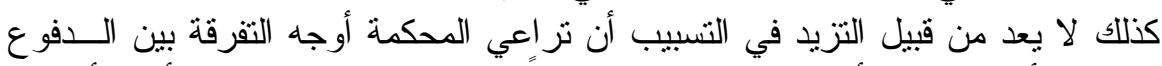

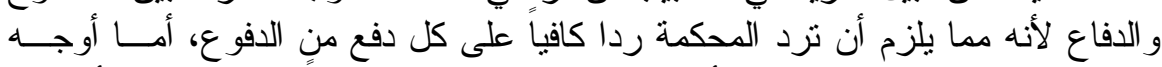

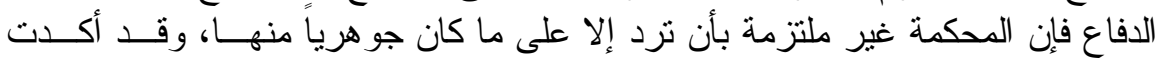

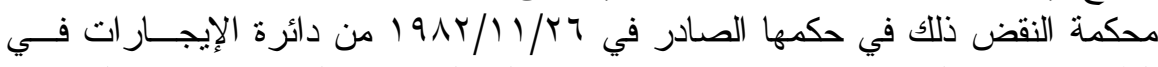

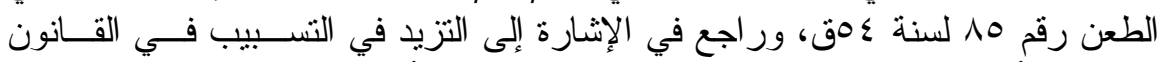

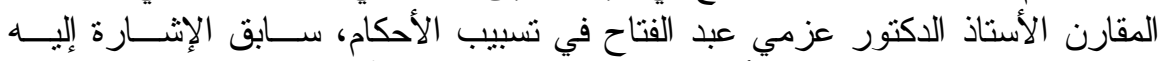

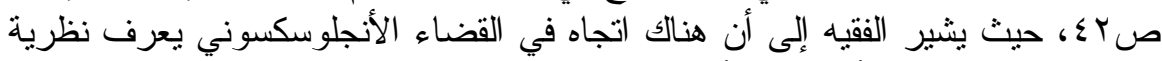

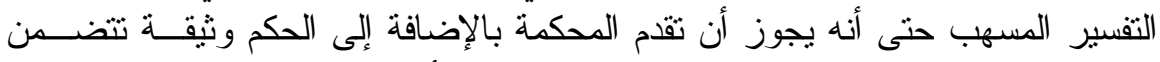

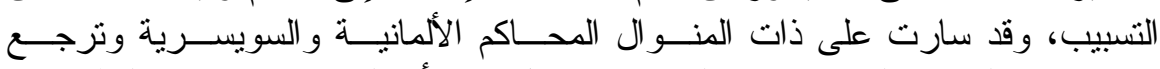

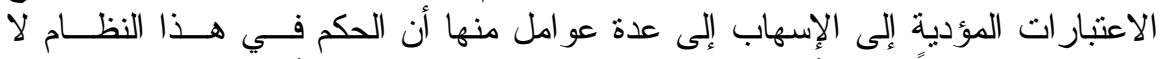

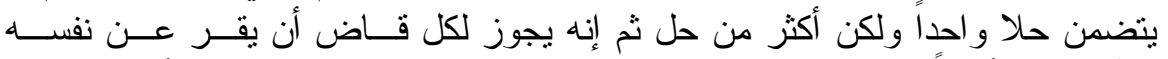

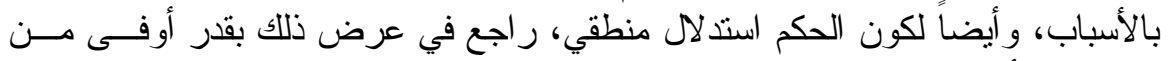

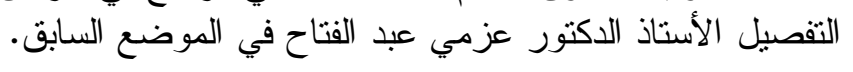




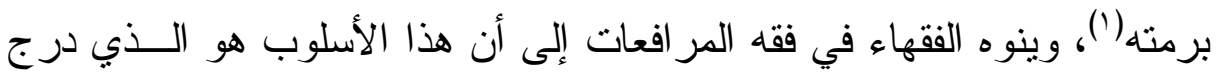

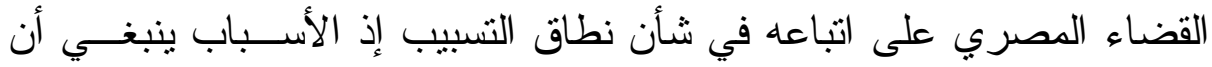

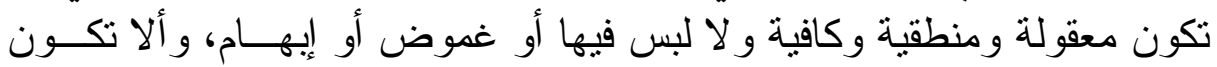

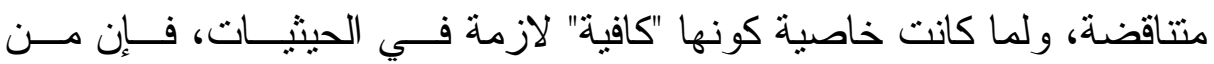

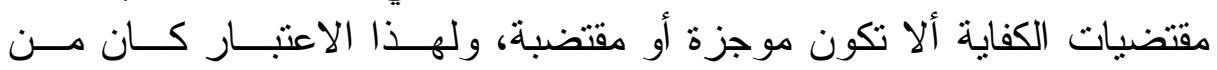

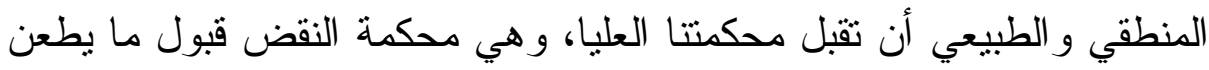

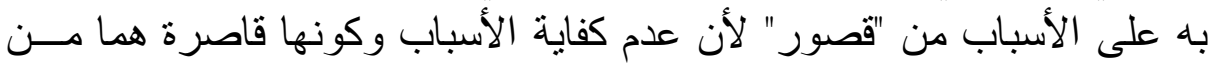

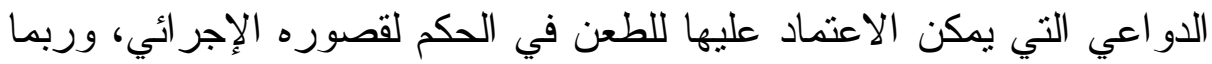

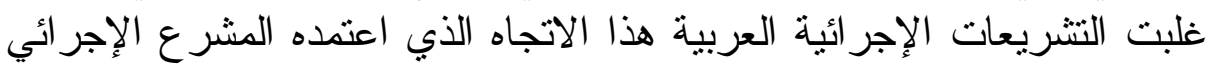

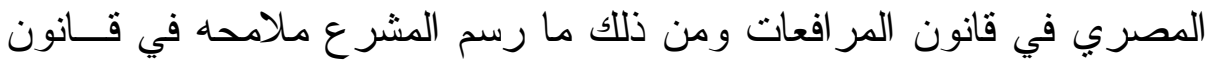

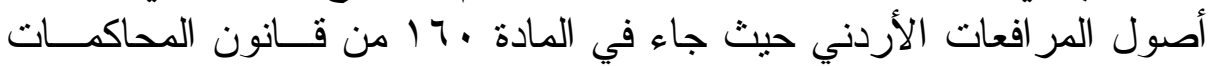

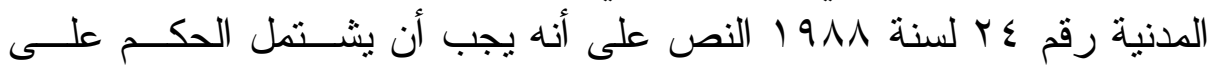

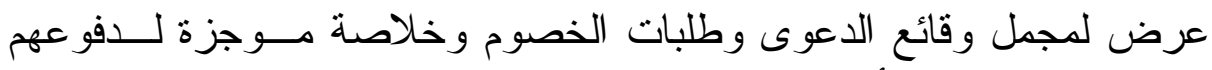

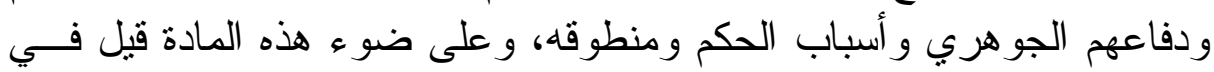

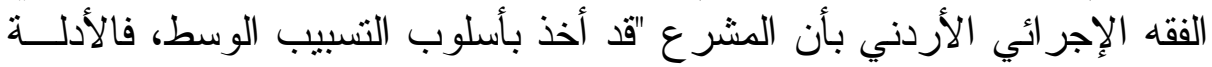

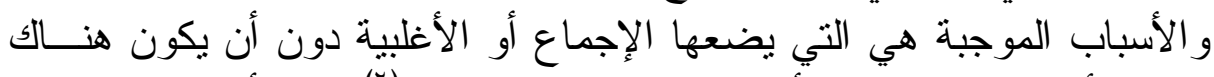

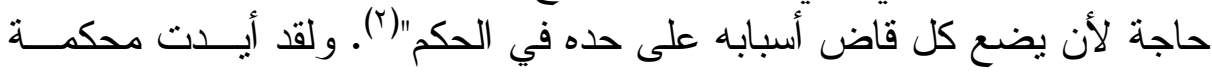

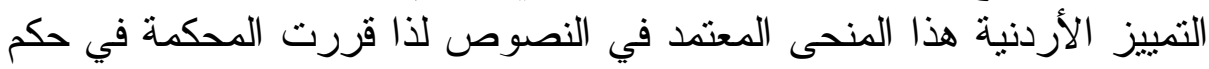

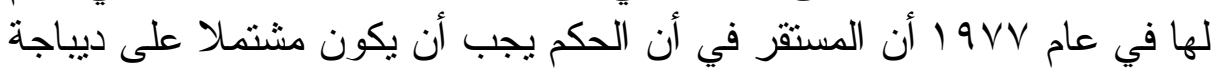

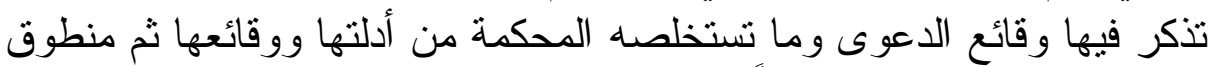

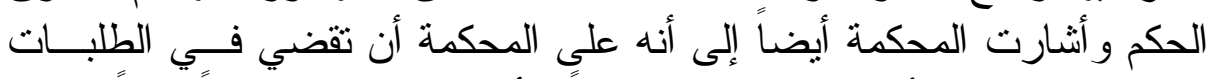

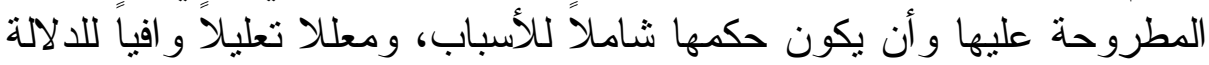

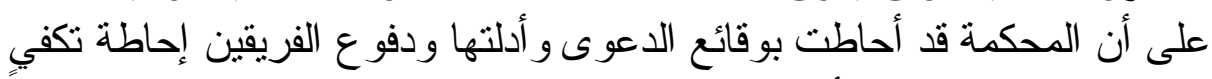

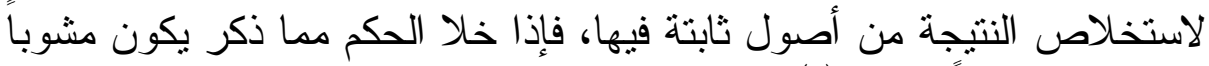

بالقصور ومخالفاً للقانون ().

(') و وعلى العكس من الإسهاب في التسبيب اتجهت بعض الأنظمة الإجرائية إلـى الإيجــاز

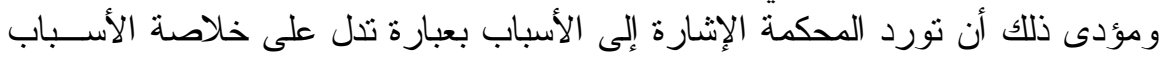

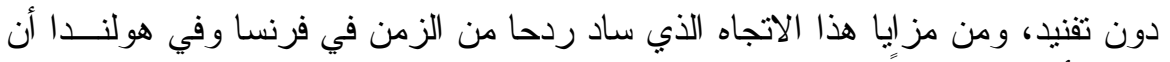

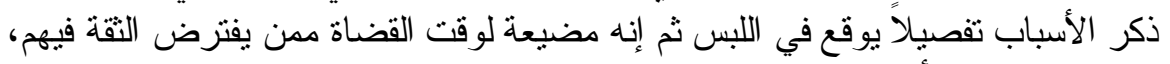

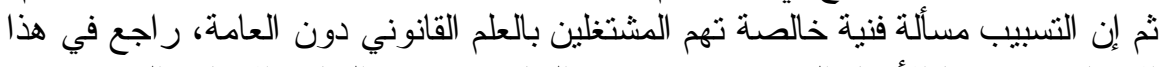

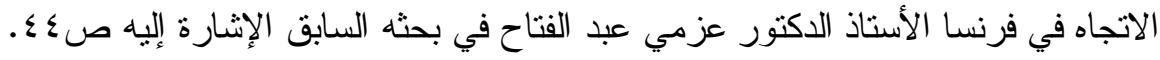

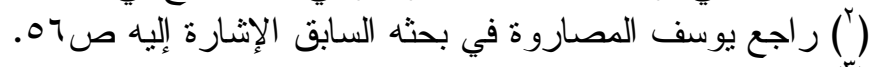

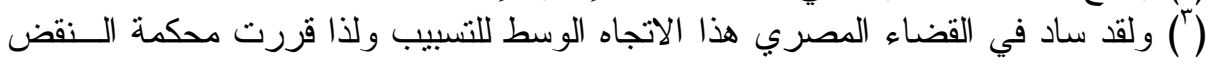




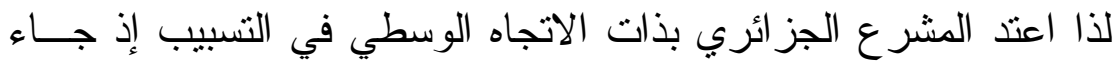

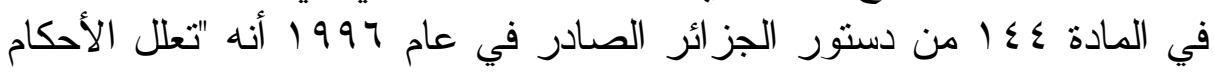

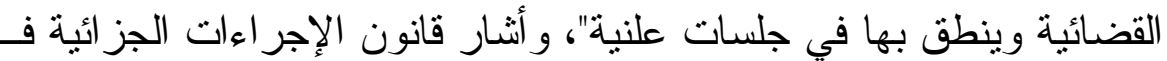

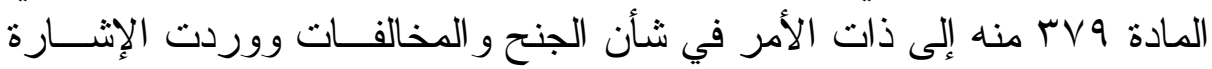

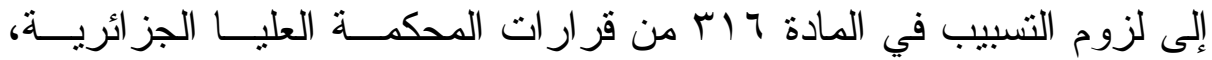

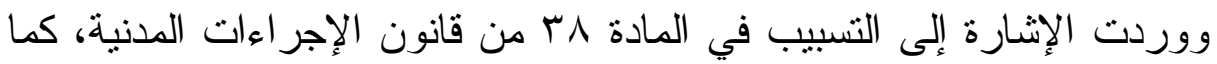

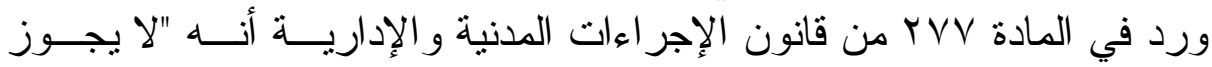
النطق بالحكم إلا بعد تسبيبه، ويجب أن يسبب الحنب الحكم من حيث الوقائع و القانون

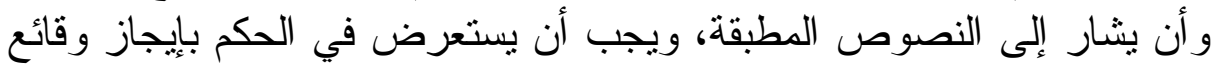

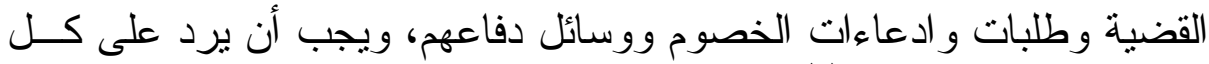

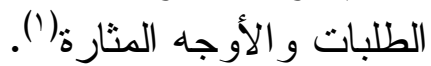

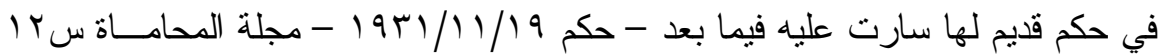

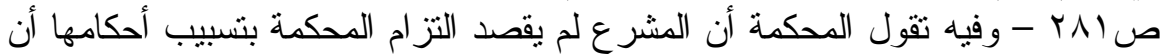

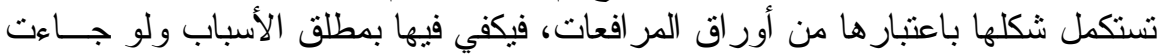

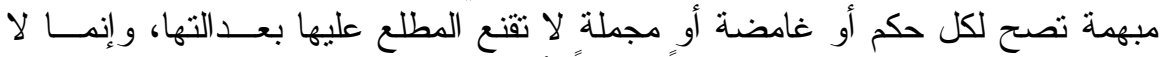

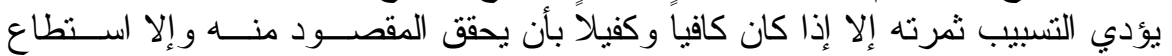

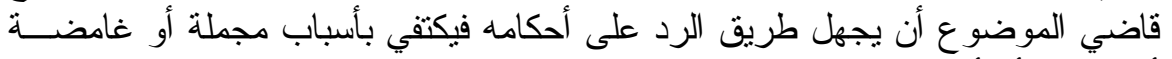

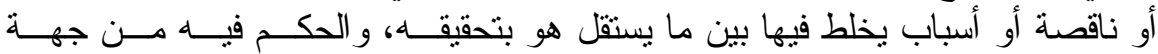

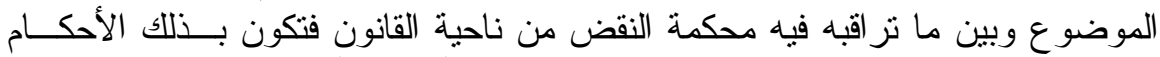

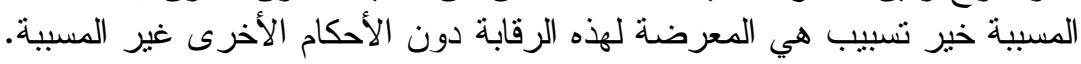

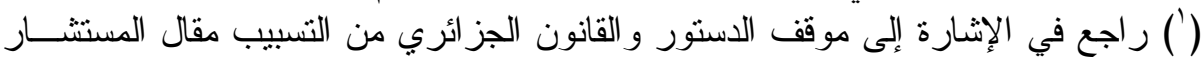

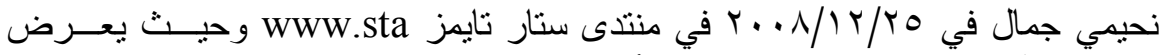

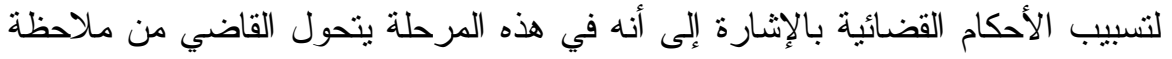

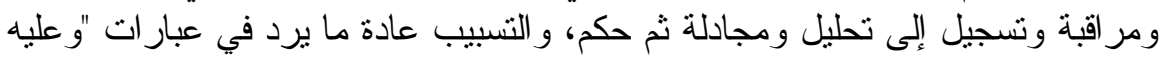

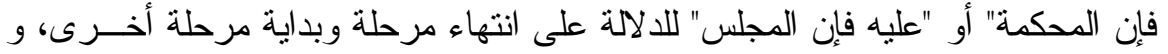

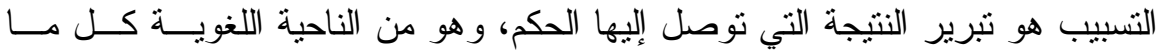

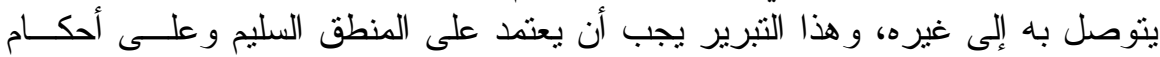

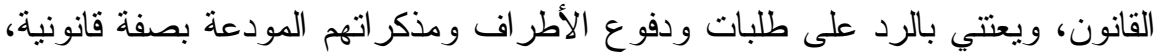

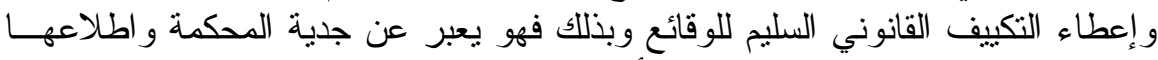

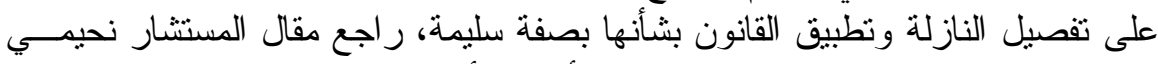

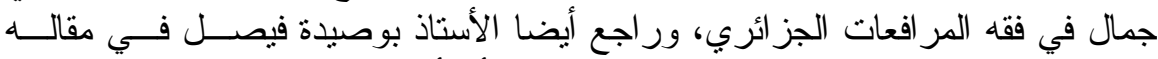

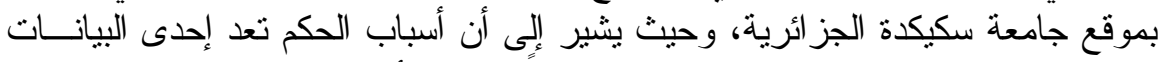

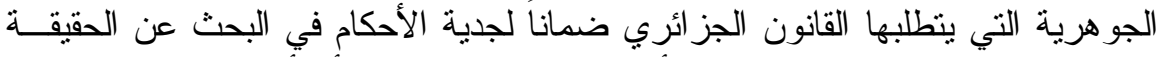

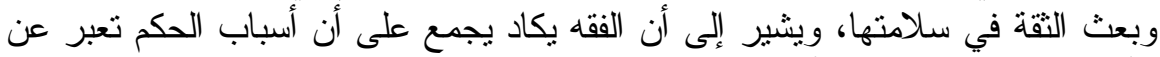
الأدلة و الحجج للو اقعة و الأسانيد القانونية التي خلص إني إليها الحكم. 


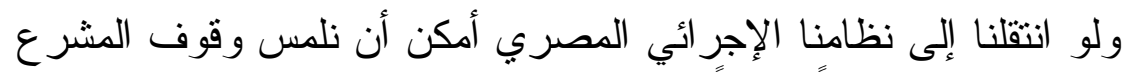

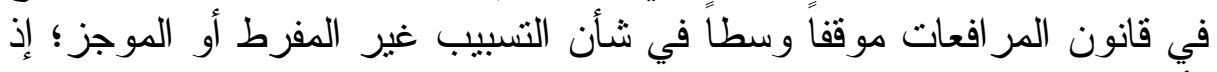

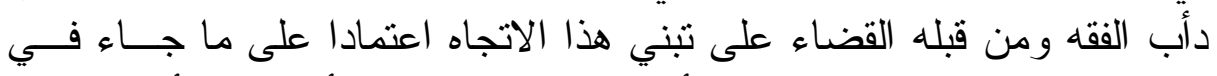

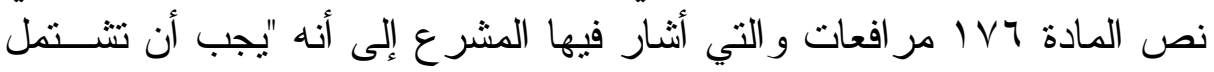

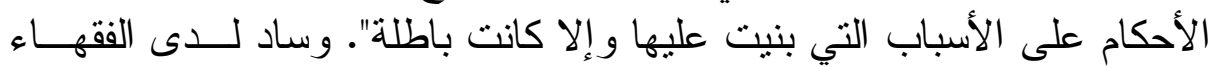

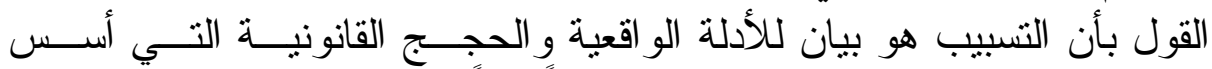

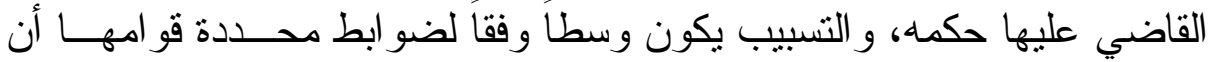

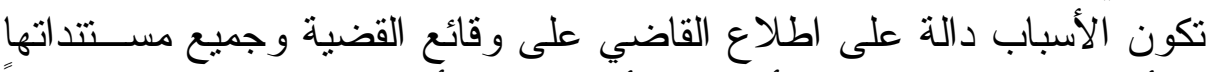

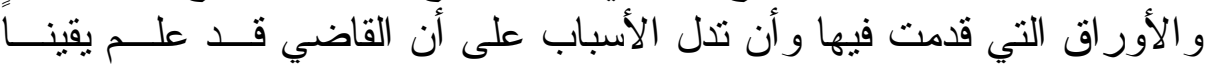

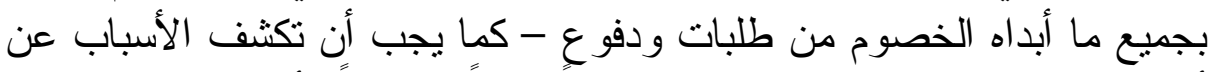

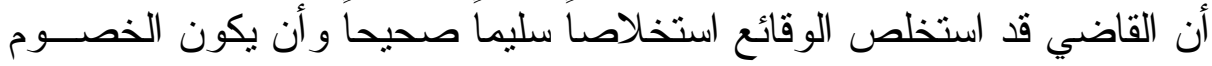

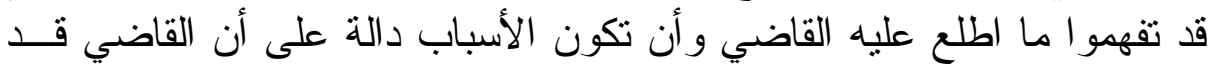

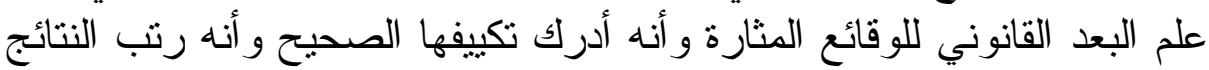

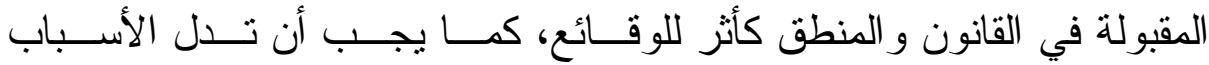

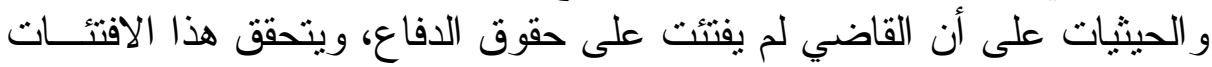

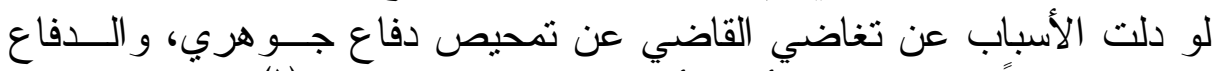

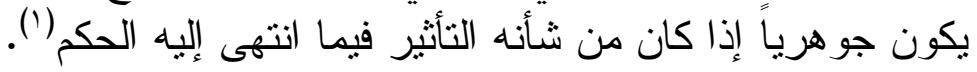

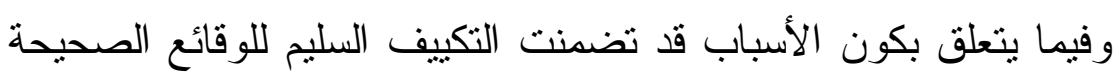

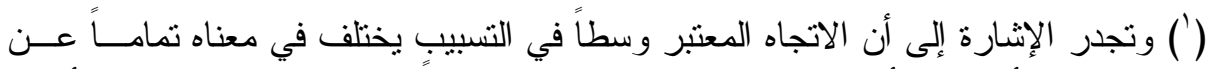

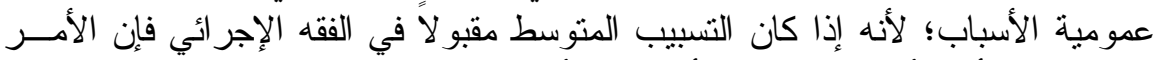

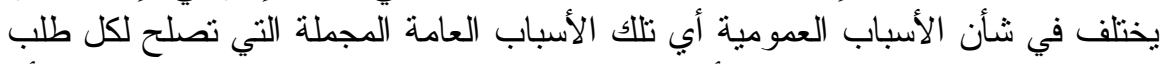

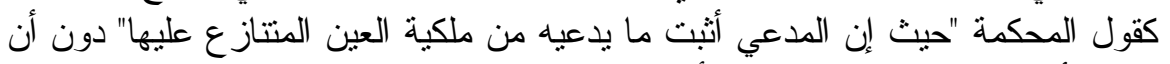

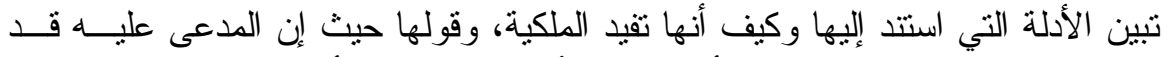

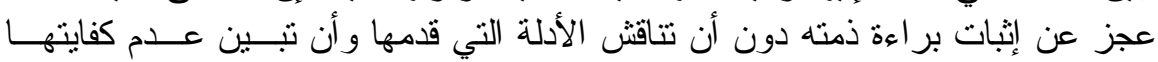

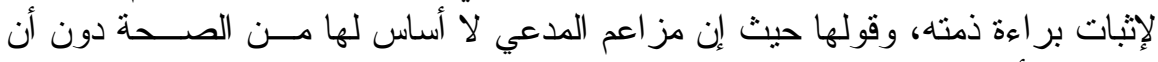

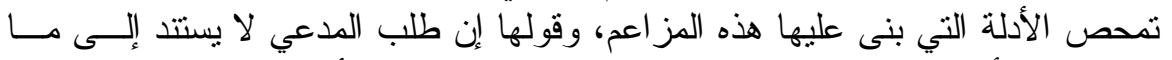

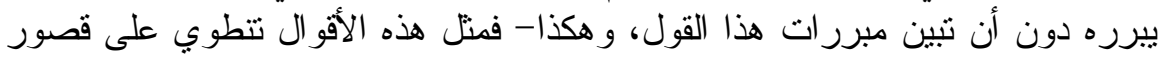

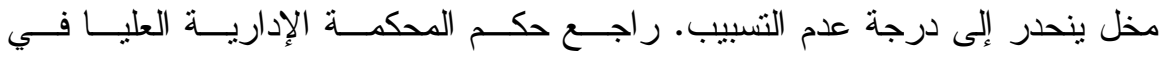
•

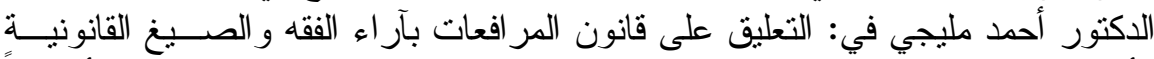

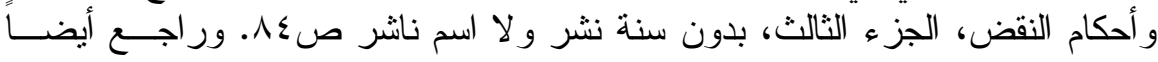

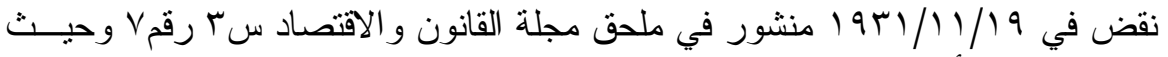

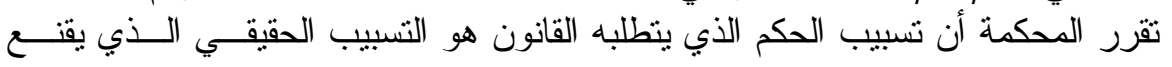

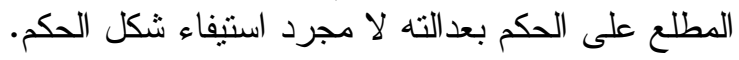


وأن يكون القاضي قد أورد في حكمه ما يعد من نتائج التحديد الصحيح للتكييف

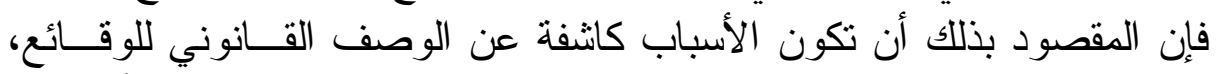

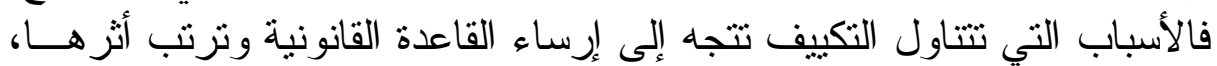

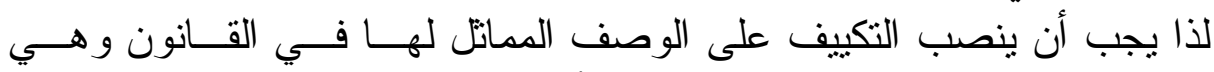

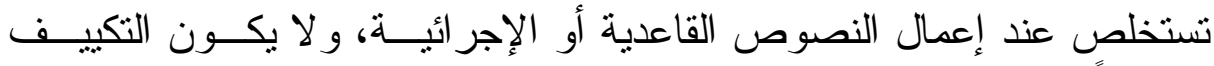

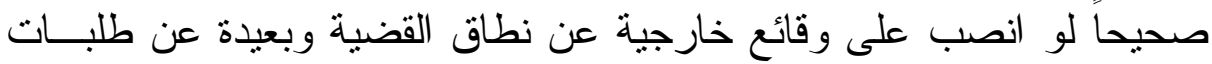

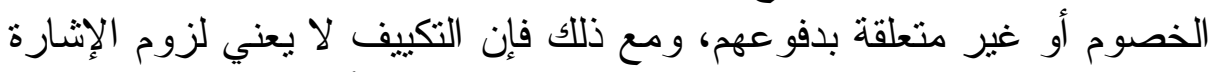

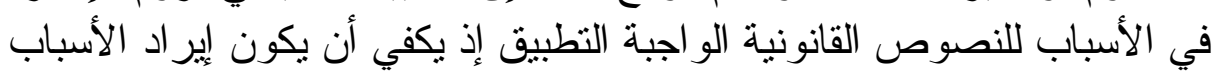

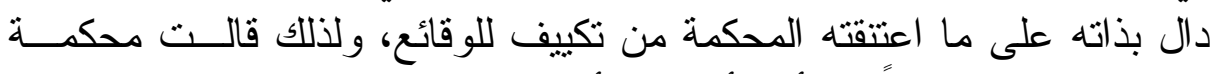

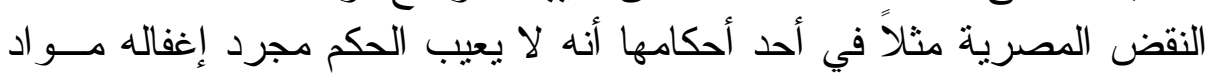

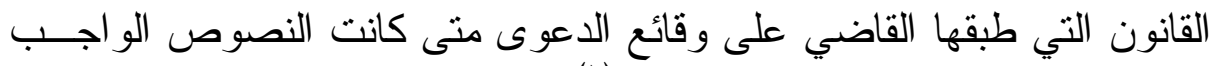

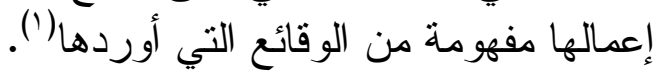

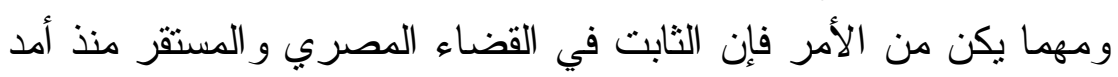

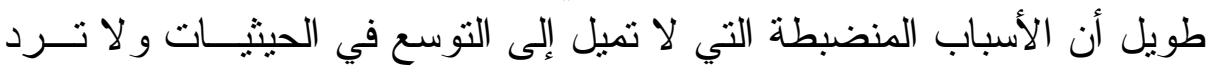

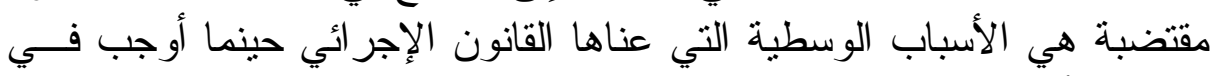

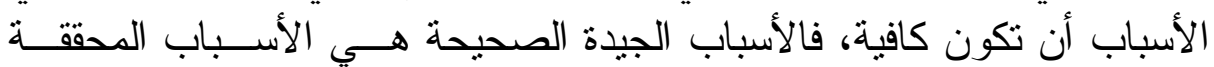

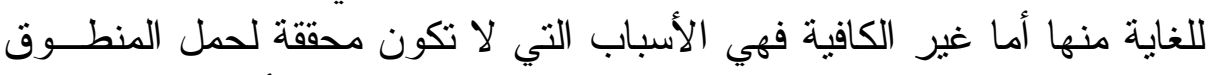

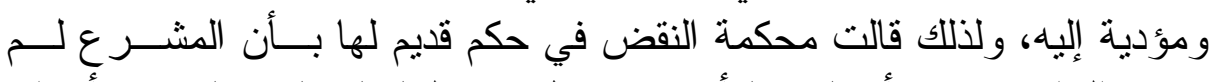

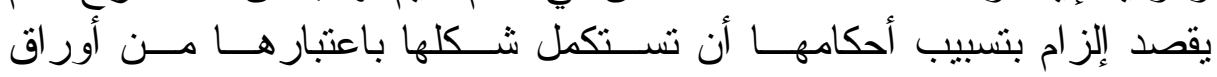

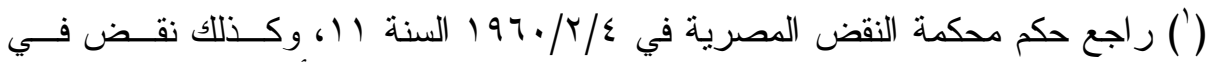

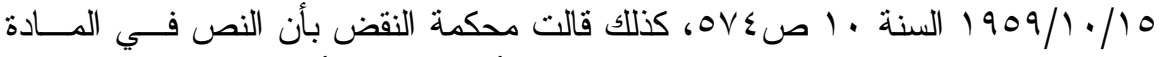

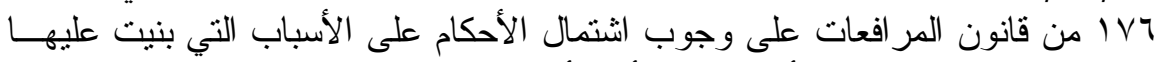

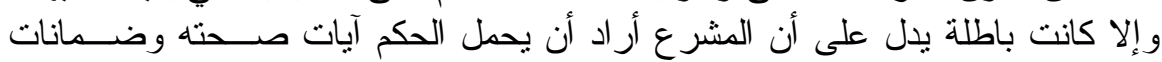

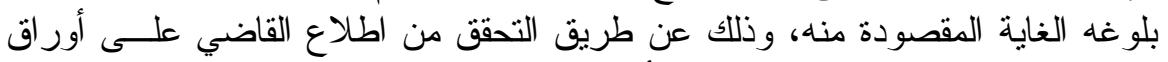

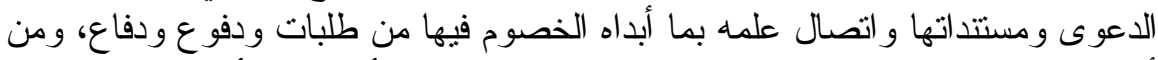

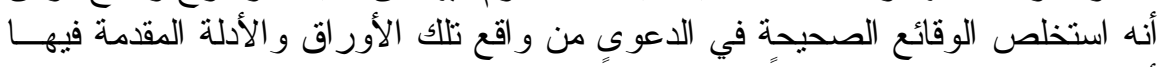

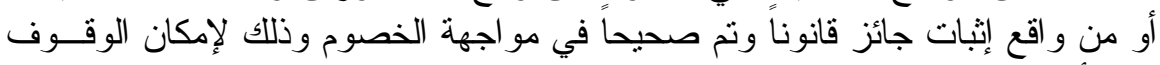

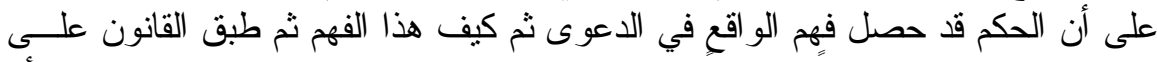

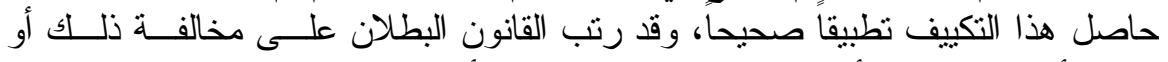

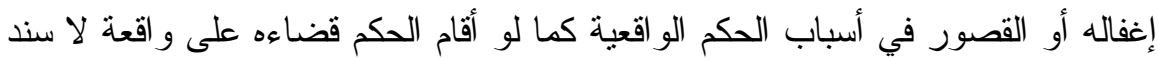

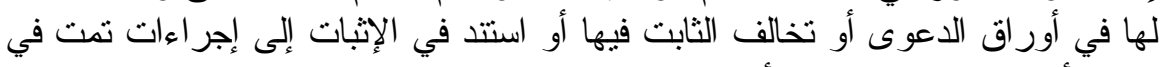

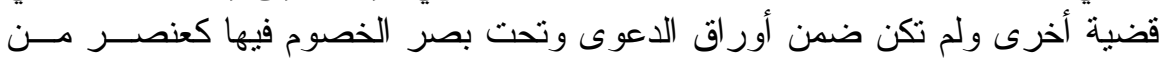

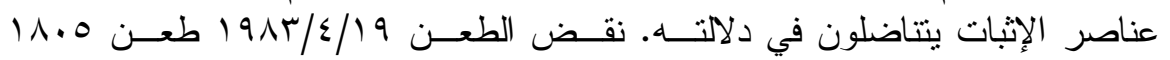

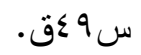




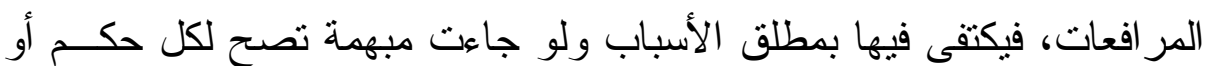

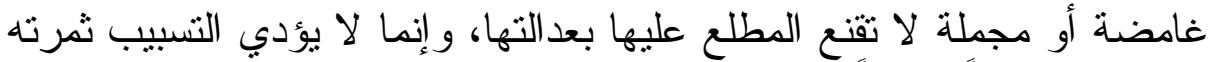

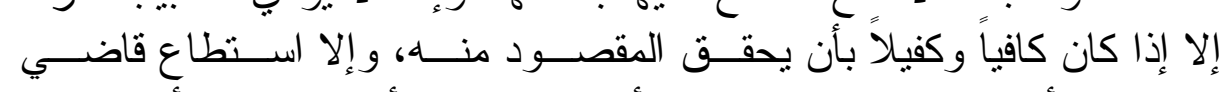

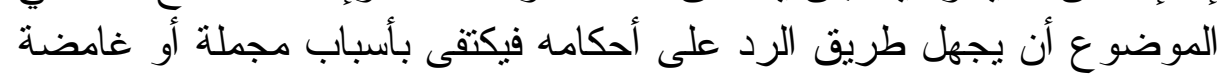

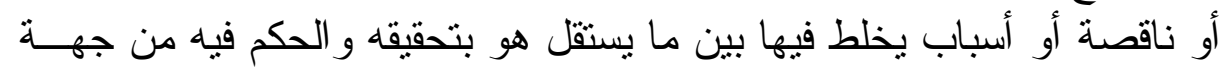

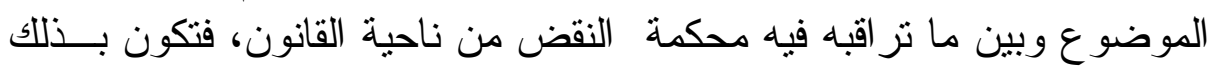

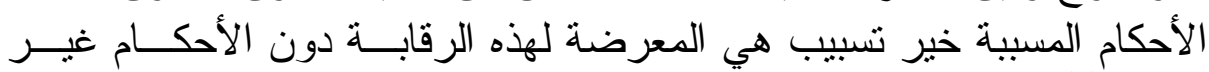

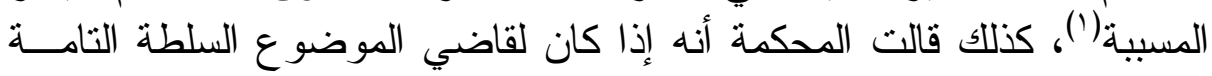

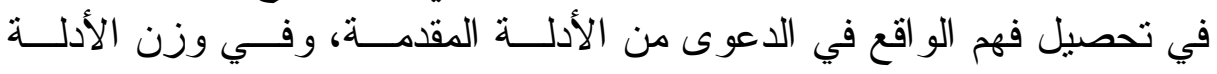

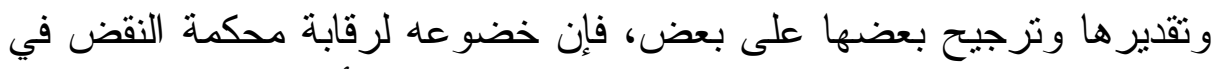

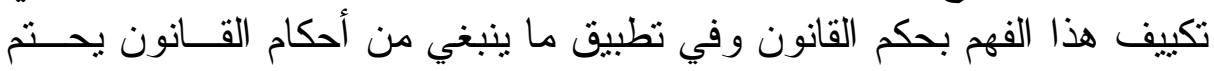

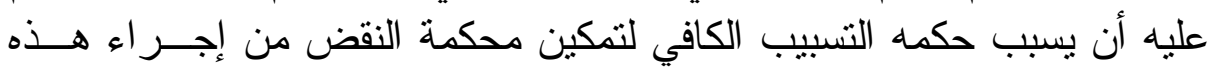

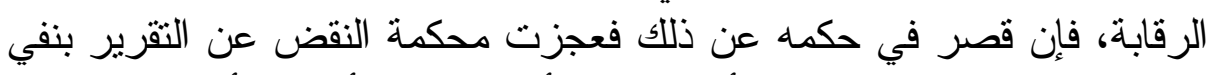

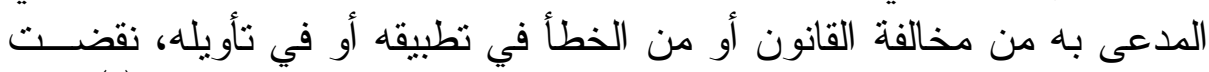

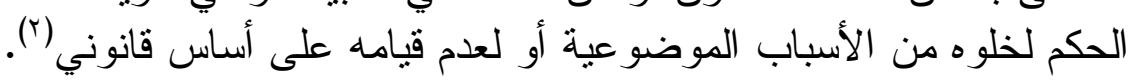

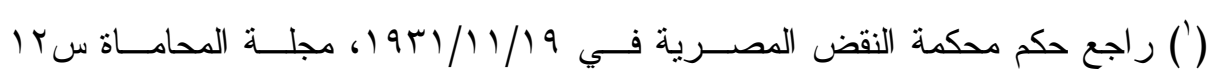

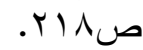

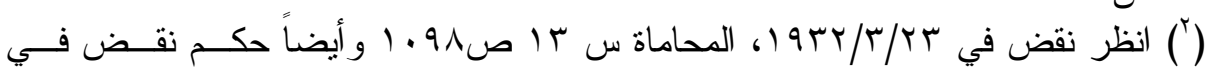

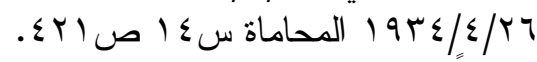

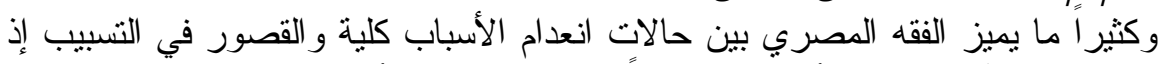

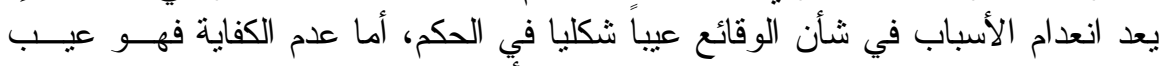

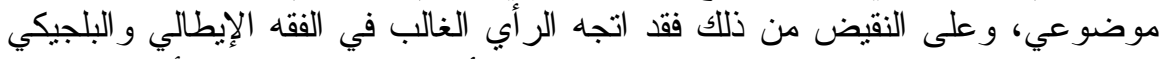

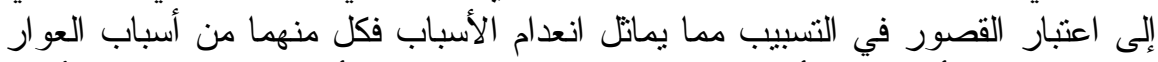

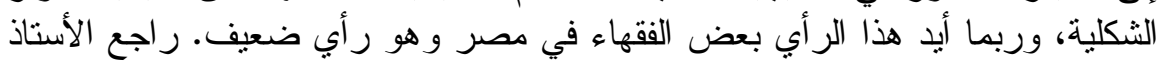

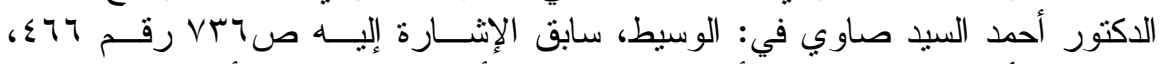

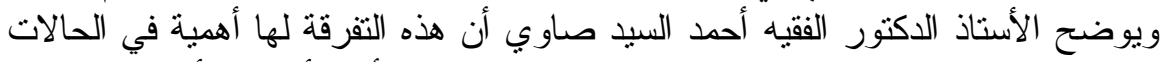

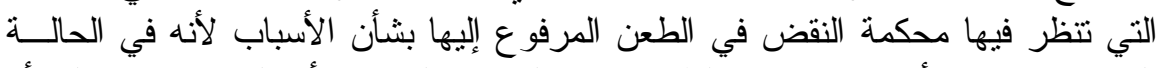

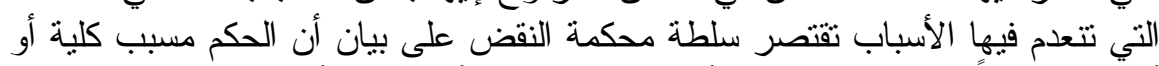

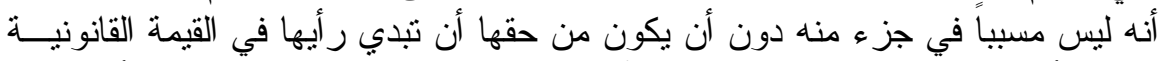

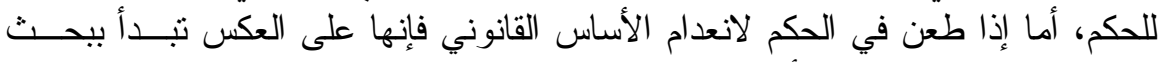

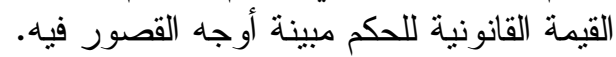

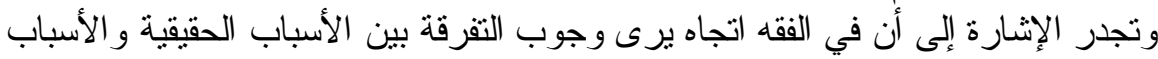

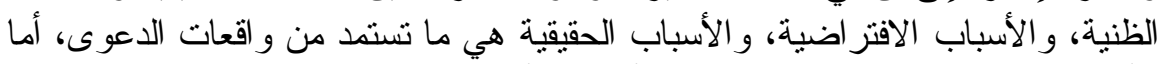

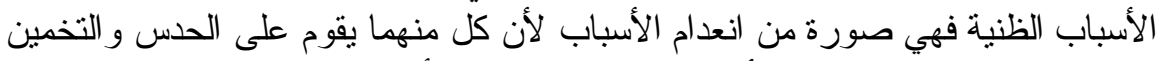

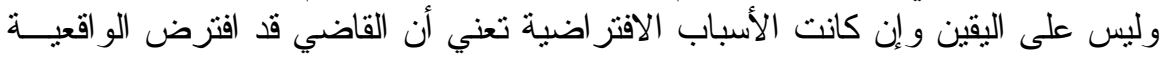


وكثيراً ما حرصت محكمة النقض على إظهار القصور في التسبيب في

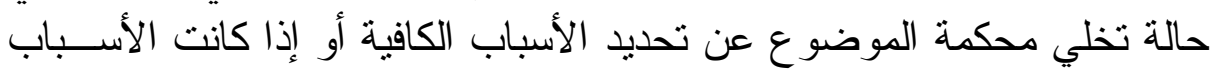

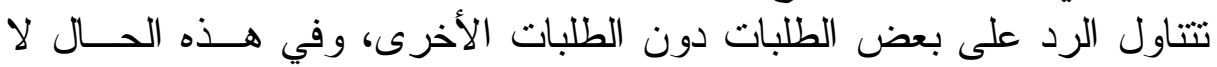

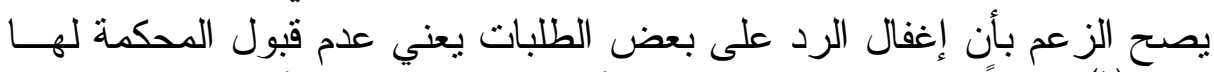

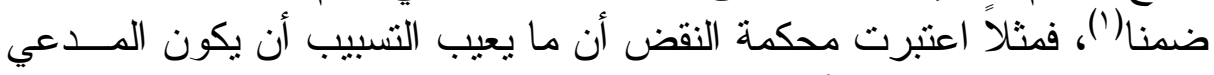

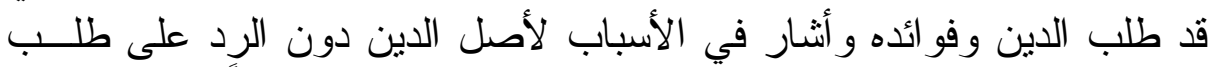

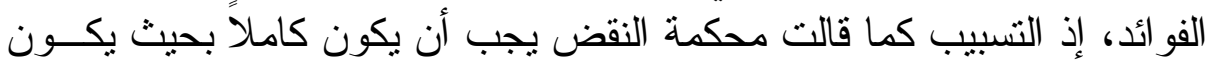
لكل طلب أو دفع أبدي في الدعوى أسبابه الخاصة أو رفض يقتضي قبـــول أو

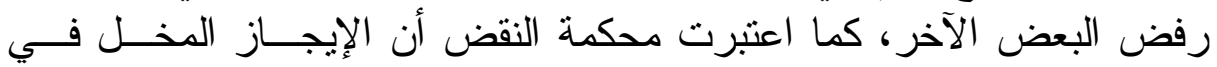
الأسباب يوجب النقض للقصور و عدم الكفاية، لذا قالت محكمتنا العليا في حكم

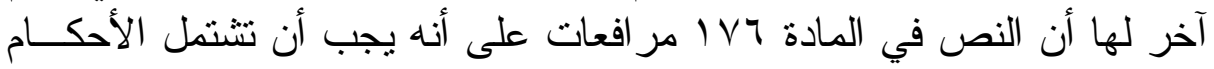
على الأسباب التي بنيت عليها و إلا كانت باطلة مؤداه و على ما جرى به قضاء

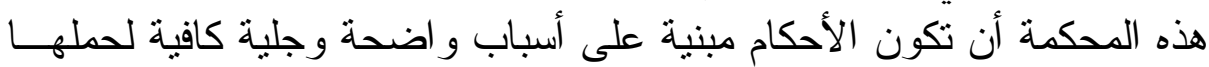
و أنه إذا ما طرح على محكمة الموضوع بالطريق القانوني طلب أو دفاع منتج

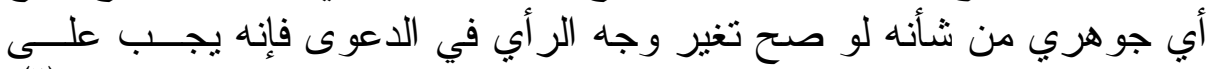

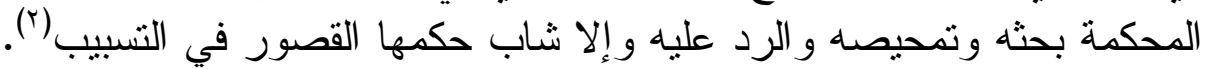

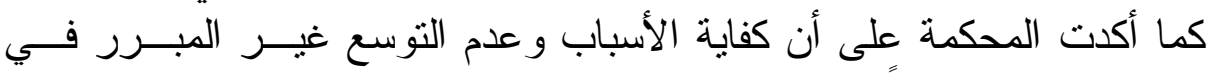

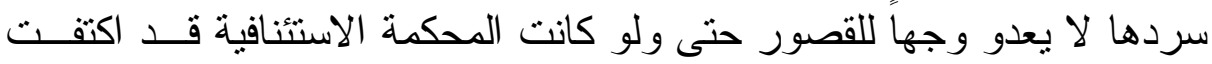

افتر اضاً فأقام الحكم على و اقعة من نسيج خياله، راجع الأستاذ الدكتور أحمد السيد صاوي

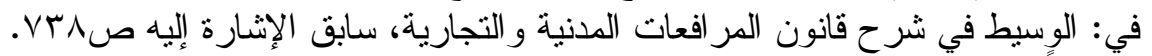

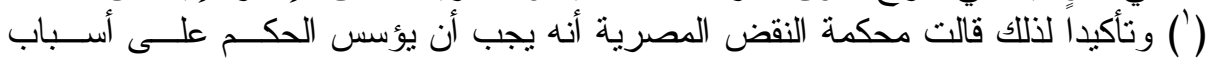

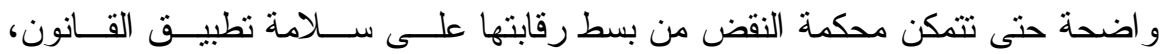

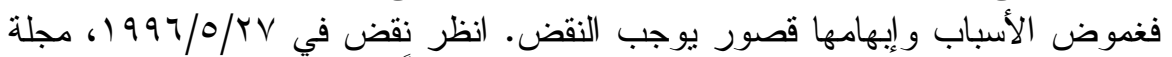

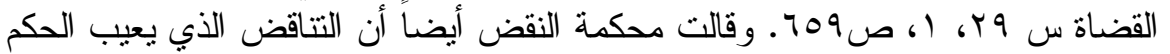

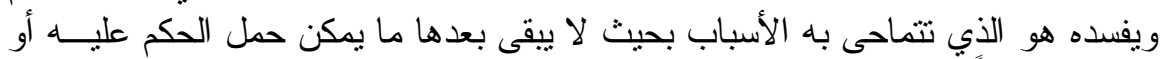

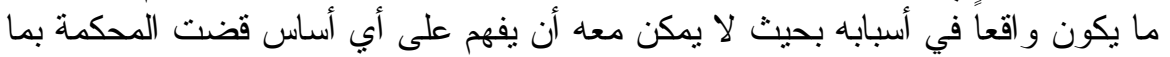

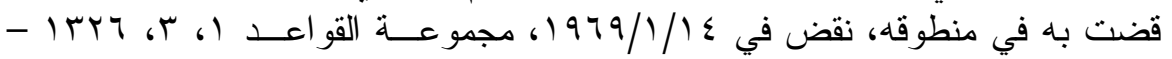
rONE

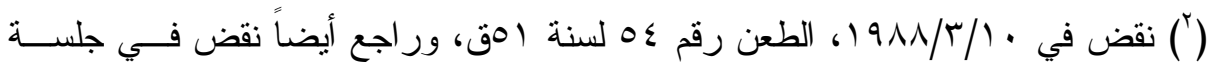

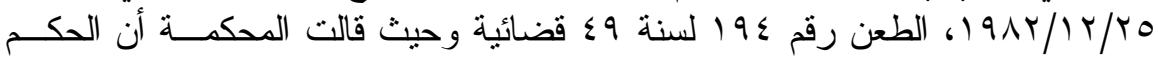

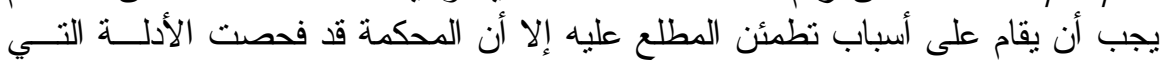

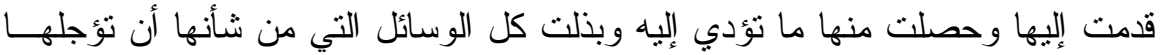

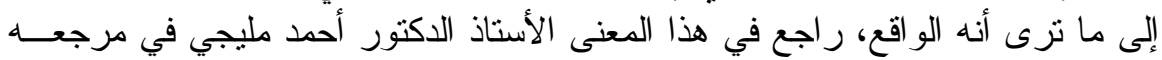

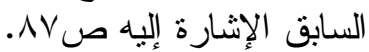


بالإحالة إلى ذات الأسباب التي بني عليها الحكم الابتدائي مادام لم تقدم طلبات

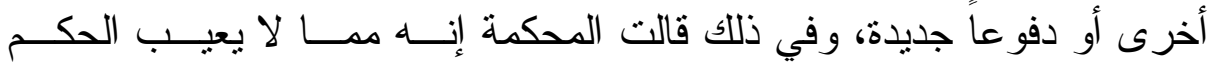

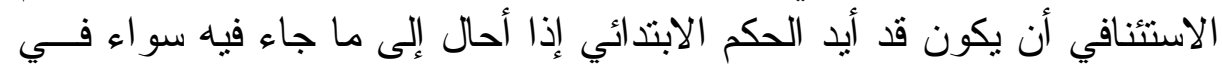

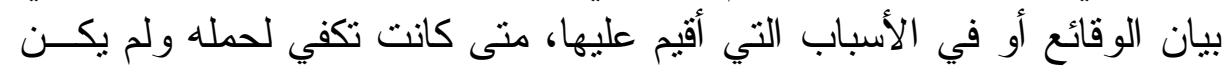

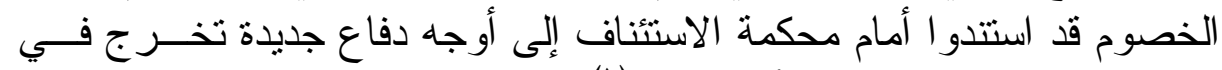

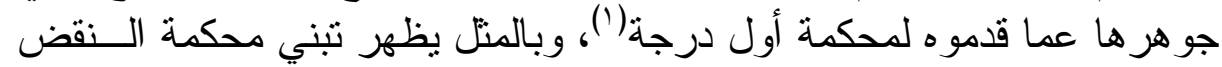
المذهب الوسطي في التسبيب في حكمها الذي قضت فئ فيه بأن محكمة الاستئناف

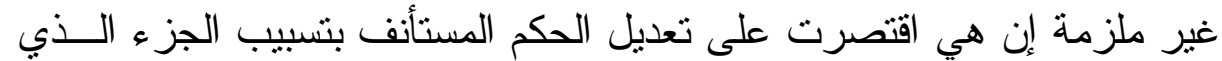

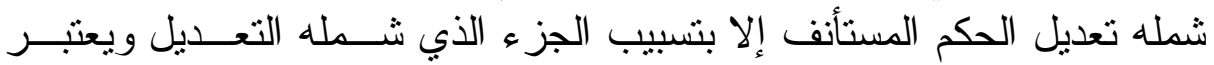

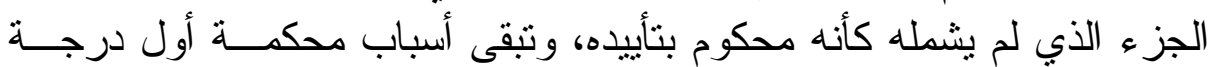

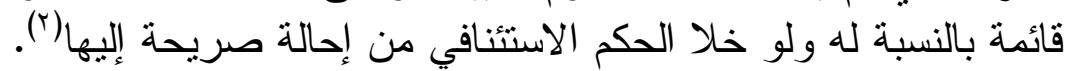

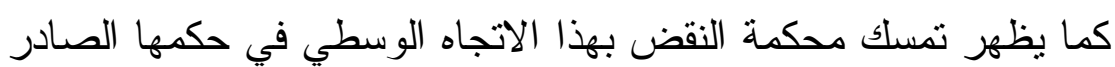

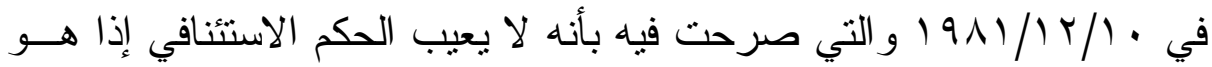

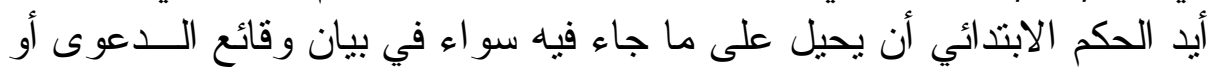

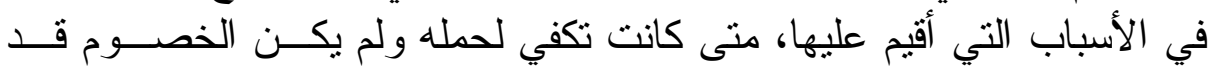

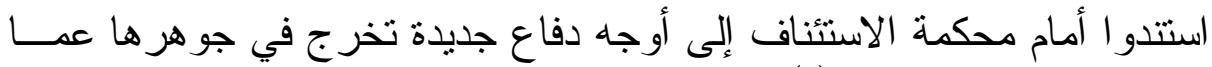

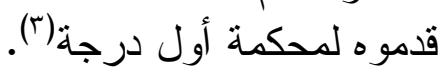

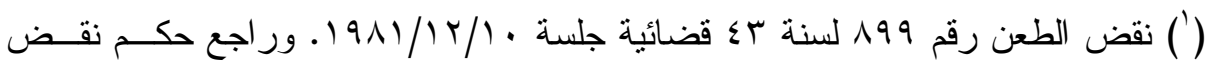

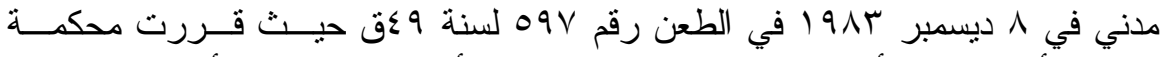

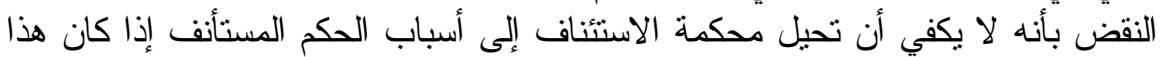

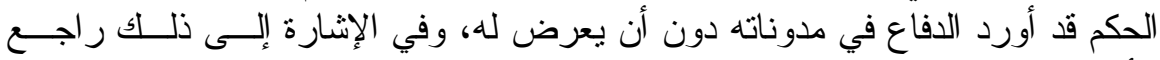

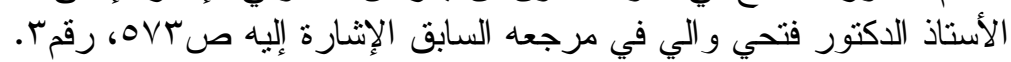

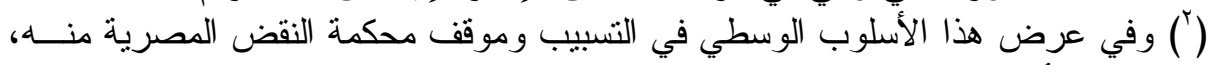

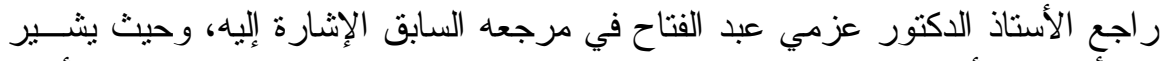

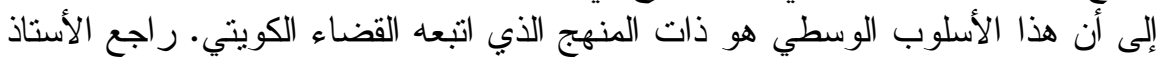

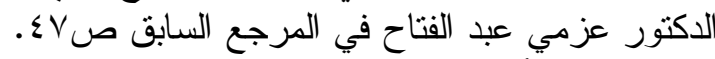

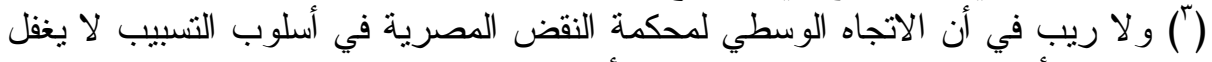

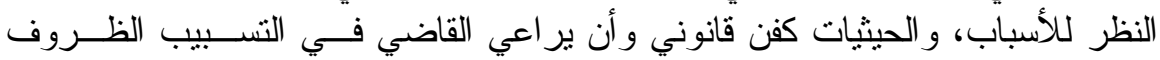

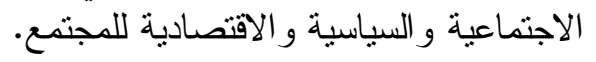




\section{المطلب الثاني \\ التفرقة بين تسبيب الأحكام القضائية \\ وبين تكييف الوقائع المعروضة الاونة في القضية الفئة}

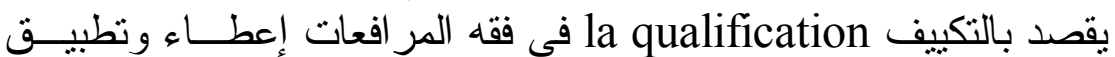

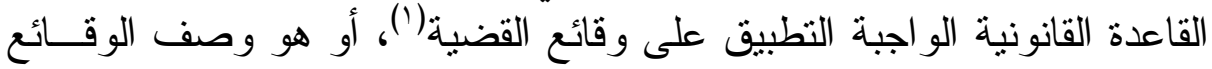

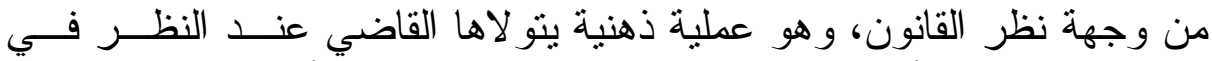

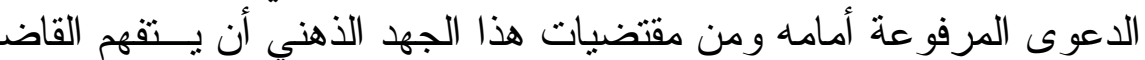

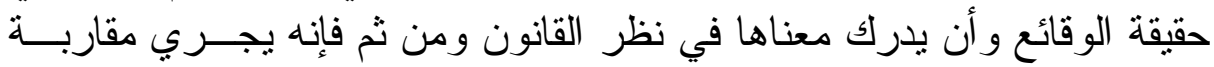

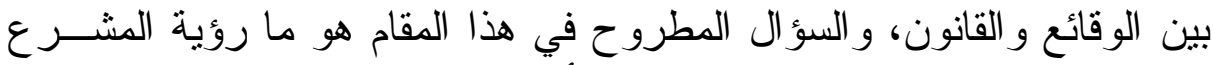

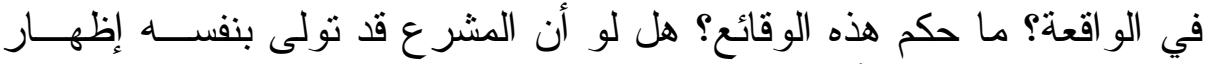

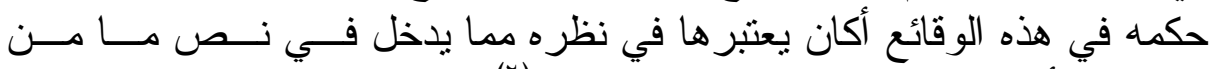

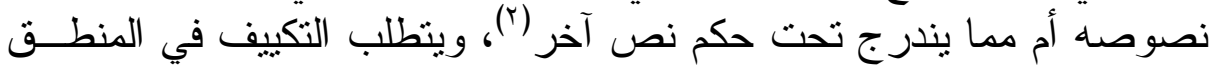

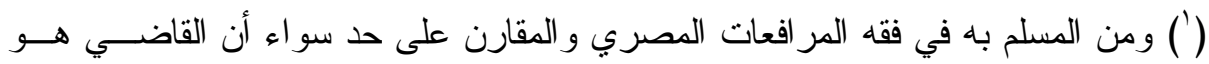

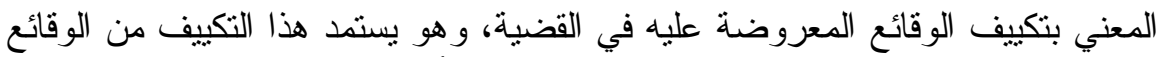

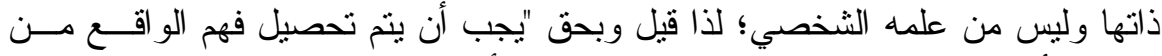

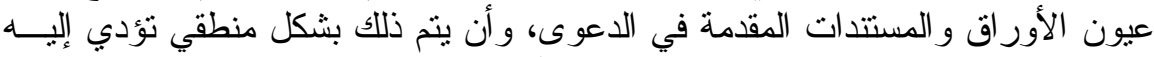

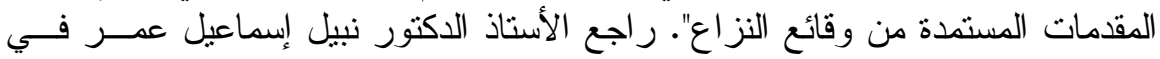

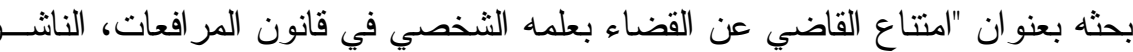

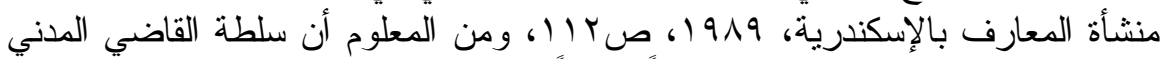

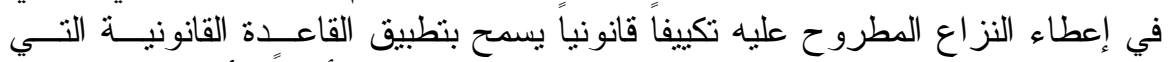

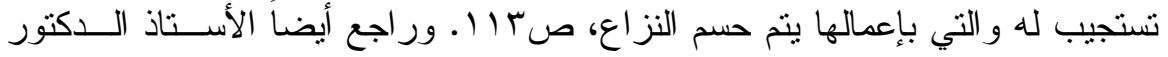

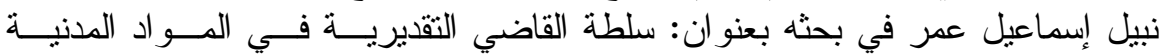

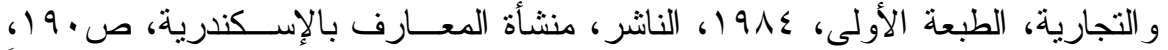

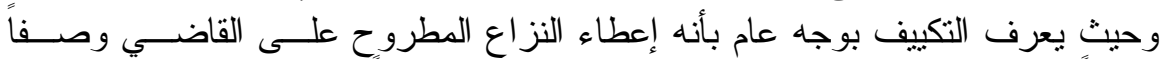

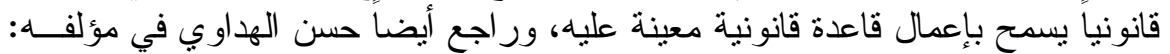

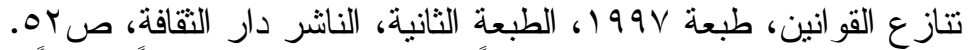

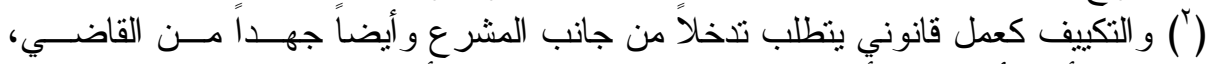

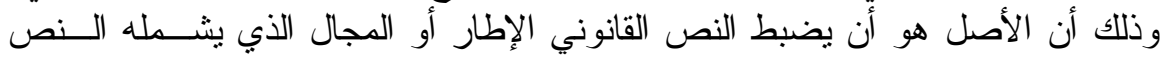

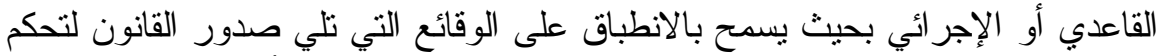

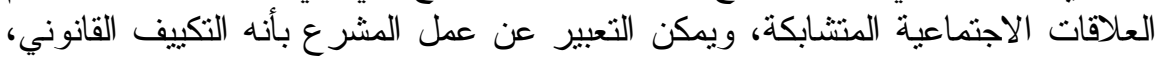

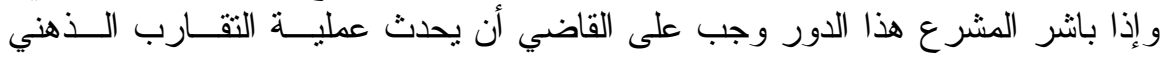

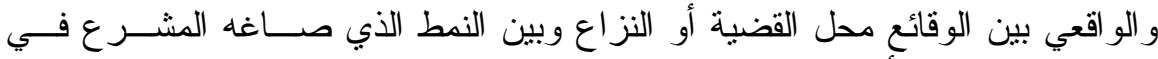

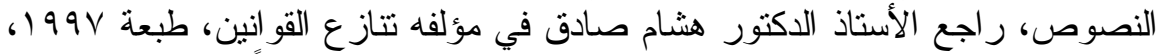

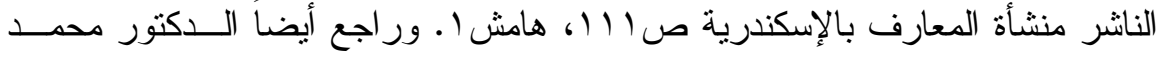

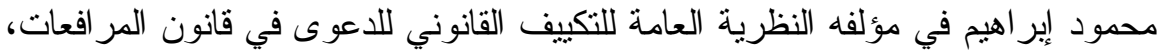

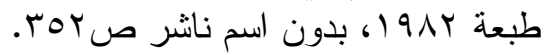


القانوني الصحيح أن ينظر القاضي في العناصر ويستخلص مفرداتها ويقــارب

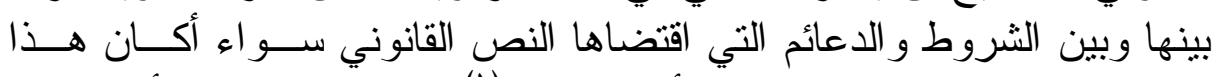

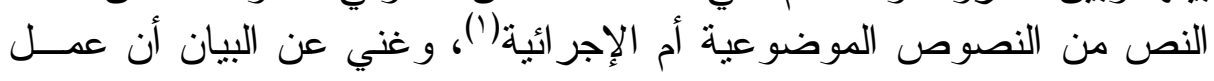

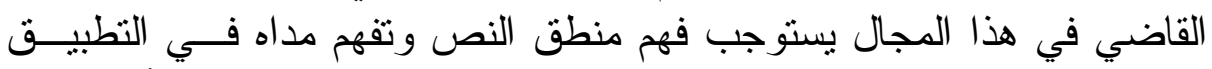
وقياس معطيات الو اقع على مفترضات النمط القاعدي المستمد من الألفاظ التي التي

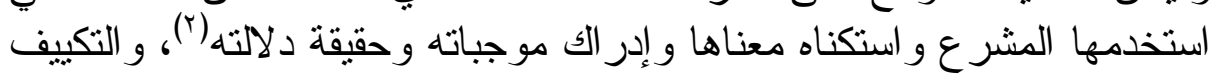

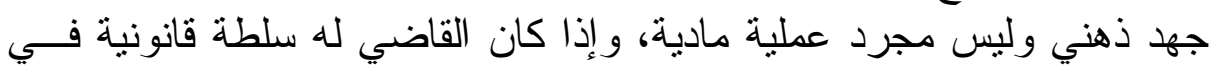

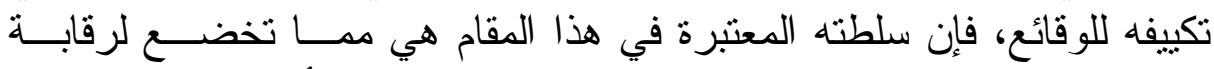

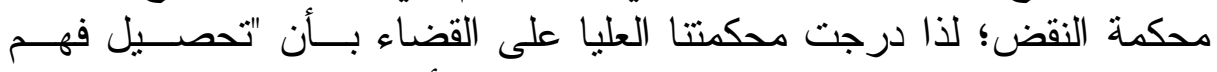

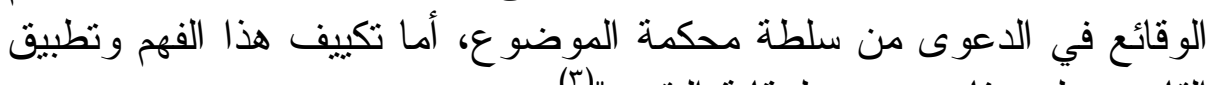

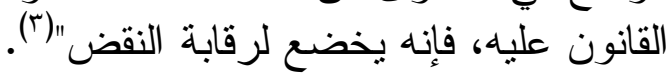

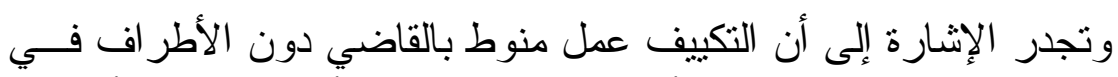

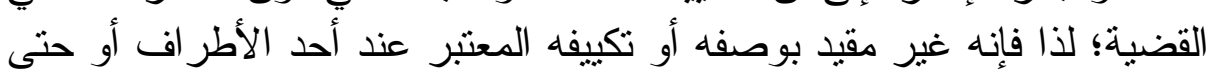

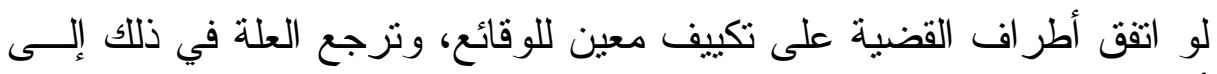

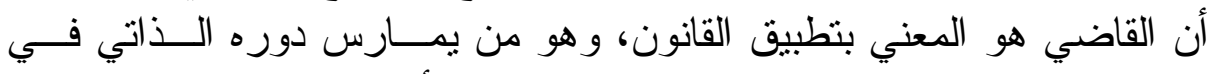

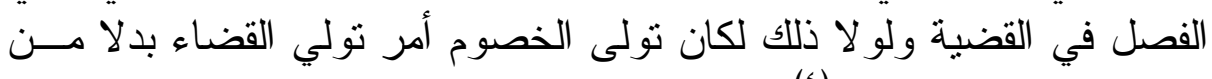

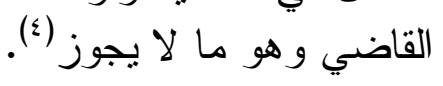

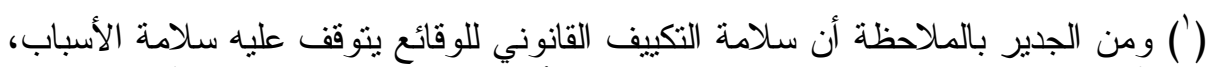

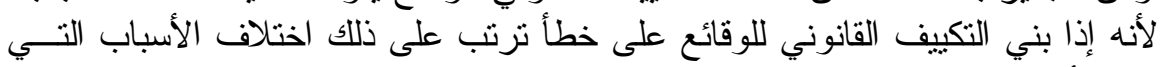

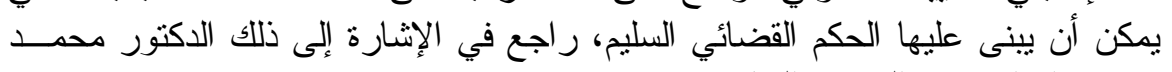

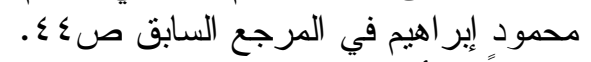

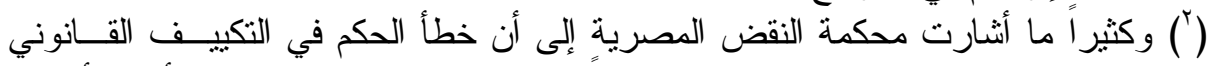

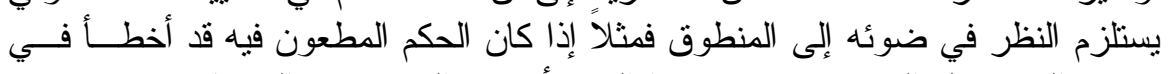

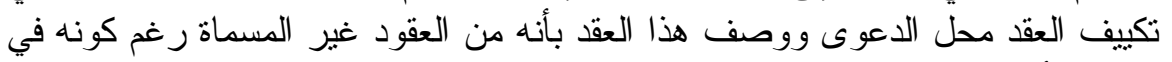

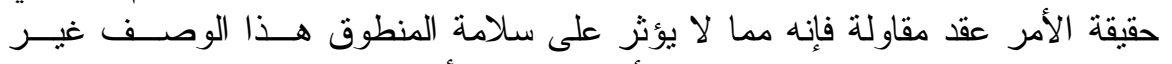

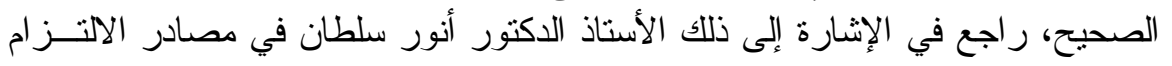

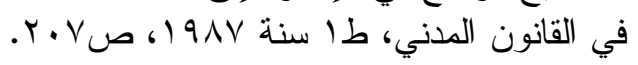

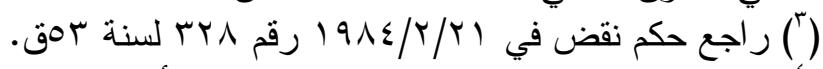

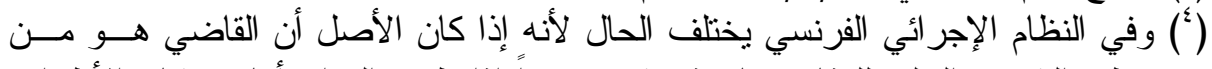

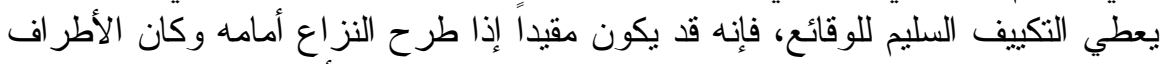

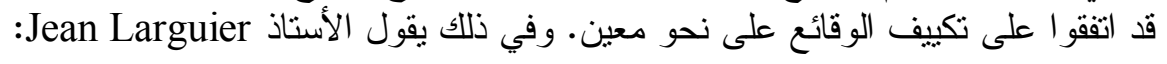
Quant au droit - le juge - peut restituer aux faits et actes leur véritable qualification; si le demandeur n' a pas indiqué le fondement juridique de sa pretention, le juge doit rechercher la règle de droit 


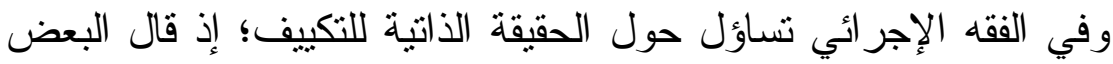

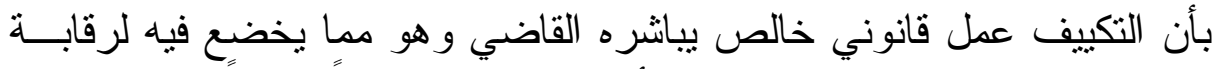

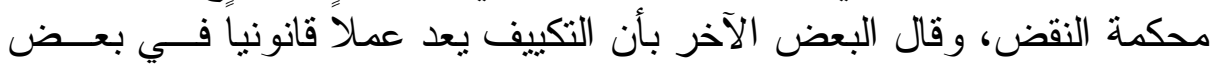
الأحيان، هو اجتهاد من القاضي في البعض الآخر ، وهو يكون كذلك في الكي الحالة

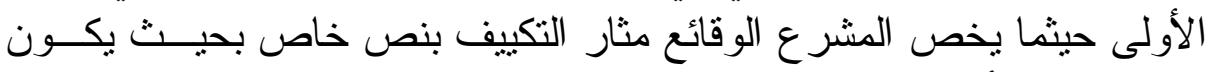

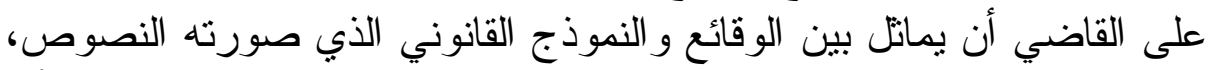

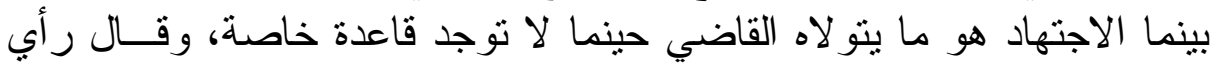

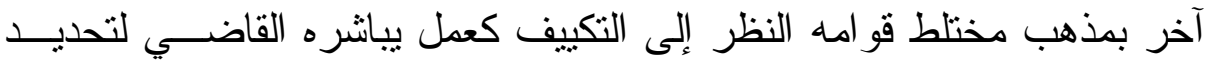

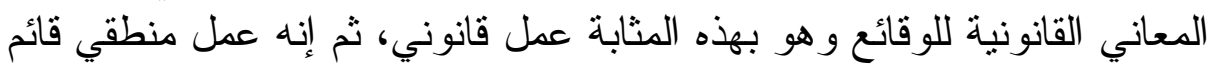

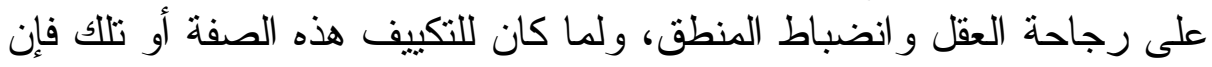
لمحكمة النقض أن تز اقب القاضي في مقتضيات تكييفه الوقائع.

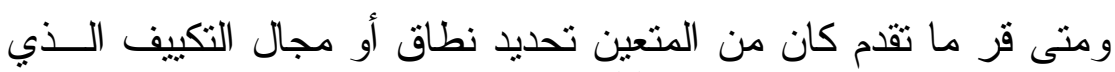

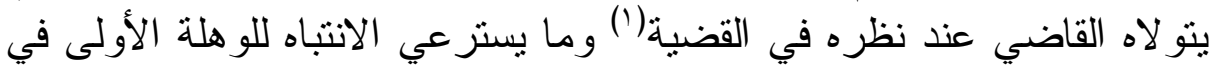

applicable, ex. responsabilité contractuelle ou délictuelle, le juge peut relever d' office les moyens de droit même non d'ordre public, sauf limitation par les parties et doit le faire pour les moyens de droit d'ordre public.

ثم يضيف الفقيه إلى ذلك قوله إن للخصوم أن يحددو ا صلاحيات القاضــي فــي شــأن التكييف بذكره

Les parties, pour les droits don't elles ont la libre disposition et à condition qu' elle, soient d' accord, peuvent restreindre ou augmenter les pouvoirs du Juge. Elles peuvent donner u Juge pouvoir des statuer comme amiable compositeur,

راجع: .70 - Jean Larguier; op. cit. p. 69

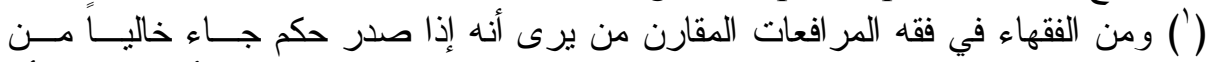

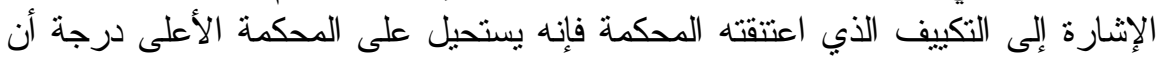

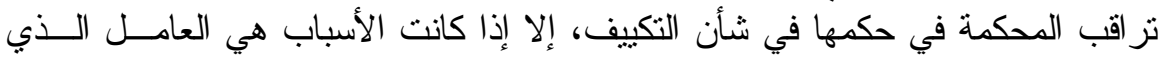

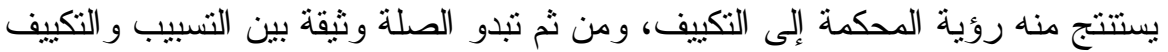

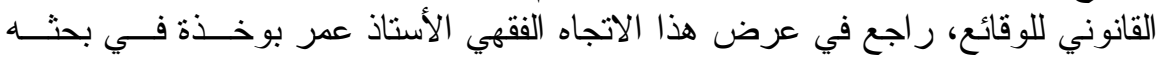

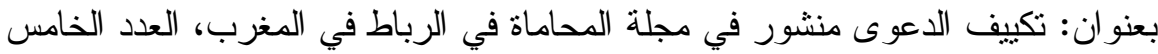

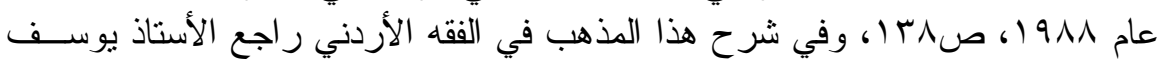

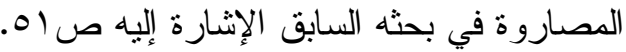

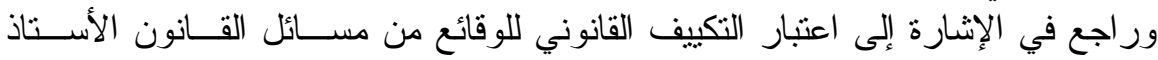

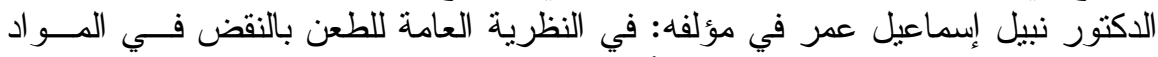

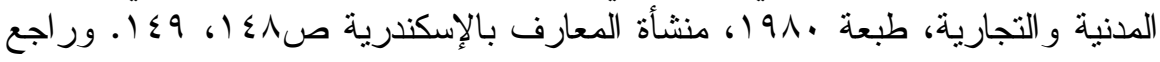




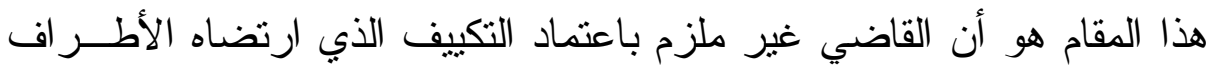

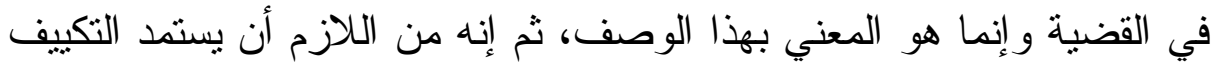

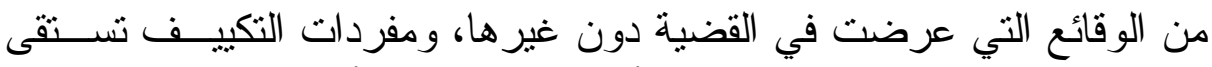

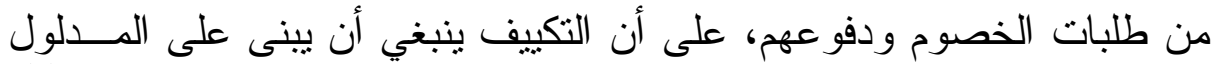

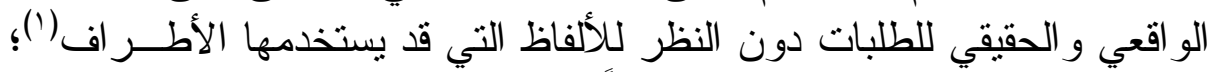

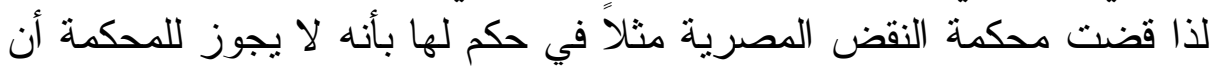

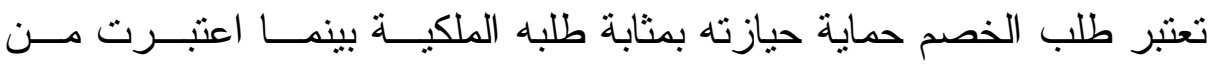

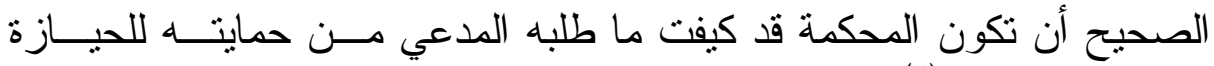
كطلب لاسترد ادهاب(r).

ويختلف نطاق تكييف الوقائع عن أسباب الحكم في القضية؛ لأنه إذا كان

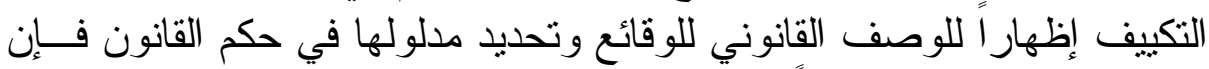

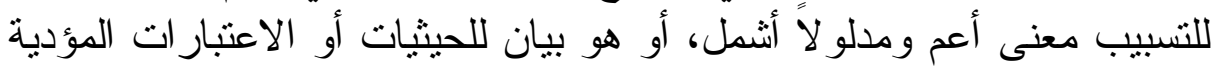

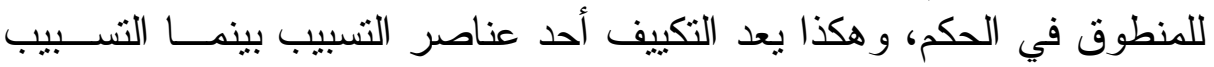

في الإثارة إلى صلة التكييف بالقانون الأستاذ محمد محمود إبر اهيم في مؤلفه: النظرية التانية

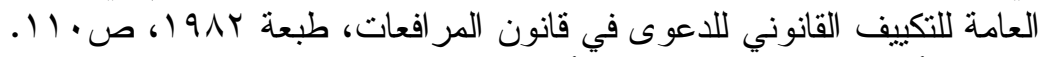

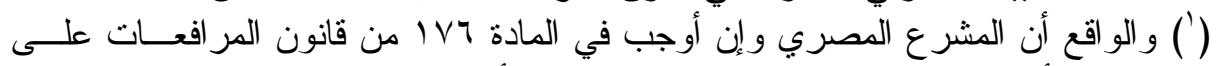

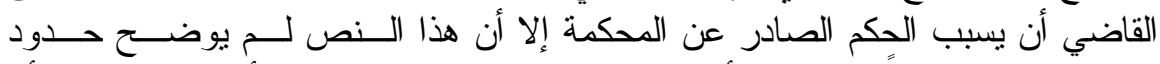

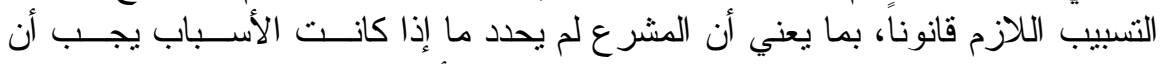

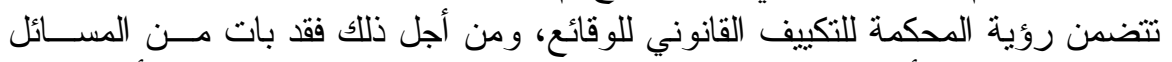

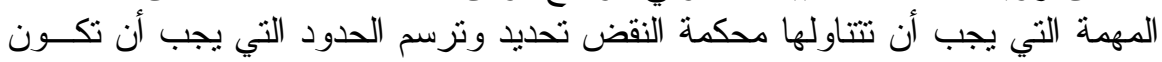

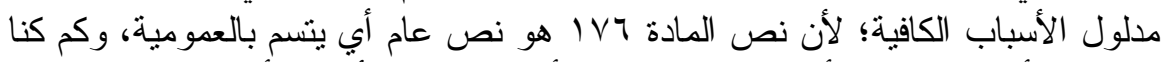

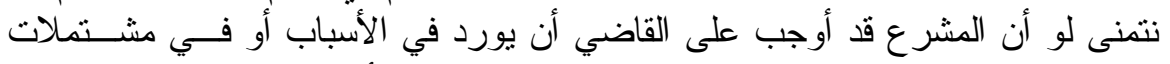

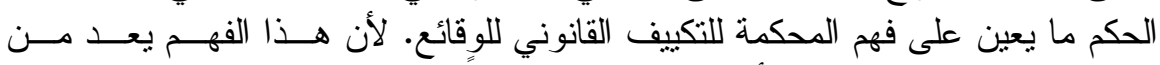

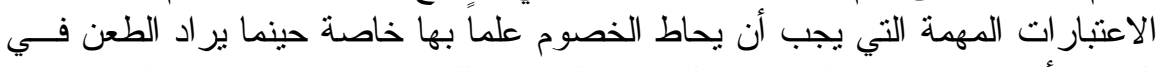

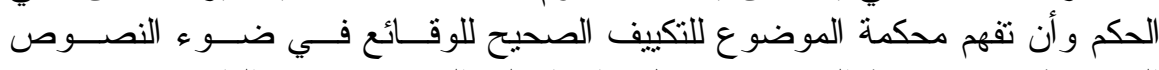

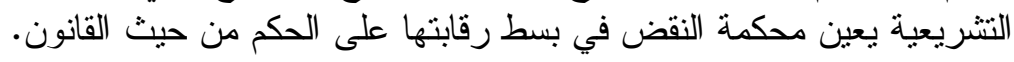

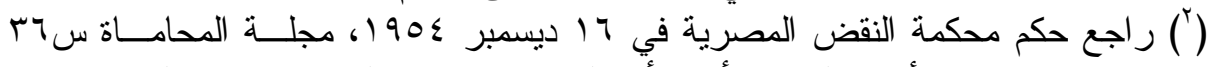

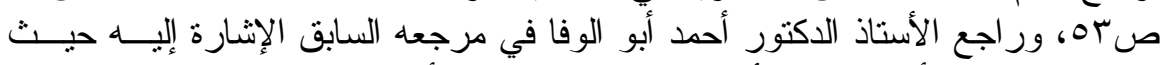

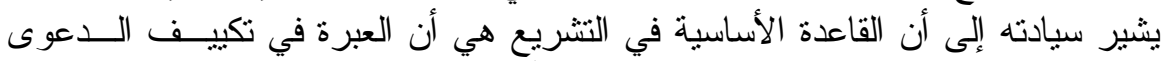

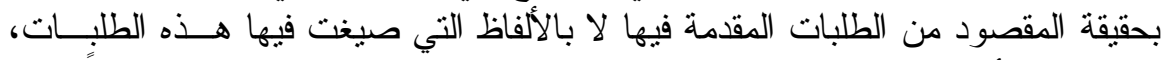

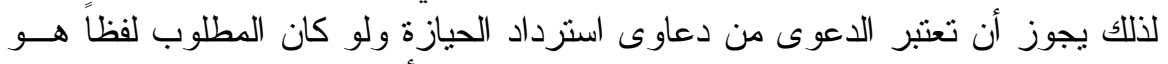

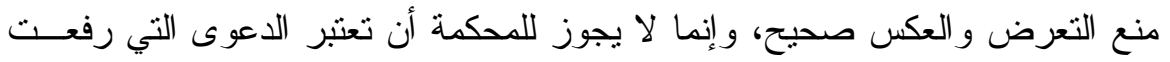

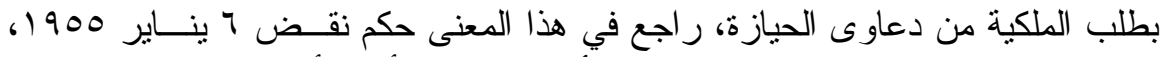

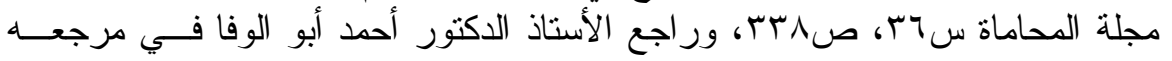

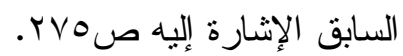


ليس كل التكييف، وتظهر أهمية التكييف في التسبيب إلـى اعتبــاره الوســـيلة

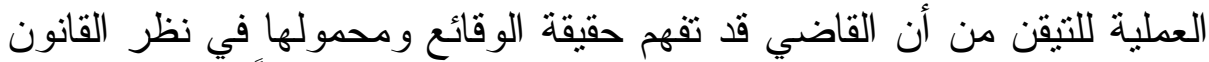

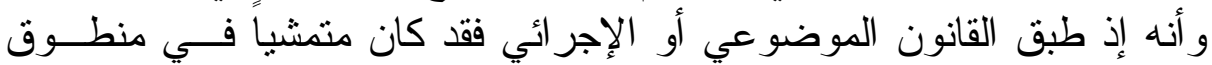

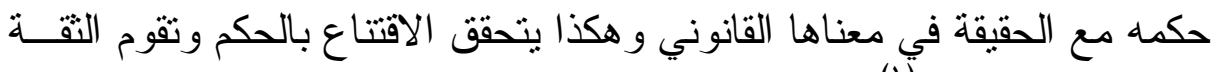

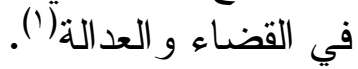

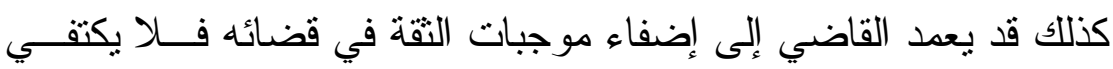

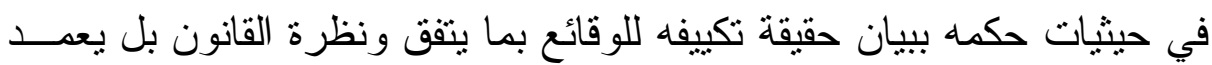

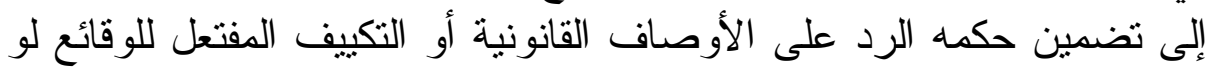

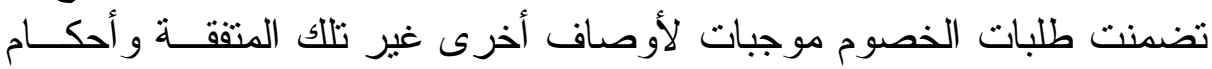

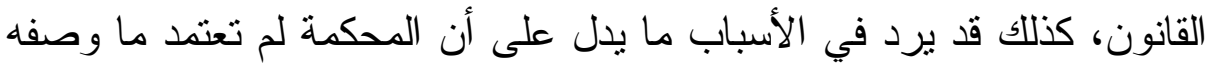

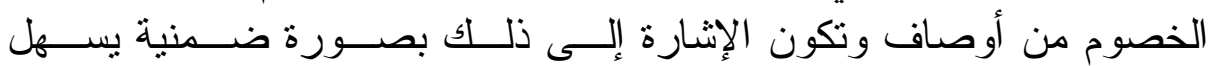

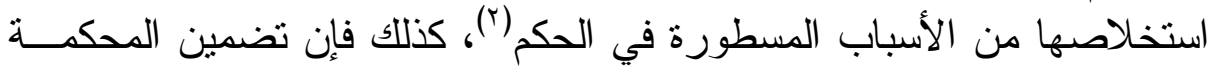

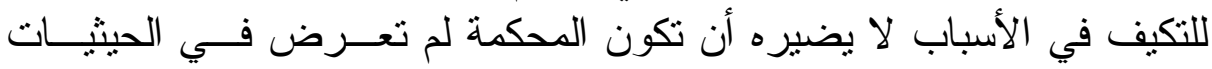

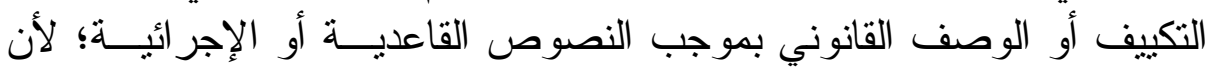

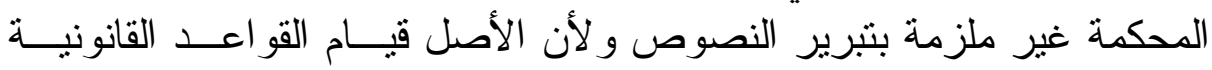

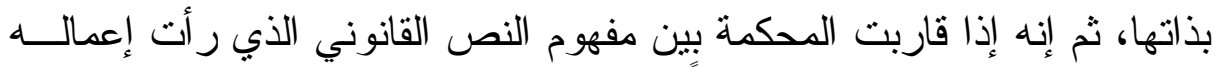

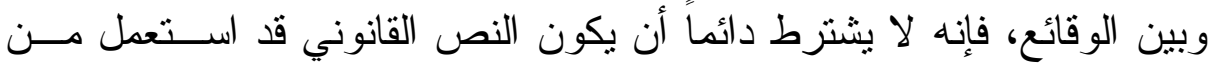

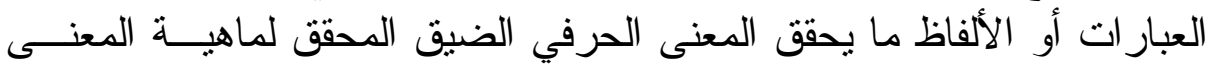

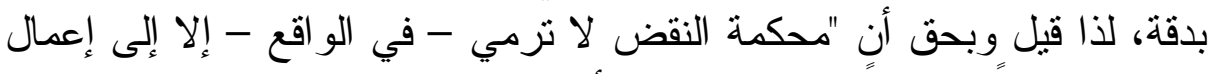

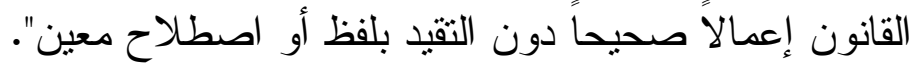

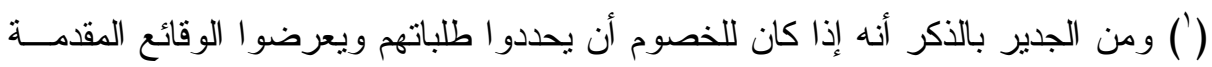

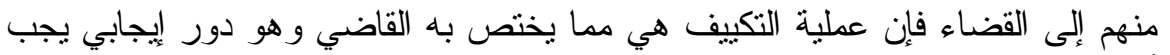

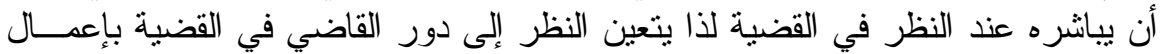

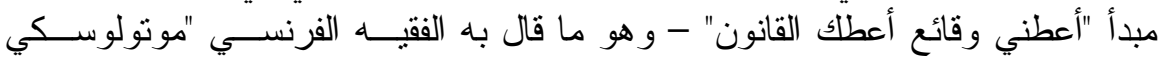
Donne moi le fait - je te donnerai le droit "Moltulsky إليه الفقيه من أن التكييف القانوني للوقائع هو إقطاعية القاضي ومن ثم يتعـــين إعـــال

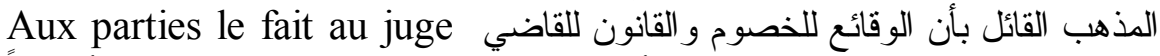
le droit

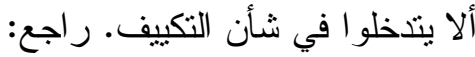

Motulsky; la cause de la demande dans la delimitation de l' office du juge. Dalloz; 1964 p. 235.

( (آ) راجع الدكتور علي مصطفى الثيخ في مؤلفه الحكم الضمني في قانون القضاء المدني.

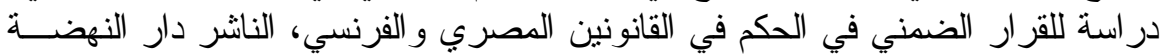

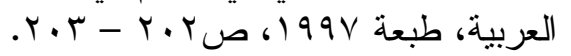




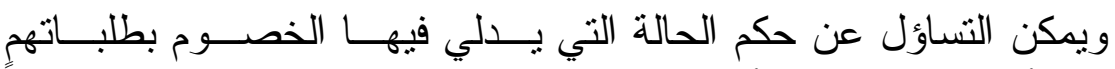

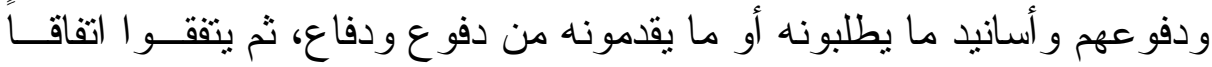

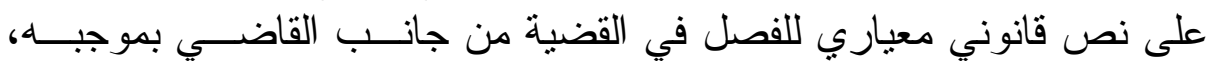

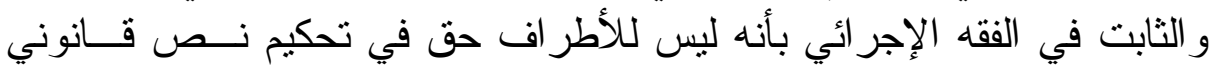

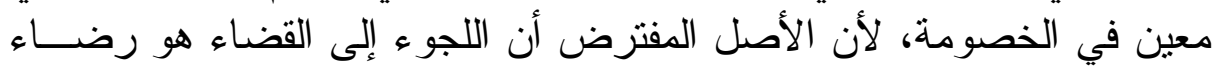

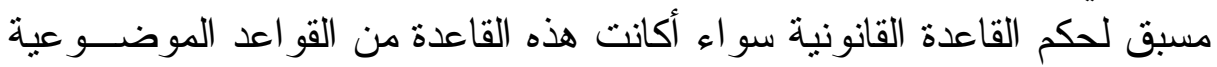

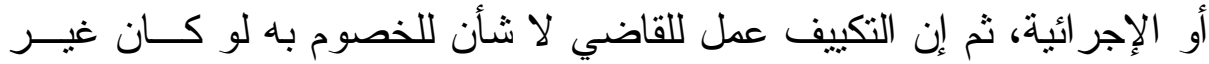

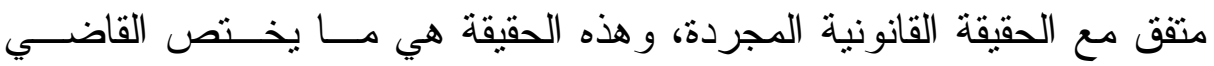

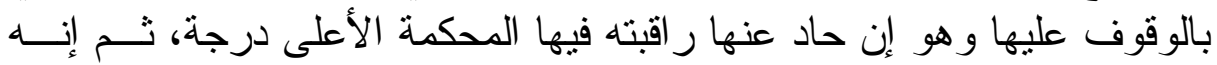

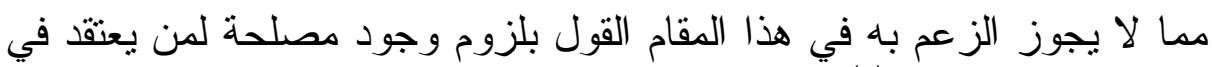

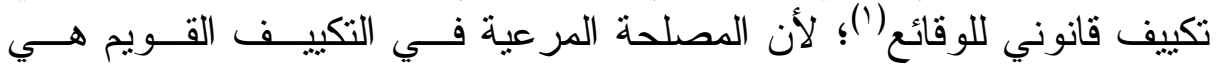

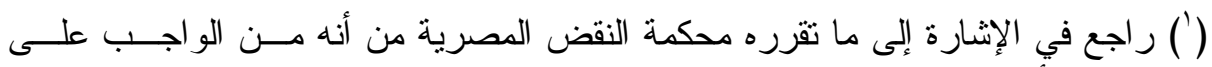

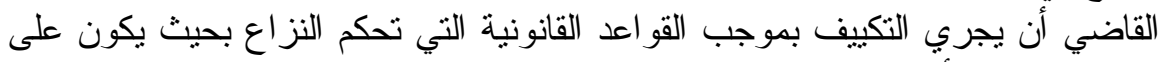

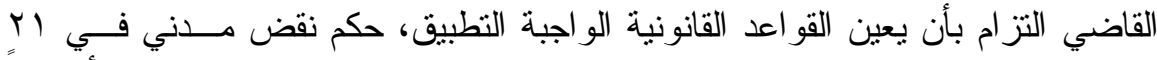

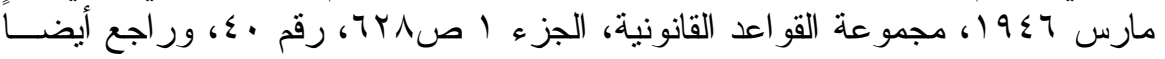

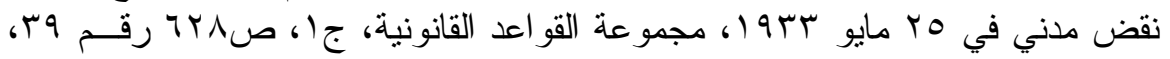

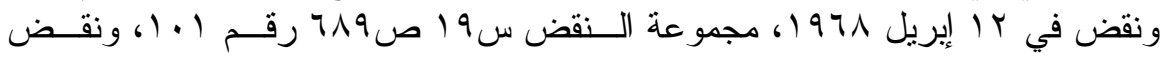

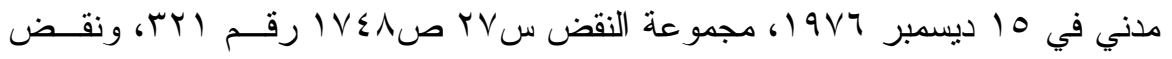

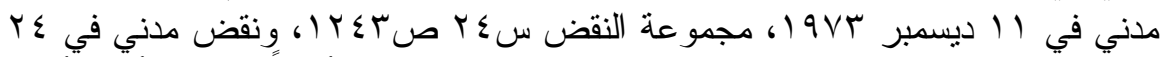

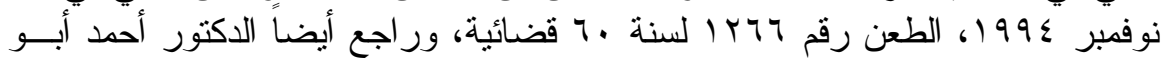

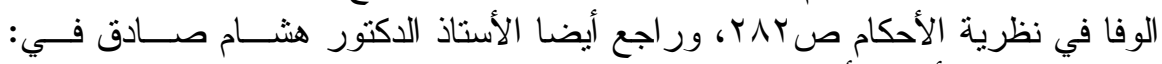

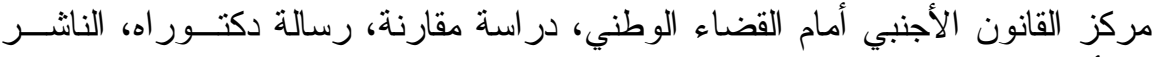

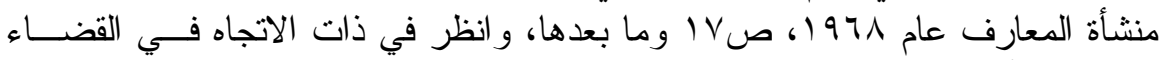

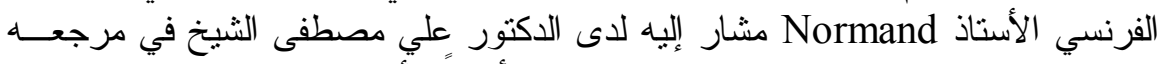

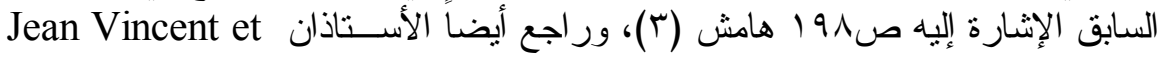

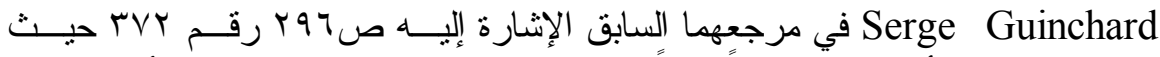

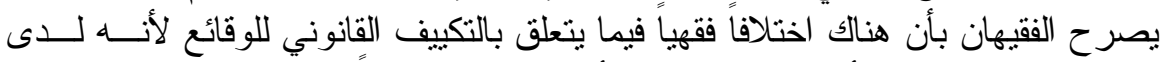

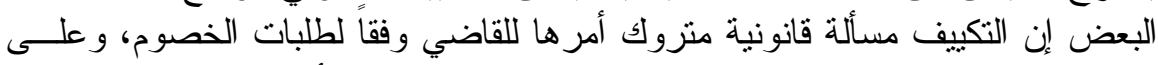

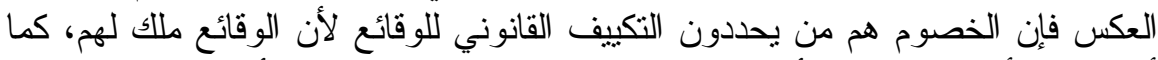

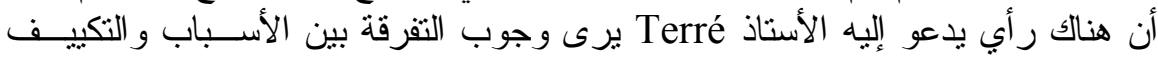
un pont entre le fait et le droit.. outil et démarche de l'esprit". حيث يرى أنه:

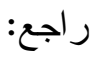

Terre; l'influence de la volanté individuelle sur les qualifications. Paris 1956 p. 551. 
المصلحة في حسن القضاء و إنزالٍ حكم القانون الذي يلبي دو اعــي العدالـــة،

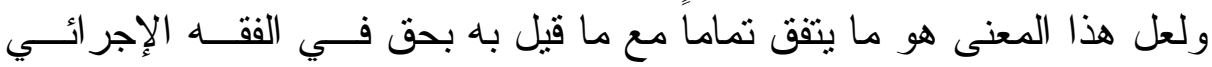

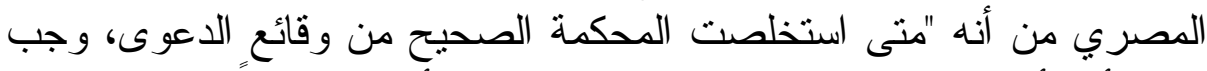

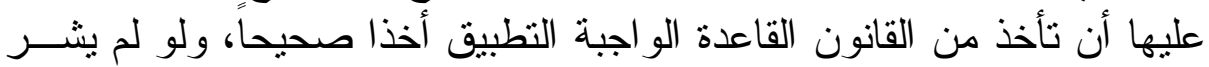

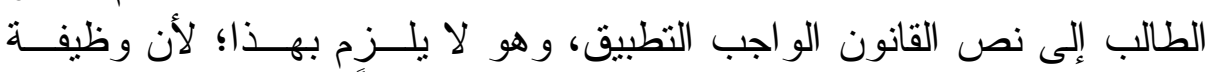

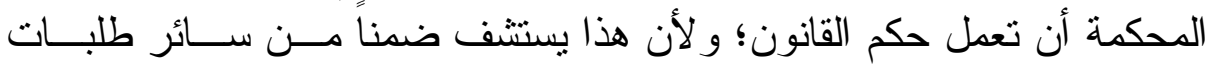

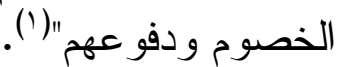

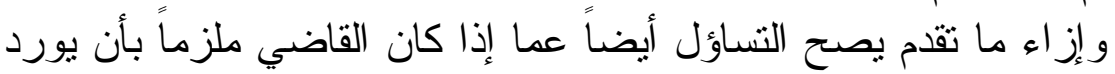

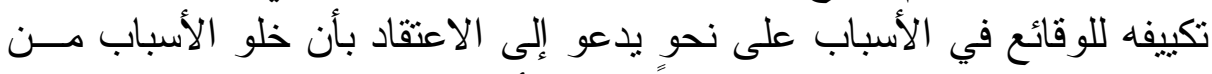

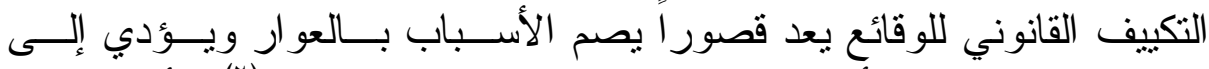

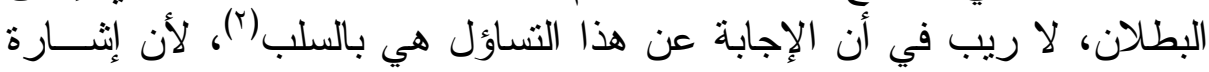

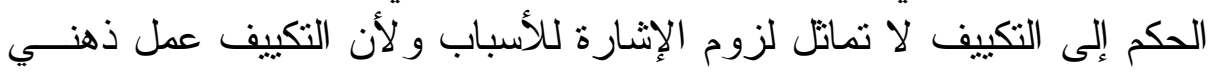

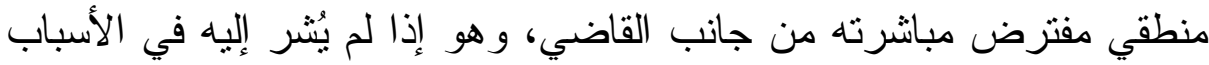

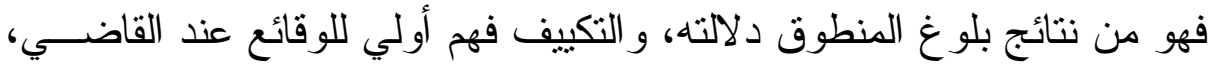

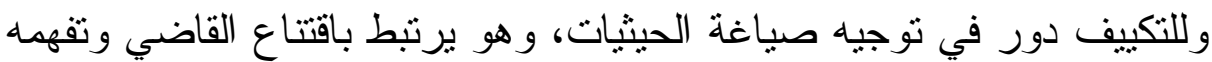

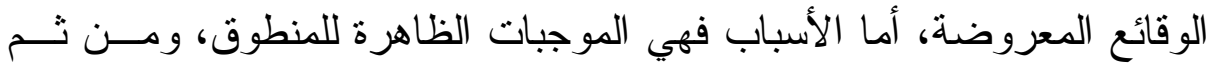

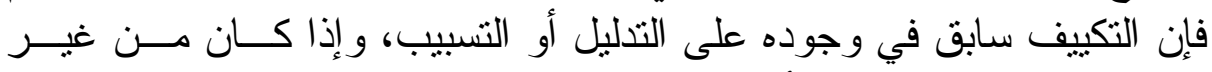

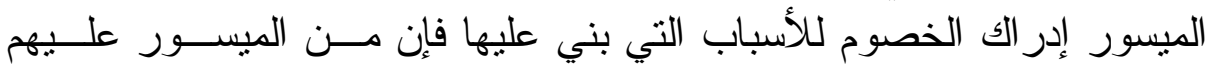
استخلاص وتفهم موجبات التكييف من المنطوق؛ كذلك فإنه إذا وردت الإن الإنشارة

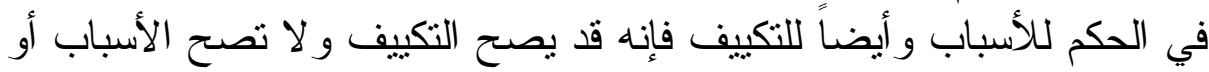

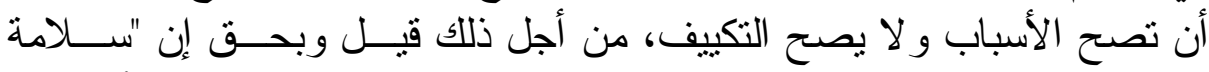

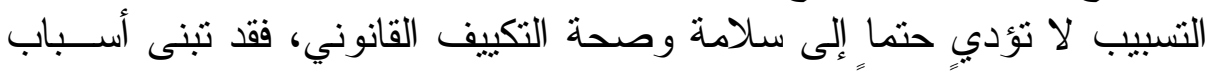

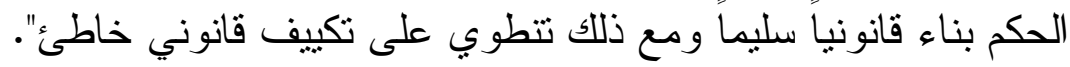

$$
\text { و انظر كذلك: }
$$

Motulsky: la cause de la demande dans la délimitiation de l'office du juge. Dalloz 1964. chron. 255.

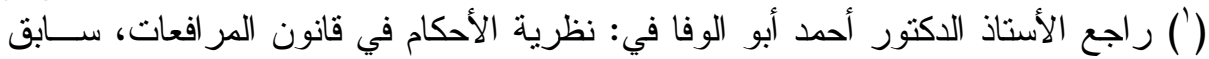

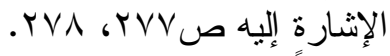

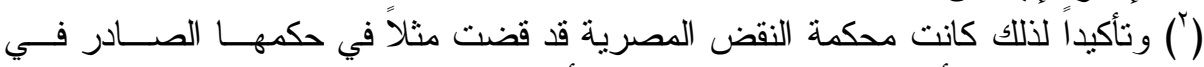

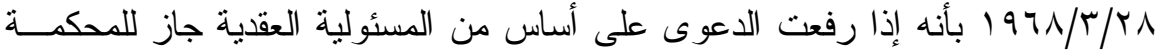

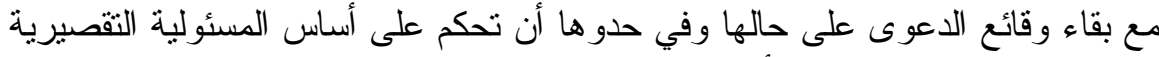

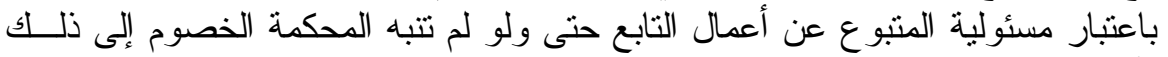

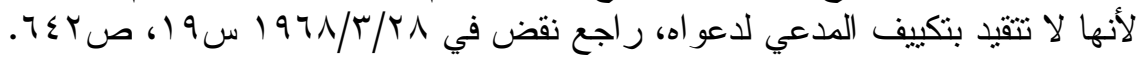


و إذا ر أت محكمة النقض سلامة الأسباب وكفايتها و عدم صحة التكييــف

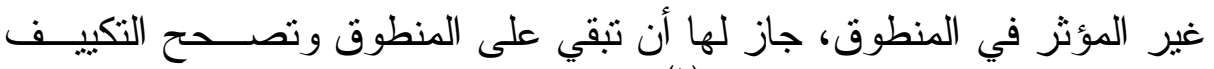
الذي ارتضنه المحكمة في حكمها ('). المطلب الثالث

\section{دور التسبيب في بسط محكمة التقض

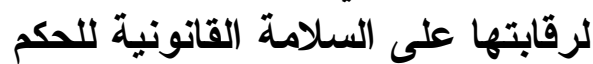

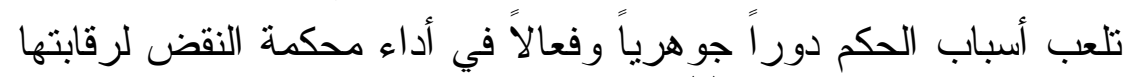

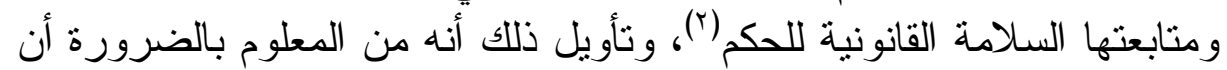
محكمة النقض هي أعلى محكمة في نظامنا القضائي المصري ولهذه المحكمــة ونة

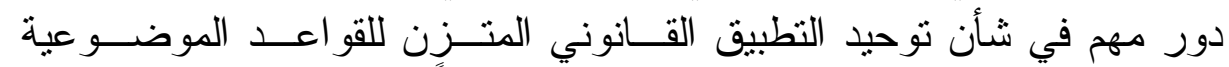

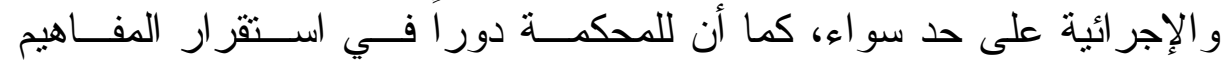
القانونية، و إيجاد قدر من التقارب في إعمال النصوص و إقرار ها في مفهومهــا الصحيح، من أجل ذلك لا تتعدد محاكم النقض و إنما هي محكمة وحيدة تقــوم في أعلى السلم القضائي ()، هي محكمة تحاكم الحكم، وهي لبست درجة مــن

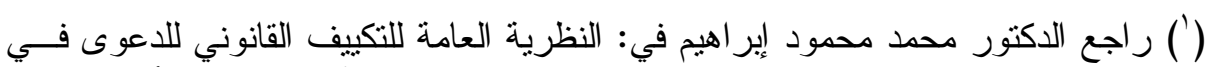

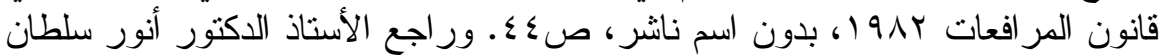

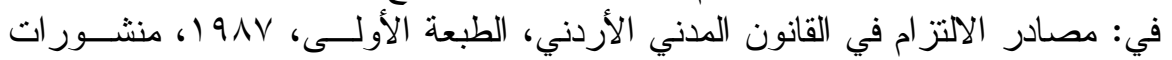

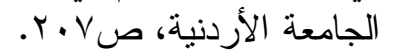

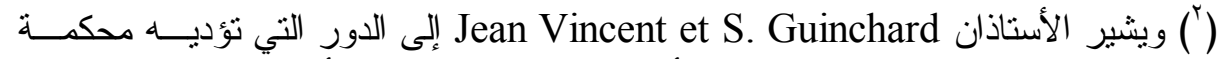

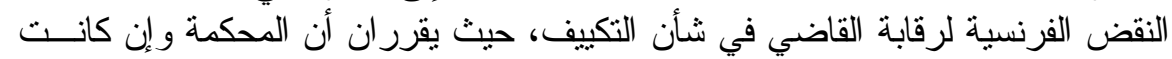

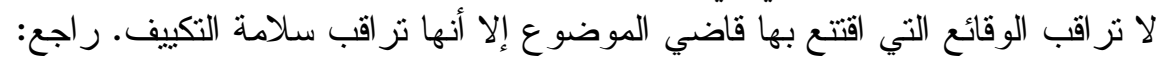
Jean Vincent et Guinchard; op. cit. P. 298 No 372

V. Marty; la distinction du fait et du droit. Thése Toulouse 1929.

$$
\text { ور اجع أيضناً: }
$$

$$
\text { و انظر أيضناً: }
$$

Croze; Recherch sur la qualification en droit processuel. Thése Lyon 1981.

(") وفي التعبير عن الرسالة الموكولة لمحكمة النقض، قال الأسناذان "فانساه وكويشار": Le pourvoi en cassation est une voie de recours d'une nature tout à fait particulière, c'est, il est vrai, une voie de recours extraordinaire, puisqu' elle n'est pas suspensive d'exécution et ne peut être formée que pour des cause limitativement determinées.

راجع: .Jean Vincent et Serge Guinchard; op. cit. p. 680 No 1023 ور اجع أيضن: J. Bore; Reflexions sur la sélection des affaires devant la cour de 


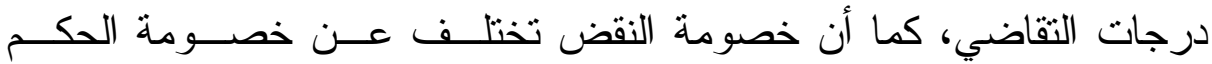

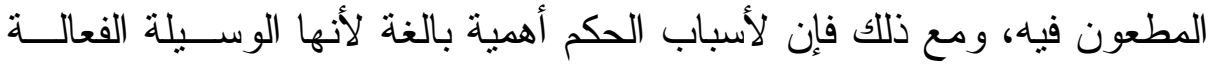

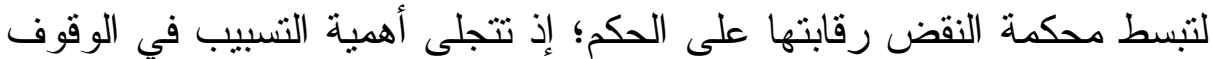

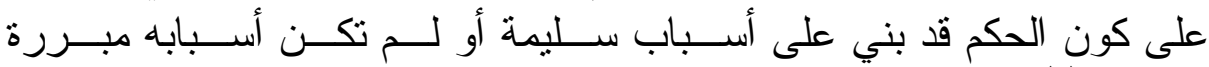
للمنطوق (')

ومحكمة النقض إذ نر اقب صحة استتتاج قاضي الموضو ع لما ســـره

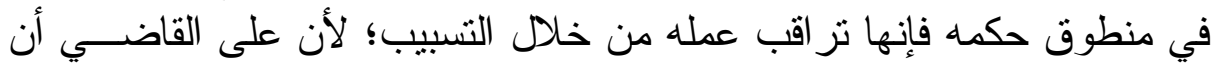

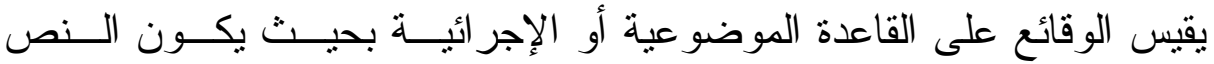

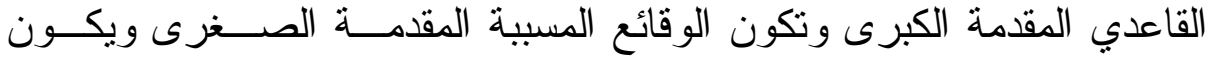

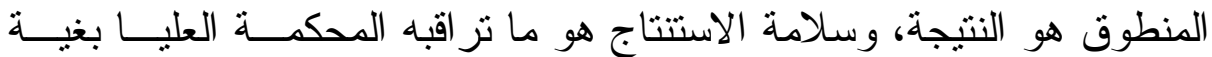

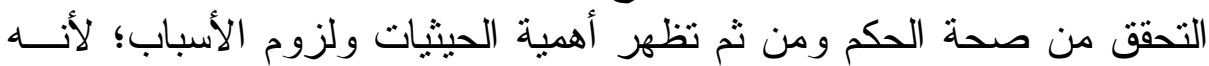

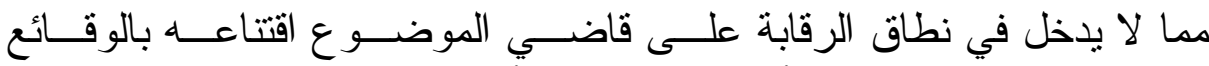

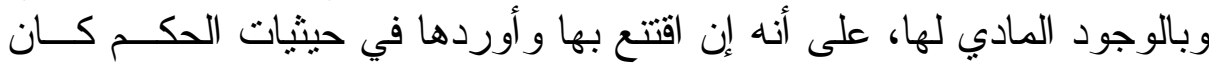

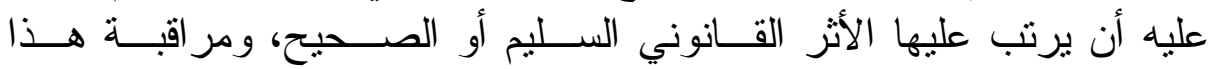

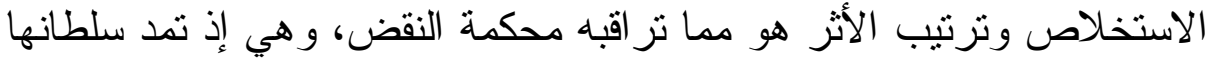

cassation. Dalloz 1979 chron. 247.

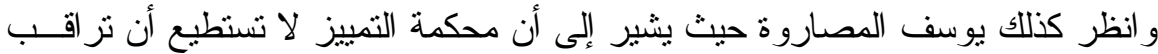

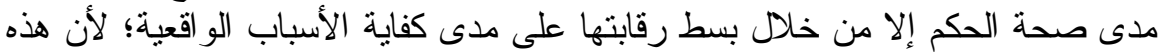

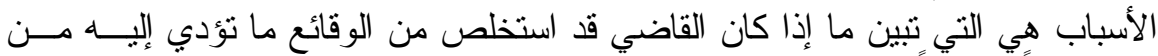

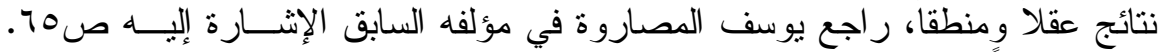

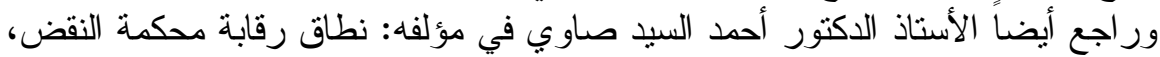

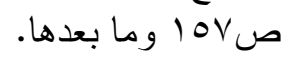

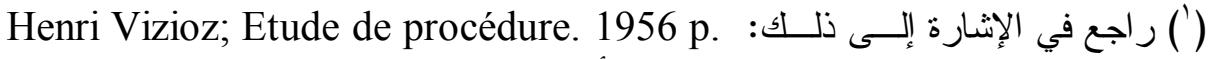
475 وحيث يشير الفقيه إلى أن التسبيب هو الوسيلة التي يمكن بمقتضــاها

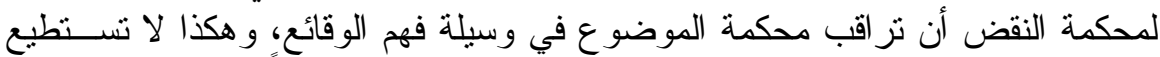

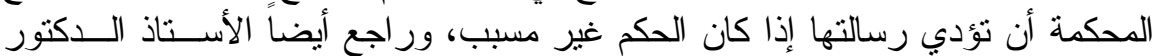

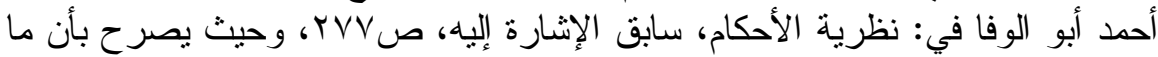

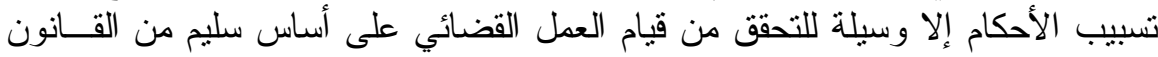

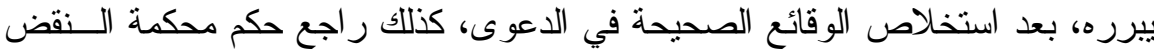

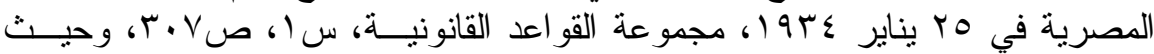

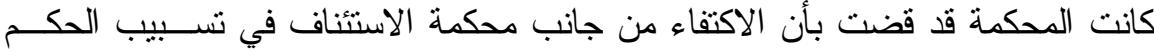
بأسباب مجملة مقتضبة بعيب حكمها ولو كان الان الحكم المستأنف الذي أيدنه وفي الأسباب مادامت هي لم تأخذ في تأييده بنلابك الأسباب. 
لمر اقبة الأثر القانوني عبر الأسباب فإنها تباشر رقابتها للإثتبــات(1)، ومر اقبـــة

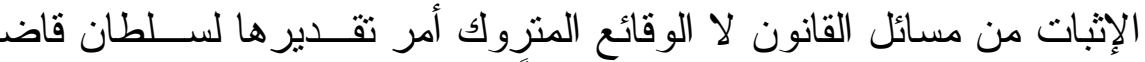

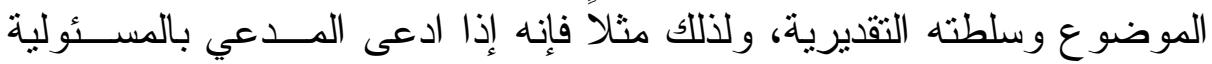

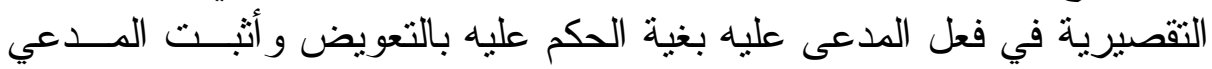

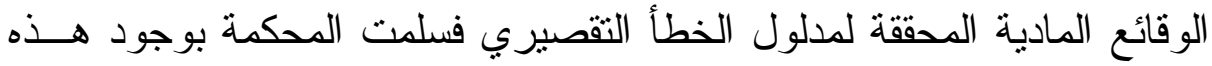

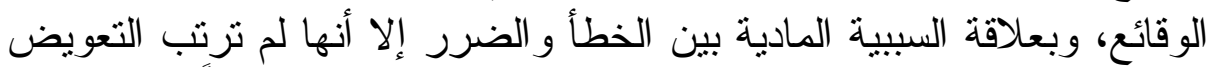

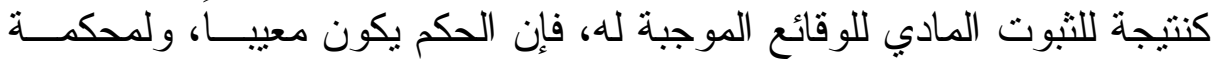

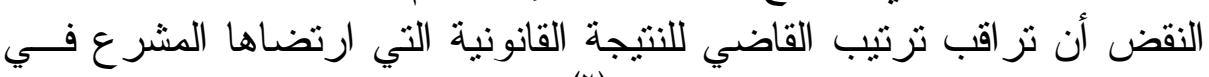

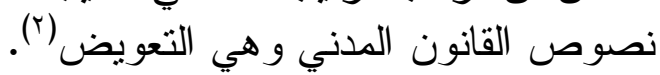

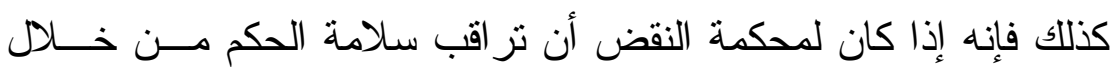

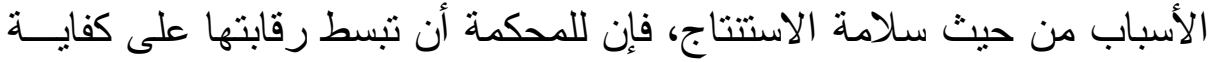

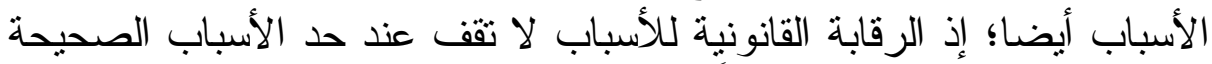

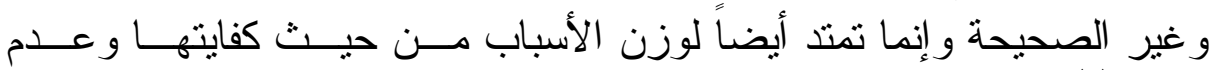

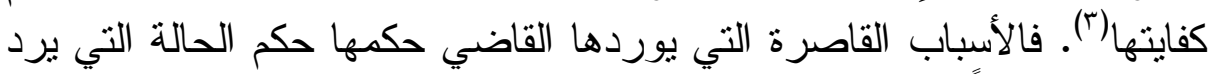

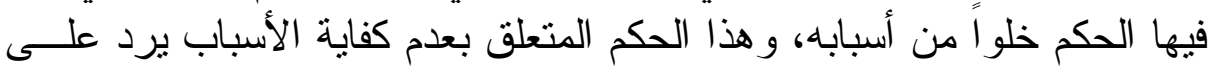

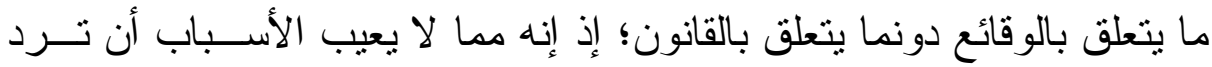

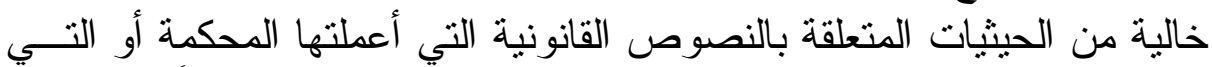

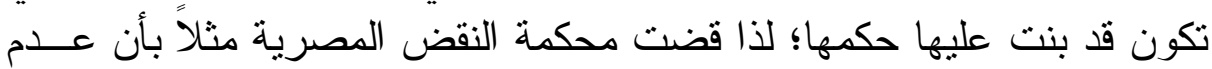

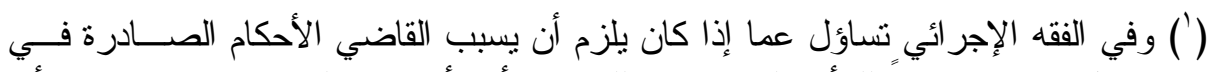

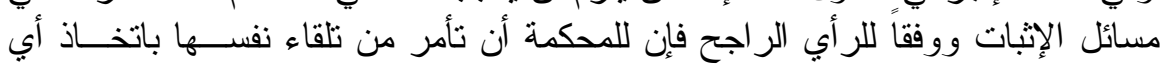

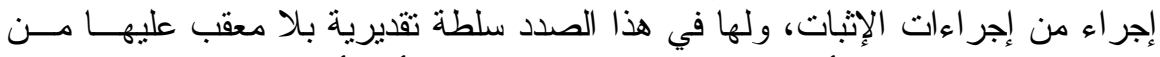

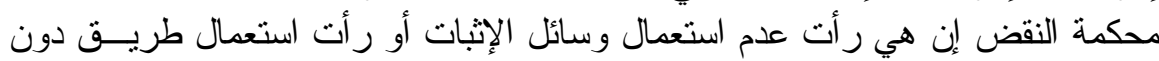

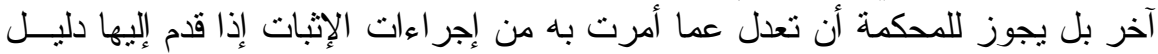

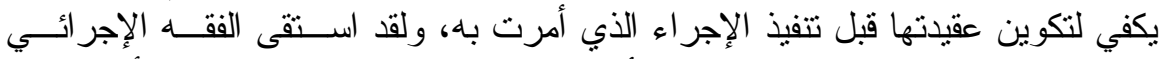

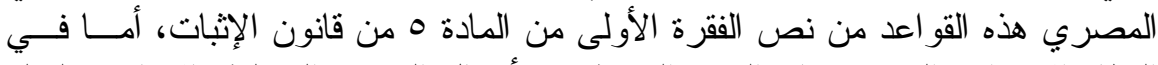

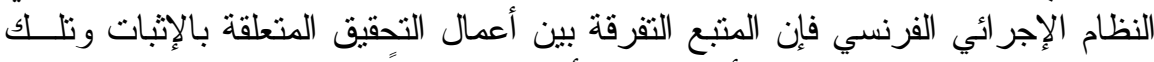

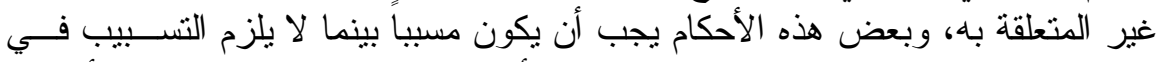

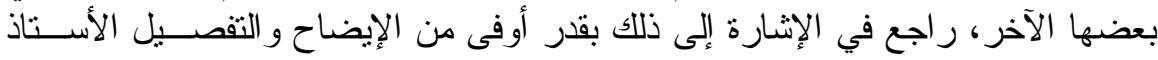

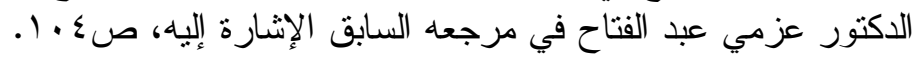

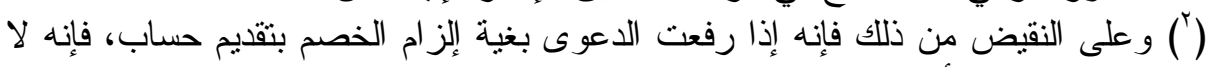

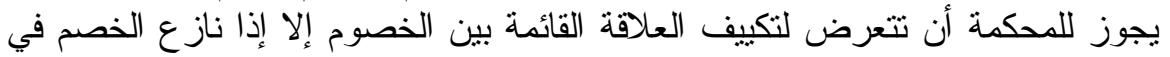

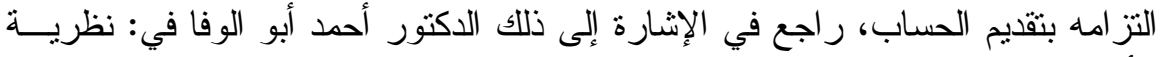

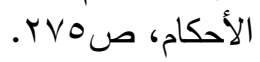

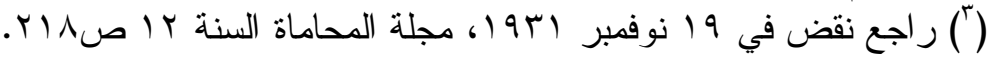


بيان الحكم لعلة عدم إلز ام الخصم بفو ائد متأخر الثمن أو فو ائد مقابل ما باتشره

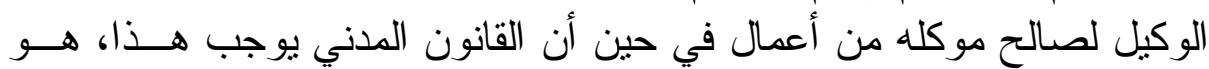

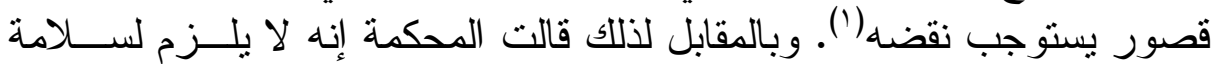

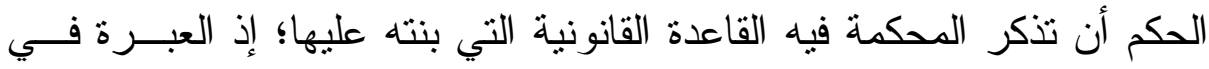

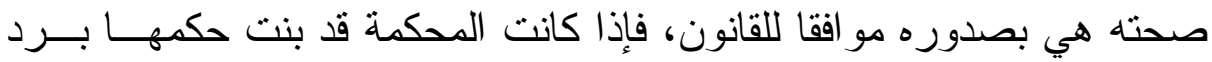

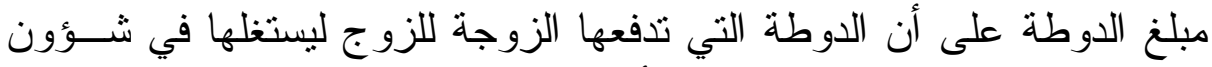

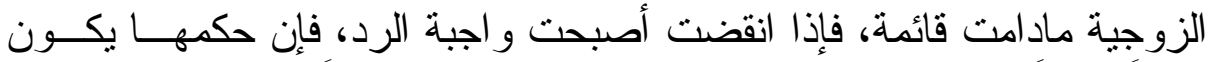

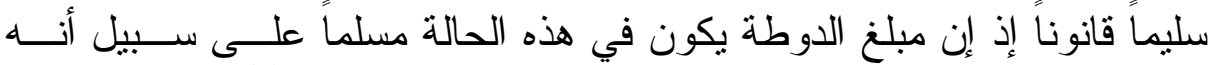

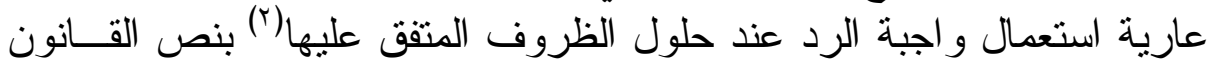

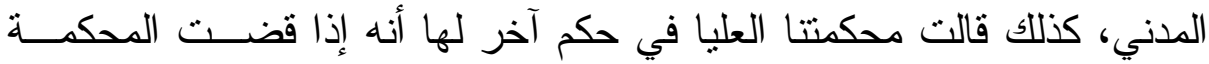

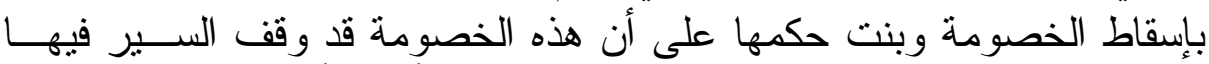

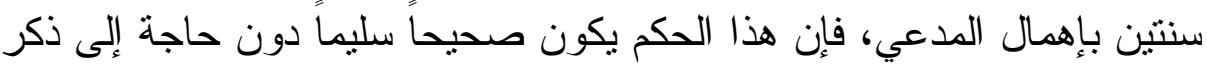
القاعدة القانونية التي تقرر الخصومة إذا وقف السير فيها مدة سنة ودون حاجة

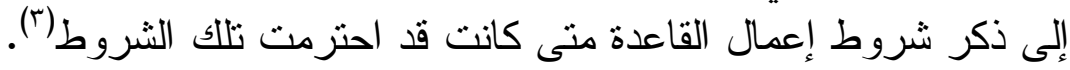

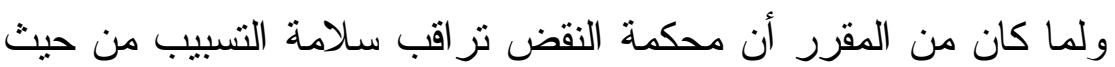

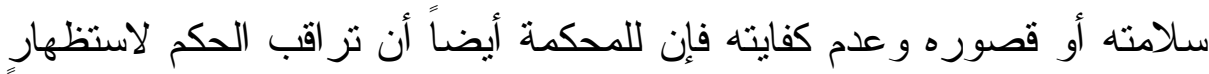

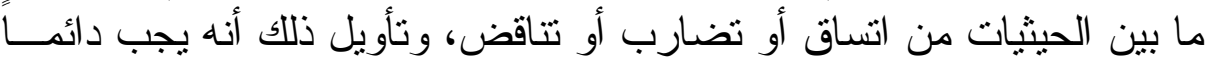

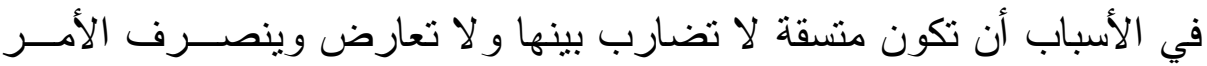

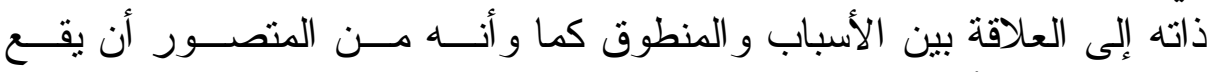

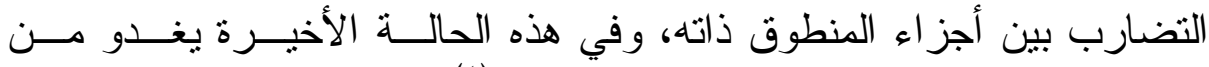
المستحيل تتفيذ الحكم ذات المنطوق المتضارب(اء)، وفي هذه الحال يكون مــن

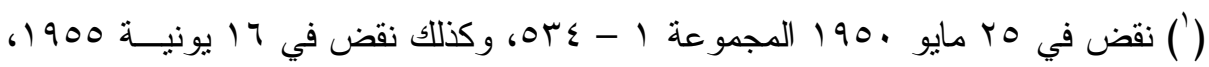

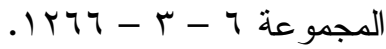

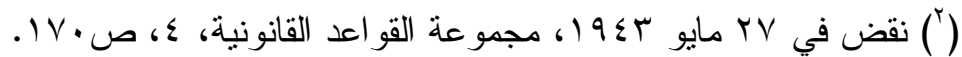

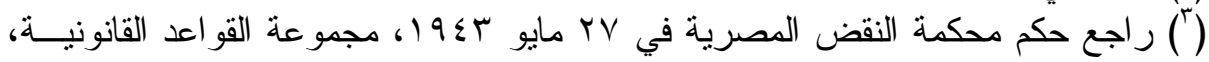

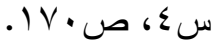

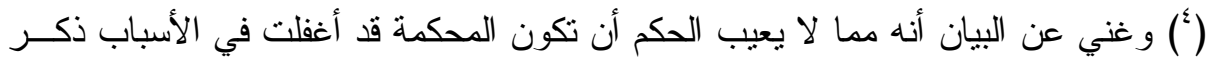

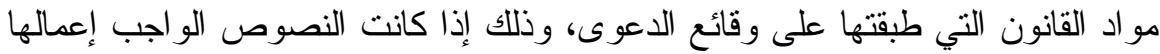

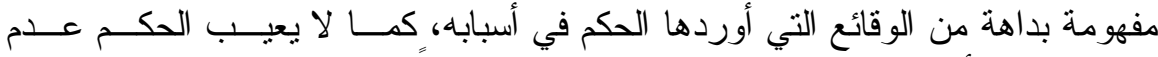

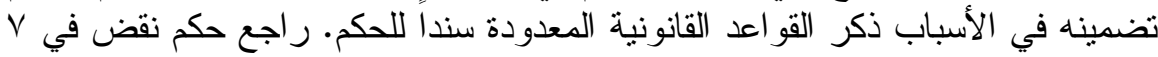

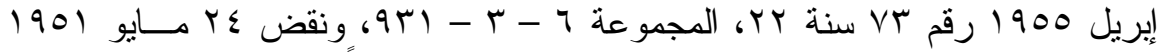

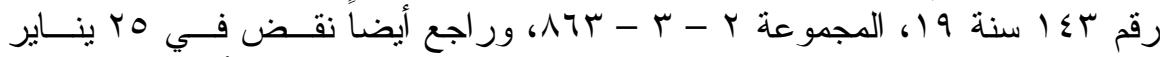

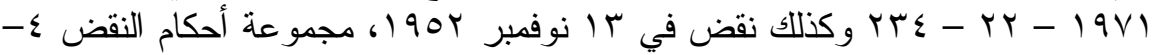


المقبول انتهاج صاحب المصلحة الخصم في القضية أن يتقدم بالتماس لإعـادة

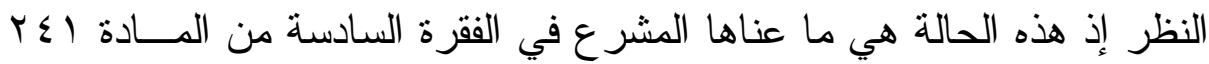

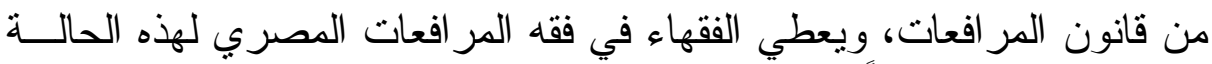

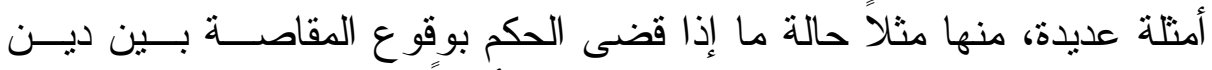

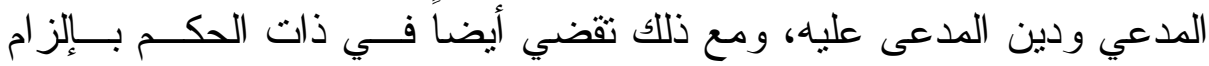

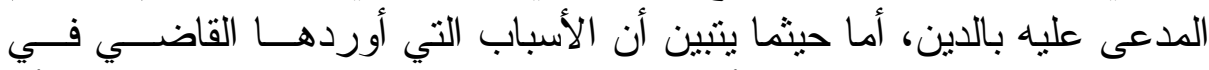

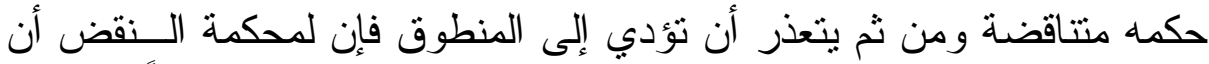
تقضي بيطلان الحكم للتناقض في الحيثيات، وتتحقق هذه الحالة أيضاً لو أسسِ

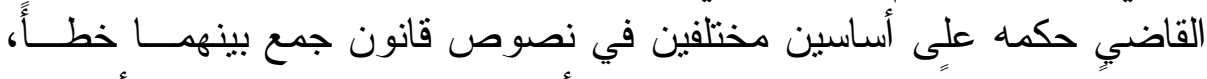

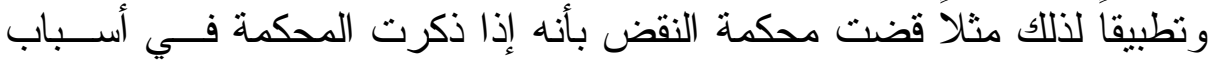

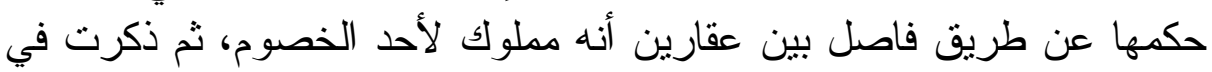

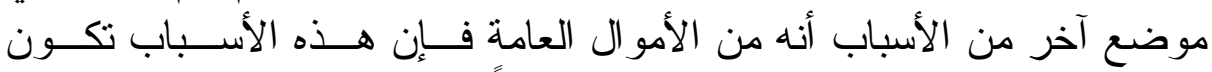

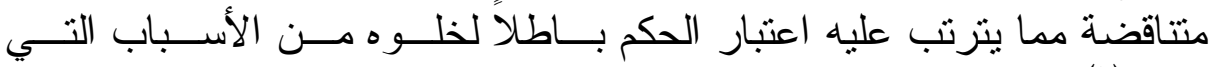

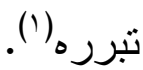

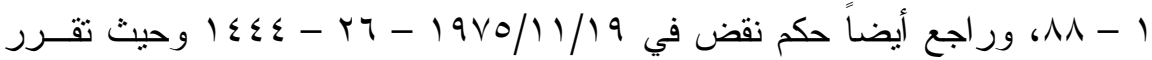
محكمة النضض أن الحكم لا يؤثز فيه أن تكون المحكمة قد أخطأت في ذكر عدد الثهود

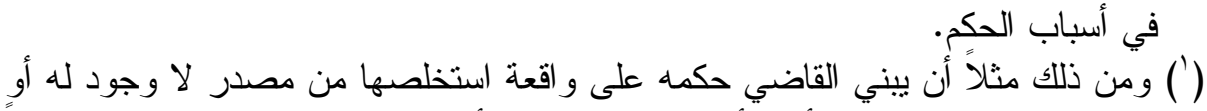

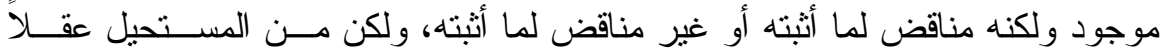

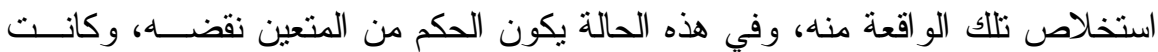

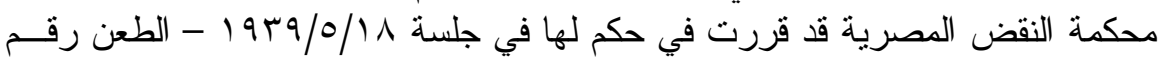

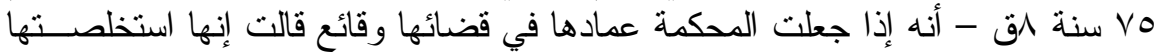

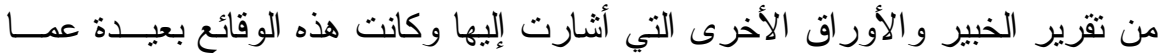

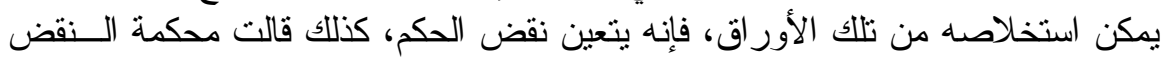

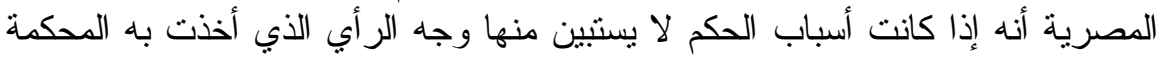

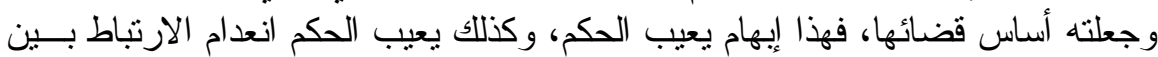

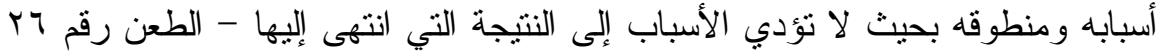

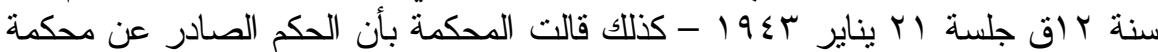

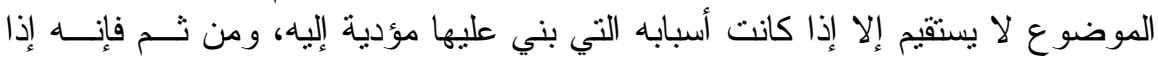

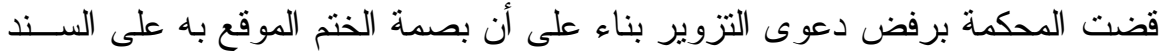

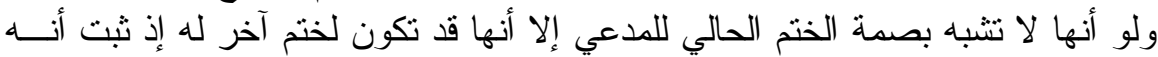

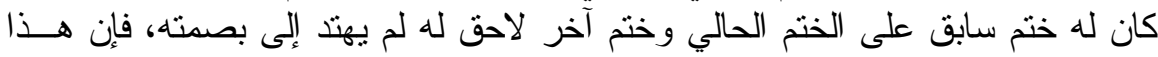

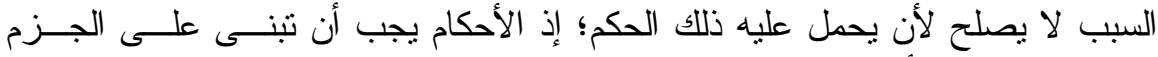

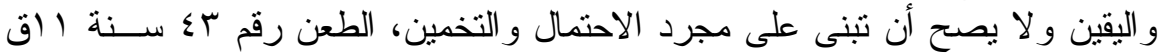

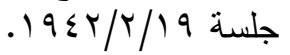




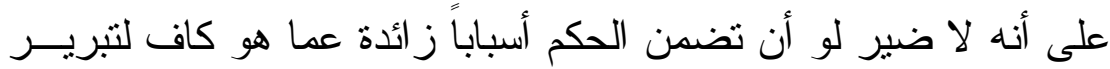

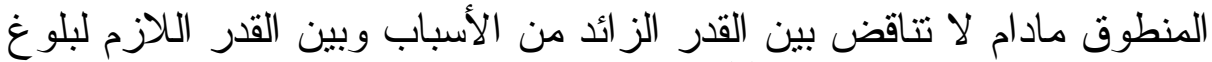

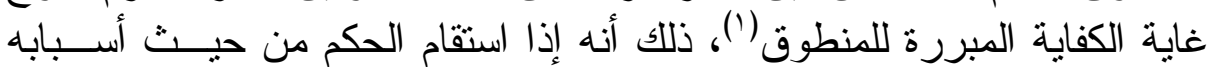

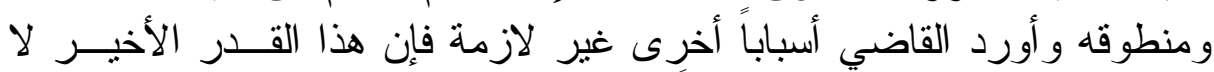

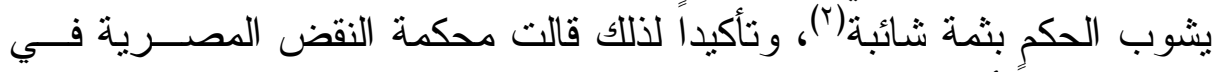

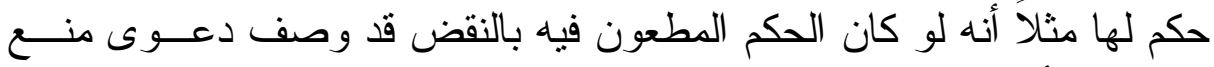

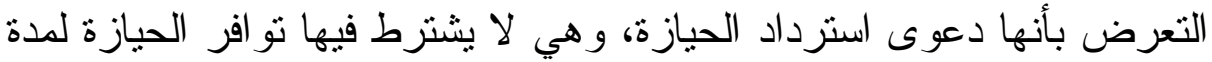

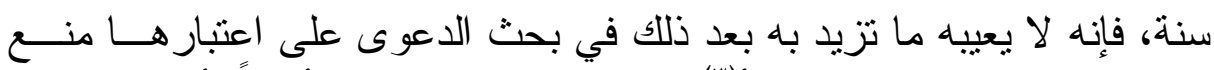

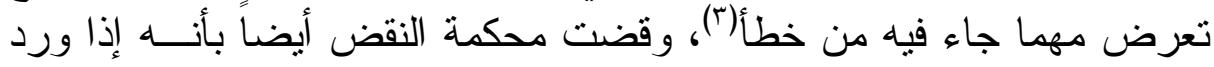

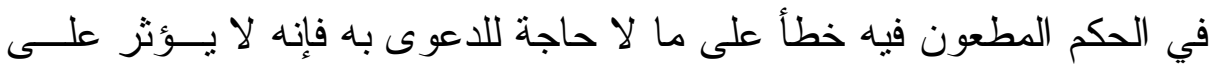

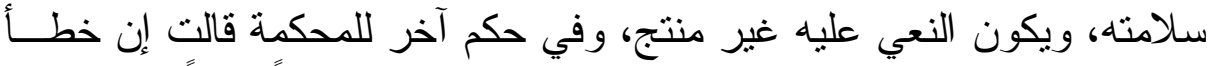

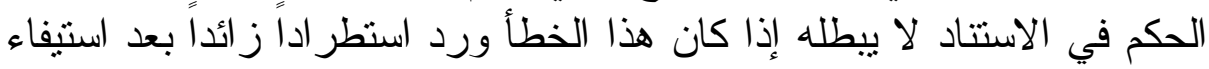

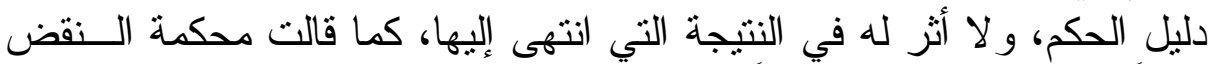

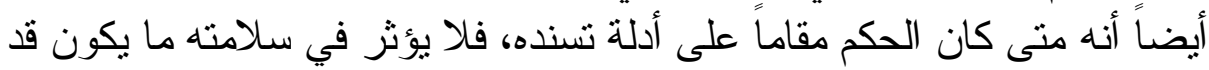

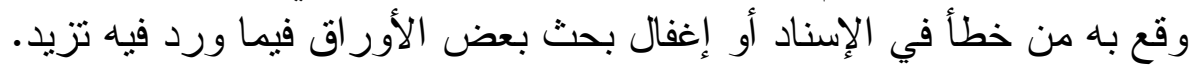

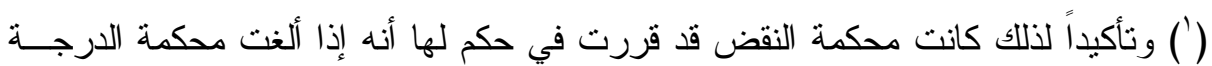

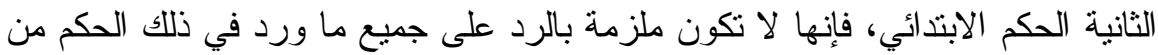

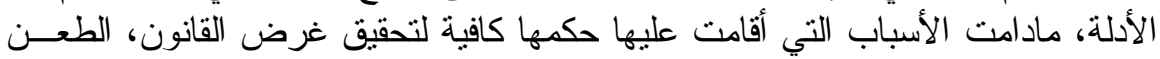

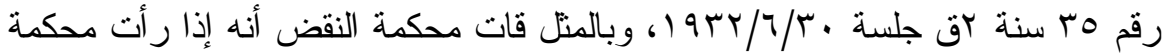

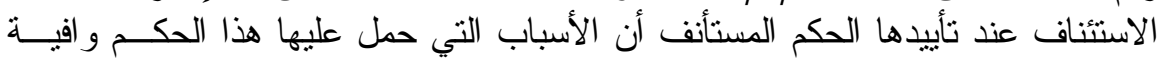

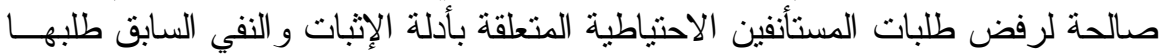

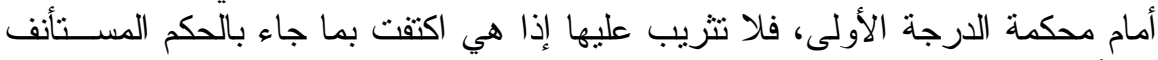

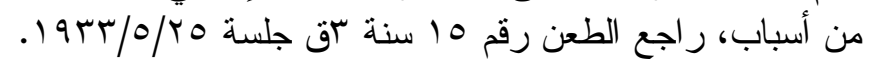

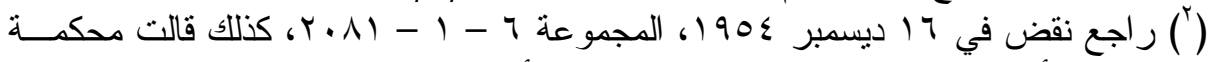

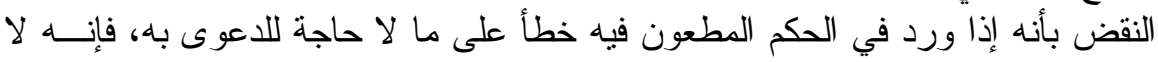

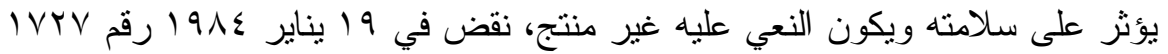

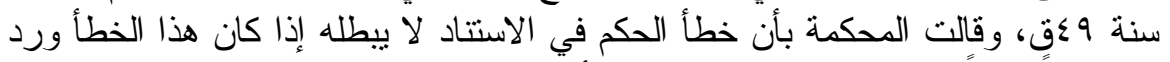

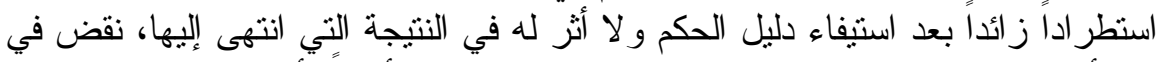

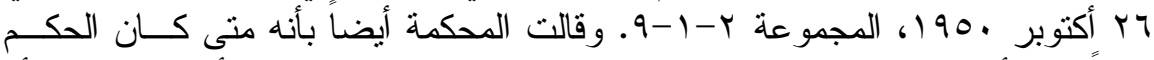

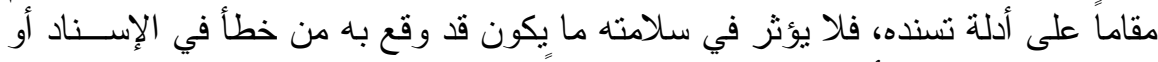

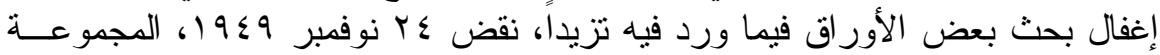
.rq-1

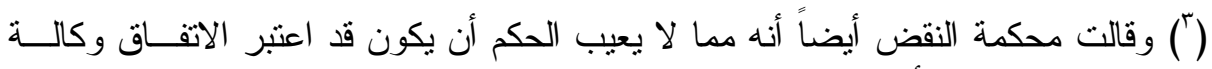

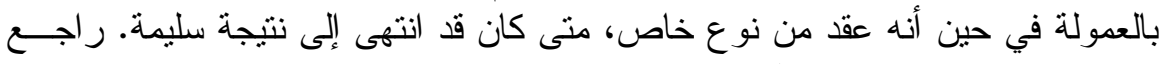

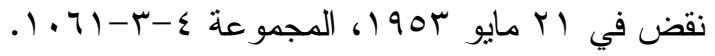




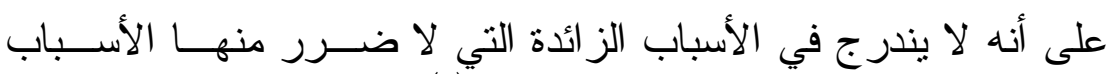

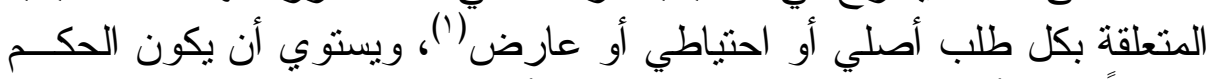

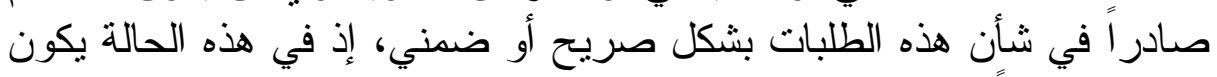

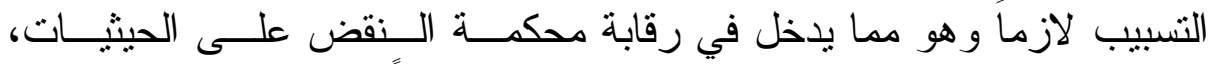

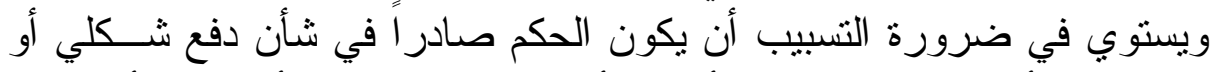

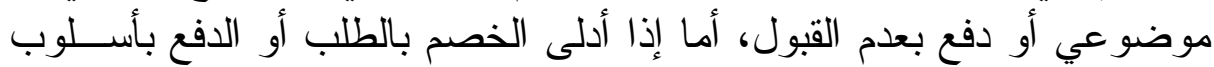

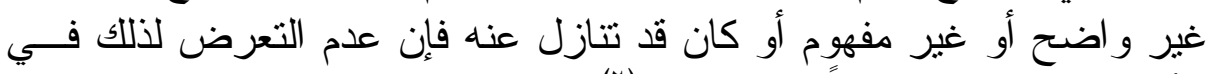

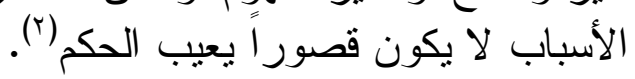

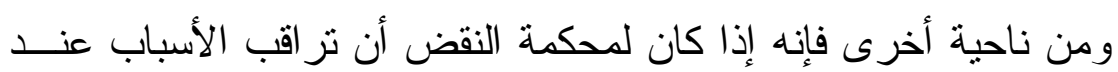

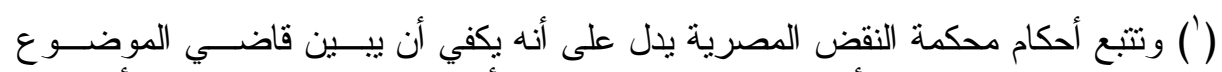

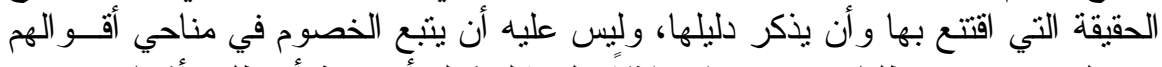

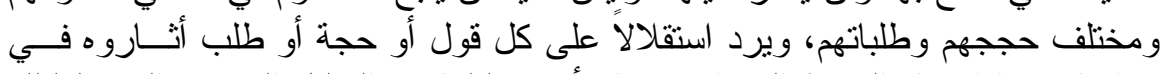

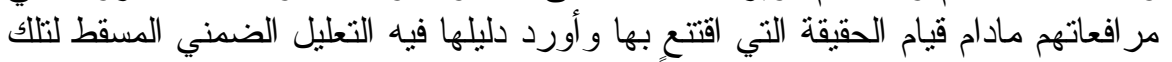

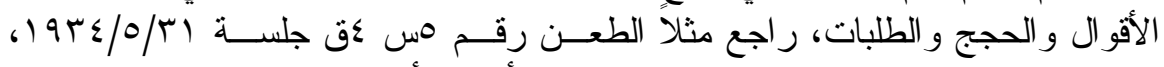

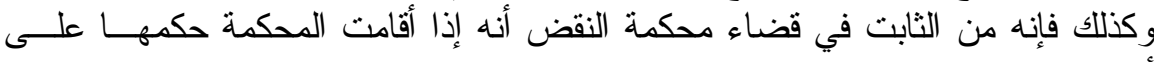

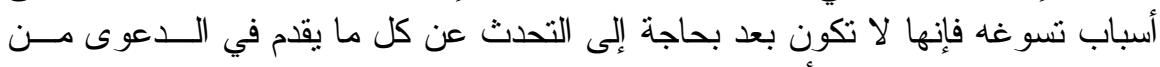

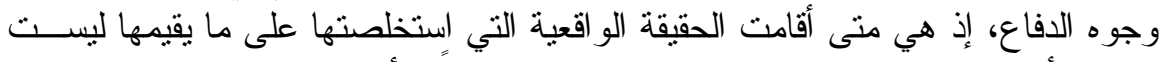

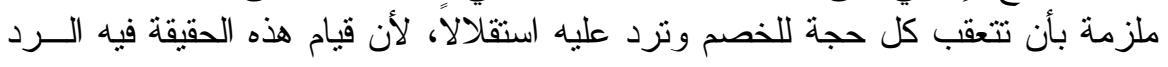

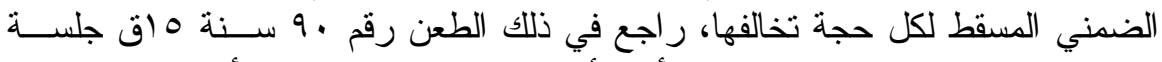

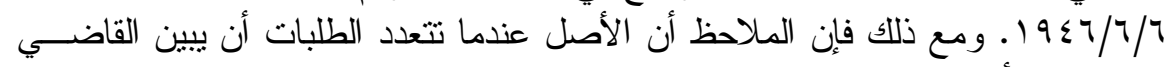

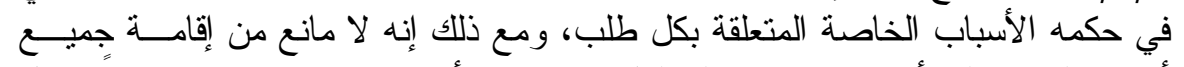

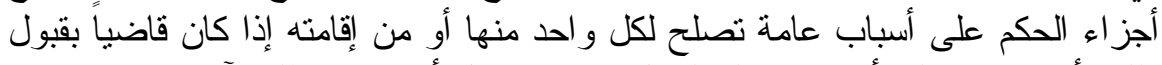

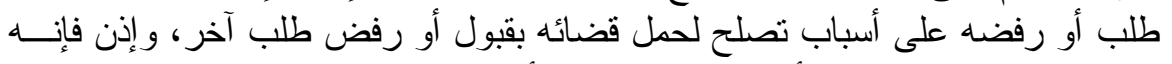

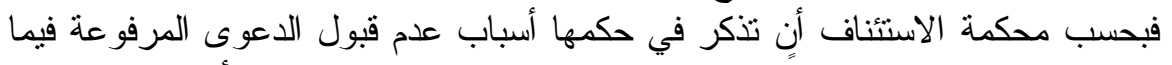

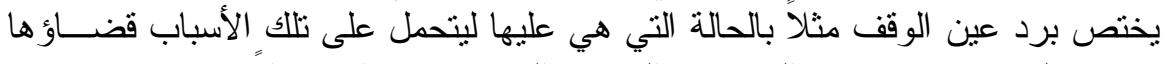

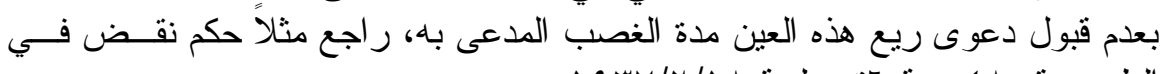

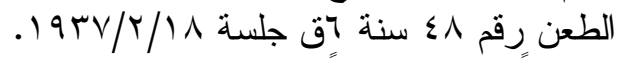

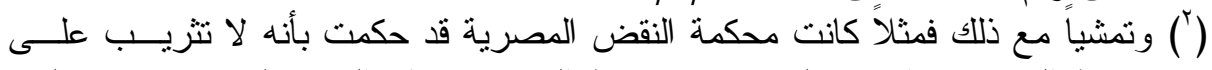

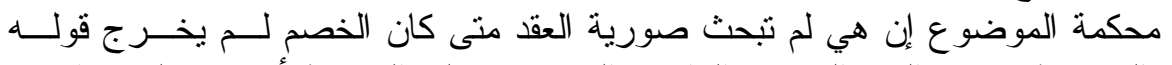

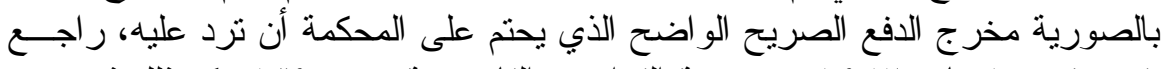

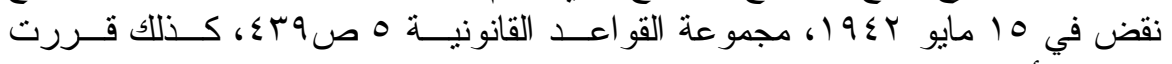

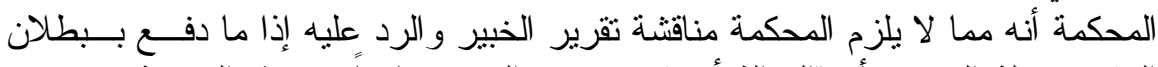

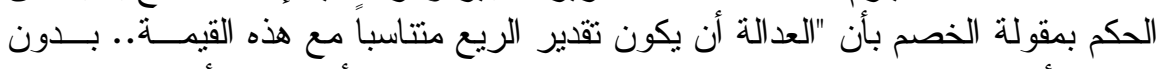

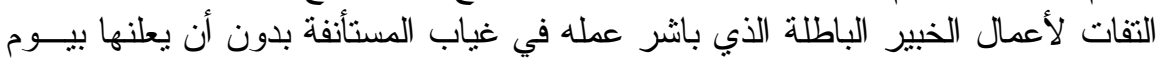

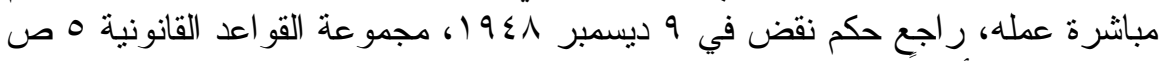

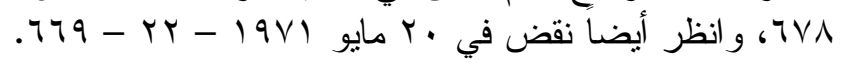


الطعن فيها فإن هناك من الأحكام ما لا يلزم تسبيبها إذا كان الحكم بحمل فــي

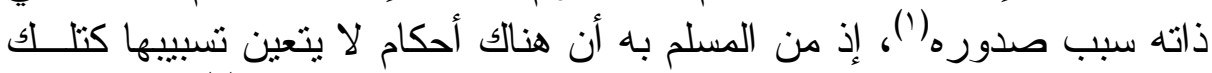
الأحكام غير القطعية المتصلة بإثبات الخصومة أو تتظيم سير هاب(؟).

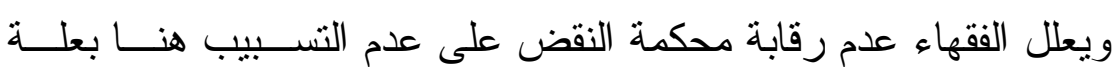

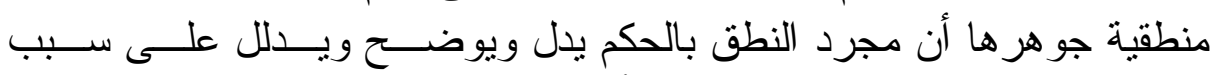
صدور ه، ومع ذلك يجب الحذر في شأن لزوم التسبيب في هذا المجال لأنه إذا

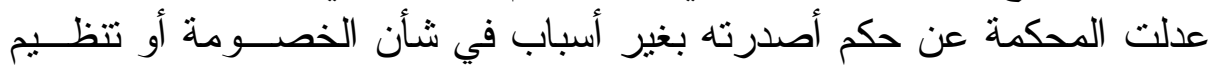

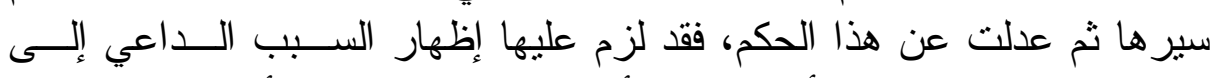

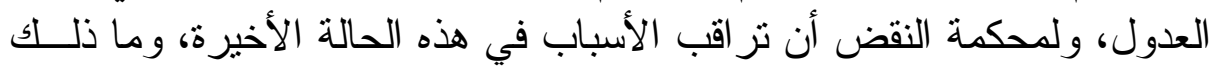
إلا إعمالا لحكم المادة 9 من قانون الإثبات المصري و وعلى اعتبار كون إعلان

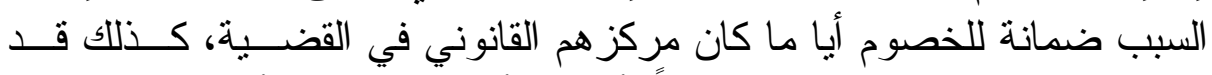

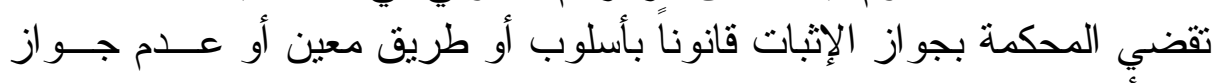

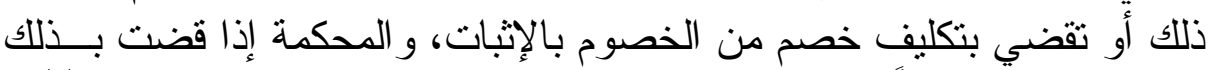

وكان قضاؤها قطعياً فقد لزم تسبيبه وما يلزم تسبيبه تر اقبه محكمة النقض (r).

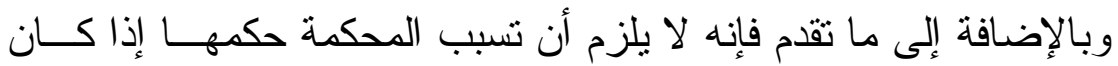

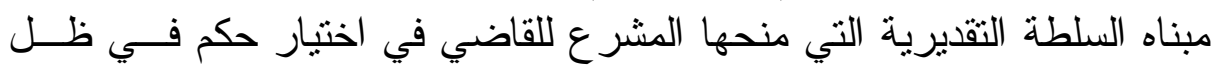

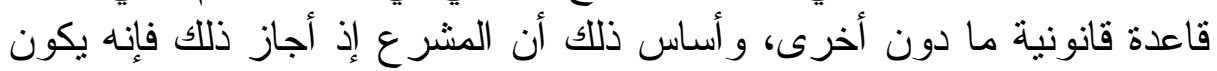

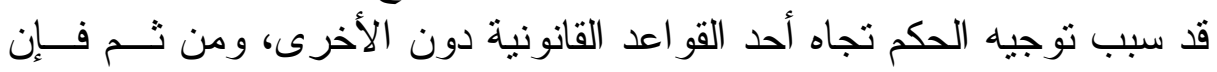

(') راجع الأستاذ الدكتور أحمد أبو الوفا في الأحكام، حيث يصرح بأن مجرد النطق باتخاذ

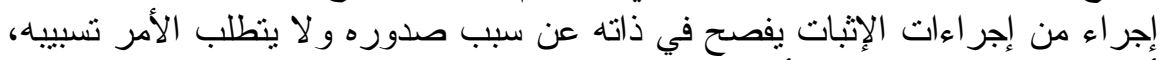

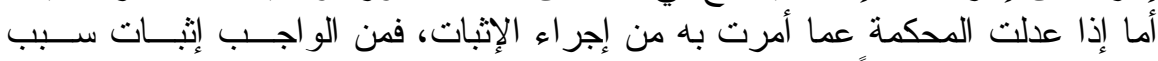

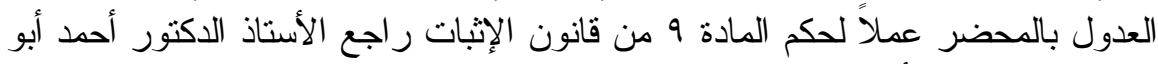

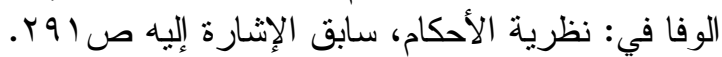

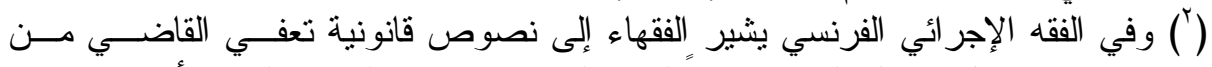

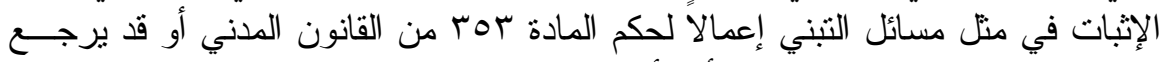

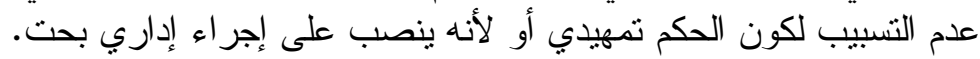
Jugement qui pronounce l'adoption, soit parce qu'ils se suffisent a' eux- meme [jugements preparatioires] soit parce qu'il s'agit d'une mesure purement administrative, remise de cause, soit encore parce que le tribunal jouit d'un pouvoir discretionnaire "décision de sursis à statuer.

راجع: . Jean Vincent et Serge Guinchard; op. cit. p. 531 No 761

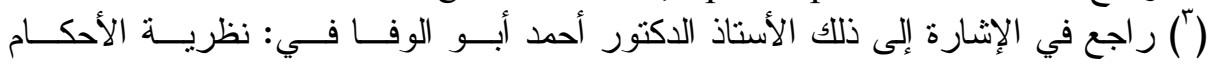




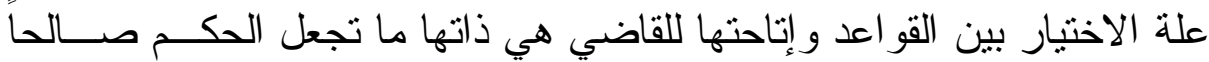

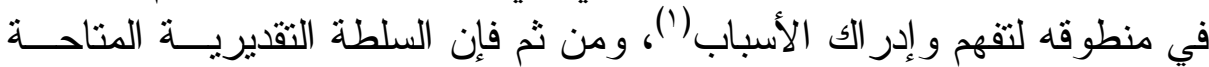
بإذن المشرع للقاضي لإعمال حكم قاعدة قانونية موضو عية أو إجر ائية تخـدو

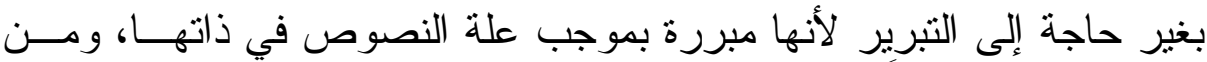

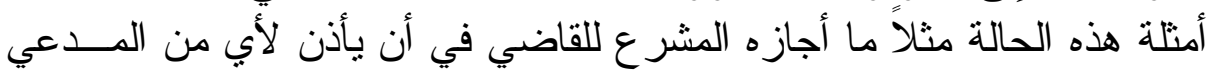

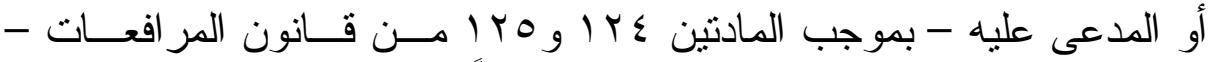

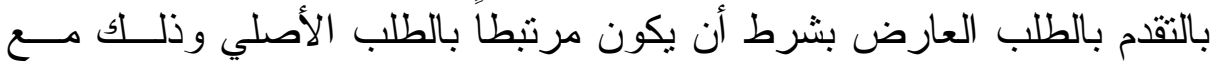

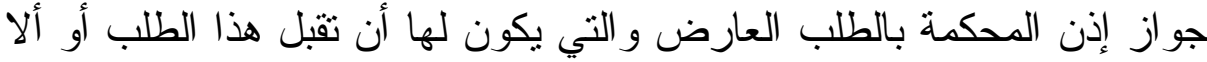

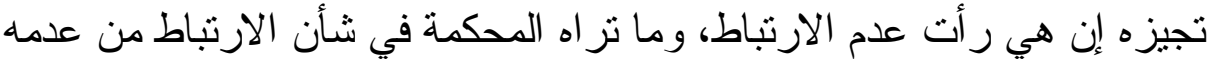

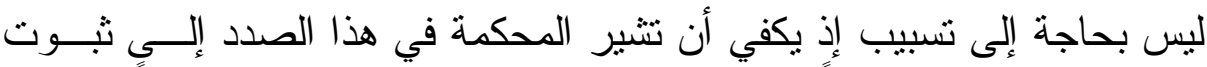

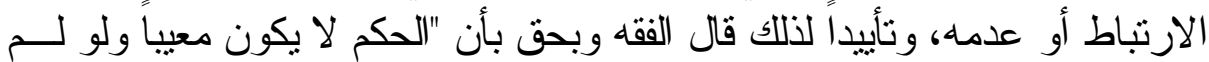

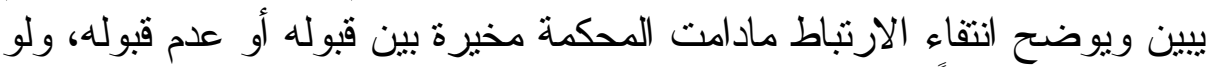

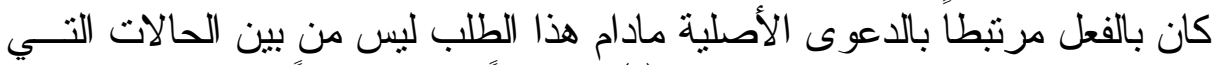

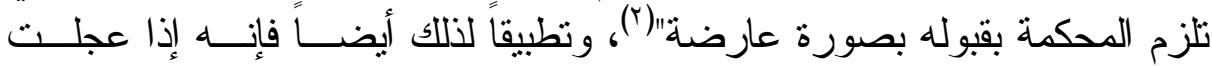

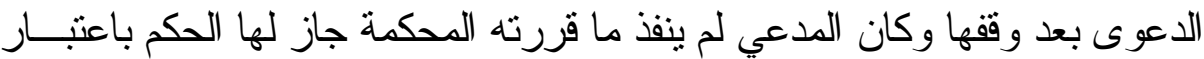

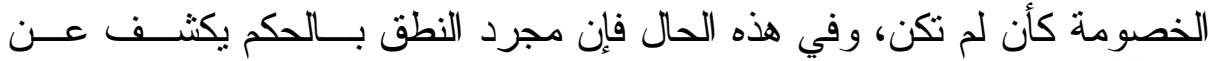
سبيه (r).

وفي مقام البحث عن الرقابة الو اقعية لمحكمة الــنقض علـىى التســبيب

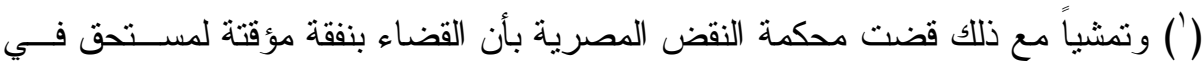

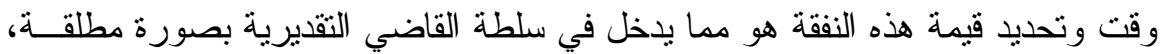

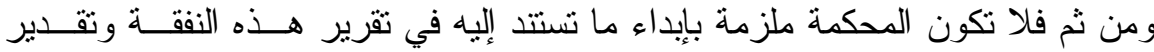

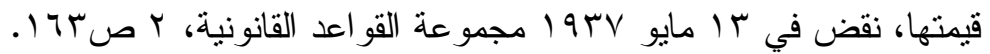

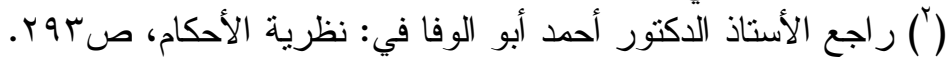

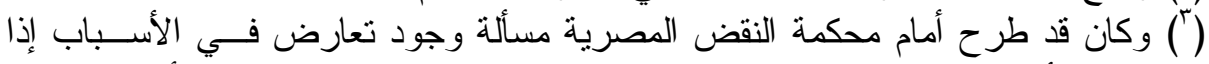

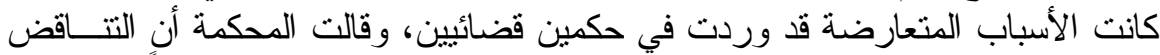

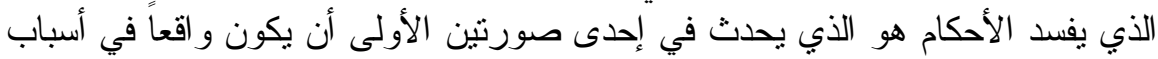

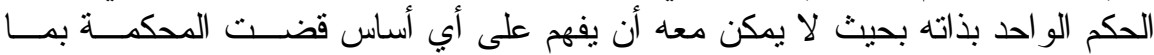

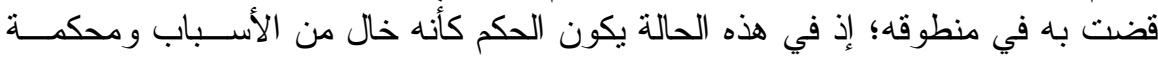

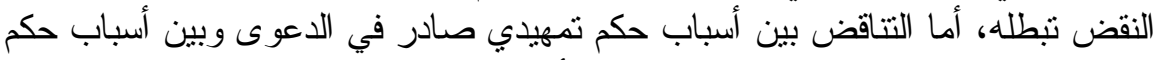

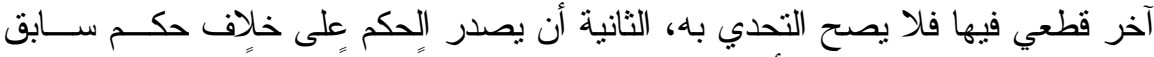

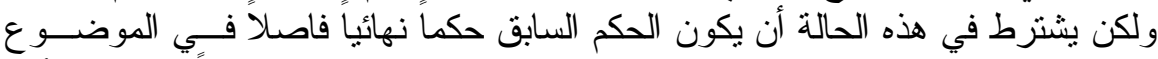

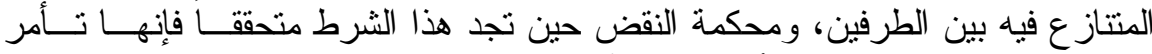

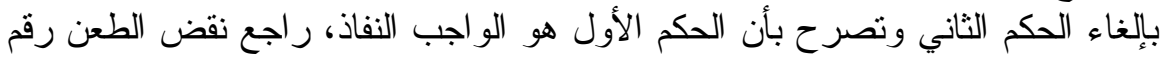

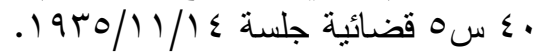




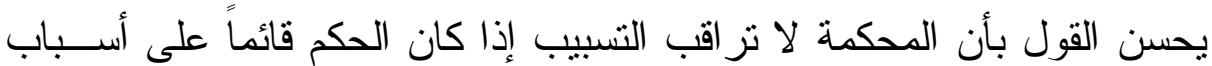

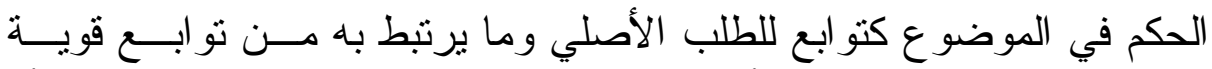

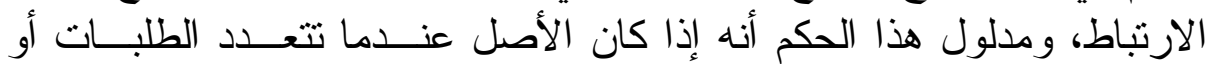

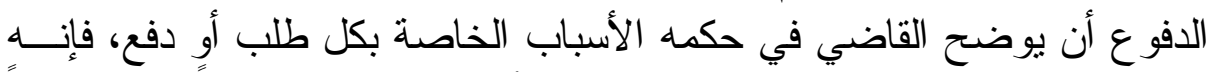

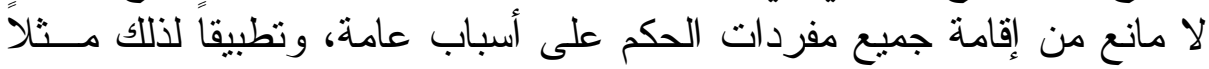

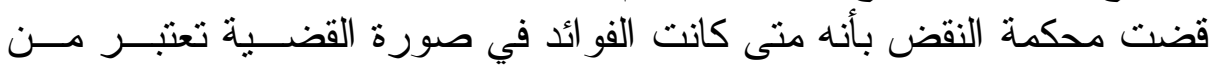

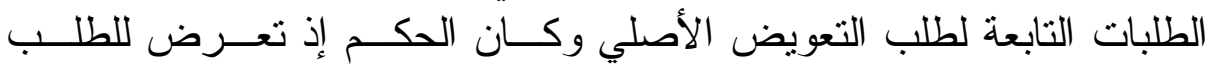

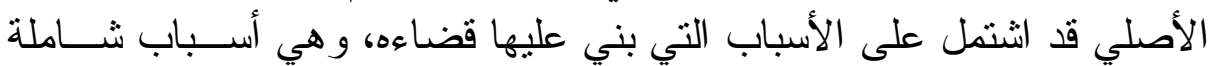

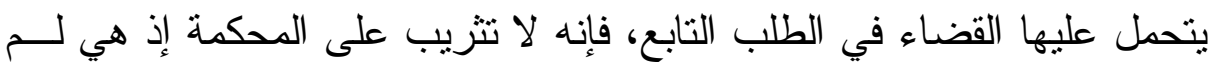

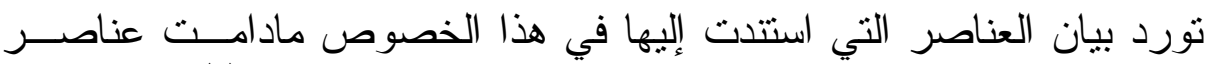
التعويض الأصلي التي أوردنها و افية البيان لا يشوبها التيان القصور (')، كذلك كانت

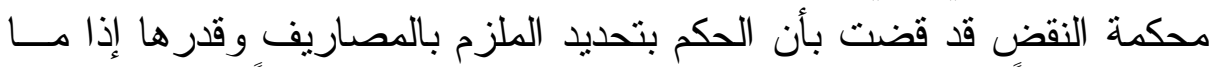

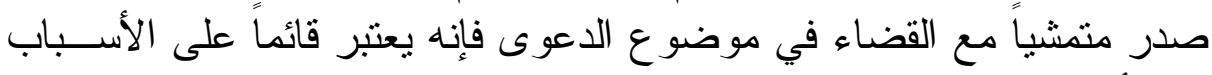

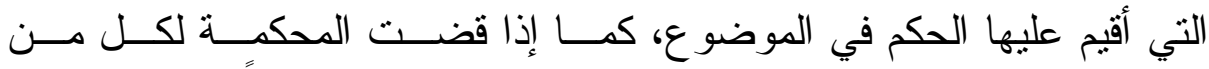

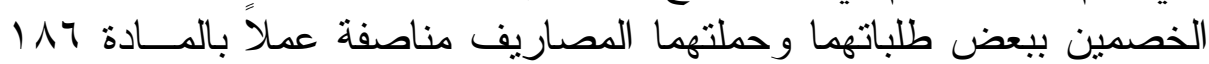
مر افعات (r) (لخمين

و إذا كان مفاد ما تقدم أن هناك أحو ال خاصة لا يلزم تنبيب الحكم فيها،

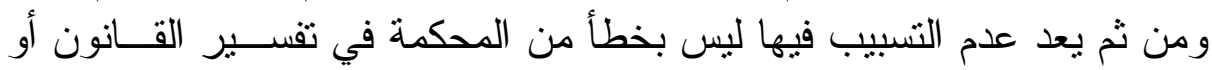

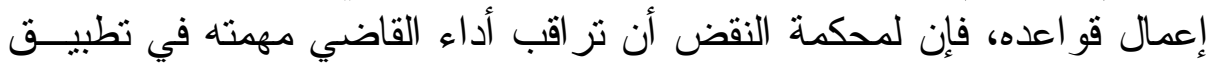

(') وكان قد طرح أمام محكمة النقض حكم الحالة التي تحيل فيها المحكمة إلى أسباب حكم

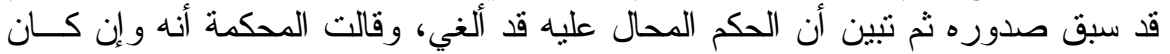

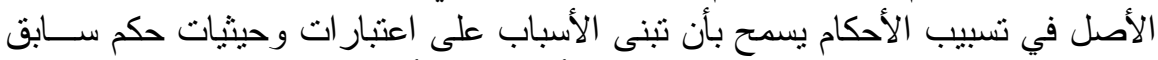

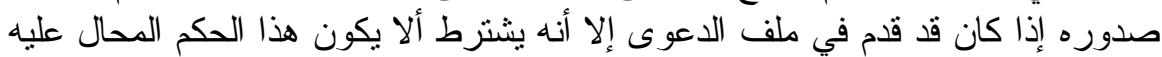

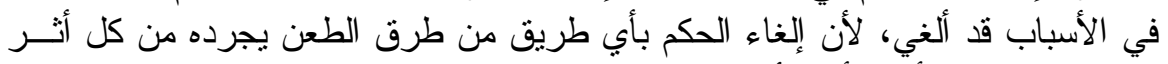

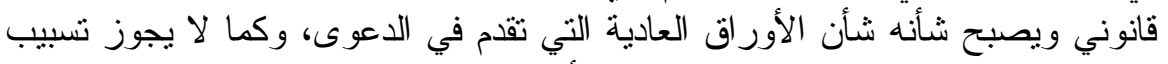

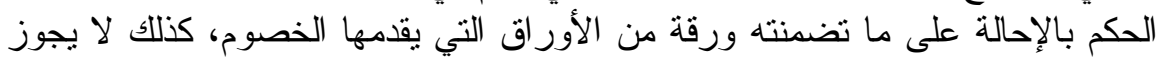

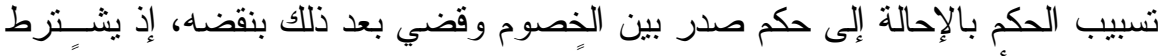

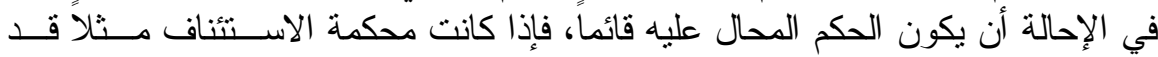

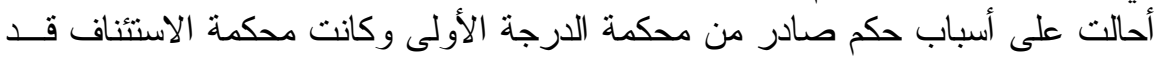

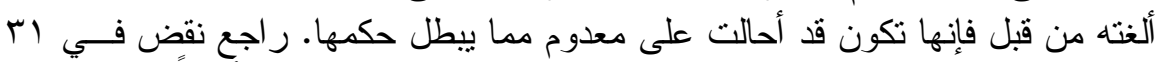

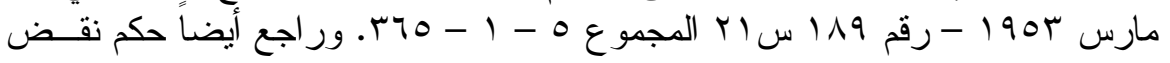

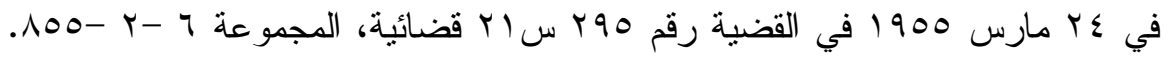

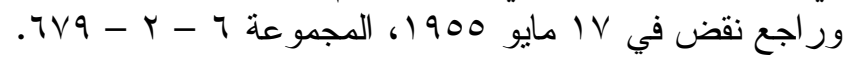

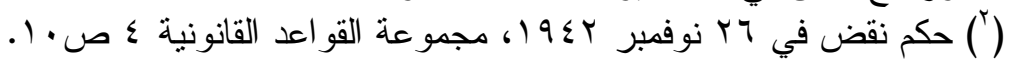




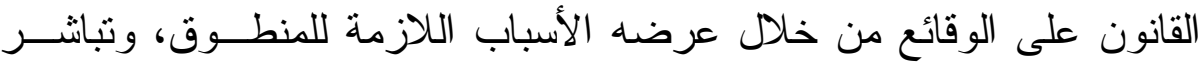

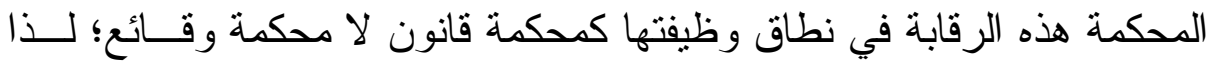

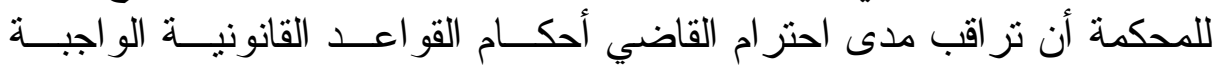

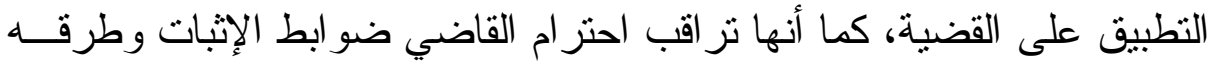

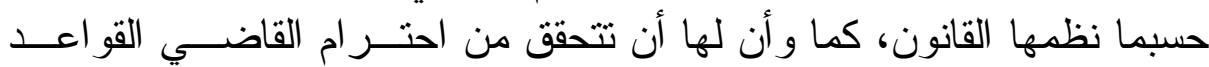

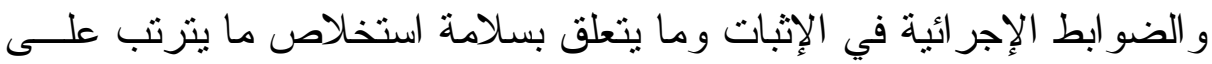

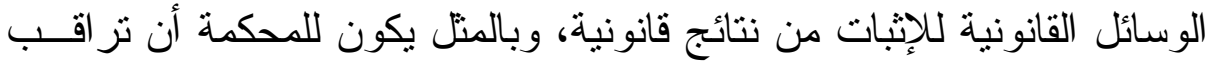
عبر التسبيب ضو ابط سير الخصومة، وبالمنل فإن للمحكمة أن تر اقب الأسباب المكملة للمنطوق و الحيثيات التي تبرره(').

$$
\text { المطلب الرابع }
$$

\section{الأثز القانوني لقصور التسبيب لوقائع الدعوى المط}

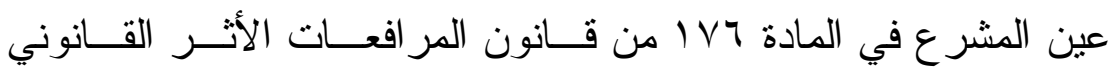
المترتب على قصور الأسباب، حيث جاء فيها الإثارة صر احة إلى الى أن الأحكام

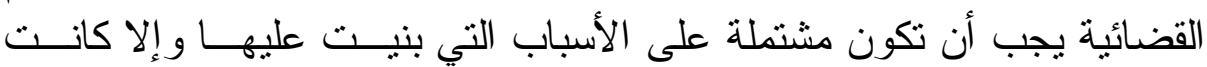

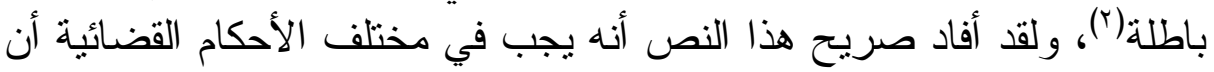

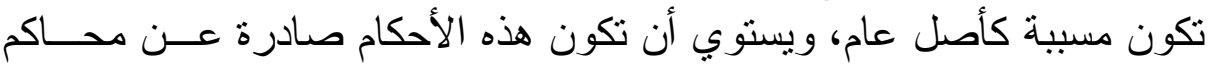
جزئية أم كلية.

ولقد رنب المشرع الفرنسي ذات الأثر لو كان الحكم غير مشنمل علـى

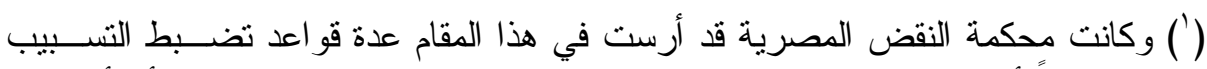

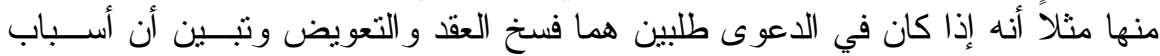

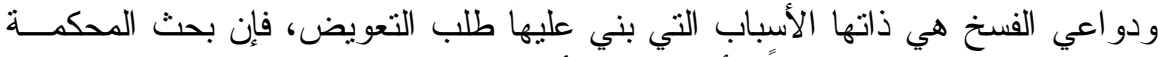

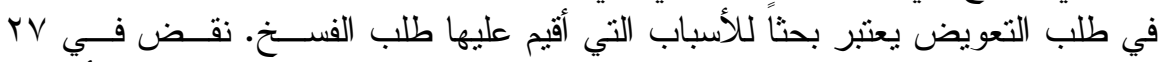

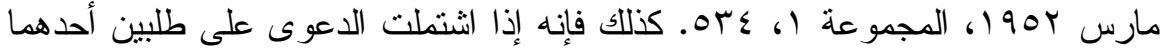

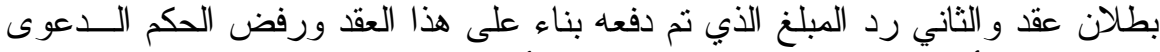

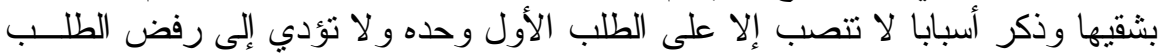

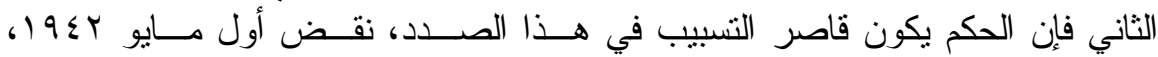

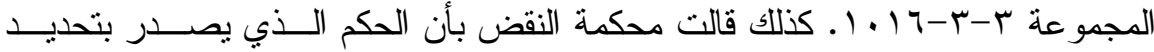

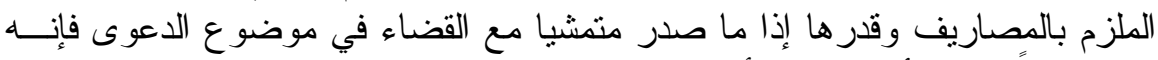

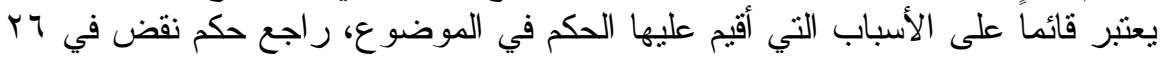

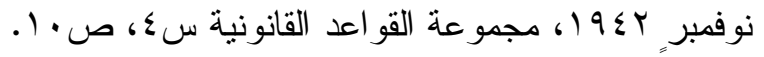

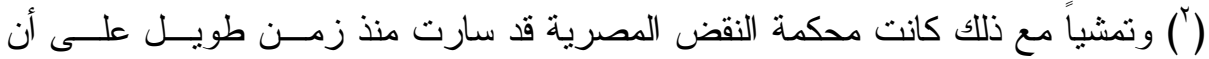

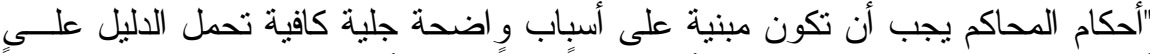

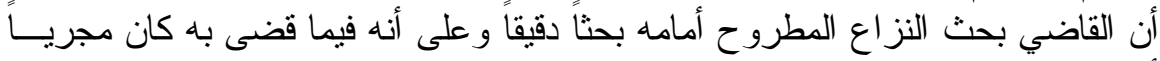

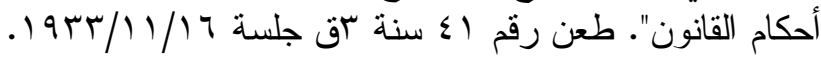


أسبابه أو كان هناك قصور في التسبيب(')، و إذا كان المشرع الفرنسي قد رتب

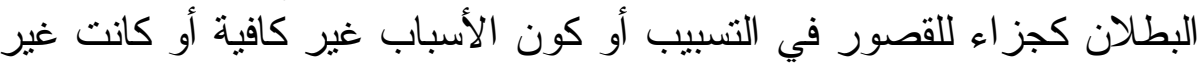

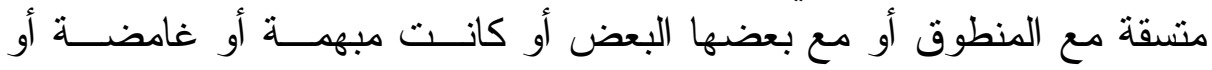

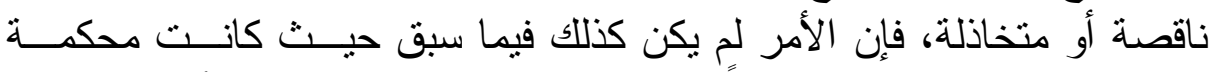

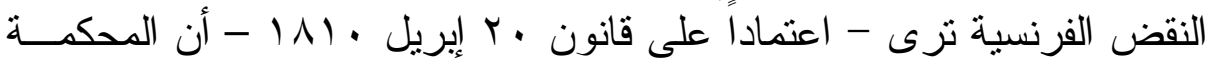

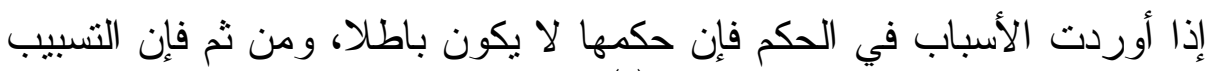

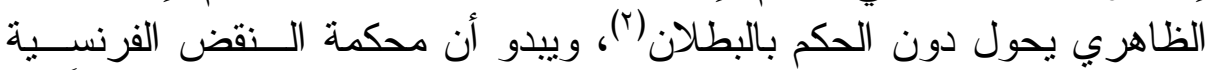

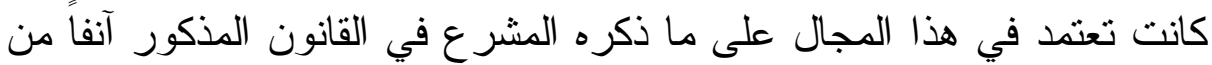

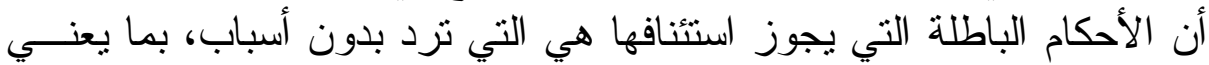

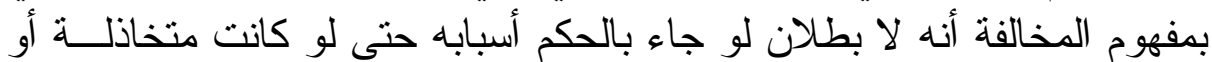

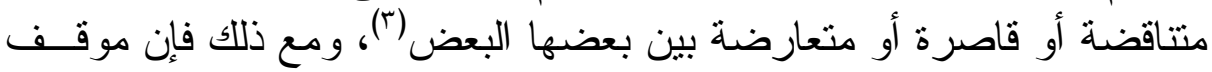

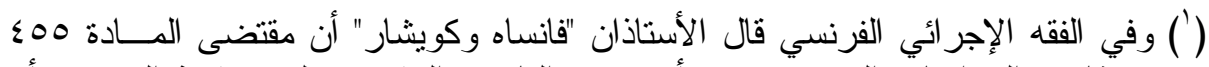

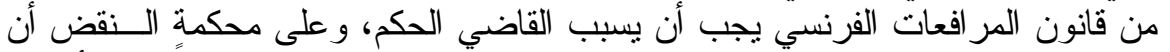

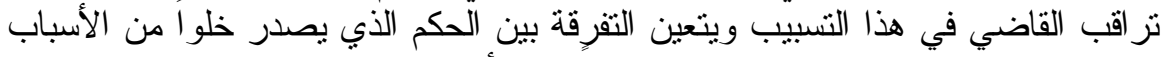
بصورة مطلقة وبين الحكم المتضمن قصورأ في الأسباب: Aux termes de l' article 455 nouv. C. le jugement doit être motivé, de cette obligation, la cour de cassation tire un contrôle de la motivation. afin d'imposer aux juges du fond son respect. Les vices de motivation présentent des aspects très varies. Mais. On peut les remener à deux grandes catégories. Le defaut de motifs et les défaud au manqué de base légale ou encore motivation in suffisante.

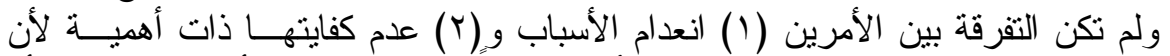

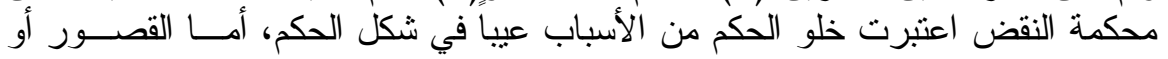

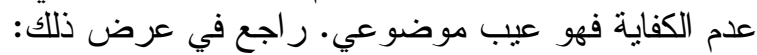
Jean Vincent et Serge; procédure civile. Op. cit. p. 692 No 1039.

$$
\text { ور اجع أيضا: }
$$

le clech; moyens de forme et moyens de fond devant la cour de cassation. J.C.P. 1947. 1.634

legros: Essai sur la motivation des jugements civile. Th. Dijon 1987

$$
\text { و وانظر أيضا: }
$$

$$
\text { و وانظر أيضاً: }
$$

voulet; l'interprétation des arrêts de cassation. J.C.P. 1970. 1. 2305.

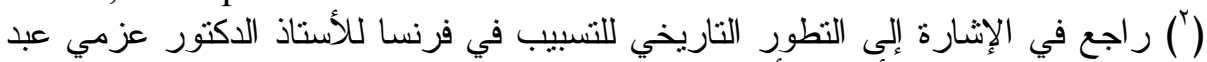

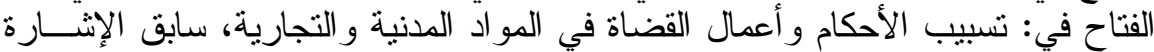

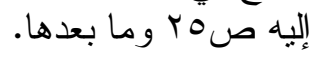

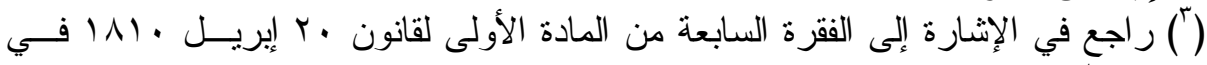


المحكمة العليا قد تبدل حديثاً حيث أصبحت نتطلب خصائص الاكتمــال فـي

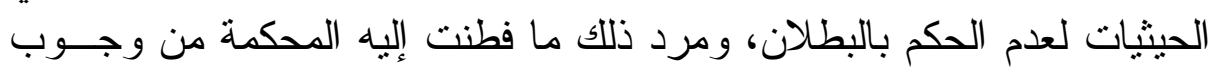

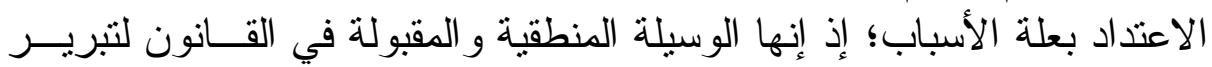
المنطوق، ومن ثث يستوي في حقيقة الأمر أن تكون غير موجودة أو قاصــرة،

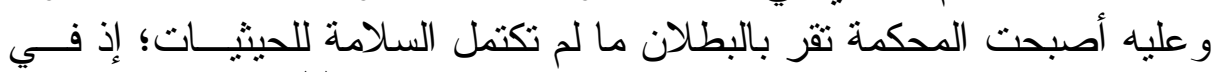
هذه الحالة تكون صحيحة وهي تكون باطلة عند قصور هال' (').

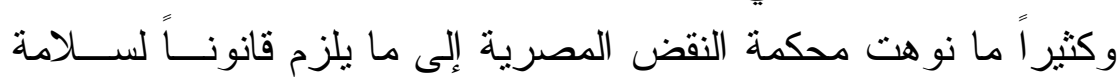
الأسباب و عدم الاكتفاء بالتسبيب الشكلي؛ لذا قالت المحكمة في حكم قديم لهــا

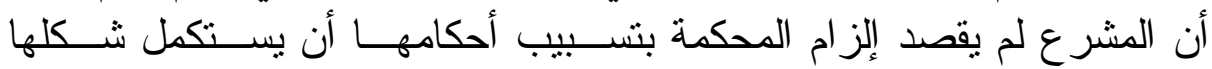
باعتبار ها من أوراق المرافعات، فيكفي فيها بمطلق الأسباب ولو جاءت مبهمة

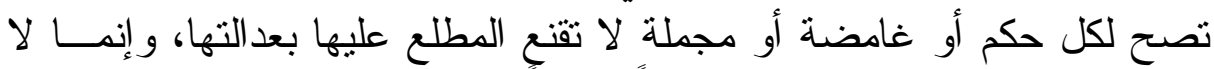
يؤدي التسبيب ثمرته إلا إذا كان كافياً وكفيلاً بأن يحقق المقصـــود منــه، و إلا استطاع قاضي الموضو ع أن يجهل طريق الرد على أحكامه، فيكتفي بأســباب

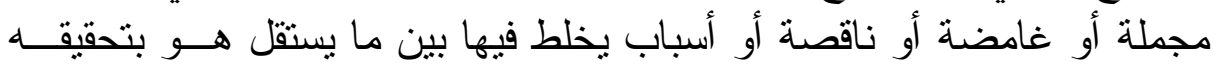

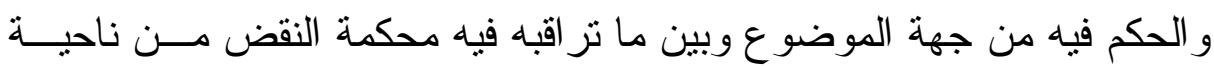

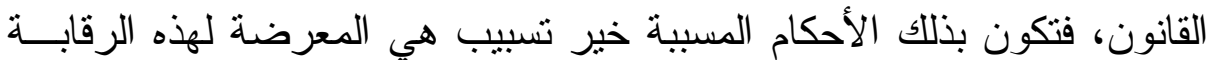

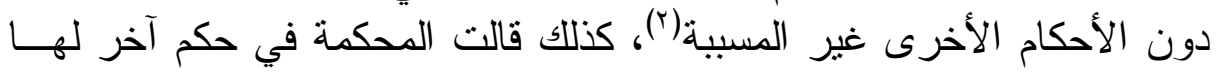
أنه إذا كان لقاضي الموضوع السلطة التامة في تحصبل فهم الو اقع في الدعوى من الأدلة المقدمة، وفي وزن هذه الأدلة وتقدير ها وترجيح بعضها على بلى بعض، فإن خضو عه لرقابة محكمة النقض في تكييف هذا الفهم بحكم القـانون، وفيـي

Gérard Cornu et Jean Foyer; op. cit. p. 437

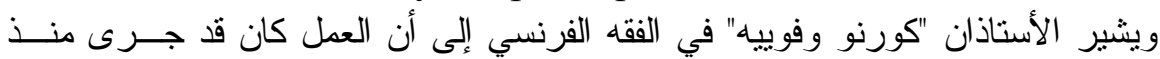

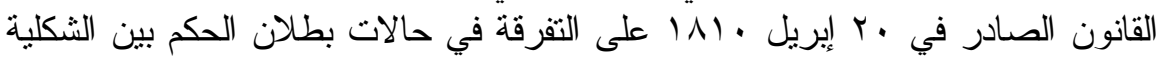
الازمة فيه و الثكلية القانونية.

La distinction des formalités substantielles et des formalités secondaires trouve encore application.

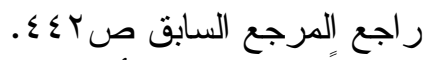

(') وتمشياً مع ذلك قال الأستاذان G. Cornu et J. Foyer أن أسباب بطلان الحكم عديدة ومن بين أسباب البطلان العوار في الموالئ الجهة وعدم كفاية الأسباب. Absence, contradiction et insuffisance des motifs, défaut de base légale.

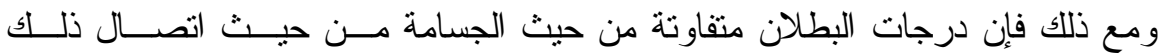

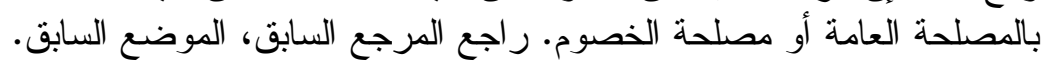

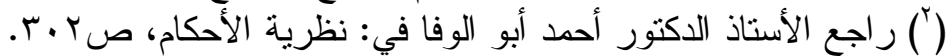


تطبيق ما ينبغي من أحكام القانون يحتم عليه أن يسبب حكمه التسبيب الكـافي

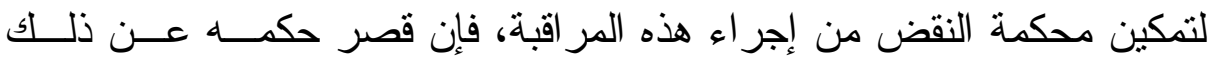

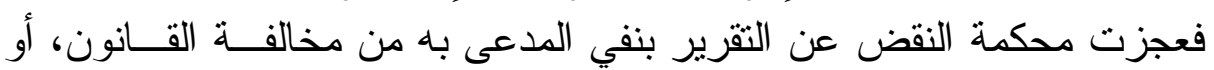

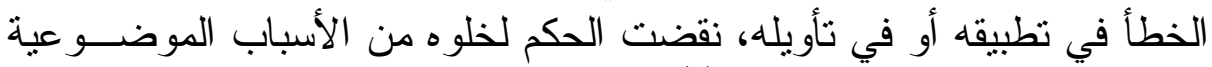

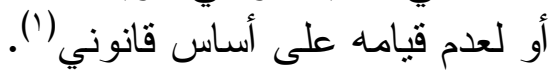

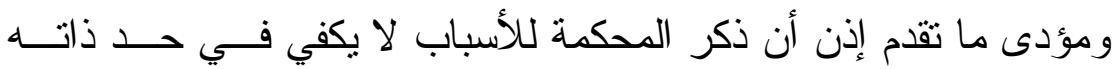

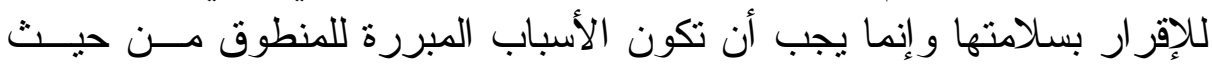

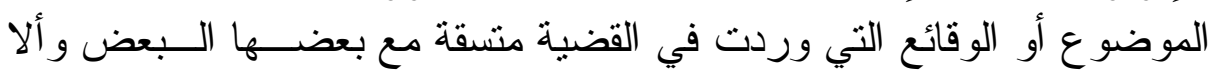

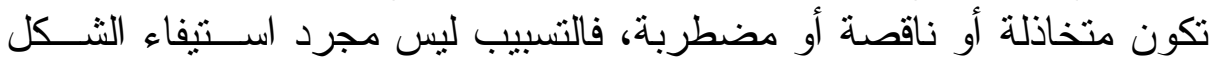

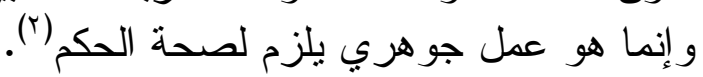
وهكذا لا يلحق البطلان بالحكم كلما كانت أسبابه صحيحة و إنما البطلان

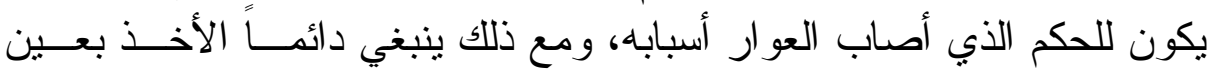

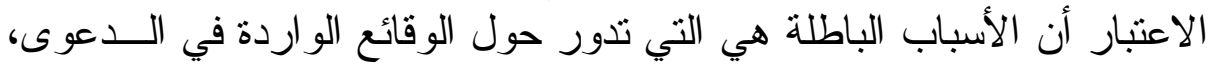

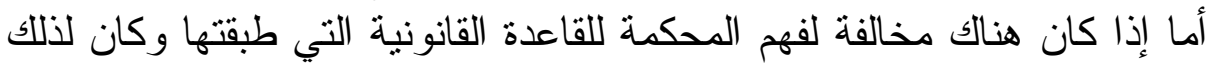

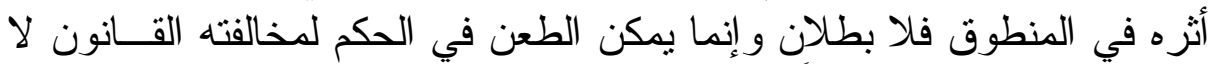

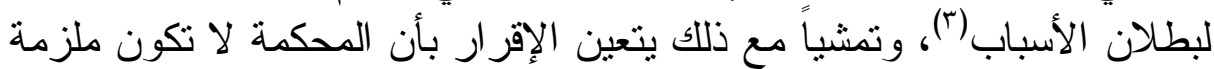

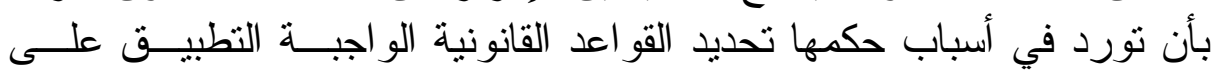

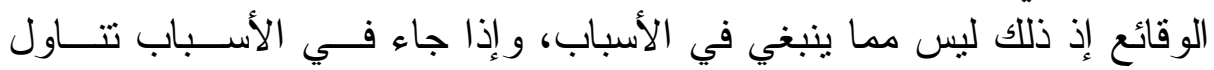

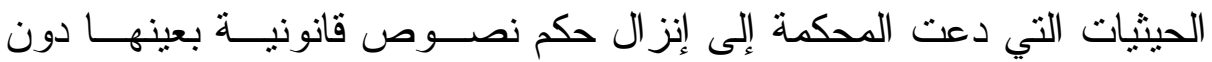

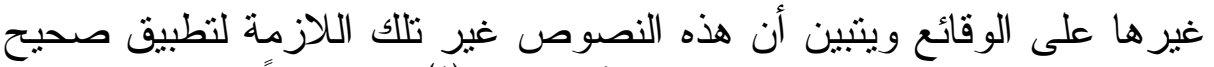

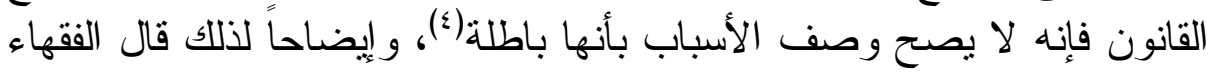

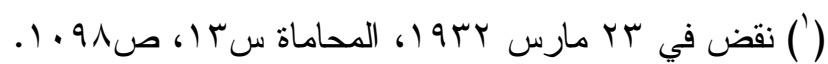

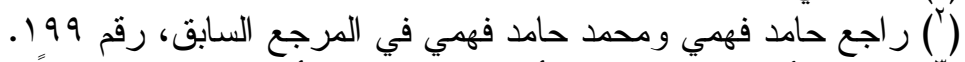

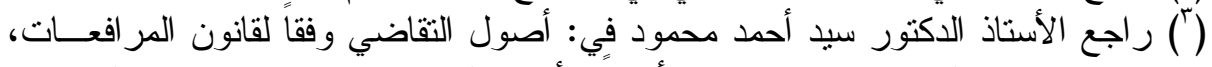

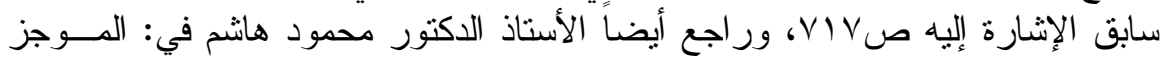

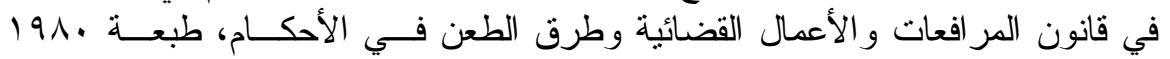

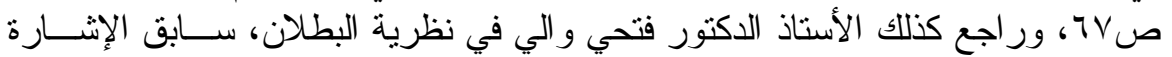

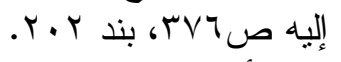

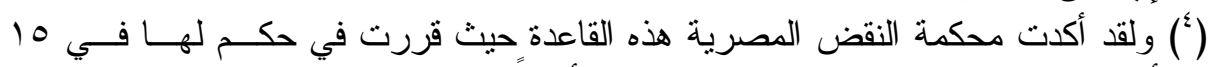

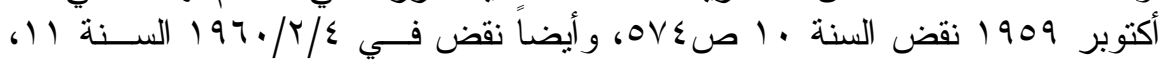

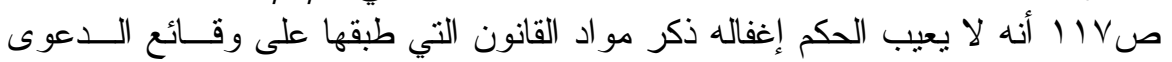

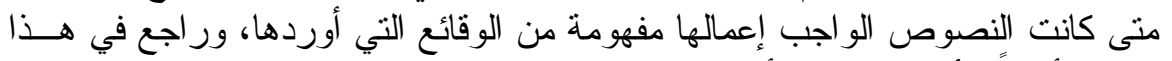

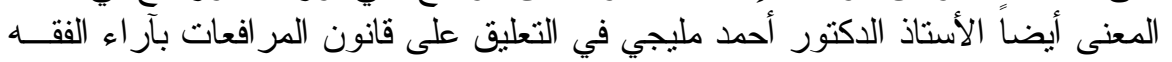




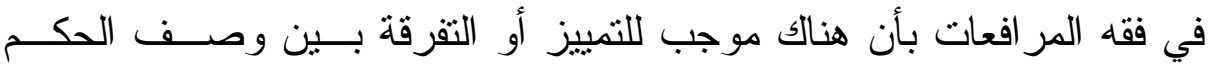

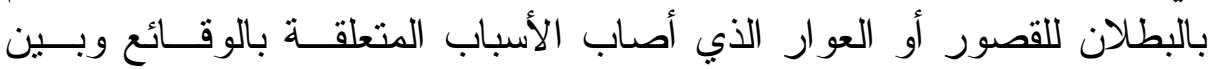

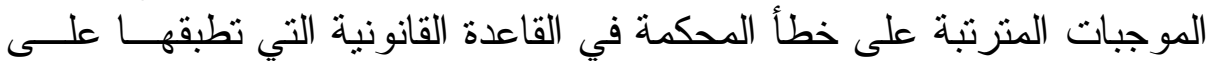

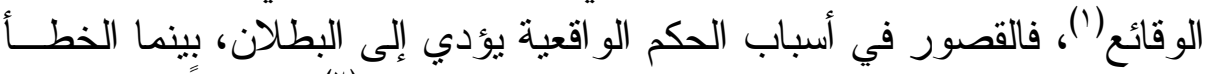

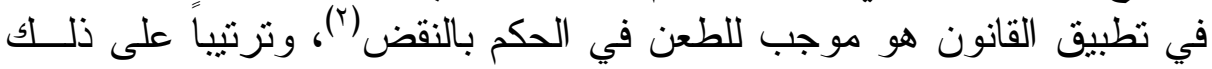

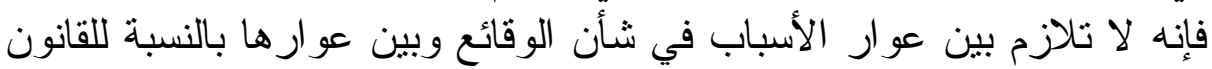

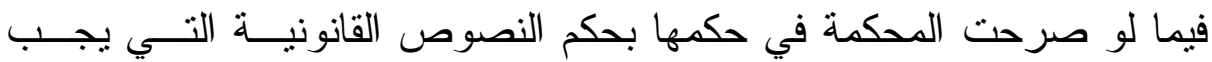

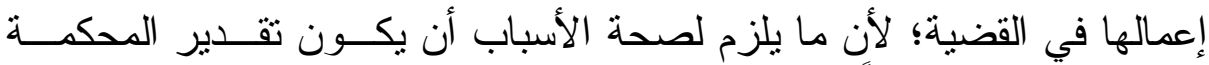

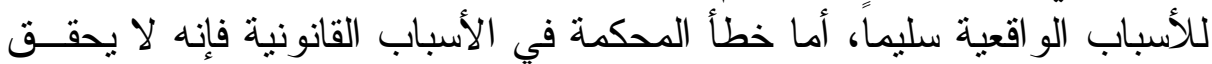

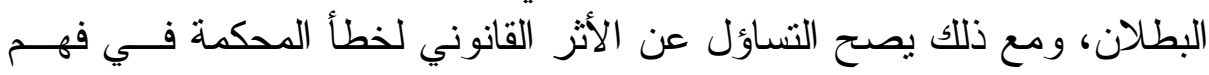

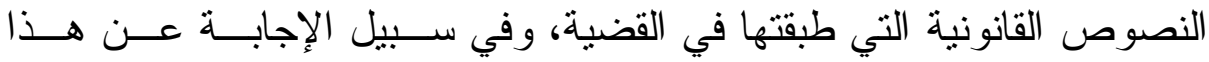

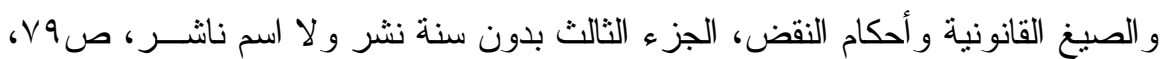

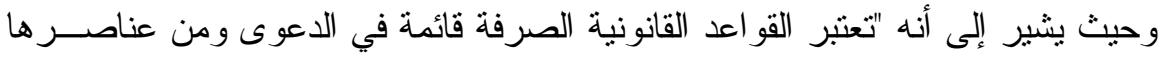

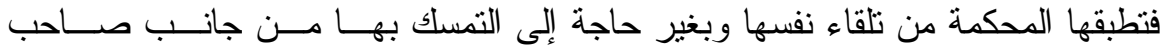

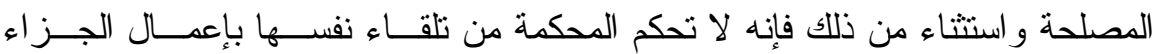

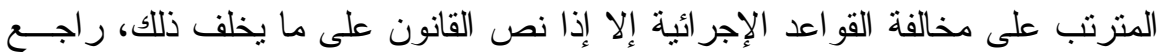

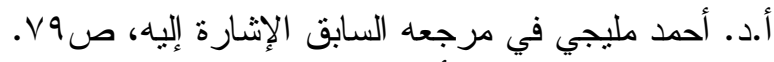

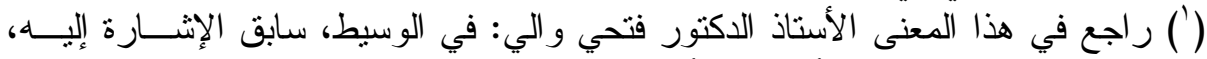

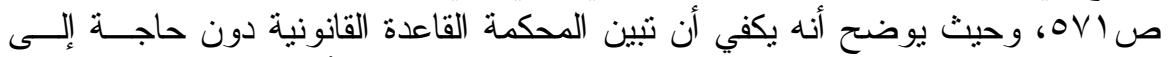

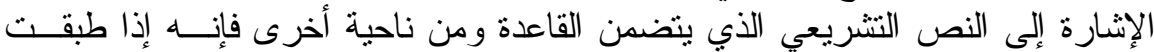

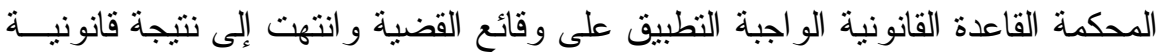

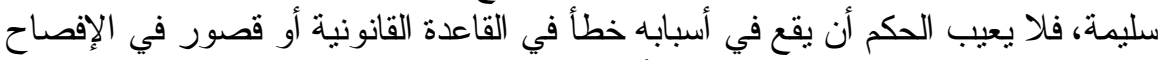

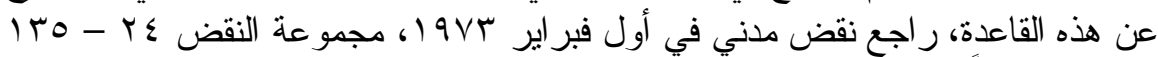

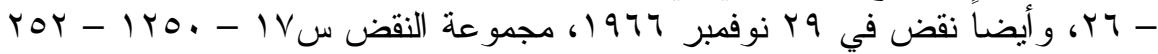

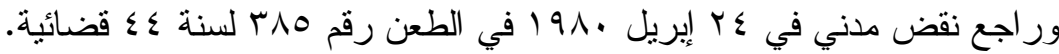

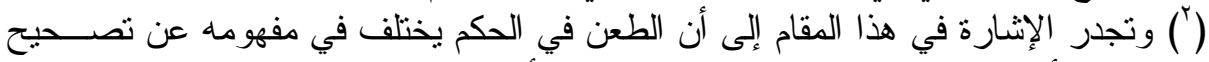

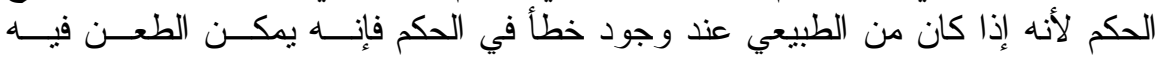

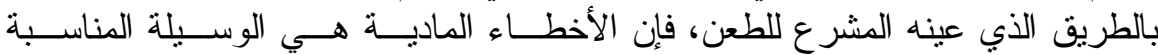

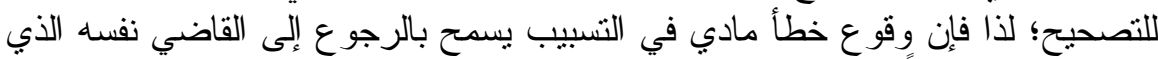

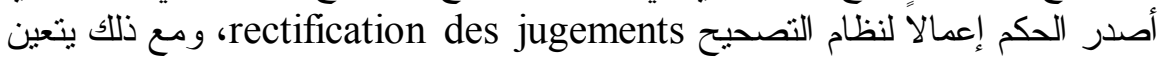

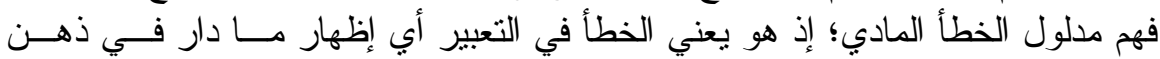

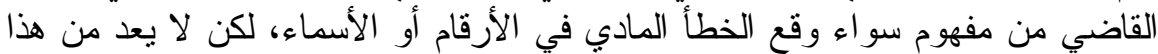

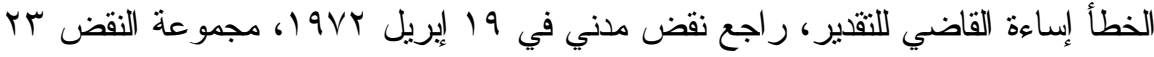

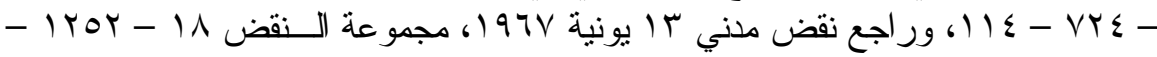

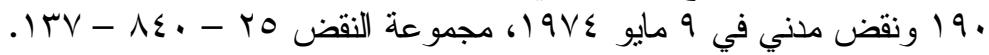


التساؤل يجب التقرقة بين الأسباب أو الحيثيات التي قدرتها المحكمــة(') فــي

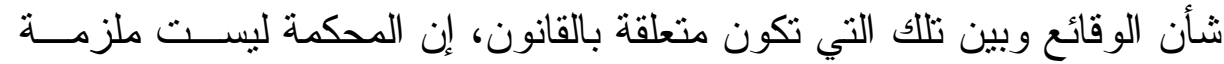

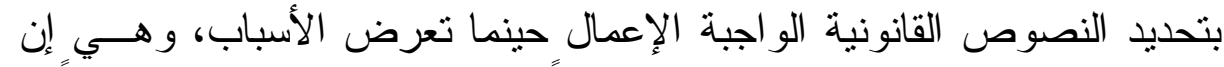

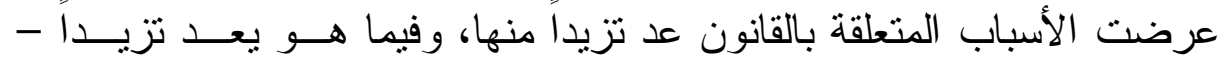

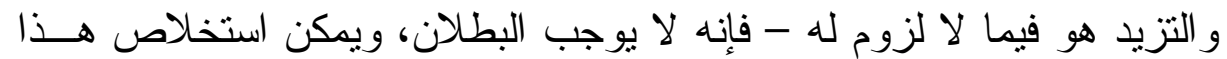

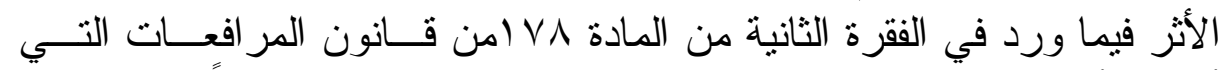

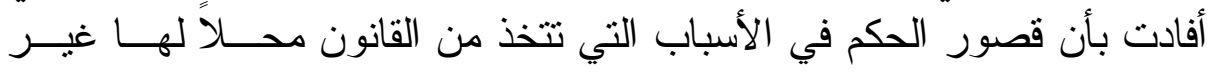

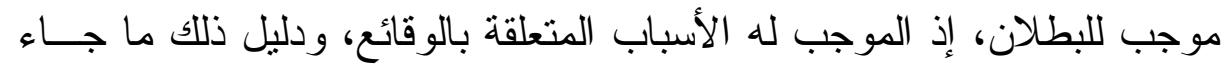

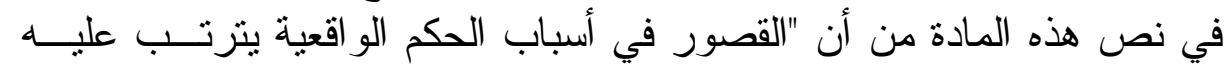

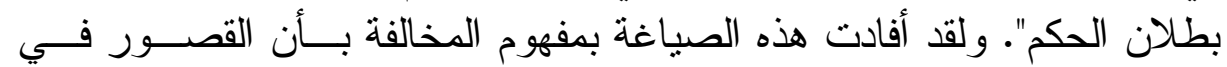

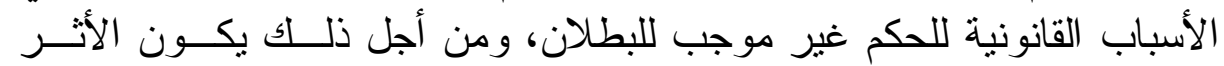

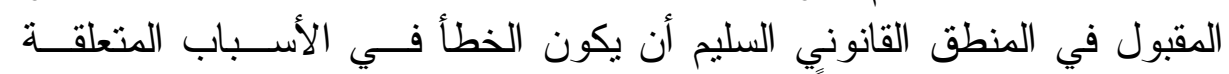

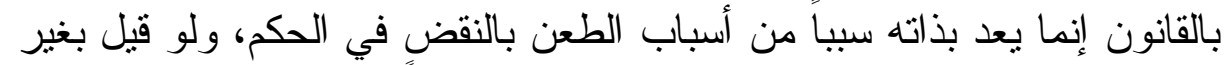

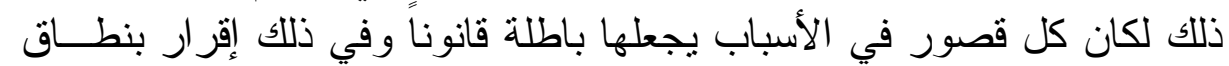
بالغ الاتساع للبطلان.

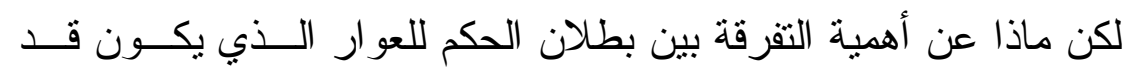

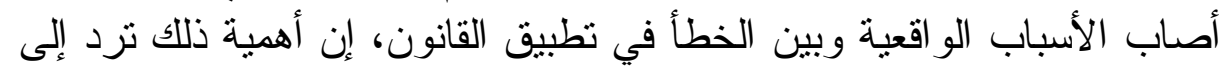

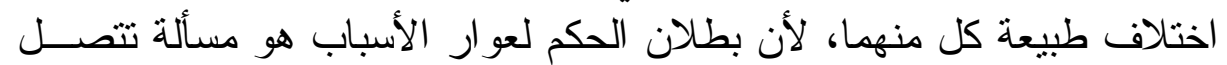

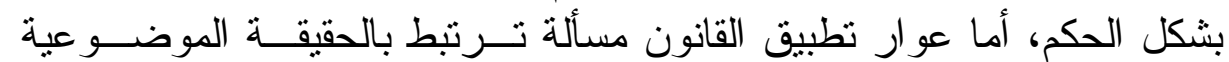

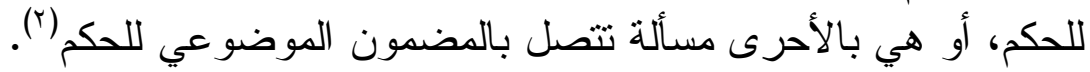

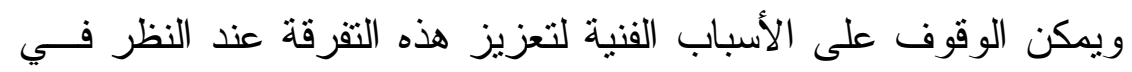
حالات الطعن بالاستئناف وتتبع الحالات التي يجوز فيها للنائب العام أن يطعن

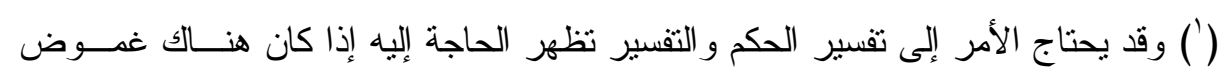

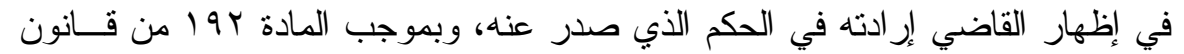

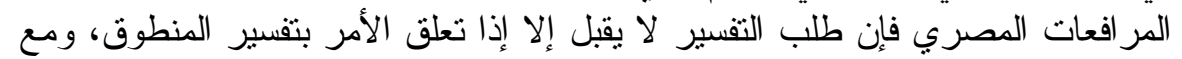

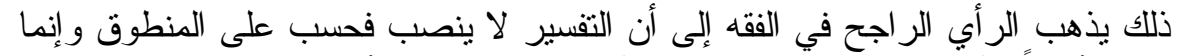

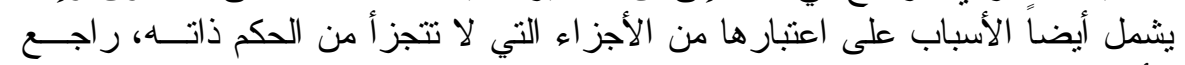

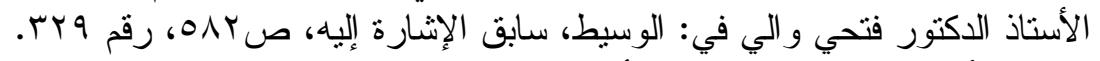

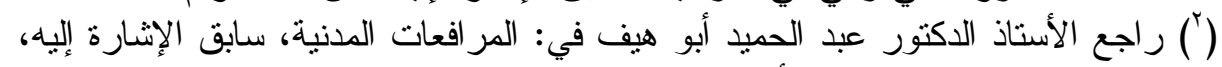

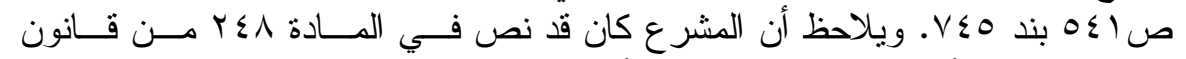

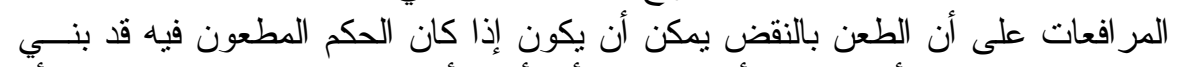

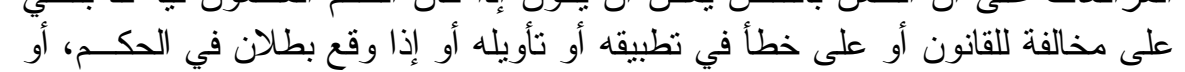
إذا وقع بطلان في الإجر اءات أثر في الحكم. 
لمصلحة القانون: إذ بموجب المادة ابr من قانون المر افعات "يجوز استثئاف

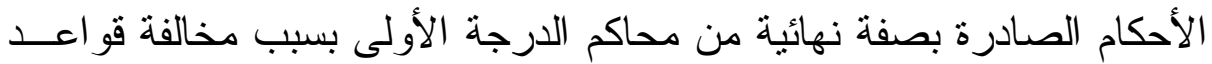

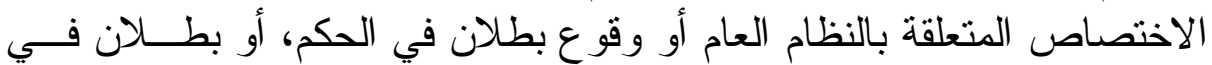

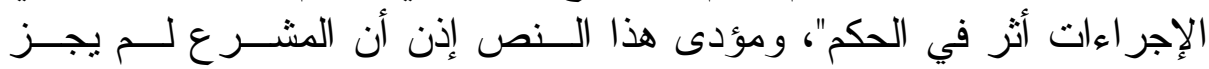
الاستئناف لأسباب أخرى متعلقة بالقانون غير ما ورد في النص، كذلك أشنارت

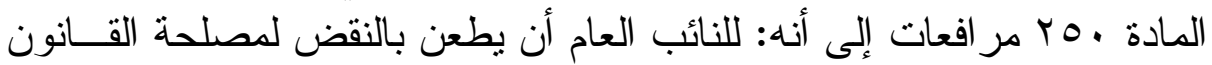

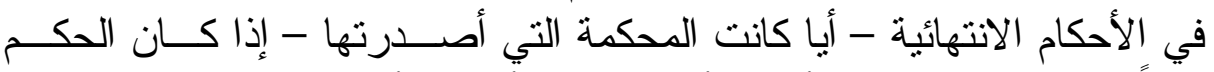

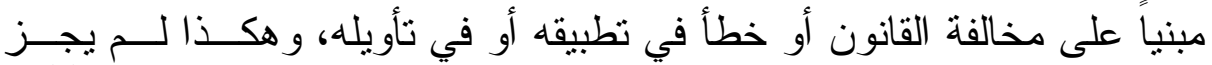

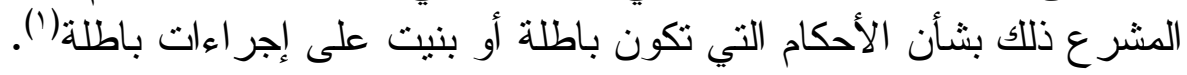

\section{المبحث الثاني \\ النطاق القانوني للتسبيب}

قلنا فيما تقدم أن المشر ع الإجرائي قد صر ح في المادة IVT مر افعــات بوجوب اشتمال الحكم على أسبابه الو اقعية إذ يجب - و وفقاً للمادة - أن تشتمل

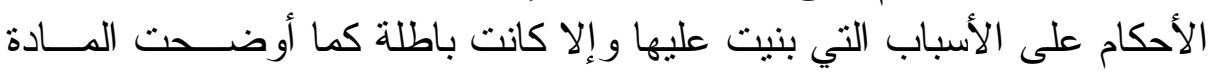

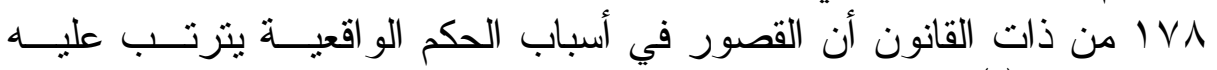

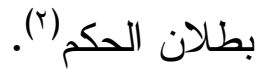

ويختلف البطلان الناتج عن تخلف الأسباب أو فسادها عن انعدام الحكم؛

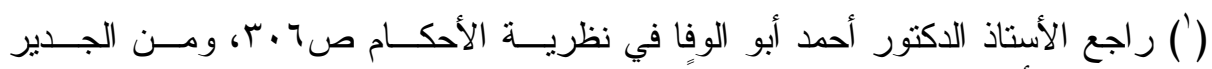

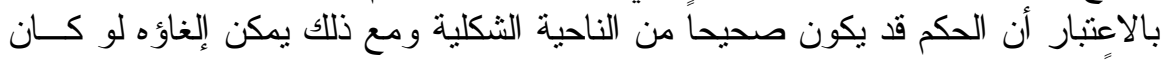

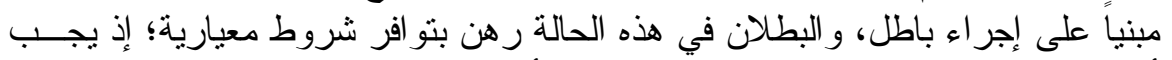

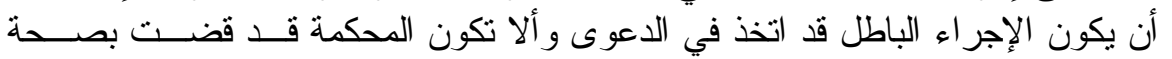

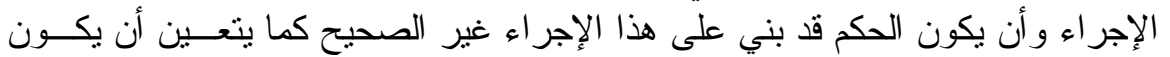

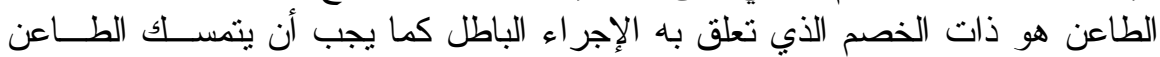

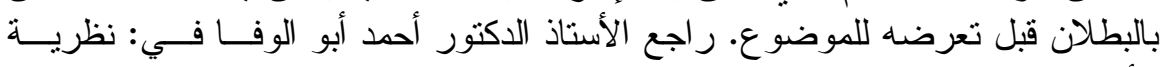

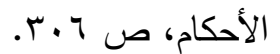

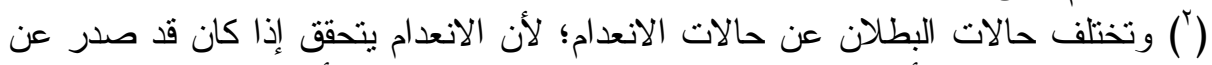

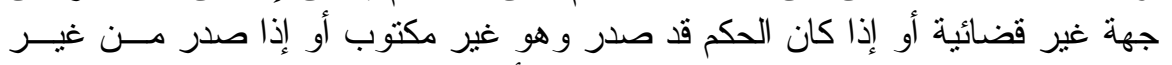

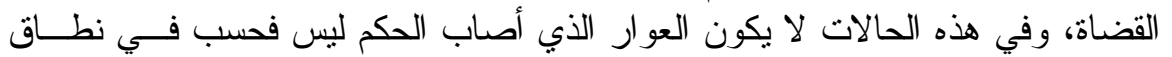

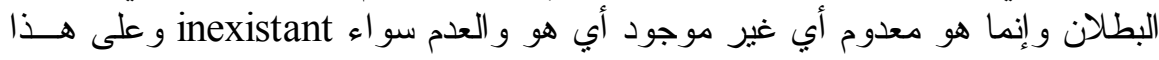

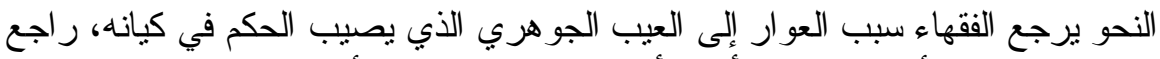

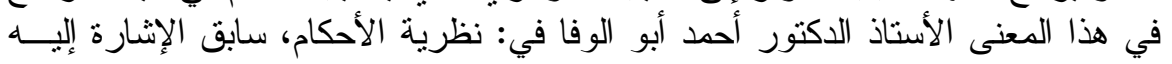

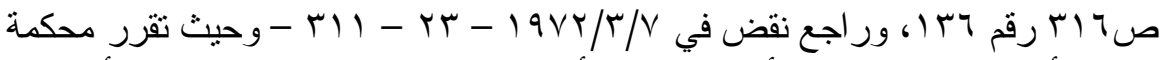

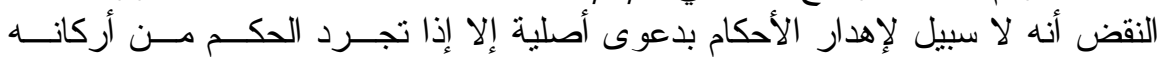




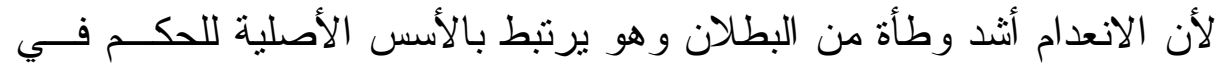

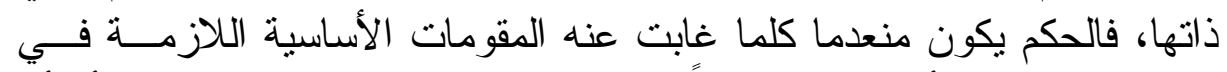

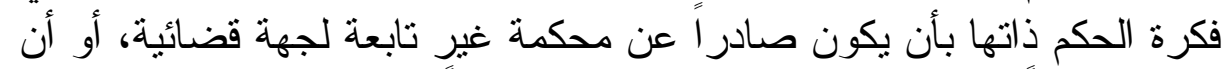

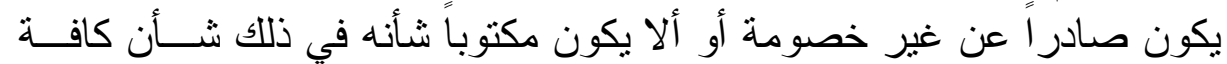

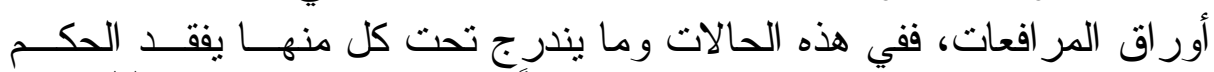

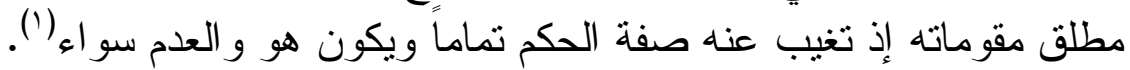

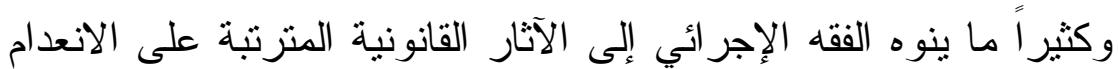

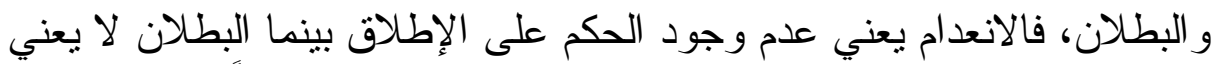

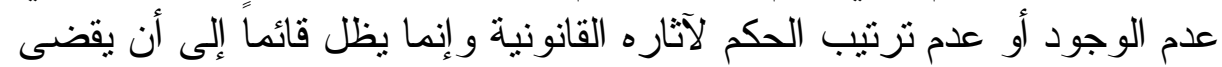

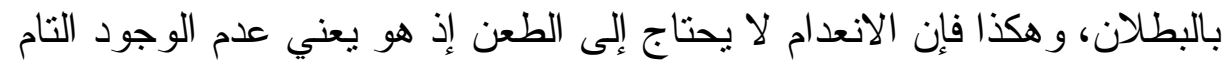

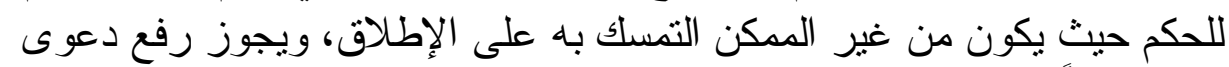

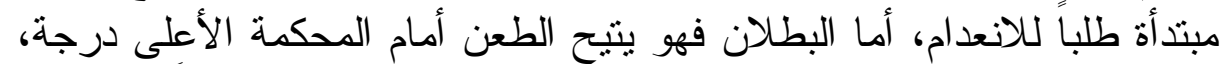
كذلك فإن بطلان الحكم يزول لو رد على البطلان البطان بما يعتبره صحيحاً (r).

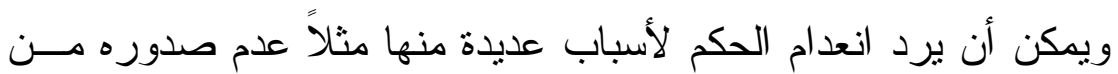

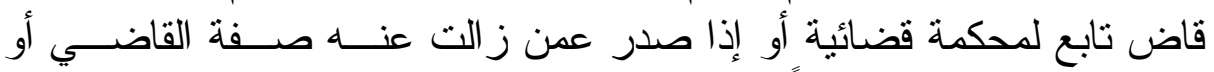

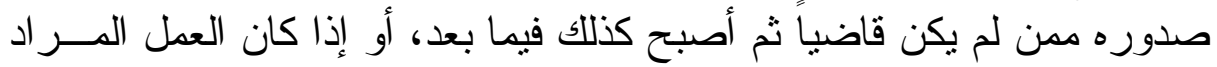
وصفه بالحكم قد صدر عن هيئة تتكون في أغلبها من قضاة وكان فئان فيها من هو

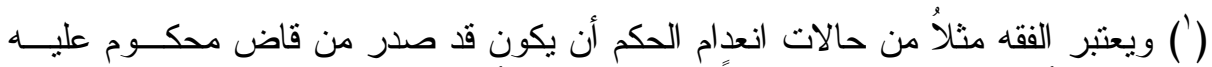

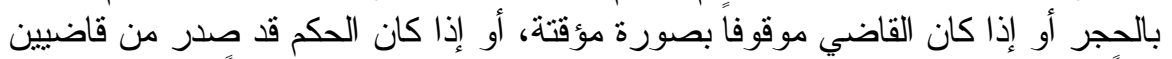

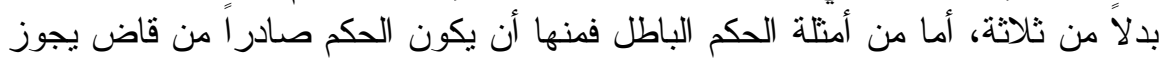

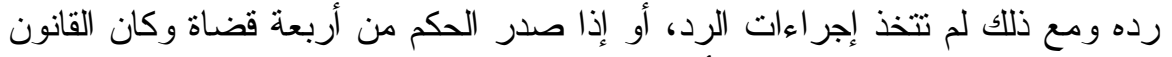

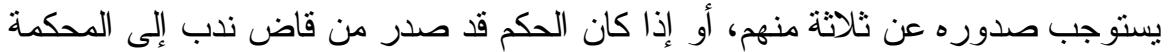

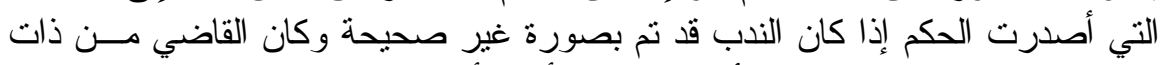

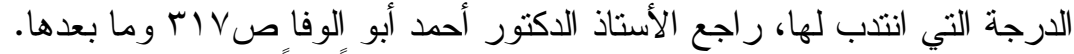

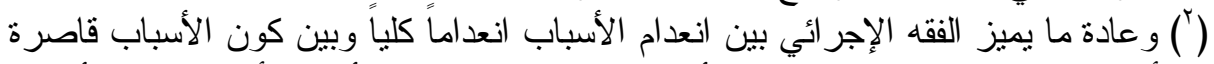

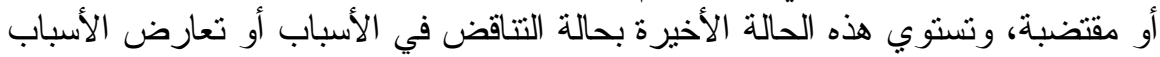

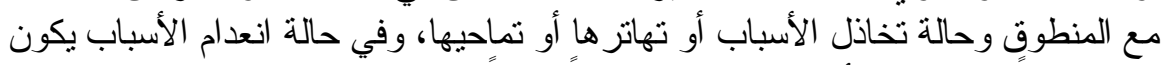

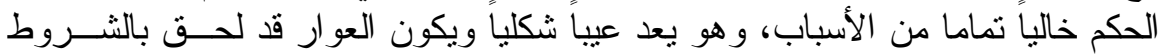

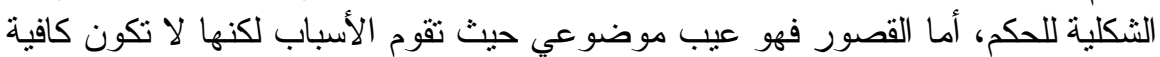

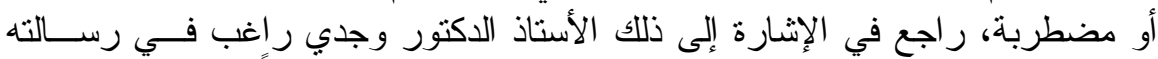

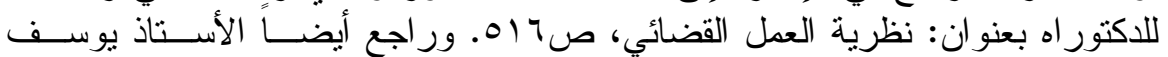

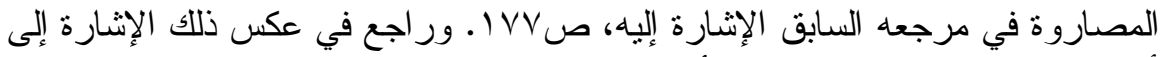

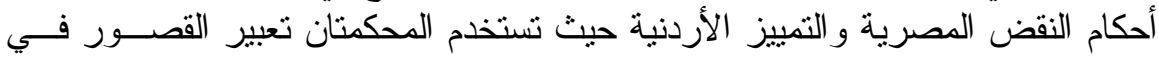

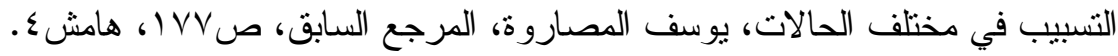


ليس بقاض ولو اتفق الخصوم على ضمه لهيئة عهدو ا إليها بنظر نز اع بينهم (').

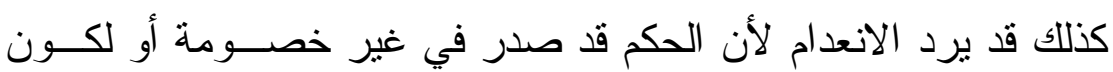

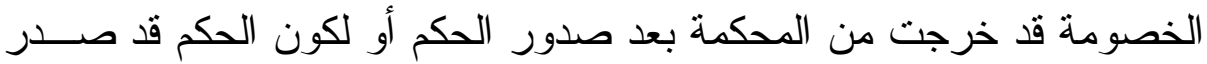

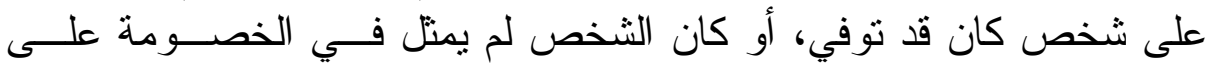

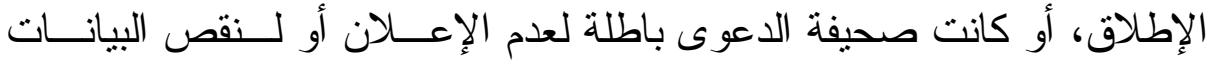

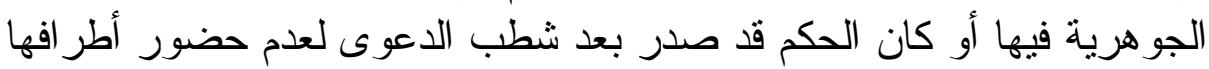

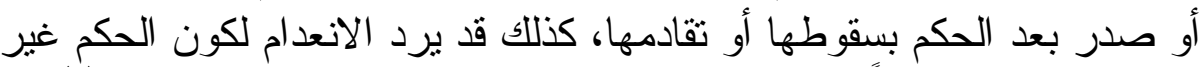

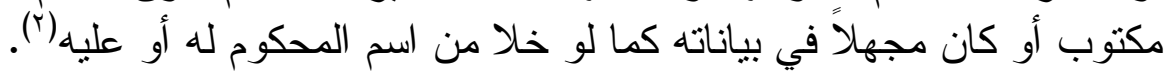

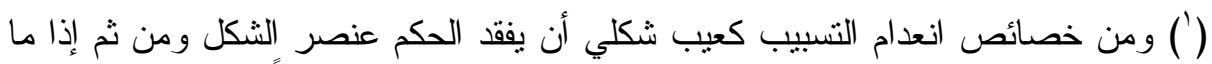

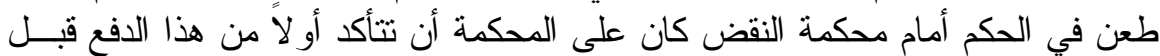

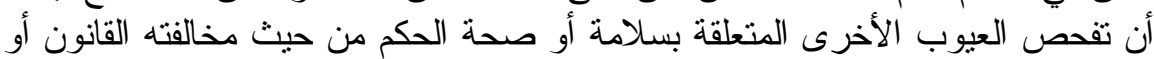

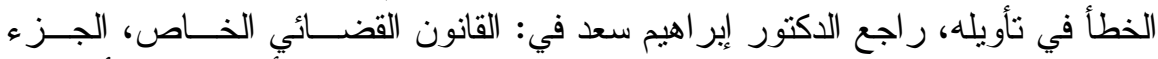

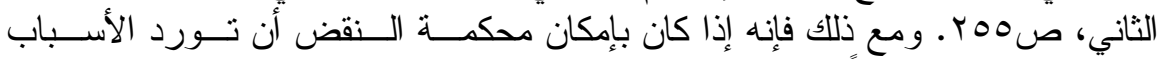

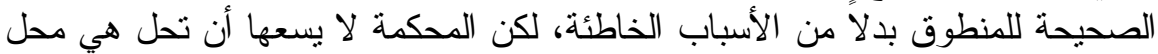

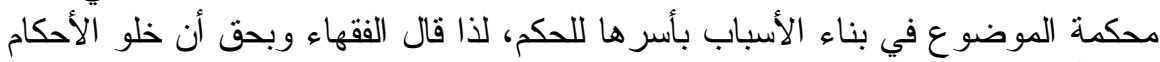

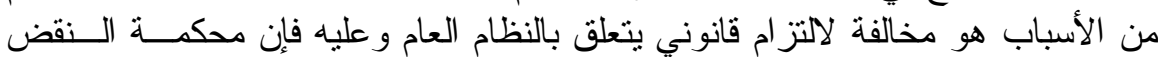

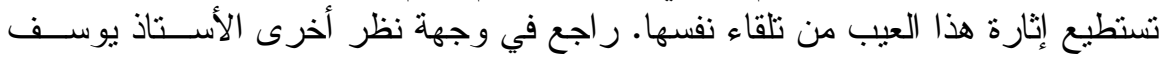

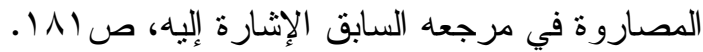

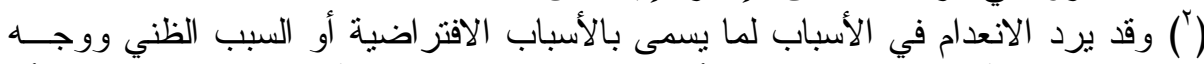

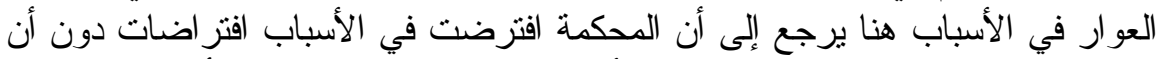

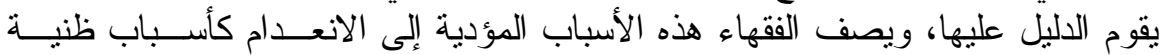

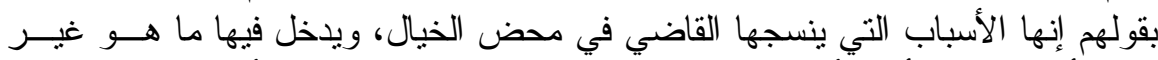

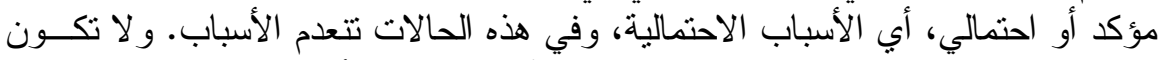

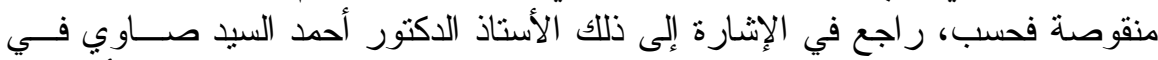

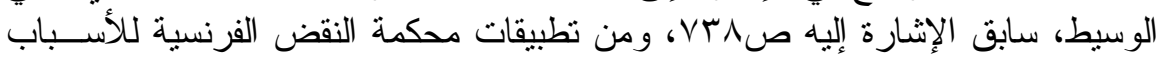

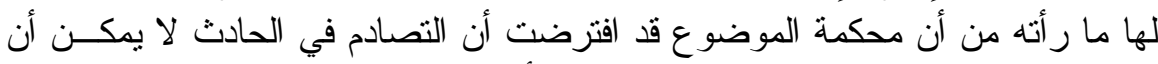

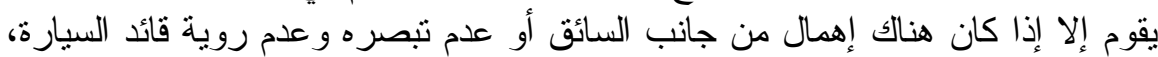

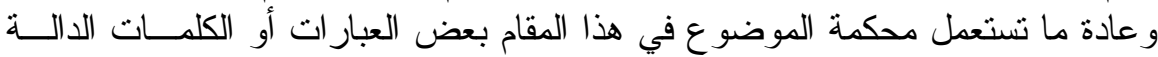

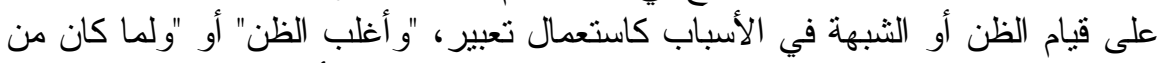

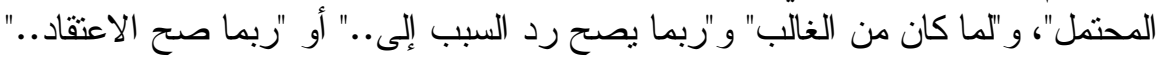

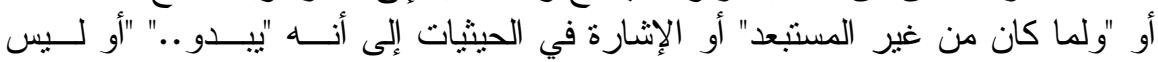

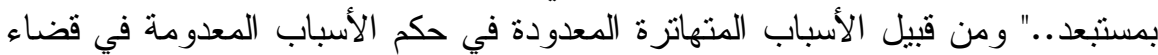

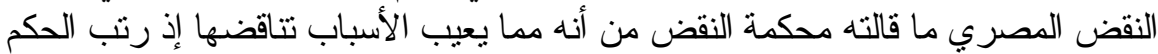

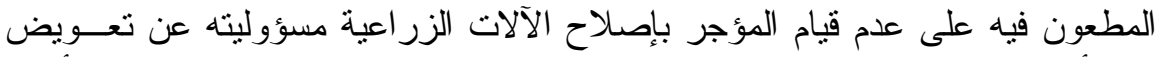

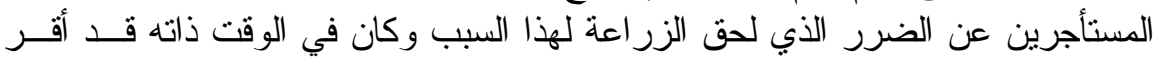

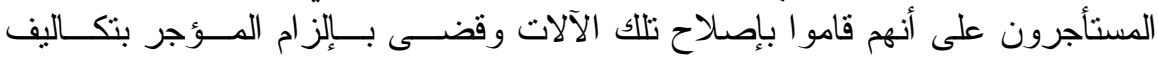


ففي هذه الحالات السابقة يكون الحكم منعدماً، لكن لو أصــاب العــوار

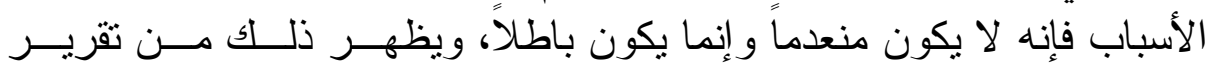

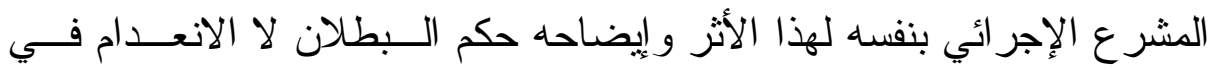

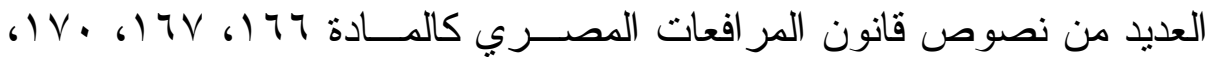

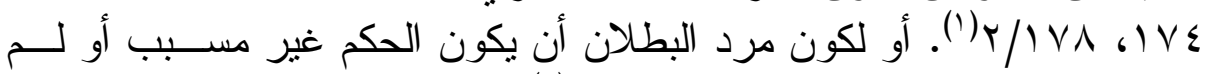

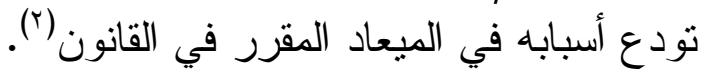

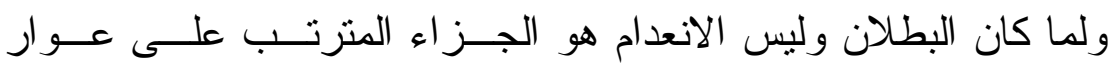

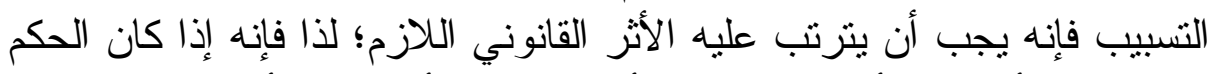

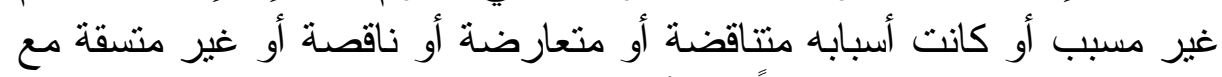

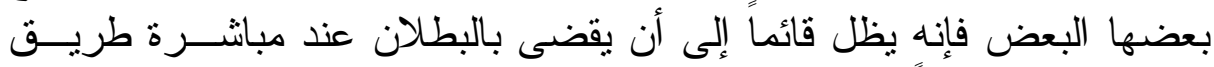

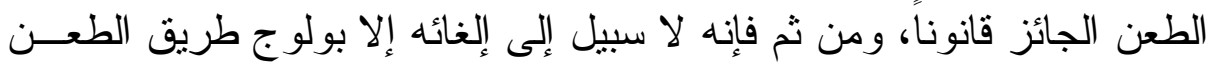

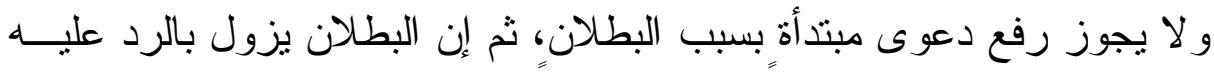

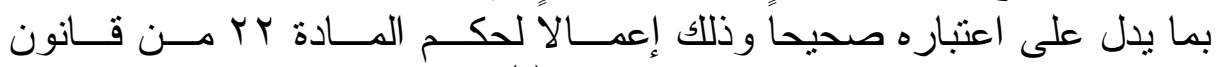

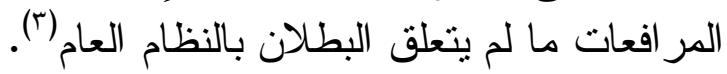

إصلاحها، راجع نقض مدني في r مايو ب79 1، مجمو عة النقض سع ا صــحة بـ ق (') ومما هو جدير بالاعتبار أن انعدام الأسباب يختلف عن انعدام الحكم حيث لا تلازم بين

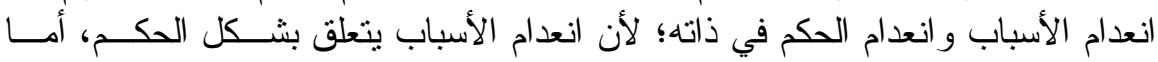

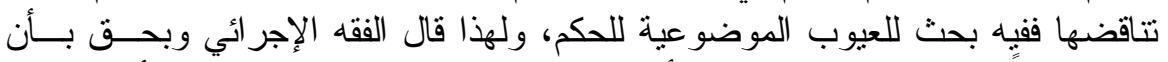

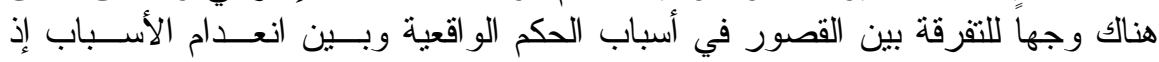

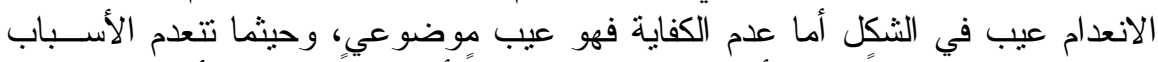

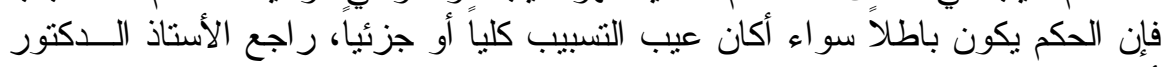

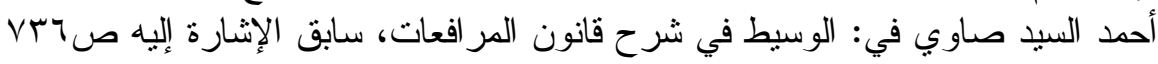

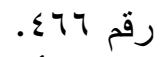
( ) ويمكن أن يرد البطلان في الحكم لأسباب عدة منها إذا كانت الأسباب قاصرة من حيث

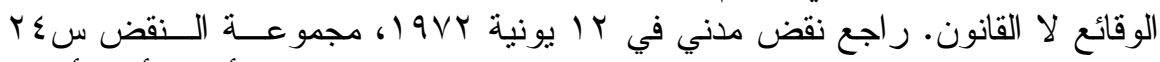

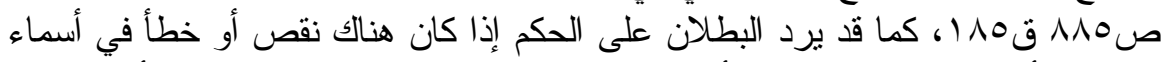

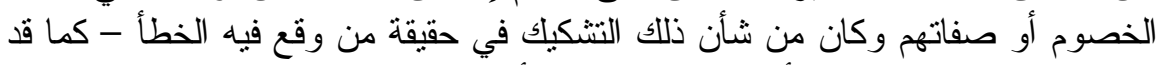

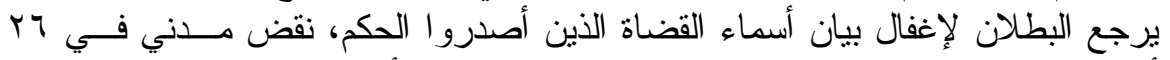

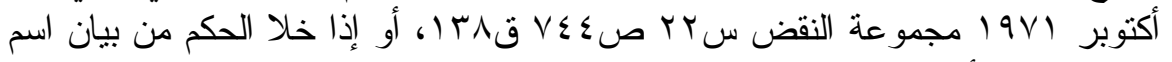

$$
\text { المكمة التي أصدرته. }
$$

Tournon. J.C.P. 1946. I. p. 553.

و وانظر أيضا: .Motulsky; These, Lyon. 1946.3p. 101

ور اجع كنللك: . Mimin. J.C.P. 1964. I. p. 541 ونظا: 


\section{المطلب الأول \\ الغرض من تسبيب الأحكام القضائية}

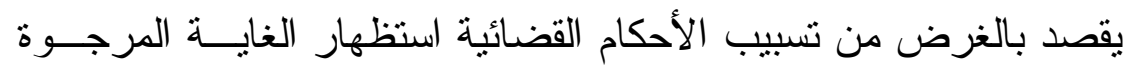

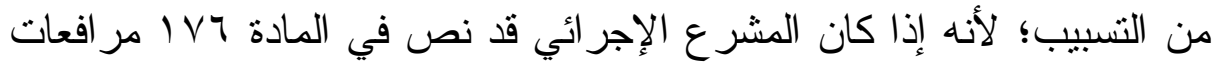

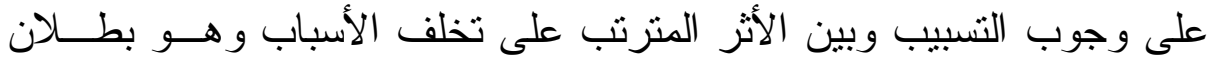

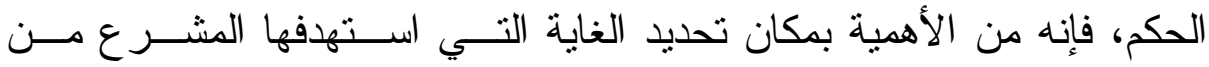

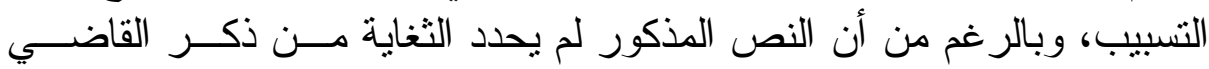

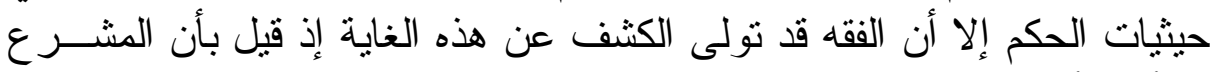

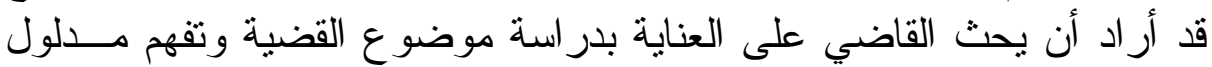

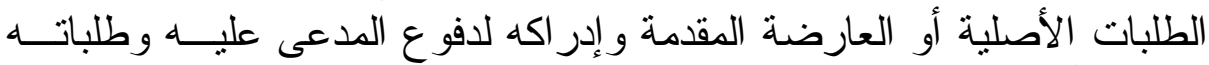

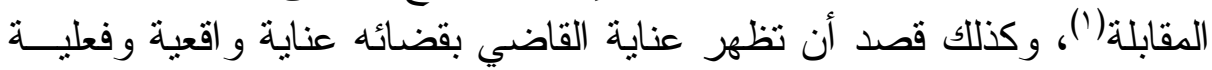

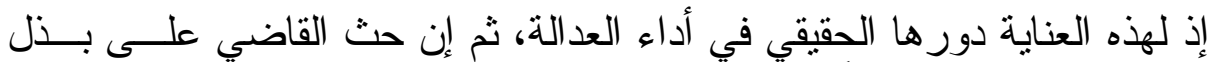

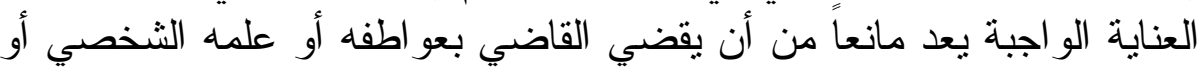

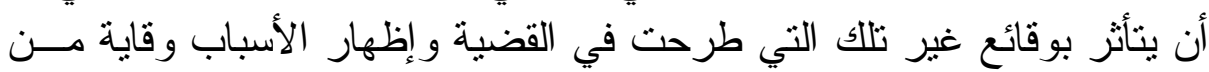

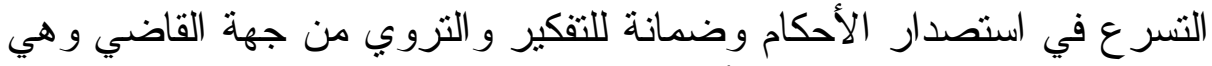

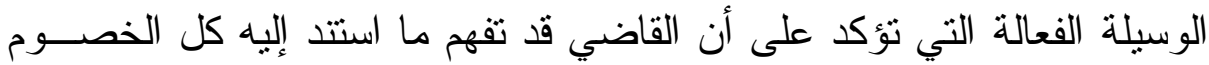

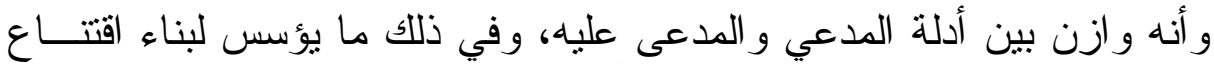

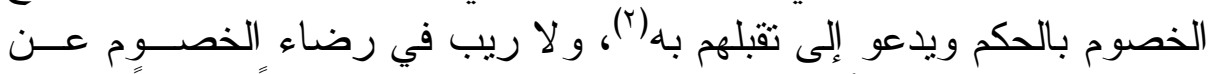

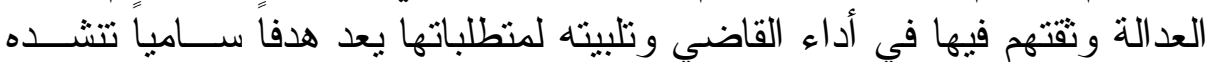

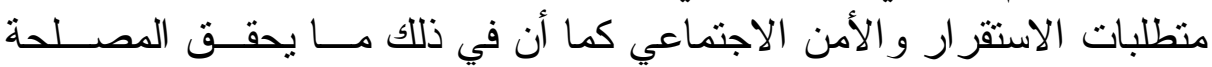
الاجتماعية ويؤكد على حق التقاضي وهو حق الصني الصيل من حقوق الإنسان(r).

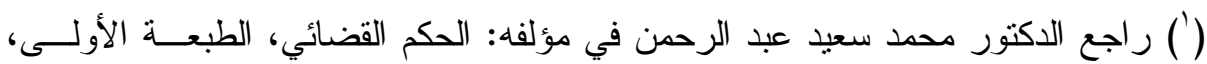

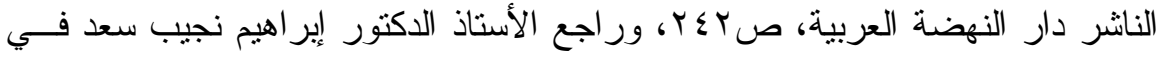

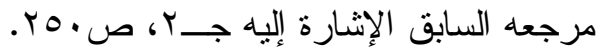

$$
\begin{aligned}
& \text { و انظر كذلك: }
\end{aligned}
$$

Fricero; Redaction des jugements. Jur. Class. Pr. Civ. Fasc. P. 508. No.3.

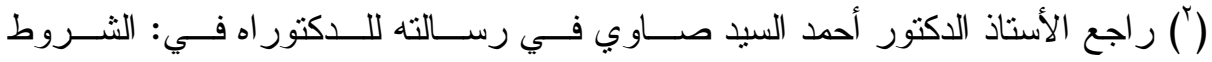

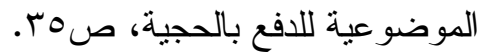

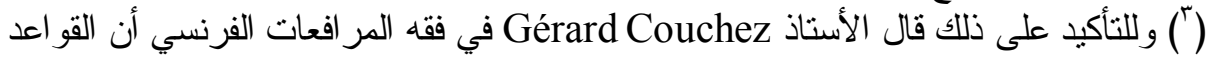

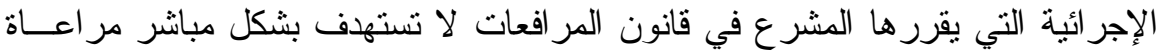

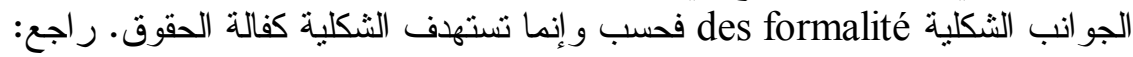
Gérard Couchez; procédure civil. Op. cit. p. 3 No. I. 


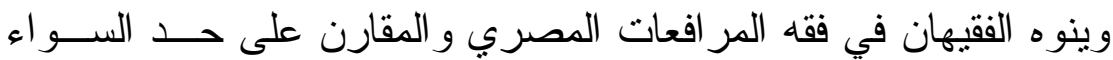

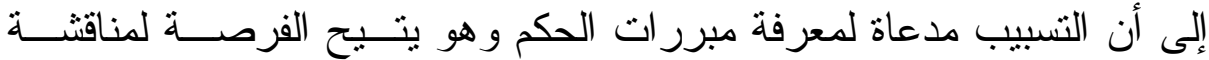

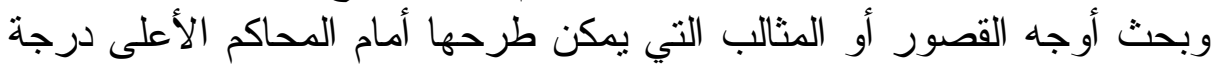

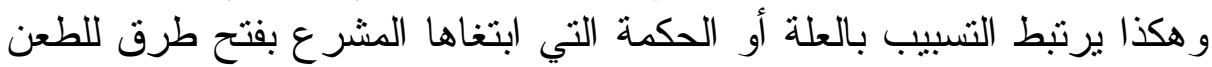

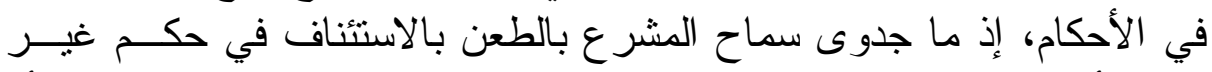

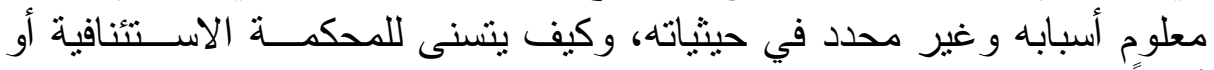

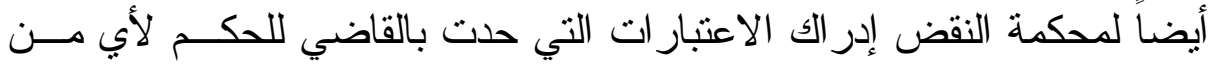

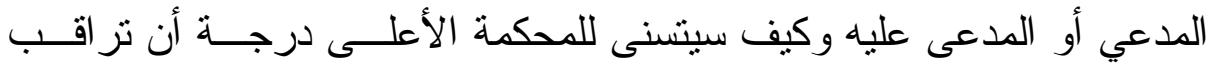

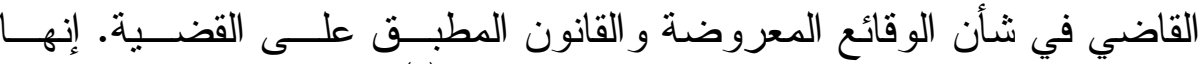

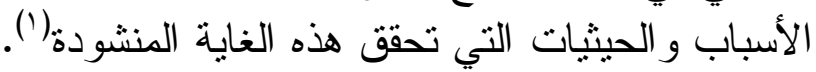

ور اجع أيضا: . Jean Larguier; procédure civil. Op. cit. p. I. No

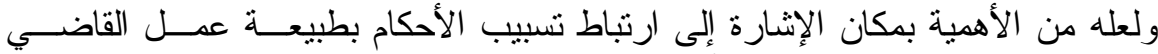

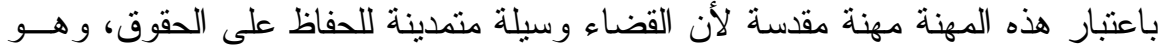

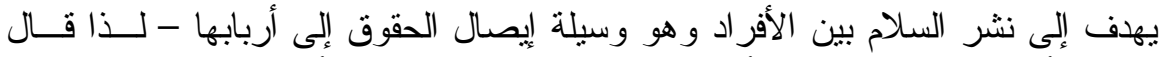

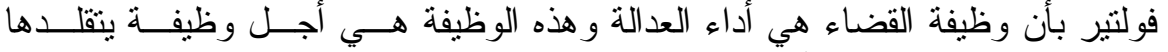

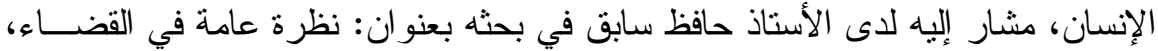

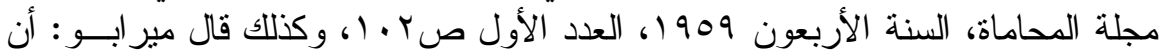

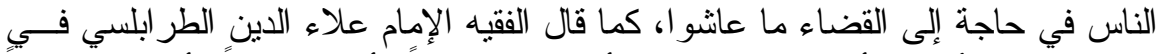

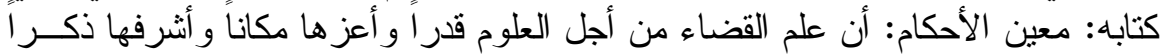

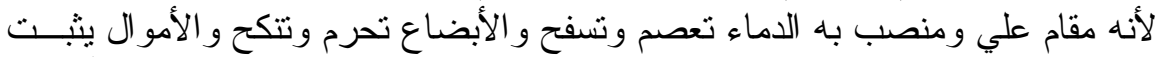

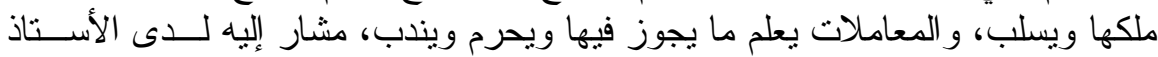

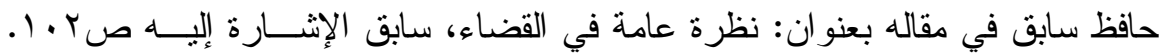

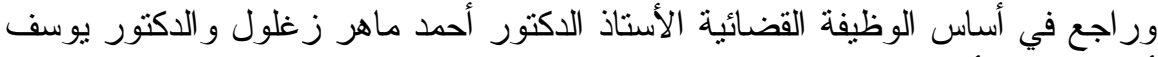

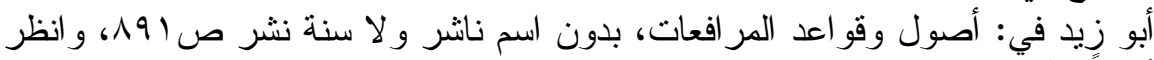

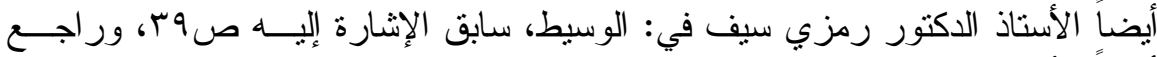

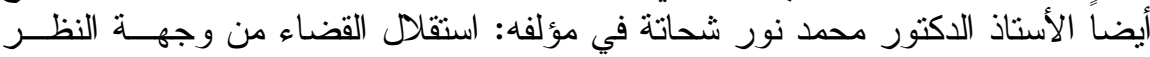

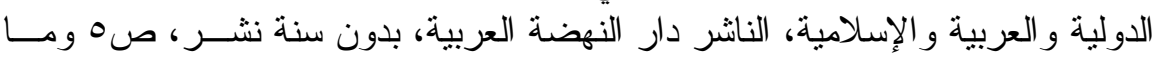

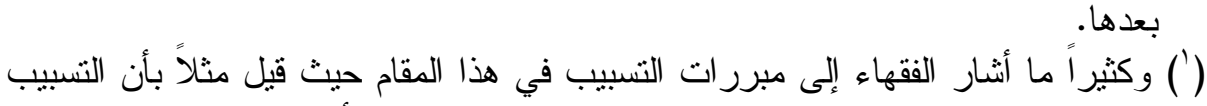

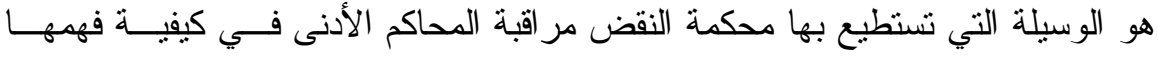

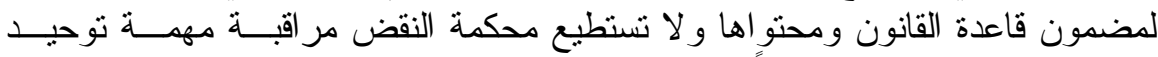

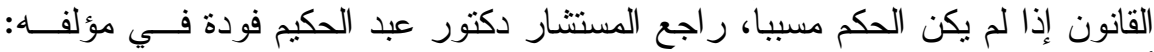

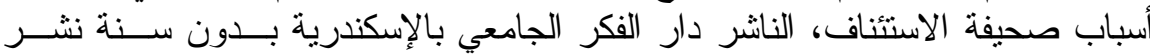

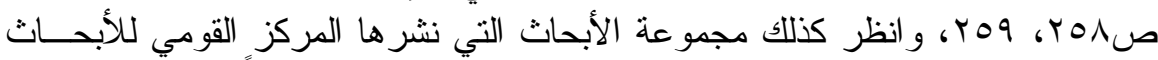

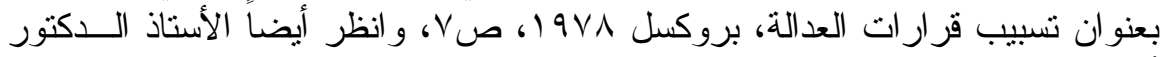

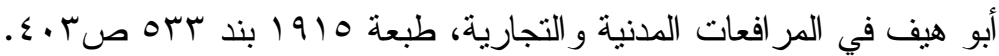


و إضافة لما قيل وطرح كمبررات للتسبيب أكد الفقهاء في الفقه الإجرائي

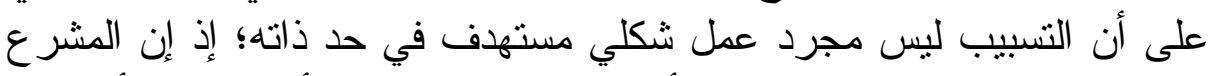

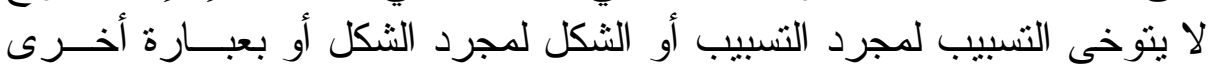

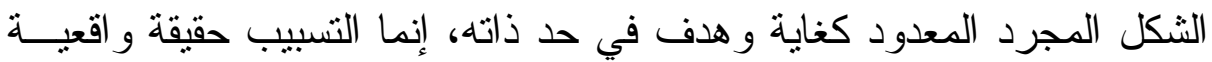

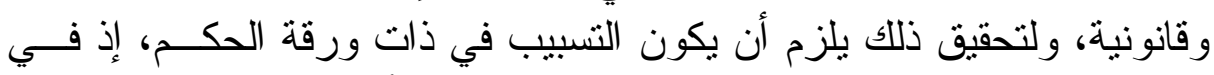

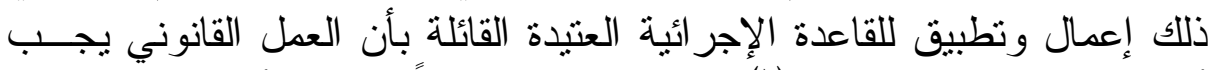

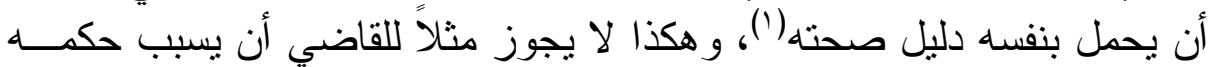

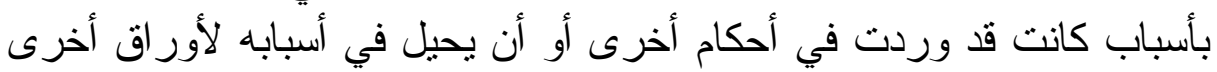

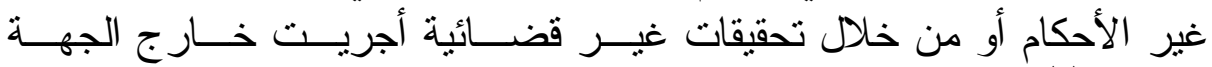

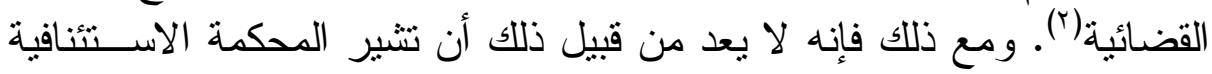

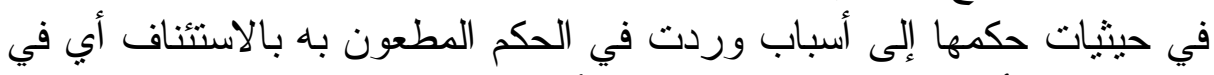

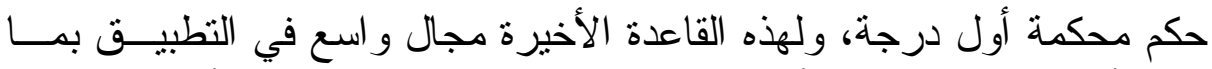

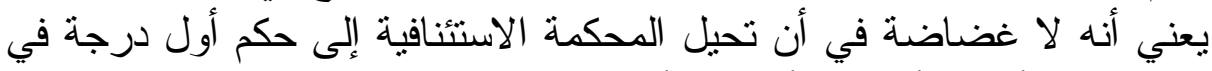

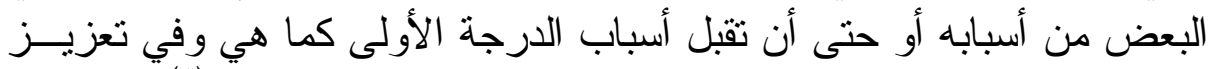

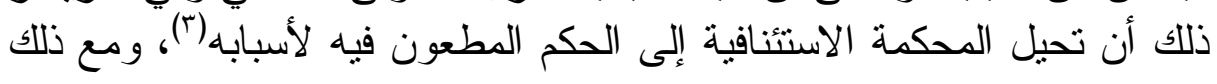

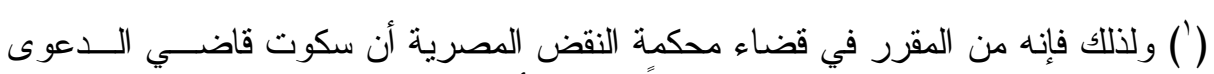

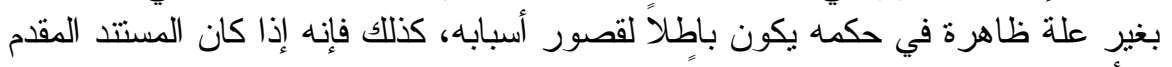

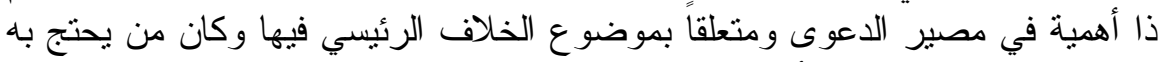

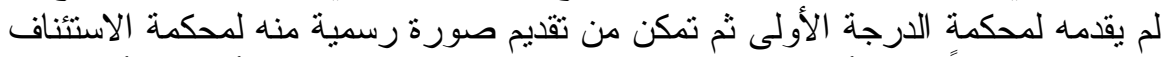

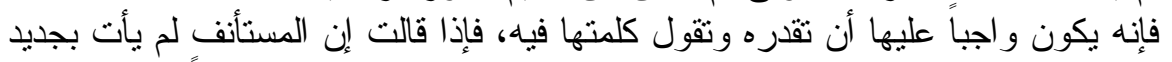

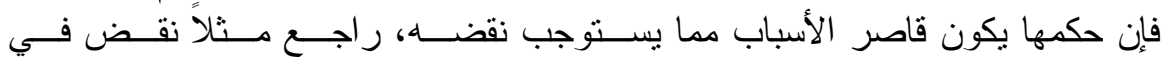

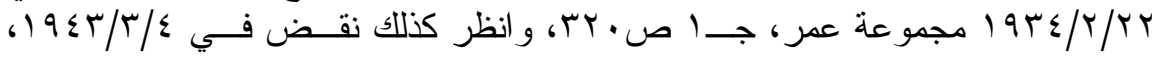

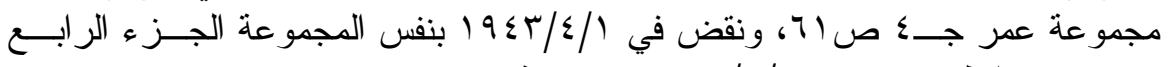

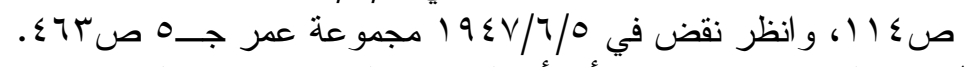

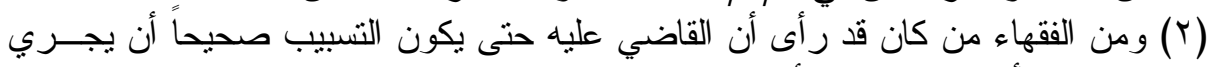

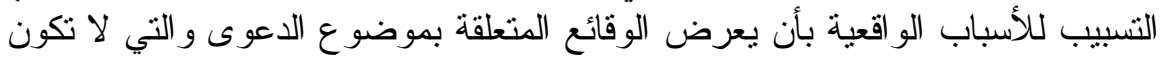

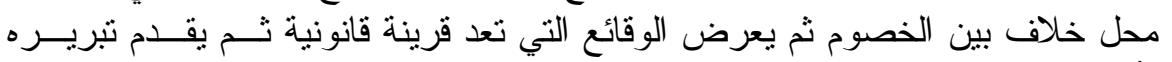

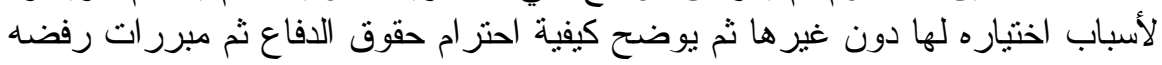

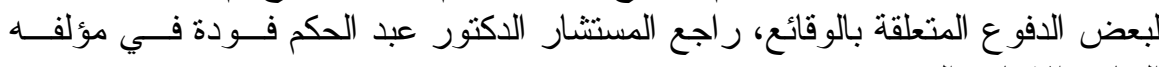

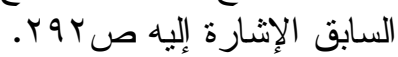

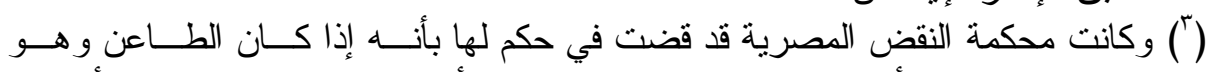

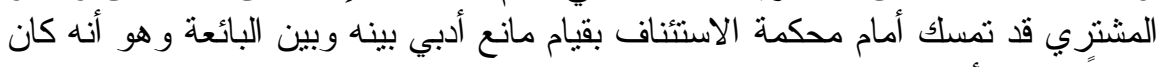

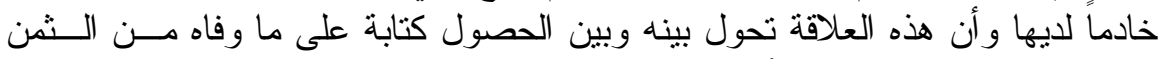

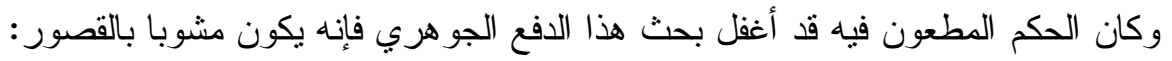

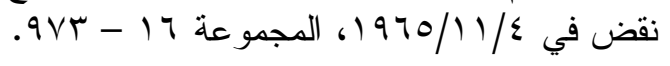




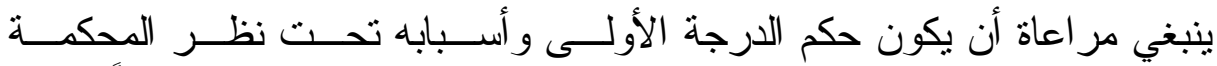

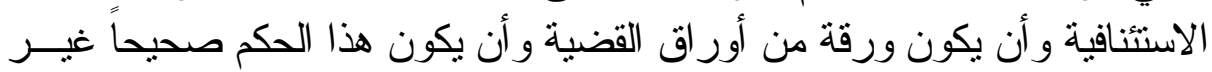

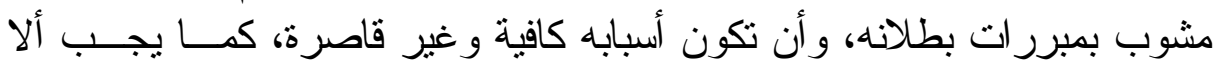

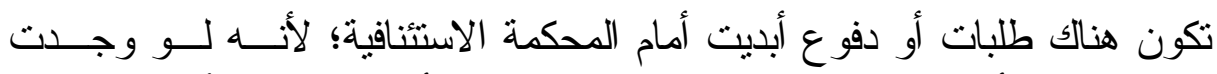

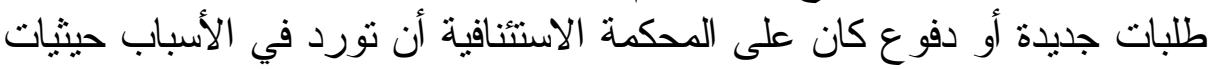
الرد عليها و إن أمكنها الإثارة إلى أسباب محكمة الدرجة الأولى فيما عدا ذلك.

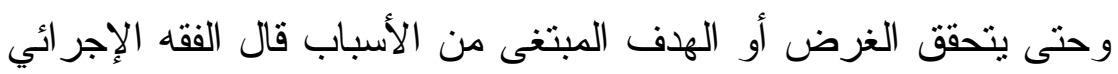

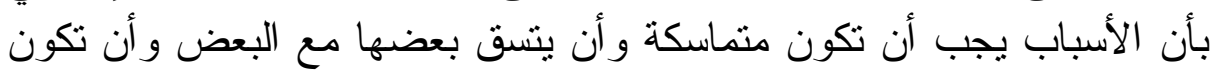
منطقية وألا يعتريها الاضطر اب أو النتاقض أو النقصان؛ لأن ذلان التك مدعاة لعدم

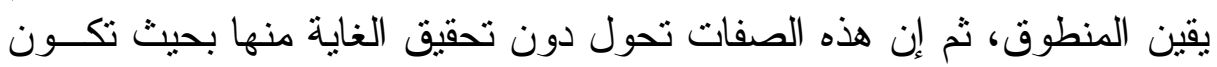

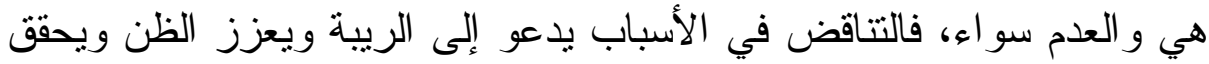

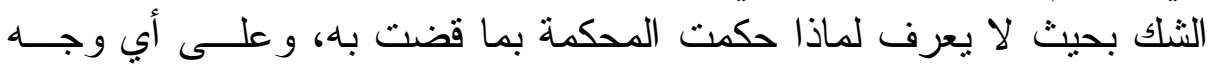

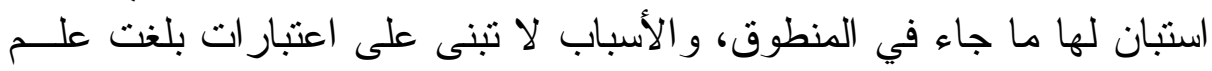

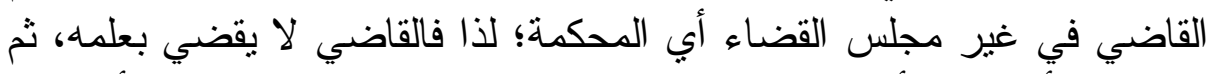

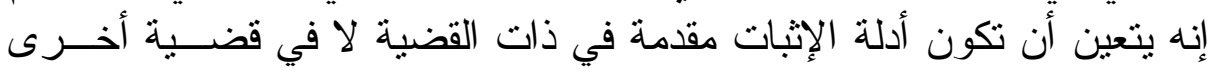

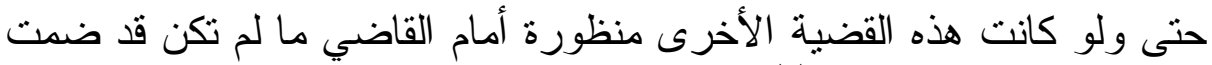

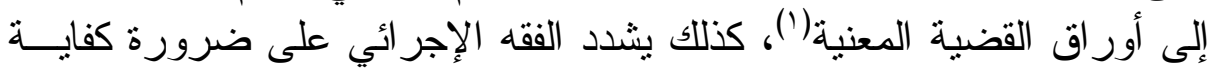

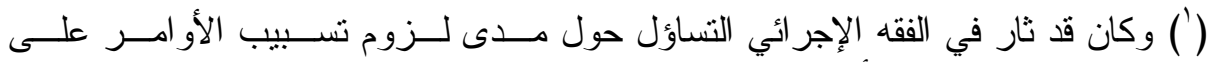

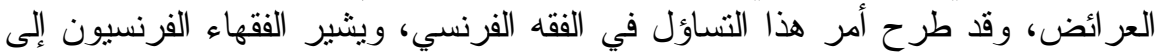

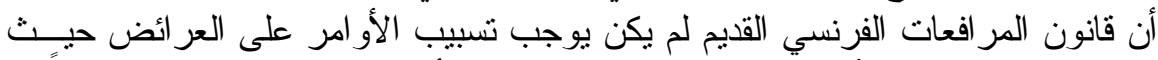

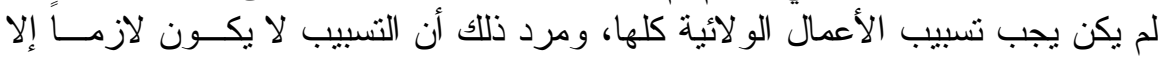

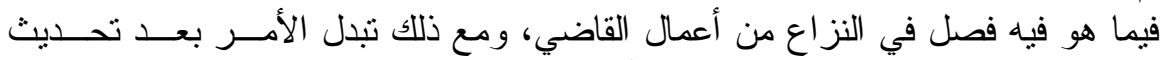

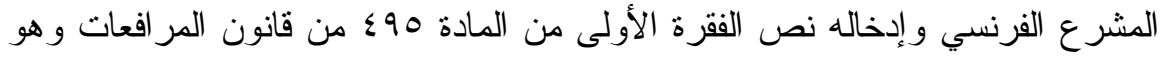

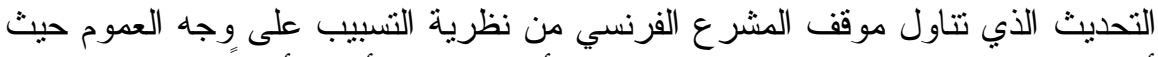

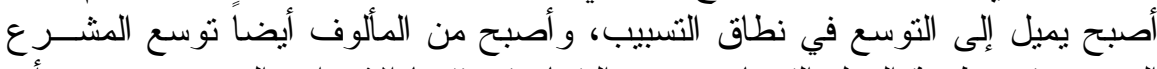

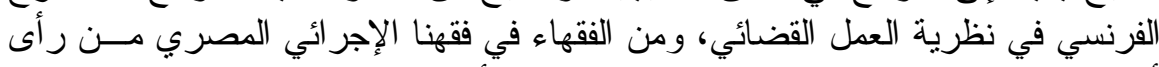

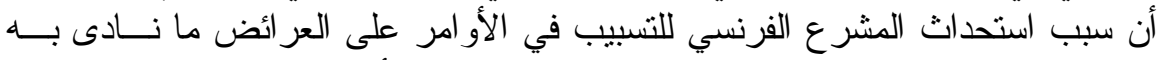

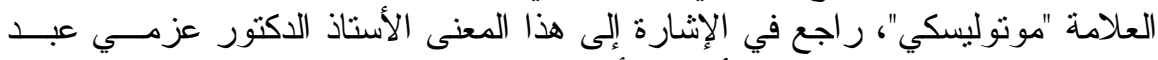

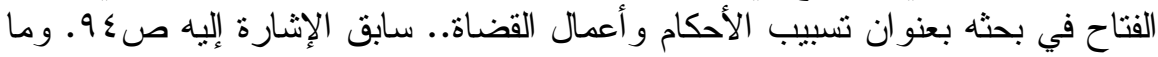

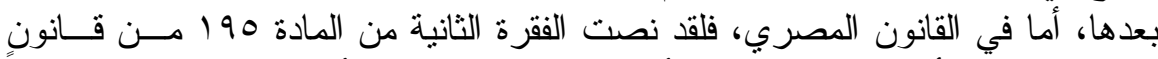

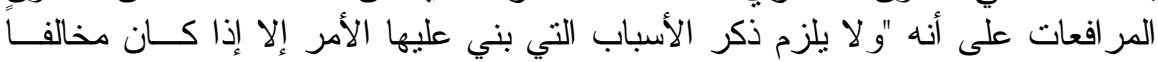

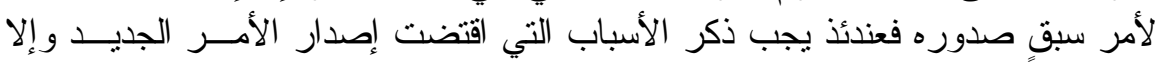

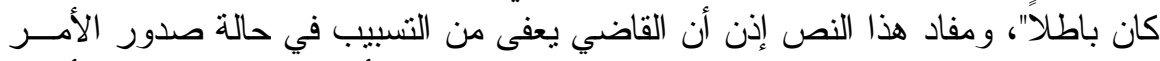

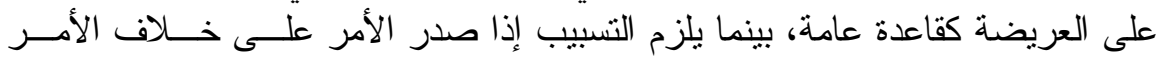


الأسباب؛ لأنها لو كانت قاصرة ما تحقق الغاية منها، ويتوقف اكتمال الأسباب

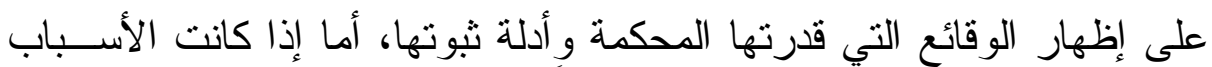

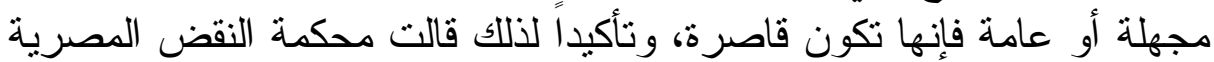

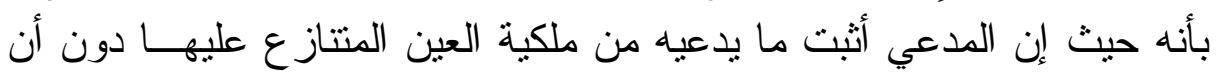

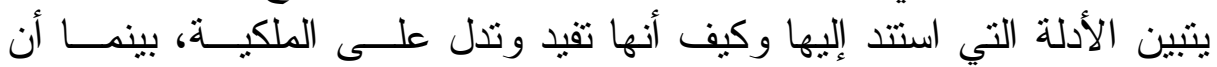

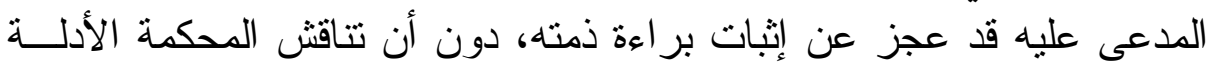

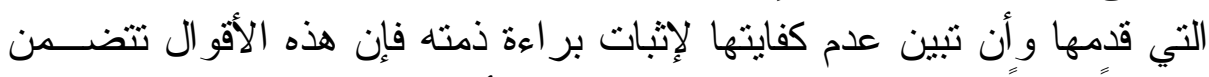

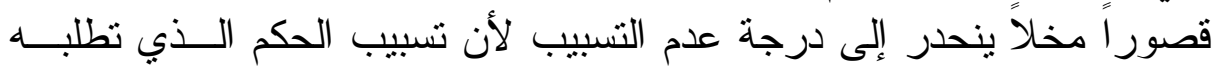

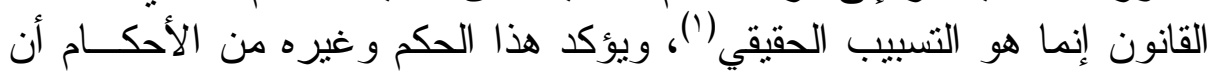

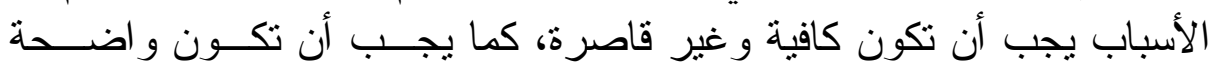

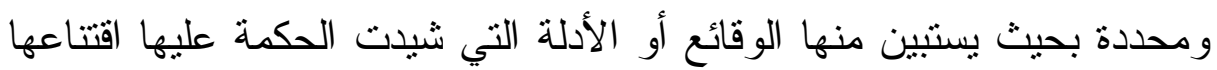

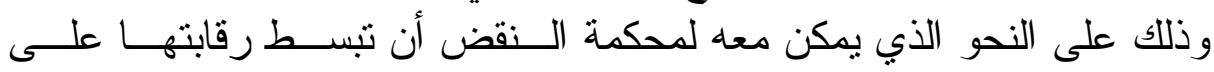

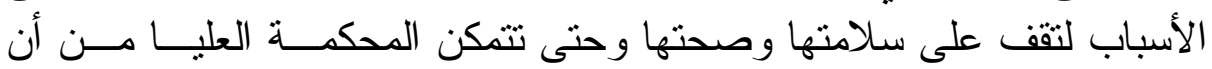

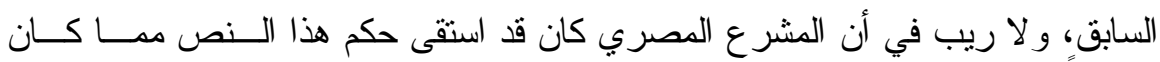

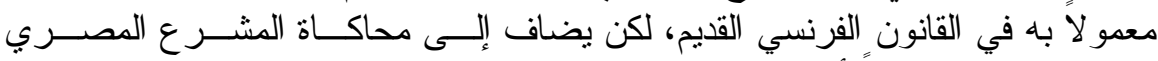

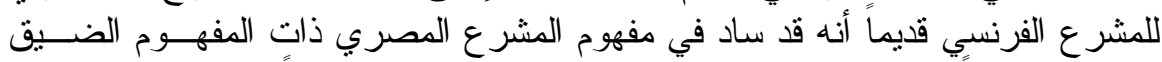

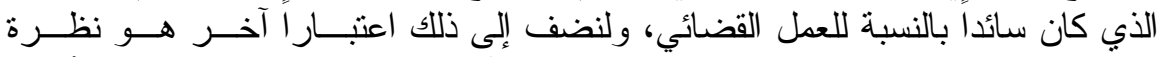

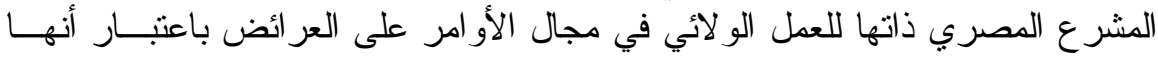

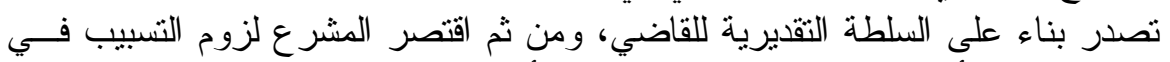

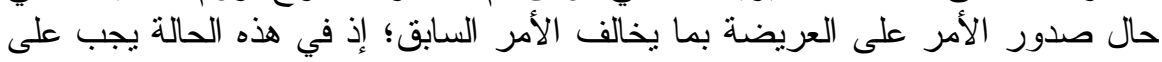

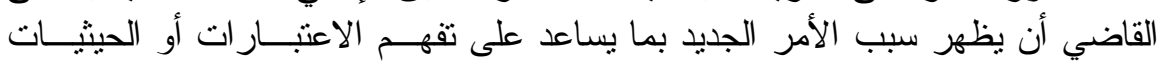

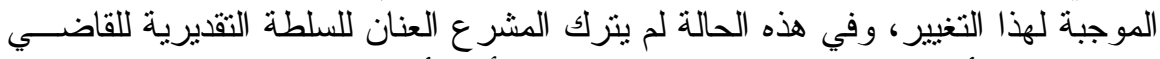

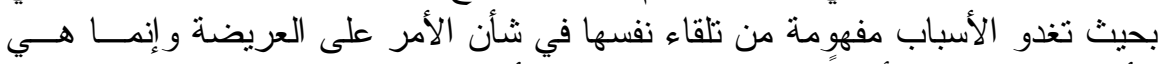

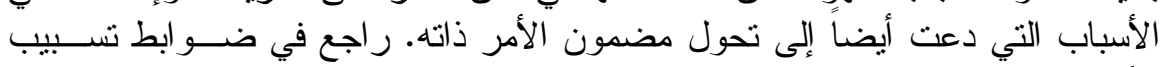

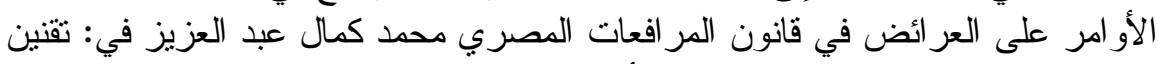

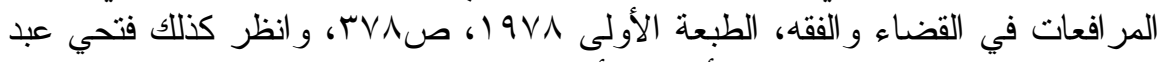

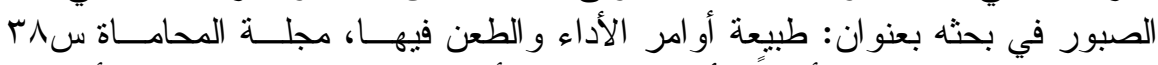

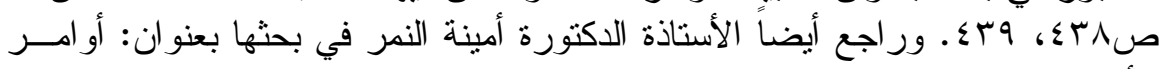

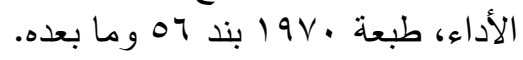

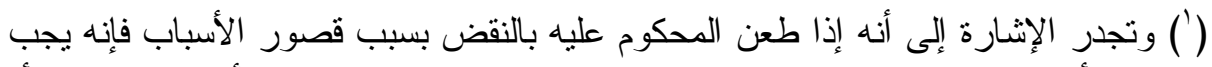

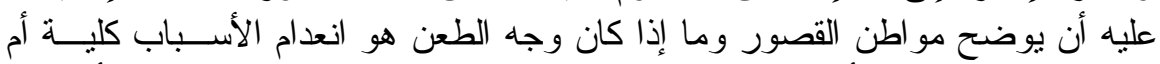

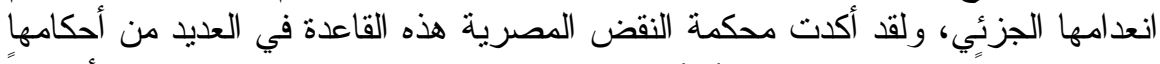

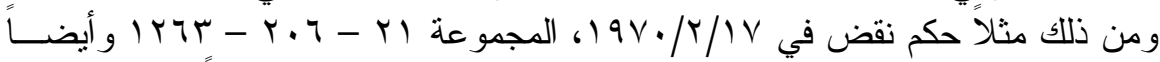

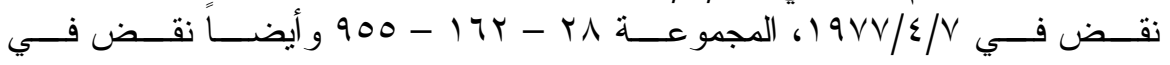

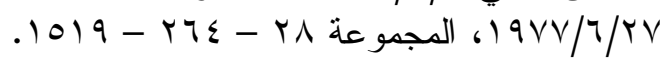


تز اقب كذلك صحة التكييف للوقائع وحكمٍٍ هذه الوقائع في نظر القانون وقيمتها

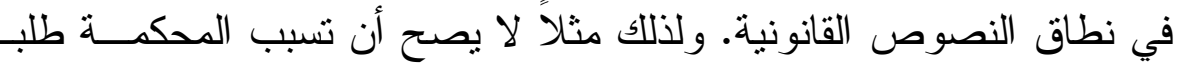

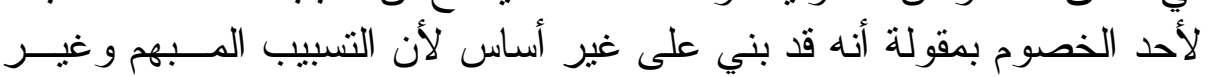

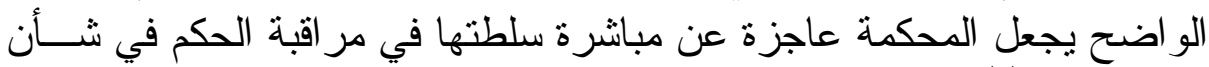
وقائع النز اع (').

ولكي يحقق التسبيب الغرض منه فإنه ينبغي ألا يكون جزئياً، ومقصــود

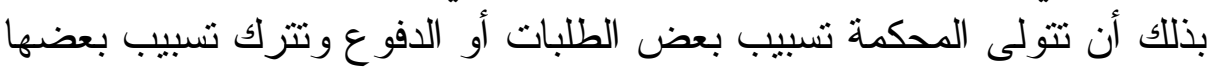

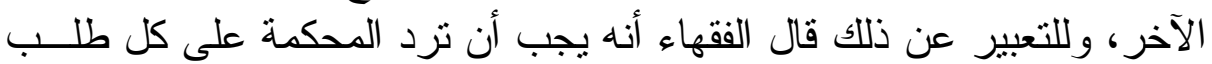

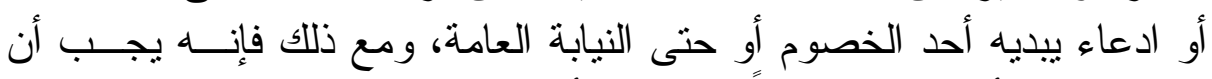

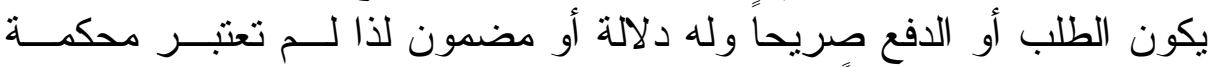

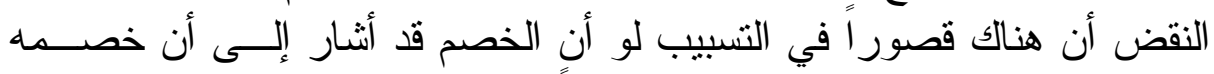

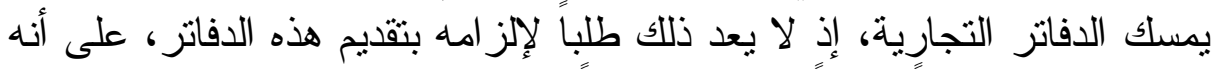

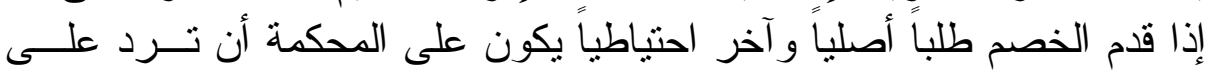
الطلب الأصلي وأن تبين مبرر ات أو حيثيات استبعاده(؟).

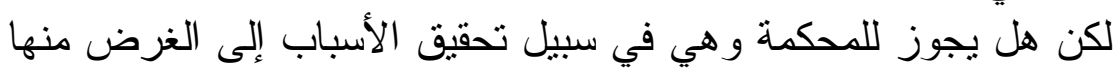

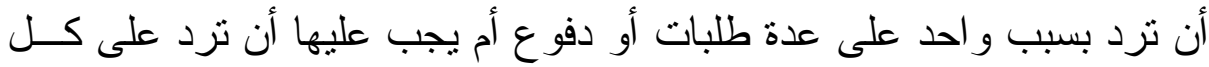

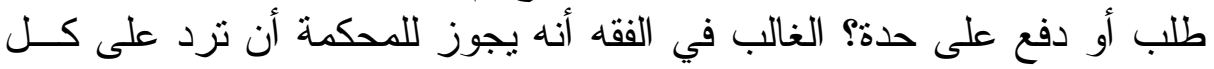

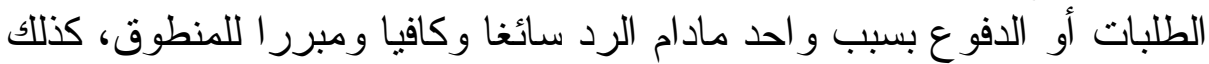

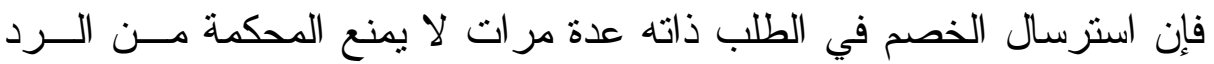

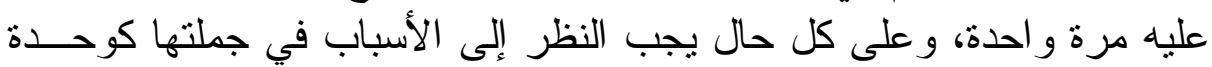

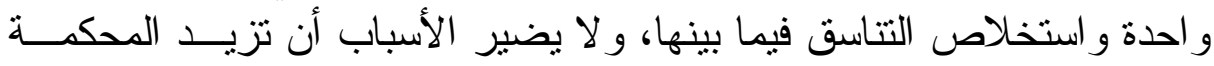

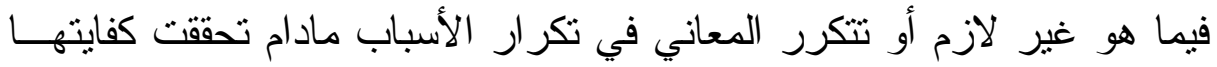

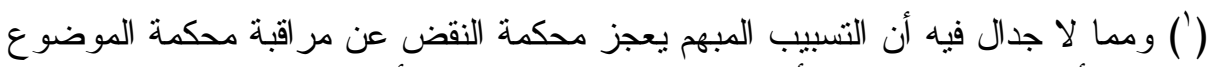

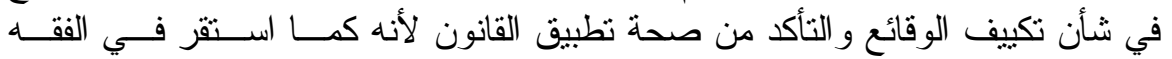

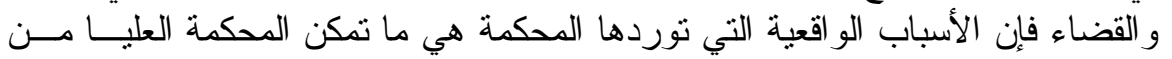

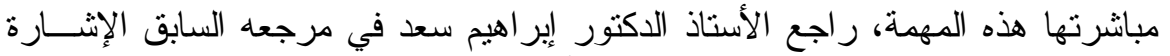

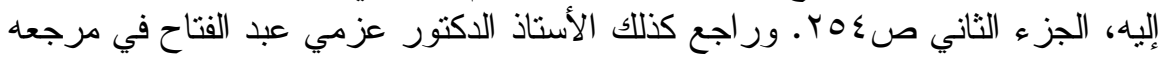

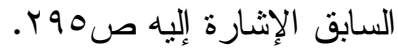

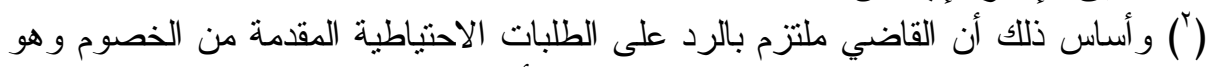

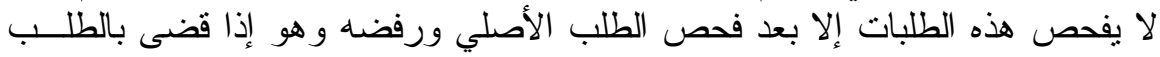

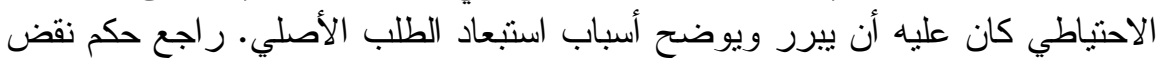

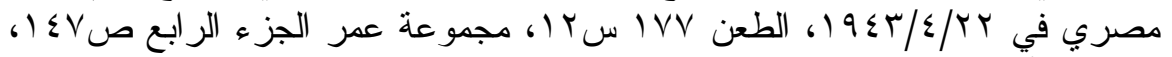

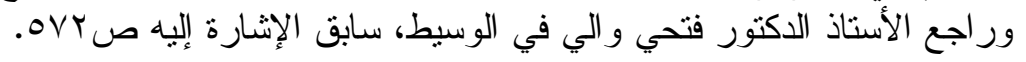




$$
\text { ولم يكن بينها تضارب أو تعارض(') }
$$

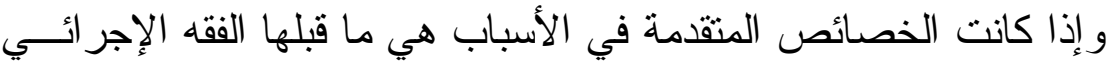
المصري و أسهبت أحكام محكمة النقض في الإشارة إلبها فإن الأمر كذلك في في الإنه الفقه الإجر ائي الفرنسي أيضاً. لذا قال الأستاذان Gérard Cornu et Jean Foyer في الفقه الفرنسي الفي الفي الفي

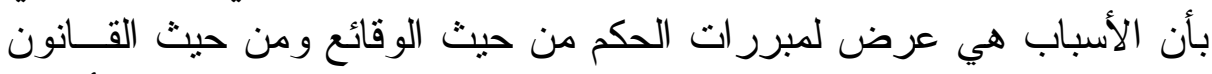

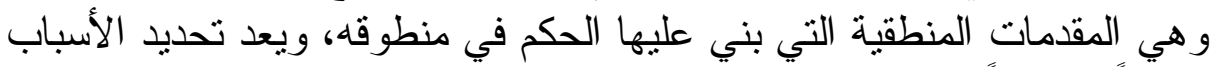

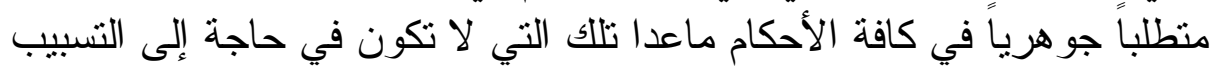
les motifs sont l'exposé des raisons de fait et de droit qui ont détermine la décision. L' indication des Motif est une règle générale applicable en toutes matières. ${ }^{(2)}$

ويضيف الفقيهان إلى ذلك قولهما بأن لكل خصم في القضية الحق فـي أن يلم الأسباب التي أدت إلى أن تصدر المحكمة حكمها، كما وأن التسبيب هو

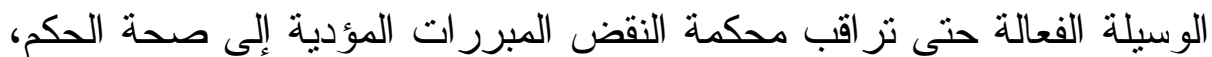

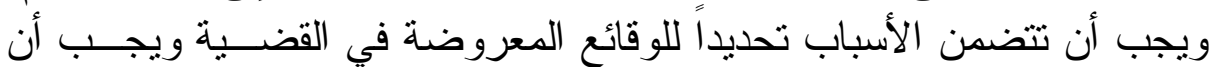

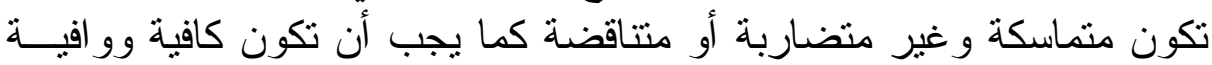
ومحققة إلى ما انتهت ونمات إليه المحكمة:

Ce n'est pas assez que d'exiger des motifs explicites, non dubitatifs, et non contradictoires, il faut encore que les motifs soient suffisants et pertinents, qu' ils donnent une base légale à la décision. C'est - à - dire qu' ils permettent de vérifier l'exactitude de l'enchaînement logique par lequel le juge a déduit de la règle applicable à la cause, la solution qu' il a donnée a' l' espèce. ${ }^{(3)}$

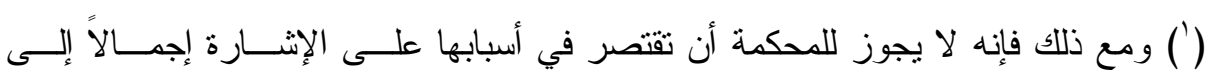

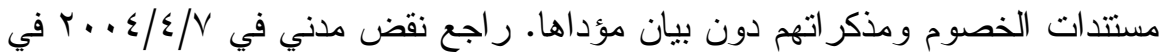

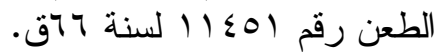

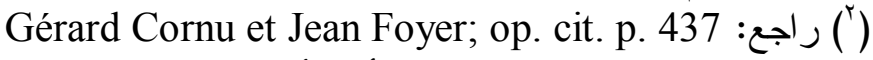

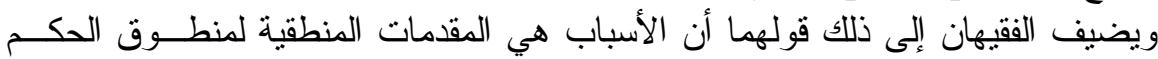

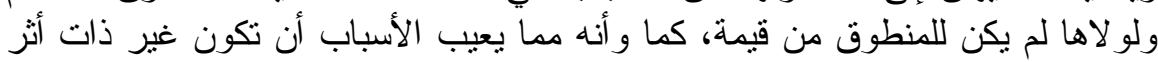

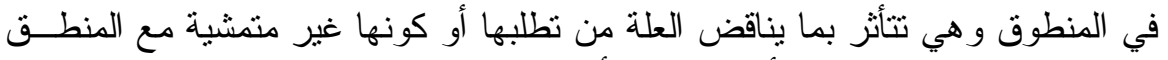

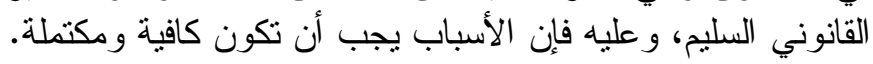

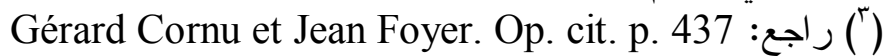




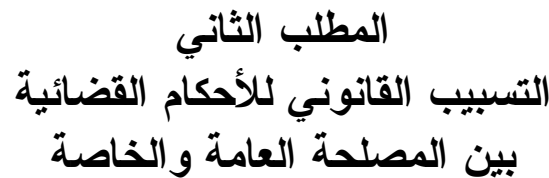

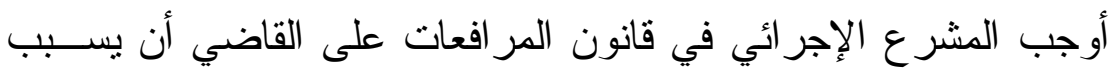

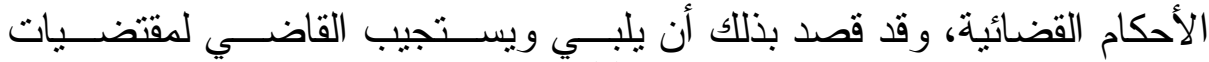

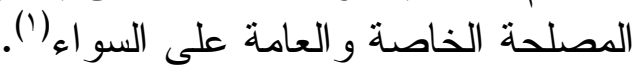

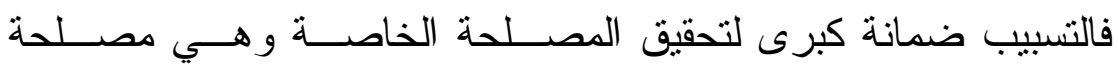

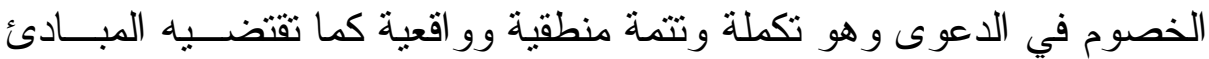

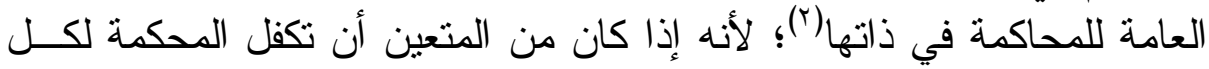

ورانظر أيضا: . Durand; Droit Social. 1954. page 280 ور اجع كذلك: . Mimin; J.C.P 1946. I. 541 ورنا: وراجع أيضا: 73 وران: 775 ورجا

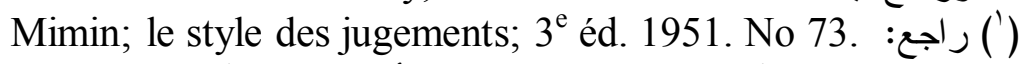

و ولإظهار هذه الأوجه من الدواعي النفعية للأسباب قال الأستاذان Gérard Cornu et

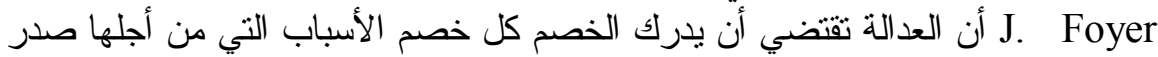

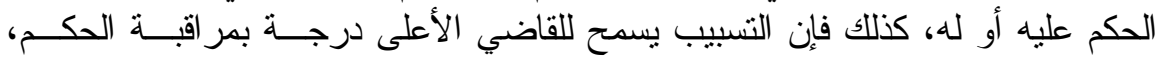
ويضيف الفقبهان إلى ذلك قوله لهما:

Le justiciable a le droit de savoir pourquoi il est condamné ou débouté, le juge des voies de recours doit être en mesure de vérifier l'exactitude du raisonnement qui lui est déféré.

Tournon; le défaut des motifs, vice de forme des jugements. J.C.P. 1946. I. 553.

ور اجع كنلك: . Voulet; le defaut de reponse à conclusions; J.C.P. 1965 I. 1912. Req. 17 mars 1868. D.P. 1868. I. 293.

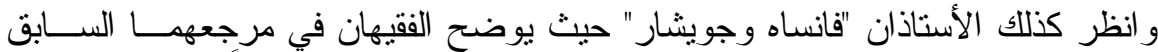

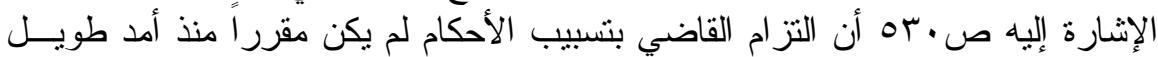

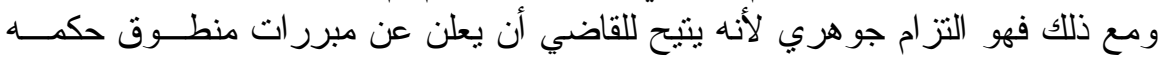

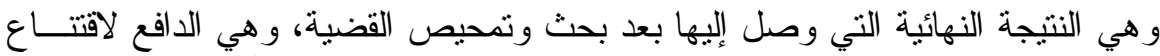

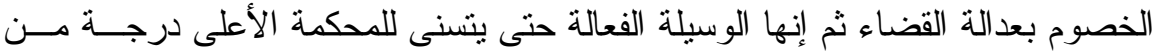

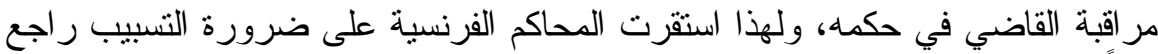

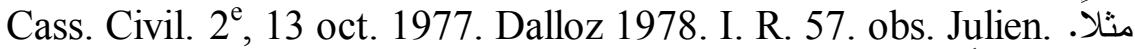
وراجع أيضاً حكم نقض فرنسي:

Cass. civ. $1^{\text {er }}, 22$ et 23 nov. 1977 J.C.P. 1978 IV. 29. civ. $3^{\text {e }}, 20$ mars 1978. J.C.P. 1978. IV. 167.

$$
\text { ور اجع في ضرورة تسبيب الأحكام الصادرة من المحاكم الإدارية القانون: }
$$




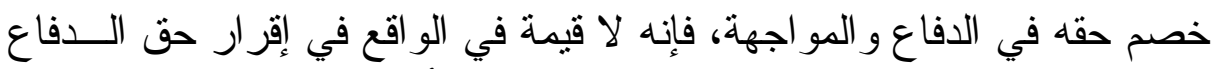

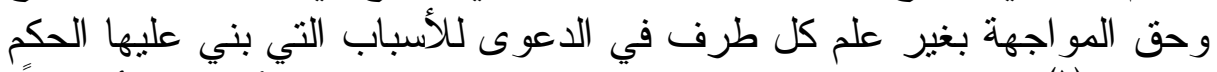
القضائي (')، و المنطوق وحده غير كاف للعلم بالحكم، و إنما الأســبـاب أيضــاً،

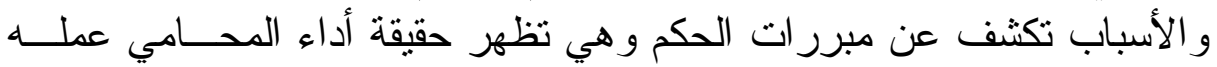

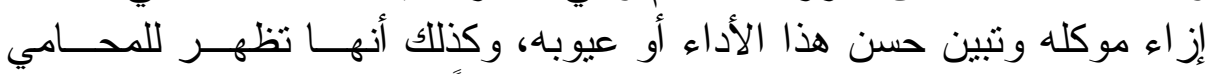

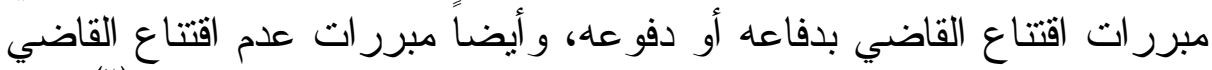

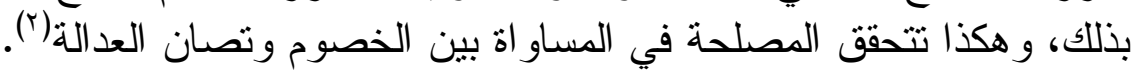

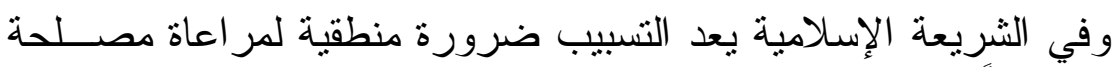

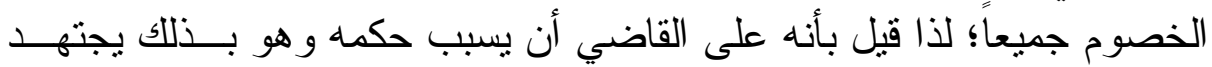

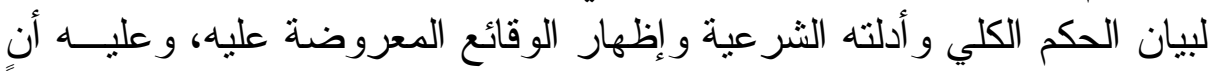

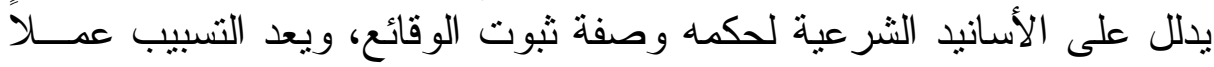

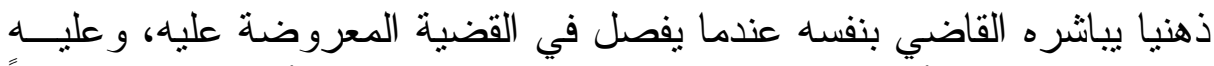
عند تسبيب الحكم أن ير اعي التوازن بين الأسباب بما يعني أنه لا يهمل جانبــاً

Loi no $79-587$ du 11 Juillet 1979.

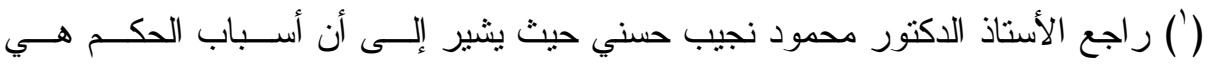

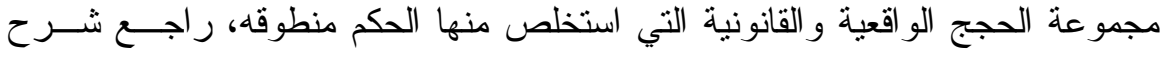

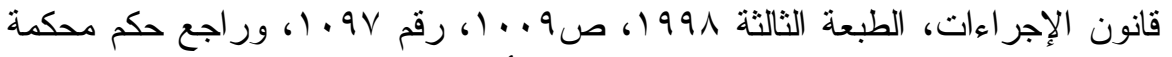

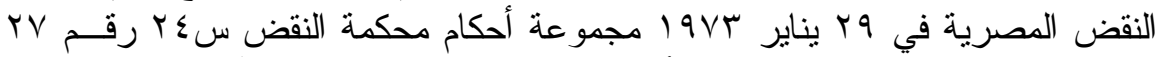

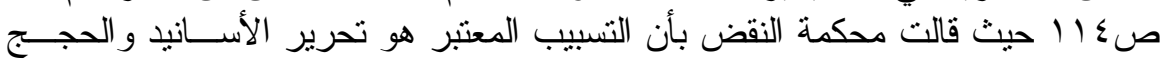

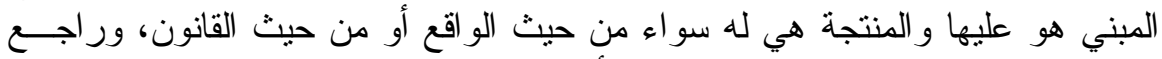

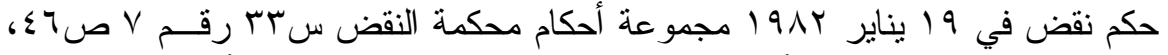

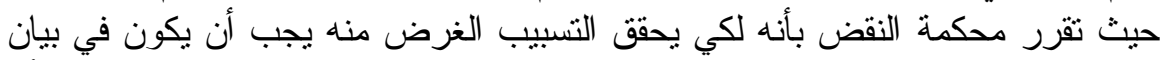

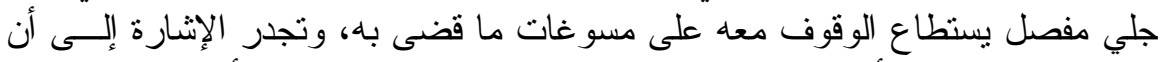

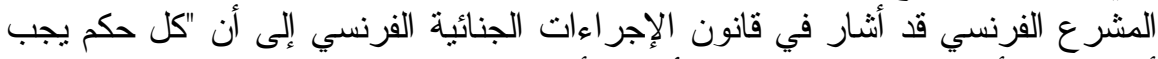

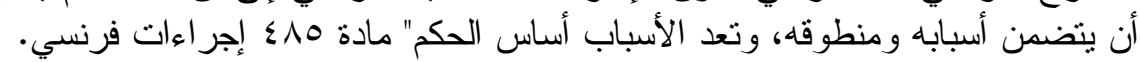

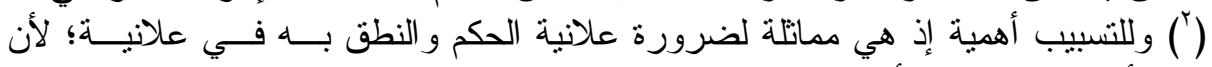

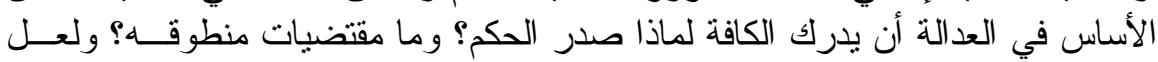

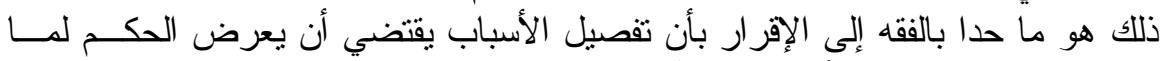

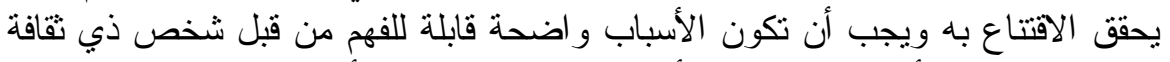

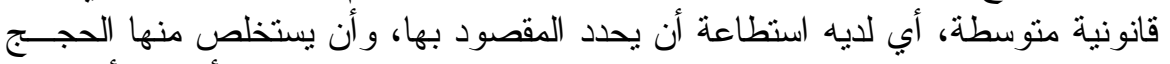

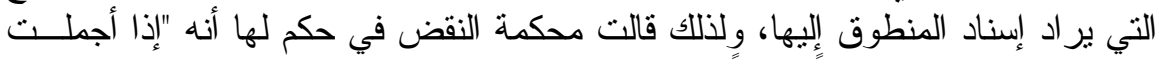

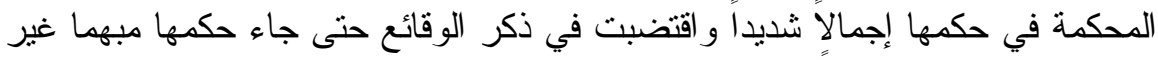

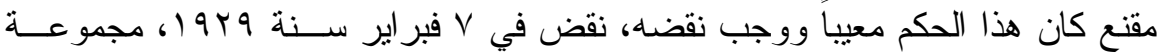

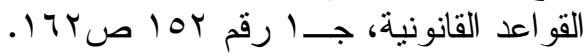


منها أو يسهب فيما هو غير لازم لأن في ذلك مصلحة للخصــوم(")، ويشــدد

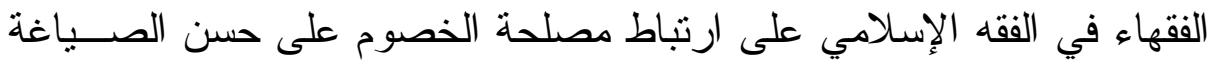
في الأسباب، ومفاد ذلك الإيجاز في الألفاظ و الكلمات وعدم الإنهات الإطالة أو التكرار

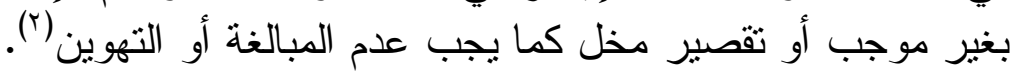

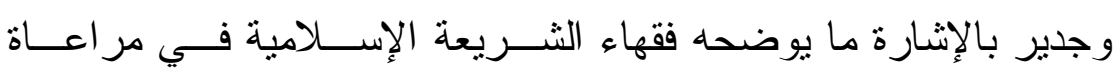

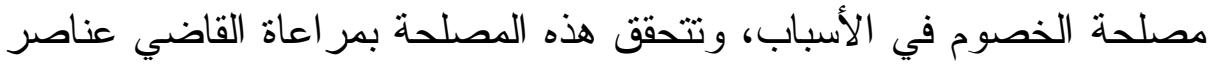

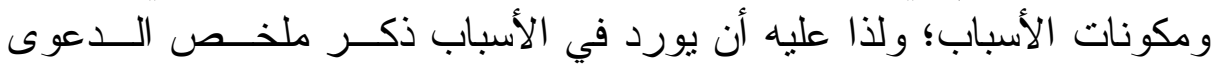

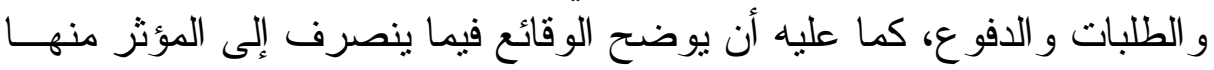

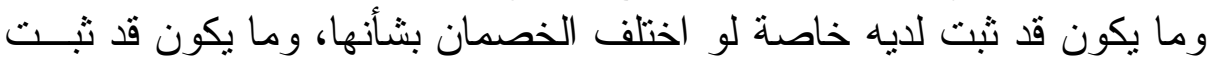

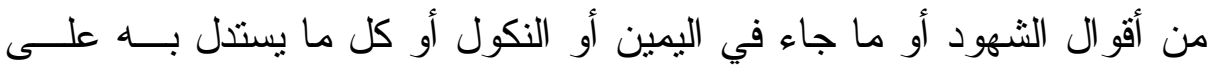

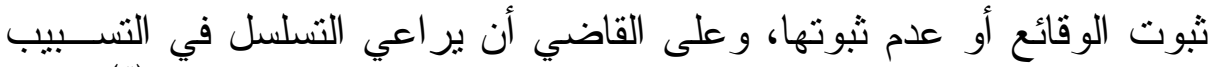

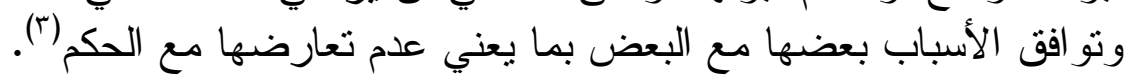

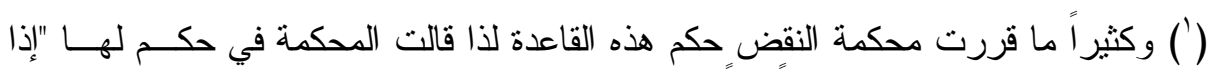

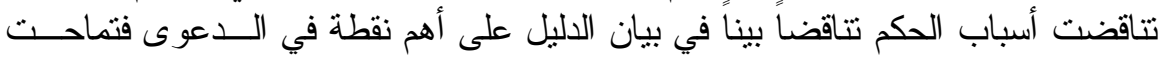

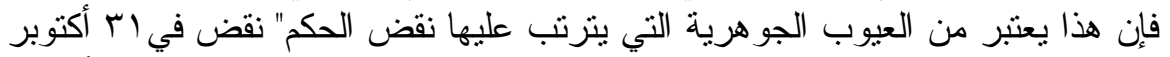

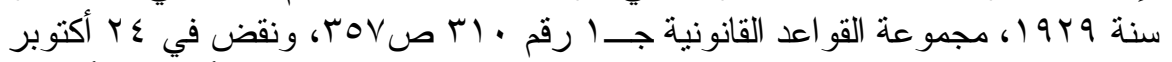

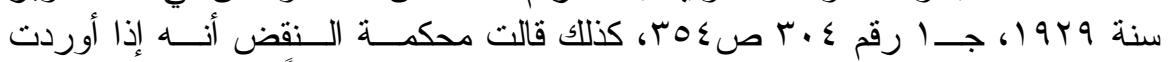

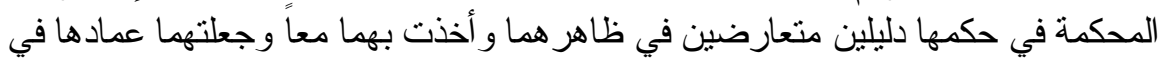

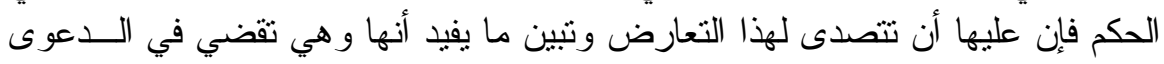

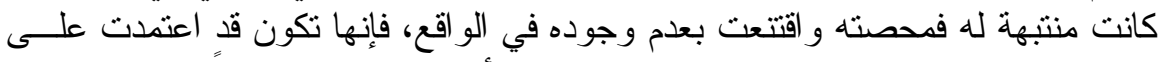

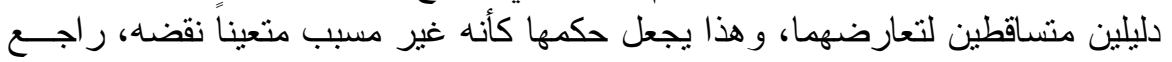

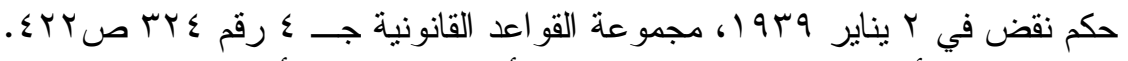

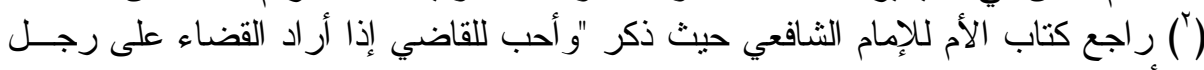

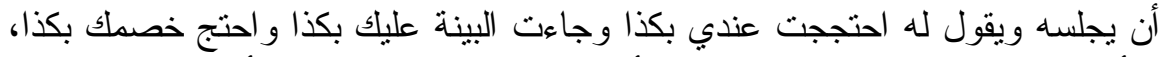

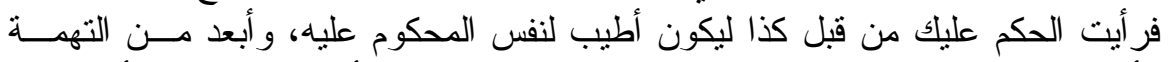

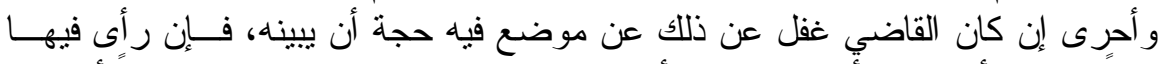

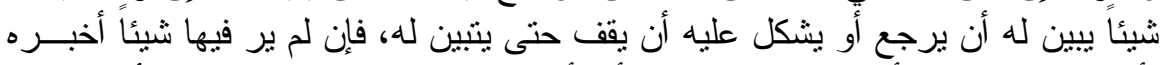

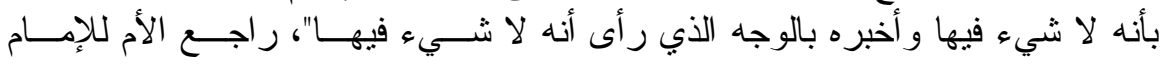

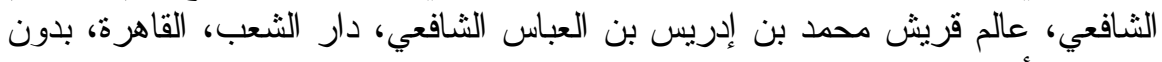

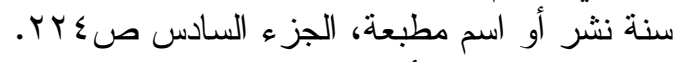

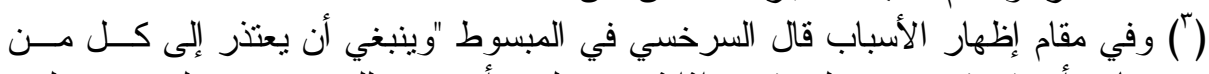

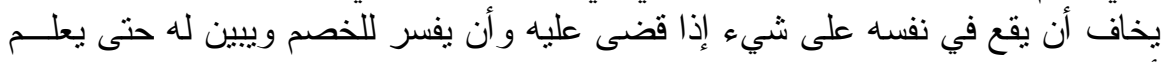

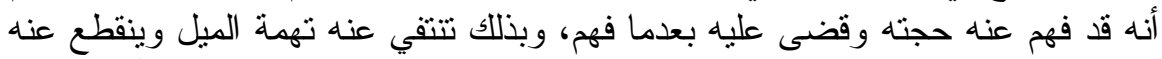

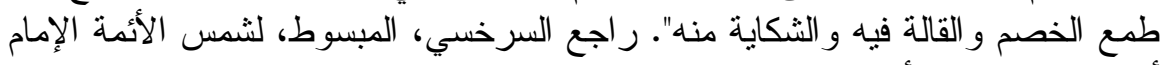

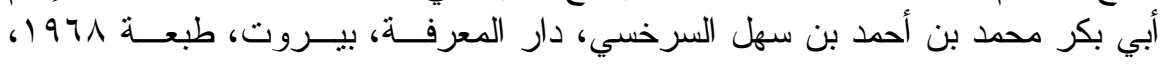


ويستدل فقهاء الثريعة الإسـلامية بوجوب تشــبيب الأحكــام القضـــائية

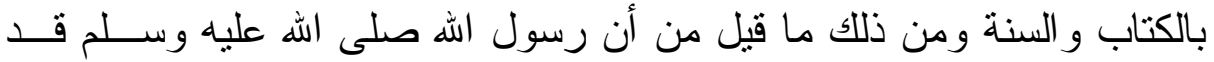

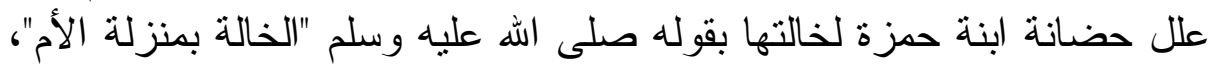
وقال ابن حجر أن في التسبيب فو ائد لأنه يعد دليل الحكم للخصم، ولقد اقتضنه

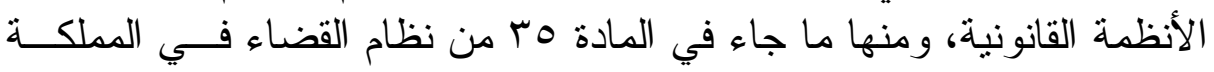
العربية السعودية حيث نصس على أنه يجب أن تشتمل الأحكام على الأســباب التي بنيت عليها و على بيان مستتد الحكم، وكذلك نصت المادة باته 17 من نظــام

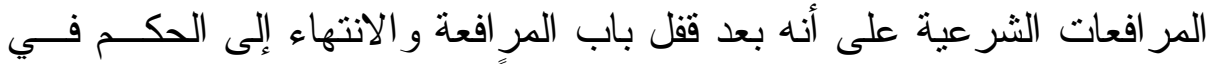

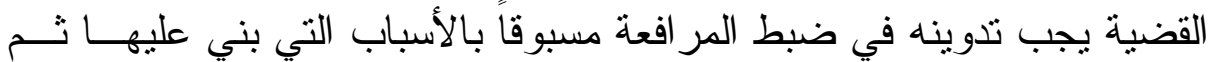
يوقع عليه القاضي أو القضاة الذين اشتركو ا في نظر القضية(')، ونصت الثي المادة با ا من ذات النظام على أنه ينطق بالحكم في جلسة علنية بتلاوة منطوقه أو بتاوة منطوقه مع أسبابه، كذللك ورد في المادة ع من من نظام القضاء بالمملكــة

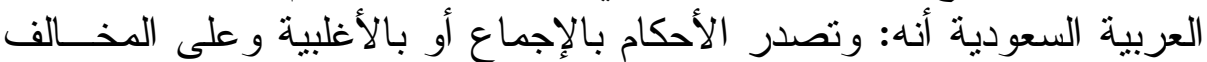

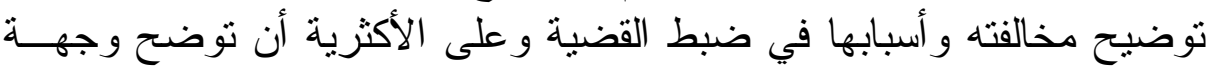
نظر ها بالرد على مخالفة المخالف في سجل الضبط، كذلك أثنارت المــادة بـان

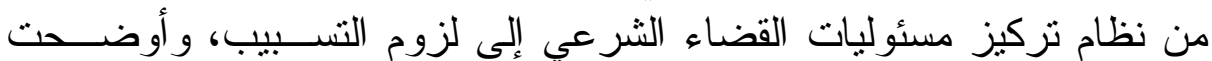

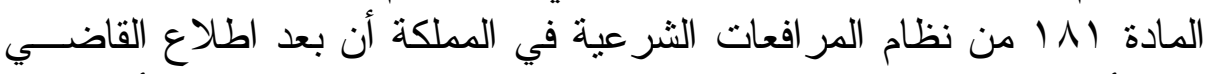

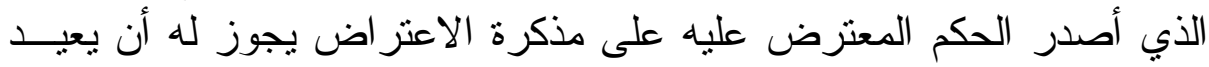

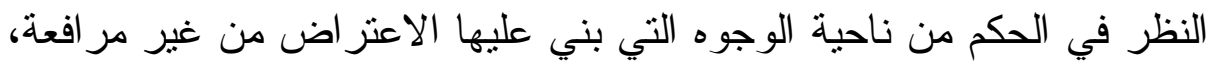

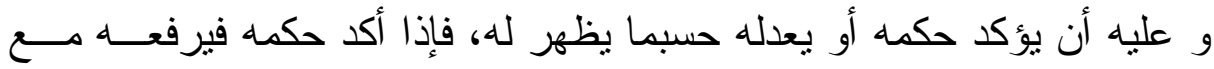

ص^^ • (، وفي ذات المعنى راجع ابن عابدين في حاثيته المحتار على الــدر المختــار

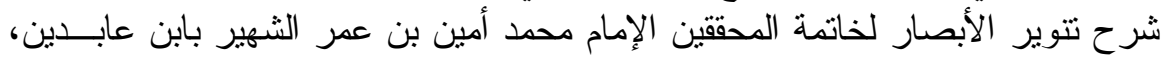

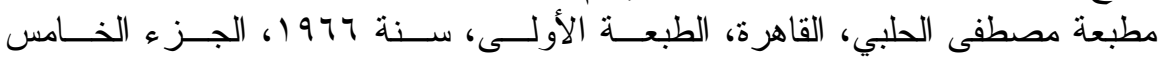

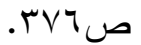

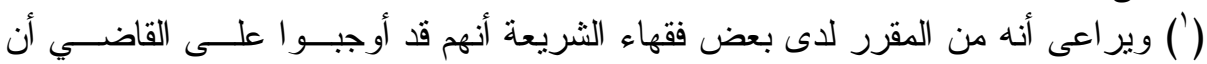

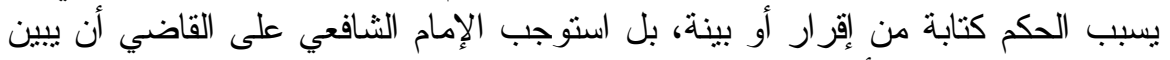

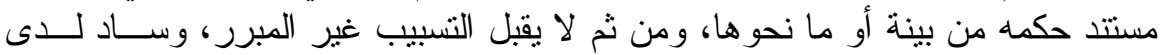

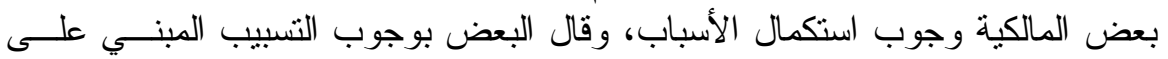

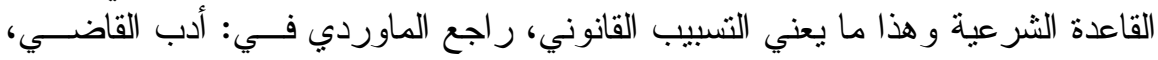

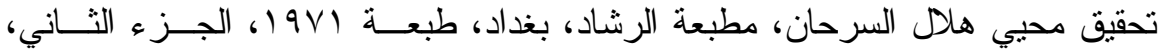

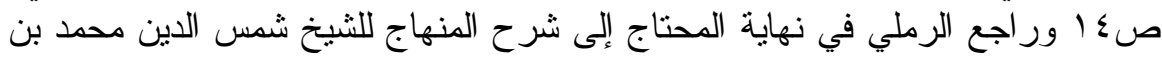

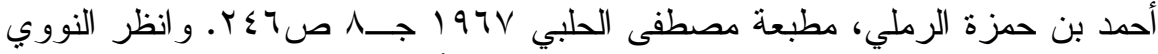

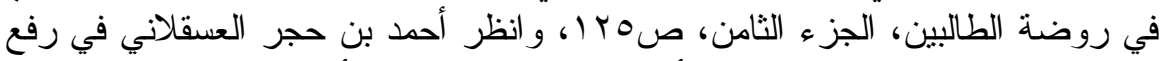

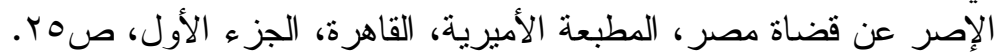




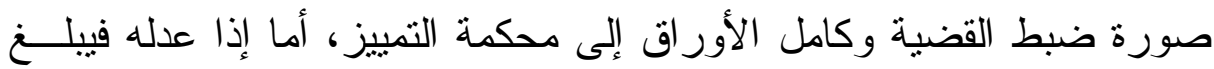

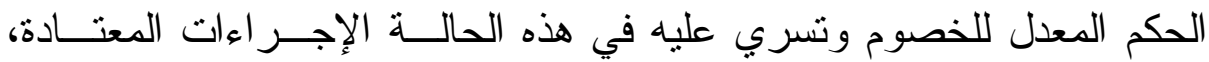

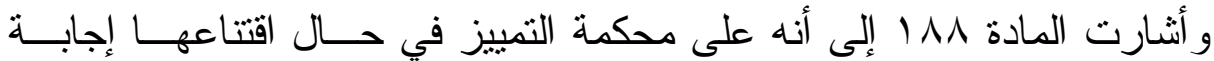

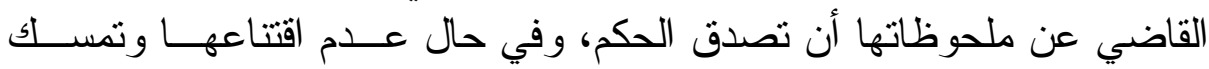

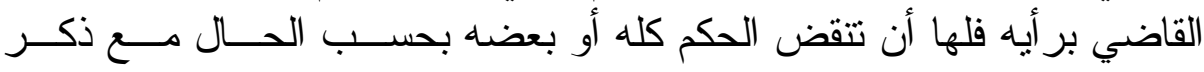

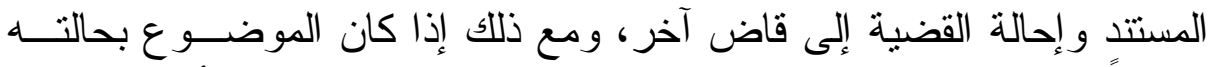

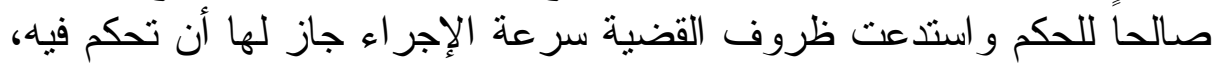

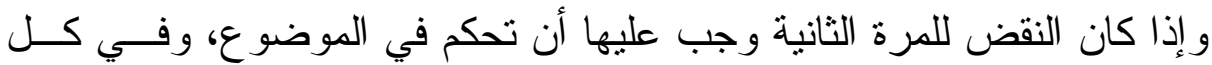

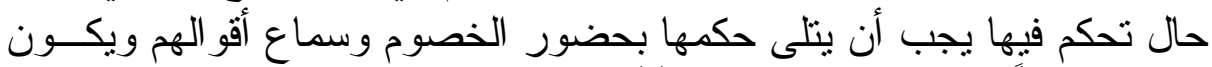

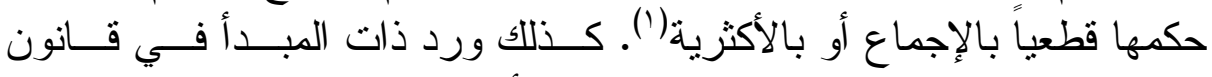

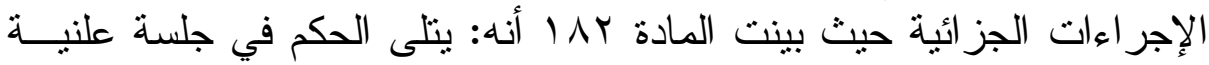

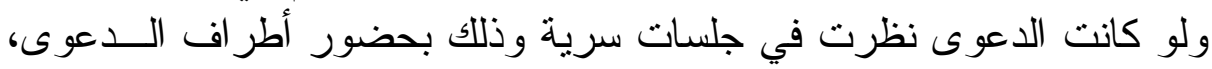

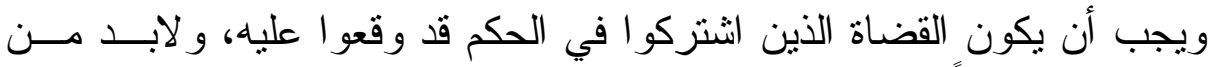

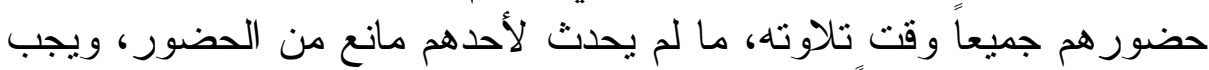

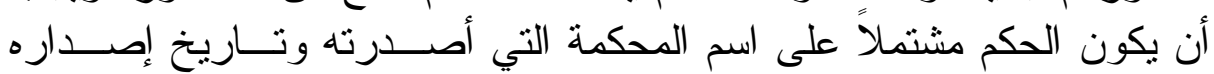

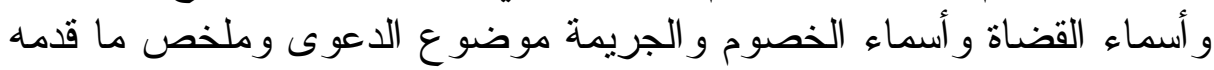

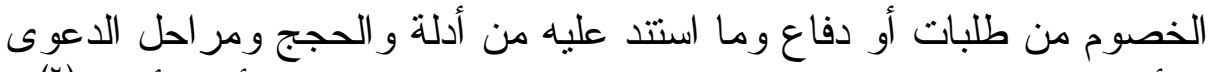

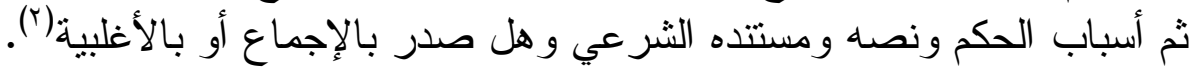

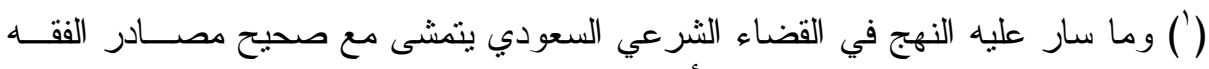

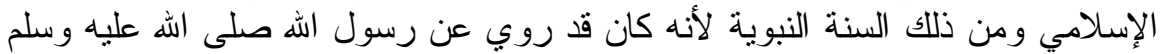

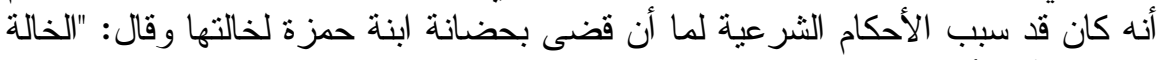

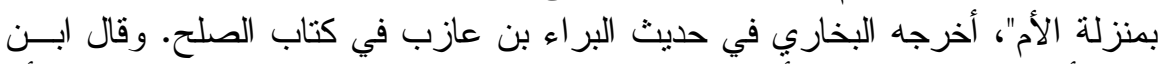

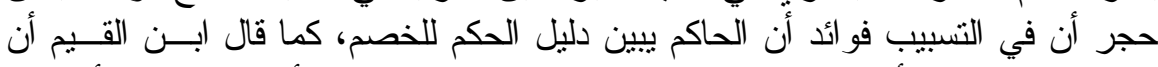

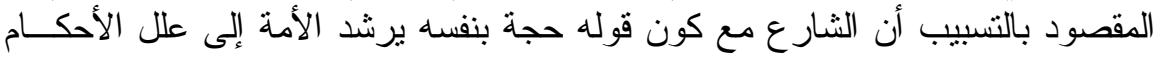

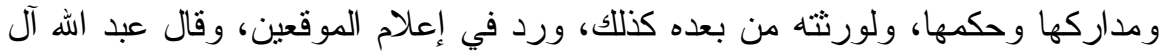

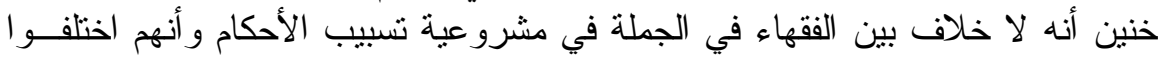

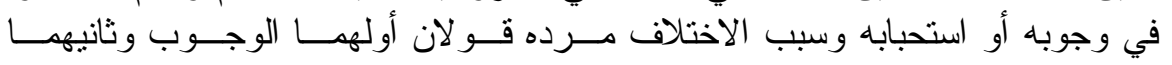

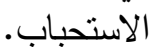

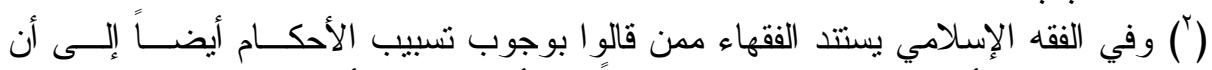

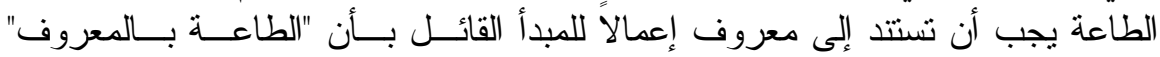

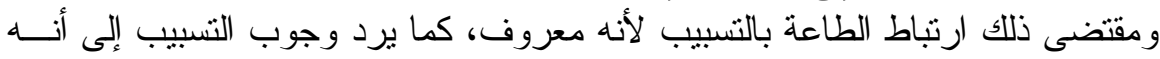

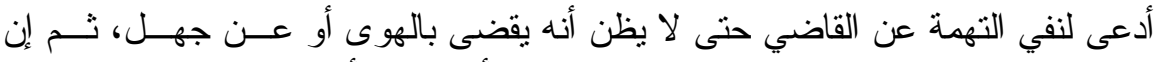

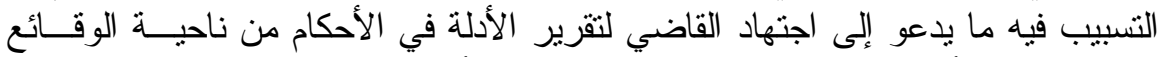

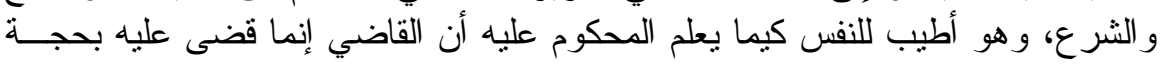


و إذا كانت الثريعة الإسلامية تقر بحق التسبيب تحقيقاً للمصلحة الخاصة

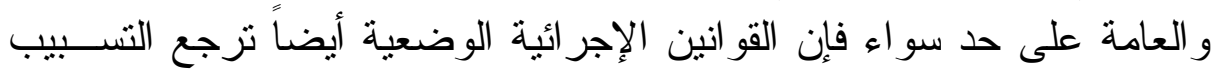

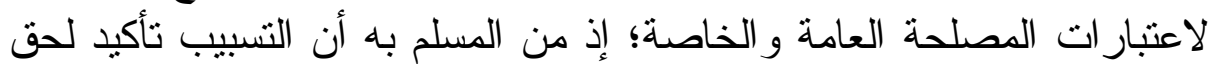

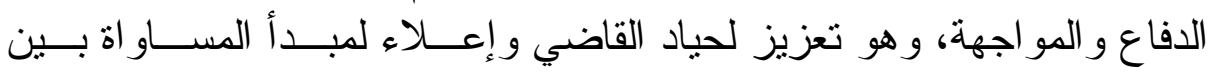

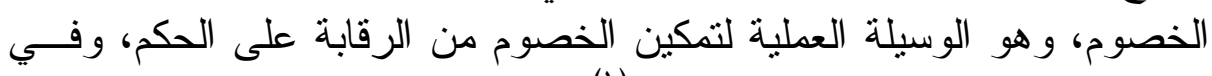
إزكاء هذه الرقابة تفعيل لعدالة القضاء ('). وتشمل رقابة الخصوم للنشاط الإجرائي للقاضي عدة أوجه أولها مر اقبته

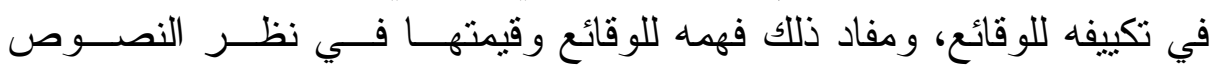
الإجر ائية و الموضو عية، ذلك أن من مهام القاضي عندما تعرض القضية عليه

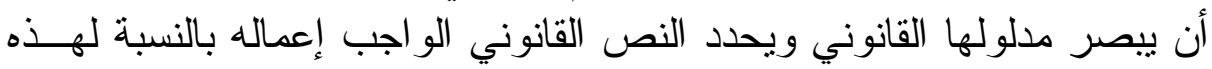

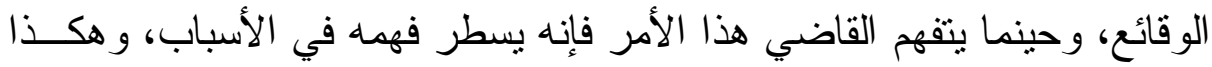

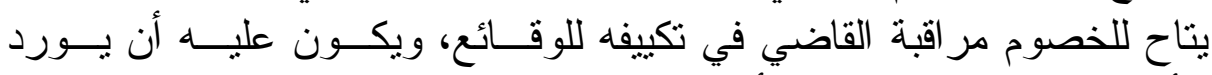

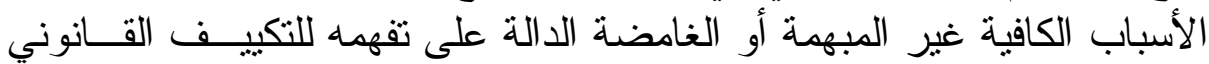
للوقائع، كذللك يسمح التسبيب بمر اقبة القاضي لحقيقة النز اع و عناصره لأن فهم

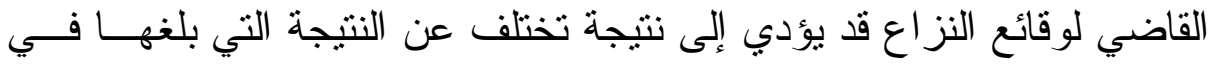

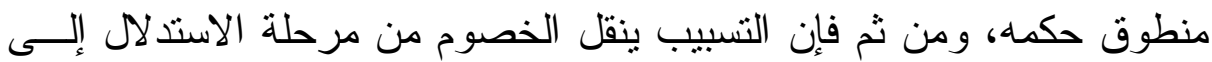

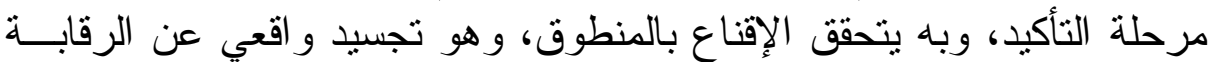

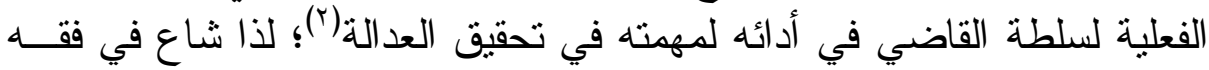

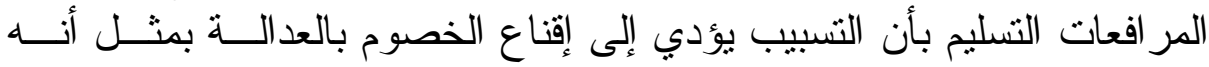
يحقق ذات الاقتتاع لدى الرأي العام وهو ما بحقق ثقة المتقاضبن في القضـــاء

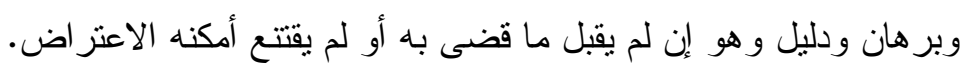

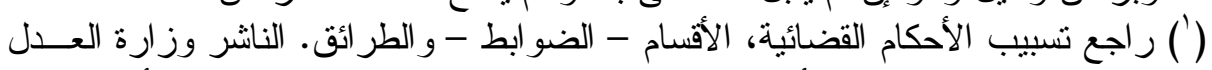

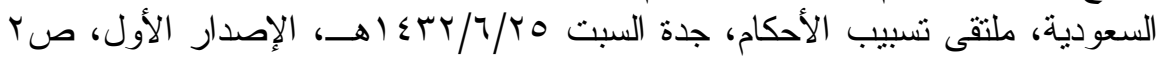

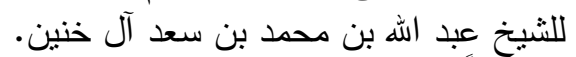
( ) وتطبيقاً لذلك قال القاضي عيسى الغيث أنه إذا توصل القاضي إلى حكم في القضية فإنه

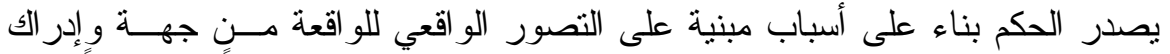

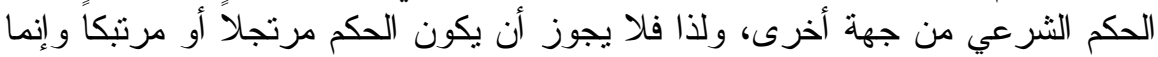
هو مبني على حيثيات تبرى ذمة القاضي، فلابد من أن تسبب الأحكام القضائية لكونهـ فيسا

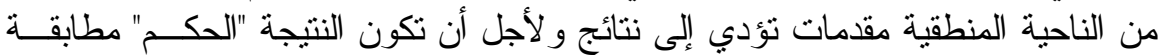

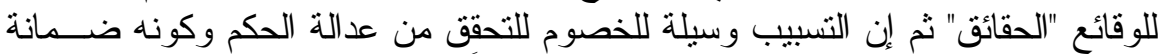

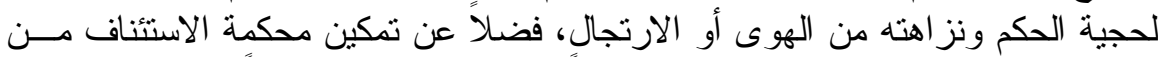

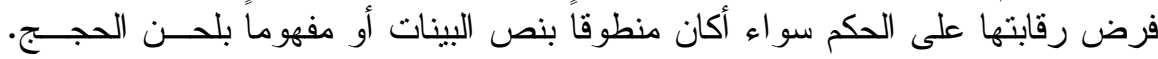
راجع منتدى القضاء العماني. سيف الحوسني. 


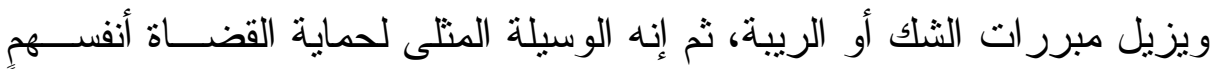

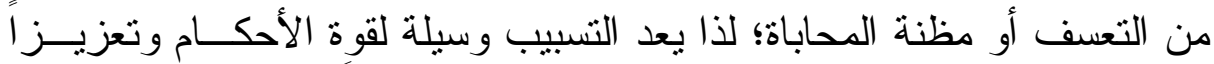

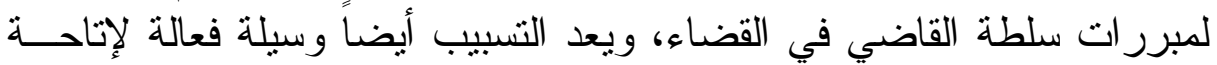

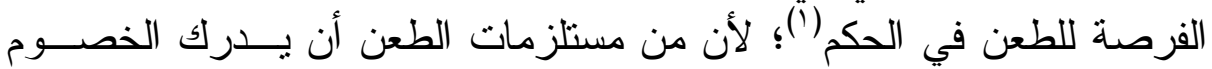

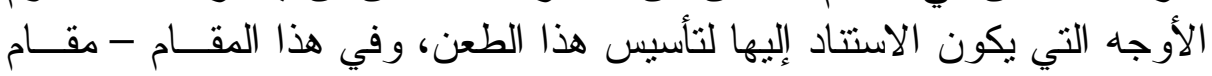

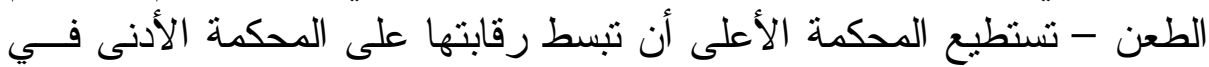

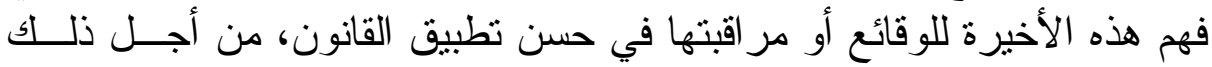

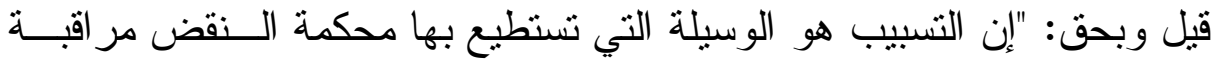

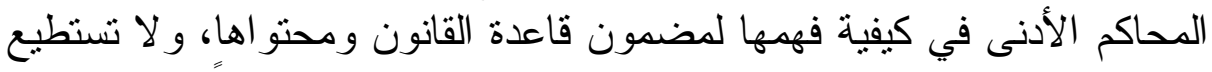
محكمة النقض مر اقبة مهمة توحيد القانون إذا لم يكن الحكم مسبيا".

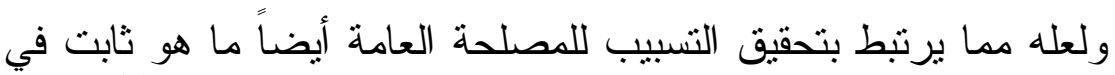

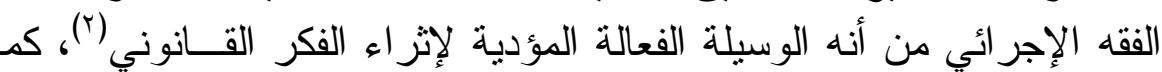

(') راجع المستشار دكتور عبد الحكم فودة في أسباب صحيفة الاستئناف، دراسة تحليليــة

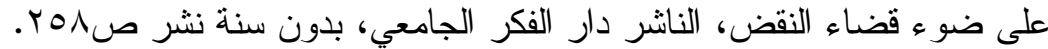

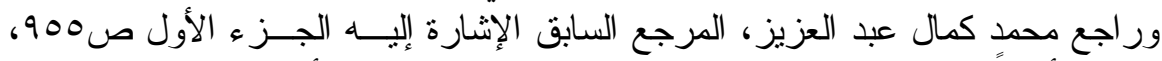

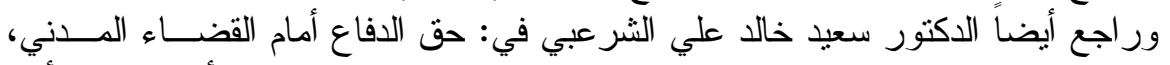

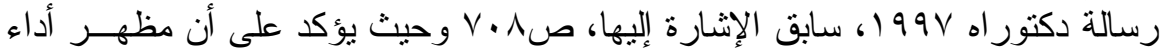

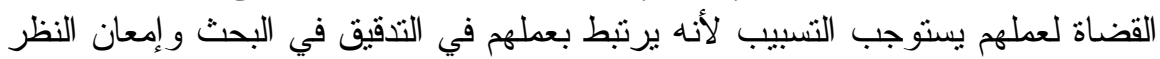

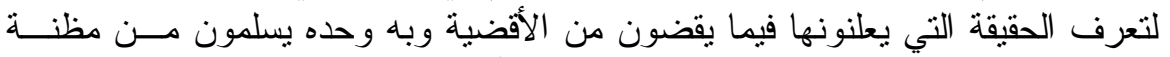

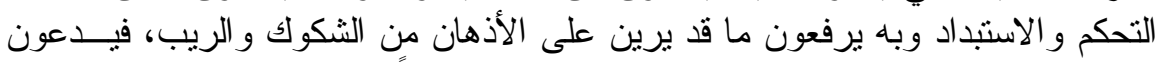

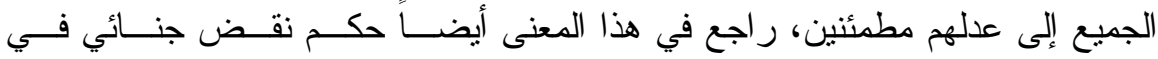

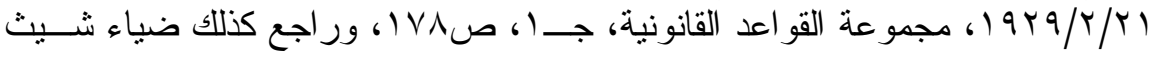

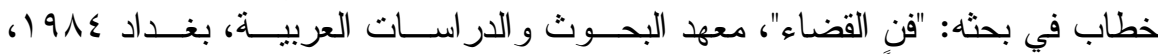

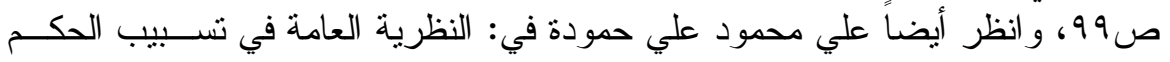

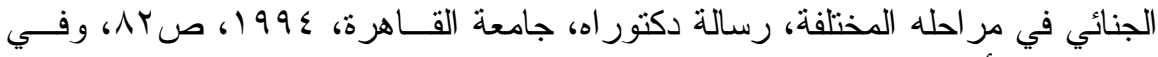

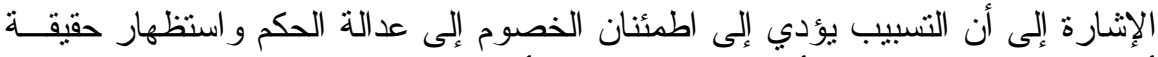

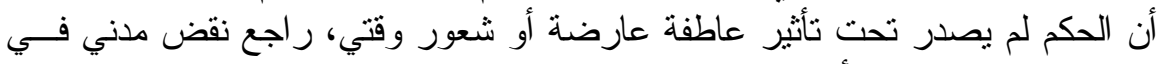

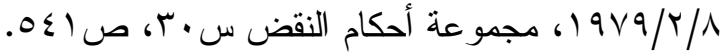

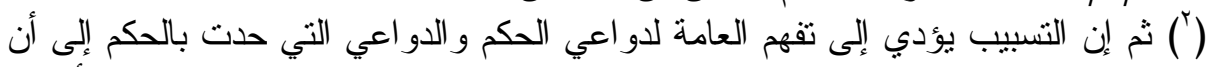

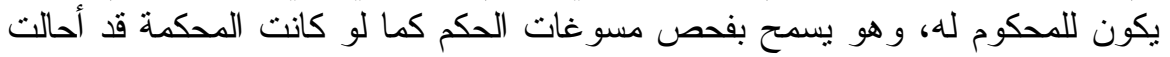

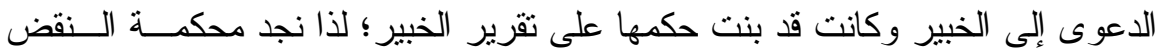

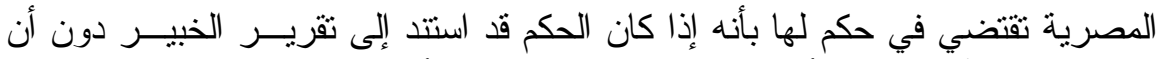

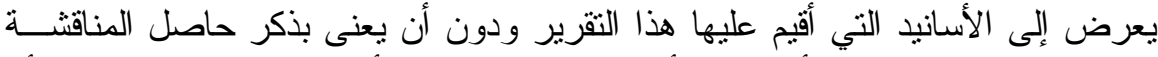

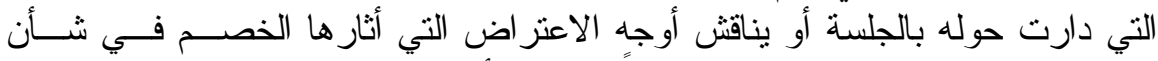

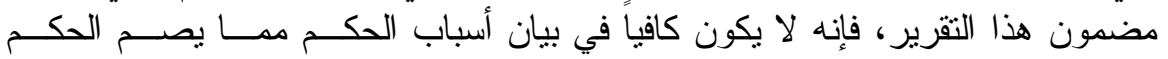


تتحقق المصلحة في التسبيب في إثبات كل ما شملته حقيقة النــز اع المطــروح

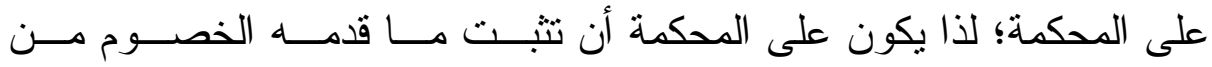

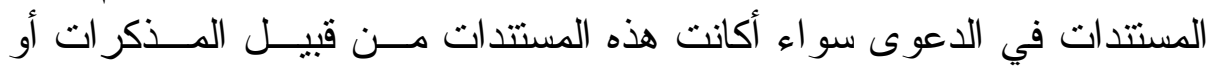

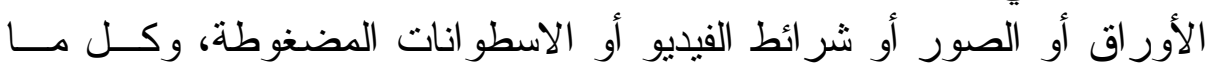

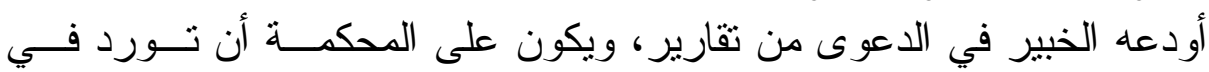

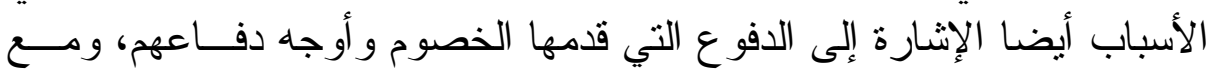

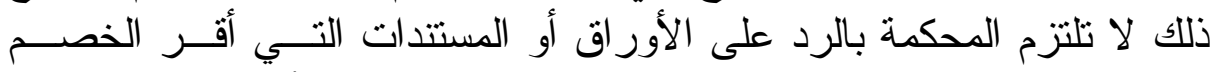

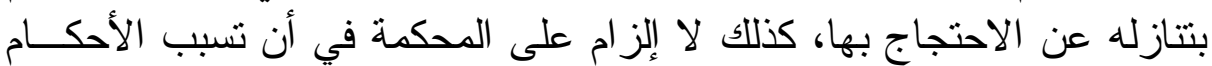

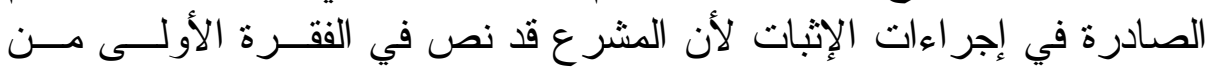

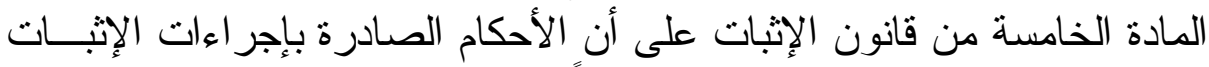

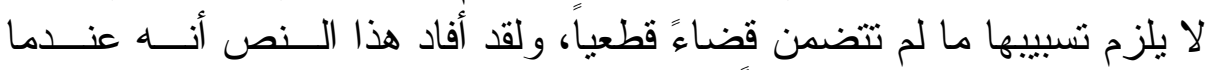

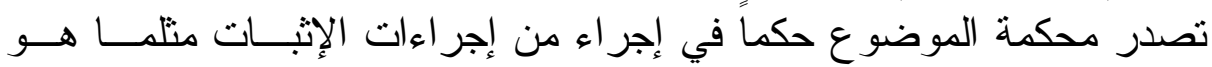

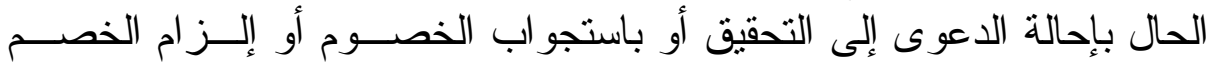

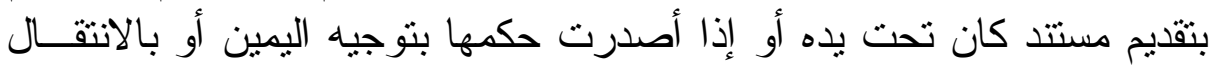

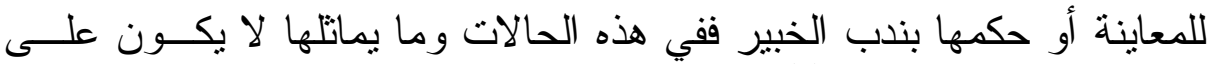

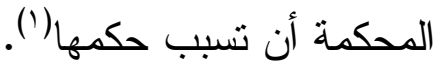

وبخلاف ما تقدم فإنه إذا كان الحكم في مسألة الإثبات قطعياً فإن المحكمة

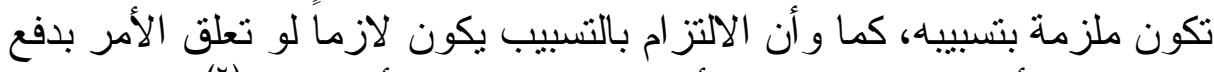
بعدم القبول أو بعدم الاختصاص أو باعتبار الدعوى كأن لم تكن لآمأ.

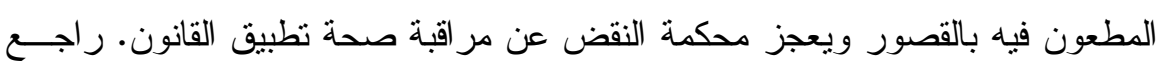

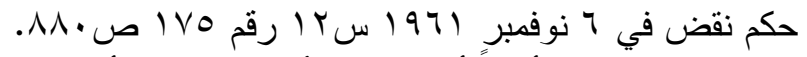

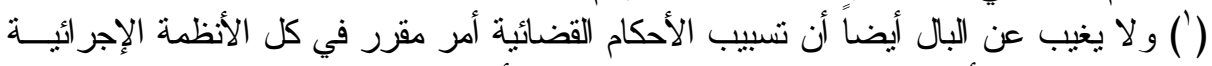

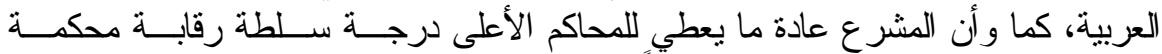

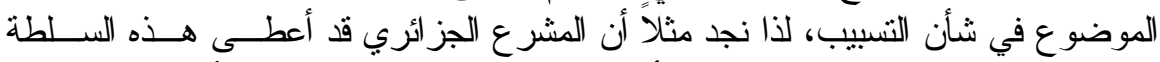

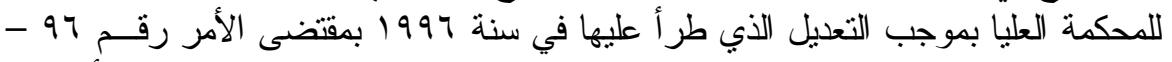

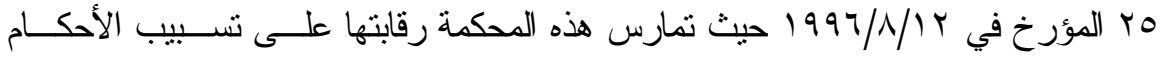

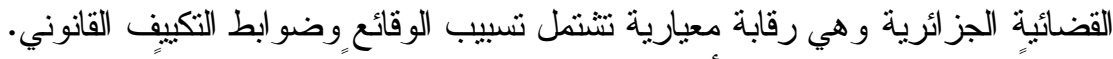

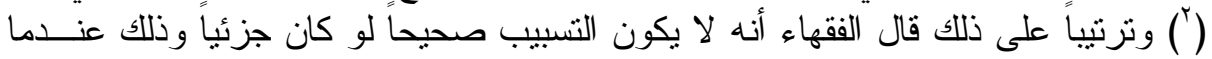

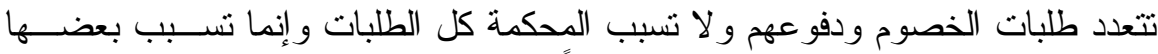

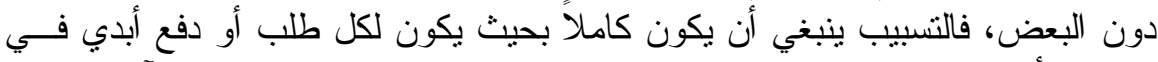

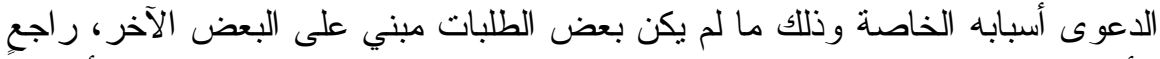

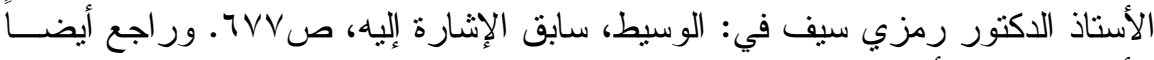

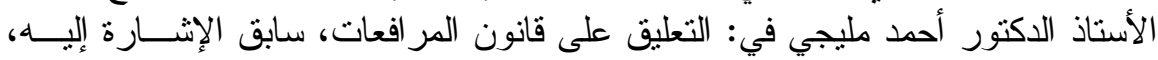

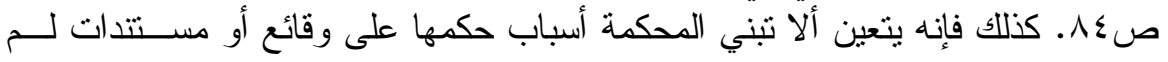




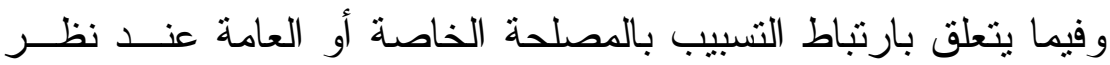

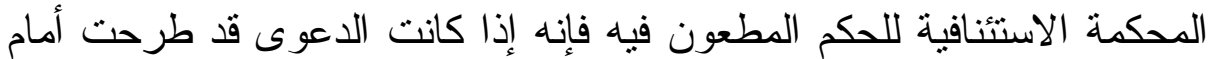

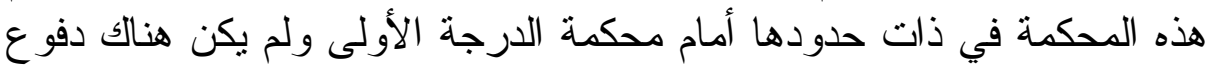

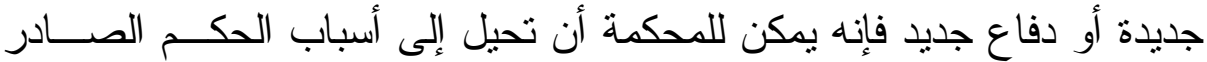

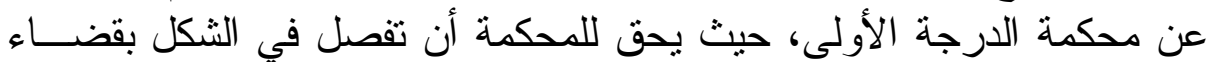

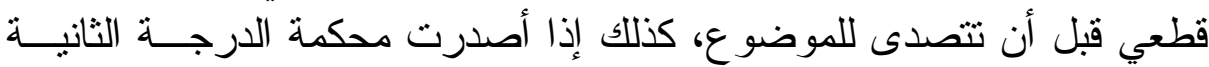

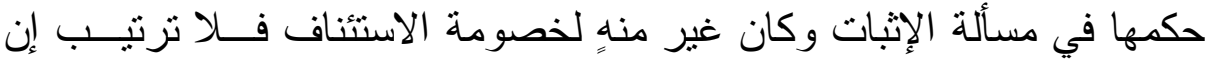

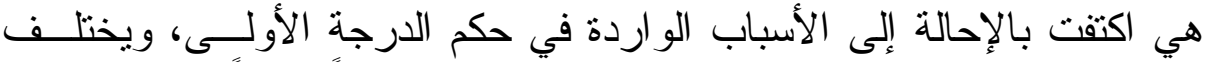

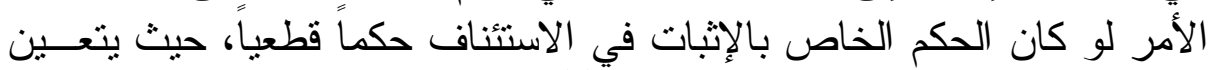
على المحكمة الاستئنافية أن تورد أسبابة (1). المطلب الثالث

\section{علاقة تسبيب الأحكام القضائية

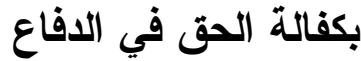

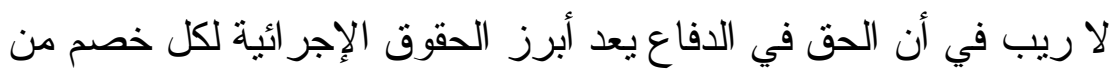

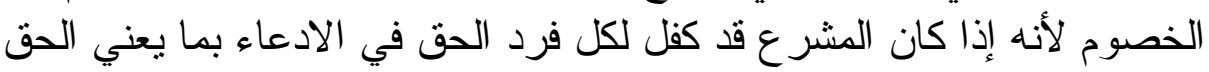

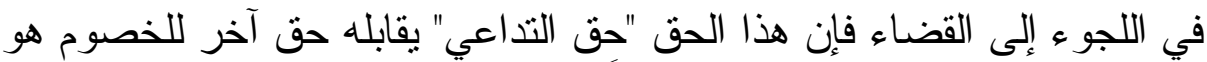

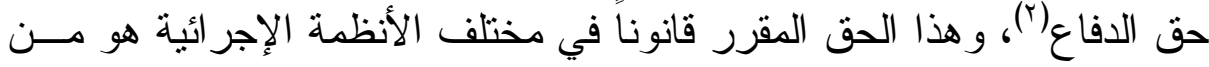

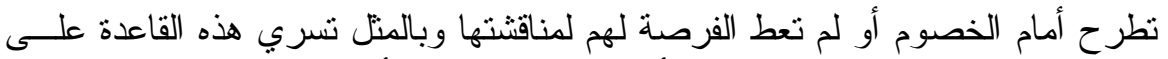

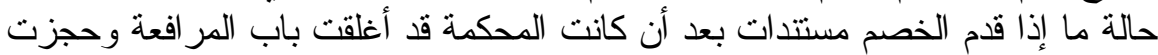

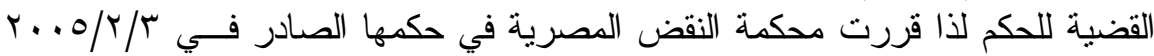

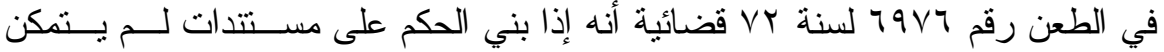

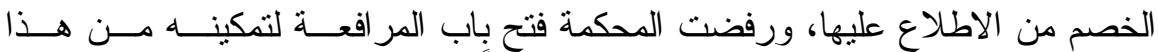

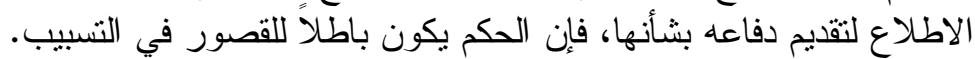

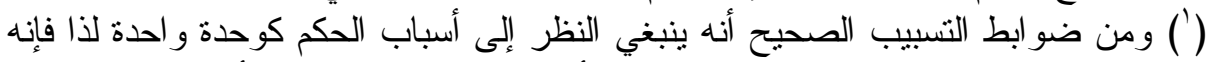

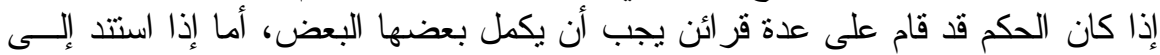

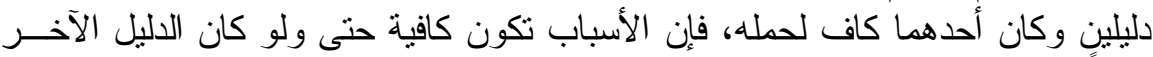

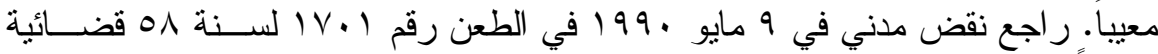

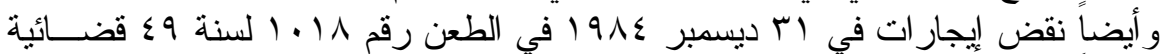

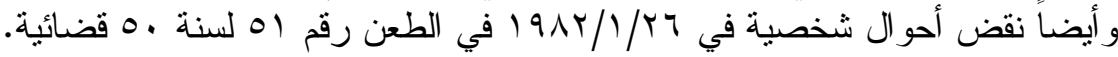

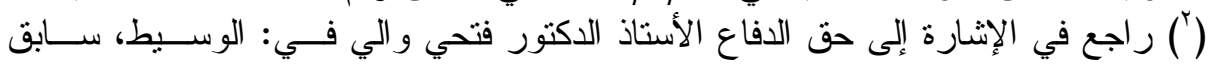

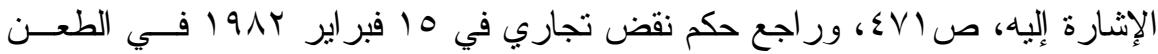

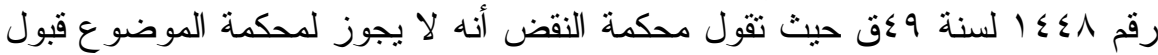

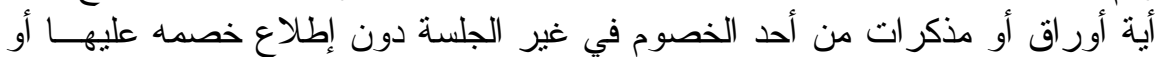

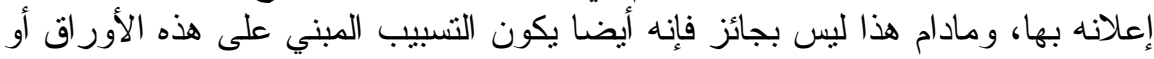


الحقوق الطبيعية، بما يعني أنه من الحقوق اللصيقة بالثخص، وهو حق لم تكفله

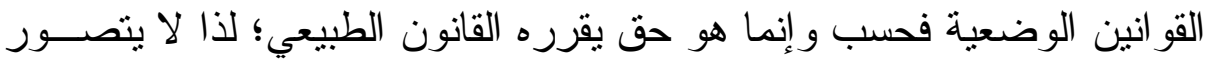

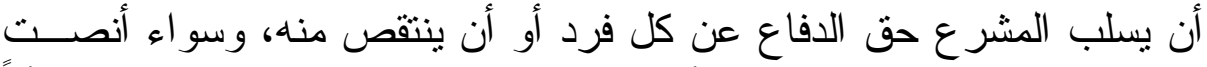

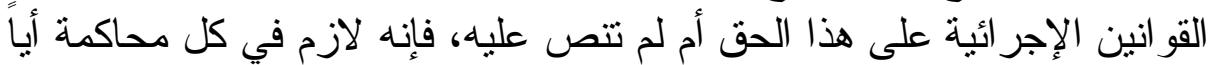

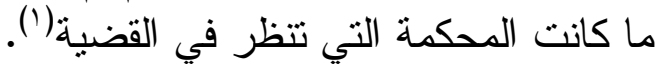

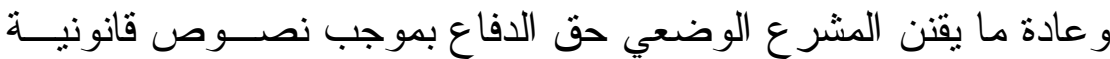

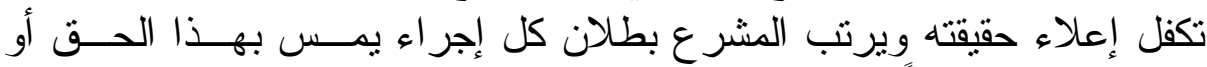

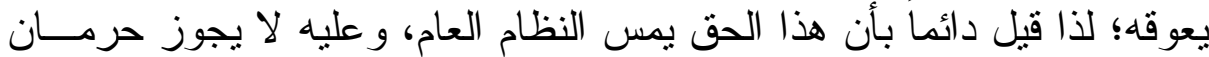

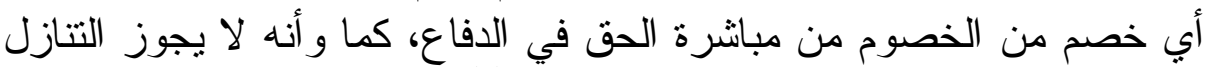

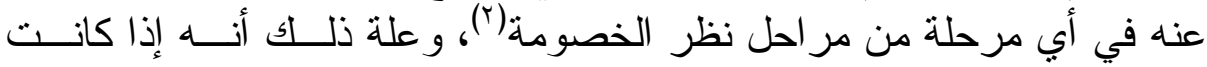

$$
\text { المستندات غير صحيح أيضا. وراجع في الإشارة إلى حق الدفاع: }
$$

Gérard Couchez; op. cit. p. 183 No. 238 et ss.

$$
\text { ور اجع أيضا: }
$$

Couchez; principe de la contradiction. J. class. Procédure. Civ. Fasc. 114.

$$
\text { وانظر أيضا: }
$$

Normand; les droits de la défense devants des juridictions du travail semaine sociale lamy. Suppl. No 410 mai 1988 D. 51.

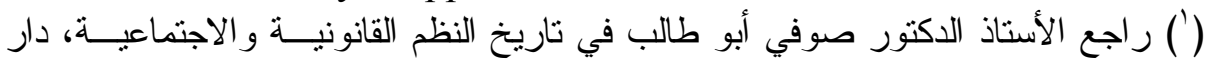

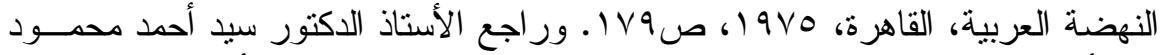

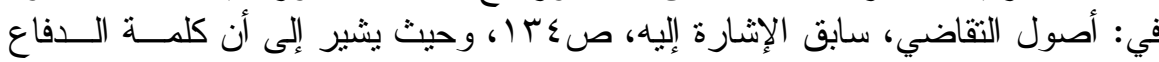

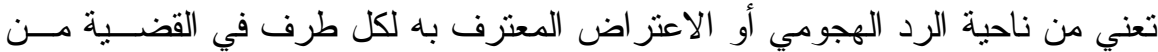

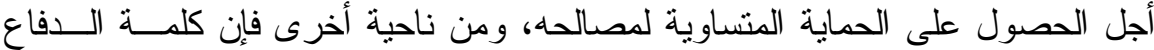

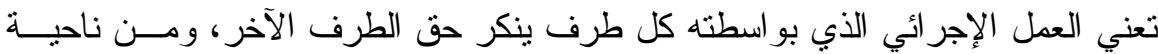

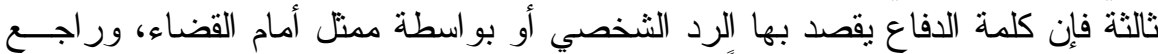

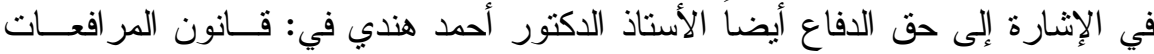

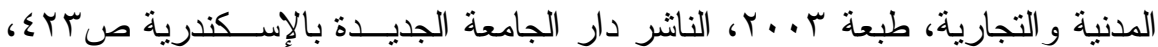

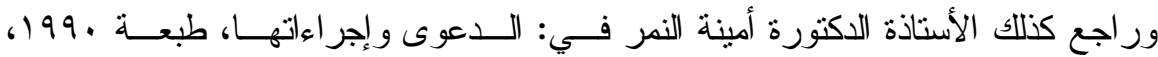

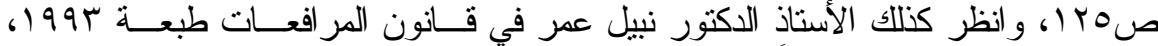

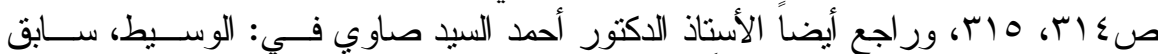

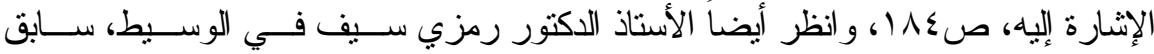

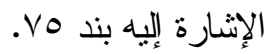

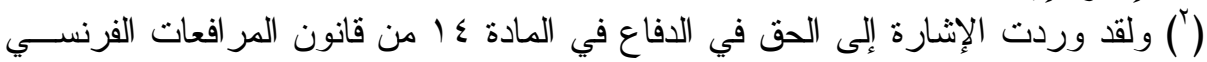

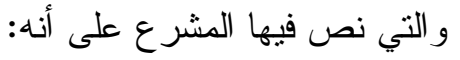

Nulle partié ne peut être jugé sans avoir été entendue au appelée. 


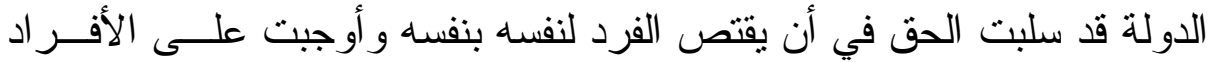

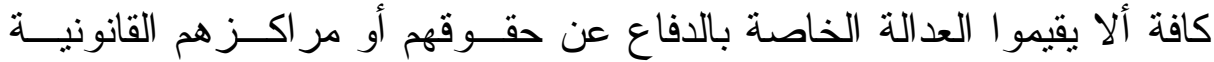

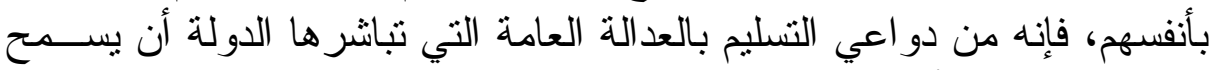

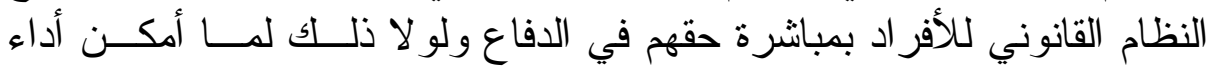

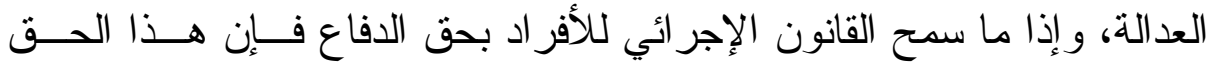

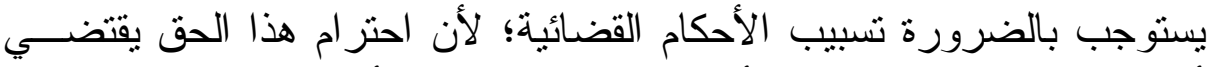

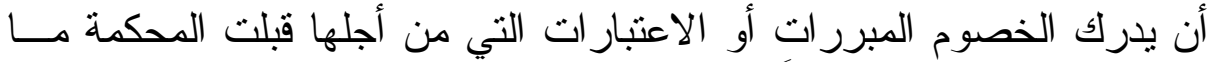

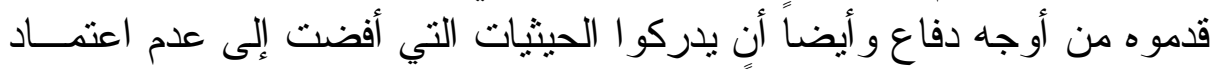

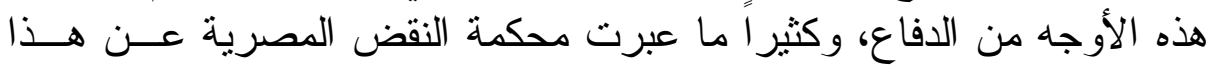

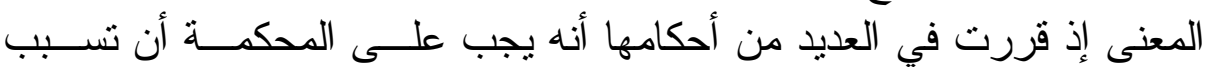

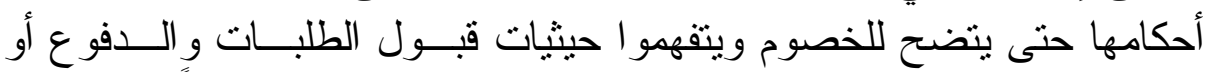

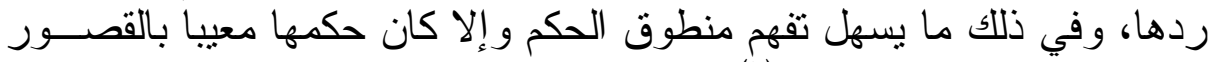

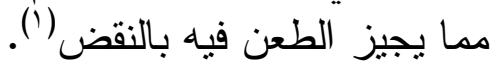
ويعد إلز ام القاضي بتسبيب الأحكام القضائية نتيجة منطقية وطبيعية في بلي

Normand; les droits de la défense devant les juridictions du travail. 1988. p. 51.

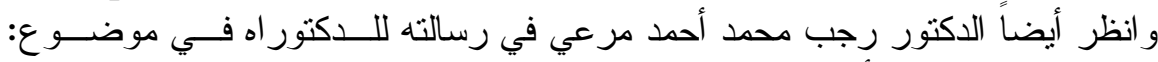

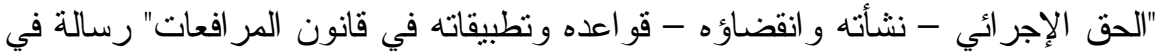

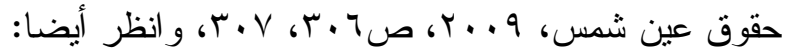

Gérard Couchez; op. cit. p. 184 No. 238.

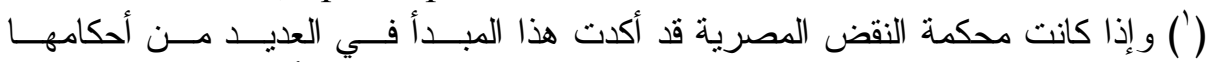

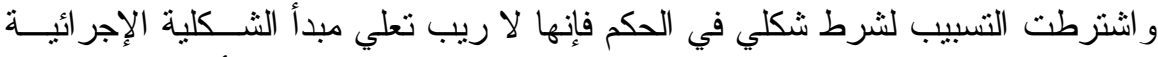

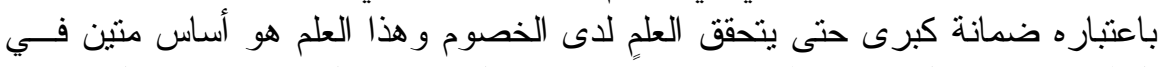

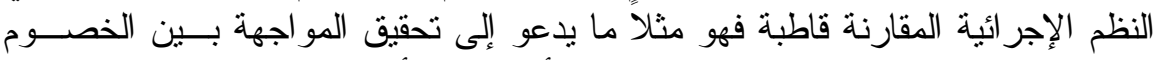

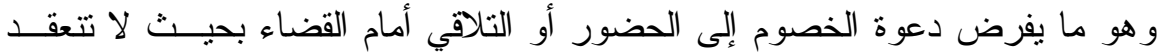

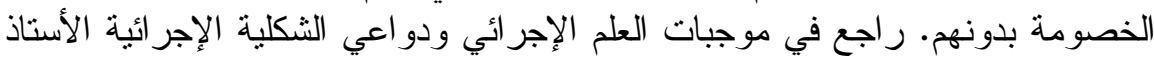

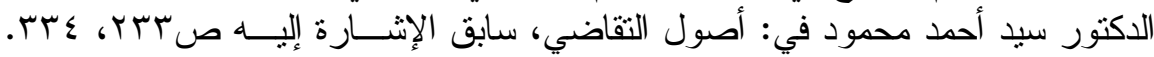

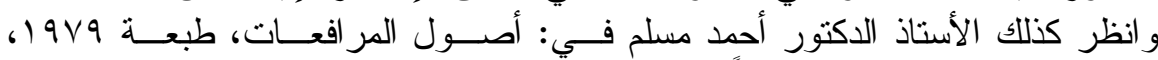

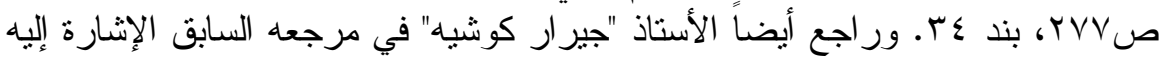

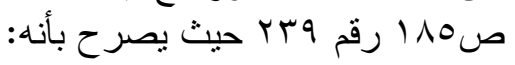

L' obligation d' observer de tels délais doit être rattacheé au principe de la contradiction.. sans doute celui qui a engage le procédure doit - il tout de même pouvoir obtenir un jugement: encore faut - il cependant que son adversaire ait bien été appelé, c'est - a - dire invite à faire voloir ses arguments. 


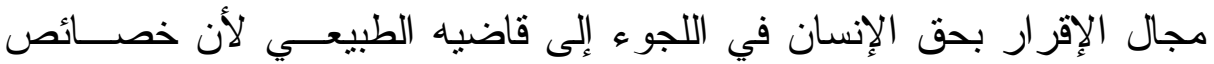

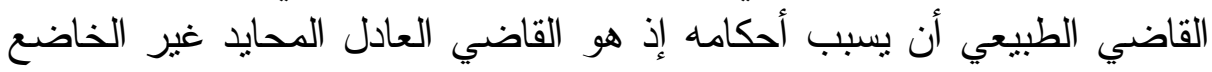

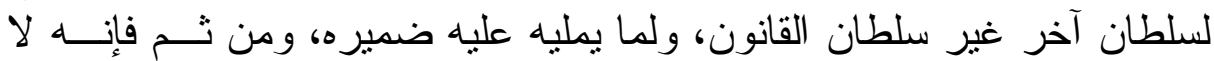

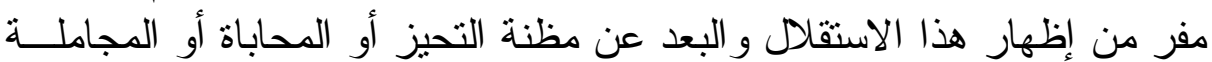

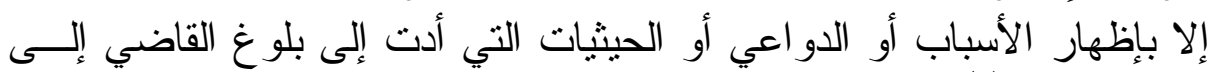

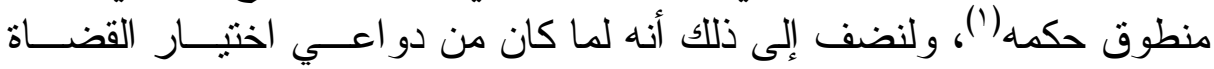

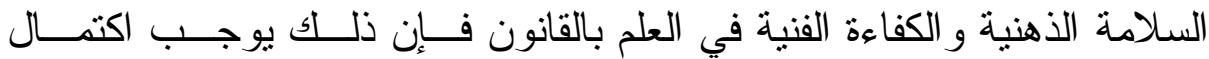

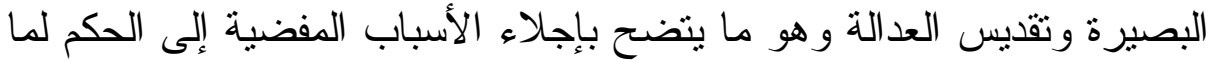

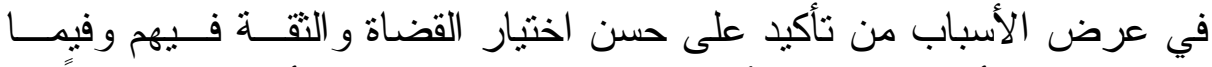

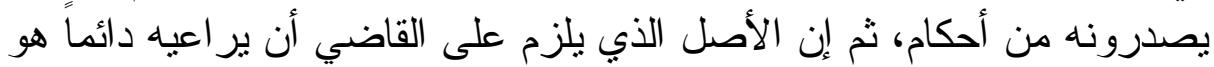

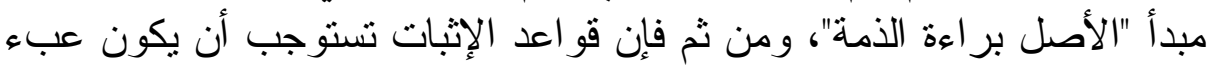

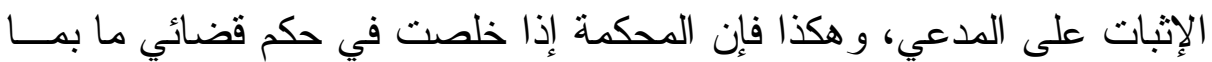

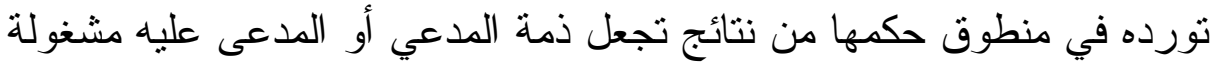

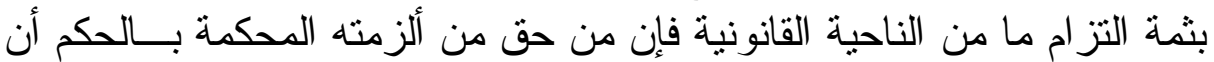

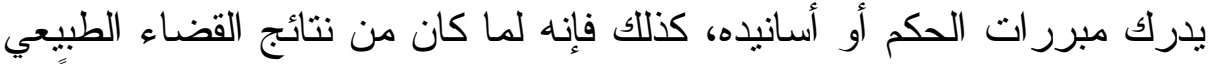

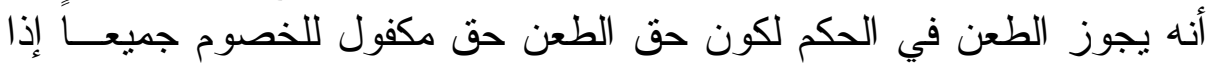

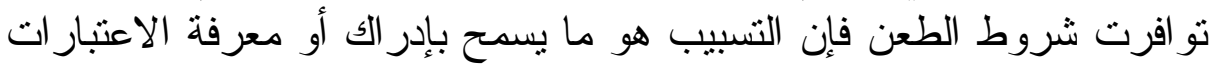
التي يمكن أن يبنى عليها الطعن، و هكذا فإننا لو أجزنا خلو إلو الأحكام من أسبابها

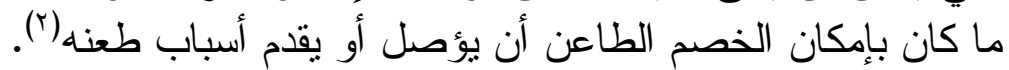

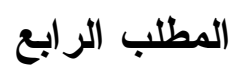

\section{علاقة تسبيب الأحكام القضائية}

$$
\text { بالحق في العلم الإجرائي }
$$

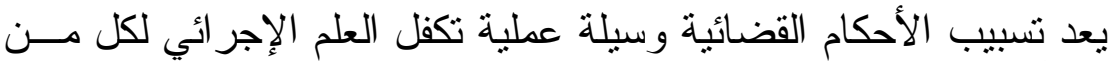

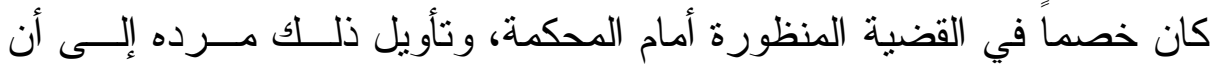

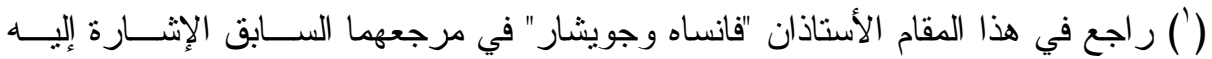

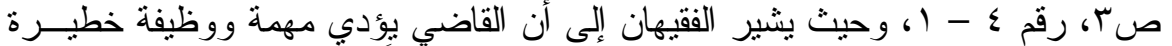

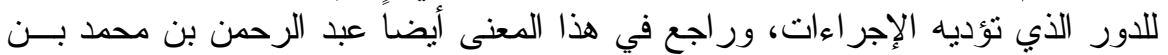

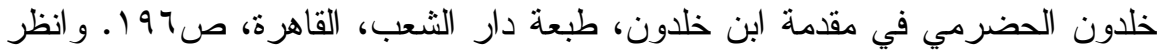

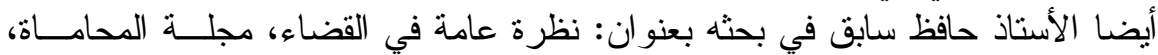

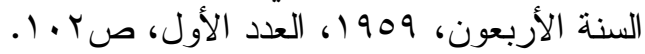

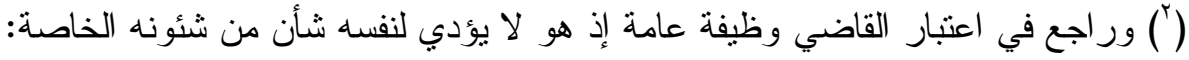
Réne Morél; Traité élémentaire de procédure civile. Op. cit. p. 122 No. 124. 


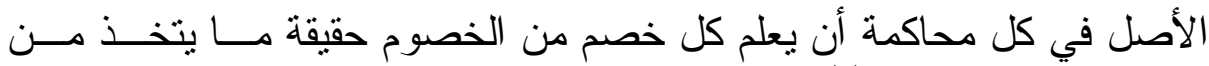

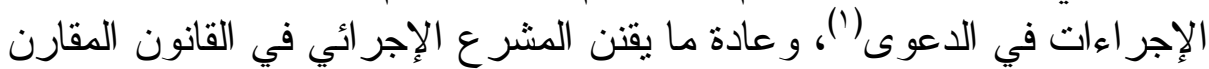

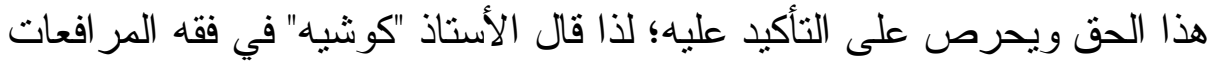

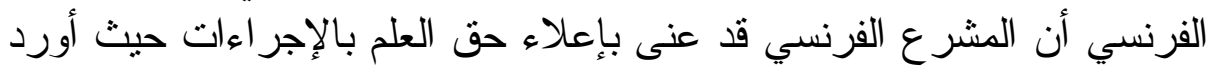

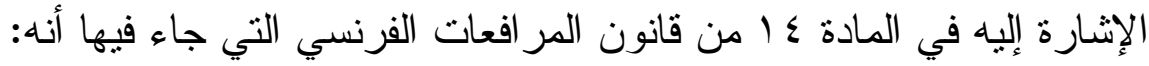

nulle partie ne peut être jugée sans avoir été entendue ou appelée. ${ }^{(2)}$

ومن نتائج هذا النص أن يتحقق لدى كل خصم العلم الفعلي بشأن كل ما

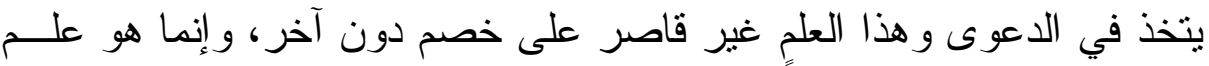

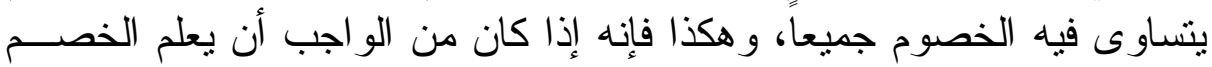

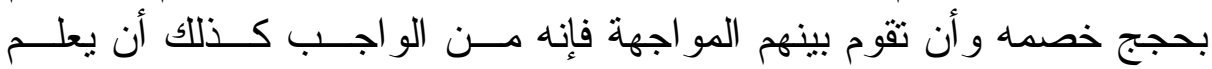

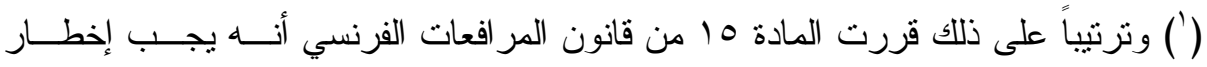

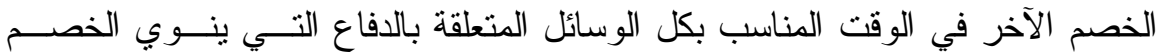

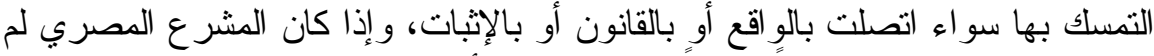

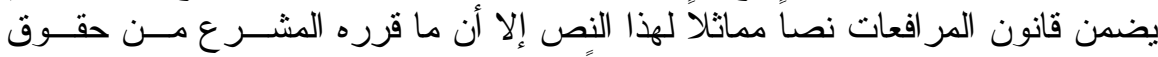

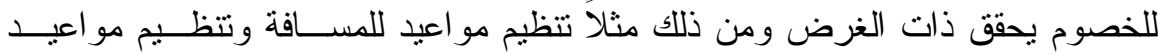

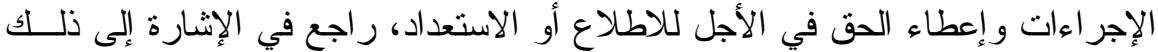

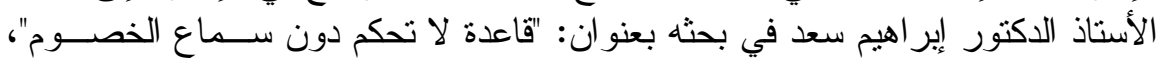

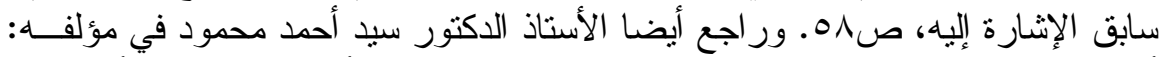

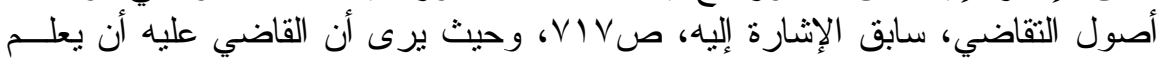

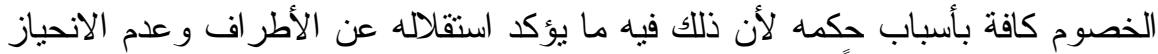

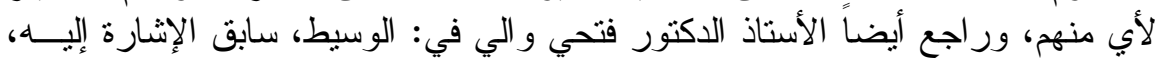

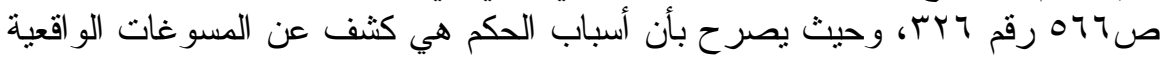

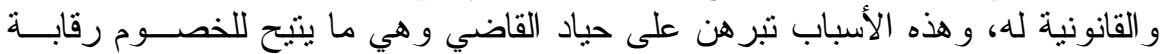
حسن استخلاص لهن و القاضي للنتيجة.

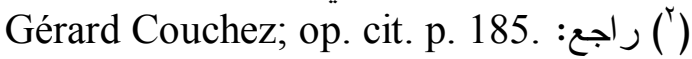

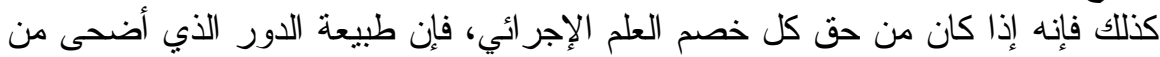

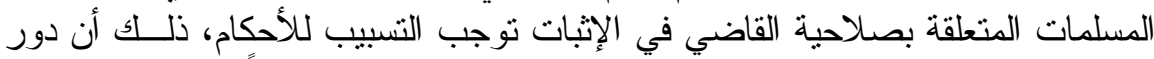

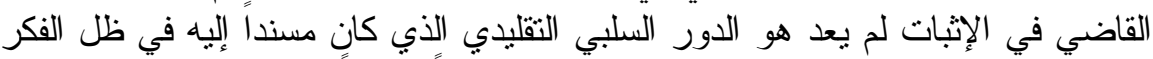

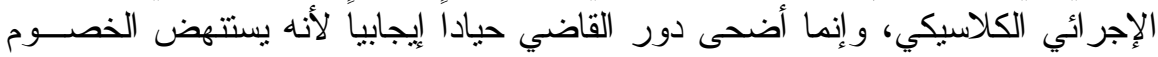

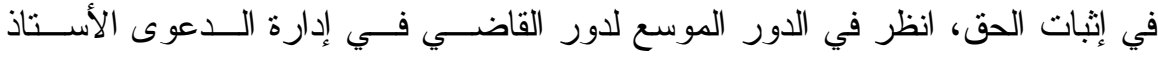

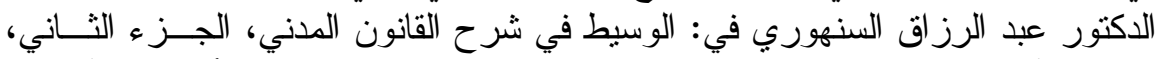

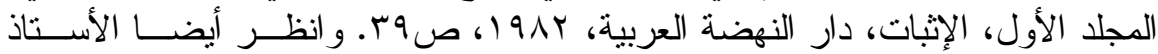

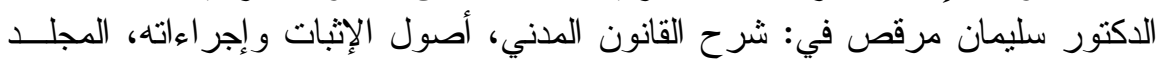

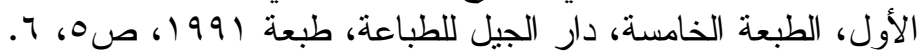




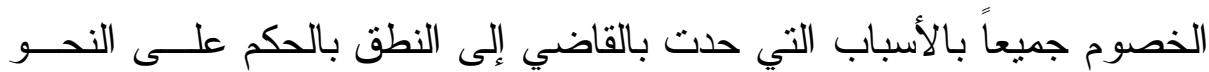

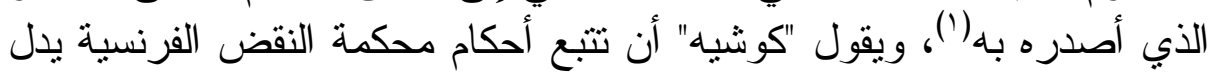

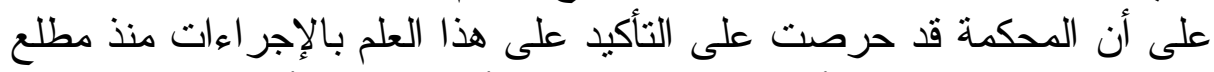
القرن التاسع عشر حيث أنثارت في العديد من أحكامها إلى أنه:

"la défense étant un droit naturel, énonçait - elle alors, personne ne doit être condamné sans avoir été interpellé et mis en demeure de se défendre". ${ }^{(2)}$

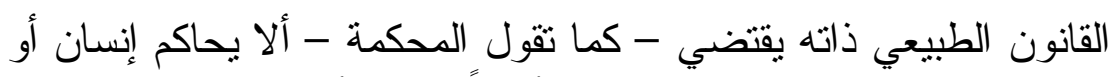

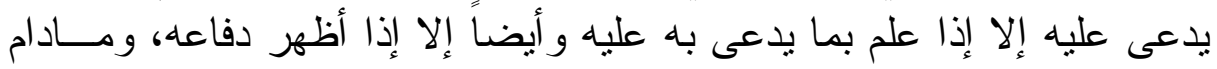

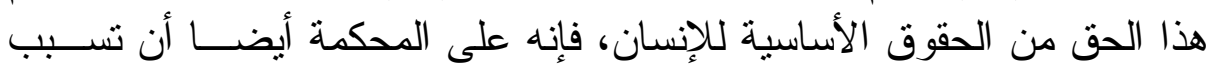

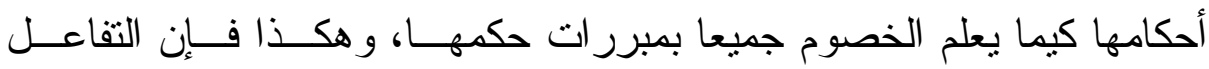

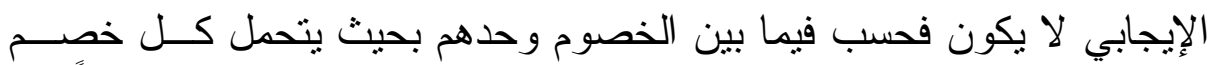

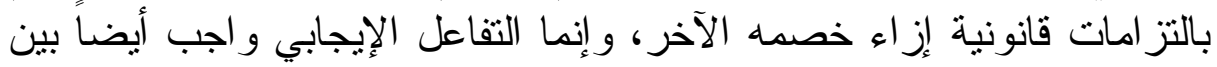

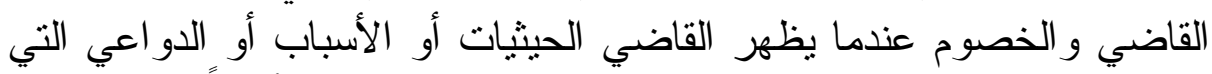

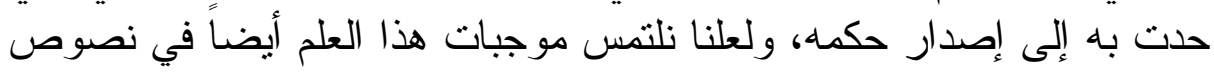

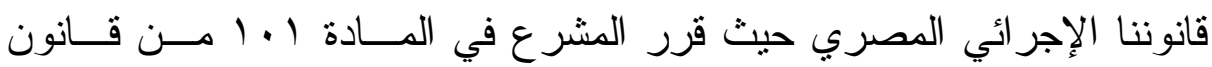

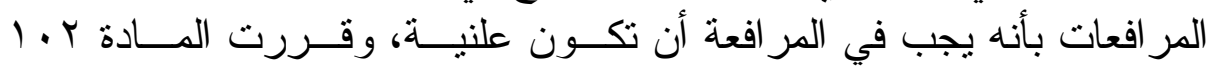

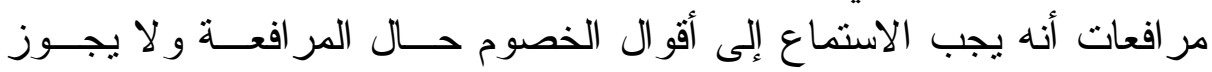

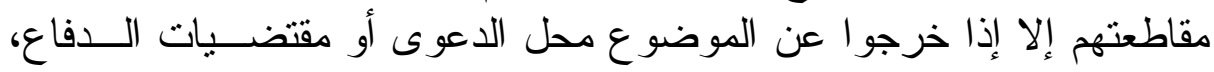

(') من أجل ذلك يجب أن نأخذ بعين الاعتبار أنه إذا كان من المقرر في النظم الإجرائيــة

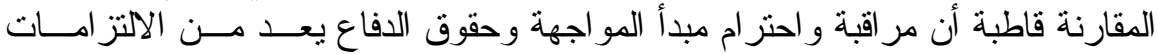

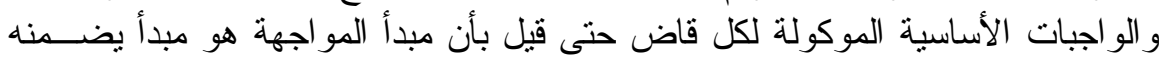

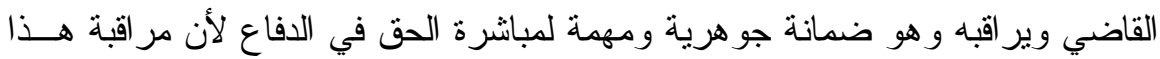

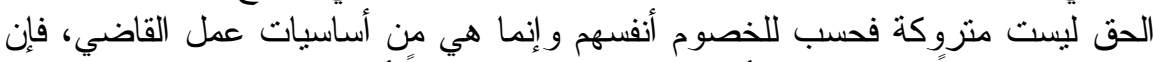

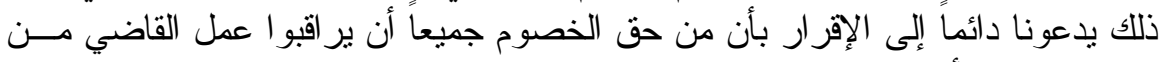

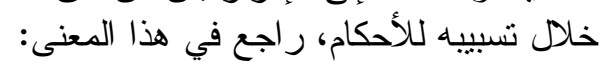
Jean Vincent et Serge Guinchard; op. cit. p. 320 No. 399.

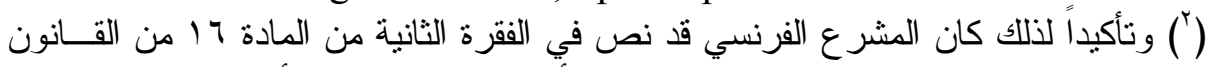

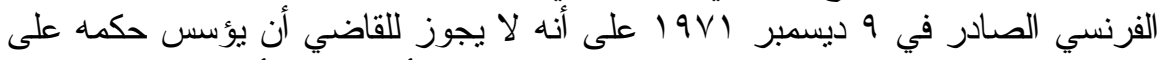

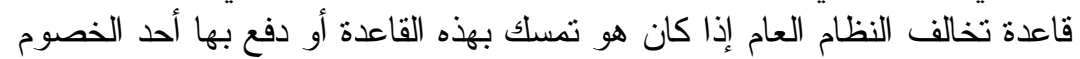
Le juge ne peut fonder sa décision sur des moyens de droits autres que d' ordre public, qu' il a relevés d' office ou sur les explications complémentaire qu' il a demandées, sans avoir au préable invité les parties à présenter leur observation. 
فكان في ذلك إزكاء لحق العلم الإجرائي وهذا العلم هو ما يوجب الأسباب التي

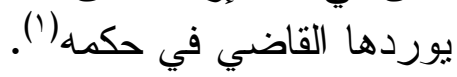

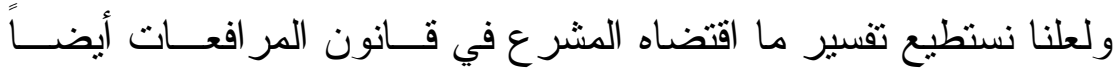

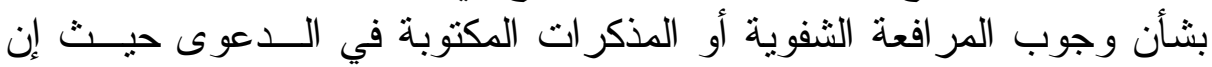
على المحكمة أن تسمع أو لا مر افعة المدعي أو محاميه ثم مر افعة المدعى عليه

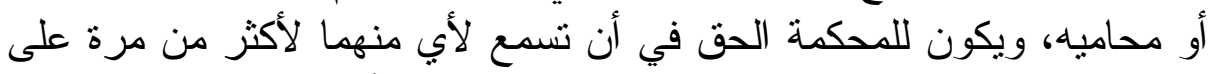

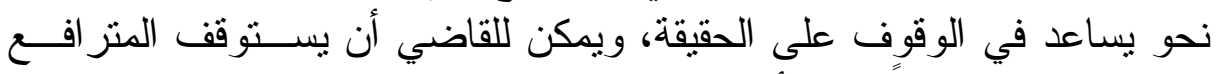

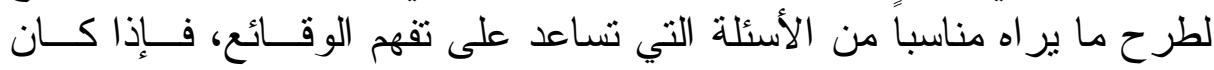

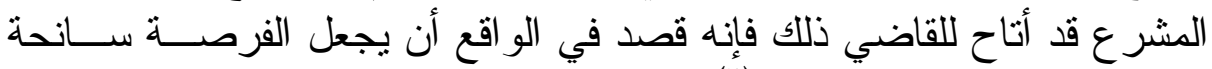
للقاضدي ليقدم أسبابه في الحكم (؟).

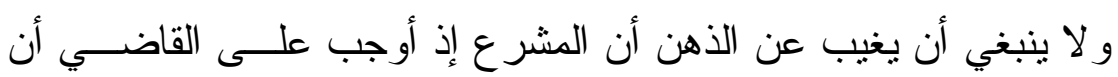
يسبب حكمه القضائي بما يتهق مع المنطوق فإنه قد كفل للقاضي نفسه وســـائل

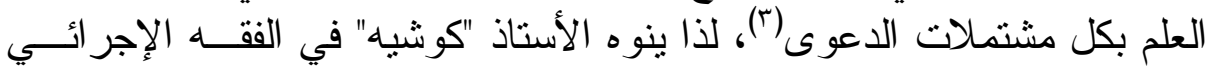

(') راجع رسالتتا للاكتور اه بعنوان حقوق الإنسان الإجرائية، جامعة عين شــمس با ــr، ص صا

( ) ومن الثابت في الفقه الإجر ائي أن المشر ع قد كفل في قانون المر افعات فرص منكافئــة

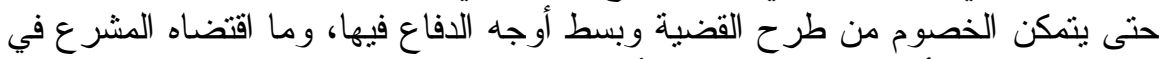
هذا الصدد يجب أن تظهر ثمرته في الأسباب التي يكون القاضي قد بنى لفي عليها حكمـــه،

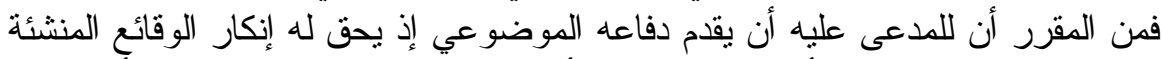

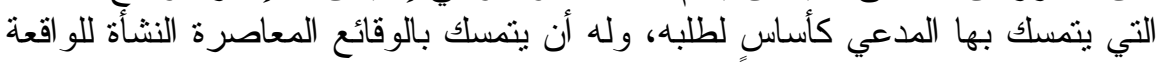

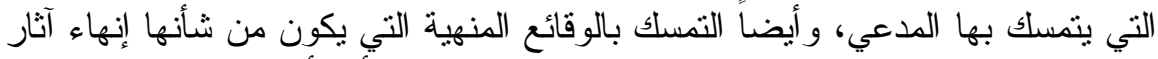

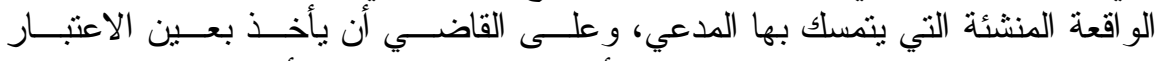

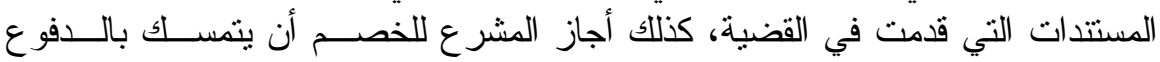

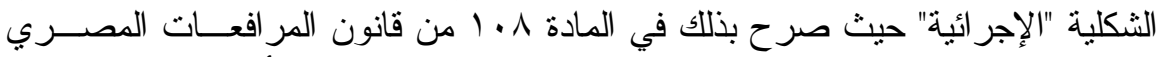

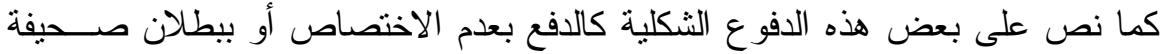

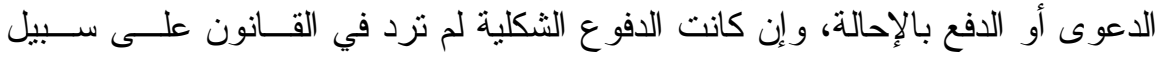

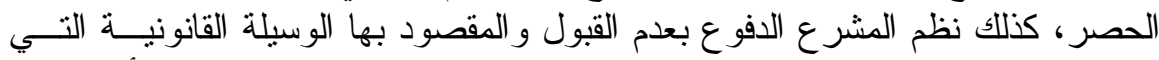

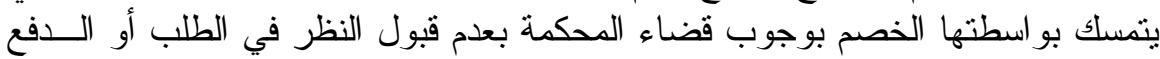

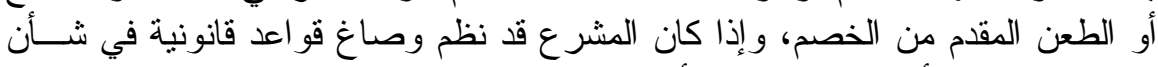

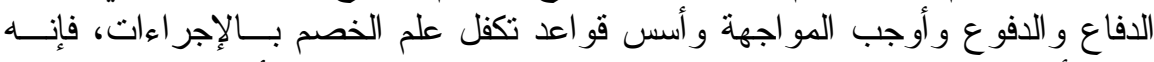

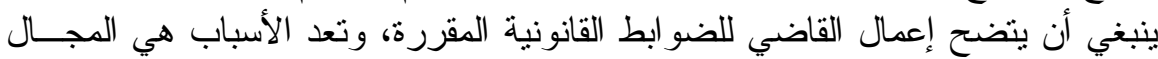

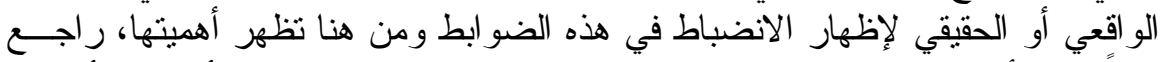

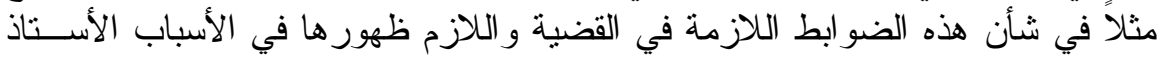

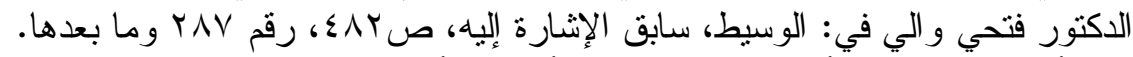

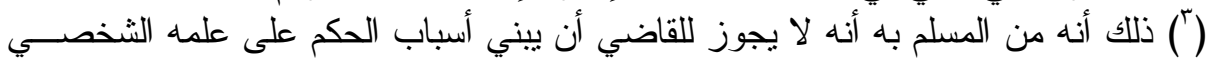


الفرنسي بأن لكل خصم حرية مطلقة في أن يحمل لعلم القاضي كافة العناصــر

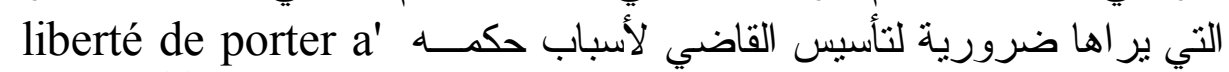

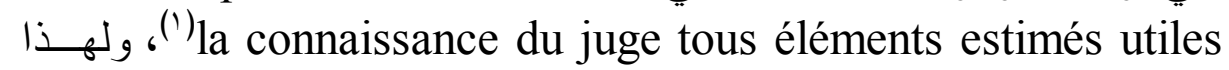
يعد من مكملات حق الادعاء أن يعرض ويقدم أو بطرح المدعي أمام القاضي

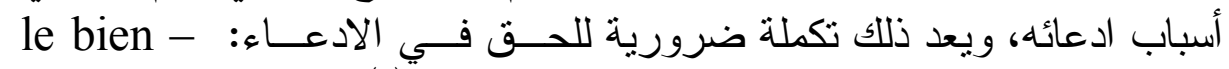
لقئ fondé de ses prétentions est fondamentale

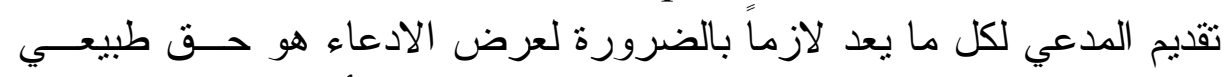

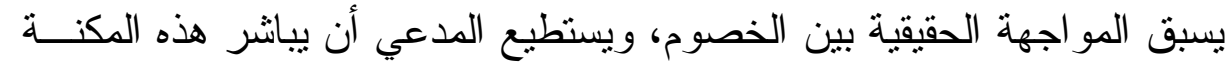

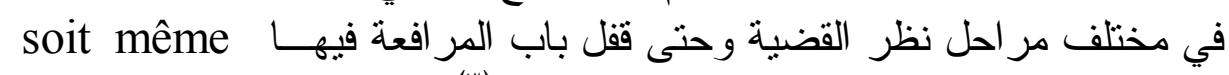
. ') parfois Jusqu' au la clâture des débats

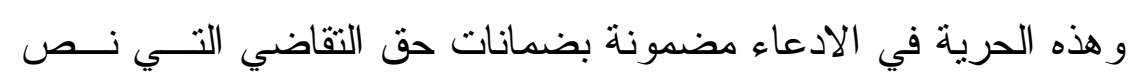

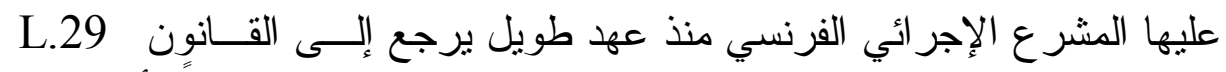
juill. 1881

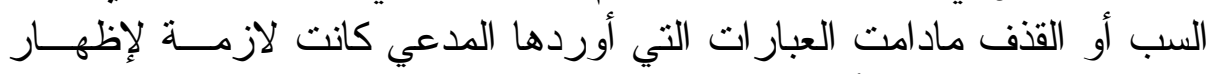

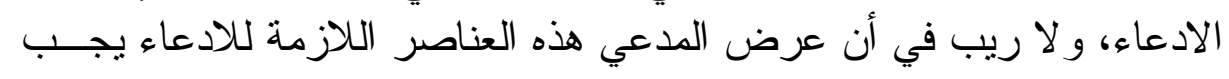

و إنما هو يبني الحكم على العناصر القائمة في الدعوى لذا قيل وبحق "لا يجوز للقاضي

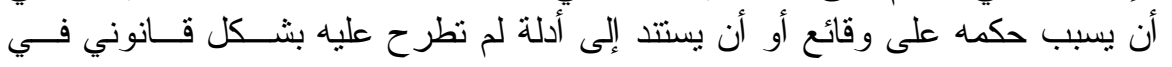

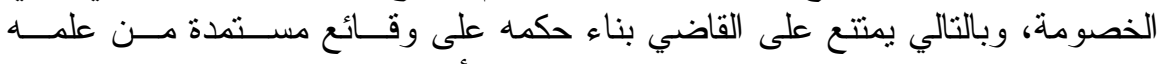

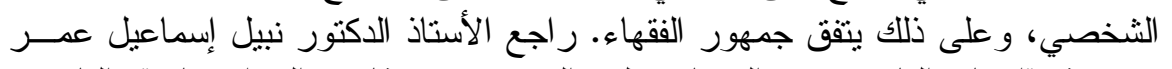

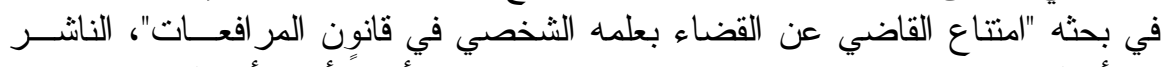

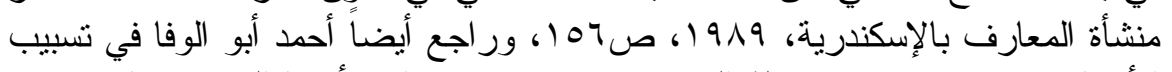

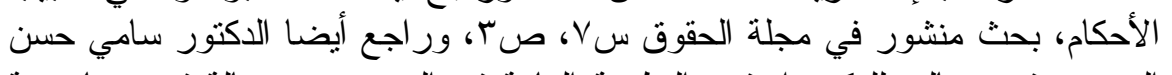

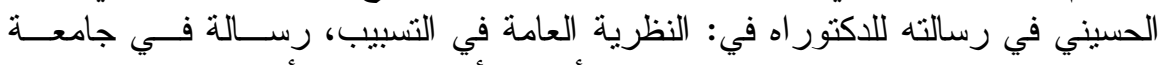

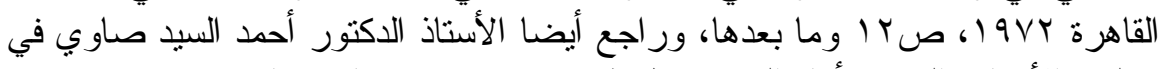

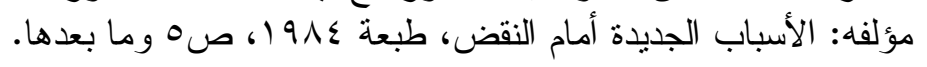

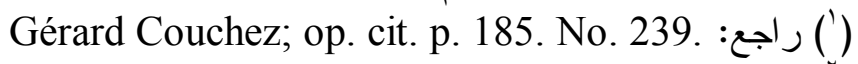

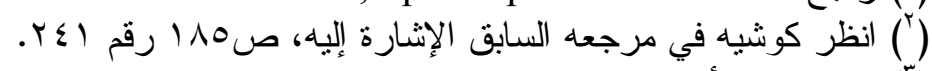

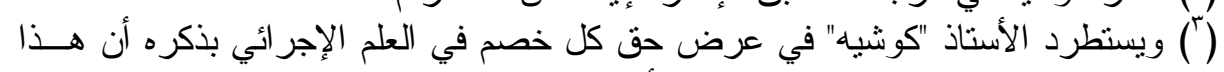

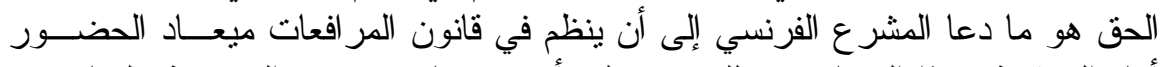

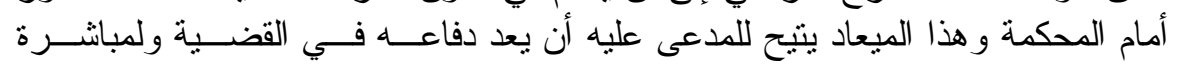
المواجهة:

Si l' on n' admet pas en effet qu' une affaire soit jugée aussitôt après $l^{\prime}$ intervention de l' assignation, c'est parce l' on que la personne assignée dispose d' un certain délai pour organiser sa défense.

$$
\text { راجع "كوشيه" في مرجعه السابق الإشارة إليه، الموضع السابق. }
$$


أن يشملها القاضي بأسباب حكمه؛ لأن المشر ع إذ قرر اعتبار عرض الخصوم

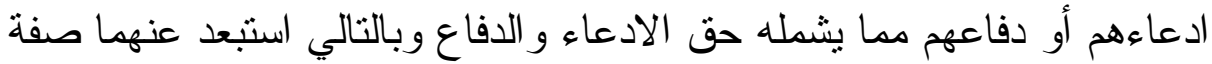
السب أو القذف فما ذلك إلا ليتمكن القاضي من استبيان وجه الحقيقة في وقائع

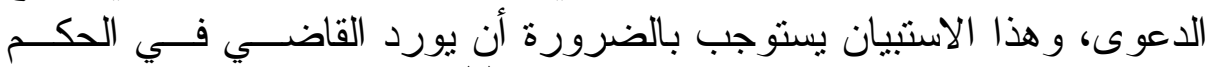
أسباب اقتتاعه بما انتهى إلبه في منطوق الحكم)(').

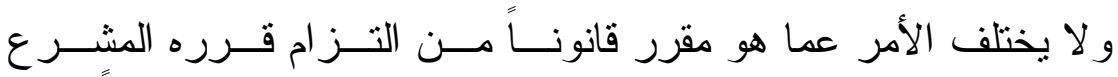

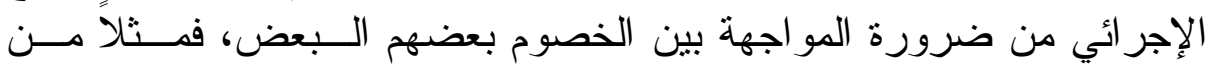
المقرر في حكم المادة 10 من قانون المر افعات الفرنسي أنه:

les parties doivent se faire connaître mutuellement en temps utile les moyens de fait sur lesquels elles fondent leurs prétentions, les éléments de preuve qu' elles produisent et les moyens de droit qu' elles invoquent, afin que chacune soit à même d' organiser sa défense.

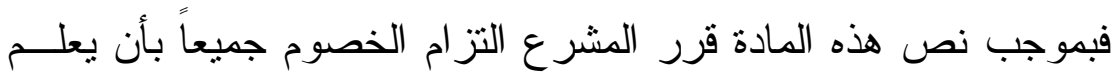

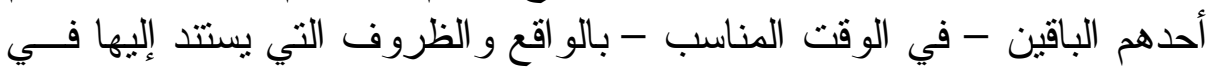

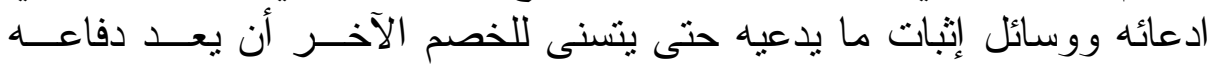
بشأنها، و إذا كان المشر ع قد قصد بذلك التعاون و العلم المنبادل بين الخصـــوم بما يحقق استجلاء أوجه الادعاء و عناصر الدفاع فإن الهدف غير المباشر من هذا العلم المتبادل التي يتم تحت نظر القاضي وفي جلسات المحاكمة أن بتمكن القاضي نفسه من تسبيب أحكامه عند استظهار وجه الحق فـي القضــية، و لا

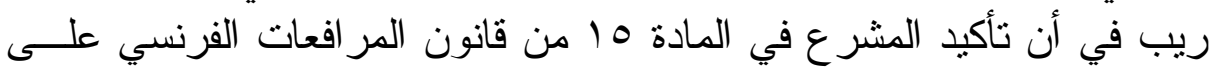
éléments que أن يكون العلم و التو اصل بين الخصوم بشأن الوقائع المنتجة فين les parties produisent تتصرف إليه الأسباب أو الحيثبات اللازمة لسلامة ولصحة الحكم القضائي (؟).

(') كذللك فإن المشرع المصري كان قد كفل للخصوم حق العلم وحرية المر افعة والادعـــاء

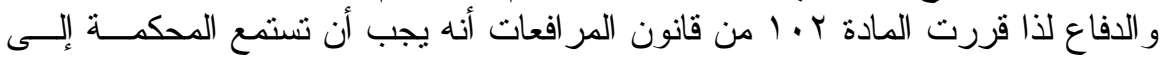

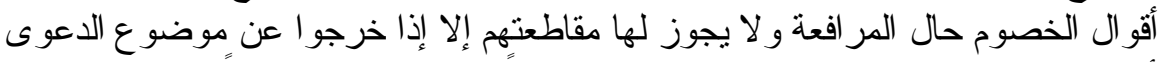

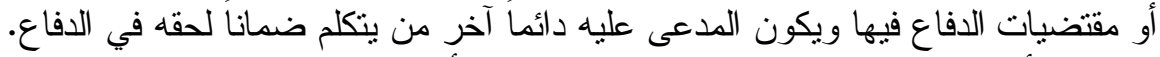

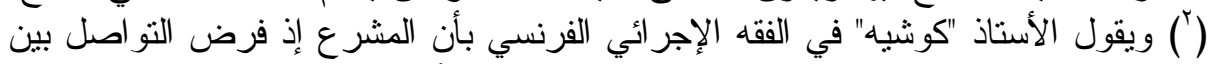
الخصوم في القضية فإنه قد بهدف بذللك إلى استظهار أوجه الإنه الادعاء المقدمة من المدئي

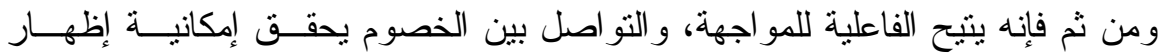

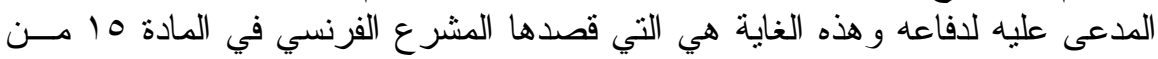




\section{المطلب الخامس \\ تسبيب الأحكام القضائية ضماتة لتفهم المحكمة

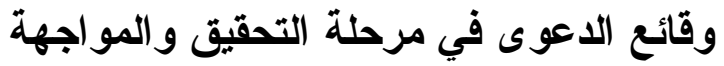

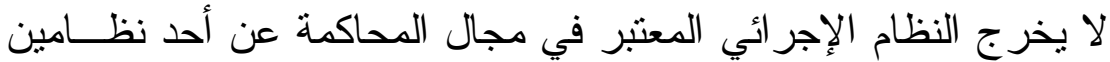

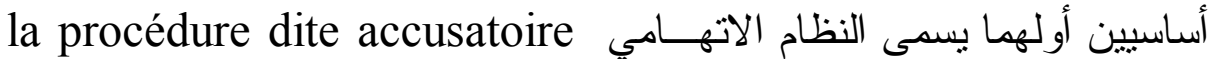
و الآخر هو النظام التنقيبي la procédure dite inquisitoire (') وخاصـية النية

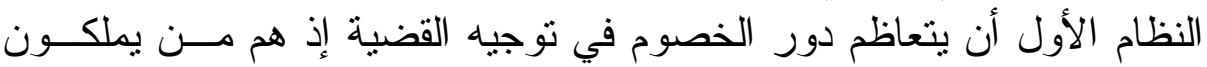

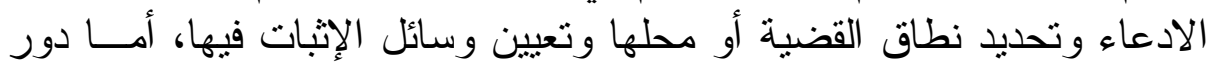

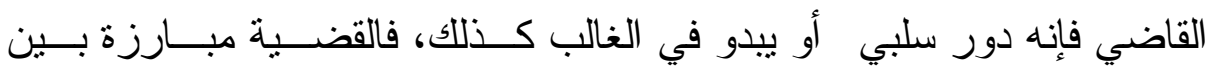

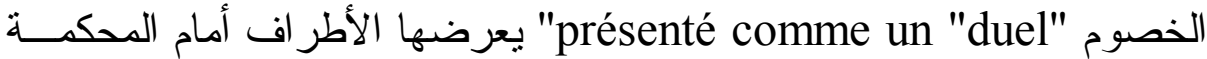

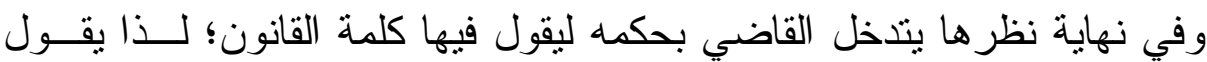
الأستاذ "كوشيه" عن هذا الدور المسند للقاضي بأنه:

$\mathrm{C}^{\prime}$ est dire que le juge joue un rôle passif, ou relativement

قانون المر افعات و هو أيضاً ما استهففه بأن يكون عرض حجج الادعاء و الــدفاع فـي

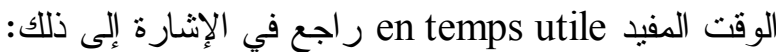

Gérard Couchez; op. cit. p. 186 No 242.

و انظر في تحليل عبارة في الوقت المناسب التي ذكرها المشرع الفرنسي في المادة 10

Perrot; Rev, trim. Dr. Civ. 1982. 466 et 1983.194 et 590

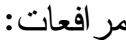

Bolard; les juges et les droits de la défense etudes Bellet. P 49 etss.

Martin; principes directeurs du procès. Rep. Dalloz. Pr. Civ. (') راجعا: (')

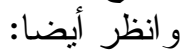

G. Bolard; les principes directeurs du procès dans le droit positif depuis Henri Motulsky; J.C.P. 1993. I. 3693.

$$
\text { و انظر أيضا: }
$$

G. Bolard; le nouveau code de procédure civile français, Mélanges J. Skapski 1994. p. 9.

$$
\text { ور اجع أيضا: }
$$

J. Normand; principes directeurs du procès. J. Class. Pr. Civ. Fasc. 150 à 152.

$$
\text { ور اجع للأستاذ "مارنين" أيضاً في المجلة الفصلية للقانون المدني: }
$$

R. Martin; un autre procès possible ou est - il interdit de rever? Rev.

Trim. Dr. Civ. 1994. 557. 
passif, quant au déroulement du procès. ${ }^{(1)}$

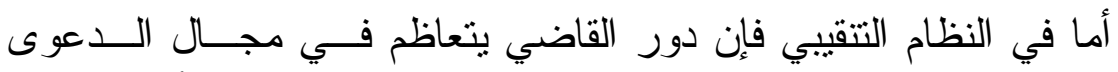

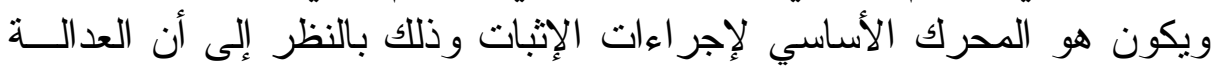

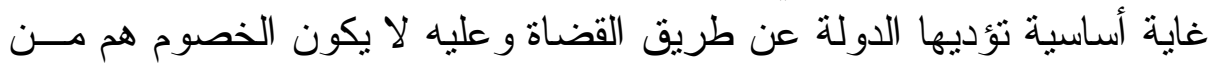

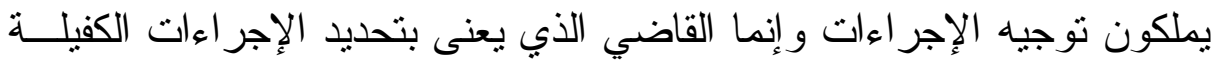

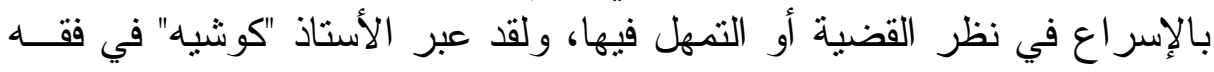
المر افعات الفرنسي عن هذا الدور المسند إلى القاضي بقوله:

Dans ce système, l' accent est mis sur le fait que la justice est un service public, que la marche de l'instance doit donc dépendre, non du bon vouloir des parties, mais des initiative du juge. ${ }^{(2)}$

و على كل حال فإنه قلما يقنع المشرع الإجر ائي في كل الأنظمة الإجر ائيــــة

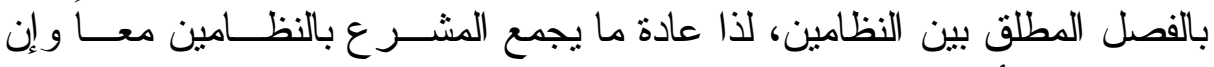

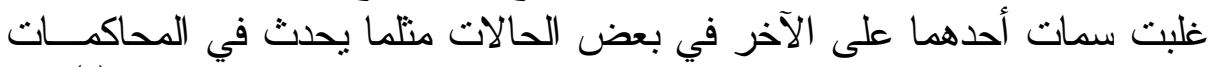

المدنية أو الجنائية حيث يغلب النظام الاتهامي في الأول و التتقيبي في الثاني (r).

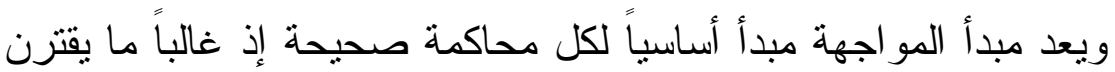

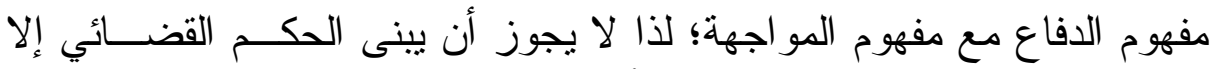

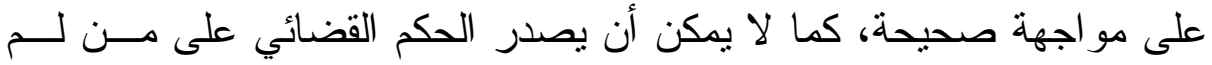

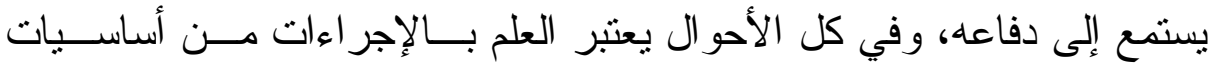

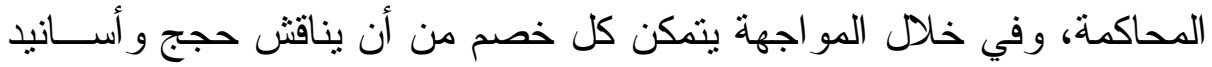

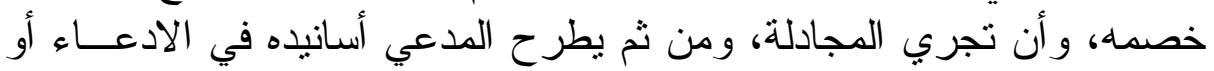

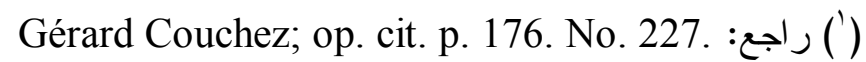

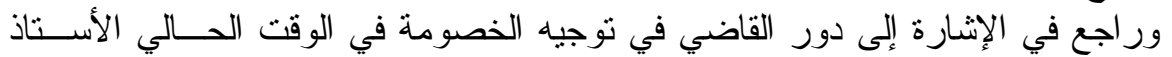

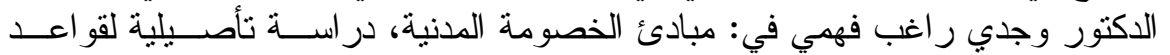

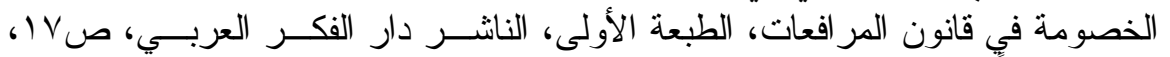

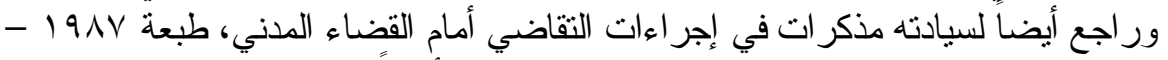

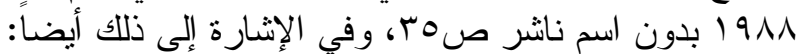
H. Motulsky: la reforme du code de procédure civil par le décret du 13 octobre 1965 et les principes directeurs du procès Dalloz $1973 \mathrm{p}$. 130 No. 77.

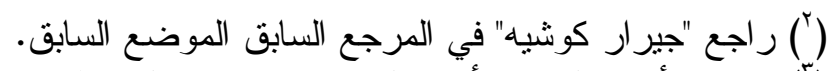

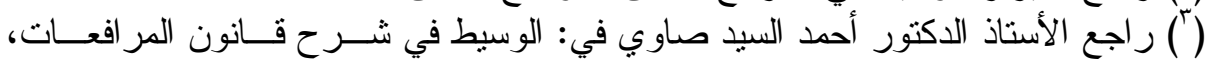

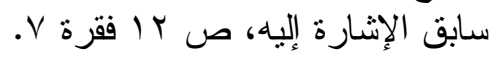




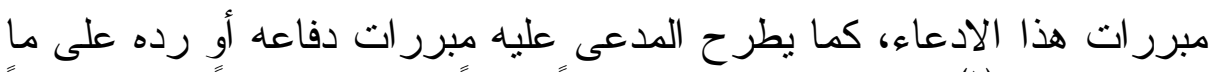

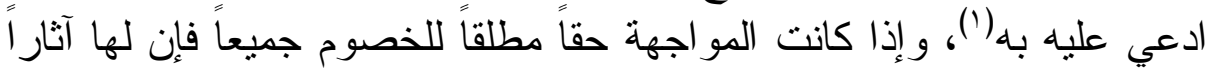

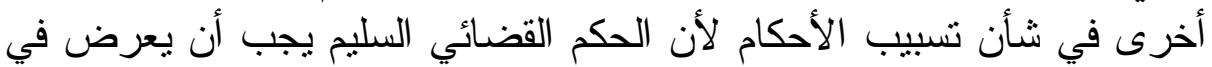

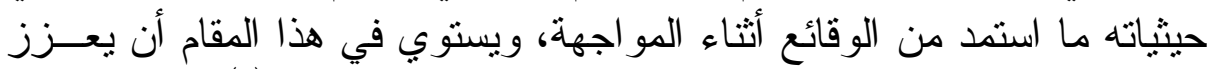

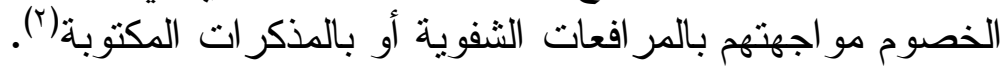

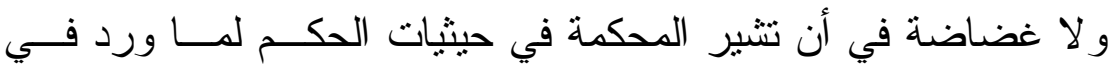

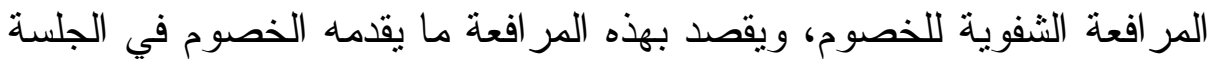

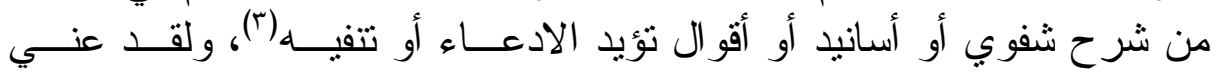

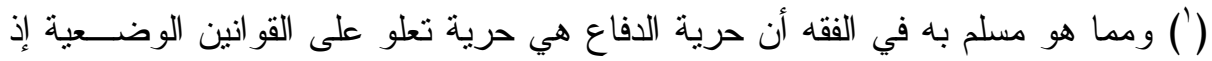

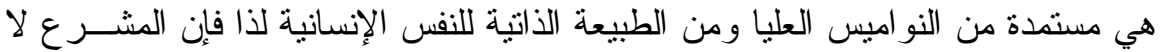

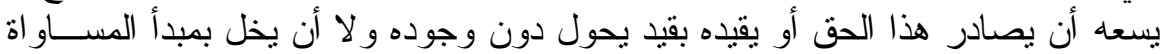

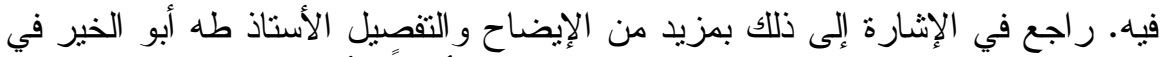

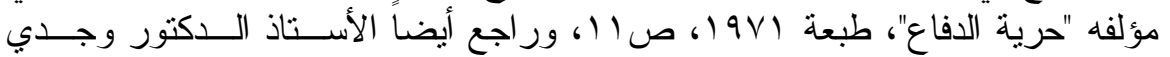

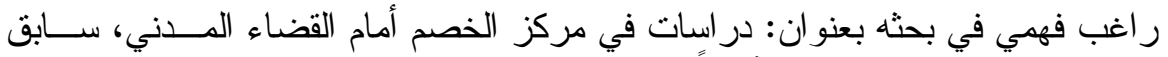

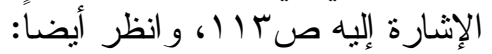

Smith and Bailley; on the modern English legal system $3^{\text {ed }}$ Edition. London 1995 p. 637.

$$
\text { وحيث يثير الفقيهان إلى أنه: }
$$

Each citizen needs to be aware of his or her right to use the tribunal where appropriate, the information given in official publications and forms must be comprehensible.

John Rawls, A theory of justice. Oxford university press. P. 201.

$$
\text { ور اجع أيضا: }
$$

و انظر كذلك الدكتور موسى مصطفى شحاتة في: "مبدأ حق الإنسان في محاكمة عادلـــة

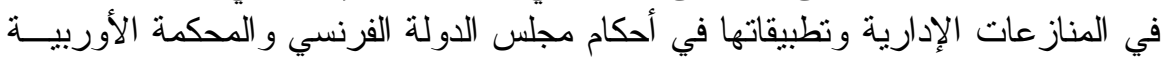

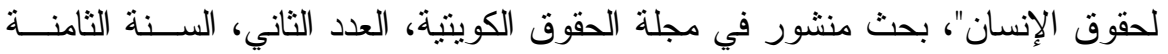

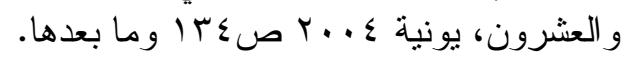

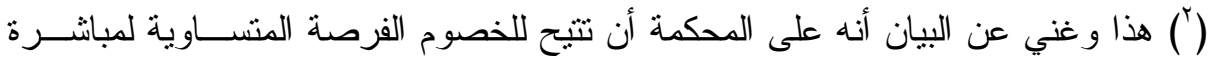

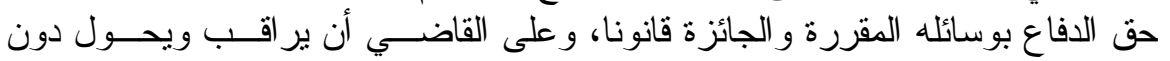
الانتقاص من هذه الحرية. راجع:

Normand; les droits de la defense devant les juridictions du travail. 1988. p. 51.

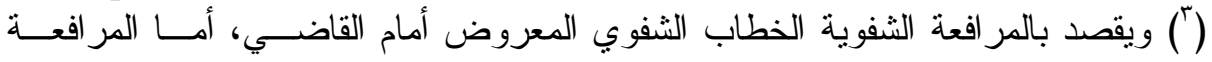

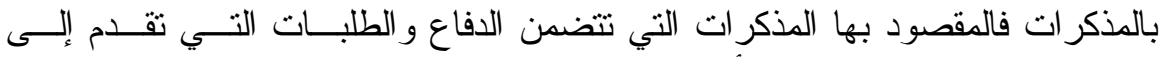

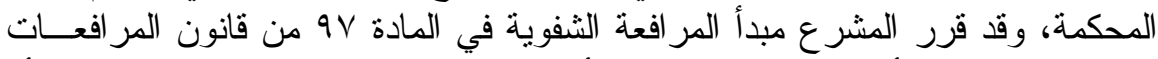

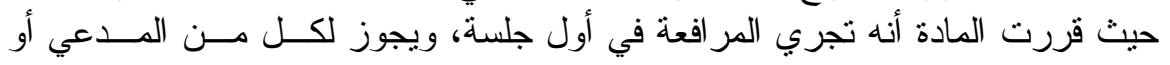




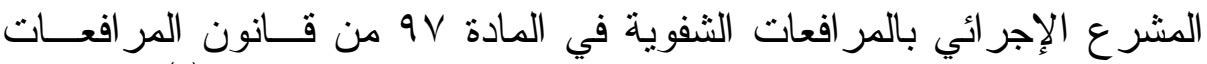

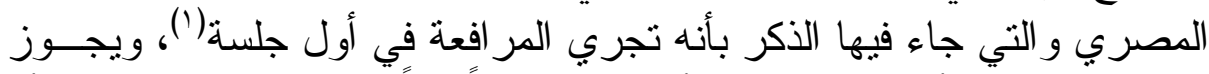

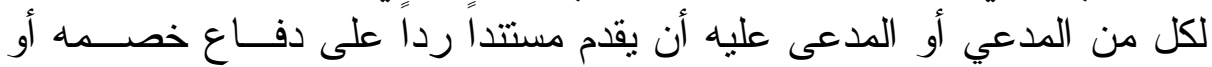

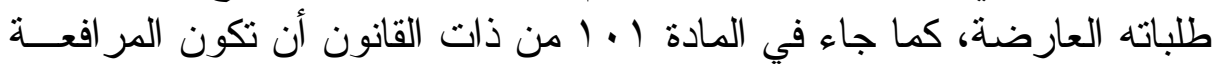

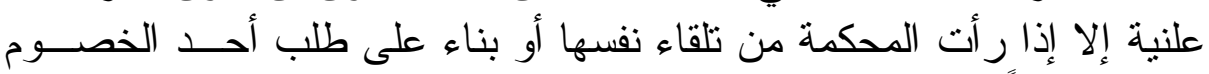

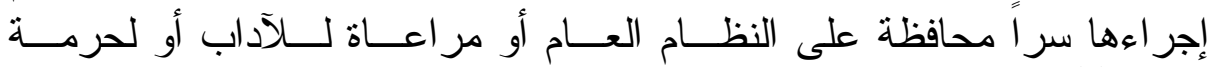

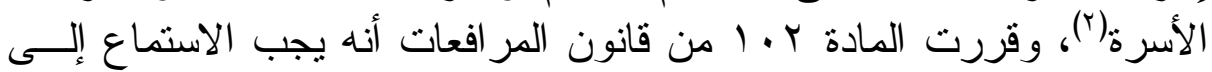

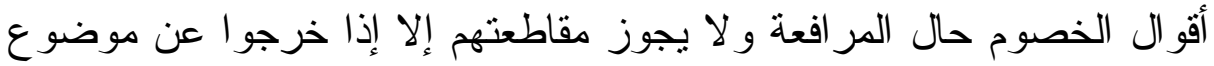
الدعوى أو مقتضيات الدفاع ويكون المدعى عليه آخر من ينكلم.

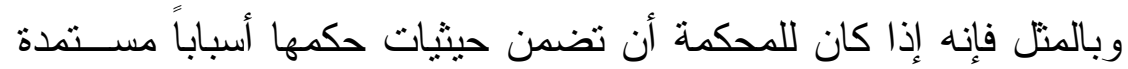

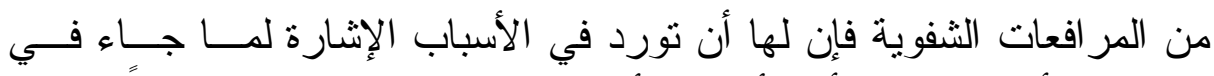

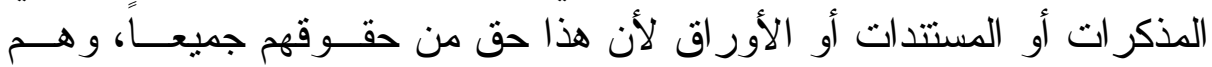

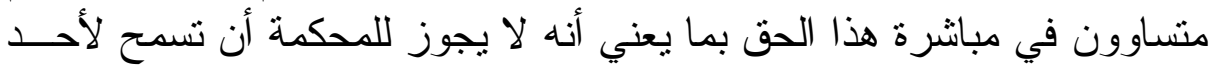

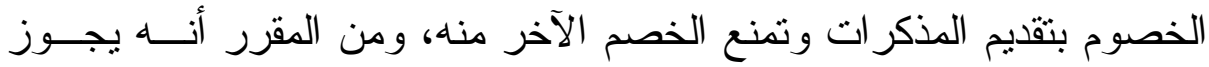

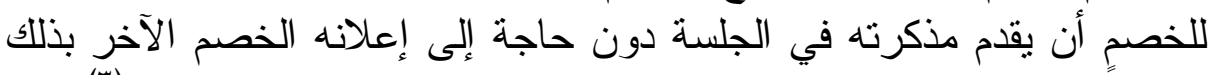

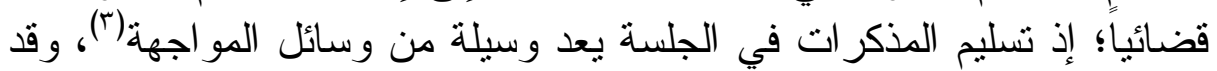

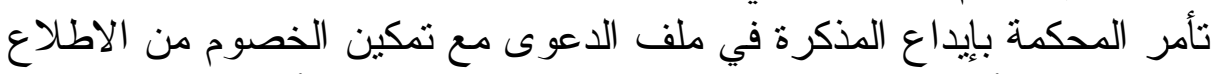

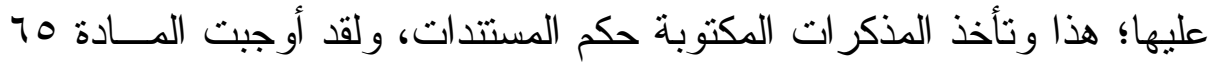

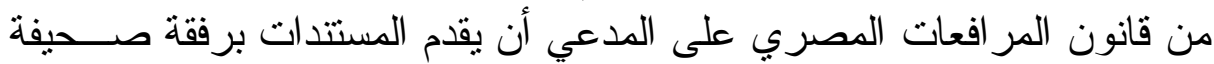

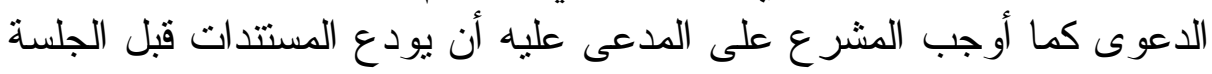

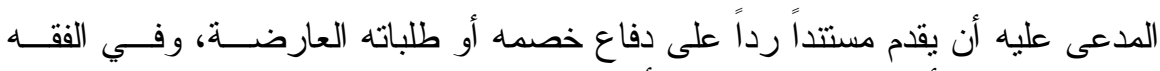
الإنجليزي قال الأستاذان سميث وبيلي أنه: At the Hearing, the chairman of the tribunal has the difficult Task of ensuring that a sufficient level of informality is achieved so that the parties do not feel inhibited in putting their respective Cases

راجع: . Smith and Bailey. P. (') راجع في النظام الإجر ائي الفرنسي:

P. Hebraud; l' élément ecrit et l' élément oral, Etude de droit comparé. Paris 1959 p. 313.

(') ر اجع رسالتتا للاكتور اه بعنو ان: حقوق الإنسان الإجر ائية، رسالة سابق الإشارة إليهــا،

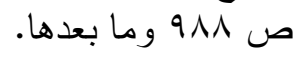

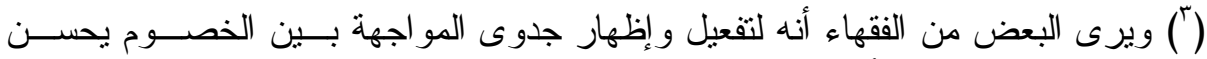

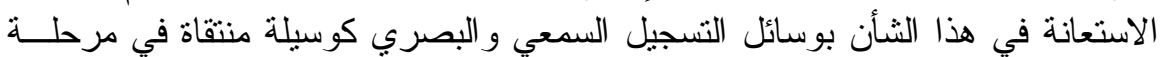
التحقيق أو اللمحاكمة. 
المحددة لنظر الدعوى بثلاثة أيام على الأقل، وللخصوم أن يتقدمو ا بالمذكر ات

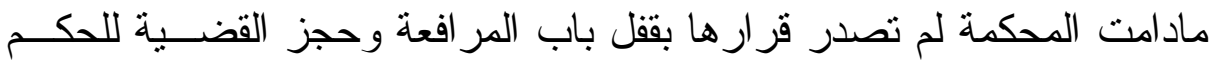

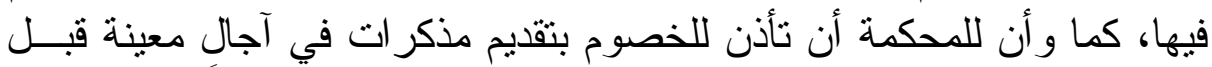

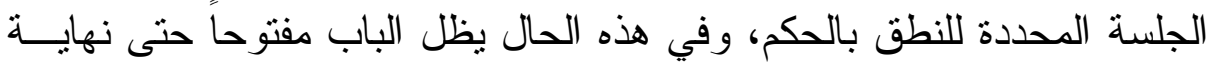

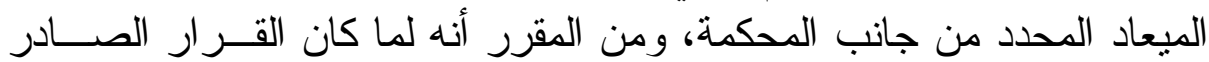

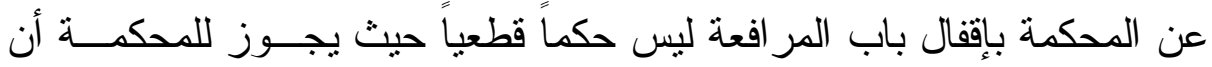

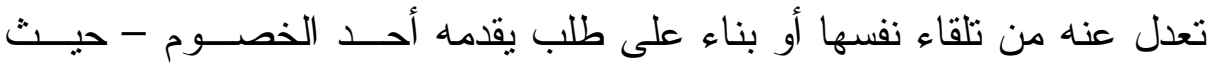

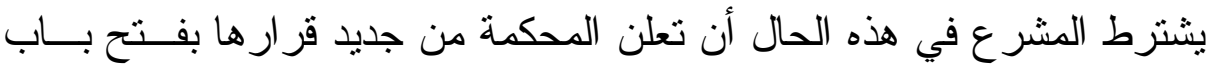

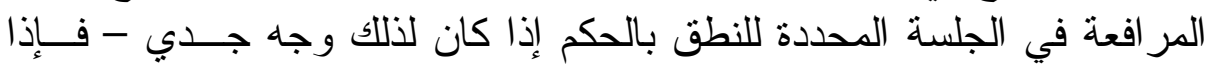

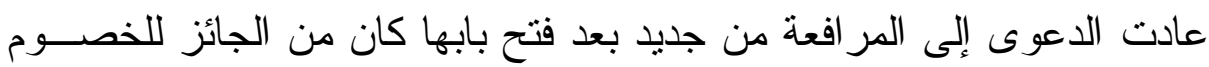

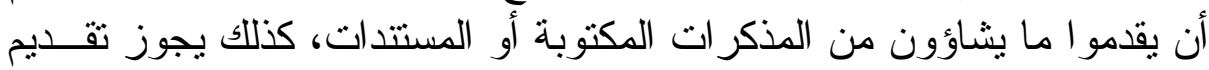

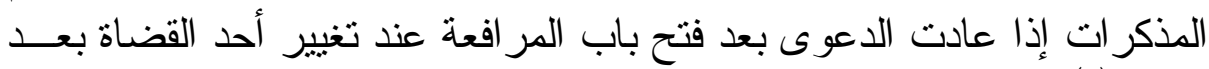
الإقفال (') (الثذكرات

و إذا كان للخصم - كل خصم - أن يتقدم بما يرى من المستتدات التـي

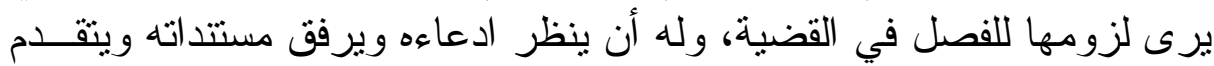

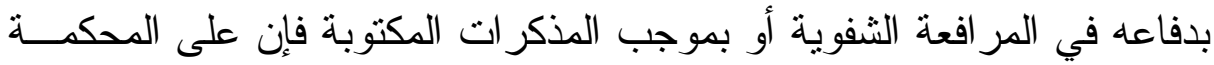

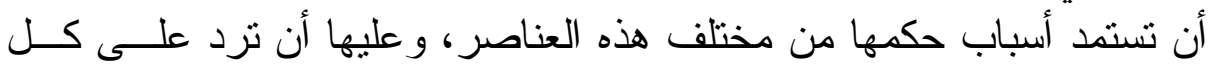

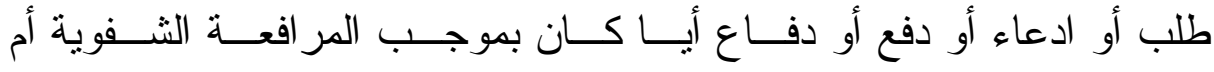

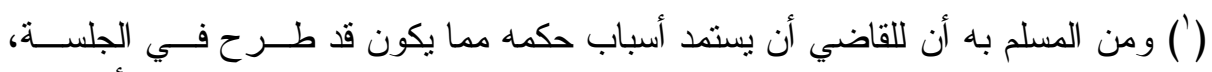

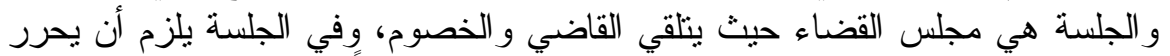

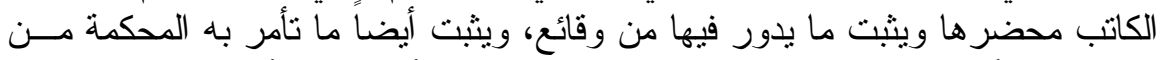

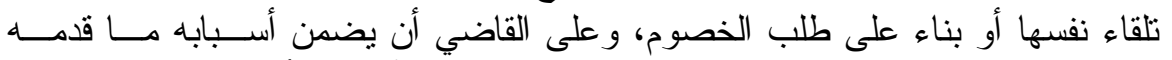

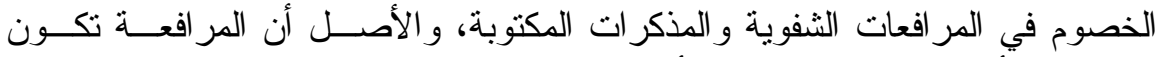

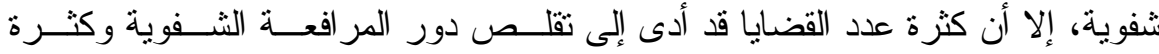

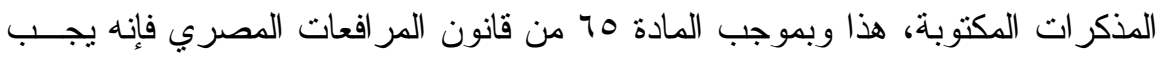

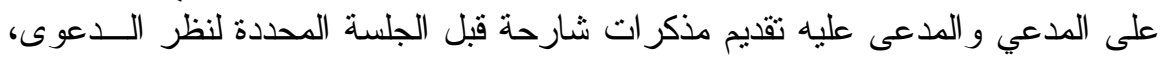

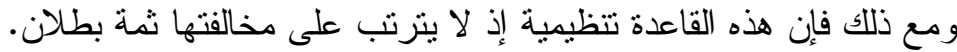

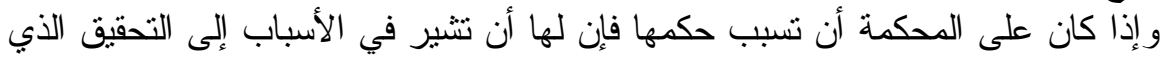

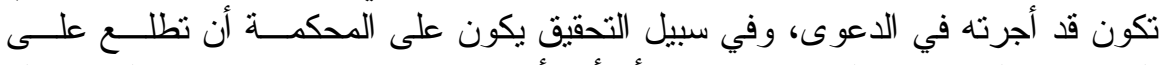

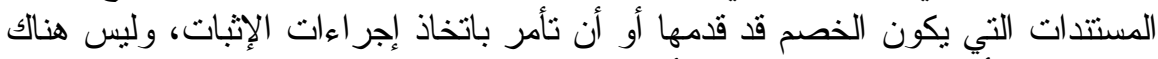

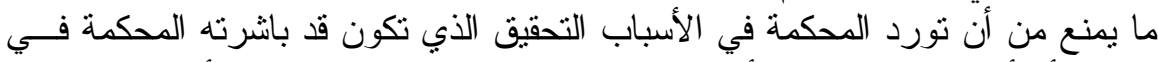

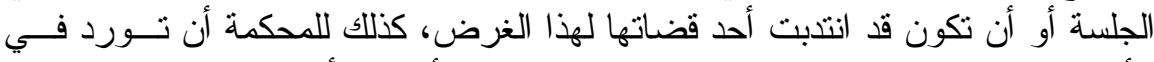

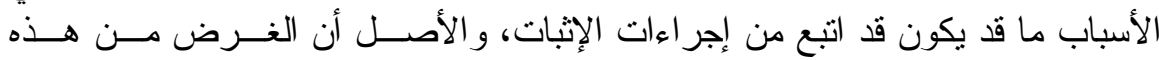

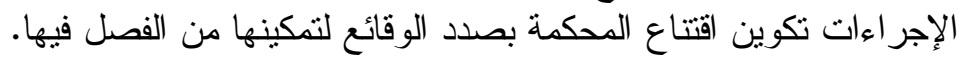




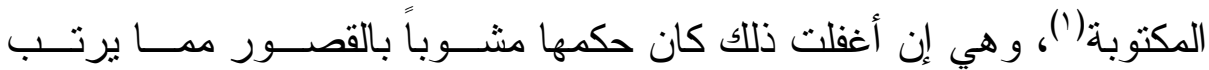

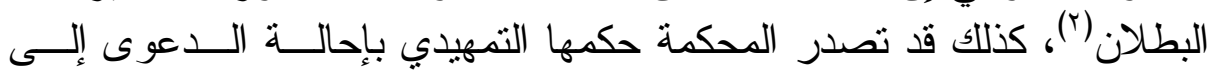

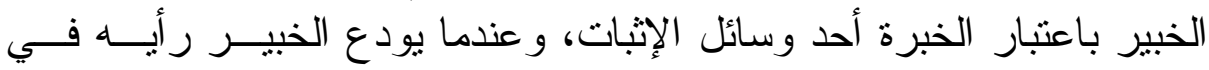

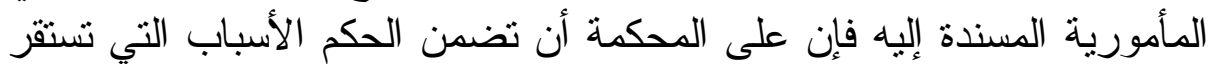

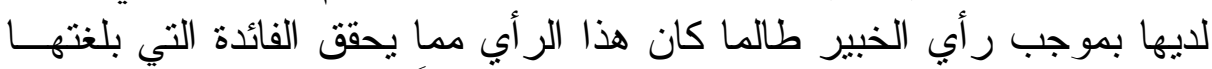

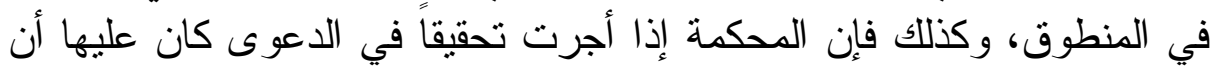

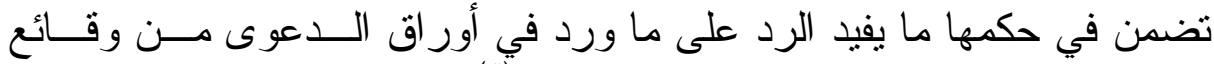

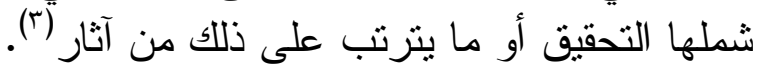

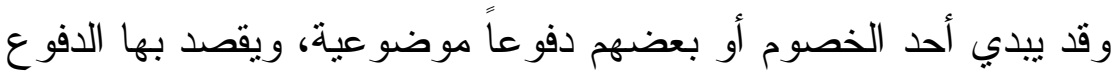

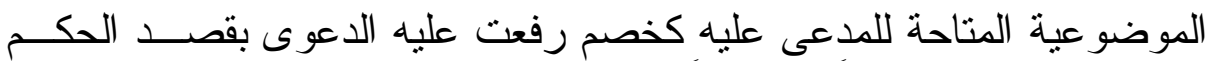

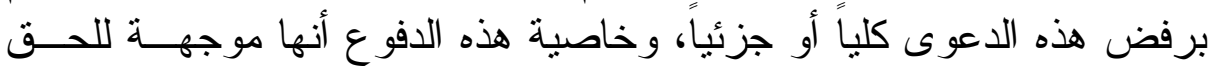

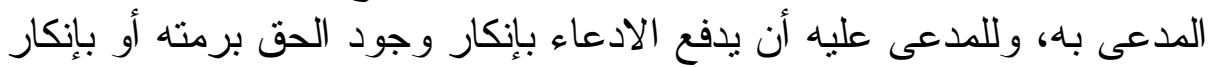

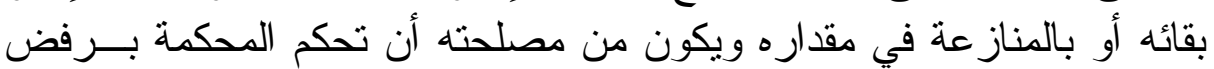

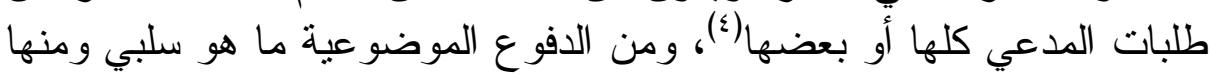

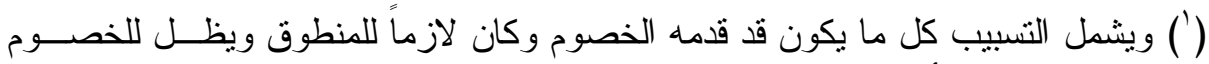

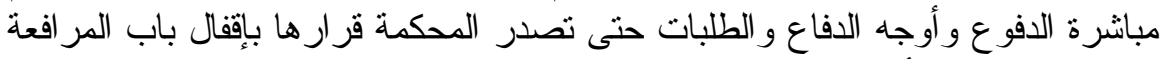

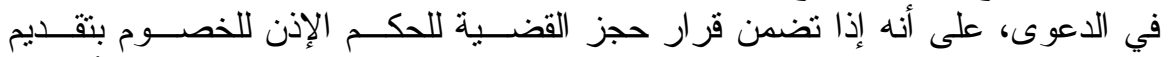

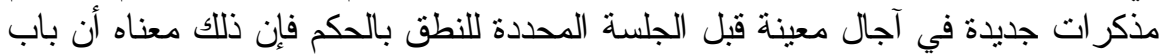

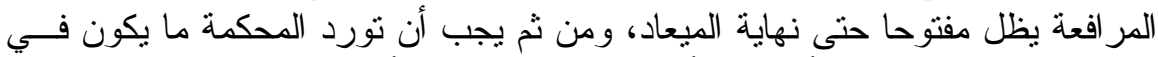

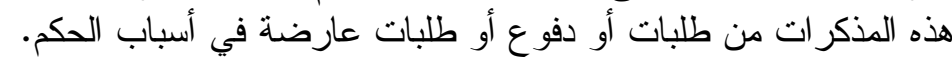

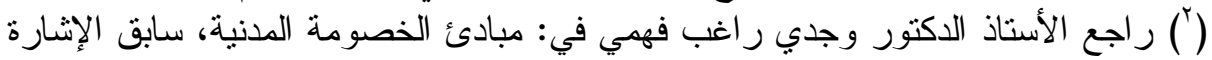
إليه، ص • بr وما بعدها، ور اجع في ذات المعنى في النظام الإجر ائي الفرنسي: Gérard Couchez; op. cit. p. 209 No 273.

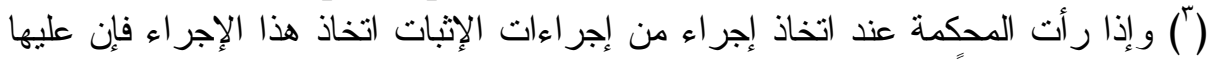

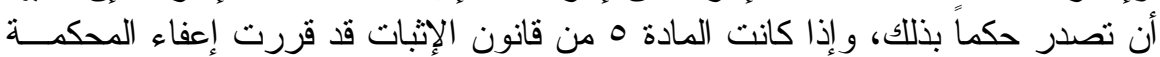

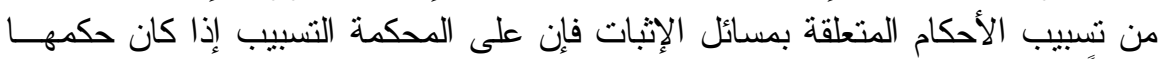

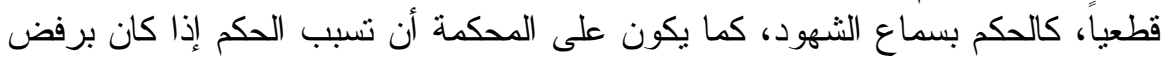

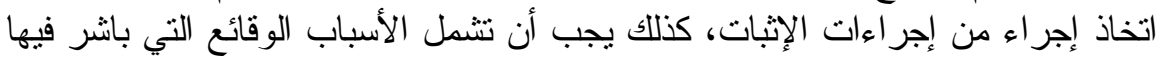

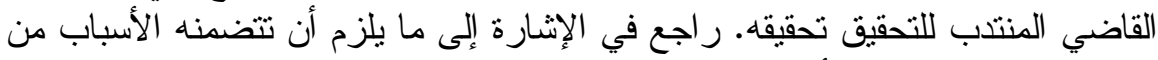

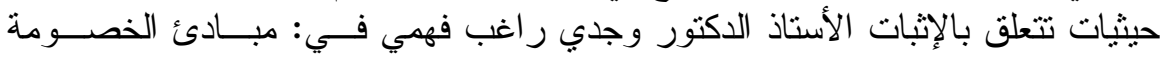

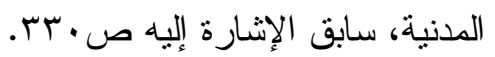

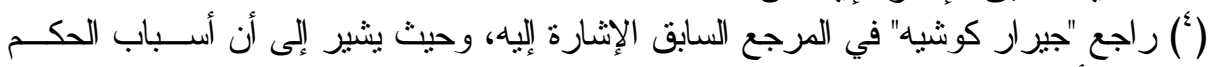

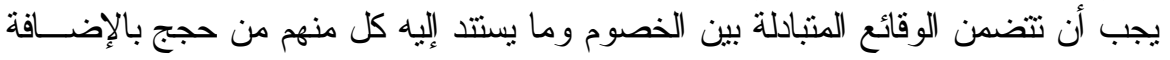

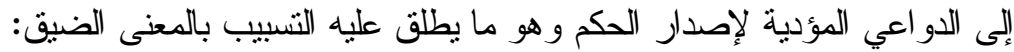
La partie motifs du jugement comprend à la vèrité deux séries d' 
ما هو إيجابي ومن مؤدى الدفع الإيجابي أن يتمسك المدعى عليه بو اقعــة مــــا

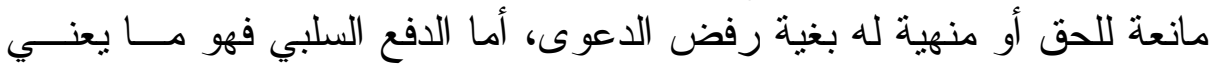

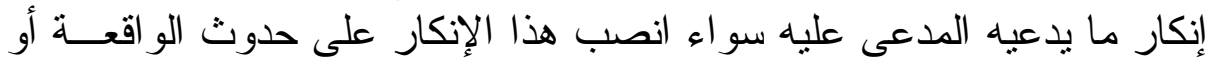

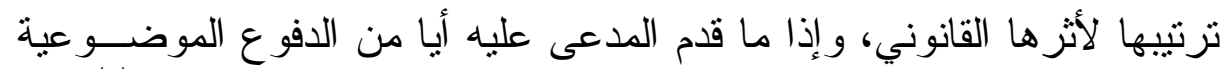

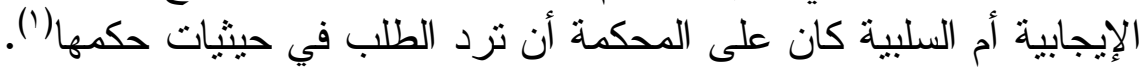

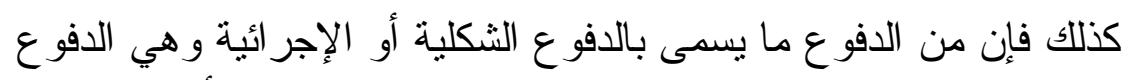

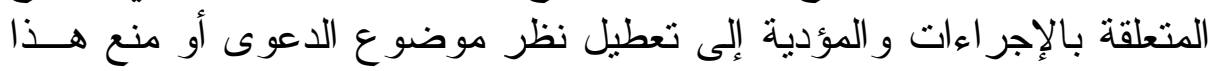

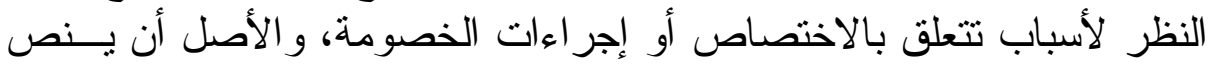

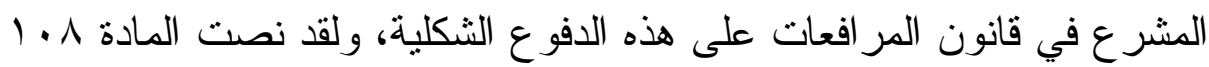

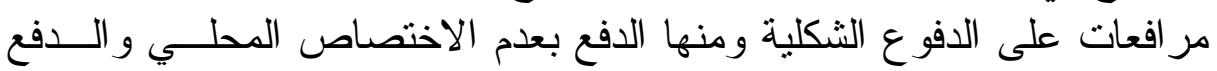

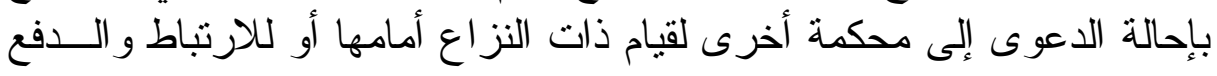

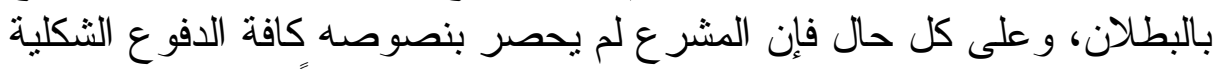

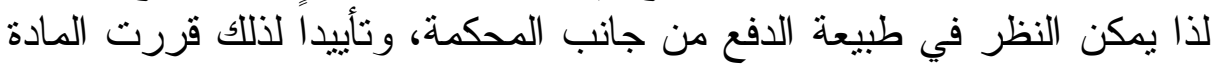

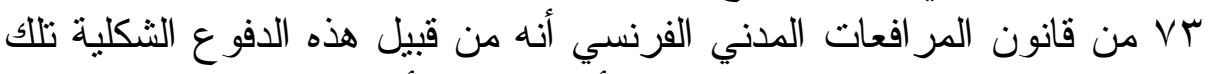

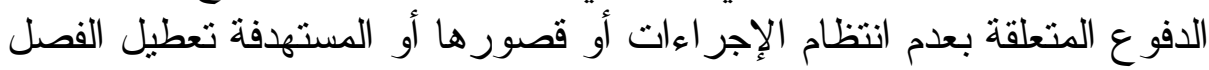

في الخصومة

Constitue une exception de procédure tout moyen qui tend soit à faire déclarer la procédure irrégulière ou éteinte, soit à en suspendre le cours. ${ }^{(2)}$

enonciations: c'est qu' en effet sont Tout d' abord exposés "succinctement les prétention respectives des parties et leurs moyents" puis sont indinquées les raison (la motivation strico sensu) de la décision.

$$
\text { (') راجع في وجوب التسبيب الحقبقي في القضاء الفرنسي حكم نقض فرنسي: }
$$

Com. 18 juin 1985. Bull. Civ. IV, no 194 P. 162.

$$
\text { و انظر في لزوم كون الأسباب باللغة الفرنسية: }
$$

civ. $2^{\mathrm{e}}$, 22 Janv. 1989, Bull. Civ. II, no. 11. p. 5.

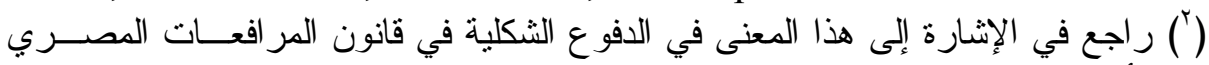

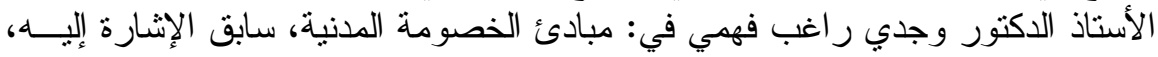

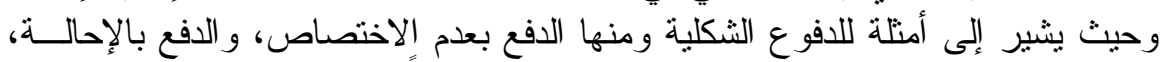

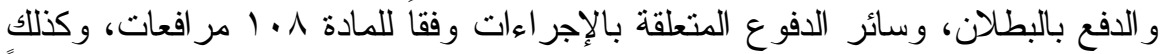

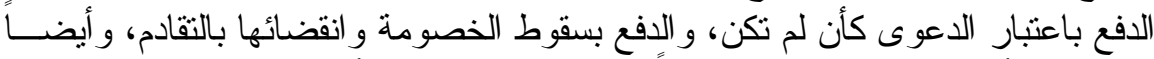

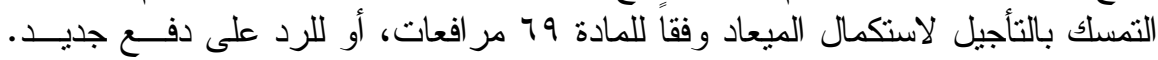

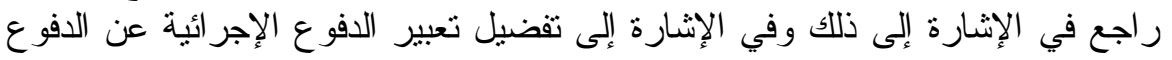

VIT V7T 
وخاصية الدفوع الثكلية أنها مكنة إجر ائية لا تتعلق بالدفوع الموضو عية

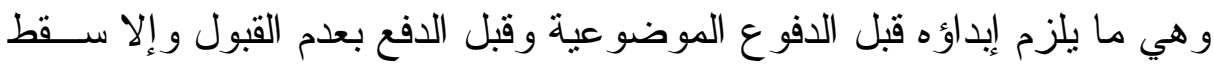

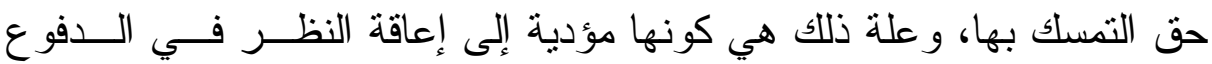

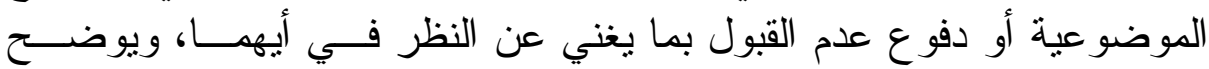

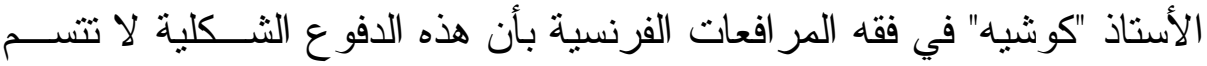

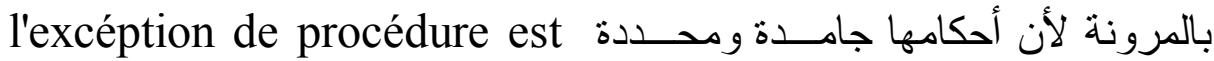
(') plus sévère que celui de la défense au fond

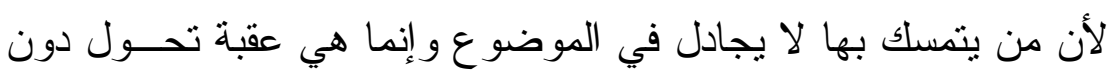

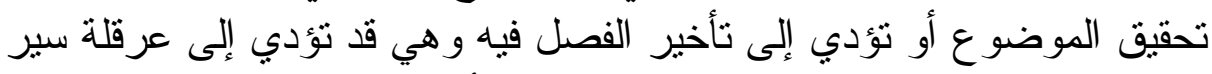

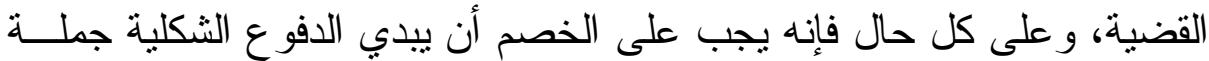

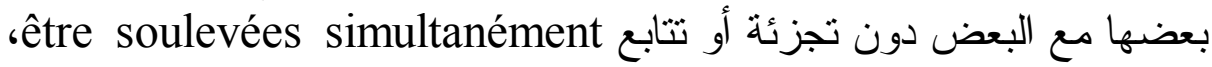

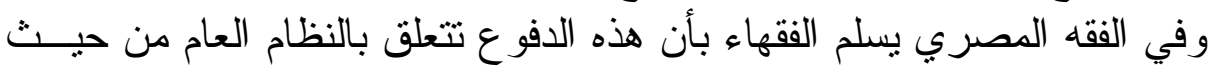

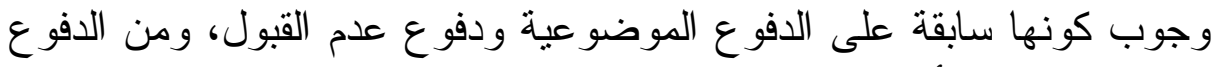

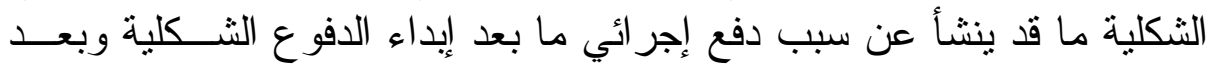

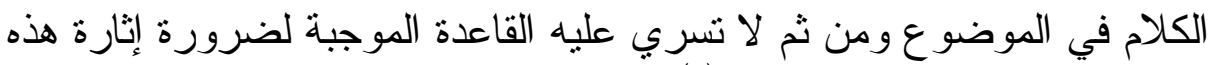

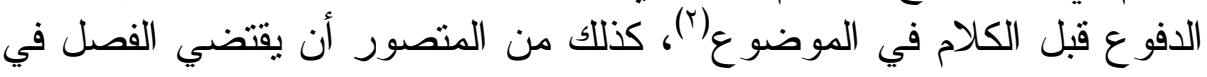

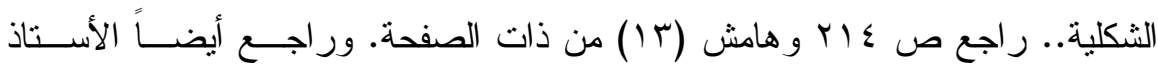

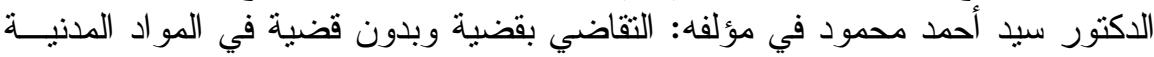

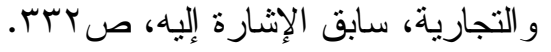

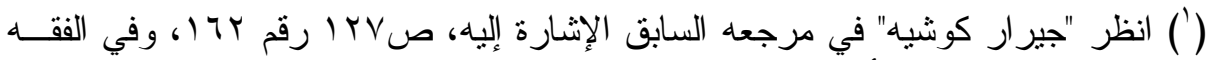

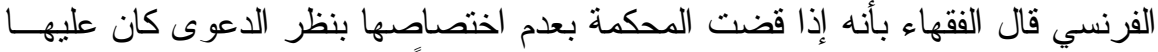

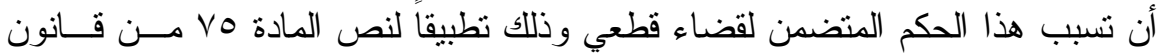
المر افعات الفرنسي، ويقول الأستاذ "كوشيه" أنه لا يكفي أن تصدر المنئ المكمة حكمها بعدم

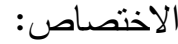

Il ne suffit pas de contester la compétence de la juridiction laquelle le demander Soumettre l' affaire; une attitude postive est requise, en ce sens que celui qui souléve l' exception "doit faire connaître dans tous les cas devant quelle juridiction" il "demande que l' affaire soit porteé.

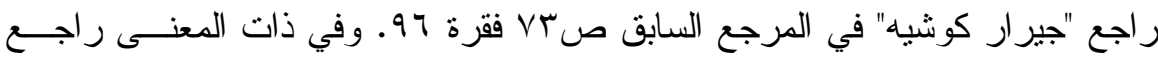

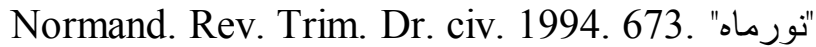

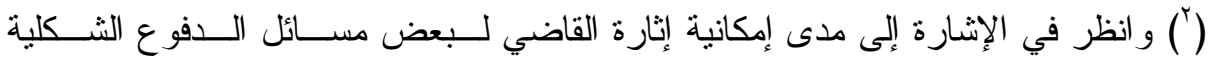

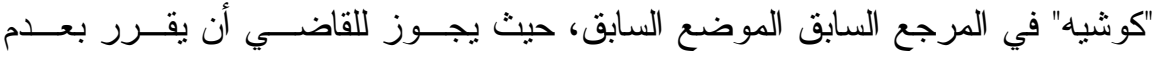

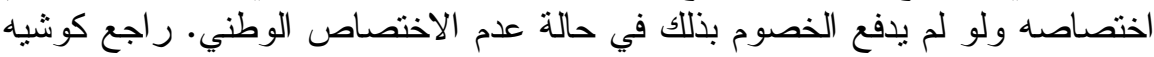

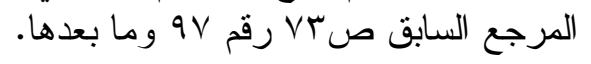




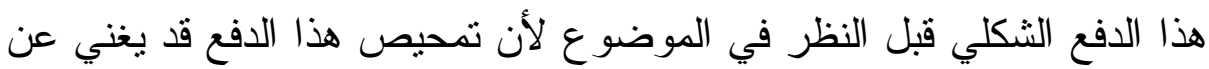

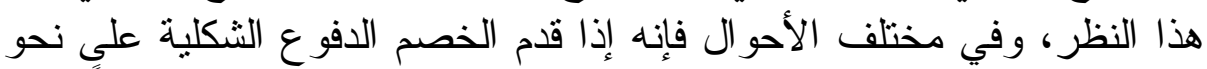

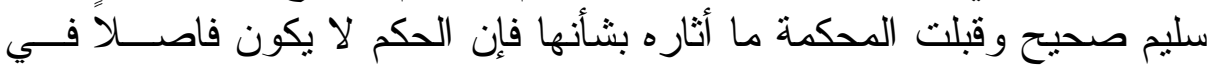

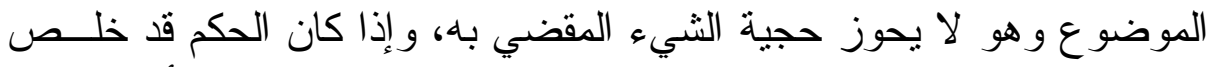

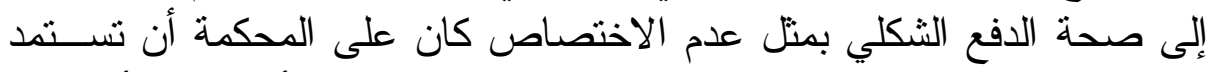

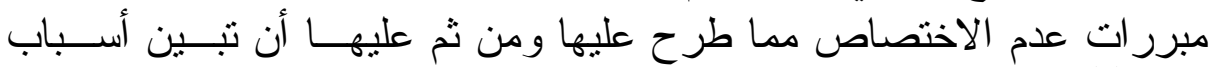
(الحكم (')

la fin de - ولا يختلف الأمر بالنسبة في مجال الدفوع بعـدم القبــول non recevoir

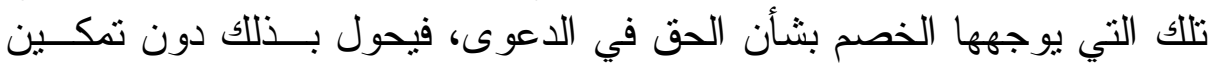

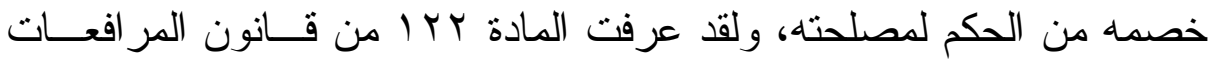
الفرنسي هذه الافوع بأنها:

Constitué une fin de non - recevoir tout moyen qui tend à faire déclarer l' adversaire irrecevable en sa demande, sans examen au fond, pour défaut de droit d' agir, tel le défaut de qualité, le défaut d' intérêt, la prescription, le délai préfix, la chose jugée. ${ }^{(2)}$

(') ومن المفيد أن نذكر في هذا المقام بالتقرقة بين الأحكام القطعية و الأحكام غير القطعية،

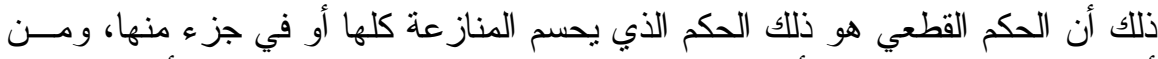

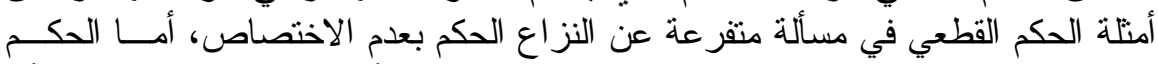

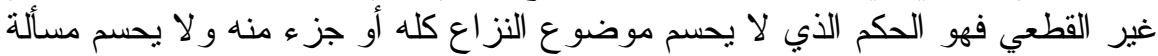

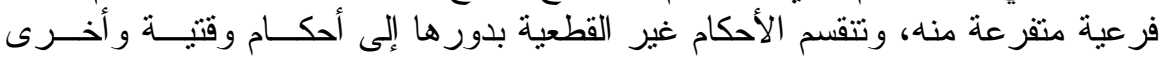

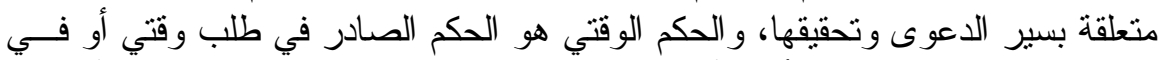

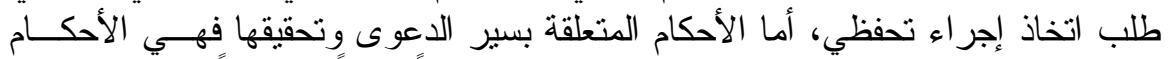

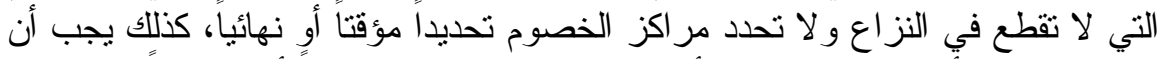

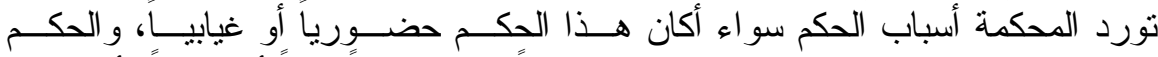
الحضوري هو الحكم الذي بكون الخصم حاضر أ فيه حضور أ فعلياً أو حكمياً، أما الحكم الغياب فهو الذي يصدر إذا لم يكن الخصم قد لد حضر .

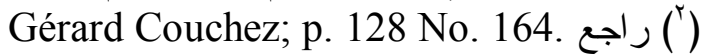

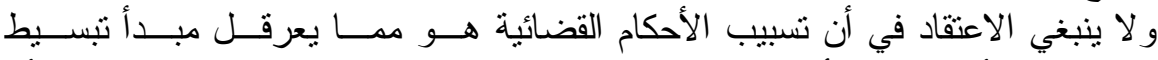

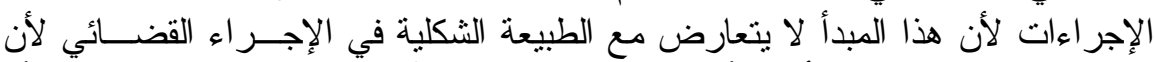

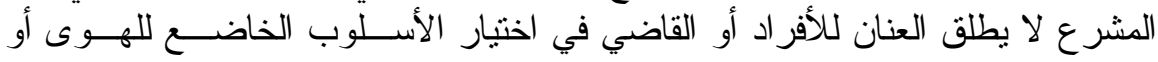

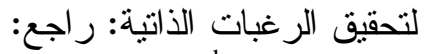

Robin C.A. White, the Englisl legal system in action $3^{\text {ed }}$ Edition. P. 239. 
وبالرغم من أن المشرع الإجر ائي عادة ما ينظم هذه الدفوع، فإنها مثنارٍ

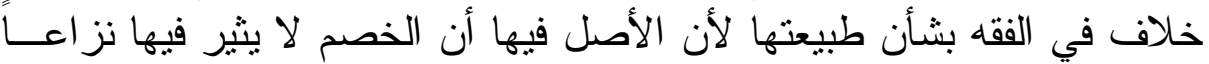

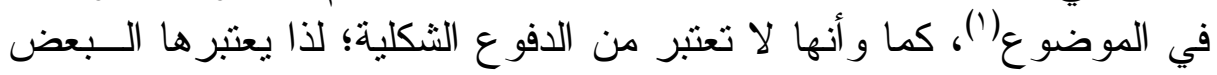

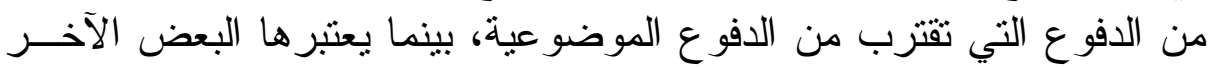

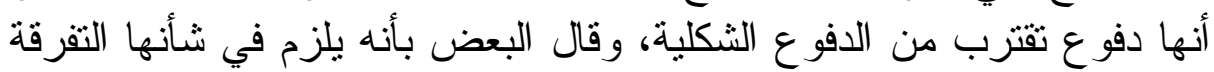

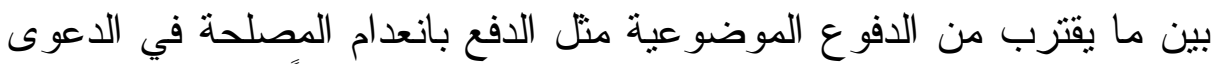

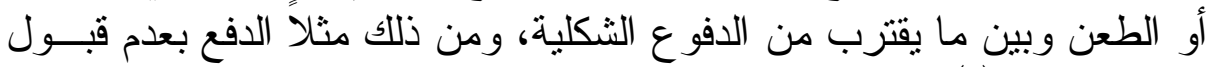

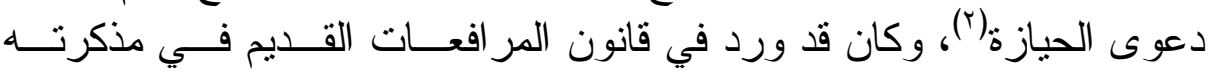

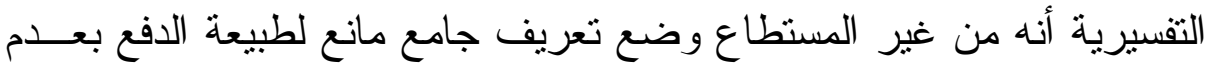

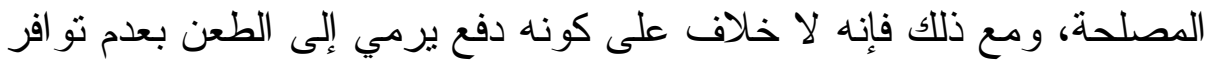

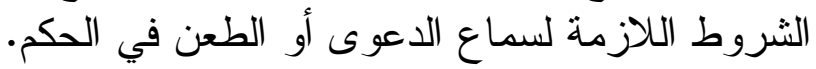

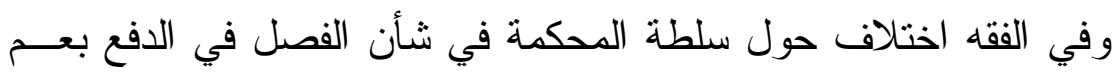

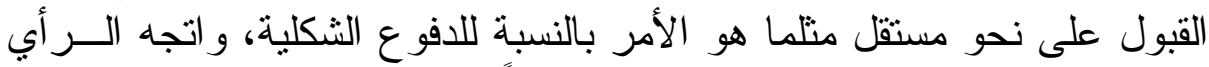

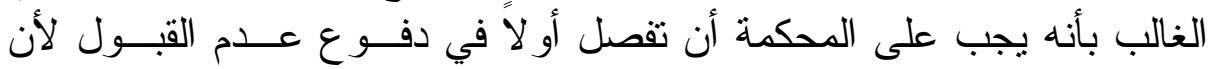

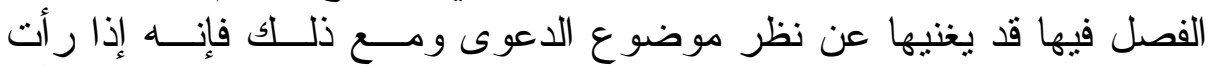

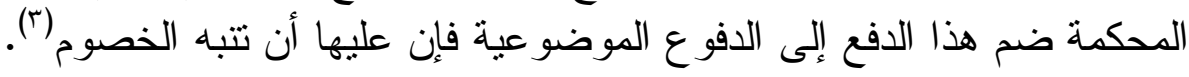

وراجع الأستاذ الدكتور وجدي راغب فهمي في رسالته السابق الإثـــارة إليهــا، ص £ عT، .

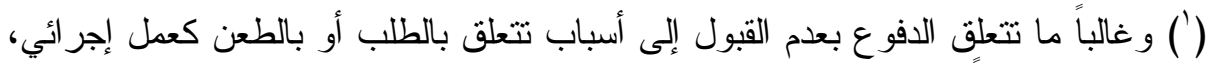

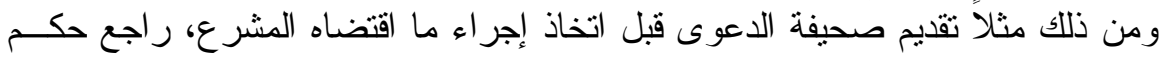

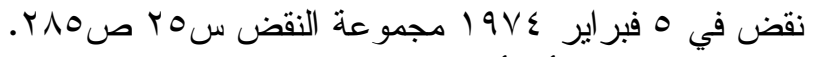

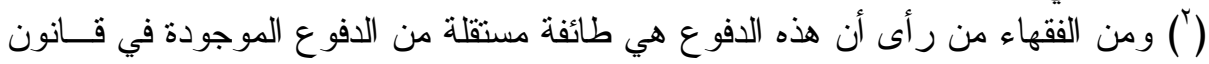

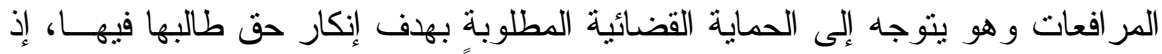

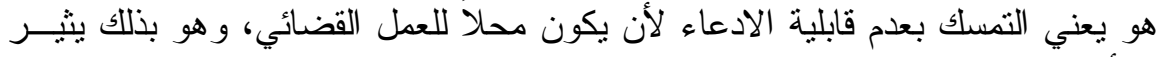

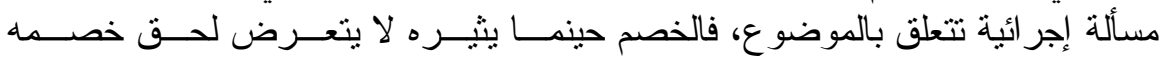

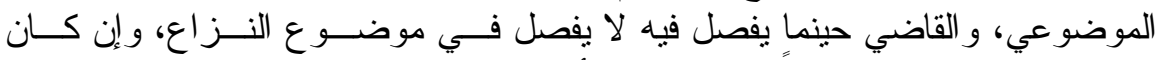

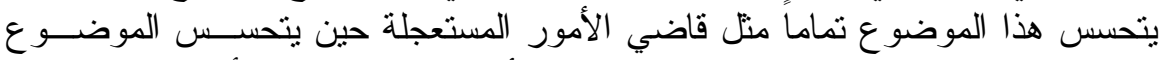

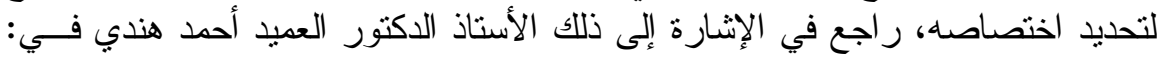

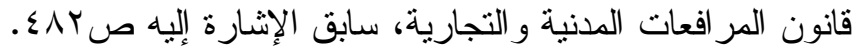

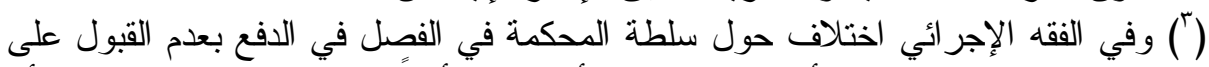

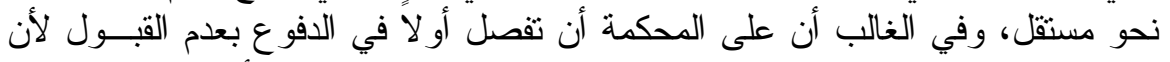

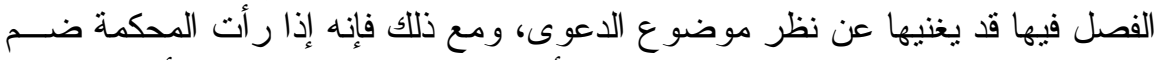

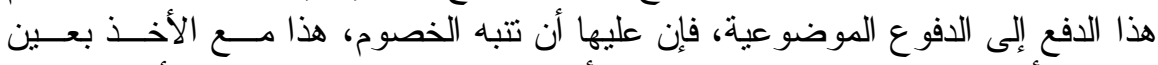

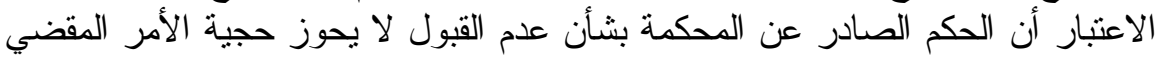


و إذا ما أثار الخصم دفعاً بعدم القبول يكون على المحكمة أن نوضح في

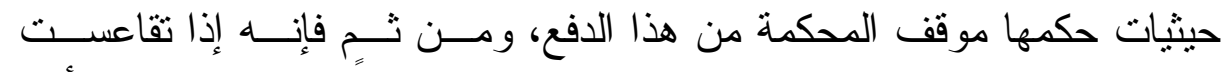
المحكمة عن إير اد الرد على هذا الدفع غدا الحكم مشوباً بالقصور مدا يستأهل الطعن فيه لهذا السبب. السعبه.

\section{المبحث الثالث \\ الأعمال القضائية اللازم تسبيبها

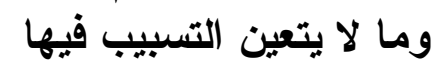

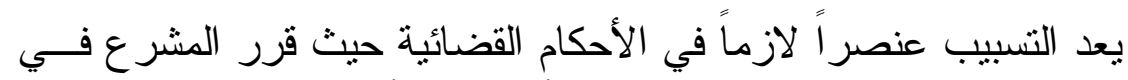

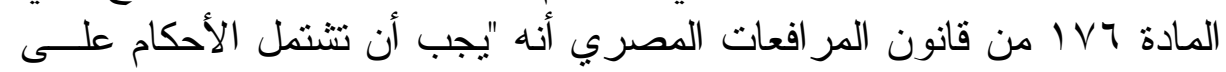

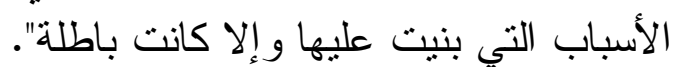

وبالرغم من أن المشرع قد عني بوجوب التسبيب في الأحكام القضــائية إلا أنه لم يحدد مدلول الأحكام القضائية ومن ثم فقد تولى الفقه الإجر ائي مهمة تعريف الحكم القضائي (1).

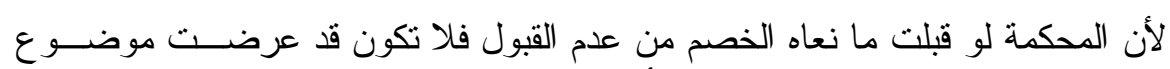

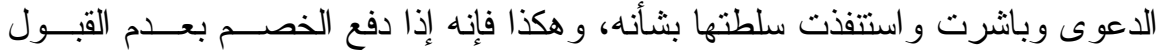

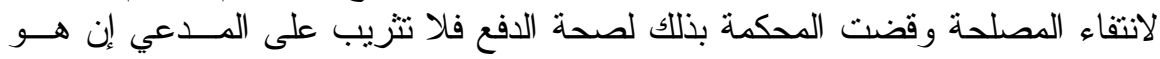
رفع دعو اه من جديد بعد تحقق مصلحته فيها.

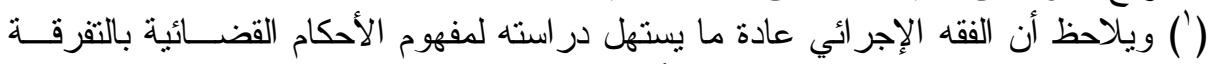

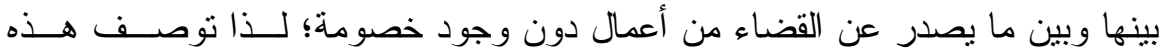

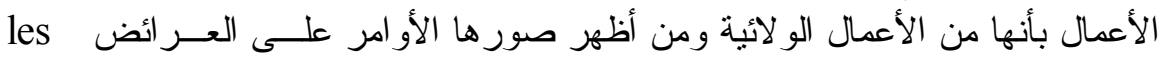
ordonnances sur reqûetes

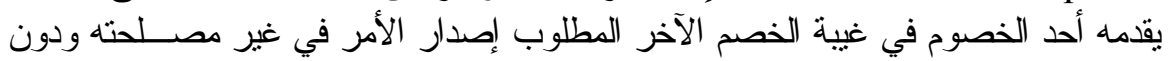

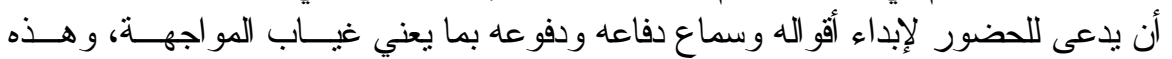

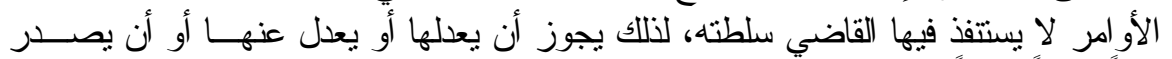

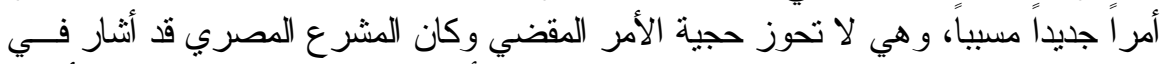

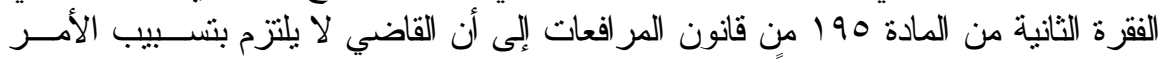

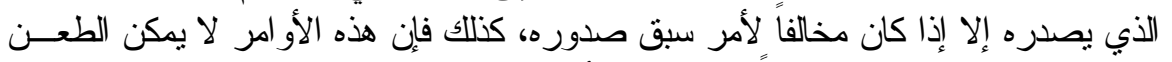

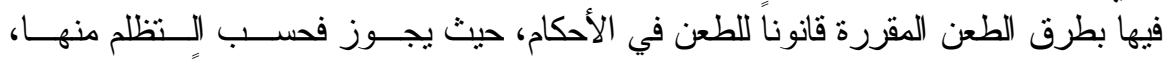

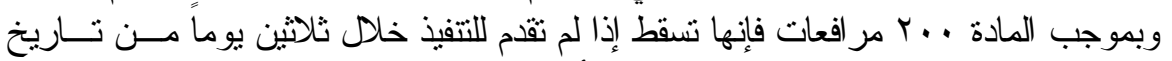

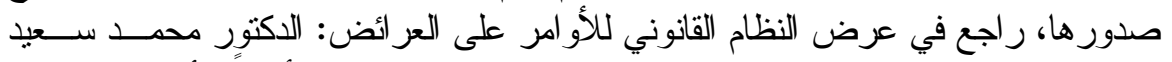

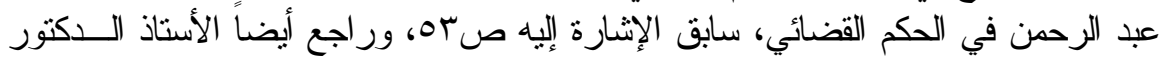

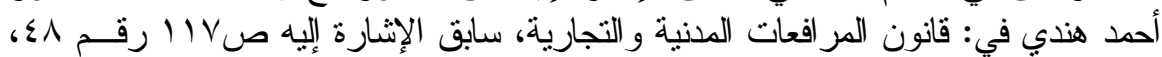

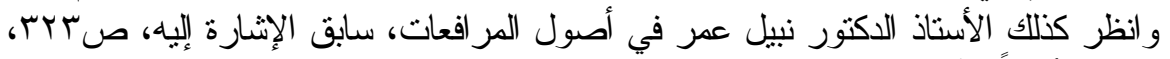

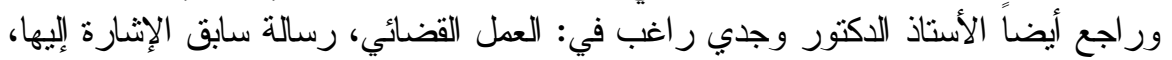

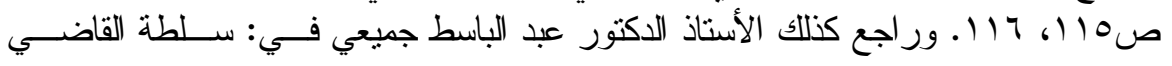




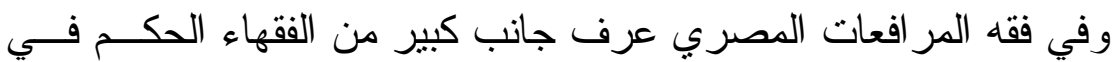

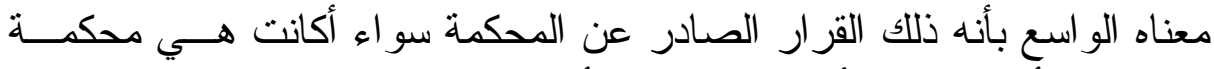

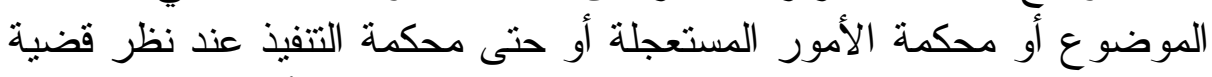

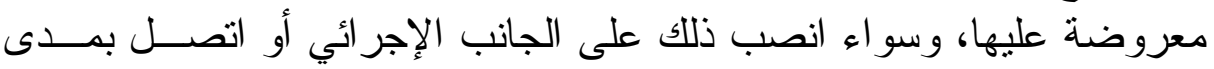

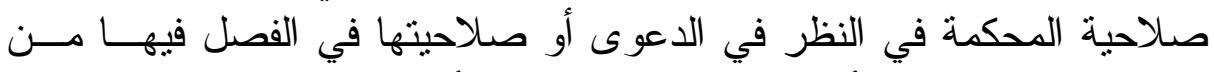

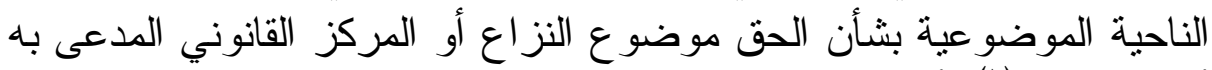

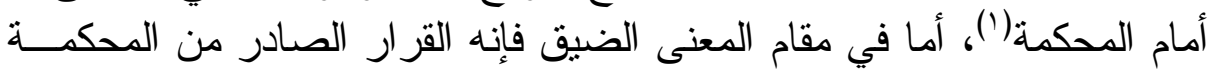

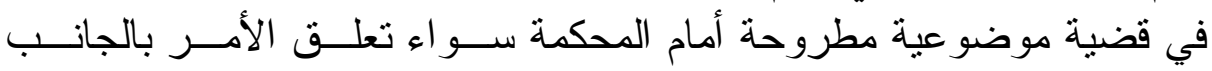

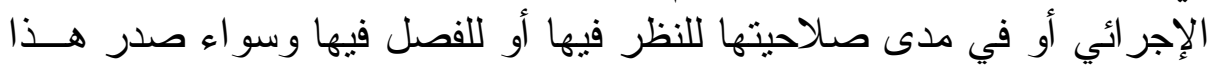

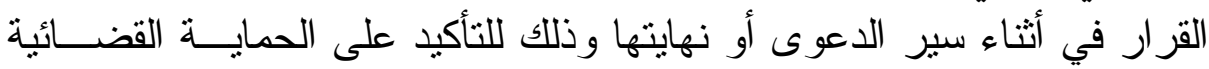

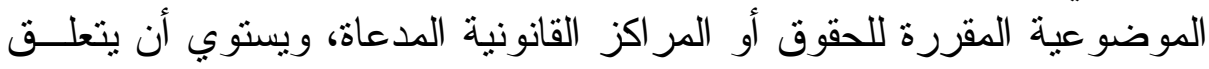
ذلك بتقرير هذه الحقوق أو إنثائها أو الإلز ام بها.

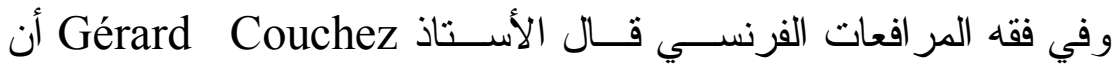

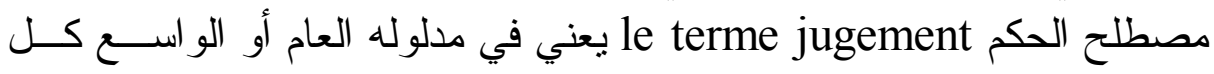

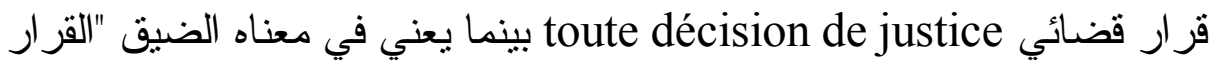

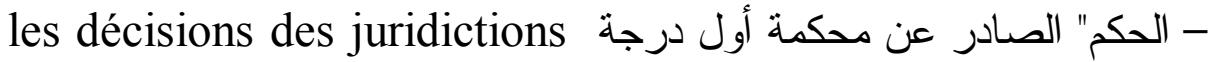
du premier degré

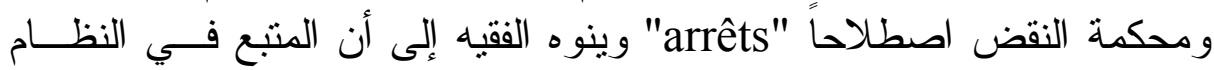

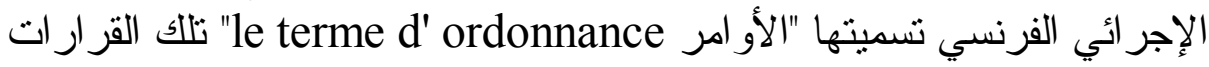

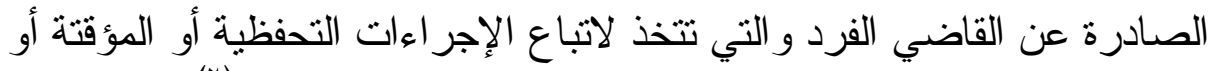
المتعلقة بالتحقيق إذا صدرت من القاضي المباتر للقضاء بمفرده(؟).

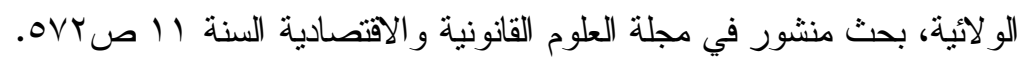

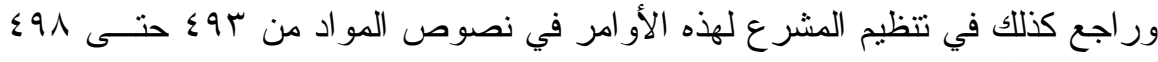
من قانون المر افعات الفرنسي: تلفئر

Réne Morel: Traité élémentaire de procédure civile, $2^{\mathrm{e}}$ éd. No. 234 و وانظر أيضنا:

Motulsky, Ecrits, Etudes et notes de procédure civil. Dalloz. P. 188.

ور اجع أيضا: 1025 Cadiet; Droit judiciaire prive. Op. cit. No.

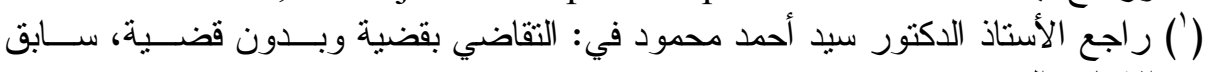

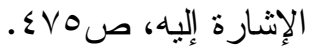

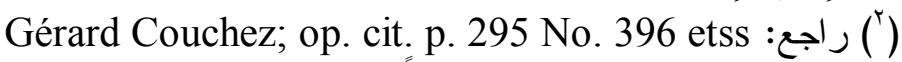

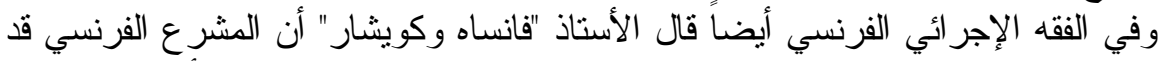

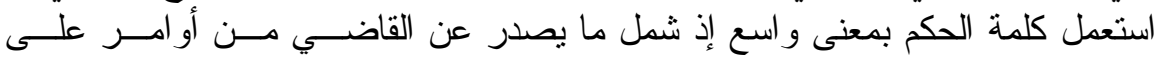


D. G. Lawrence, P. وفي الفقه الإجر ائي الإنجليزي قال الأستاذان في تعريف الحكم القضائي أنه الإجر اء التـالي للاســـــ ST. J. Langan

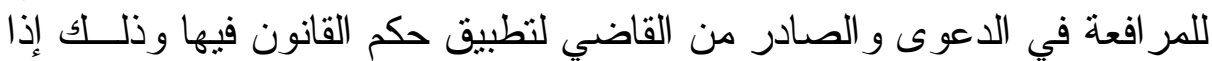

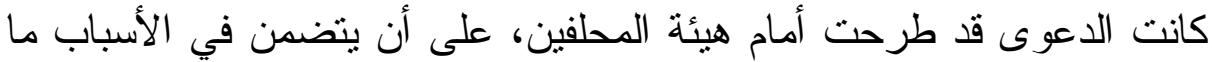

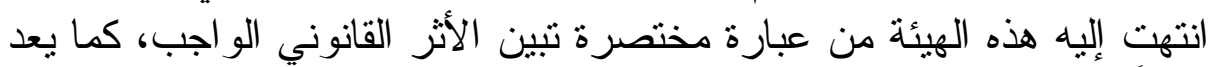

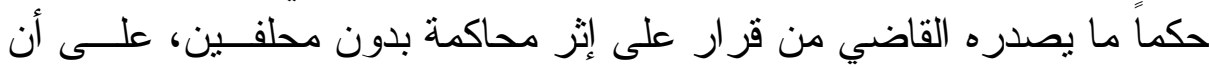

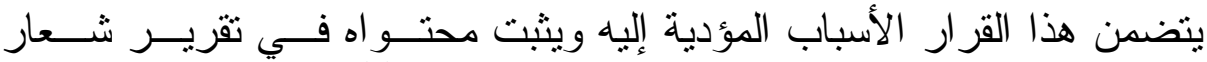

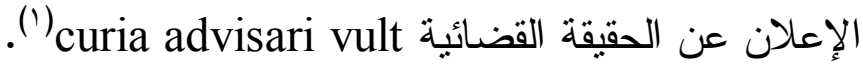

وترجع حقيقة الأحكام القضائية في الو اقع العملي إلى النظر في الوظيفة

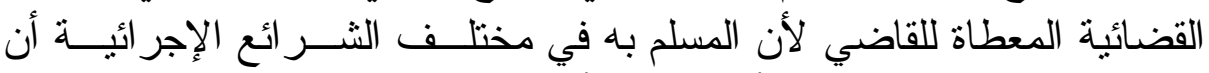

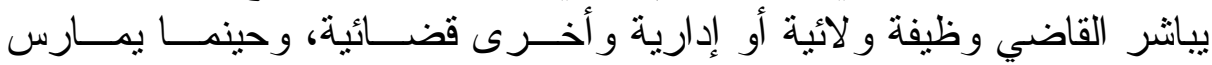

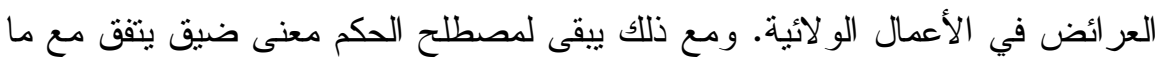

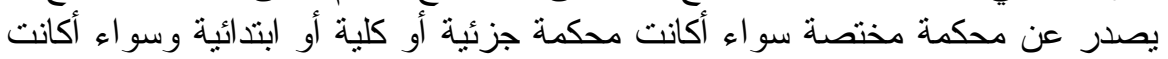

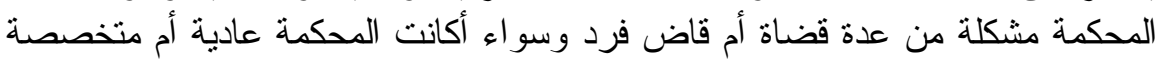

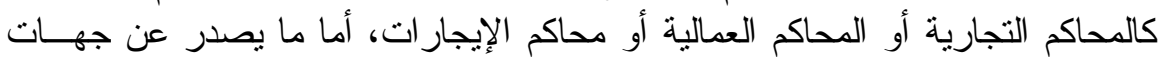
القضاء الأعلى كمحاكم الاستئناف أو النقض فإنها تسمى بمصطلح القرار التهار التهات القضائية. Il désigne alors la décision emanant d' un tribunal inférieur "tribunal de grande instance siégeant en formation collégiale ou à juge unique, tribunal de commerce, tribunal. d' instance, conseil de prud' hommes, tribunal paritaire de baux ruraux". Tandis que les decisions des juridictions supérieurs: Cours d'appel, cour de cassation, portent le nom d'arrets.

راجع: .Jean Vincent et Serge Guinchard; op. cit. P. 509 No 723

$$
\text { وفي تعريف الحكم أيضاً في الفقه الإجر ائي الفرنسي راجع: }
$$

M. Rolland "l' escroquerie au jugement, in la chambre criminelle et sa jurisprudence" Melanges patin. P. 248.

(') كذلك أثنار الأستاذ Robin C. A White إلى أن الحكم هو القرار القضائي الصــادر عن قاض للفصل فيها..

In England and Wales, use of the courts to resolve.. disputes is seen very much as a matter of last resort. Even when proceedings have been started, there are usually procedures which encourage the parties to settle without the need for a court hearing.

Robin C. A. White; the English legal System in Action $3^{\text {rd }}$ Edition. Oxford; p. 234. 


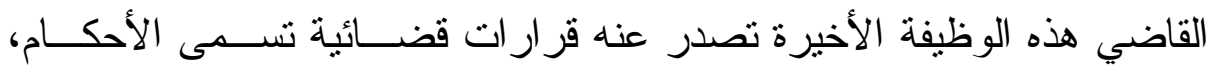

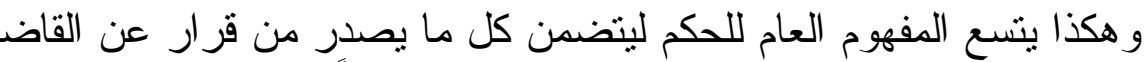

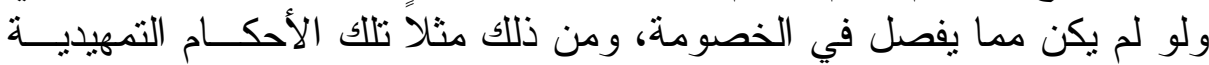

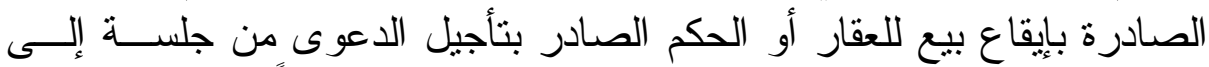

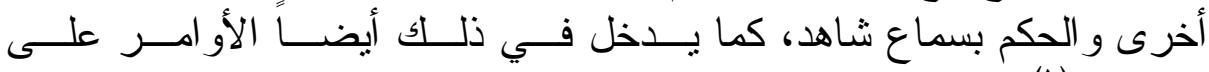

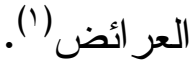

ويتميز الحكم القضائي بخصائص ذاتية تضفي عليه قيمة قانونية معتبرة

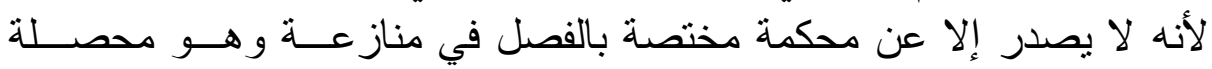

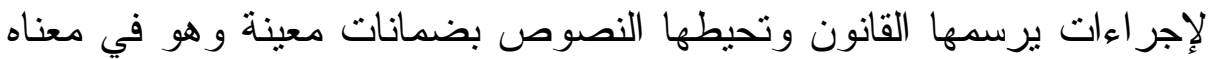

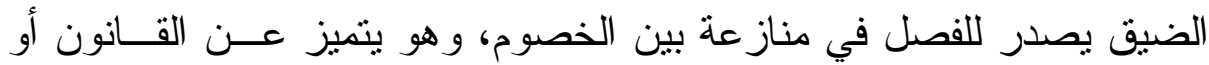

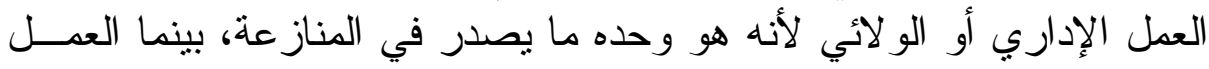

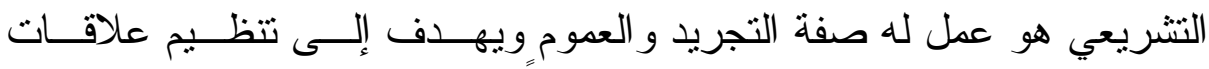
يتتاولها المشرع ويرمي إلى ضبطها مستقبلا بعد كفالة علم الكافة بها ونها ونفاذها،

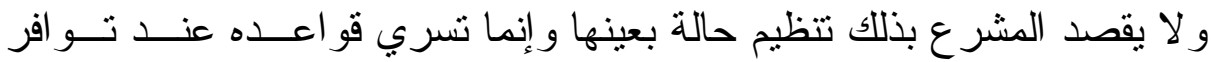

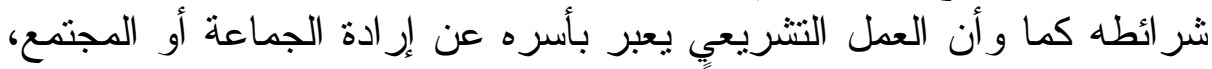

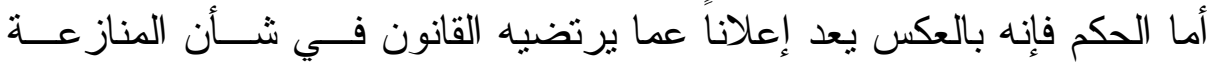

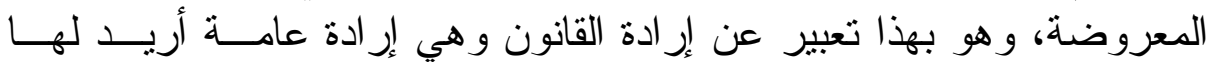

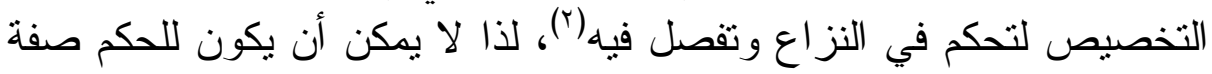

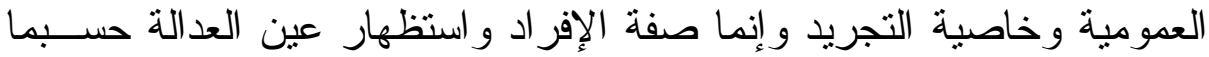

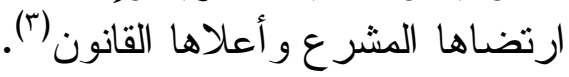

(') راجع في دراسة الأوامر على العرائض في الفقه الإجرائي الفرنسي:

Barbier; le nouveau régime des ordonnances sur requéte; Caz. Pal. 1974, Doct. 223.

$$
\text { ور اجع أيضاً: }
$$

Cezar. Bru, Hérraud, seignolle; traité de reférés et des ordonnance sur requête. T. 11. $4^{\mathrm{e}}$ éd 1980.

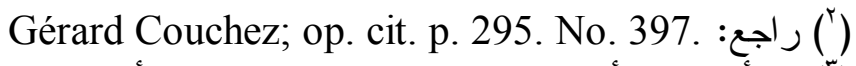

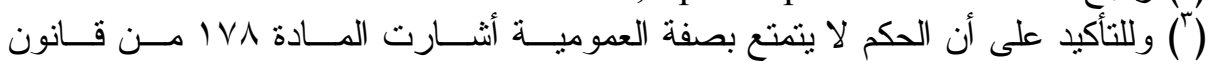

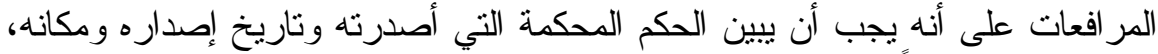

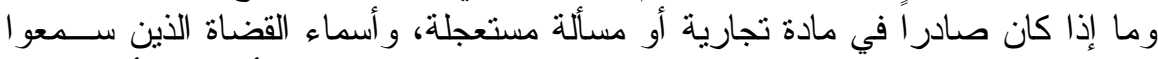

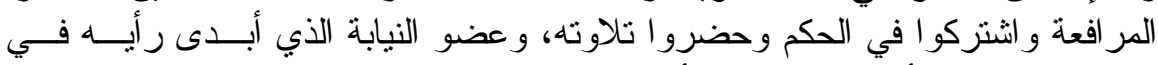

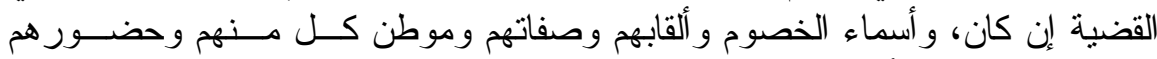

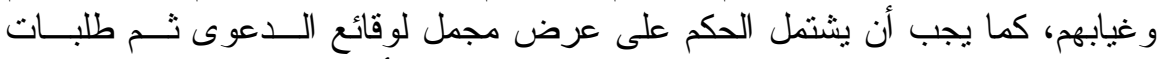

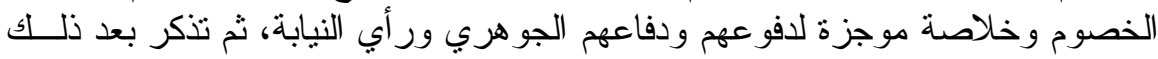


كذلك يختلف الحكم القضائي عن القرار الإداري؛ لأن الغاية المبتخــاة مــن

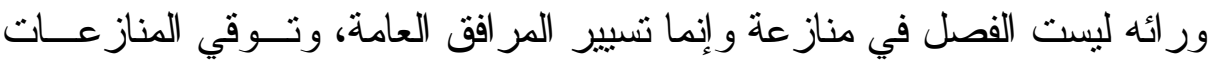

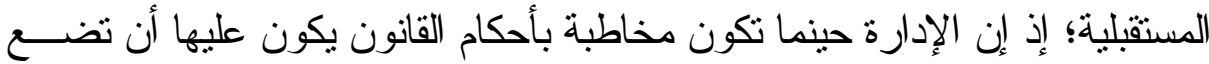

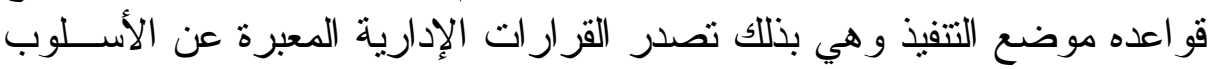

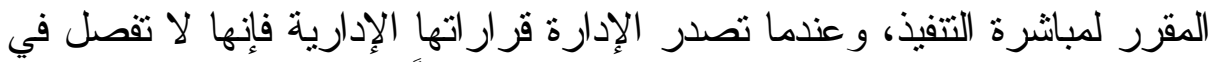

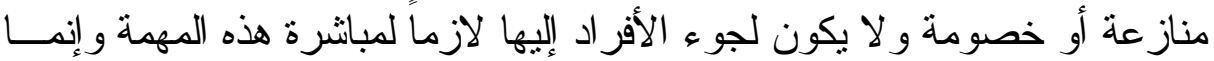

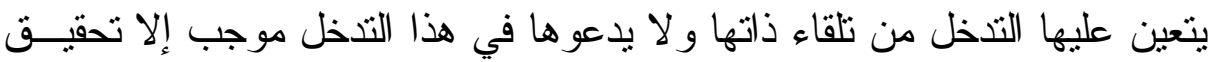

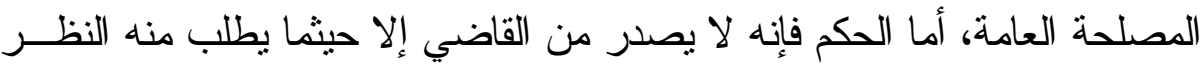

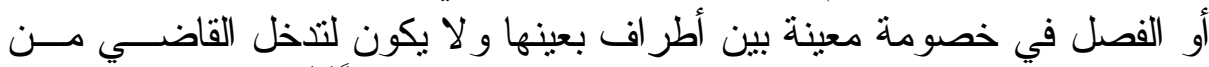

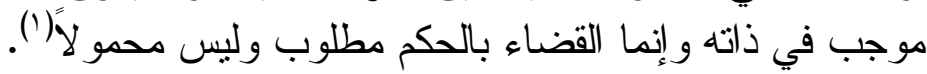
و على كل حال فإننا نلمس بعض السمات المشتركة بين العملٍ التشريعي

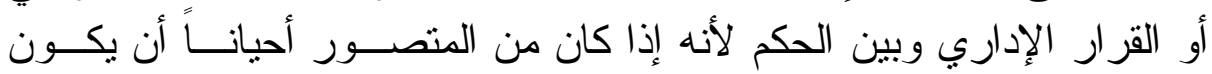

أسباب الحكم ومنطوقه، و القصور في أسباب الحكم الو اقعية والنقص أو الخطأ الجســيم

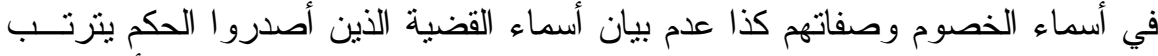

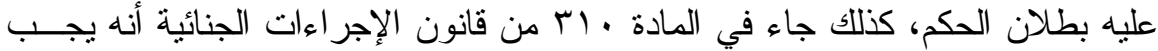

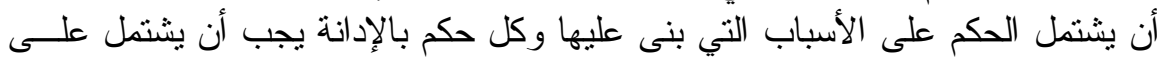

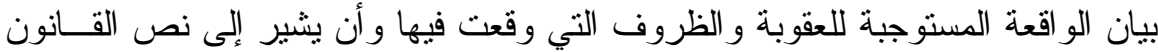

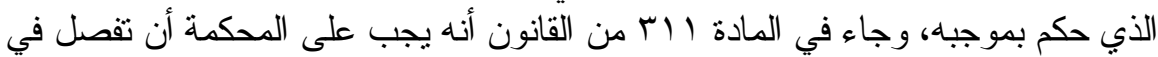

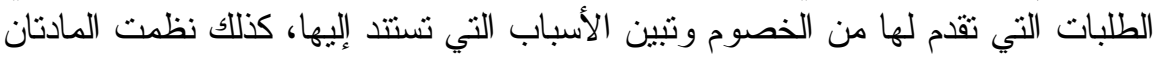

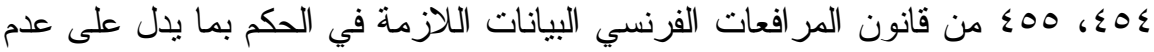

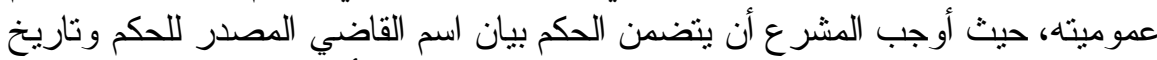

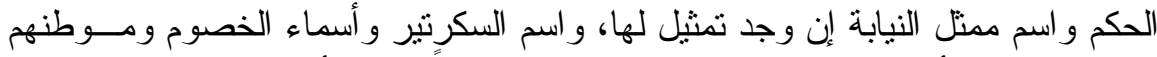

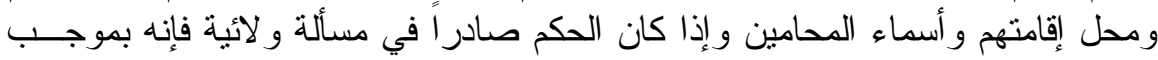

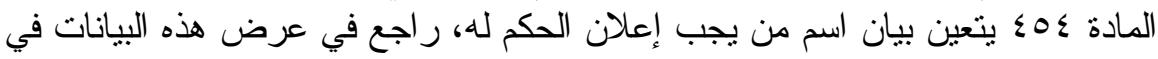

Gérard Couchez; op. cit. p. 299. No. 400.

$$
\text { قانون المر افعات الفرنسي: }
$$

(') وتجدر الإثارة في هذا المقام إلى أن هنالك خلافاً فقهياً حول حقيقة الحكم القضائي وما إذا

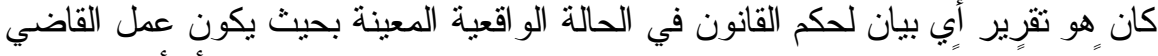

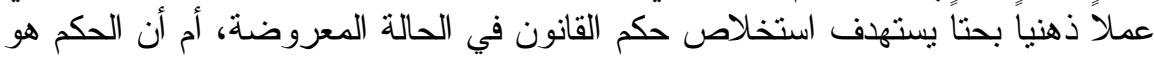

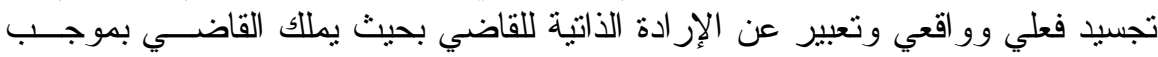

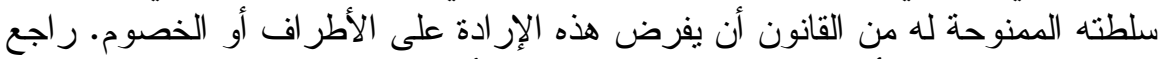

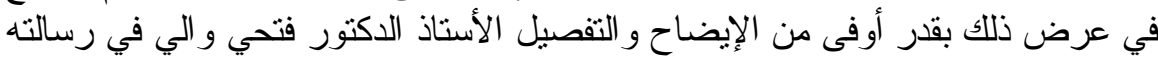

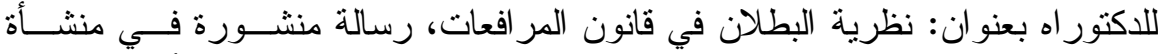

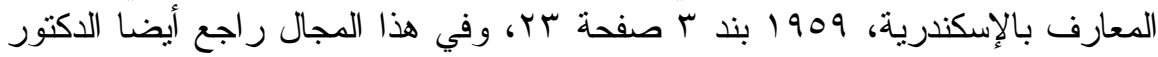

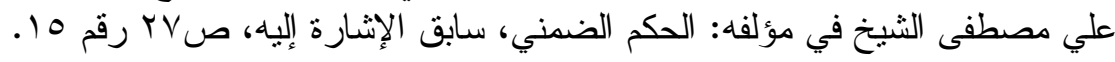




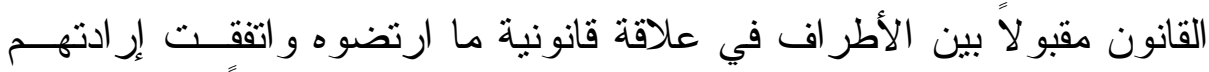

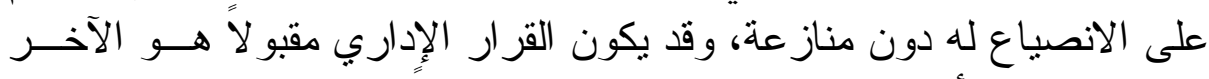

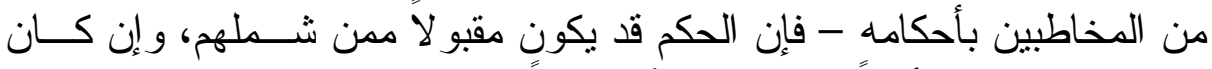

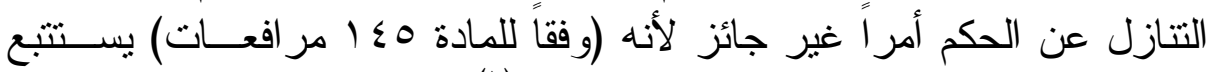

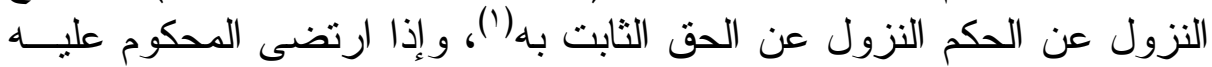

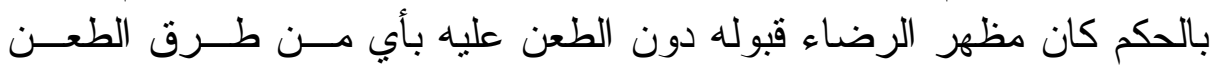

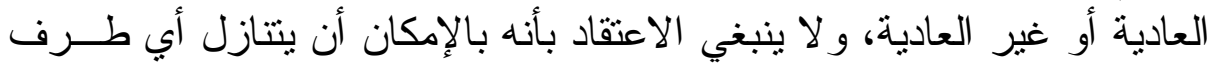

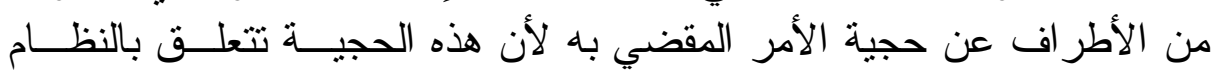

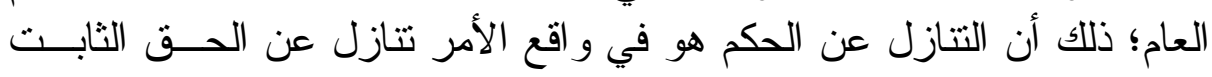

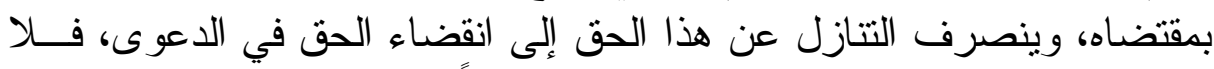

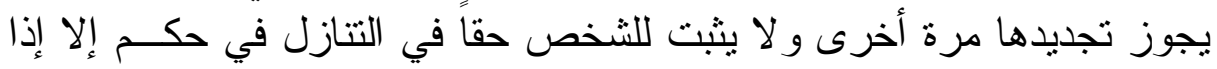

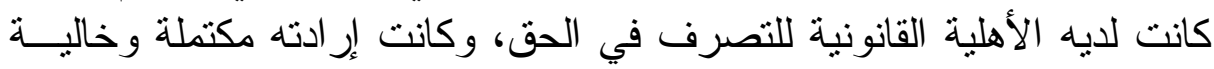

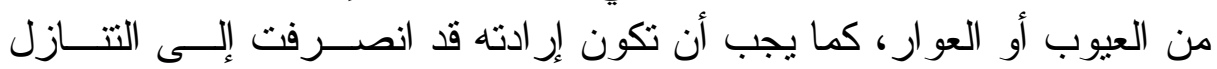

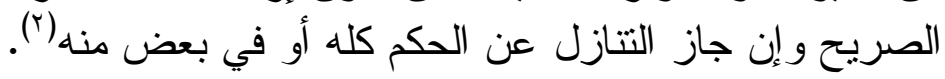

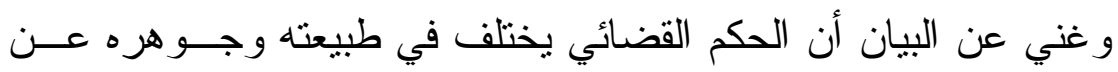

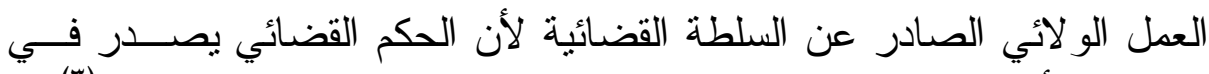

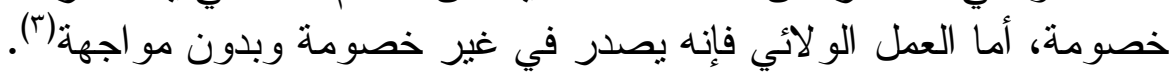

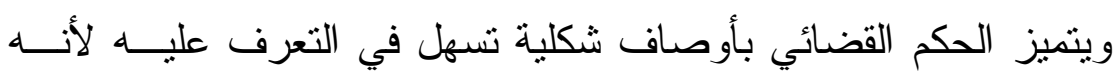

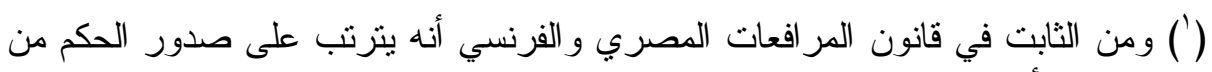

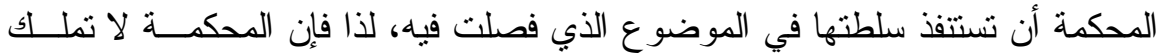

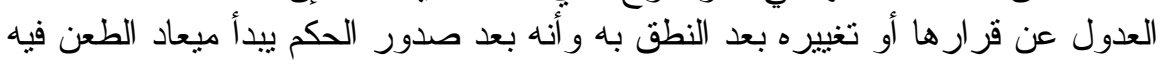

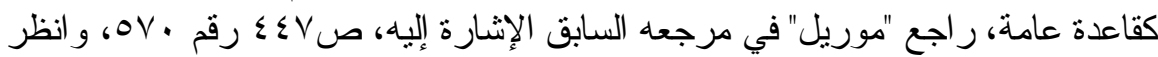

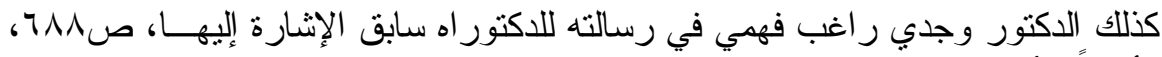

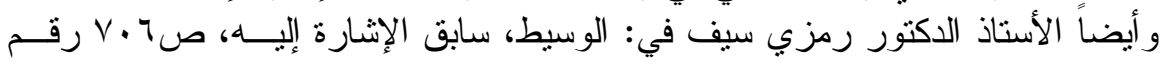
.070

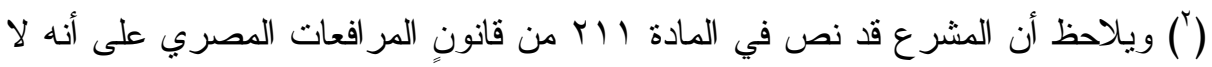

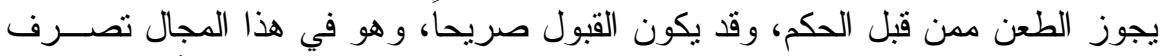

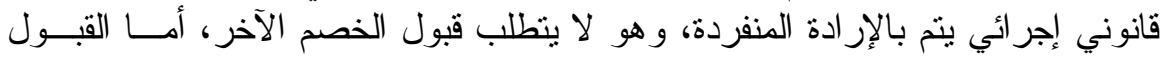

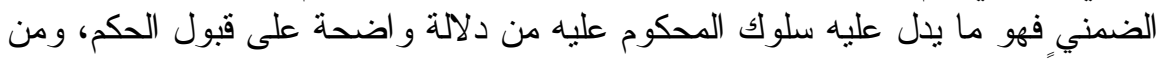

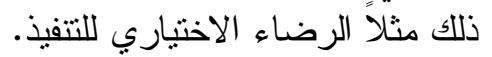

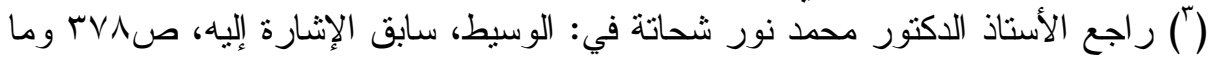
بعدها، وانظر كذلك:

J. Bruilliard; l' evolution de juridiction gracieuse, Rev. Inter. Dr. Comp. 1957. p. 5. 
كعمل إجر ائي له مظهر خارجي وهو لا يمكن أن يعتد به إلا إذا كان صــادراً

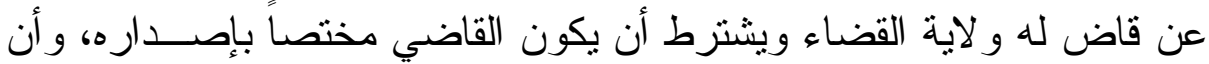

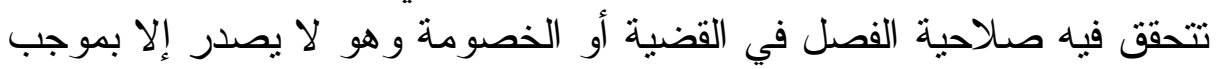

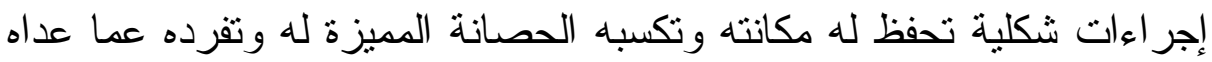

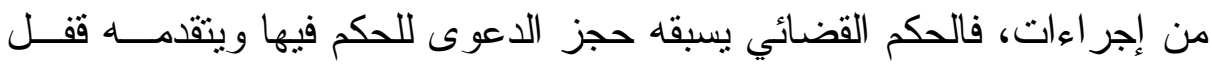

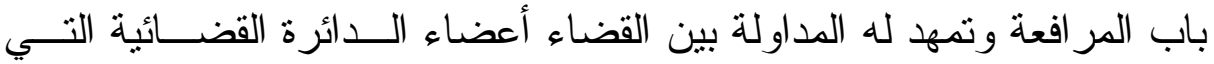

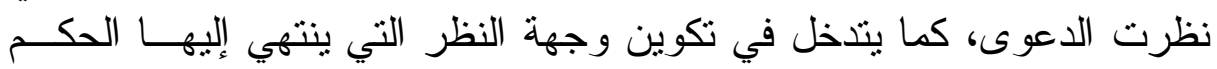

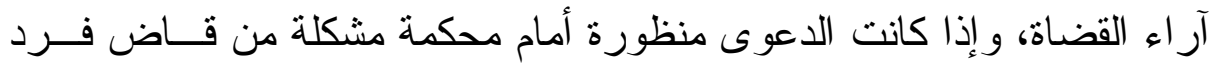

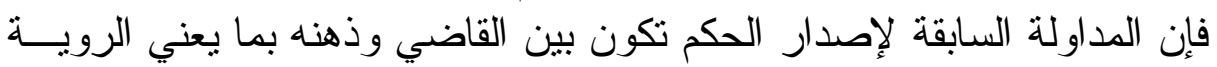

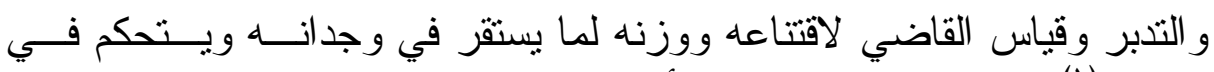

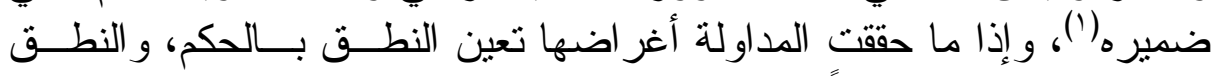

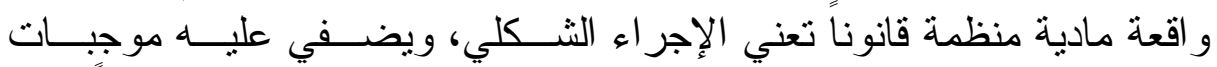

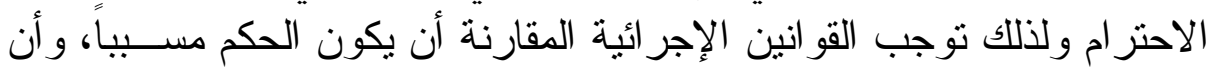

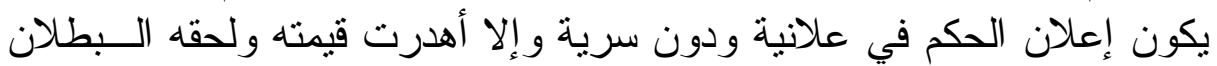

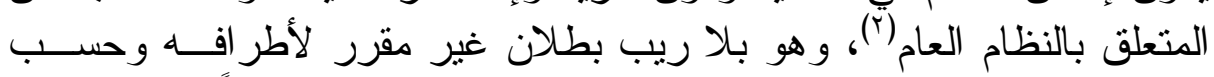

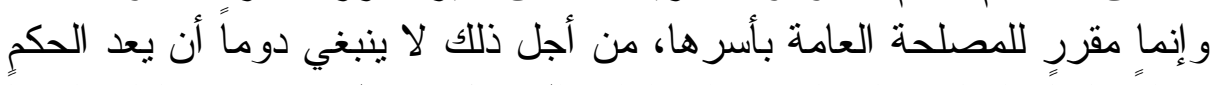

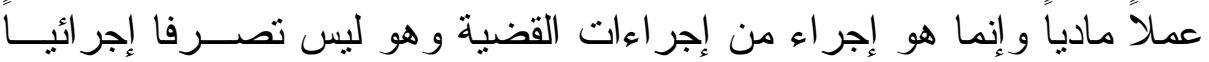

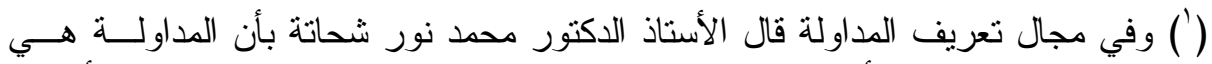

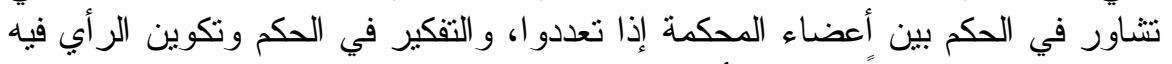

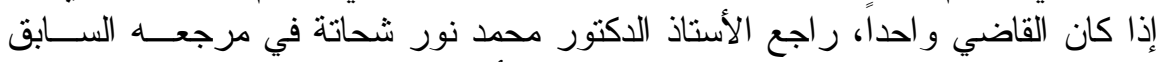

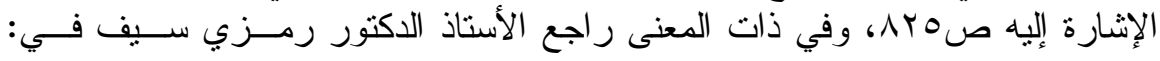

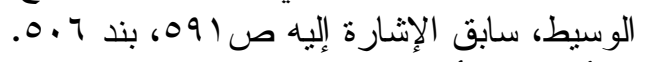

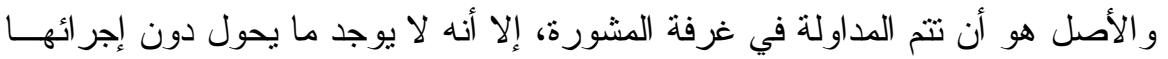

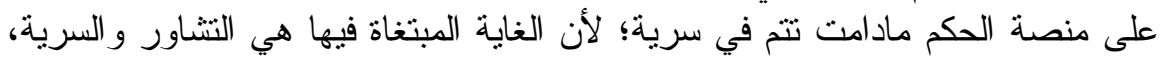

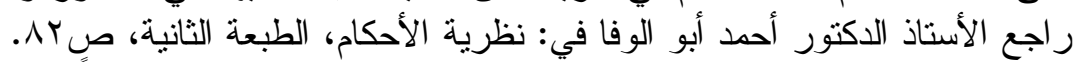

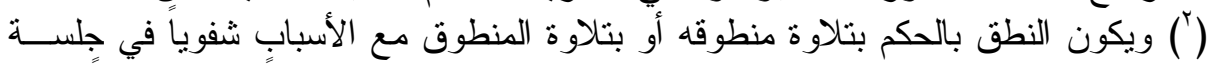

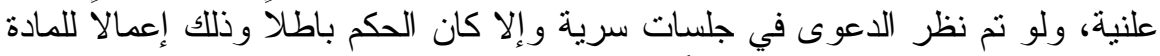

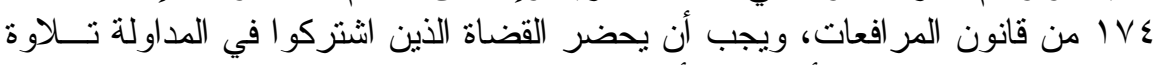

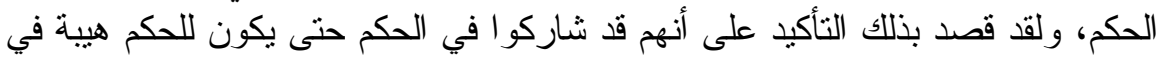

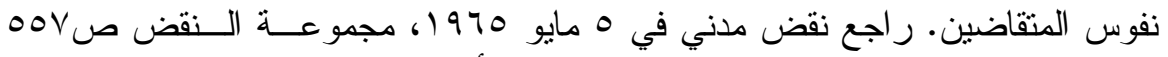

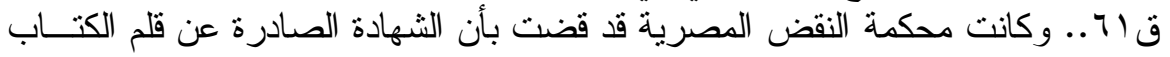

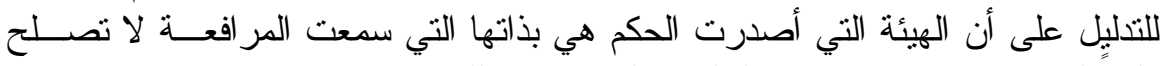

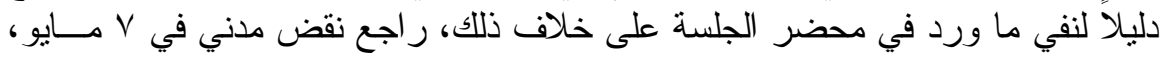

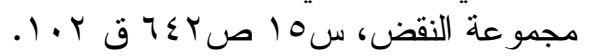


و إنما هو قر ار من طبيعة قضائية قصد بـه تتظيم العلاقة بين الأطـــر اف فــي

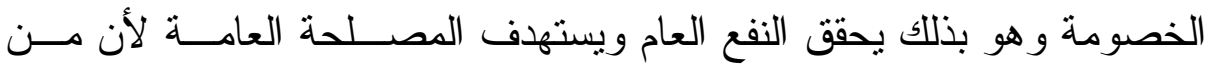

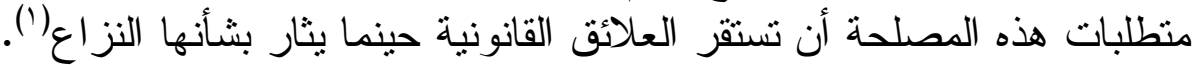

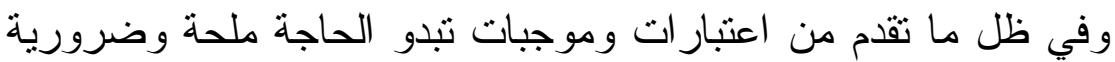

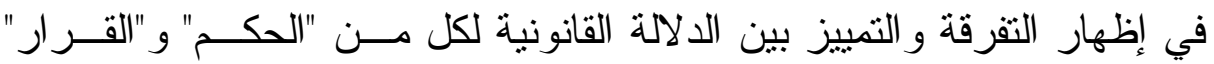

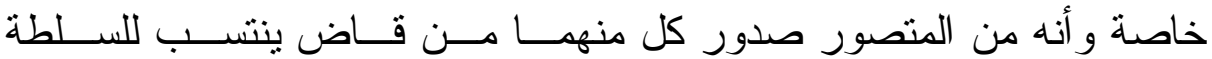

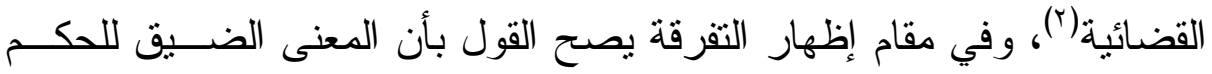

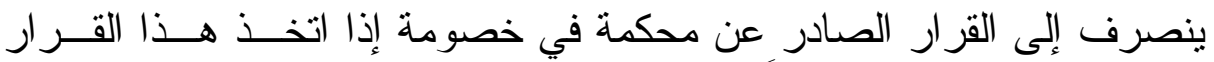

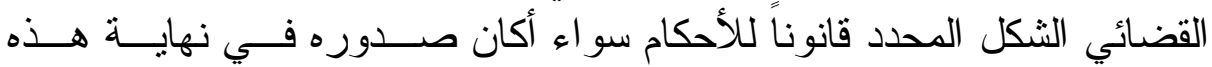

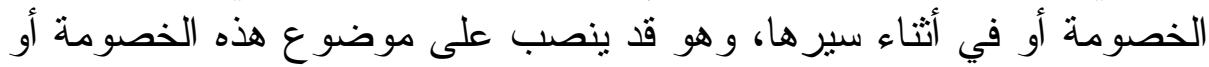

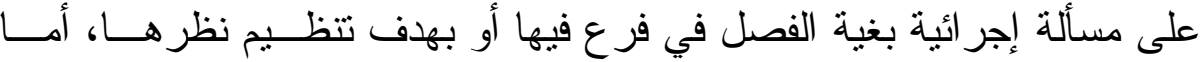

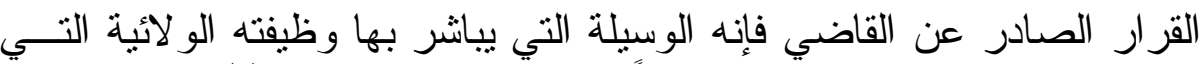

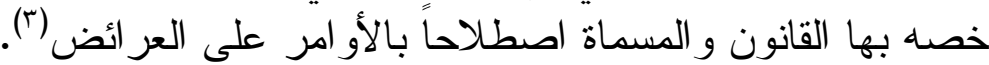

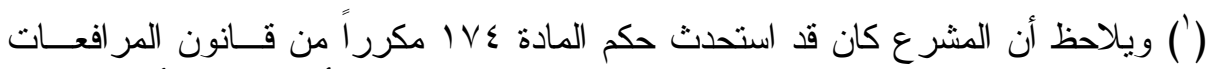

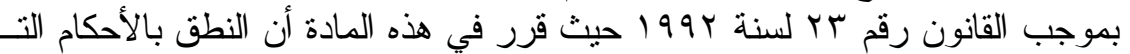

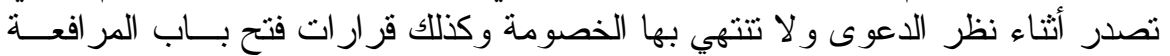

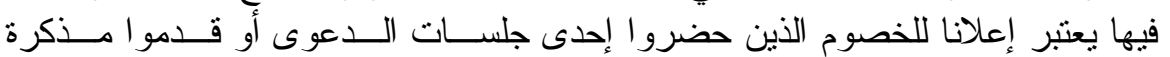

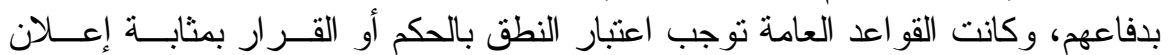

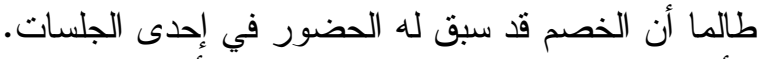

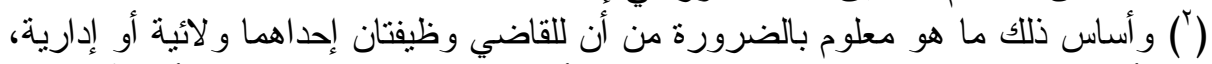

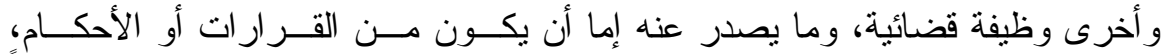

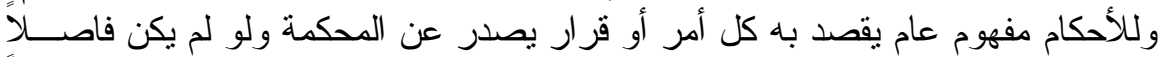

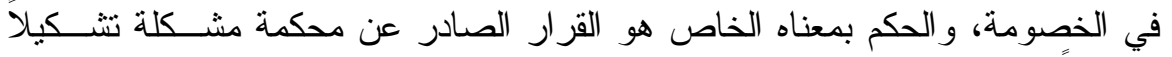

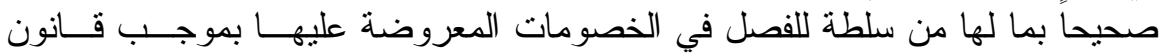

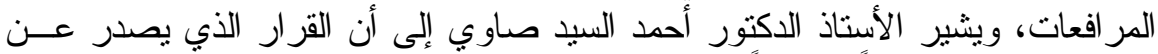

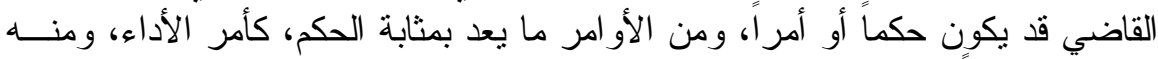

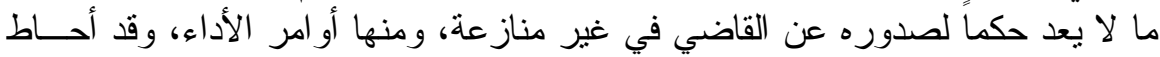

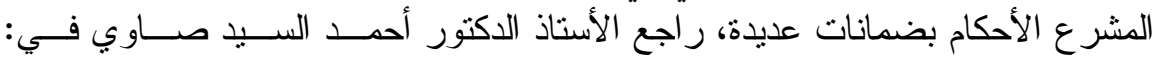

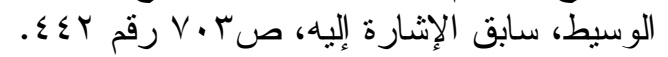

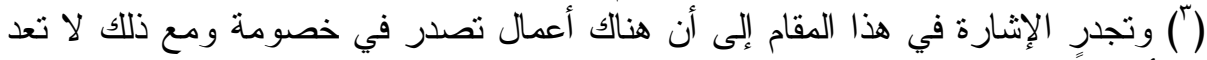

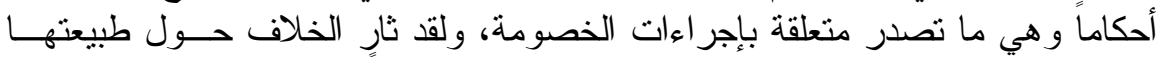

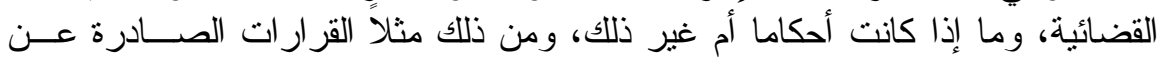

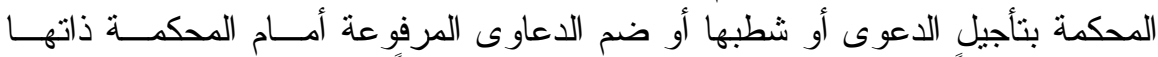

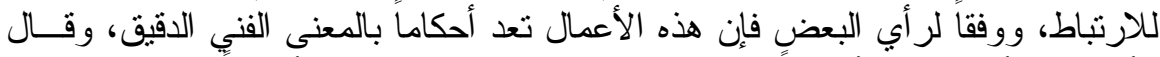

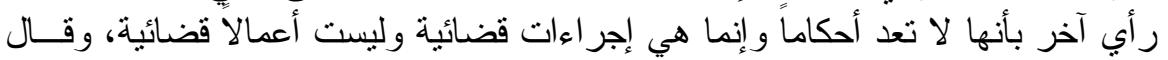


ولا ريب في أن هناك حاجة ملحة لتحديد المجال الو اقعي لكل من الحكم

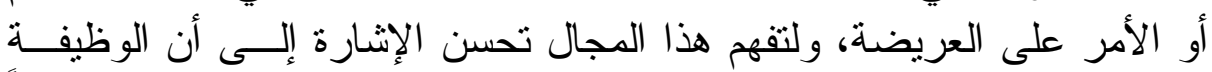

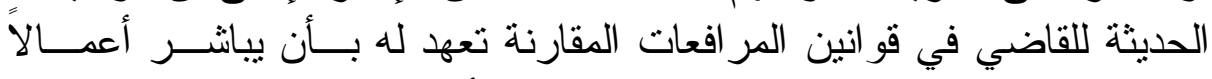

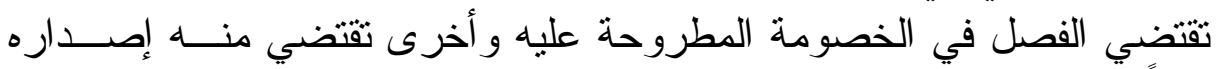

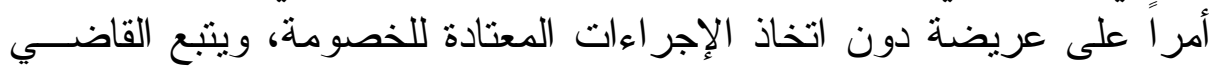

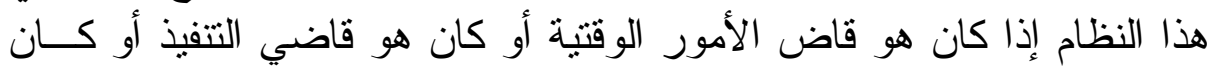

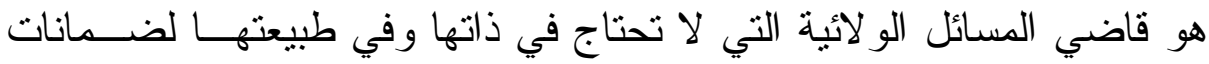

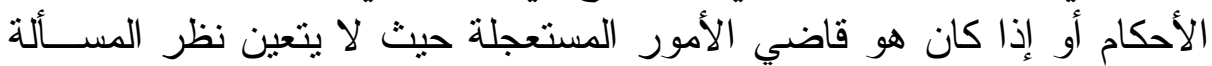

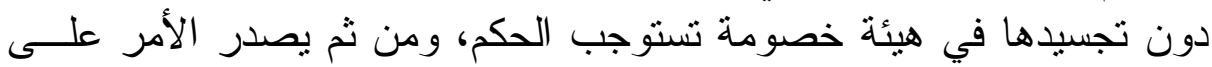

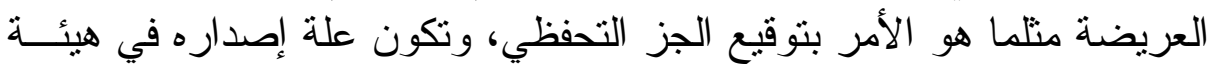

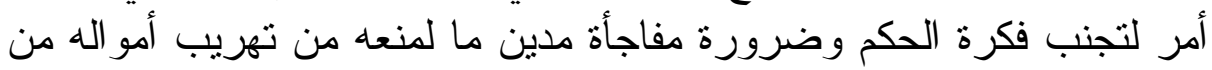

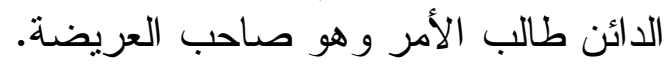

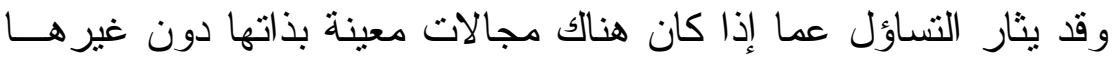

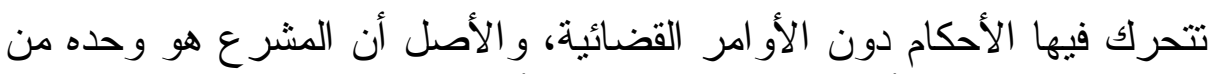

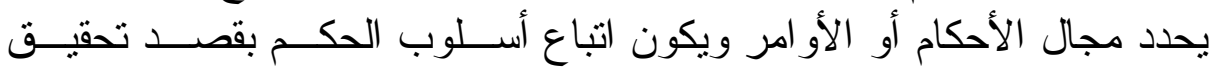

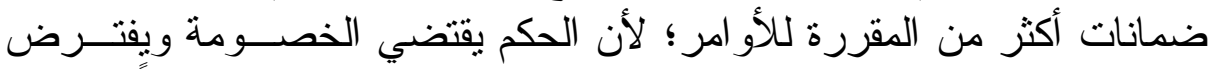

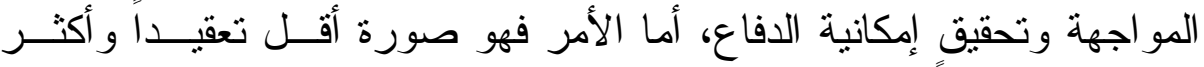

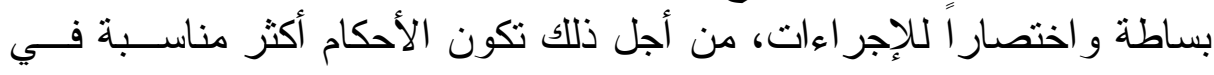

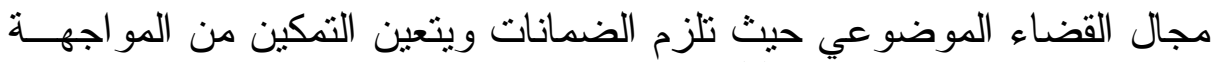

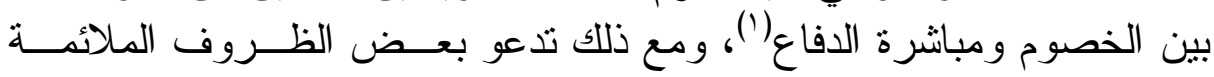

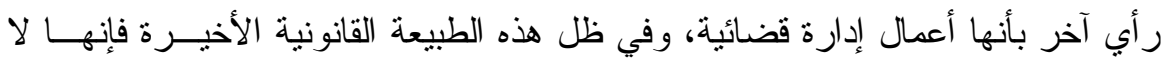

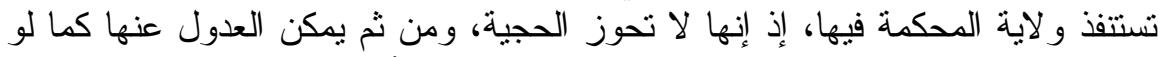

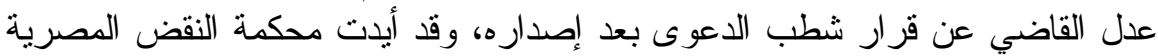

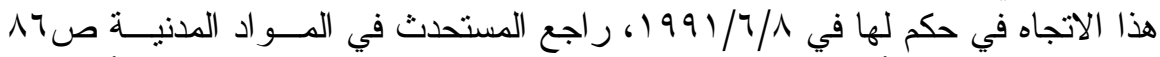

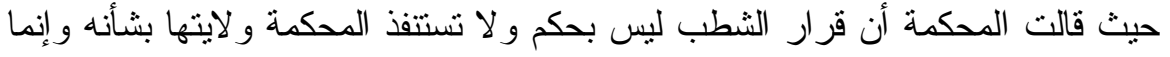
يجوز لها العدول عنه إذا تبين بطلانه.

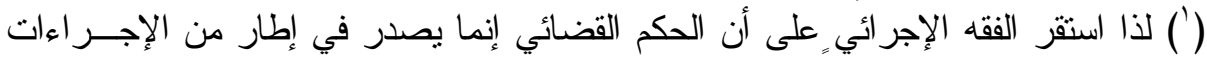

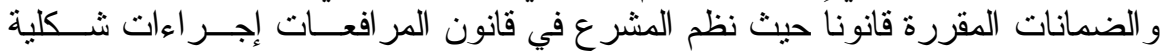

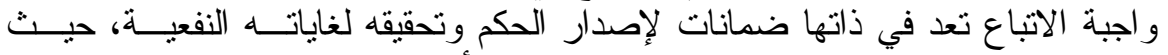

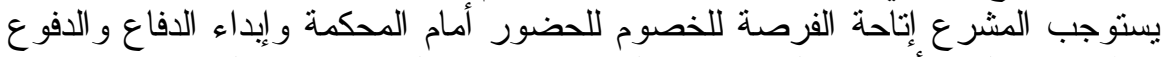

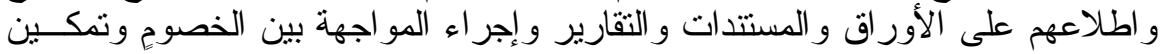

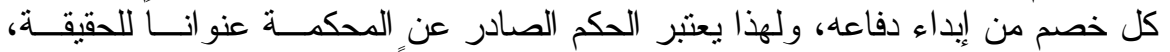

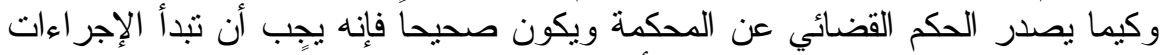

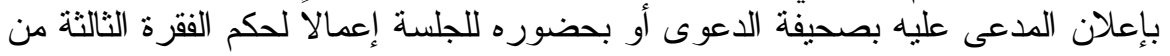




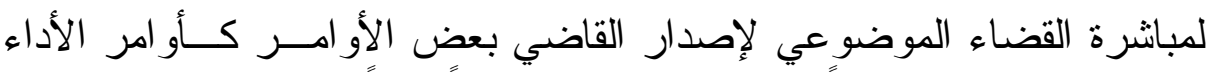

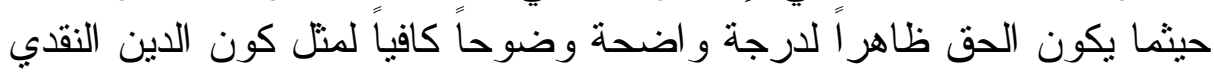

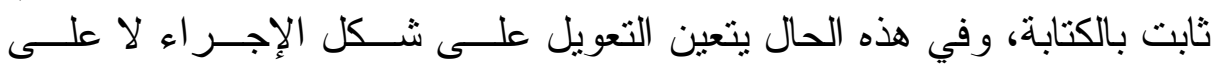

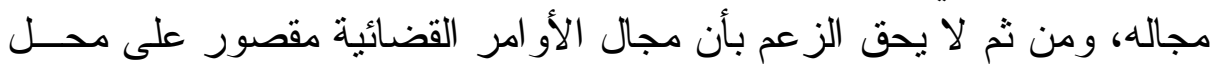

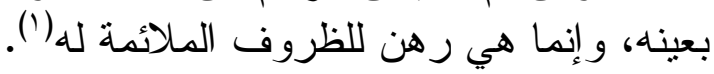

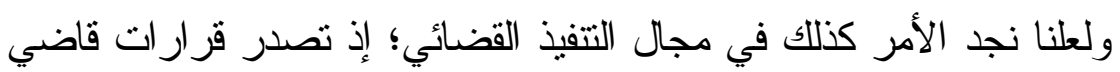

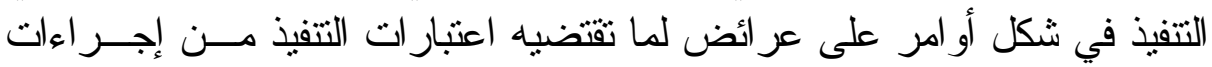

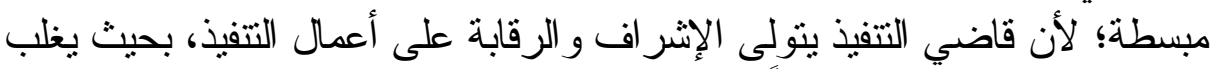

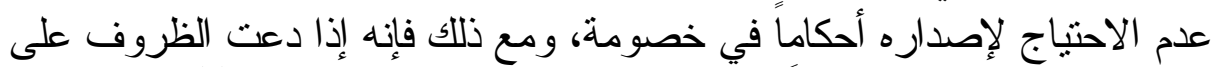

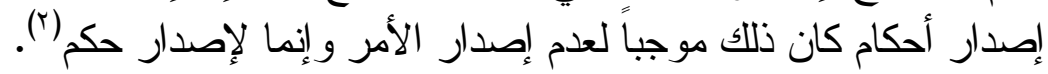

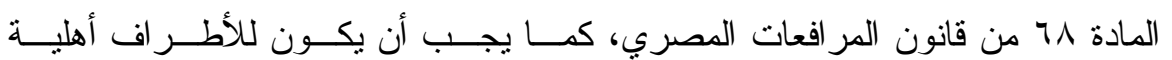

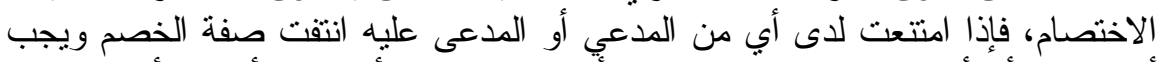

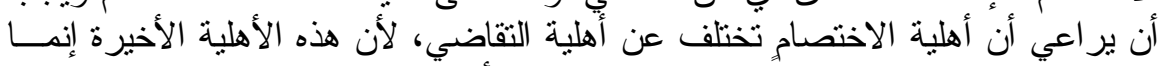

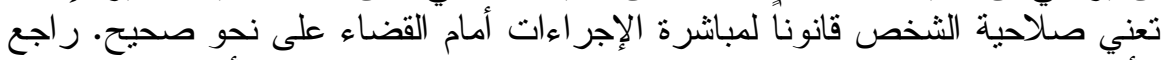

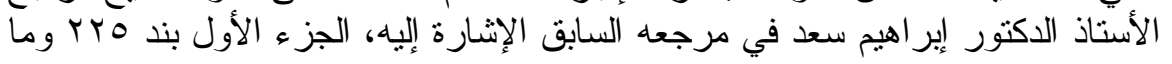

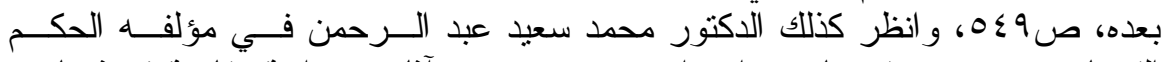

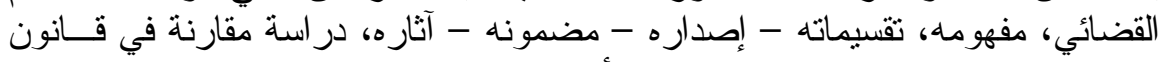

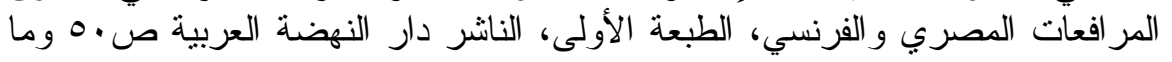

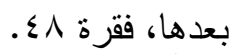

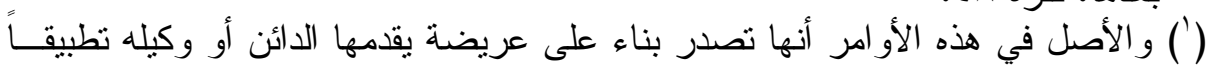

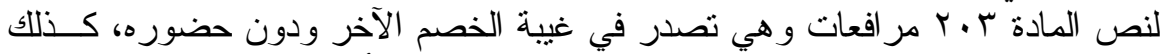

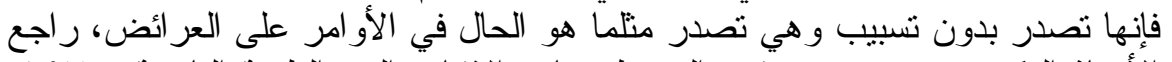

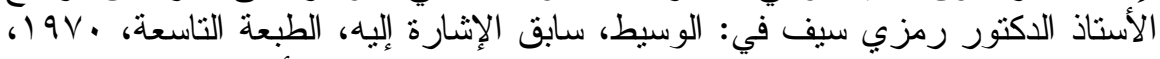

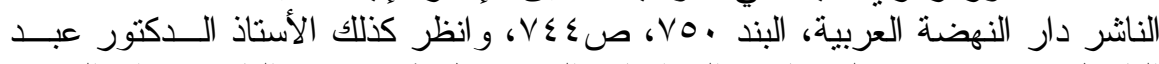

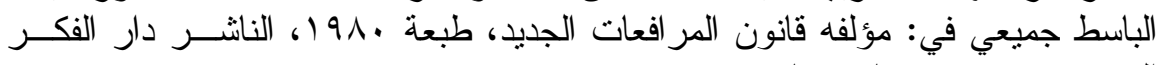

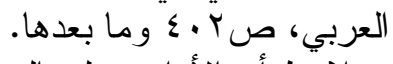

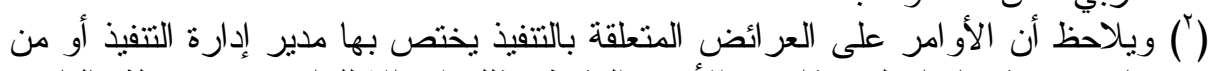

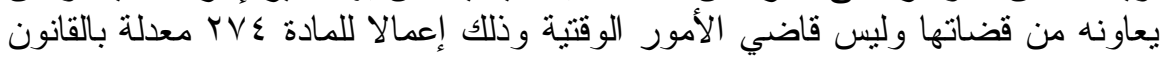

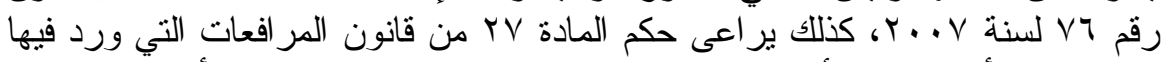

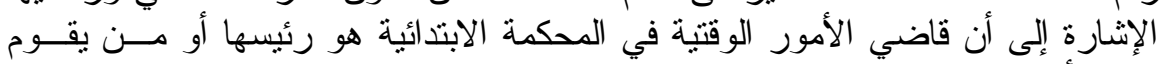

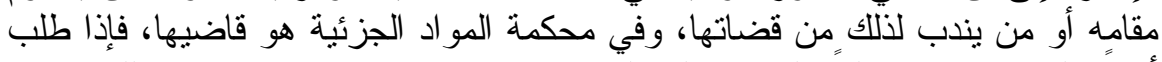

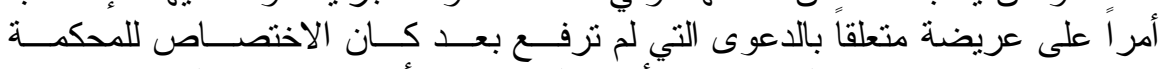

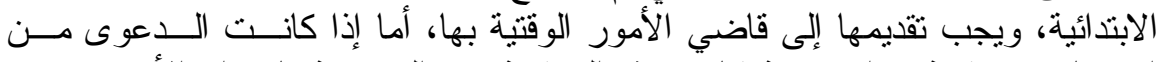

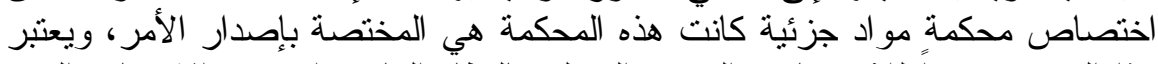

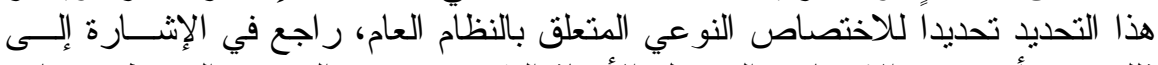

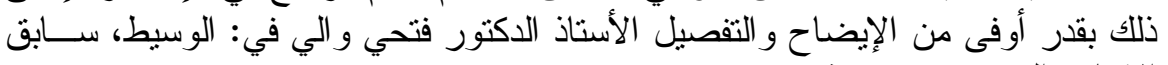

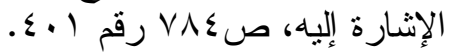




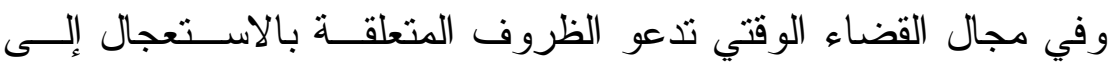

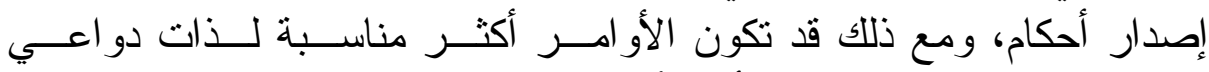

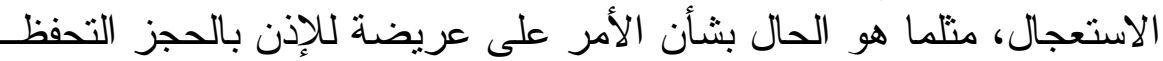

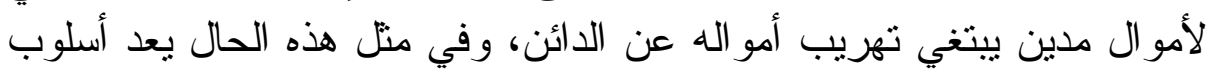

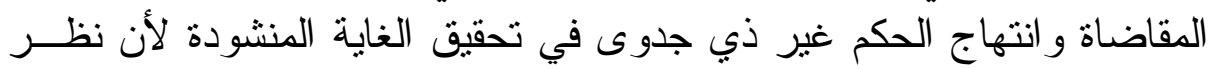

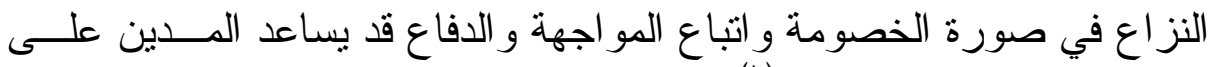
إنجاز غرضسه وتحقيق مآربه (').

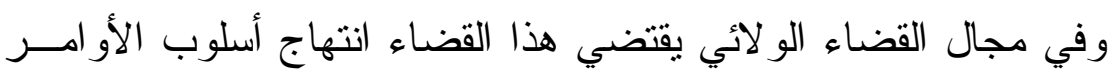

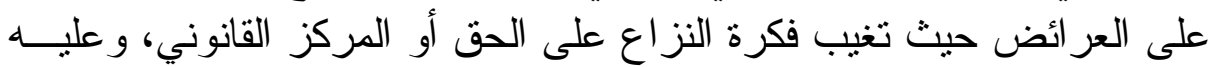

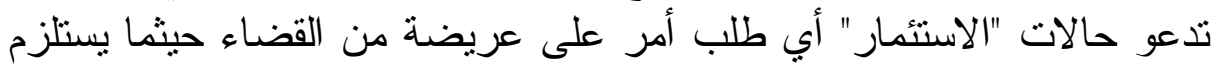

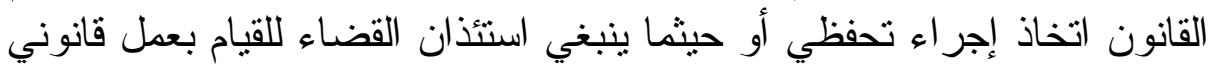

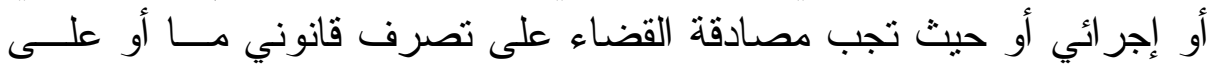

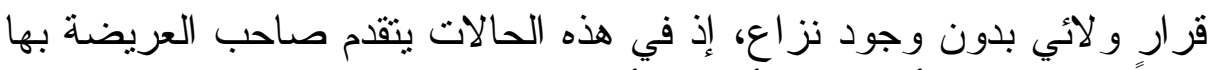

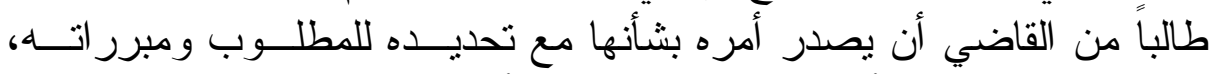

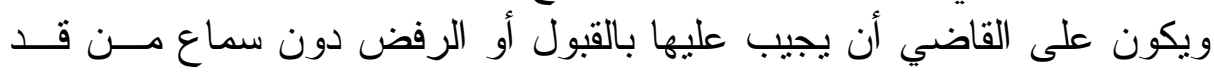

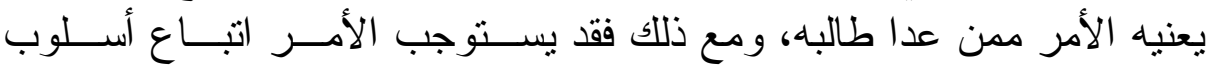

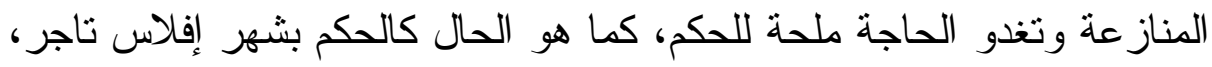

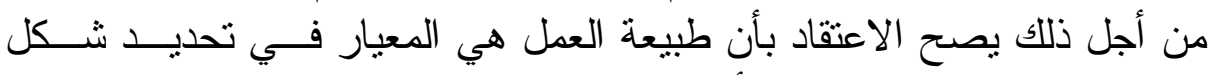

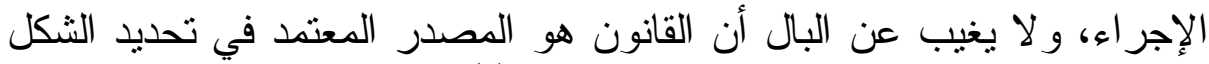
الإجر ائي وما وإذا كان هو اللازم كحكم أو أمر (r).

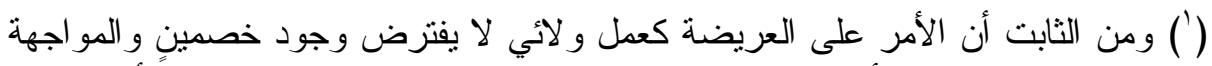

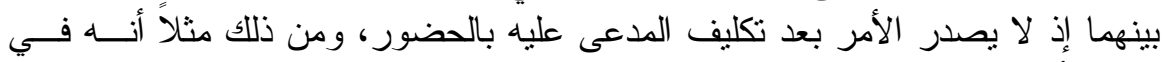

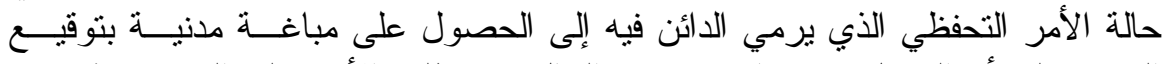

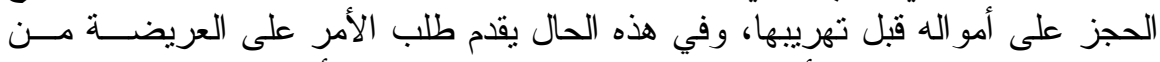

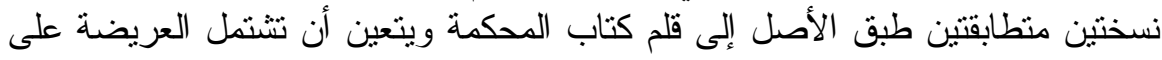

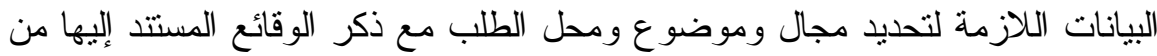

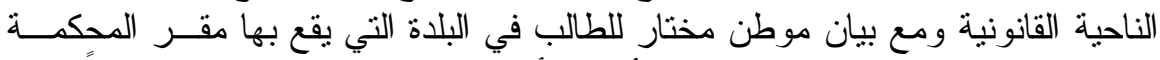

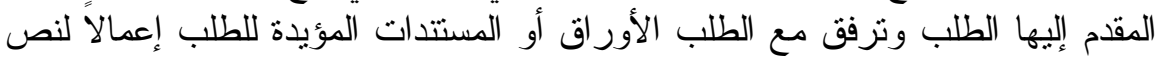
المادة ـ 19 مر افعات.

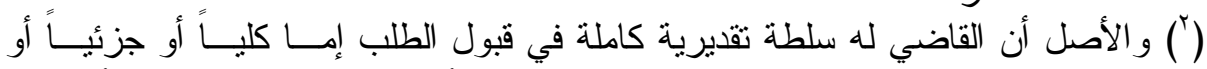

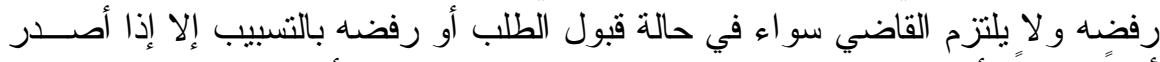

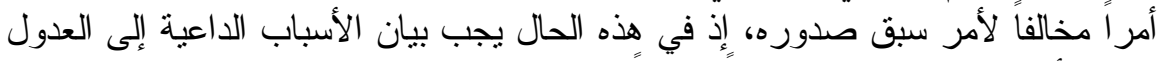

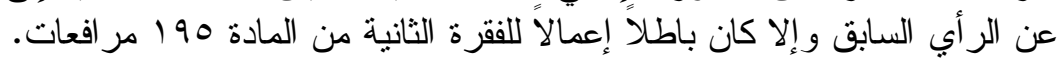




\section{المطلب الأول \\ تسبيب الأحكام القضائية

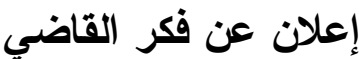

من الحقائق المؤكدة أن الأحكام القضائية عمل من الأعمال القضـــائية،

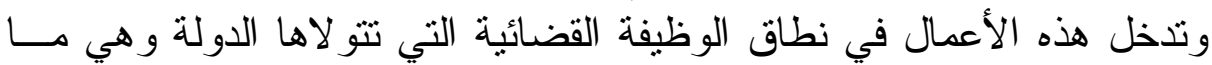

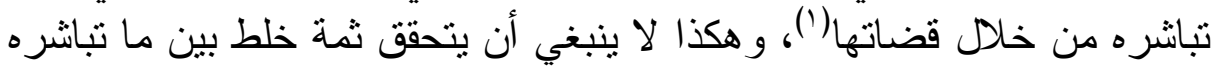

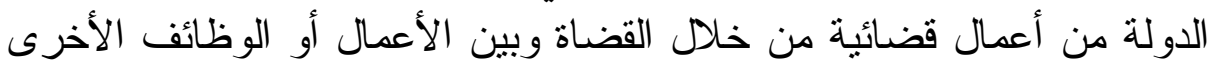

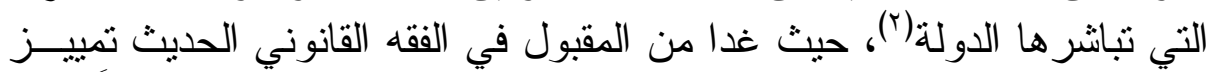

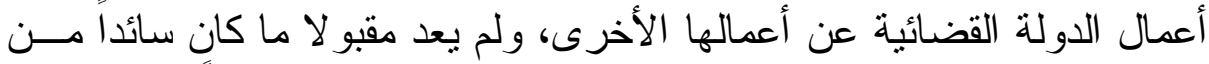

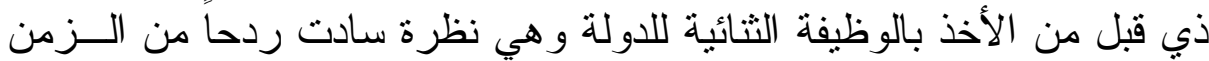

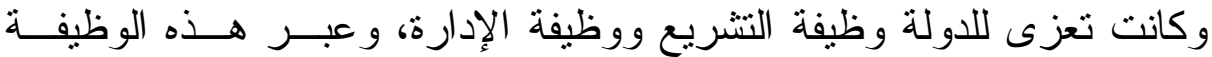

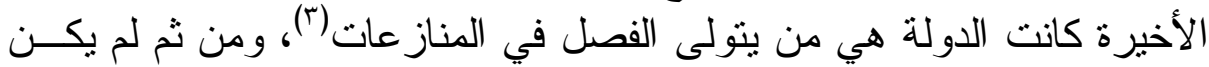

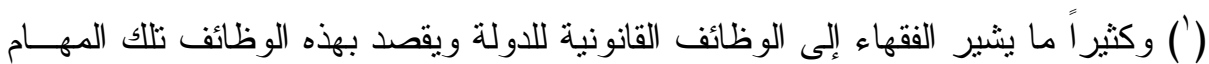

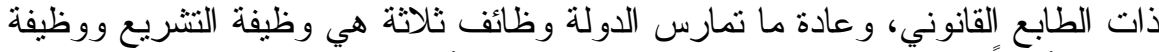

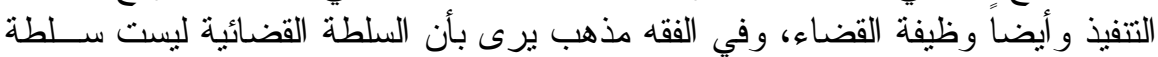

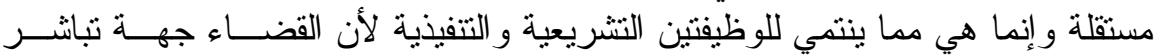

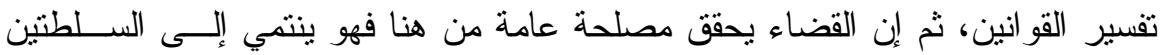

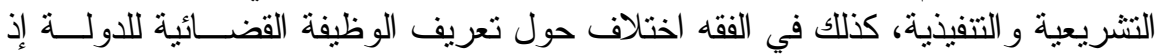

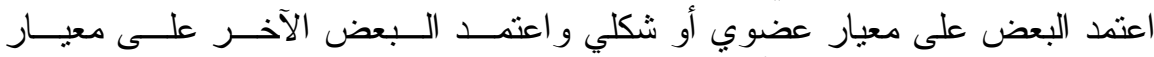

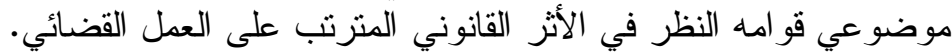

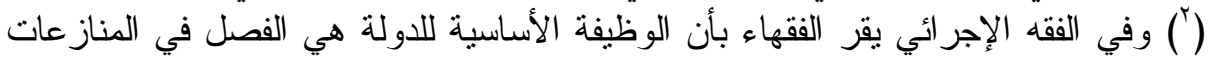

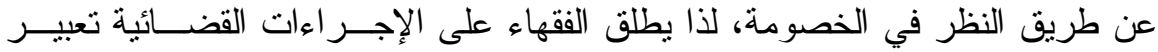

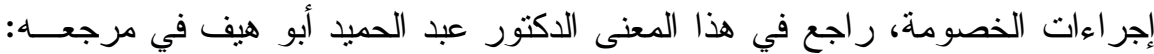

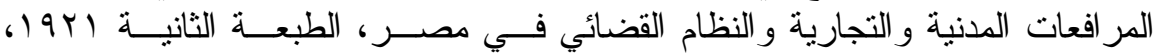

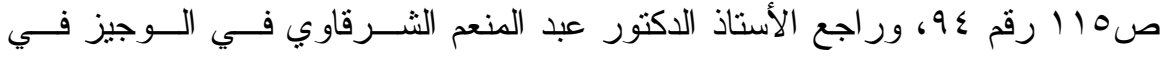

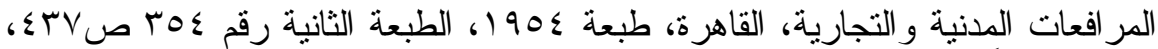

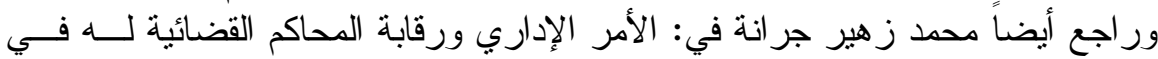

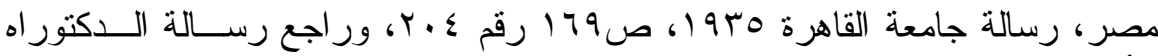
للأستاذ الدكتور محمد عبد الخالق عمر في: Le notion d' irrecevabilité en droit judiciaire privé thése paris 1967 p. 101.

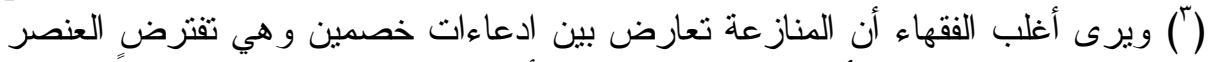

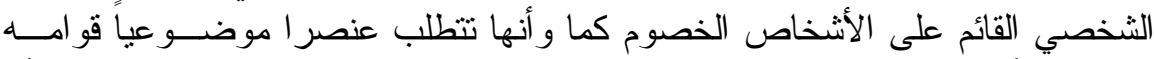

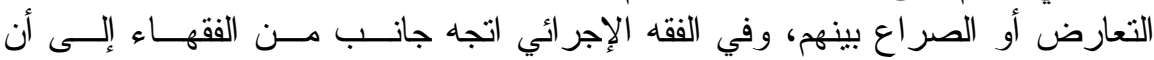

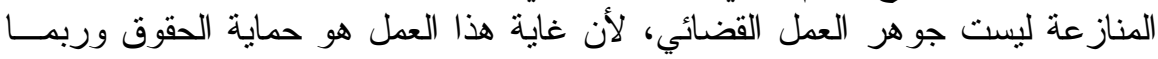


من المتعين أن تكون الأحكام مشتملة على أسبابها لأن اقتضاء التسبيب في هذا

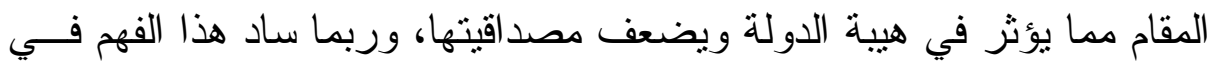

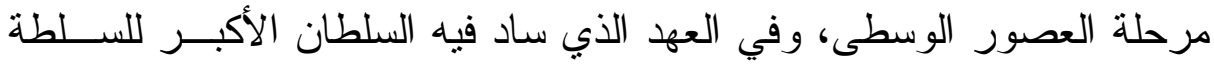

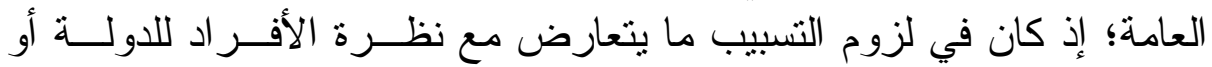

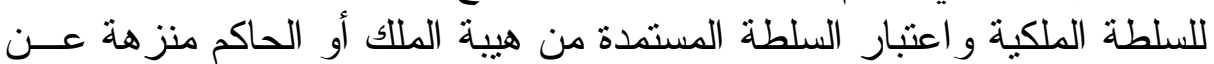
التبرير أو إظهار الاعتبار ات (').

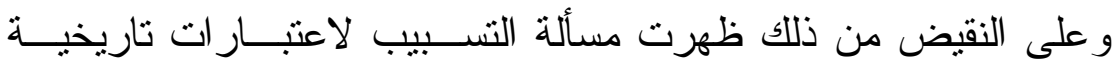

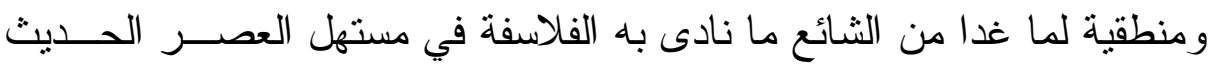

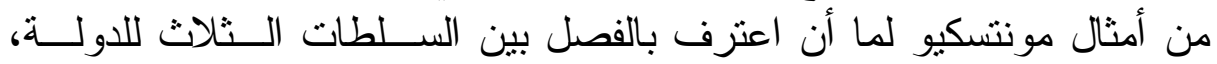

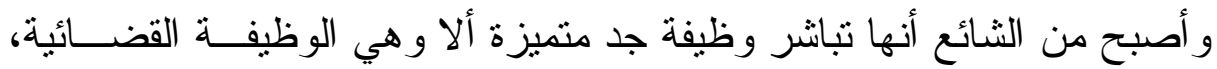

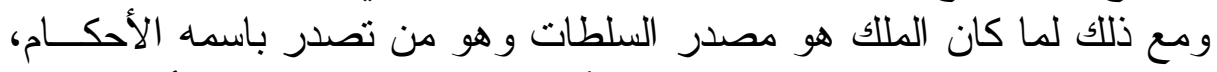

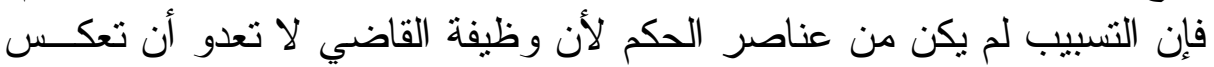

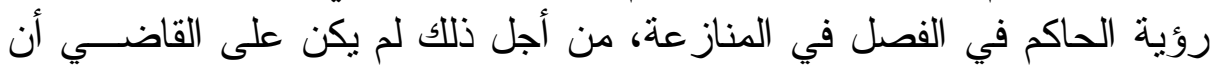

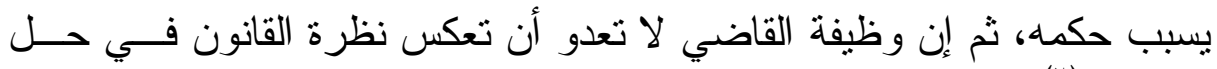

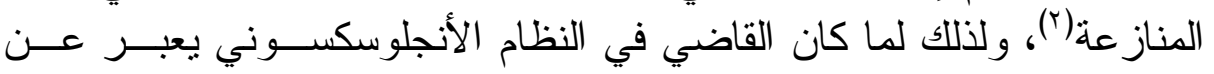

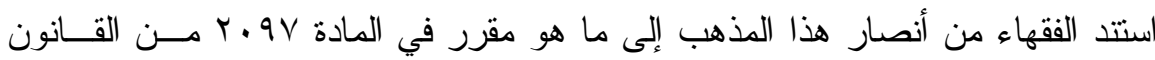

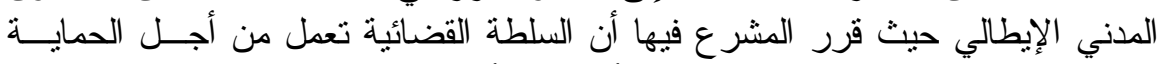

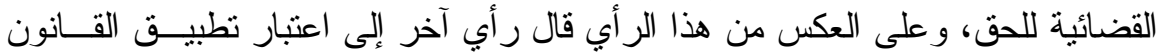

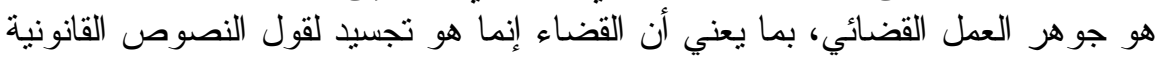

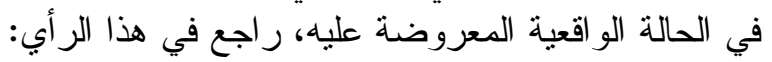
Morcel Laborde la coste; Exposé Methodique de procédure civile 3ed. paris 1951.p. 73 No. 217.

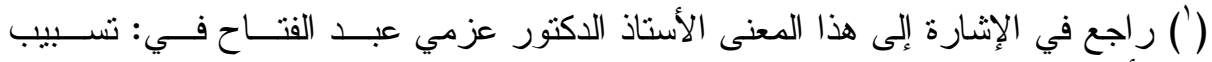

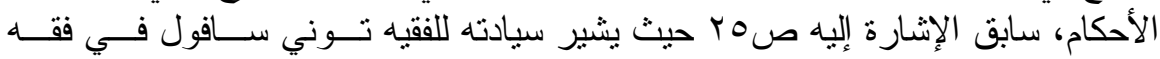

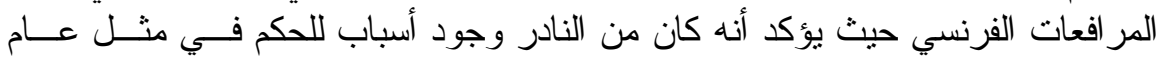

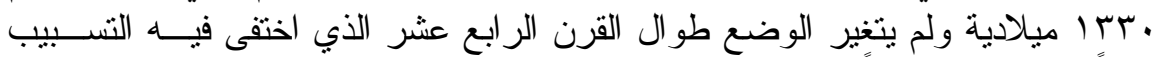

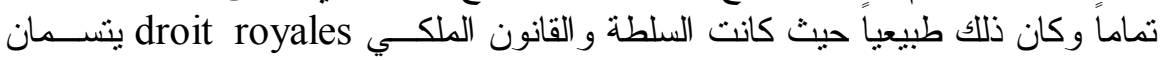

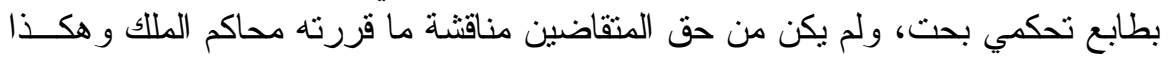

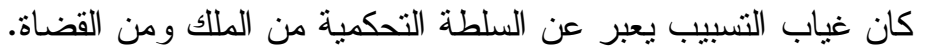

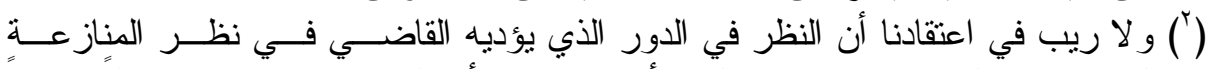

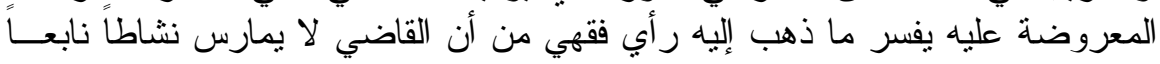

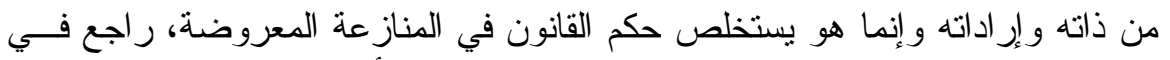

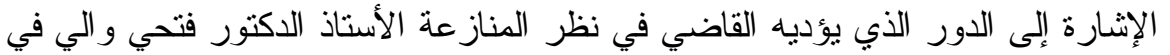

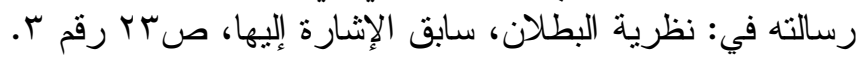




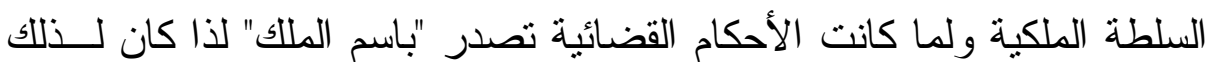

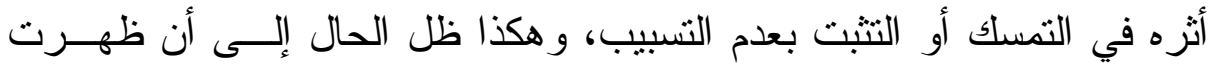

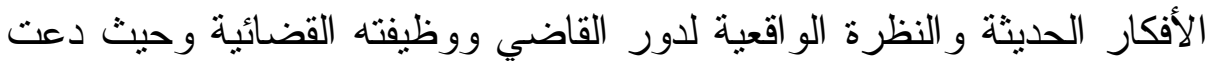

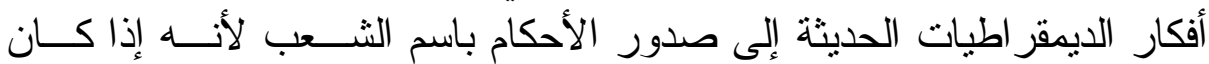

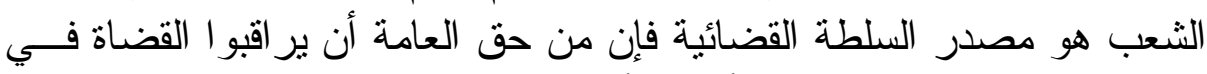

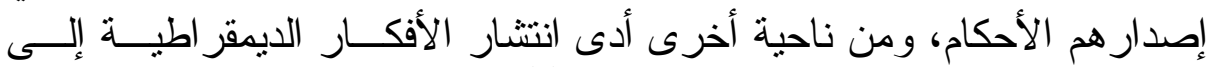

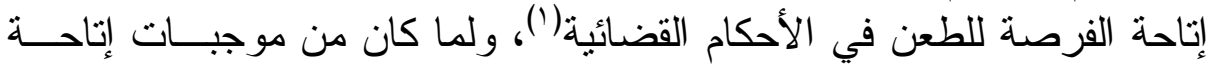

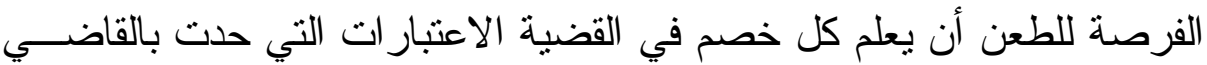
إلى إصداره الحكم فقد ظهرت الأهمية العملية للتسبيب.

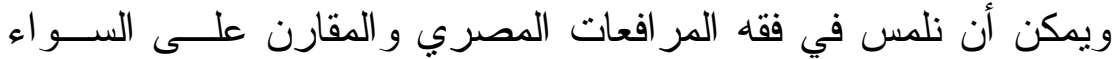

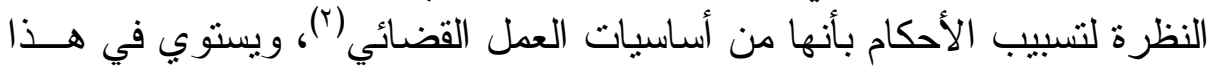

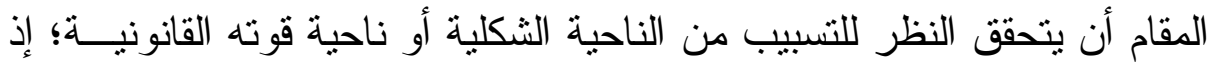

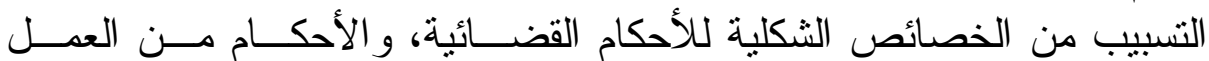

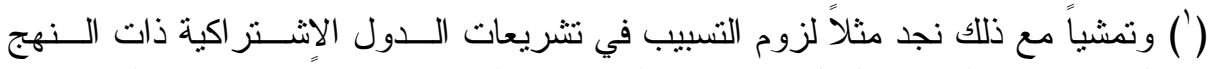

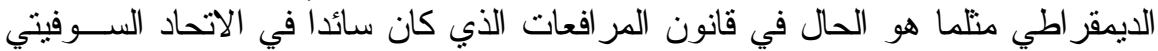

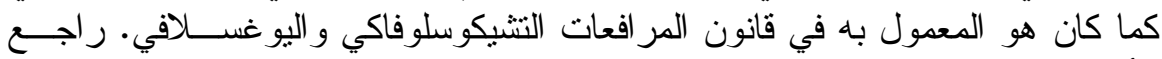

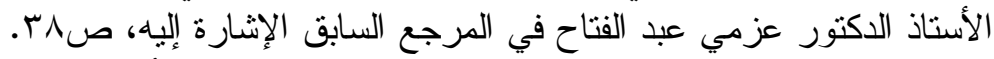

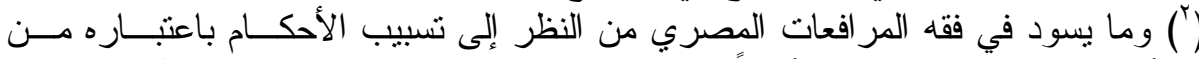

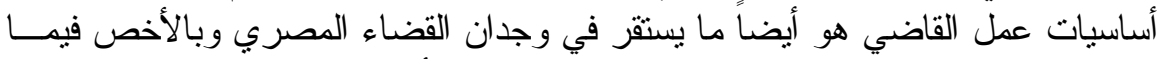

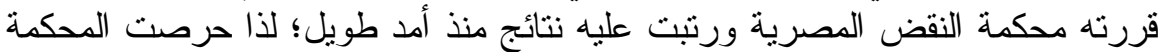

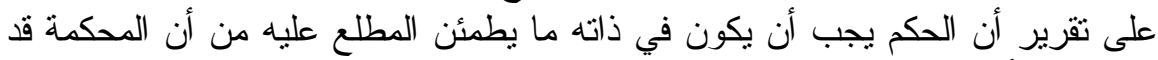

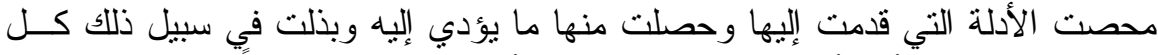

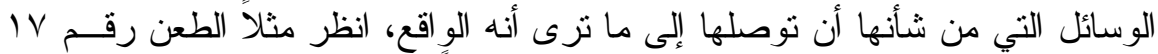

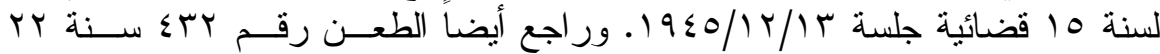

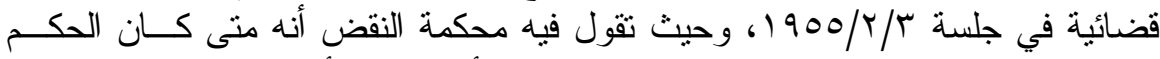

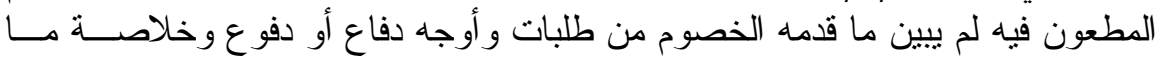

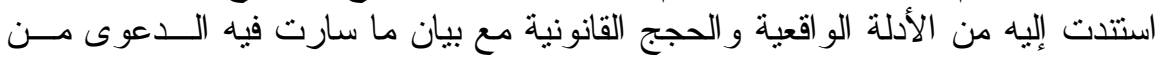

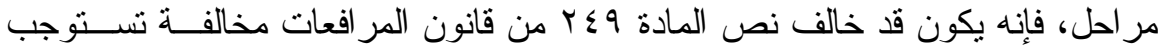

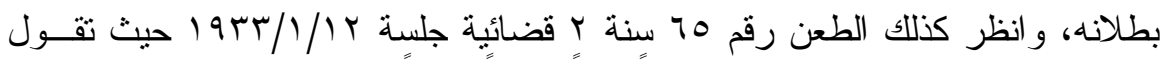

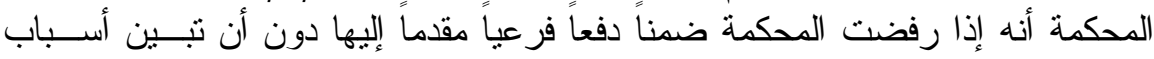

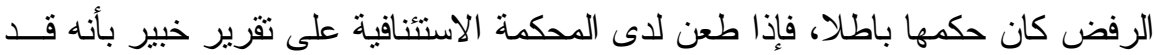

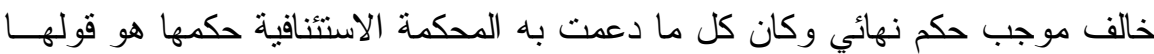

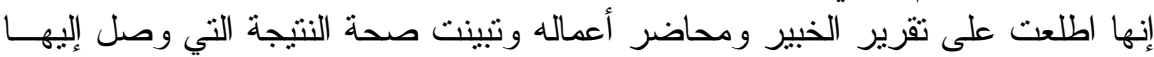

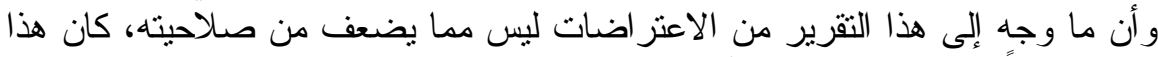
الحكم باطلاً باعنباره خال من الأسباب ويتعين نقضه. 
القضائي؛ لأن الأحكام تميز الوظيفة القانونية و الو اقعية لما يباشره القضاة مــن القـان

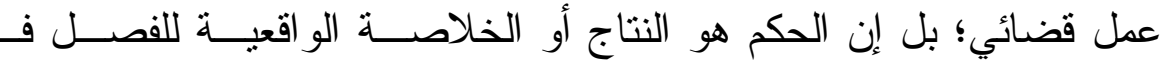

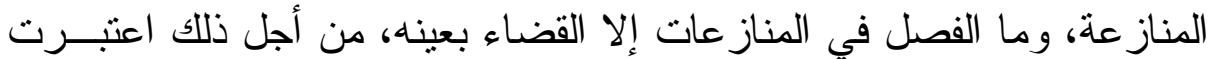

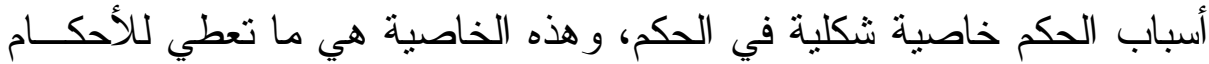

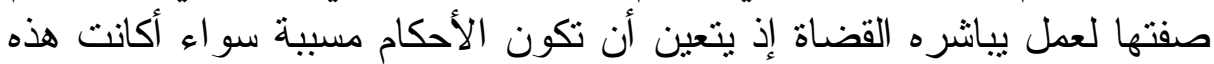

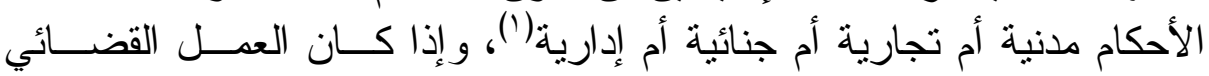

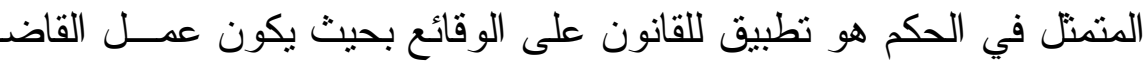

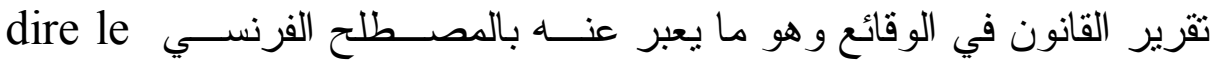
droit

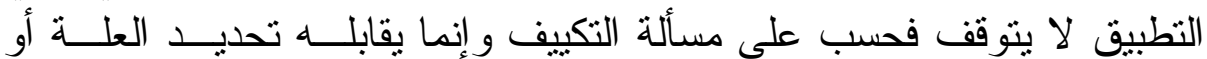

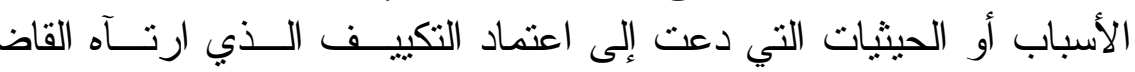

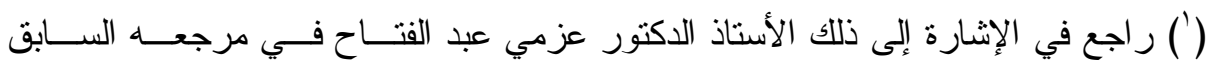

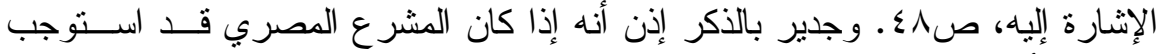

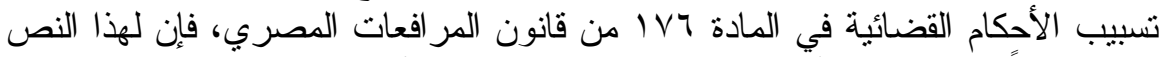

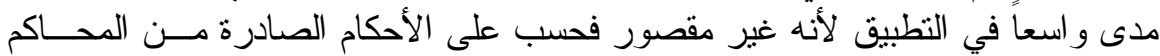

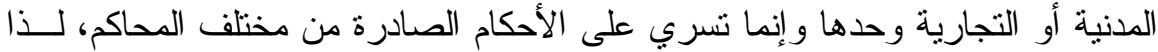

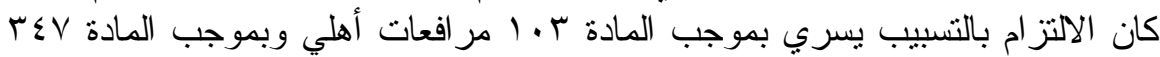

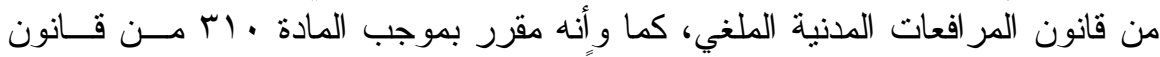

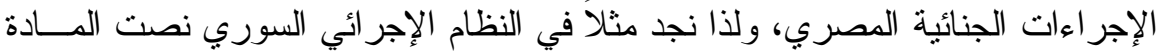

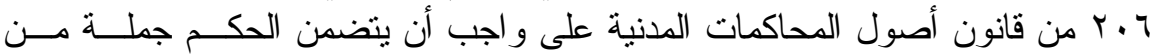

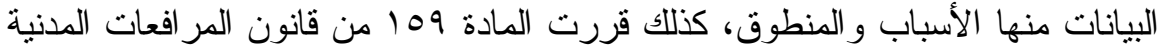

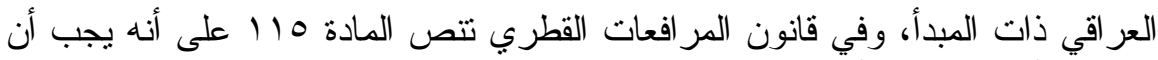

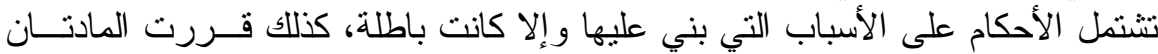

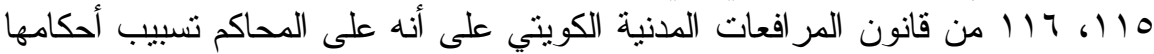

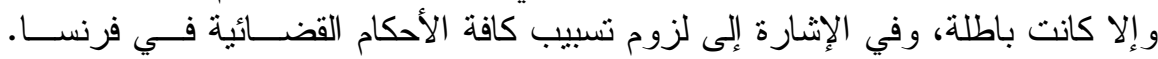
Jean Vincent et Serge Guinchard; op. cit. p. 530 No 761.

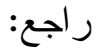

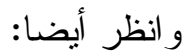
Touffait et Tung; Pour une motivation plus explicite des decisions de justice, notamment celles de la cour de cassation; rev. trim. 1974. 487.

$$
\text { وانظر أيضا: }
$$

Perelman et Foriers; la motivation des décisions de justice; travaux du cenrtre national de recherche de logique, Bruylant éd. Bruxelles 1978. 
و ارتضاه لحكم النزاع أو إيجاد الحل القانوني للقضية(').

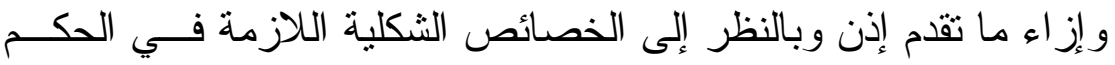

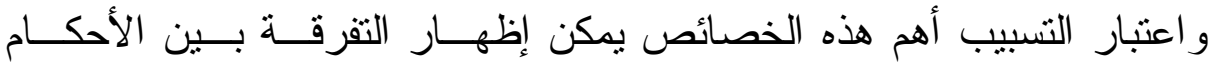

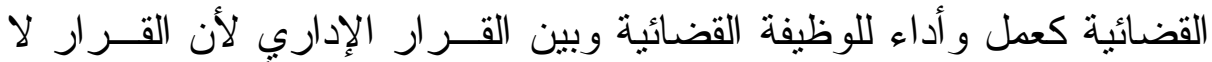

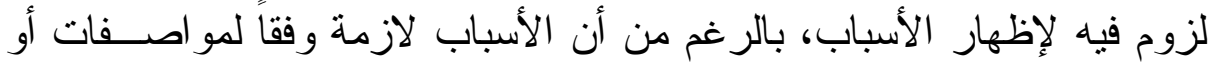

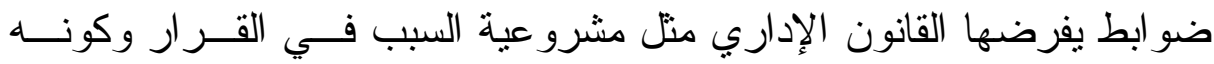

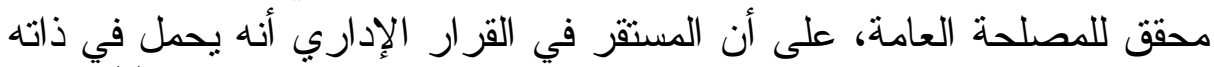

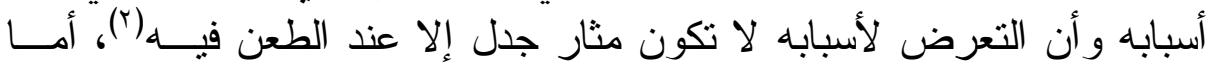

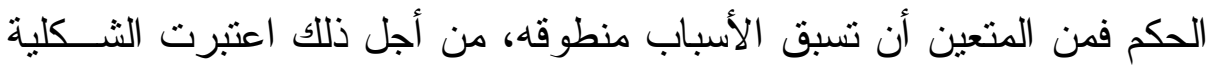

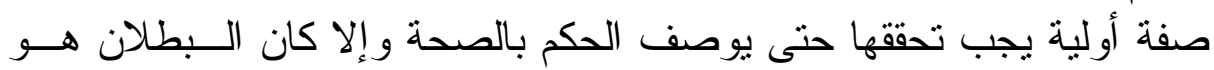
الأثز القانوني المترتب على تخلف الأبناب المؤدية إلى المنطوق.

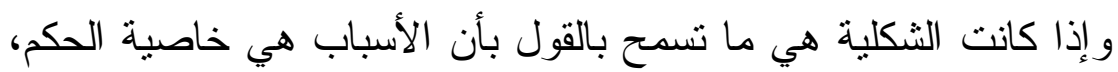

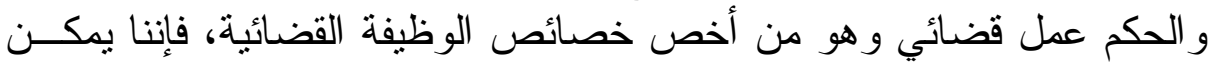

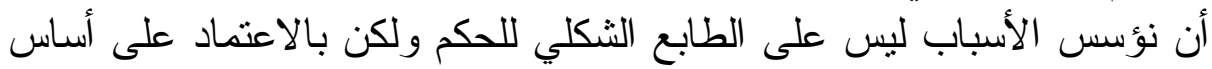

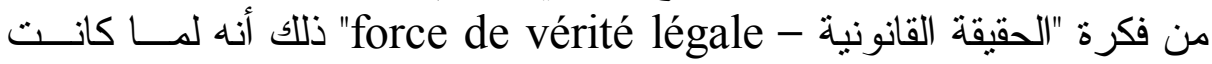

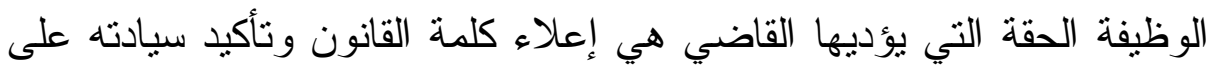

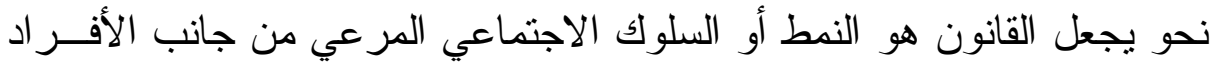

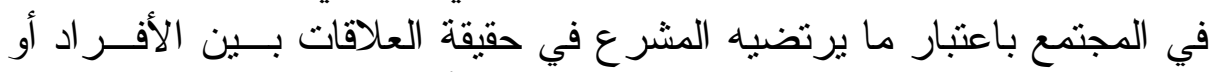

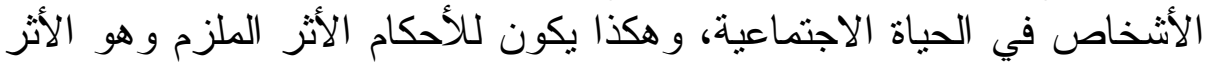

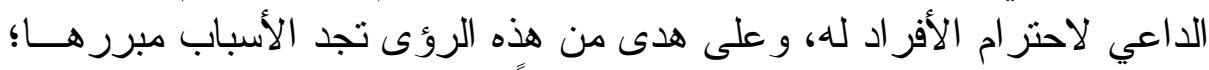

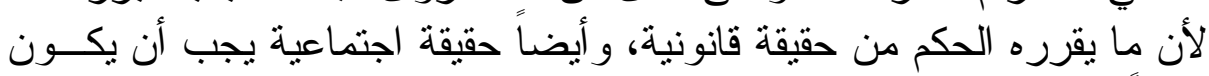

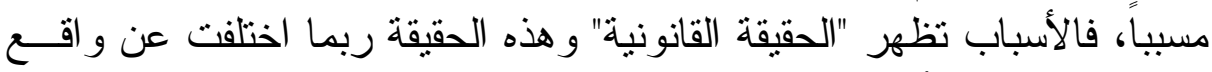

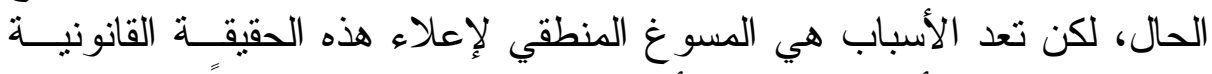

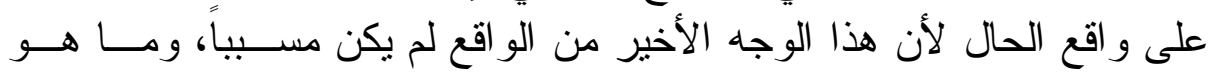

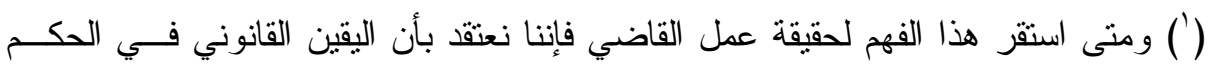

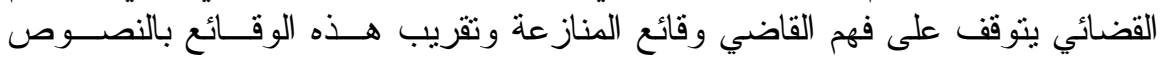

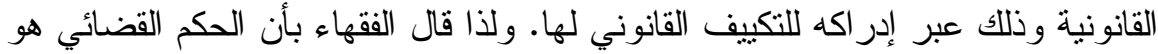

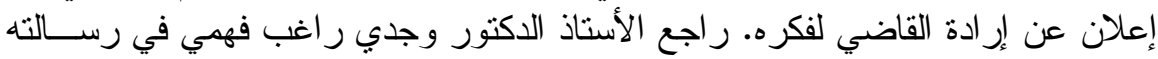

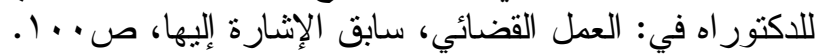

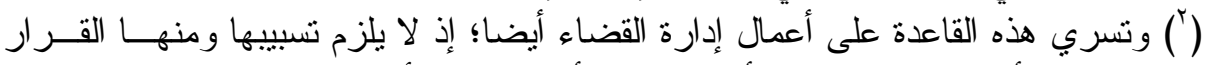

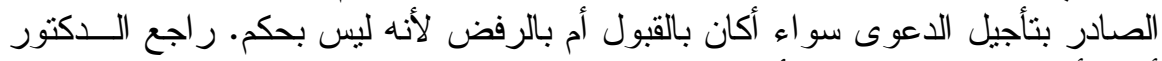

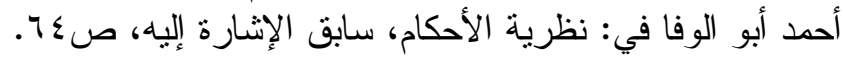


مسبب هو الأحرى بأن يوصف بوصف الحقيقة، وهو بلاشك أدعى للتقــديس بين الأفر اد و أولى بالاتباع من جانبهم.

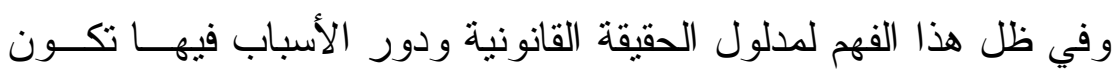
النظرة للأسباب نظرة غائية تختلف عن النظرة الثكلية لها؛ لأن اعتماد الثكل في الأسباب ربما لا يحقق المثالية القانونية أو الغاية المنشودة فيها، إذ ما قيمة أسباب قائمة من حيث الثكل في حكم قضائي دون تحقيق الغاية المطلوبة مــن

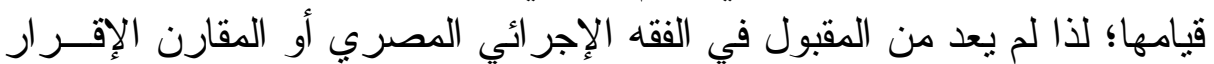

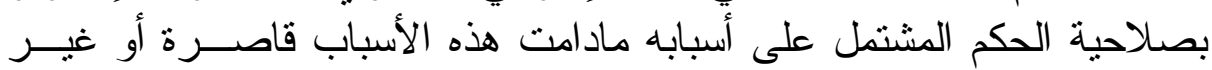

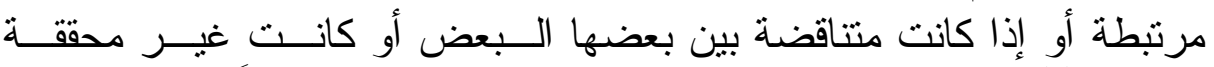

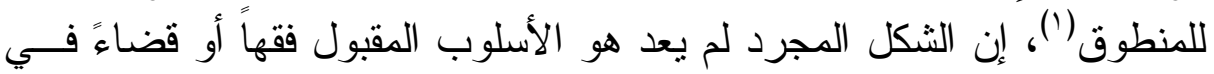

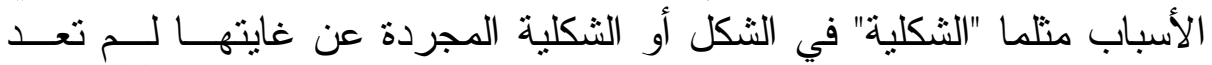
الأسلوب الأمثل في العمل القضائي و لا في الوظيفة القضائية في ذاته(؟).

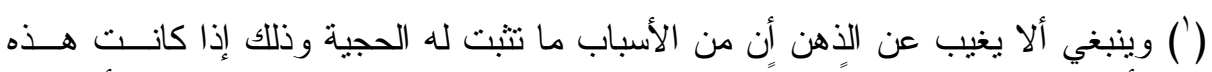

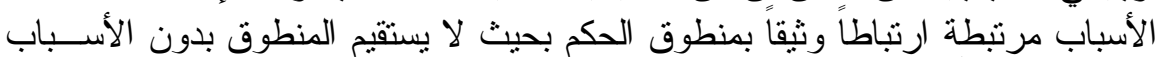

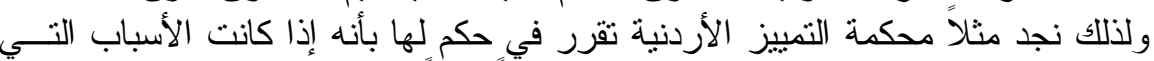

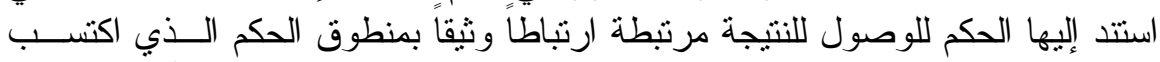

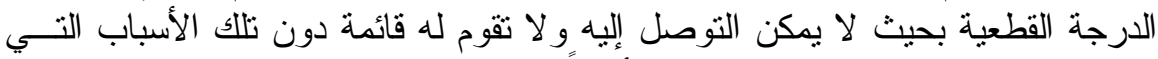

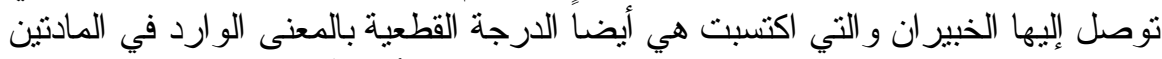

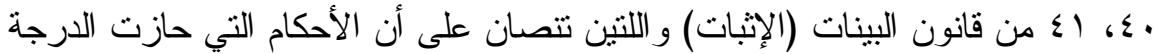

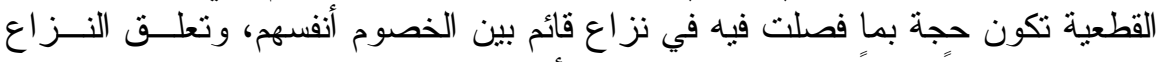

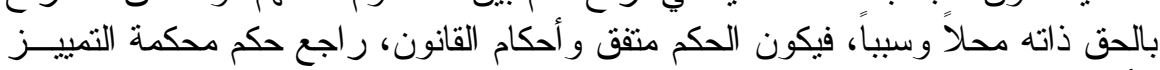

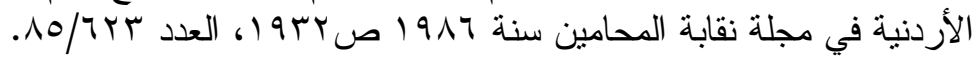

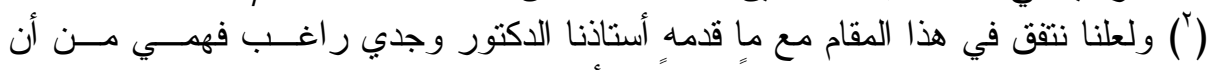

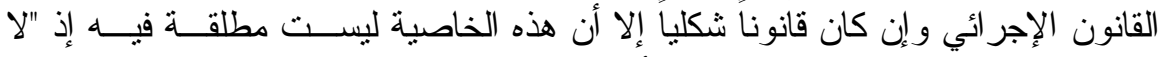

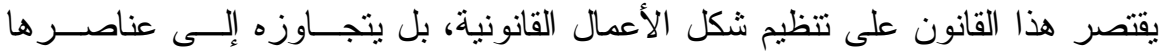

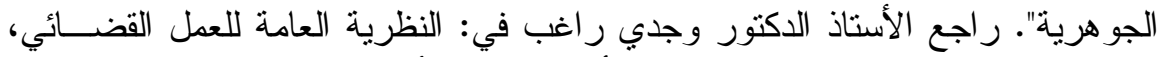

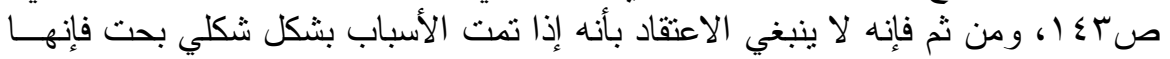

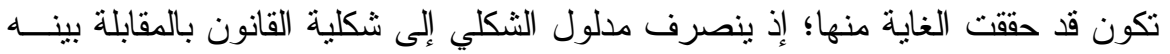

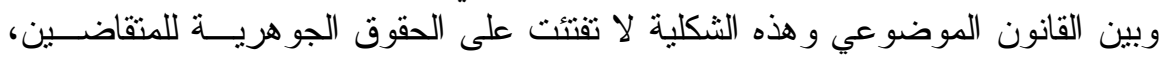

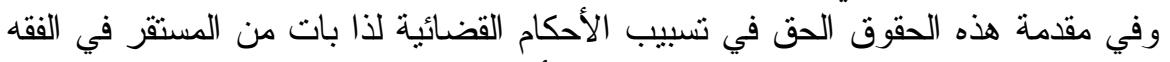
و القضاء في فرنسا وفي مصر وجوة الحفو كفاية الأسباب. راجع: Lion Husson; les trois dimensions de la motivation in la motivtion des décisions de justice, travaux du center nationale de recherché des logique. Etudes publieés par ch Perelman et P. Foriers. Bruxelles. Bruylant. 1978. p. 70. 


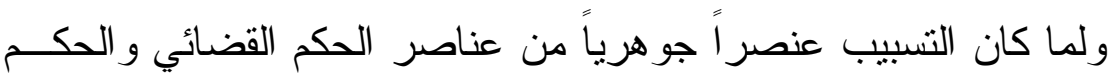

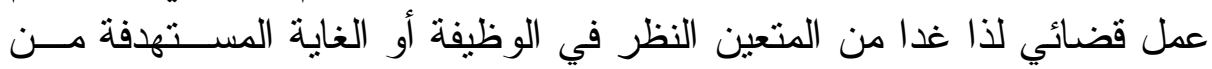

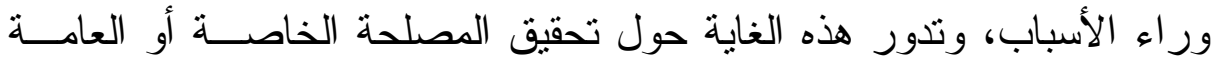

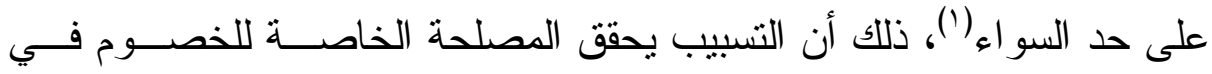
القضية وتذور هذه المصلحة حول إثتعار كل خصم بنز اهة القضاة و التثبت من دن جدوى دفاعهم في القضية و اطمئنانهم إلى أن عناصر القضية كانت تحت نظر المحكمة وهي تعلن المنطوق، ومن ثم فإنها تفتح لهم الباب للطعن في الأحكام. كذللك تحقق الأسباب مصلحة عامة من عدة أوجه إذ إنها من ناحية تؤكد العدالة وتبر هن على دو اعي التقة في القضاة، وهي تســتهدف إلـى اســـتهر ار

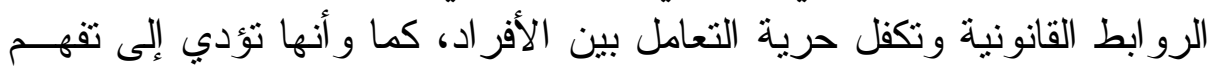
الأسس القانونية التي تحكم العلائق الاجتماعية بأسر ها وهي تتمة لمبدأ العلانية وفي ذللك تأكيد على مصالح الجماعة السياسية حيث إنها تأكيد على أن الأحكام

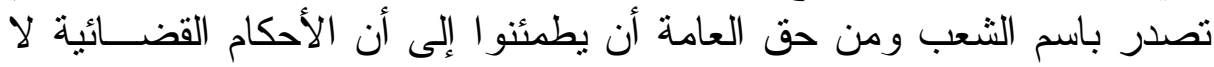

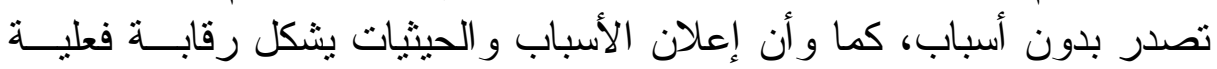
على السلطة التقديرية الممنوحة للقاضي (؟).

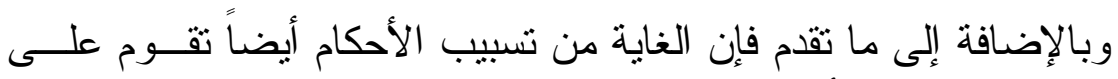
أساس من طبيعة العمل أو الوظيفة القضائية في حد ذاتها في مجال الفصل في

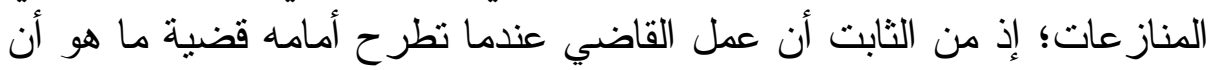

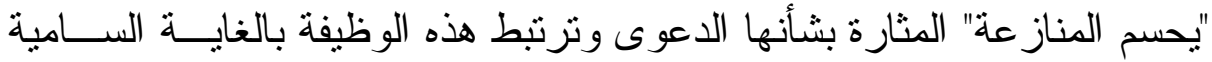

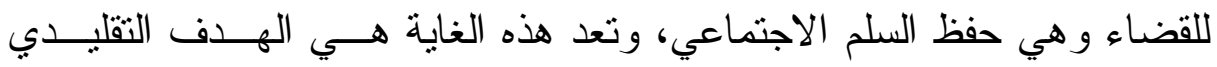

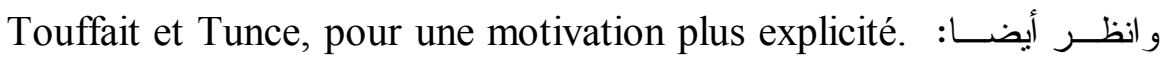
I ف Rev. trim. Dr. civ. 1974 p. 499

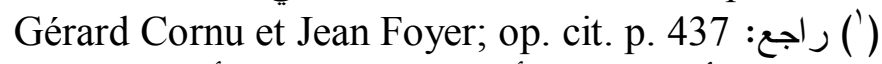

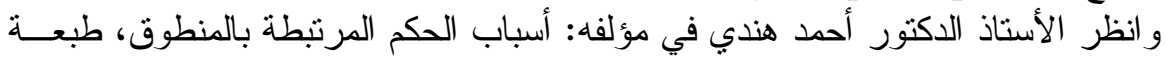

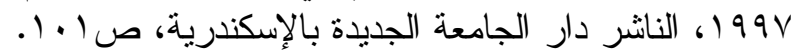

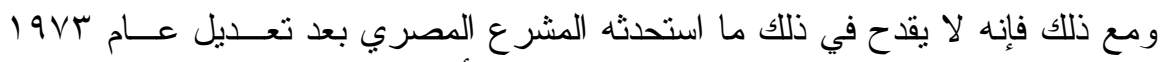

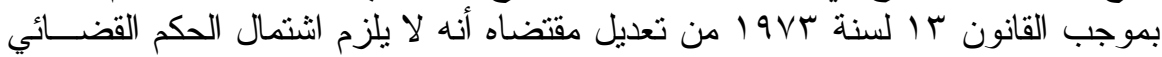

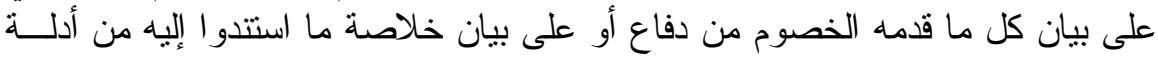

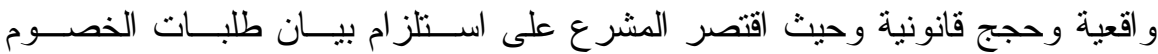

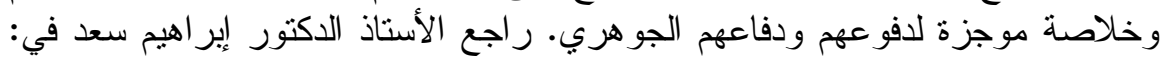

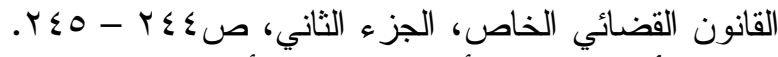

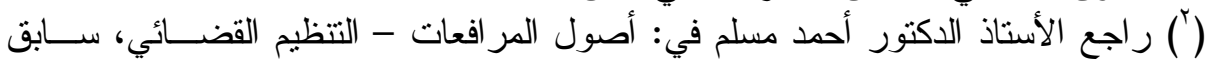

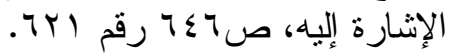




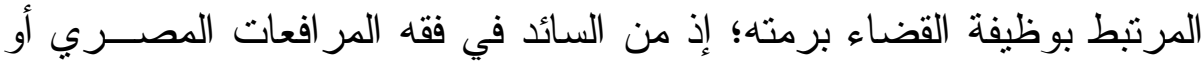

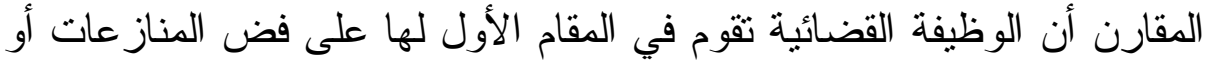

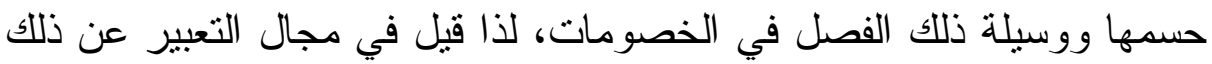

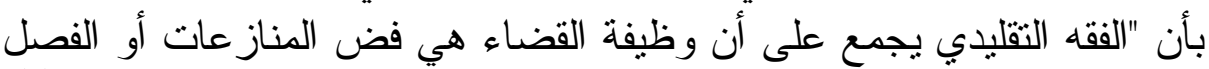

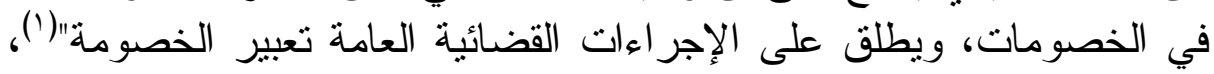
وكان أن ساد في الفقه الإجرائي الفرنسي أن الوظيفة القضائية تقوم في الأساس أفئس

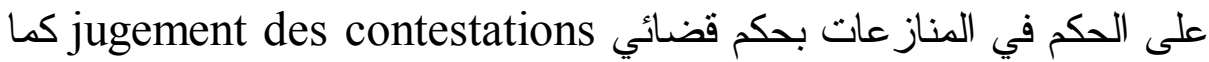

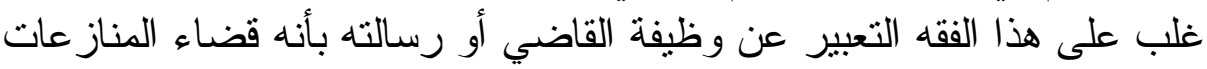

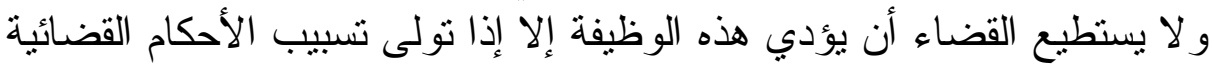

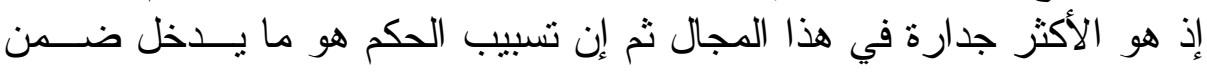
صميم عمل القضاء في حسم المناز عات.

وتتفق هذه الفكرة الأخيرة التي تعزي تسبيب الأحكام القضائية إلى أصل

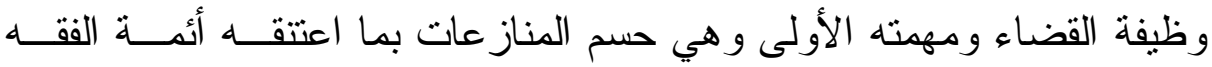

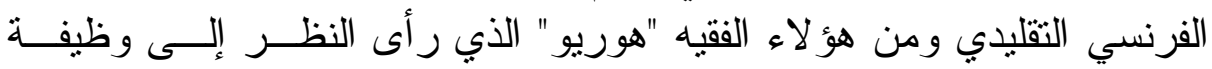

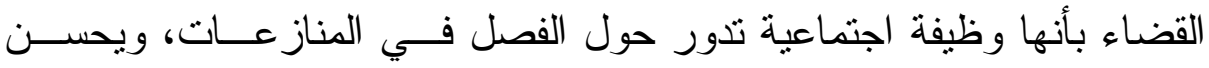

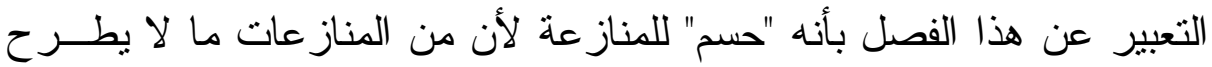

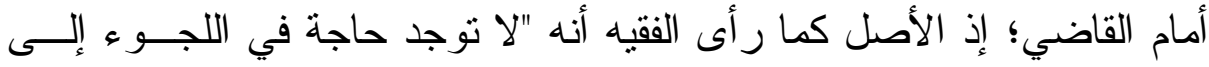

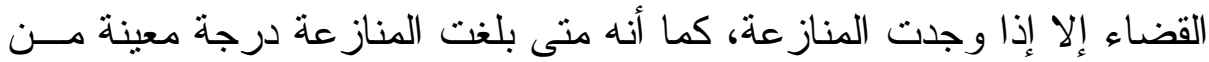
الحدة فإنها تستدعي وجود قاض إلاض (؟).

و المنازعة تعارض بين خصمين وتضاد في الادعاء وهي شــرط شــــي

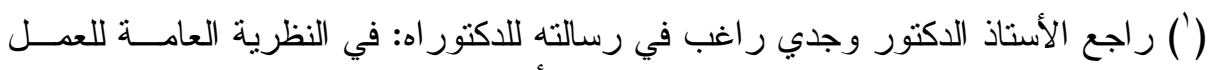

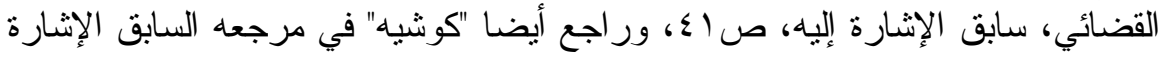

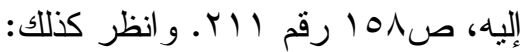

Moury; de quelques aspects de l' evolution de la jurisdiction en droit judiciaire privé; mélanges Perrot. P. 209.

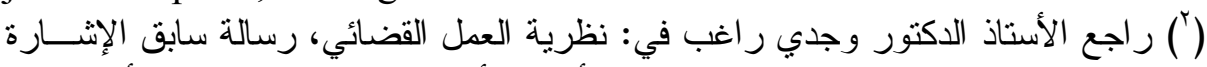

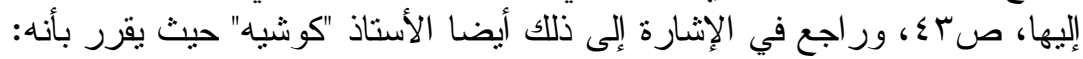

La première activité du juge à laquelle l' on pense est evidemment son activité constentieuse, celle par laquelle il tranche des litiges; c'est qu' en effet un aspect assentiel du role du juge.

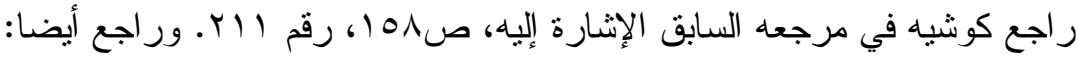

Wiederkehr; "qu' est - ce qu' un juge? Mélanges Perrot. P. 575.

Jean larguier; op. cit. p. 19 


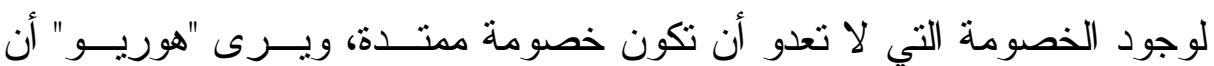

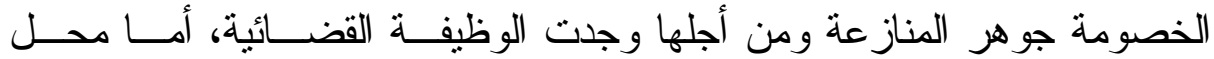

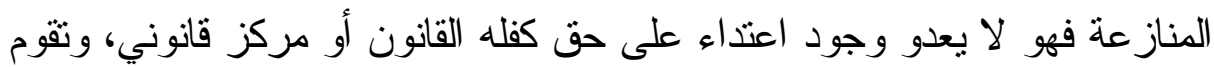

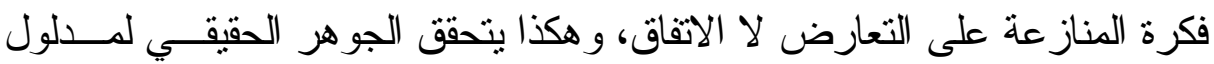

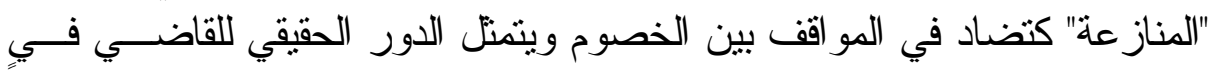

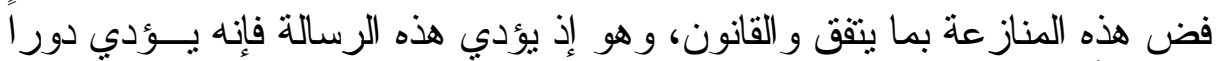

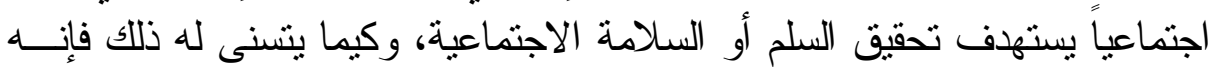

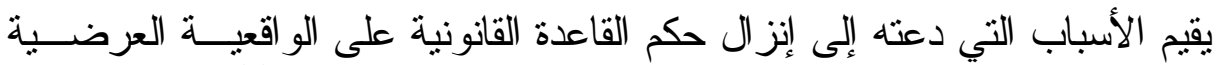

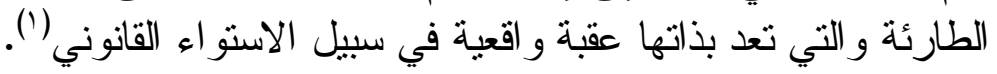

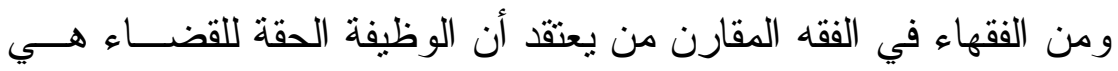

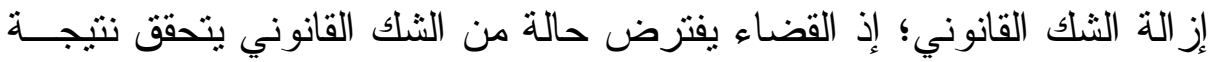

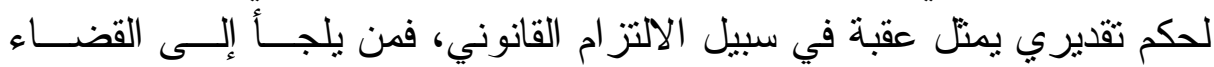

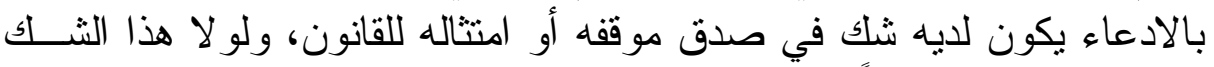

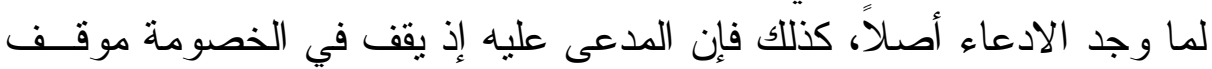

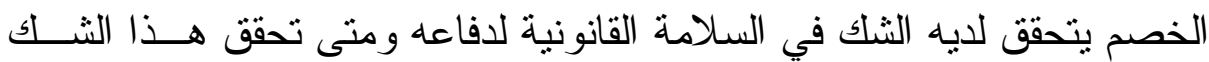

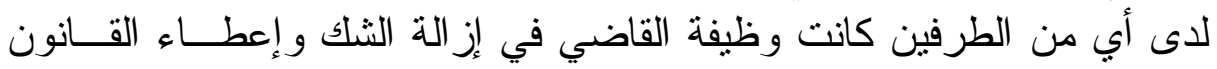

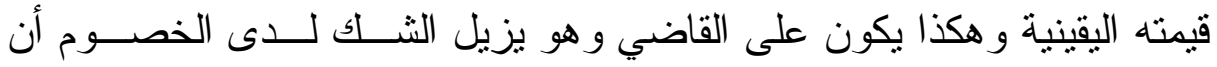

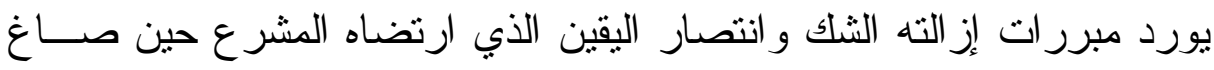

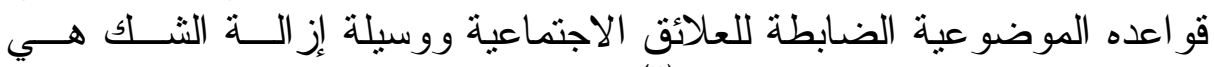
عرضه للأسباب المؤدية إلى الحكم (؟).

M. Hauriou; les elements du contentieux, Recueil de legislation de (') (') (') (1) Toulouse. 1905p. 13 - 45.

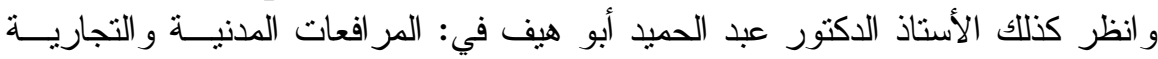

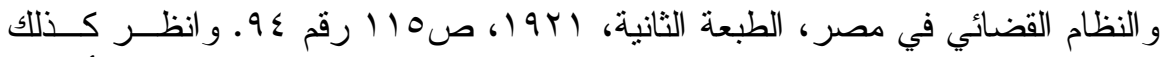

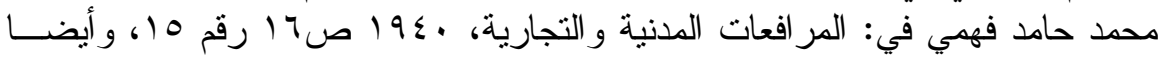

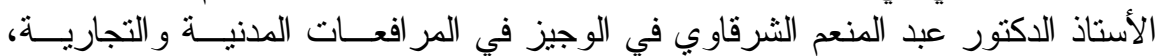

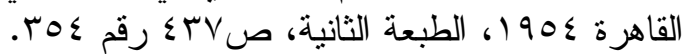

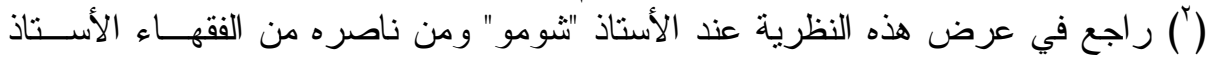

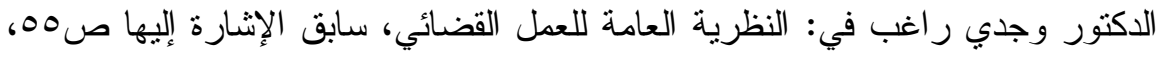

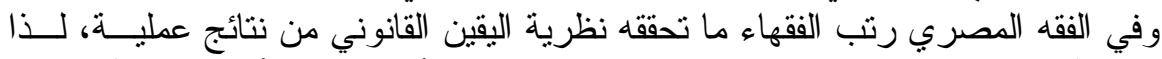

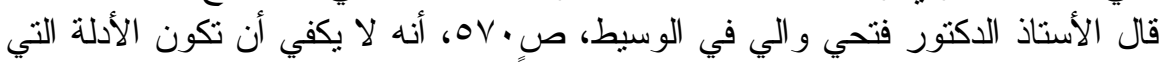

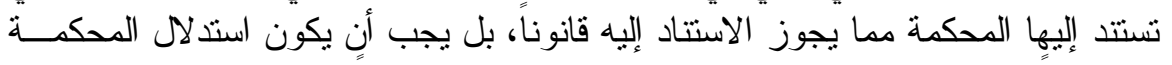

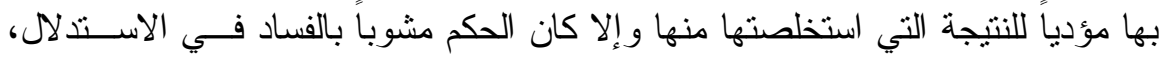




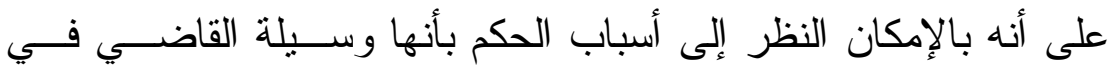

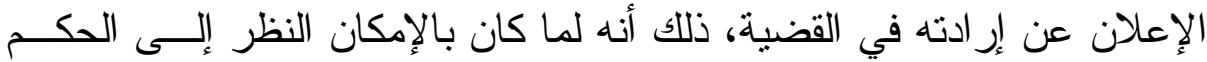

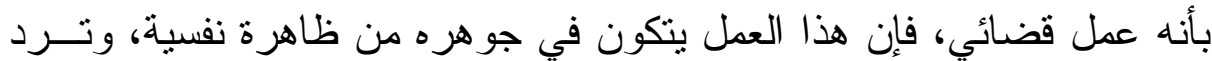

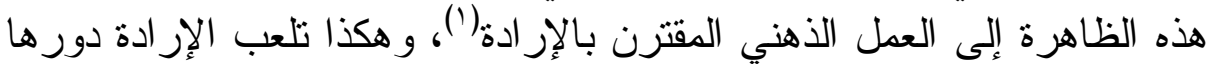

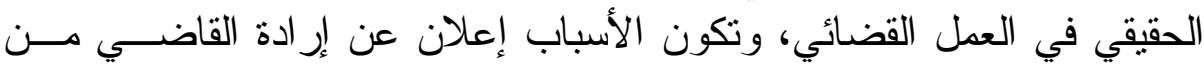

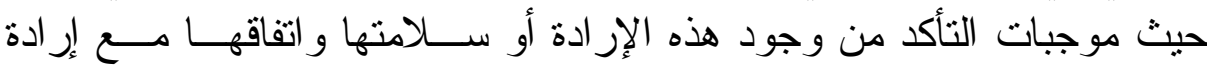
القانون، ويعد استظهار هذه الإر ادة من الحقائق القانونية اللازمة فــي عمـــل

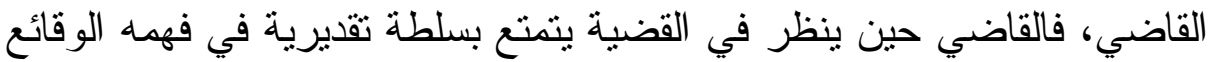

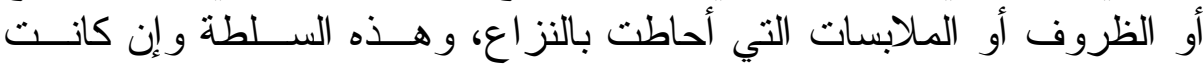
تقديرية في ظاهرها إلا أنها محكومة بالمنطق الموضو عي أو القانوني، ومستـن

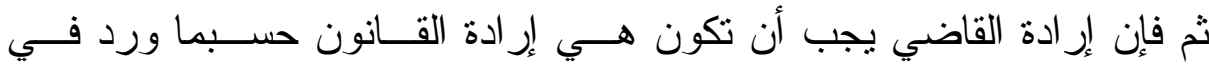

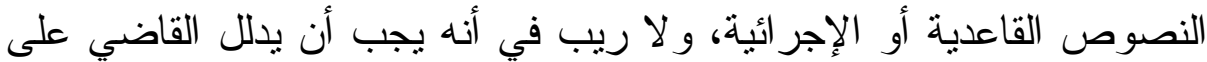

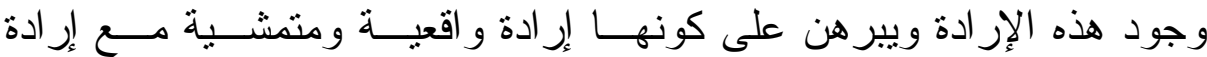

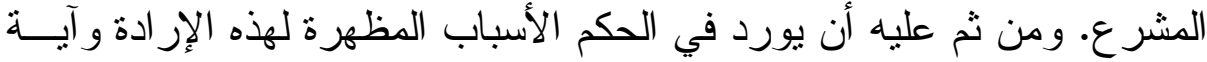

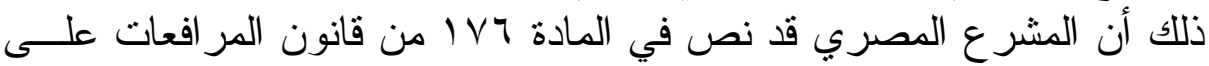

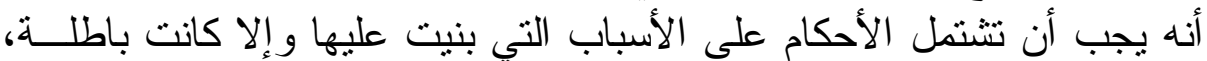

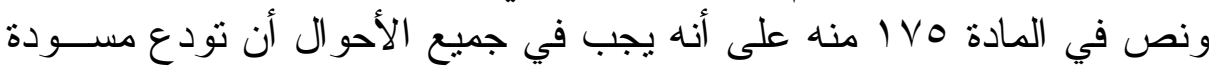

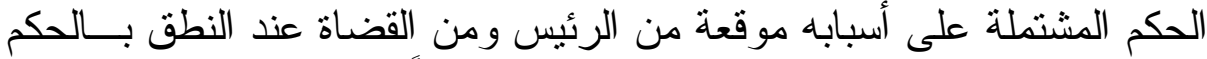

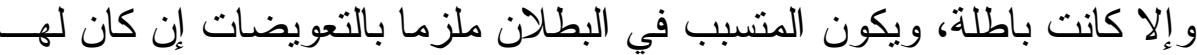

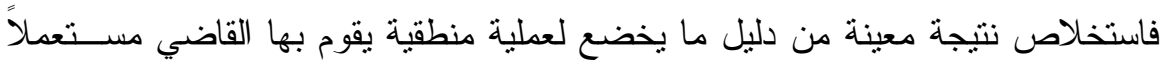

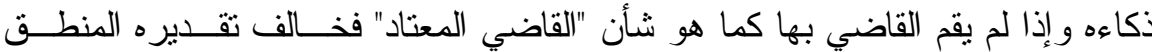

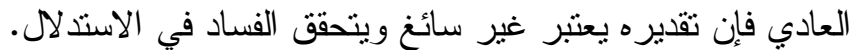

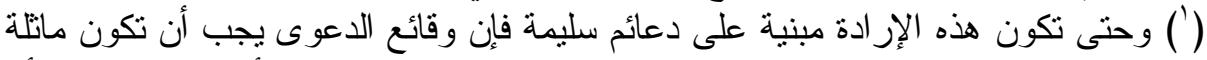

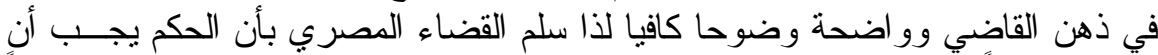

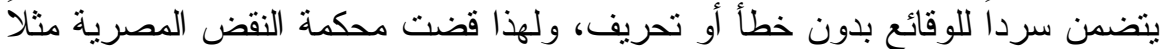

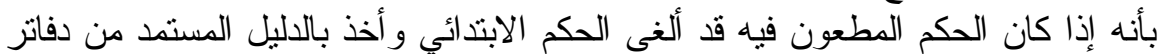

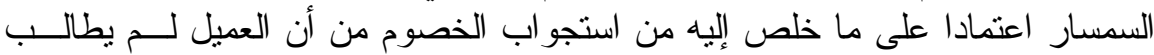

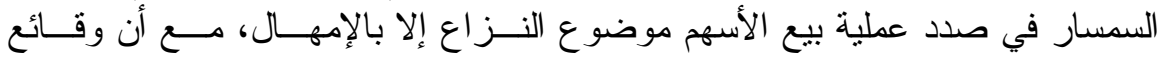

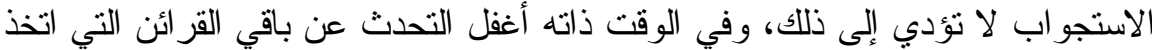

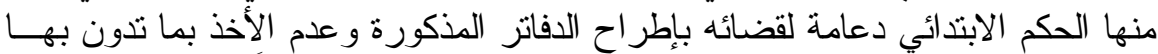

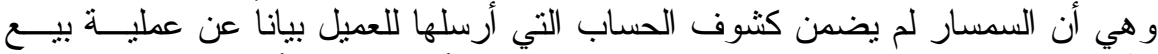

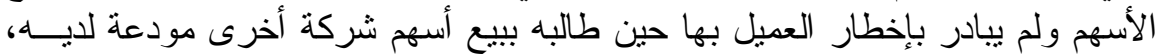

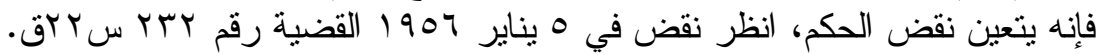




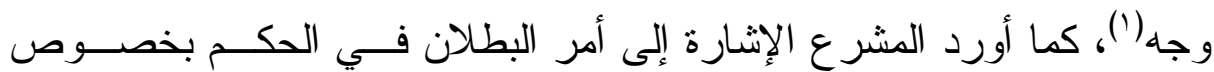

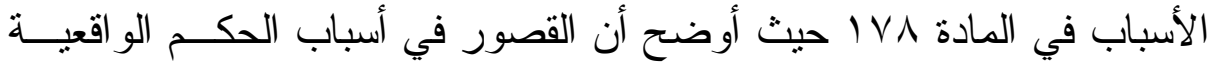

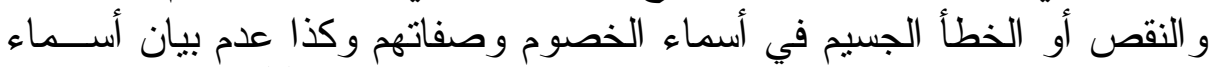

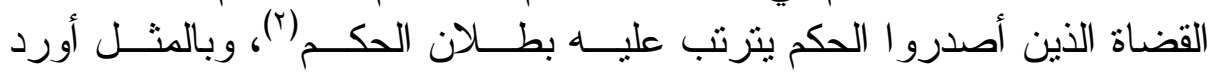

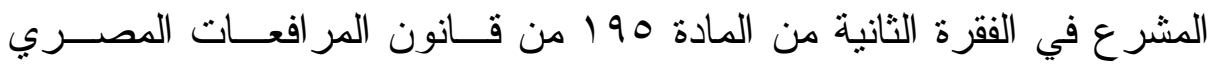

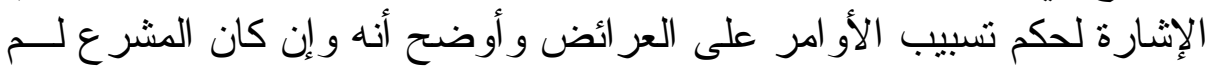

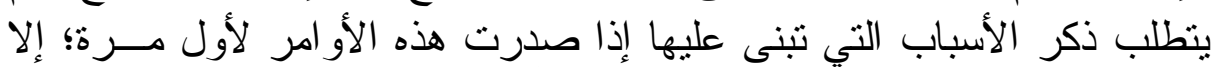

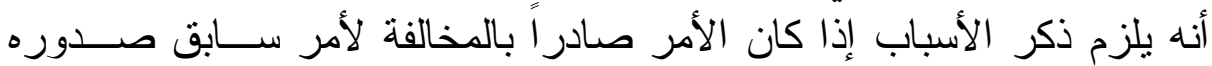

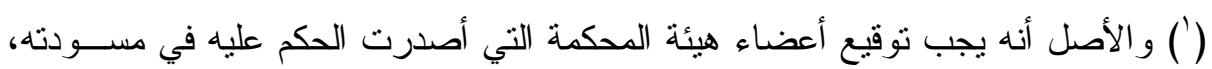

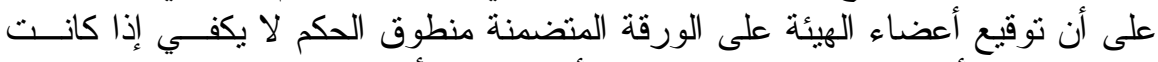

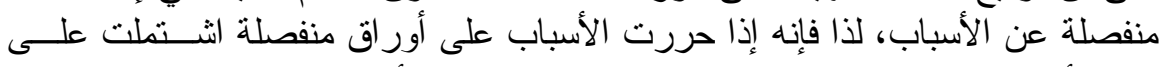

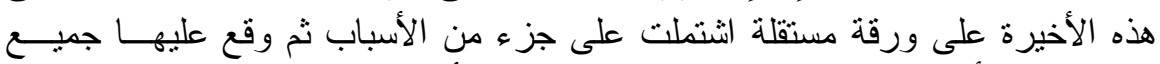

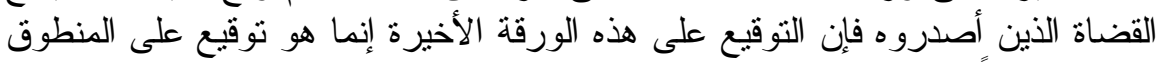

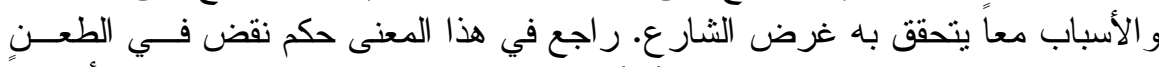

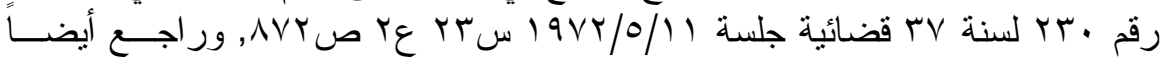

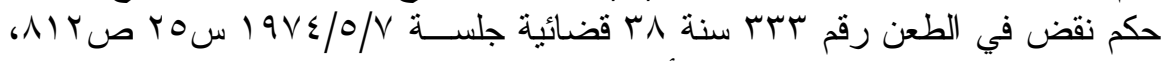

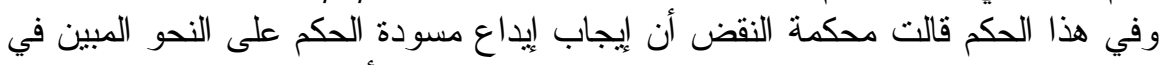

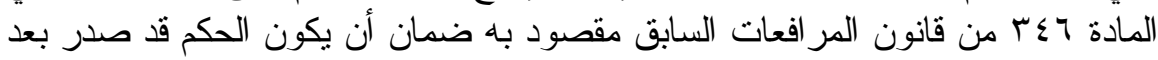

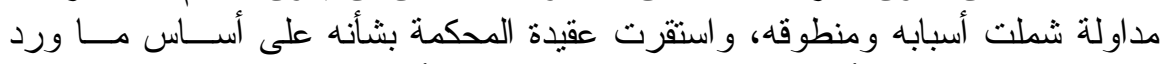

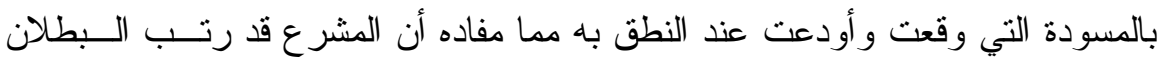

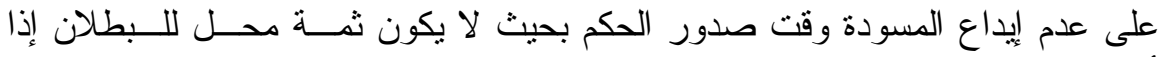

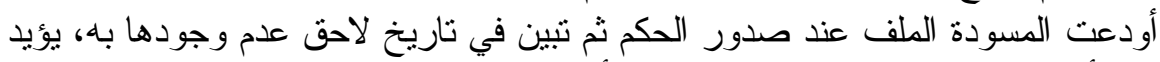

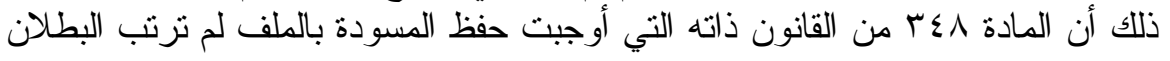

$$
\text { جز اء على مخالفة حكمها. }
$$

ومن المستقر في قضاء محكمة النقض المصرية أن نسخة الحكم الأصلية التي أفرد لها

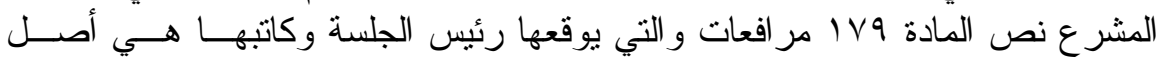

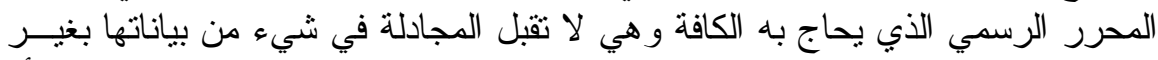

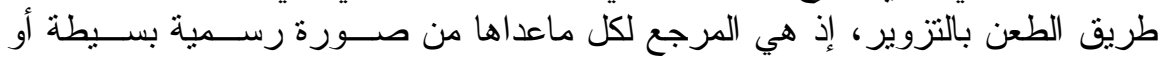

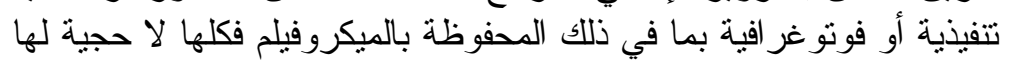

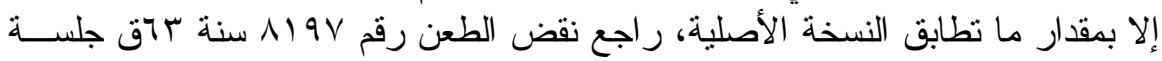

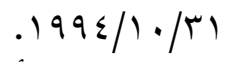

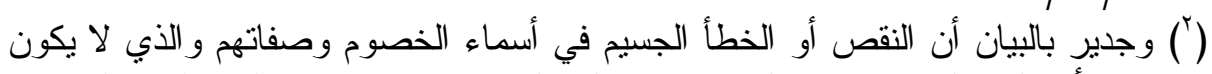

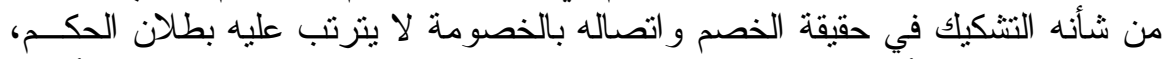

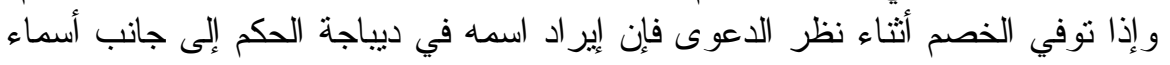

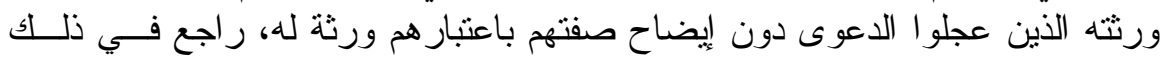

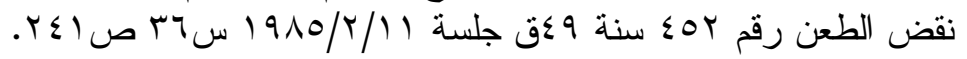




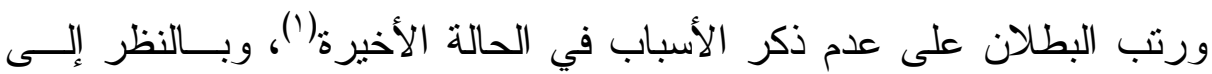

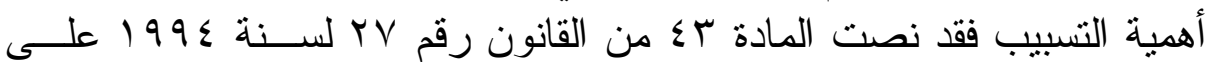
ضرورة تسبيب أحكام المحكمين (r). وفي القانون الإجر ائي الفرنسي أوجب المشر ع تسبيب الأحكام منذ قيــام

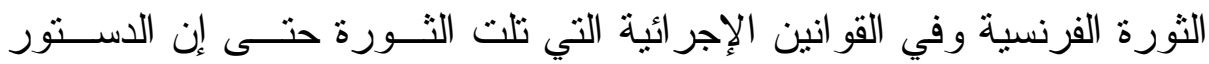

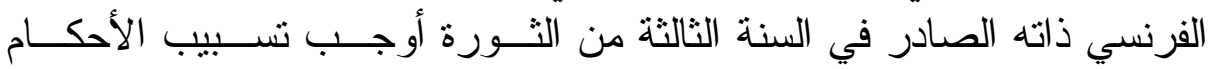

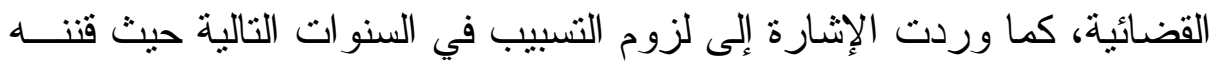

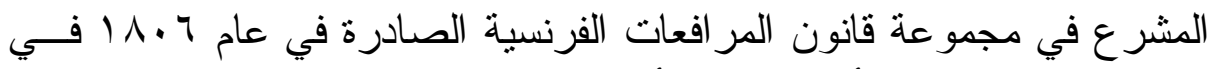

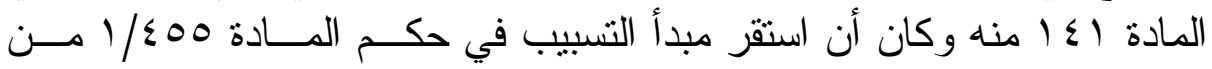

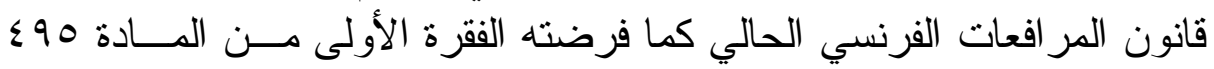

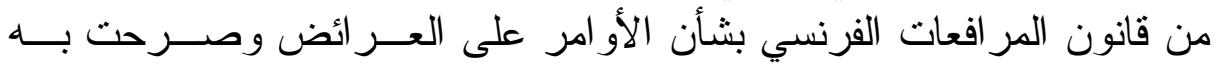

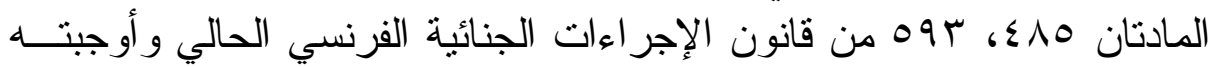

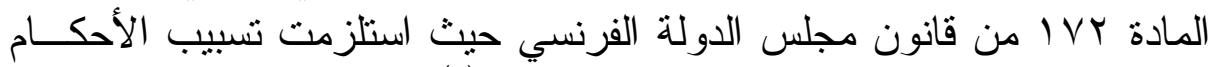

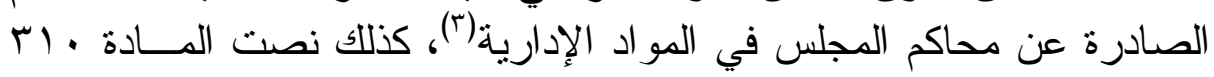

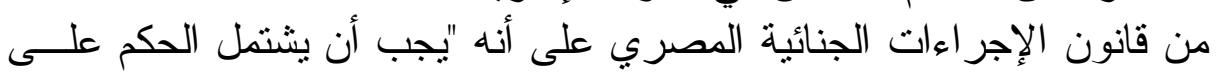

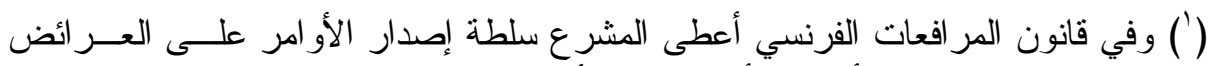

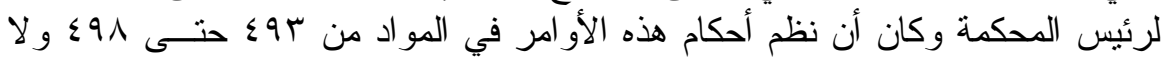

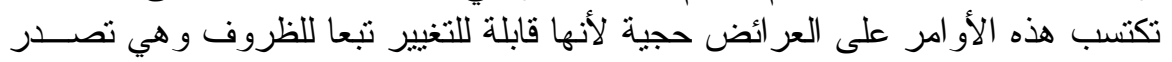

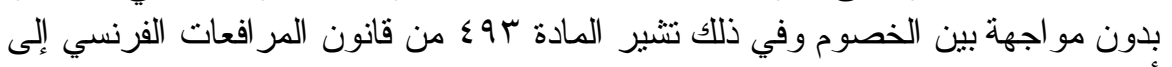
أن:

L'ordonnance sur requête est une décision provisoire rendue non cotraditoirement dans les cas oû le requérant est fondé à ne pas appeler de partie adverse.

$$
\text { راجع في التعليق على هذه المادة: . }
$$

Soc. 17 mai 1977, Bull. civ. No 327 p. 259. D. 1977. J. 645. note Jeammaud, Gaz. Pal. 1977. J. 612.

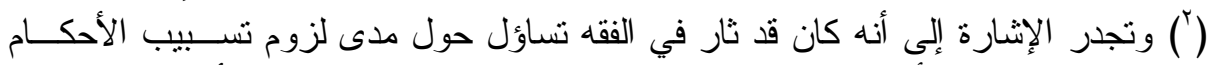

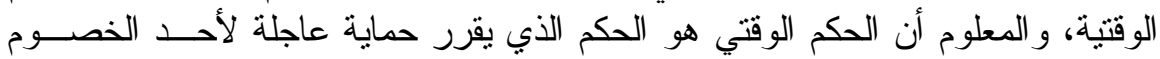

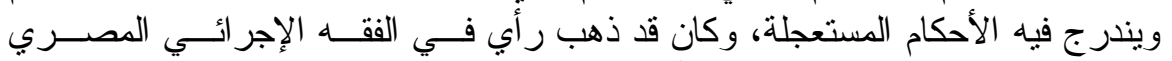

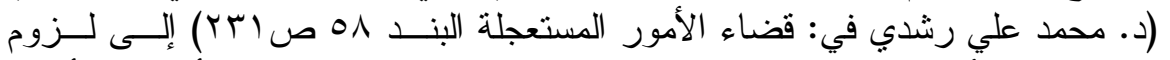

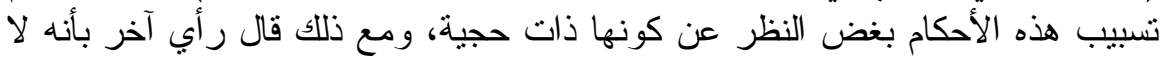

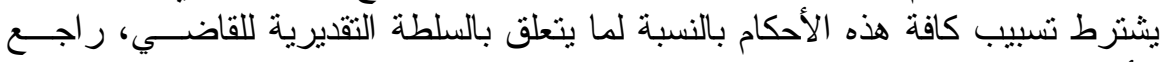

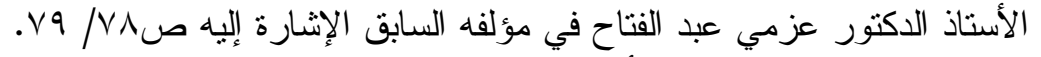

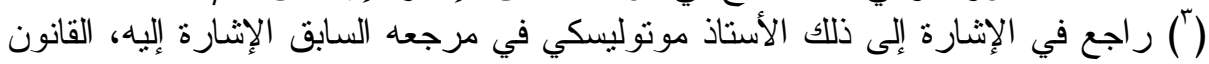

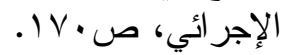


الأسباب التي بني عليها، وكل حكم بالإدانة يجب أن يشتمل على بيان الو اقعــة

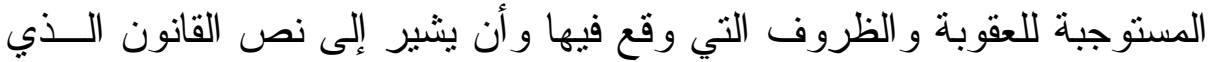

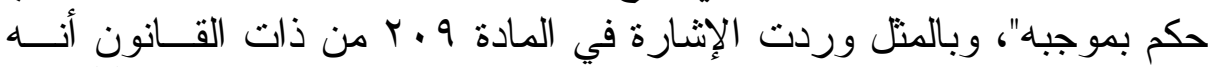

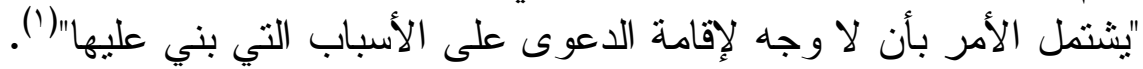
المطلب الثاني

\section{الملامح الأصولية فيما يلزم تسبيبه في الأحكام القضائية}

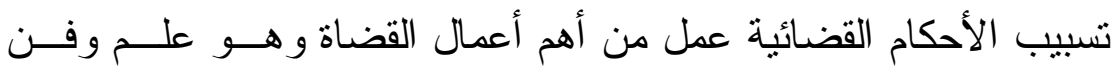

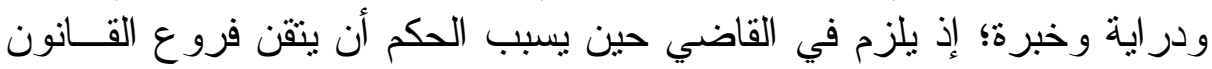

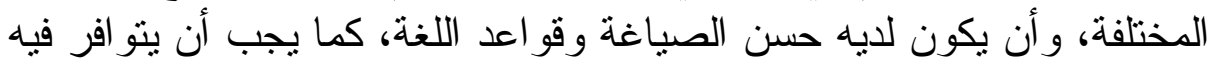

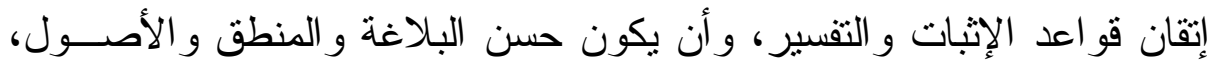

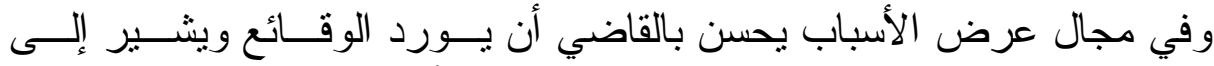

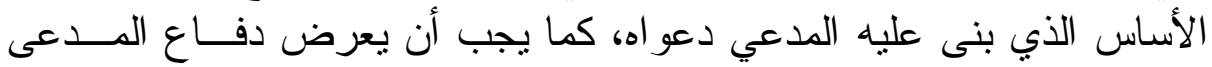

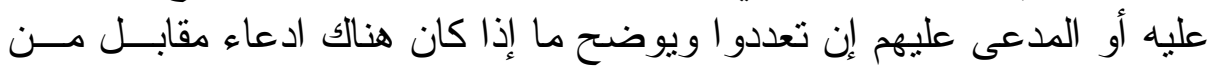

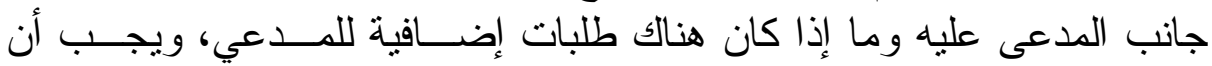

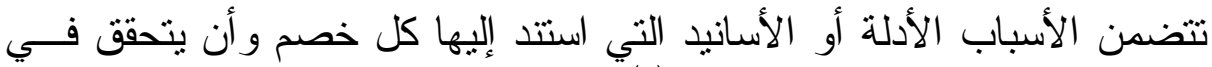

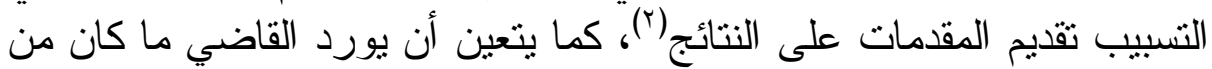

(') راجع الأستاذ الدكتور رؤوف عبيد في: مبادئ الإجراءات الجنائية، طبعة 9 أو، دار

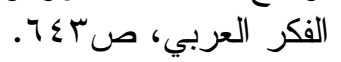

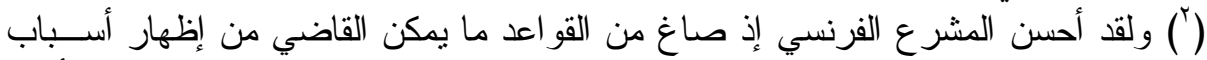

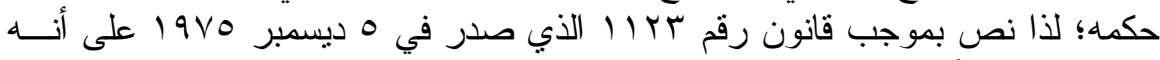

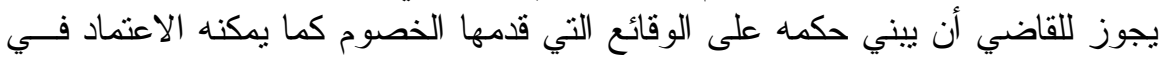

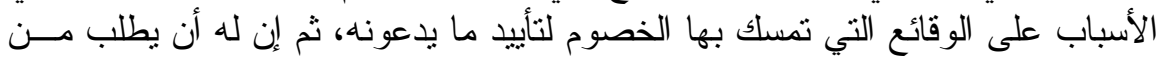

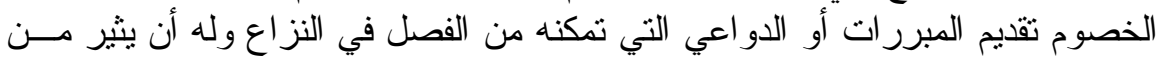

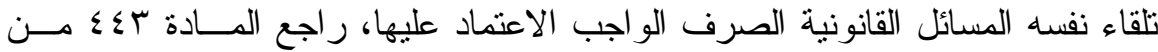

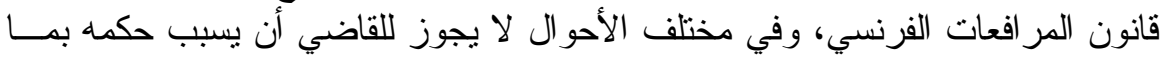

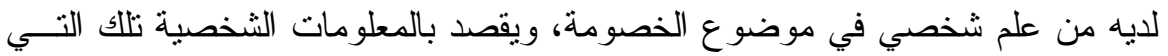

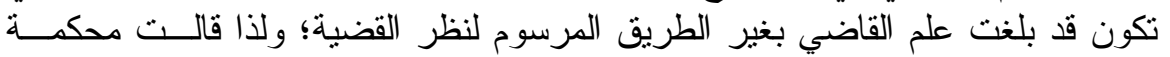

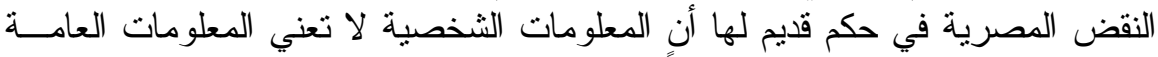

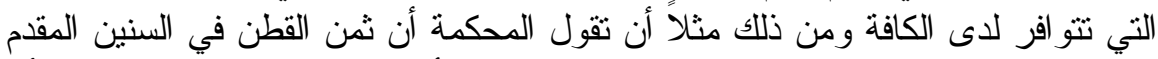

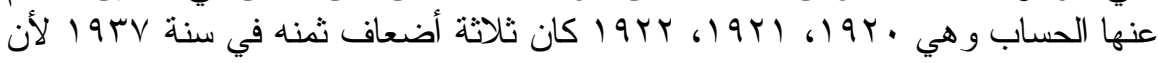

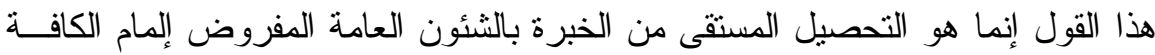

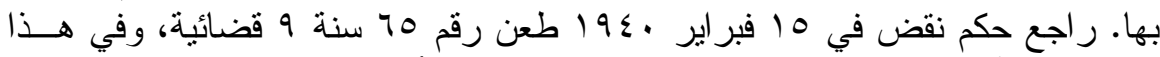

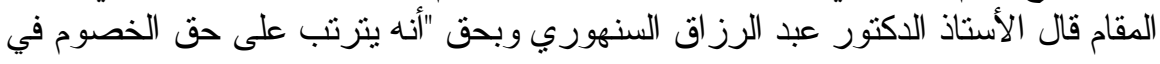




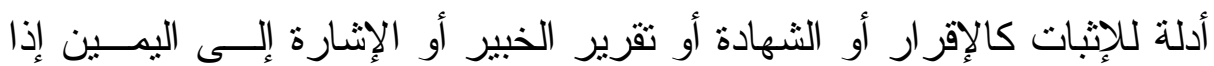

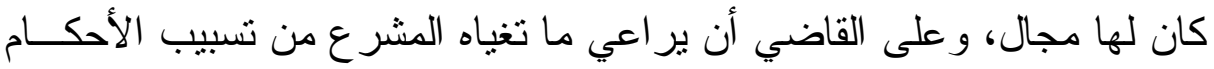

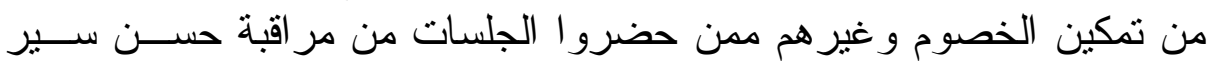

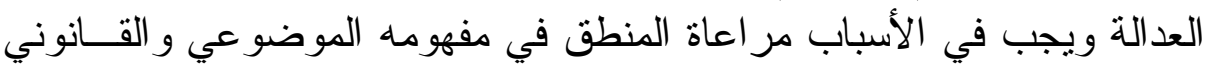

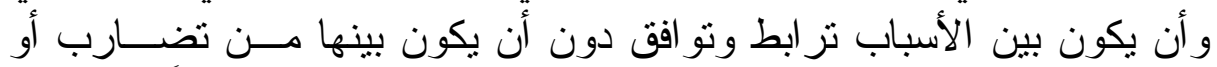

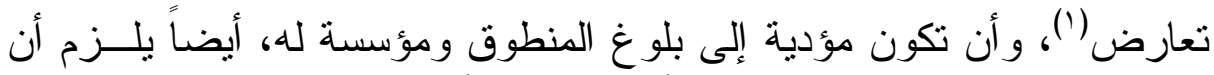

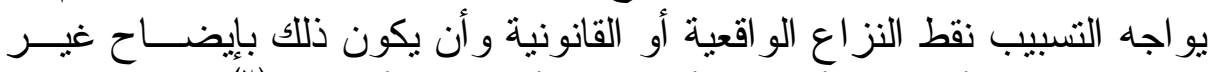

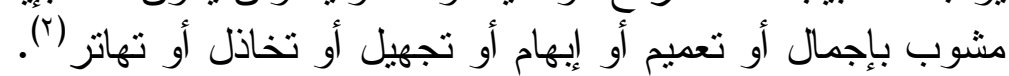

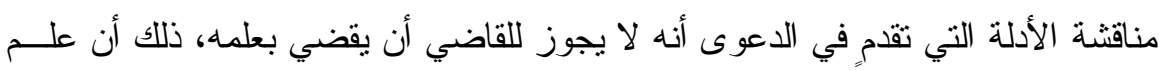

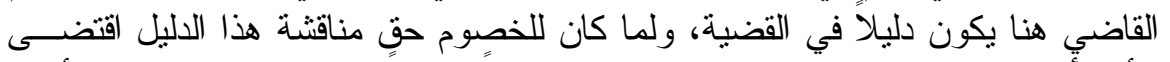

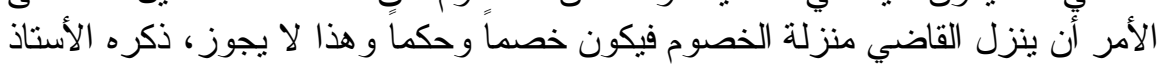

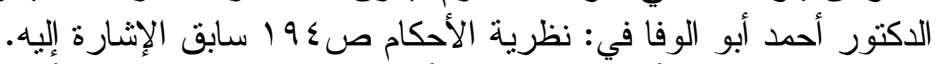

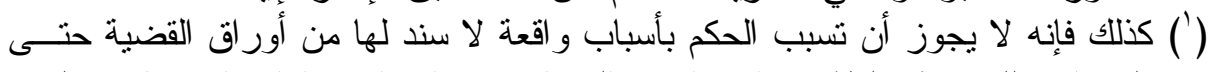

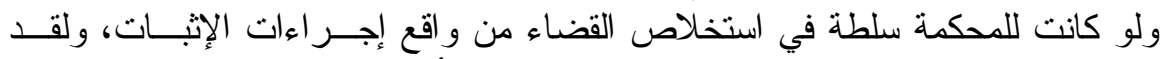

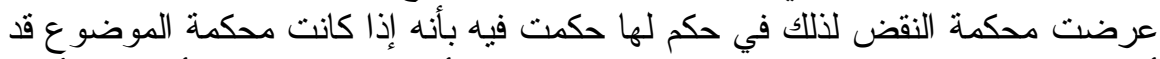

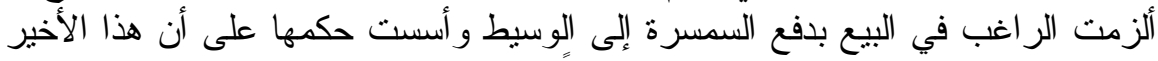

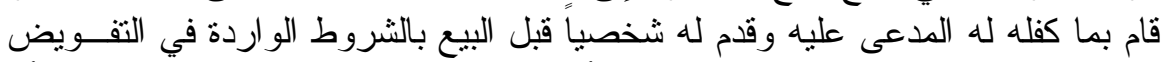

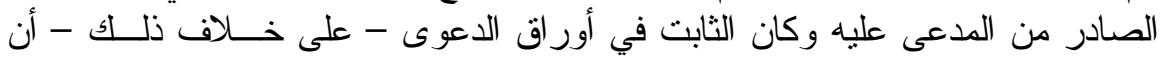

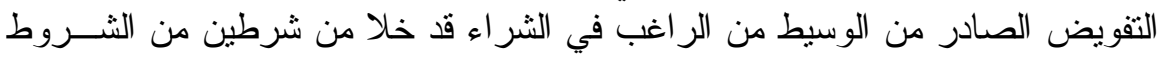

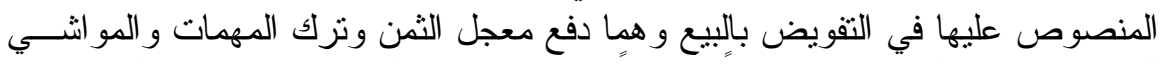

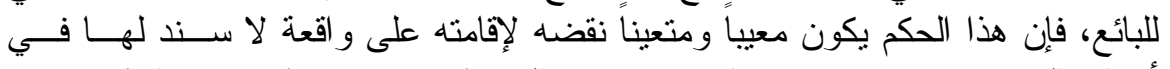

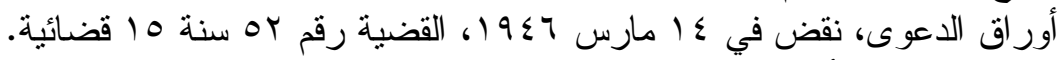

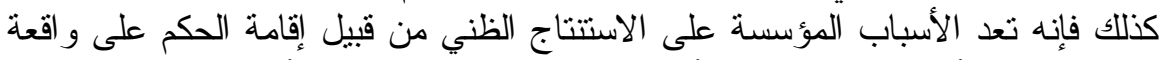

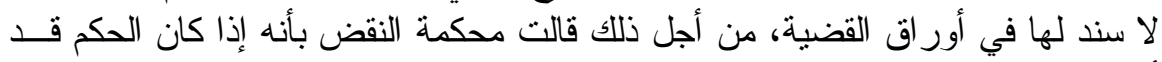

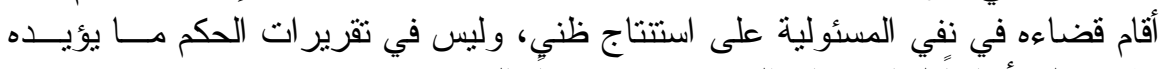

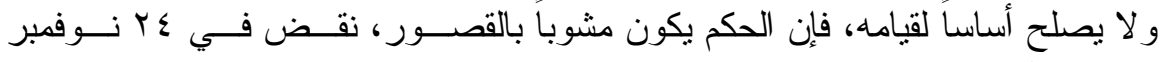

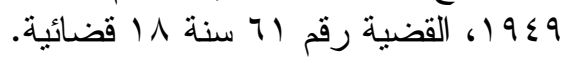

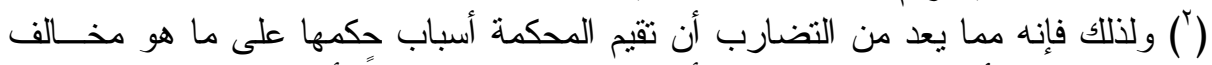

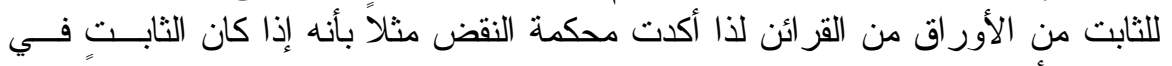

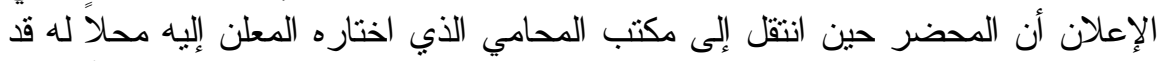

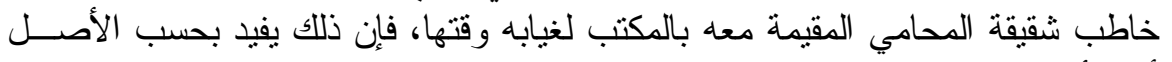

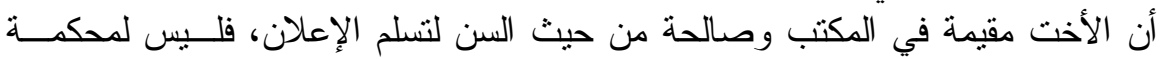

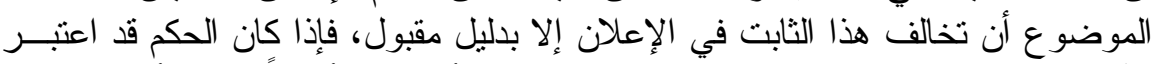

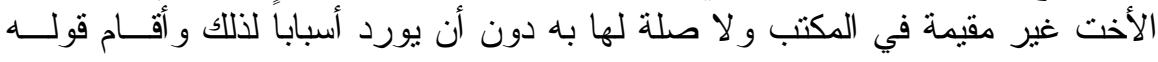

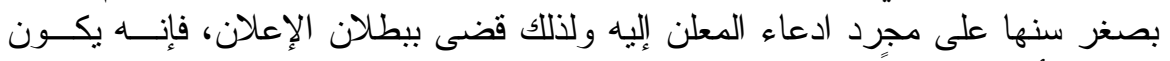

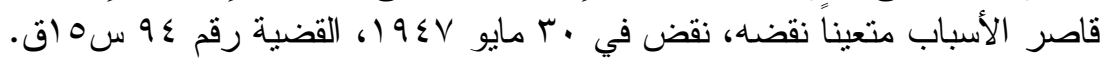


وكثير اً ما أرشدت محكمة النقض المصرية إلى هذه الملامح الضرورية

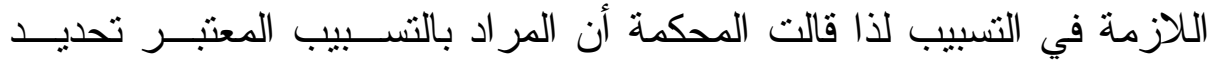
الأسـانيد و الحجج المبني عليها و المنتجة هي له سواء من حيث الو اقع أو مــن فئ

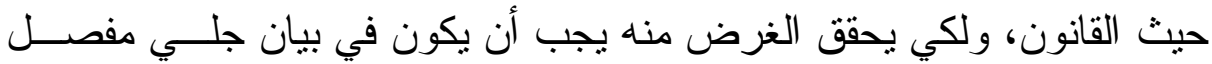

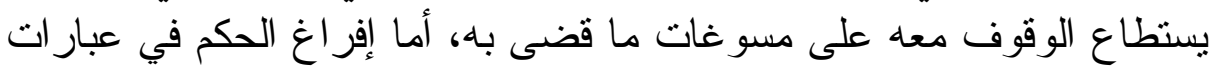
عامة معماة أو وضعه في صورة مجهلة مجملة فلا بحقق الغرض الذي قصدي فيده

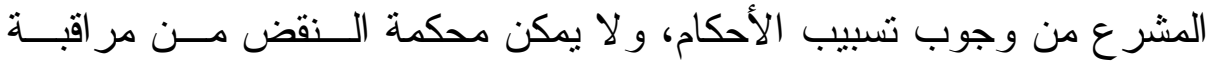

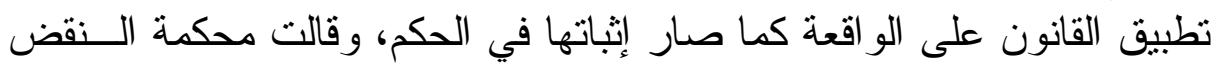
في حكم لها صدر عن الدائرة الجنائية في شأن التسبيب أنه "لما كانت الأحكام في المو اد الجنائية تبنى على الجزم و اليقين لا على الظن و الاحتمــال، وكـــان الشار ع يوجب في المادة • اب من قانون الإجراءات الجنائية أن يشتمل الحكم

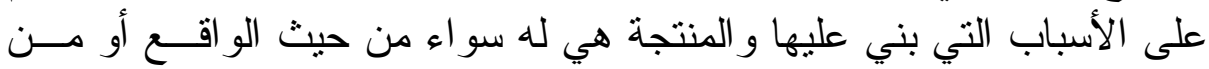

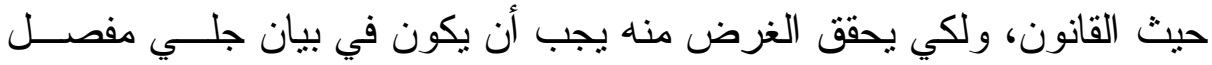
بحيث يستطاع الوقوف معه على مسو غات ما قضى بـه، أما إفراغ اغ الحكم فـي في

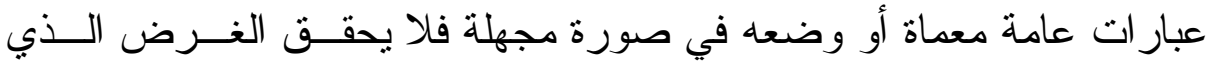
قصده الثار ع من وجوب تسبيب الأحكام، و لا يمكن محكمة النقض من مر اقبة صحة تطبيق القانون على الواقعة كما صار إثباتها بالحكم" (1).

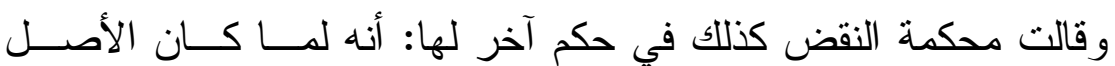
المقرر أنه يتعين ألا يكون الحكم مشوباً بإجمال أو إبهام مما يتعذر معه تبــين

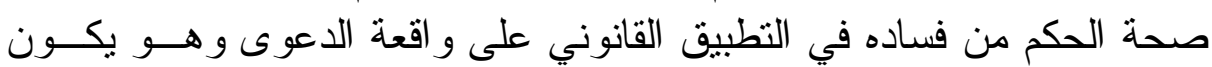

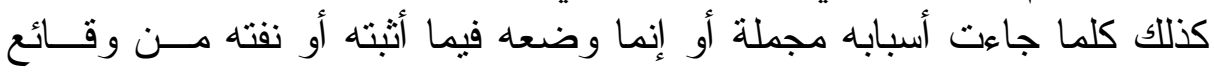

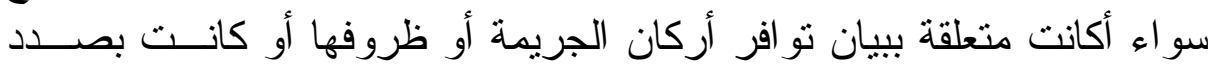

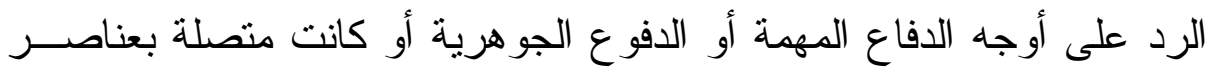

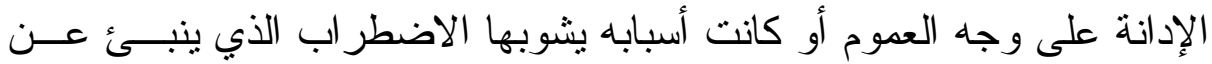

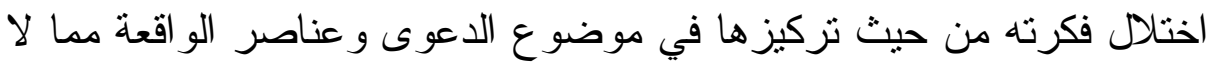

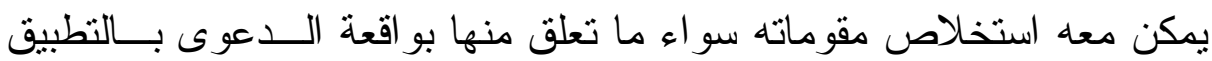

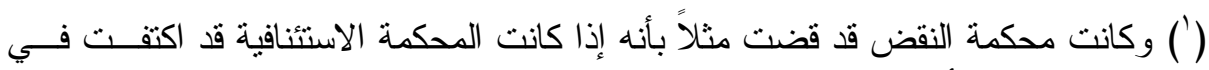

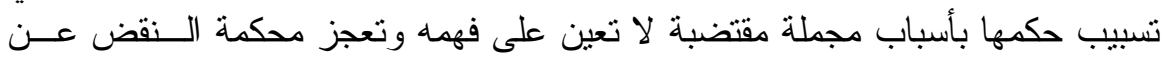

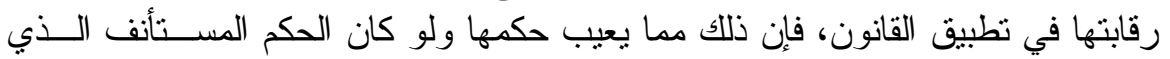

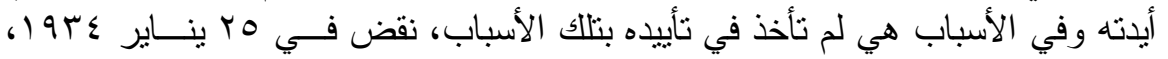

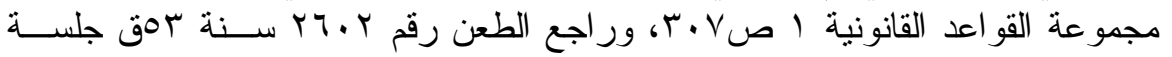

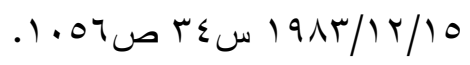




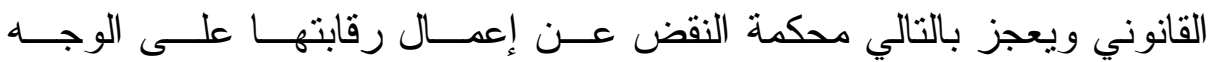

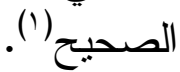
كذلك أقرت محكمة النقض المصرية ذات القو اعد بالنسبة للأسباب فـي الكي

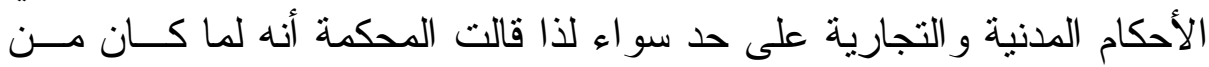

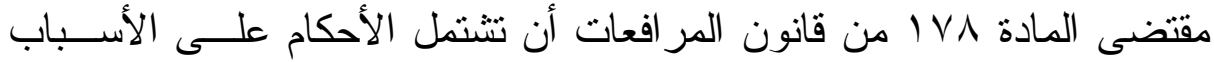

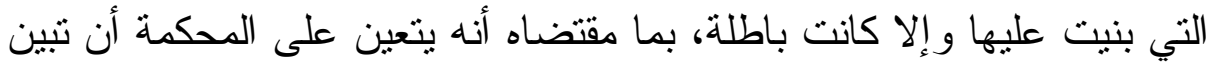

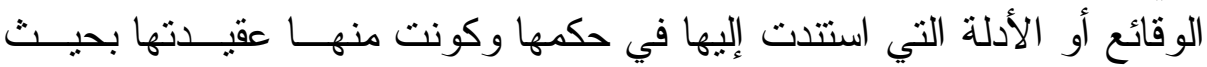

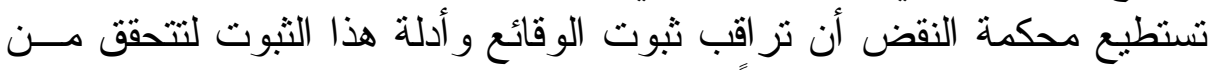

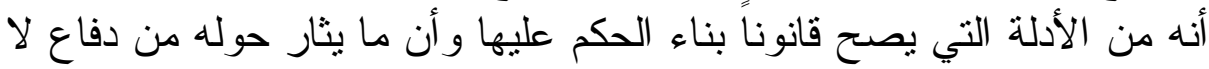

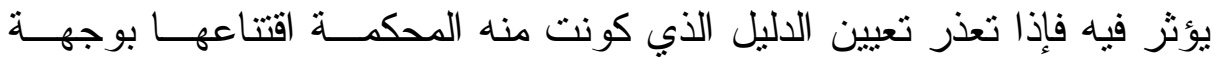

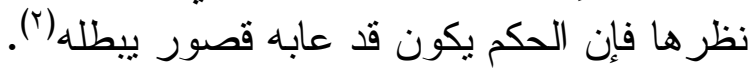

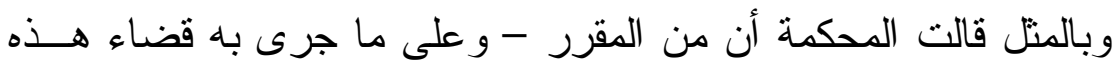

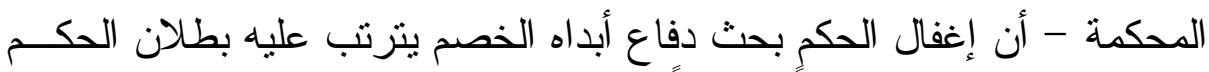

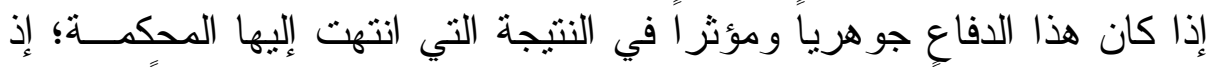

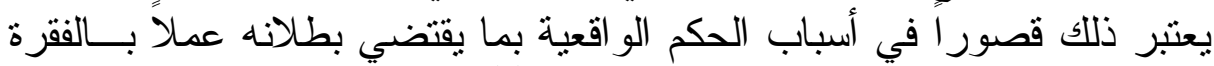

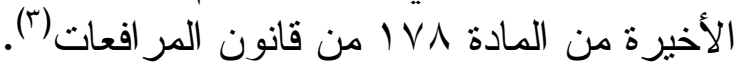

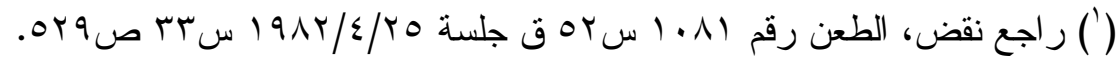

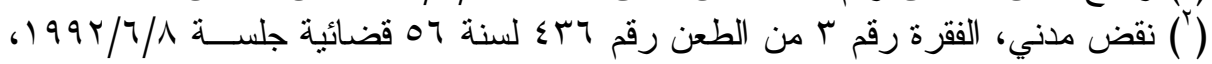

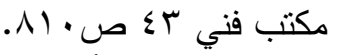

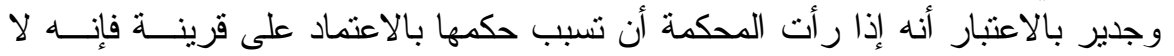

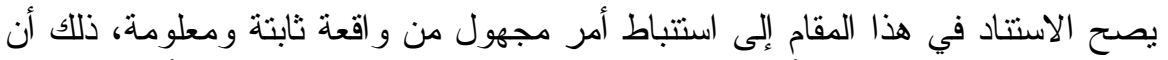

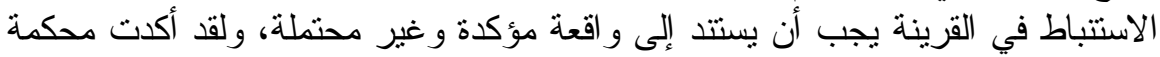

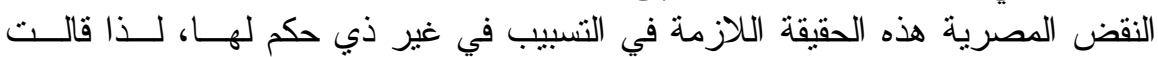

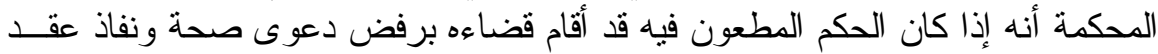

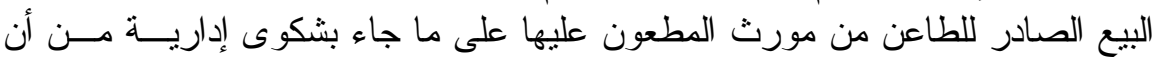

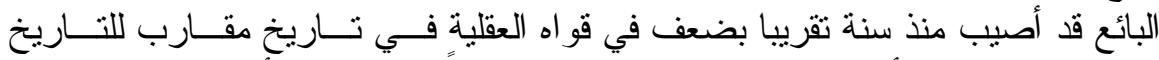

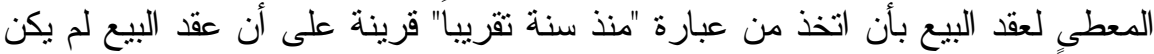

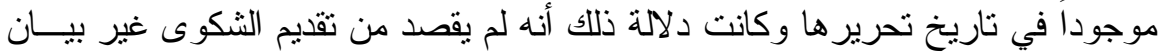

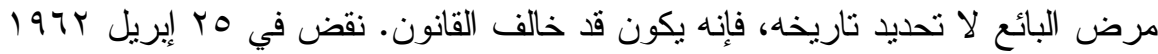

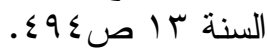

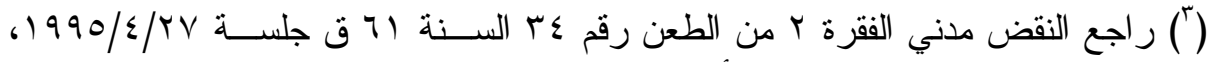

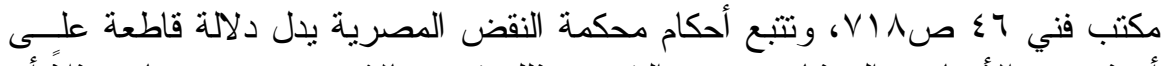

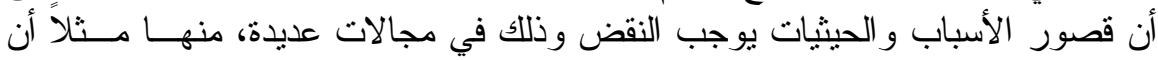
تورد محكمة الموضوع في الأسباب الدلالة على ثبوت فئل اتحاد الثيء المبيع في عقدين 
وما قدمته محكمة النقض المصرية من أحكام عديدة فــي هـــذا المقــام يوضتح حقيقة التسبيب و أصوله الفنية؛ إذ التسبيب مقدمات تؤدي إلــى نتــائج محددة تهدف إلى هدف قاطع هو المنطوق ومن ثم هي مقدمات تشــاق بدقــة

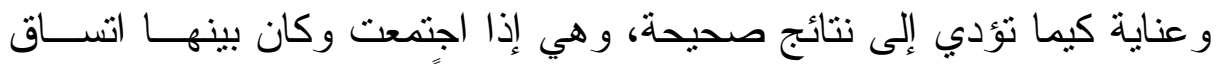

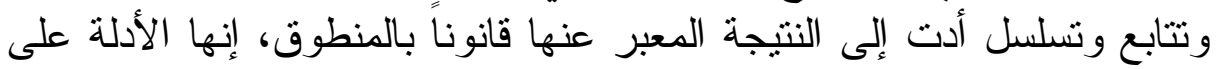

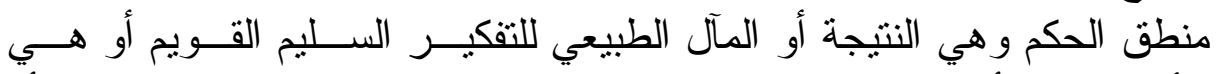

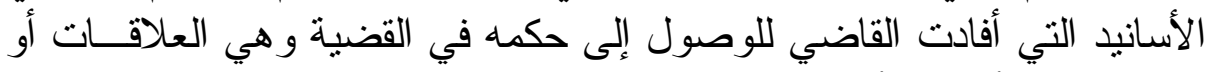

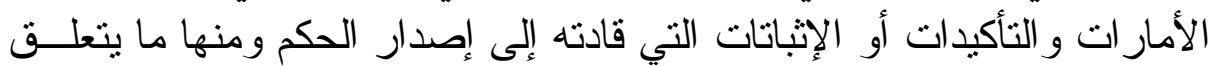

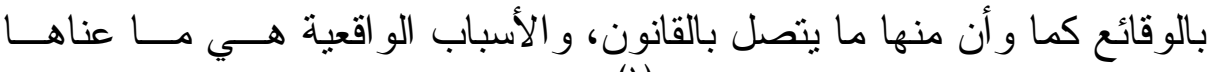

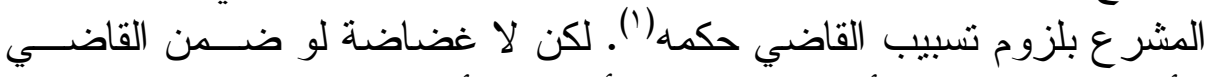
الأسباب ما بتصل بالأسباب "القانونية" أو هذه الأسباب القانونية المعينة له على فئ لهن التكييف القانوني للوقائع، و التسبيب نشاط ذهني منكامل من القاضي.

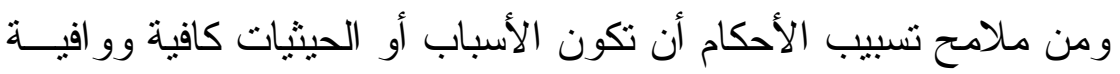
و أن يكون لها أصل في أور اق الدعوى؛ لذا قيل في فقه المر افعات الفرنسي أن

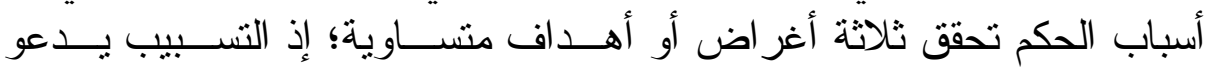

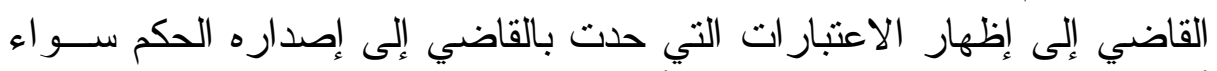

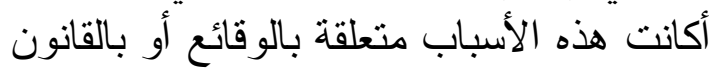

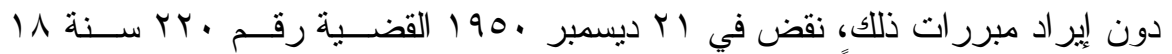

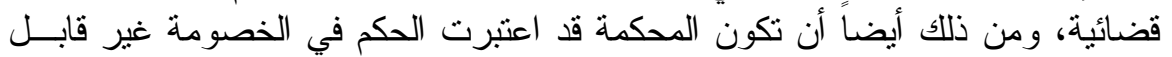

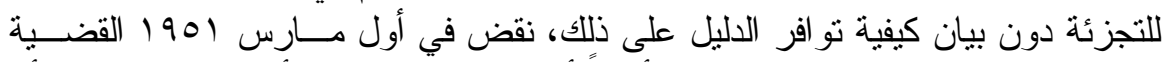

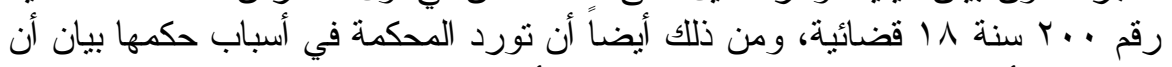

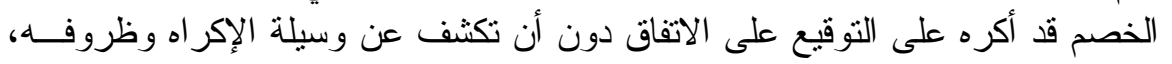

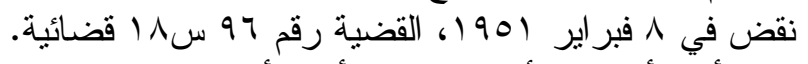

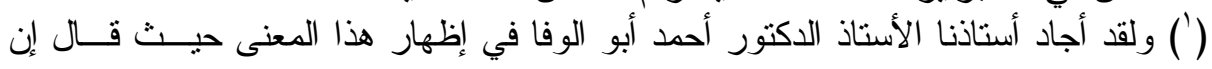

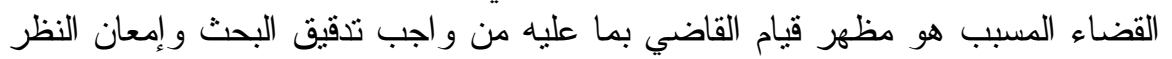

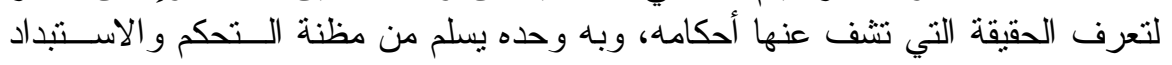

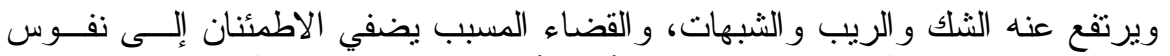

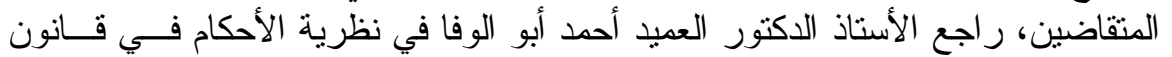

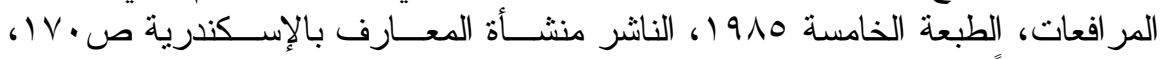

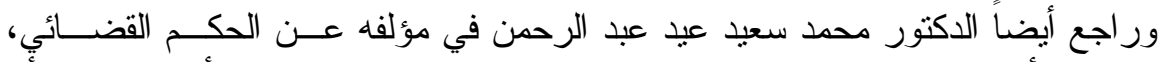

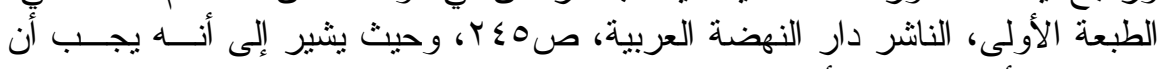

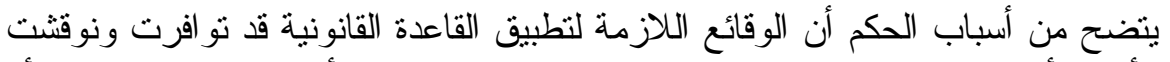

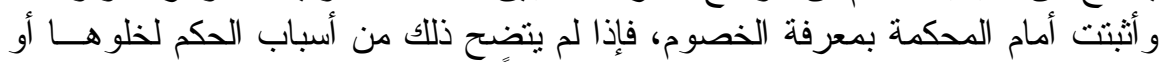
لقصور ها عن إير اد هذه الوقائع، كان الحكم مشوباً بعيب في تسبيبه يؤدي إلى بطلانه. 
En matière civile, l' obligation de motivation des jugements répond a' une triple finalité, elle oblige le juge au raisonnement juridique, $c^{\prime}$ est à dire à la confrontation du droit et des faits. ${ }^{(1)}$

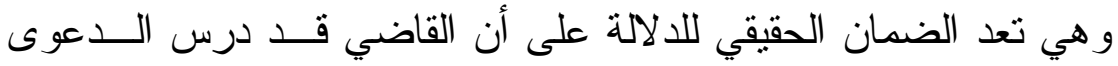

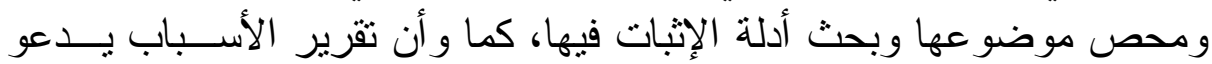

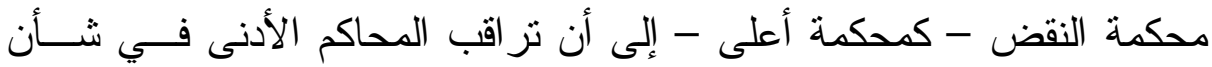

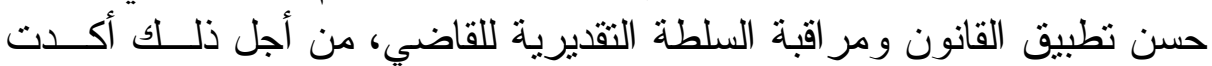

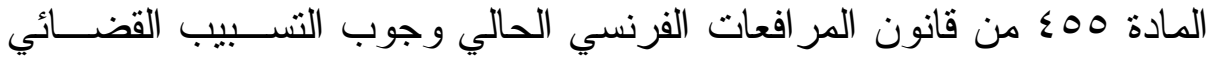

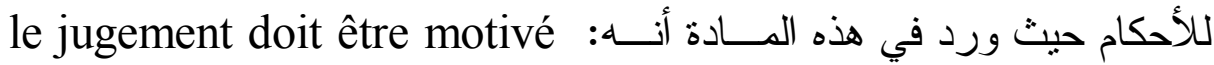

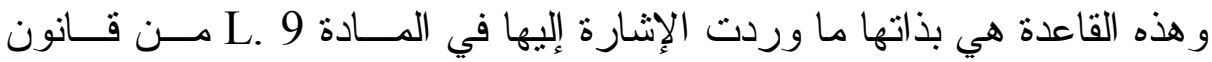

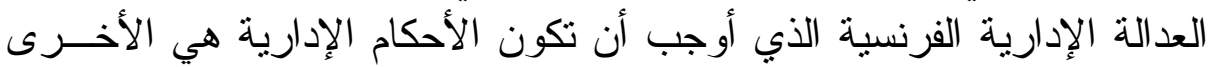

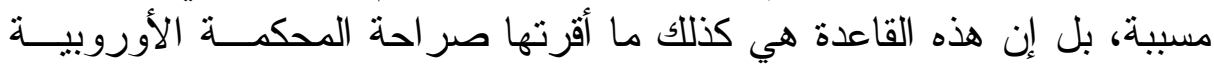

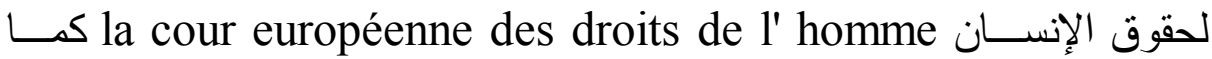

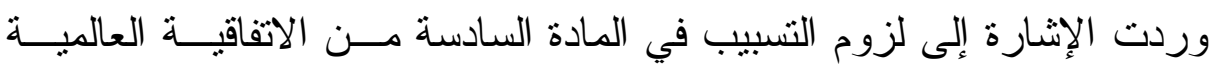
لحماية الحقوق و الحريات للإنسان:

L' article 6 de la convention de sauvegarde des droits de 1' homme et des libertés fondamentales. ${ }^{(2)}$ وكثير اً ما يشير الفقه الفرنسي إلى أنه قلما لا تكون الأحكــام القضــائية

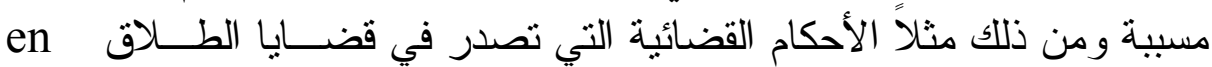
matière de divorce

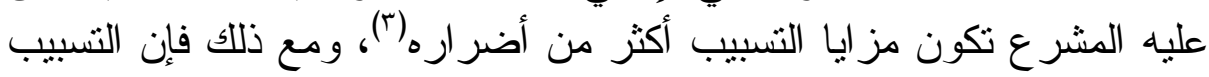

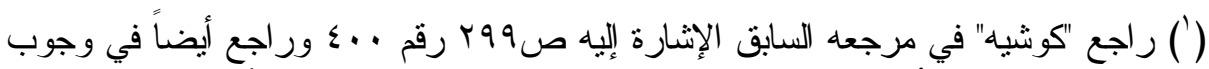
النسبيب الحقيقي للأحكام ما تقرر محكمة النقض الفرنس الفرنسية في العديد من أحكامها:

V. Cass. Com. 18 juin 1985, Bull. civ. IV no 194 p. 162. Rev. Trim. Dr. Civ. 1986. 423, obs. Perrot, civ. $2^{\mathrm{e}}, 16$ avr. 1986. D. 1986. J. 591.

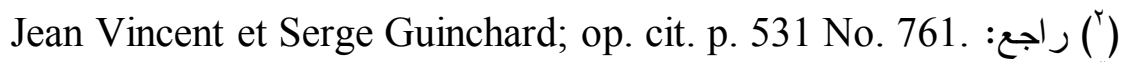

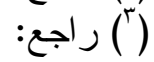

M. Grimaldi, in la motivation de l' association Henri Capitant L.G.D.J. 2000 P.2 و وانظر كذلك:

S. Guinchard et autres. Droit Processuel - droit Commun et droit 
له ملامح في الثكل و أيضاً في المضمون، فهو يشمل الوقائع و أيضاً القـانون motiver, c'est pour le juge, fond sa décision en fait et en droit

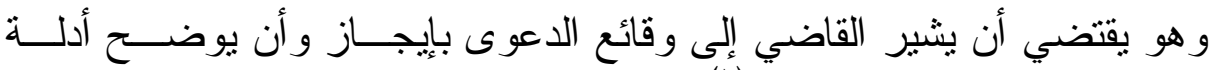

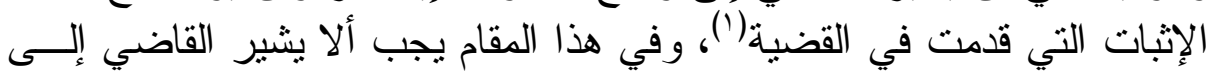

Comparé du procès equitable. Dalloz $4^{\mathrm{e}}$ éd. 2007. no. 436.

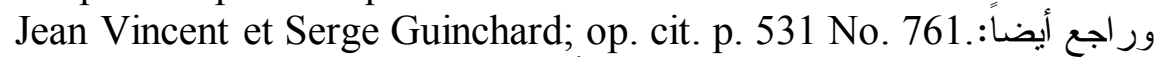

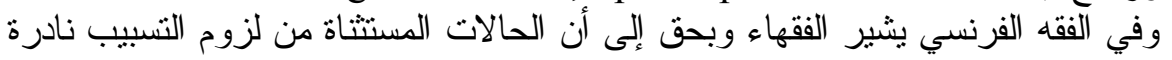

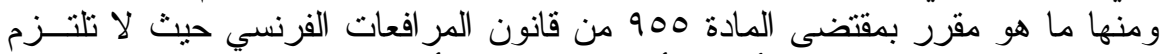

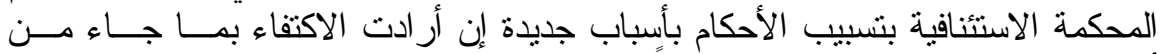
أسباب في الحكم المطعون فيك الستئنافياً.

Les exceptions légales a' l' obligation de motivation sont peu nombrauses. On cite souvent la jugement $\mathrm{d}^{\prime}$ adoption ou certaines décisions rendues en matiére de divorce, comme la jugement sans enonciation des torts et griefs à la demande des parties; ... cour de cassation.

M. Grimaldi in la motivation, travaux de l'association Henri Capitant. L. G. D. J. 2000 P. 2.

(') ومن الفقهاء في فقه المر افعات الفرنسي من يرد لزوم تسبيب الأحكام القضائية الفرنسية

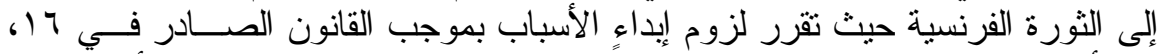

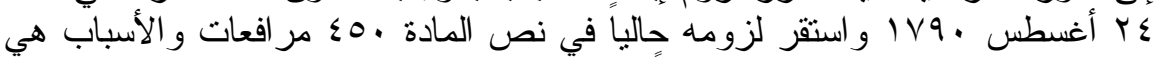

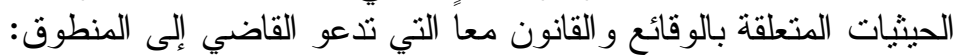

Ce sont les raisons de fait et de droit qui ont mené le juge a prendre sa decision

و الأسباب هي ما تدعو إلى أن يظهر القاضي المبررات المنطقية لحكمه، وكثبراً ما ناصر

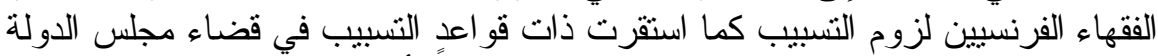

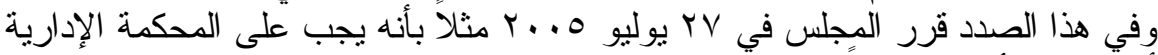

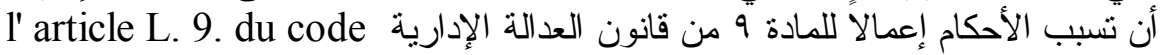
de Justice administrative

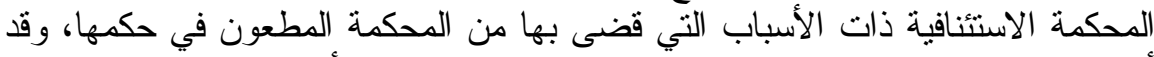

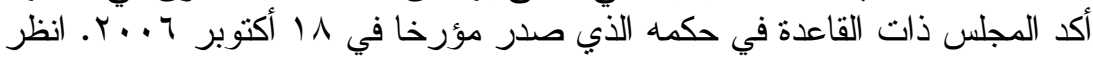
Case conseil d' Etat, 6 éme et 1 ére sous Sections réunies, du 18 octobre 2006, 273064, mentionné aux tables du recueil lebon.

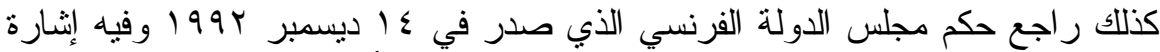

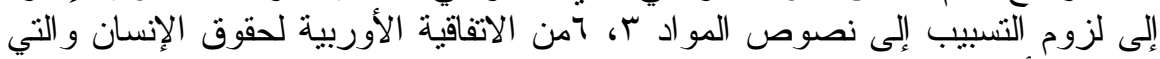

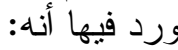

Toute personne a droit à ce que sa cause soit entendue equitablement.

$$
\text { ويدخل هذا الحكم في مضمون المحاكمة العادلة لزوم التسبيب: }
$$


قو اعد عامة أو يسرد نصوص القانونِ الموضوعي إذ عليه أن يقـارب بـين

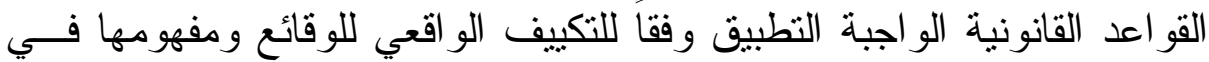

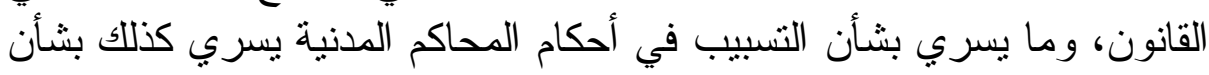

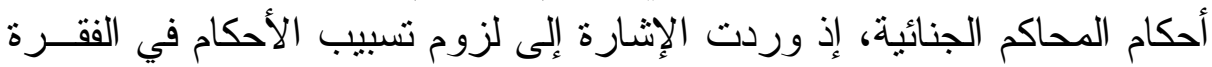

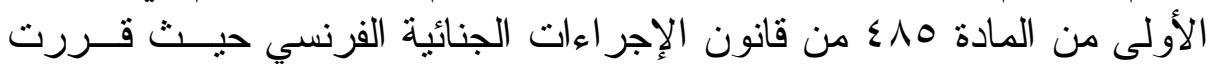

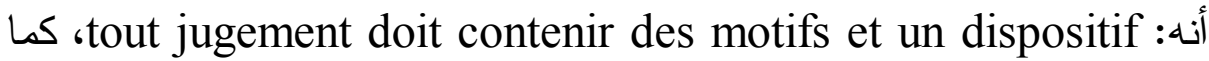
وردت الإشارة إلى مر اقبة محكمة النقض الفرنسية للأحكام من حيث تســبيبها

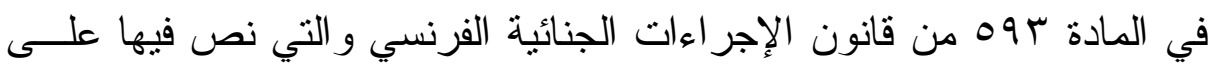
أنه:

"les arrêts et jugements en dernier ressort sont déclares nuls s' ils ne contiennent pas des motifs ou si leurs motifs sont insuffisants et ne permettent pas à la cour de cassation d' exercer son contrôle et de reconnaître si la loi a' été respectées dans le dispositif"

$$
\text { ولعلنا نجد صباغة أخرى و اضحة في شأن لــزوم التشــبيب المباثـــر }
$$

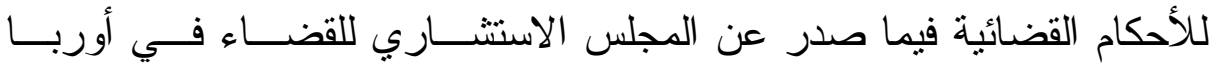
C.C.J.E.

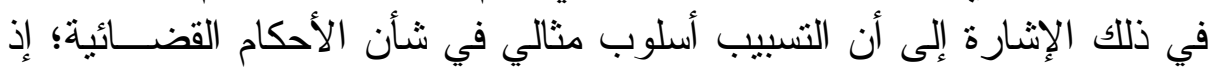

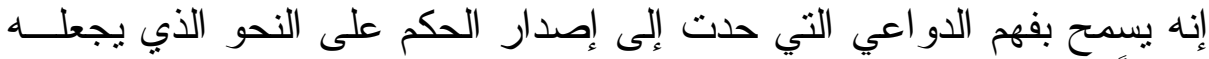

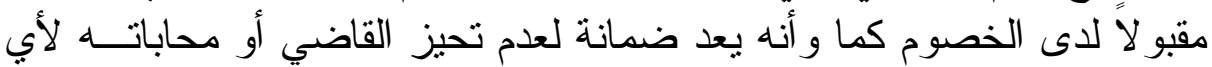

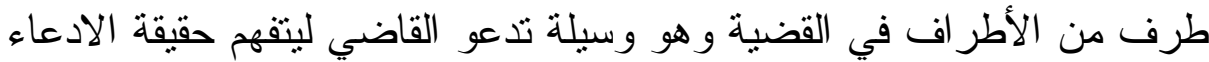

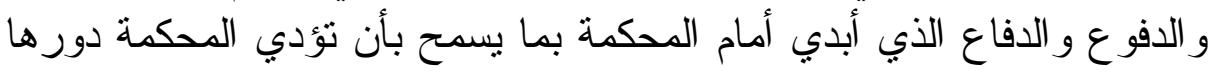

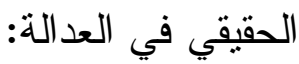

La motivation permet non seulement une meilleure compréhension et acception de la décision par le justiciable mais elle est surtout une garantie contre l' arbitraire, d' une part, elle oblige le juge a' rencontrer les moyens de défense des parties et a préciser les éléments qui justifient sa décision

La notion de procés equitable inclut la motivation du jugement.

Case conseil d' Etat 7I 10 ssR. du 14 décembre 1992. 130261 mentionné aux tables du recueil lebon. 
et rendent celle - ci conforme a' la loi, et, d' autre part elle permet une compréhension du fonctionnement de la justice par la société. ${ }^{(1)}$

وجاء في هذه التوصية المعلنة أيضناً الإثـارة إلى أن تســبيب الأحكـام

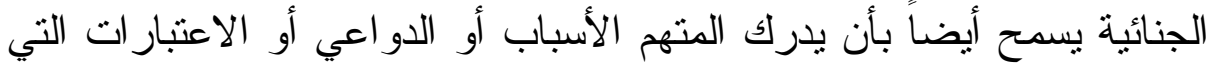

(') وكان قد طرح في القضاء الفرنسي مسألة عدم لزوم النسبيب فيما لو صدر الحكم بشأن الأني

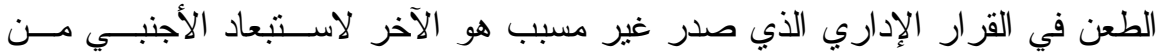

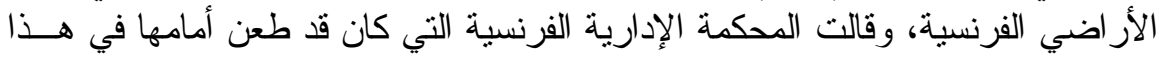
الحكم في الطعن رقم

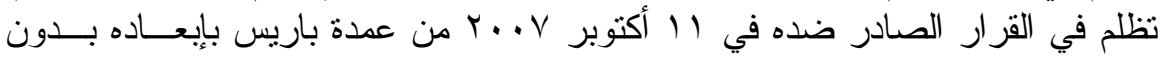

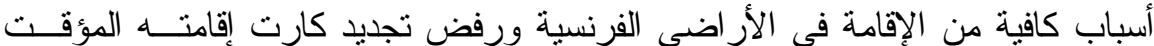

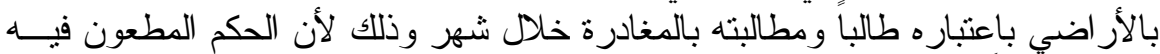

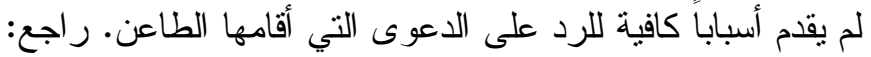
Cour administrative d' appel No. 07PA03936. 1ère chambre inédit au recueil lebon.

وراجع أيضاً حكم آخر بشأن قصور الحكم الصادر عن المِحكمة الإدارية فـــي أســبابه

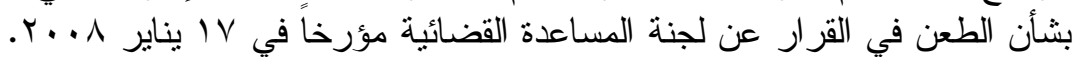

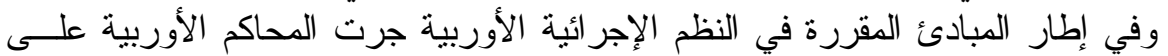

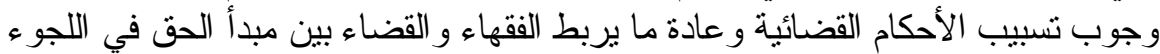

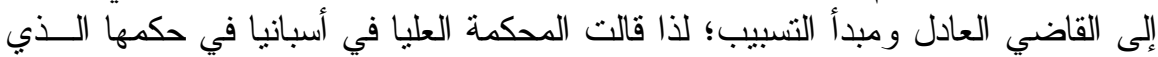

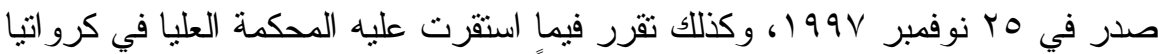

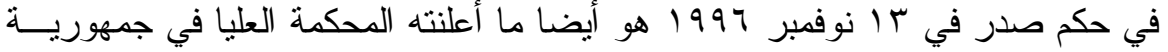
التشيك من لزوم تسبيب الأحكام و لا يكفي مجرد الأسباب و إنما يجب أن أن تكون كافية: $\mathrm{C}^{\prime}$ est également du droit à la défense que sera deduit le droit des jugements; Celle - ci est un élément de base du droit fondamental à la protection judiciaire effective" Espagne, 25, nov. 1997; Croatie, 13 nov. 1996. qui est violé si la decision judiciaire se borne à reproduire une decision antérieure et à se servir de ses motifs "dans un cas inopportun. "Repulique techéque, 20 nov. 1997. il en est de même si la motivation est insuffisants, ce qui equivaut a' un déni de justice par "incohérence ou omission", au mepris du droit de la protection judiciaire effective (Espagne, 28, sep. 1998.

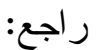

Paul Martens; les principes constitutionnels du procés dans la jurisprudence recente des juridictions constitutionnelles européennes, cahiers du conseil constitutionnel no 14. Dossier; la justice dans la constitution. Mai 2003. 
دعت إلى إدانته و أيضاً أن يدرك المبررات التي دعت إلى حبسه احتياطياً:

"la motivation des décisions des juridictions répressives permet au prévenu de savoir pour quelles raisons il a été condamne ou a' la personne mise en examen de connaître les raisons de son placement en détention provisoire. ${ }^{(1)}$

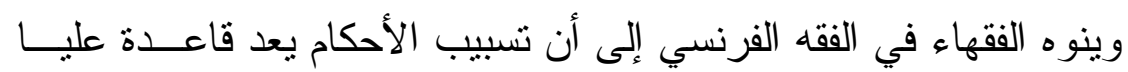

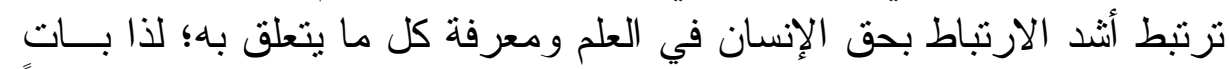

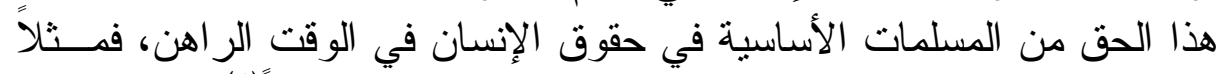

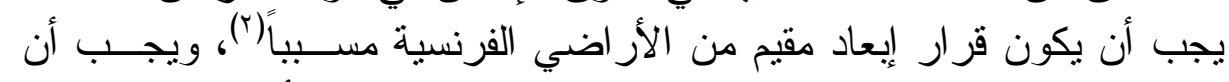

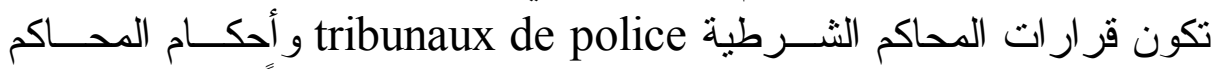

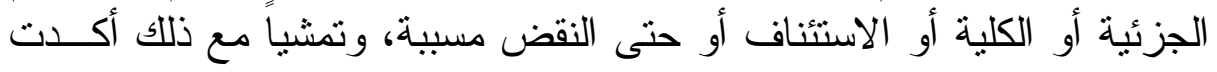

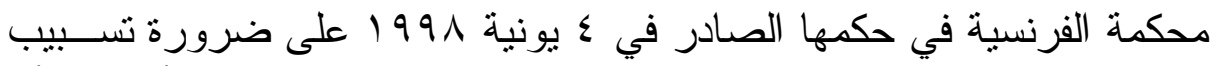

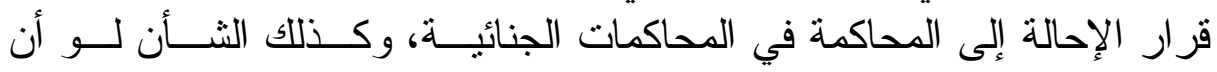

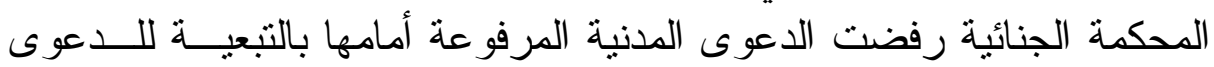

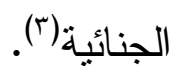

وفي بلجيكا نص الدستور البلجيكي الحالي على قاعدة تســبيب الأحكــام

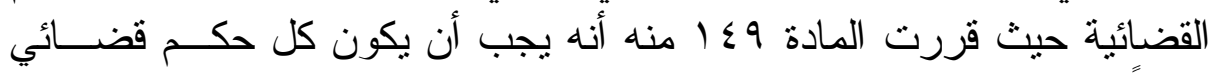

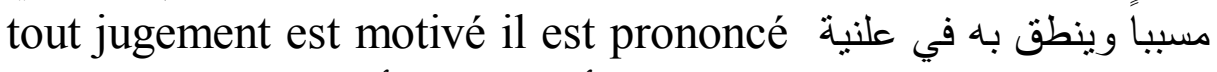
en audience publique

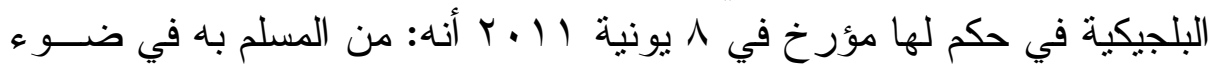

$$
\text { (') راجع في الإشارة إلى النسبيب: }
$$

H. Motulsky; la couse de la demande dans la delimitation de l' office du juge; Dalloz 1964 p. 235

ورانظر: 2003 J.P. Ancel; la motivation des arrêts BICC $1^{\text {er }}$ mai

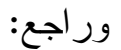
P. Estoup; la pratique des jugements en matière civile, prud' home et commerciale: principes et méthods de rédaction, paris 1990, litec.

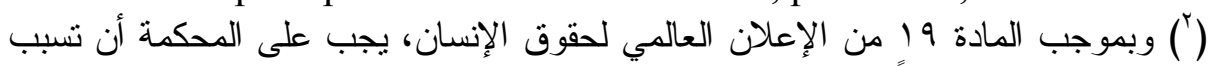

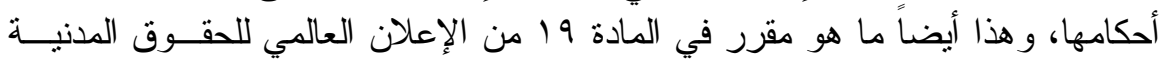

$$
\text { و السياسية. }
$$

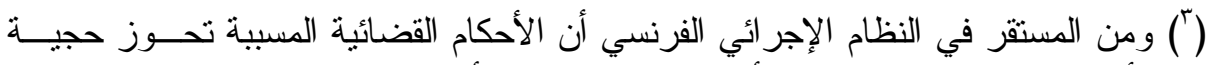

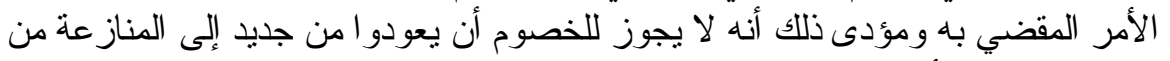

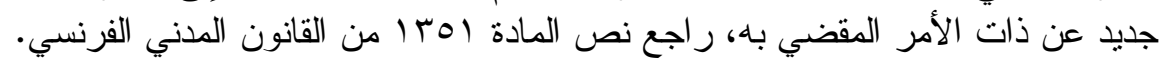




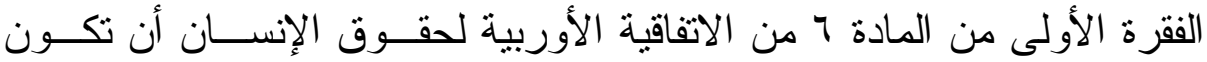

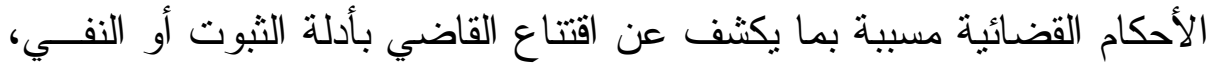

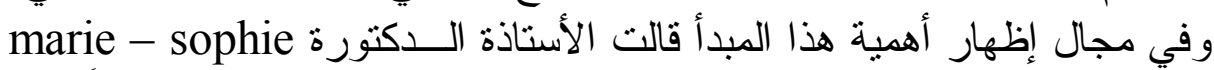

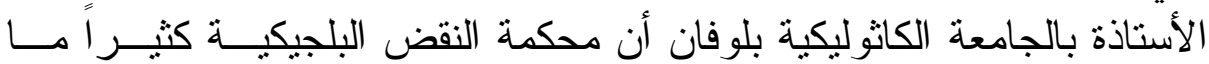

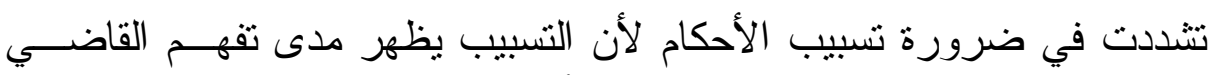

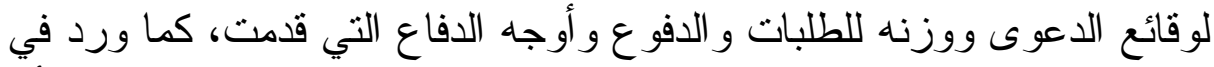

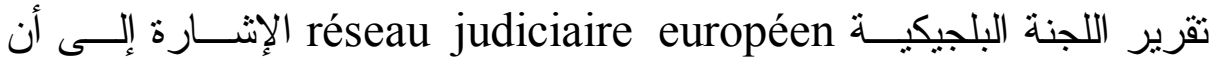

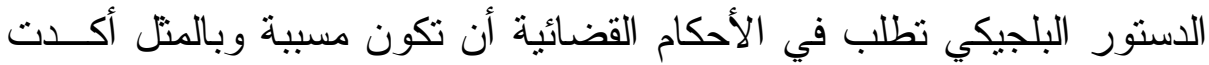

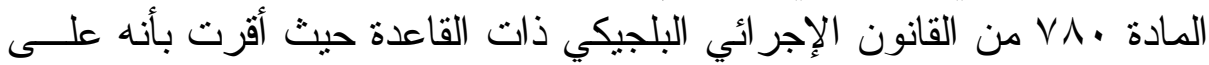

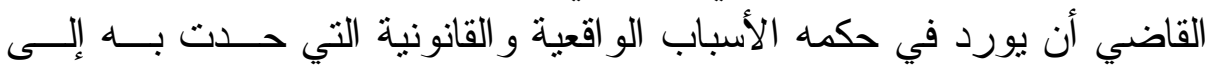

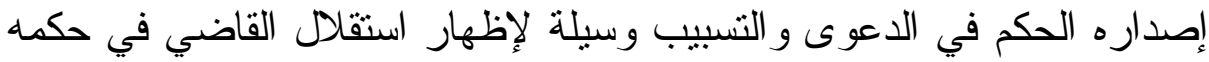

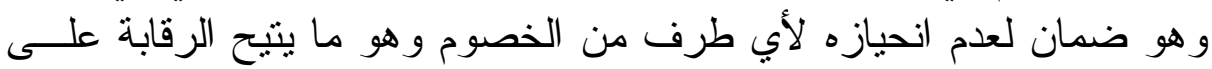

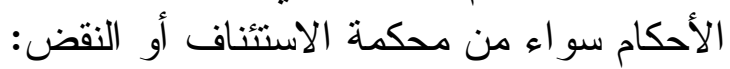

la motivation doit être complète, claire précise et adéquate, l' obligation de motivation des jugements au même titre que l' indépendance du juge, garantit le justiciable contre l' arbitraire éventuel du juge et lui permet au regard de la motivation, d'évaluer 1 ' introduction d'un recours auprès du juge d' appel au devant la cour de cassation. ${ }^{(1)}$

(') وفي الفقه الإجر ائي البلجيكي قالت الأستاذة Marie - Sophie Devresse إن إن محكمة النقض البلجيكية اثشترطت في العديد من أحكامها الددنية و الجنائية أن تكون هذه الأحكام

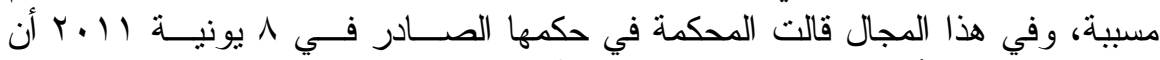

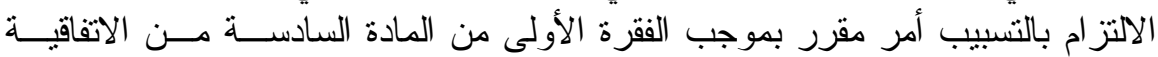

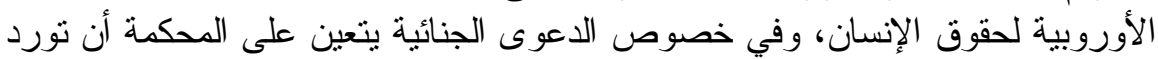

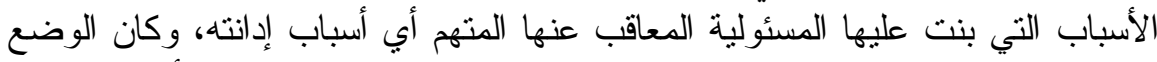

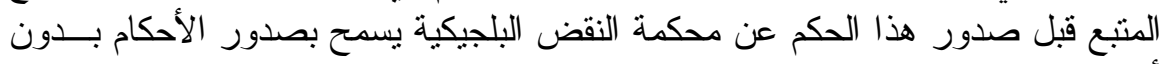

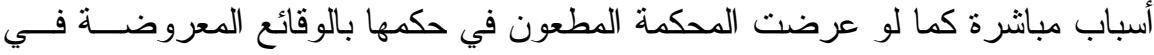

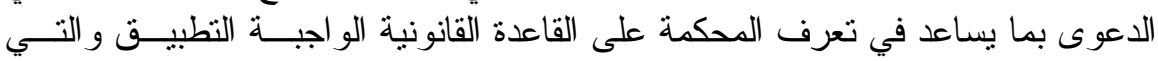

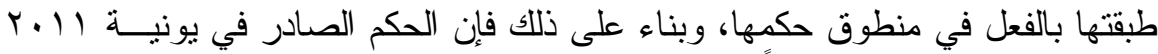

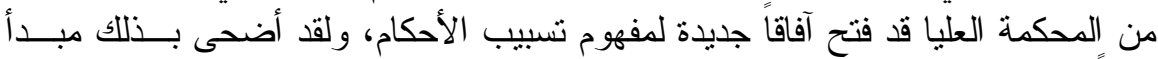

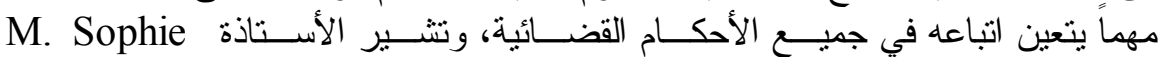

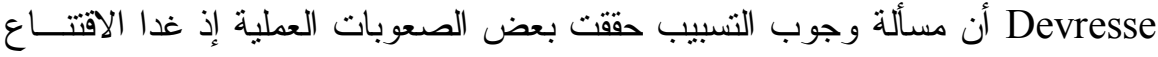
الداخلي للقاضي ليس هو الحكم المسيطر على القاضي في إصداره للحكم منلما قال مسن الصن

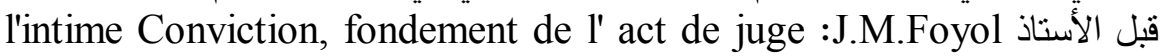




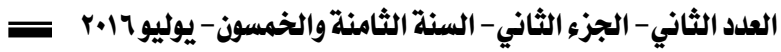

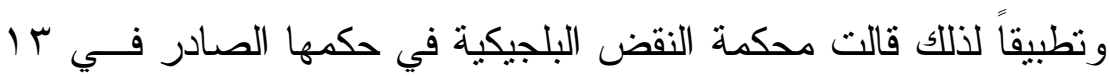

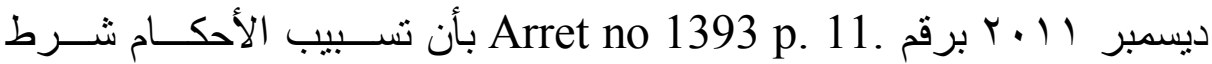

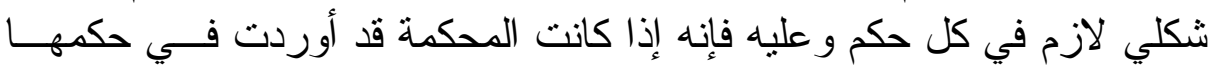
الأسباب الكافية فإن ذلك لا لإن ولب الطعن في الحكم بالنقض.

ثم إن الالتز ام بالتسبيب قد غدا منهجا حديثاً في إصدار الأحكام ومن ثم فإنه يؤدي إلـى تعطيل الفصل في القضايا. راجع: Marie - Sopie Devresse; "par ces motifs". Petit reflexion sur l' obligation de motiver les jugements et sur l'émergence d' un "droit de comprendre" du justiciable. Justice en ligne. 29 Novembre 2011. 


\section{الفصل الثاني \\ الضوابط المعيارية لصحة التسبيب أو قصوره}

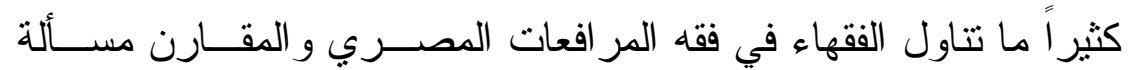

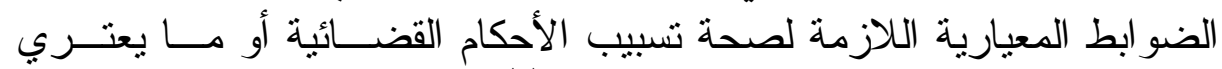

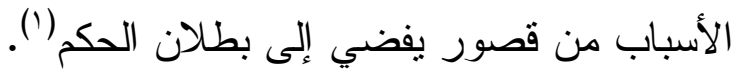

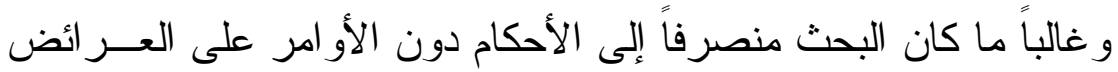

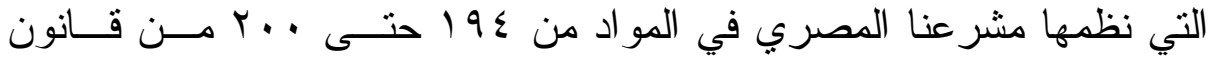

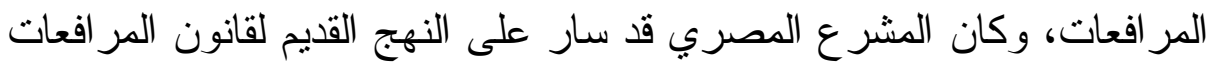

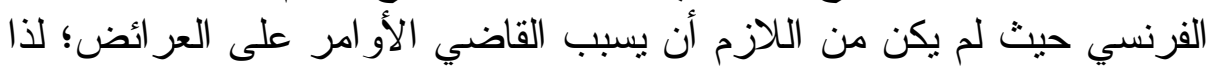

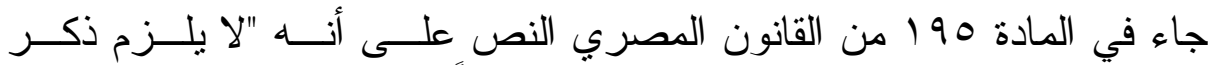

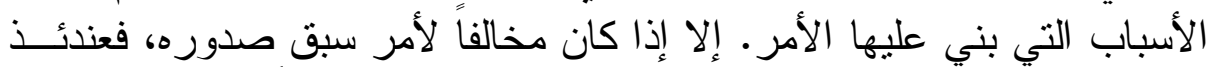

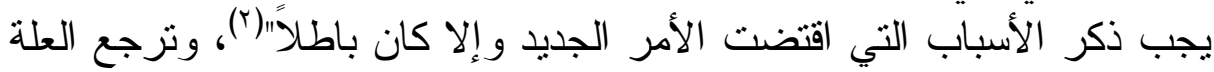

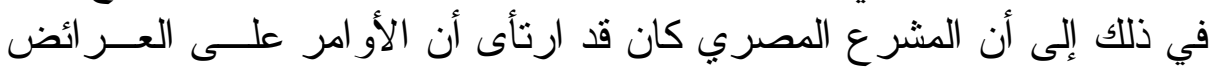

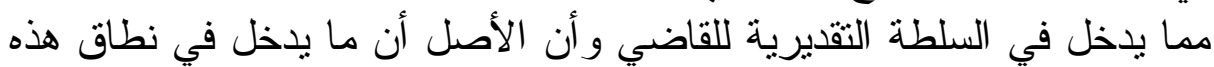

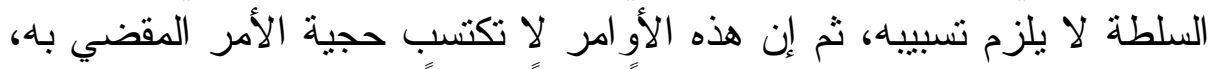

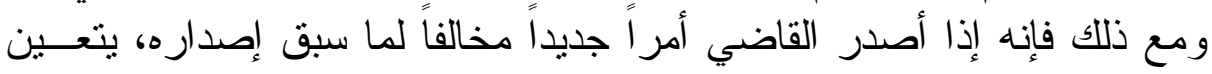

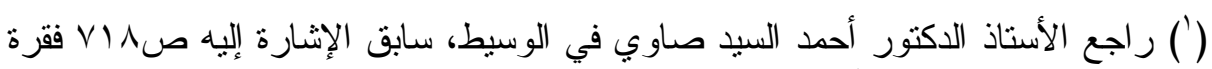

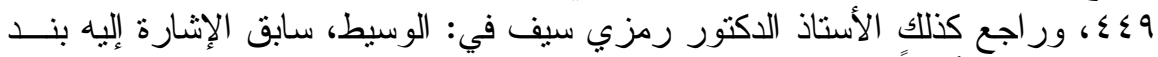

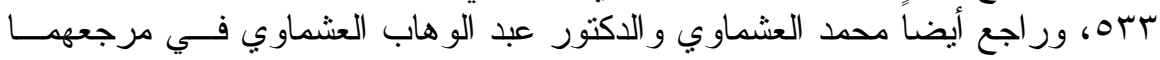

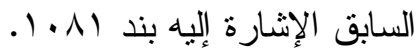

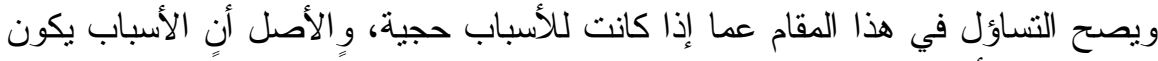

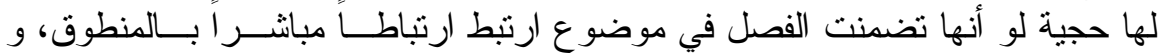

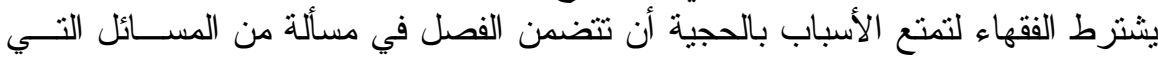

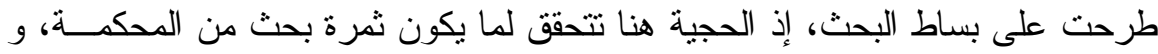

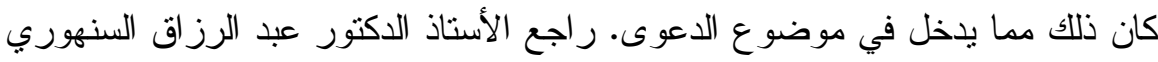

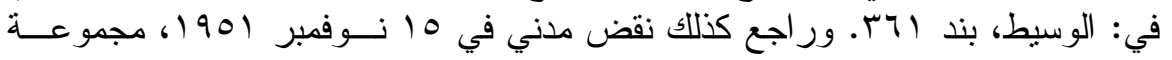

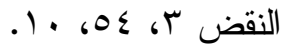

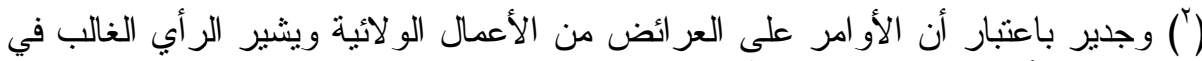

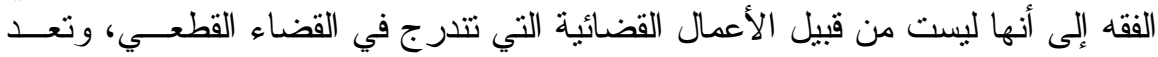

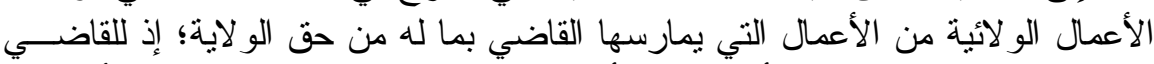

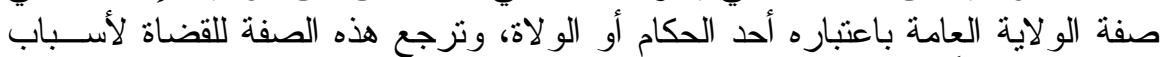

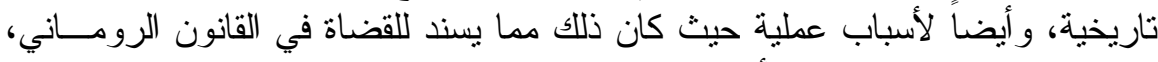

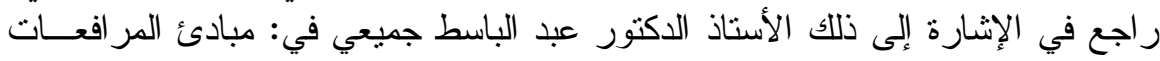

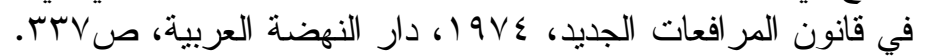


ذكر الأسباب، لأن ذلك هو ما تستوجبه طبيعة الأمور وحتى لا تظل الســلطة

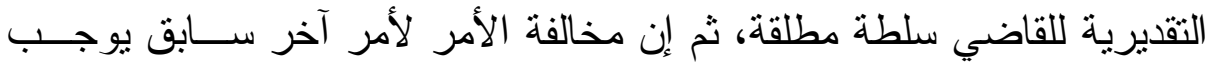

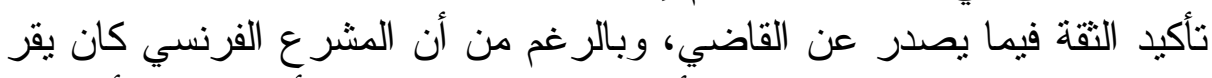

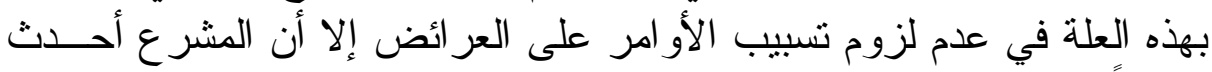

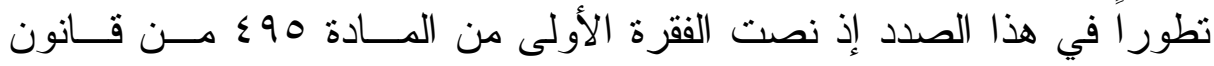

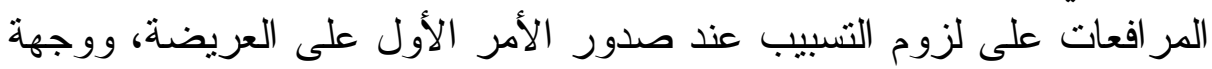

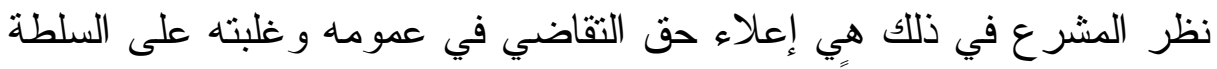

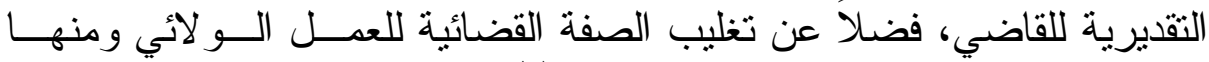

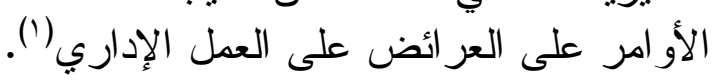

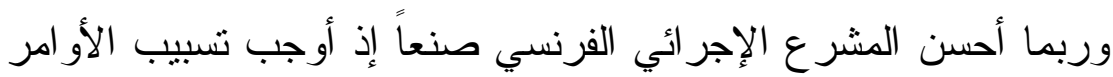

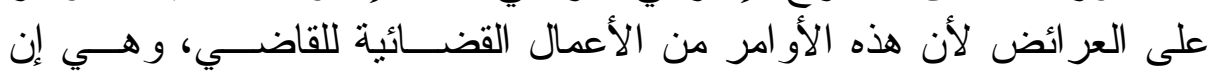

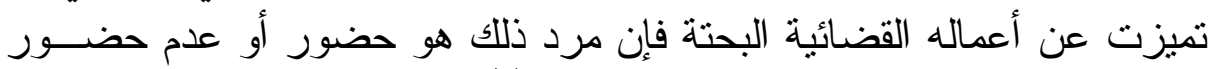

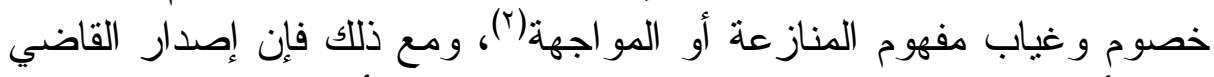

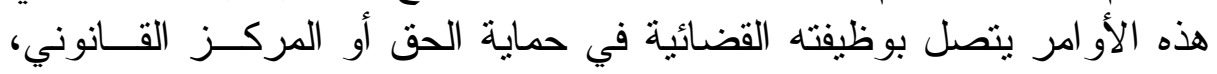

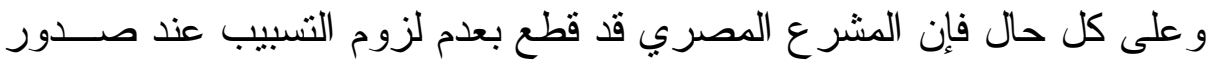

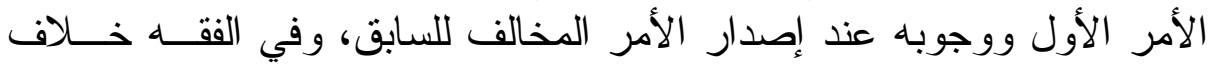

(') ر راجع الأستاذ الدكتور عزمي عبد الفتاح في بحثه بعنوان: تشــبيب الأحكــام وأعمــال

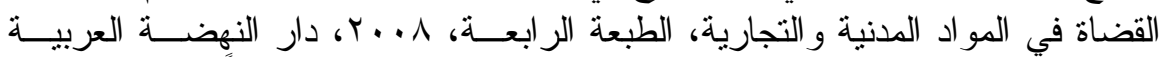

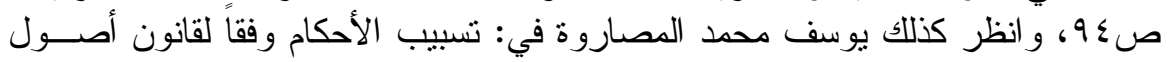

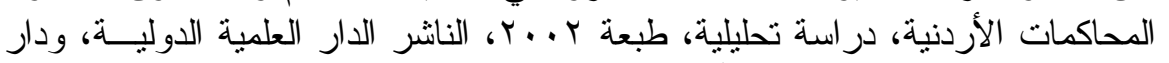

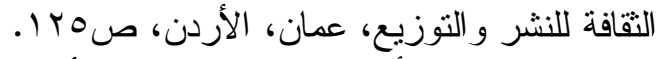

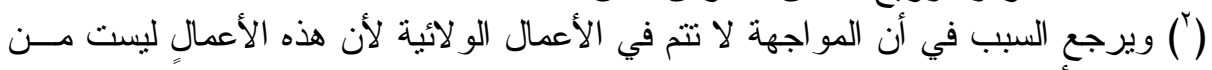

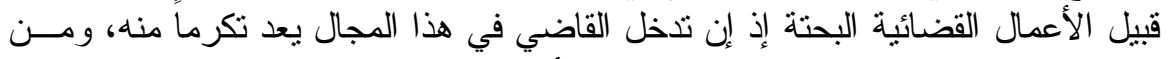

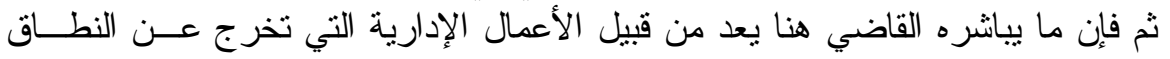

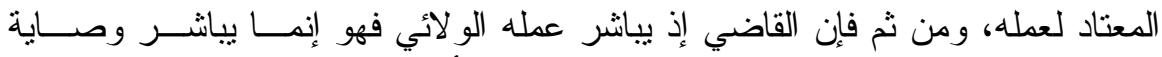

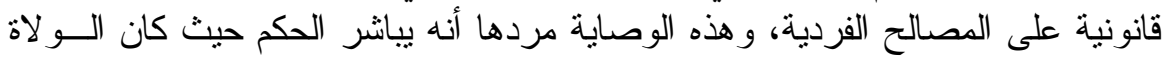

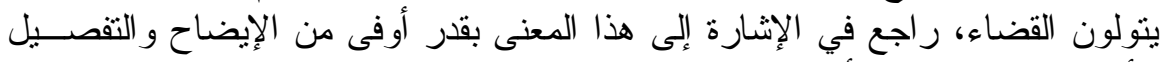

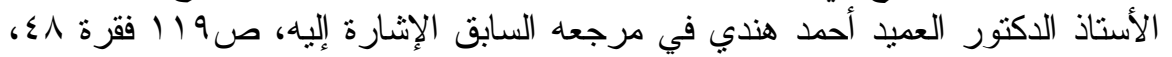

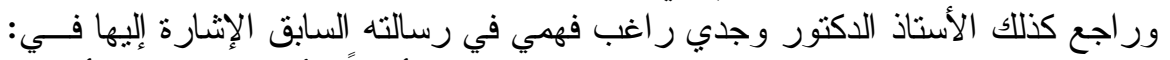

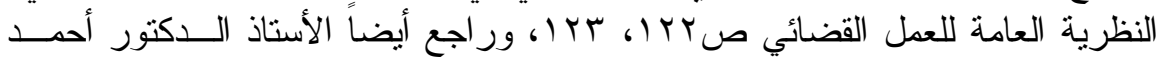

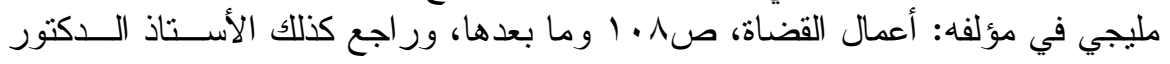

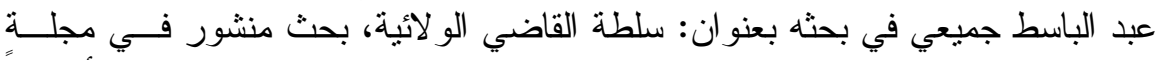

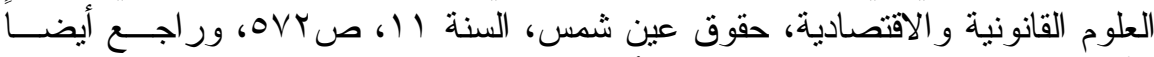

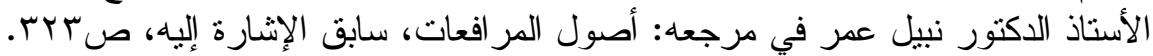


حول ما إذا كان القاضي قد أصدر أمره الأول بالرفض ثم صدر الأمر الجديد

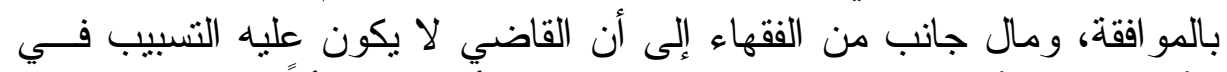

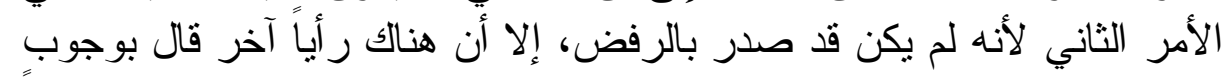

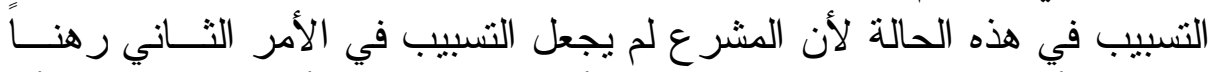

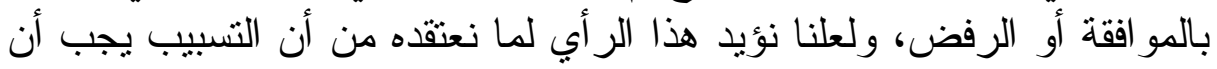

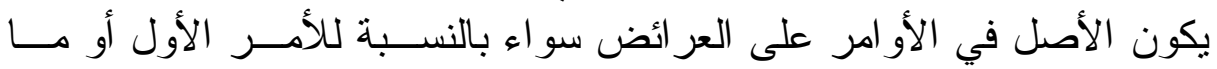

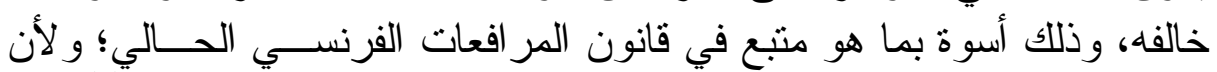

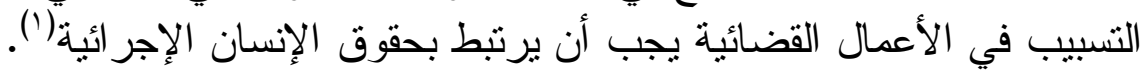

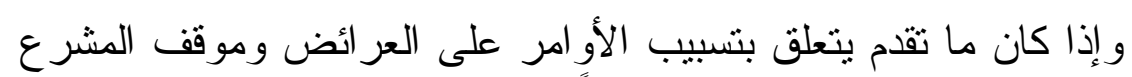

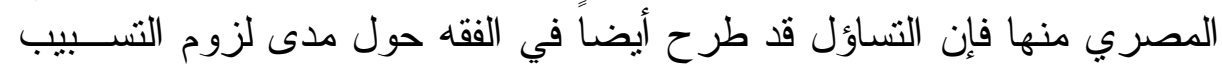

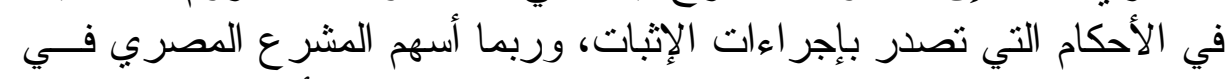

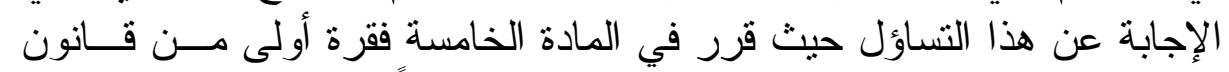

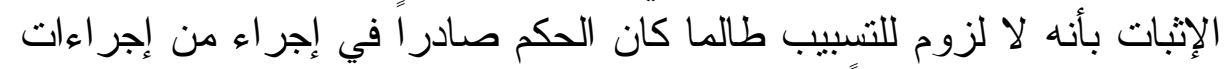

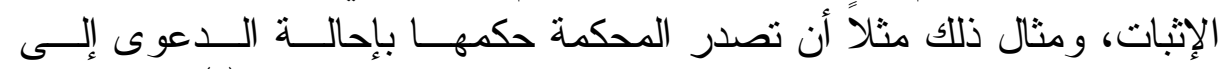

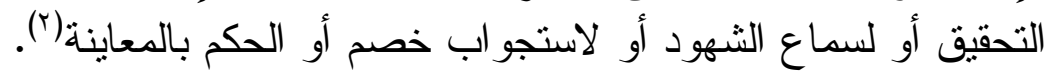
ولو تساءلنا عن علة ذلك أمكن القول بأن المحكمة عندما تصدر حكمها لأباء

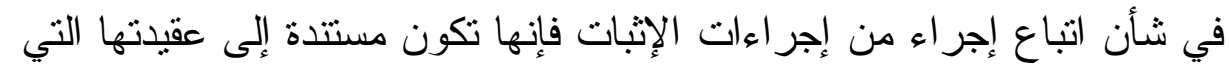

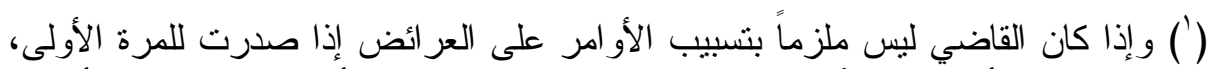

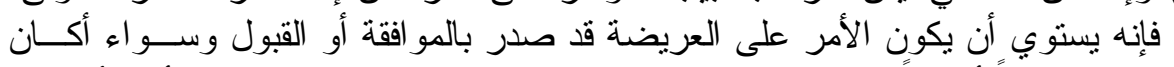

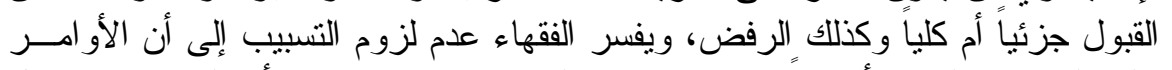

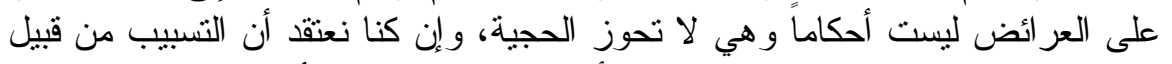

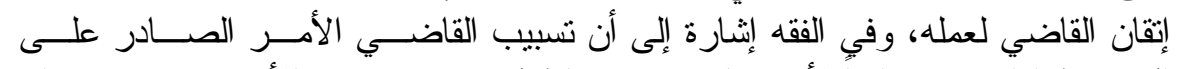

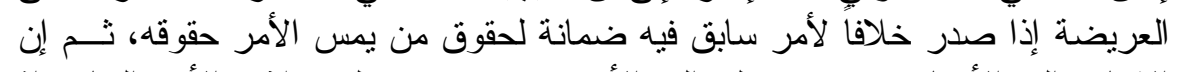

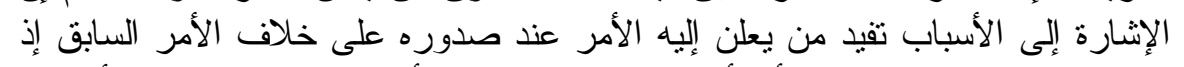

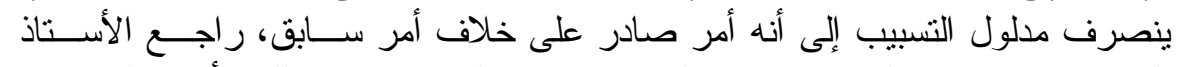

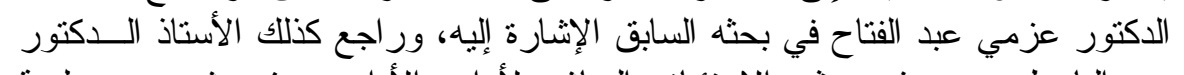

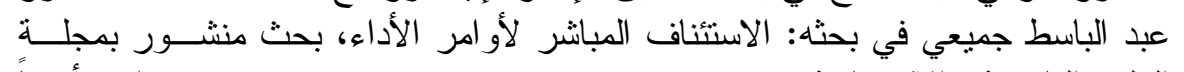

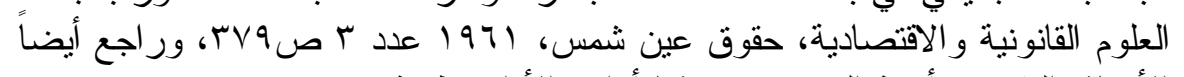

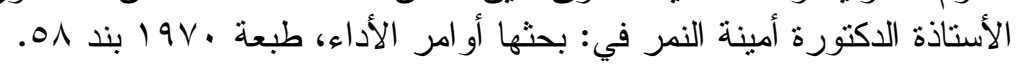

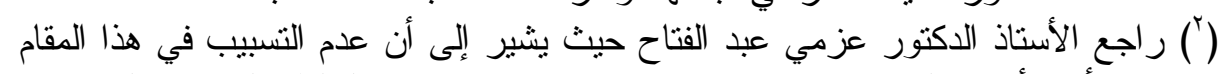

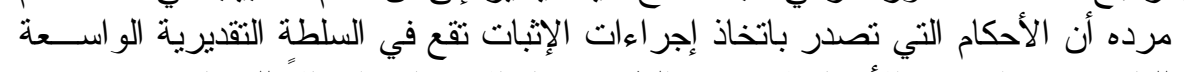

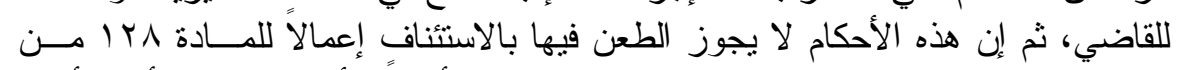

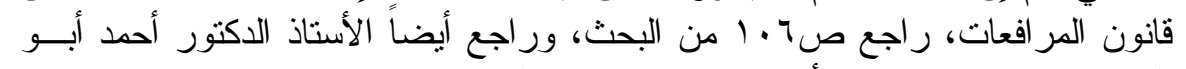

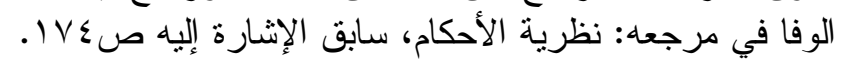


كونتها من و اقع المستتدات، و الأصل أن ما يتعلق بالسلطة التقديرية للقاضي لا

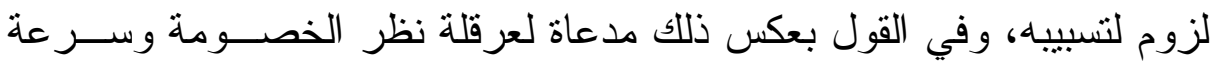

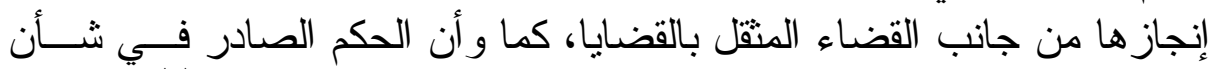
إجر اء الإثبات لا يجوز الطعن فيه مباشرة أمام المحكمة الاستئنافية (1).

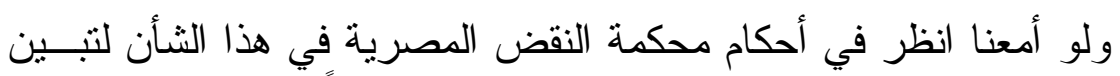

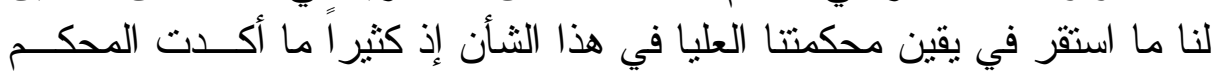

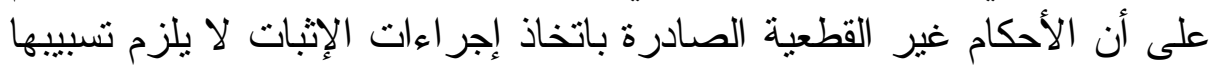

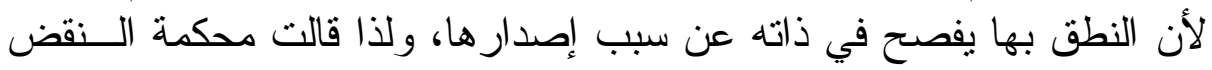

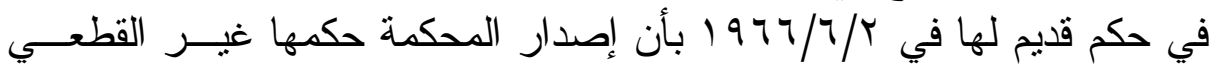

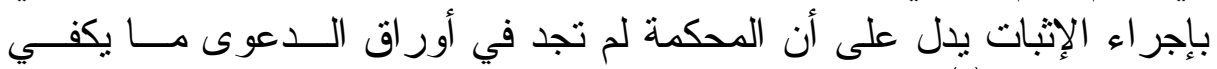

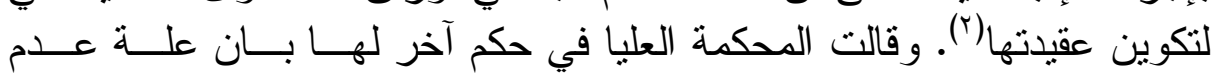

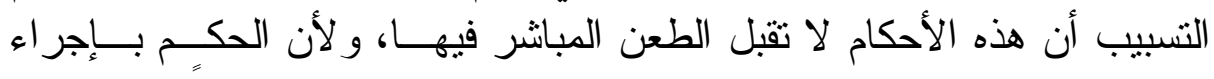

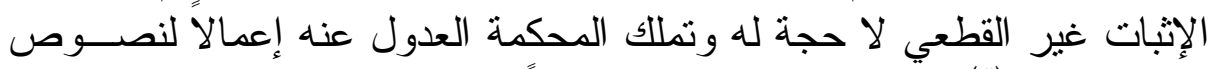

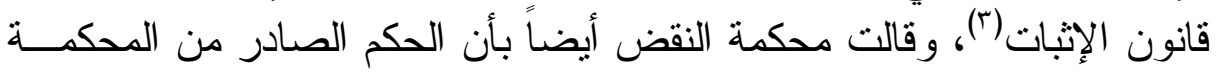

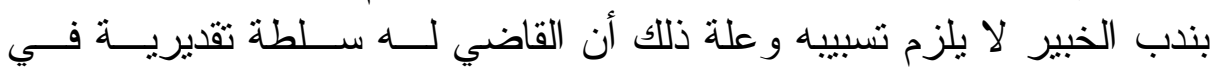

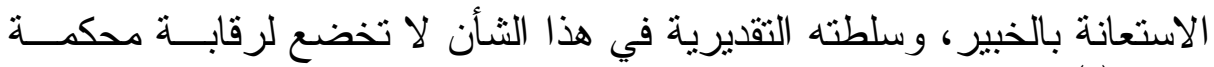

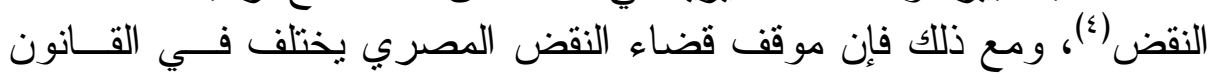

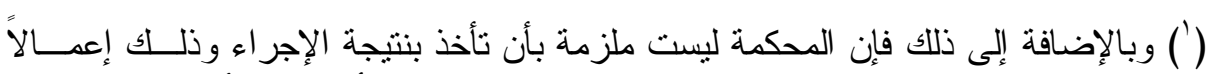

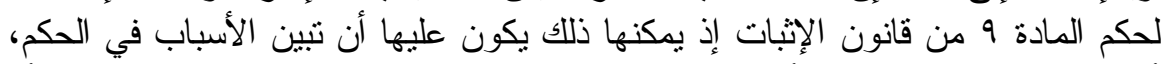

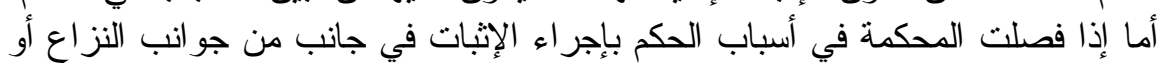

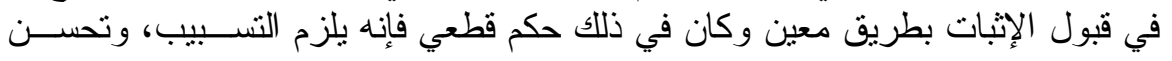

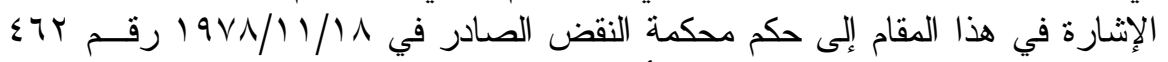

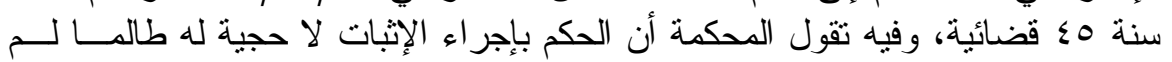

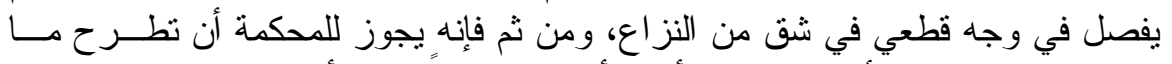

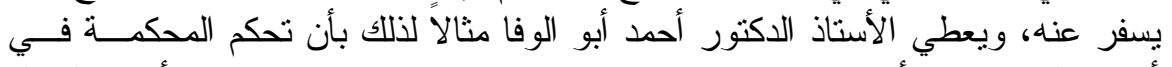

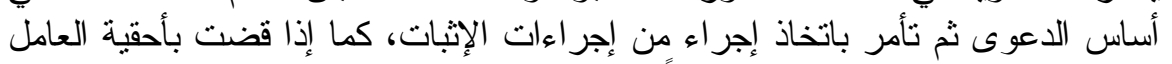

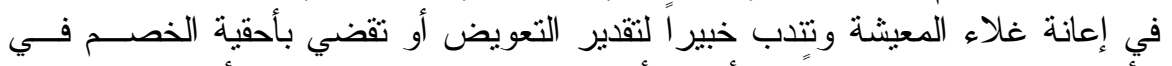

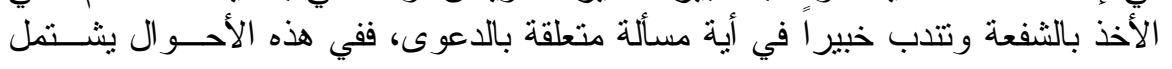

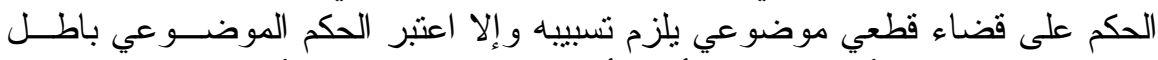

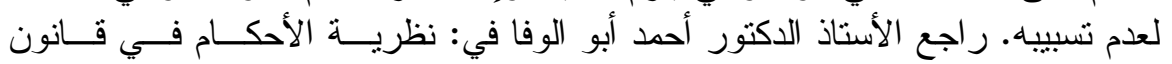

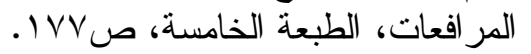

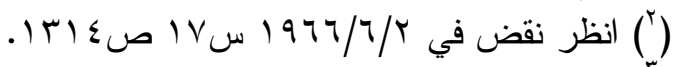

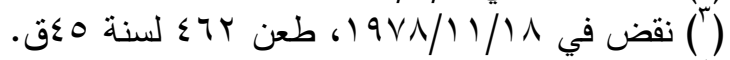

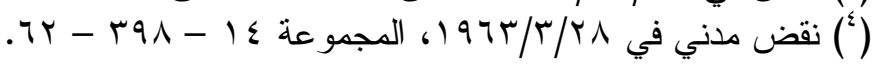




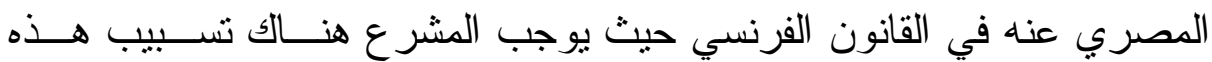
الأحكام الصادرة بندب الخبير؛ لأنها و إن كانت مما بدخل في السلطة التقديرية

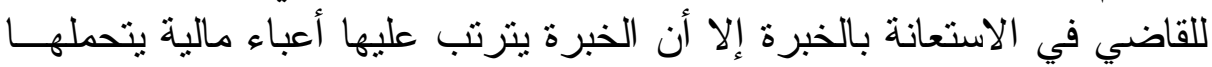

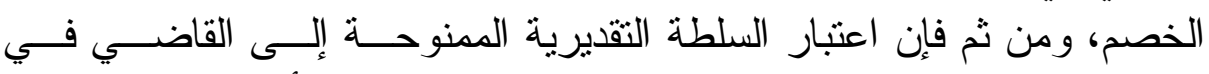
الاستعانة بالخبير بتزتب عليه حقوق الخصوم في معرفة الأساس الو اقهي الذي

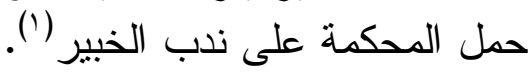
وما يقال بشأن السلطة التقديرية للقاضي في ندب الخبير و وعـدم لــزوم

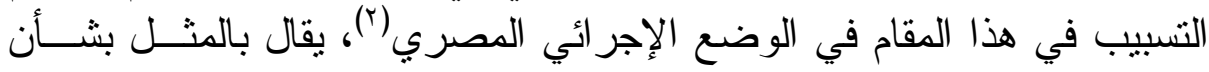

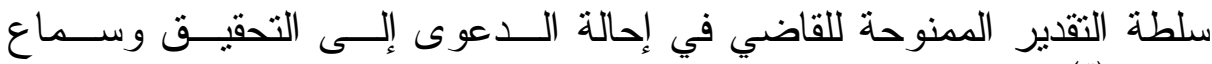
الشهود (r)؛ إذ لا لزوم للتسبيب في هذا الحكم، وسند ذلك مـــا قررتـــه الفقــرة

(') ومن المبادئ المقررة في فقه المر افعات أن القاضي ليس له أن يقضي بعلمه الثخصي

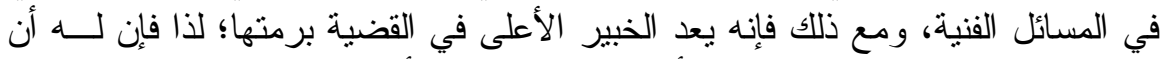

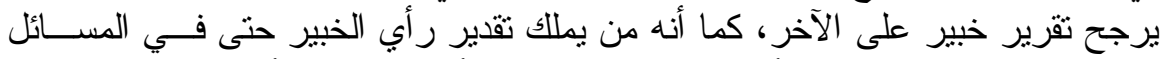

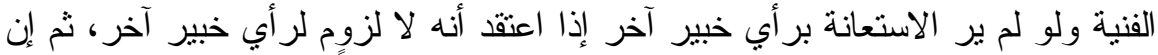

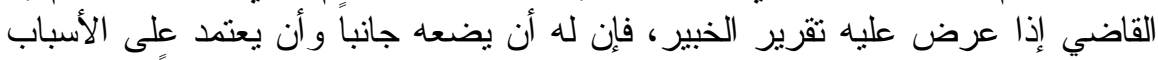

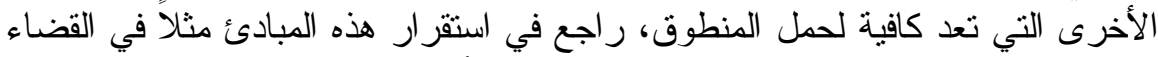

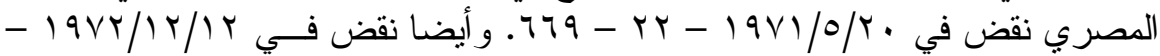
و

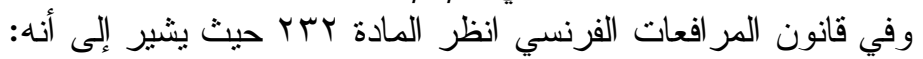
Le juge peut commettre toute personne de son choix pour l' éclairer par des constatations, par une consultation ou par une expertise sur une question de fait qui requiert les lumières d' un technicien.

راجع في عرض هذه المادة و القيمة القانونية لــر أي الخبيــر فــي قـانون المر افعـات

Gérard Couchez; op. cit. p. 269 No. 364 etss. الفرنسي:

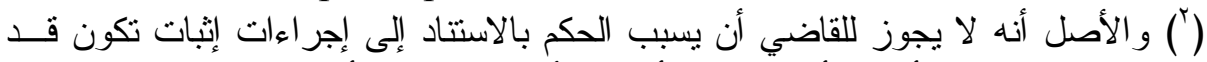

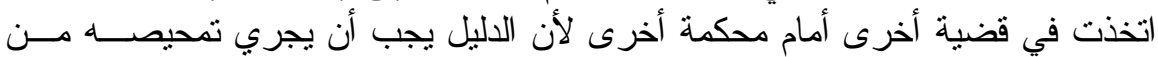

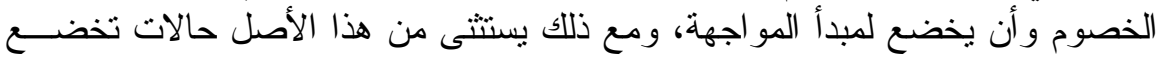

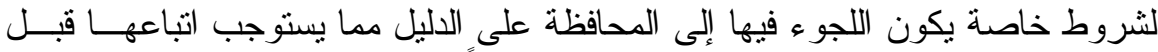
رفع الدعوى، وقد وصف المشرع هذه الحالات مثنال في المادة

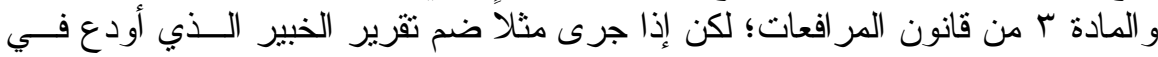

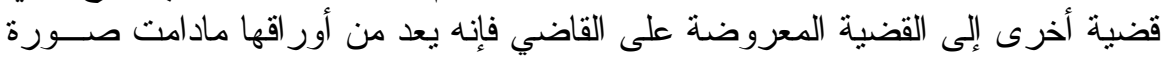
هذا التقرير قد قدمت و أصبحت من أور اق القضية يناضية فئل كل خصم في في دلالتها.

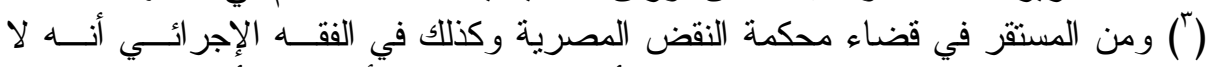

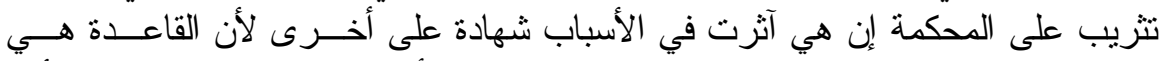

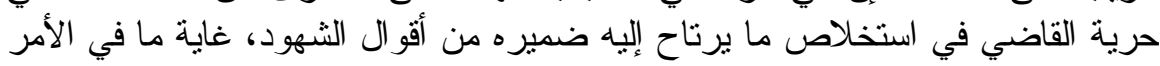


الأولى من المادة • V من قانون الإثبات المصري، ويستوي أن تكون الإحالـــة

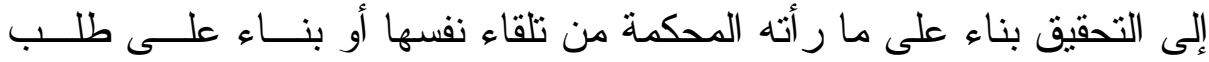

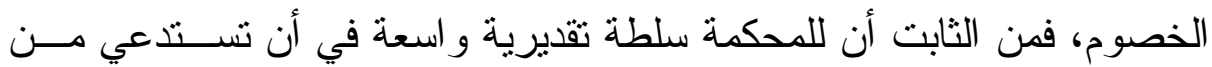

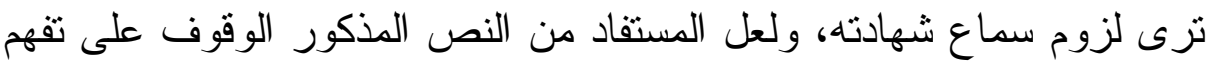

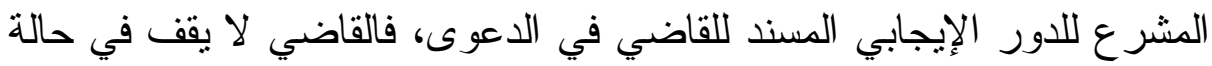

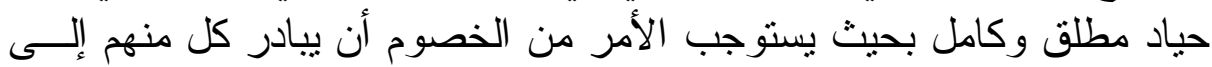
عرض أسانيد دعو اه أو دفاعه، و إنما دور القاضي هو هو الأبر الحياد الإيجابي باعنبار

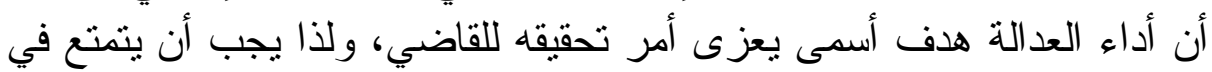

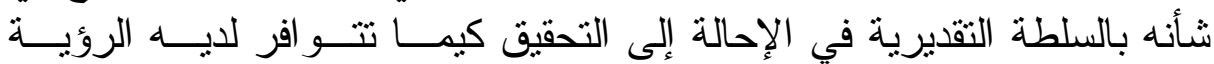

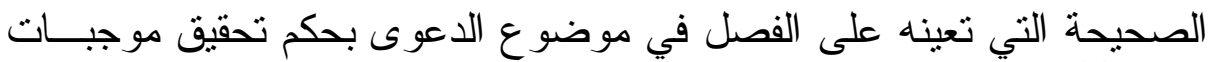

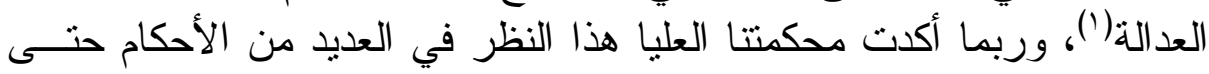

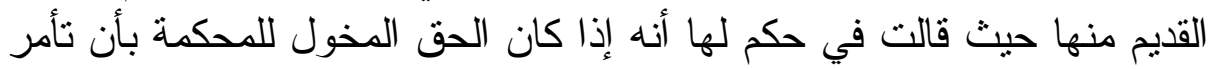

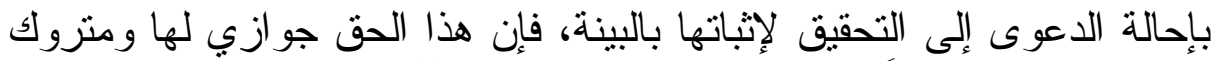

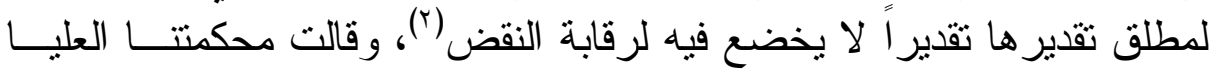

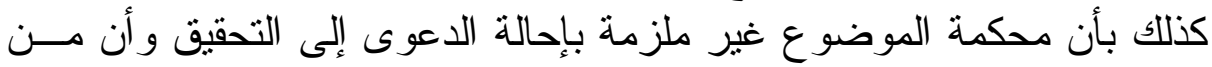

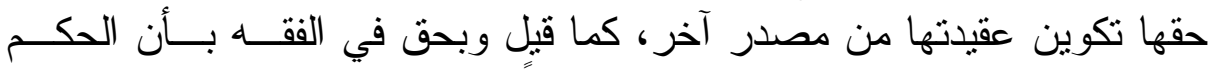

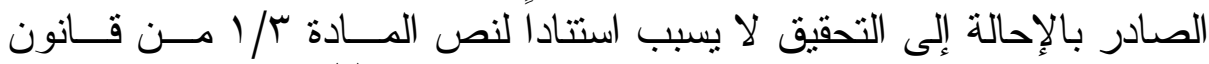
الإثبات ولتعلق الأمر بالسلطة التقديرية المطلقة للقاضي (r).

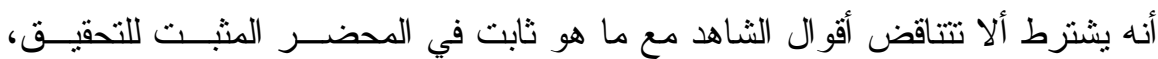

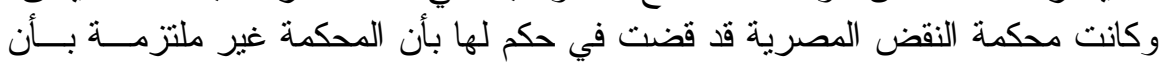

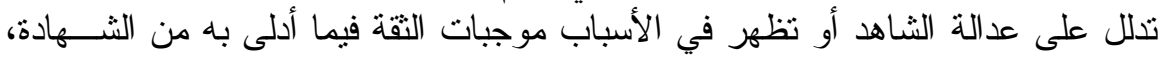

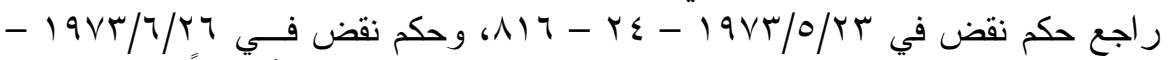
צ $.1 T V V-r T-19 V T / 1 Y / 1 T$

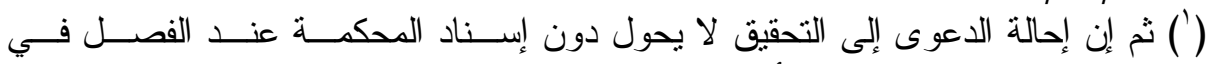

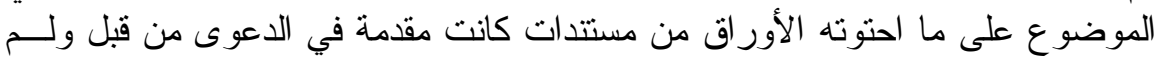

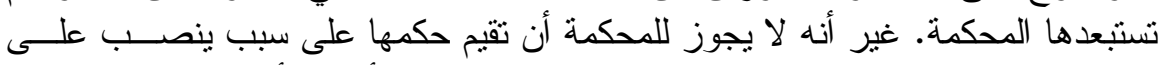

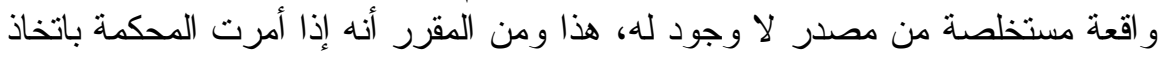

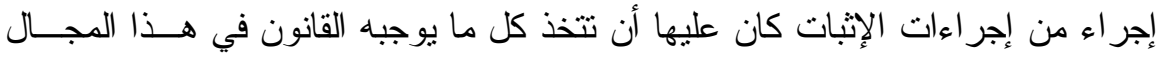

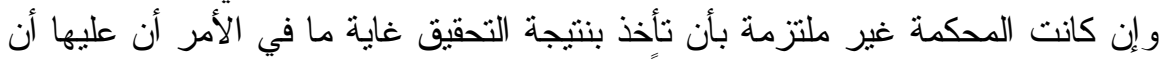

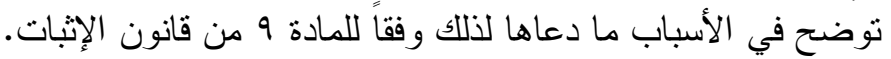

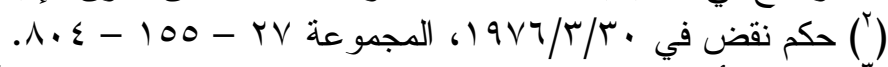

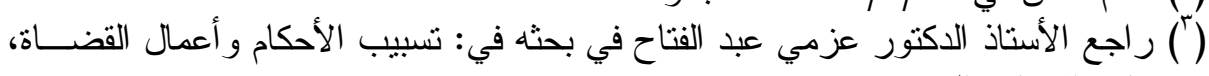

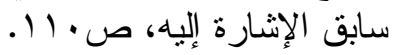




\section{المبحث الأول \\ التسبيب والسلطة التقديرية للقاضي الاول \\ المطلب الأول \\ مفهوم السلطة التقديرية للقاضي الاول \\ باعتبار ها علة لعدم لزوم تسبيب الأحكام}

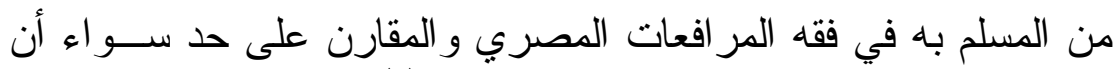

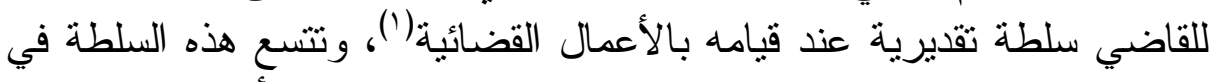

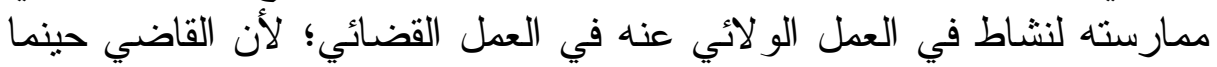

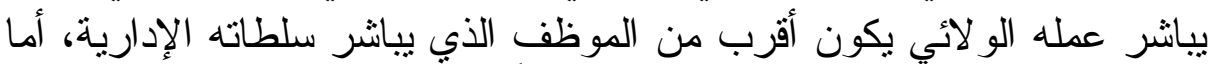

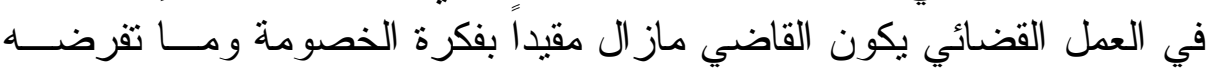

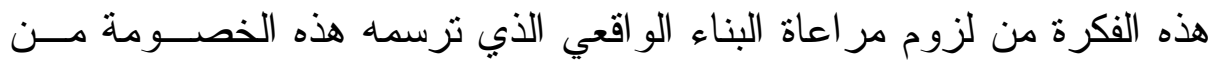

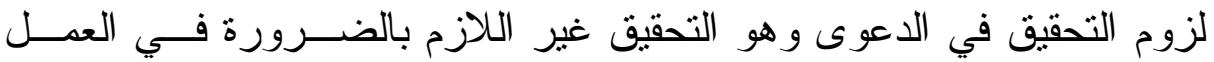

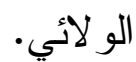

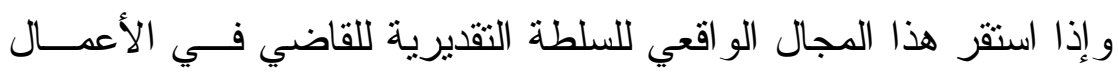

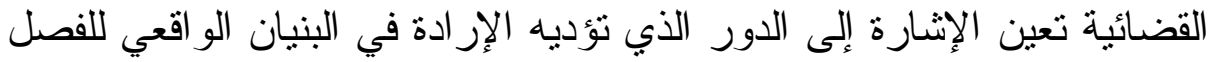

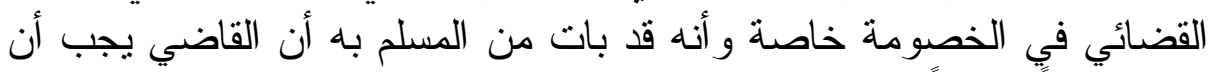

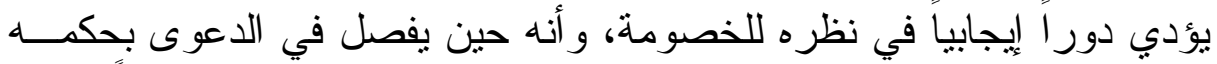

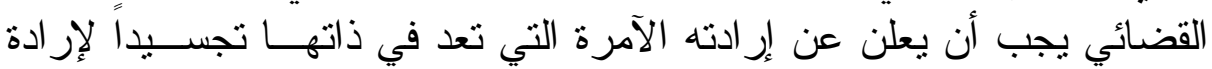

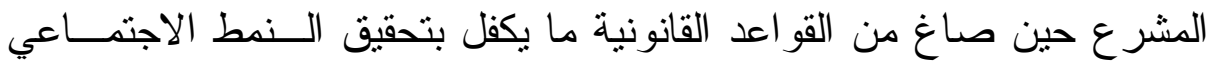

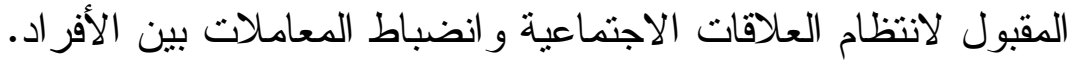

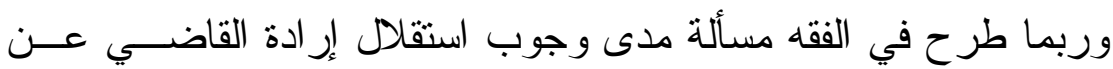

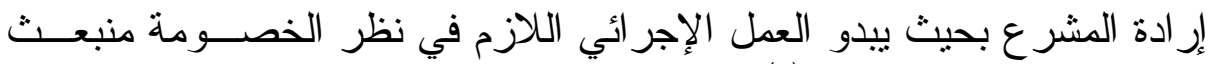

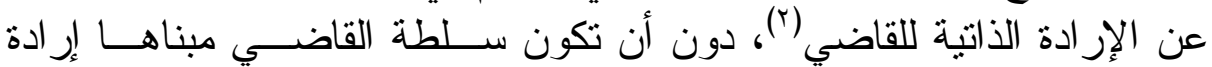

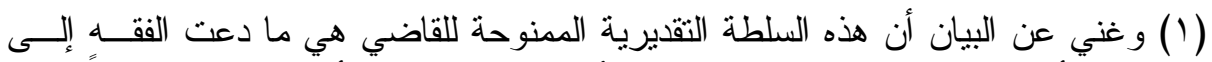

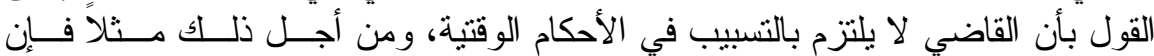

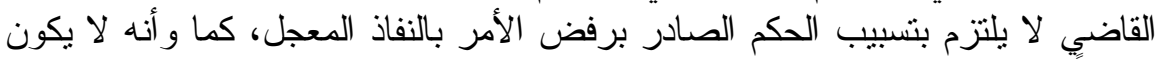

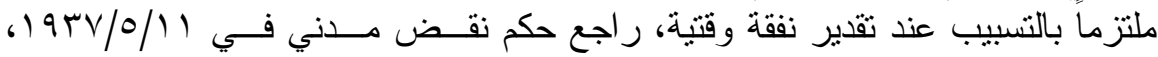

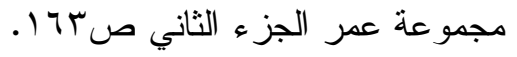
(') ومن الققهاء من يستند في هذا المجال إلى طبيعة العمل القضائي الذي يبانشره القاضي؛

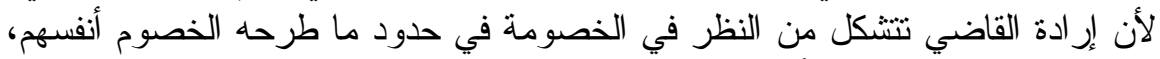

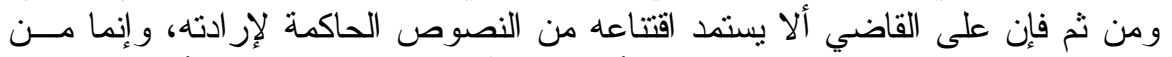

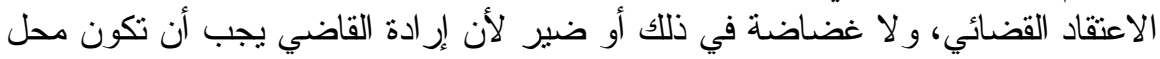


المشرع بينما تتو ارى أو بالأقل تخف حدة إر ادة القاضي الذاتية، ومن ثم تكون

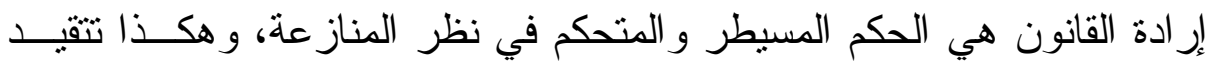

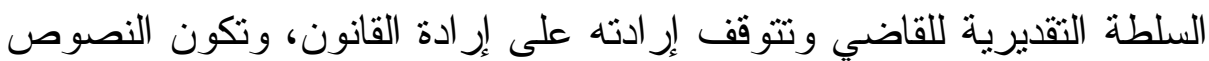

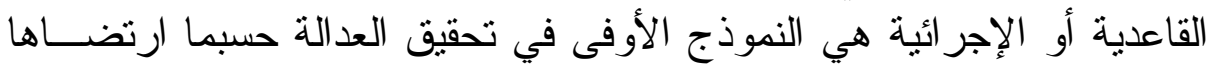

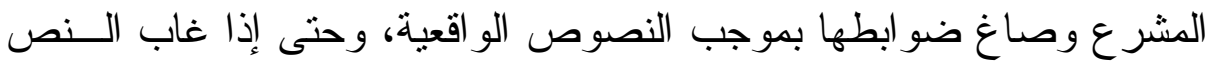

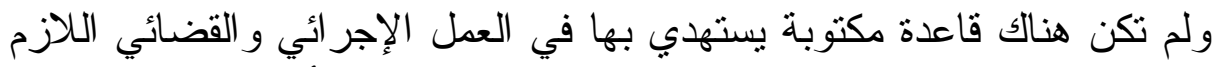

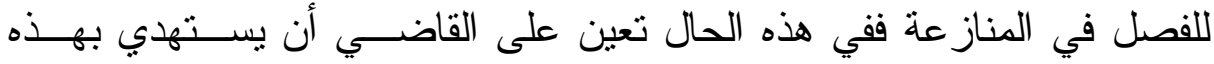

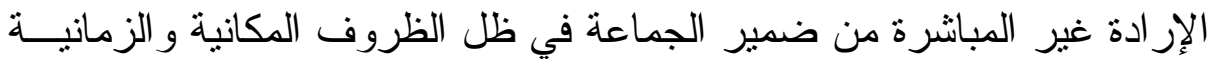

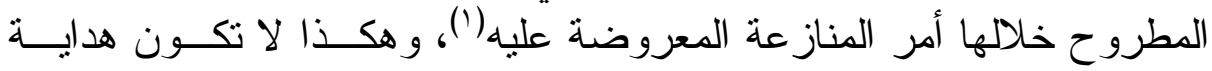

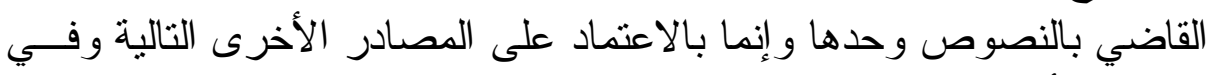

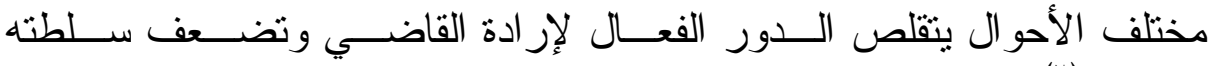

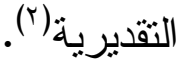

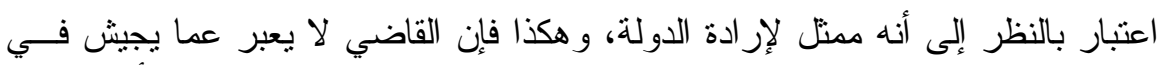

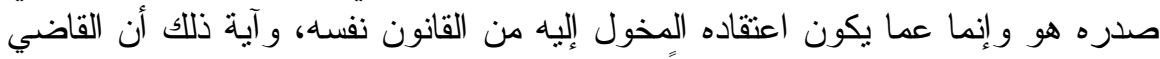

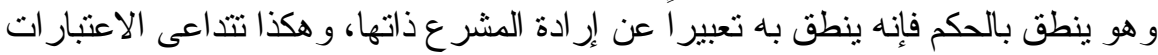

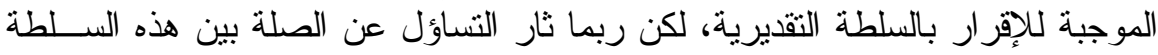

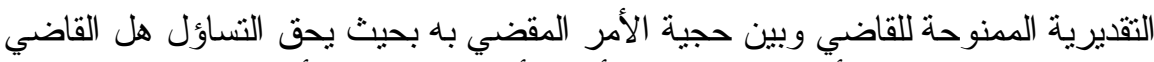

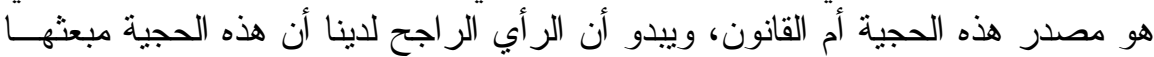

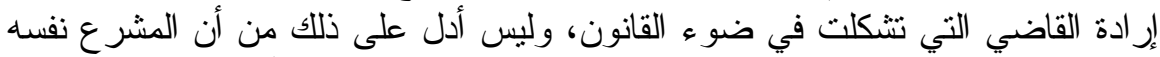

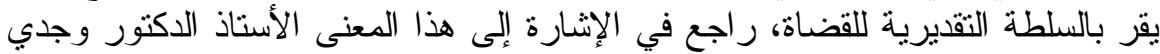

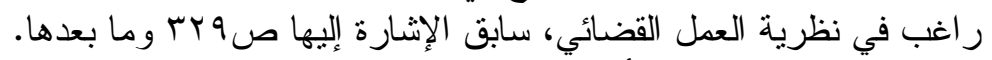

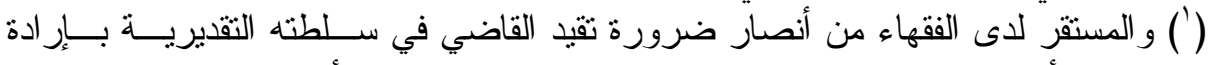

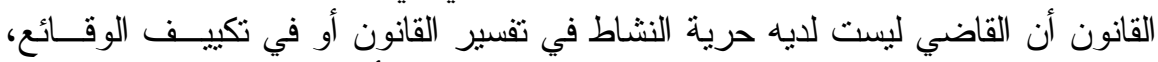

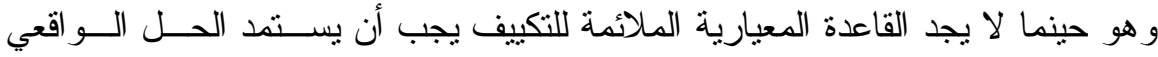

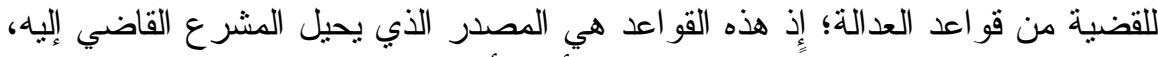

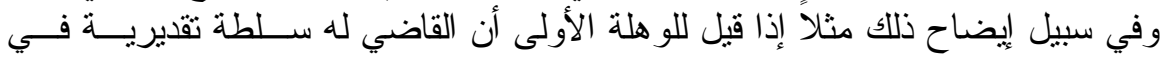
تقدير قدر التعويض عن الفعل الضار فإن حريته في الاختيار لا تعكس سلطته التقديريةٍ

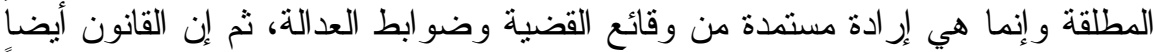

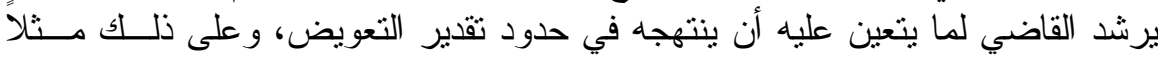

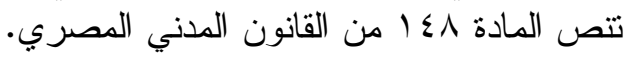

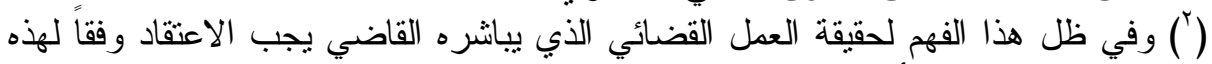
الوجهة من النظر بأن السلطة التقديرية للقاضي هي حقيقة استثنائية إذ سياج هذه السلطة

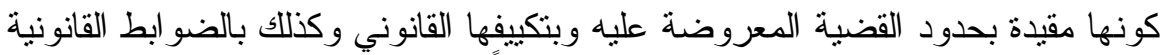

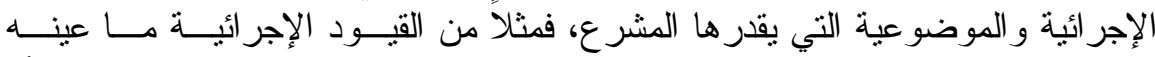

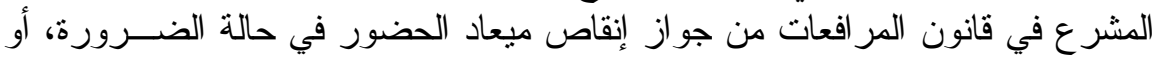




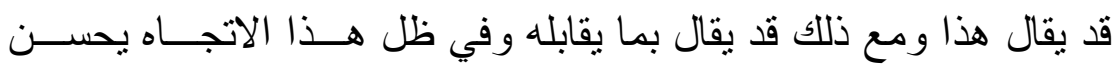

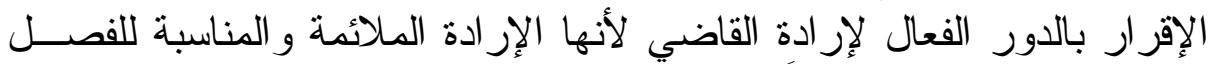

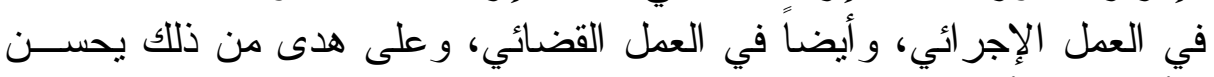

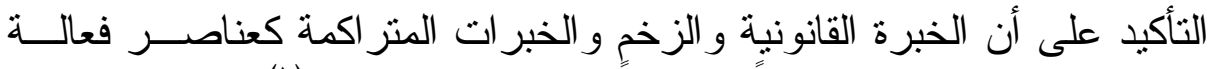

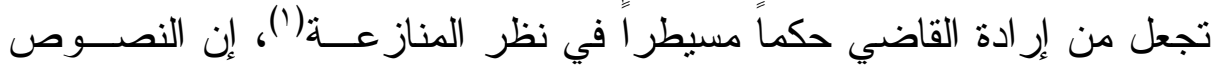

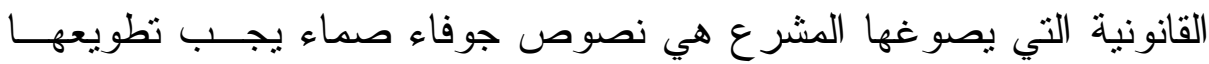

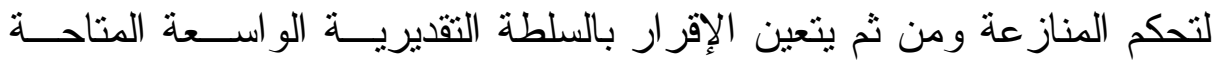

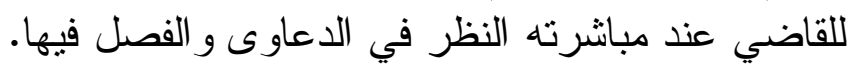

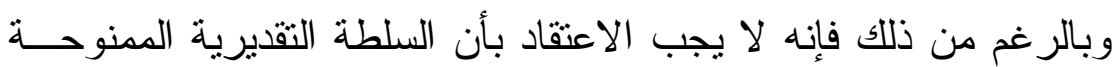

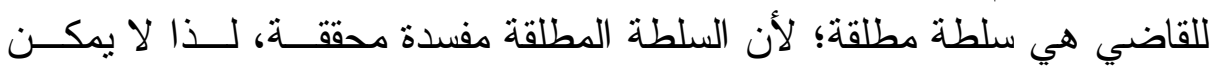

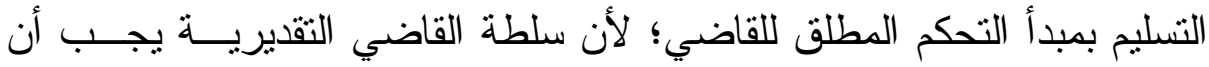

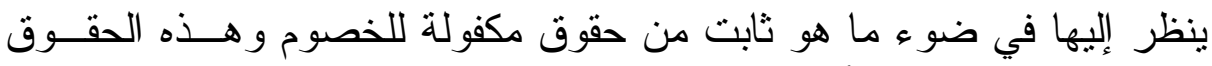

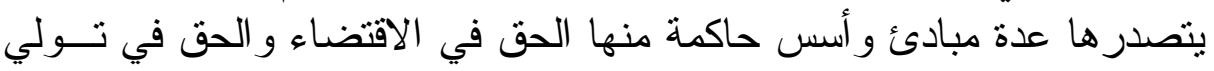

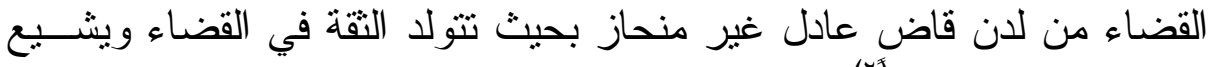
الاطمئنان إلى العدالة) لأب).

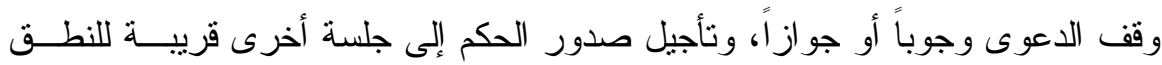

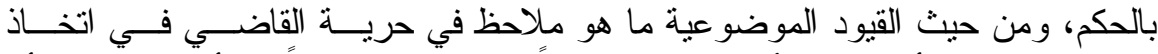

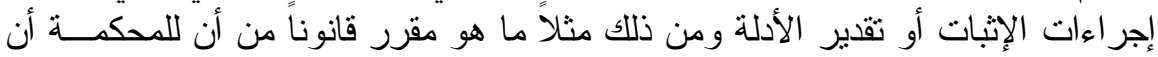

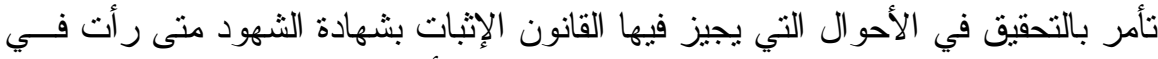

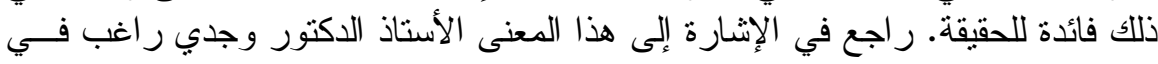

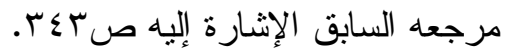

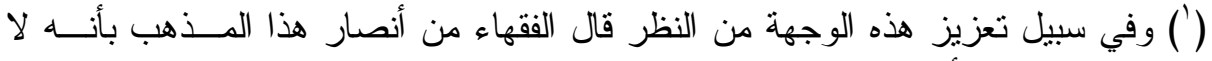

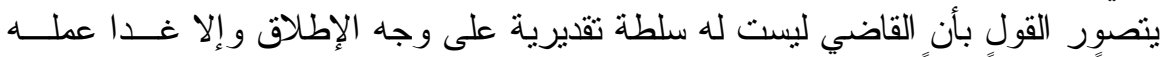

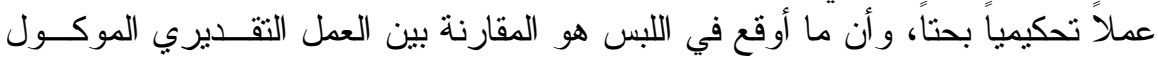

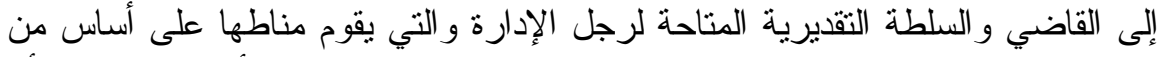

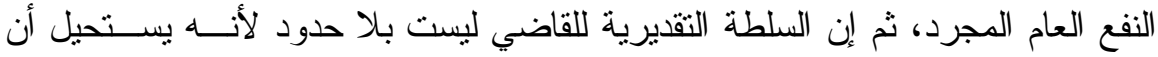

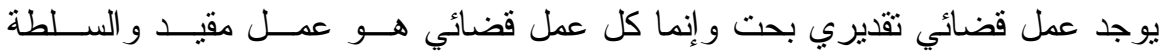

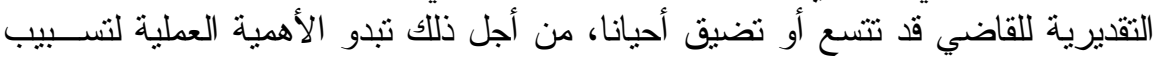

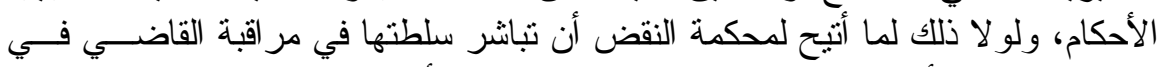

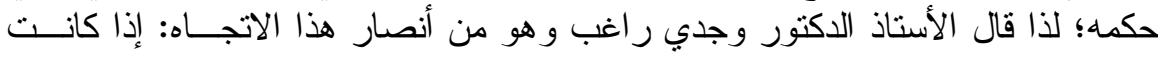

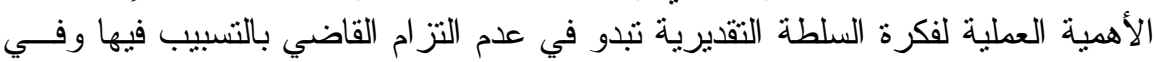

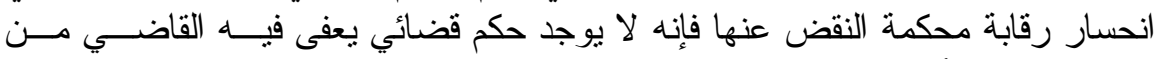

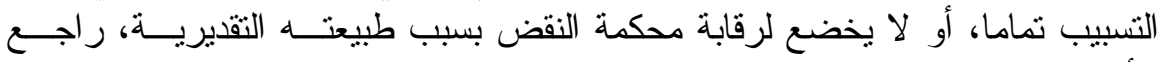

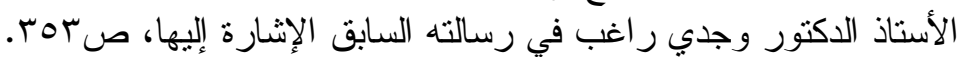

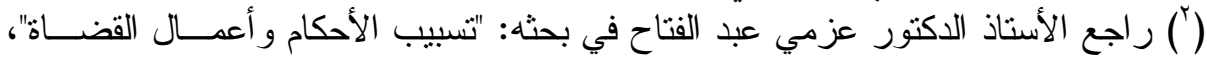




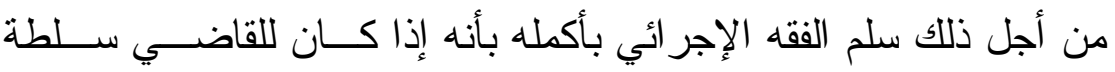

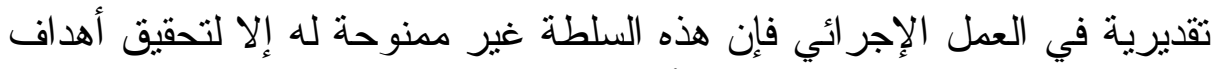

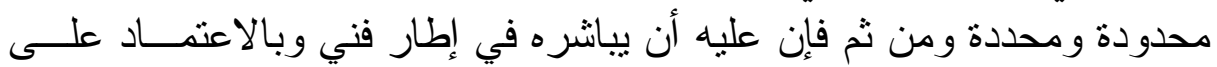

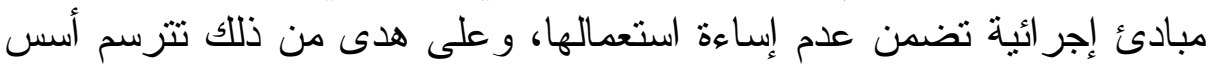
تسبيب الأحكام.

وفي مجال التساؤل حول الحدود المتاحة للسلطة التقديرية للقاضي قـال

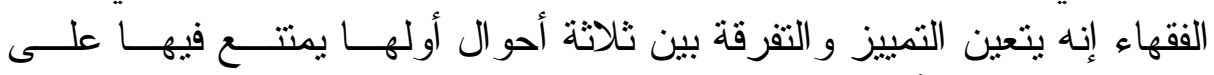

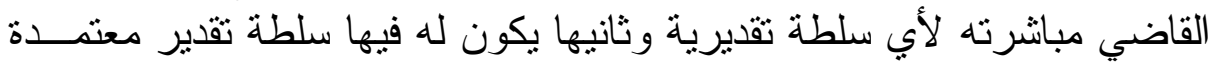

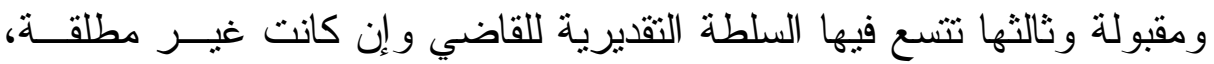

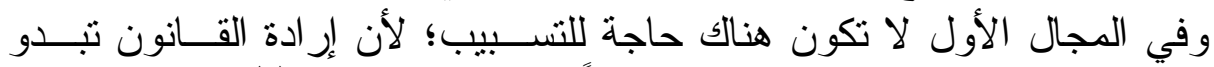

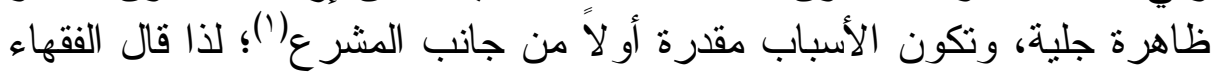

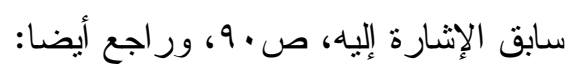

René Morel; Traité élémentaire de procédure civile. Op. cit. p. 377 No. 470.

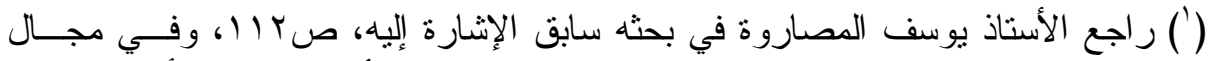

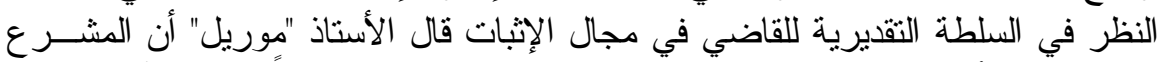

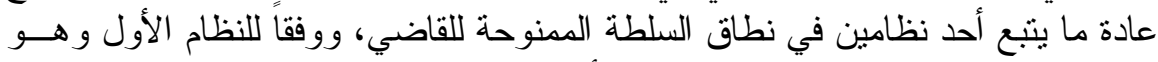

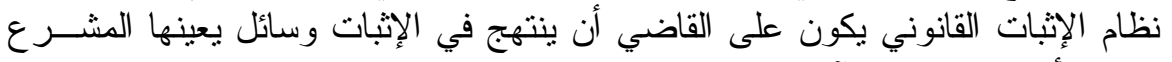

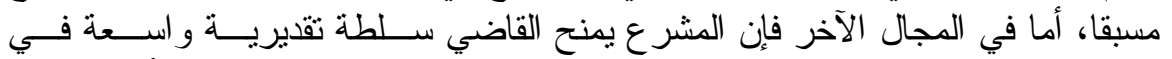

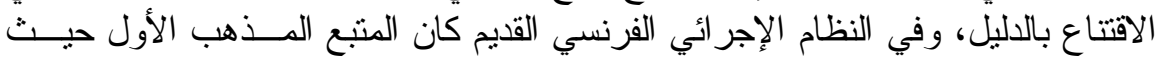

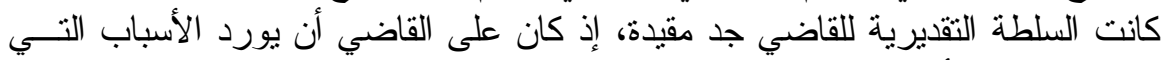

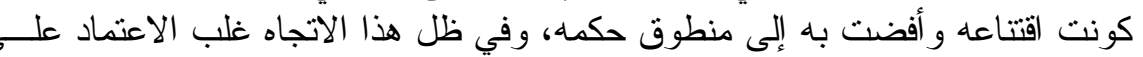

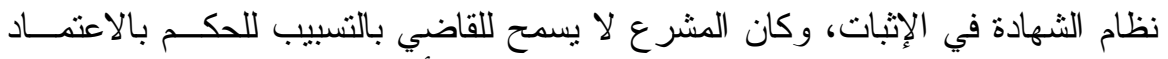

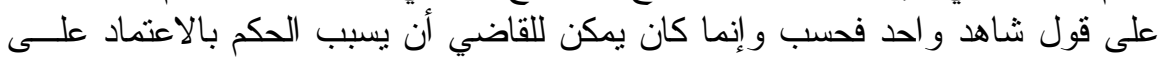

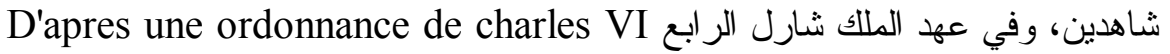

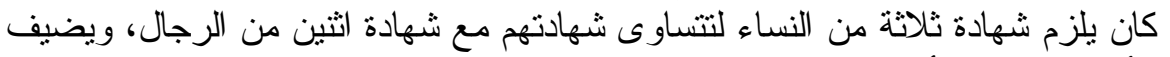

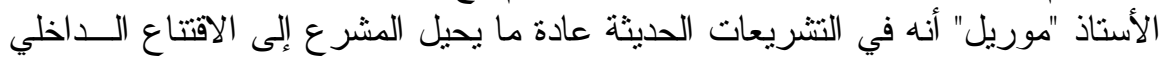

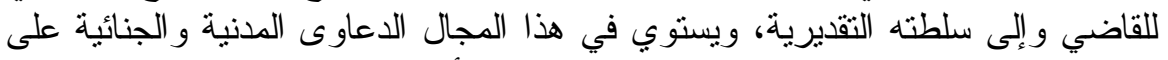

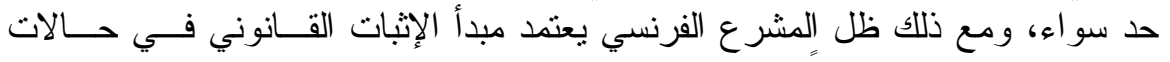

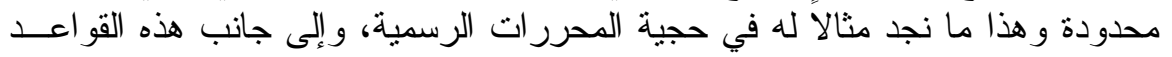

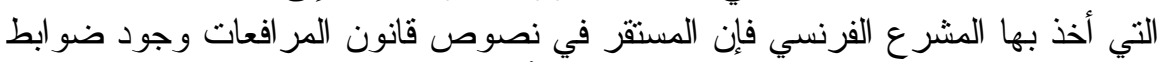

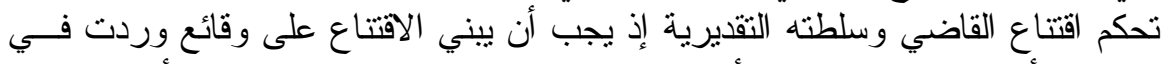

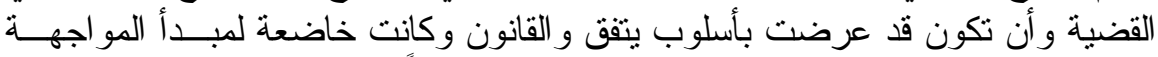

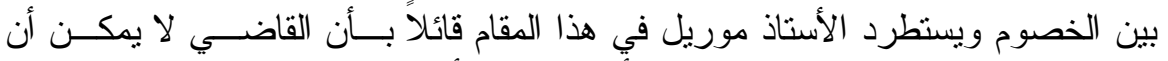

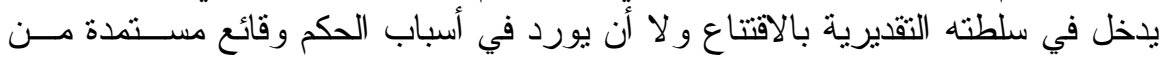




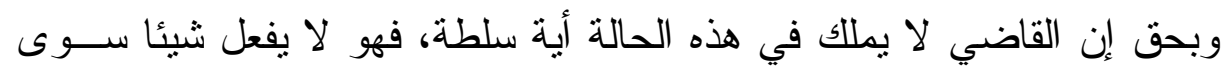

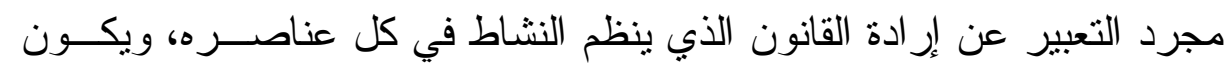

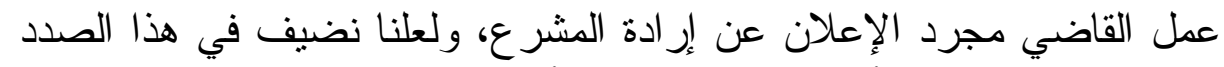

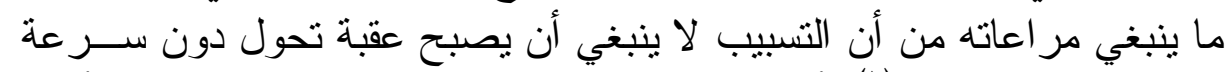

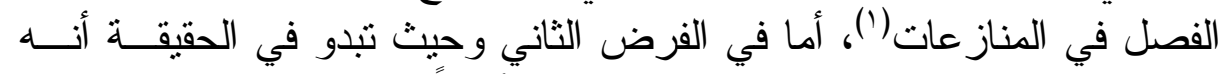

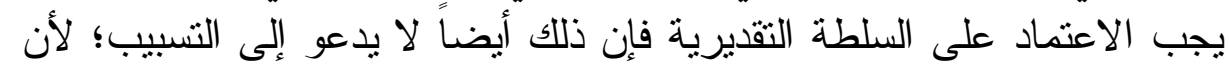

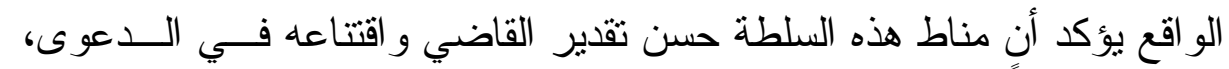

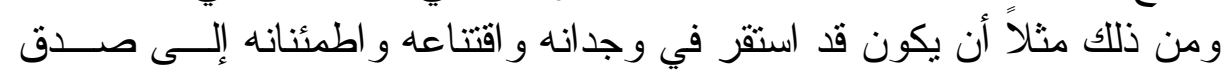

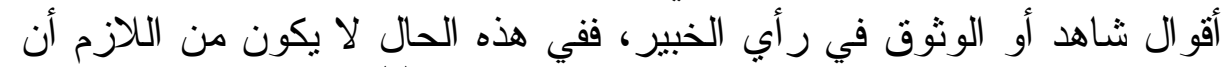

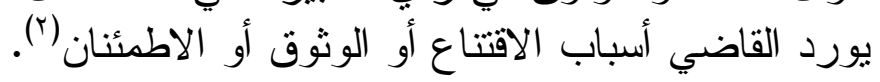

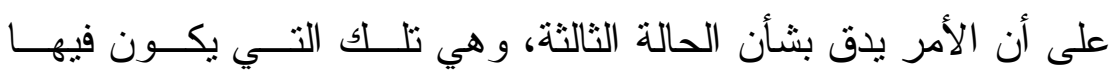

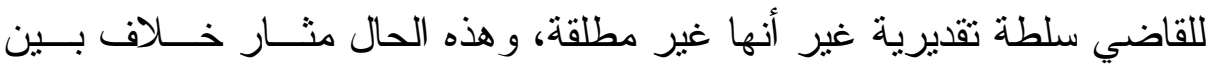

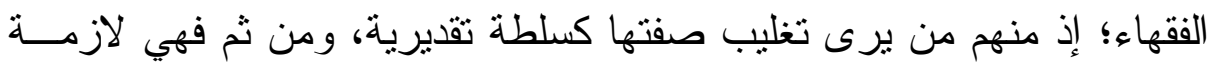

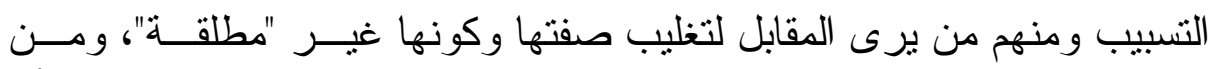

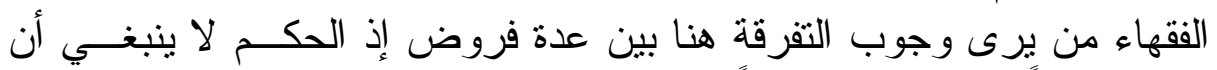

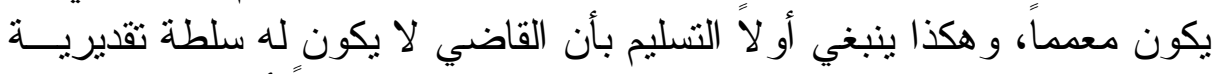

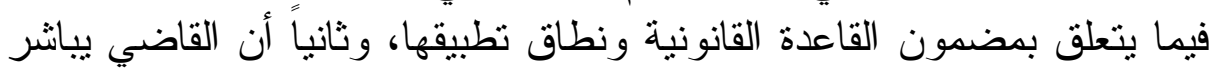

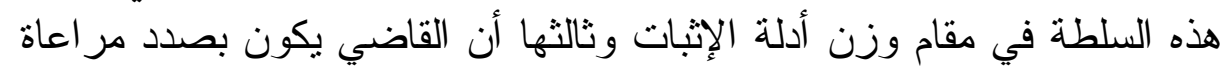

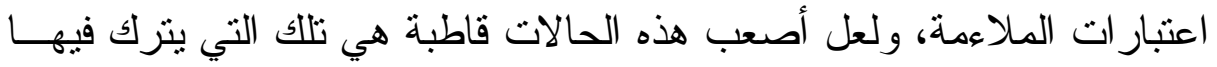

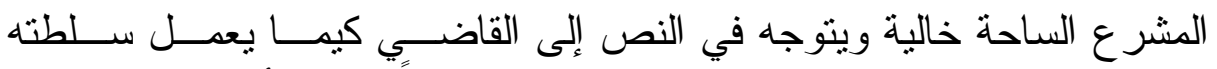

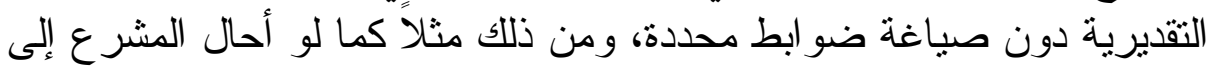

علمه الثخصي أو ما قد يكون هو قد باشره من تحريات خارج قاعة الجلسات وبــدون

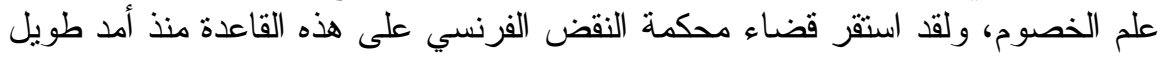

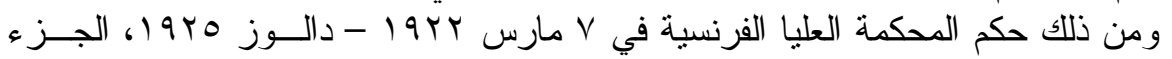

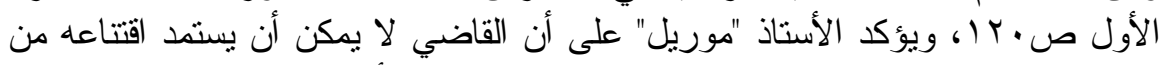

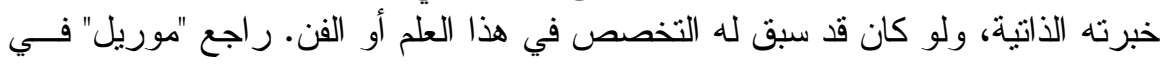

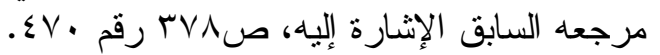

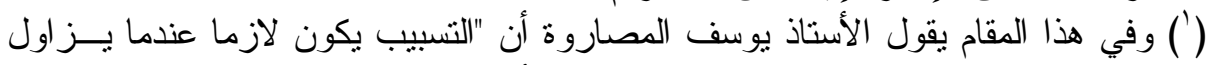

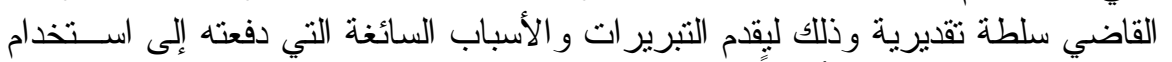

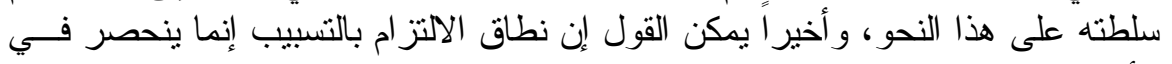

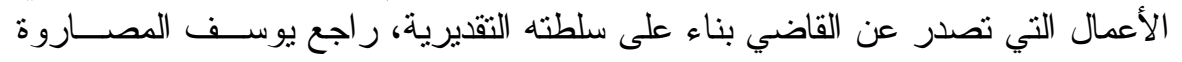

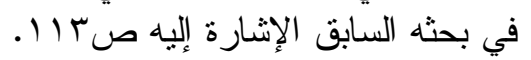

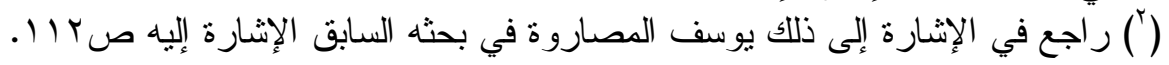




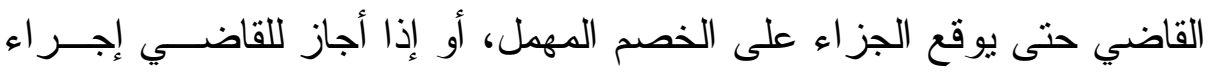

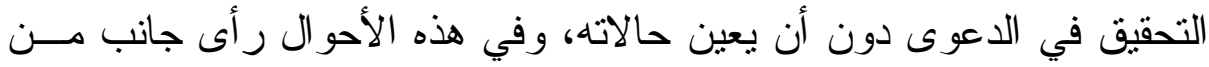

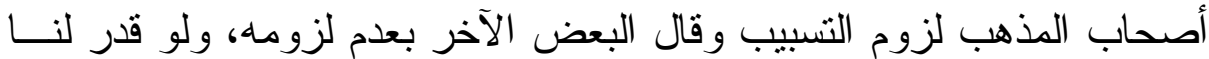

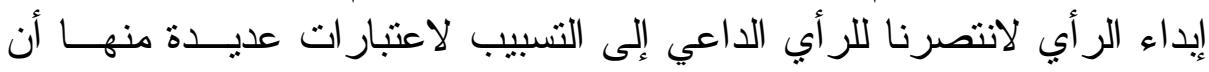

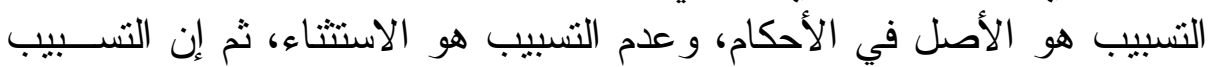

ليس تفضلا من القاضي و إنما هو حق مؤكد من حقوق الإنسان الإجر ائية(').

$$
\text { والأحكبيب الوقي الأحكام القطعية والثانية }
$$

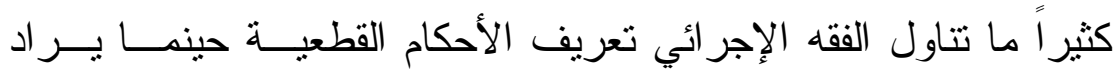

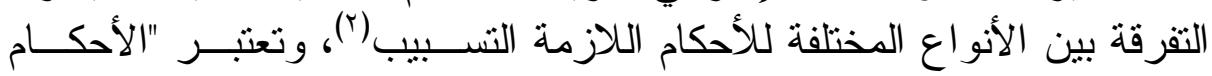

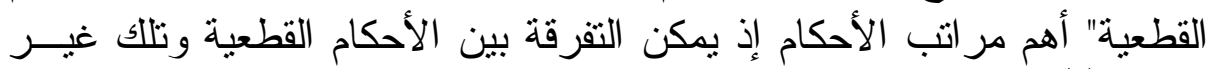

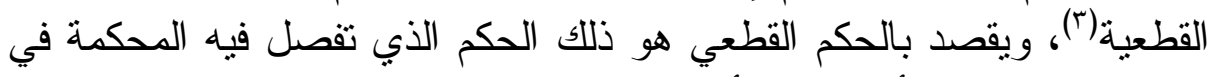

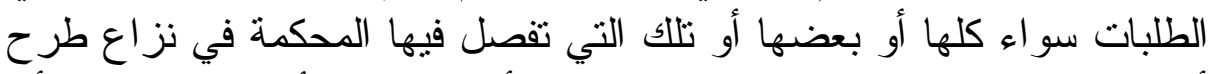

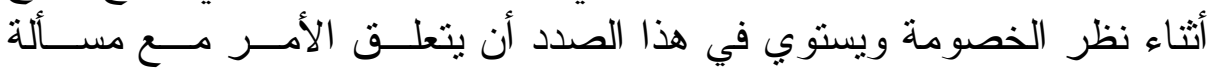

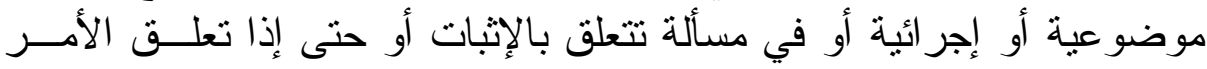

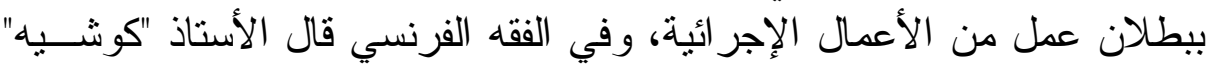
في تعريفه لهذه الأحكام "العادية" بأنها:

Le jugement ordinaire est celui qui tranche un véritable (') راجع في الإثارة إلى ذلك رسالتتا للاكتور اه بعنوان حقوق الإنسان الإجر ائية، رســالة

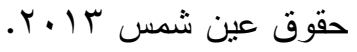

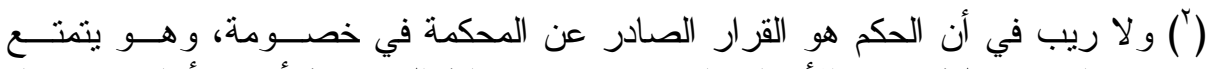

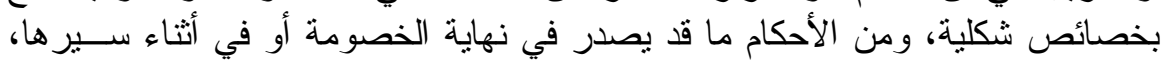

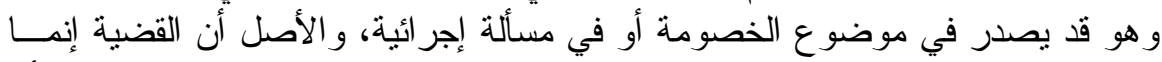

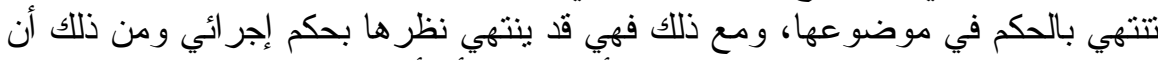

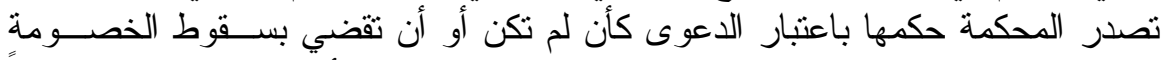

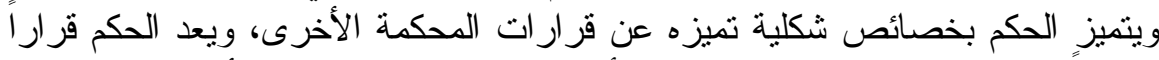

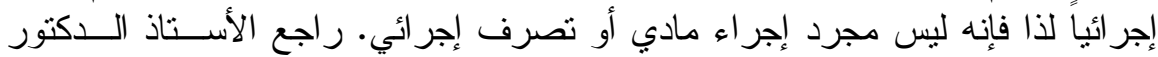

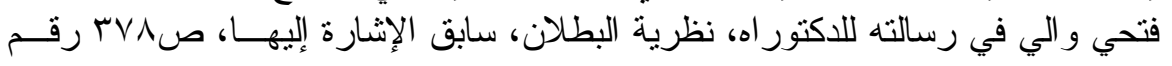
r.r (") راجع: Gérard Cornu et Jean Foyer; op. cit. p. 434 حيث يعرفان الحكم بأنه: Le jugement est le type de l' acte solennel, la loi règle avec minutie l' elaboration de la décision et la rédaction du document qui la constate et l' explique. 
litige entre les parties, celles - ci s' étant opposées jusqu' à l' intervention de la décision de justice". ${ }^{(1)}$

و هكذا نتبدى الخاصية القانونية لهذه الأحكام وهي كونها "فاصلة"، وهى لهى

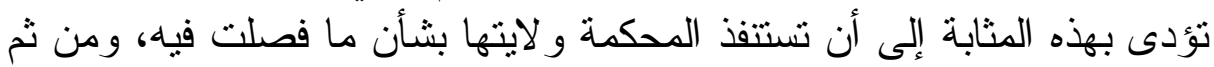

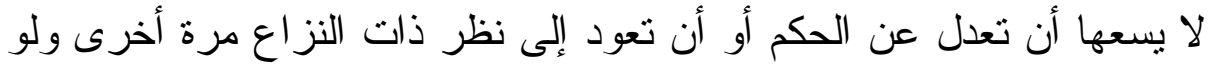

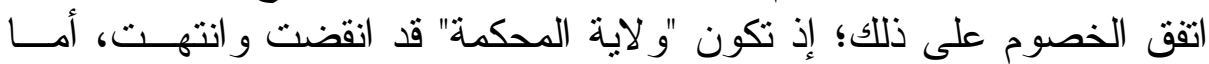

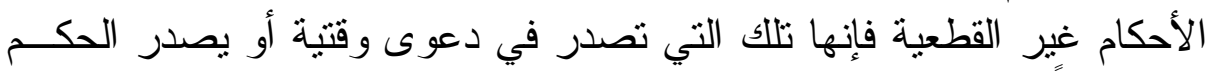

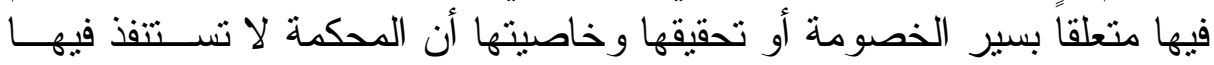

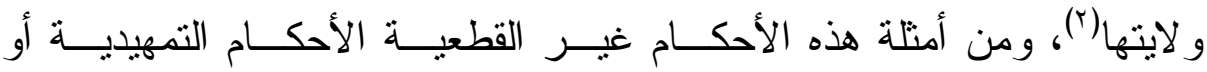

(') راجع: Gérard Couchez; op. cit. p. 295 No. 357 (') كنلك قال الأستاذان "فانساه وجويشار" في فقه المر افعات الفرنسي أن الحكم القطعي هو الحكم الذي يصدره القاضي الأنيان في القضية المعروضة فليه عليه. Le jugement définitif est celui qui règle soit tout le procès ou seulement certains points du procès, soit incidents autre que ceux relatifs à des mesures d' instruction et à des demandes provisoires, de telle façon que l' examen du juge n'ait plus a' s' exercer sur les points tranchés par ce jugement.

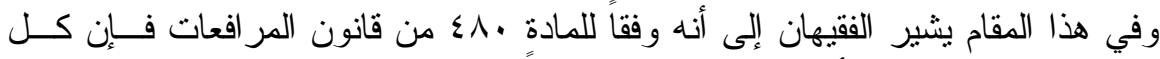

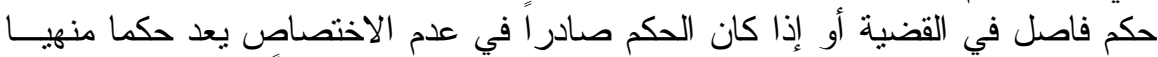

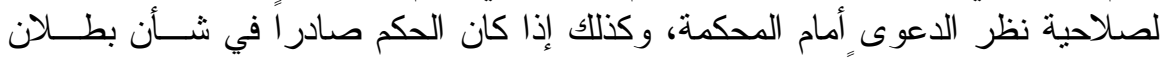

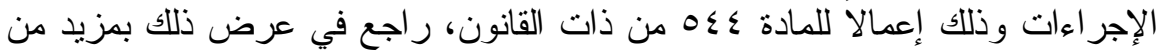

$$
\text { الإيضاح و التفصيل: التونيل }
$$

Jean Vincent et Serge Guinchard; op. cit. p. 511. No 728.

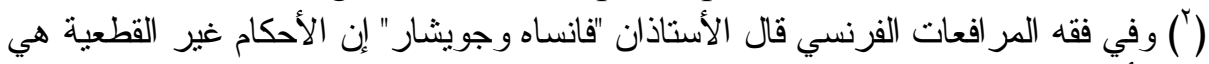

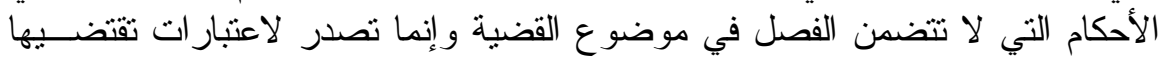

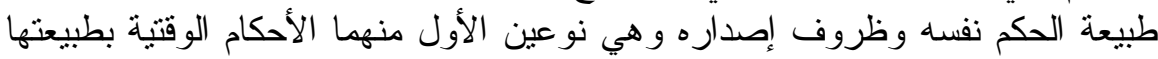
les jugements provisoires par nature ظروف متغيرة عادة ما يعاد النظر فيها dits provisoires parce qu' ils ordonnent des mesures elles - mêmes provisoires, c'est - à - dire essentiellement révisables و هذا النوع الأخير ينقسم إلى قسمين أولهما أحكام تصدر ها المحكمة أثتــــاء

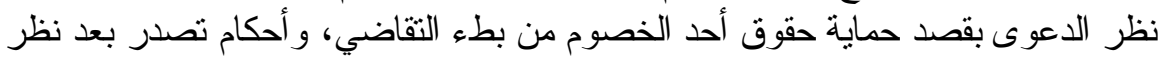

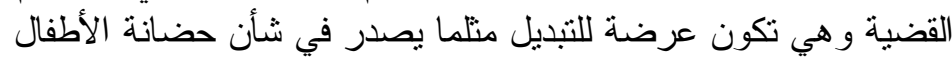
Il en est ainsi des decisions relatives à la garde des enfants ou a' une pesion alimentaire après divorce; on mesure l'ambiguité qu' il y a qualifier de provisoires de tels jugements alors que ces mesures sont en réabité incluses dans un jugement définitif 


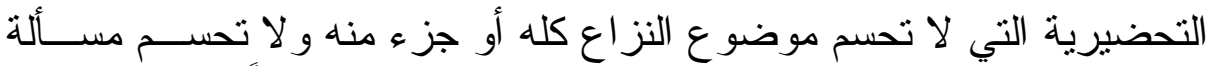

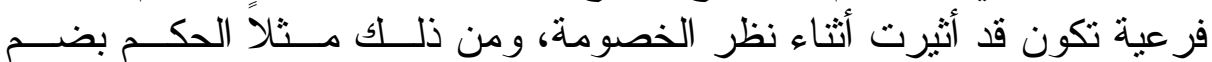

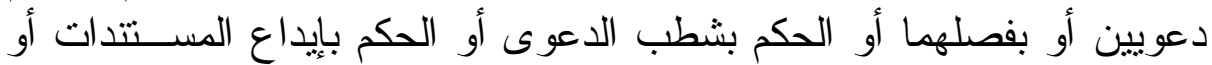

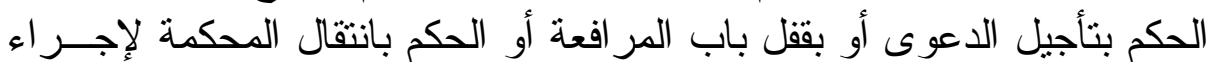
المعاينة، أو الحكم بإحالة الدعوى إلى الـى التحقيق (').

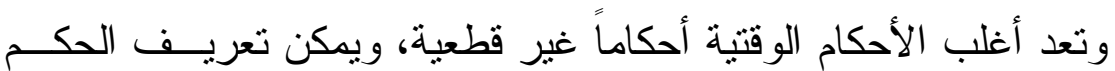

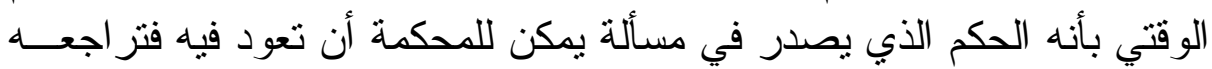

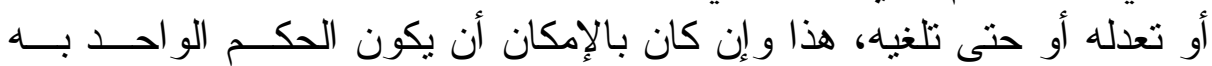

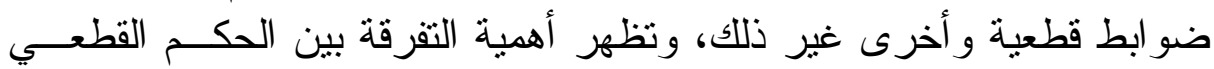

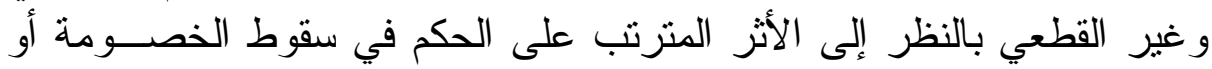

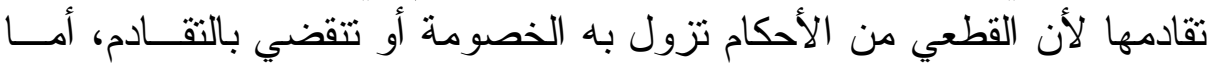

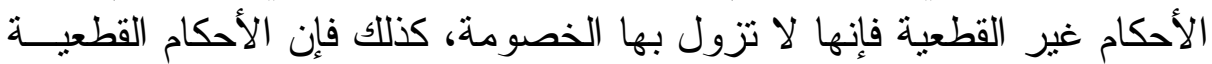

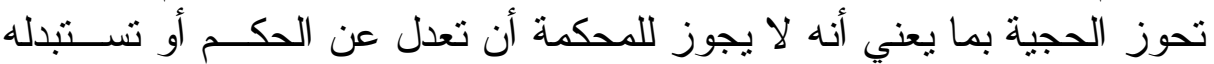

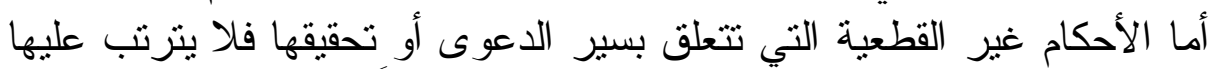

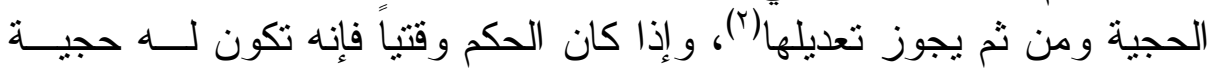

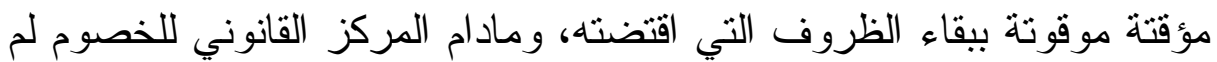

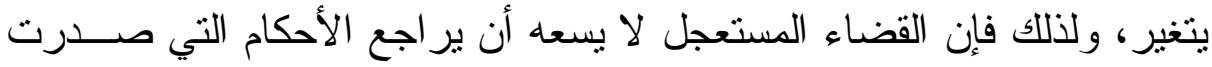

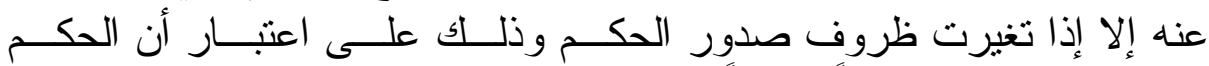

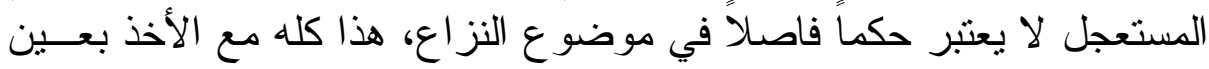

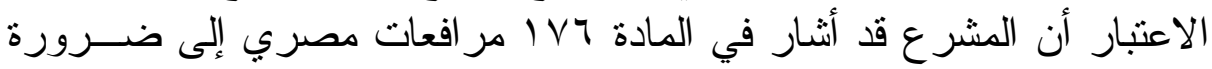

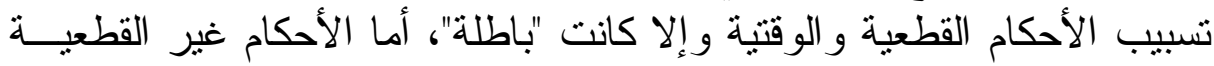

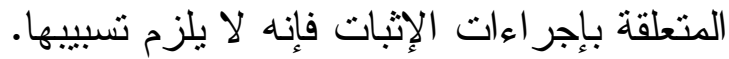

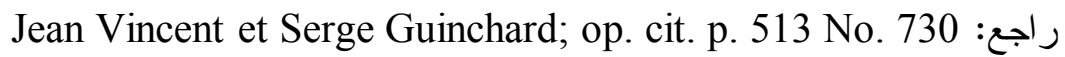

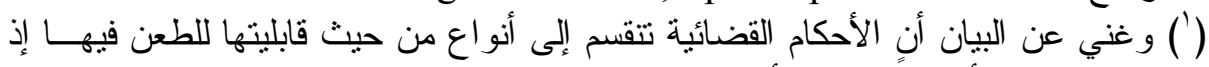

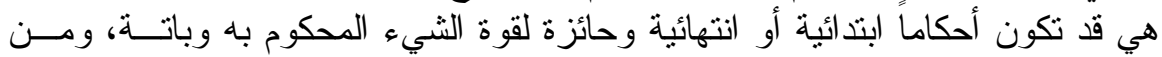

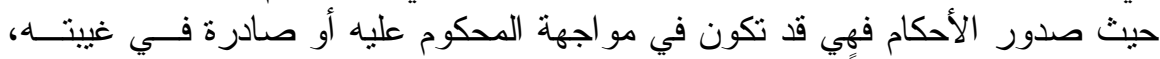

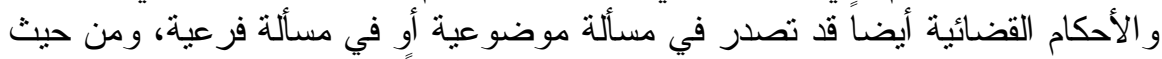

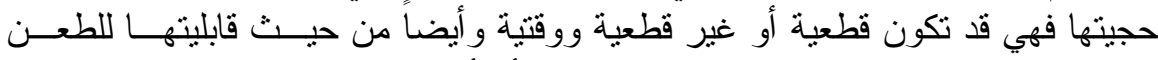

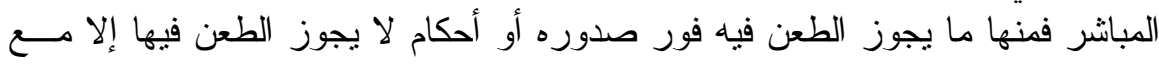

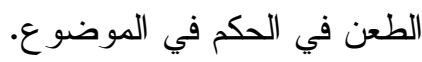

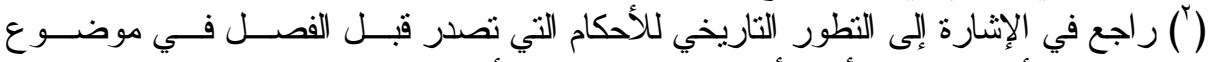

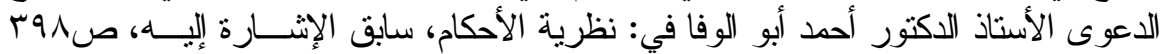


ومؤدى ما تقدم من اعتبار ات إذن أن هناك إجماع في الفقه على وجوب

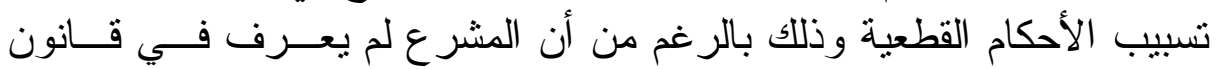

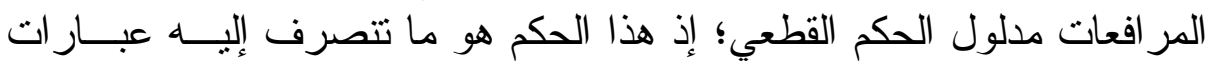

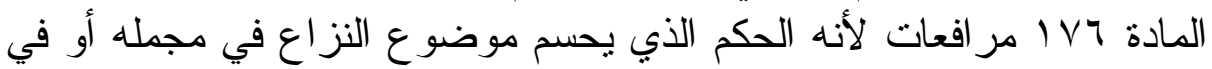

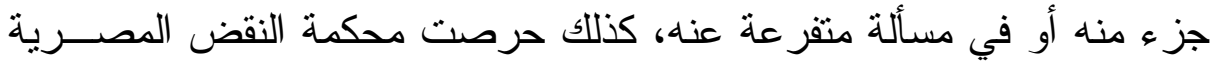

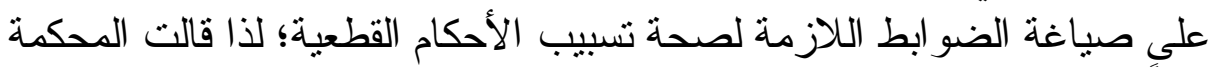

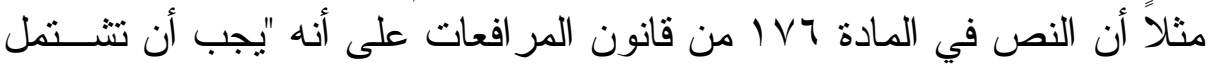

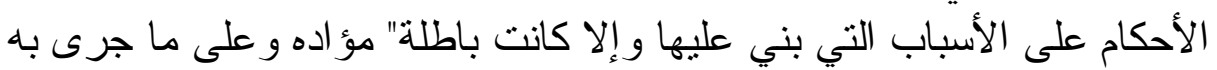

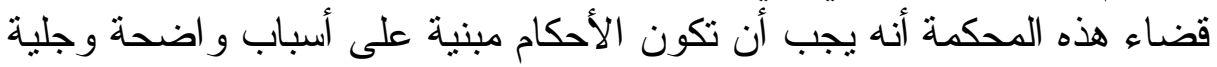

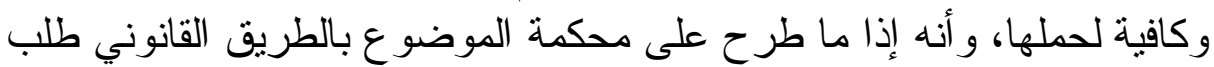

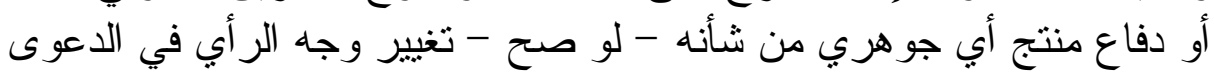

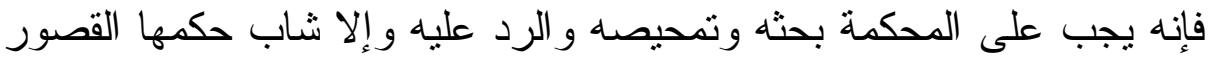

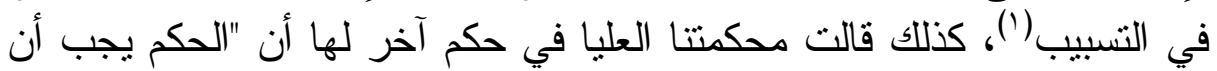

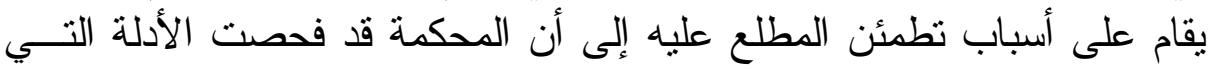

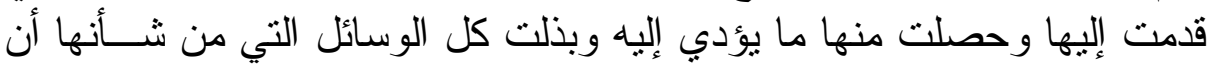

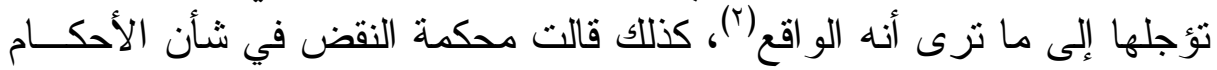

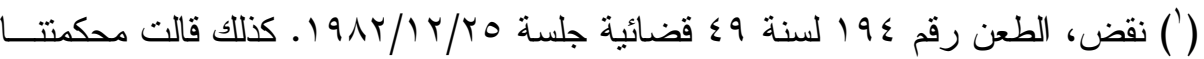

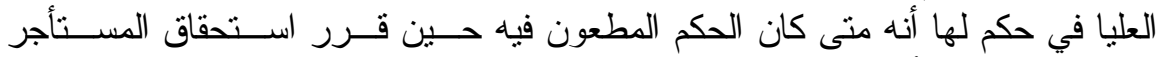

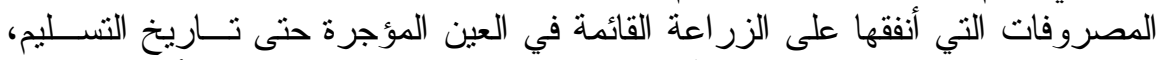

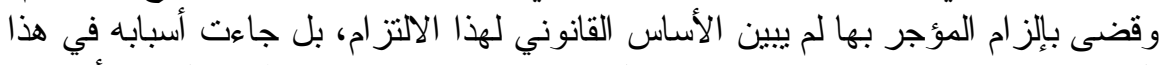

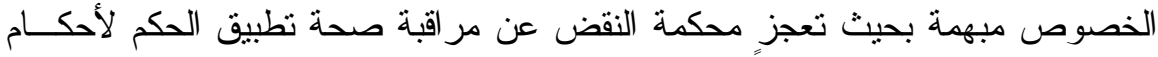

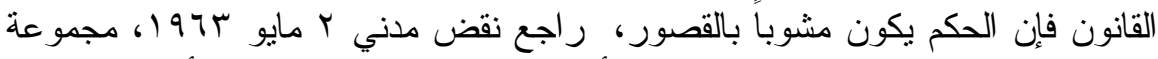

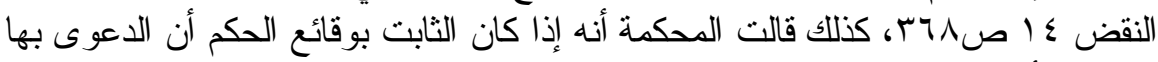

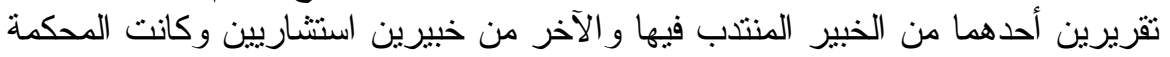

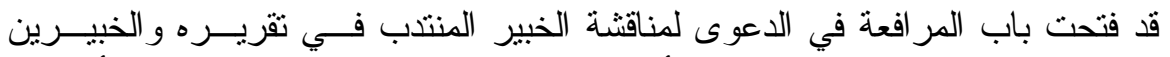

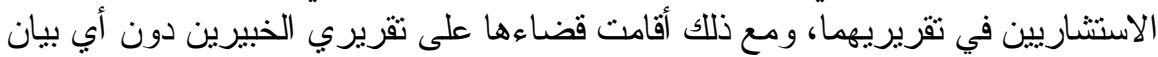

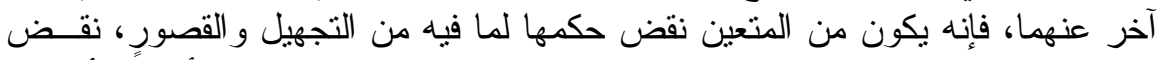

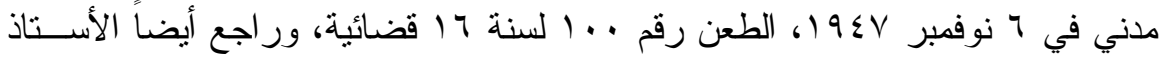

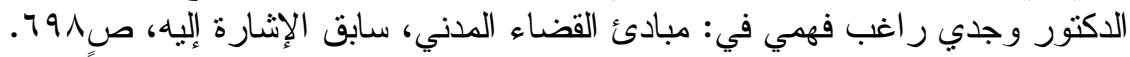

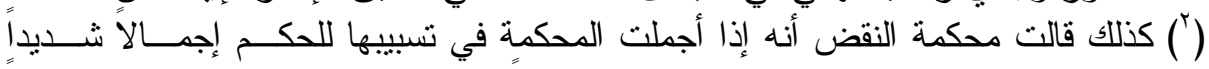

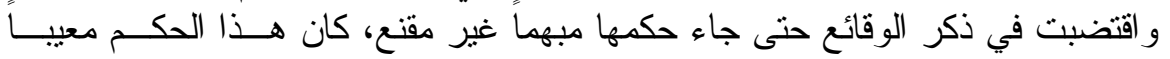

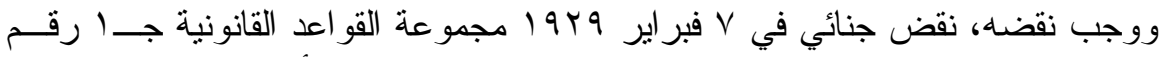

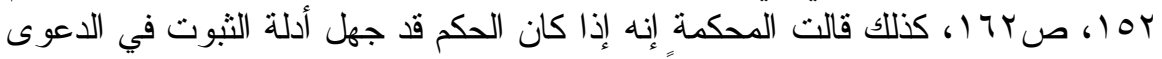

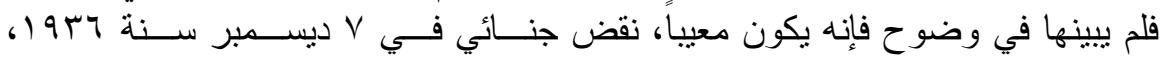


القطعية بأن محكمة الموضوع لا تكون ملزمة بإبداء ر أيها وتسبيبه إلا بالنسبة

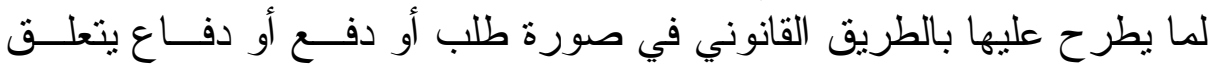

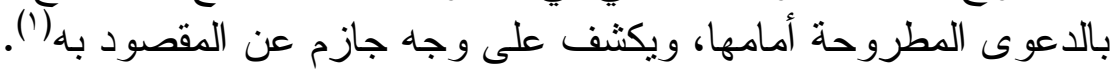

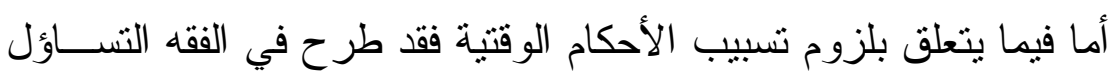

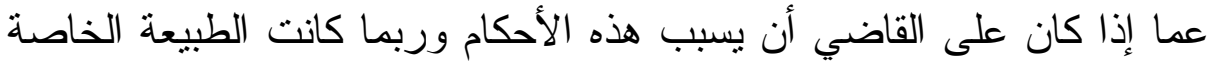

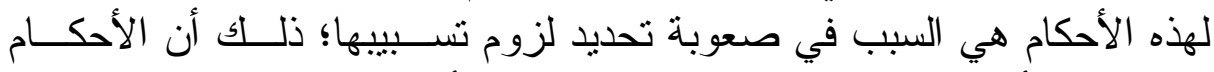

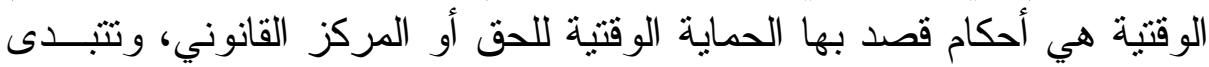

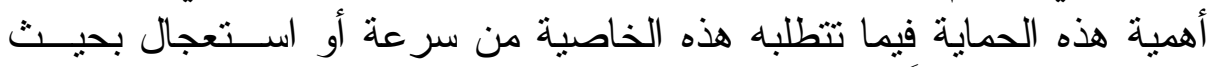

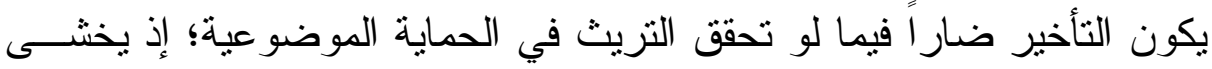

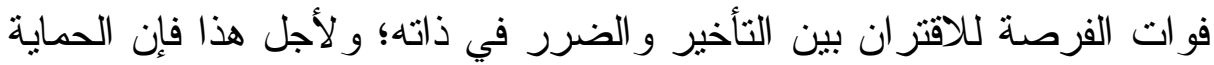

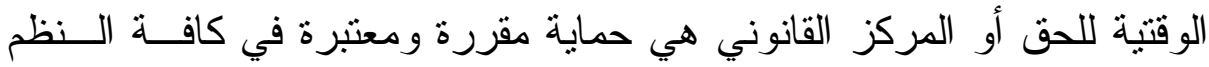

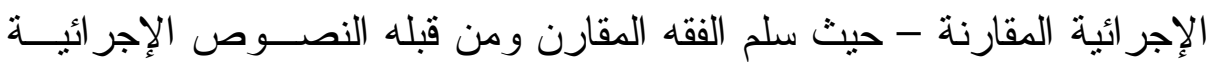

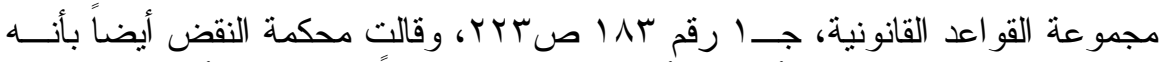

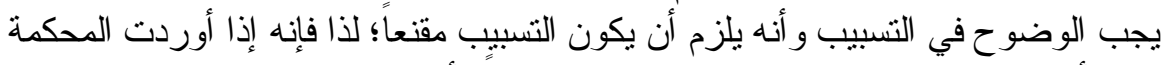

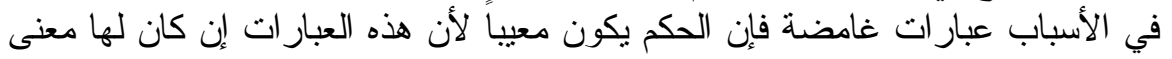

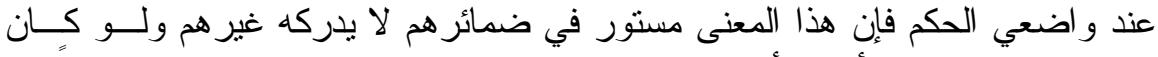

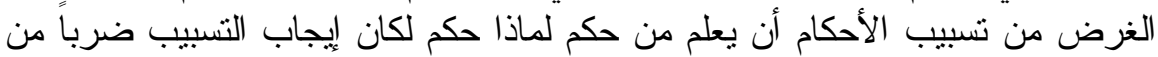

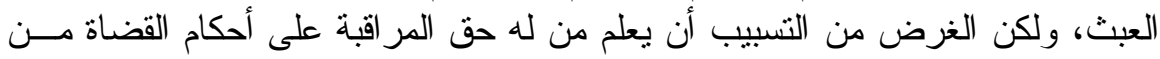

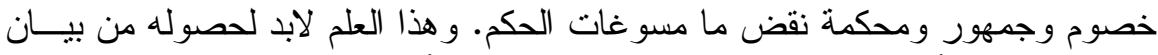

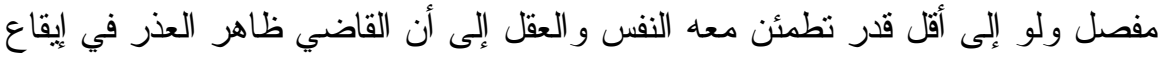

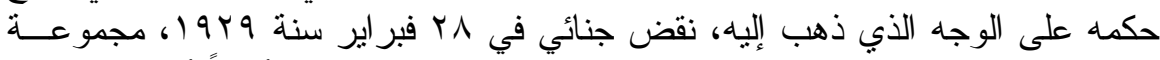

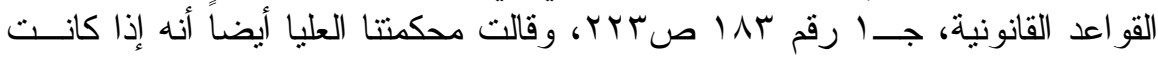

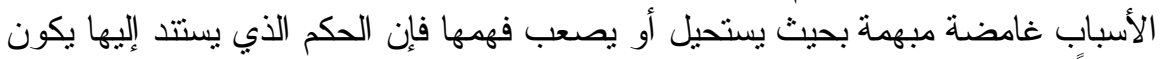

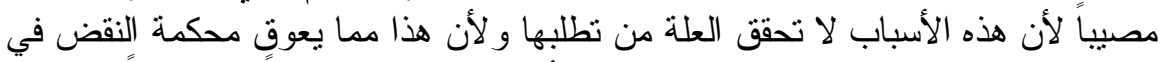

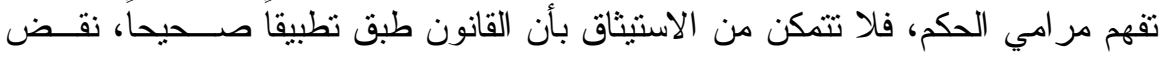

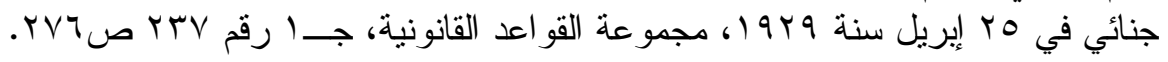

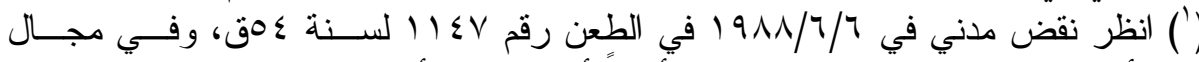

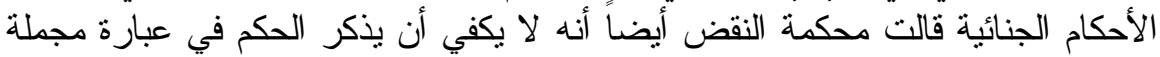

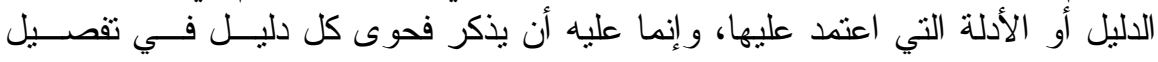

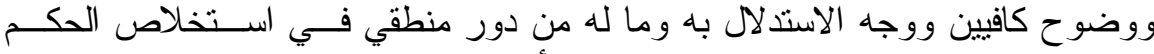

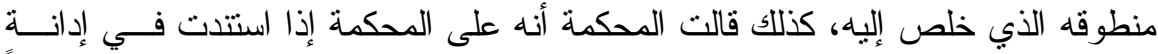

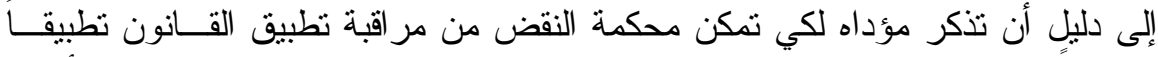

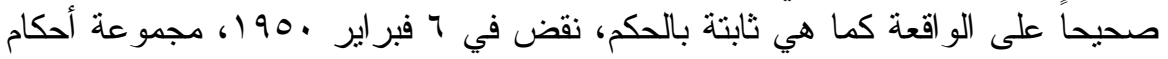

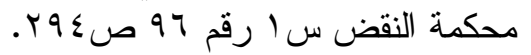


بوجوب مر اعاة ما يتزتب عن بطء الإجر اءات من أضرار يتعذر نالفيها(').

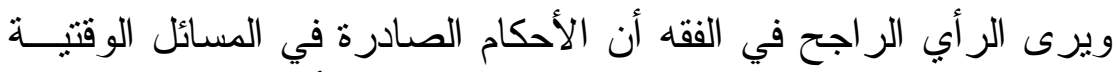

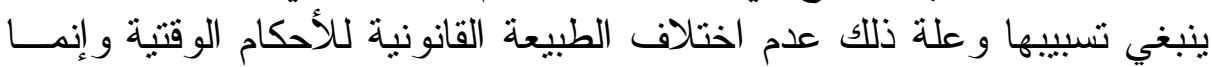
الاختلاف في ظروف الإصدار لأن الحكم الوقتي لا بختلف عن الحكــم فـي

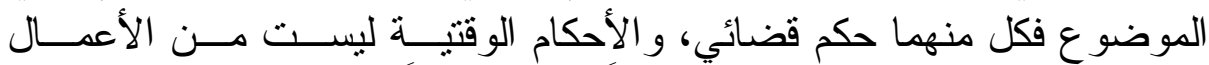

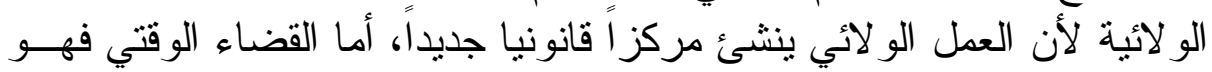

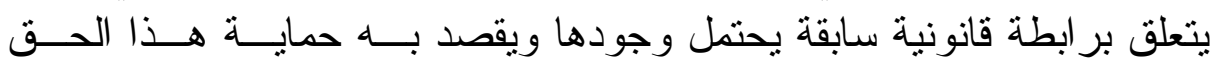

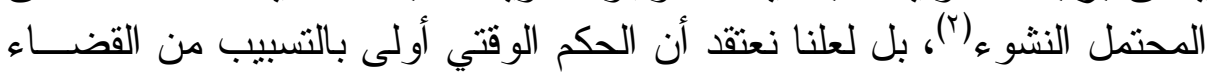

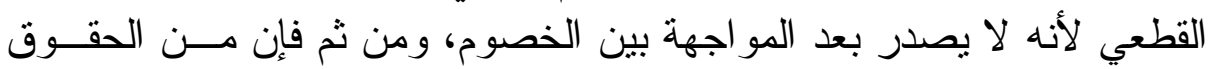
الإجر ائية للإنسان أن يعلم مبررات الحكم الوقتي، ثم إن الحكم الوقتي هو قضاء بمعناه الفني الدقيق لأن القاضي إذا ما أصدر هذا الحكم فإنه إنما يعلن عن قبول أو رفض ادعاء قانوني على مصلحة جديرة بحماية المشر ع لها، ولقد أكد الفقه

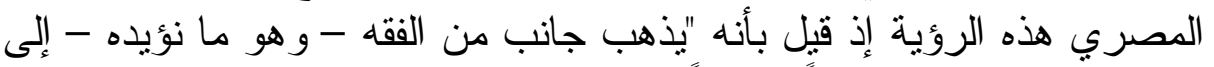

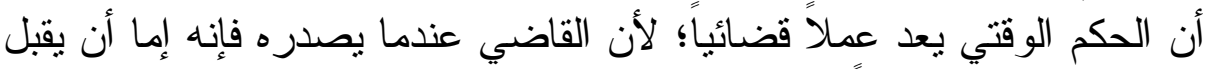
أو يرفض ادعاء قانونياً حيث يوجد تتاز ع بين المصالح conflit d'intérêts". و على كل حال فإنه إذا كانت الأحكام الوقتية ينبغي تسبيبها فإنه يســتنثى

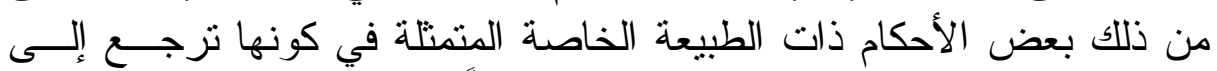
السلطة التقديرية المطلقة للقاضي، ومن ذلك مثلاً الحكم برفض النفاذ المعجــل دئل

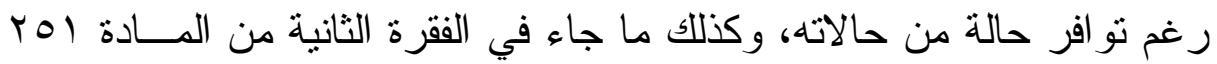

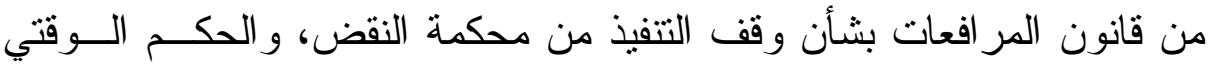
بتقدير النفقة الوقتية.

\section{التسبيب ذو الطبيعة الخاصة في الاعاوى المستعجلة:} أسند المشرع المصري الفصل في الدعاوى المستعجلة للمحكمة الجزئية

(') راجع في الإشارة إلى ذلك الأستاذ الدكتور عزمي عبد الفتاح في بحثة السابق الإشــارة

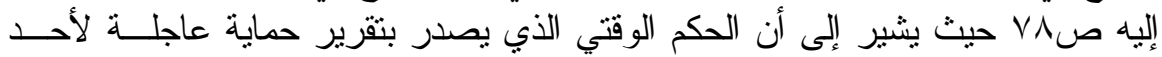

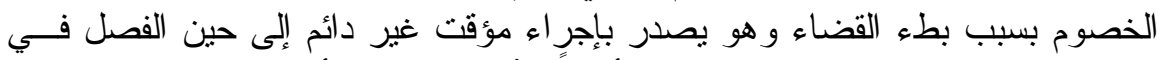

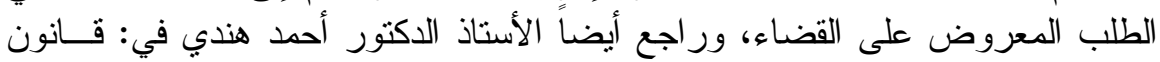

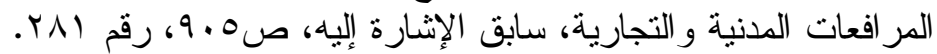

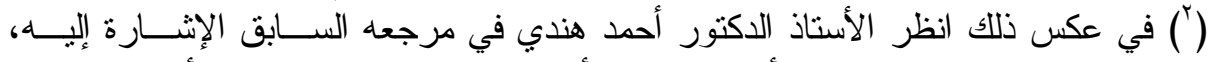

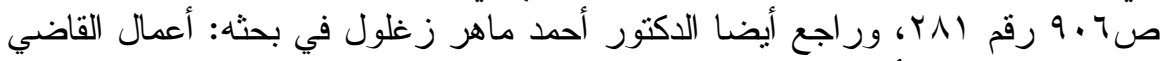

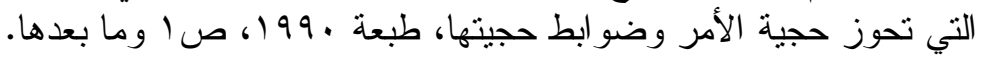




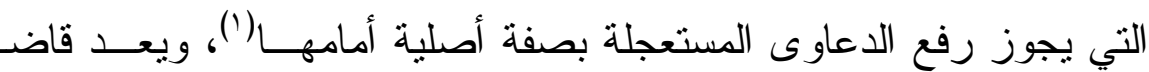

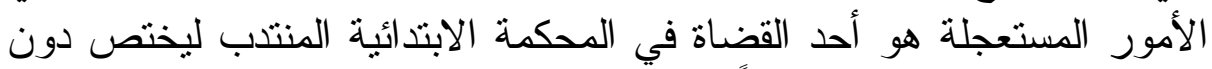

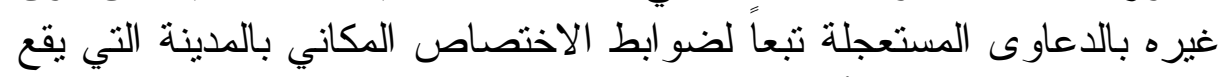

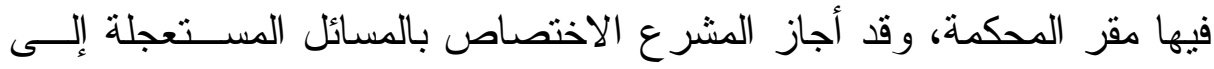

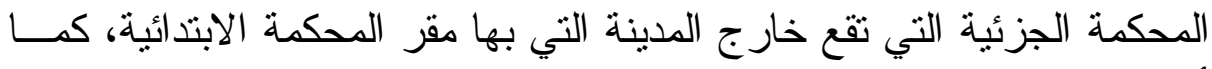

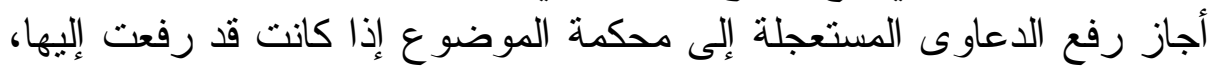

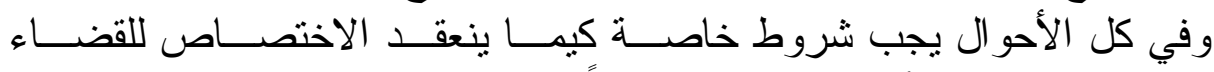

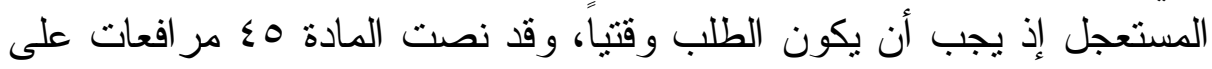

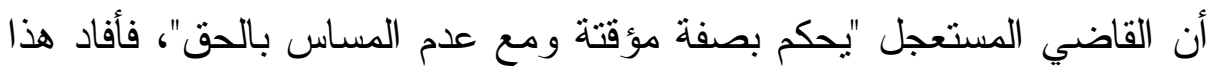

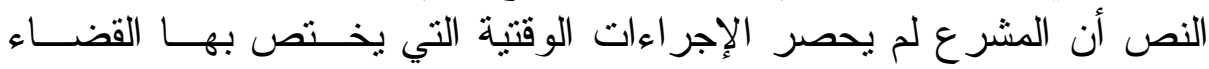

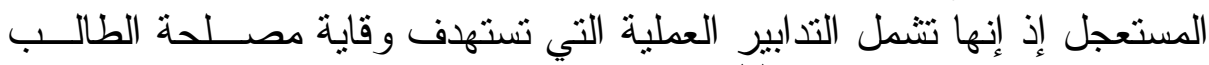

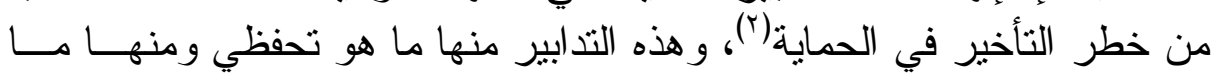

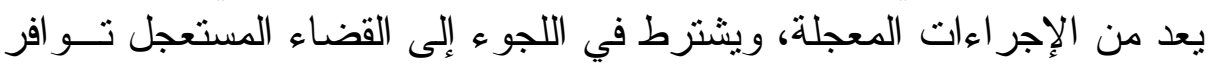

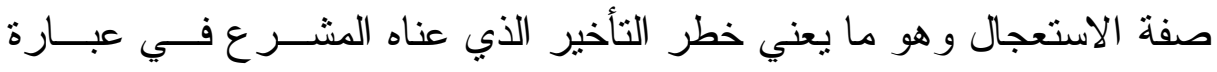

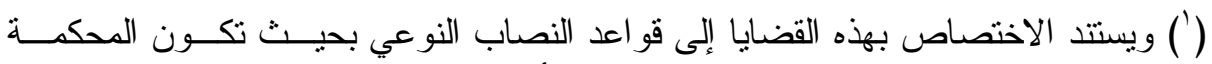

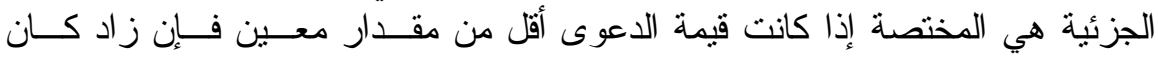

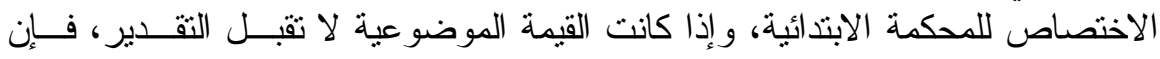

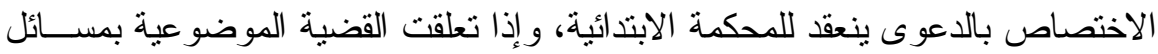

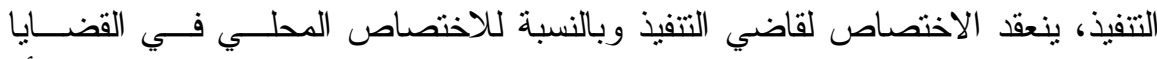

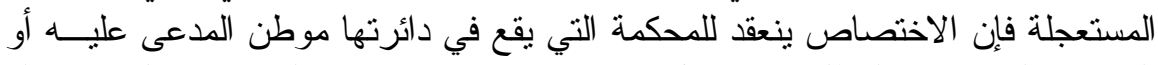

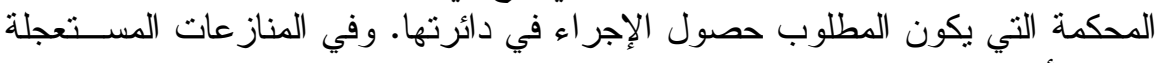

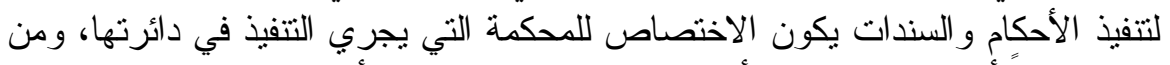

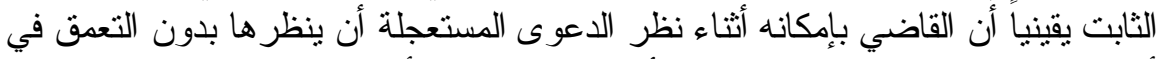

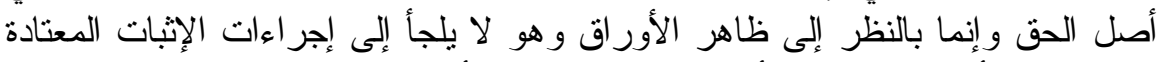

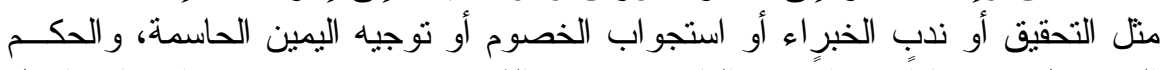

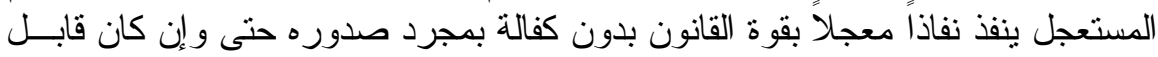

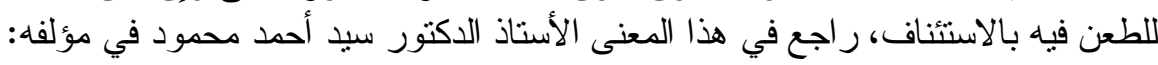

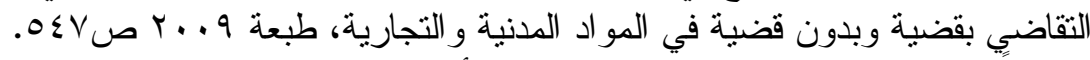

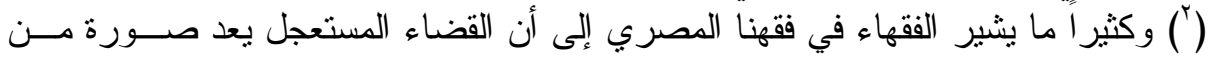

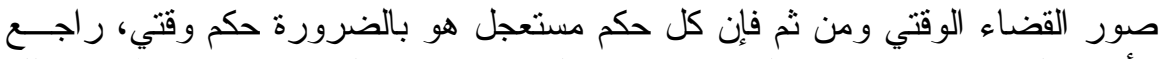

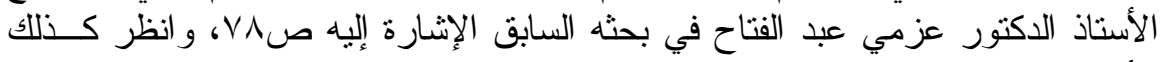

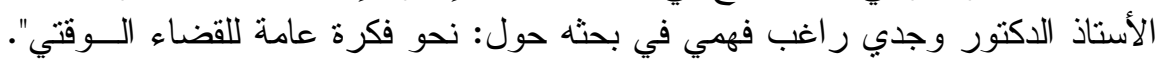

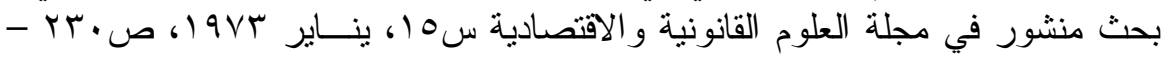


"يخشى عليها من فو ات الوقت" في المادة 0ـ مـ مر افعات(")، ويعــد الاســتعجال

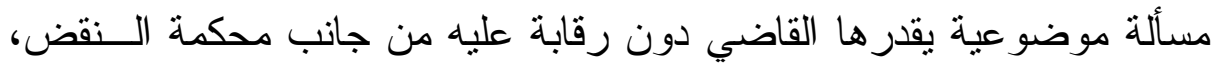

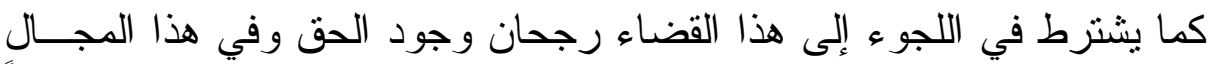

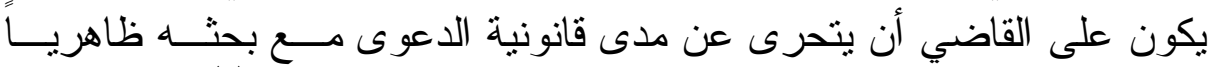

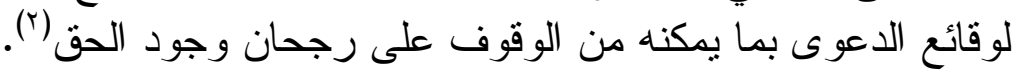

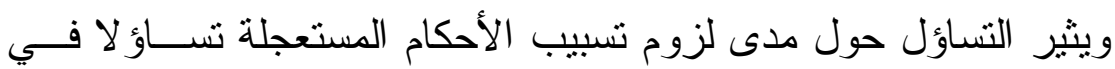

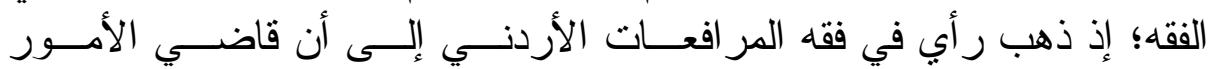

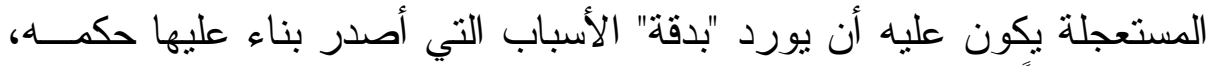

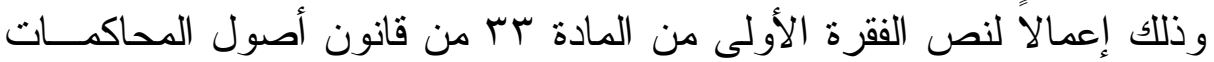

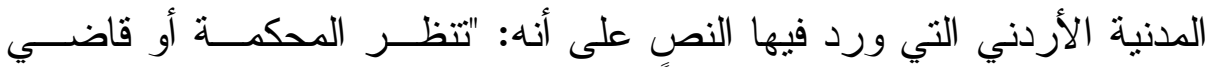

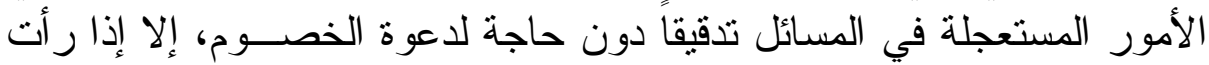

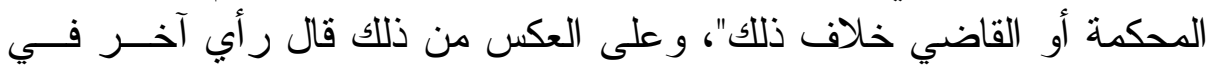

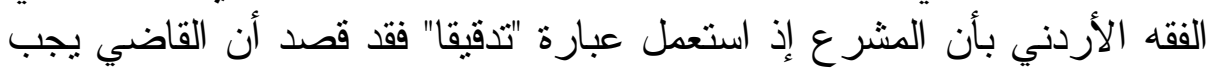

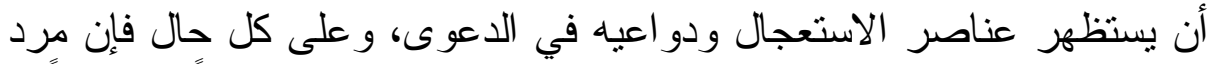

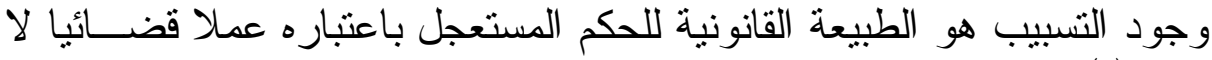

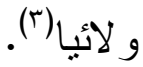

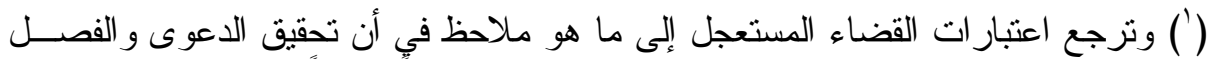

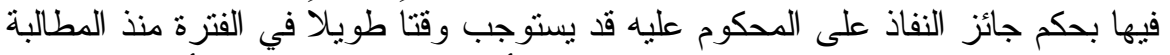

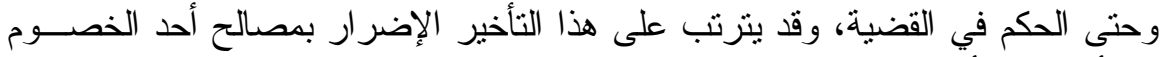

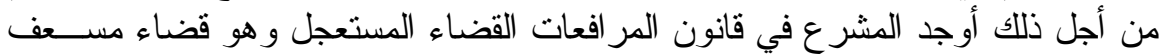

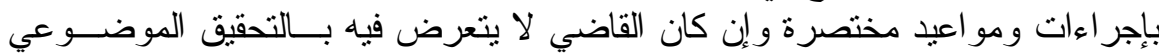

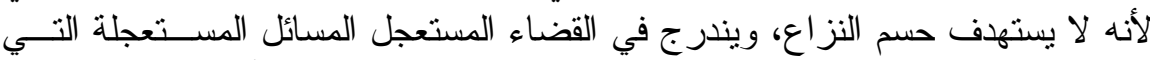

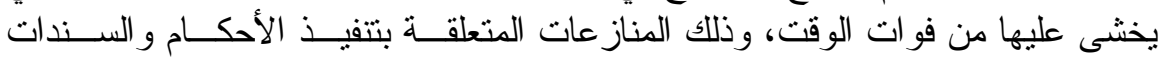

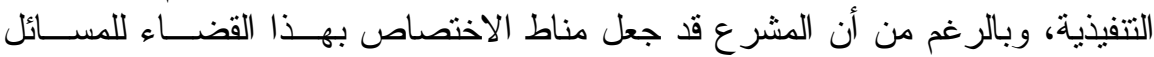

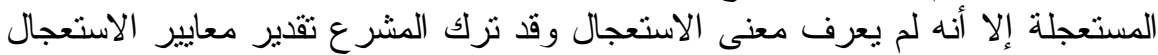

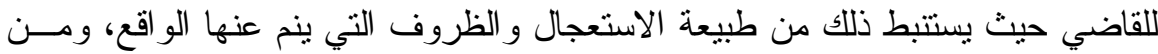

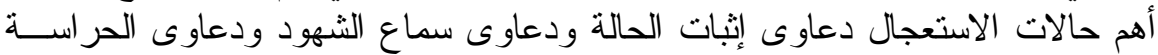

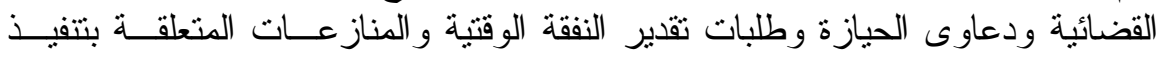

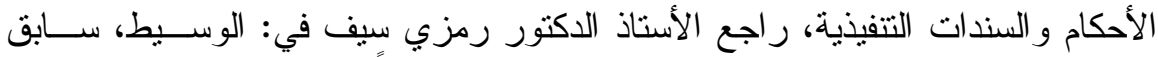

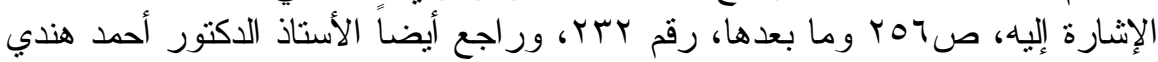

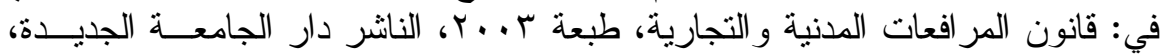

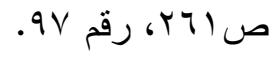

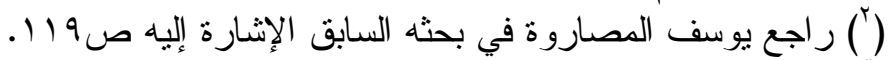

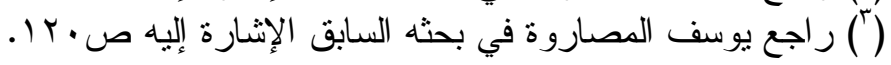




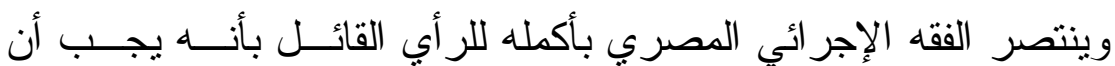

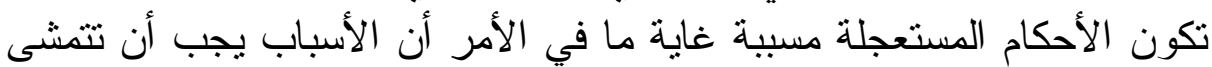

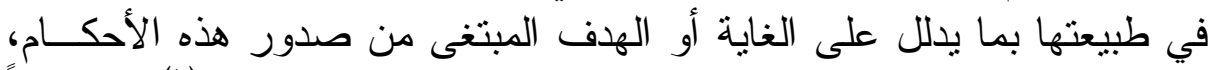

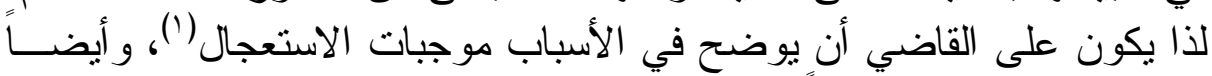

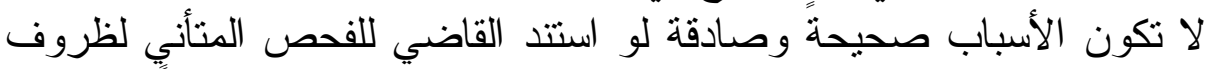

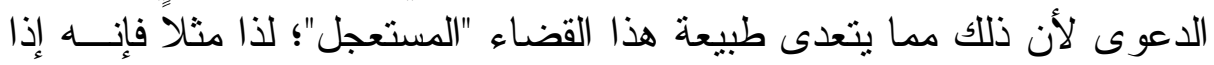

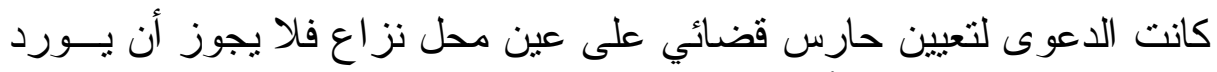

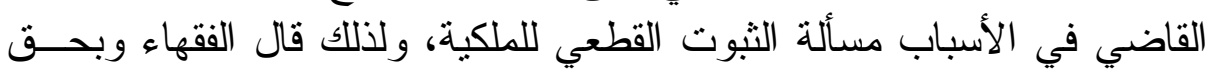

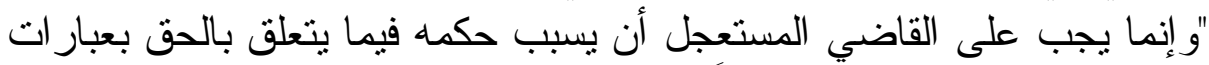

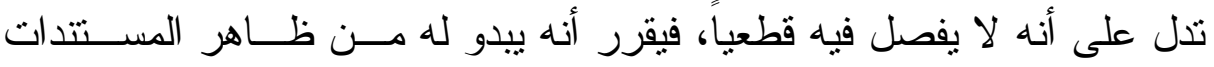

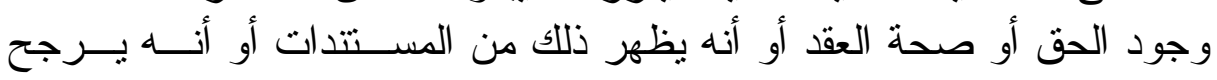

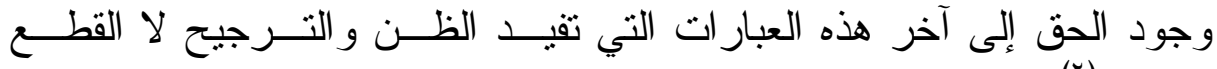

\section{المطلب الثالث

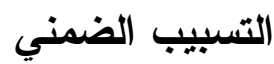

من المسلم به في فقه المر افعات المصري و الأجنبي على السو اء أنه إذابا

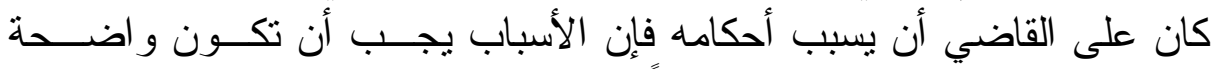

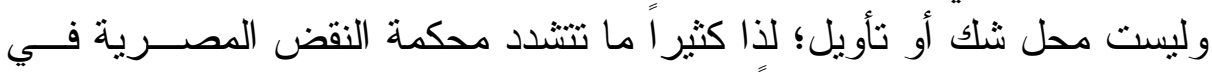

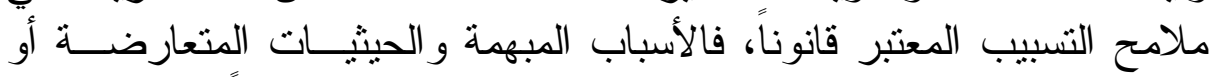

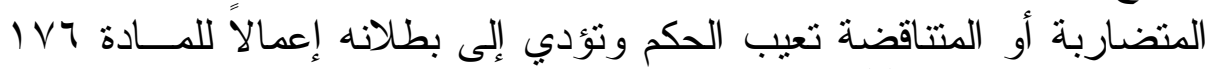
من قانون المر افعات(").

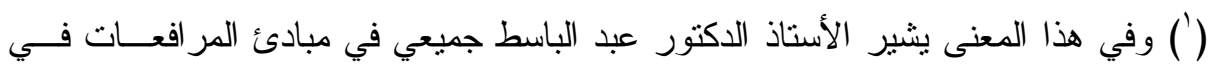

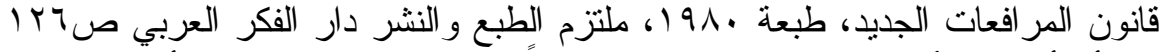

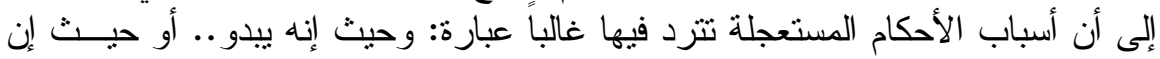

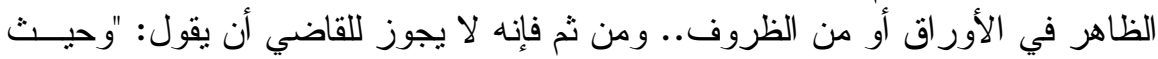

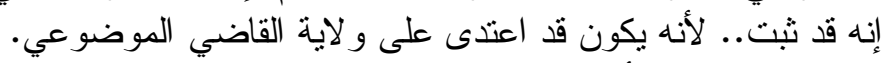

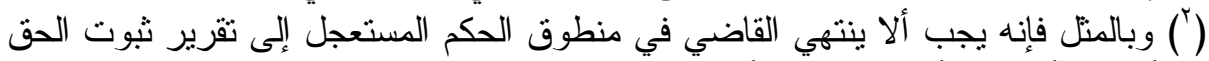

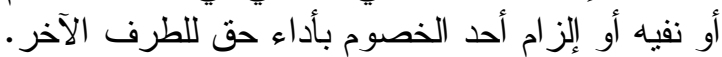

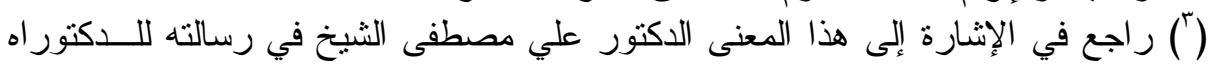

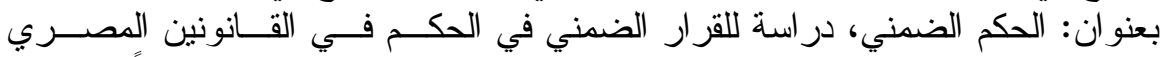

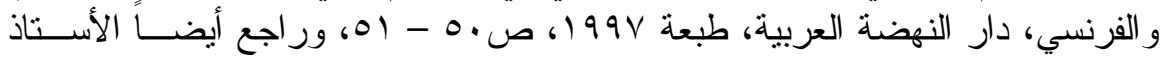

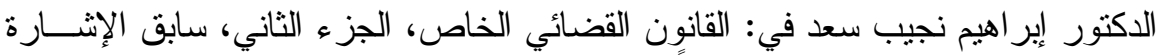

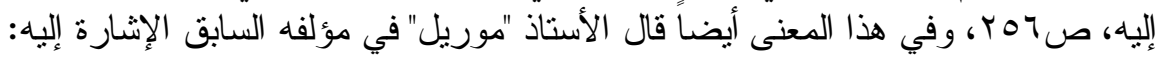




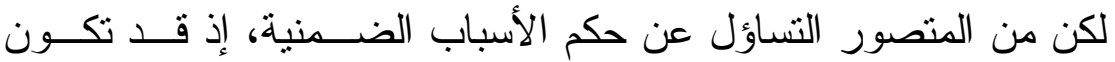

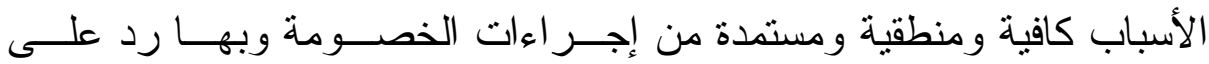

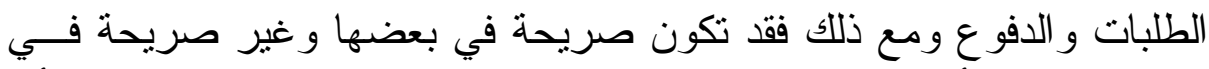

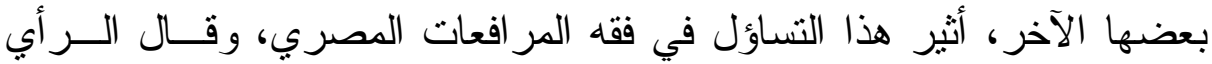

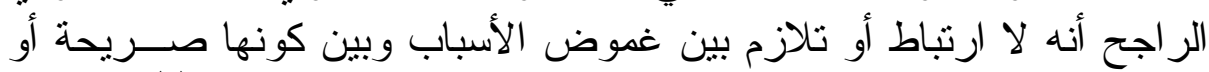

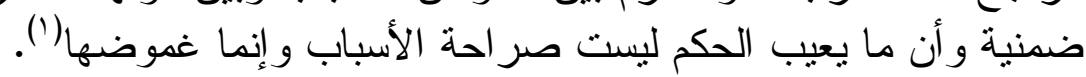

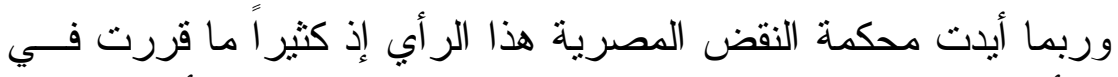

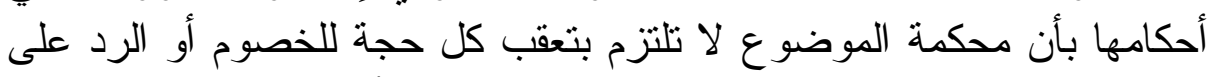

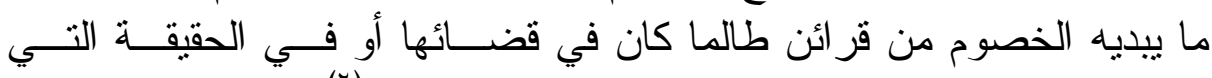

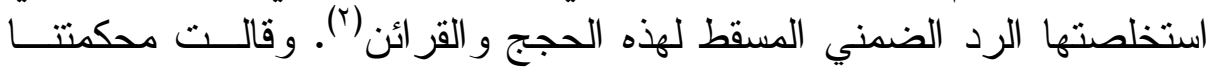

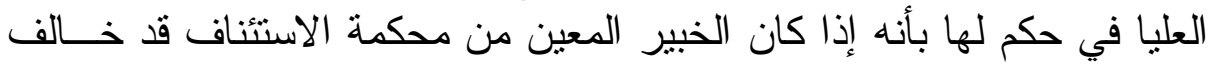

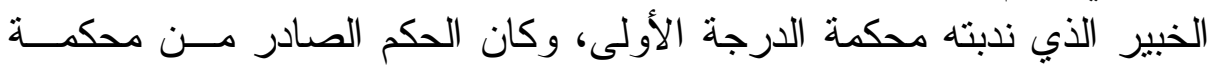

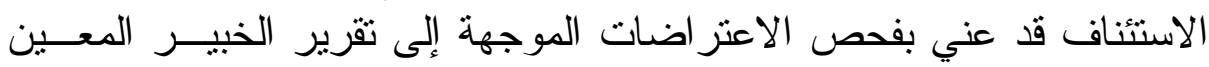

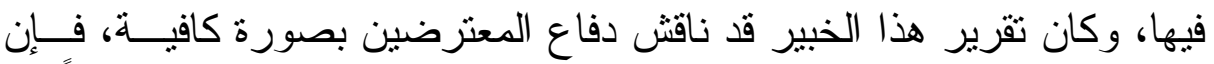
أخذ الحكم بتقرير الخبير في هذا الثأن معناه أنه اتخذ أسباب التقرير أسباباً له، وفيها ما يفبد أن المحكمة اطرحت أقو ال الخبير الأول (؟).

Les juges doivent répondre à tous les chefs de conlusions pour les admettre ou les rejeter avec motifs à l' appui.

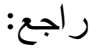

Réne Morel; Traité élémentaire de procédure civile Deuxième Edition. P. 559 No. 439.

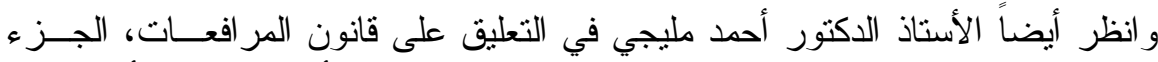

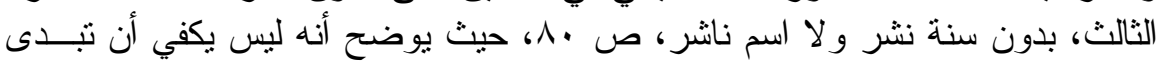

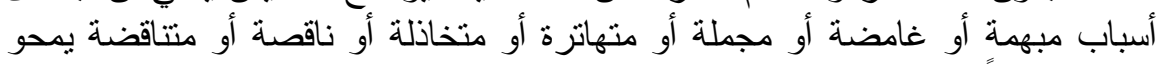

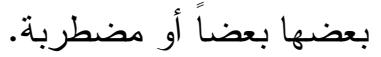

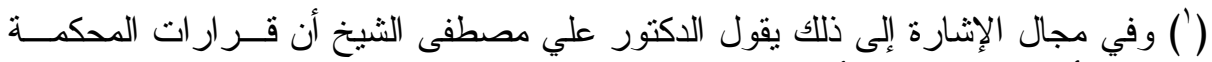

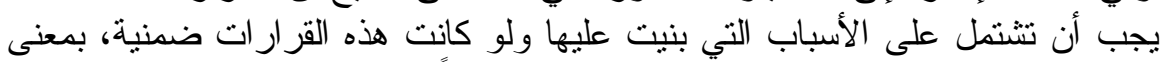

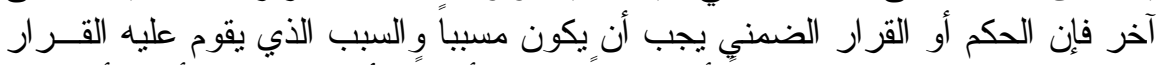

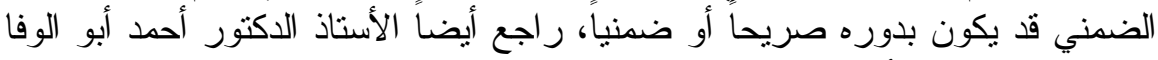

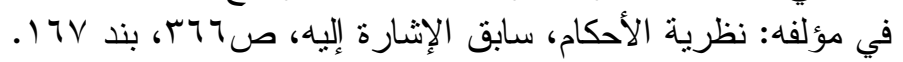

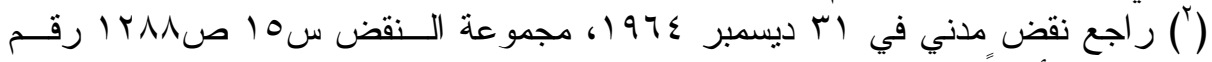

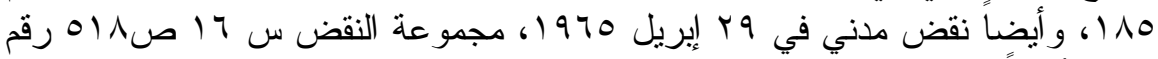

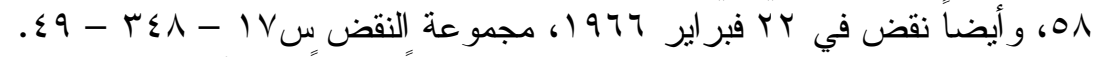

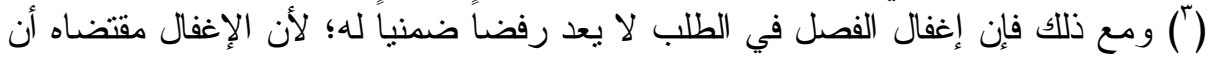


وقالت محكمتتا العليا كذلك أنه بحسب المحكمة أن تبــين فــي حكمهـــا

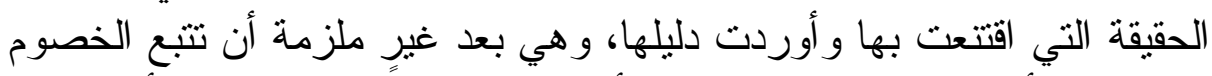

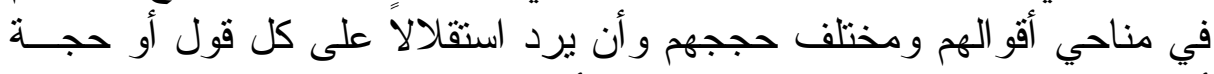

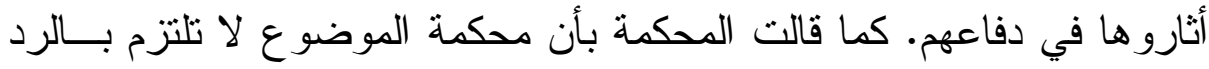

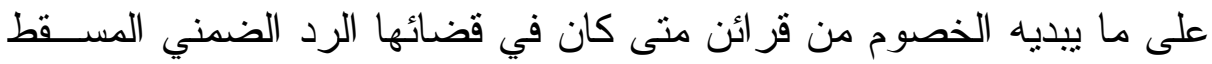

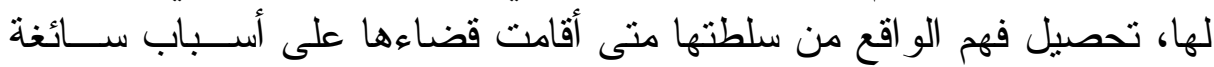

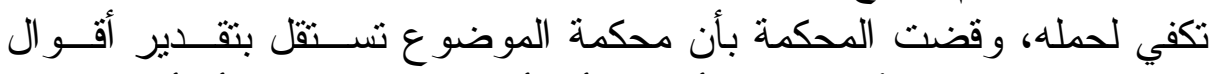

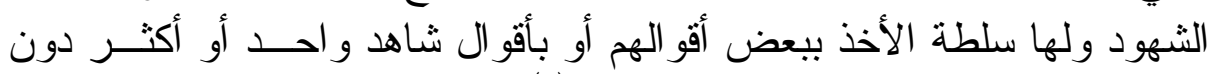

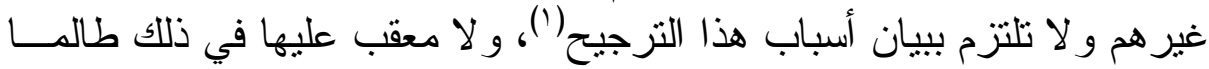

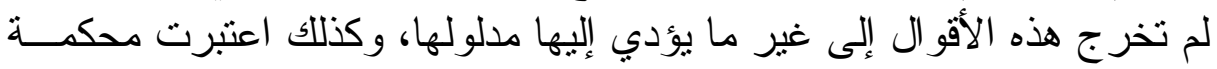

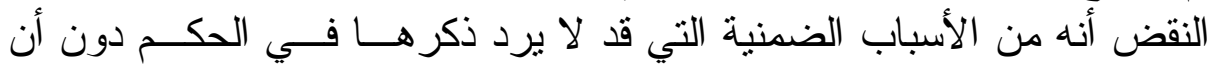

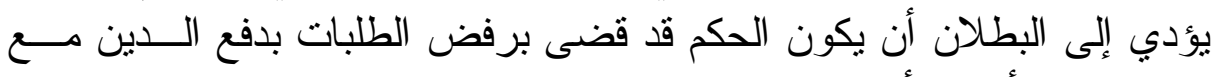

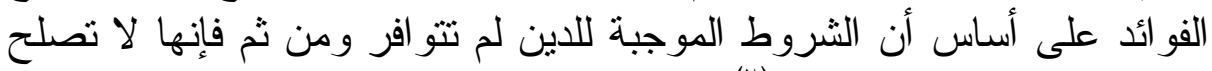
للمطالبة بالفو ائد غير المسبية (r).

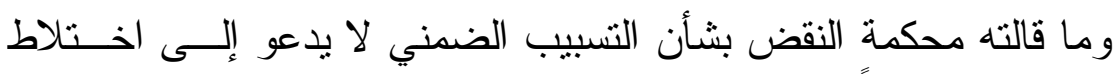

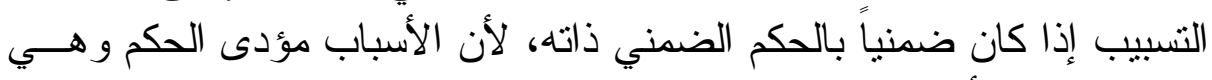

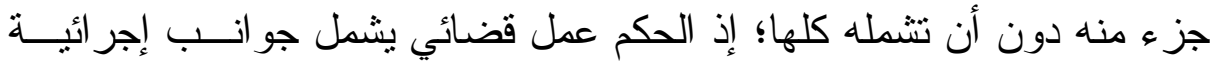

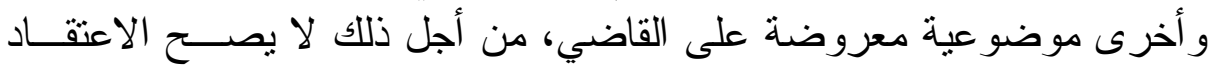

يظل تجاهل المحكمة للطلب لاز ال قائماً لا دليل على الرد الضمني عليه في الأســباب: راجع في هذا المعنى تعليق الأستاذ لإل

Perrot. Cass. Soc. 5 Janvier 1973, Bull. Civi. 1973.

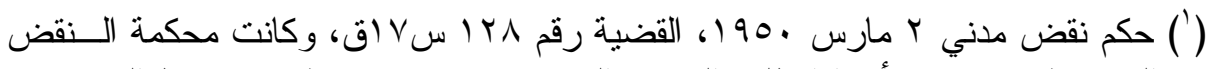

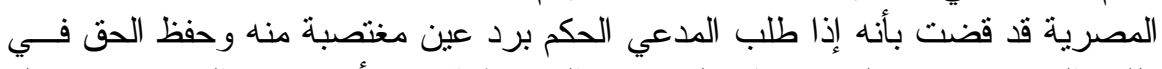

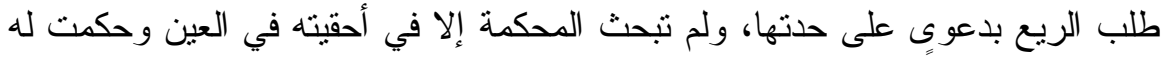

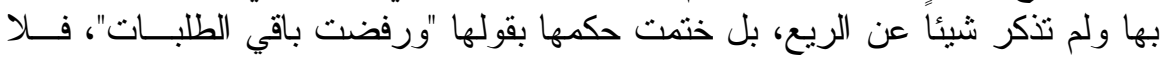

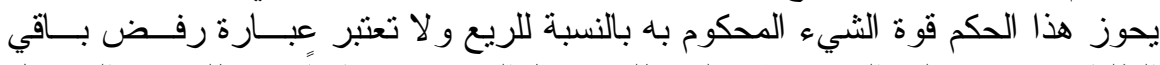

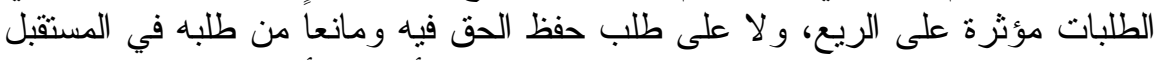

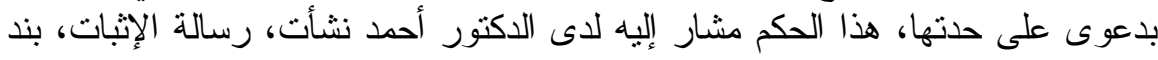

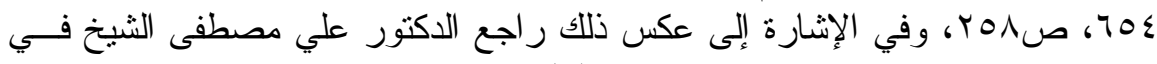

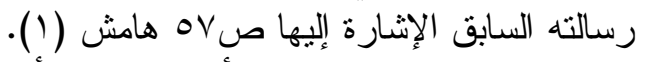

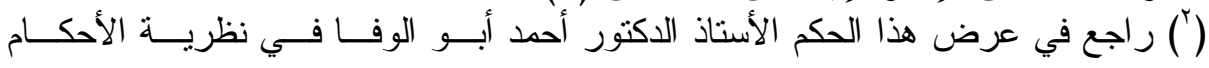

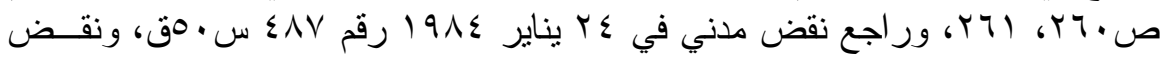

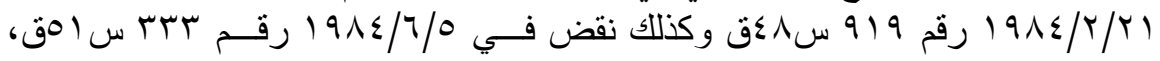

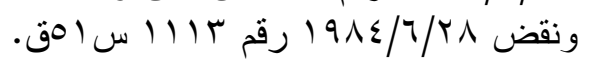


بأن الأسباب الضمنية تعني الحكم الضمني ذاته(')، ومؤدى ذلك بطبيعة الحــال

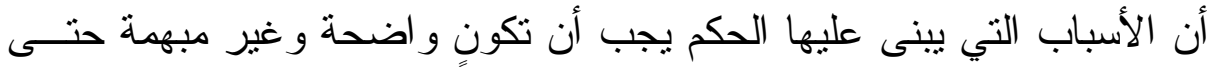

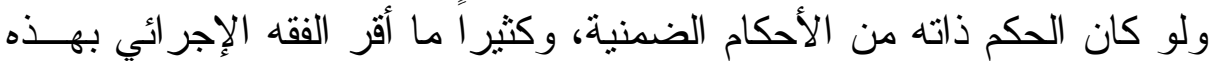

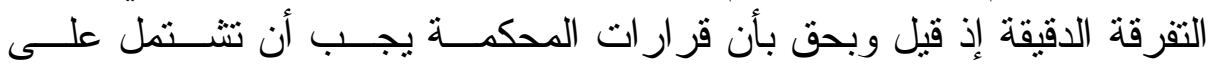

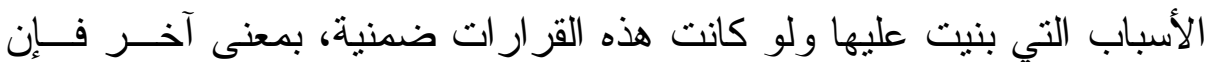

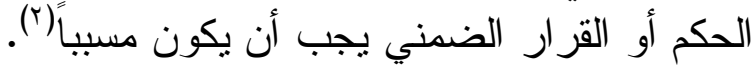

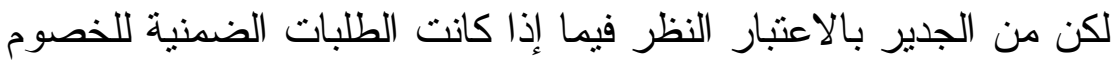

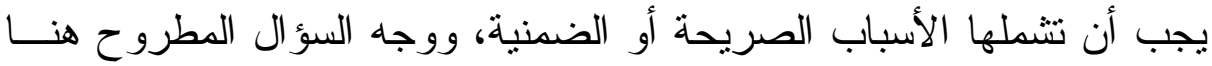

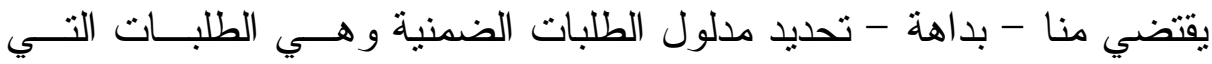

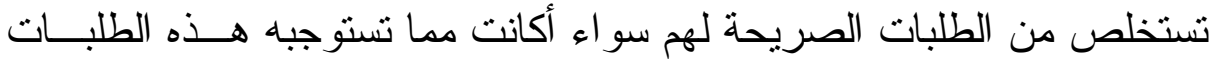

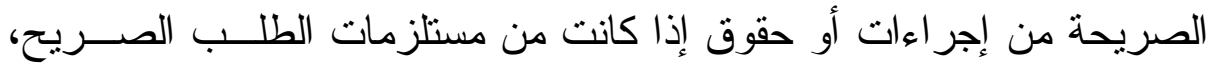

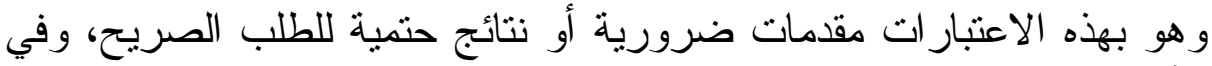

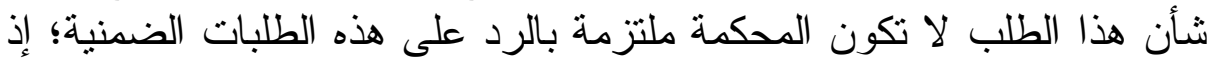

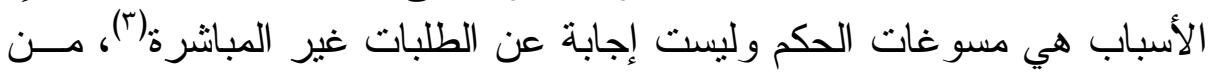

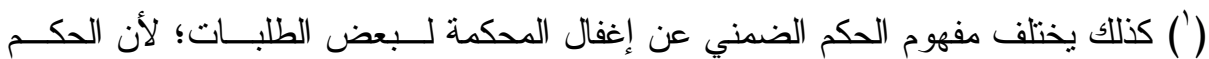

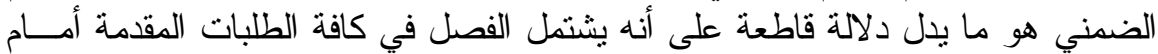

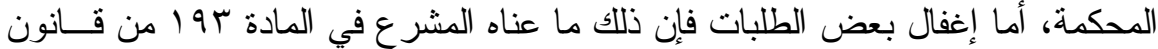

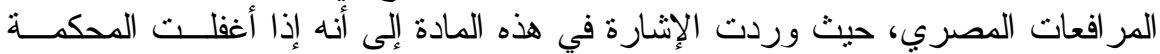

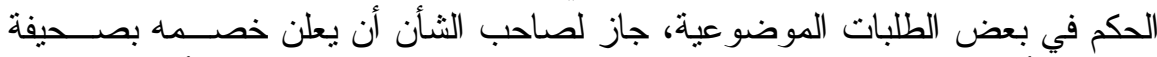

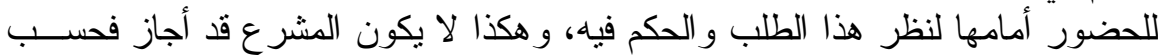

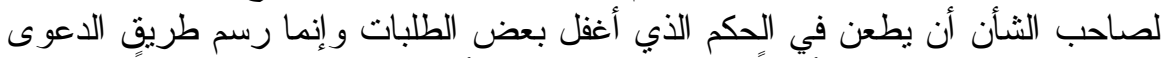

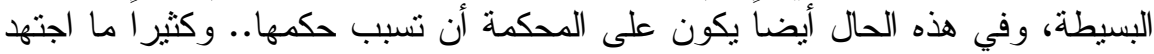

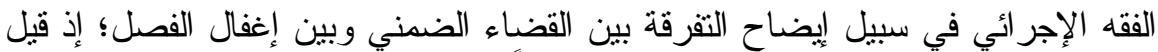

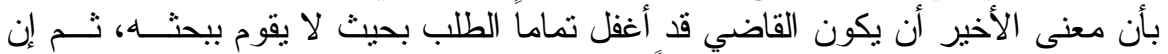

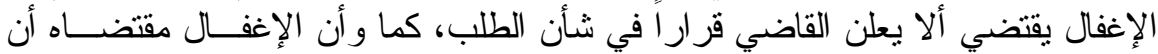

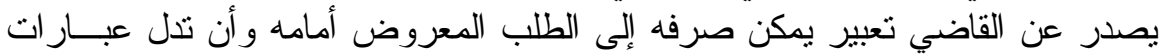

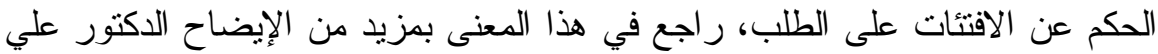

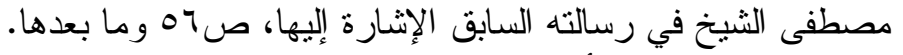

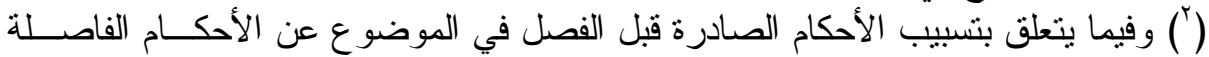

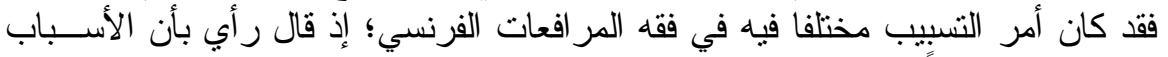

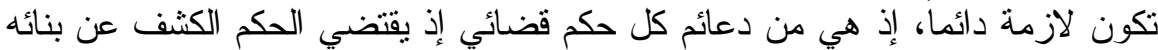

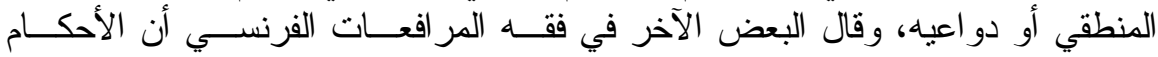

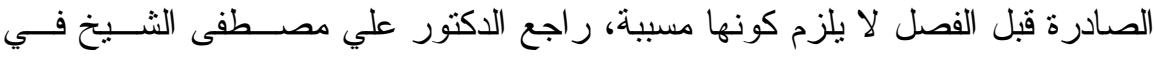

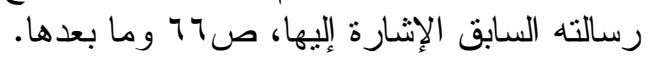

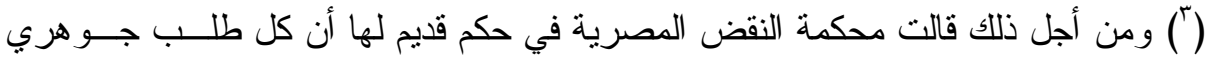


أجل ذلك قالت محكمة النقض المصرية وبحق أنه "بحسب المحكمة أن تبين في

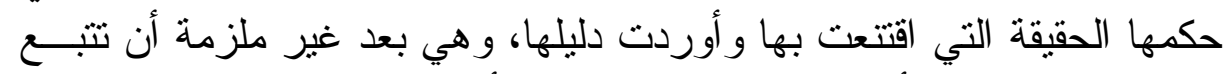

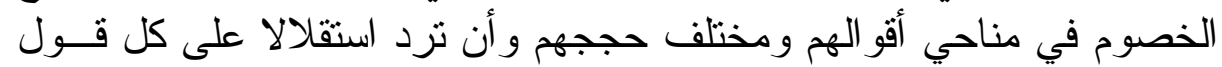

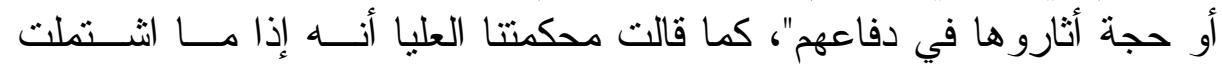

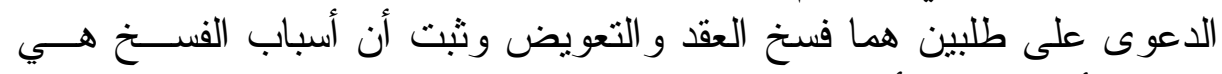

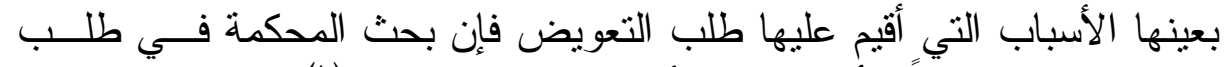

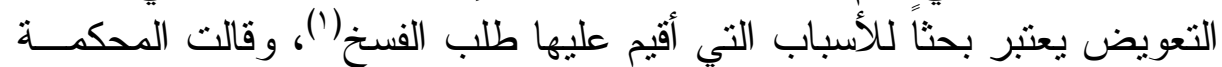

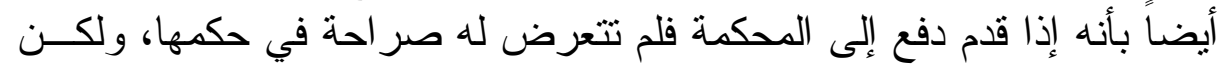

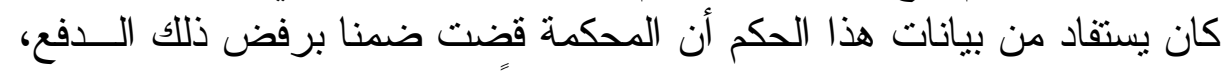

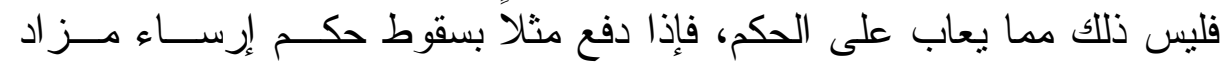

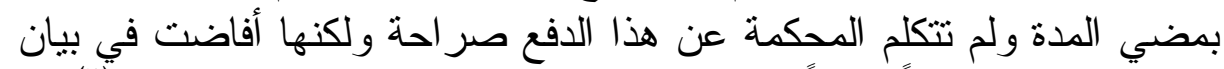

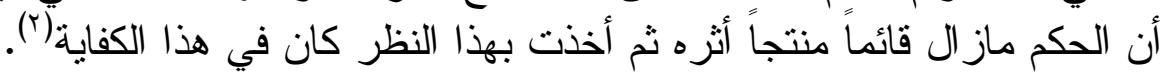

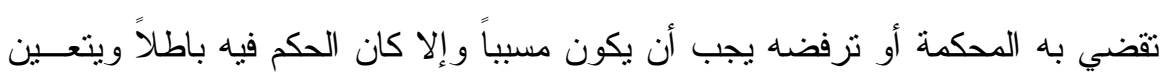

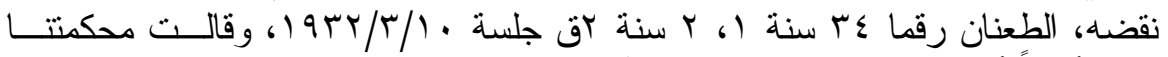

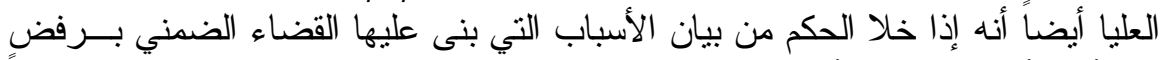

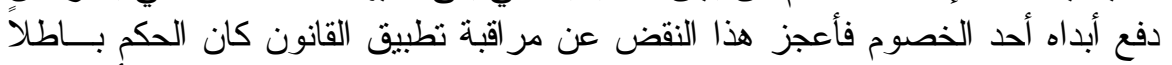

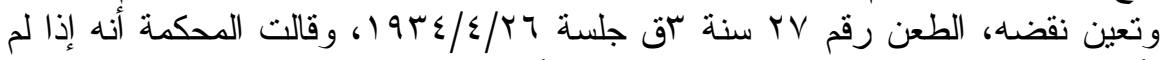

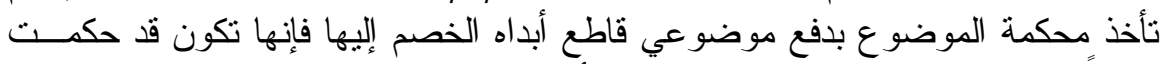

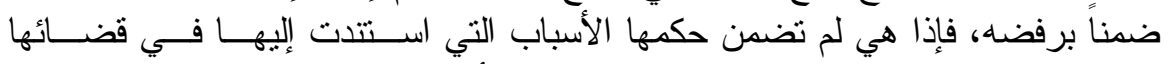

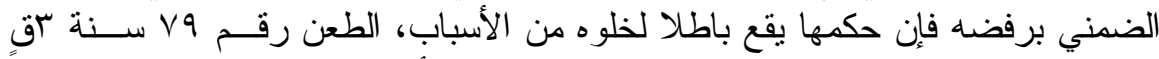
جلسة

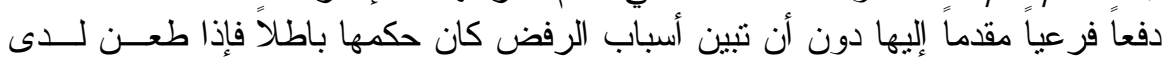

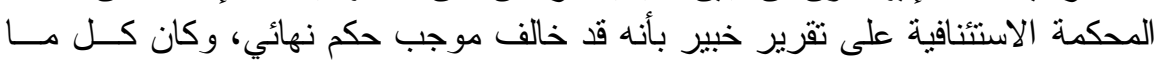

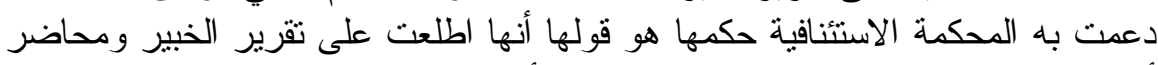

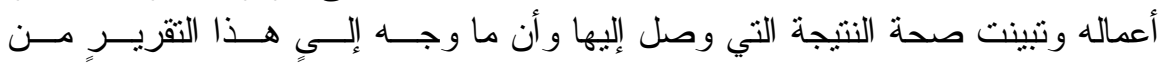

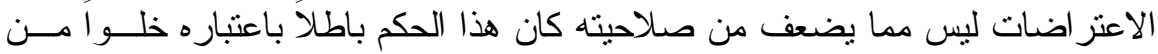

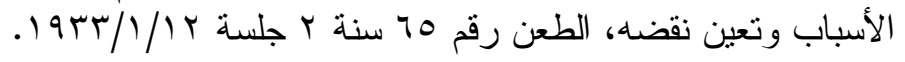

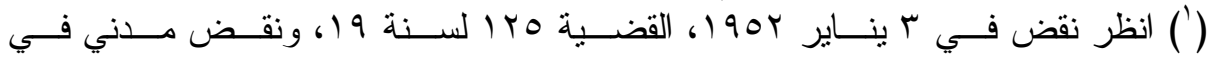

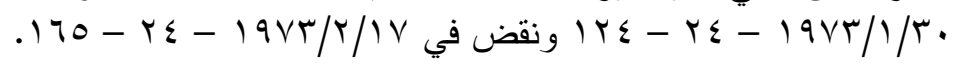

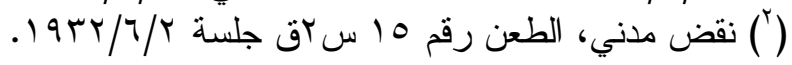




\section{المجالات الواقعية لتسبيب الثاني الأحكام

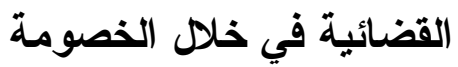

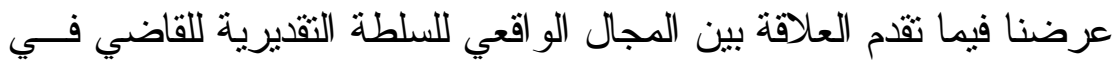

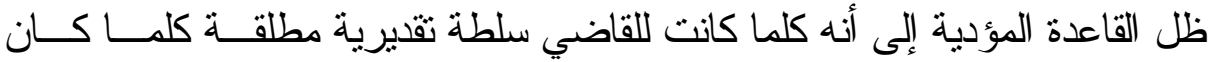

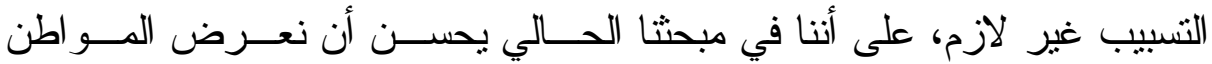

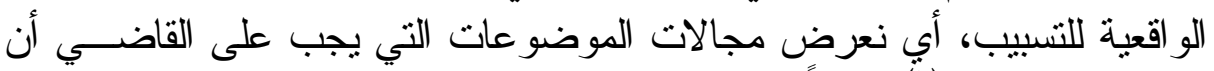

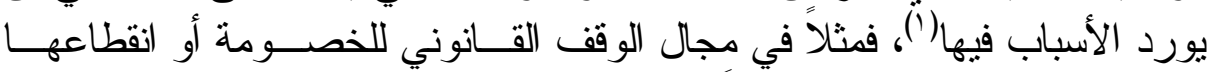

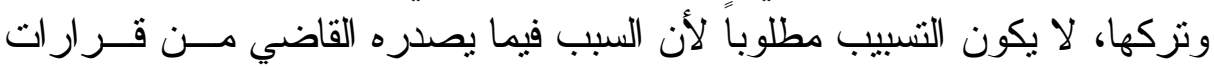

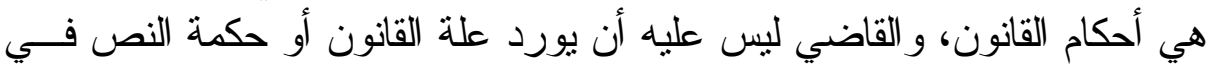

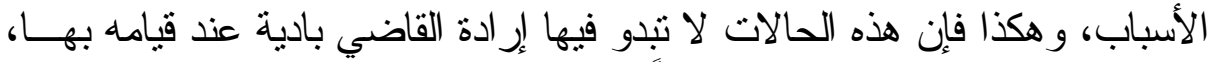
ولو قلنا بغير ذلك لكانت الأسباب سبياً في عرقلة فئة نظر القضات القايا و الفصل فيها.

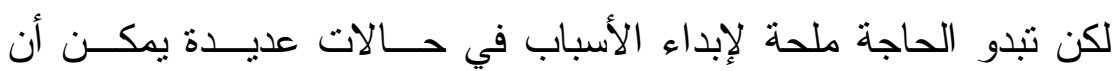
نعرض بعضها في المطالب الآتية:

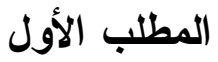

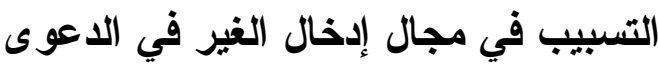

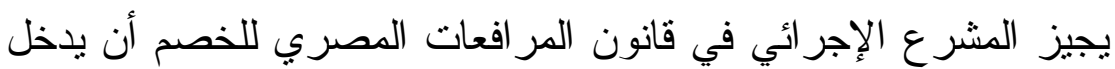

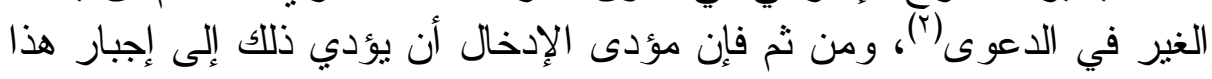

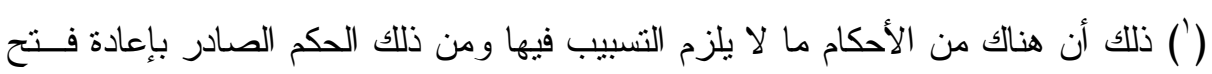

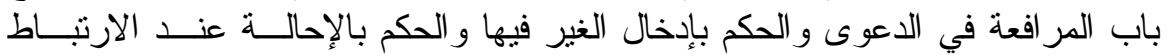

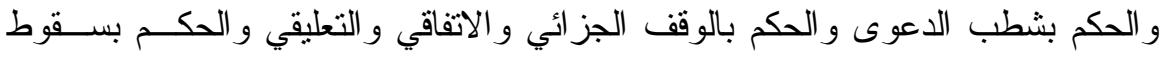

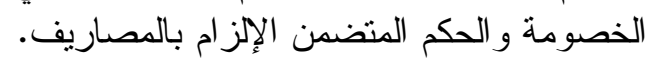

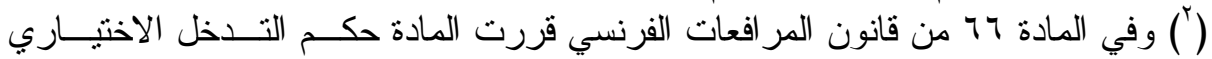
حيث عرفته المادة بقولها:

L' intervention est une demande dont l'objet est de rendre un tiers partie au procès engagé entre les parties originaires".

$$
\text { أما عن الإدخال غير الاختياري فإن الأستاذ "كوشيه" يعرفه بقوله: }
$$

En revanche, il est question d'intervention forcée ou encore de mise en cause, lorsque c'est partie au procès qui forme ladite demande, obligeant donc le tiers à devenir lui-même partie audit procès.

راجع: 159 رفي 159

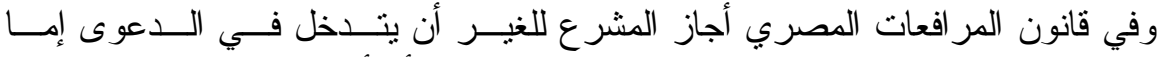

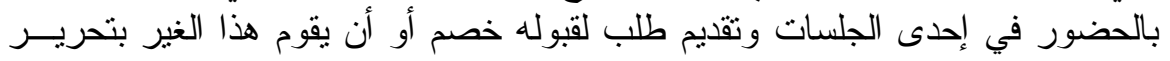

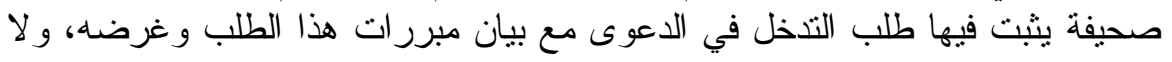




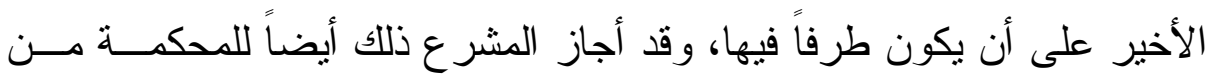

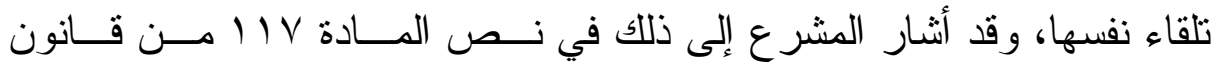

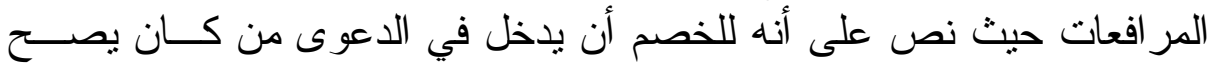

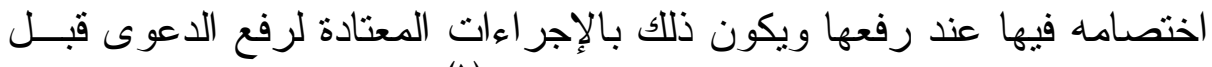

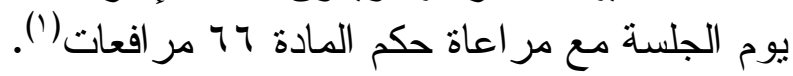

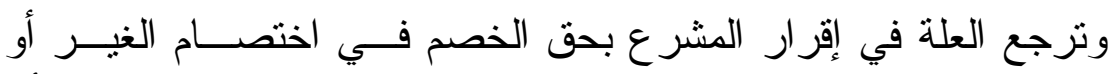

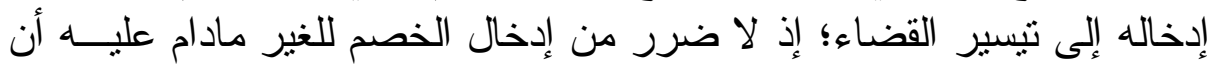

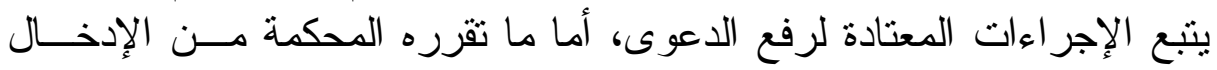

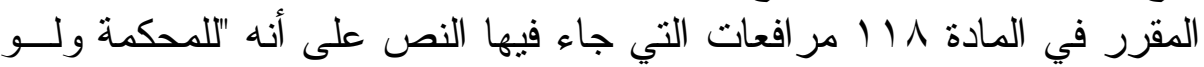

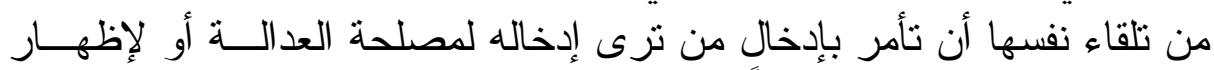

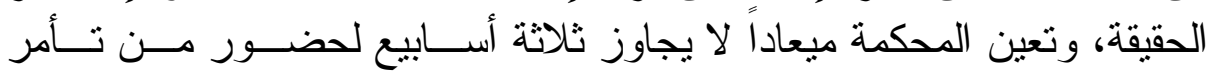

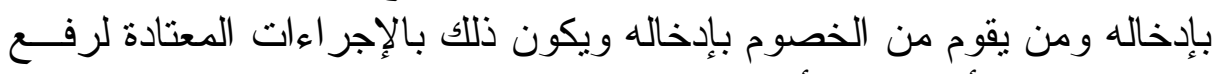

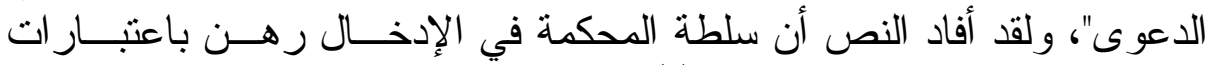

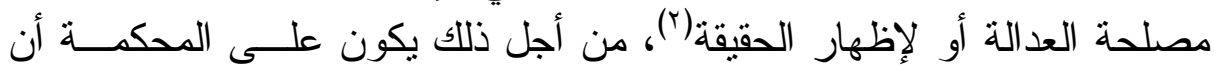

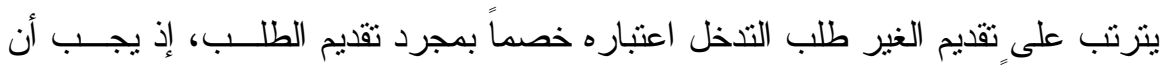

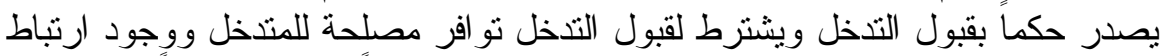

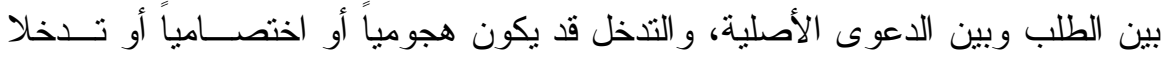

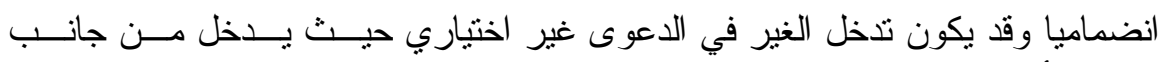

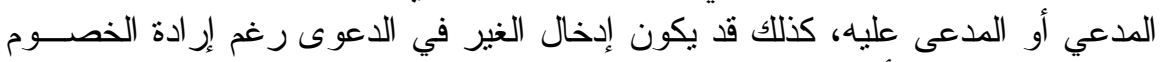

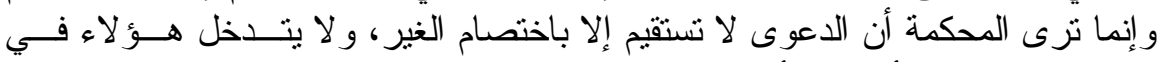

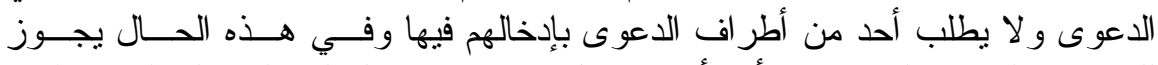

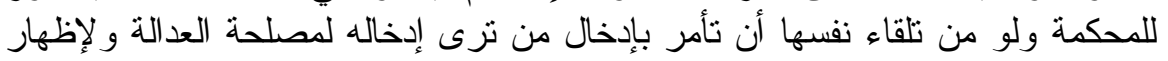

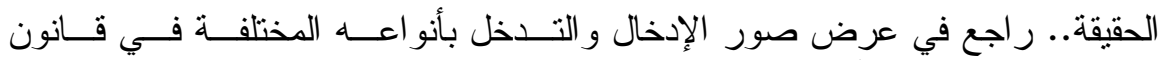

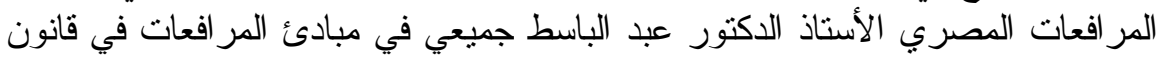

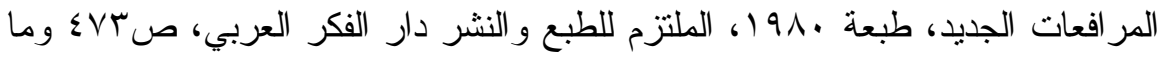

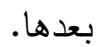

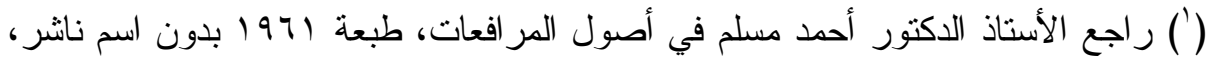

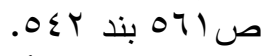

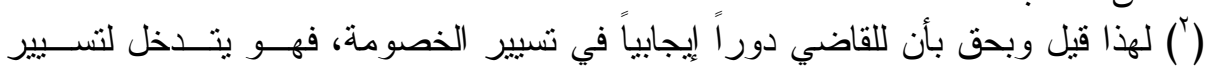

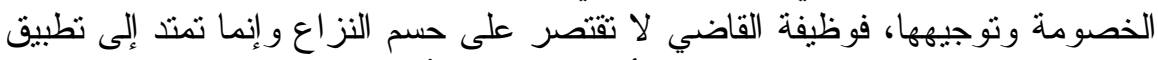

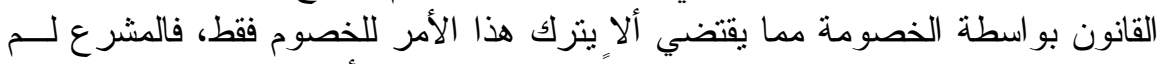

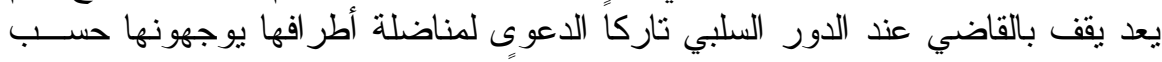

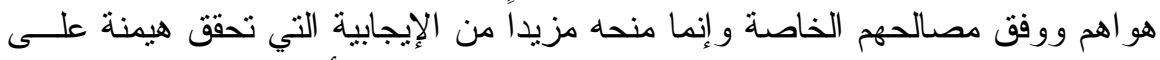

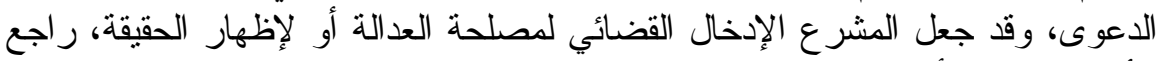

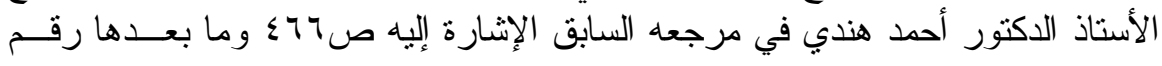


تبرز من و اقعات الدعوى أو ظروفها ما يبرر مباشرتها سلطتها في الإدخــال

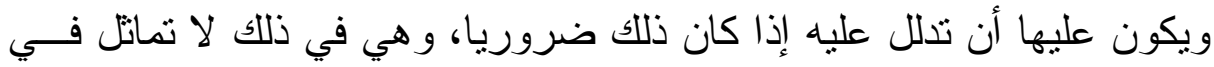

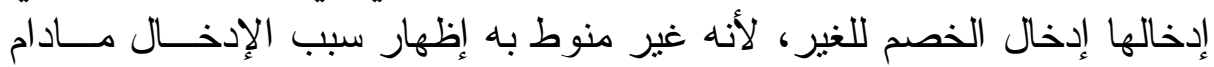

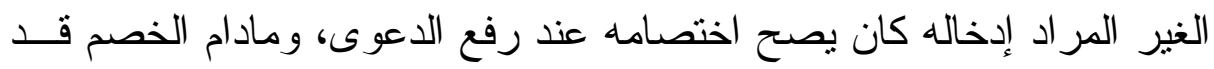
راعى الإجر اءات المعتادة.

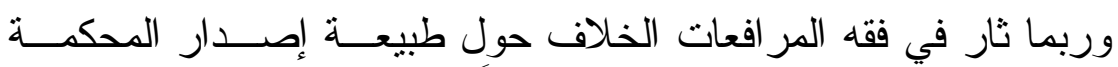

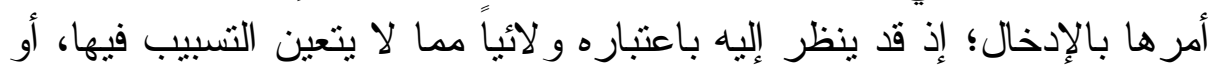

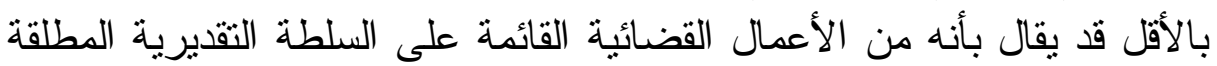

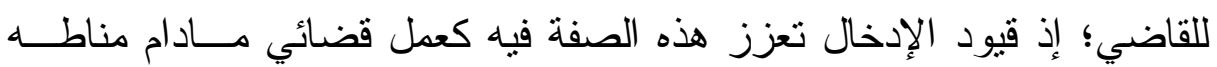

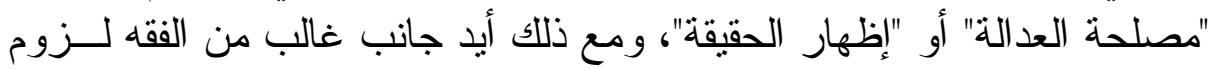

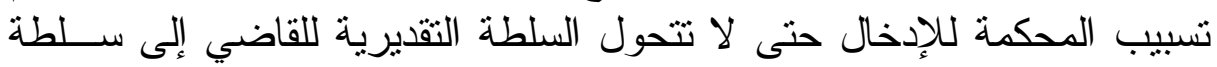

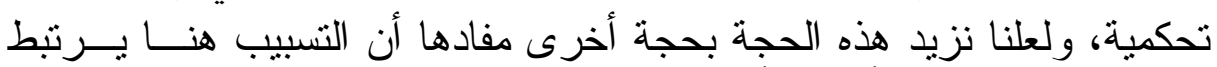

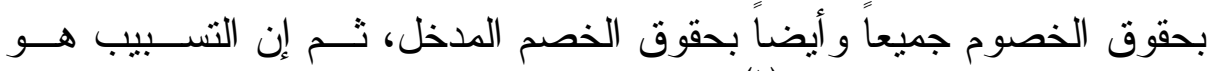
الأصل في الأحكام القضائية (1).

\section{المطلب الثاني \\ الارتباط كعلة لعدم التسبيب

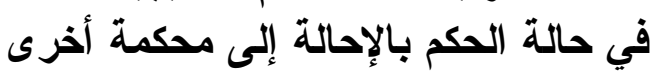

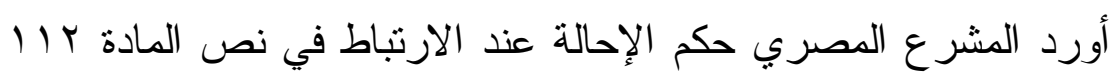

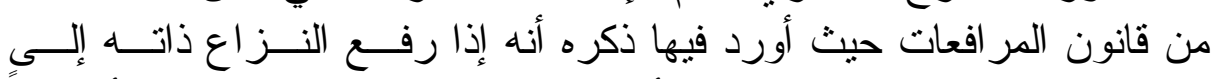

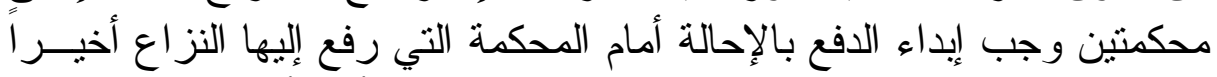

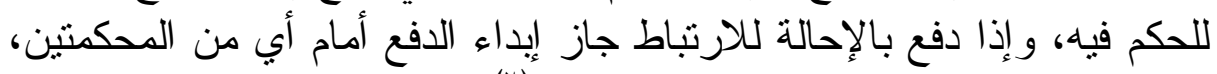

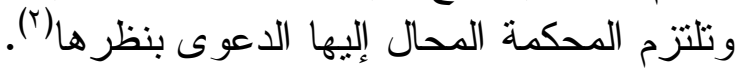

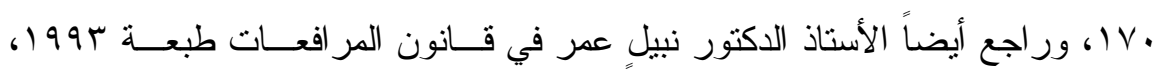

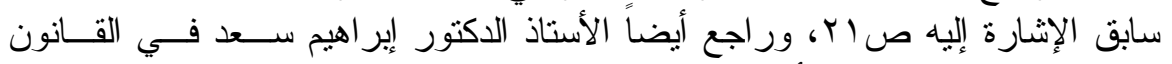

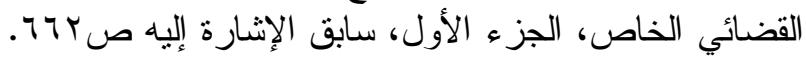

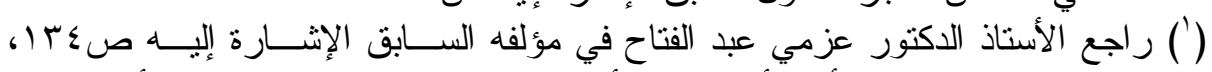

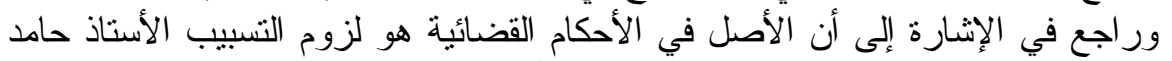

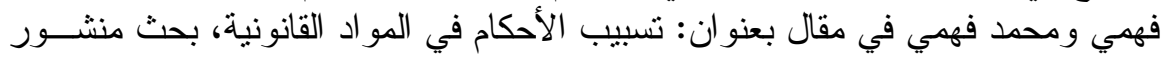

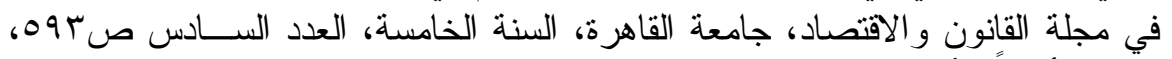

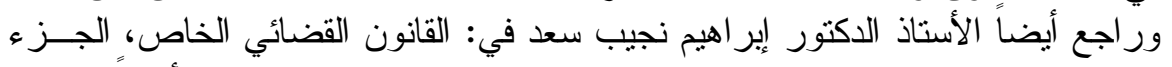

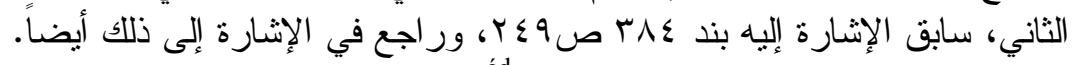

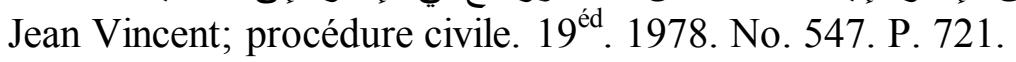

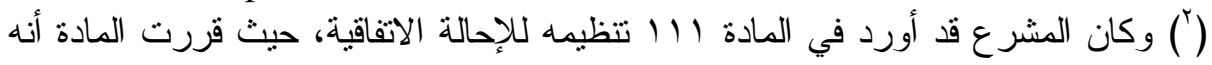




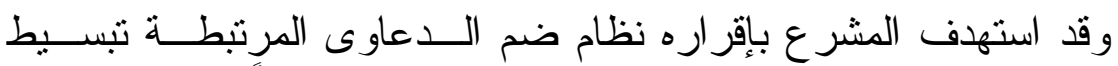

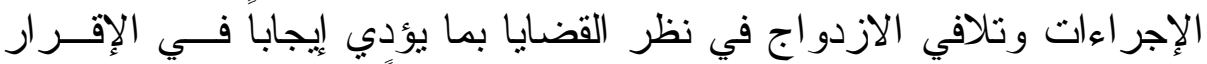

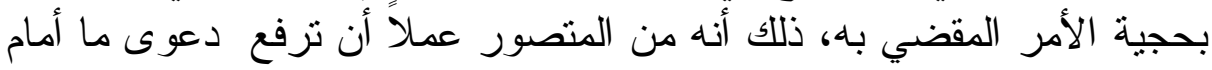

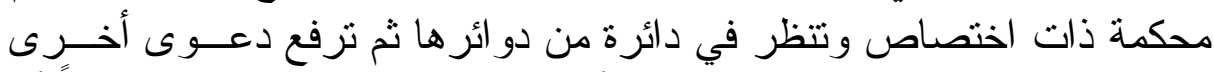

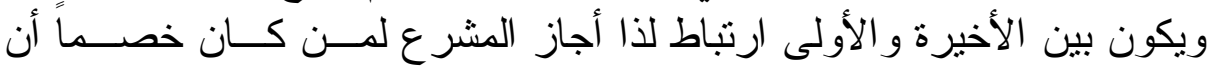

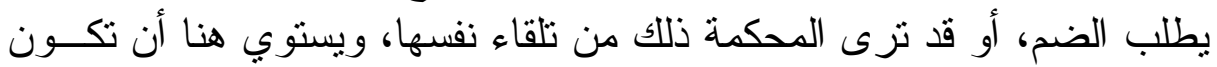

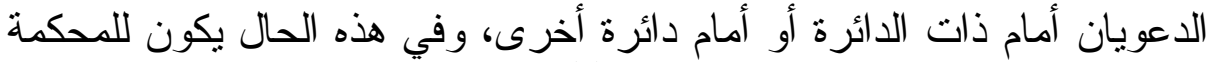

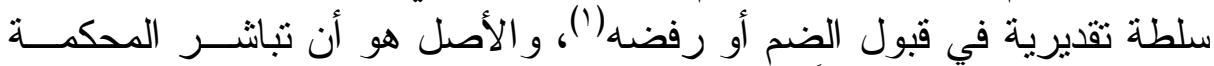

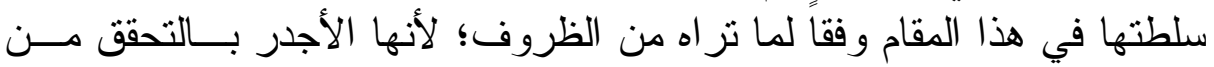

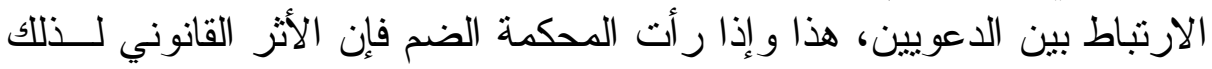

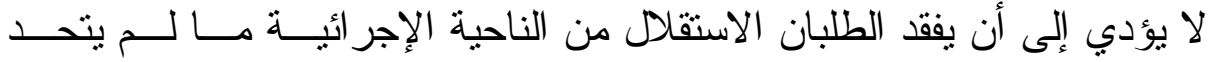

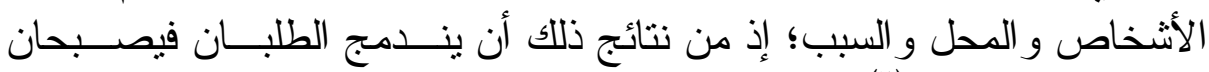

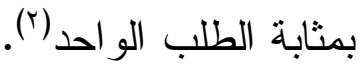

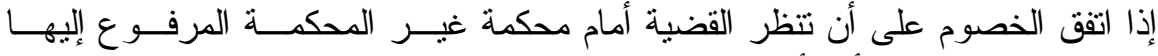

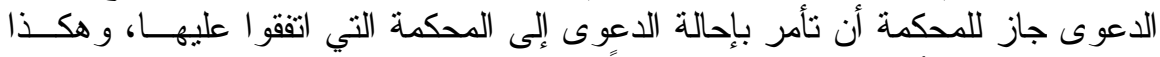

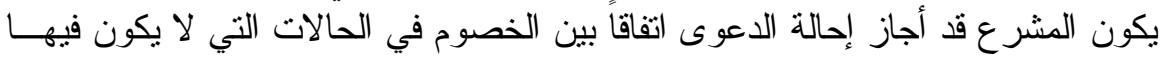

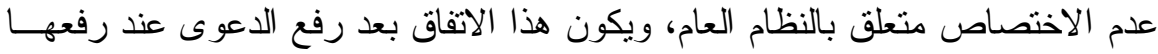

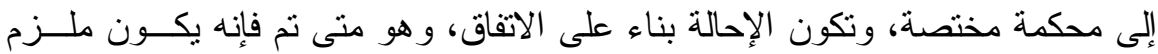

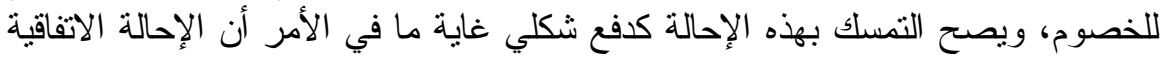

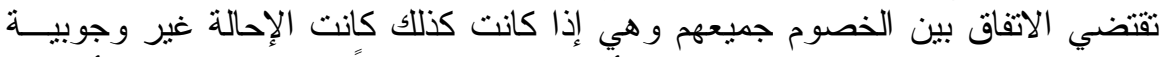

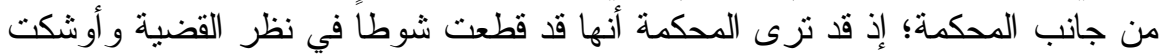

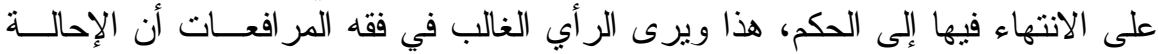

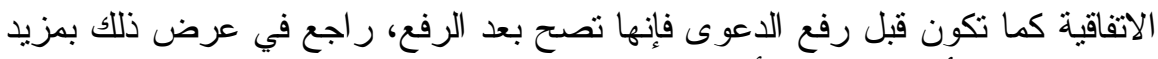

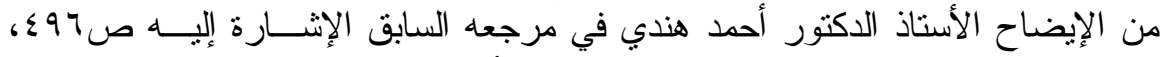

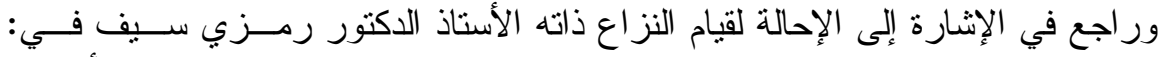

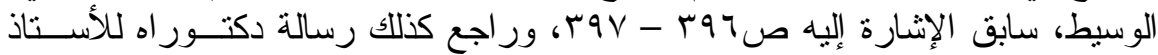

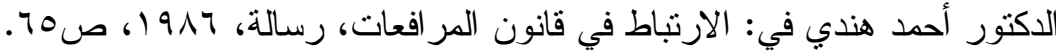

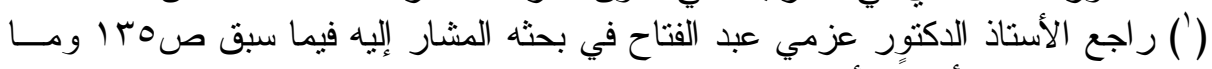

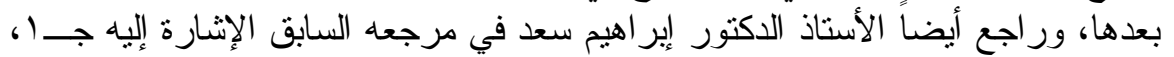

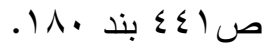

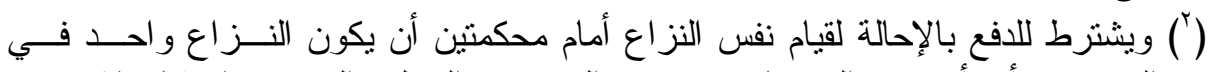

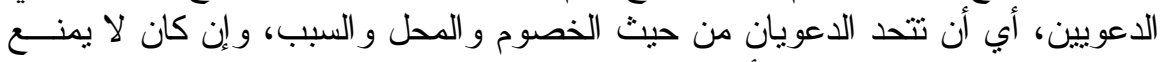

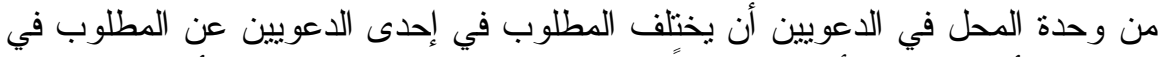

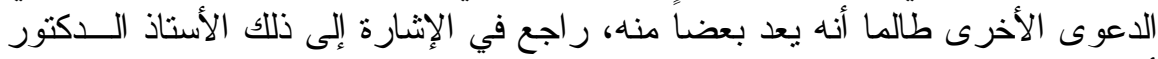

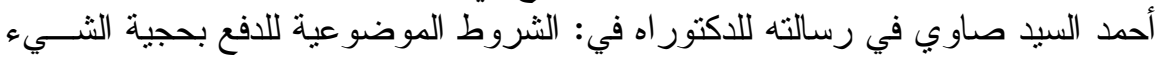




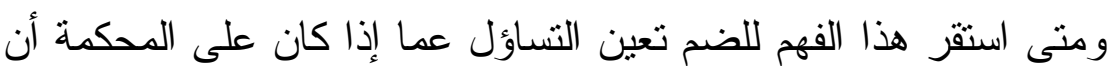

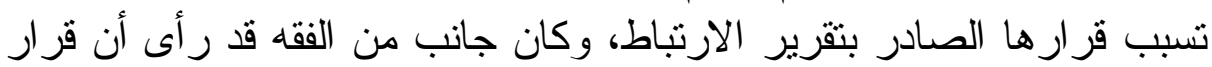

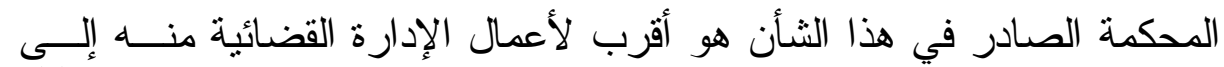

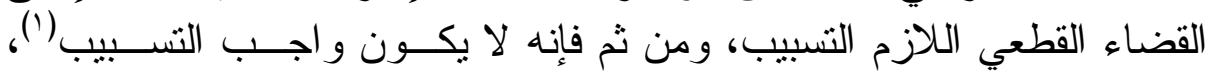

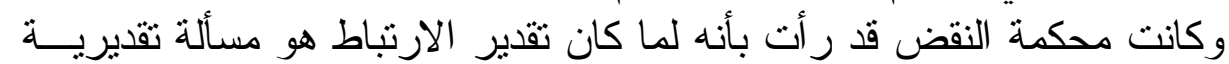

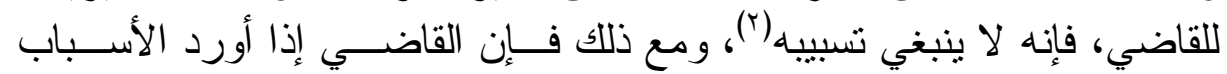

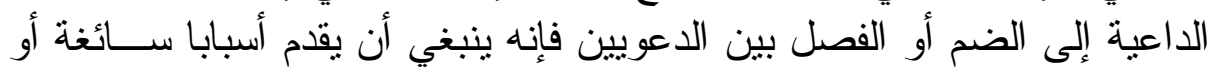

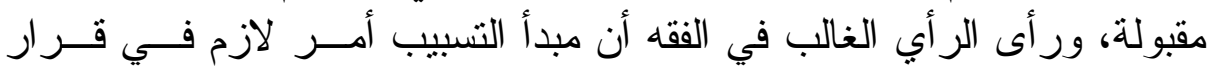

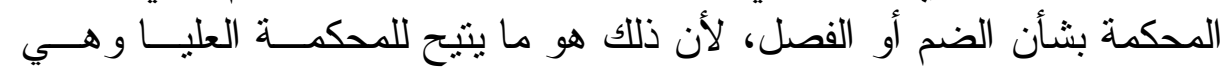

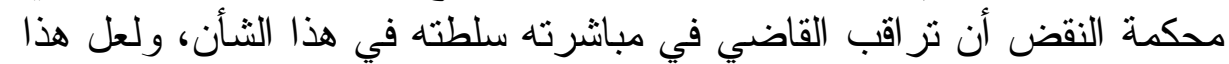

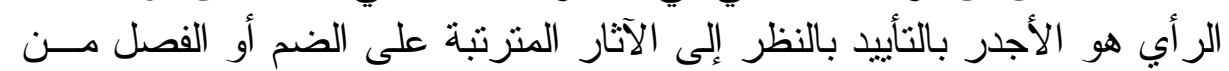

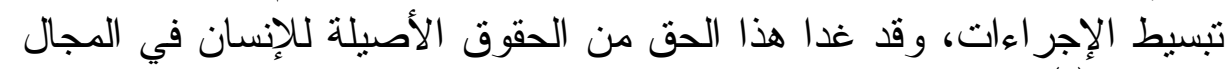

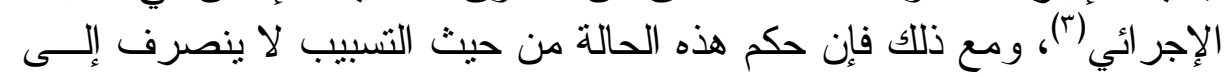

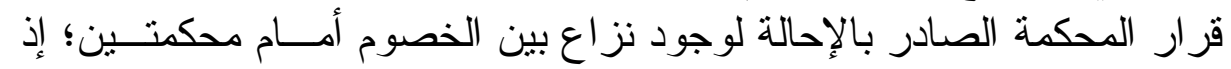

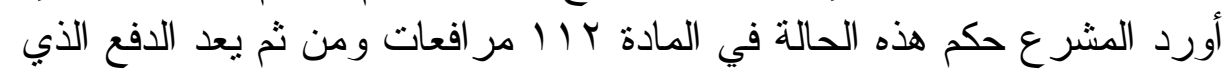

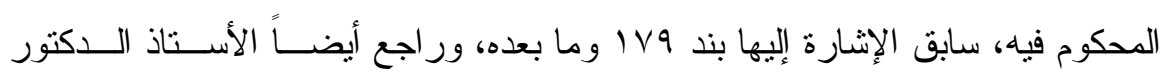

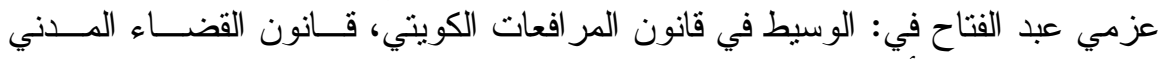

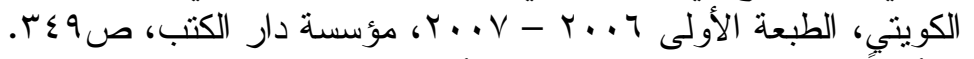

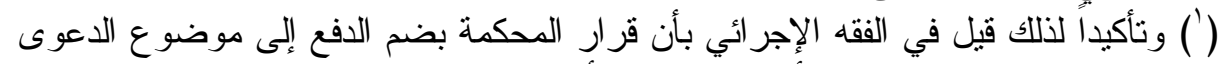

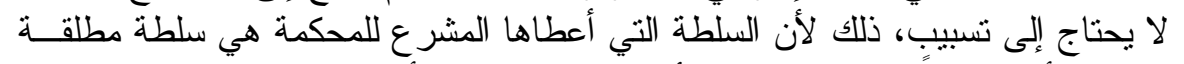

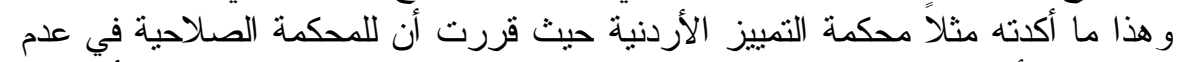

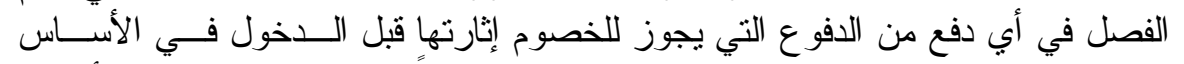

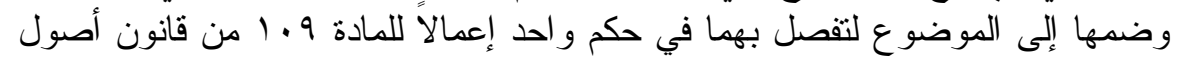

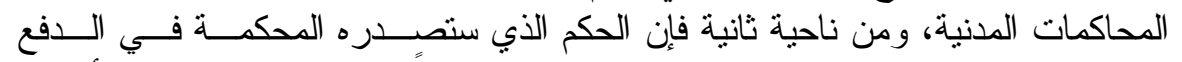

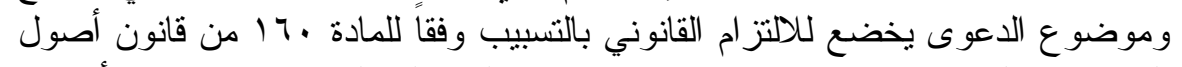

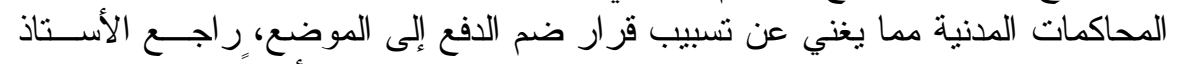

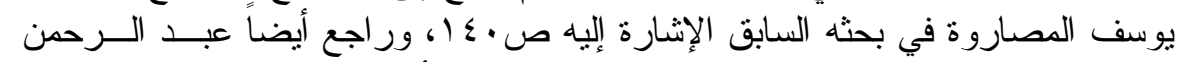

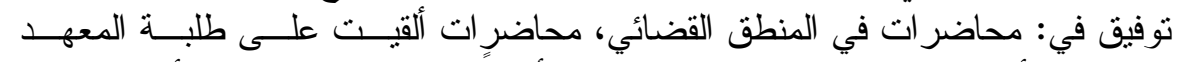

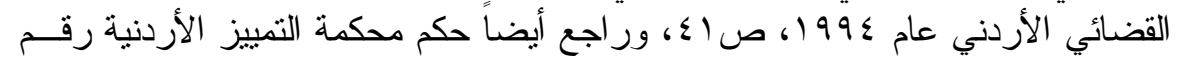

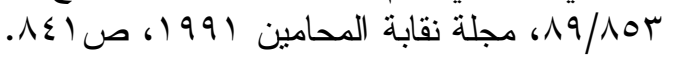

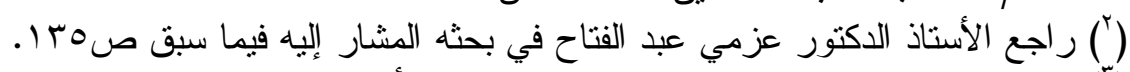

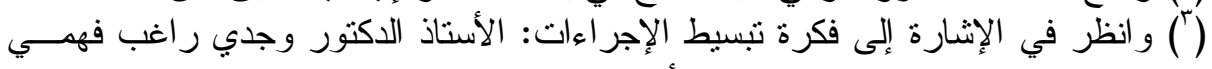

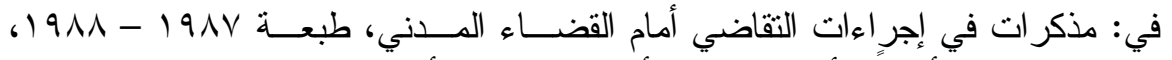

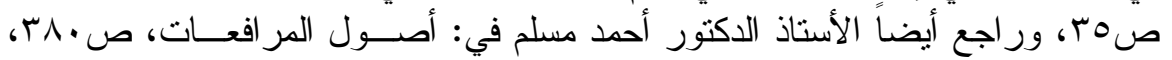
. 
يبديه أحد الخصوم في شأنه هو من الدفوع الثكلية التي يجــب إبــــاءها قبــلـ المطلب الثالث

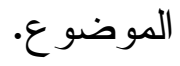

\section{الاختلاف الفقهي حول لزوم المبار

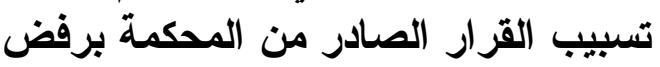

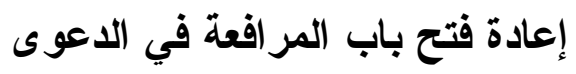

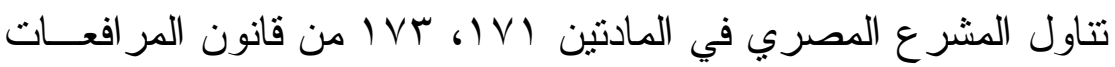

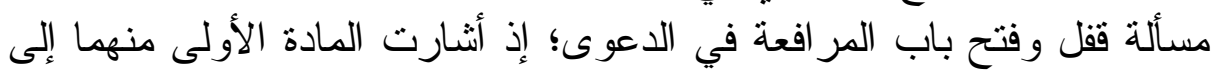

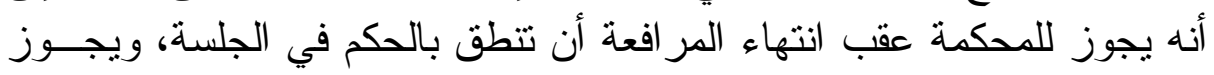

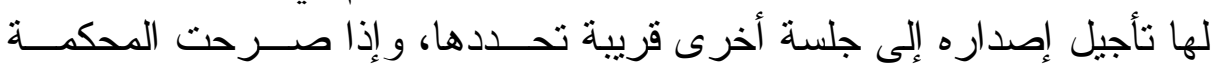

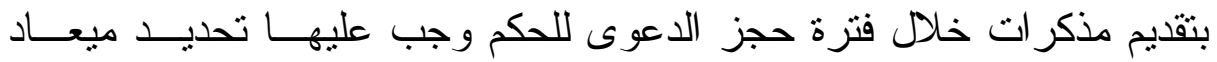

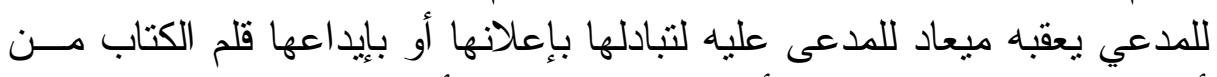

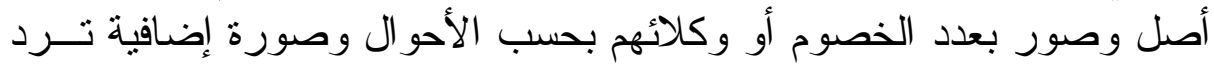

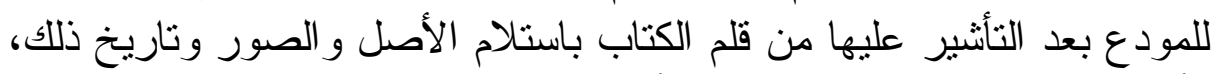

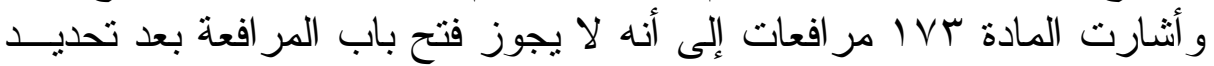

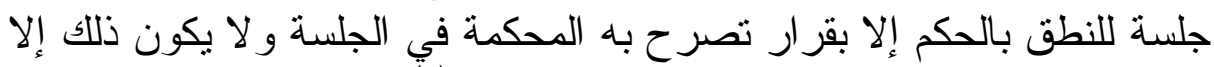

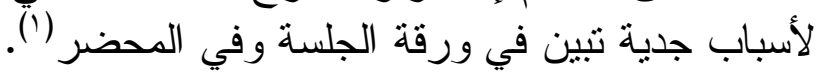

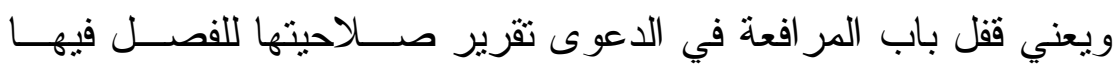

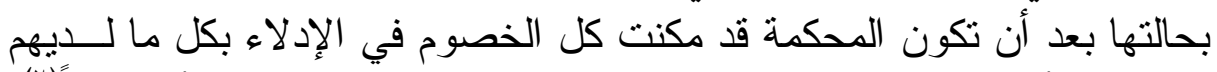

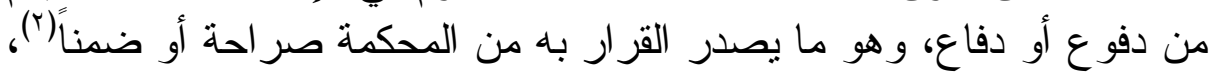

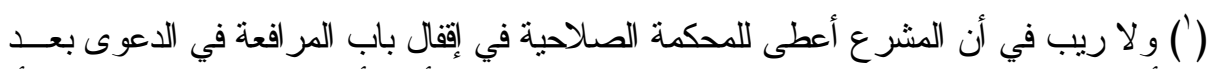

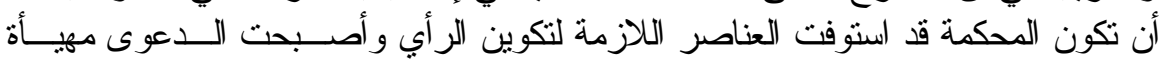

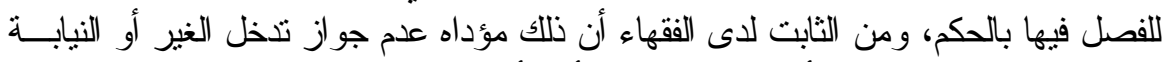

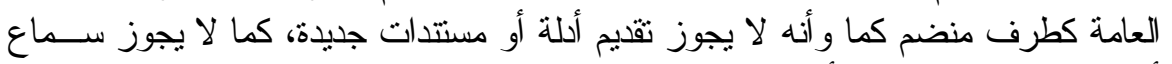

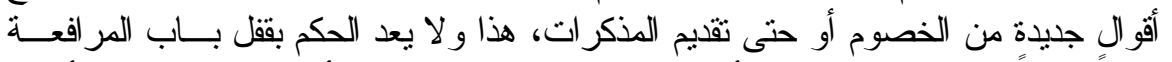

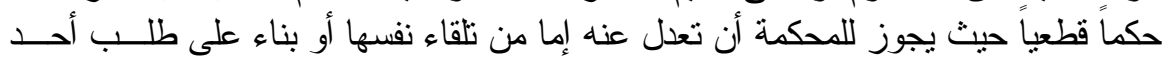

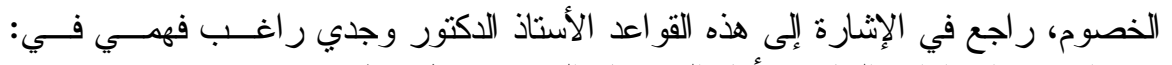

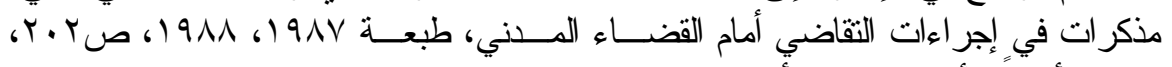

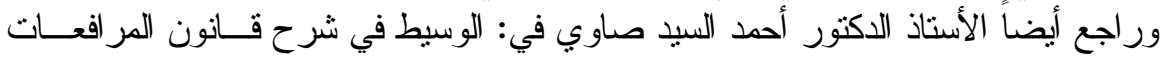

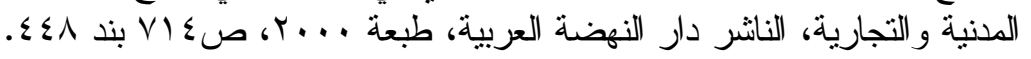

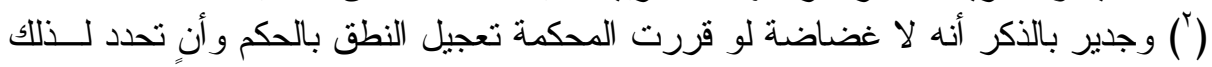

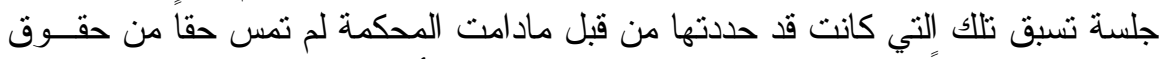

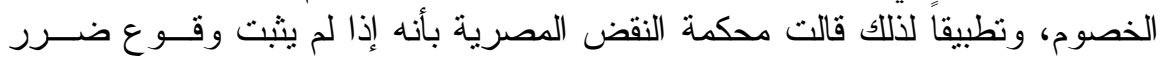


و إذا أصدرت المحكمة قرارًا بققل باب المر افعة صر احة عد مققو لاً، كما يكون

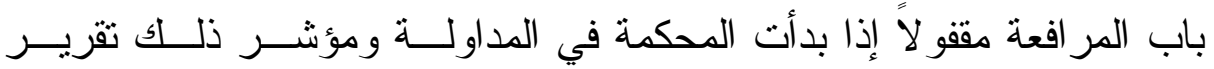

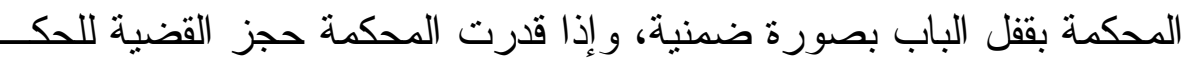

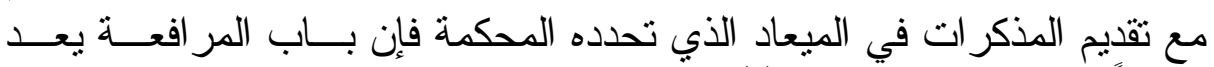

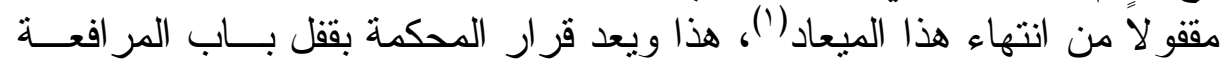

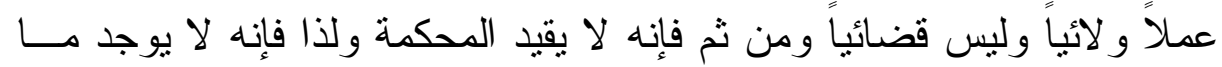

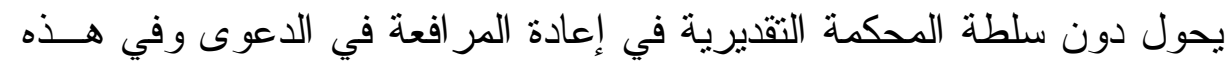

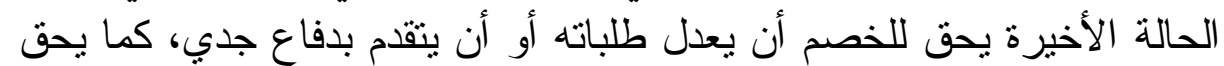

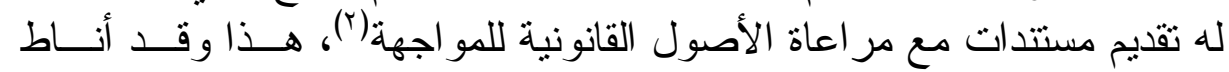

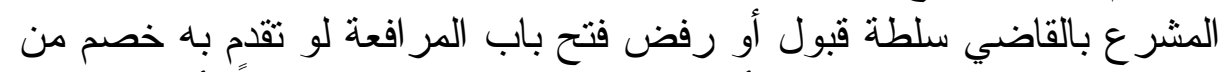

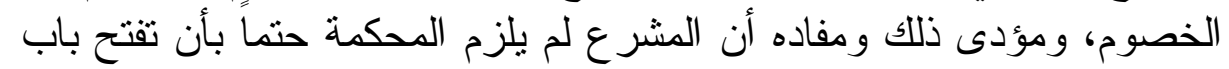

للطاعن بسبب تعجيل تاريخ النطق بالحكم لأن ميعاد الطعن يبدأ من تاريخ إعلان الحكم

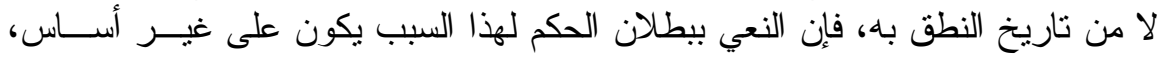

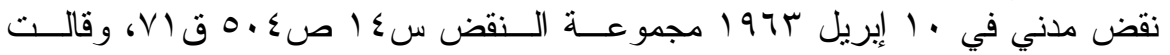

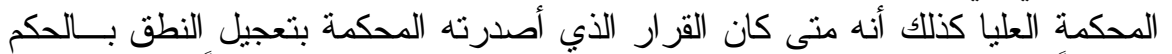

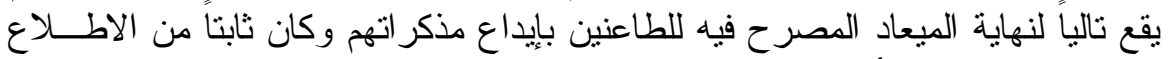

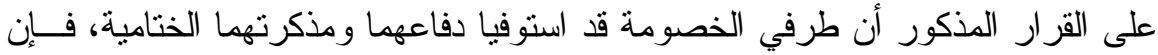

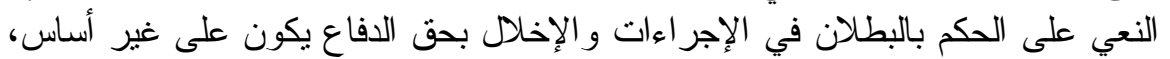

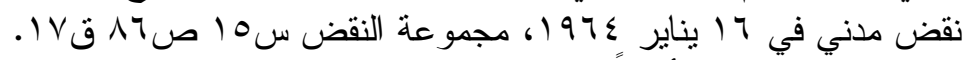

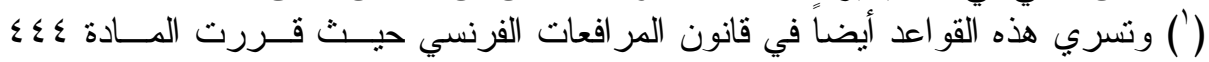

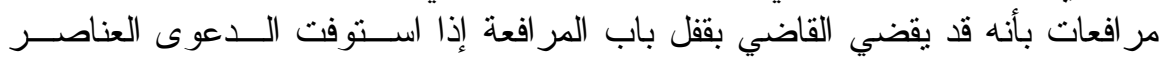

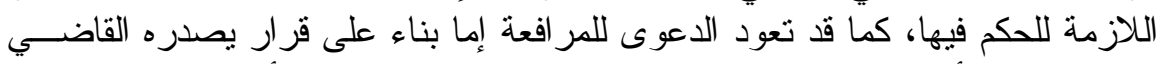

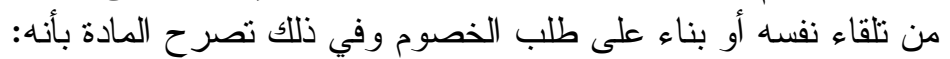

Dans les cas prévue a' l' article 444. Il s'agit des hypothèses de réouverture des débats, soit parce que le juge l' estime nécessaire, soit obligatoirement parce que les parties n'ont pas été à même de s'expliquer contradictoirement sur les parties n'ont pas été a même de s'expliquer contradictoirement sur les éclaircissements de droit ou de fait qui leur avaient été demandes.

راجع: 533 Jean Vincent et Serge Guinchard; op. cit. p. 403 No

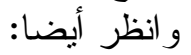

J. Pierson; les notes en délibéré dans les procès civils. J.C.P. 1952. I. 1036.

(r) ور اجع في الإشارة إلى لزوم مر اقبة القاضي لمبدأ المو اجهة في هذه الحال: حكم نقض .

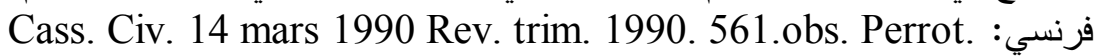




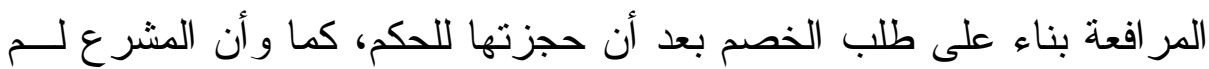

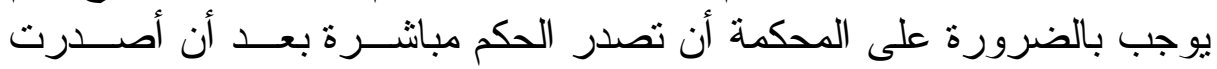

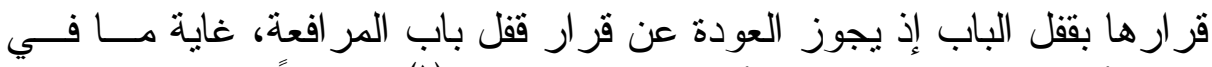

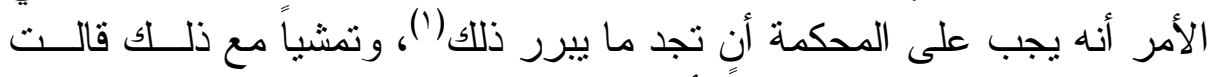

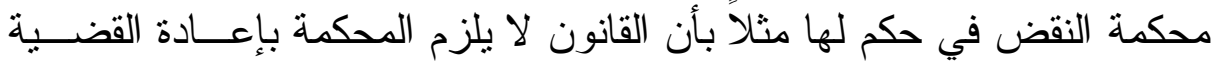

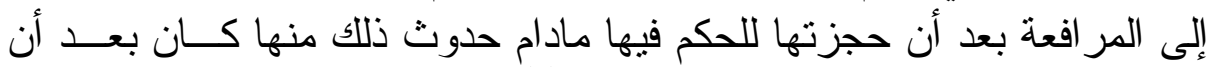

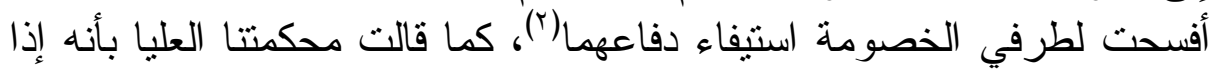

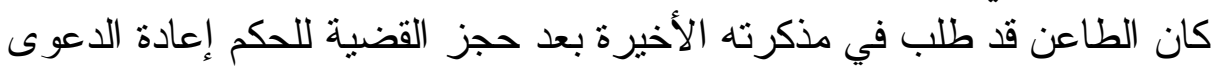

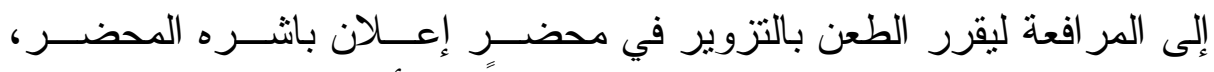

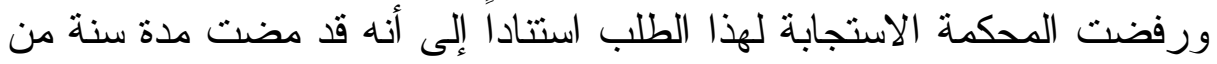

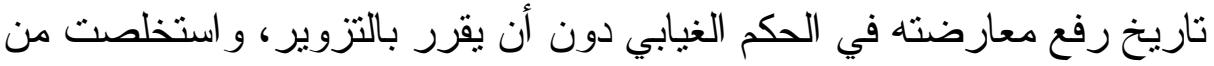

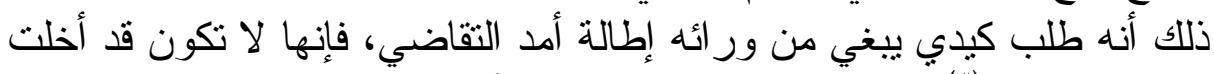

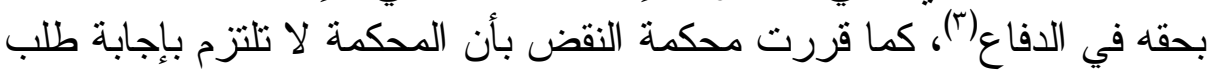

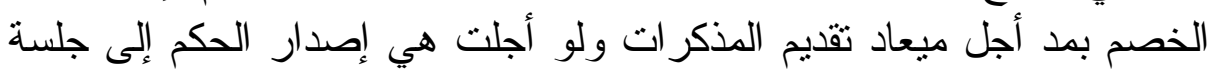

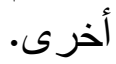

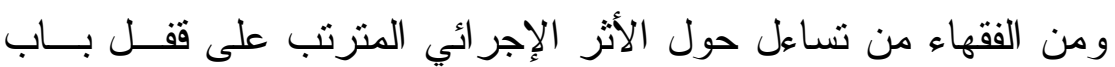

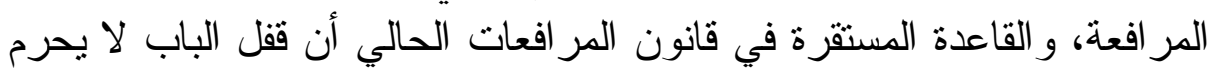

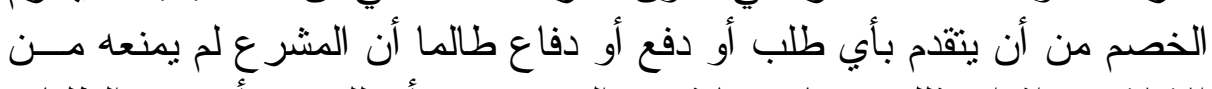

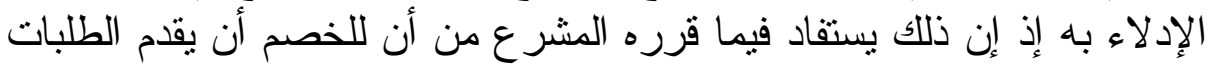

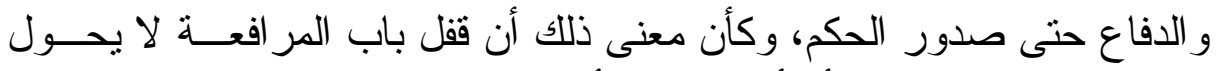

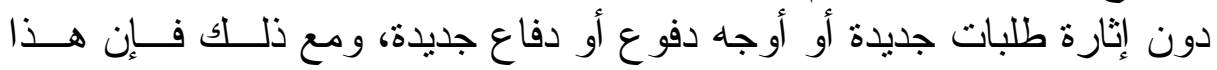

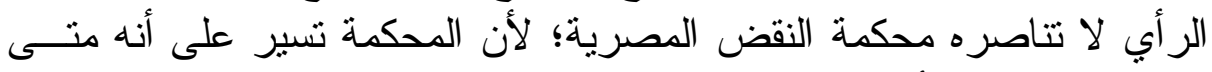

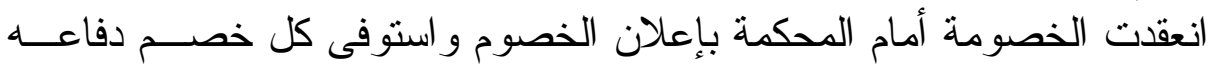

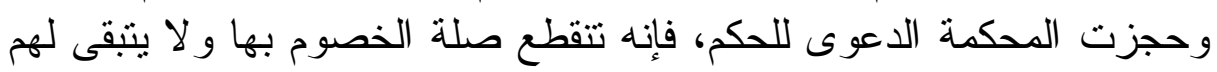

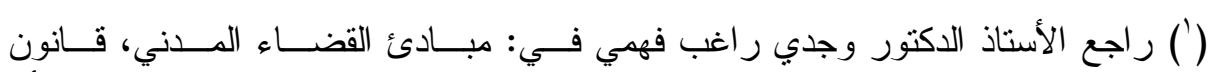

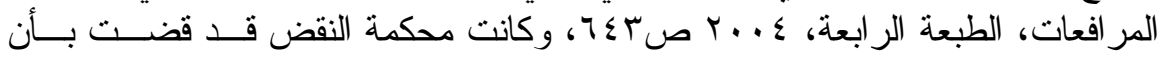

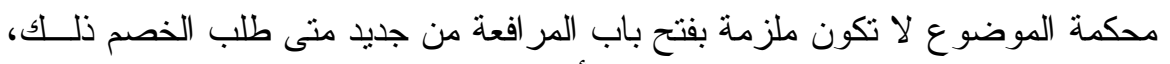

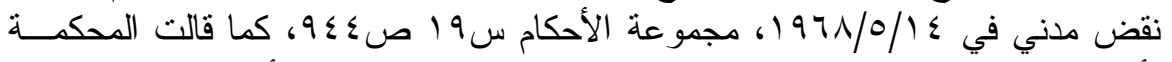

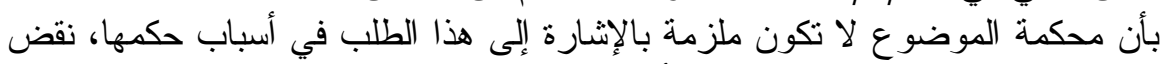

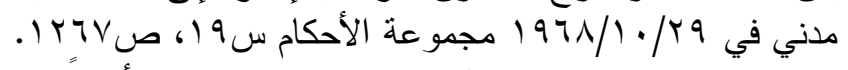

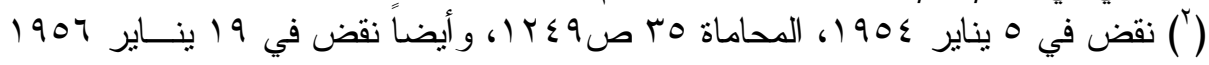

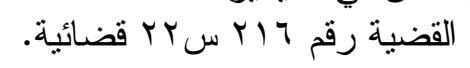

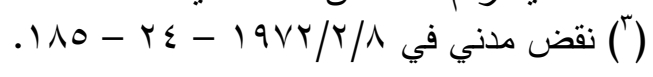


الاتصال بالاعوى إلا بالقدر الذي تعينه المحكمة(').

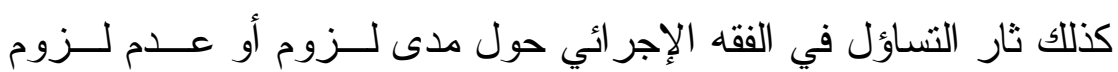

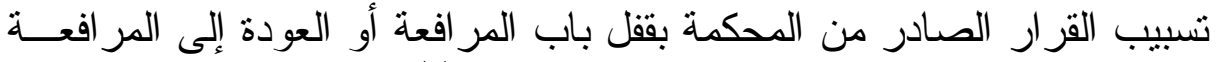
من جديد من جانب الخصوم أو من تلقاء المحكمة (؟).

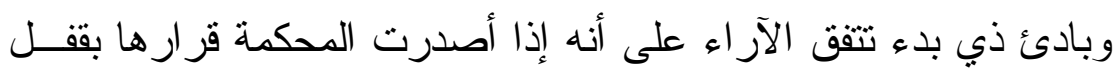

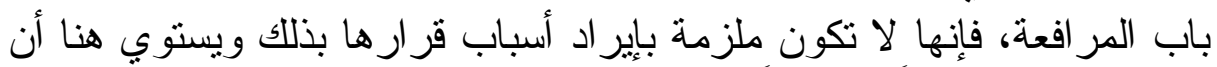

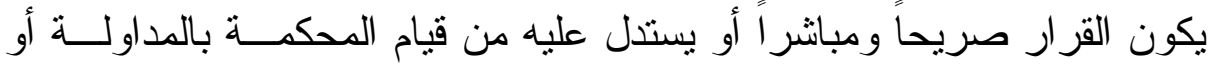

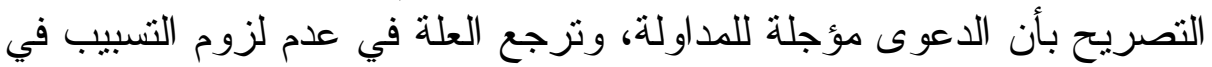

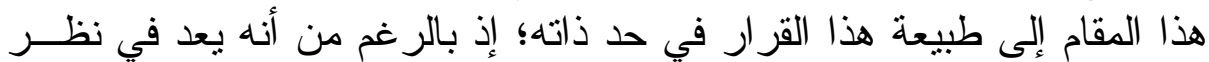

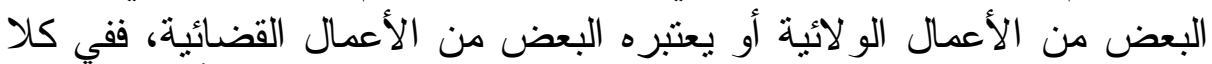

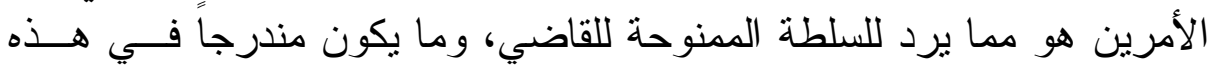

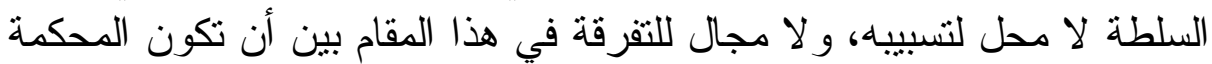

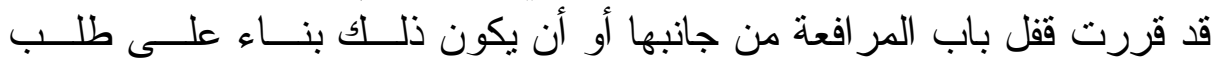

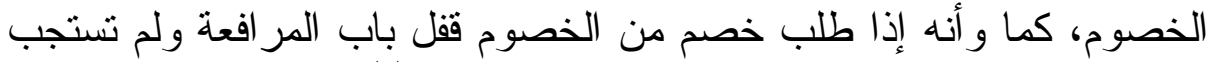

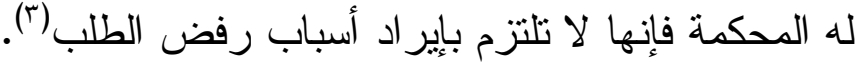

(') راجع في عرض هذا الرأي وموقف محكمة النقض منه: الأستاذ الدكتور أحمد أبو الوفا

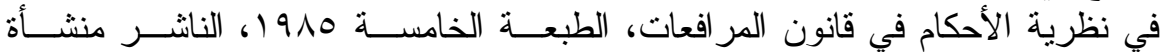

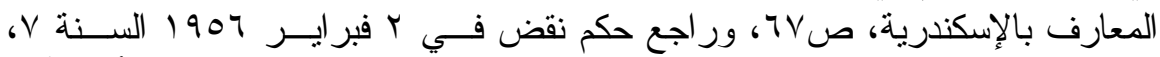

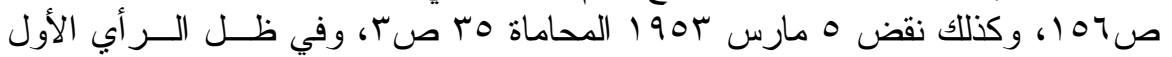

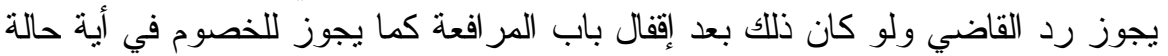

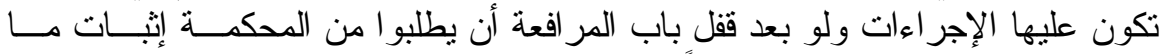

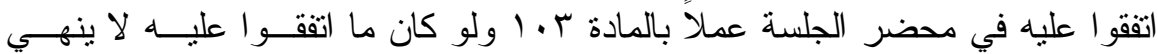

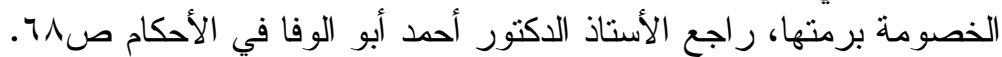

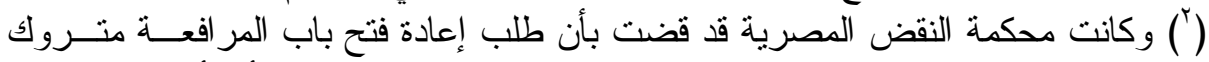

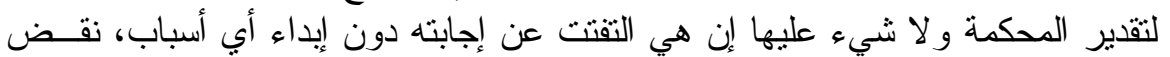

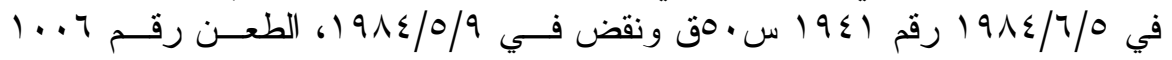

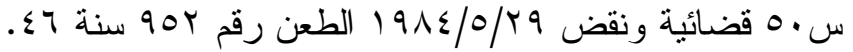

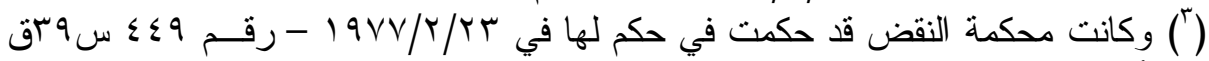

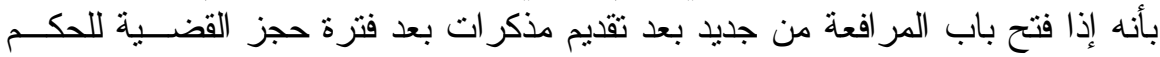

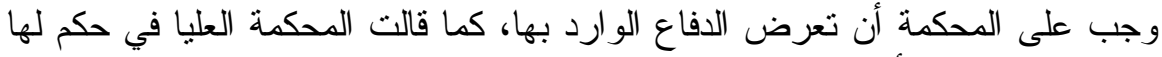

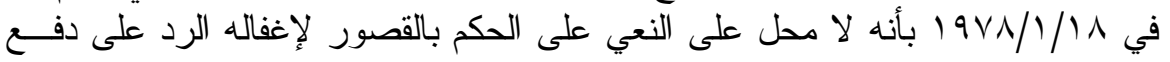

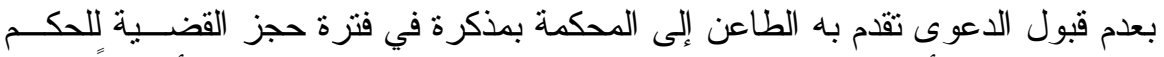

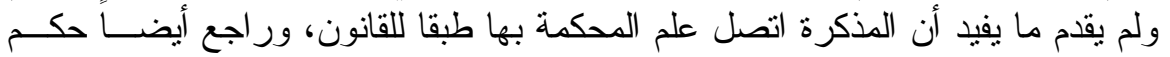

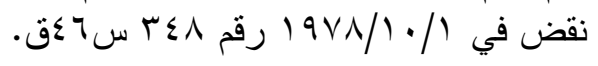




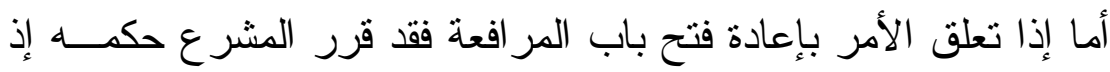

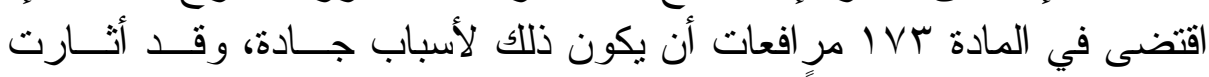

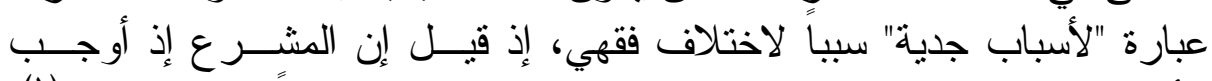

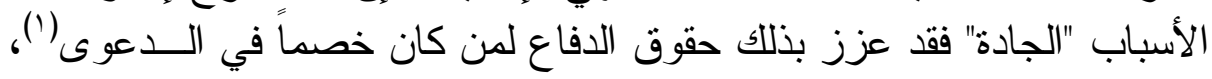

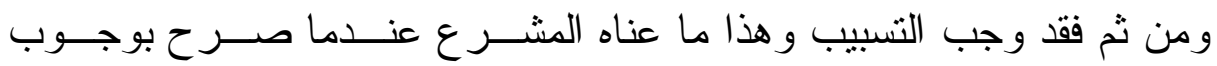

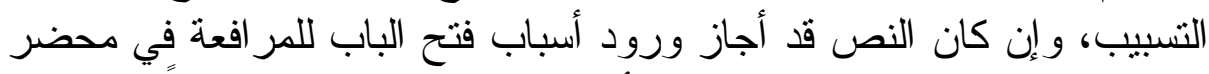

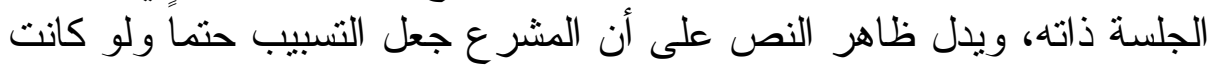

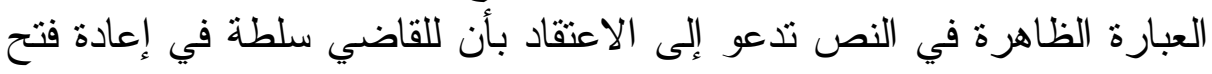

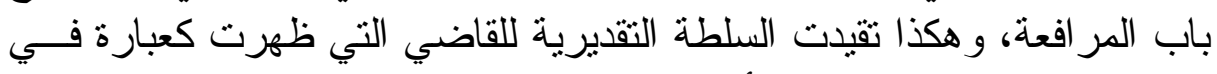

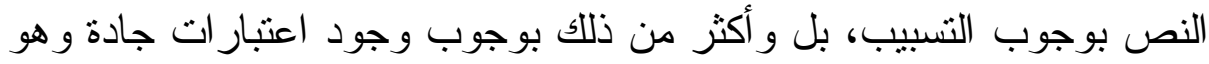

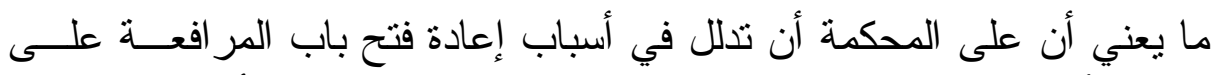

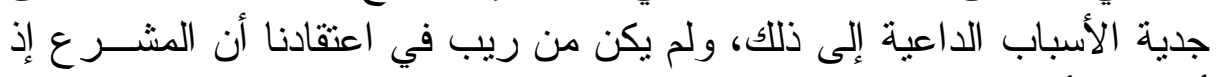

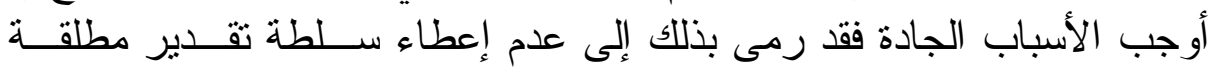

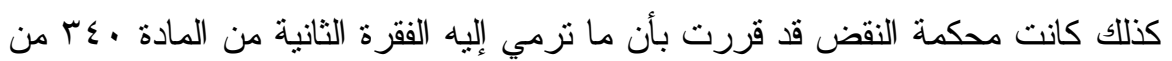

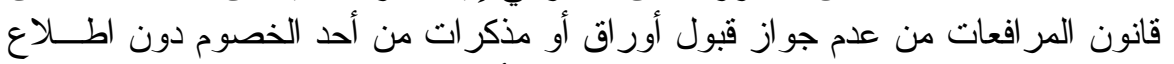

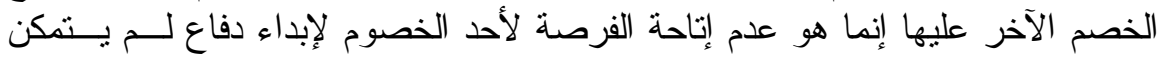

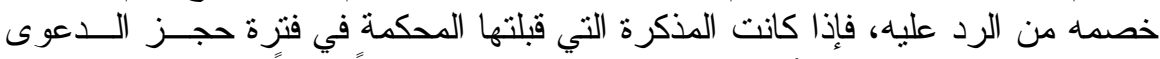

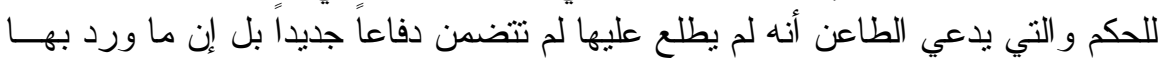

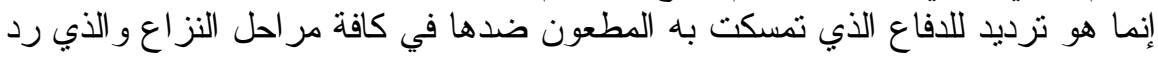

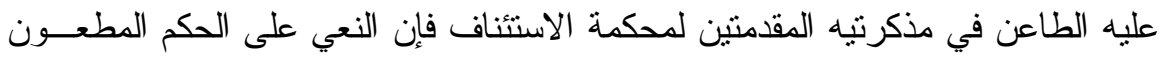

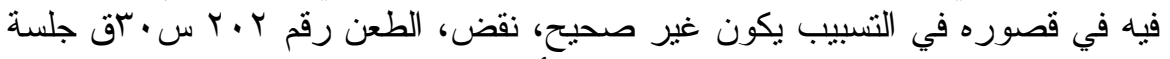

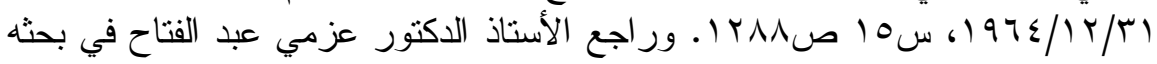

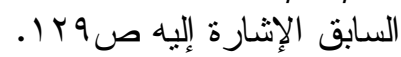

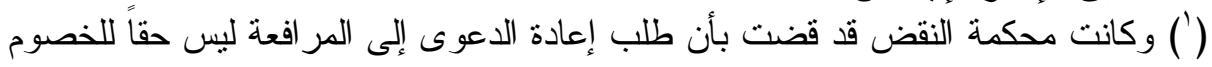

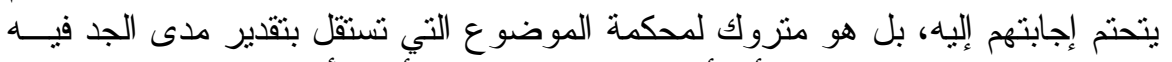

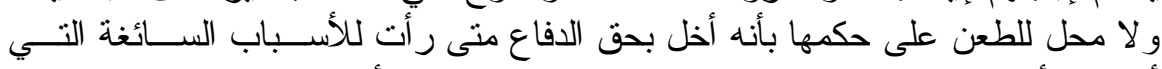

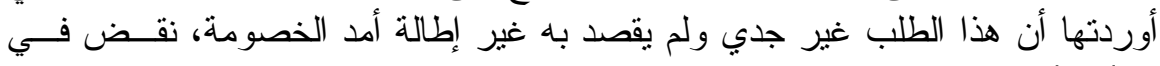

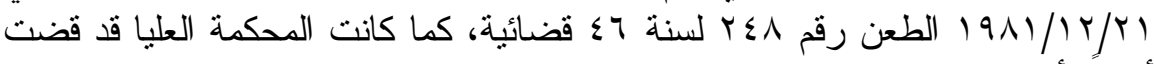

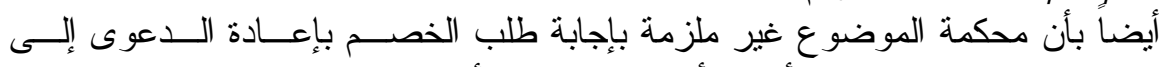

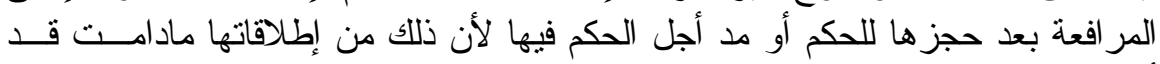

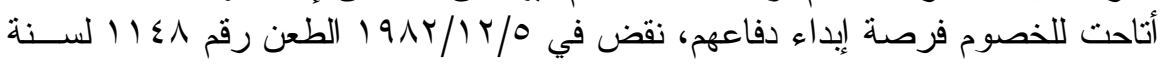

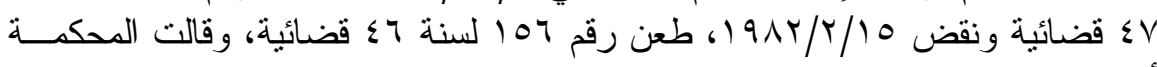

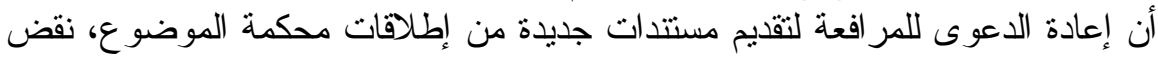

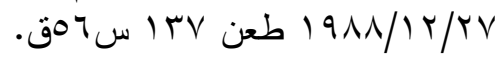


للقاضي، أو اتخاذ إعادة فتح باب المر افعة كوسيلة لإطالة أمد التقاضي (')، ومع ذلك فلقد لوحظ في العمل أنه قد يجري فتح لابح باب المر افعة بعد إذ قفلته المحكمة

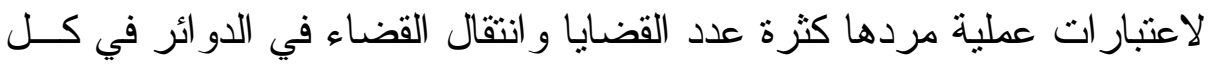

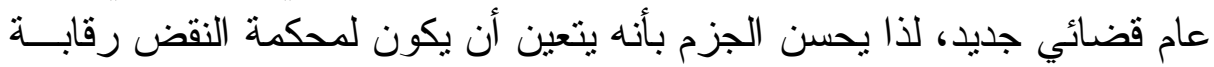

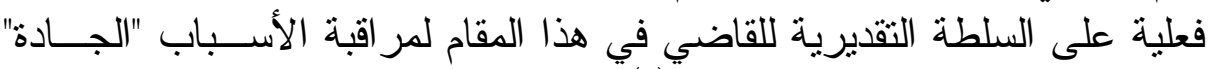
الداعية لفتح باب المر افعة من جديد" (؟).

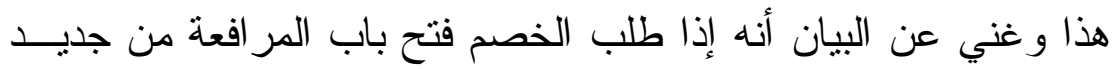

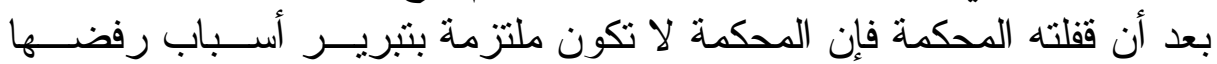

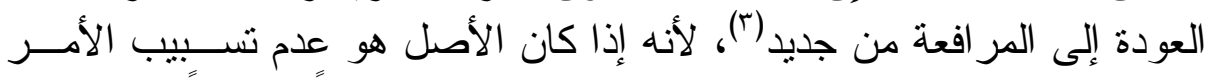

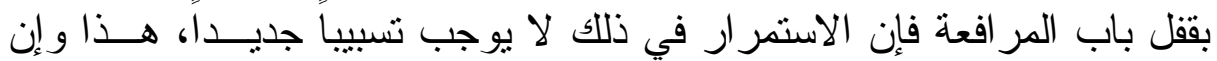

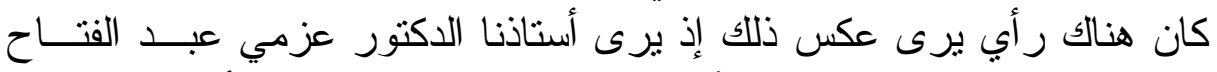
بوجوب التسبيب هنا لارتباط الأمر بحقوق الدفاع، وإن برى إن استدل أستاذنا الدكتور

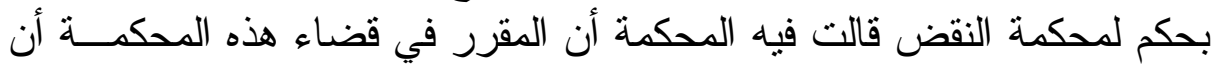

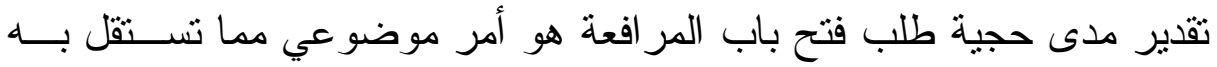

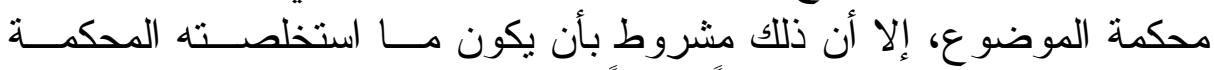

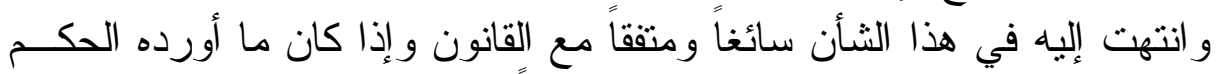

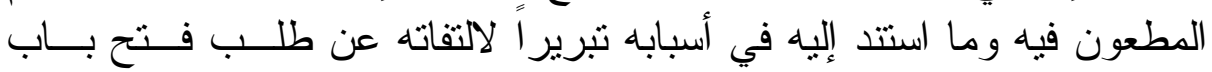

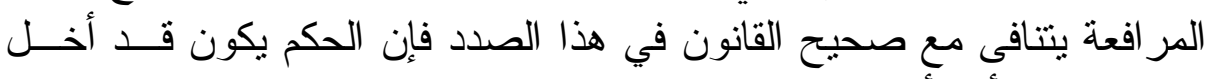

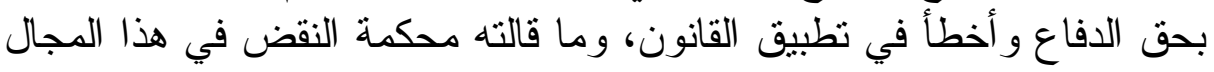

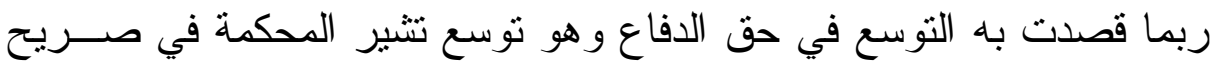

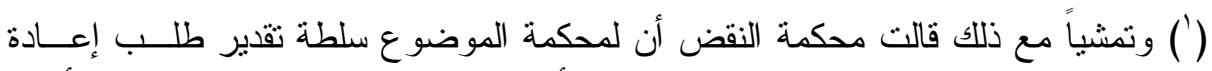

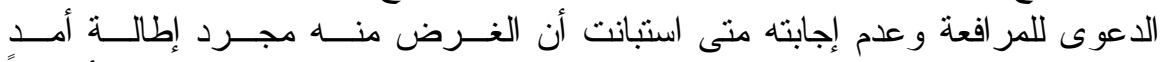

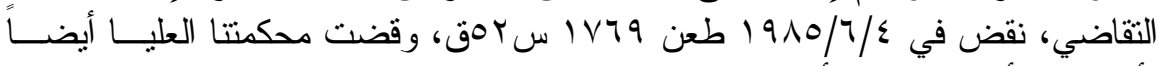

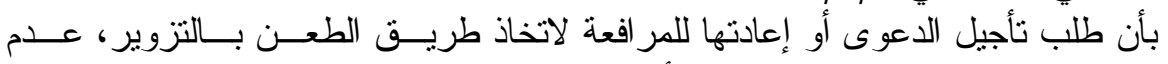

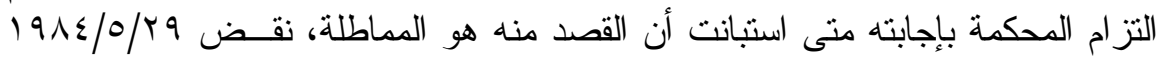

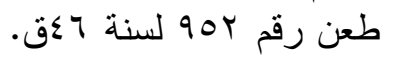

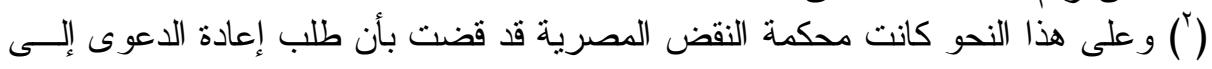

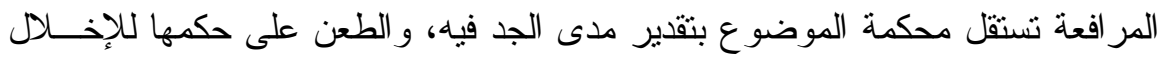

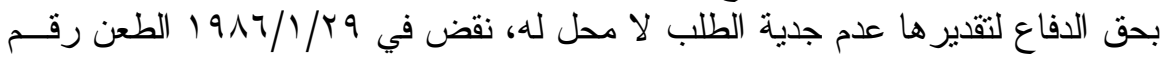

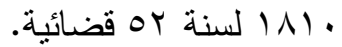

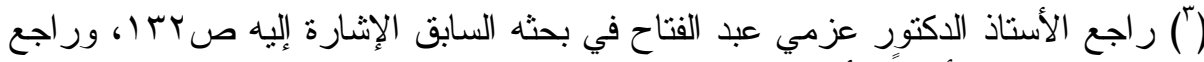

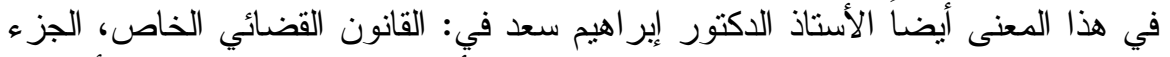

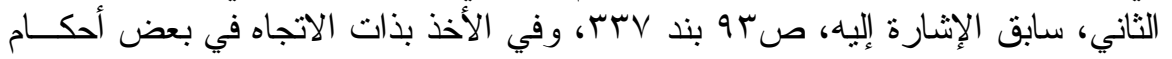

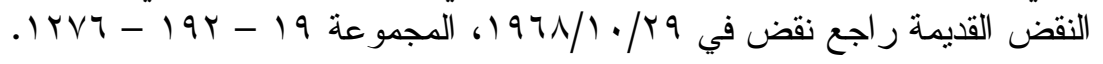




\section{حكمها إلى أنه بتتافى مع صحيح القانون (').

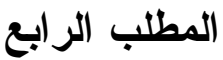 \\ التسبيب في مجال وقف الخصومة}

يقصد بوقف الخصومة عدم السبر فيها لفترة معينة أو لسبب ما، وهو قد يكون إما بنص القانون أو بموجب حكم تصدر ه المحكمة أو بناء علــى اتفـاق الأطر اف (r)، و الوقف يؤدي إلى ركود الخصومة ومن ثم فإنه لا يجوز اتخــاذ

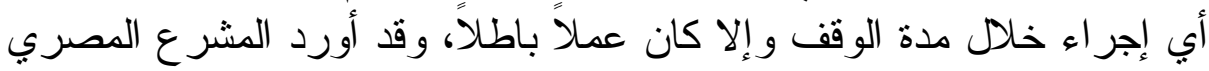

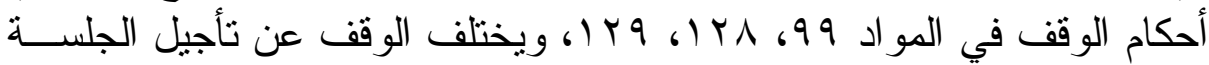

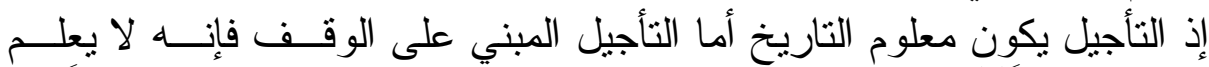

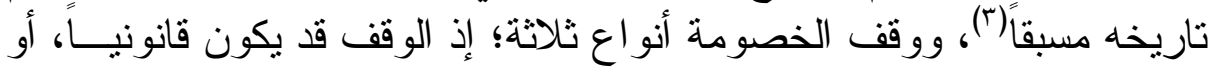

(') راجع الأستاذ الدكتور عزمي عبد الفتاح في بحثه: تنبيب الأحكام و أعمال القضاة فـي الإني

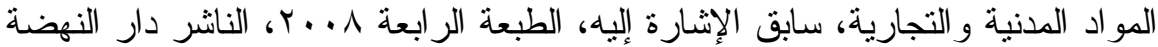

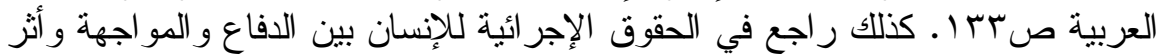

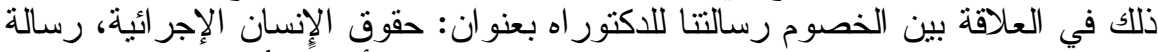

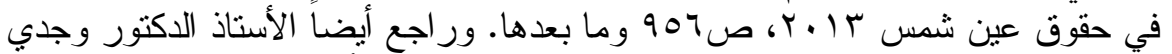

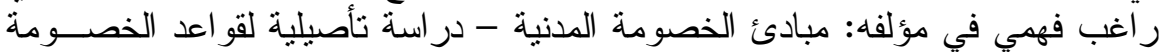

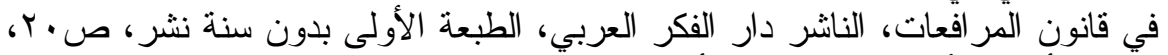

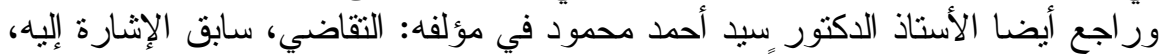

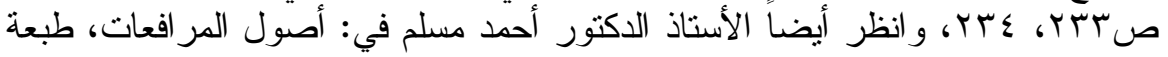

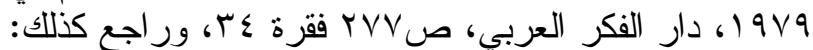
Gérard Couchez; procédure civile. 10 . Sirey p. 184 No. 240

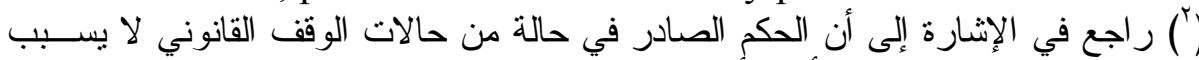

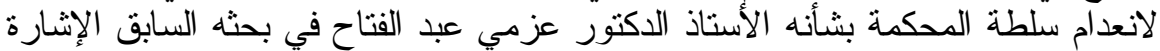

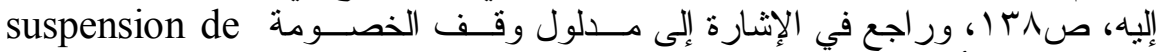

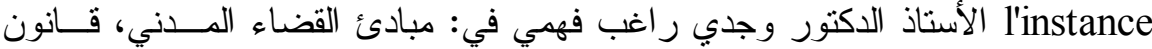

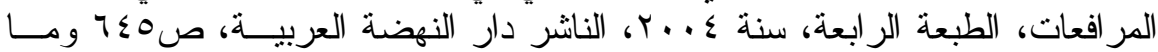
بعدها، ور اجع أيضا:

Gérard Cornu et Jean Foyer; procédure civile. Op. cit. p. 462.

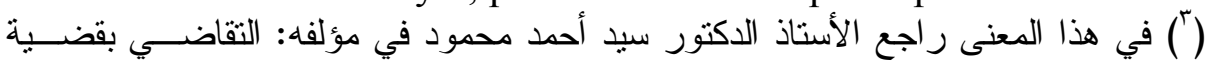

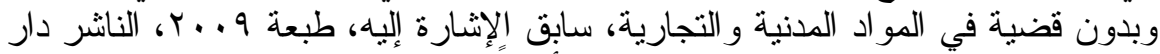

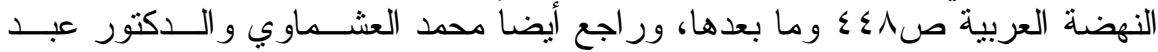

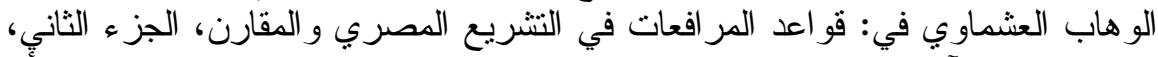

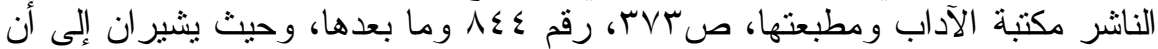

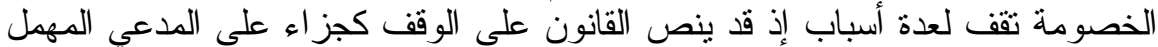

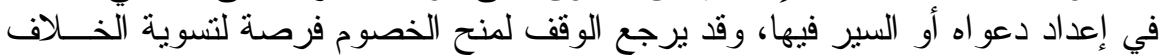

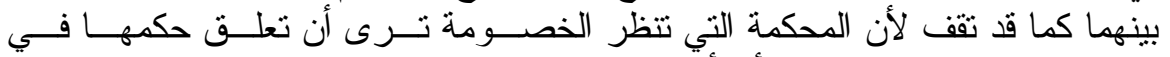
الموضوع على الفصل في مسألة أخرى لا تلانل فئل في و لايتها. 
قضائياً أو بناء على اتفاق الخصوم فيسمى بالوقف الاتفاقي (')، وقــــ أثنــارت

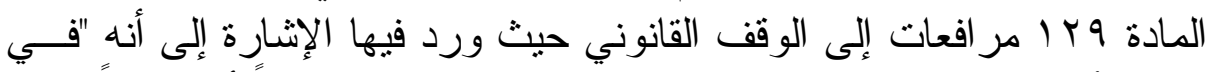

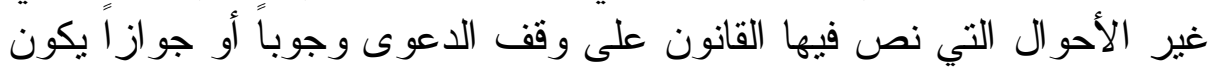

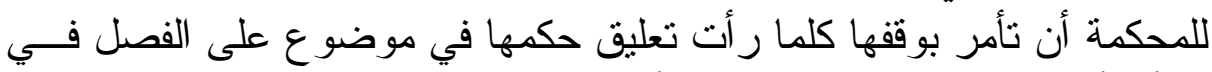

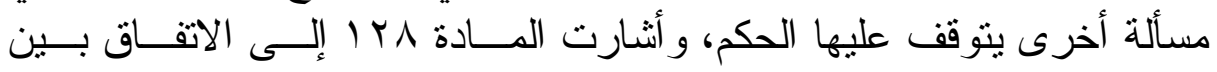

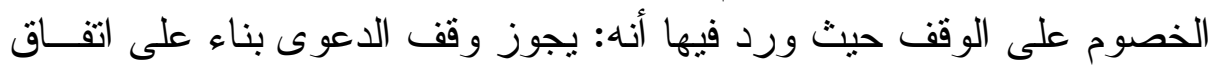

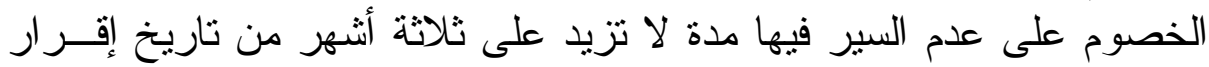

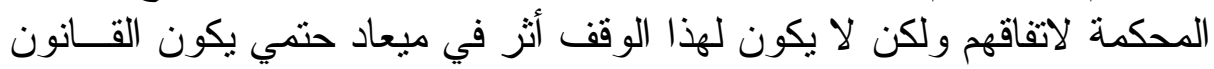

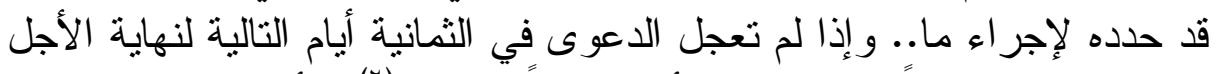

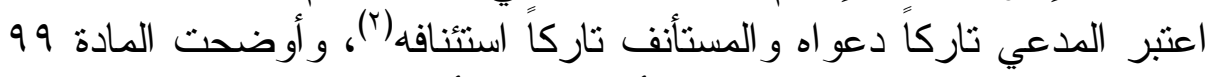

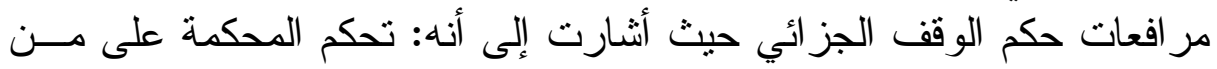

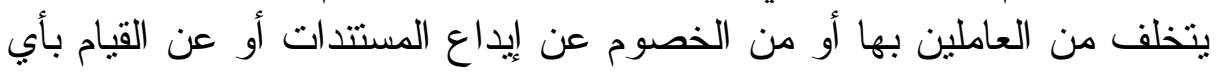

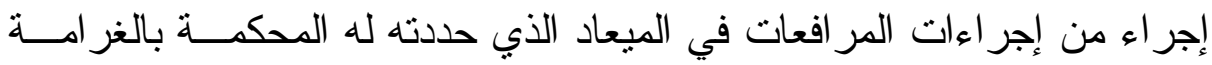

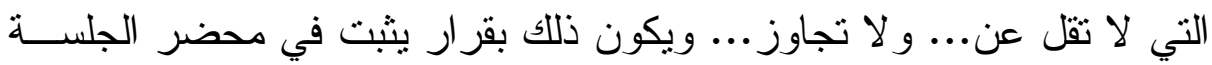

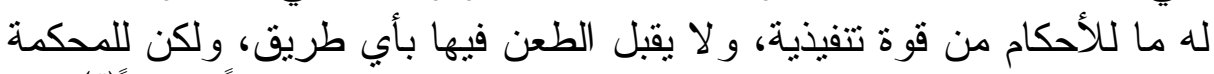

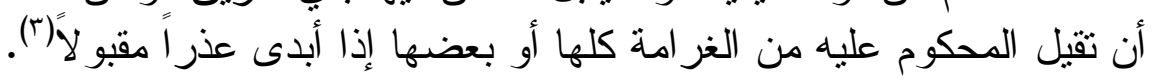

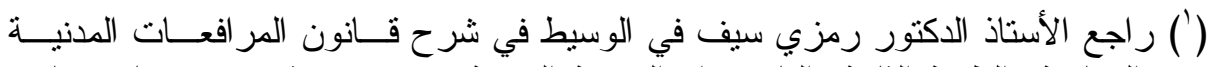

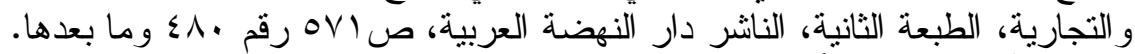

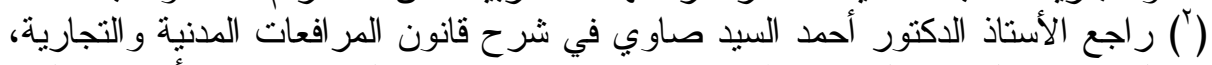

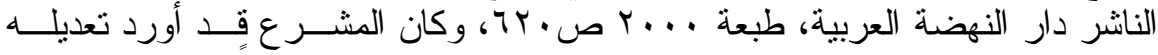

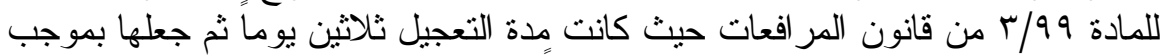

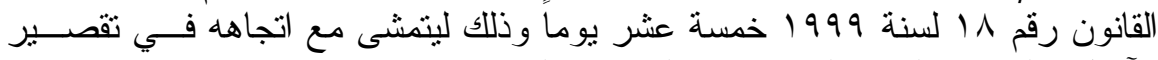

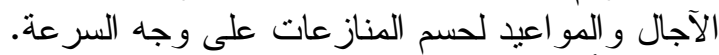

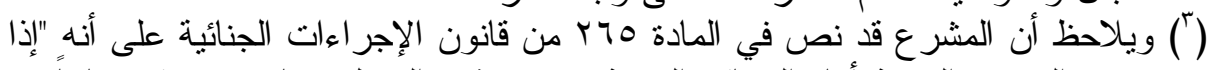

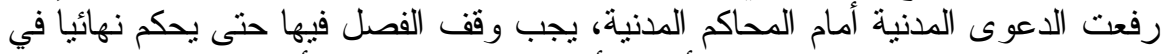

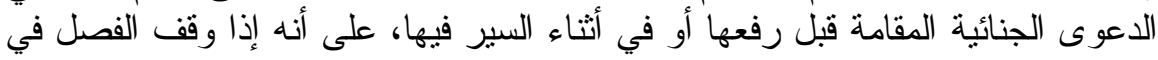

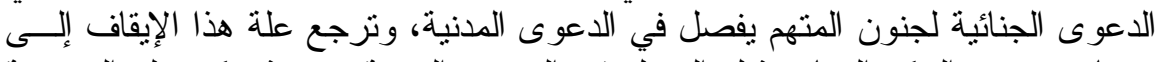

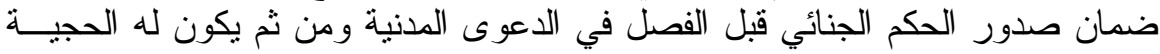

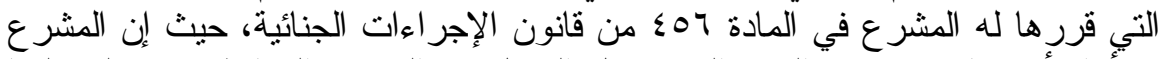

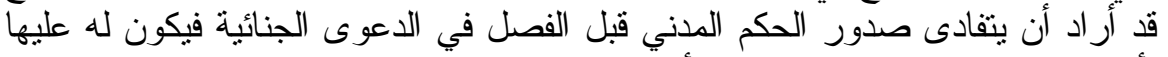

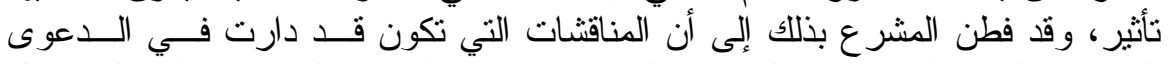

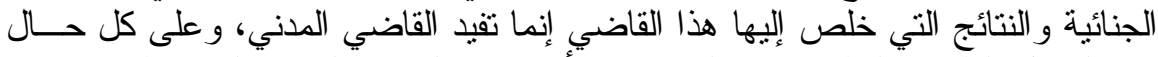

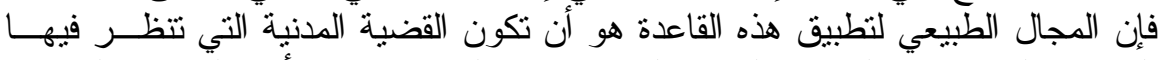

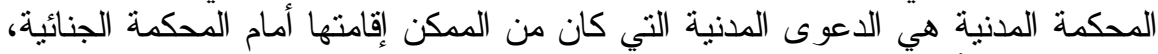

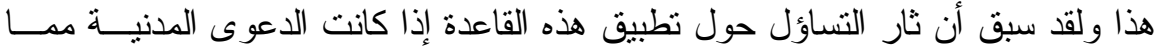

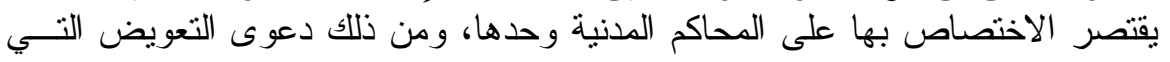


وللوقف القانوني حالات مصدر ها القانون أي النص ومن ثم فإنه يجــبـ

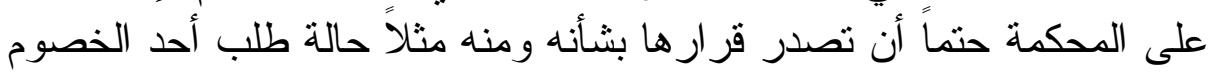

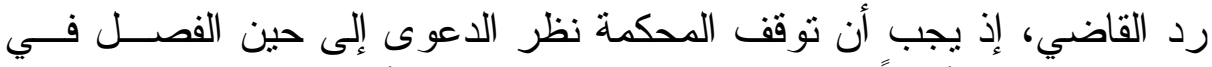

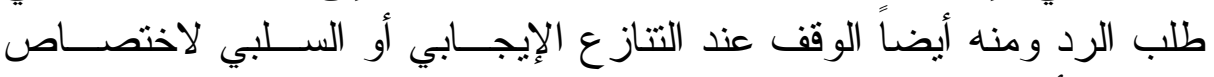

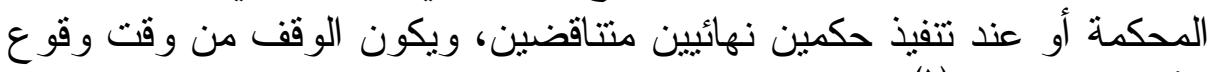
الأمر الموجب له اله (1). وفي الفقه الإجر ائي المصري تعرض الفقهاء لمدى لزوم تســبيب الأحكــام

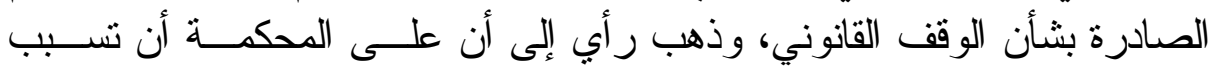

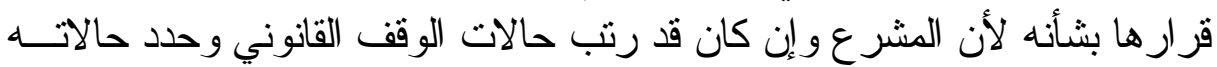

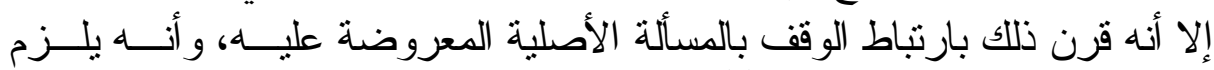

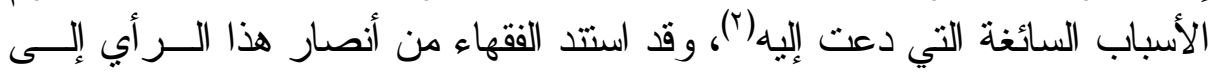

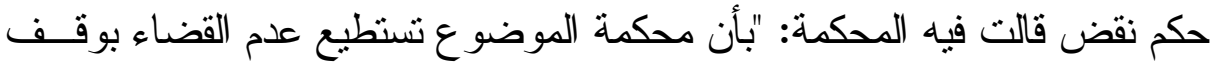

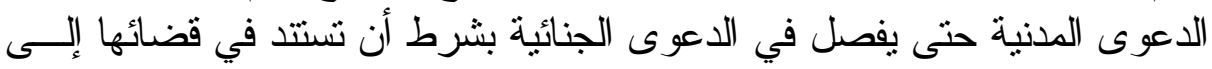

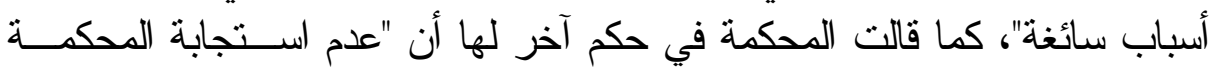

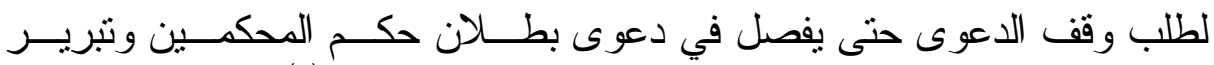

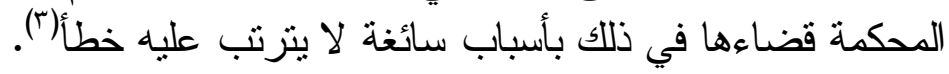

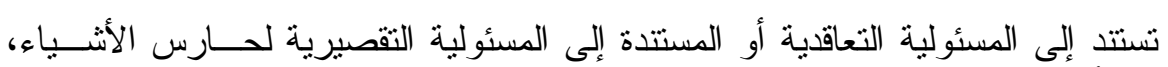

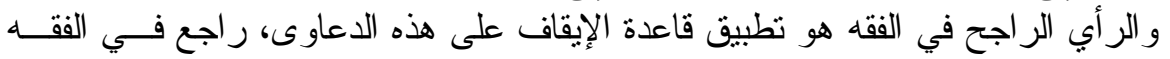

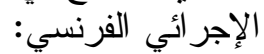

Réne Garroud; Traité théorique et pratique d'instruction criminelle et de procédure pénal. T. I. 1907. No. 204 p. 449.

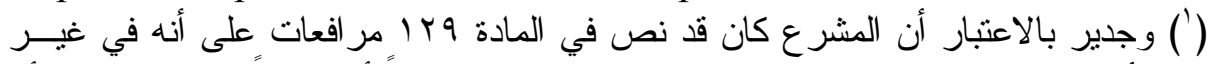

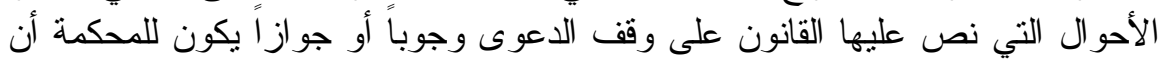

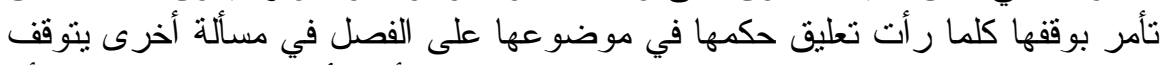

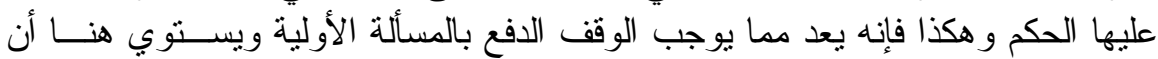

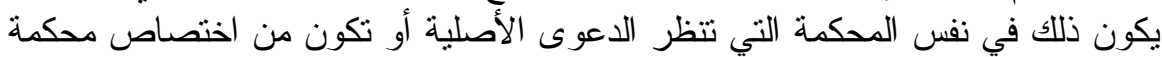

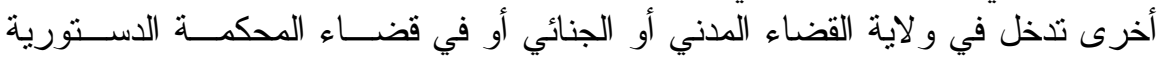

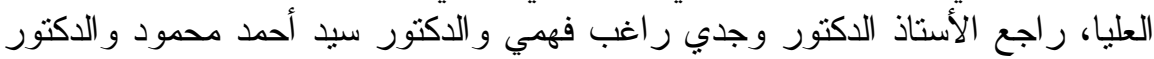

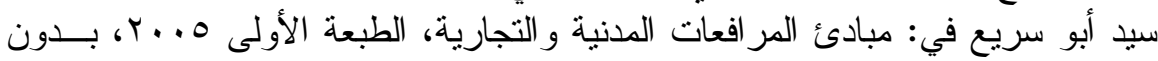

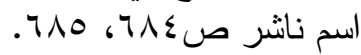

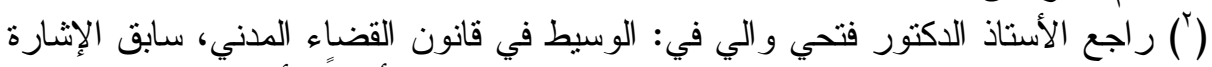

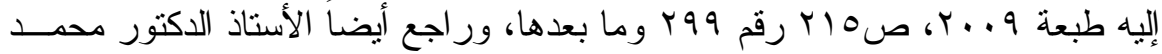

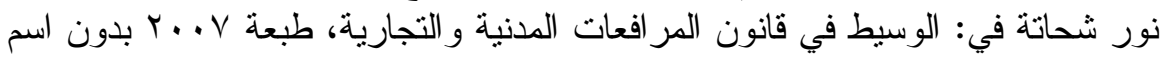

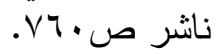
(") راجع الدكتور عاشور مبروك في: الوسيط في قـانون القضـــاء المصــري، قـــوانين 
ومع ذلك فإننا نستأذن في مخالفة هذا الر أي إذ نعتقد أنه لا يلزم تســبيب

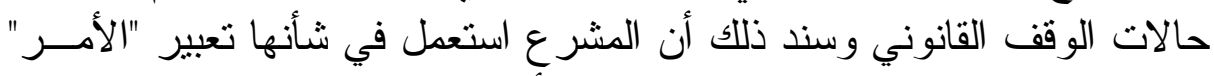

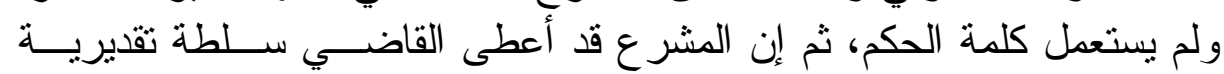

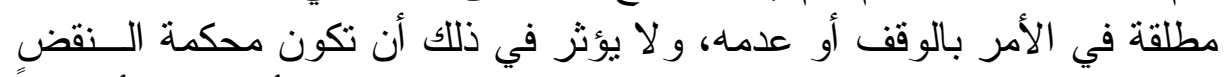

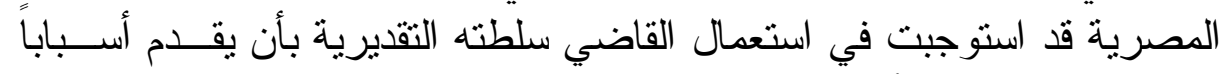

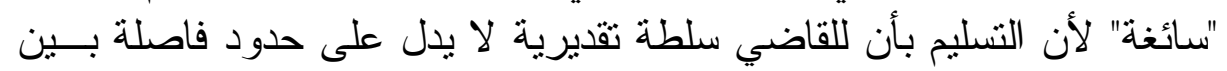

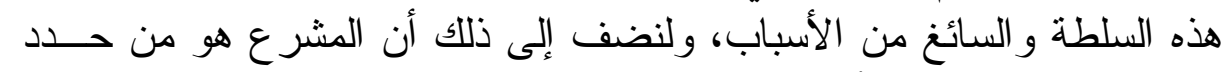

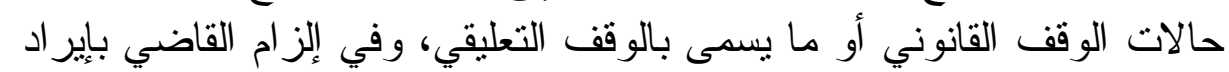

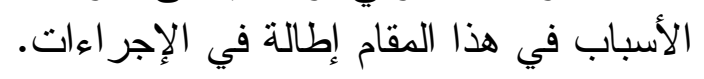

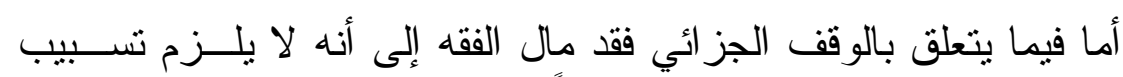

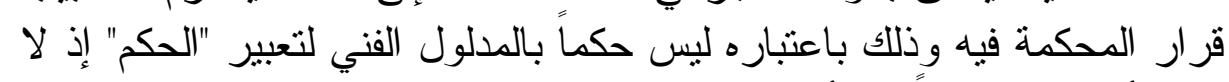

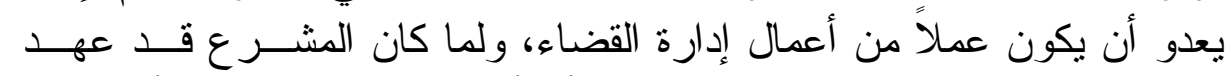

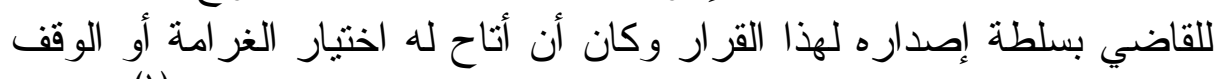

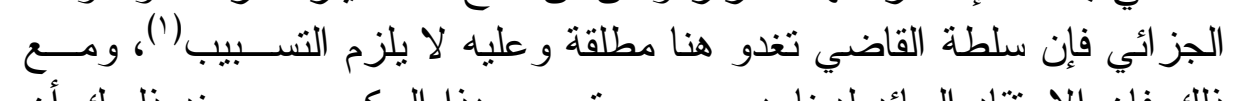

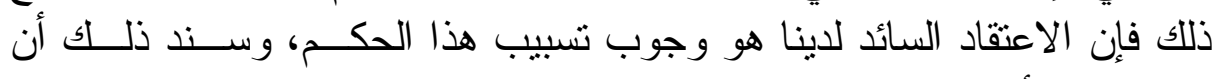

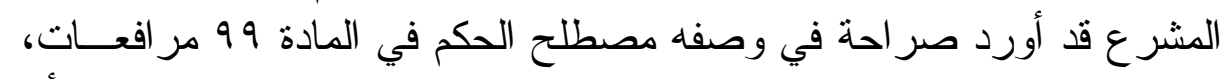

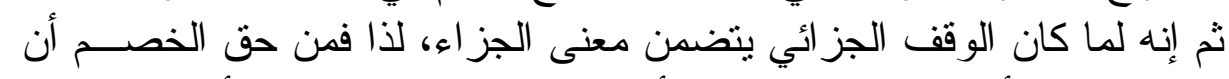

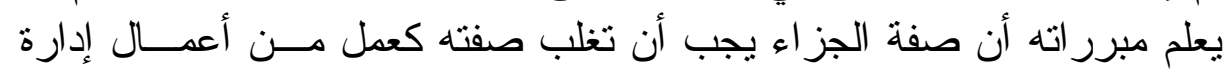
القضاء.

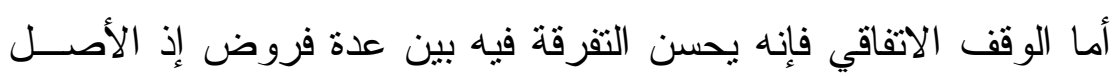

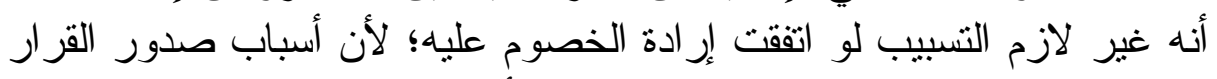

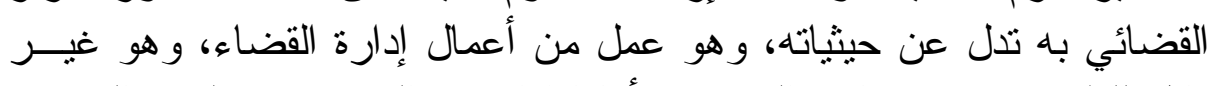

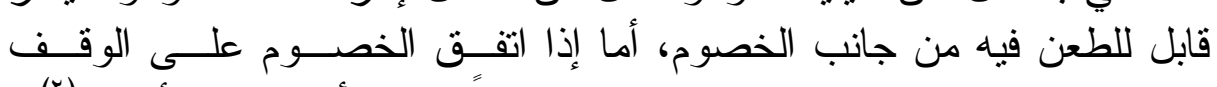

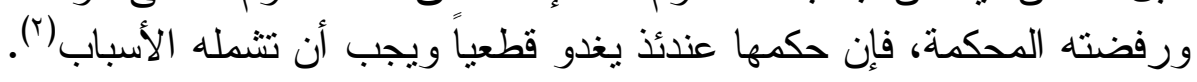

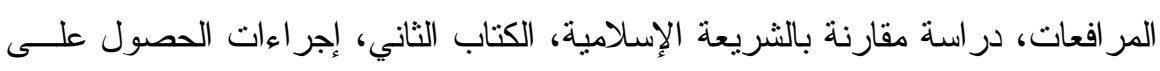

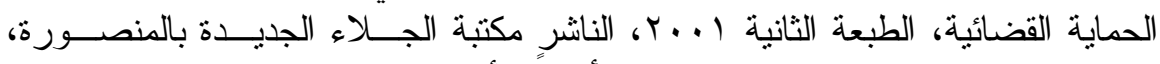

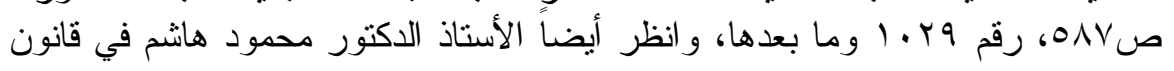

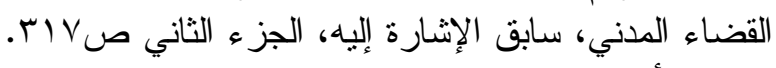

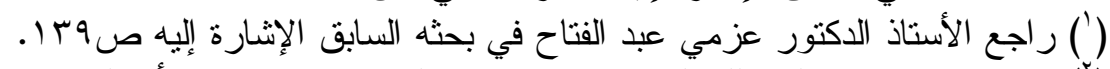

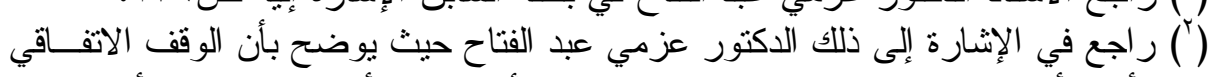

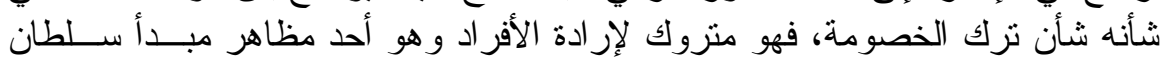

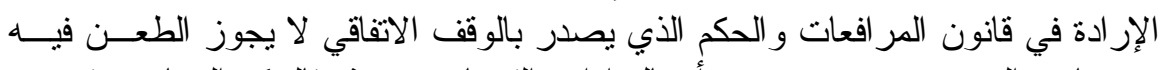

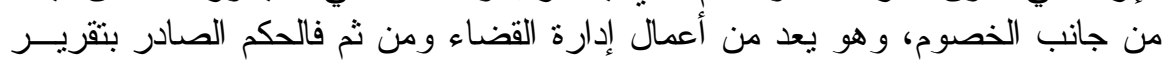




\section{المطلب الخامس \\ عدم لزوم التسبيب عند إصدار المحكمة

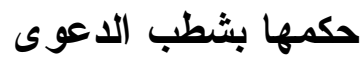

يقصد بشطب الدعوى عدم السير في الخصومة وهو بذلك عارض مــن

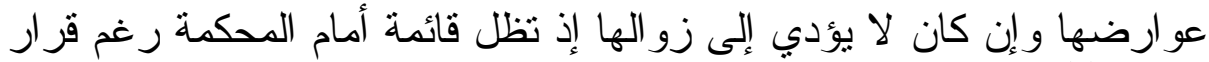

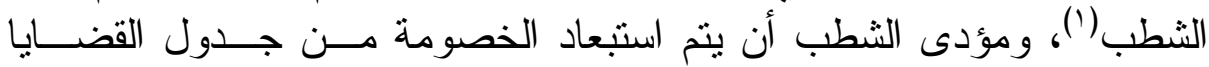
المتداولة في الجلسات، و هكذا لا يستمر تحديد جلسة تالية للنظر في القضــية،

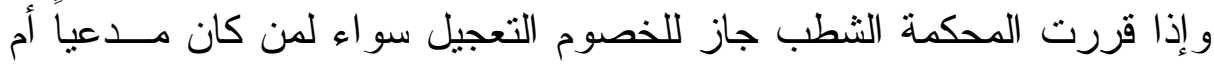

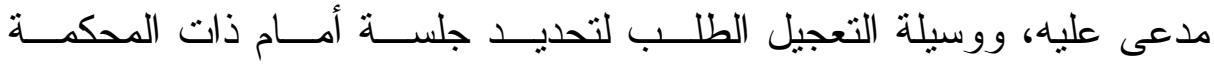

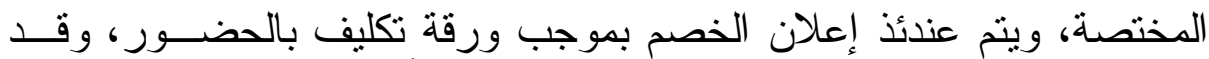
أوجب المشرع أن يتم هذا الإعلان خلال ستين يوماً من تاريخ الحكم بالثطب

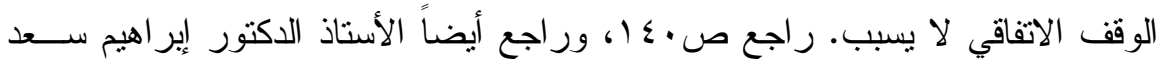

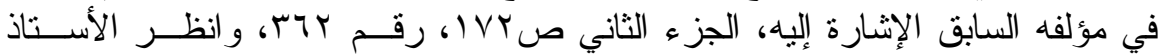

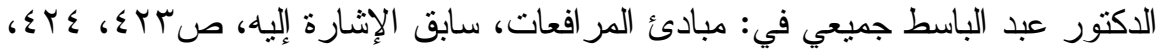

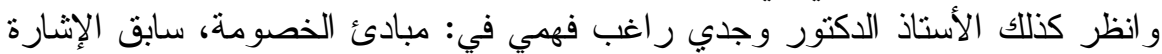

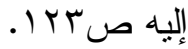

(') و عادة ما يعالج الفقه الإجرائي مسألة شطب الدعوى عند التعرض لغياب الخصوم، وقد

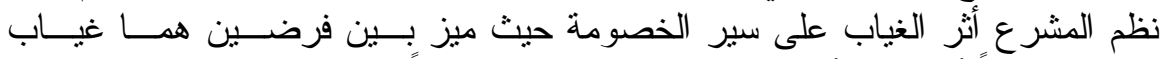

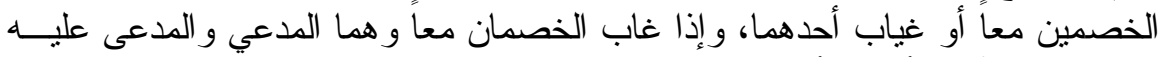

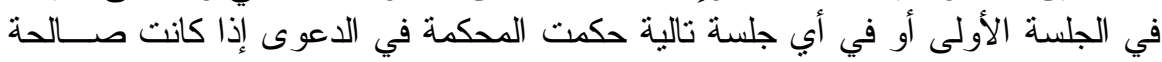

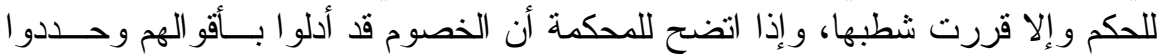

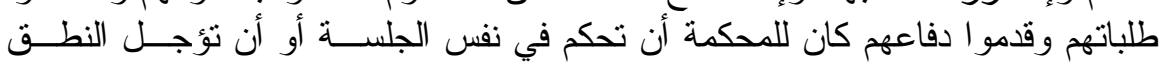

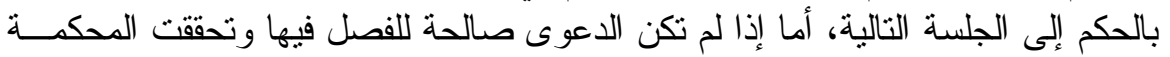

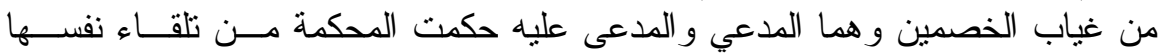

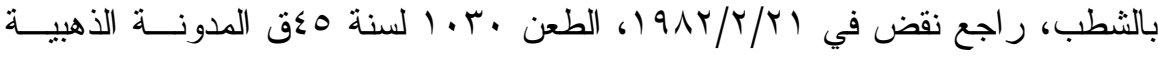

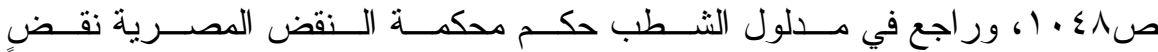

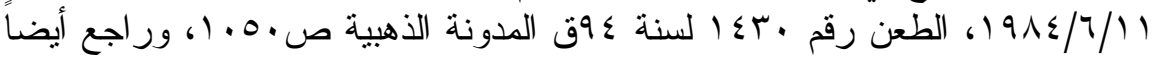

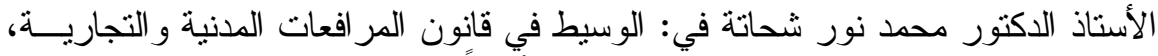

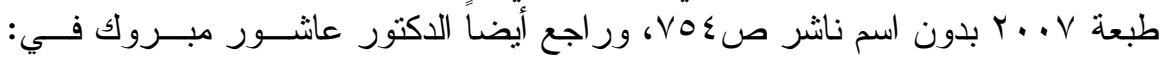

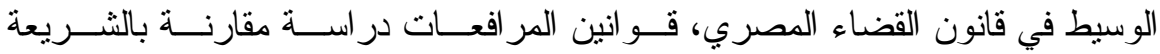

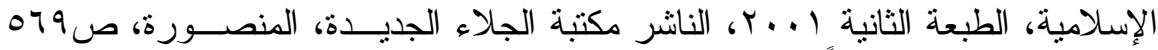

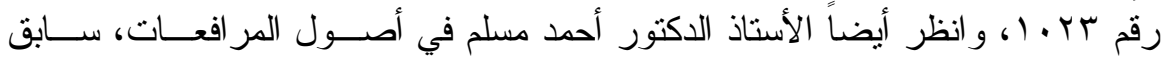

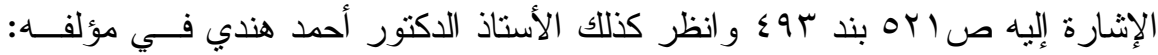

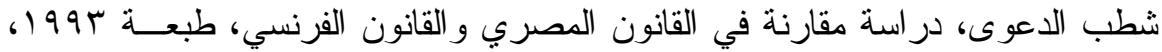

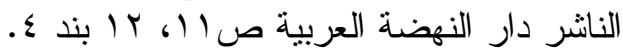


و إلا اعتبرت الدعوى كأن لم تكن (')، ويترتب على اعتبار الدعوى كأن لم تكن

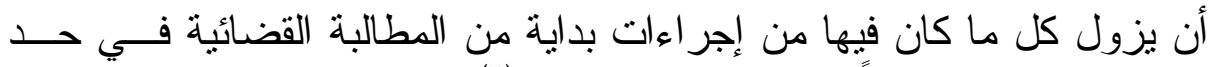

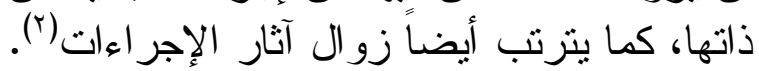

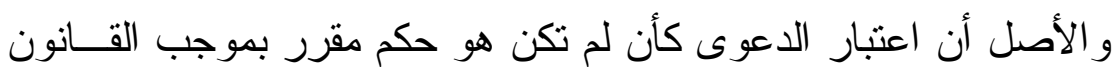

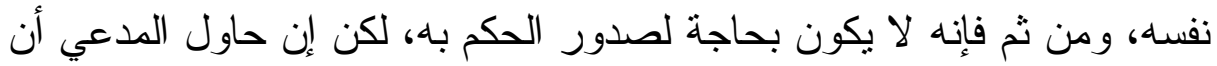

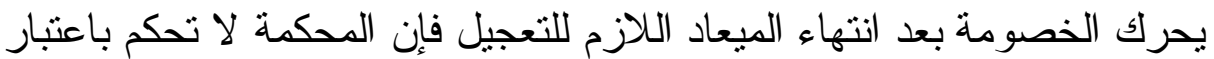

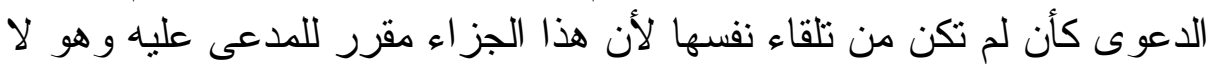

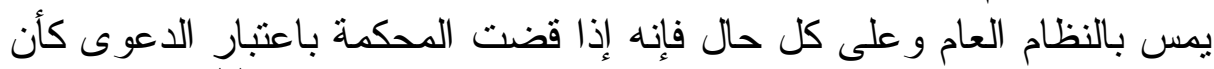

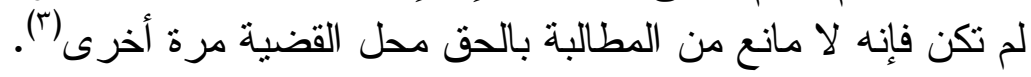
هذا ولما كان المشرع المصري قد نظم أحكام شطب الدان الدعوى في في الفقرة

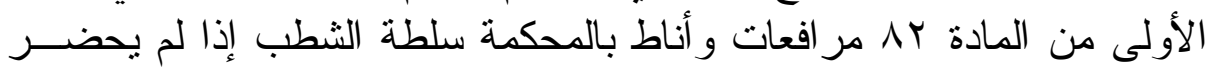

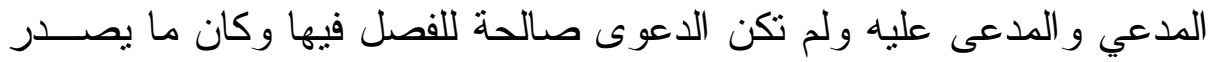

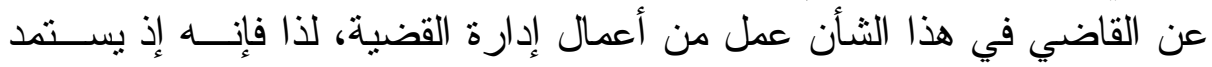

(') و هكذا يعد الثطب عارضا من العو ارض المانعة لسير الخصومة القضائية، راجع فـي الإبي

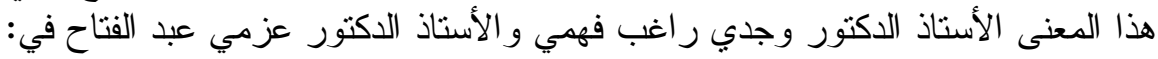

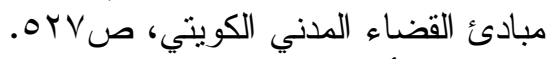

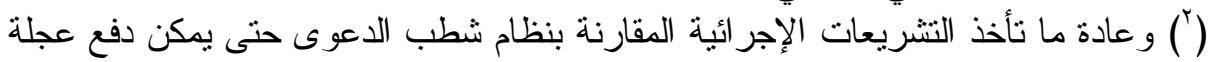

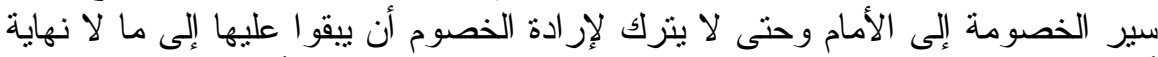

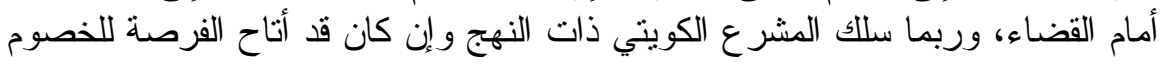

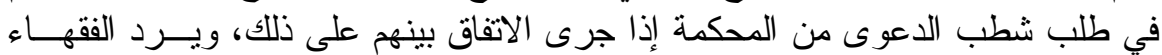

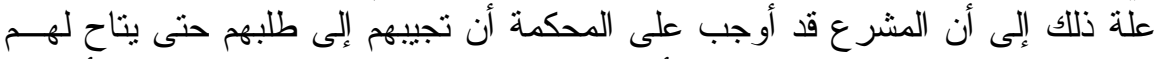

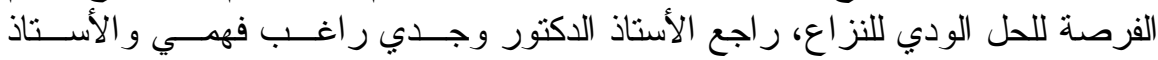

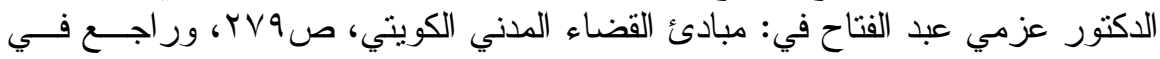
Vincent et Guinchard; op. cit. p. 517 الثطب في النظام الإجر ائي الفرنسـيسئ فئادي

No. 542. ور اجع أيضا:

R. Guillien; J. Vincent; Lexique de termes juridiquees, Dalloz, Paris. 1981. p. 58.

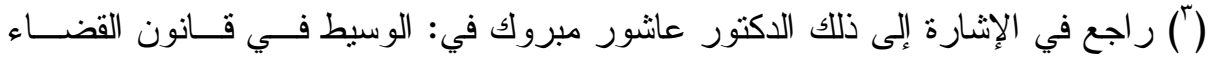

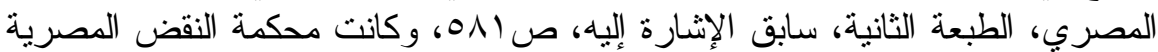

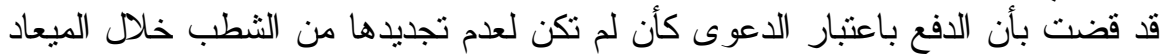

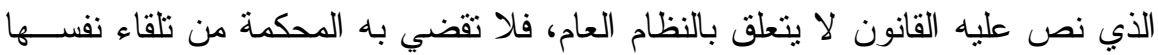

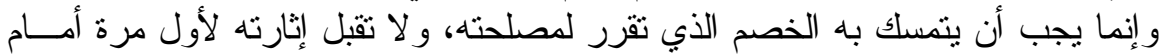

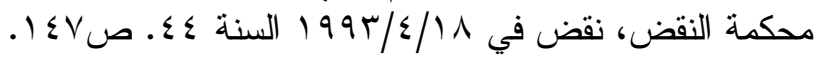


صفته من هذه الطبيعة لا يكون لازم التسبيب(1).

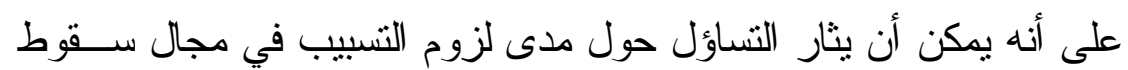

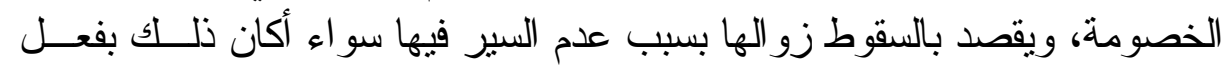
المدعي أو امتتاعه، وقد اثثترط المشر ع للسقوط انقضاء ستة أشنهر مــن تــاريخ

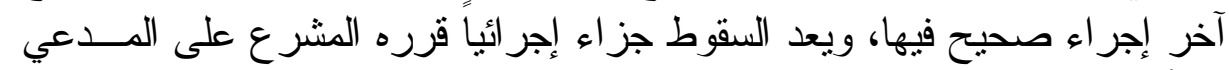

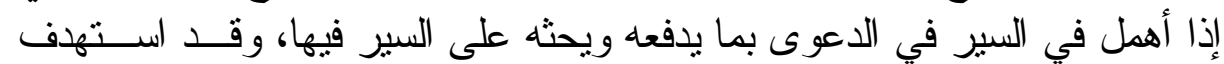

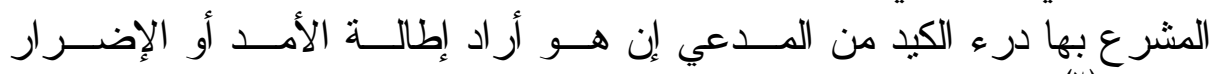

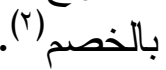

ويشترط المشر ع لسقوط الخصومة عدم السير فيها وذللك كما لو كانــــ الخصومة في حالة وقف أو انقطاع، كما يجب أن يتو افر الإهمال من المدعي؛

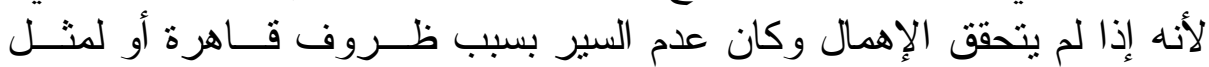

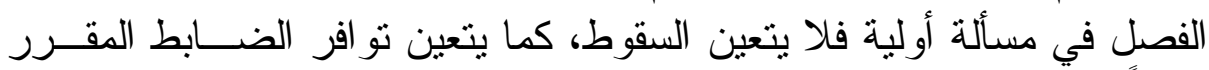

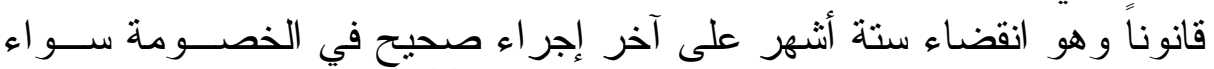

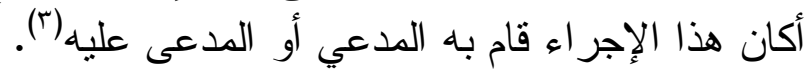

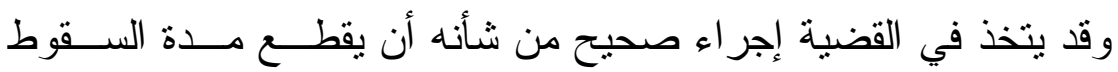

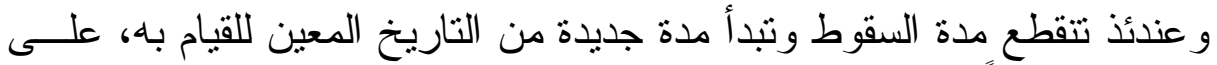

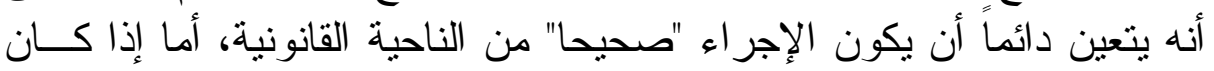
الإجر اء غير صحيح أو خار ج عن نطاق الخصومة ذاتها منل مجــرد إنــذار الخصم فلا انقطاع.

ويجوز لمن كان مدعياً عليه في القضية أن يتمسك بسقوط الخصومة إما

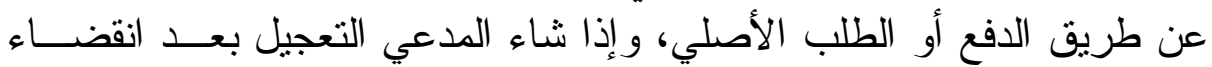
الستة أثهر كان للمدعى عليه أن يدفع بالسقوط أمام ذات المحكمة، هذا ويعتبر

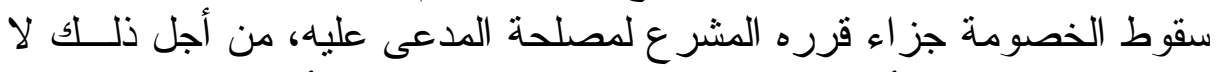

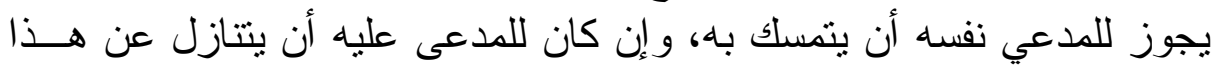
الدفع فليكن ذلك بصورة صريحة أو ضمنية و الأصل هو تحقق السقوط بقــوة

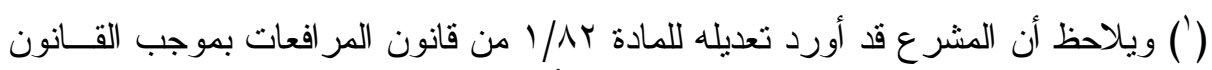

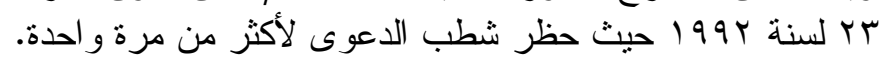

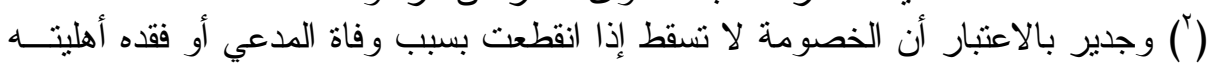
أو زو ال صفة من يمنايه.

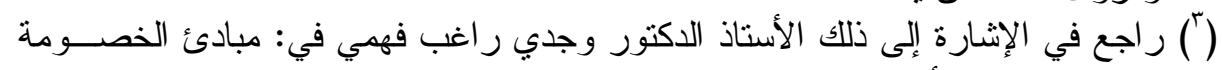

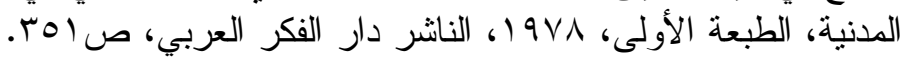




\section{القانون؛ لذا يعد الحكم به تقريرياً وليس منشئًاً (1).}

ويعد انقضاء الخصومة بسبب سقوطها انقضـــاء مبتســر اً للقضـــية لأنِ

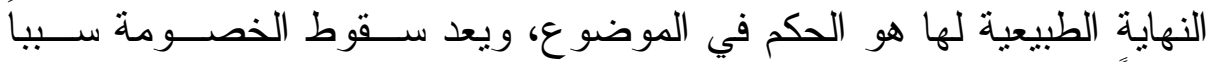

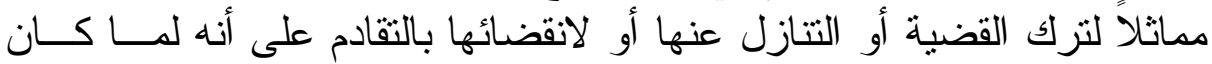

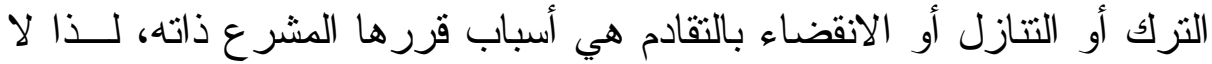

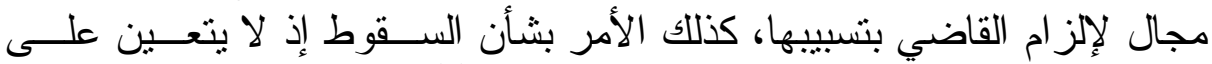
المحكمة إير اد أسباب أو حيثيات حكمها في شأنه(؟).

(') وتجدر الإثشارة إلى أن نظام سقوط الخصومة لا يسري على خصــومة الطعـن أمسام

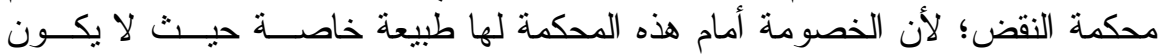

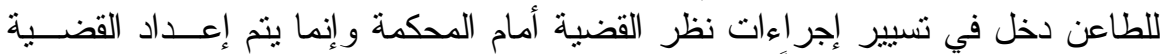

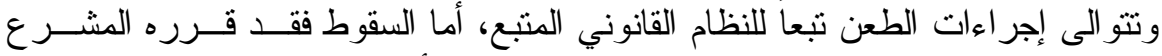

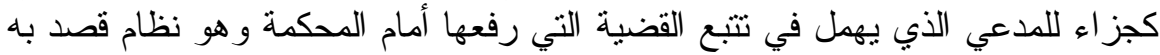

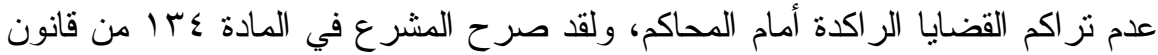

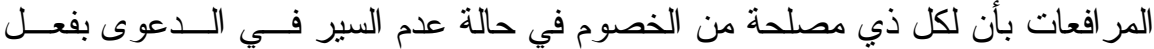

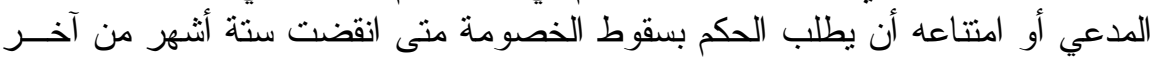

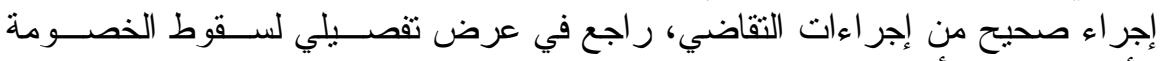

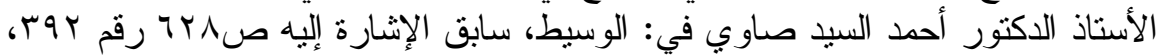

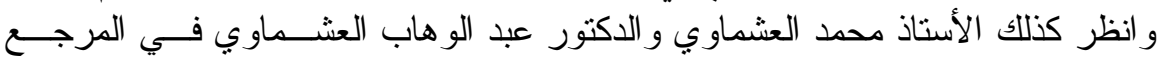

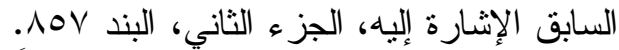

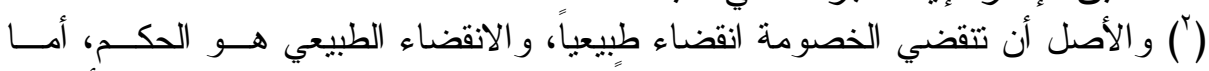

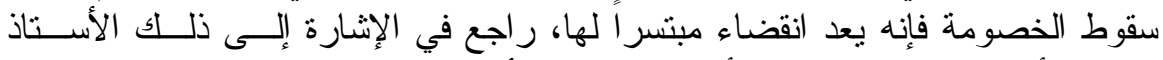

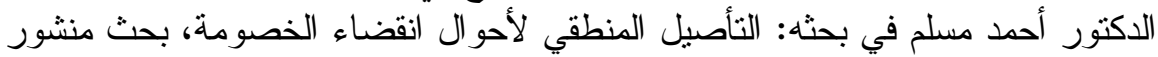

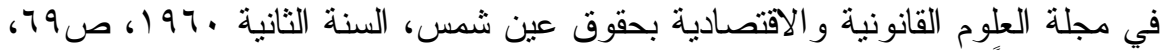

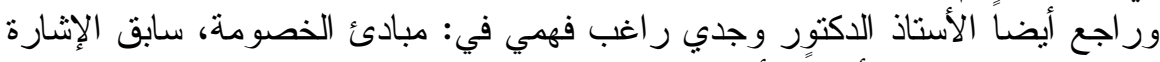

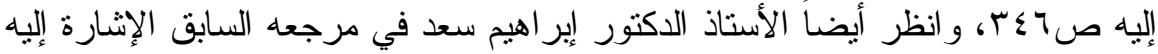

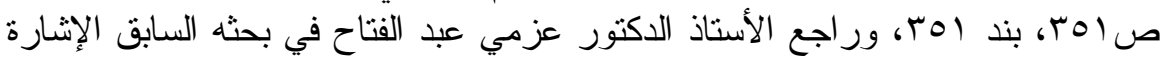

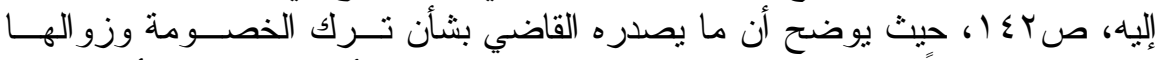

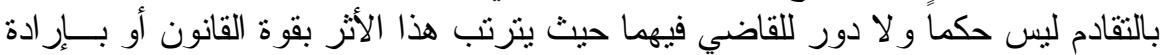

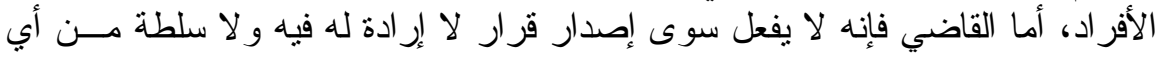

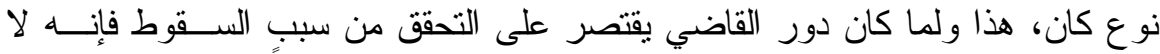

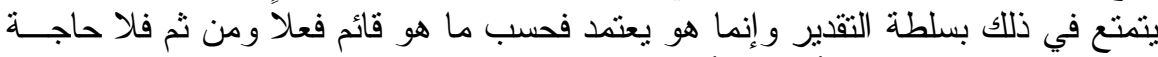
لتسبيب قراره في هذا الثأن و إن أطلق المشر عـ على هذا القر ار لفظ الحكم. 


\section{المطلب السادس \\ الحكم بالمصاريف بين التسبيب وعدم لزومه}

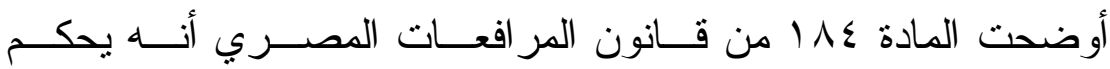

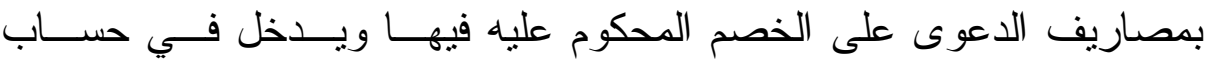
المصاريف مقابل أتعاب المحاماة، و إذا تعدد المحكوم علبهم جاز الحكم بقسمة المصاريف بينهم بالتسوية أو بنسبة مصلحة كل منهم في الدعوى على حســب الدابـ

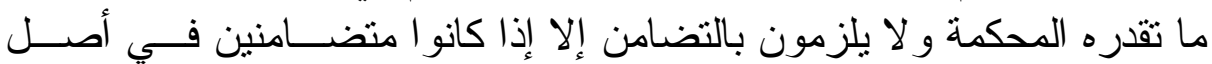

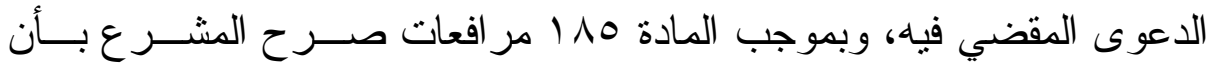

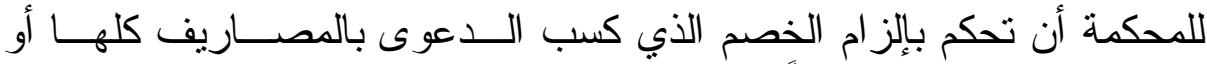

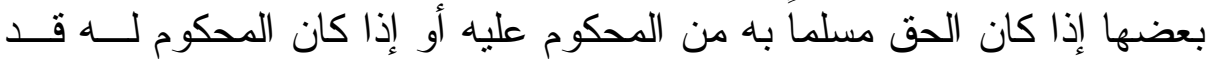

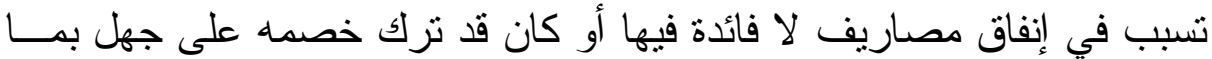

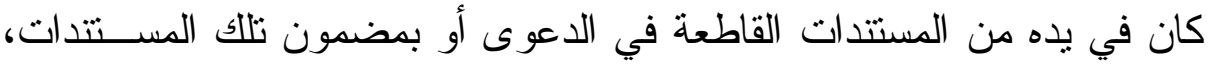
وبموجب المادة \1 1 فإنه إذا أخفق كل من الخصمين في بعض الطلبات جاز الحكم بأن يتحمل كل خصم ما دفعه من المصاريف أو بتقسيم المصاريف بين فين فئ الخصمين على حسب ما تقدره المحكمة في حكمها، كما يجوز لها أن تحكم بها جمبعاً على أحدهما (')

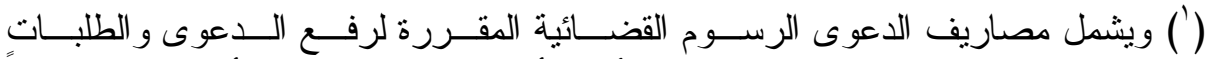

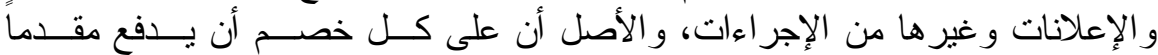

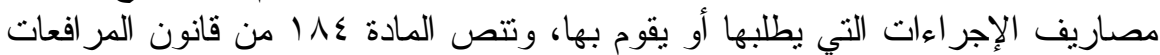

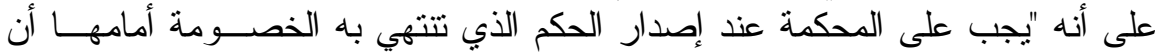

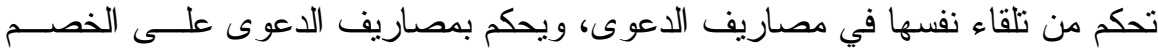

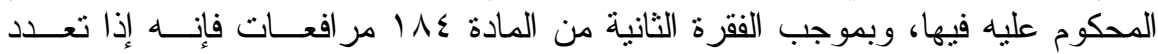

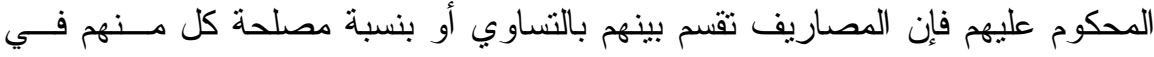

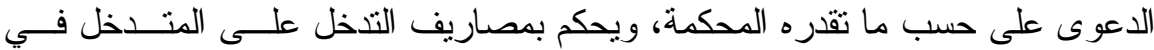

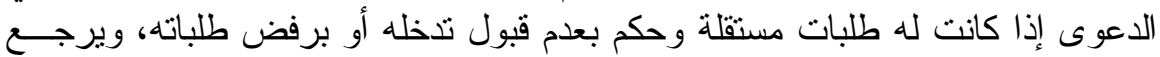

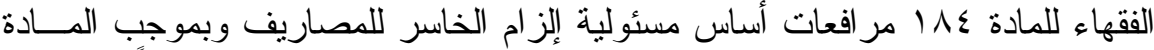

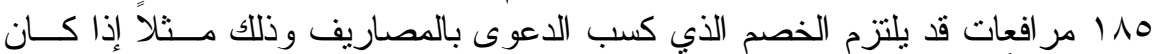

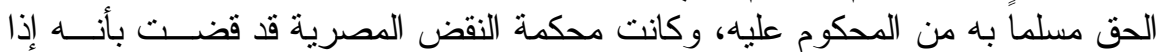

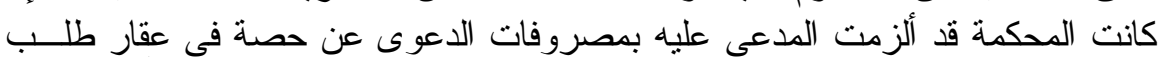

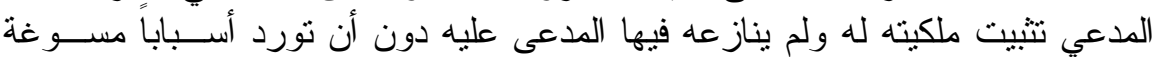

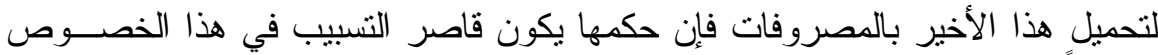
قصور ا يستوجب نقضنه، حكم نقض في 
ومن المقرر بداهة أنه يكفي للحكم بمصاريف الدعوى أن يكون المحكوم عليه قد خسرها دون حاجة لإير اد أي سبب آخر في الحكم، كما و أن للقاضد

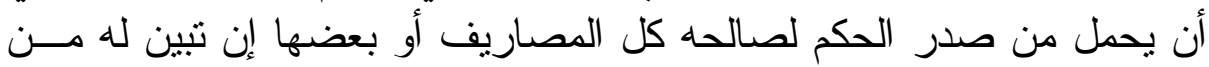

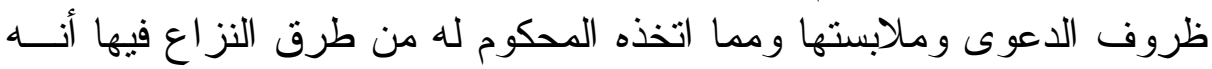

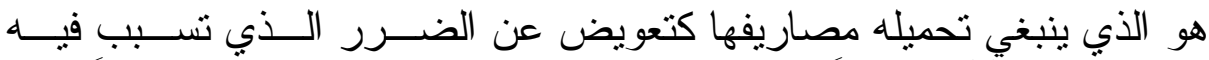

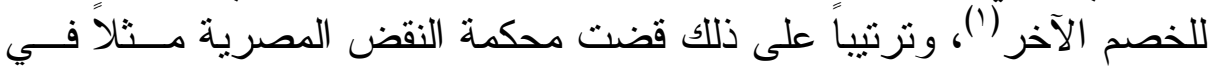

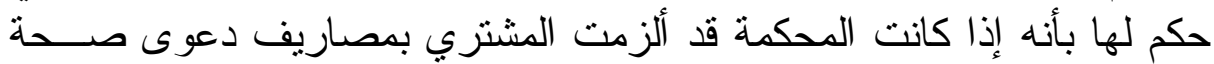

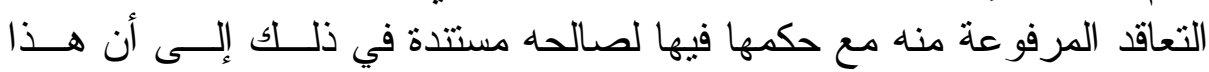
المشتزي بعد أن رفع دعو اه بطلب تتقيص الثمن قد قصر طلباته الختامية على

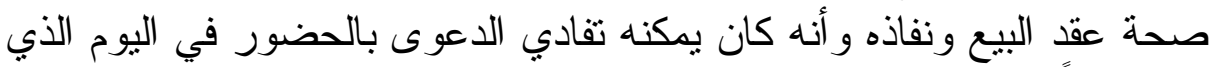

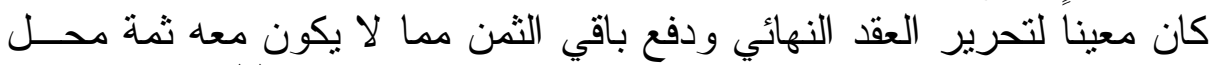
لتحميل البائع مصروفاتها فان هذا الحكم لا مخالفة فيه للقانون (؟). لكن على من تقع مصاريف التذخل في الدعوى؟ الأصل أن التـدخل إذا (') راجع الأستاذ الدكتور عزمي عبد الفتاح في تسبيب الأحكــام، ســابق الإثــارة إلبـــه ص ص 1 . ( ) وكانت محكمة النقض قد قضت بأنه إذا كان الثابت أن المدعى عليه قد ناز ع خصـــه

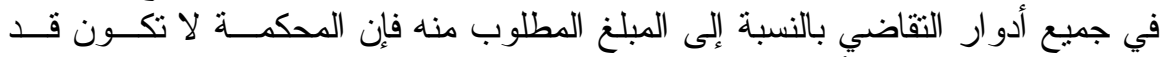

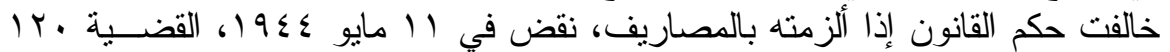

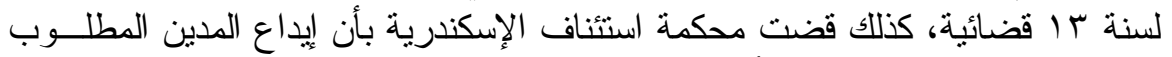

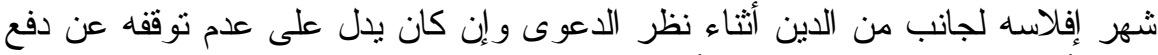

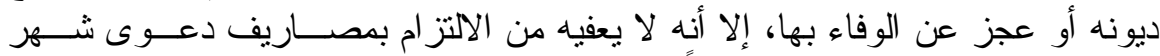

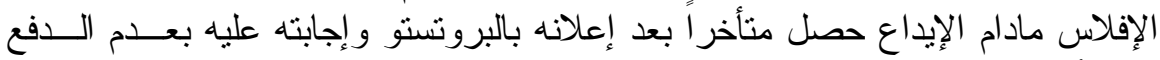

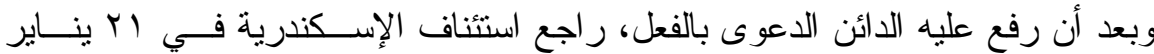

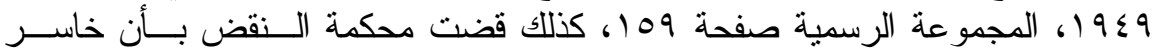

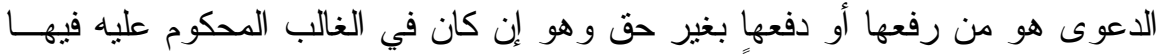

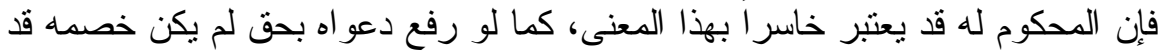

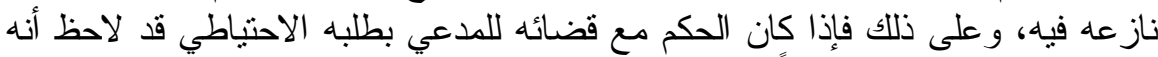

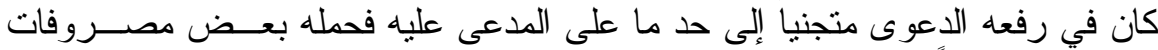

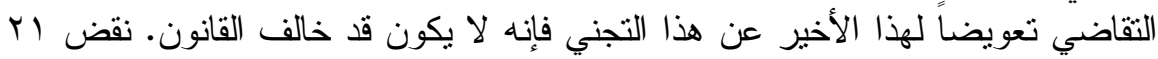

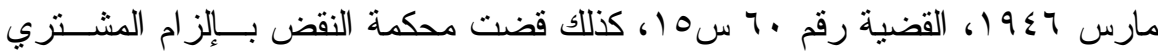

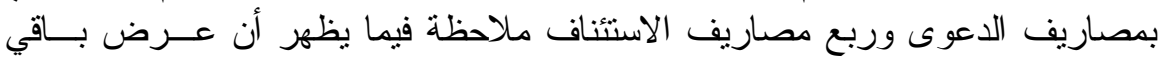

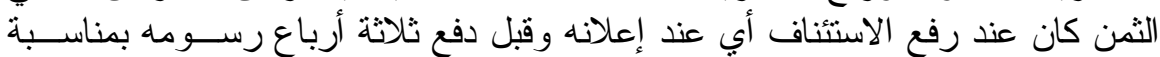

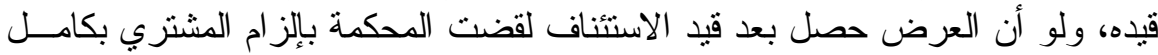

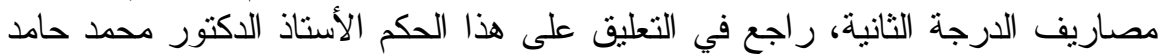

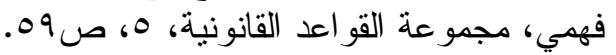




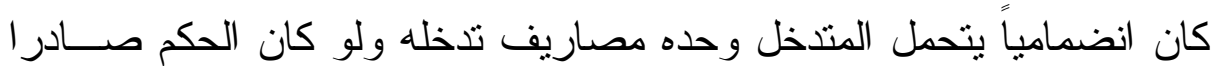

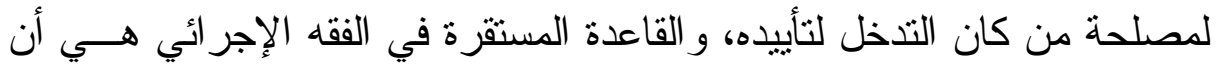

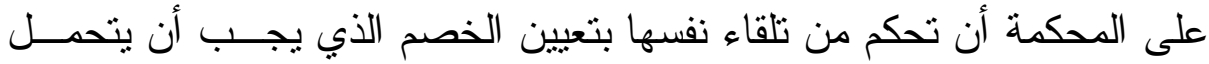

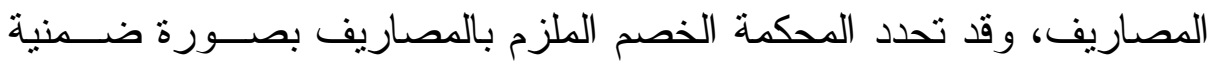

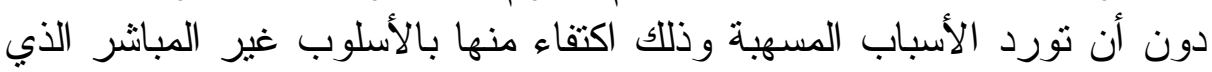

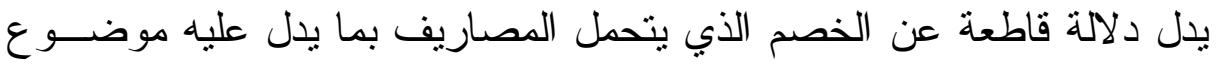

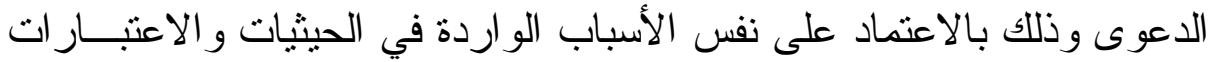

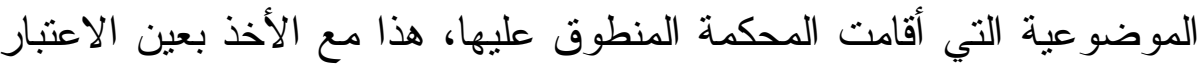

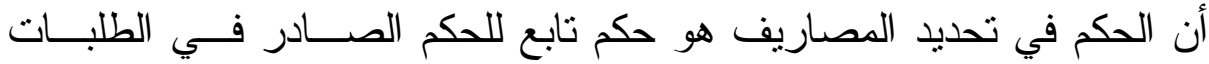

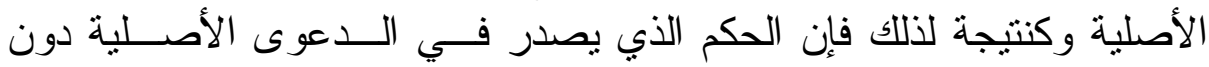

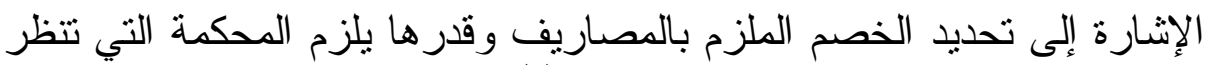

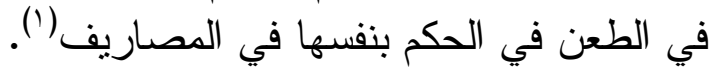

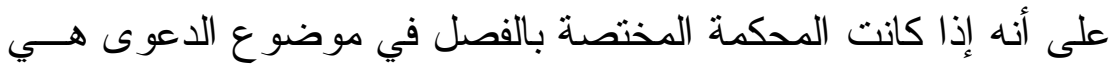

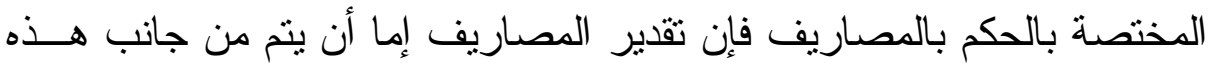

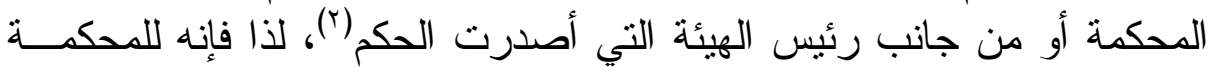

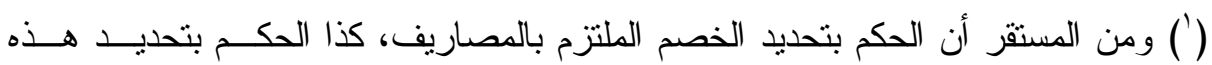

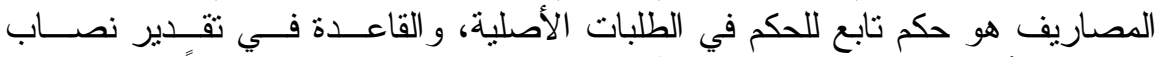

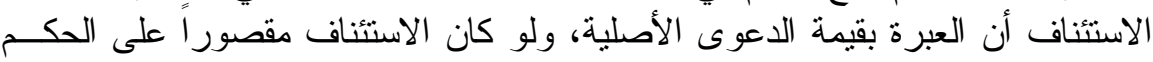

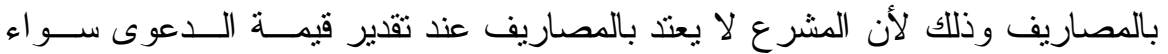

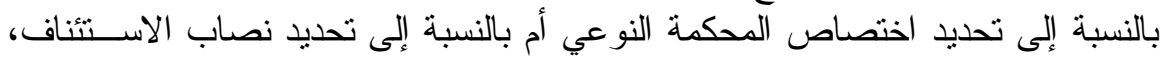

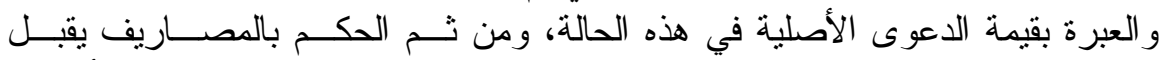

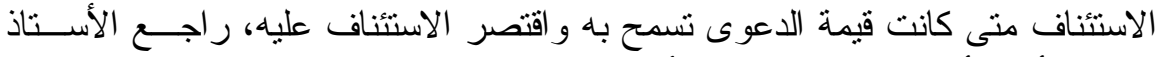

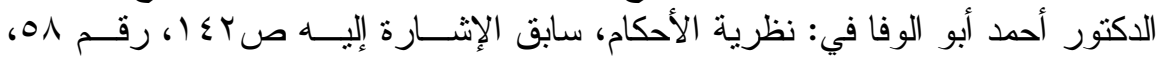

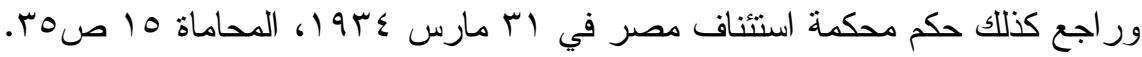

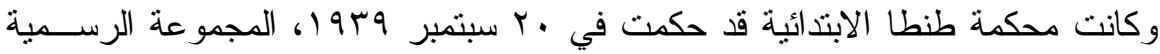

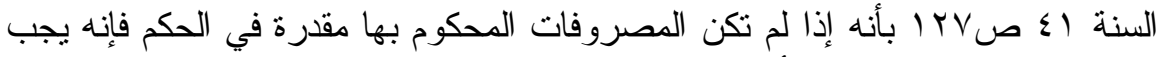

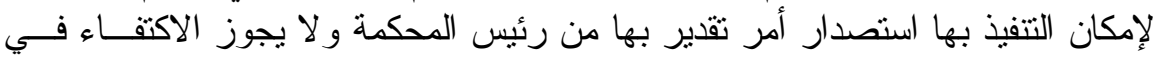

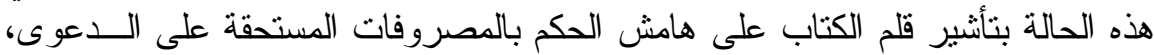

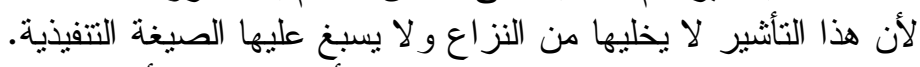

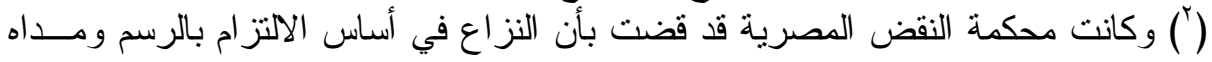

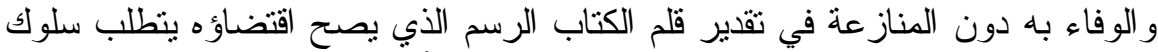

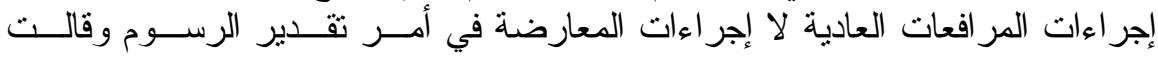

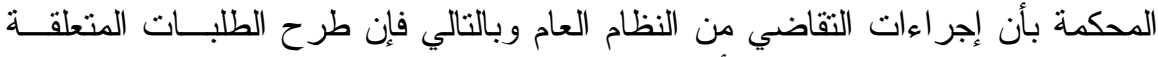

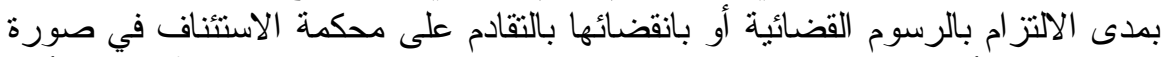

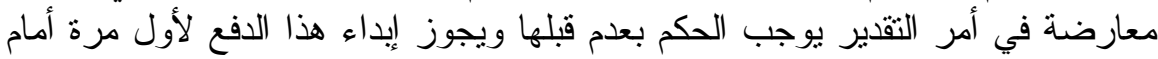




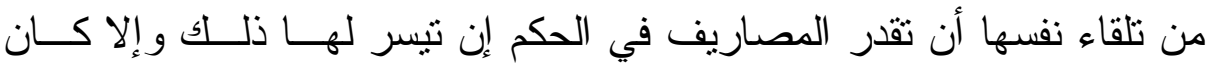

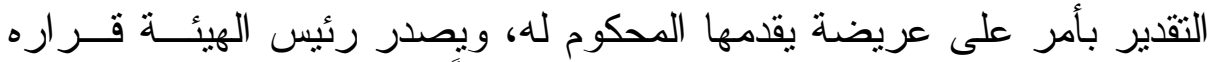

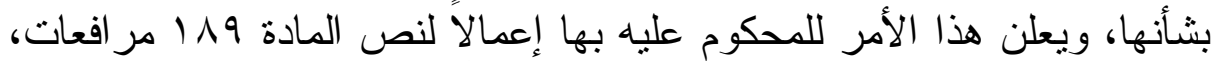

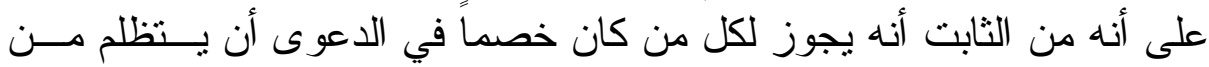

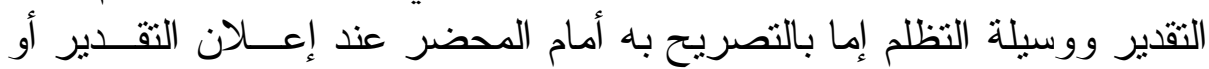
بتقرير في قلم كتاب المحكمة التي أصدرت الحكم في ظرف التهات الثمانية أيام التالية

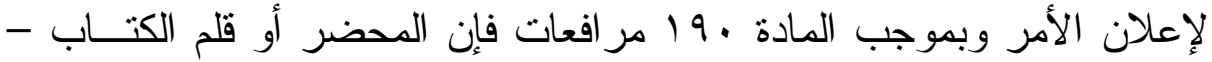

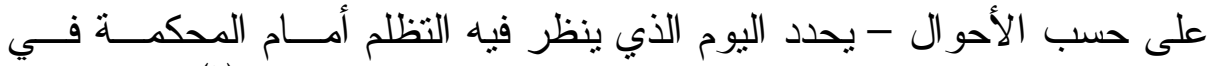

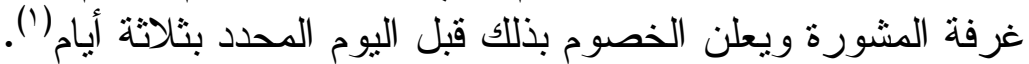

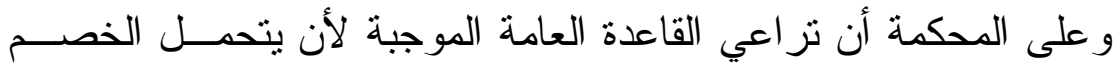

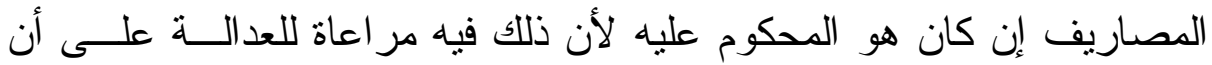

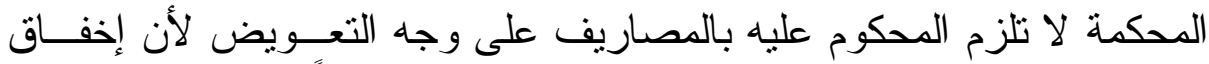

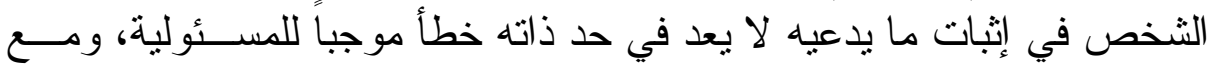

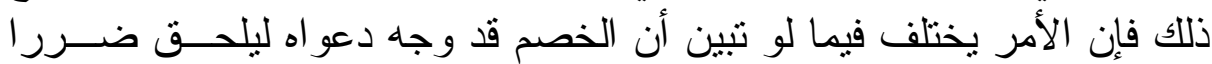

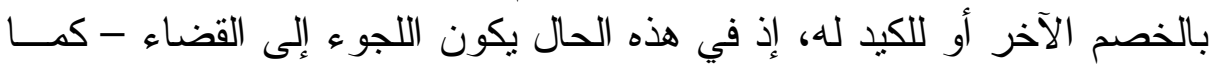

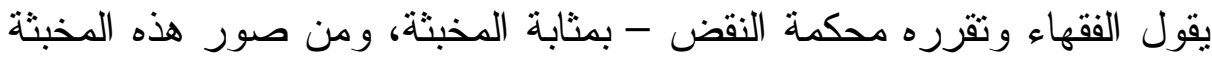

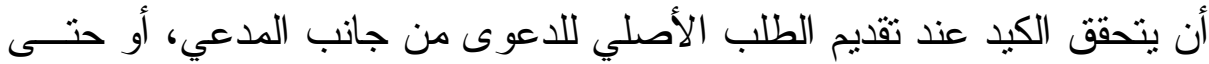

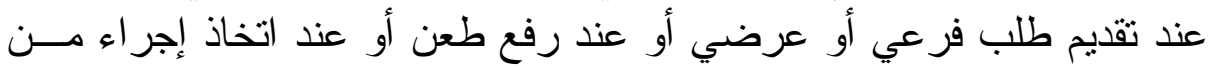

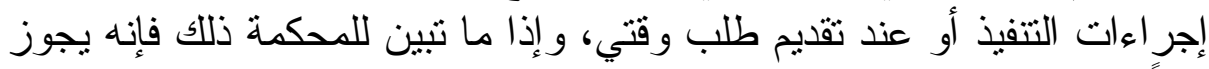

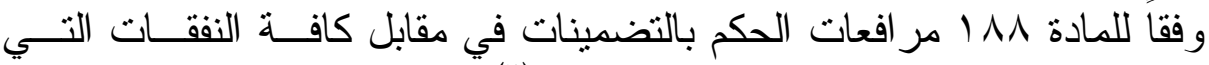

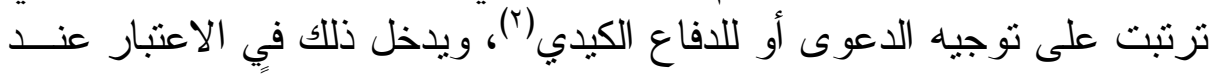

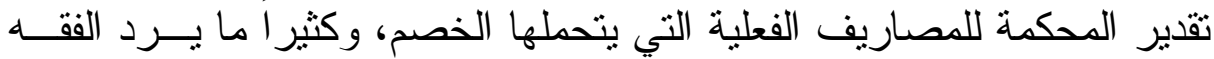

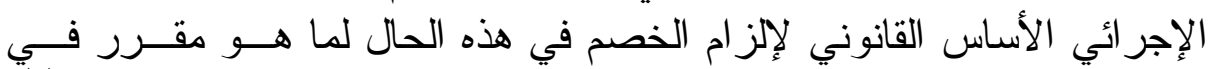

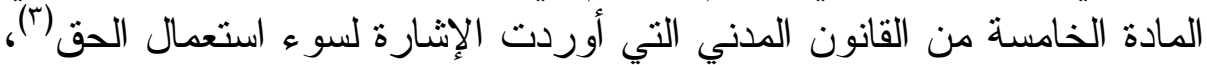

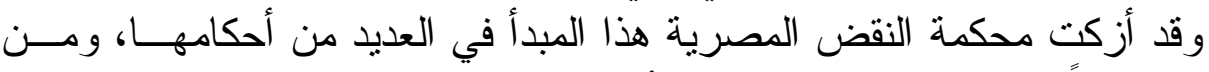

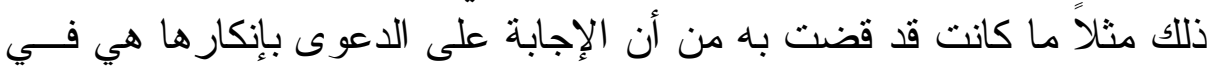

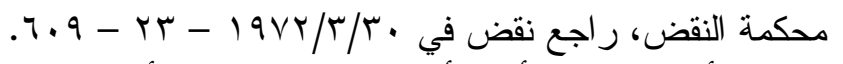

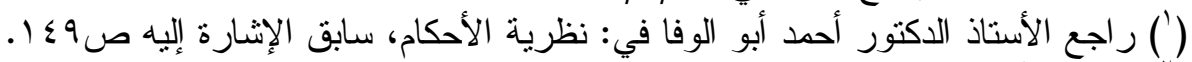

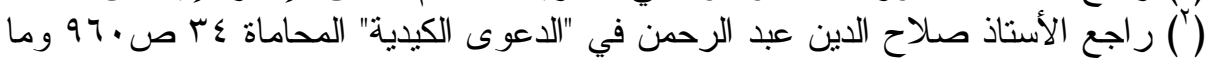
بعدها. (") راجع الأستاذ أبو هيف في: المر افعات المدنية و التجارية، سابق الإثــــارة إليـه، فقــرة 
الأصل حق مشروع لكل مدعى عليه يقتضي بـه إلز ام خصمه بإثبات مــدعاه،

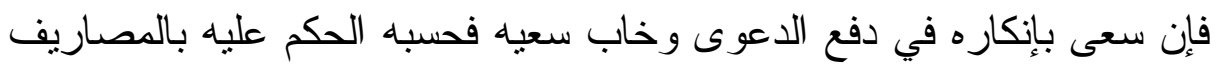

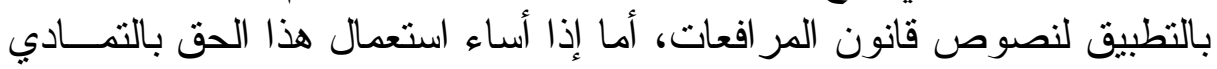

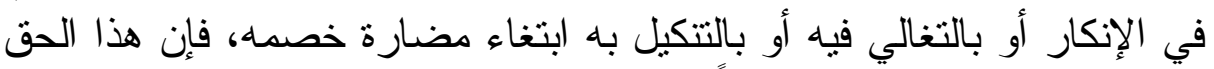

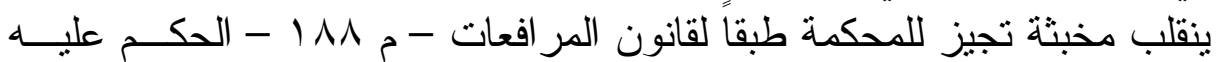

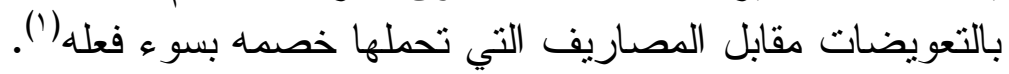

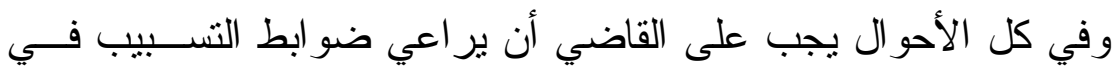

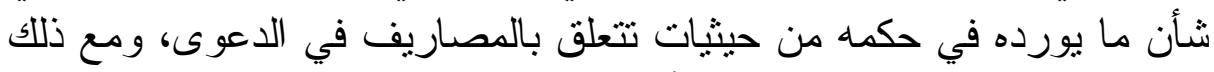

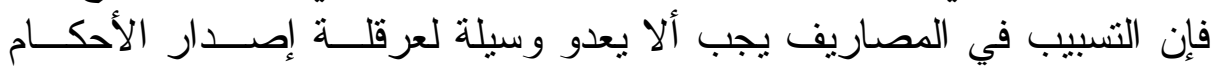

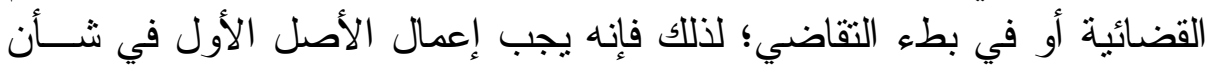

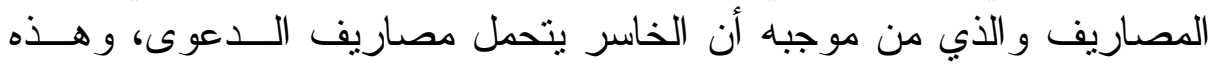

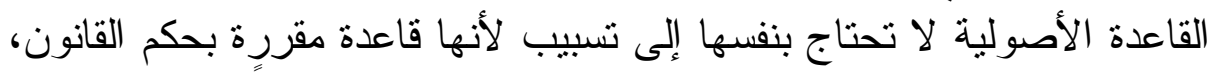

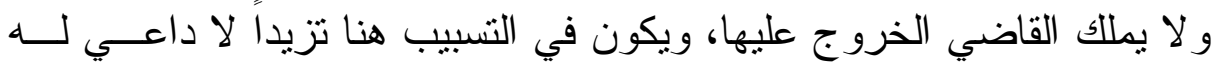

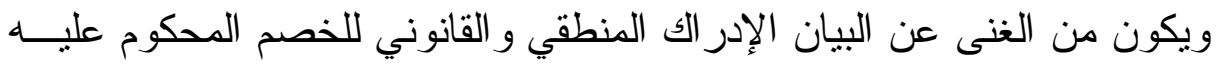

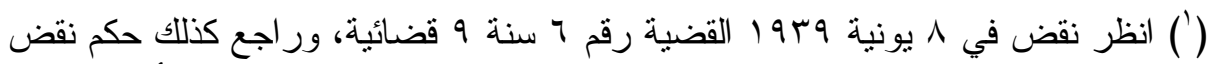

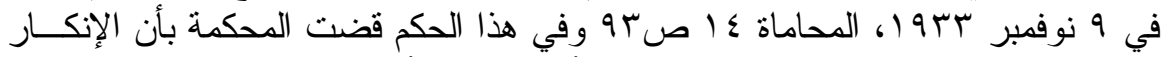

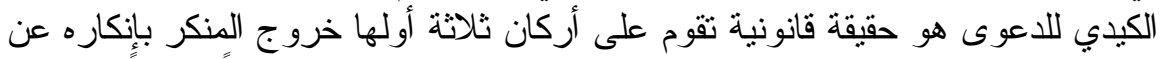

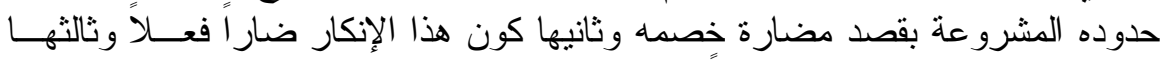

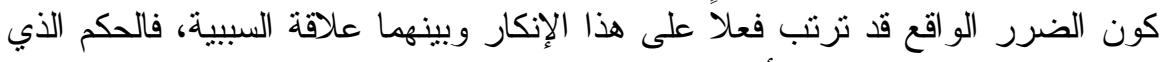

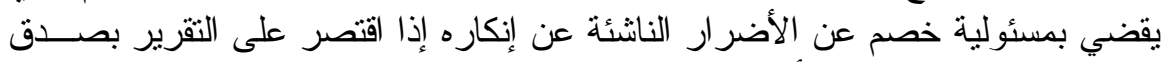

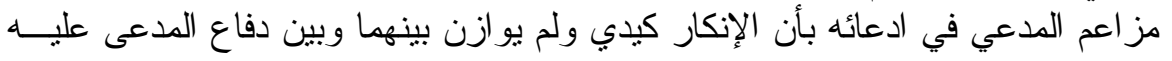

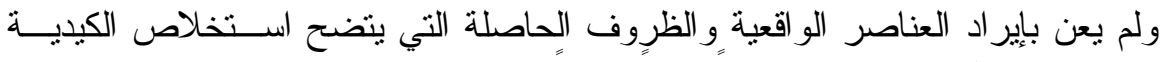

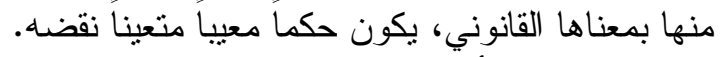

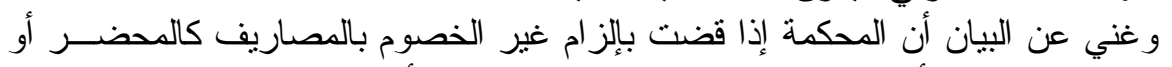

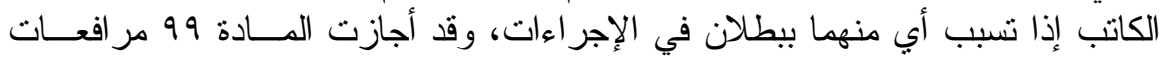

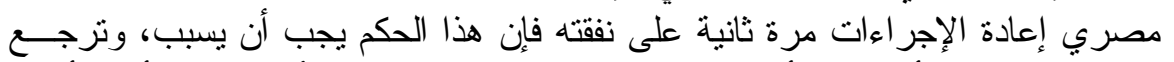

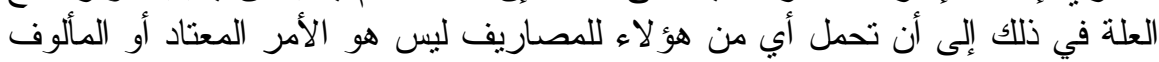

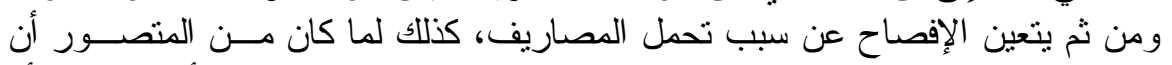

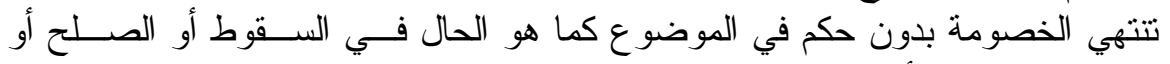

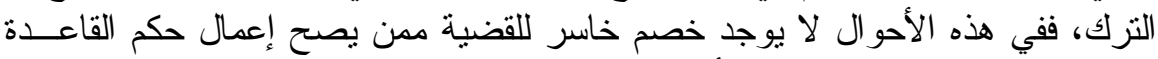

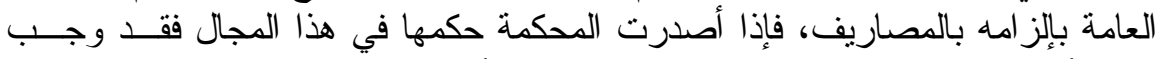

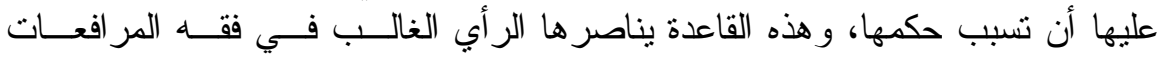

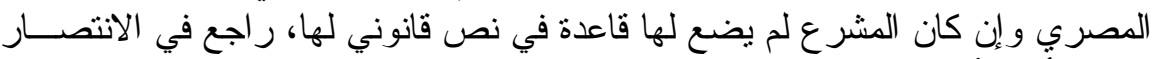

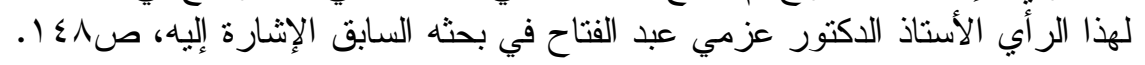




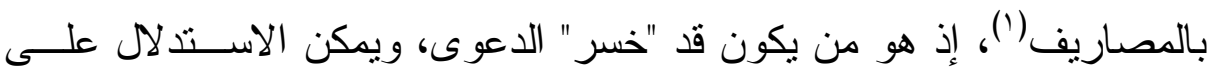

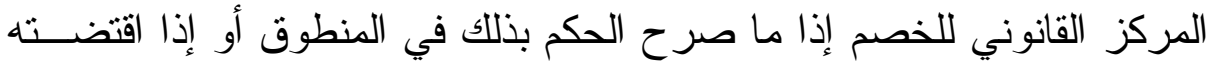

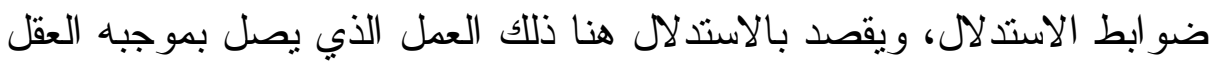

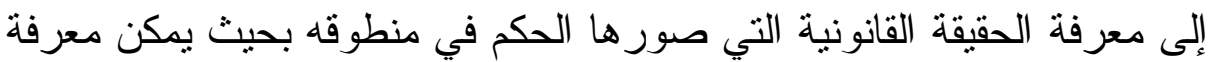

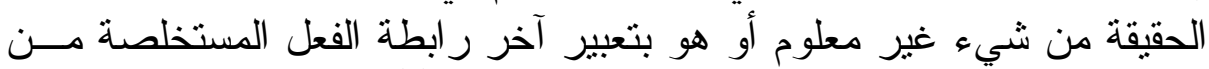

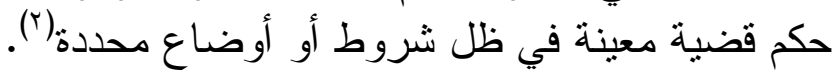

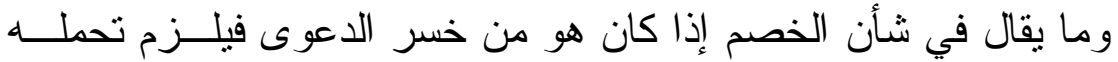

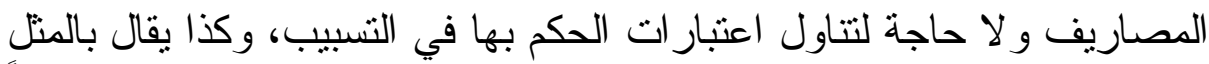
عندما يخفق الخصمان في بعض الطلبات، وحيث يتعين على المحكمة - إعمالاً

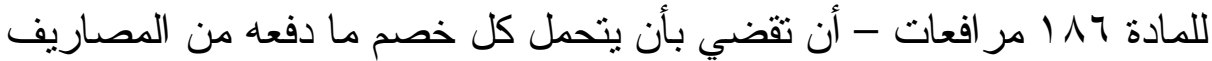

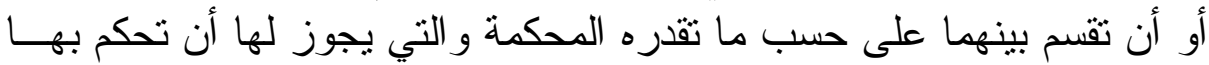

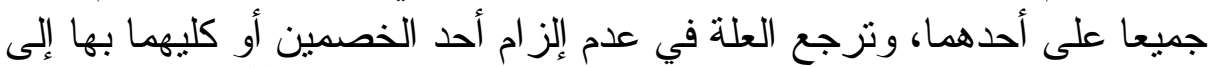

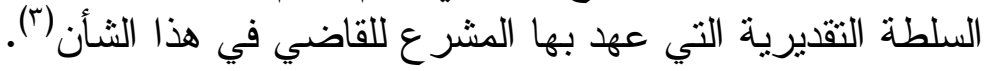

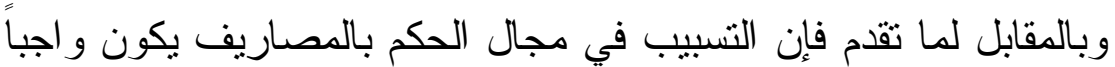

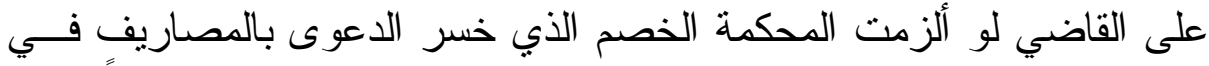

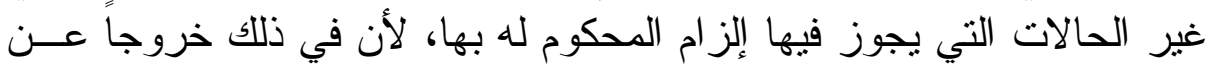
حكم القو اعد العامة، وما فيه خروج عن حكم هذه القو اعد يجب لإن تسبيبه (ء).

(') راجع في الإثشارة على ذلك الأستاذ الدكتور فتحي و الي في الوسيط، سابق الإثشارة إليه،

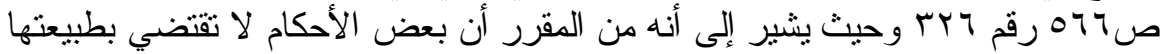

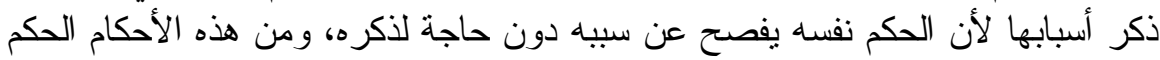

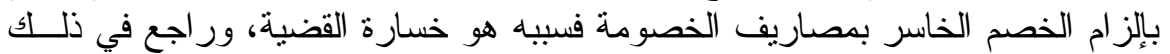

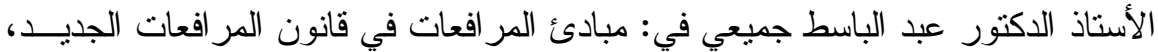

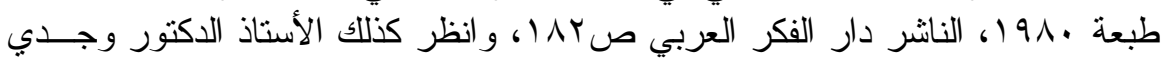

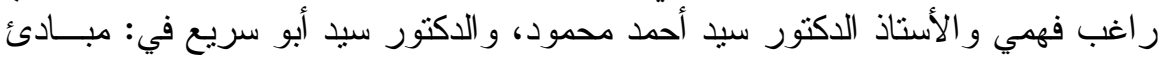

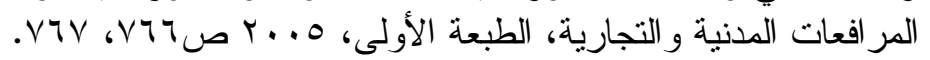

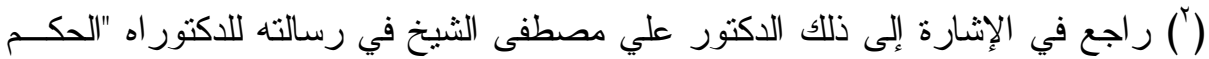

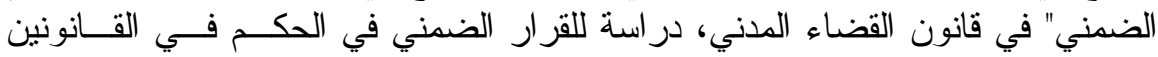

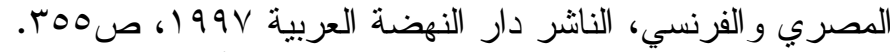

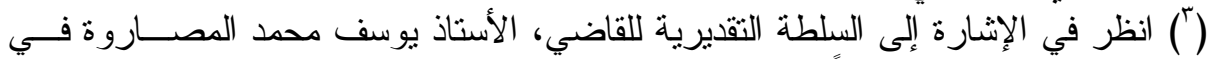

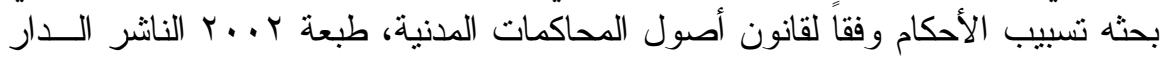

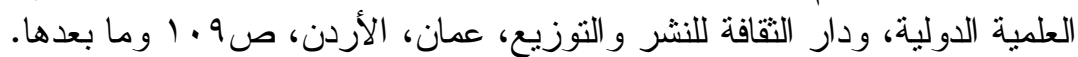

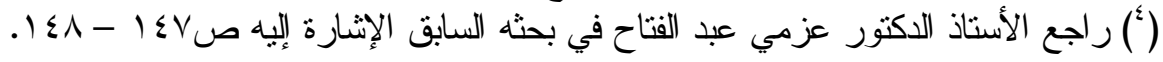




\section{المبحث الثالث \\ حقيقة التسبيب في الأحكام القضائية \\ بين الانعدام و القصور}

على القاضي أن بهتدي في صياغة حكمه بالأسس المحققة للغاية التـي توخاها المشرع في لزوم تسبيب الأحكام(')، ومن الضو ابط المنطقية المتعـين فيني

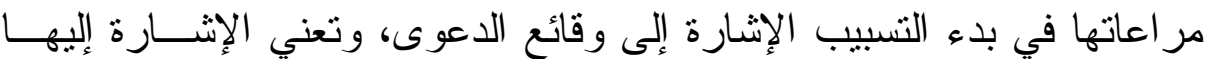

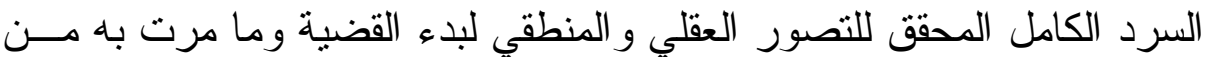
تطور حتى أن أصدرث المحكمة قرار ها بقفل باب المر افعة فيها(؟)، ومدا يعيب

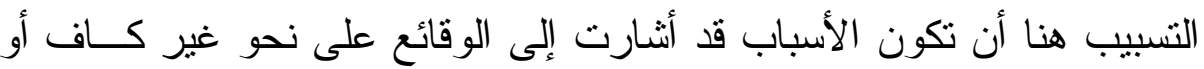
غير صحيح أو أن يكون القاضي في تسبيبه لم ير اع التزنيب الو اقعي للأحداث بما بدعو إلى الثك أو الريبة أو بعزز الظن ويبعد البقين (r)، كما بعد من عقبات

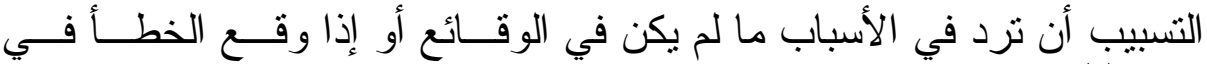
السرد(ع)، و لا بعد من التزيد أن نتضمن الأسباب ذكر أسماء الخصم و ألقــابهم

(') ولقد أحسن الأستاذ يوسف إلمصاروة حين صدر بحثه في تسبيب الأحكام بالإشتارة إلـى الـى

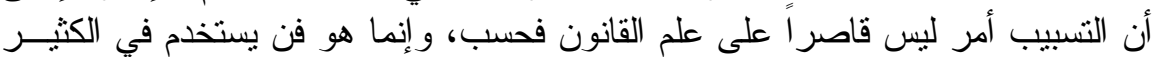

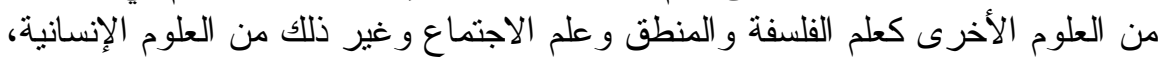

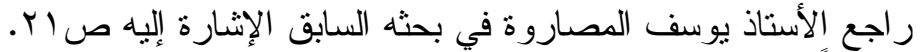

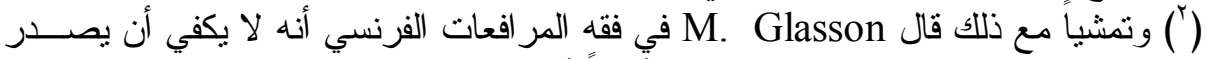

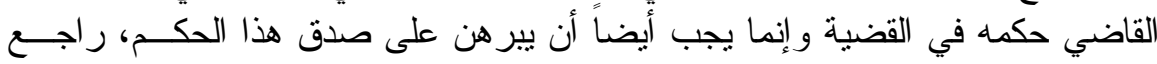

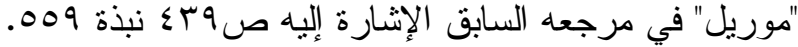

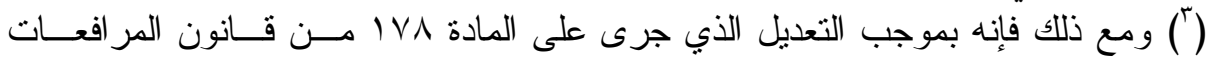

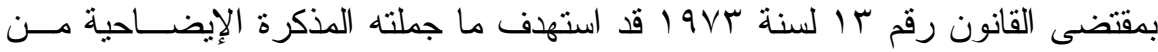

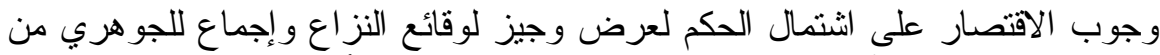

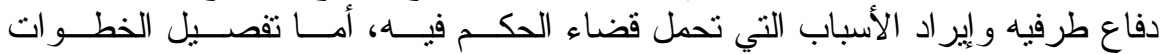

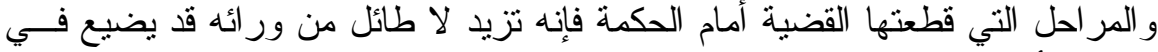

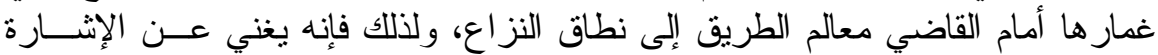

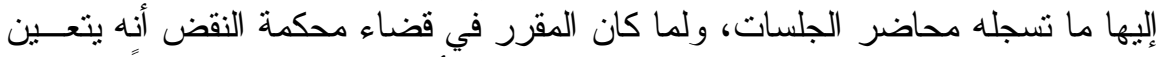

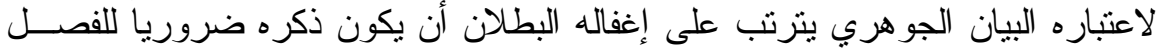

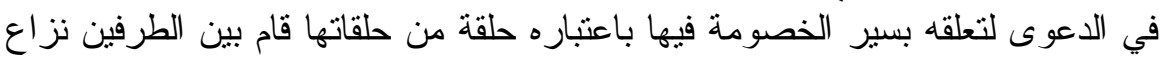

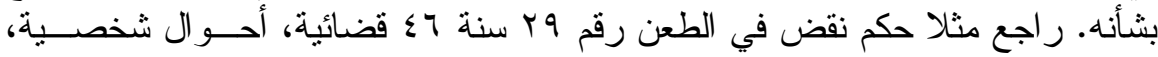

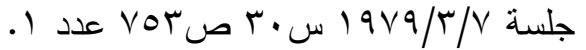

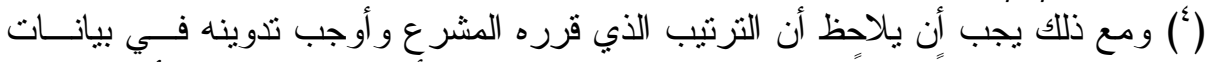

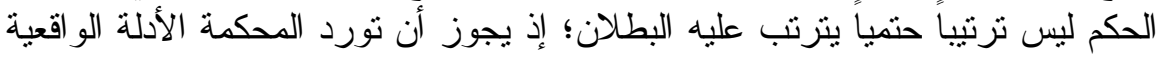

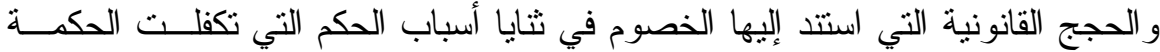

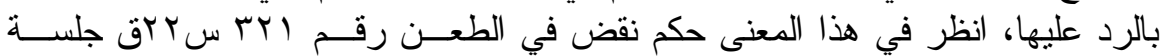




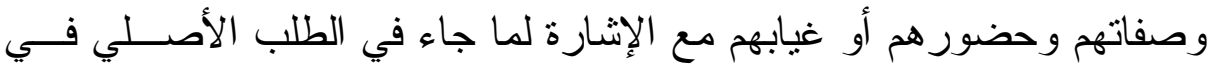

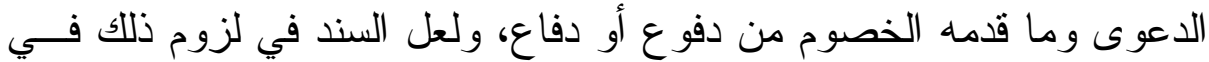

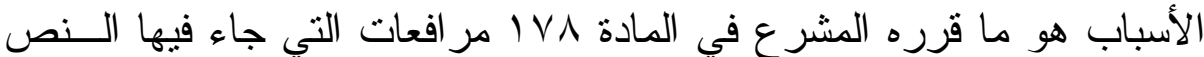

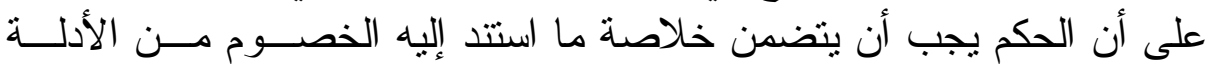

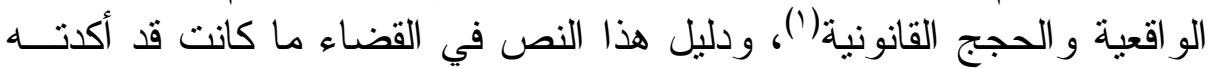

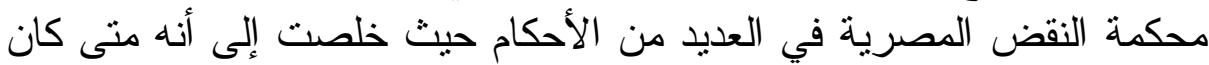

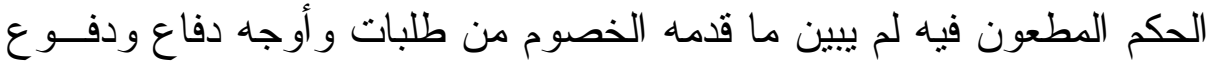

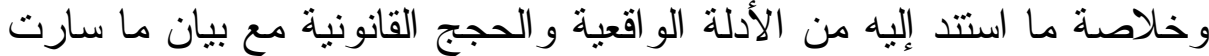

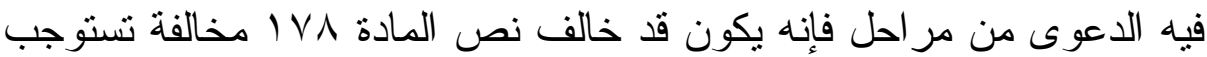
بطلانه. - مبه.

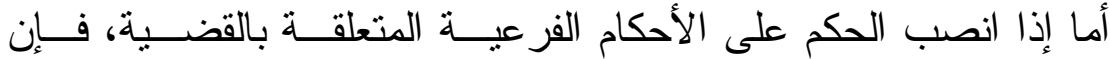

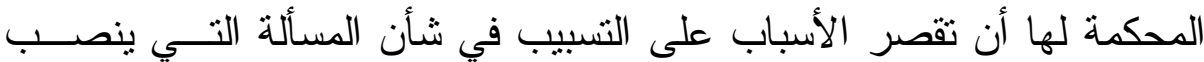

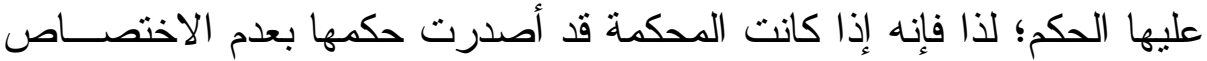

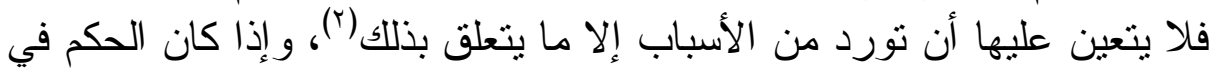

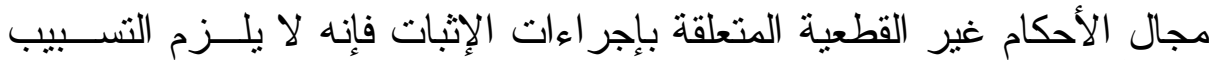

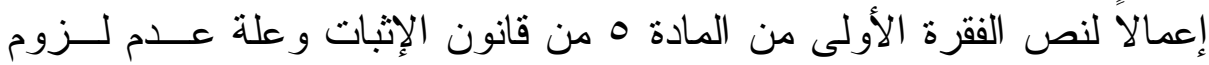

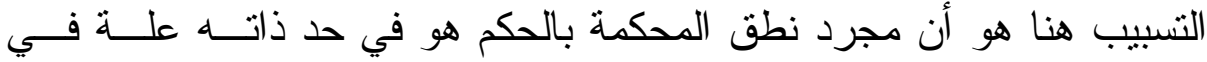

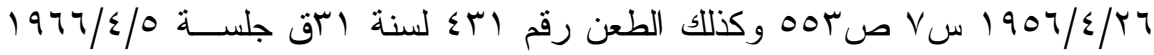
(1)

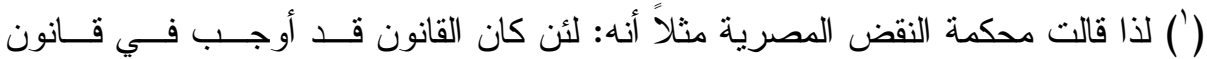

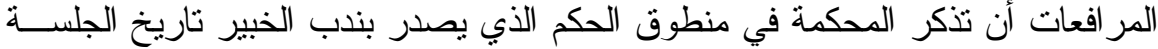

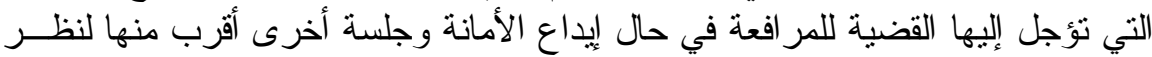

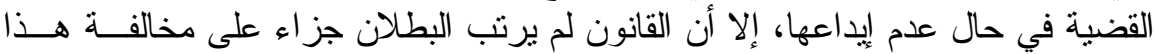

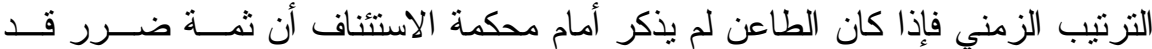

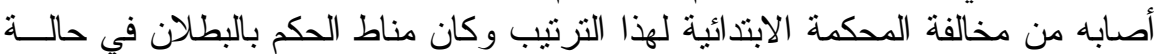

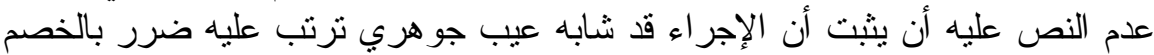

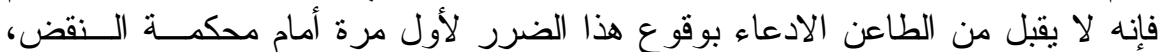

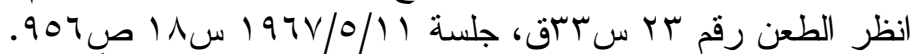

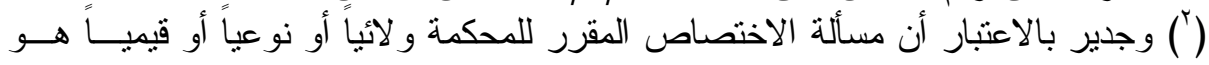

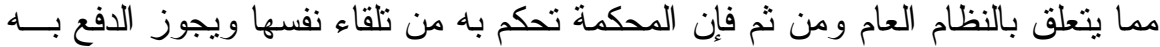

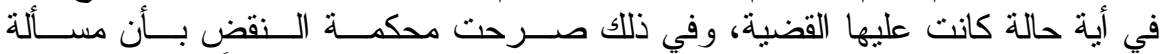

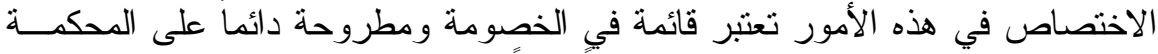

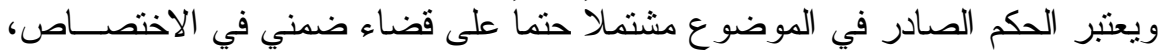

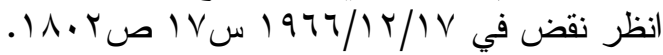


التسبيب، ثم إن هذه الأحكام غير قابلة للطعن فيها، كما وأن حكم المحكمة فــي

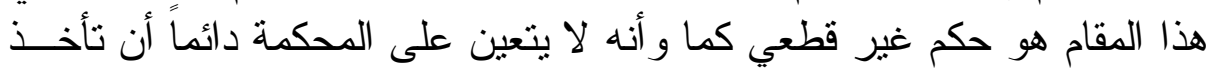
بالنتيجة التي انتهى إلبها دليل الإثبات، و غنٍي عن البيان أن هذه القاعدة لا تجد

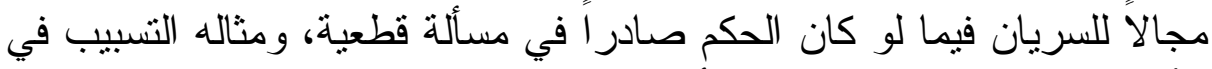

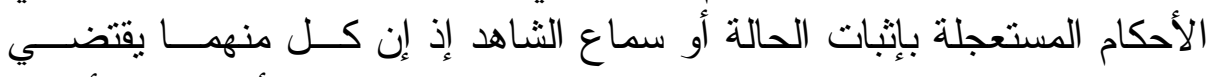
التحقيق في شروط متطلبه تقبد المحكمة ومن ثم يجب عليها أن تورد الأسباب

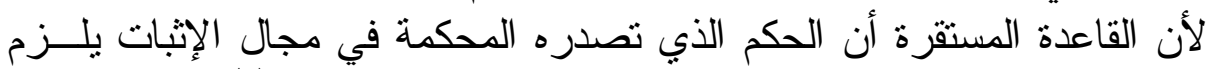
تسبيبه لو أنه قد كثف عن وجهة نظر المحكمة في الموضوع|' وينبخي في الأسباب الصحيحة أن تعكس التفكير المنطقي للقاضــي فــي فئسي وقائع الدعوى(r)" ويجب أن يضدن القاضي أسباب الحكم في ورقة الحكم ذاتها وبيرر الفقهاء هذه القاعدة على اعتبار الأصل الذي يجب مر اعاته دائماً من أن

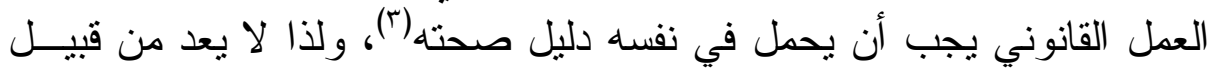

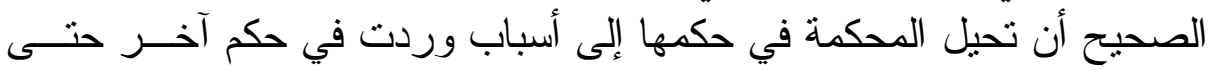

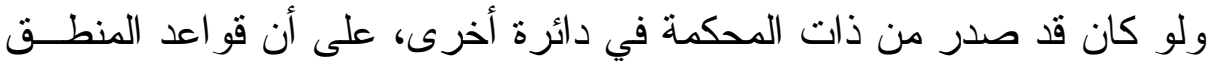

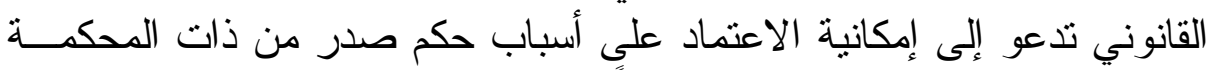
بين نفس الخصوم ومن قبيل ذلك أيضاً أن تصدر المحكمة الاسنئنافية حكمهــا الذي تؤيد فيه حكم محكمة أول درجة لأسبابه، أو أن تحيل لبعض الأسباب في

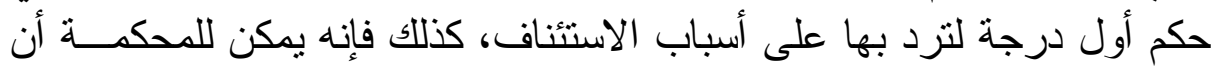

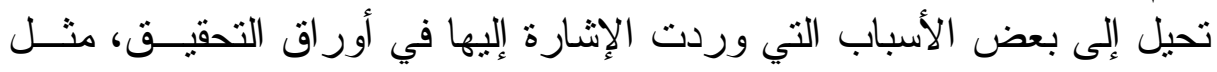
الإحالة إلى ما جاء في تقرير الخبير في القضية.

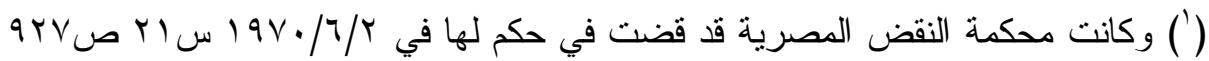

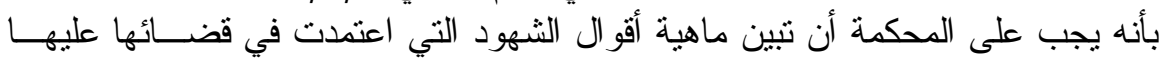

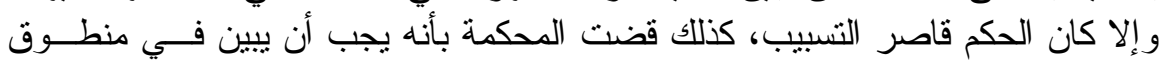

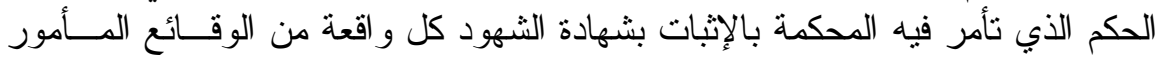

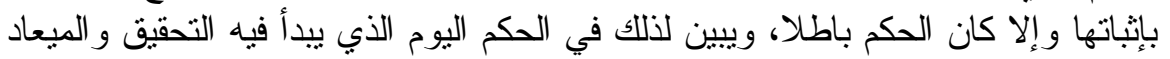

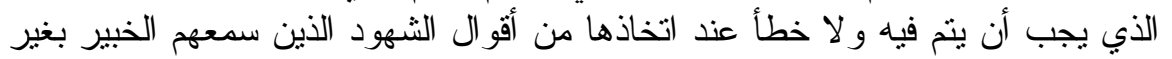
حلف يمين ضمن قر ائن أخرى في لأن الإثبات.

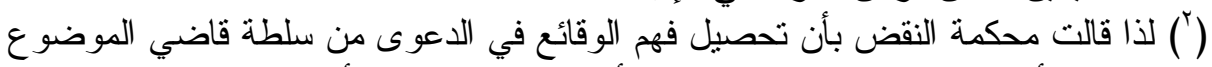

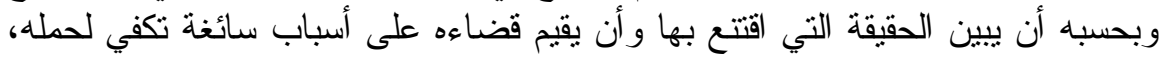

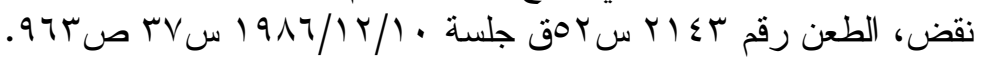

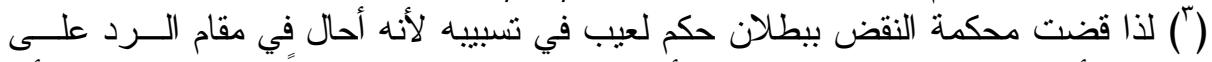

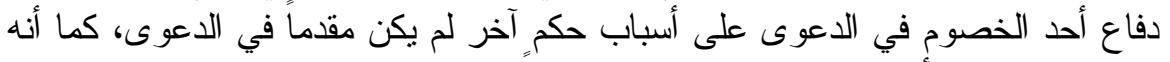

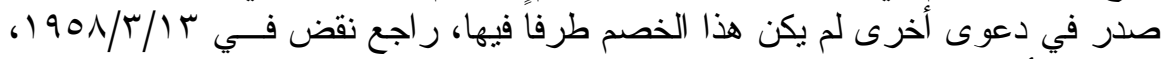

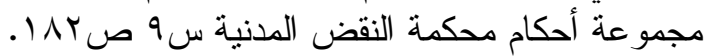


لكن قو اعد التسبيب الصحيح تقتضي دائماً أن تستتد الأسباب إلــى أدلـــة

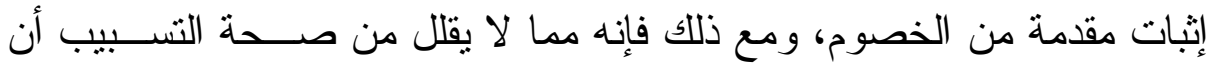

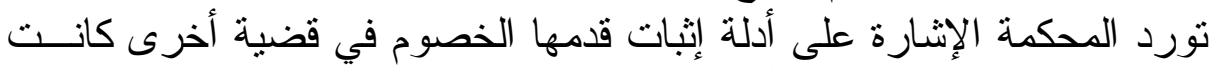
منظورة أمام نفس المحكمة (').

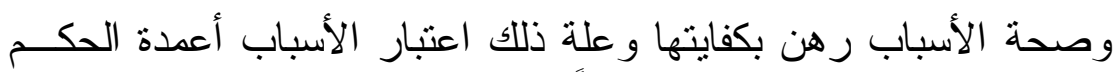

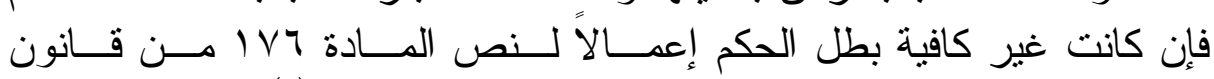

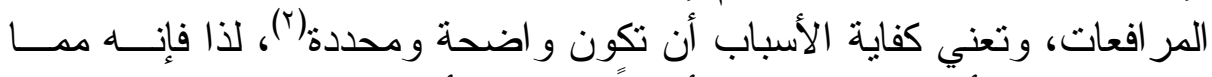

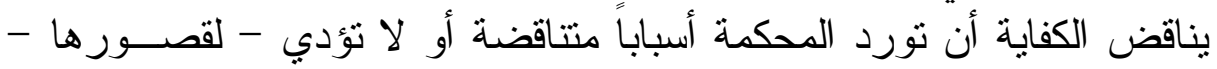

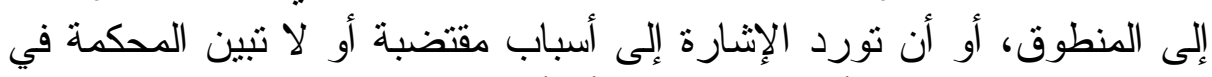

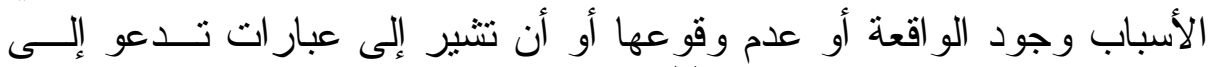

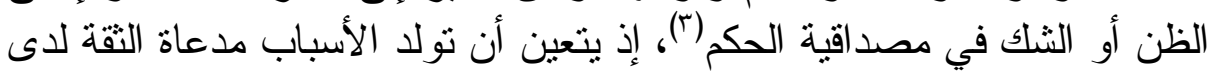

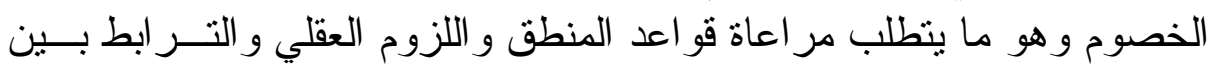

(') وتمشياً مع ذلك قالت محكمة النقضٍ بأنه حق الالتجاء إلى القضاء من الحقوق المكفولة

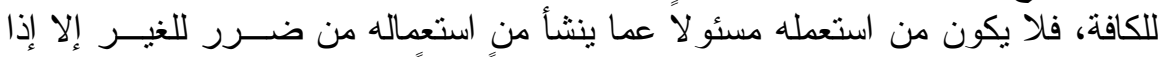

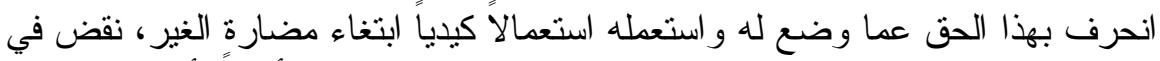

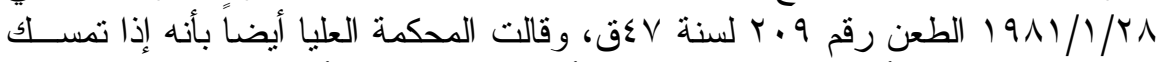

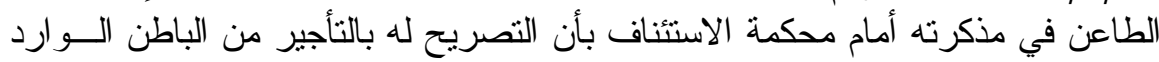

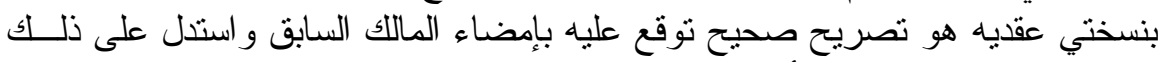

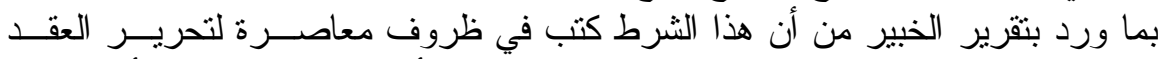

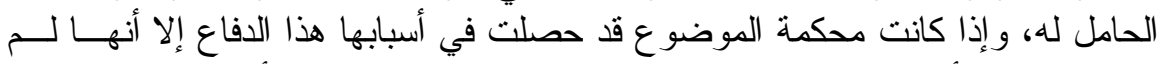

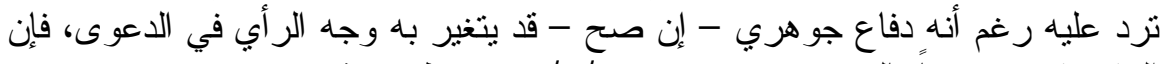

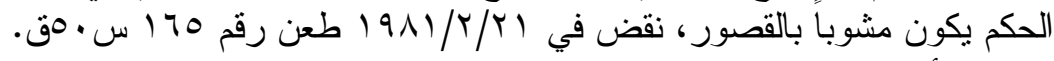

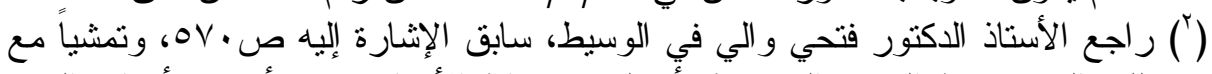

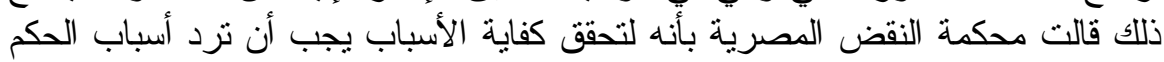

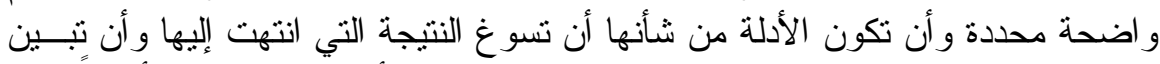

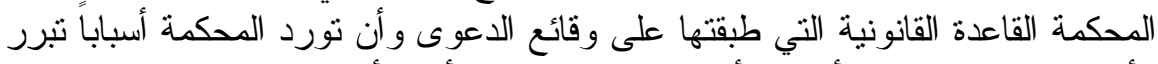

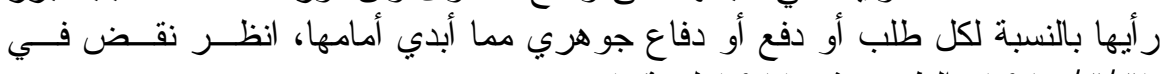

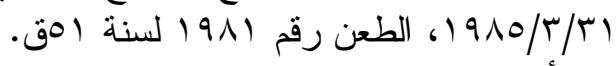

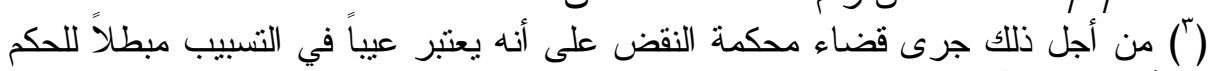

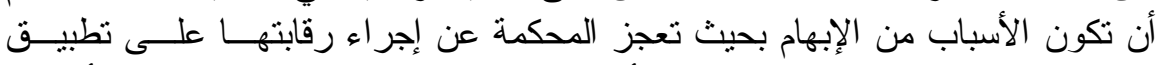

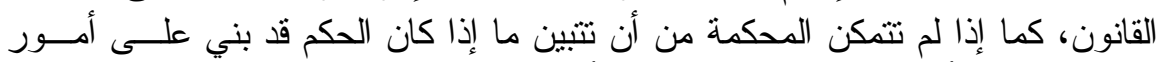

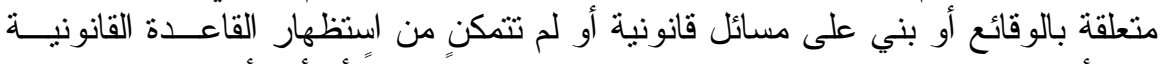

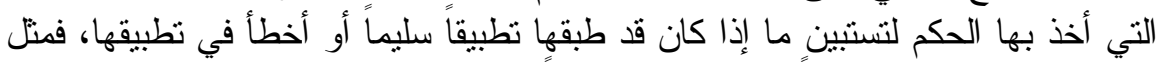

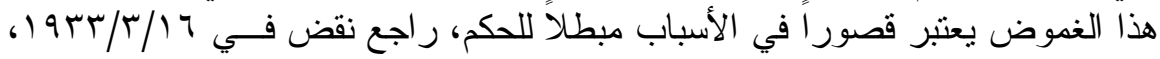

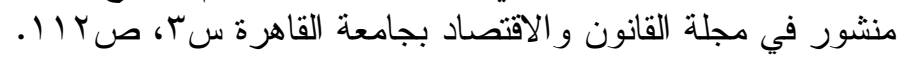


الوقائع وصحة الاستتناج القانوني و التتاسق مع أدلة الإثبات(')، كذلك يعد قضاء

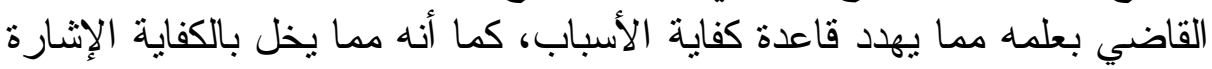

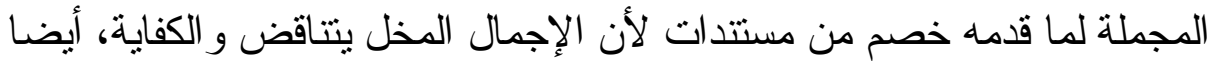

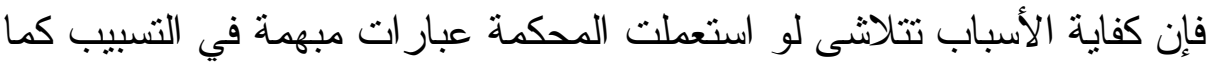

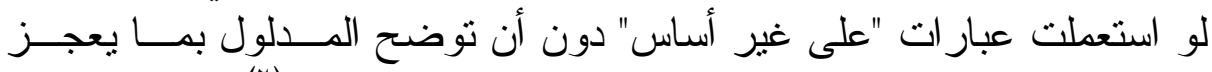

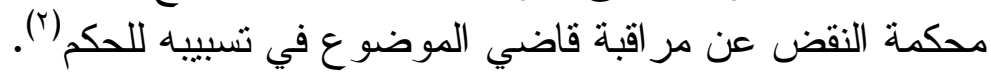
ومر اعاة القاضي مبدأ كفاية التسبيب يقتضي منه أن يوضر فرضح في الحيثيات

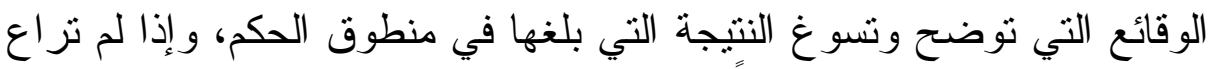

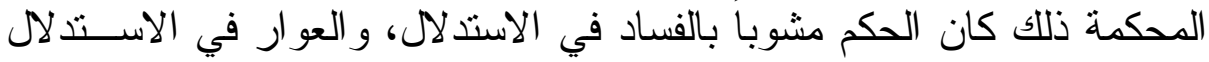

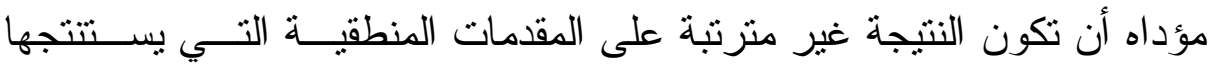

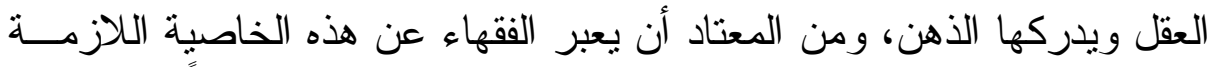

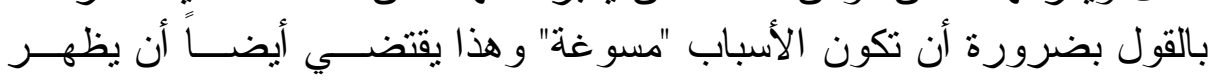

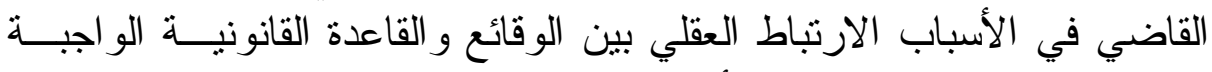
النطبيق بحيث يستبين من ذلك أن النتيجة التي استقرت في المنطوق التئ ولي نتيجة

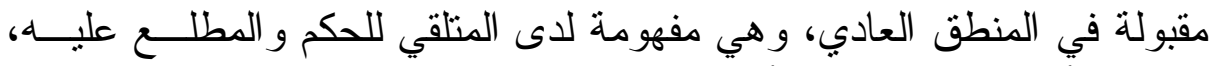

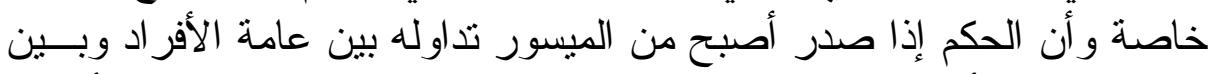
القانونيين، من أجل ذلك لا يصح القصور فِي الإفصاح عن القاعدة التي أعملها

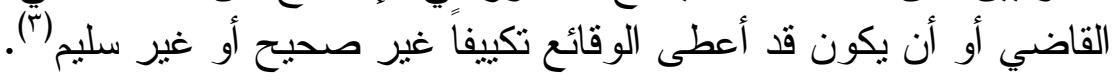

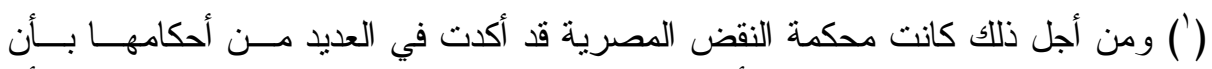

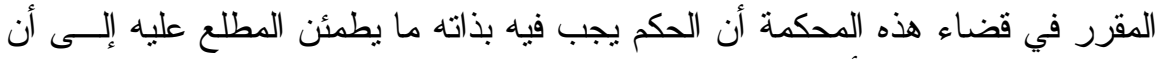

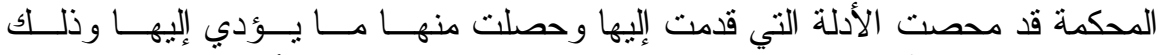

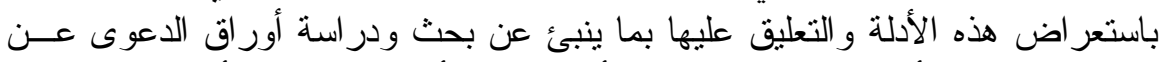

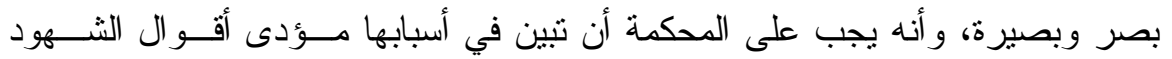

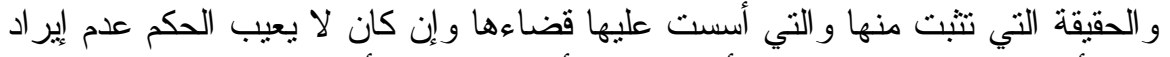

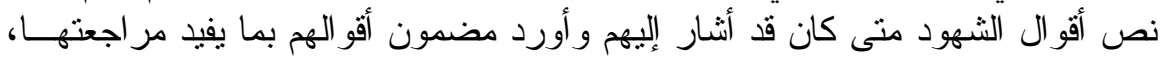

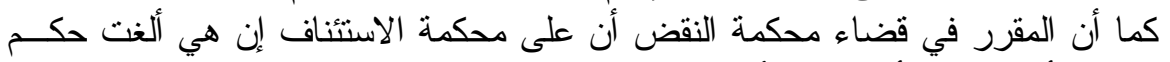

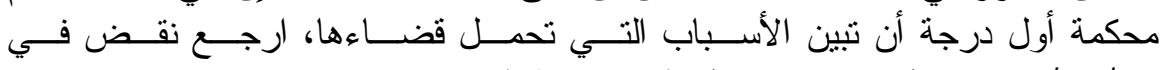

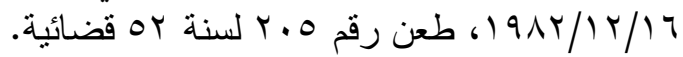

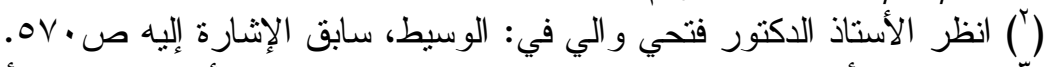

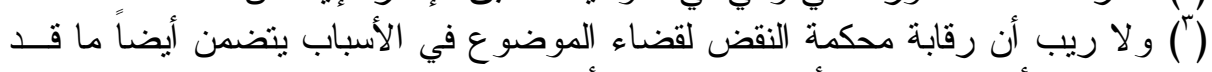

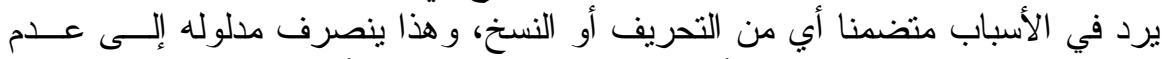

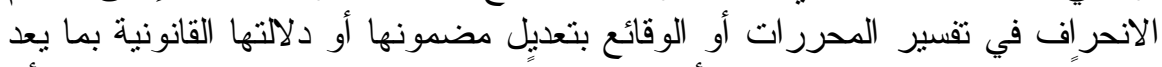

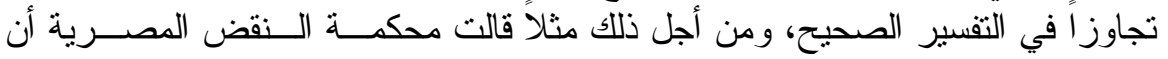

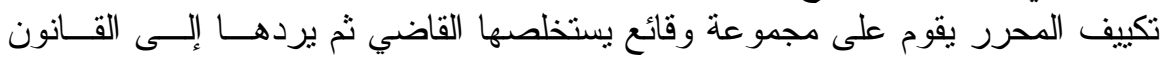




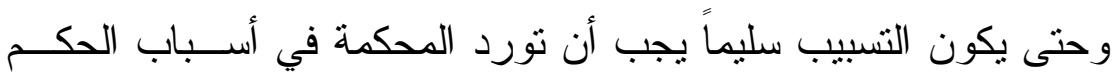

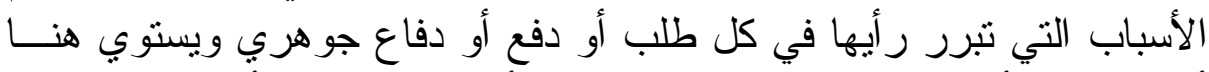

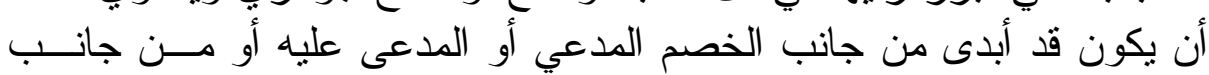
الخصم المتدخل أو المدخل من أو من جانب الني النيابة العامة (').

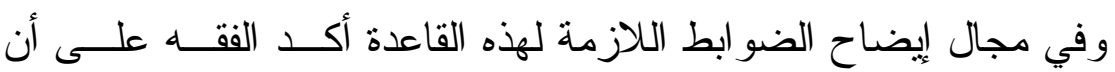

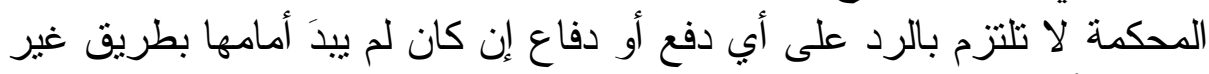

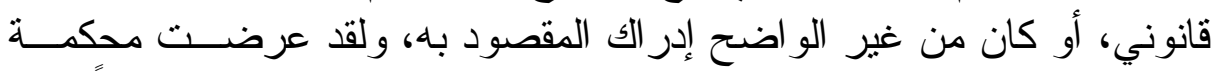

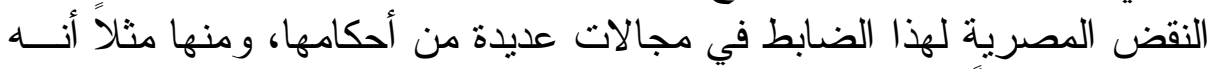

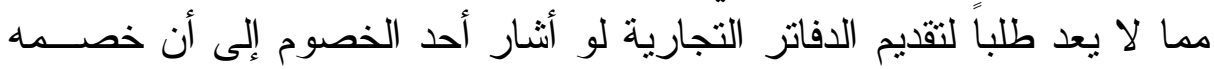

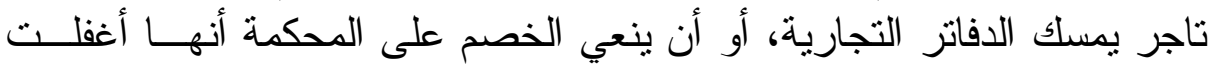

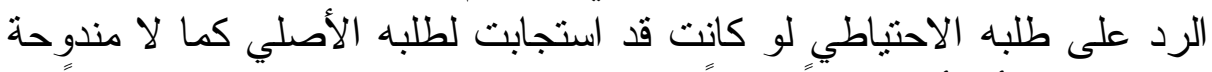

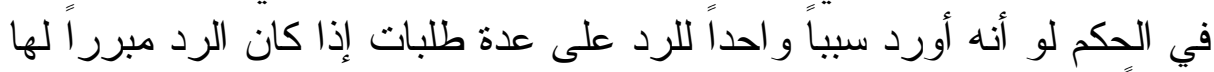
وكافياً للرد عليها.

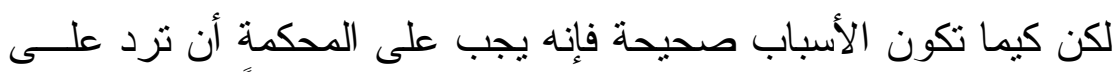

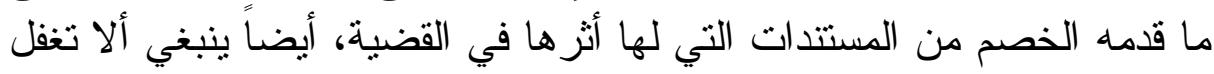

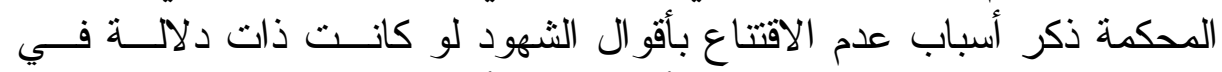

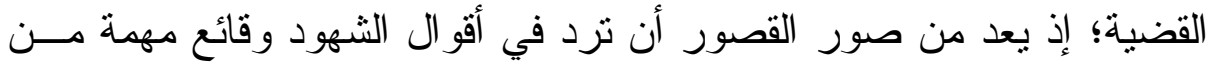

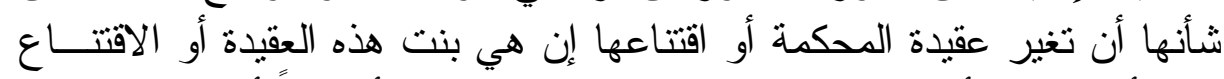

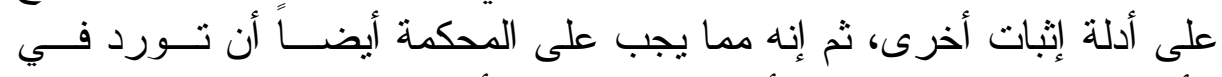

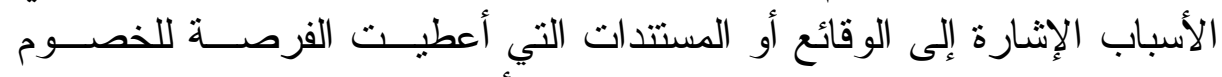

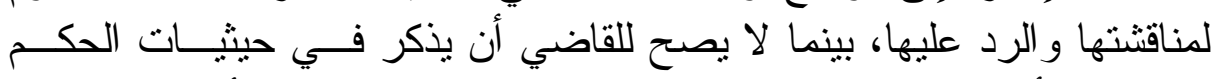

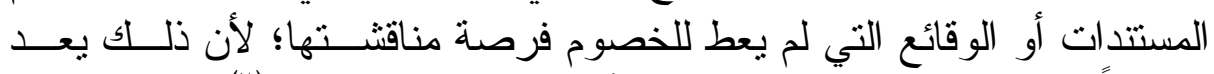
قصوراً في الأسباب لو حدث لائع لان يصح أن يبنى عليها المنطوق (؟).

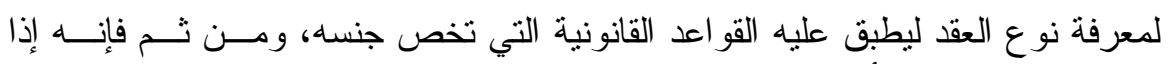

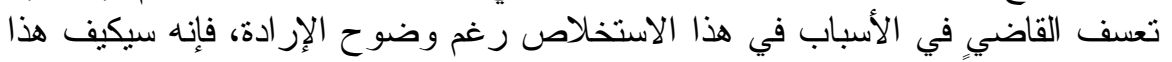

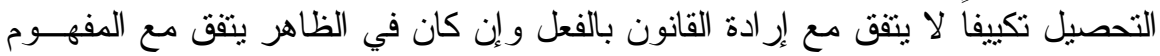

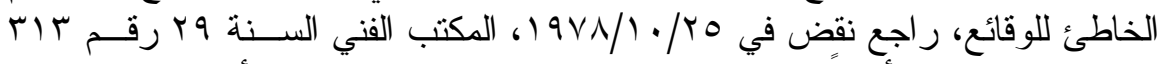

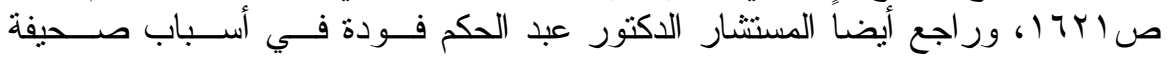

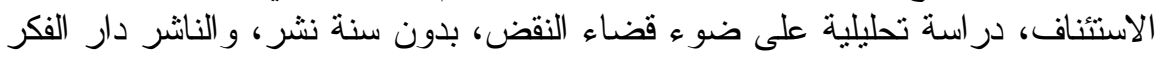

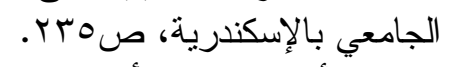

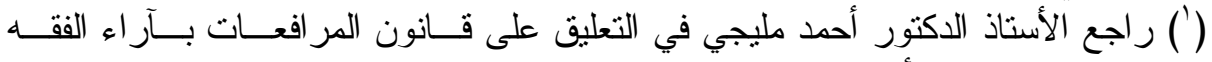

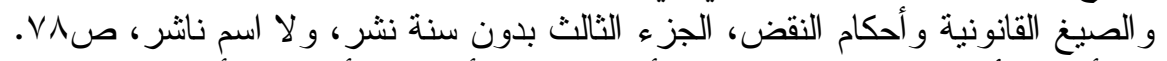
(r) لذا أثنار الأستاذ الدكتور عبد الحميد أبو هيف إلى أنه يجب أن تكون أحكــام القضـــاء 
وكيما تكون الأسباب مكتملة فإنها يجب أن تكون صريحة و لا غضاضة

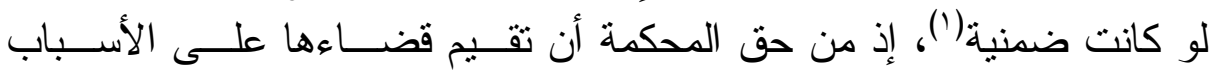

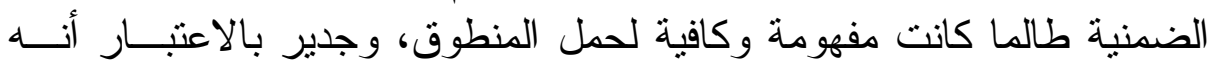

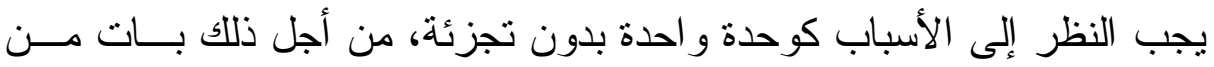

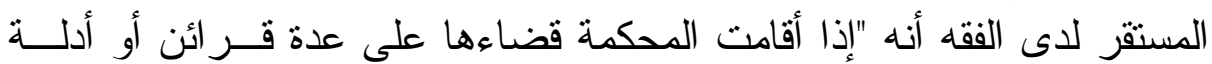
استتدت إلبها مجتمعة و لا يبين أثز كل و احد فيها في تكوين عقيدة المحكمة و لا

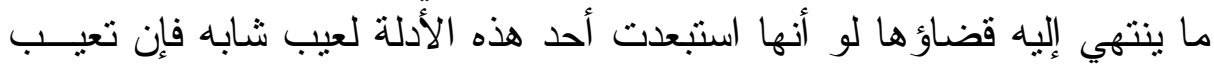
إحداها يؤدي إلى قصور في التسبيب، و على العكس فإنه إذا استتدت المحكمــة إلى دليلين أو دعامتين يكفي أحدهما لحمله فإن أسبابه نكون كافية ولــو كــان الدليل الآخر معيبا، و عندئذ لا يقبل النعي على هذا الدليل إذ هذا النعي بفرض

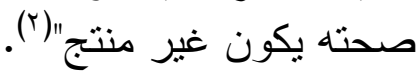

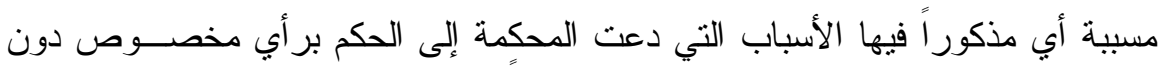

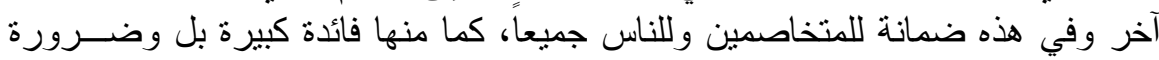

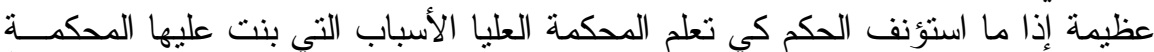
الدنيا حكمها، هذا ويتزك لفطنة القاضي تقدير مقدار الأسباب الإزمة لجعل الجعل حكمه مبنياً

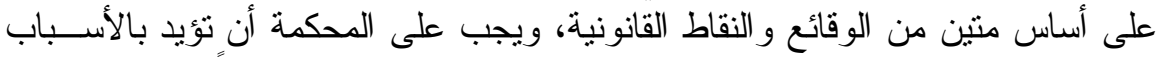

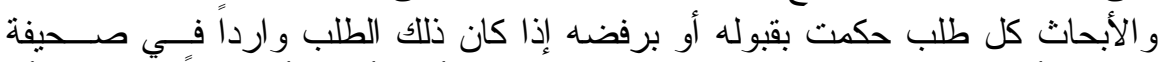

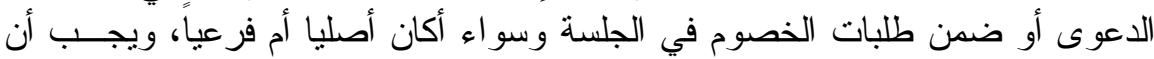

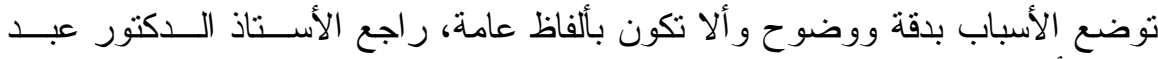

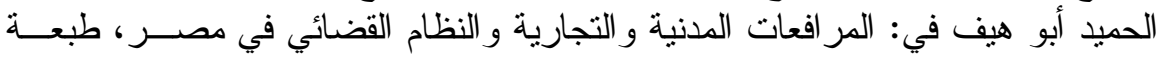

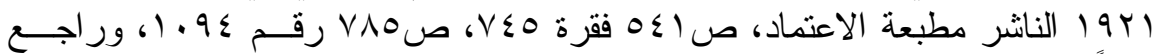

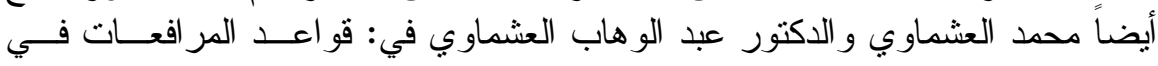

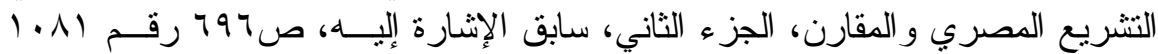

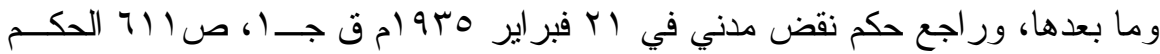

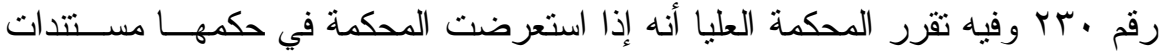

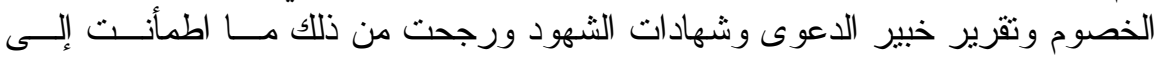
ترجيحٍة، ثم قضت في الدعوى على حاصل خلى فهم الو اقع فيها، فذلك كاف لاعتبار حكمها

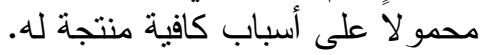

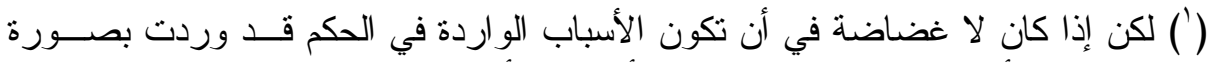

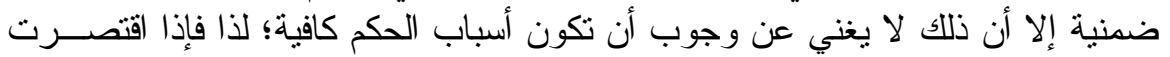

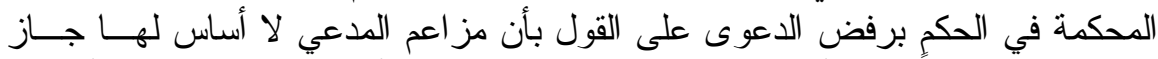

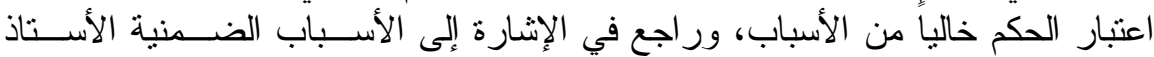

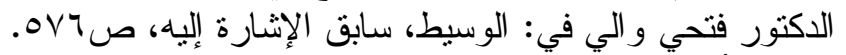

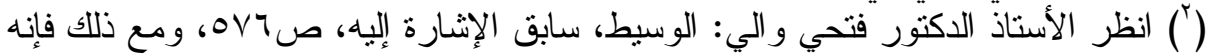

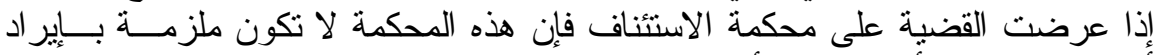

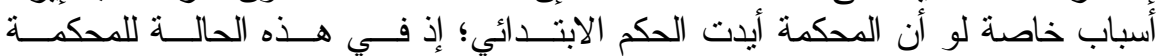


وفي الفقه إثنار ات إلى أنه مما لا يعيب الحكم أن تزد فيه أسباب معينـــة

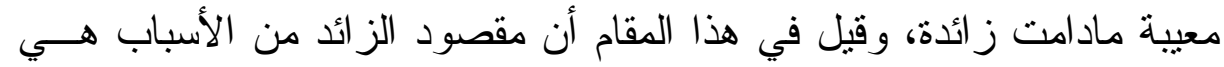

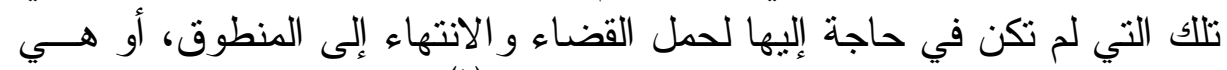

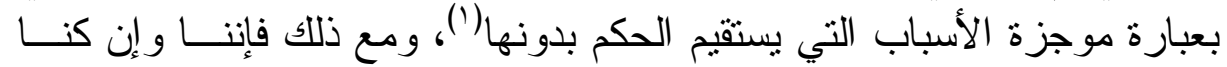

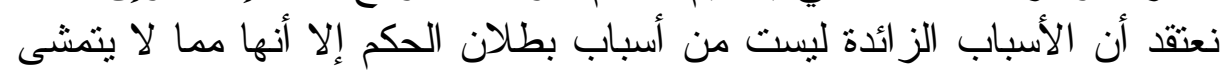

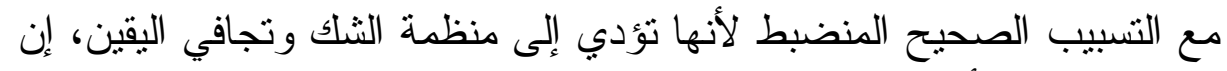

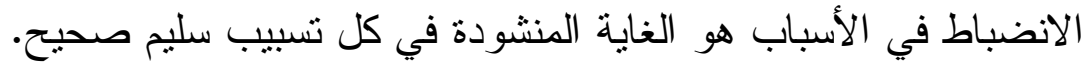

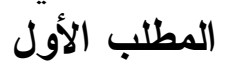

\section{انعدام التسبيب كعوار شكلي في الحكم}

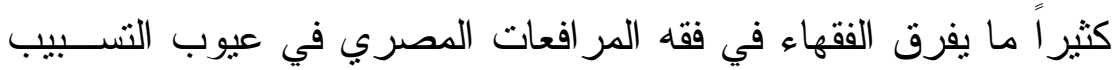

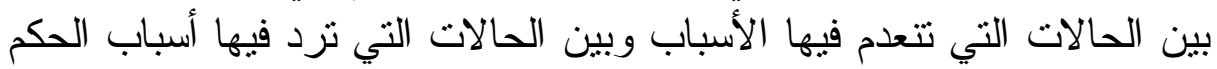

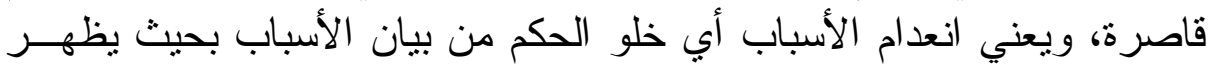

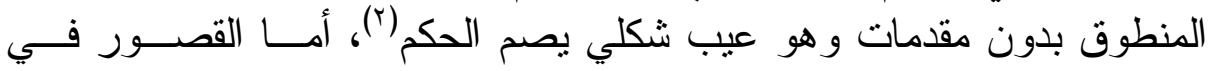

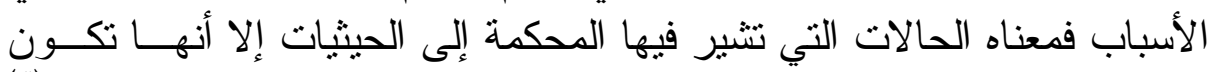

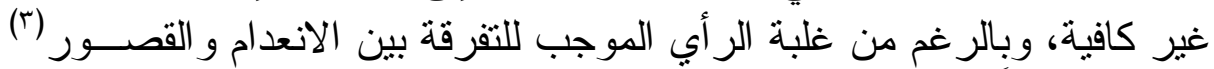

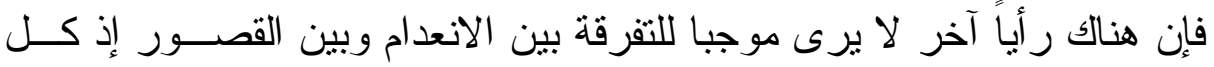

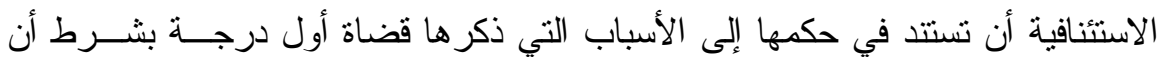

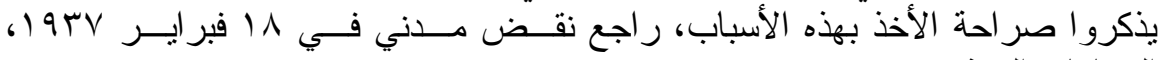

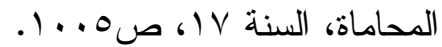

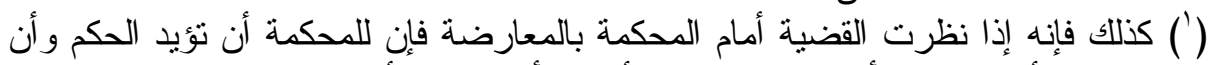

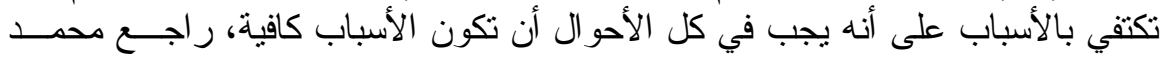

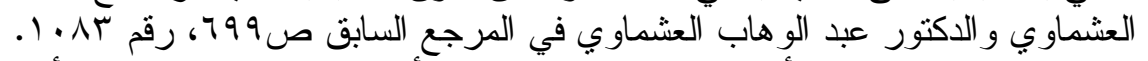

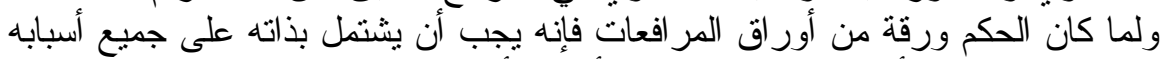

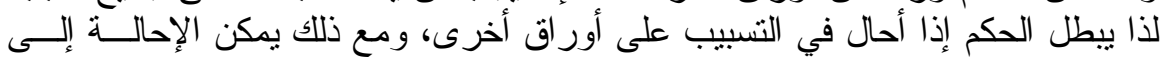

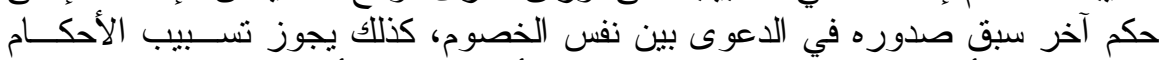

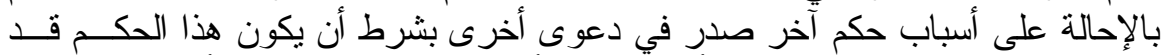

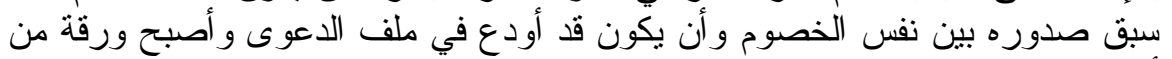

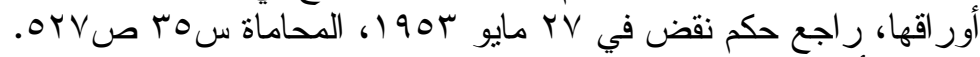

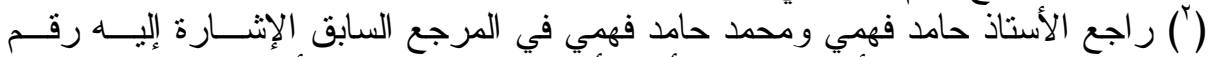

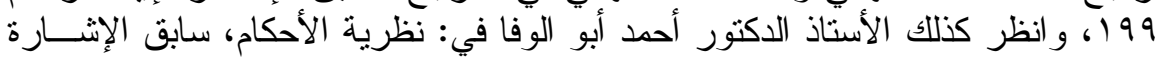

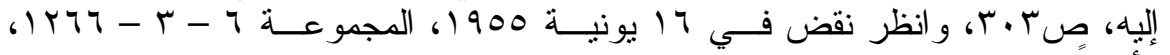

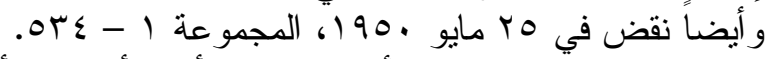

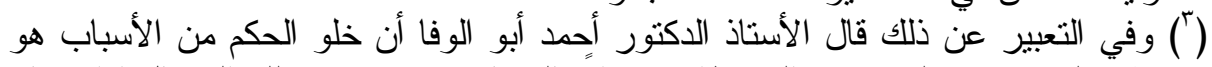

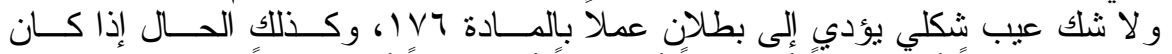

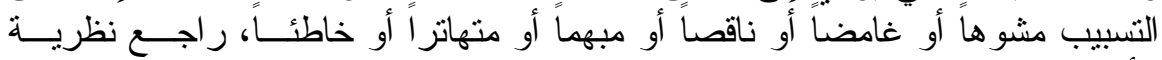

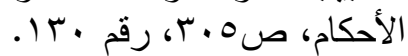




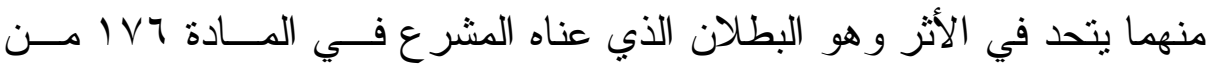

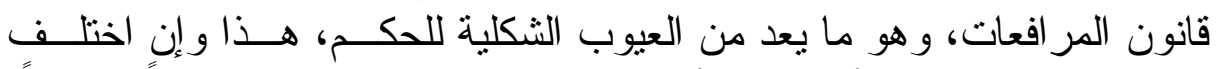

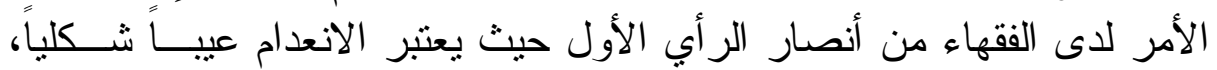

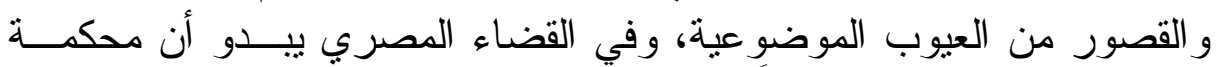

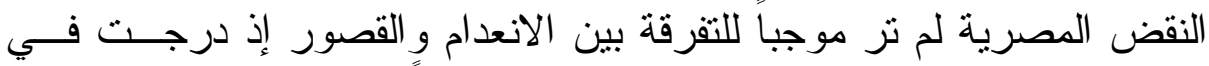

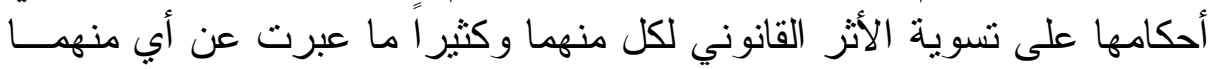

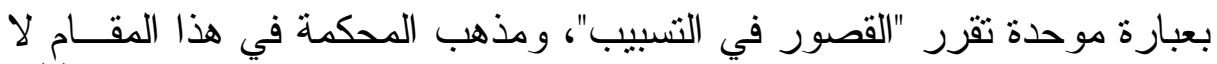

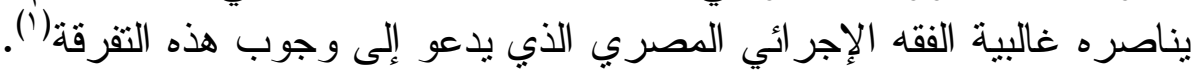

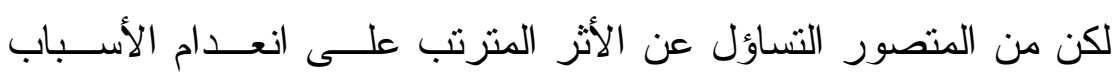

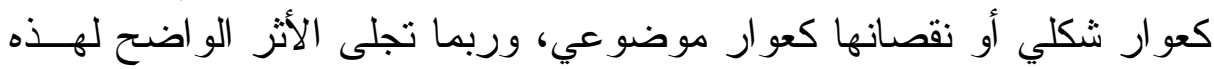

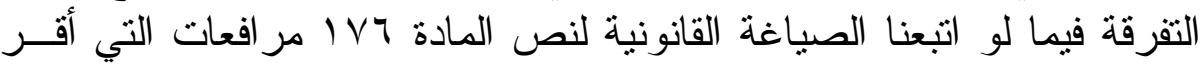

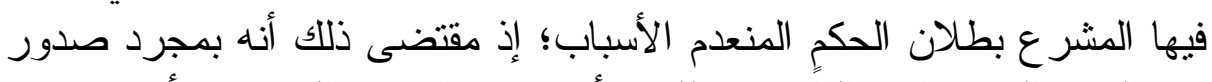

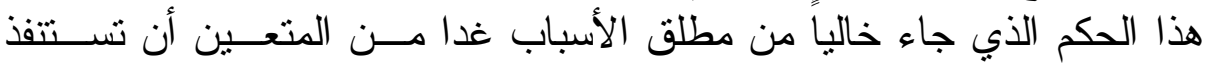

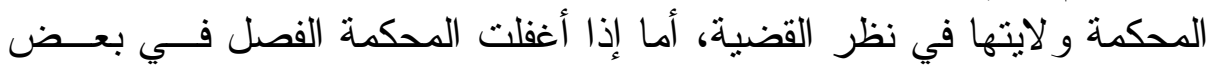

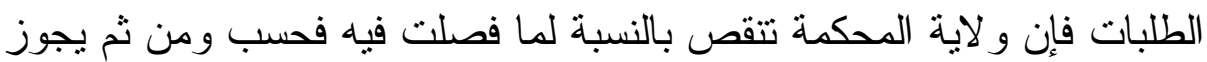

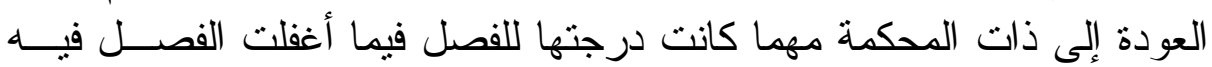

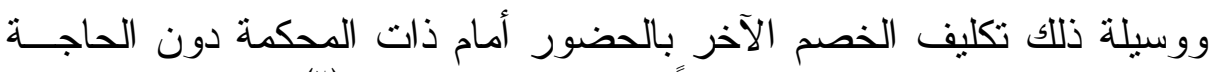

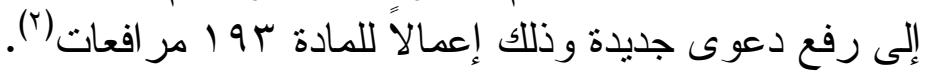

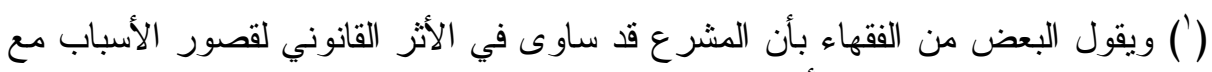

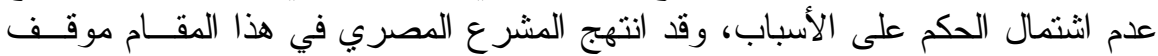

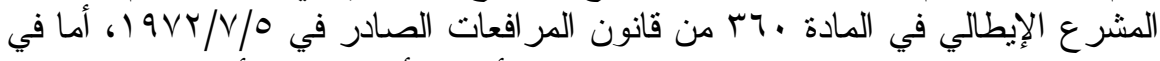

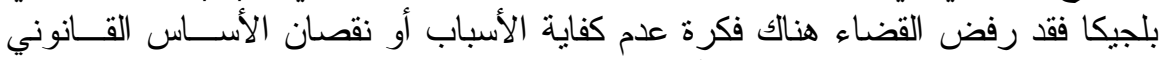

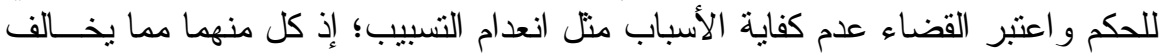

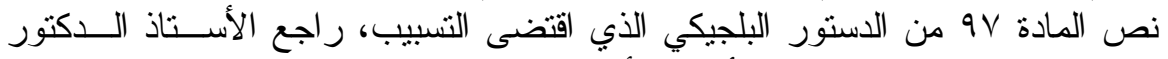

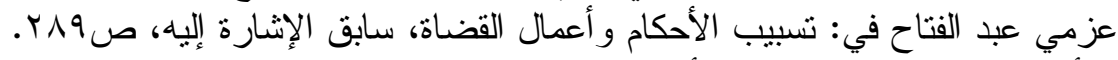

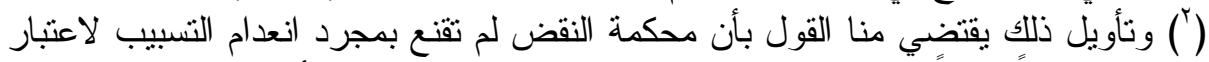

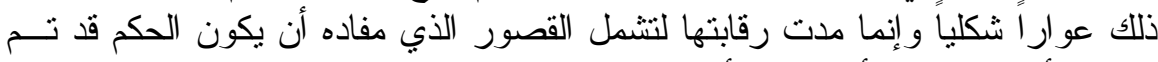

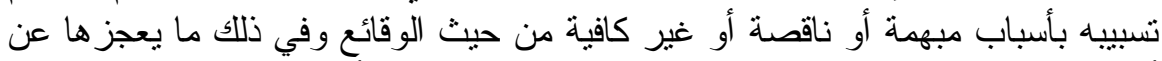

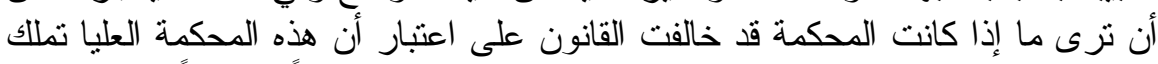

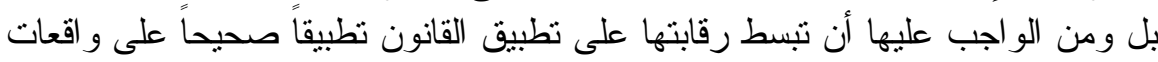

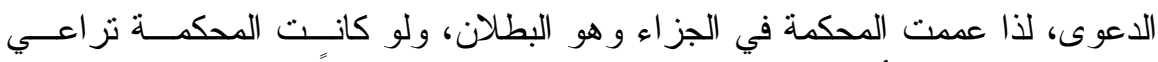

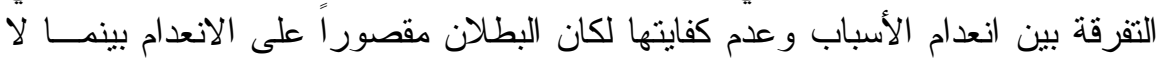

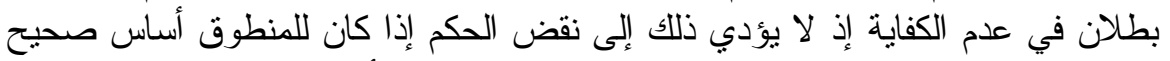

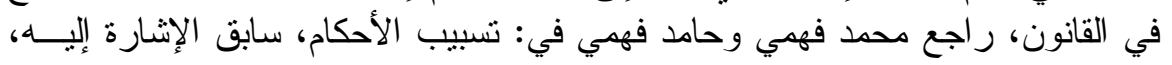




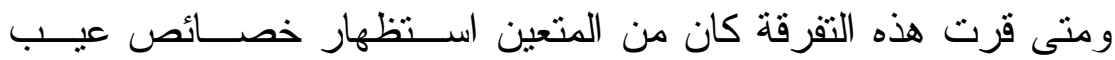

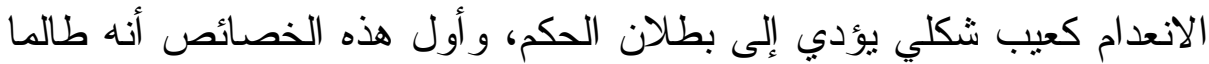

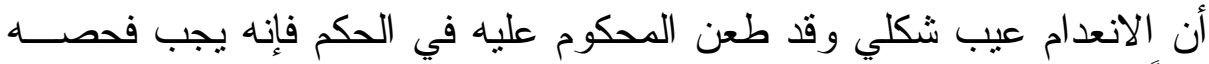

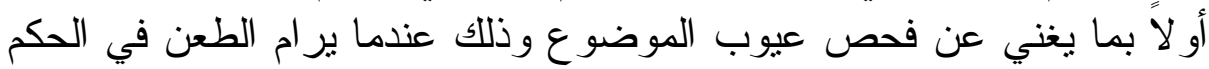

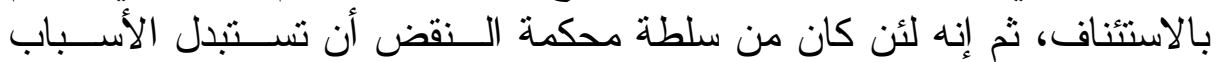

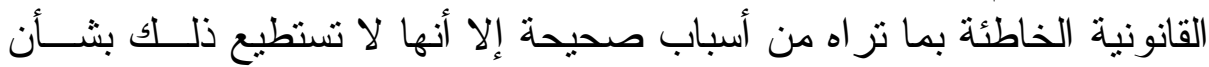

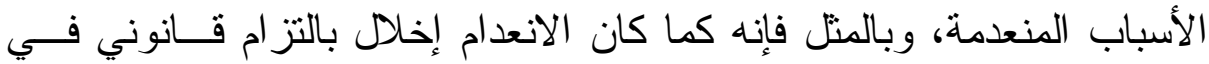

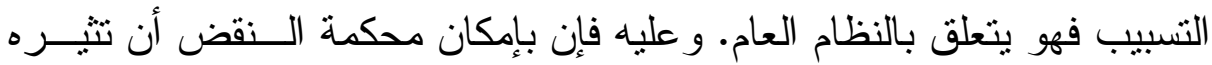

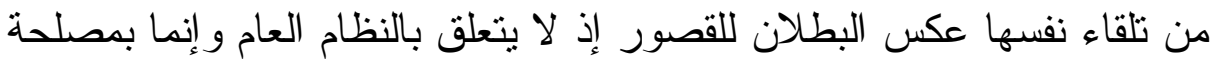

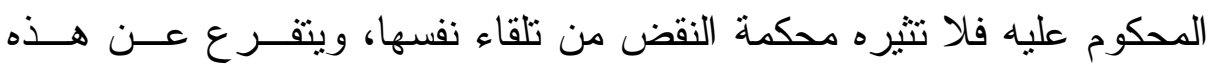

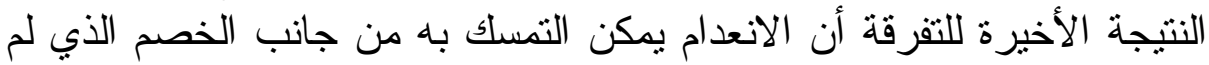

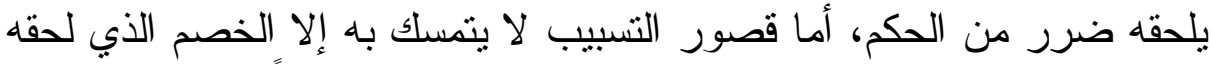

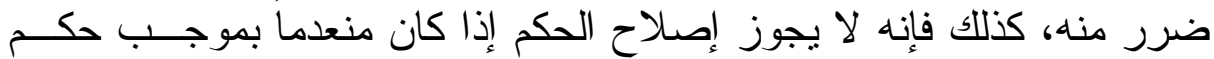
تفسيري لأن الحكم التفسيري يكمل الحكم غير المنعدم (').

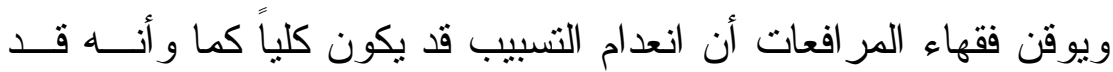

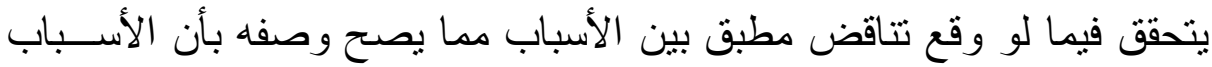

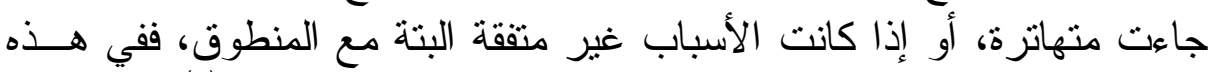

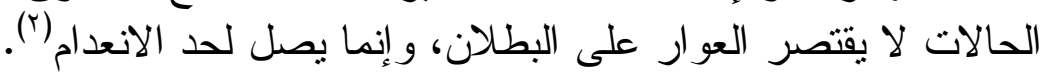

ور اجع أيضاً الأستاذ الدكتور وجدي راغب فهمي في: نظرية العمل القضــائي، ســابق

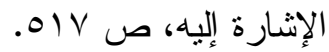

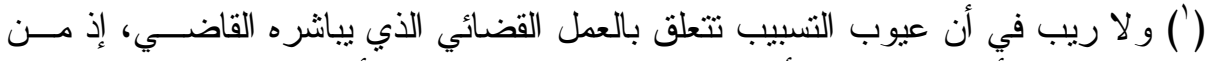

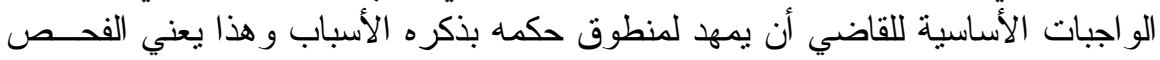

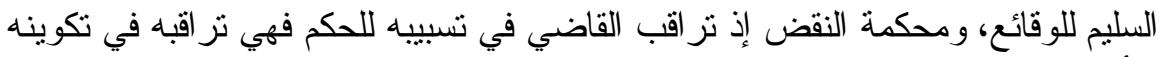

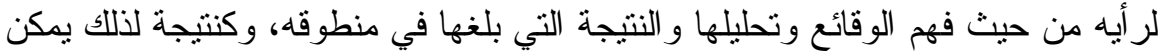

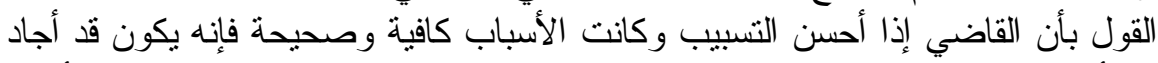

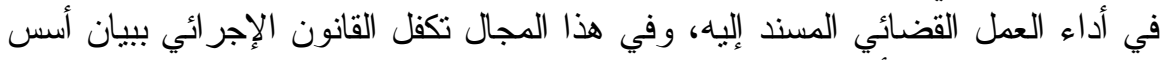

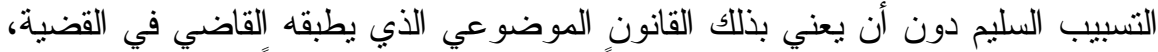

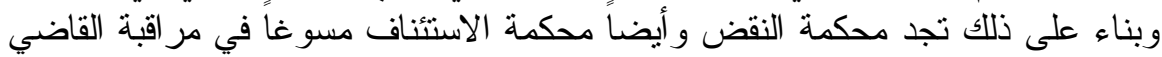

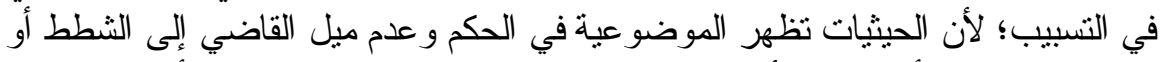

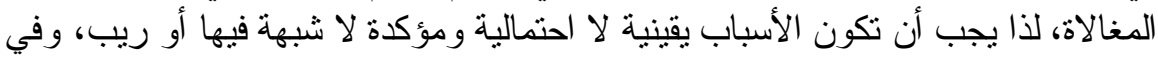

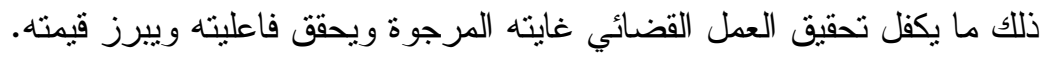

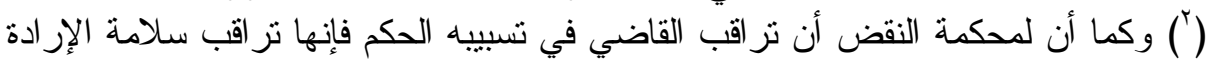

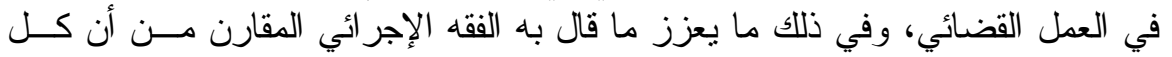

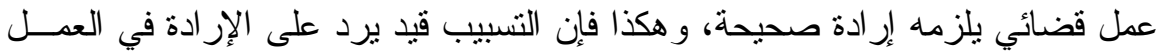




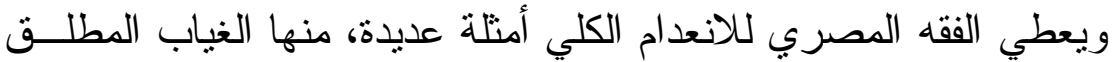

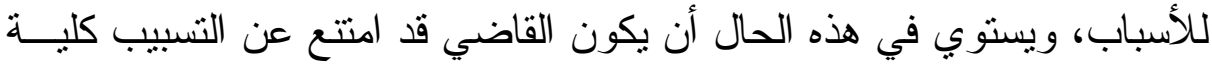

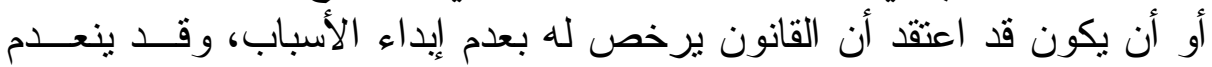

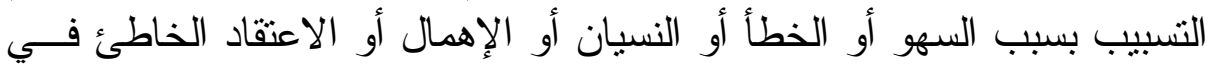

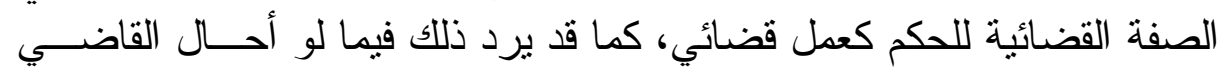

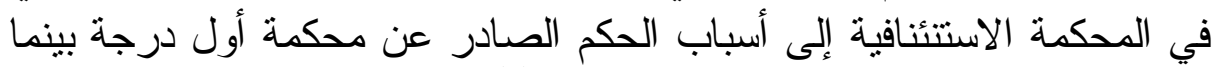
كان هذا الحكم لم يتضمن هو الآخر الآند الأسباب(').

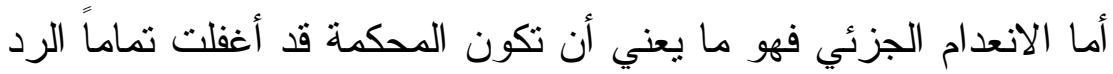

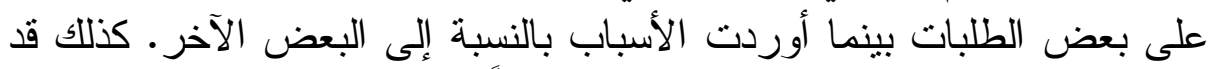

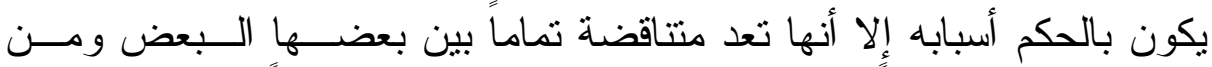

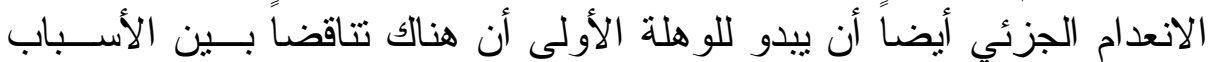

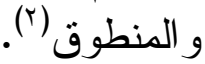

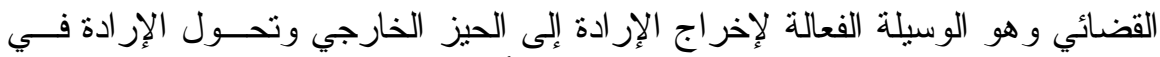

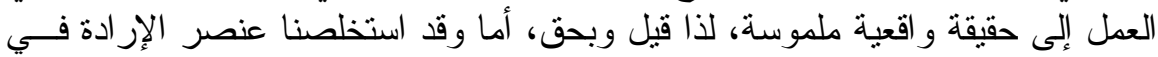

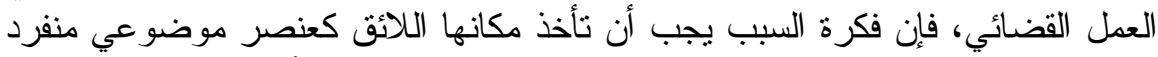

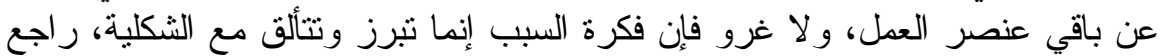

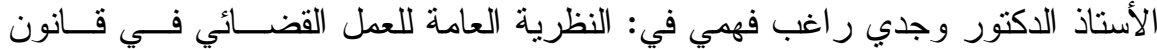

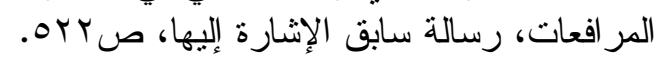

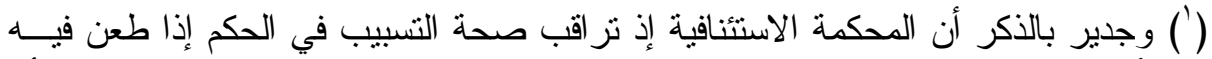

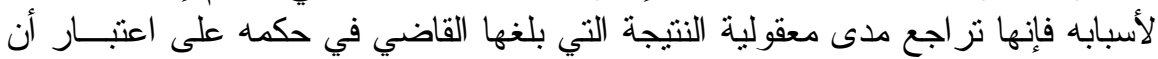
التسبيب و الحيثيات فيها قياس منطقي syllogysme حيث تكون المقدمة الكبرى فئ فيه هي

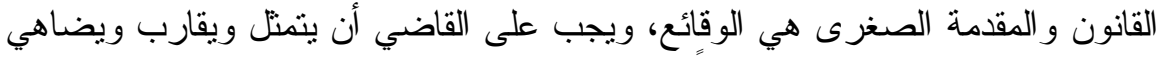

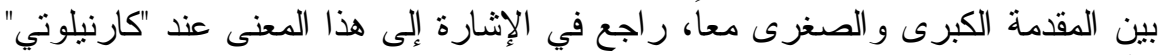

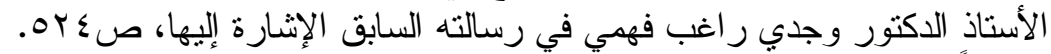

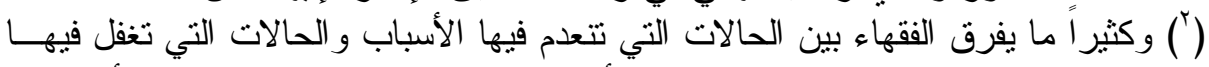

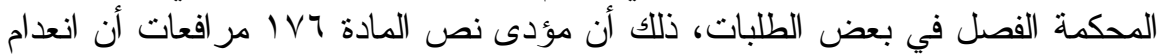

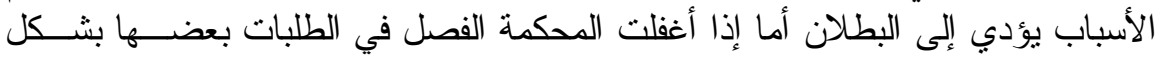

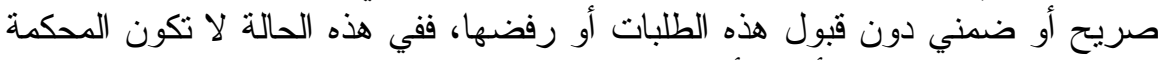

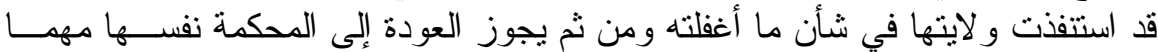

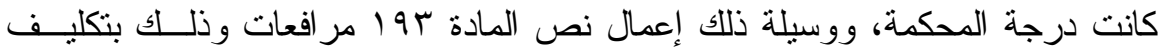

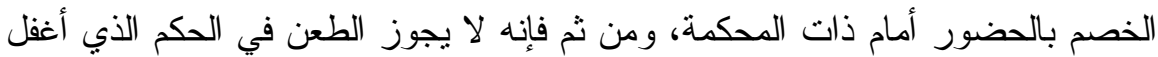

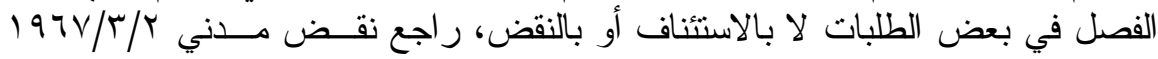

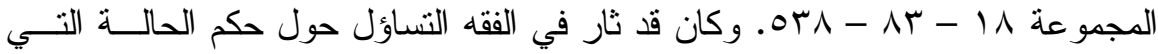

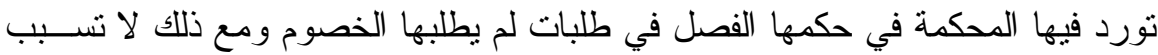

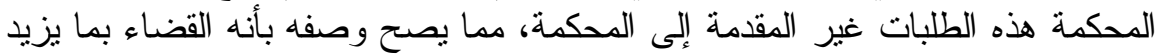




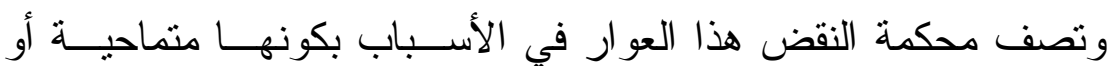

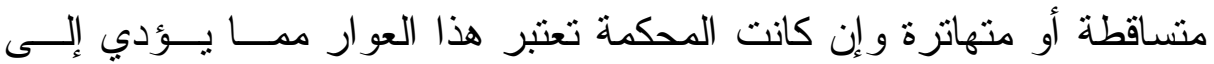

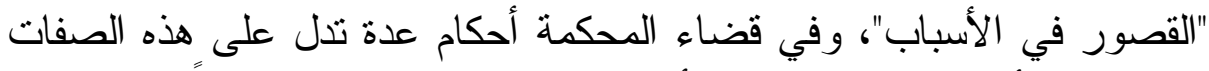

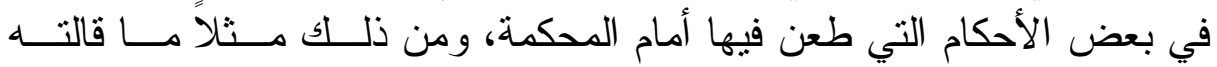

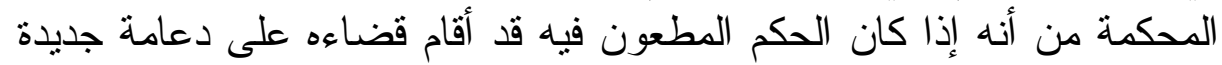

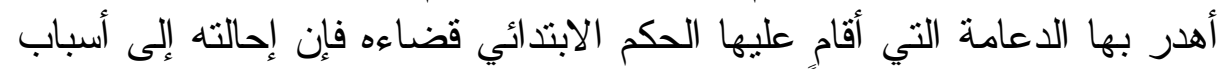

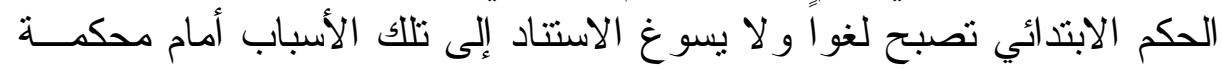

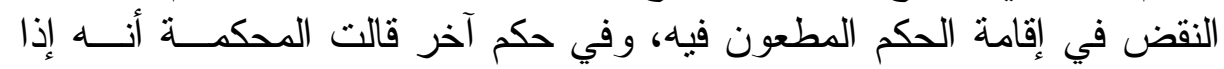

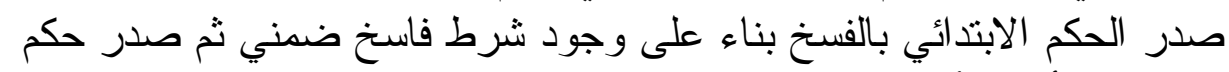

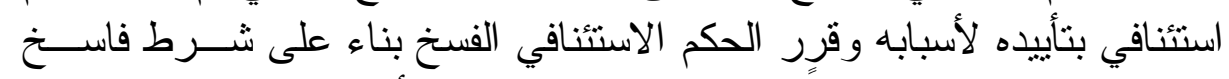
صريح فإن ذلك يعد تتاقضاً يبطل الحكم لإقامته على أمرين متغايرين.

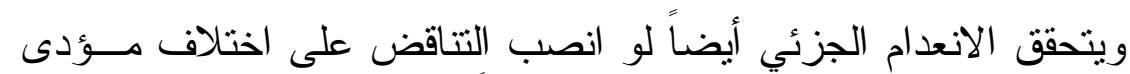

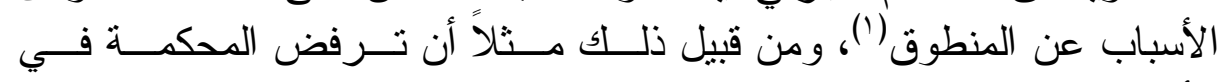

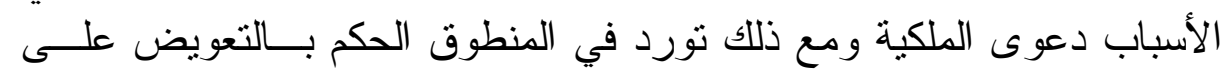

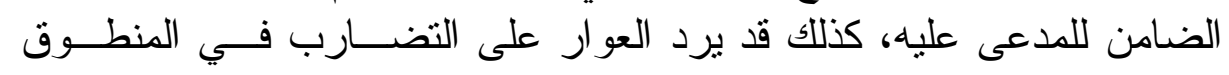

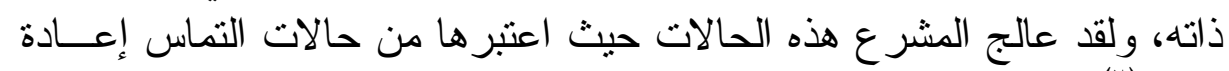

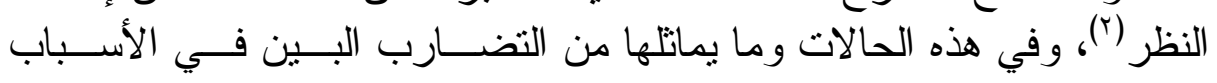

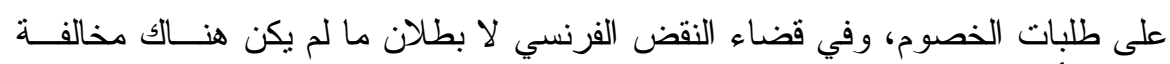

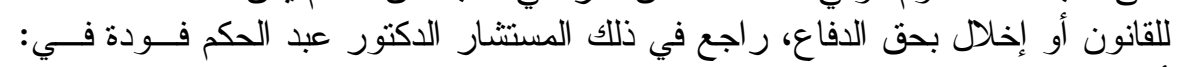

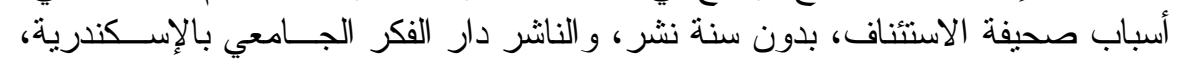
ص المباب

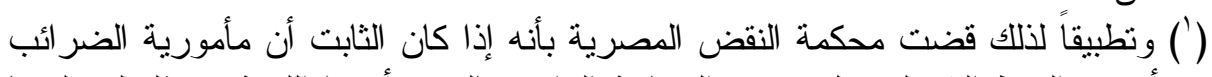

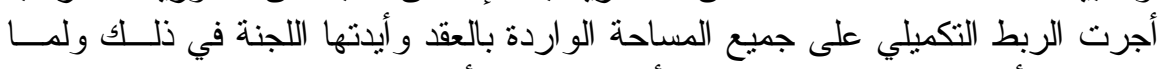

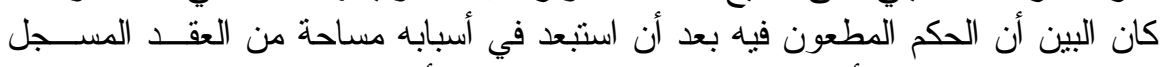

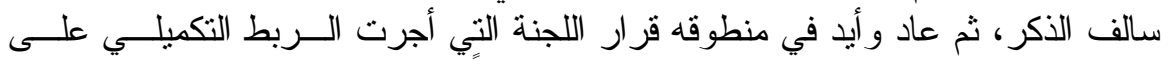

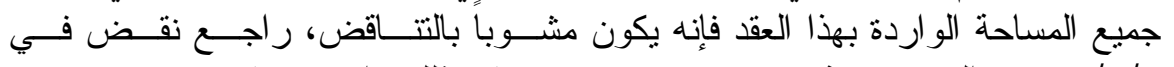

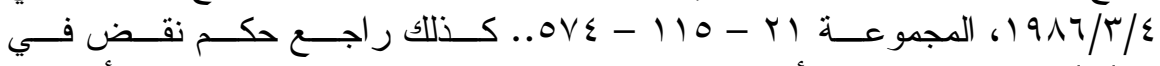

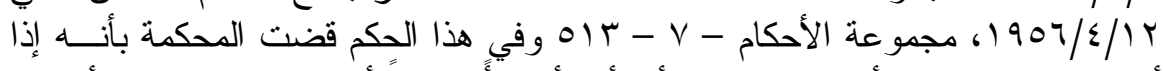

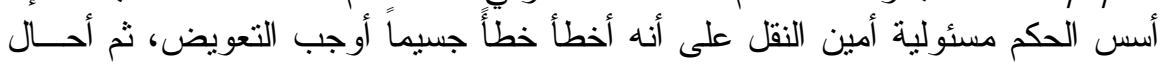

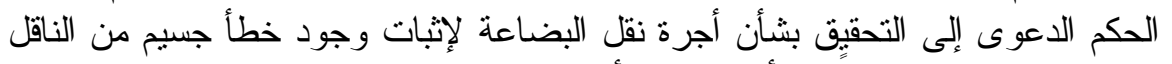

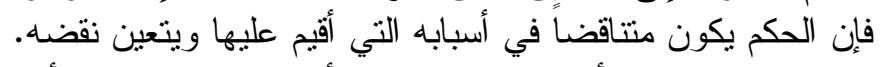

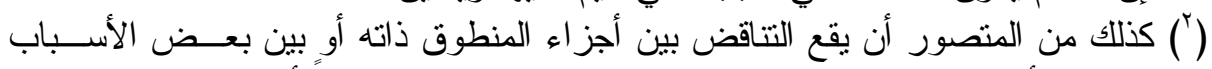

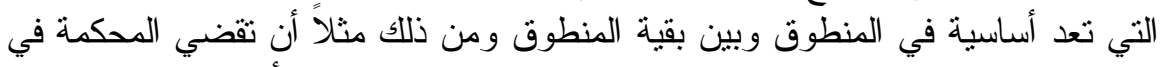

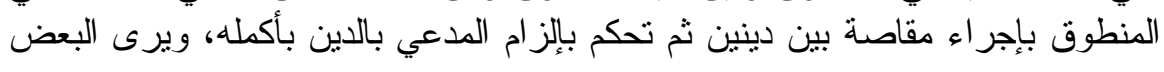




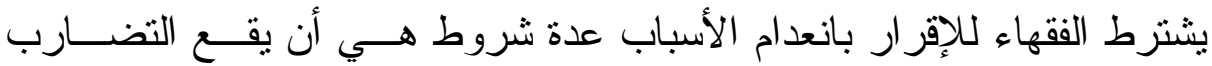

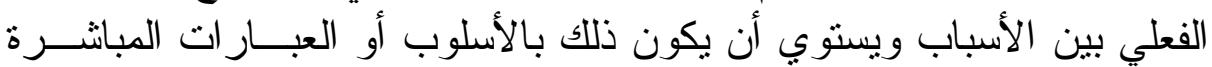

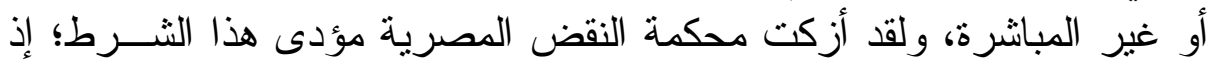

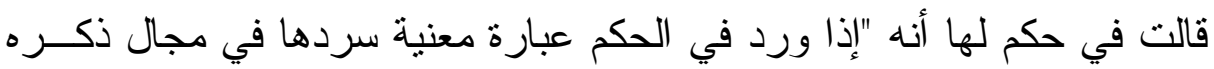

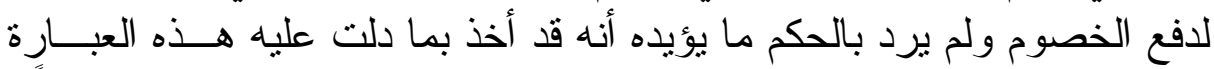

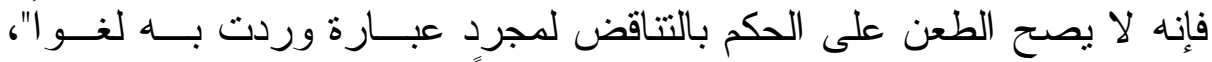

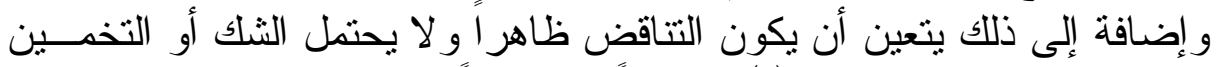

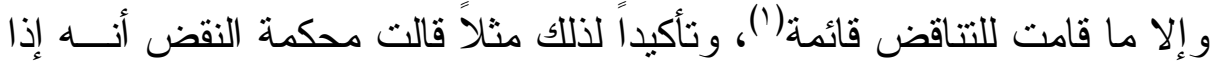

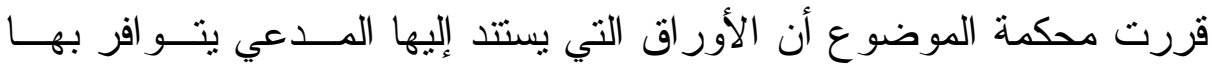

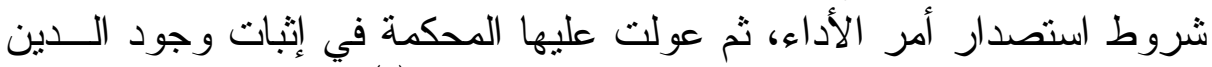

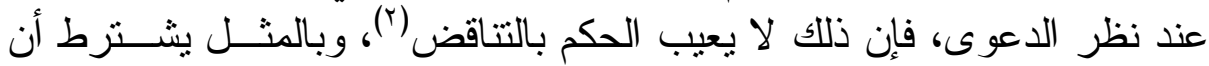

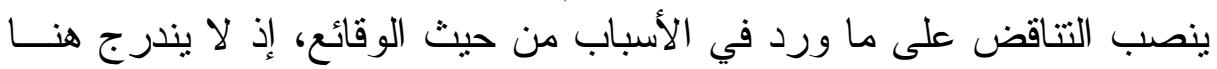

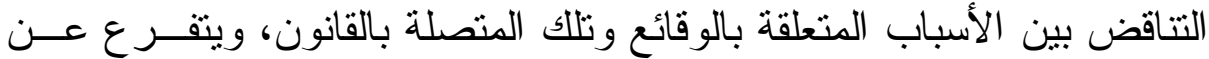

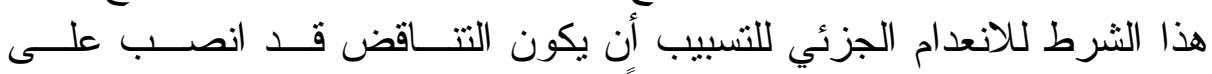

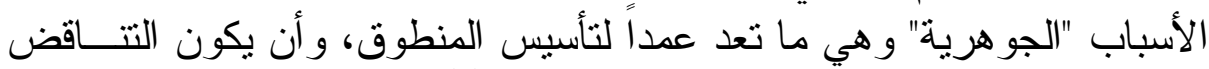

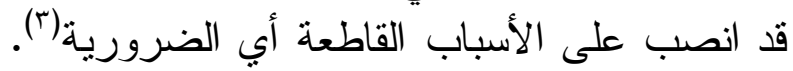

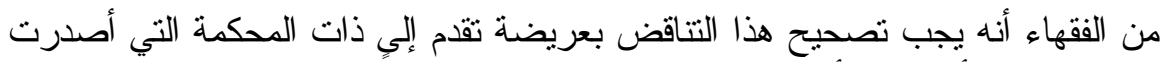

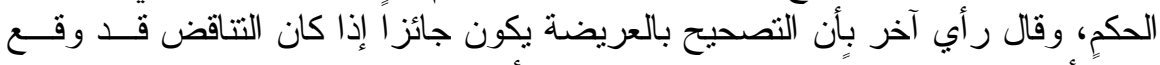

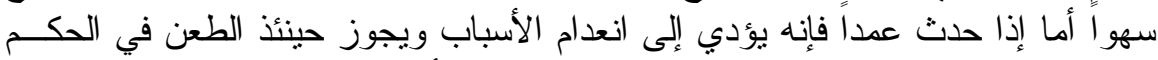

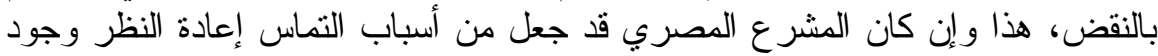

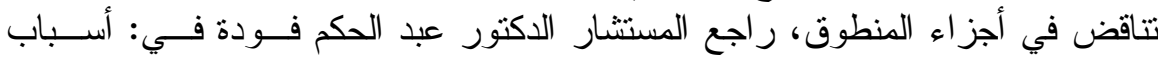

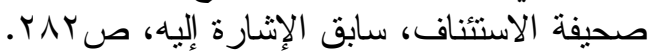

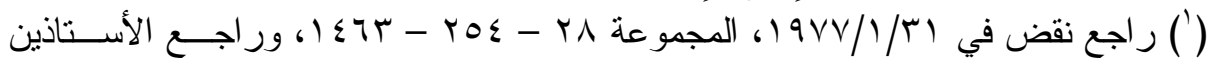

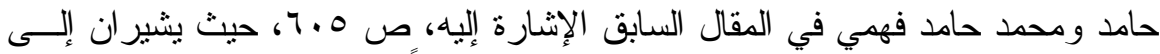

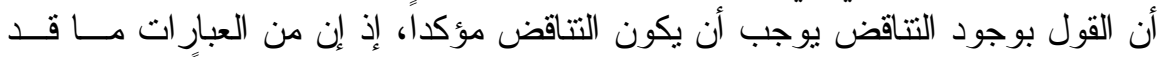

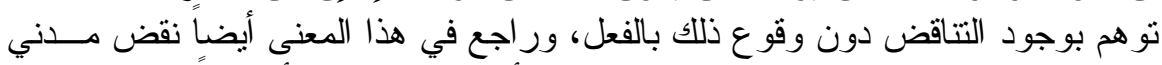

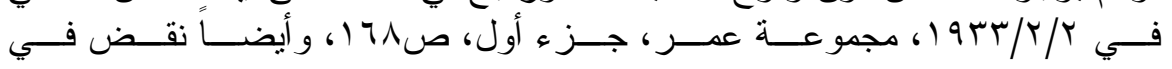
.

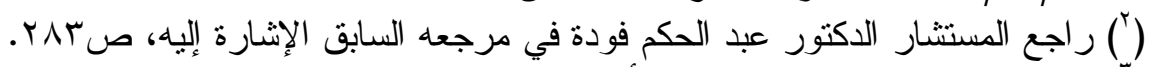

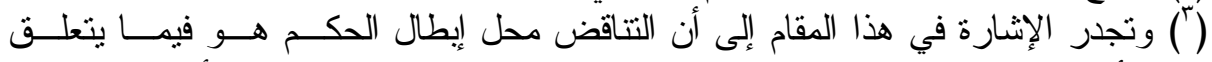

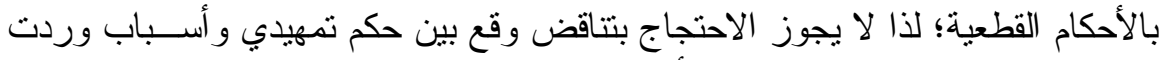

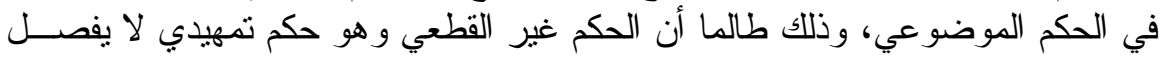

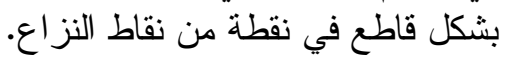




\section{المطلب الثاني \\ مواطن القصور في التسبيب المؤدي إلى بطلان الحكم}

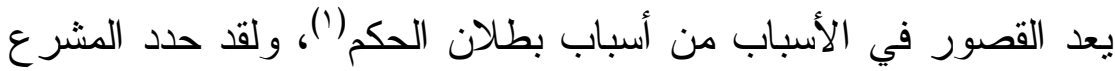

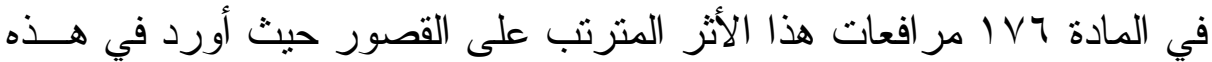

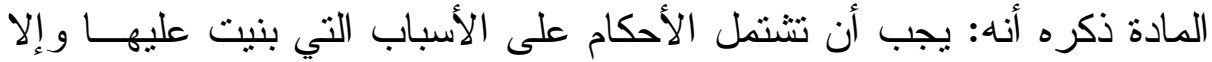

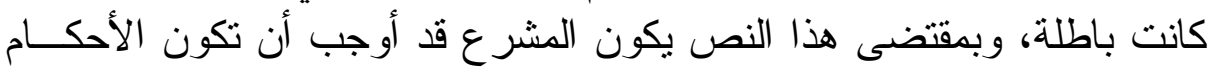
مشتملة على الأسباب التي بنيت عليها، وهو لم يقصد من ذلك الك استتمام الأحكام

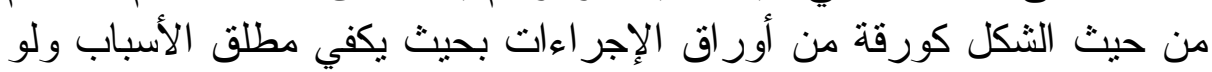

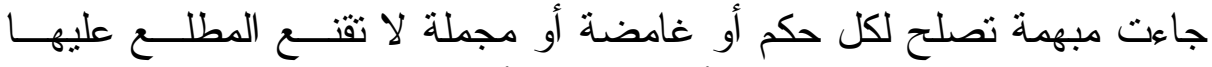

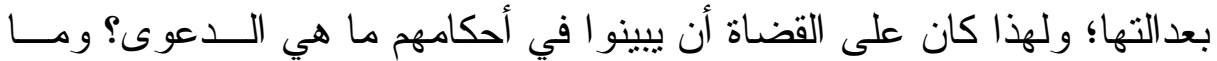

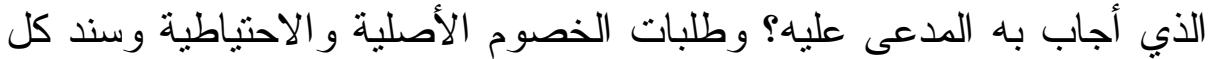

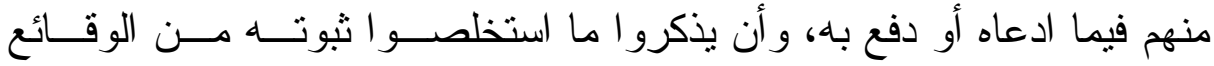

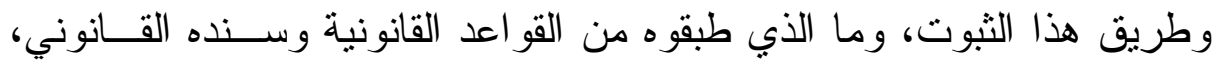

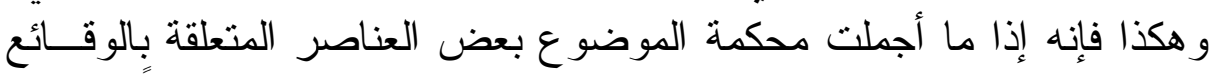

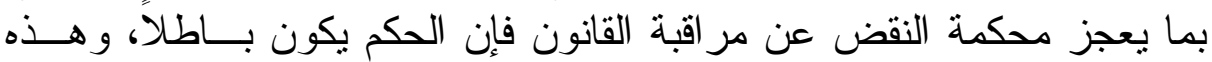

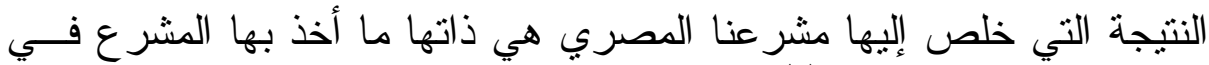

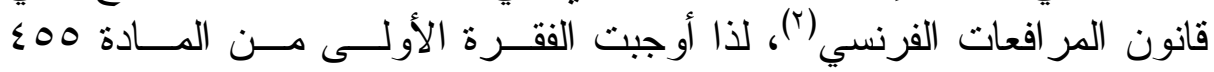

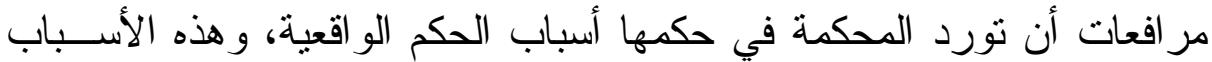

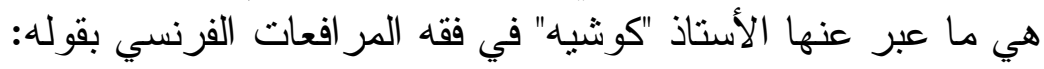

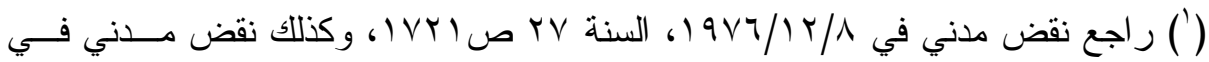
(إ)

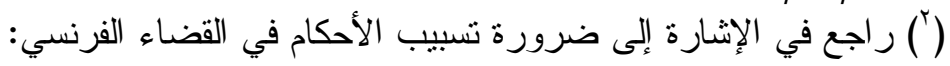

Com. 18 Juin 1985. Bull. civ. IV. No 194. p. 162. Rev.

Trim. dr. Civ. 1986. 423. J.C.P. 1990. IV. 43.

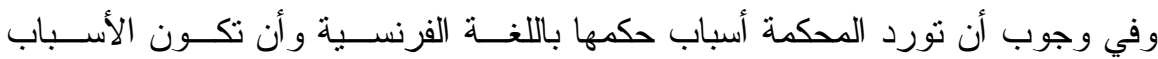

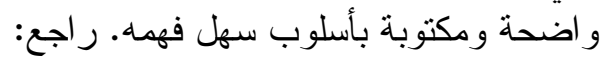

Cass. Civ. 2e, 11 Janv. 1989, Bull. civ. II. No 11. p. 5

و انظر كذلك: . Cass. civ. $1^{\text {er }}$.9mars, 1994, Bull, civ. 1, no 92, rev Trim. Dr. Civ. 1994 et S. spéc. P. 423, obs. Perrot.

وراجع أيضا: .Gérard Cornu et Jean Foyer; op. cit. p. 437

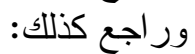

Garsonnent, Cezer - Bru. Traité théorique et pratique de procédure civile et commerciale. T. 3. nos 620 etss.

$$
\text { وراجع أيضا: .Motulsky. J.C.P. 1949. I. 775 }
$$


"C'est qu'en effet sont tout d'abord exposés succinctement les prétentions respectives des parties et leurs moyens".(1)

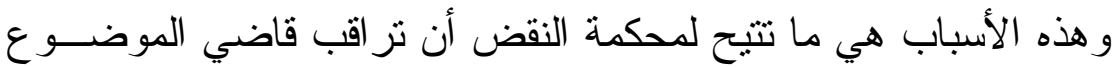

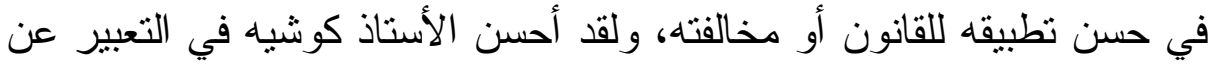

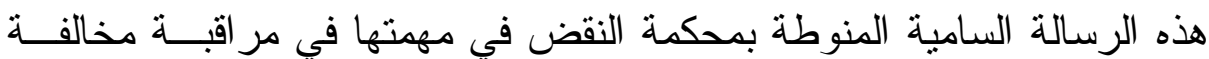
القانون حيث قال:

La fonction de la cour de cassation est d'assurer la sanction des violation de la règle de droit. L'on parle traditionnellement de la violation de la "loi" mais ce dernier terme ne doit pas être entendu strictement: toute méconnaissance d'une règle juridique est susceptible de justifier un pourvoi en cassation. Et il faut préciser qu' une mauvaise interprétation de la loi est une violation de celle $-\mathrm{ci}^{(2)}$.

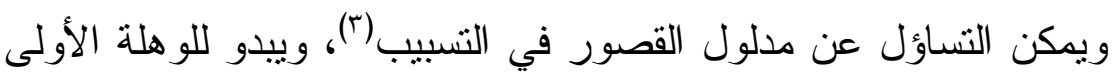

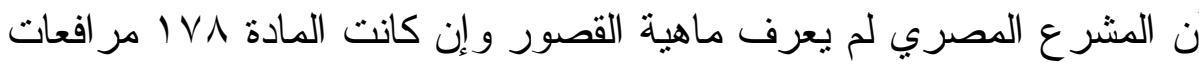

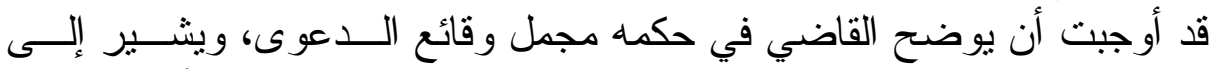
طلبات الخصوم وخلاصة موجزة لدفو عهم ودفاعهم الجوهري، ورئ ور أي النيابة ثم

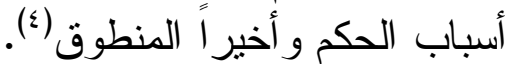

Gérard Couchez; op. cit. p. 299 No. 400 راجع: (') (')

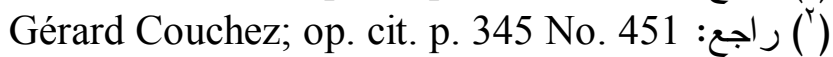

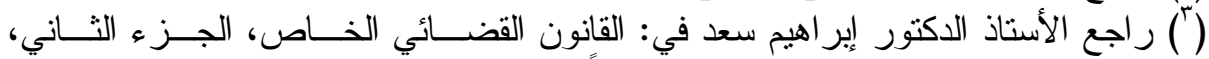

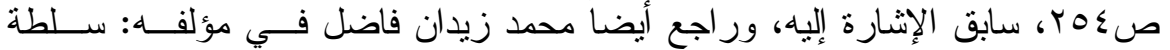

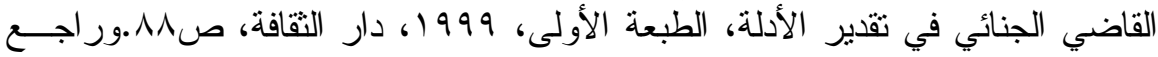

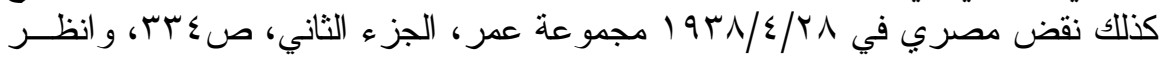

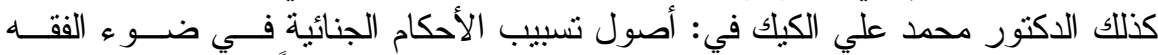

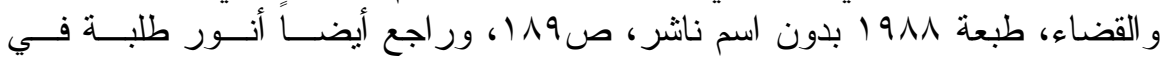
موسوعة المر افعات المدنية و التجارية، الجزء الثالث، دار المطبو عات الجامعية، بــدون البـان

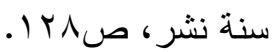

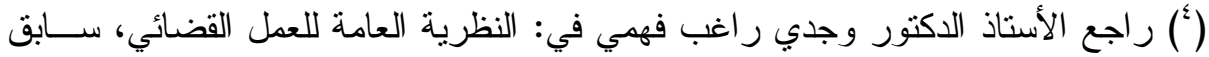

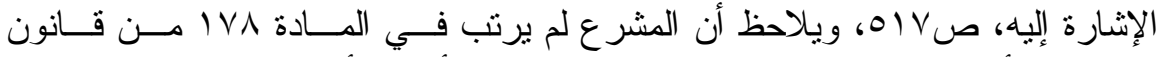

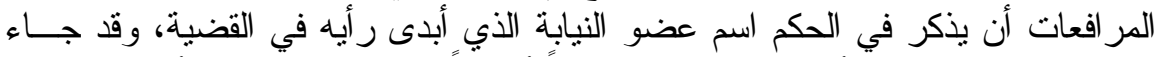
في المذكرة الإيضاحية أن هذا الذكر ليس بياناً أساسياً ما دادت النيا لنيابة قد أبدت بالفعـل 
وهكذا يتعين أن تشتمل الأسباب على عرض الوقائع الواردة في القضية

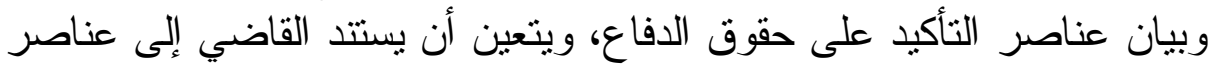

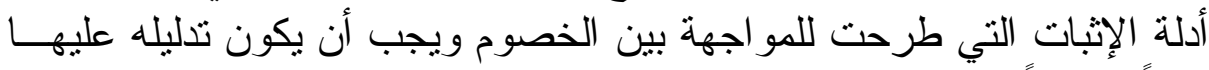

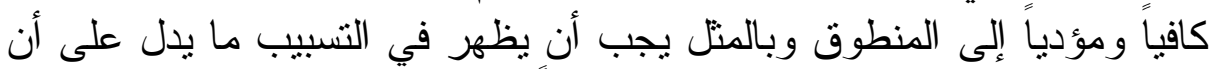

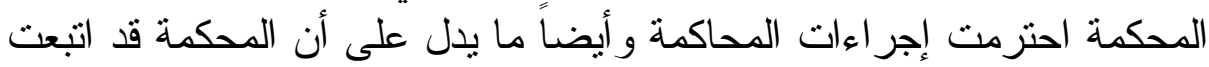

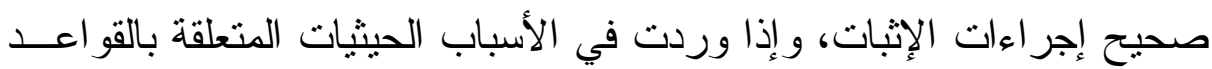

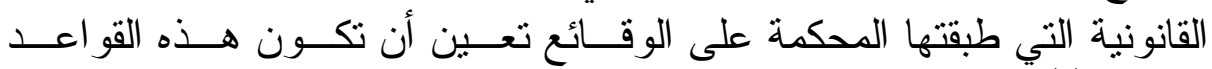

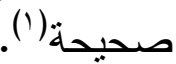

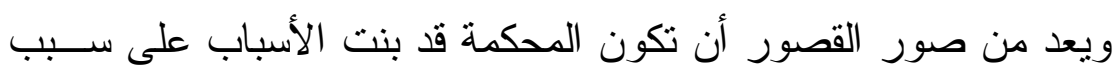

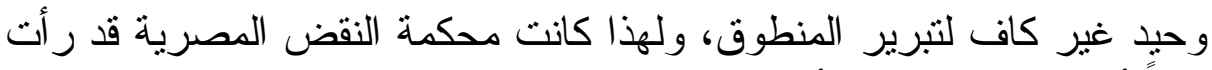

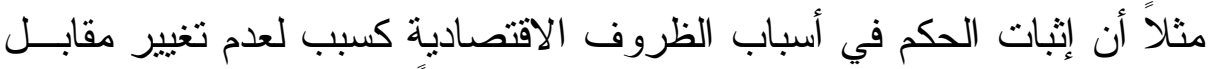

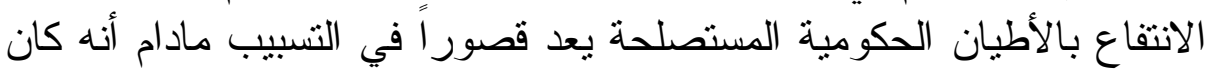

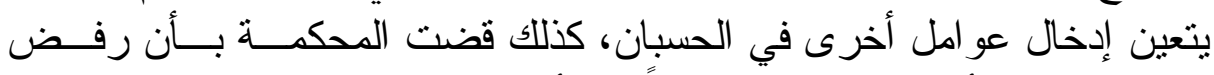

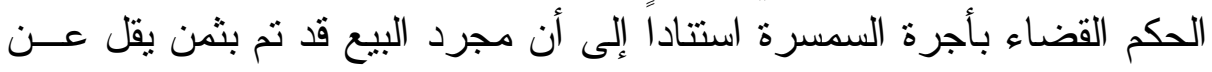

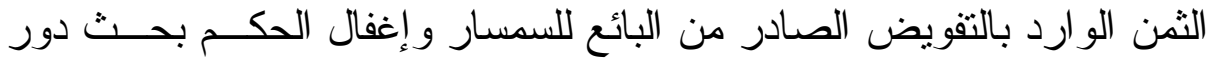

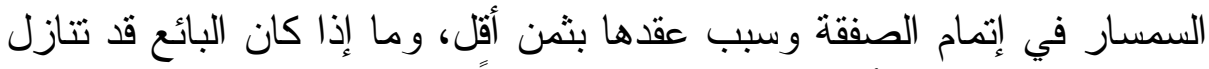

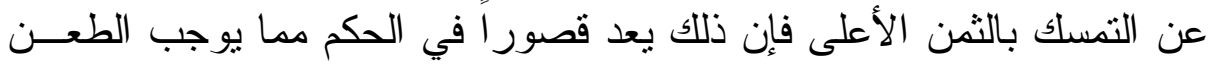

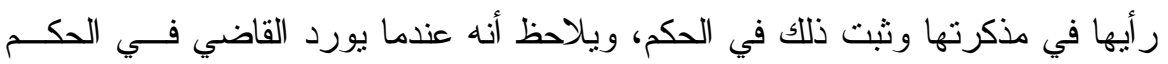

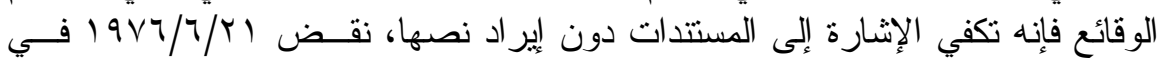

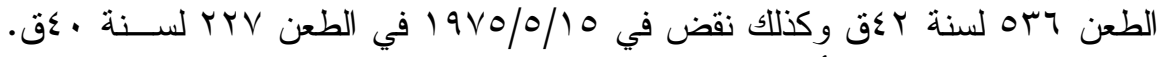

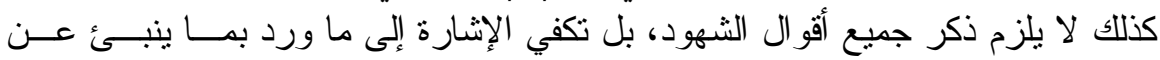

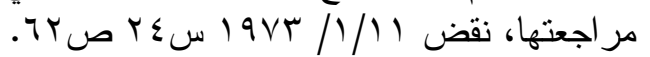

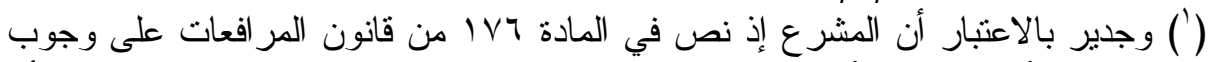

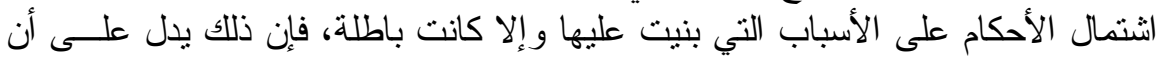

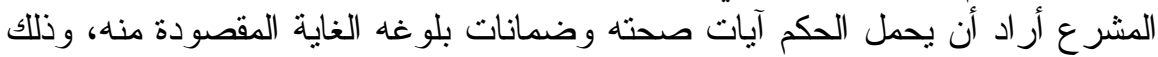

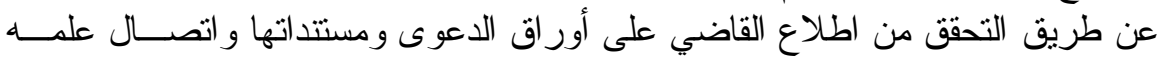

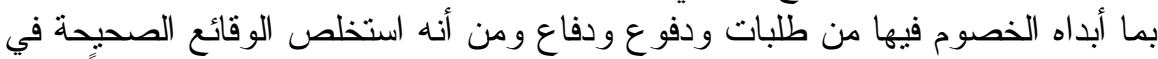

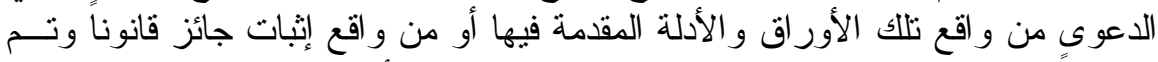

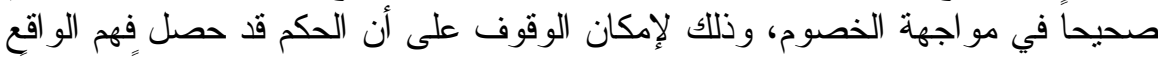

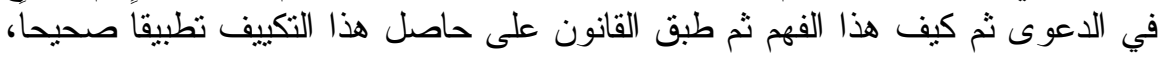

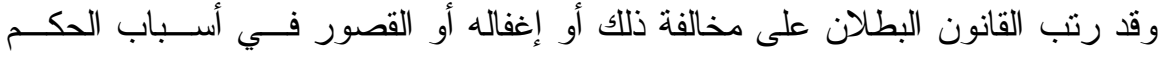

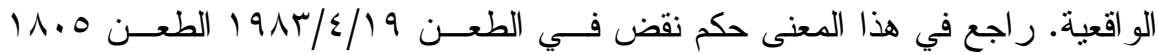

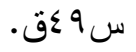




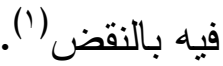
وقد يتحقق القصور الو اقعي في الأسباب لو كان عدم كفابــة الأســباب يعيق عمل محكمة النقض في مر اقبة القاضي في استظهار الأسـاس القـانوني

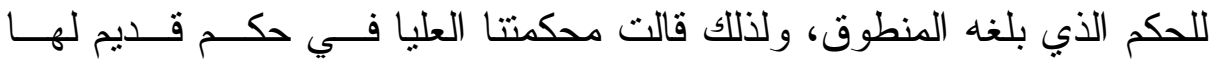

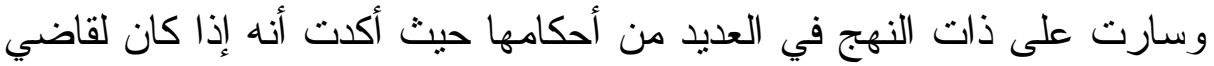

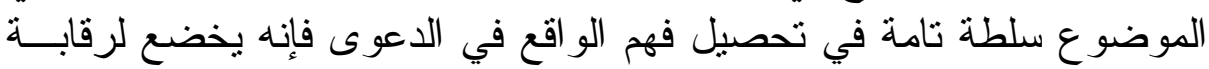
محكمة النقض في تكييف هذا الفهم مدا يتعين عليه أن بسبب حكمه التشــبيب

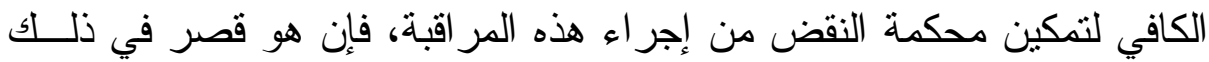

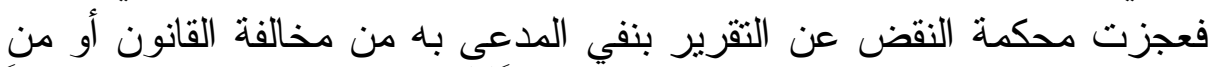

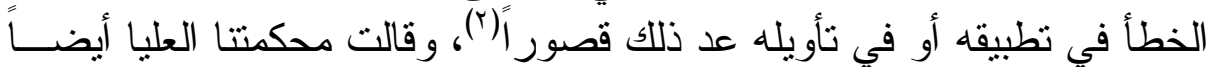

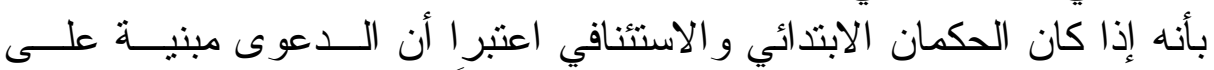

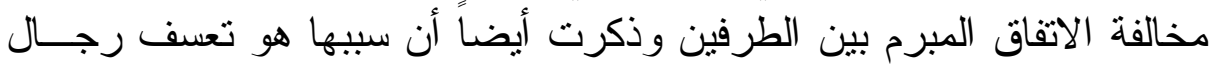

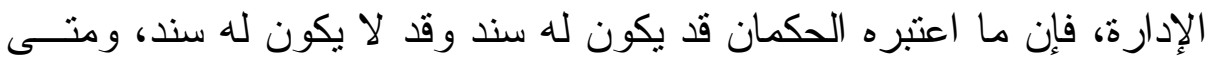

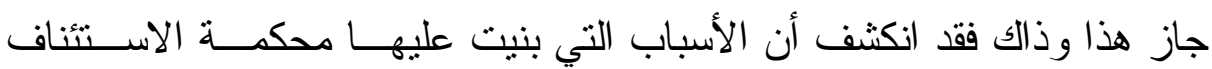

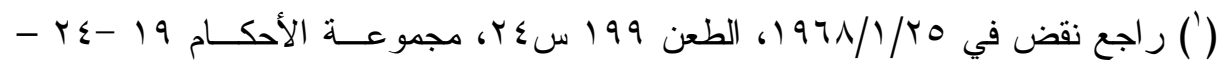

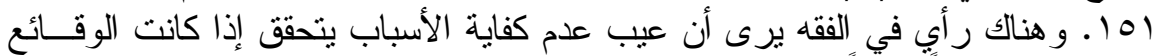

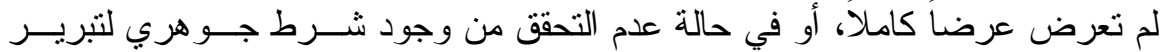

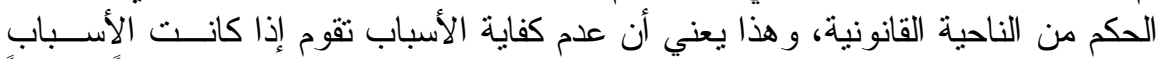

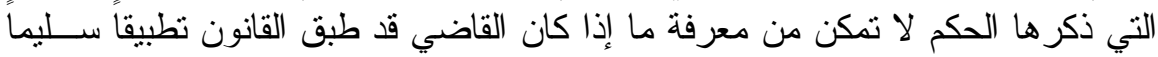

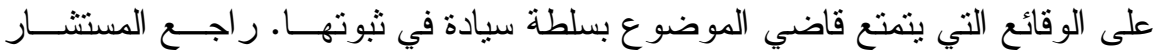

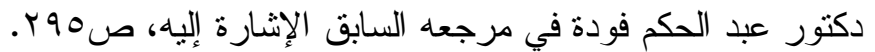

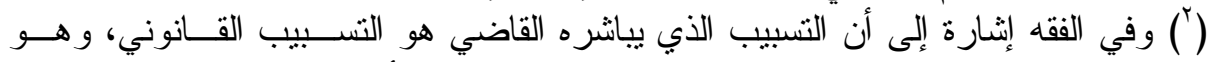

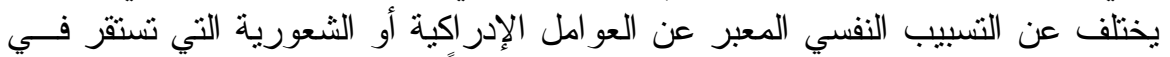

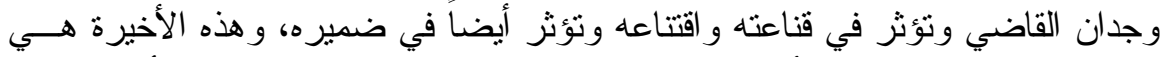

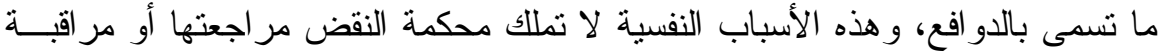

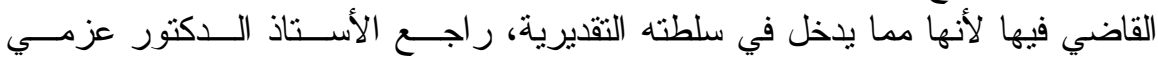

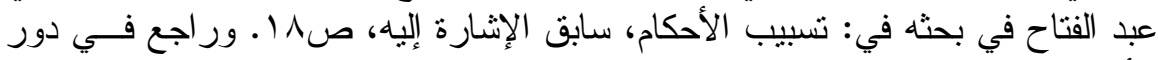

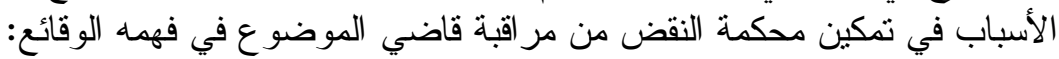
J. Flour; Aubert, les obligation. Vol. I, l'acte juridique 1975 p. 197 198.

Lion Husson; les trois dimensions de la motivation in la motivation des décisions de justice. Travaux du centre nationale de recherché des logique. Etudes publiées par ch perelman et P. Foriers. Bruxelles. Bruylant 1978 p. 73. 
حكمها إما أنها غير منتجة أو ناقصة وهذا الإبهام يعجز محكمة الــقضض عـن مر اقبة الخطأ المدعى به في تطبيق القانون (').

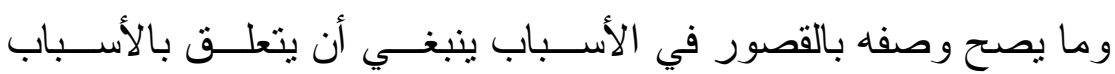

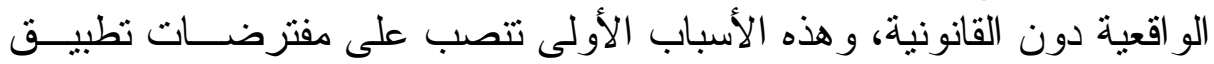

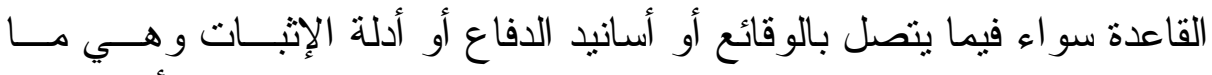

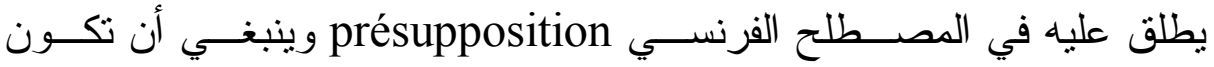
متساندة ومنطقية ومسو غة أو مبررة للمنطوق، أما الحيثيات القانونية فهي مــــا

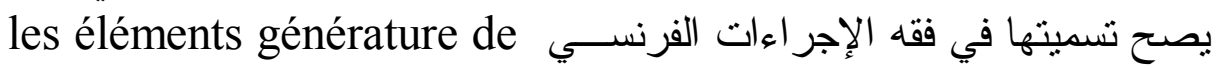
droit

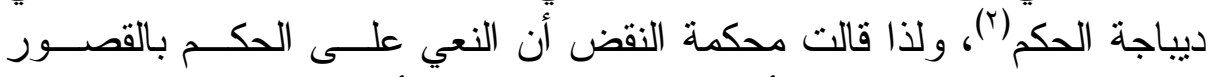
و التدليل عليه بما جاء في الأسباب لا في الديباجة؛ لأن الديباجة لا تحل محــل

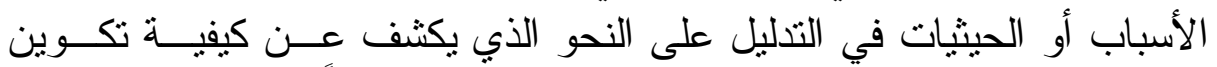

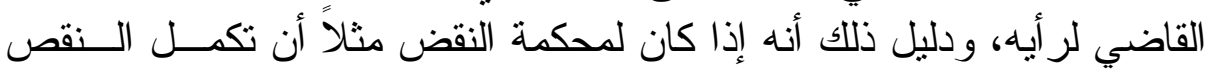
الذي أصاب الأسباب القانونية، فإنه ليس لها أن تكمل التسبيب في الوقائع حتى الونى

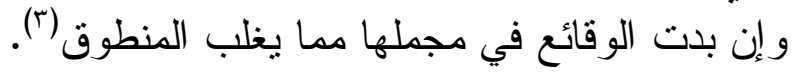

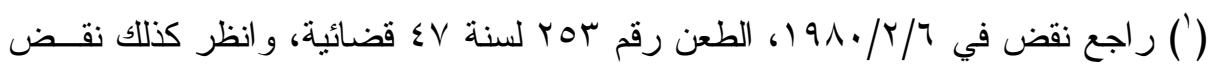

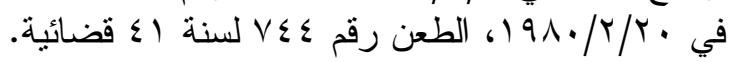

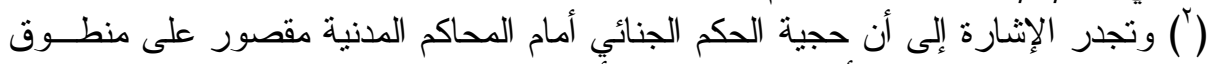

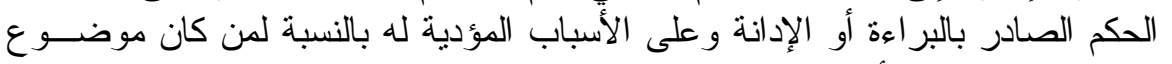

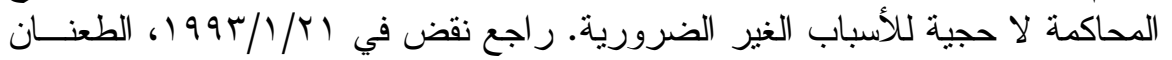

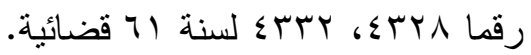

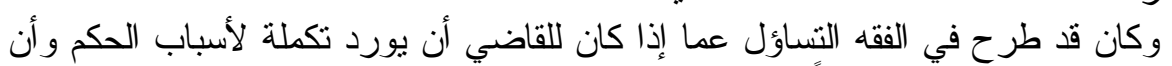

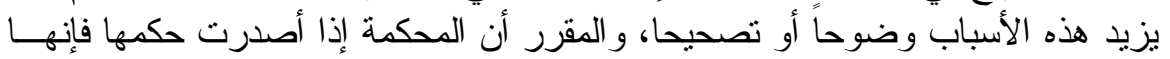

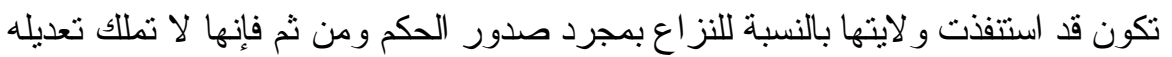

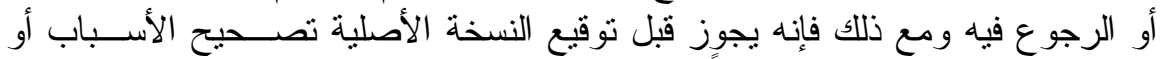

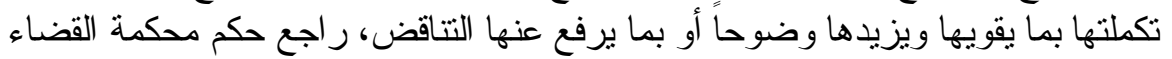

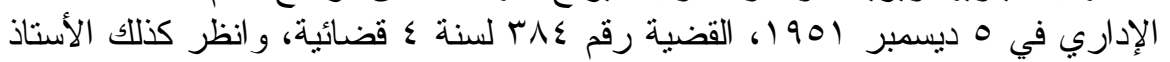

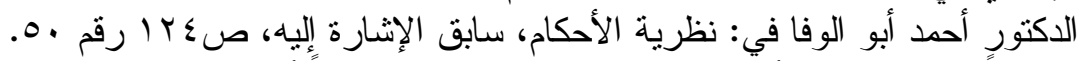

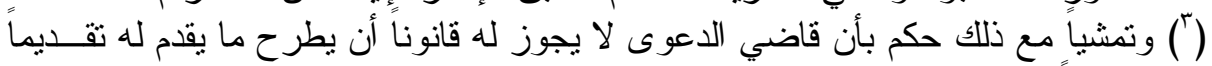

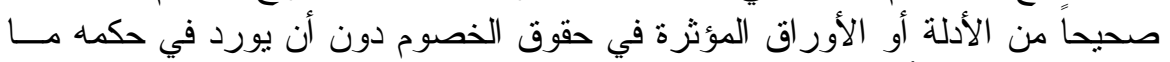

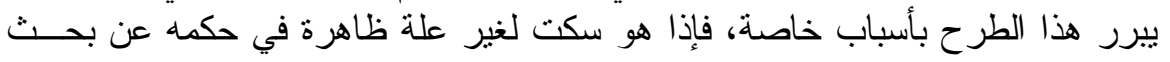

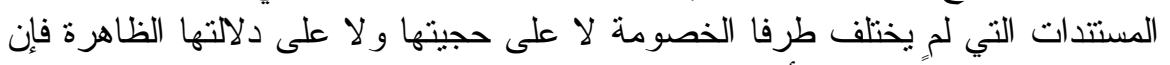

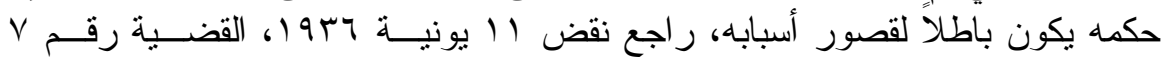


وقد يرد القصور في الأسباب إلى عدم كفاية الحيثيات المتعلقة بالحق في الدفاع؛ لأن الأسباب ينبخي أن تتضمن الرد على كل دفاع جوهري سواء أورد

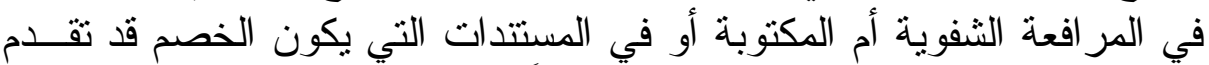

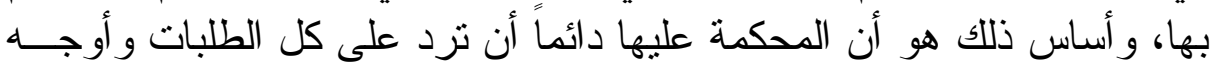

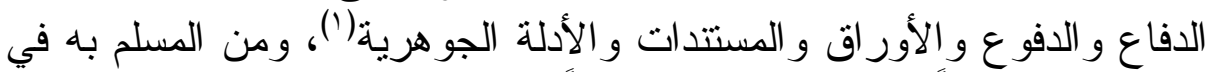

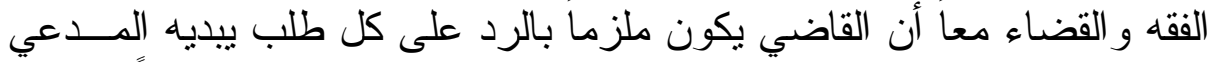

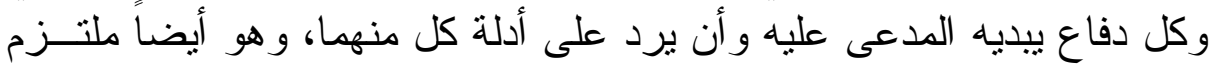

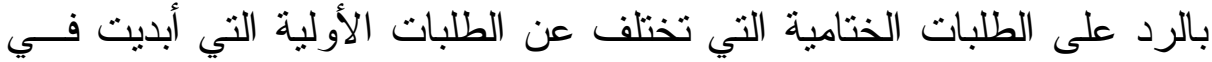
مستهل القضية، ويستوي في هذا المقام أن يتعلق الطلب بما يكون قد أبدي في

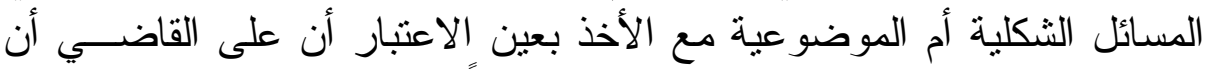

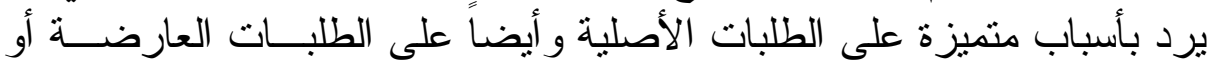

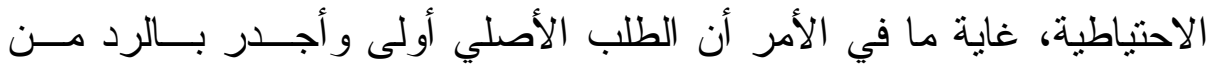

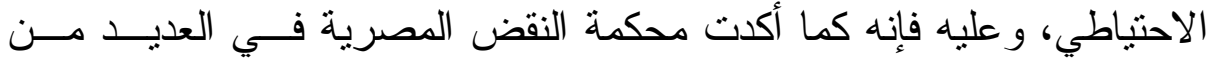
أحكامها فإن المحكمة إذا قضت في الطلب الاحتياطي فإن ذلك لا بغنيها عــن

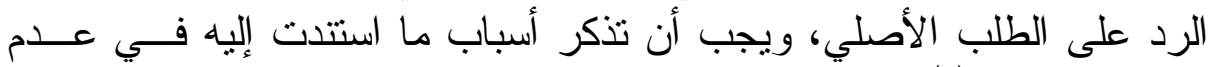
الإجابة للأصلي (r)، هذا وإن اقتضى الرنى ولجنق القانوني اعتبار استجابة المحكمة

(') ولذلك قضت محكمة النقض بأنه يجب أن تكون أسباب الحكم منصبة على مقطع النز اع

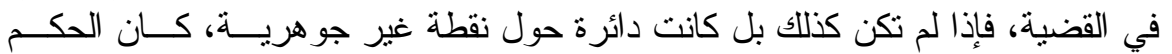

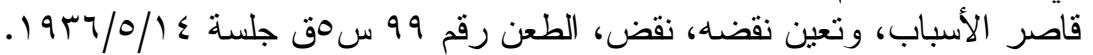

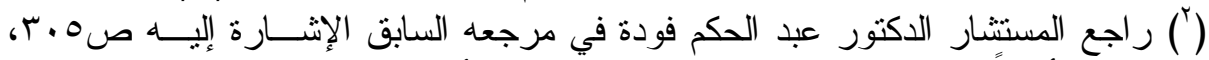

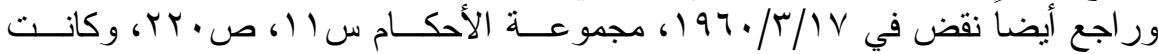

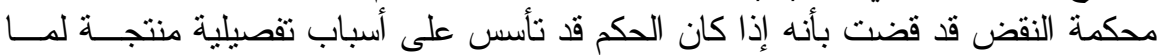

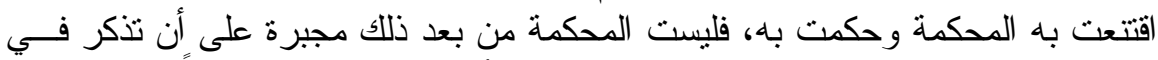

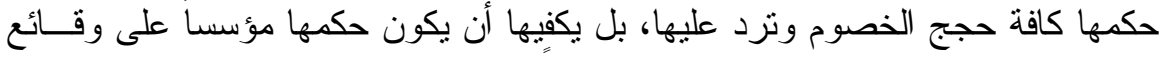

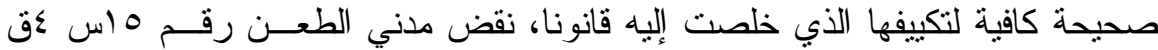

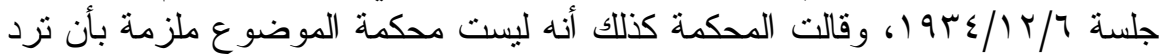

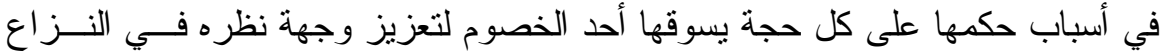

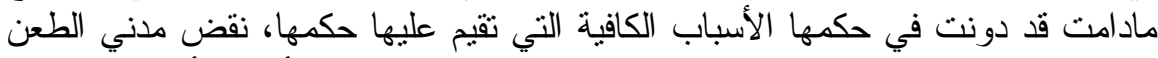

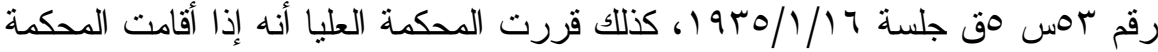

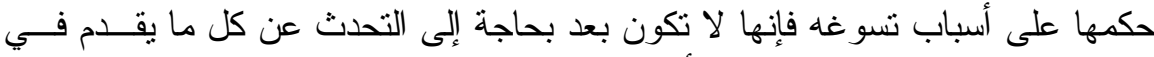

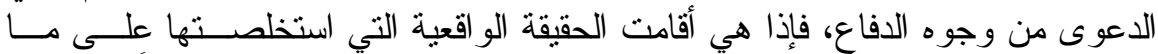

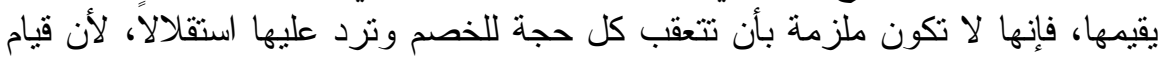

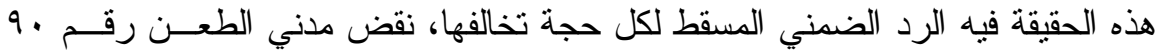

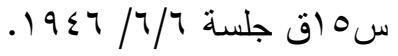


للطلبات الأصلية مع تسبيبها بمثابة تسبيب ضمني لاستبعاد الطلبات الاحتياطية

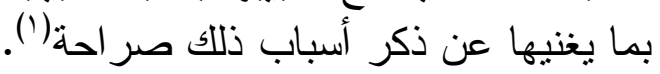

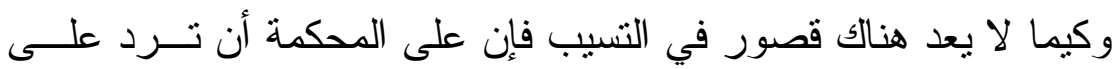

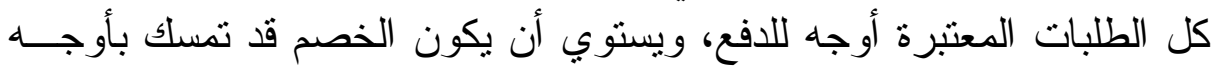

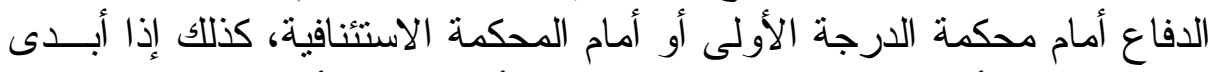

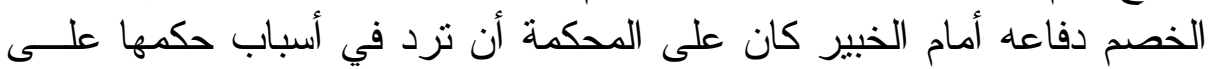

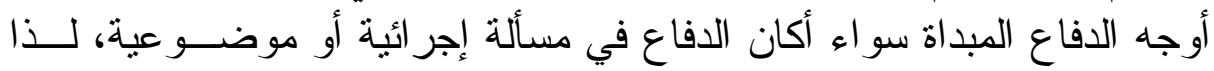

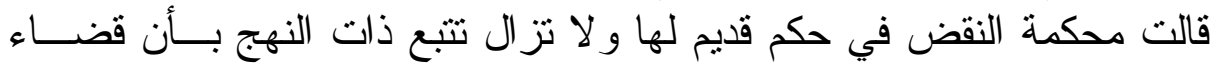

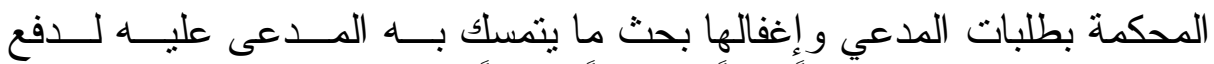

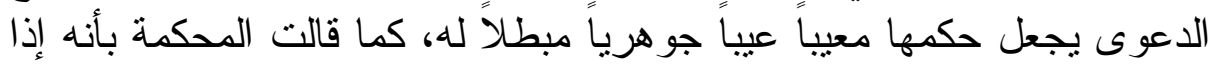

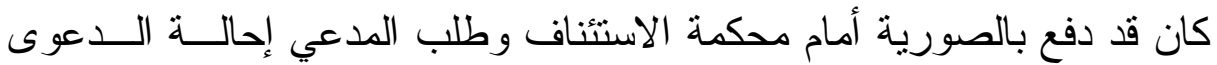
إلى التحقيق لإثبات الصورية فإن خلو الحكم من الرد على هذا الطلب يــؤدي إلى عوار الحكم وبطلانه(ب).

(') وتطبيقاً لذلك قالت محكمة النقض أنه متى كان الحكم قد أقيم على ما استتبطته المحكمة

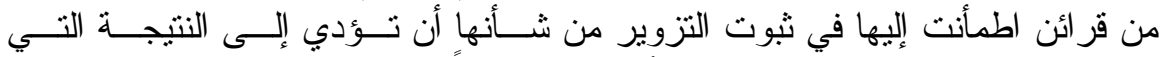

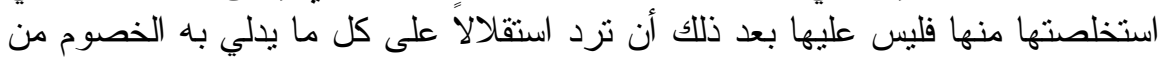

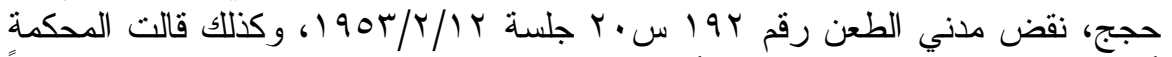

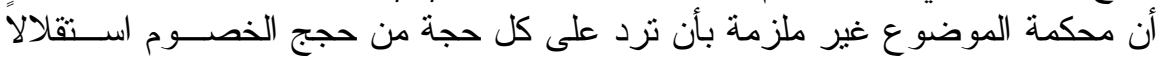

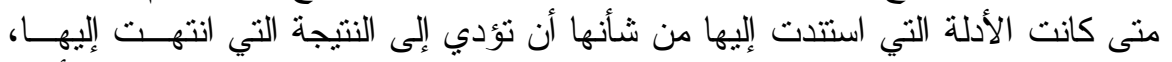

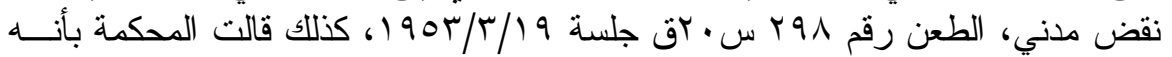

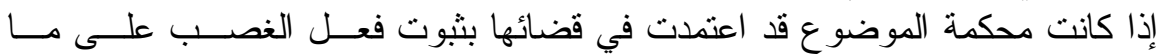

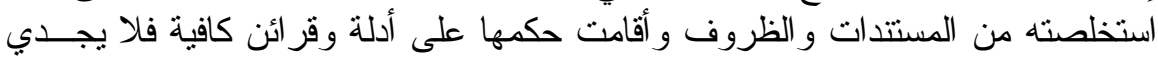

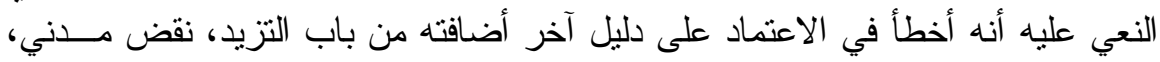

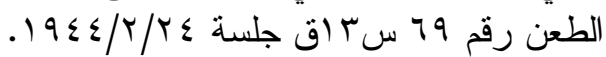

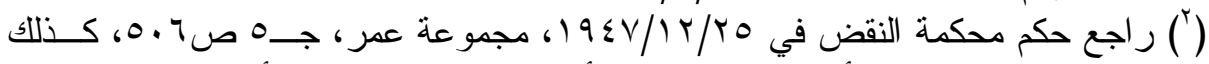

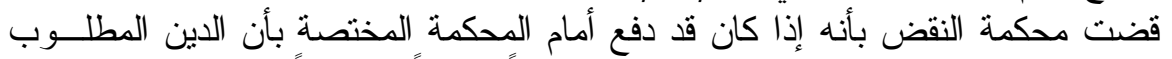

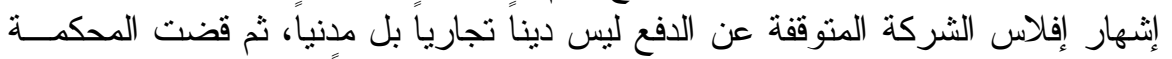

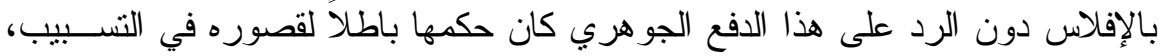

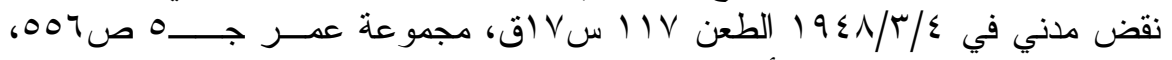

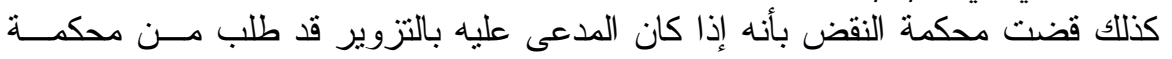

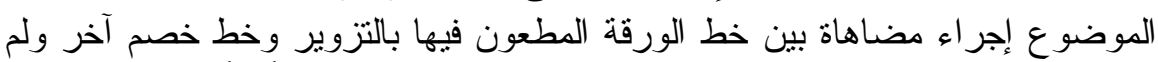

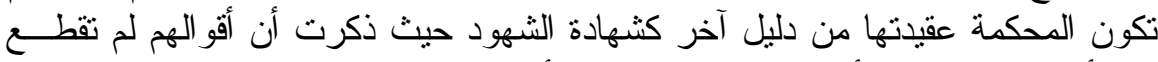

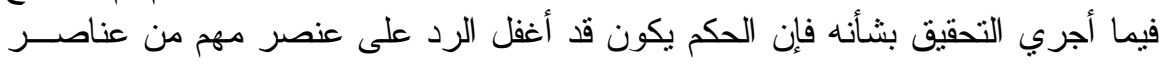

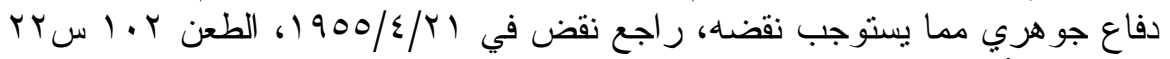

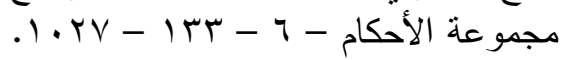


و غني عن البيان أن نفي القصور في التسبيب يستوجب من المحكمة أن

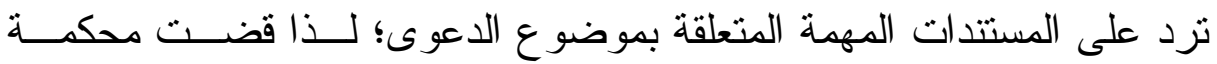

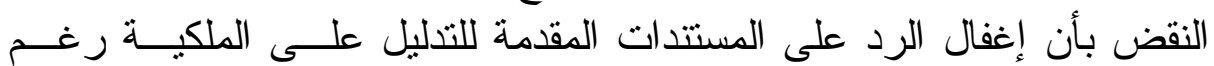
أهميتها هو قصور في الأسباب يعيب الحكم، كما قضت بأن التفات المحكمة -

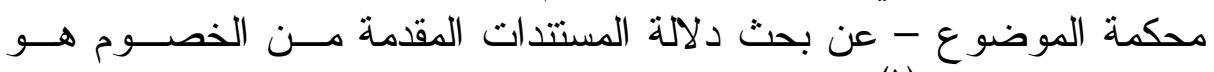

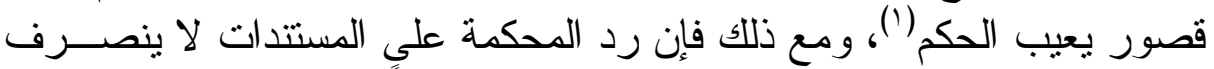

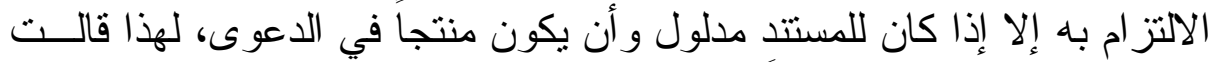

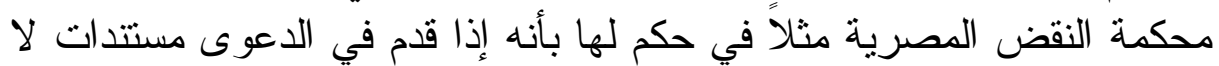

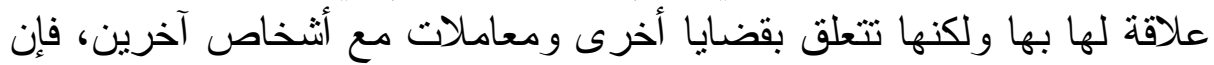

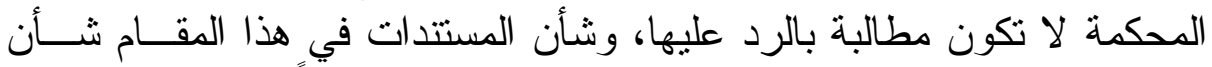

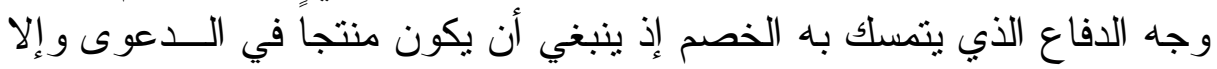

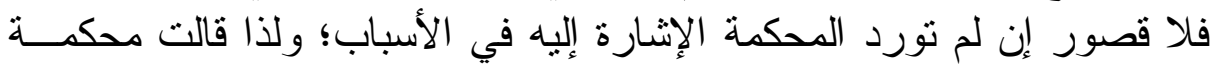

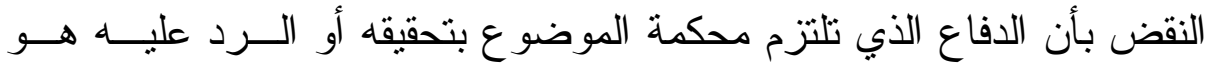

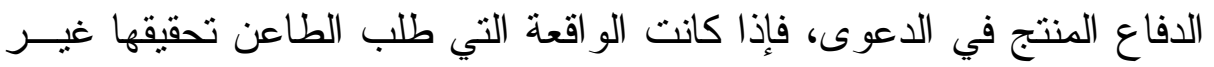

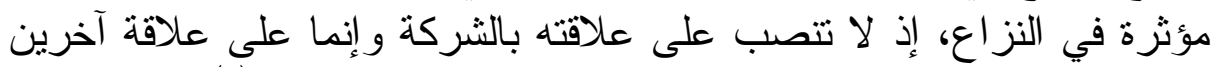

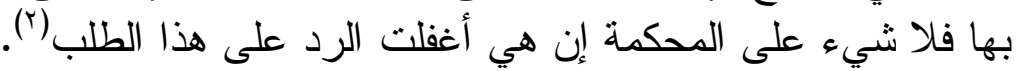

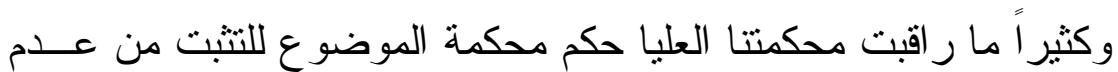

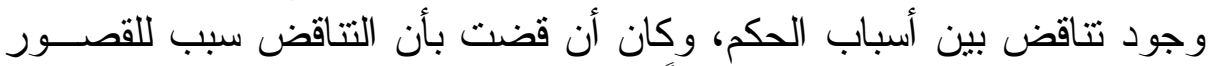

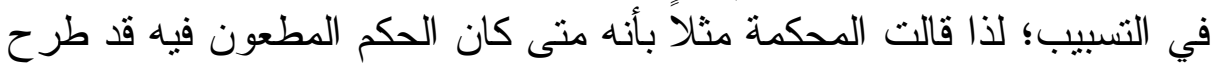

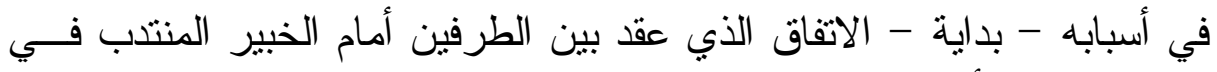

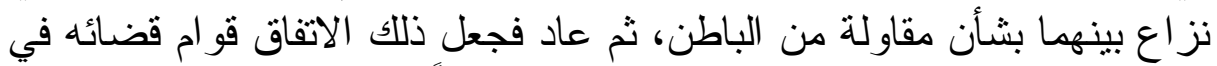

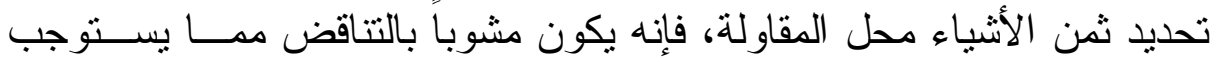

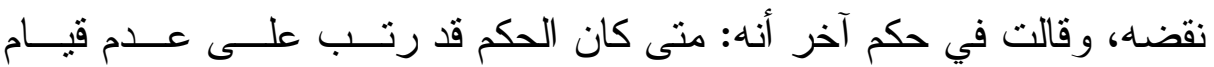

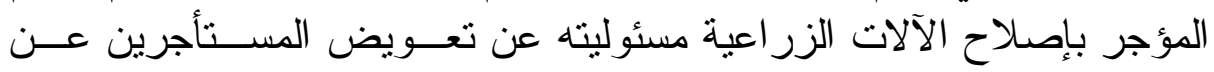

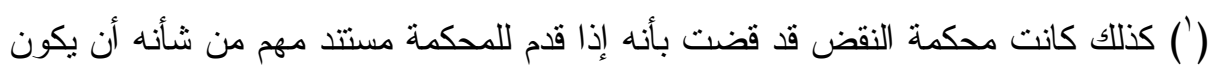

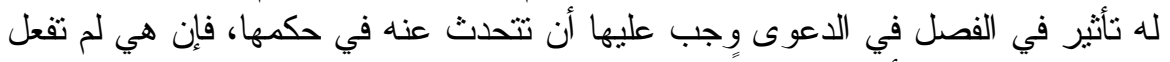

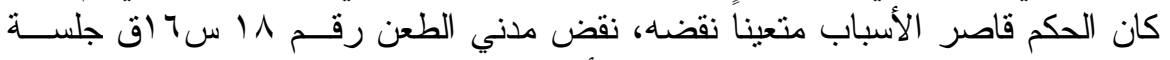

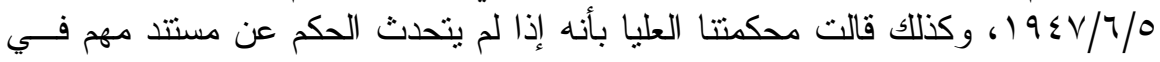

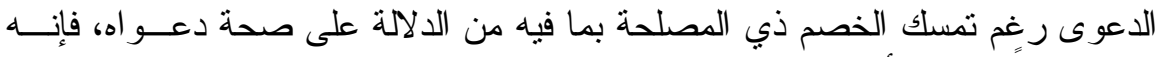

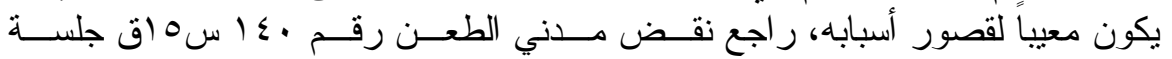
. $19 \leq 7 / 0 / 4 r$

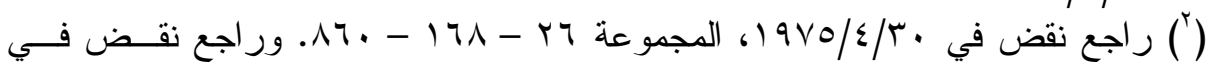
إ 


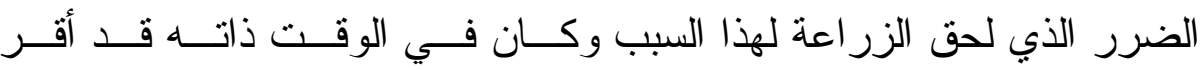

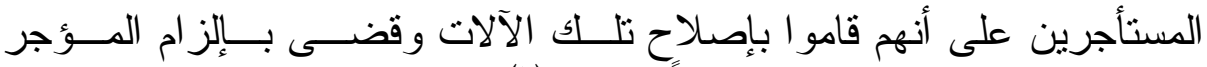

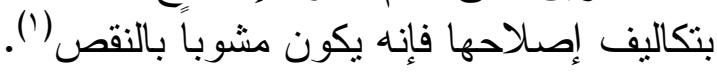

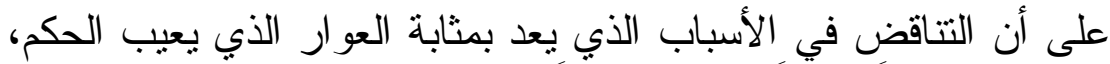

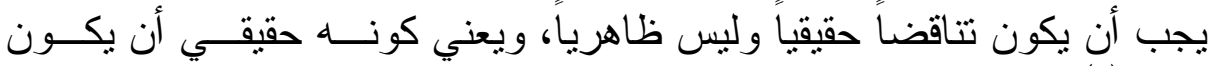
مؤكدا(Y)، ولقد أجادت محكمتنا العليا في بيان جوهر هذا فئا التناقض المعيب حيث

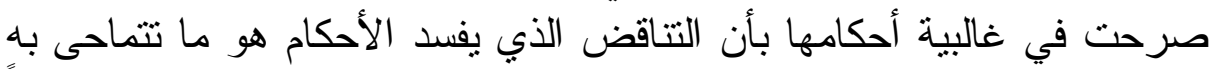

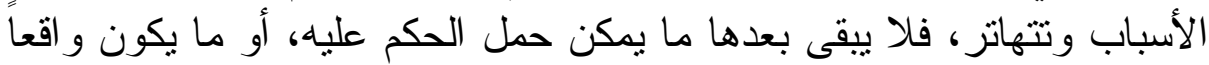

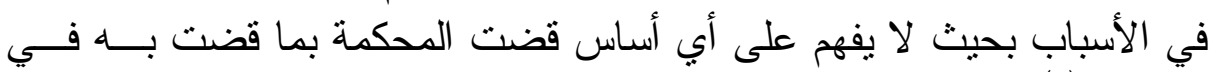

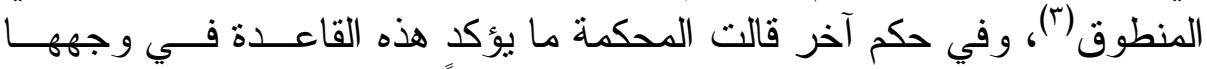

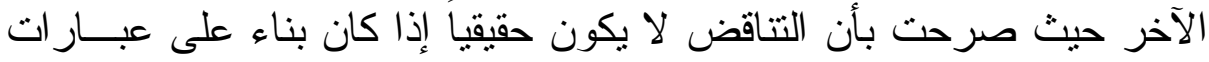

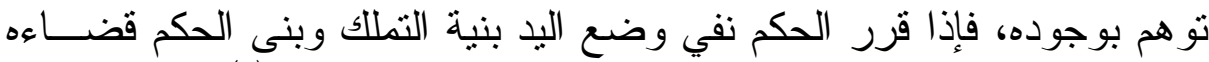

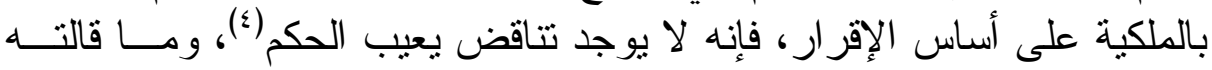

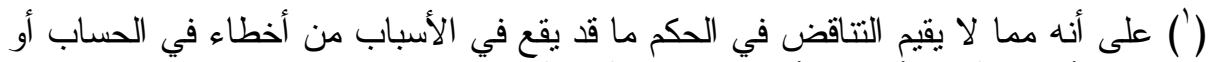

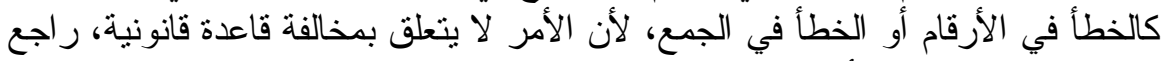

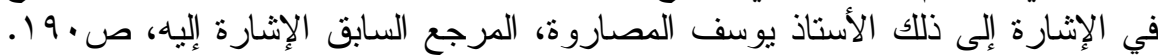

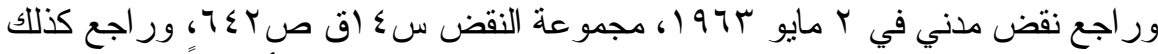

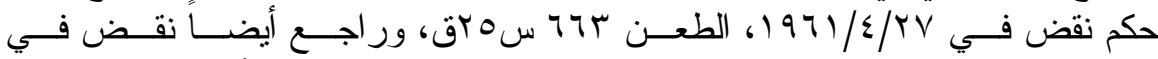

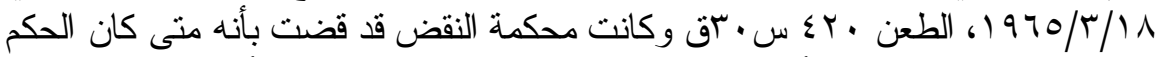

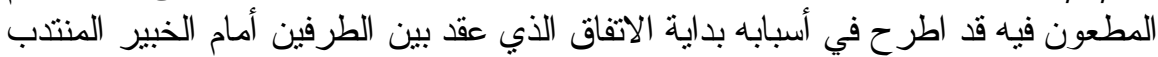

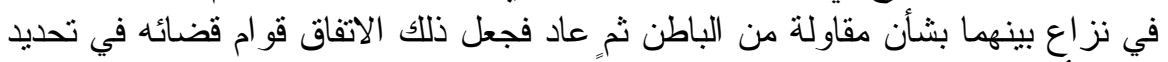

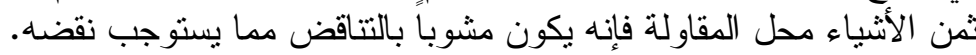

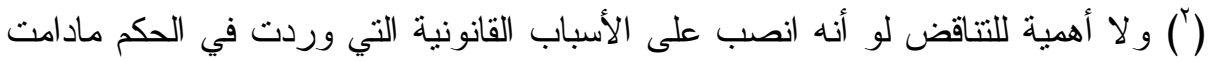

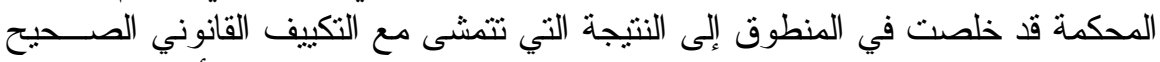

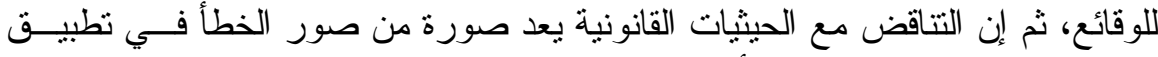

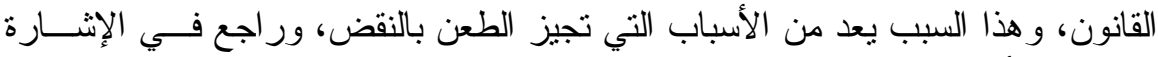

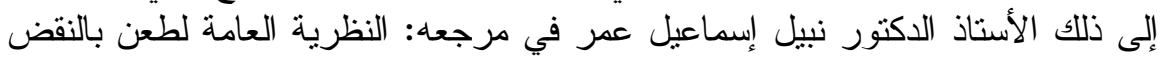

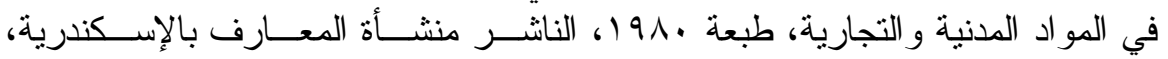

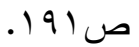

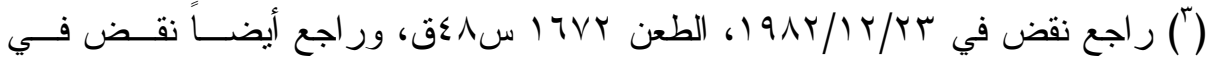

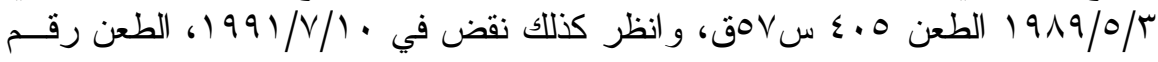

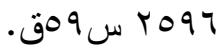

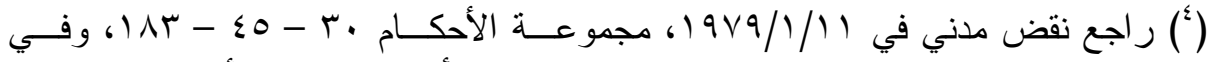

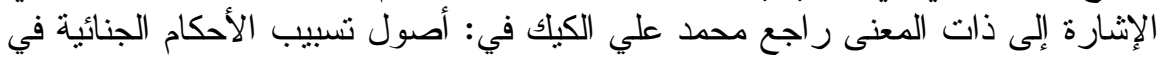

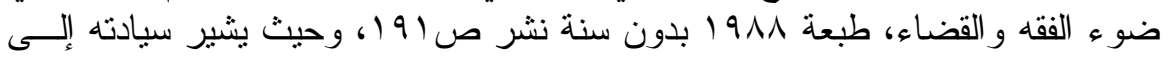




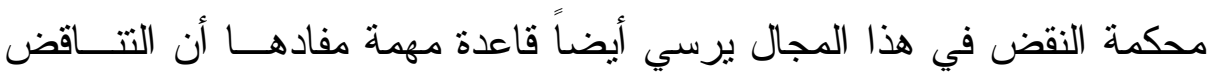

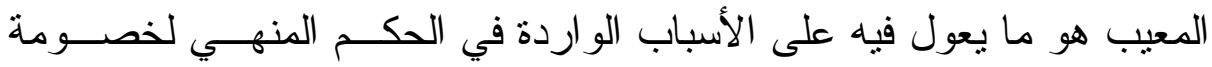

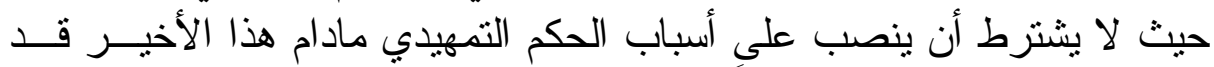

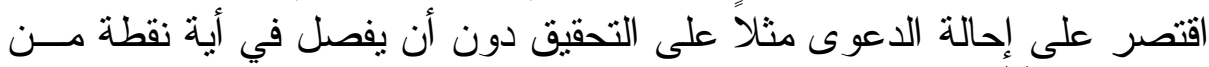

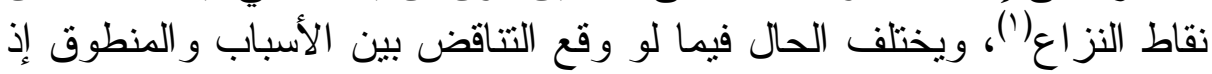

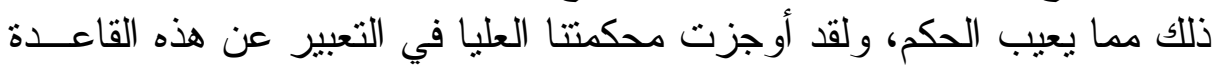

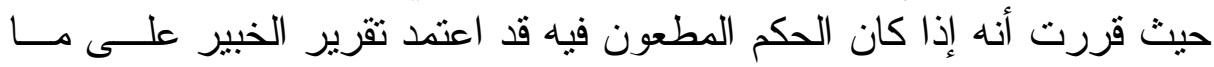

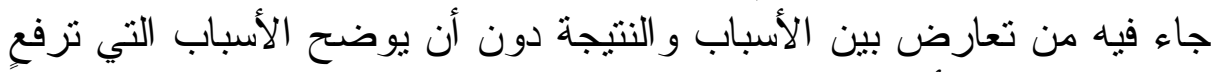

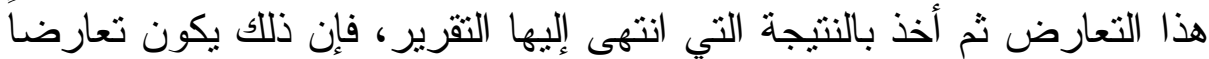

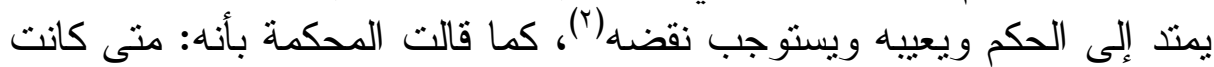

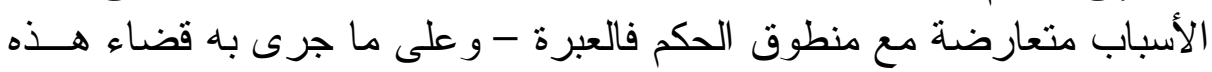

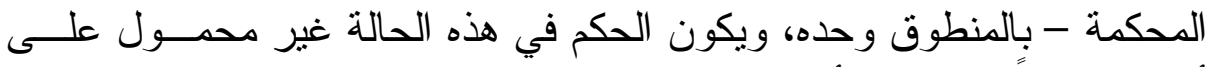
أسبابه وقائماً على غير أساس.

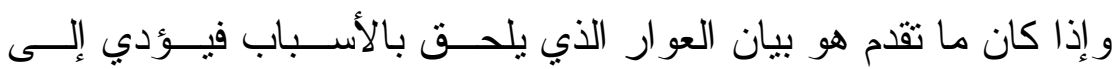

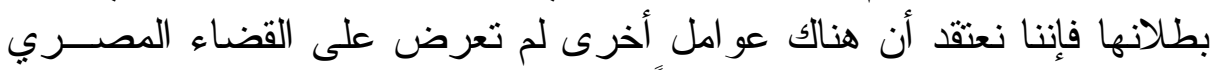

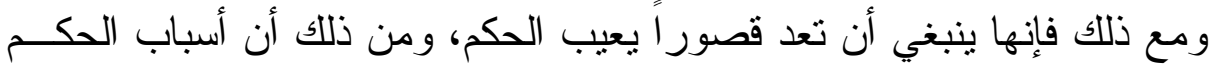

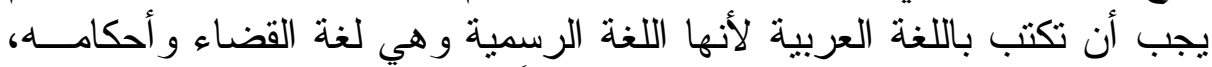

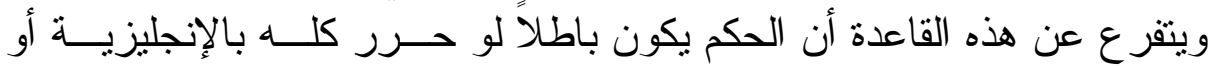

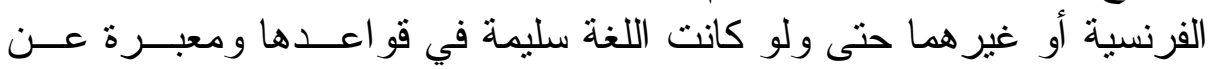

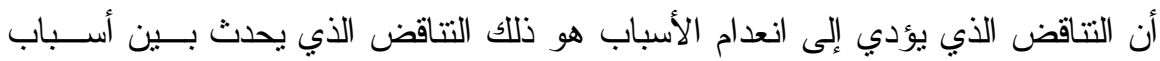

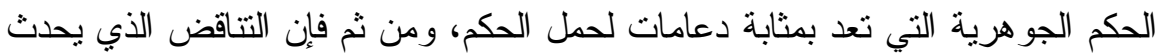

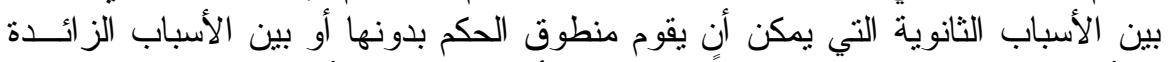

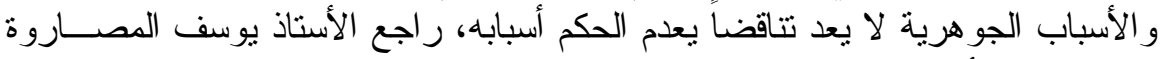

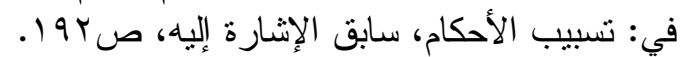

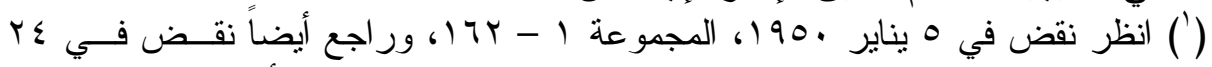

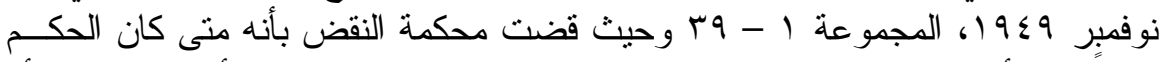

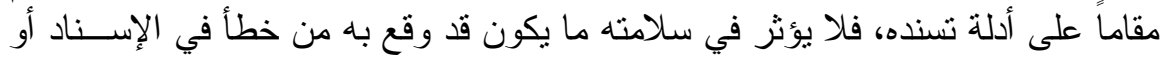

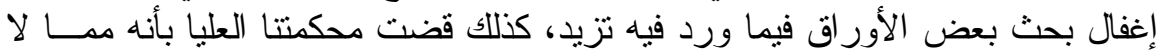

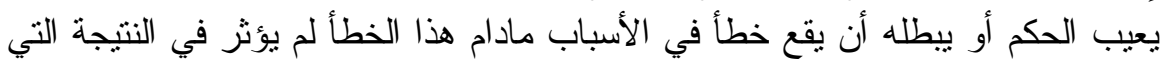

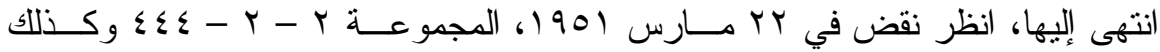

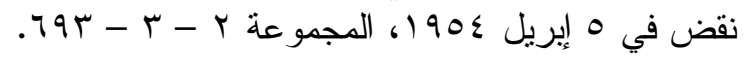

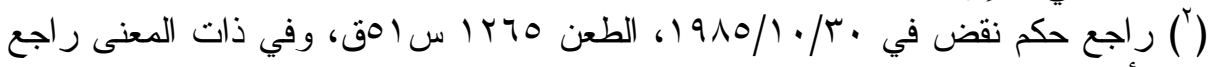

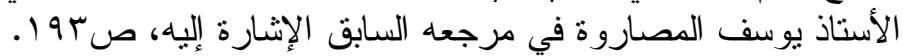




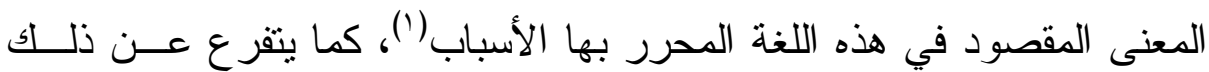

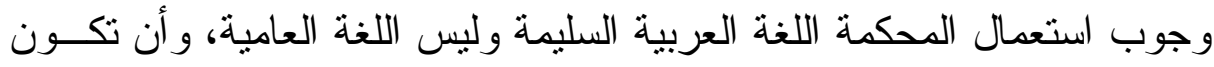

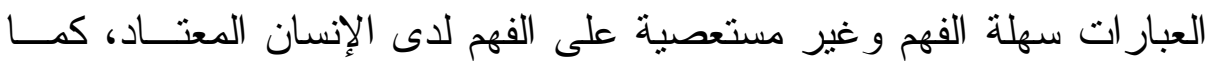

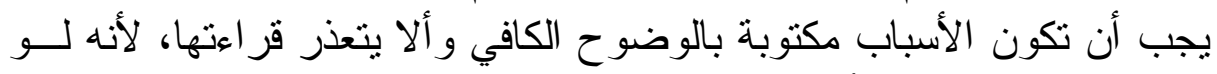

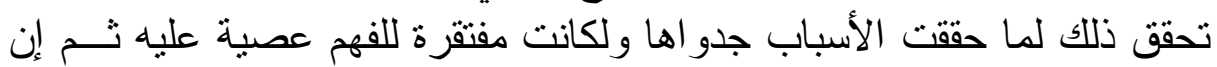

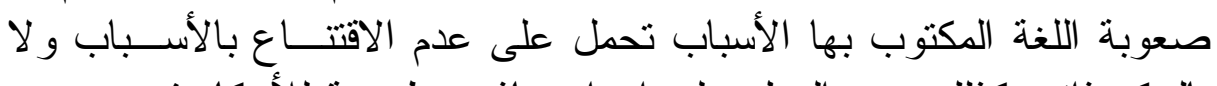

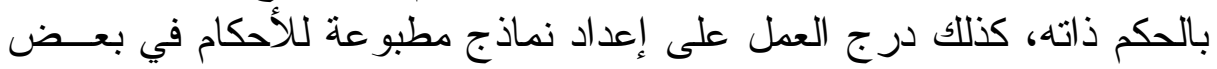

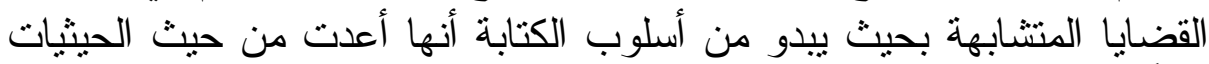

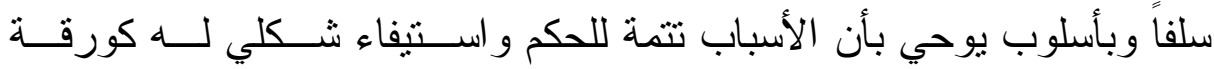

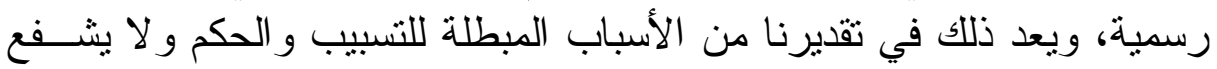

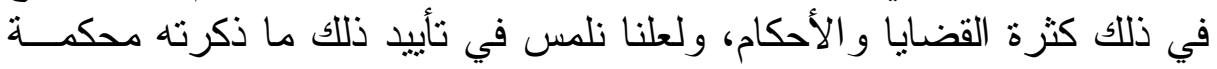

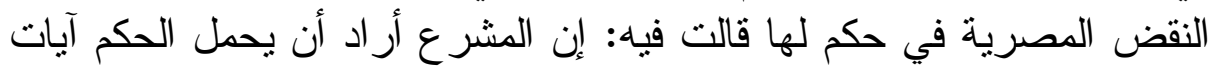

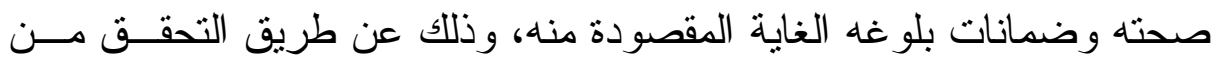

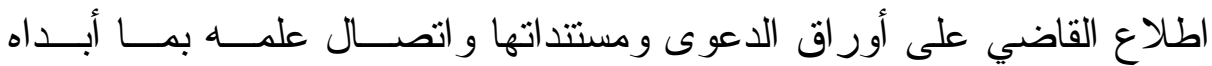

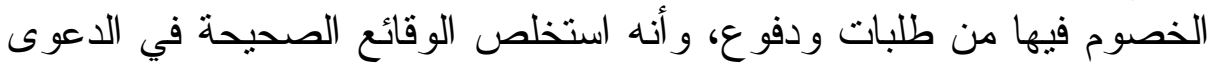

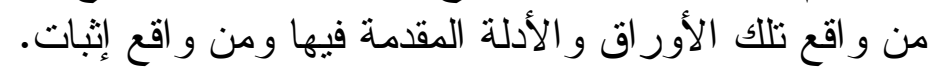

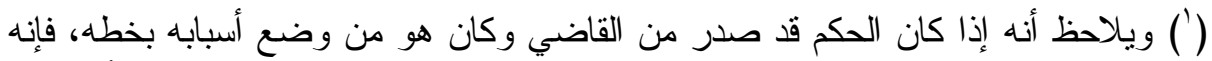

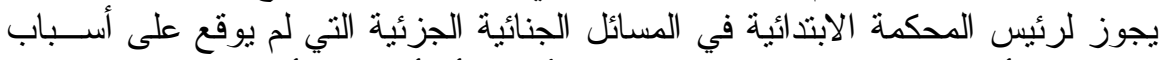

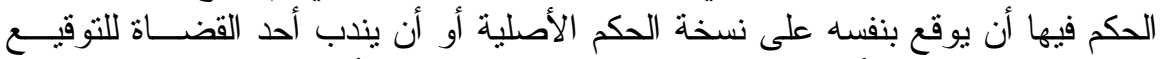

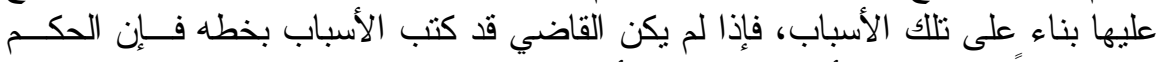

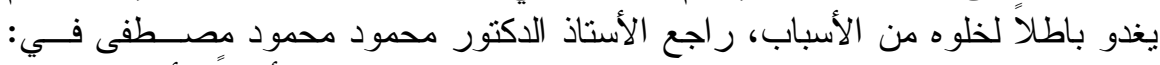

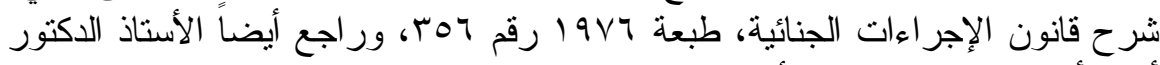

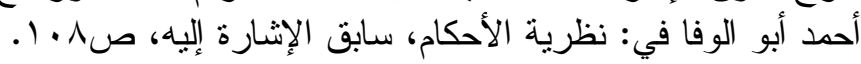




\section{خاتمـــة}

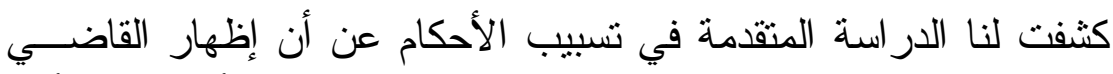

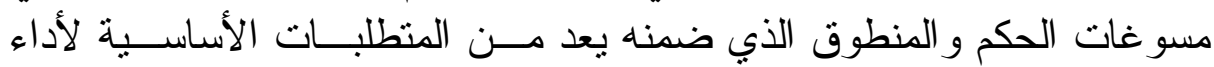

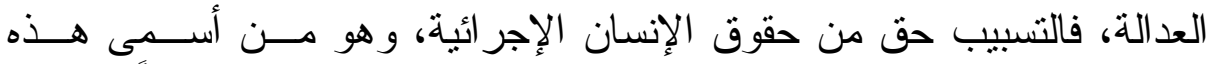

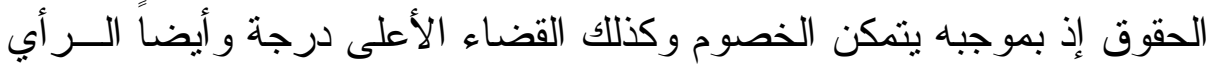

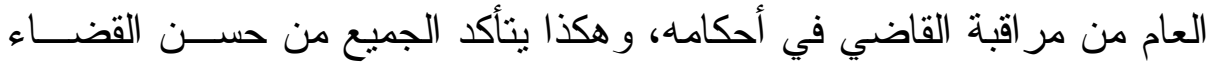

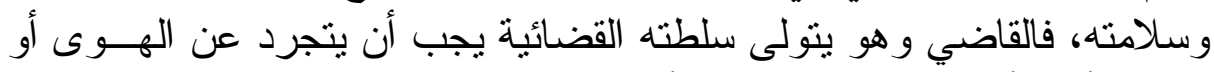

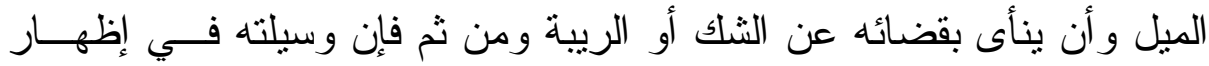

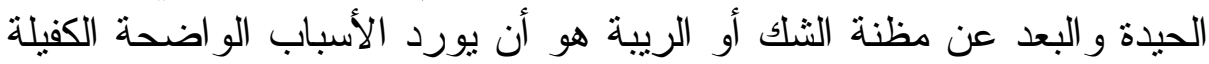

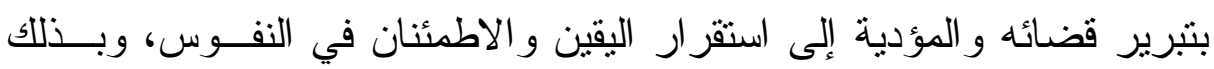
يتحقق للعد الة موجباتها.

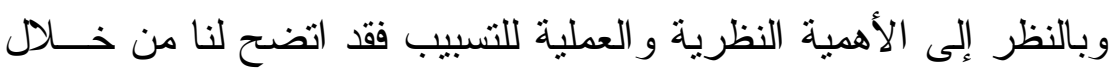

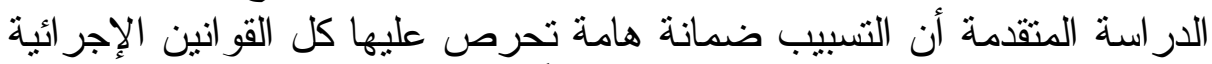

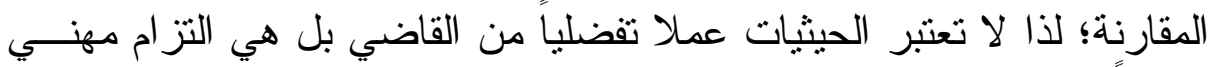

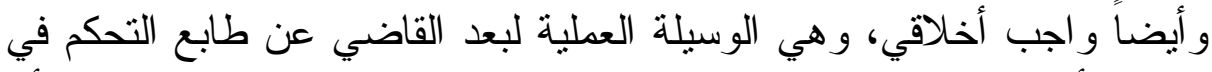

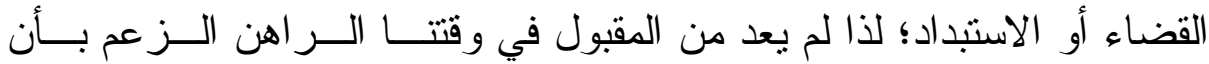

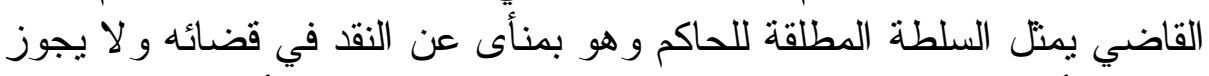

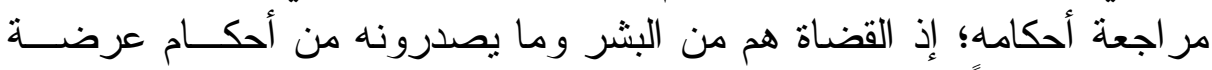

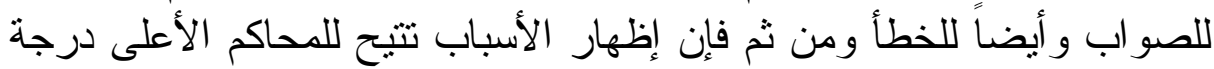

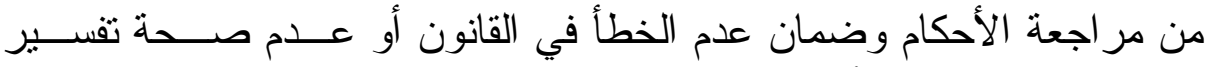
نصوصه الموضو عية أو الإجر ائية.

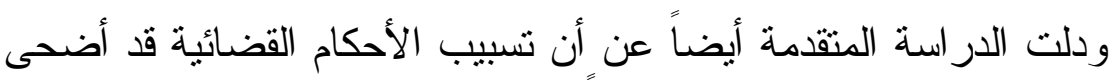

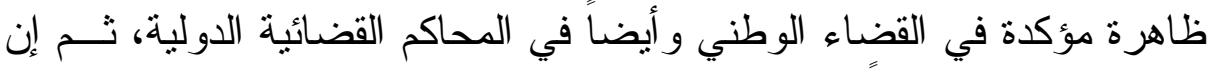

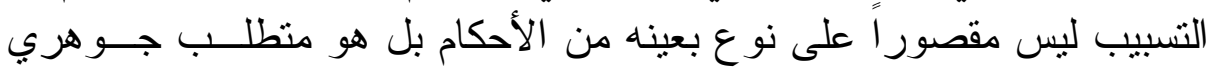
و أساسي في كافة أنو اع المحاكم سو اء أكانت محاكم مدنية أم تجارية التهاية أم جنائية

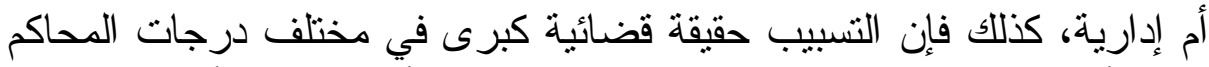

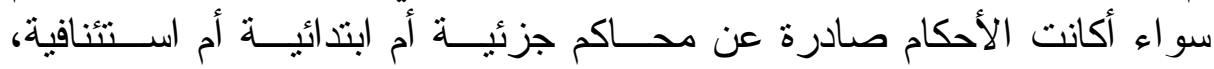

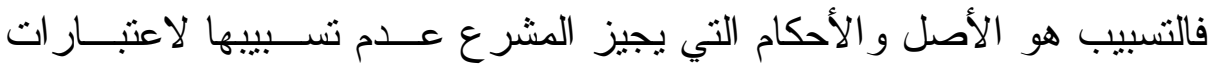

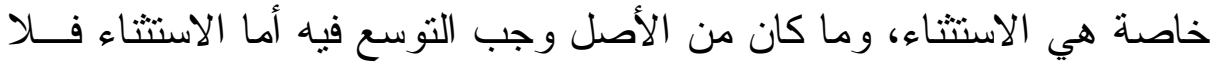
قياس عليه و لا نوسع. و أفادت در استتا المتقدمة أيضاً عن أن التسبيب ليس مجرد عمل قضائي 
شكلي، ومن ثم لا يكفي أن يورد القاضي في حكمه أسباب أو حيثيات أيـــا مــــا

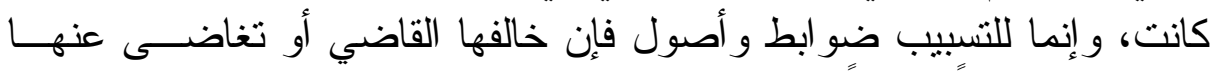

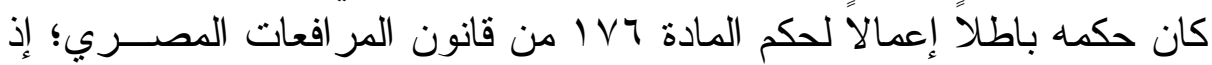

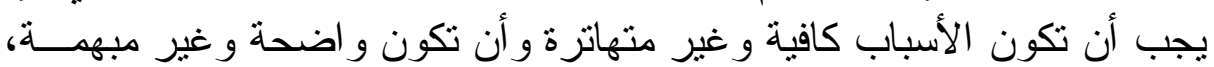

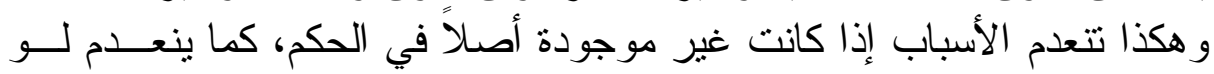

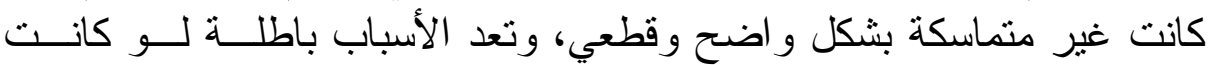

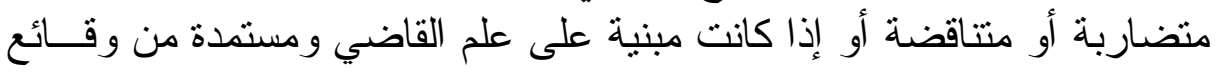

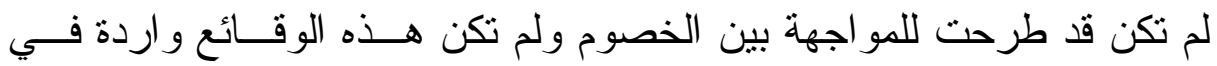

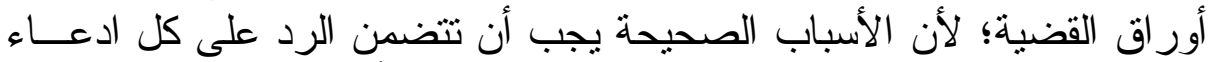

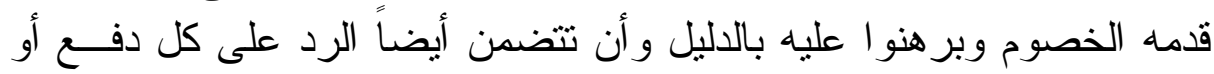

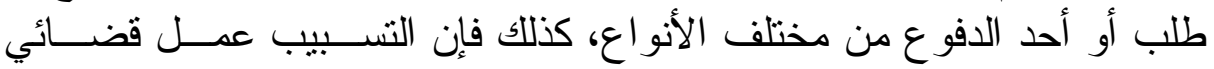

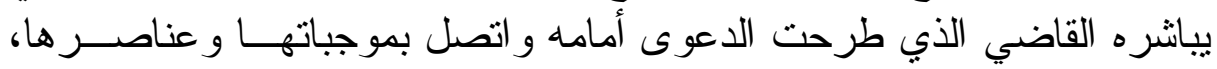

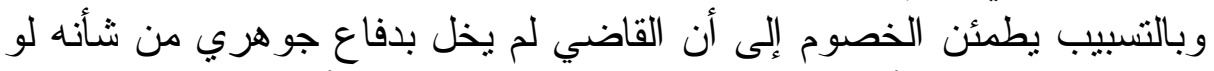

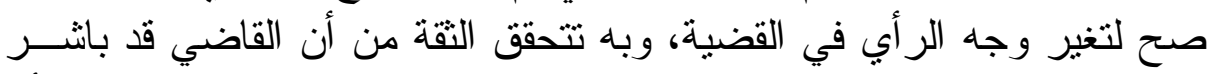

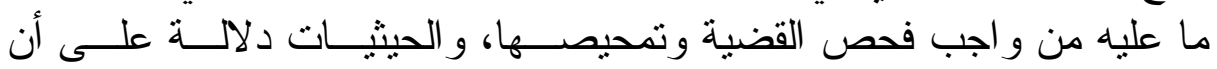

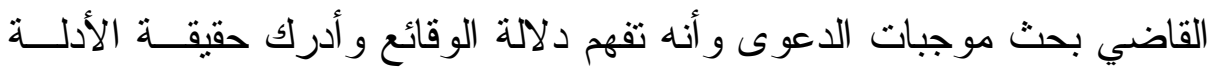
و الحجج الو اقعية و القانونية المعروضة عروضة عليه.

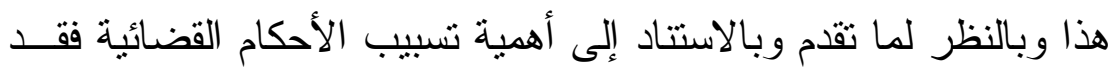

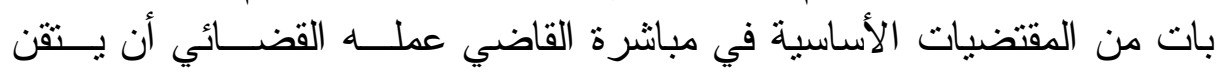

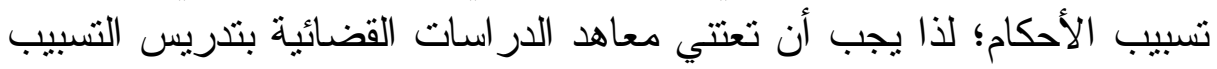

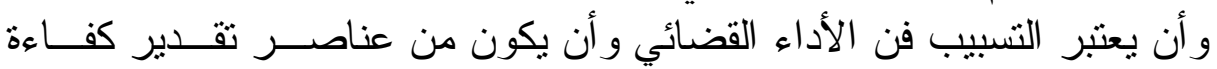

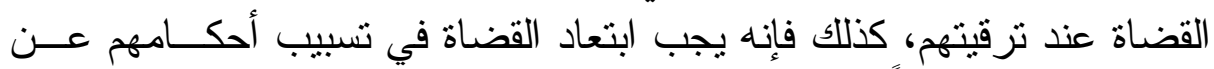

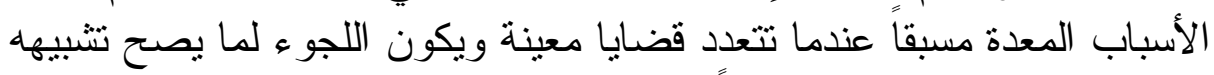

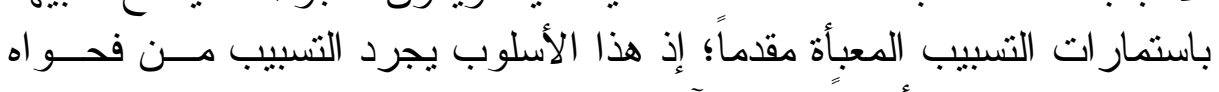

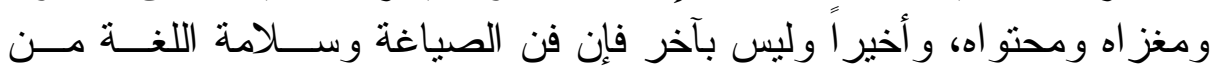

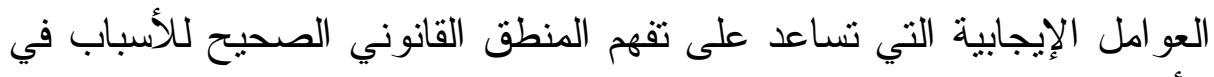
الأحكام القضائية. 
